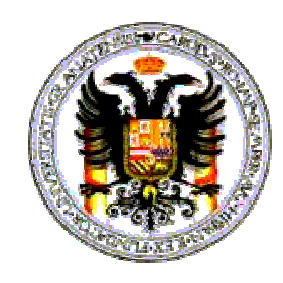

\title{
El mecenazgo musical de las Casas de Osuna y Benavente (1733-1844). Un estudio sobre el papel de la música en la alta nobleza española
}

\author{
Tesis Doctoral \\ presentada por \\ Juan Pablo Fernández González \\ Directora: Dra. María Gembero Ustárroz \\ VOLUMEN 1 \\ Universidad de Granada \\ Facultad de Filosofía y Letras \\ Departamento de Historia del Arte \\ Programa de Doctorado en Historia y Ciencias de la Música \\ Granada, diciembre de 2005
}


Editor: Editorial de la Universidad de Granada Autor: Juan Pablo Fernández González

D.L.: Gr. 74 - 2006

ISBN: 84-338-3744-3 


\section{ÍNDICE GENERAL}

\section{VOLUMEN 1}

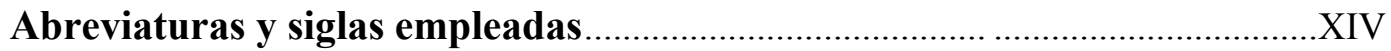

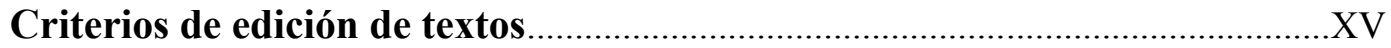

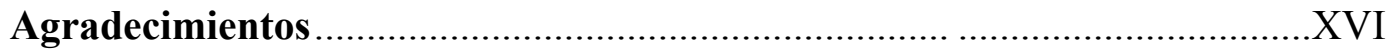

\section{Introducción}

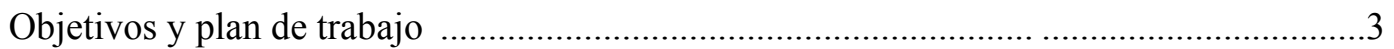

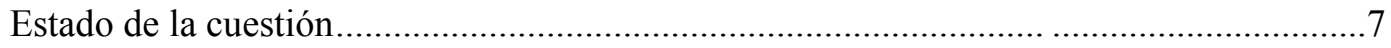

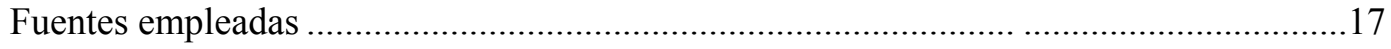

Capítulo I. Las Casas de Osuna y Benavente: una aproximación histórica... 23

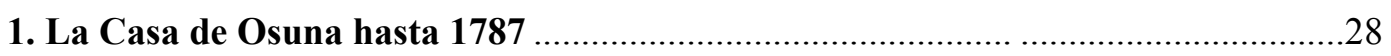

1.1. Orígenes de la Casa de Osuna. El condado de Ureña...........................................28

1.2. Titulares de la Casa de Osuna hasta 1787 .............................................................33

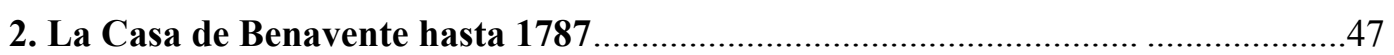

3. Las Casas de Osuna y Benavente desde 1787 hasta la actualidad ........................53

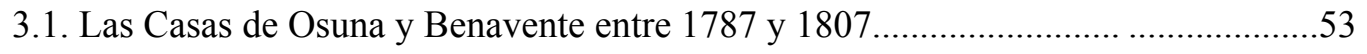

3.2. Las Casas de Osuna y Benavente desde 1807 ......................................................64

3.2.1. La titularidad del XII Duque de Osuna. Quiebra y enajenación del

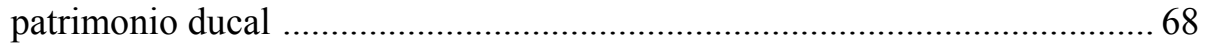

3.2.2. Las Casas de Osuna y Benavente en el siglo XX .......................................... 72

4. Estructura administrativa de las Casas de Osuna y Benavente en los siglos

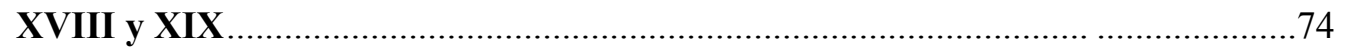

5. EI mecenazgo artístico de las Casas de Osuna y Benavente entre los siglos XVI y XIX. 


\section{Capítulo II. Antecedentes musicales de las Casas de Osuna y Benavente.}

1. La música en las Casas de Ureña y Osuna

1.1. Actividades musicales de los Condes de Ureña y los Duques de Osuna en la España peninsular (1531-1720).

1.1.1. Actividades musicales en la villa de Osuna en los siglos XVI y XVII

1.1.2. La música en las cortes nobiliarias de los Duques de Osuna (1656-1716).

1.2. El mecenazgo musical de José Téllez Girón, VII Duque de Osuna (1720-1733)

1.2.1. La capilla musical del VII Duque de Osuna

1.2.2. Funciones de teatro musical en español patrocinadas por el

VII Duque de Osuna.

1.3. La música en las cortes italianas de los Duques de Osuna en el siglo XVII

2. La música en la corte nobiliaria de los Condes-Duques de Benavente en los siglos XVI y XVII.

3. La música en las casas nobiliarias de Arcos y Gandía (siglos XVI-XVIII) ......... 139

3.1. Formación y práctica entre los titulares de las Casas de Arcos y Gandía ............ 140

3.2. La capilla musical de los Duques de Arcos en los siglos XVI y XVII ................. 145

3.3. Espectáculos dramático-musicales promovidos por los Duques de Arcos .......... 149

Capítulo III. Recursos humanos: músicos y maestros de baile al servicio de las Casas de Osuna y Benavente (1733-1844).

\section{La formación musical de los miembros de las Casas de Osuna y Benavente:} profesores de música y maestros de baile.

1.1. Profesores de música

1.1.1. Profesores de música de la Casa de Benavente hasta 1787:

G. B. Mele, J. A. Morotti, L. Marescalchi, A. Literes Montalvo,

J. Lidón y B. de Laserna

1.1.2. Manuel Carreras y Gaetano Brunetti, profesores de violín de Pedro de Alcántara Téllez Girón, Marqués de Peñafiel. 164 
1.1.3. La educación musical de los hijos de los IX Duques de Osuna:

Carlo Marinelli

1.1.4. Otros profesores de música al servicio de las Casas de Osuna

y Benavente en la primera mitad del siglo XIX

1.2. Maestros de baile 176

1.2.1. Maestros de baile al servicio de las Casas de Osuna y Benavente y Benavente hasta 1787

1.2.2. Maestros de baile de los hijos de los IX Duques de Osuna:

Domenico Rossi, Pierre G. Gardel y Jean Joly

1.2.3. Otros maestros de baile al servicio de las Casas de Osuna y

Benavente en la primera mitad del siglo XIX

\section{Instrumentistas y compositores al servicio de los Duques de Osuna}

y de los Condes-Duques de Benavente 186

2.1. Músicos al servicio de las Casas de Osuna y Benavente entre 1733 y 1787 ....... 188

2.1.1. Músicos al servicio de la Casa de Osuna 188

Músicos de la Real Capilla

Músicos catalanes al servicio del VIII Duque de Osuna.. 198

2.1.2. Músicos al servicio de la Casa de Benavente

2.2. La orquesta de María Josefa Alfonso Pimentel, de Benavente ( $c$. 1781-1792)

2.2.1. Estructura y funcionamiento de la orquesta.

Músicos asalariados e instrumentistas de refuerzo

2.2.2. La dirección de la orquesta: Bonifacio Zlotek, Luigi Boccherini

y Rafael García de Sena

2.2.3. Músicos de la Real Capilla y de otras agrupaciones estables en la orquesta de la Condesa-Duquesa

2.2.4. La protección de la Condesa-Duquesa a los músicos de su orquesta $\quad . .238$

2.3. La Capilla musical del IX Duque de Osuna según el Allgemeine musikalische Zeitung (Leipzig, 1799)

2.4. Otros músicos al servicio de las Casas de Osuna y Benavente entre 1793 y 1844 
1. Fondos musicales de las Casas de Osuna y Benavente

1.1. La formación del repertorio musical de las Casas de Osuna y Benavente... 261

1.1.1. Dedicatorias y regalos

1.1.2. Contratos de adquisición de música y obras de compositores al servicio de la Casa .....

1.1.3. Encargos de obras 266

1.1.4. Compras a proveedores españoles y europeos 266

1.1.5. Copias de música..

1.2. Inventarios de los archivos y bibliotecas de las Casas de Osuna y Benavente... 277

1.2.1. Materiales musicales propiedad de las Casas de Osuna y Benavente hasta 1781 278

1.2.2. La "papelera de música" de la XV Condesa-Duquesa de Benavente Los inventarios de 1824 y $c a .1838$.

1.2.3. Inventario de los libros de música y partituras de los palacios de los Osuna subastados en 1897

1.3. Fondos de interés musical procedentes de la Casa de Osuna conservados en la Biblioteca Nacional de España (Madrid)

\section{Los instrumentos musicales de los Duques de Osuna y de la}

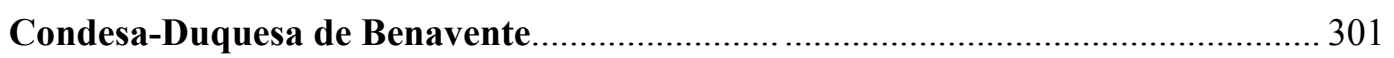

2.1. Instrumentos de teclado

2.1.1. Clavicémbalos y clavicordios del VII Duque de Osuna (ca. 1733-1745)

2.1.2. Un clavicordio importado de Inglaterra para Pedro Zoilo

Téllez Girón, VIII Duque de Osuna

2.1.3. Los instrumentos de teclado de la XV Condesa-Duquesa de Benavente

2.1.4. Otros instrumentos de tecla propiedad de las familias Osuna y Benavente en la primera mitad del siglo XIX

2.1.5. Templadores de claves y "pianistas" al servicio de las

Casas de Osuna y Benavente (siglos XVIII y XIX).

2.2. Instrumentos de cuerda y viento 


\section{Capítulo V. La música de iglesia en las Casas de Osuna y Benavente}

\section{El mecenazgo de los Duques de Osuna en la Colegiata de Santa María}

y en la Capilla del Santo Sepulcro de Osuna, Sevilla (ca. 1750-1844)..

1.1. El mecenazgo musical de los Duques de Osuna en la Colegiata de

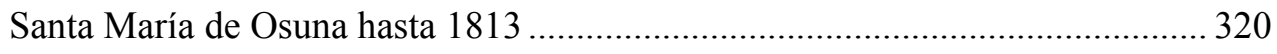

1.2. La Capilla Musical del Santo Sepulcro de Osuna en el siglo XIX ....................... 326

2. Música y ceremonial en las funciones religiosas relacionadas

con las Casas de Osuna y Benavente.

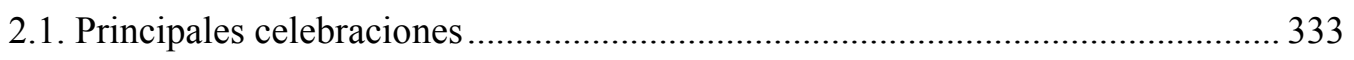

2.1.1. Funciones en honor a San Francisco de Borja y a la Virgen del Pilar ..... 333

2.1.2. Otras funciones religiosas con participación musical .............................. 341

2.2. La música en las celebraciones religiosas familiares ……………………......... 342

2.2.1. Música y ceremonial en los funerales del VIII Duque de Osuna (1787) .. 343

2.2.2. Otras celebraciones religiosas familiares con participación musical ........ 355

2.3. Conjuntos contratados para las funciones religiosas. Capillas musicales

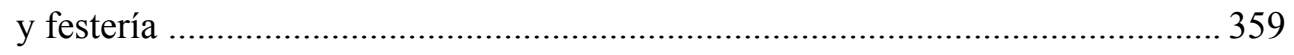

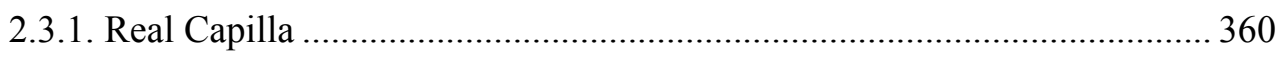

2.3.2. Capilla de Música del Colegio Imperial de Madrid..................................... 362

2.3.3. Capilla de Música del Real Oratorio de San Felipe Neri ......................... 364

2.3.4. Capilla Musical del Real Convento de la Encarnación................................ 366

2.3.5. Capilla Musical del Convento de las Descalzas Reales ........................... 370

2.3.6. Real Capilla de San Cayetano.................................................................... 372

2.3.7. Otras agrupaciones musicales no estables .............................................. 377

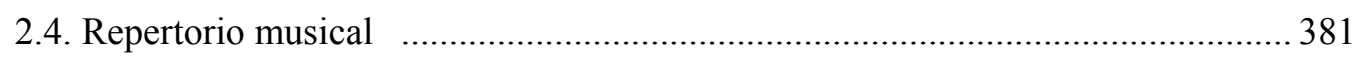

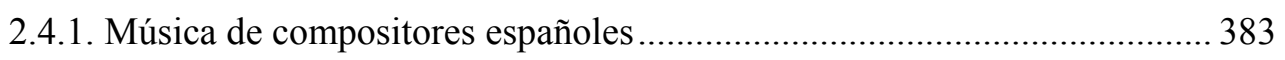

2.4.2. Música de compositores italianos y centroeuropeos.................................. 387

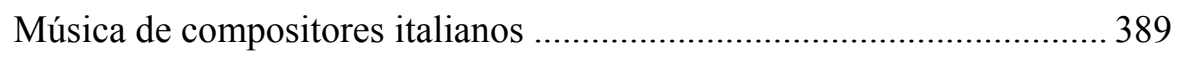

Música de compositores centroeuropeos................................................... 398 


\section{Capítulo VI. El teatro musical en las Casas de Osuna y Benavente}

1. EI mecenazgo de las Casas de Osuna y Benavente en las compañías públicas de ópera de Madrid (1738-1834). 409

1.1. La VII Duquesa viuda de Osuna y la compañía de ópera italiana del Teatro de los Caños del Peral de Madrid (1738-1739) 409

1.2. Ópera italiana en los Teatros del Príncipe y de la Cruz de Madrid patrocinada por la Casa de Benavente (1783-1787)

1.3. Las Casas de Osuna y Benavente, accionistas en la Asociación de Óperas italianas del Teatro de los Caños del Peral de Madrid (1790-1795)................... 416 1.3.1. Primera etapa (Primavera de 1790-marzo de 1793) .................................. 420

1.3.2. La Asociación de los ocho señores (abril de 1793-febrero de 1795) ...... 429

1.4. La relación de la Condesa-Duquesa María Josefa con las Compañías de ópera de los teatros públicos de Madrid (1796-1834)

1.4.1. Adquisición de partituras 441

1.4.2. Protección de cantantes y compositores de ópera 442

2. Música teatral de Pablo Esteve y Grimau dedicada al VIII Duque de Osuna estrenada en los teatros públicos de Madrid (1765-1768)

2.1. La buena muchacha, adaptación de Cecchina o La buona figlioula de Carlo Goldoni y Niccolò Piccinni (1765) 450

2.2. No hay en amor fineza mas constante (1766) 454

2.3. Los Jardineros de Aranjuez. (1768) 459

3. EI mecenazgo de las Casas de Osuna y Benavente en las compañías de ópera de los Teatros de los Reales Sitios (1767-1776)

3.1. La Compañía de los Reales Sitios en Valencia: Luigi Marescalchi y la Casa de Benavente y Gandía.

3.2. Financiación de la Compañía de Ópera de los Reales Sitios (1770-1776).

4. Teatro musical en los palacios de la Casa de Benavente (1744-1787)

4.1. Teatro musical en el Palacio de los Condes-Duques de Benavente entre 1744 y 1756 485 
4.2. Obras de teatro musical en español escritas para las funciones

privadas organizadas por María Faustina Téllez Girón (1781-1787)

4.2.1. El día de Campo de R. de la Cruz y B.de Laserna (1781) ........................ 490

4.2.2. El extranjero de R. de la Cruz y G. Ponzo (1785) .................................... 492

4.2.3. Clementina de R. de la Cruz y L. Boccherini (1786) ............................... 499

4.2.4. El Barón de L. Fernández de Moratín y J. Lidón (1787) ............................ 504

4.3. Otras funciones domésticas con música celebradas en los palacios de los Benavente

\section{Capítulo VII. El repertorio doméstico: la música instrumental y la} música vocal de cámara en las familias Osuna y Benavente (1757-1844) .... .509

1. Los escenarios de la música de cámara: academias, bailes y fiestas.................... .513

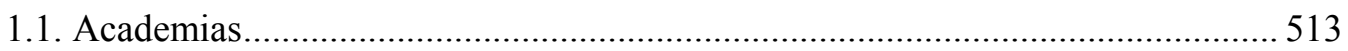

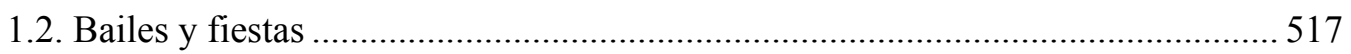

2. La música instrumental en las Casas de Osuna y Benavente................................521

2.1. La música de cámara en la época del VIII Duque de Osuna:

Obra armónica en seis sonatas de cámara de violín y bajo solo

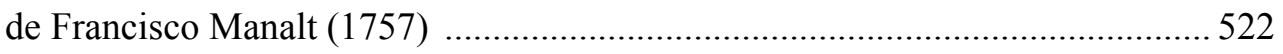

2.2. La música instrumental en las Casas de Osuna y Benavente

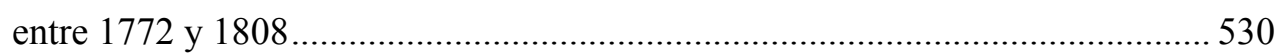

2.2.1. Música de cámara de Gaetano Brunetti ..................................................... 531

2.2.2. Música de cámara y música orquestal de Luigi Boccherini...................... 533

2.2.3. Sinfonías y música de cámara de Joseph Haydn, Ignaz Pleyel y otros autores centroeuropeos

2.2.4. Música instrumental de otros compositores e instrumentistas vinculados a las Casas de Osuna y Benavente

2.3. El repertorio de música de baile de la Casa de Osuna-Benavente en la primera mitad del siglo XIX. 551

2.4. Música para piano 


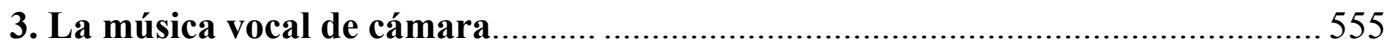

3.1. El Libro de cantatas y arias italianas de la Duquesa de Osuna ............................ 557

3.1.1. [Giovanni] Bononcini: Pastorella che tra le selve. Aria ......................... 561

3.1.2. Alejandro Scarlatti: E penar deggio ancora. Cantata para voz

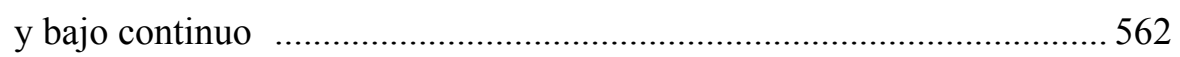

3.1.3. [Georg Friedrich Händel]: Lilla vedi quel colle. Cantata para voz y bajo continuo

3.2. La música vocal de cámara en los palacios de los Osuna y Benavente

(1770-1799). 570

3.3. El repertorio vocal de cámara de las Casas de Osuna y Benavente (1800-1844) 571

3.3.1. El repertorio italiano y francés: Rossini, Asioli, Inzenga y Langlé ........... 571

3.3.2. La Collecçao de modinhas portuguezas ................................................... 578

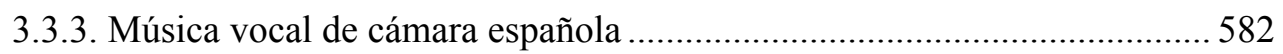

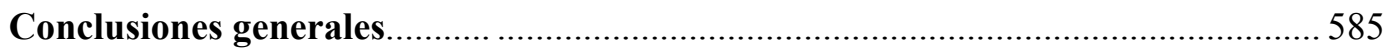

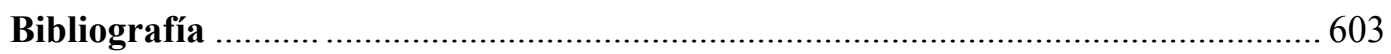

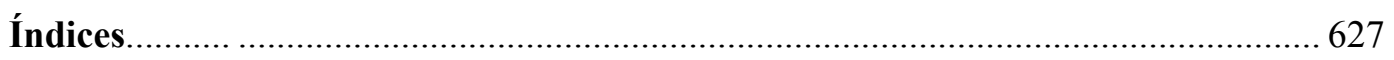

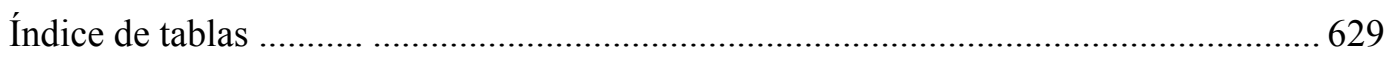

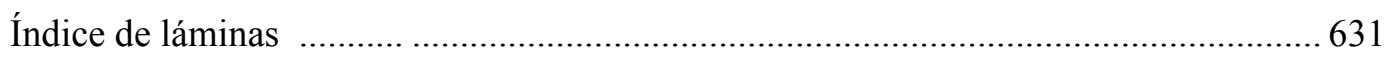

\section{VOLUMEN 2: APÉNDICES}

1. Cuadros genealógicos de las Casas de Osuna y Benavente .................................... 1

2. Edición de obras musicales seleccionadas................................................................... 7

Criterios de selección y transcripción........................................................................ 9

2.1. Libro de cantatas y arias italianas de la Duquesa de Osuna.................................... 11

[Giovanni] Bononcini $(* 1670-\uparrow 1747)$ Pastorella che tra le selve. Aria ......................... 13

Alessandro Scarlatti (*1660-†1725): E penar deggio ancora, cantata para voz

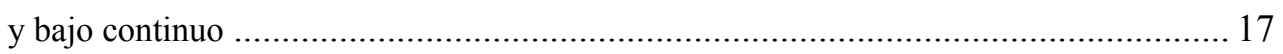

[Georg Friedrich Händel $(* 1685-\dagger 1759)$ ]: Lilla vedi quel colle, cantata para voz

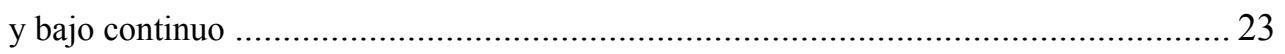

2.2. Luigi Boccherini (*1743-†1805): Quinteto, Op. 39/2 (G. 338) ........................... 31

2.3. José Palomino (1755-1810): Todos dizem. Modinha (ca. 1801) ............................ 61

2.4. Ángelo Inzenga: La tomba. Arietta per voce di basso ............................................ 71 


\section{Inventarios de libros de música y partituras de las Casas de Osuna}

y Benavente en los siglos XVIII y XIX

\section{Catálogos de música de las Casas de Osuna y Benavente}

(ca. 1781- ca. 1898)

\section{Información biográfica sobre los principales músicos y bailarines que estuvieron al servicio de las Casas de Osuna y Benavente}

(ca. 1720-1844), por orden alfabético de apellidos.

A) Documentos sobre funciones y actos religiosos patrocinados por las Casas de Osuna y Benavente (1755-1830)

$\mathrm{N}^{\circ} 1$. Lista de músicos que asistieron a las funciones religiosas celebradas por el XIV Conde-Duque de Benavente en acción de gracias a San Francisco de Borja el 9 y 10 de agosto de 1755 .

$\mathrm{N}^{\circ}$ 2. Orden de pago a los músicos que intervinieron en los intermedios y función en honor a Santo Toribio de Mogrovejo realizada por el XIV Conde-Duque de Benavente en el Convento de Portaceli de Madrid el 27 de abril de 1757.

$\mathrm{N}^{\circ}$ 3. Orden de pago a Francisco Basset por los músicos de refuerzo que asistieron a las funciones religiosas de San Francisco de Borja celebradas en 1781

$\mathrm{N}^{\circ}$ 4. Orden de pago a Francisco Basset por los músicos de refuerzo que asistieron a las funciones religiosas de San Francisco de Borja celebradas en 1781

$\mathrm{N}^{0}$ 5. Orden de pago a Pedro Ochoa, festero de la Capilla de Música del Real Convento de la Encarnación de Madrid por la asistencia de dicha capilla a las funciones religiosas de San Francisco de Borja celebradas en 1783

$\mathrm{N}^{\mathrm{o}}$ 6. Orden de pago a Francisco Basset por la copia de una misa de [Joseph] Haydn y la asistencia de nueve músicos para completar la orquesta de las funciones religiosas de San Francisco de Borja celebradas en 1785.

№ 7. Orden de pago a Joaquín Agramuntell, festero de la Capilla de Música del Convento de las Descalzas Reales de Madrid por la asistencia de dicha capilla a las funciones religiosas de San Francisco de Borja celebradas en 1788 .

$\mathrm{N}^{0}$ 8. Orden de pago a la Capilla de Música de San Cayetano de Madrid y a otros músicos por los servicios prestados en las funciones religiosas de San Francisco de Borja celebradas en 1800

$\mathrm{N}^{\circ}$ 9. Orden de pago a la Capilla de Música de San Cayetano de Madrid y a otros músicos por los servicios prestados en las funciones religiosas de San Francisco de Borja celebradas en 1802 
$\mathrm{N}^{\circ} 10$. Lista de músicos que asistieron a las funciones religiosas de San Francisco de Borja celebradas en 1808 y obras que se interpretaron en dichas funciones.

$\mathrm{N}^{\circ} 11$. Lista de los músicos que asistieron al funeral de Josefa Manuela Téllez-Girón, marquesa de Camarasa e hija de los IX Duques de Osuna, que se celebró el día 11 de diciembre de 1817 en la iglesia de San Felipe Neri de Madrid

$\mathrm{N}^{\circ}$ 12. Lista de músicos que asistieron a las funciones religiosas de San Francisco de Borja y Nuestra Señora del Pilar patrocinadas por la XV Condesa-Duquesa de Benavente en 1825

$\mathrm{N}^{\circ}$ 13. Lista de músicos que asistieron a las funciones religiosas de San Francisco de Borja y Nuestra Señora del Pilar patrocinadas por la XV Condesa-Duquesa de Benavente en 1829

$\mathrm{N}^{\circ}$ 14. Lista de músicos que asistieron a las funciones religiosas de San Francisco de Borja y Nuestra Señora del Pilar patrocinadas por la XV Condesa-Duquesa de Benavente en 1830.

B) Documentos sobre teatro musical patrocinado por las Casas de Osuna y Benavente: funciones privadas y financiación de los teatros públicos de ópera de Madrid (1755-1794)

$\mathrm{N}^{\mathrm{o}} 15$. Cuenta de gastos por la copia de música y letra de la función teatral titulada Endimión y Diana encargada en 1755 por María Faustina Téllez-Girón, Condesa-Duquesa de Benavente

$\mathrm{N}^{\circ} 16$. Actas y anexos de las Juntas de Accionistas de la Asociación de Óperas Italianas del Teatro de los Caños del Peral de Madrid de los días 3 y 13 de septiembre de 1790 .

$\mathrm{N}^{\circ}$ 17. Informe sobre los gastos de la temporada de 1791-1792 del Teatro de los Caños del Peral de Madrid, y solicitud a la XV Condesa-Duquesa del importe de la segunda acción del año de 1792.

$\mathrm{N}^{\circ}$ 18. Carta de los Comisionados de la Asociación de Óperas Italianas a María Josefa Alfonso Pimentel, XV Condesa-Duquesa de Benavente, comunicándole la decisión de contratar a la cantante Luisa Todi para la temporada de 1794

C) Documentación sobre los grupos instrumentales y orquestas que intervinieron en las fiestas, bailes y academias organizados por la XV Condesa-Duquesa de Benavente y el IX Duque de Osuna (1789-1819)

$\mathrm{N}^{\circ} 19$. Lista de músicos de refuerzo que asistieron a la fiesta realizada el 26 de de septiembre de 1789 con motivo de la Coronación de Carlos IV, y la Jura del Príncipe de Asturias por el IX Duque de Osuna en su palacio de Madrid 
$\mathrm{N}^{\circ}$ 20. Lista de músicos que asistieron a la academia de música celebrada por la Condesa-Duquesa de Benavente el 31 de octubre de [1819?].

$\mathrm{N}^{\mathrm{o}} 21$. Lista de músicos que asistieron a la academia de música celebrada el 5 de diciembre de 1819 en casa de la Condesa-Duquesa de Benavente.

D) Correspondencia con músicos, cantantes, bailarines y otros personajes: peticiones de protección y recomendaciones solicitadas a los miembros de las Casas de Osuna y Benavente (1784-1807)

$\mathrm{N}^{\mathrm{o}}$ 22. Carta de la cantante Rosa Agostini a Pedro de Alcántara Téllez-Girón,

Marqués de Peñafiel, solicitando su protección para volver a actuar en las academias de música que se celebraban en los Reales Sitios

$N^{o}$ 23. Carta del cantante Giacomo Panati a María Josefa Alfonso Pimentel, XV Condesa-Duquesa de Benavente, solicitando su intercesión para actuar en las Óperas que se representaban en los Reales Sitios.

$\mathrm{N}^{\mathrm{o}}$ 24. Carta de la bailarina María Medina a la XV Condesa-Duquesa de Benavente solicitando su intercesión para actuar en la compañía de baile de los teatros públicos de Madrid y borrador de la respuesta .....

$\mathrm{N}^{\mathrm{o}}$ 25. Carta de la XV Condesa-Duquesa de Benavente a la bailarina María Medina Viganò

$N^{o}$ 26. Carta del bailarín Salvatore Viganò a la XV Condesa-Duquesa de Benavente..... 253

$\mathrm{N}^{\mathrm{o}}$ 27. Carta del empresario de ópera Domenico Botti a la XV Condesa-Duquesa de Benavente, recomendando a la cantante Catalina Lusini y borrador de la respuesta

$\mathrm{N}^{\mathrm{o}}$ 28. Carta de la cantante Luigia Todi a la XV Condesa-Duquesa de Benavente comentándole los conciertos que dio en Italia y borrador de la respuesta.

$\mathrm{N}^{\text {o } 29 .}$ Carta de la cantante Luigia Todi a la XV Condesa-Duquesa de Benavente comunicándole su llegada a Nápoles y borrador de la respuesta.....

$\mathrm{N}^{\mathrm{o}}$ 30. Carta de la cantante Luigia Todi a la XV Condesa-Duquesa de Benavente comentándole sus actuaciones operísticas en Nápoles y borrador de la respuesta.

$N^{o}$ 31. Carta de la cantante Luigia Todi a la XV Condesa-Duquesa de Benavente comentándole sus proyectos operísticos.

$\mathrm{N}^{\text {o } 32 . ~ C a r t a ~ d e ~ l a ~ c a n t a n t e ~ L u i g i a ~ T o d i ~ a ~ l a ~ X V ~ C o n d e s a-D u q u e s a ~ d e ~ B e n a v e n t e ~}$ relatando la llegada a Caserta de la Princesa de Nápoles en 1797 y borrador de la respuesta

No 33. Carta de la cantante Luigia Todi desde Nápoles a la XV Condesa-Duquesa de Benavente relatando sus actuaciones en el teatro San Carlo y borrador de la respuesta

$\mathrm{N}^{\mathrm{o}}$ 34. Carta de la cantante Brigida Banti desde Londres a la XV Condesa-Duquesa de Benavente y borrador de la respuesta 
$\mathrm{N}^{\mathrm{o}}$ 35. Carta de la cantante Brigida Banti desde Londres a la XV Condesa-Duquesa de Benavente y borrador de la respuesta

$N^{o}$ 36. Carta de Francisco Solano Ortiz de Rozas a la XV Condesa-Duquesa de Benavente recomendando al violinista Alejandro Boucher y borrador de la respuesta.

No 37. Carta del Conde de Valdeparaiso a la XV Condesa-Duquesa de Benavente recomendando a la cantante y violinista Luisa Gerbini y borrador de la la respuesta

$\mathrm{N}^{\mathrm{o}}$ 38. Borrador de la carta que la XV Condesa-Duquesa de Benavente dirigió a Agustín Lancaster, Teniente General y Comandante General Interino de Cataluña para recomendarle a la cantante Luigia Todi.

$\mathrm{N}^{\mathrm{o}}$ 39. Borrador de la carta que la XV Condesa-Duquesa de Benavente dirigió al Conde de Valparais y al coronel Joseph Capelleti, para recomendarles a la cantante Luigia Todi

$\mathrm{N}^{\mathrm{o}}$ 40. Carta de la bailarina Teresa Monticini a la XV Condesa-Duquesa de Benavente, solicitando su intercesión para resolver problemas profesionales con el bailarín Charles-Auguste Favier en sus actuaciones en Cádiz y borrador de la respuesta

$\mathrm{N}^{\mathrm{o}}$ 41. Carta de Manuel Arenas a la XV Condesa-Duquesa de Benavente, informando del éxito de la bailarina Teresa Monticini en una actuación en Cádiz

$\mathrm{N}^{\mathrm{o}}$ 42. Carta del Barón Josef Capelleti a la XV Condesa-Duquesa de Benavente recomendando a la cantante Mariana Vinci que había sido contratada para la temporada de ópera del Teatro de los Caños del Peral de Madrid

$N^{o}$ 43. Carta de los bailarines Louis Moreau y Achille Monroy a Giacomo Panati empresario del Teatro de los Caños del Peral de Madrid, expresándole su intención de solicitar la intercesión de la XV Condesa-Duquesa de Benavente, si no le pagan las cantidades que se les adeudan.

$N^{o}$ 44. Carta del político francés Charles Maurice de Tayllerand a la XV

Condesa-Duquesa de Benavente recomendándole al pianista João

Domingos Bomtempo

E) Documentos sobre músicos que trabajaron al servicio de las Casas de Osuna y Benavente (1781-1824)

$\mathrm{N}^{\mathrm{o}}$ 45. Borrador de la carta que la XV Condesa-Duquesa de Benavente dirigió al Cardenal Patriarca recomendando a Manuel Carriles para una plaza de viola vacante en la Real Capilla

$\mathrm{N}^{\circ}$ 46. Decreto de nombramiento de Lorenzo Geisel como músico de la

Casa de Osuna

$\mathrm{N}^{\circ}$ 47. Copia de la partida de defunción de Carlo Marinelli 
F) Música y festejos populares en los estados de la Casa de Benavente..

$\mathrm{N}^{\circ}$ 48. Relato de los festejos celebrados en la villa de Benavente para celebrar el nacimiento de Josefa Manuela Téllez-Girón el 17 de agosto de 1783. 


\section{Abreviaturas y siglas empleadas}

AHN

AHN NOBLEZA

AHPM

AnM

AVM

B

BHM

BNE

c./cc.

$c a$

cap.

$\mathrm{cb}$

CSIC

coord.

$D M E H$

Emilio

ed./eds

f./ff.

$\mathrm{fl}$

$N G$

Sadie

Ibid.

ITB

leg

Ms.

$\mathrm{n}^{\mathrm{o}}$

$\mathrm{ob}$

p./pp.

$R M S$

S
Archivo Histórico Nacional (Madrid)

Archivo Histórico Nacional. Sección Nobleza. Hospital Tavera (Toledo)

Archivo Histórico de Protocolos de Madrid

Anuario Musical (Barcelona: CSIC, 1946 y siguientes)

Archivo de la Villa de Madrid. Ayuntamiento de Madrid

bajo [voz]

Biblioteca Histórica Municipal del Ayuntamiento de Madrid.

Biblioteca Nacional de España (Madrid)

compases

circa [aproximadamente]

capítulo

contrabajo

Consejo Superior de Investigaciones Científicas

coordinador

Diccionario de la Música Española e Hispanoamericana,

Casares Rodicio, director (Madrid: Sociedad General de

Autores y Editores, 1999-2002), 10 vols.

editor/es

folio/s

flauta

The New Grove dictionary of music and musicians, Stanley y John Tyrrell, editores (New York: Grove, 2001), 29 vols.

ibidem [en el mismo lugar]

Biblioteca del Institut del Teatre (Barcelona)

legajo

manuscrito

número

oboe

páginas

Revista de Musicología (Madrid: Sociedad Española de

Musicología,1978 y siguientes)

soprano [voz] 


$\begin{array}{ll}\text { s.f. } & \text { sin fecha } \\ \text { s. fol. } & \text { sin foliación } \\ \text { s. n. } & \text { sin número } \\ \text { s. l. } & \text { sin lugar } \\ \text { ss. } & \text { siguientes } \\ \text { tp } & \text { trompa } \\ \text { va } & \text { viola } \\ \text { vc } & \text { violonchelo } \\ \text { vn } & \text { violín } \\ \text { vol } & \text { volumen }\end{array}$

\section{Criterios de edición de textos}

En la transcripción literal de textos manuscritos e impresos he desarrollado las abreviaturas y he actualizado la ortografía y el uso de dobles consonantes, mayúsculas, puntuación y acentuación. Las omisiones voluntarias del texto aparecen señaladas con el signo [...]. 


\section{Agradecimientos}

Quiero comenzar expresando mi más sincera gratitud a la Doctora María Gembero Ustárroz, directora de este trabajo y mi guía en la investigación durante los últimos años, por su permanente apoyo y generosidad intelectual. Sus precisos y constantes consejos han sido fundamentales para la culminación de esta Tesis Doctoral.

Muchas otras personas me han ayudado de diferentes formas, y a todas ellas deseo agradecer el tiempo que me han dedicado y su interés por mis investigaciones. La profesora Inmaculada Cárdenas, de la Universidad de Santiago de Compostela, me facilitó algunos de sus artículos sobre las Colegiatas de Osuna y Olivares publicados en revistas de difícil acceso. Mis buenos amigos Mar Sanz y Ángel Olmos (filóloga y musicólogo, respectivamente) me ayudaron a resolver algunas dudas en la transcripción y traducción de algunos textos literarios. Jaime Salazar, eficiente informático y gran amigo, me aconsejó sobre la elaboración de las bases de datos y me solucionó numerosos problemas técnicos. Mi hermano Julio consiguió para mí copias de varios documentos conservados en archivos alemanes y María Teresa Ferreira me ayudó en la maquetación de algunos materiales musicales.

También quiero dejar constancia de mi agradecimiento a todos los empleados de las bibliotecas y archivos consultados. Mención especial merece el personal de sala de la Sección Nobleza del Archivo Histórico Nacional de Toledo y su Directora, Aránzazu Lafuente, por su amabilidad, paciencia y eficacia a la hora de proporcionarme todos los materiales y resolver mis dudas; y el personal 
auxiliar de la Biblioteca Histórica Municipal de Madrid, siempre rápido $\mathrm{y}$ eficiente. Ascensión Aguerri, Jefa de Colecciones especiales de esta institución, me facilitó un valioso inventario con las obras de Pablo Esteve conservadas en esa biblioteca. Asimismo quiero agradecer las gestiones realizadas por el Servicio de Préstamo Interbibliotecario de la Biblioteca Nacional de España (Madrid) para conseguir materiales musicales de difícil acceso conservados en archivos de Italia.

Este trabajo no hubiera llegado a su fin sin el importante apoyo familiar de mis padres, y especialmente de mi esposa Pilar, que me animó en los momentos más difíciles y declinó aceptar compromisos profesionales en numerosas ocasiones para que yo pudiera dedicarme a realizar esta investigación. No puedo dejar de mencionar la alegría que me proporcionó el nacimiento de mi hijo Daniel que, sin saberlo, me acompañó durante sus primeros meses de vida en mis insomnios y desvelos por las familias Osuna y Benavente. 


\section{Introducción}





\section{Objetivos y plan de trabajo}

Este trabajo se propone estudiar la actividad de apoyo, promoción y difusión de la música culta que llevaron a cabo los miembros de las casas ducales de Osuna y Benavente entre 1733 y 1844. Durante el período elegido ocuparon la titularidad de la Casa de Osuna Pedro Zoilo Téllez Girón (VIII Duque, 17331787), Pedro de Alcántara Téllez Girón (IX Duque, 1787-1807), Francisco de Borja Téllez Girón (X Duque, 1807-1820) y Pedro de Alcántara Téllez Girón y Beaufort (XI Duque, 1820-1844). En la misma época, la Casa de Benavente estuvo regida por Antonio Alfonso Pimentel (XIII Conde, 1709-1743), Francisco Alfonso Pimentel, (XIV Conde, 1743-1763), María Josefa Alfonso Pimentel (XV Condesa, 1763-1834) y Pedro de Alcántara Téllez Girón y Beaufort (XVI Conde 1834-1844). La etapa cronológica estudiada es particularmente interesante porque permite analizar la evolución de las prácticas de mecenazgo musical de la nobleza española en el tránsito desde el Antiguo Régimen a los inicios de la sociedad contemporánea.

Aunque las familias Téllez Girón (titular de la Casa de Osuna) y Pimentel (titular de la Casa de Benavente) tuvieron importantes vínculos entre sí, ambas casas sólo estuvieron unidas bajo una única administración en el período 17871807 (coincidiendo con el matrimonio formado por el IX Duque de Osuna y la XV Condesa de Benavente) y desde 1834 en adelante (después de que Pedro de Alcántara Téllez Girón y Beaufort, XI Duque de Osuna, heredase la titularidad de la Casa de Benavente a la muerte de su abuela María Josefa Alfonso Pimentel)..

Las Casas de Osuna y Benavente fueron dos de los linajes más influyentes de la alta nobleza española entre los siglos XVI y XIX. Durante toda la Edad 
Moderna, los titulares de ambas casas nobiliarias desempeñaron importantes cargos palaciegos y administrativos al servicio de la monarquía, y llegaron a acumular un considerable patrimonio territorial que se extendió por gran parte de la España peninsular y por algunas localidades italianas. A finales del siglo XVIII, la unificada Casa de Benavente-Osuna se hallaba entre las más importantes familias de la alta nobleza titulada española, junto a las poderosas casas ducales de Alba, Medina-Sidonia y Medinaceli.

La escasa bibliografía que existía hasta ahora sobre música y nobleza en España había puesto de manifiesto la relación de algunos miembros de las Casas de Osuna y Benavente con importantes compositores europeos de los siglos XVIII y XIX (como Franz Joseph Haydn, Luigi Boccherini o Saverio Mercadante, entre otros). Esta constatación despertó mi interés por investigar en profundidad la relación de esas familias nobles con la música.

Un aspecto que me resultó particularmente complejo fue decidir si debía estudiar el mecenazgo musical de las Casas de Osuna y Benavente conjuntamente o por separado. En una buena parte de la bibliografía histórica y en la gran mayoría de publicaciones musicológicas advertí que las referencias a la genealogía y a la titularidad de las Casas de Osuna y Benavente durante los siglos XVIII y XIX eran con frecuencia confusas y contradictorias. En la historiografía musical se había generalizado el empleo de la expresión "Casa de BenaventeOsuna", un término equívoco, que se utilizaba también para los períodos en que ambos linajes no estaban unidos administrativamente. La opción de estudiar ambas casas como si fueran una sola no parecía, por tanto, aconsejable. 
La ausencia de una unión administrativa entre las Casas de Osuna y Benavente durante gran parte de la etapa estudiada puede hacer pensar que lo más idóneo hubiera sido estudiar por separado la relación de ambas familias con la música. Sin embargo, a medida que avanzaba en mi investigación constaté que existían importantes aspectos comunes en el mecenazgo musical de ambas casas, debido a las estrechas relaciones familiares que les unían. Un estudio por separado de cada una de ellas hubiera generado numerosas reiteraciones. Por ejemplo, las funciones religiosas de San Francisco de Borja que anualmente se celebraban en Madrid con importante participación musical, fueron patrocinadas según las épocas por tres familias nobles distintas: 1) la familia Borja, titular del ducado de Gandía, que patrocinó originalmente dicha fiesta; 2) la familia Pimentel, titular de la Casa de Benavente (que heredó el Ducado de Gandía en 1740); y 3) la familia Téllez Girón, titular de la Casa de Osuna, que al fusionarse en 1787 con la de Benavente, asumió las prácticas musicales de ésta (incluidas las que provenían de la Casa de Gandía). En el caso descrito, resulta más provechoso analizar las características de la función de San Francisco de Borja conjuntamente y una sola vez que repetirlas al estudiar las diferentes casas nobiliarias. Esta misma problemática, que se produce con otros muchos aspectos del mecenazgo musical en las Casas de Osuna y Benavente, fue lo que me llevó a desechar también la opción de estudiar ambas casas de forma completamente independiente.

Finalmente, opté por una vía intermedia y me decidí a estudiar las actividades de mecenazgo musical de las Casas de Osuna y Benavente de forma paralela pero al mismo tiempo diferenciada, tratando de aclarar tanto sus puntos comunes como los aspectos específicos de cada una de ellas. Estimo que este 
planteamiento es el más adecuado y ágil para ofrecer una visión de conjunto sobre la relación de ambas familias con la música y para poder apreciar la importante repercusión de su mecenazgo en el contexto general de la música española del período estudiado.

Esta Tesis Doctoral consta de dos volúmenes. El primer volumen contiene el estudio propiamente dicho, articulado en siete capítulos. En el primer capítulo presento una breve historia de las Casas de Osuna y Benavente, poniendo especial énfasis en la actividad pública y el mecenazgo artístico que desempeñaron los principales titulares de las mismas desde sus orígenes hasta el siglo XX. Aunque se trata de un capítulo en el que no se estudian aspectos musicales, en él aporto material nuevo, especialmente sobre la genealogía de las dos familias. El segundo capítulo aborda los antecedentes musicales de las Casas de Osuna y Benavente hasta 1733 e incluye también materiales inéditos. Los capítulos III-VII constituyen el núcleo central de la Tesis, que se centra en el mecenazgo musical de las familias Osuna y Benavente entre 1733 y 1844. En los capítulos III y IV analizo los recursos materiales y humanos que tuvieron a su disposición los titulares de ambas casas nobiliarias para las actividades musicales que se desarrollaron bajo su mecenazgo (archivos de música, instrumentos, profesores de música y baile, compositores e instrumentistas). Los capítulos V, VI y VII se dedican al estudio de cada uno de los géneros en los que se concretó el mecenazgo musical de los Osuna y Benavente: la música de Iglesia, el teatro musical y la música de cámara. En cada género he analizado una selección de obras musicales relacionadas con ambas familias. Con el análisis musical no pretendo dar una visión evolutiva del repertorio de las Casas de Osuna y Benavente, sino mostrar 
las características principales y las peculiaridades de algunas obras representativas que sonaron o fueron creadas en el entorno de estas casas nobiliarias en los siglos XVIII y XIX.

El segundo volumen de la Tesis contiene seis apéndices: 1) cuadros genealógicos de las Casas de Osuna y Benavente; 2) edición musical de seis de las obras musicales estudiadas, de las que cuatro se transcriben por primera vez; 3) y 4) inventarios y catálogos de los libros de música y partituras propiedad de los titulares de ambas casas; 5) información biográfica sobre los principales músicos y bailarines que trabajaron para las Casas de Osuna y Benavente; y 6) cuarenta y ocho documentos de interés musical sobre las Casas de Osuna y Benavente, clasificados temáticamente.

\section{Estado de la cuestión}

La labor que desarrolló la nobleza española en la promoción, gestión y difusión de la música es una de las parcelas menos estudiadas de la Historia de la Música en España. Describiré en primer lugar los principales trabajos sobre música y nobleza de carácter general y sobre casas nobiliarias diferentes a las de Osuna y Benavente, y después analizaré las aportaciones existentes sobre éstas últimas.

La primera investigación monográfica y extensa sobre la relación entre la nobleza española y la música fue La Música en la Casa de Alba. Estudios 
históricos y biográficos (1927) de José Subirá ${ }^{1}$. En esta pionera publicación Subirá describió y analizó las obras musicales que se conservaban en el archivo del Palacio de Liria (propiedad de la Casa de Alba) y estudió las biografías de sus autores. También aparecen datos sobre música y nobleza en diversas publicaciones de Emilio Cotarelo y Mori $^{2}$ y en artículos de diferentes investigadores aparecidos hasta comienzos de la década de los años 70 del siglo $\mathrm{XX}^{3}$. Antonio Martín Moreno, en su Historia de la música española. 4. Siglo XVIII (1985), incluyó un capítulo sobre "Músicos de la Nobleza", en el que presentó una síntesis de las investigaciones realizadas hasta entonces sobre el particular ${ }^{4}$. María Ester-Sala publicó en 1988 un completo y muy documentado estado de la cuestión de los estudios sobre mecenazgo musical de la nobleza en el siglo XVI, en el que subrayó la necesidad de emprender análisis sistemáticos

1 José Subirá, La Música en la Casa de Alba: Estudios Históricos y Biográficos (Madrid: Tip. Sucesores de Rivadeneira, 1927). También hay algunas referencias sobre la relación de la nobleza española con la música en José Subirá, La tonadilla escénica (Madrid: Tipografía de la Revista de Archivos, Bibliotecas y Museos, 1928-1930).

2 Emilio Cotarelo y Mori, Orígenes y establecimiento de la ópera en España hasta 1800 (Madrid: Tipografía de la Revista de Archivos, Bibliotecas y Museos, 1917); Idem, Historia de la zarzuela, o sea el drama lírico en España, desde su origen a finales del siglo XIX (Madrid: Tipografía de Archivos, 1934). Las publicaciones de Joaquín Ezquerra del Bayo y Solar Quintes relacionadas con las casas de Osuna y Benavente serán mencionadas más adelante.

3 Jaime Moll Roqueta, "Músicos en la corte del cardenal Tavera (1523-1545): Luis Venegas de Henestrosa", AnM, VI (1951), pp. 155-178; Nicolás A. Solar-Quintes. "Morales en Sevilla y Marchena. Estampa de la época", AnM, VIII (1953), pp. 27-38; Idem, "Nuevos documentos para la biografía del compositor Sebastián Durón”, AnM, X (1955), pp. 137-164; Jaime Moll Roqueta, "Notas para la historia musical de la corte del duque de Calabria", AnM, XVIII (1963), pp. 123135; Eleanor Rusell, “The Patrons of Juan Vásquez: a biographical contribution”, AnM, XXVI (1971), pp. 61-74.

4 Antonio Martín Moreno, Historia de la Música Española, 4. Siglo XVIII (Madrid: Alianza, 1985), pp. 257- 287. 
sobre las principales cortes nobiliarias españolas como centros de producción musical vinculados a la formación del nuevo gusto y en los que la música tuvo una función muy diferente a la descrita en el ámbito religioso ${ }^{5}$.

En los últimos quince años, los estudios sobre música y nobleza en España han despertado el interés de investigadores muy diversos, tanto dentro como fuera del país. La Tesis Doctoral de Roberta Freund Schwartz (2001) es uno de los pocos trabajos que, hasta la fecha, han estudiado de forma global el patronazgo de la alta nobleza española en la música ${ }^{6}$. Esta aportación, que se centra en el período 1470-1640, analiza principalmente las actividades musicales desarrolladas en el entorno de las casas de Alba, Lerma, Calabria e Infantado, y aporta también algunos datos sobre la música en las casas de Gandía, Pastrana, Medina Sidonia, Benavente y Medinaceli. A pesar del indudable valor de este amplio estudio, algunas de las conclusiones y generalizaciones a las que llega su autora no son suficientemente justificadas y deberían ser verificadas en futuros trabajos ${ }^{7}$.

Las investigaciones sobre la Casa de Alba iniciadas por José Subirá fueron continuadas por George Truett Hollis, que en 1993 dio a conocer un inventario del

\footnotetext{
5 María Ester-Sala, "El Mecenazgo de la Nobleza en la Música del siglo XVI". Nassarre. Revista Aragonesa de Musicología, 4 /1-2 (1988), pp. 37-58.

${ }^{6}$ Roberta Freund Schwartz, En busca de liberalidad: music and musicians in the courts of the Spanish nobility, 1470-1640 (Illinois: University of Illinois at Urbana-Champaign, 2001).

${ }^{7}$ Según Schwartz, el patronazgo musical de la nobleza española disminuyó a partir del siglo XVII, por lo que el período renacentista es para esta autora el más importante de toda la historia en lo que al mecenazgo musical de la nobleza hispana se refiere (Schwartz En busca pp.488-489). Esta idea no se justifica adecuadamente a lo largo del estudio, pues la autora sólo alude a los problemas económicos de ciertas casas nobiliarias. Es peligroso establecer valoraciones comparativas sobre el peso que tuvo la nobleza en una u otra época hasta que no contemos con estudios históricos sistemáticos de la actividad musical de las grandes casas nobiliarias españolas.
} 
archivo de música y de los instrumentos que fueron propiedad de Fernando de Silva Álvarez de Toledo $(* 1733-\uparrow 1776)$, XII Duque de Alba ${ }^{8}$. Posteriormente, Truett Hollis publicó una transcripción anotada de dicho inventario, precedida por un breve estudio introductorio ${ }^{9}$.

Las relaciones de la nobleza peninsular con la ópera han generado varias aportaciones. Roger Alier, en su libro sobre la ópera en la Barcelona del siglo XVIII, señaló el papel central de la nobleza militar en la consolidación de este género $^{10}$. María Gembero estudió la actividad operística desarrollada en las cortes de los Marqueses de Castelfuerte en Pamplona y Madrid, de la que surgieron los Divertimenti Musicali per camera, una antología manuscrita en varios volúmenes que se conserva en la Biblioteca Nacional de España (Madrid) y fue recopilada por el compositor italiano Girolamo Sertori hacia $1758-60^{11}$. Louis K. Stein analizó el patronazgo de algunos personajes de la alta nobleza peninsular (como el Marqués de Heliche, el Duque de Veragua, el Duque del Infantado y el Conde de

${ }^{8}$ George Truett Hollis, "Musical Patronage in Eighteenth Century Spain. The Music Library and Music Instrument Collection of the XII Duke of Alba (d. 1776)", RMS, XVI/6 (1993), pp.34763485 .

9 George Truett Hollis, “Inventario y Tasación de los Instrumentos y Papeles de Música, de la Testamentaria del Exmo. Sr. Don Fernando de Silba Albarez de Toledo, Duque que fue de Alba (1777)" AnM, 59 (2004), pp.151-172.

10 Roger Alier, L'òpera a Barcelona: orígens, desenvolupament i consolidació de l'ópera com a espectacle teatral a la Barcelona del segle XVIII (Barcelona: Institut d'Estudis Catalans, Societat Catalana de Musicología, 1990), véanse especialmente las páginas 127-133 y 220- 234.

11 María Gembero Ustárroz, "El repertorio operístico en una Corte Nobiliaria española del siglo XVIII: La obra de Girolamo Sertori al Servicio de los Marqueses de Castelfuerte”, Emilio Casares Rodicio y Álvaro Torrente (eds.), La ópera en España e Hispanoamérica (Madrid: ICCMU, 2001), vol. I., pp.403-454. Sobre esta misma casa nobiliaria véase también el breve estudio de Pestelli sobre las seis sonatas para clave de Sertori. Giorgio Pestelli, "Contributi alla storia della forma-sonata. Sei sonate per cembalo di Girolamo Sertori (1758)", Rivista Italiana di Musicologia, II/1, pp. 131-139. 
Monclova) en la recepción de la ópera en Hispanoamérica a finales del siglo XVII y comienzos del XVIII ${ }^{12}$.

Eleanor Rusell, en un artículo que se publicó póstumamente, estudió algunos aspectos del mecenazgo musical de Francisco de Zúñiga y Guzmán, III Duque de Béjar en el siglo XVI, y dio a conocer la importante colección de instrumentos de cuerda y viento que este noble poseyó en su corte nobiliaria de Belalcázar $(\text { Córdoba })^{13}$. Emilio Ros Fábregas analizó la relación de las familias Cardona y Fernández de Córdoba con el Chigi Codex (Biblioteca Apostólica Vaticana) y subrayó la necesidad de profundizar en la investigación del patronazgo musical de la nobleza española ${ }^{14}$. Marcelino Díez Martínez estudió el papel que desempeñaron el Marqués de Valde-Íñigo y el Marqués de Méritos, dos personajes de la nobleza gaditana, en el encargo de Las Siete Palabras de Cristo en la Cruz de Franz Joseph Haydn ${ }^{15}$. A estos trabajos editados hay que añadir algunas investigaciones, todavía inéditas, sobre las casas ducales de Medinaceli y Medina Sidonia ${ }^{16}$.

\footnotetext{
12 Louise K. Stein, "De la contera del mundo: Las navegaciones de la ópera entre dos mundos y varias culturas" en Casares Rodicio y Torrente (eds.), La ópera, vol. I., pp.79-94.

13 Eleanor Russell, "Music in the house of the third Duke of Béjar: ca. 1520-1544", Encomium Musicae. Essays in memory of Robert J. Snow, D. Crawford y G.G. Wagstaff, eds. Hillsdale, New York: Pendragon Press, 2002), pp. 285-303.

14 Emilio Ros Fábregas, "The Cardona and Fernández de Córdoba Coats of Arms in the Chigi Codex”, Early Music History, 21 (2002), pp. 223-258.

${ }^{15}$ Marcelino Díez Martínez, "Las siete palabras de Cristo en la Cruz de Franz Joseph Haydn: un caso paradigmático de mecenazgo musical de la nobleza", RMS, XXVI/ 2 (2003), pp. 491-512.

16 Antonio Carrera Sevillano, El mecenazgo musical de la Casa de Medinaceli en Andalucía (siglos XVII-XIX): aproximación a las fuentes archivisticas andaluzas, Trabajo de Investigación Tutelada presentado para la obtención del Diploma de Estudios Avanzados (DEA), dirigido por Emilio Ros Fábregas (Granada: Universidad de Granada, 2003); Lucía Gómez Fernández,
} 
Por lo que se refiere a las Casas de Osuna y Benavente, en las últimas décadas se han publicado varios trabajos que estudian aspectos concretos de su mecenazgo cultural durante la Edad Moderna. Entre ellos destaca la Tesis Doctoral de Ignacio Martínez del Barrio sobre el patronazgo cultural de la Casa de Osuna en España e Italia entre 1558 y $1694^{17}$. Mercedes Simal López, en una reciente y documentada monografía, ha estudiado el patronazgo artístico de los Condes-Duques de Benavente en el siglo $\mathrm{XVII}^{18}$. La obra ya clásica de Ignacio Atienza sobre la Casa de Osuna, centrada fundamentalmente en aspectos socioeconómicos, presenta también información relevante sobre la vida cotidiana de los titulares de esta casa entre los siglos XVI y XIX ${ }^{19}$.

La biografía de María Josefa-Téllez Girón, XV Condesa-Duquesa de Benavente, escrita por la Condesa de Yebes (1958) aportó datos sobre el ambiente doméstico que rodeó a esta dama y su relación con otros miembros de la alta nobleza española ${ }^{20}$. A pesar de la abundante documentación que manejó la autora, esta aportación no es propiamente un estudio de carácter científico, sino más bien

Mecenazgo musical de la Casa de Medina Sidonia (1500-1645): aproximación a las fuentes documentales, Trabajo de Investigación Tutelada presentado para la obtención del Diploma de Estudios Avanzados (DEA), dirigido por Emilio Ros Fábregas (Granada: Universidad de Granada, 2003).

17 Javier Ignacio Martínez del Barrio, Mecenazgo y Política Cultural de la Casa de Osuna en Italia (1568-1694). Tesis doctoral (Madrid: Universidad Complutense, Servicio de Reprografía, 1989).

18 Mercedes Simal López, Los condes-duques de Benavente en el siglo XVII. Patronos y coleccionistas en su villa solariega (Benavente: Centro de Estudios Benaventanos Ledo del Pozo, 2002).

19 Ignacio Atienza Hernández, Aristocracia, poder y riqueza en la España Moderna. La Casa de Osuna, siglos XV-XIX (Madrid: Siglo Veintiuno, 1987).

20 Condesa de Yebes, La Condesa-Duquesa de Benavente. Una vida en unas cartas (Madrid: Espasa Calpe, 1958). 
una biografía novelada, y sus conclusiones deben contrastarse con las fuentes originales de las que la autora extrajo la información ${ }^{21}$.

La mayor parte de las publicaciones que han estudiado específicamente el mecenazgo musical de las Casas de Osuna y Benavente se han centrado sobre todo en María Josefa Alfonso Pimentel (XV Condesa-Duquesa de Benavente) o en María Faustina Téllez Girón (Condesa-Duquesa viuda de Benavente y madre de la anterior). El primero en dar a conocer la conexión entre la XV CondesaDuquesa de Benavente y algunos importantes músicos europeos fue Joaquín Ezquerra del Bayo en un libro de 1934, al que sucedieron diversos artículos publicados por Nicolás A. Solar-Quintes entre 1947 y $1963^{22}$. Desde la aparición de estos trabajos gran parte de la bibliografía musicológica se ha limitado a reiterar o sintetizar los datos presentados por dichos autores ${ }^{23}$.

A partir de los años 90 del siglo XX se han publicado varios artículos que aportan materiales nuevos sobre determinados aspectos del mecenazgo musical de las Casas de Osuna y Benavente. María Asunción Gómez Pintor describió una selección de la documentación de interés musical conservada en la Sección Osuna

\footnotetext{
${ }^{21}$ En los apartados que la Condesa de Yebes dedicó al mecenazgo musical de la Condesa-Duquesa de Benavente hay diversos errores y anacronismos derivados de la interpretación errónea de algunas fuentes, como comentaré en el momento oportuno.

22 Joaquín Ezquerra del Bayo, Retratos de la familia Téllez Girón. Novenos duques de Osuna (Madrid: Junta de Iconografía Nacional, 1934); Nicolas A. Solar Quintes, "I. Las relaciones de Haydn con la casa de Benavente. II. Nuevos documentos sobre Luigi Bocherini. III. Manuel García Íntimo”, AnM, II (1947), pp. 81-104. Idem, “Saverio Mercadante en España y Portugal. Su correspondencia con la condesa de Benavente", AnM, VII (1952), pp 201-208; Nicolas A. Solar Quintes e Yves Gérard, "La bibliothèque musicale d'un amateur éclairé de Madrid: La DuchesseComtesse de Benavente, Duchesse de Ossuna (1752-1834), Recherches sur la Musique française classique, III (1963), pp.179-188.

${ }^{23}$ Véase, por ejemplo, Martín Moreno, Historia, pp. 276-279.
} 
del Archivo Histórico Nacional ${ }^{24}$. Marc Heilbron estudió la correspondencia entre la XV Condesa-Duquesa de Benavente y algunos cantantes y bailarines que actuaron en las temporadas de ópera de Madrid y de otros teatros europeos ${ }^{25}$. Miguel Ángel Marín analizó el contexto que rodeó la producción de la zarzuela Clementina, obra encargada por María Faustina Téllez Girón, Condesa-Duquesa viuda de Benavente, al dramaturgo Ramón de la Cruz y al compositor Luigi Boccherini $^{26}$. Mi propia investigación se plasmó en el estudio y edición crítica de la zarzuela Los Jardineros de Aranjuez (1768), de Pablo Esteve y Grimau dedicada al VIII Duque de Osuna ${ }^{27}$, y en dos aportaciones sobre aspectos concretos del mecenazgo musical de las Casas de Osuna y Benavente en los siglos XVIII y $\mathrm{XIX}^{28}$.Cuando la redacción de esta Tesis Doctoral se hallaba ya

${ }^{24}$ María Asunción Gómez Pintor, "Fuentes documentales para el estudio de las Casas de Osuna y Arcos", RMS, XVI/6 (1993), pp. 3459-3475. Los datos de este artículo aparecen sintetizados también en María Asunción Gómez Pintor, “Osuna, Casa de, DMEH, vol. 8, pp.291-292.

25 Marc Heilbron Ferrer, "Umilissimi, devotissimi servi. Correspondencia de cantantes de ópera italiana con la Duquesa de Osuna", AnM, 57 (2002), pp.199-227.

26 Miguel Ángel Marín, “La zarzuela Clementina di Luigi Boccherini”, en Ramón de la Cruz: Clementina, introducción de Maria Grazia Profeti y Miguel Ángel Marín, texto crítico, traducción y notas de Nicoletta Lepri (Firenze: Alinea Editrice,: 2003), pp. 15-36.

27 Pablo Esteve y Grimau, Los Jardineros de Aranjuez (1768) Zarzuela en dos actos. Estudio y edición crítica de Juan Pablo Fernández Cortés (Granada: Universidad de Granada, 2005). Esta obra obtuvo en 2004 el Premio de Investigación Musicológica "Manuel de Falla" de la Universidad de Granada; una primera versión de la misma fue presentada en 2003 en la misma universidad con el título Los Jardineros de Aranjuez de Pablo Esteve y Grimau (1768). Una zarzuela para la Casa de Osuna (Estudio y Edición Crítica) (Trabajo de Investigación Tutelada para la obtención del Diploma de Estudios Avanzados, DEA, dirigido por la Dra. María Gembero Ustárroz).

28 Juan Pablo Fernández-Cortés, "El mecenazgo musical de Mariano Téllez Girón, XII Duque de Osuna (1844-1882)". Actas del VI Congreso de la Sociedad Española de Musicología. Oviedo 2004, RMS, XVIII/1 (2005), en prensa. Juan Pablo Fernández-Cortés, "Las relaciones de Luigi Boccherini con la Casa de Benavente. Nuevas perspectivas para su estudio”. Comunicación 
prácticamente terminada ha aparecido un artículo firmado por Judith Ortega sobre el mecenazgo musical de la Casa de Osuna en la segunda mitad del siglo XVIII ${ }^{29}$. A pesar de la abundante documentación original manejada por la autora, este trabajo perpetúa la costumbre habitual en la mayoría de los estudios musicológicos de considerar globalmente las actividades musicales patrocinadas por las Casas de Osuna y Benavente como si fueran de una única casa nobiliaria, algo que no corresponde a la realidad, como he mencionado antes. Ortega parte de la consideración errónea de que ambas casas nobiliarias se unieron en 1771, tras el matrimonio de Pedro de Alcántara Téllez Girón (Marqués de Peñafiel y heredero de la Casa de Osuna), con María Josefa Alfonso Pimentel (XV Condesa-Duquesa de Benavente $)^{30}$. En el artículo de Ortega se mezclan las actividades musicales que patrocinaron los personajes de las Casas de Osuna y Benavente, y hay erratas e imprecisiones importantes que obligan a tomar con precaución los materiales presentados por la autora ${ }^{31}$.

presentada en el Congreso Internacional Luigi Boccherini y la música de su tiempo, celebrado en Madrid entre los días 17 y 19 de noviembre de 2005.

29 Judith Ortega, "El mecenazgo musical de la Casa de Osuna durante la segunda mitad del siglo XVIII: el entorno musical de Luigi Boccherini en Madrid, RMS, XVII/ 2 (2004), pp. 659-698. ${ }^{30}$ Ibid, p. 645.

31 Por ejemplo, Ortega cita a María Faustina Téllez Girón como "duquesa-condesa de BenaventeOsuna" (Ibid., p. 658), cuando en realidad era Condesa-Duquesa (viuda) de Benavente; algunos documentos pertenecientes al VIII Duque de Osuna son atribuidos erróneamente por dicha autora al "conde de Benavente" (p. 664), y en su artículo se mezclan todos los instrumentistas que trabajaron por separado para las Casas de Osuna o de Benavente en la segunda mitad del siglo XVIII en una tabla titulada "Músicos contratados en la Casa de Osuna (pp. 693-697). Ortega menciona además erróneamente varios nombres de personajes y títulos de obras suficientemente conocidos; por ejemplo, el título de la comedia Agradecer y no amar se transcribe como “Ayradeses y no amar” (p. 659); el compositor Ferdinando Paer aparece nombrado como "Per” (p. 
La recuperación de las obras musicales directamente relacionadas con el patronazgo de las Casas de Osuna y Benavente se inició en 1992, con la edición de la zarzuela Clementina, de Luigi Boccherini y Ramón de la Cruz (publicada por Antonio Gallego y Jacinto Torres) ${ }^{32}$, y ha proseguido con la publicación de Lothar Siemens de la Obra Armónica de Francisco Manalt ${ }^{33}$ y mi estudio y edición crítica de la zarzuela en dos actos Los jardineros de Aranjuez de Pablo Esteve y Grimau ${ }^{34}$.

A pesar del valor de las aportaciones comentadas, hasta la fecha sólo contamos con visiones parciales del mecenazgo musical de las Casas de Osuna y Benavente durante los siglos XVIII y XIX, por lo que en esta Tesis me propongo realizar un estudio sistemático y más amplio del papel que tuvieron estas importantes casas nobiliarias en la promoción y difusión de la música en España. Mi trabajo pretende contribuir a ampliar el conocimiento de la realidad musical

656), el tenor y empresario Santiago Panati como "Santiago Parrati" (p. 687), y el impresor y almacenista de música Gabriel de Sancha, como "Gabriel de Dancha" (p. 691). La misma autora sitúa en 1765 la dedicatoria de Pablo Esteve y Grimau al Duque de Osuna de la zarzuela Los jardineros de Aranjuez (ibídem, p. 660), cuando desde las investigaciones de Emilio Cotarelo y Mori se sabe que esa obra fue compuesta en 1768, fecha que también aparece en la dedicatoria del libreto publicado para el estreno (Cotarelo, Historia, pp. 142-143). A partir de ese dato erróneo, Ortega concluye que después de 1766 no existen referencias que relacionen a Esteve con la Casa de Osuna, lo que no es correcto (véase Pablo Esteve y Grimau, Los Jardineros de Aranjuez, y datos presentados sobre Esteve en esta Tesis). Otras precisiones sobre el artículo de Judith Ortega serán detalladas a lo largo de este trabajo, en los lugares oportunos.

32 Luigi Boccherini, Clementina, Revisión y adaptación del texto por Jacinto Torres Mulas. Transcripción musical por Antonio Gallego. (Madrid: Consorcio para la Organización de Madrid Capital Europea de la Cultura, 1992)

${ }^{33}$ Francisco Manalt, Obra Armónica en seis Sonatas de Cámara de violín y bajo solo. Edición de Lothar Siemens (Madrid: Sociedad Española de Musicología, 2001).

${ }^{34}$ Esteve, Los jardineros. 
española en el contexto de una historiografía musicológica que se ha centrado sobre todo, hasta fechas muy recientes, en el estudio de las catedrales o de las capillas reales $^{35}$

\section{Fuentes empleadas}

El núcleo central de la documentación manejada para la realización de esta Tesis Doctoral procede del archivo administrativo de la Casa de Osuna, que se conserva dentro de la Sección Nobleza del Archivo Histórico Nacional (AHN), ubicada desde 1993 en el Hospital de Tavera (Toledo). Este centro, de titularidad estatal, es uno de los archivos fundamentales para la investigación de la historia y las prácticas culturales de la nobleza española y, sin embargo, hasta la fecha apenas ha recibido la atención de los musicólogos. En sus fondos se reúnen y conservan los archivos generados por la nobleza española que han sido adquiridos por el Estado o cedidos en depósito por sus propietarios. En el año 2000 en esta sección del AHN se conservaban doscientos cuarenta y un archivos familiares, de muy diversas características, contenido y ámbito geográfico, entre los que

\footnotetext{
${ }^{35}$ Un factor que pudo contribuir a que la nobleza española quedara prácticamente excluida de los estudios musicológicos es que sus gustos se suponían contaminados por las corrientes estéticas foráneas, algo que gran parte de la historiografía hispana consideraba negativo. Sobre la influencia del Nacionalismo en la historiografía y el predominio de los estudios sobre catedrales, véase Emilio Ros Fábregas, "Historiografía de la música en las catedrales españolas: Nacionalismo y Positivismo en la investigación musicológica", CODEXXI. Revista de la Comunicación Audiovisual, I (1998), pp. 68-135. La visión negativa del italianismo en la música española del XVIII ha sido tratada por Juan José Carreras. Véase Juan José Carreras, "Hijos de Pedrell. La historiografía musical española y sus orígenes nacionalistas (1780-1980)" Il Saggiatore musicale VIII (2001), pp. 123-171.
} 
destacan por su volumen e interés histórico los archivos de Osuna, Frías, Fernán Núñez, Baena, Mendigorría o Luque ${ }^{36}$.

El archivo administrativo de la Casa de Osuna conservado en la Sección Nobleza del AHN consta actualmente de 7581 cajas con documentos que van desde el año 943 hasta el 1882. Sólo una pequeña parte de este archivo se ha digitalizado, y la única herramienta de acceso a sus contenidos (al menos hasta mayo de 2004) son los 43 tomos del inventario en el que se recogen copias de las fichas manuscritas realizadas desde las primeras décadas del siglo XX, con descripciones generales de los legajos.

El principal reto que se presenta al investigador que utiliza los fondos administrativos de la Casa de Osuna del AHN es discriminar e identificar a qué casa nobiliaria pertenece cada uno de los documentos utilizados, ya que en las cajas aparecen mezclados con frecuencia legajos y expedientes procedentes de los archivos de las numerosas casas nobiliarias que se fueron uniendo a la Casa de Osuna a lo largo de la historia. Concretamente, dentro del archivo administrativo de la Casa de Osuna ubicado en la Sección Nobleza del AHN se conserva documentación de los Ducados de Arcos, Béjar, Belalcázar, Cabrera, Gibraleón, Jabalquinto, Lombay, Medina de Ríoseco, Melgar, Mandas, Osuna, Peñafiel, Ureña, de los Condados de Benavente, Gandía, Maqueda, Modica, Nules, Oliva, Osuna, Pastrana, Terranova, de los Marquesados del Cid, Infantado, Lerma, Luna, Quirra, Santillana, Tavara, Tendilla, y del Vizcondado de Cenete.

\footnotetext{
${ }^{36}$ Rosario García Aser y Aránzazu Lafuente Urién, Archivos nobiliarios: cuadro de clasificación / Sección Nobleza del Archivo Histórico Nacional (Madrid: Ministerio de Educación Cultura y Deporte, Centro de Publicaciones, 2000).
} 
Las fuentes más interesantes para el estudio del mecenazgo musical de las Casa de Osuna y Benavente proceden de los legajos que contienen informaciones de carácter económico (libros de cuentas, nóminas, recibos y libramientos, memoriales solicitando ayudas económicas), administrativo (notas de mayordomía, cartas de nombramiento) o jurídico (testamentos y expedientes de bienes de difuntos, capitulaciones matrimoniales). El archivo administrativo de la Casa de Osuna conserva asimismo abundante documentación sobre el linaje de la familia que incluye varios árboles genealógicos de interés artístico y un importante fondo epistolar que muestra la protección que otorgaron los titulares de las Casas de Osuna y Benavente y sus familiares a compositores, bailarines y cantantes durante los siglos XVIII y XIX.

La Biblioteca Nacional de España (Madrid) conserva también fuentes documentales y musicales fundamentales para el estudio del mecenazgo musical de las Casas de Osuna y Benavente. En el Fondo Barbieri, ubicado en la sección de Manuscritos, Incunables y Raros de esa Biblioteca, hay varios documentos administrativos originales que fueron tomados por dicho investigador del archivo administrativo de la Casa de Osuna en el siglo XIX. La documentación del Fondo Barbieri ha sido de gran importancia sobre todo para el estudio del capítulo dedicado a la música teatral. En la misma sección de Manuscritos de la Biblioteca Nacional se hallan varios panegíricos, encomios fúnebres y obras genealógicas, dedicados a los Duques de Osuna o a los Condes-Duques de Benavente, que resultan fundamentales para el conocimiento del linaje y de las prácticas culturales de ambas casas ducales. El Servicio de Dibujos y Grabados de la Biblioteca Nacional conserva documentación gráfica inédita sobre los funerales del VIII 
Duque de Osuna y en la Sección de Música de la misma institución he localizado varias obras y colecciones musicales que nacieron en el entorno doméstico de la Casa de Osuna o que pertenecieron a su biblioteca.

En el Archivo "Rodríguez Marín” de la Biblioteca Central del Consejo Superior de Investigaciones Científicas (Madrid) he consultado varios documentos sobre los orígenes de las fundaciones religiosas de Osuna y sobre la educación de los jóvenes de las familias Osuna y Benavente, que fueron reunidos por el polígrafo e investigador Francisco Rodríguez Marín (*1855-†1943)

De particular interés para el estudio de la música teatral han sido los ricos fondos musicales y literarios consultados en la Biblioteca Histórica del Ayuntamiento de Madrid (procedentes del llamado "caudal" de las compañías de los teatros madrileños de la Cruz y el Príncipe) y la documentación administrativa de dichas compañías teatrales, que se conserva en las Secciones Secretaría y Corregimiento del Archivo de Villa de Madrid. Asimismo he consultado algunos libretos de ópera y zarzuela de la Biblioteca del Institut del Teatre de Barcelona.

Para el trabajo de documentación bibliográfica he utilizado los fondos de numerosas bibliotecas, entre las que destacan la Biblioteca Nacional de España (Madrid), la Biblioteca de la Facultad de Filosofía y Letras de la Universidad de Granada, la de Humanidades de la Universidad Autónoma de Madrid, y las bibliotecas del Centro de Humanidades, del Instituto de Historia, y del Centro de Información y Documentación (CINDOC), estas tres últimas pertenecientes al Consejo Superior de Investigaciones Científicas (Madrid).

Además de los archivos y bibliotecas visitados personalmente, por diversas vías he conseguido información y documentación de utilidad procedente de la 
Biblioteca del Senado (Madrid), Biblioteca Nacional de Cataluña (Barcelona), la Bibliothèque Nationale de France (París), la Staatsbibliothek zu Berlin (Alemania) y las bibliotecas italianas del Conservatorio "Giuseppe Verdi” de Milán y del Conservatorio de Nápoles. 

Capítulo I

Las Casas de Osuna y Benavente:

una aproximación histórica 

Una de las tareas esenciales que debe abordar el investigador a la hora de enfrentarse al estudio de una casa nobiliaria y de las actividades de sus titulares, es el conocimiento de la genealogía y la actividad pública de la familia o familias que han ostentado la titularidad de dicha casa a lo largo de la historia. En el caso concreto de las Casas de Osuna y Benavente, a pesar de la relevancia histórica de estos linajes, no disponemos hasta la fecha estudios globales de carácter científico que puedan ser utilizados como referencia. La síntesis más completa sobre la genealogía de la Casa de Osuna es la realizada por Ignacio Atienza (1987) en la que sólo figuran sucintamente las actividades de los principales titulares de la Casa entre los siglos XVI y XIX ${ }^{1}$. La Casa ducal de Benavente tampoco ha sido estudiada globalmente hasta el momento ${ }^{2}$. Una importante aportación para el conocimiento de los personajes que ostentaron la titularidad de esta casa nobiliaria es la reciente monografía de Mercedes Simal López en la que se reconstruye la genealogía de la Casa de Benavente durante el siglo XVII ${ }^{3}$.

La abundante bibliografía genealógica, aunque puede ser de gran ayuda para el historiador actual, plantea diversos problemas que obligan a utilizarla con suma precaución. La necesidad de buscar los gloriosos orígenes de las familias aristocráticas en un pasado glorioso, contribuyó a la consolidación, a partir del siglo XVI, de un género casi literario en el que los datos históricos se embellecían,

\footnotetext{
${ }^{1}$ Ignacio Atienza Hernández, Aristocracia, poder y riqueza en la España Moderna. La Casa de Osuna, siglos XV-XIX (Madrid: Siglo Veintiuno, 1987), pp. 96-112.

${ }^{2}$ Sobre la historia de la Casa de Benavente hasta el siglo XV véase Isabel Beceiro Pita, El condado de Benavente en el siglo XV (Salamanca: Centro de Estudios Benaventanos Ledo del Pozo, 1998).

${ }^{3}$ Mercedes Simal López, Los condes-duques de Benavente en el siglo XVII. Patronos y coleccionistas en su villa solariega (Benavente: Centro de Estudios Benaventanos Ledo del Pozo, 2002).
} 
retocaban, suprimían y añadían, con la única finalidad de agradar y honrar al noble que encargaba la obra o al que se pretendía elogiar. El afán por ubicar los ascendientes de un linaje en una época lo más remota posible, condujo con frecuencia a situar los orígenes de algunas familias nobiliarias en la Antigüedad clásica o incluso en los orígenes del género humano ${ }^{4}$.

Los primeros ejemplos de historia genealógica adolecían de un planteamiento básicamente apologético que tenía como objetivo enaltecer los hechos y circunstancias de valor para la familia nobiliaria, y ocultar otros datos que pudieran empañar el esplendor de su trayectoria a lo largo de los siglos. El interés fundamental de la literatura genealogista por establecer las filiaciones y relaciones de la familia estudiada, solía dar como resultado un texto consistente en un largo listado de nombres y apellidos (más o menos documentado) pero de limitada validez para el historiador, mientras los aspectos socioeconómicos o culturales se obviaban o pasaban a un segundo plano.

Las principales obras genealógicas de los siglos XVI al XVIII que reconstruyen los antecedentes de los Téllez Girón, rama principal de la Casa de Osuna, no pueden tomarse como un resumen objetivo de la historia y actividades de esta Casa, sino como un punto de partida para la reconstrucción de su genealogía, y por lo tanto deben utilizarse con la suficiente cautela para no caer en el error de considerar históricamente válidos todos los elogiosos datos y las construcciones de un pasado ficticio que abundan en estos textos. Dos ejemplos notorios de textos genealógicos dedicados a la Casa de Osuna son Compendio de

\footnotetext{
4 Antonio Domínguez Ortiz, Las clases privilegiadas en la España del Antiguo Régimen (Madrid: Istmo, 1973), pp. 20-22.
} 
algunas historias de España de Jerónimo Gudiel ${ }^{5}$, uno de los pocos textos anteriores al siglo XVIII que presenta una relación histórica lineal de los antecedentes de la Casa de Osuna, y Compendio de las antigüedades de la villa de Osuna de Antonio García de Córdoba ${ }^{6}$. En ambas obras figuran amplios apartados dedicados a la descripción de los logros y hazañas de los titulares de la Casa de Osuna, en donde se mezclan los datos históricos con numerosos elementos ficticios $^{7}$.

Dada la citada carencia de estudios de carácter científico que reconstruyan la historia de las Casas de Osuna y Benavente desde sus orígenes, se hace necesario partir de una etapa descriptiva basada en la síntesis bibliográfica y documental, teniendo en cuenta que ésta no constituye una finalidad en sí misma, sino un simple medio para comprender las particularidades de la vida pública y privada de esta familia de la nobleza, una clase social que basa sus derechos y privilegios en los vínculos familiares y en la toma de conciencia del linaje. Por ello, antes de abordar el estudio de las actividades del mecenazgo musical de las Casas de Osuna y Benavente, reconstruiré las principales líneas de la historia de ambas casas nobiliarias, completando y corrigiendo los datos que figuran en la

5 Jerónimo Gudiel, Compendio de algunas historias de España donde se tratan muchas antigüedades dignas de memoria y especialmente se da noticia de la antigua familia de los Girones, y de otros muchos linajes (Alcala de Henares: Juan Iñiguez de Lequerica, 1577).

${ }^{6}$ Antonio García de Córdoba, Compendio de las antigüedades de la villa de Osuna, y noticias de los preexcelsos dueños que ha tenido desde su fundación (ca. 1740). BNE, Ms. 10479. Existe una copia incompleta de esta misma obra con el título Antigüedades de Osuna en AHN NOBLEZA, OSUNA-CARTAS, leg 1-1.

7 La tendencia a ubicar los orígenes de la familia Osuna en un pasado mitológico sigue perpetuándose incluso en textos escritos a finales del siglo XVIII. Véase, por ejemplo, Tomás Fernández de Mendoza, Elogio fúnebre en que se da una idea cabal, de las circunstancias virtudes y premios del Excelentísimo Señor Don Pedro Zoilo Téllez Girón, $8^{\circ}$ Duque de Osuna (1787). BNE Ms. 10494. 
escasa bibliografía publicada con otros materiales inéditos resultado de mi investigación.

\section{La Casa de Osuna hasta 1787}

Desde sus orígenes en el siglo XV en el modesto condado castellano de Ureña, hasta la quiebra y disgregación de su patrimonio a finales del siglo XIX, los bienes y la presencia pública de la Casa de Osuna crecieron continuamente hasta llegar a situarse a mediados del siglo XIX entre las casas nobiliarias más importantes de España junto con las de Alba, Medinaceli y Medina-Sidonia.

A lo largo de estos cuatro siglos, el patrimonio de la Casa de Osuna se incrementó progresivamente con la incorporación sucesiva de importantes títulos que se obtuvieron a través de la celebración de matrimonios endogámicos, herencias o con las concesiones de nuevas dignidades por parte de la monarquía. Al margen de los privilegios simbólicos que conllevaba la acumulación varias dignidades nobiliarias en una sola familia, este proceso supuso también la agregación de bienes tangibles, en forma de rentas, territorios o vasallos que engrandecieron el patrimonio de la Casa de Osuna ${ }^{8}$.

\subsection{Orígenes de la Casa de Osuna. EI condado de Ureña}

Aunque en sentido estricto no puede hablarse de la Casa de Osuna hasta 1562 (cuando Felipe II otorgó el titulo de Duque de Osuna a Pedro Girón de la Cueva, V Conde de Ureña), los orígenes de esta casa nobiliaria se remontan, como

\footnotetext{
${ }^{8}$ Atienza, Aristocracia, pp. 71-77.
} 
en muchos otros ejemplos de la alta nobleza española, a la época de la Reconquista.

El linaje de los Téllez Girón comenzó a gestarse en el siglo XI. En la batalla de la Sagra (1086) don Rodrigo González, Señor de Cisneros, salvó la vida al monarca Alfonso VI de Castilla al colocarse el manto real para despistar a las tropas musulmanas que tenían cercado al rey. Según el relato que se repite en las obras genealógicas, los musulmanes siguieron a don Rodrigo, creyendo que se trataba del rey, y en la lucha consiguieron hacer tres jirones en su manto. Como agradecimiento por esta gesta, el rey impuso a don Rodrigo en el escudo de Señor de Cisneros la representación de los tres jirones del manto, le concedió la utilización del apellido Girón y le desposó con su hija doña Sancha. El apellido Téllez, que completa el patronímico familiar de los Osuna, se incorporó en el siglo XIV tras la boda del caballero Gonzalo Ruiz de Girón con María Téllez, señora de Villasís 9 .

La gran figura en este período de formación de la Casa de Osuna fue Pedro Girón, Maestre de Calatrava entre 1445 y 1466. Gracias a su participación en la Reconquista junto a Enrique IV, éste personaje pudo obtener varios señoríos y donaciones reales como pago a sus servicios militares, y realizar compras o permutas de territorios. Su gran ambición le llevó a acumular varias villas, aldeas y títulos nobiliarios, que añadió al maestrazgo de Calatrava. Pedro Girón colaboró en diversas batallas contra los musulmanes en Andalucía, y realizó compras, ventas y trueques de posesiones, la mayoría en colaboración con su hermano conocido como Juan Pacheco, uno de los personajes centrales del reinado de

\footnotetext{
9 Emilio Cotarelo y Mori, "Las armas de los Girones. Estudios de Antigua Heráldica Española”, separata facticia de Revista de Archivos, Bibliotecas y Museos, Julio 1903.
} 
Enrique $\mathrm{IV}^{10}$. La labor de expansión territorial de la familia Téllez-Girón comenzó en 1445, tras la batalla de Olmedo, con la adquisición de las villas de Ureña, Tiedra y Arévalo, entre otras. En 1446, Pedro Girón obtuvo los bienes de las villas de Jaén, Baeza, Úbeda y Andujar, en 1448 la villa de Peñafiel y en 1453 consiguió los derechos sobre la villa de Santisteban del Puerto. De esta manera, se comenzó a gestar el Estado de Osuna, que a la muerte de Pedro Girón en 1466 abarcaba las villas andaluzas de Archidona, Osuna, Puebla de Cazalla, Olvera, Ortegicar, Morón de la Frontera y El Arahal con sus territorios, a las que se sumaban las posesiones de Ureña y Peñafiel en Castilla. La familia Téllez-Girón, de origen castellano, desplazó tras estas anexiones gran parte de sus intereses políticos y económicos a Andalucía, ubicando la "capital" de su estado en la sevillana villa de Osuna, que a partir del siglo XVI dio nombre a esta casa nobiliaria ${ }^{11}$.

Pese a su condición de religioso, Pedro Girón tuvo tres hijos ilegítimos con Isabel de las Casas (Véase Lámina 1) además de dos hijas con Inés de Meneses. La descendencia masculina de Pedro Girón, legitimada por el rey ${ }^{12}$, continuó la labor iniciada por su padre y la tradición bélica familiar. El primogénito Alfonso Téllez Girón $(* 1453-\uparrow 1468)$ ostentó brevemente el título de I Conde de Ureña, mientras que Rodrigo, segundo de los hijos, siguió la carrera religiosa y heredó el maestrazgo de Calatrava.

\footnotetext{
${ }^{10}$ La figura de este personaje se analiza detalladamente en John O' Callaghan, “Don Pedro Girón master of the Order of Calatrava 1445-1466", Hispania, 83 (1961), pp. 342-390. Sobre este personaje véase también Ana Viña Brito, Don Pedro Girón Maestre de Calatrava y los orígenes de la Casa de Osuna, Tesis Doctoral inédita (Sevilla: Universidad de Sevilla, 1986).

${ }^{11}$ Para los orígenes del señorío de Osuna véase Francisco Javier Aguado González, El ascenso de un linaje castellano en la segunda mitad del siglo XV: Los Téllez Girón, Condes de Ureña. El Origen del Señorío de Osuna, Tesis Doctoral (Madrid: Universidad Complutense, 1991).

12 AHN NOBLEZA, OSUNA, leg 1, 18-19. Segovia 30 de octubre de 1459.
} 


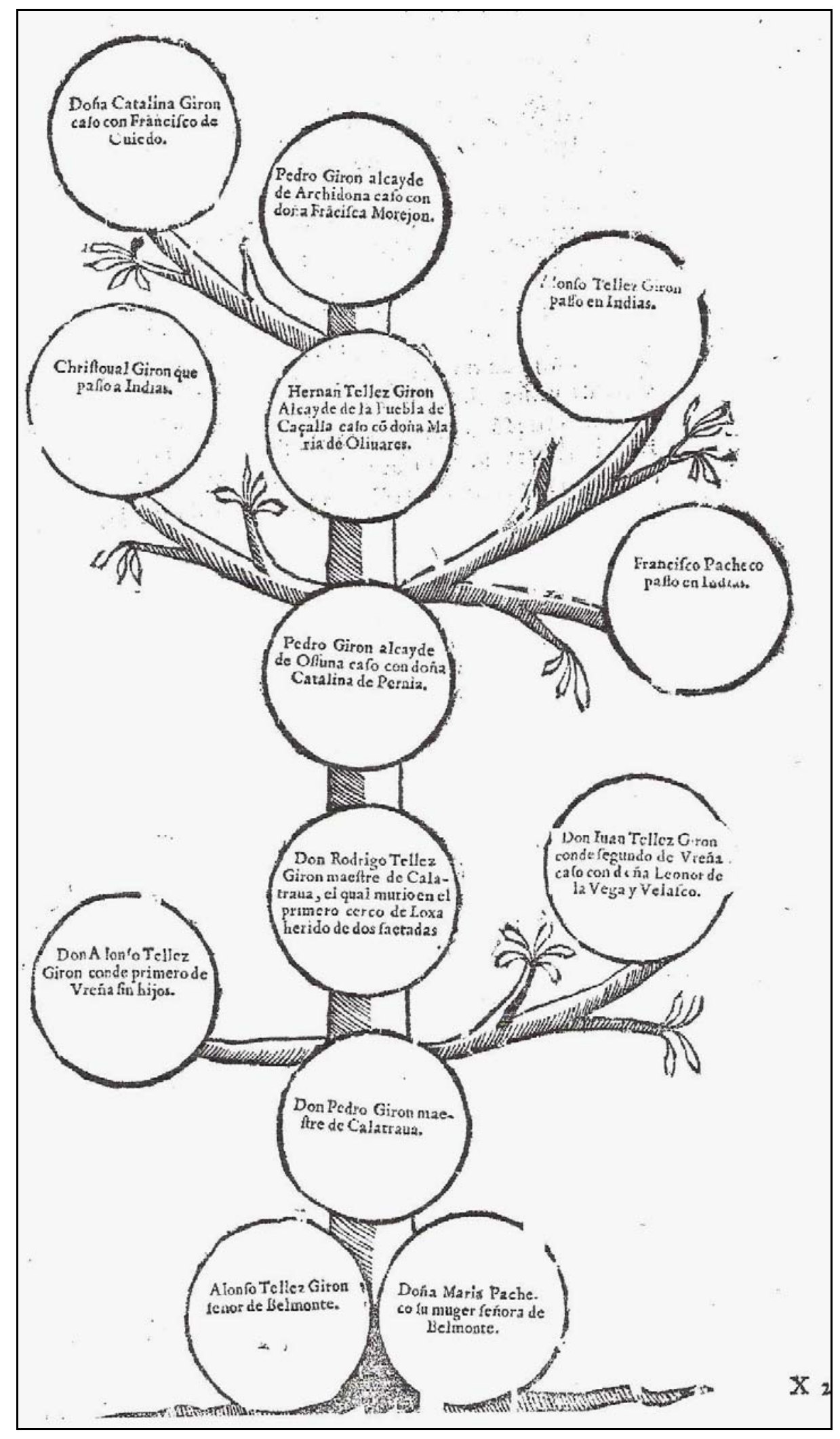

\section{Lámina 1.}

Órígenes del Maestrazgo de Calatrava y primeros Condes de Ureña.

Gerónimo Gudiel: Compendio de algunas historias de España, s.f. 
Tras la prematura muerte de su hermano Alfonso, Juan Téllez Girón (*1456-†1528) heredó el título de Conde de Ureña con el mayorazgo fundado por su padre y continuó la trayectoria militar de la familia, participando junto a los Reyes Católicos en la conquista de Granada ${ }^{13}$. El II Conde de Ureña fue un gran aficionado a la poesía y tuvo a su servicio al poeta y músico Juan del Encina a quien, según Gregorio Leti, el Conde le asignó un importante salario [honorevole salario $]^{14}$.

A Juan Téllez Girón le sucedió su hijo Pedro Girón y Velasco (†1531), III Conde de Ureña, y último de los Téllez Girón que mantuvo la tradición feudal de aportar ejércitos al monarca para participar en sus campañas. Pedro Girón participó en numerosas batallas, como la de Orán, donde fue gravemente herido ${ }^{15}$. Su hermano Juan Téllez Girón, apodado "El Santo” (*1494-†1558), abandonó la tradición militar de la familia y se trasladó a la Corte, donde desempeñó diversos oficios palaciegos. Ostentó, entre otros, los cargos de Camarero Mayor y miembro del Consejo de Estado con Carlos V. A la muerte de su hermano en 1531, Juan Téllez Girón, heredó el título de Conde de Ureña, y tras este nombramiento renunció a la vida cortesana y trasladó su residencia a Osuna para ocuparse de la administración del patrimonio familiar ${ }^{16}$.

\footnotetext{
${ }^{13}$ La trayectoria de la familia Girón hasta el V Conde de Ureña puede seguirse en Gudiel, Compendio.

${ }^{14}$ Gregorio Leti, Vita di Don Pietro Giron, Duca d'Ossuna, Vicere di Napoli e di Sicilia, sotto il regno di Filippo Terzo (Amsterdam: Georgio Gallet, 1699), libro II, p. 151.

${ }^{15}$ Atienza, Aristocracia, p. 98.

${ }^{16}$ Su hermano sólo había tenido una hija con Mencía de Guzmán que no podía heredar el título debido a las prescripciones establecidas en la fundación del condado de Ureña en las que se limitaba la herencia a los varones.
} 


\subsection{Titulares de la Casa de Osuna hasta 1787.}

A la muerte de Juan Téllez-Girón en 1588, le sucedió su hijo Pedro Téllez Girón de la Cueva, V Conde de Ureña (*1531-†1590), que ocupó importantes empleos al servicio de la monarquía, lo que le obligó a un progresivo alejamiento de la administración de los estados andaluces de Osuna. El V Conde de Ureña fue, entre otros cargos, Camarero Mayor del Rey, Notario Mayor de Castilla y miembro del Consejo de Estado al servicio de Felipe II. En 1562, poco antes de su boda en Toledo con doña Leonor Ana de Guzmán, hija mayor del Duque de Medina Sidonia ${ }^{17}$, el rey le concedió el título de Duque de Osuna, con la condición de grandeza de España por los "muchos buenos y leales servicios" que su padre (Juan Téllez-Girón, IV Conde de Ureña) había hecho al monarca ${ }^{18}$.

A partir de este nombramiento, Pedro Téllez Girón se convirtió en uno de los principales delegados del monarca en las labores de política exterior. Además de los empleos ya citados, el Duque de Osuna fue embajador en Portugal, y participó en las gestiones para la incorporación de este reino a la corona de España. Entre 1582 y 1586 ejerció como Virrey y Capitán General de Nápoles. Tras ser sustituido por Juan de Zúñiga, Conde de Miranda, el I Duque de Osuna regresó a Madrid enfermo e intentó recuperar infructuosamente sus antiguos cargos de miembro del Consejo de Estado y Camarero Mayor del Rey ${ }^{19}$.

\footnotetext{
${ }^{17}$ Las capitulaciones matrimoniales firmadas en 1549 se conservan en AHN, NOBLEZA, OSUNA, leg 7-14.

${ }^{18}$ AHN NOBLEZA, OSUNA, leg 9-2. 5 de febrero de 1562.

${ }^{19}$ Luis Cabrera de Córdoba, Luis. Felipe II, Rey de España (Madrid: Aribau, 1874), vol. III, p.269.
} 
El ducado de Osuna fue heredado por Juan Téllez Girón y Guzmán (*1554-†1600), hijo primogénito del anterior Duque, quien desde 1568 ostentaba el título de Marqués de Peñafiel, dignidad nobiliaria que le había concedido el rey Felipe II y que, desde entonces, sería utilizada por los herederos de la Casa de Osuna.

El representante más destacado de la Casa de Osuna durante el siglo XVII fue Pedro Téllez Girón y Velasco (*1574-†1624), llamado “El Grande”, II Marqués de Peñafiel, y III Duque de Osuna tras la muerte de su padre en 1600. Pedro Téllez Girón vivió durante su niñez en Nápoles en el período en que su abuelo ejerció el virreinato en este territorio italiano. Tras su regreso a España, estudió en la Universidad de Salamanca y parece ser que llevó una vida un tanto veleidosa en Madrid y Sevilla. En 1593 se casó con Catalina Enríquez de Ribera. Los años que siguieron a su boda estuvieron plagados de escándalos. Era habitual su participación en las riñas callejeras de Sevilla lo que le obligó a buscar frecuente refugio en sus dominios de Puebla de Cazalla, o a permanecer confinado en los castillos de Arévalo y Peñafiel ${ }^{20}$.

En 1602, el III Duque de Osuna abandonó su vida pendenciera y se alistó en el ejército de Flandes, probablemente para huir de algún asunto turbio ${ }^{21}$. Por los méritos militares obtenidos en esta guerra, Felipe III le nombró Notario Mayor

\footnotetext{
${ }^{20}$ Sobre este destacado personaje existe una amplia bibliografía dedicada principalmente a glosar sus hazañas militares. Véase Leti, Vita; Luis de Armiñán Odriozola, El Gran Duque de Osuna (Madrid: Gran Capitán, 1948) y Emilio Beladíez, Osuna el Grande. El Duque de las Empresas (Madrid: Alhambra, 1954). Sobre las andanzas juveniles del III Duque existe asimismo una interesante comedia histórica de Cristóbal Monroy. Cristóbal Monroy y Silva, Las Mocedades del Duque de Osuna (Madrid: Rivadeneyra, 1884).

${ }^{21}$ Beladíez, Osuna, p. 19.
} 
de Castilla en $1606^{22}$. En 1609, tras regresar de Flandes, el III Duque de Osuna residió de nuevo en Sevilla donde se relacionó con artistas y literatos. Parece ser que fue en esa época cuando conoció al poeta Francisco de Quevedo que se convertiría en su amigo, consejero y secretario personal. Quevedo no escatimó nunca elogios para el Duque de Osuna y sus testimonios poseen un gran valor histórico ya que asistió al lado del Duque a algunos de los hechos que relató ${ }^{23}$.

El III Duque de Osuna fue nombrado en 1610 Virrey y Capitán General de Sicilia, cargo en el que permaneció hasta 1615 cuando fue promovido al mismo puesto en Nápoles. En ambos destinos el Duque de Osuna consiguió importantes victorias militares, contribuyendo a la pacificación de los territorios sublevados del sur de Italia. A partir de la llamada Conjura de Venecia (1618) su prestigio comenzó a decaer. En 1620 fue relevado de su puesto bajo la acusación de participar en dicha conspiración y de dilapidar las arcas reales ${ }^{24}$.

A la muerte de Felipe III, con la subida al trono de Felipe IV y su valido el Conde Duque de Olivares, el Duque de Osuna fue acusado de defraudar a la corona y malversar sus fondos. Como consecuencia de ello, fue apresado el 7 de abril de 1621 y se le confinó en el castillo de la Alameda (Madrid). Tras pasar por distintas “cárceles privadas" falleció preso el 20 de septiembre de $1624^{25}$. A su

\footnotetext{
22 AHN NOBLEZA, OSUNA, leg 13-1.

${ }^{23}$ Beladíez, Osuna, p.78.

24 Según Ignacio Atienza, que sintetiza los principales datos de la vasta bibliografía existente sobre este tema, aunque parece incuestionable que Pedro Téllez Girón intentó dominar Venecia con una flota organizada para luchar contra los turcos; la acusación de que el Duque de Osuna pretendió proclamarse soberano de Nápoles pudo haber sido únicamente un invento del pueblo veneciano amenazado. La enemistad que llegó a gozar el Duque en Nápoles pudo haber sido producto de la oposición de la nobleza local que veía peligrar sus privilegios al formar parte de la corona española. Véase Atienza, Aristocracia, pp. 101-102.

${ }^{25}$ Por su condición de noble, el Duque de Osuna podía permanecer confinado en sus residencias.
} 
muerte su consejero y amigo Francisco de Quevedo le dedicó cuatro famosos sonetos fúnebres, en los que criticó la injusticia que supuso su encarcelamiento y muerte en prisión.

El sucesor en la titularidad de la Casa fue Juan Téllez Girón Enríquez de Ribera (*1597-†1656), hijo del III Duque de Osuna. Este personaje reanudó la colaboración con la corona y recuperó el prestigio familiar poco después de la muerte de su padre. En 1625 fue nombrado Notario Mayor de Castilla, cargo que ya había sido asignado a sus antepasados, y en 1646 Gentilhombre de la Cámara de su Majestad ${ }^{26}$. Al igual que su padre, el IV Duque de Osuna ocupó el cargo de Virrey de Sicilia, aunque brevemente pues falleció poco después de su llegada a Palermo en 1656.

El prestigio militar y político de la familia se consolidó gracias a la figura de Gaspar Téllez Girón $(* 1625-\uparrow 1694)$, IX Duque de Ureña y V Duque de Osuna $^{27}$. A lo largo de su vida, el V Duque de Osuna desempeñó numerosos cargos políticos y militares. En 1646 fue nombrado Clavero de la Orden de Calatrava y en 1655 General de la Caballería de Milán y Capitán General de la Armada del Océano. Al fallecer su padre en 1656 desempeñó el puesto de Virrey de Sicilia. Su prestigio siguió ascendiendo, y en 1667 fue nombrado Virrey y Capitán General de Cataluña. Dos años más tarde, en 1669, culminó su carrera política y administrativa al ser designado gobernador del Estado de Milán, cargo

\footnotetext{
26 APR Empleados. C 774/7. Citado en Javier Ignacio Martínez del Barrio, Mecenazgo y Política Cultural de la Casa de Osuna en Italia (1568-1694), Tesis doctoral (Madrid: Universidad Complutense, Servicio de Reprografía, 1989).

27 Sobre personaje véase Lorna Jury Gladstone, Aristocratic landholding \& finances in seventeenth century Castille: The case of Gaspar Téllez Girón, Duke of Osuna (1656-1694) Tesis doctoral inédita (Virginia: University of Virginia, 1977).
} 
que abandonó en $1674^{28}$. A su regreso a España, ocupó los cargos de Presidente del Consejo de Órdenes y Caballerizo Mayor de la Reina ${ }^{29}$.

A través del testimonio del embajador francés François Bertaut sabemos que Gaspar Téllez Girón mantuvo una suntuosa corte nobiliaria en sus dominios andaluces. Cuando este diplomático llegó en 1659 a Écija contempló la llegada de la comitiva del Duque de Osuna "en tres carrozas de seis mulas y dos de a cuatro". Detrás venía su mujer que era transportada en una litera rodeada por doce hombres a caballo y dos cornetas. Más tarde el embajador asistió a una velada en la casa del Duque donde se representó una comedia. La Duquesa, vestida con gran lujo, se sitúo bajo un dosel acompañada de diez damas de honor y varias "dueñas" con vestidos blancos ${ }^{30}$.

El Duque de Medinaceli promovió intrigas políticas contra el V Duque de Osuna que propiciaron que se repitiera la situación de acoso político que había padecido su abuelo. Gaspar Téllez-Girón fue acusado de corrupción y encarcelado, aunque finalmente logró suspender los procedimientos judiciales a costa del secuestro de sus estados, el pago de una multa y la pérdida del cargo de Caballerizo Mayor.

Cierra el siglo en la titularidad de la Casa, Francisco María de Paula Téllez Girón $\left(^{*} 1678-\uparrow 1716\right)$, VI Duque de Osuna (Véase Lámina 2). Hombre de confianza de Felipe V, fue uno de los nobles que le acompañó a su llegada a la Península desde la frontera francesa hasta Madrid, y posteriormente participó a su

\footnotetext{
28 En AHN NOBLEZA OSUNA se conserva una abundante documentación sobre la importante labor del V Duque de Osuna como virrey en los estados italianos.

${ }^{29}$ García de Córdoba, Compendio, f. 99.

30 François Bertaut, “Journal du voyage d'Espagne, 1659”, Revue Hispanique, XLVII (1919), pp. 135-137. Citado en Domínguez Ortiz, Las clases privilegiadas, pp. 147-149.
} 
lado en las campañas bélicas de Cataluña e Italia. Desde la época de Carlos II, el VI Duque de Osuna ostentó el título de Gentilhombre de Cámara y fue Lugarteniente General del rey en Andalucía. El VI Duque participó en el conflicto dinástico apoyando la causa borbónica al frente de una compañía de las Reales Guardias de Corps.

Francisco María de Paula Téllez Girón fue primer plenipotenciario de España en la firma de la Paz de Utrech $(1713)^{31}$, y representó a Felipe V en el tratado de paz firmado entre España y Portugal en 1715. Su inquietud política le llevó a redactar un amplio proyecto en el año de 1712, en el que estudió y propuso soluciones para asuntos económicos y administrativos fundamentales para la Corona española, como el comercio con América, el contrabando del tabaco o la necesidad de proceder a una repoblación organizada de la Península Ibérica ${ }^{32}$.

El VI Duque de Osuna estuvo casado desde 1695 con María Remigia de Velasco, marquesa de Berlanga, hija única del Duque de Frías († 1734).El Duque Falleció en París el 3 de abril de 1716 sin descendencia masculina ${ }^{33}$.

\footnotetext{
${ }^{31}$ Memoria que en fecha de 12 de abril de 1712, envía un correspondiente de París, de las prevenciones y gastos que el Duque de Osuna está ejecutando en aquella Corte, para entrar en el Congreso de paces, como primer plenipotenciario de Su Majestad Católica. BNE Ms.12026.

32 Leopoldo Zumalacárregui, "El proyecto del duque de Osuna para la reconstrucción económica de España en el siglo XVIII", Anales de Economía, 28 (Octubre-Diciembre 1947), pp. 476-494.

${ }^{33}$ AHN NOBLEZA, OSUNA, leg 20-18. Fe del depósito del cadáver de Francisco Téllez Girón VI Duque de Osuna en la iglesia de San Sulpicio de París.
} 


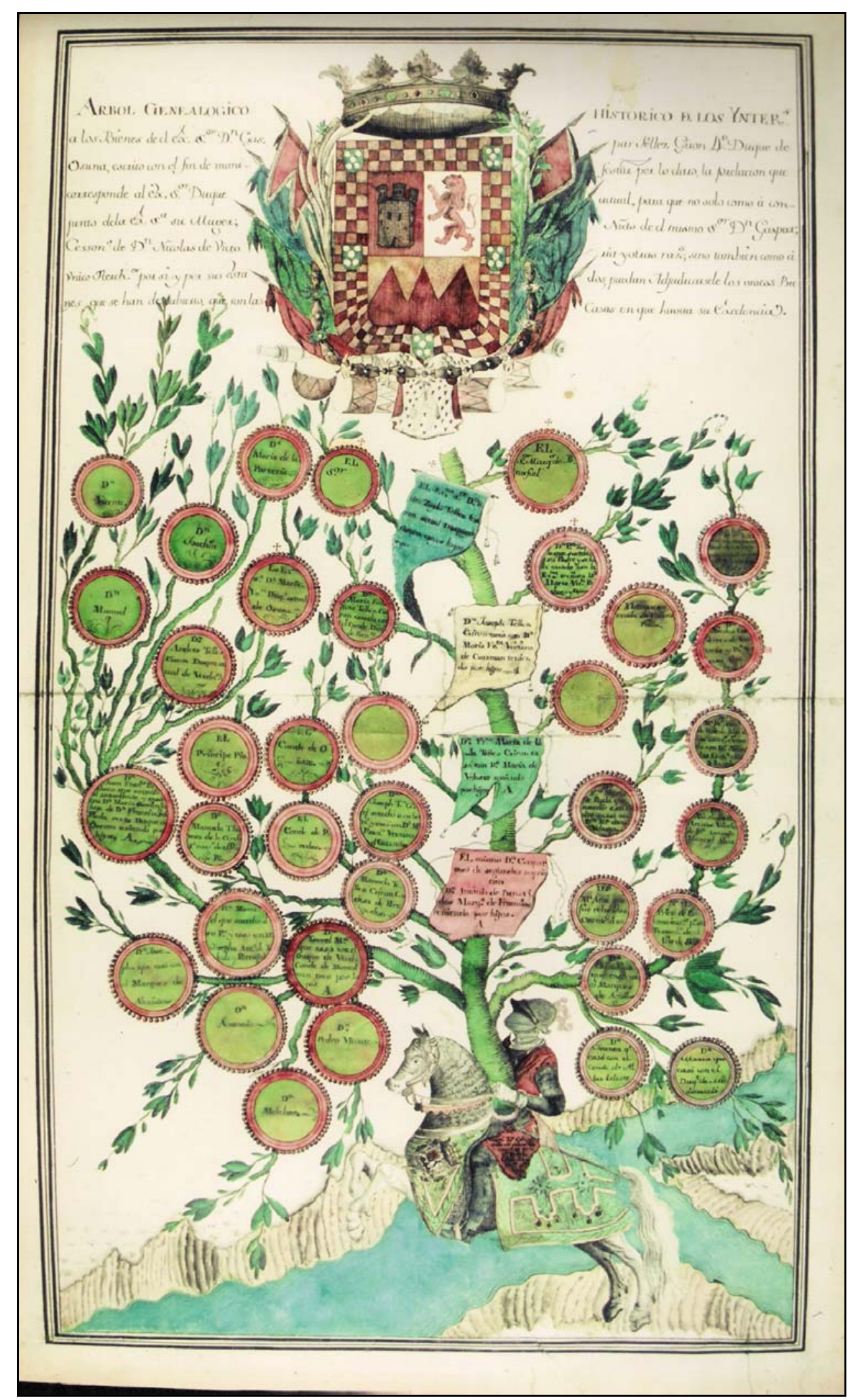

Lámina 2.

Árbol genealógico de la Casa de Osuna desde el V al VIII Duque AHN NOBLEZA, OSUNA, Genealogía. CD. 9 D. 26. 
A la muerte del VII Duque de Osuna se entabló un litigio por la sucesión de la titularidad de la Casa de Osuna y la herencia de sus posesiones que fueron reclamadas por su hija María Domínguez Téllez Girón y Velasco, apoyada por la Duquesa viuda de Osuna. El procedimiento judicial se prolongó durante cuatro años y fue objeto de un gran escándalo en la Corte, ya que la Duquesa viuda presentó un documento burdamente falsificado para intentar probar que cuando se fundó el Ducado de Osuna en el siglo XVI no se prescribió la obligación de sucesión masculina. El 17 de mayo de 1720, la justicia otorgó definitivamente la titularidad de la Casa de Osuna a José María Joaquín Téllez Girón y Benavides, hermano menor de Francisco María de Paula, VI Duque de Osuna ${ }^{34}$.

El séptimo titular de la Casa de Osuna había nacido el 25 de mayo de 1685 y contrajo matrimonio en 1721 con Francisca Bibiana Manuel Alonso, hija del Duque de Uceda. Falleció el 18 de marzo de 1733, dejando dos hijos legítimos: Pedro Zoilo, heredero en la titularidad de la Casa de Osuna, y María Faustina, que mas tarde sería la segunda esposa de Francisco Alfonso Pimentel, XIV CondeDuque de Benavente ${ }^{35}$.

Según su panegirista José Antonio Pastor, el VII Duque de Osuna fue una persona profundamente cristiana y bondadosa que solía colaborar activamente en las actividades de asistencia a los enfermos de la Real Congregación de San

\footnotetext{
34 Atienza, Aristocracia, pp. 92-95. Sobre esta sucesión véase también AHN NOBLEZA, OSUNA, leg 20-19, y leg 21-3 y Memorial ajustado de el pleito de tenuta de el estado de Osuna, litigan este pleito Don Antonio de Sadava, Curador ad litem de Doña Maria Dominga Téllez Girón y Velasco [...] y Don Joseph Téllez Girón, Marqués de Caracena, y Fromista, y Conde de Pinto: sobre la tenuta, y posesión del estado de Osuna, con todos los bienes, y lugares, patronatos, y demás derechos que le pertenecen [...]. Madrid, 11 de marzo de 1718. Real Academia de Historia (Madrid), 14/11518(1).

${ }^{35}$ García de Córdoba, Compendio, f. 99. Sobre la figura de María Faustina Téllez Girón véase el punto 2 de este capítulo.
} 
Francisco Javier de la cual era uno de sus máximos benefactores:

[...] siendo el primero de esta congregación en ofrecer el hombro al trabajo: era tan ejemplar y constante en ejercitar las acciones mas humildes, que parece había tomado a su cargo desterrar del vulgo el necio error de que las prendas de caballero, y el esplendor de la nobleza se desluce entre las sumisiones de la humildad cristiana. ¿Cuántas veces visteis por esas calles a la humildad cristiana triunfar de su grandeza? ¿Cuántas veces visteis por esas calles al Duque de Osuna? (joh ejemplo portentoso que no puede mirarse, ni aun referirse sin ternura!) cuantas veces le visteis oprimido el hombro con la olla de los pobres, siendo este trabajo muy superior a sus delicadas fuerzas: ni lo recio y destemplado del día pudo jamás entibiar sus fervores; ni los hielos, ni las nieves, ni las lluvias pudieron apagar el fuego de su caridad. Aquae multae non potuerunt extinguere charitatem . (Cant. cap. 8 v.6). Cuando el día era áspero, y lluvioso, y le rogaban que cediese aquel empleo, y aquel trabajo a otros, respondía con festivo agrado: eso no, que hoy hay mérito, y cargaba sobre sus hombros el mayor, y mas humilde peso: así marchaba, pisando lodo y agua: mucho mas el viento; salpicado de barro, y cubierto de sudor y fatiga, llegaba así al Hospital; pero allí descansaba muy a su gusto, porque a los enfermos mas postrados, que no podían incorporarse en la cama, los levantaba, y mantenía en sus brazos, y con sus manos les servía el alimento, consolando, y confortando al mismo tiempo su espíritu con palabras llenas de caridad y piedad cristiana ${ }^{36}$.

Siguiendo la tradición familiar de servicio militar a la corona, José Téllez Girón ocupó los cargos de Teniente General de los Reales Ejércitos y Coronel del Regimiento de la Guardia de Corps. Al igual que sus antepasados, participó

\footnotetext{
${ }^{36}$ José Antonio Pastor (S.I), Oración fúnebre [...] que la Real Congregación de San Francisco Xavier consagra a la memoria del Excelentísimo Señor don Joseph Téllez Girón, Duque de Osuna (Madrid: Imprenta de Pedro Enguera, [1733]), pp. 20-21.
} 
también en la vida activa de la corte como Gentilhombre de Cámara, Camarero Mayor de Felipe V y Embajador Extraordinario del monarca en el matrimonio de la princesa de Montpensier con el futuro Luis I de Francia.

Cuando el VII Duque de Osuna falleció en 1733, su hijo Pedro Zoilo era aún un niño de corta edad. Por ello, su madre Francisca Bibiana (Duquesa viuda de Osuna) tuvo que ejercer la titularidad efectiva y la administración de la Casa hasta que el VIII Duque de Osuna alcanzó la mayoría de edad. Desde los ocho años, el Duque se formó militarmente en el Regimiento de Reales Guardias de Infantería del cual llegaría a ser Coronel, y en el que en 1770 alcanzó el puesto de Director del Regimiento. Entre 1765 y 1770 el VIII Duque de Osuna ocupó también el cargo de Capitán de la Real Guardia de Alabarderos ${ }^{37}$. Paralelamente a su actividad militar, Pedro Zoilo Téllez Girón llevó a cabo una importante labor diplomática. En 1764, fue nombrado por el rey Carlos III Embajador Extraordinario para la boda de la infanta Maria Luisa con el Archiduque Pedro Leopoldo en Viena, y más tarde sería llamado en varias ocasiones para representar al rey en las Cortes de Nápoles, Parma, y Turín.

El 28 de febrero de 1753, el VIII Duque de Osuna se casó en la Iglesia de San Martín de Madrid con María Vicenta Pacheco, hermana del Duque de Uceda e hija de Don Juan Francisco Pacheco Téllez-Girón, perteneciente a la misma rama de la Casa de Osuna (Véase Lámina 2) ${ }^{38}$.

\footnotetext{
${ }^{37}$ Mientras no se indique lo contrario los datos de la biografía del VIII Duque que figuran en este capítulo proceden de Tomás Fernández de Mendoza, Elogio fúnebre en que se da una idea cabal, de las circunstancias virtudes y premios del Excelentísimo Señor Don Pedro Zoilo Téllez-Girón, $8^{\circ}$ Duque de Osuna [...], BNE Ms. 10494.

${ }^{38}$ Una copia de la partida del matrimonio del VIII Duque con María Vicenta Pacheco se conserva en AHN NOBLEZA, OSUNA, leg 450-65 bis.
} 
Una de las singularidades de la personalidad del VIII Duque de Osuna, parece haber sido su exacerbada religiosidad o al menos así lo relató su panegirista Tomás Fernández Mendoza:

Congregaba la familia al oratorio de su Casa y asistiendo allí todos los días del Santo Sacrificio de la misa; clamaba a Dios para que le dirigiese los pasos todo el día, luego dejando a dios por Dios para asistir a las obligaciones de sus empleos vuelve con fervor al templo de la Victoria a reiterar la asistencia al Santo Sacrificio, de donde acudía al despacho y expedientes que miraban a sus estados, concediendo solo el tiempo preciso a su alimento, por no faltar un instante, a las obligaciones que le llaman a Palacio: y cuando éstas se lo permitían por las tardes, acudía al mismo templo, a rezar el santo Rosario a María Santísima de la Soledad con tierna y profunda devoción ${ }^{39}$.

Pedro Zoilo Téllez Girón falleció el 2 de abril de 1787 “a los cincuenta y ocho [años], nueve meses y cinco dias". El día 5 del mismo mes “se hizo depósito del cadaver [...], y urna de su sepulcro, con toda la pompa fúnebre, política y militar correspondiente a su grandeza, carácter y ministerios ${ }^{~}, 40$. Para los funerales públicos, celebrados tres meses más tarde, su hermana encargó la construcción de un gran catafalco del cual ha quedado un testimonio gráfico que da muestra la magnificencia de los solemnes ceremoniales religiosos patrocinados por la Casa de Osuna ${ }^{41}$.

El VIII Duque de Osuna debió de emplear una buena parte de su patrimonio en la beneficencia, las limosnas y el bienestar de sus súbditos, o al menos así lo

\footnotetext{
${ }^{39}$ Fernández de Mendoza, Elogio fúnebre, f. 51 r.

${ }^{40}$ Ibíd., f. $38 \mathrm{v}$.

${ }^{41}$ Los detalles del ceremonial del funeral se estudian en el Capítulo V.
} 
relataba uno de sus panegiristas en un elogio fúnebre publicado poco después de su muerte:

El desvelo y amor de Su Excelencia a sus vasallos no podremos explicar ni comprender, tan continuos ejemplos de su amor de su benignidad y bizarría. Siempre patente a sus súbditos, el tribunal de sus piedades; abre sus tesoros y los aplica con larga mano para su alivio [...] miraba el labrador, secas de sed las plantas, sin otro riego que el del sudor infructuoso de su rostro o de sus llantos; y admiraremos al Duque de Osuna, que penetrado de compasión por sus vasallos; no quiere cobrar de los pobres sus derechos $\operatorname{atrasados}^{42}$.

En la misma línea se manifestaba la carta publicada el 5 de mayo de este mismo año en el Correo de Madrid firmada por G. F. A. en la que se glosaba las virtudes del Duque de Osuna. Este texto da a entender que Pedro Zoilo Téllez Girón residió durante un período de su vida en Barcelona, seguramente ocupando algún destino militar:

El Señor Duque de Osuna, merece sin duda en la historia de los hombres piadosos, benéficos, y amigos de la humanidad, uno de los más encumbrados lugares de ella, o por mejor decir, ha sido de aquellos hombres, que para el bien de la patria debían conservarse hasta el cabo del mundo, sin pagar el tributo acostumbrado de la vida a la naturaleza, pues hombre que con todo su anhelo mira por el bien de sus semejantes, parece que debiera ser eterno; pero la indiferente parca, que con igual pie abate las humildes chozas de los pobres, que los altos palacios de los Reyes, cortó la vida de nuestro Duque piadoso, sin reparar en el bien que nos quitaba, y en el desconsuelo que nos traía. Mas ya que el recuperarle sea empresa tan destituida de los términos posibles, cuanto lo es la del querer variar el admirable orden de la sana providencia, quede su nombre eternamente impreso en nuestros corazones,

\footnotetext{
${ }^{42}$ Fernández de Mendoza, Elogio fúnebre, f. 49 r.
} 
publiquemos sus virtudes y perpetuemos en los siglos los efectos de su mucha y constante caridad. Poseía esta virtud nuestro difunto en sumo grado, entre otras que no le faltaban, por ser anexas a esta, y precisos efectos de su buena índole, y bello natural. Pasan de sesenta mil ducados las limosnas que en solo el año pasado distribuyó, según era costumbre caritativa, no pudiendo ver infeliz, cuyas desgracias y miserias no le penetrase en lo íntimo del corazón, y que no le sugiriesen el mayor deseo de remediarlas. Siempre cobraba los impuestos de sus lugares uno o dos años atrasados, no por descuido ni desidia natural, sino únicamente con el fin de ayudarles a llevar mejor la carga, y de mirar por el mayor alivio y menor miseria de sus vasallos pobres. Igualmente les mantenía a su costa la comadre, maestra de niñas, y cirujano en los lugares en donde faltaban. Llegan a cuatro mil los huérfanos, que socorrió en el año pasado, a cuatrocientos mil el dinero que gastó en la composición de varias iglesias, y a cincuenta los soldados del servicio por inválidos, y no bastándoles el prest ${ }^{43}$ que les deja la ordenanza, mantenía en solo Barcelona, dando 2, o 4 reales a cada uno $[\ldots]^{44}$.

Pedro Zoilo Téllez Girón fue hasta el siglo XIX el miembro de la familia que ostentó durante más tiempo la titularidad del Ducado de Osuna (Ver Tabla 1). A pesar de la importancia de su actividad pública y del largo período en que se desarrolló ésta, la figura y la figura del VIII Duque de Osuna ha pasado prácticamente desapercibida en los estudios sobre la nobleza y ha sido confundida en diversas ocasiones con la de su hijo y sucesor, Pedro de Alcántara Téllez Girón, que ocupó la titularidad de la Casa de Osuna entre 1787 y $1807^{45}$

\footnotetext{
${ }^{43}$ El "prest" o pre era el socorro diario que se le daba a los soldados. Diccionario de la lengua castellana compuesto por la Real Academia Española, reducido a un tomo para su más fácil uso. Madrid: Joachín Ibarra, 1780, p. 742.

${ }^{44}$ Correo de Madrid, 56, Sábado 5 de Mayo de 1787, pp. 238-239.

${ }^{45}$ La confusión se extiende también a los estudios relacionados con la música. Véase por ejemplo la introducción de Lothar Siemens a Francisco Manalt, Obra Armónica en seis Sonatas de Cámara de violín y bajo solo. Edición de Lothar Siemens, (Madrid: Sociedad Española de Musicología, 2001).
} 
Tabla 1.

Titulares de la Casa de Osuna hasta su unión con la Casa de Benavente en 1787

Fuentes: AHN NOBLEZA, OSUNA genealogía

AHN NOBLEZA, OSUNA legs 450-bis y leg 1953-14.

\begin{tabular}{|c|c|c|}
\hline TITULAR & $\begin{array}{l}\text { PERÍODO DE } \\
\text { TITULARIDAD }\end{array}$ & OBSERVACIONES \\
\hline $\begin{array}{c}\text { Pedro Girón de la Cueva } \\
(* 1531-\uparrow 1590) \\
\text { I Duque de Osuna }\end{array}$ & $1562-1590$ & $\begin{array}{c}\text { V Conde de Ureña } \\
\text { Titulado Duque de Osuna } \\
\text { el } 5 \text { de febrero de } 1562\end{array}$ \\
\hline $\begin{array}{c}\text { Juan Téllez-Girón y Guzmán } \\
(* 1554-\dagger 1600) \\
\text { II Duque de Osuna }\end{array}$ & $1590-1600$ & $\begin{array}{c}\text { I Marqués de Peñafiel } \\
\text { desde } 1568\end{array}$ \\
\hline $\begin{array}{c}\text { Pedro Téllez-Girón y Velasco } \\
(* 1574-\dagger 1624) \\
\text { III Duque de Osuna } \\
\end{array}$ & $1600-1624$ & \\
\hline $\begin{array}{c}\text { Juan Téllez-Girón Enríquez de Ribera } \\
(* 1597-\dagger 1656) \\
\text { IV Duque de Osuna } \\
\end{array}$ & $1624-1656$ & \\
\hline $\begin{array}{c}\text { Gaspar Téllez-Girón y Sandoval } \\
(* 1625-\uparrow 1694) \\
\text { V Duque de Osuna } \\
\end{array}$ & $1656-1694$ & \\
\hline $\begin{array}{c}\text { Francisco } \mathrm{M}^{\mathrm{a}} \text { de Paula } \\
\text { Téllez-Girón y Benavides } \\
(* 1678-\dagger 1716) \\
\text { VI Duque de Osuna }\end{array}$ & $1694-1716$ & \\
\hline $\begin{array}{c}\text { José Téllez-Girón y Benavides } \\
\left({ }^{*} 1685-\dagger 1733\right) \\
\text { VII Duque de Osuna }\end{array}$ & $1720-1733$ & $\begin{array}{l}\text { Obtiene la titularidad de } \\
\text { la Casa el } 17 \text { de Mayo de } \\
1720 \text { tras ganar el pleito } \\
\text { entablado por su cuñada a } \\
\text { la muerte de su hermano, } \\
\text { el VI Duque de Osuna }\end{array}$ \\
\hline $\begin{array}{c}\text { Pedro Zoilo Téllez Girón y Pérez de } \\
\text { Guzmán el Bueno } \\
\left({ }^{*} 1728-\dagger 1787\right) \\
\text { VIII Duque de Osuna }\end{array}$ & $1733-1787$ & $\begin{array}{l}\text { Bajo la tutela de su madre } \\
\text { hasta su mayoría de edad. }\end{array}$ \\
\hline
\end{tabular}




\section{La Casa de Benavente hasta 1787}

La casa nobiliaria de Benavente tiene sus orígenes en la época de la Reconquista. Los estudios más recientes, identifican como fundador de la dinastía al portugués Vasco Martins, apodado "Pimentel", personaje que trabajó en las cortes del rey Alfonso III de Portugal y de Alfonso X de Castilla fallecido durante el sitio de Córdoba en $1283^{46}$.

El Condado de Benavente se fundó en mayo de 1398, tras la concesión de este título por Enrique III a Joâo Alfonso Pimentel como pago a sus servicios en las campañas militares lusas. El II Conde de Benavente Rodrigo Alfonso de Pimentel $(\dagger 1440)$ consiguió ampliar notablemente sus propiedades territoriales. Gracias a su alianza con don Álvaro de Luna y su participación en las principales contiendas del reinado de Enrique IV, incorporó a sus dominios los territorios de Mayorga, Villalón, Gordoncillo, Retuerta, y Sanabria, todo ellos de gran interés por su intensa actividad agrícola, ganadera y mercanti1 ${ }^{47}$. El IV Conde, Rodrigo Alonso Pimentel (†1499), apoyó la causa sucesoria de Isabel la Católica. Sus servicios fueron recompensados por los Reyes Católicos que crearon para él el singular titulo de Conde-Duque de Benavente.

A finales del siglo $\mathrm{XV}$, la familia Pimentel formaba parte del círculo cercano a los reyes, y como tal era uno de los linajes más influyentes de Castilla. Con la llegada de Carlos V a la península, los Condes-Duques de Benavente se incorporaron al selecto grupo de los Grandes de España, y ostentaron importantes cargos en la política y administración del reino. El VI Conde y III Duque de Benavente, Antonio Alfonso Pimentel de Herrera $(* 1514-\dagger 1575)$, mecenas y

\footnotetext{
${ }^{46}$ Simal, Los condes-duques, p. 19.

${ }^{47}$ Sobre los orígenes y formación del condado de Benavente véase Beceiro, El condado.
} 
amante de las artes, fue Virrey y Capitán General del reino de Valencia. Su sucesor, Juan Alfonso Pimentel, ocupó a partir de 1603 el cargo de Virrey de Nápoles y tras su regreso a España formó parte del Consejo de Estado ${ }^{48}$.

El proceso de incorporación de títulos nobiliarios a la Casa de Benavente, se acentuó especialmente a partir de la titularidad del VIII Conde-Duque, Juan Alfonso Pimentel (Ver Tabla 2). Tras el matrimonio de este presonaje con Catalina Vigil de Quiñones, el Condado de Luna se incorporó a la Casa de Benavente. El título de Conde (o Condesa) de Luna fue utilizado habitualmente por el primogénito de la familia Pimentel hasta heredar la titularidad de la Casa.

En el siglo XVII, tras la muerte de Isabel Francisca de Benavides, madre del XII Conde-Duque Francisco Casimiro Pimentel, se incorporaron a la Casa de Benavente los marquesados de Jabalquinto y Villareal. Ya en el siglo XVIII, el importante ducado valenciano de Gandía, con dignidad de Grandeza de España, aumentó la amplia lista de títulos nobiliarios de los Benavente. Tras la muerte en 1740 sin descendencia de Luis Ignacio de Borja, titular de la Casa de Gandía, el ducado y sus extensas posesiones territoriales, se incorporó a la Casa de Benavente $^{49}$. Este título con sus territorios valencianos fue uno de los más estimados la familia Pimentel, ya que les enlazaba con el glorioso pasado de la familia Borgia y con la figura de San Francisco de Borja, que fue exaltado como símbolo y patrón de la Casa especialmente a partir del siglo XVIII ${ }^{50}$.

\footnotetext{
48 Simal, Los condes-duques, pp. 33-51.

49 Ibid.

${ }^{50}$ Sobre las fiestas religiosas celebradas en honor a San Francisco de Borja, véase el Capítulo V.
} 
Tabla 2.

Principales títulos nobiliarios de la Casa de Benavente hasta su unión con la Casa de Osuna en 1787

Fuentes: López de Haro, Nobiliario Genealógico; Simal López, Los condes-duques

\begin{tabular}{|c|c|c|}
\hline TíTULO & $\begin{array}{c}\text { AÑO DE } \\
\text { INCORPORACIÓN }\end{array}$ & OBSERVACIONES \\
\hline Condado de Mayorga & $i ?$ & $\begin{array}{c}\text { Anterior a la fundación de la } \\
\text { Casa de Benavente }\end{array}$ \\
\hline Condado de Benavente & 1398 & \\
\hline Ducado de Benavente & 1473 & $\begin{array}{c}\text { Concedido por Real Decreto } \\
\text { el 28 de Enero de 1473 }\end{array}$ \\
\hline Condado de Luna & 1569 & $\begin{array}{c}\text { Ostentado por los herederos } \\
\text { del Condado Ducado de } \\
\text { Benavente }\end{array}$ \\
\hline $\begin{array}{c}\text { Marquesados de Jabalquinto } \\
\text { y Villareal }\end{array}$ & 1653 & \\
\hline Ducado de Gandía & 1740 & \\
\hline Ducado de Béjar & 1777 & \\
\hline $\begin{array}{c}\text { Ducado de Arcos } \\
\text { Ducaros }\end{array}$ & 1780 & \\
\hline
\end{tabular}

Francisco de Borja Alfonso Pimentel, XIV Conde-Duque de Benavente $(* 1706-\uparrow 1763)$ continuó la labor de expansión de su casa nobiliaria con la obtención para su hija Maria Josefa de los marquesados de Monteagudo, el condado de Osilo y el principado de Anglona ${ }^{51}$. En 1738 Francisco de Borja se desposó con $\mathrm{M}^{\mathrm{a}}$ Faustina Téllez-Girón $(* 1724-\uparrow 1797)$, hija del VII Duque de Osuna, que se convertiría en uno de los personajes centrales de la sociedad madrileña de la segunda mitad del siglo XVIII. María Faustina fue Dama de la Reina desde 1757, y desempeñó la titularidad de la Casa y Estados de Benavente hasta la mayoría de edad de su hija María Josefa ${ }^{52}$.

51 Armas de los duques de Osuna. Su apellido Girón. Ejemplar conservado en el Archivo Histórico Nacional. Citado en Simal, Los condes-duques, p. 30.

52 Pedro Antonio Mugaburu y la Encina, Oración fúnebre hecha en Valencia a las honras de la Excelentísima Condesa Duquesa de Benavente, f. 11v. BNE Ms.11319/12. 
El personaje central de la Casa de Benavente durante la segunda mitad del siglo XVIII y una buena parte del siglo XIX, fue María Josefa Alfonso Pimentel (Lámina 3), XV Condesa y XII Duquesa de Benavente $(* 1751-\uparrow 1834)^{53}$. Fue la heredera única de los títulos y de las extensas propiedades de la Casa de Benavente tras la muerte de su padre Francisco de Borja en $1763^{54}$. Al fallecer su tío Joaquín Diego López de Zúñiga en 1777, la XV Condesa-Duquesa incorporó a sus dominios el ducado de Bejar. Igualmente, a la muerte en 1780 de Antonio Ponce de León, XI Duque de Arcos, y después de numerosos litigios, obtuvo los derechos sucesorios de esta importante casa nobiliaria. La incorporación de la Casa de Arcos y de sus amplios territorios, colocó a la Casa de Benavente entre los primeros propietarios de la nobleza en Andalucía, sólo superada por las extensas propiedades de la Casa de Medina-Sidonia ${ }^{55}$.

\footnotetext{
${ }^{53}$ De aquí en adelante me referiré a este personaje como XV Condesa-Duquesa de Benavente.

${ }^{54}$ Concretamente llegó a poseer los títulos de Condesa-Duquesa de Benavente, Duquesa de Béjar, Arcos, Gandía, Plasencia, Monteagudo, Mandas y Villanueva, Princesa de Anglona y Esquilache, Marquesa de Jabalquinto, Gibraleón, Zahara, Lombay, Terranova y Maquini, Condesa de Mayorga, Bañares, Belalcázar, Bailén, Mayalde, Casares, Oliva, Osilo y Loella. Sobre este personaje puede consultarse la biografía novelada escrita por al Condesa-Duquesa de Yebes basada en gran parte en la documentación conservada en la Sección Nobleza del Archivo Histórico Nacional. Condesa de Yebes, La Condesa-Duquesa de Benavente. Una vida en unas cartas (Madrid: Espasa Calpe, 1958).

55 AHN NOBLEZA, OSUNA-CARTAS, leg 309-9. A pesar del reconocimiento de los derechos sucesorios a favor de la Casa de Benavente en 1780, los litigios por los derechos de la Casa de Arcos se prolongaron durante varios años. En 1784, Pedro Ponce de León, Gobernador de Milán le ofreció a la Condesa-Duquesa de Benavente renunciar a los derechos que le correspondían sobre la Casa de Arcos a cambio de una importante suma económica.
} 


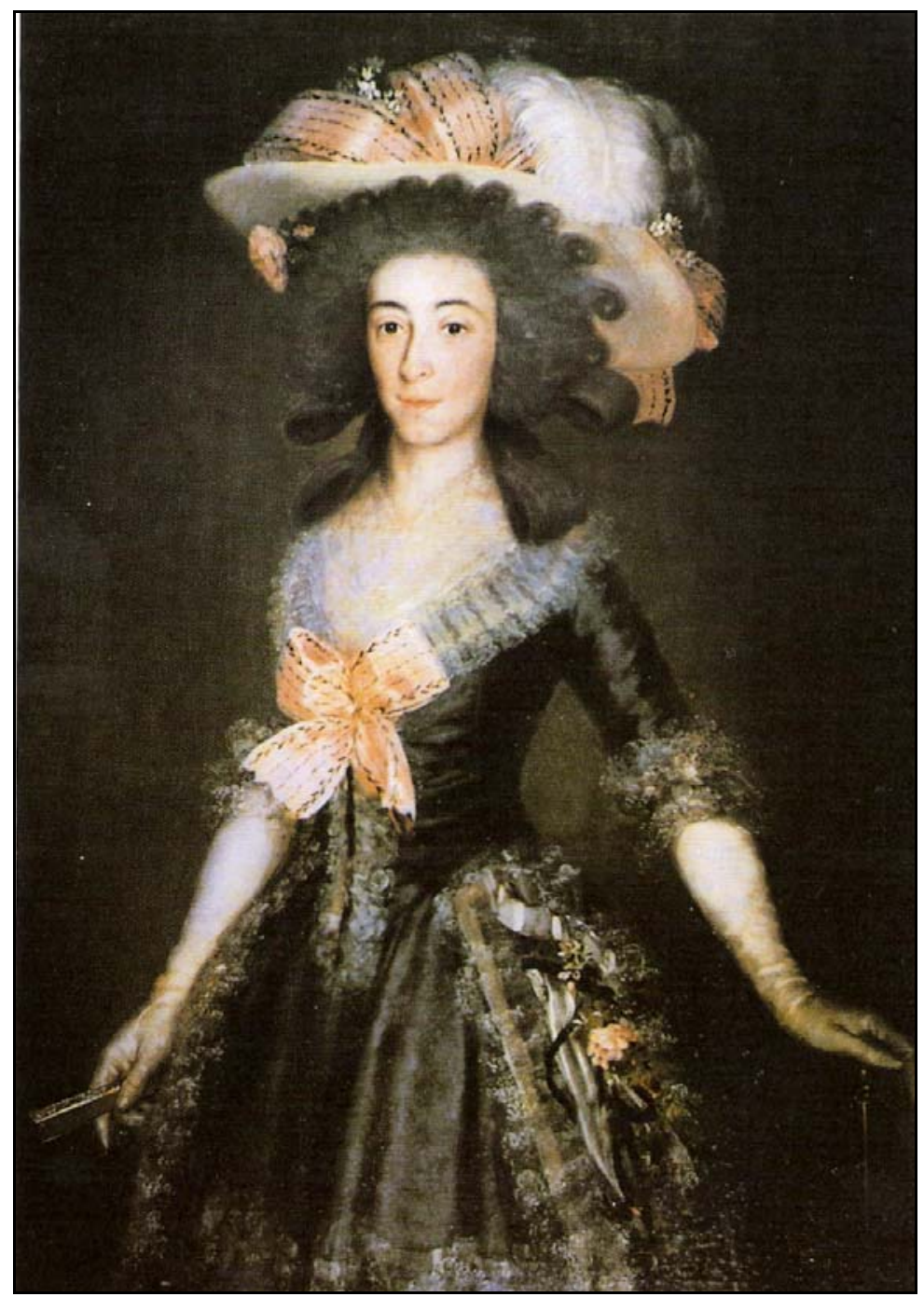

Lámina 3.

Francisco de Goya y Lucientes:

La Condesa-Duquesa de Benavente (1785)

Óleo sobre lienzo, Madrid, colección March,

La política matrimonial endogámica que caracterizó a la nobleza española tenía como objetivo la perpetuación de la clase dominante a través de la acumulación de títulos que posibilitaba la realización de matrimonios pactados entre miembros de importantes familias nobiliarias. Las bodas solían concertarse 
entre familias de similar rango, a veces muy cercanas ${ }^{56}$. El matrimonio en 1771 entre la XV Condesa-Duquesa de Benavente y su primo hermano Pedro de Alcántara Téllez Girón, segundo hijo de los VIII Duques de Osuna (que se convirtió en inesperado heredero de esa Casa nobiliaria tras la prematura muerte del primogénito José María Téllez Girón, IX Marqués de Peñafiel), supuso el primer paso para el enlace efectivo de las importantes Casas de Osuna y Benavente. La unión de ambas casas no se produjo hasta abril de 1787, cuando Pedro de Alcántara Téllez Girón, X Marqués de Peñafiel, heredó la titularidad de la Casa de Osuna tras la muerte de su padre Pedro Zoilo, VIII Duque de Osuna. De este modo, un tanto fortuito, se unieron dos de los linajes más destacados de España en una única administración. Como veremos en el apartado subsiguiente, la unificada Casa de Benavente-Osuna, ocupó un papel fundamental en la sociedad, la economía, la política y la cultura española de las últimas décadas del siglo XVIII y las primeras del XIX.

\footnotetext{
${ }^{56}$ Sobre la importancia de la política matrimonial en la nobleza pueden verse Fernando Sánchez Marroyo, "La mujer como instrumento de perpetuación patrimonial", Norba, Revista de Historia, 8-9 (1987-1988), pp. 207-213 e Ignacio Atienza, "Las mujeres nobles: Clase dominante, grupo dominado. Familia y orden social en el Antiguo Régimen", Actas de las IV Jornadas de Investigación Interdisciplinaria: ordenamiento jurídico y realidad social de la mujer, (Madrid: Instituto Universitario de Estudios de la Mujer, 1986), pp. 140-167.
} 


\section{Las Casas de Osuna y Benavente desde 1787 hasta la actualidad}

\subsection{Las Casas de Osuna y Benavente entre 1787 y 1807}

La titularidad de la Casa de Osuna fue ostentada a partir de abril de 1787 por Pedro de Alcántara Téllez Girón, Marqués de Peñafiel, quien desde su boda con la XV Condesa-Duquesa de Benavente fue también conocido por los títulos de Conde-Duque de Benavente, Bejar y Gandía, que pertenecían a su esposa ${ }^{57}$.

Pedro de Alcántara Téllez Girón había nacido en Madrid el 8 de agosto de 1755. Hasta la muerte de su hermano mayor en 1771, ostentó el título de Conde de Fontanar que solía concederse al segundogénito de la Casa de Osuna ${ }^{58}$. Desde muy joven, Pedro de Alcántara desarrolló una importante actividad pública. En 1772 participó junto con otros nobles en el cortejo que, encabezado por el Duque de Arcos, el rey Carlos III envió a Nápoles para festejar el nacimiento de su nieta María Teresa Carlota ${ }^{59}$. Gran parte de la actividad pública del futuro IX Duque de Osuna se desarrolló en el ámbito militar donde, siguiendo la tradición familiar, ocupó importantes cargos llegando a alcanzar el grado de Coronel del Regimiento de Reales Guardias Españolas de Infantería ${ }^{60}$ y Director General del Supremo Consejo de la Guerra. El futuro IX Duque de Osuna inició desde muy joven la carrera militar en el Regimiento de Guardias Españolas. Como Coronel del

\footnotetext{
${ }^{57} \mathrm{Su}$ esposa, la Condesa-Duquesa de Benavente, también aparece citada en ocasiones con el título de "Marquesa de Peñafiel” Véase por ejemplo AHN, NOBLEZA, OSUNA-CARTAS, leg 458.

58 Así aparece citado, por ejemplo, en una memoria de los gastos extraordinarios y limosnas del VIII Duque de Osuna de julio y agosto de 1766. AHN, NOBLEZA, OSUNA-CARTAS, leg 452.

${ }^{59}$ Yebes, La Condesa-Duquesa, p.10.

${ }^{60}$ Con motivo de la Guerra de la Convención Francesa en 1793, el IX Duque de Osuna creó seis compañías de cazadores artilleros de Reales Guardias Españolas de Infantería que fueron organizadas, armadas y vestidas a su costa. Véase Emilio Becerra de Becerra, "El ejercito Español desde 1788 hasta 1802”, Revista de Historia Militar, 56 (1984), p. 108.
} 
Regimiento de Infantería de América combatió en el infructuoso asedio de la plaza de Gibraltar que finalizó en 1781. Tras la derrota en esta plaza, se dirigió con su batallón a Menorca que estaba en poder de los ingleses. A las órdenes del Duque de Crillón, Pedro de Alcántara participó en la toma de Mahón y en otras batallas contra los ingleses que permitieron recuperar para la corona española la isla balear. En 1782, durante su estancia en Menorca, falleció en Madrid su hijo Pedro Ramón de cuatro años de edad, tras lo cual su esposa $\mathrm{M}^{\mathrm{a}}$ Josefa viajó hasta esta isla. El matrimonio residió en Menorca hasta principios de 1783 cuando se trasladó a Barcelona, lugar al que había sido destinado el Regimiento de Infantería de América. El 17 de agosto de 1783 nació en la Ciudad Condal Josefa Manuela, la primera hija de los Condes-Duques que sobrevivió más allá de la niñez. En noviembre del mismo año la Condesa-Duquesa María Josefa regresó a Madrid ${ }^{61}$.

Paralelamente a su actividad militar, el futuro IX Duque de Osuna participó activamente en la vida cortesana. Desde 1780 ocupó el puesto de Gentilhombre de Cámara, primero con Carlos III y a la muerte de este con su sucesor Carlos IV ${ }^{62}$.

Cuando falleció su padre en 1787, Pedro de Alcántara heredó los títulos y las propiedades de la Casa de Osuna. En los años siguientes prosiguió su carrera militar. Desde el año 1791 fue Teniente General, y con esta graduación intervino en la llamada Guerra de la Convención (1793-1795) contra Francia. A pesar de sus numerosos méritos militares, el IX Duque de Osuna no llegó a alcanzar la máxima graduación militar, posiblemente por su manifiesta enemistad con la reina

\footnotetext{
${ }^{61}$ Yebes, La Condesa-Duquesa, pp.22-31. Sobre los festejos que tuvieron en la villa de Benavente para celebrar el nacimiento de la hija primogénita de los Condes-Duques véase el Apéndice $6, \mathrm{n}^{\circ}$ 48.

${ }^{62}$ AHN NOBLEZA, OSUNA-CARTAS, leg 335.
} 
Maria Luisa de Parma y con su valido Godoy ${ }^{63}$.

En 1798, Pedro de Alcántara fue nombrado por el rey embajador en Viena, una maniobra que posiblemente intentaba alejarle de la Corte debido a sus ideales políticos. Hacia 1798, seguramente con ocasión de su nombramiento como embajador $^{64}$, el IX Duque de Osuna fue retratado por Francisco de Goya (Lámina 4). Antes de salir de Madrid, la prensa parisina desató rumores sobre posibles sentimientos anglófilos del Duque, acusándolo de haber acogido y ayudado a numerosos emigrados franceses amigos suyos. Estas injurias fueron respondidas por el Duque en un memorial dirigido al rey donde negó las acusaciones y solicitó ser resarcido por los que consideraba como infundios ${ }^{65}$. Finalmente el asunto se moderó con la intervención del embajador español Nicolás José de Azara.

La familia Benavente-Osuna partió de Madrid el 26 de enero de 1799 y llegó a París el 5 de marzo de 1799, instalándose en el palacio de los Duques del Infantado a la espera de órdenes para trasladarse a Viena, un traslado que nunca se produjo debido a los cambios en la política de Austria respecto a Francia y consecuentemente contra su aliada España.

\footnotetext{
${ }^{63}$ Francisco Javier Gutiérrez Núñez, "El IX Duque de Osuna: Político, militar y mecenas (17551807)", Milicia y Sociedad Ilustrada en España y América, Actas de las XI Jornadas Nacionales de Historia Militar, organizada por la Cátedra General Castaños de la Región Militar Sur (Sevilla: Demus, 2003), pp.103-120.

${ }^{64}$ Fernando Regueras Grande, Pimentel, fragmentos de una iconografia (Benavente: Centro de Estudios Benaventanos Ledo del Pozo, 1998) p. 97.

65 AHN NOBLEZA, OSUNA-CARTAS, leg 3-26. Pasaporte al Duque de Osuna para ir a Viena de embajador.
} 


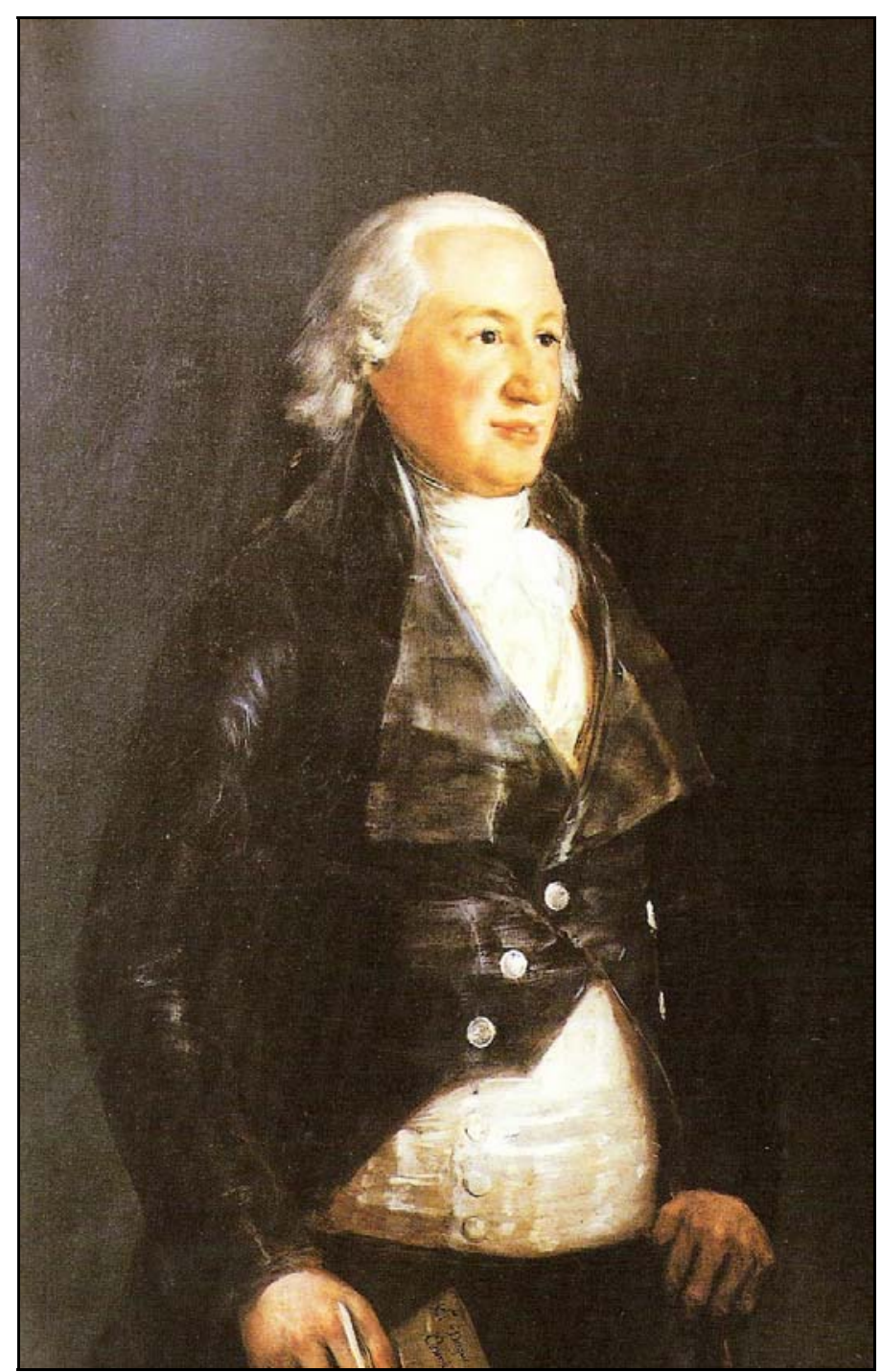

Lámina 4.

Francisco de Goya y Lucientes:

El IX Duque de Osuna (ca. 1798)

Óleo sobre lienzo, Nueva York, Colección Frick.

Tras meses de espera, en junio de 1799 el IX Duque de Osuna fue nombrado Inspector de los ejércitos del Rin con la misión de informar de los movimientos y operaciones de las tropas francesas en la citada zona ${ }^{66}$. Finalmente, a petición del propio Duque, se le concedió la licencia necesaria para volver a España. La familia Benavente-Osuna partió de París el 4 de diciembre de 1799 y ${ }^{66}$ AHN, NOBLEZA, OSUNA-CARTAS, leg 306-1. Yebes, La Condesa-Duquesa, pp. 160-187. 
llegó a Madrid el 7 de enero de $1800^{67}$.

La política y el ejército no fueron los únicos intereses de Pedro de Alcántara. Durante su juventud participó en los proyectos reformistas ilustrados promovidos por la monarquía borbónica. Presidió la Sociedad Económica de Amigos del País de Madrid desde su fundación en 1775. En 1786 ingresó en esta sociedad su esposa la Condesa-Duquesa de Benavente ${ }^{68}$, que además fue una de las promotoras y la primera presidenta de la Junta de Damas, entidad que se creó en 1787 a iniciativa de Carlos III dentro de la Sociedad Económica de Amigos del País de Madrid para intentar transformar la situación económica de los más necesitados de la sociedad. Esta institución, en la que participaron las principales representantes de la nobleza de la capital, tuvo como fin sustituir el antiguo ideal de la caridad cristiana por un moderno concepto de la asistencia social ${ }^{69}$.

En este ambiente ilustrado se enmarca también el interés por la literatura y el coleccionismo de libros de los novenos Duques de Osuna y Condes Duques de Benavente. Pedro de Alcántara fue desde 1787 miembro honorario de la Real Academia Española, y en 1793 se incorporó como miembro de número. Los Duques de Osuna fueron propietarios de una de las bibliotecas privadas más

${ }^{67}$ Yebes, La Condesa-Duquesa pp. 160-187.

${ }^{68}$ Discurso que la Excelentísima Señora Condesa Duquesa de Benavente, Marquesa de Peñafiel, hizo a la Real Sociedad Económica de Madrid el día de su recepción 22 de Julio de 1786 (Madrid: Antonio de Sancha, [s.f.]).

${ }^{69}$ Entre los proyectos más importantes de la Junta de Damas estuvo la administración de la Inclusa de Madrid que, gracias a las mejoras introducidas por esta asociación en alimentación, limpieza y educación consiguió reducir notablemente los altos índices de mortalidad infantil de sus residentes. Sobre la labor de esta Junta véase María del Carmen Iglesias, "La nueva Sociabilidad: mujeres nobles y salones literarios y políticos”, en María del Carmen Iglesias (coord.), Nobleza y Sociedad en la España Moderna I (Oviedo: Fundación Central Hispano y Ediciones Nobel, 1997), pp. 203-215; y Paula Demerson: Catálogo de Socias de honor y mérito de la Junta de Damas matritense (Madrid: Instituto de Estudios madrileños, 1971). 
importantes de Europa cuyos orígenes se remontaban al siglo XVII. En las capitulaciones de la boda del V Duque de Osuna con Ana de Benavides, se estipuló la aportación como dote por parte de la novia de una biblioteca que contenía varios cientos de volúmenes ${ }^{70}$. Este fondo se fue incrementando con la compra de libros que se hacían traer de distintos puntos de Europa y, ya en el siglo XIX, con la incorporación de la biblioteca de la Casa del Infantado, una de las más ricas de España ${ }^{71}$. Antes de su venta y dispersión a finales del siglo XIX ${ }^{72}$, la Biblioteca de la Casa de Osuna conservaba, además de otras joyas bibliográficas, varios códices florentinos de los siglos XIV y XV, una importante colección de Biblias (entre las cuales figuraba un ejemplar de la Biblia Complutense) e innumerables manuscritos de obras teatrales con los textos de autos, loas, comedias zarzuelas, entremeses, mojigagangas, bailes y fines de fiesta $^{73}$.

Además de esta afición por la literatura, Pedro de Alcántara y su esposa Maria Josefa mantuvieron a lo largo de su vida una intensa labor de apoyo de las artes, las letras y las ciencias, que les convirtió en uno de los mecenas y

\footnotetext{
${ }^{70}$ Atienza, Aristocracia, p. 278.

${ }^{71}$ AHN, NOBLEZA, OSUNA, legs. 3445-2 y 3521. Estos legajos conservan numerosos documentos de compra de libros y encuadernaciones realizadas en el período 1789 a 1794, y un Inventario de la Biblioteca del Duque de Osuna fechado en 1823. Sobre los fondos de interés musical que figuraban en esta biblioteca véase el Capítulo IV.

72 Una parte de estos fondos que fueron adquiridos por el Estado tras la quiebra de la Casa de Osuna a finales del siglo XIX están repartidos entre la Biblioteca Nacional de Madrid, la Biblioteca del Senado, la Biblioteca de la Universidad Complutense de Madrid y la Biblioteca de la Universidad de Granada. También se conservan algunas obras manuscritas en AHN, NOBLEZA- OSUNA.

73 Un catálogo alfabético de esta biblioteca realizado a finales del siglo XVIII y actualizado durante el siglo XIX se conserva en la BNE bajo las signaturas Mss 10958-10983. Sobre los manuscritos véase Jose María Rocamora, Catálogo Abreviado de los manuscritos de la Biblioteca del Señor Duque de Osuna e Infantado (Madrid: Imprenta de Fortanet, 1882).
} 
patrocinadores de artistas y científicos más activos de la nobleza española de la segunda mitad del siglo XVIII ${ }^{74}$.

En su residencia madrileña situada en la Puerta de la Vega, muy cerca del Palacio Real, la Condesa-Duquesa María Josefa mantuvo uno de los salones más activos de la Villa y Corte, por el cual pasó lo más selecto de la cultura y el arte de su época. Su casa fue escenario de frecuentes fiestas, academias musicales y saraos nocturnos. Ramón de la Cruz, Bernardo y Tomás de Iriarte y Leandro Fernández de Moratín, entre otros, participaron en las tertulias, donde se discutía e literatura, política o de la faena más reciente del torero en boga, y se escuchaba música ejecutada por algunos de los más destacados intérpretes europeos ${ }^{75}$.

La actividad del salón de la Condesa-Duquesa de Benavente se trasladaba en ocasiones al ámbito campestre. Siguiendo la moda cortesana de amor a la naturaleza, la Condesa-Duquesa adquirió en 1783 una finca situada a las afueras de Madrid, donde se hallaba el castillo de la Alameda, que había sido lugar de prisión de Pedro Girón, III Duque de Osuna. En estos terrenos mandó construir un palacete de estilo neoclásico, rodeado por jardines y estanques en cuya decoración participaron los más importantes artistas de la época. El Palacio de la Alameda, llamado por la Condesa "El Capricho", fue un importante centro de diversión de la aristocracia madrileña en la última década del siglo XVIII y las primeras del siglo $\mathrm{XIX}^{76}$.

\footnotetext{
${ }^{74}$ Véase el punto 5 de este capítulo.

${ }^{75}$ Sobre la actividad musical de los salones de la Condesa-Duquesa véase el capítulo VII.

${ }^{76}$ Sobre la construcción de este palacio véase Pedro Navascués, Antecedentes de la Alameda de Osuna (Madrid, COAM, 1977); y Carmen Añón Feliu y Mónica Luengo, El Capricho de la Alameda de Osuna (Madrid : Ayuntamiento de Madrid, Área de Medio Ambiente, 2003).
} 
La Condesa-Duquesa también organizó actividades culturales en otras localidades cercanas a Madrid durante las llamadas Jornadas Reales, períodos en los que la Corte se desplazaba a los Palacios Reales de San Lorenzo, San Ildefonso, Aranjuez y El Pardo dando lugar a un increíble trasiego de miles de personas que acompañaban a los monarcas y que se solían alojar en los pueblos adyacentes $^{77}$. Para remediar la escasez de alojamiento que se daba en las localidades donde se establecía la Corte, los IX Duques de Osuna adquirieron en 1787 una vivienda en la calle del Príncipe de Aranjuez, muy cercana al Palacio Real, que sería su residencia durante los períodos primaverales en la que se celebraron numerosas fiestas y academias musicales ${ }^{78}$.

El IX Duque de Osuna falleció en Madrid el 7 enero de 1807. Tras la invasión francesa y ante el temor de la llegada de Bonaparte a la capital, su viuda la Condesa Duquesa de Benavente, abandonó Madrid y se trasladó con sus hijas y nietos, primero a Sevilla donde ya residía en junio de 1809 y después a Cádiz, ciudad en la que se instaló gran parte de la alta nobleza española durante la Guerra de la Independencia y en la que residió la Condesa-Duquesa con sus hijos hasta los últimos meses de $1813^{79}$.

La invasión francesa contribuyó al progresivo deterioro económico de las Casas de Osuna y Benavente debido a la escasez de rentas percibidas durante este período y a la destrucción de algunas de sus propiedades más importantes. En diciembre de 1808 la fortaleza de Benavente, símbolo de esta casa nobiliaria, fue

\footnotetext{
${ }^{77}$ Una parte importante de la correspondencia de los Duques de Osuna durante la segunda mitad del siglo XVIII, está escrita desde Aranjuez, San Ildefonso o San Lorenzo del Escorial.

78 AHN, NOBLEZA OSUNA leg 3516. El llamado "Palacio de Osuna"de Aranjuez de líneas sobrias y clásicas aún se conserva.

${ }^{79}$ Ibid., pp. 232- 259
} 
incendiada por las tropas francesas:

[...] todo el suntuoso edificio de la Fortaleza se redujo a cenizas y pavesas, con cuanto había dentro de ella muy exquisitos y por consiguiente se consumieron y abrasaron la contaduría, archivo, estantes, papeles, y más muebles ricos y preciosos que se contenían en dicha contaduría y fortaleza ${ }^{80}$

Con la destrucción de la fortaleza de Benavente desapareció gran parte de la documentación administrativa de esta Casa y de los referentes culturales y artísticos que la familia había reunido durante siglos en su villa solariega.

De los ocho hijos de los IX Duques de Osuna, sólo cinco superaron la niñez, tres mujeres y dos varones ${ }^{81}$. Las mujeres contrajeron matrimonio con destacados personajes de la nobleza española. La primogénita Josefa Manuela (*1783-†1817), nacida durante la estancia de sus padres en Barcelona, ostentaba por línea familiar el título de Condesa de Osilo, y tras su matrimonio con Joaquín María Gayoso de los Cobos fue conocida por el título de Marquesa de Camarasa. Su hermana Joaquina María (1785-1851) casada desde 1801 con José Gabriel Silva Bazán, Marqués de Santa Cruz, ha pasado a la historia gracias al retrato de espíritu clasicista realizado en 1805 por Francisco de Goya. En esta excelente pintura, la Marquesa de Santa Cruz aparece recostada en un diván sosteniendo una guitarra-lira que simboliza su gran afición musical (Lámina 5).

\footnotetext{
${ }^{80}$ AHN, NOBLEZA, OSUNA-CARTAS, leg 340.

${ }^{81}$ AHN, NOBLEZA, OSUNA, leg 450 bis- 63.
} 


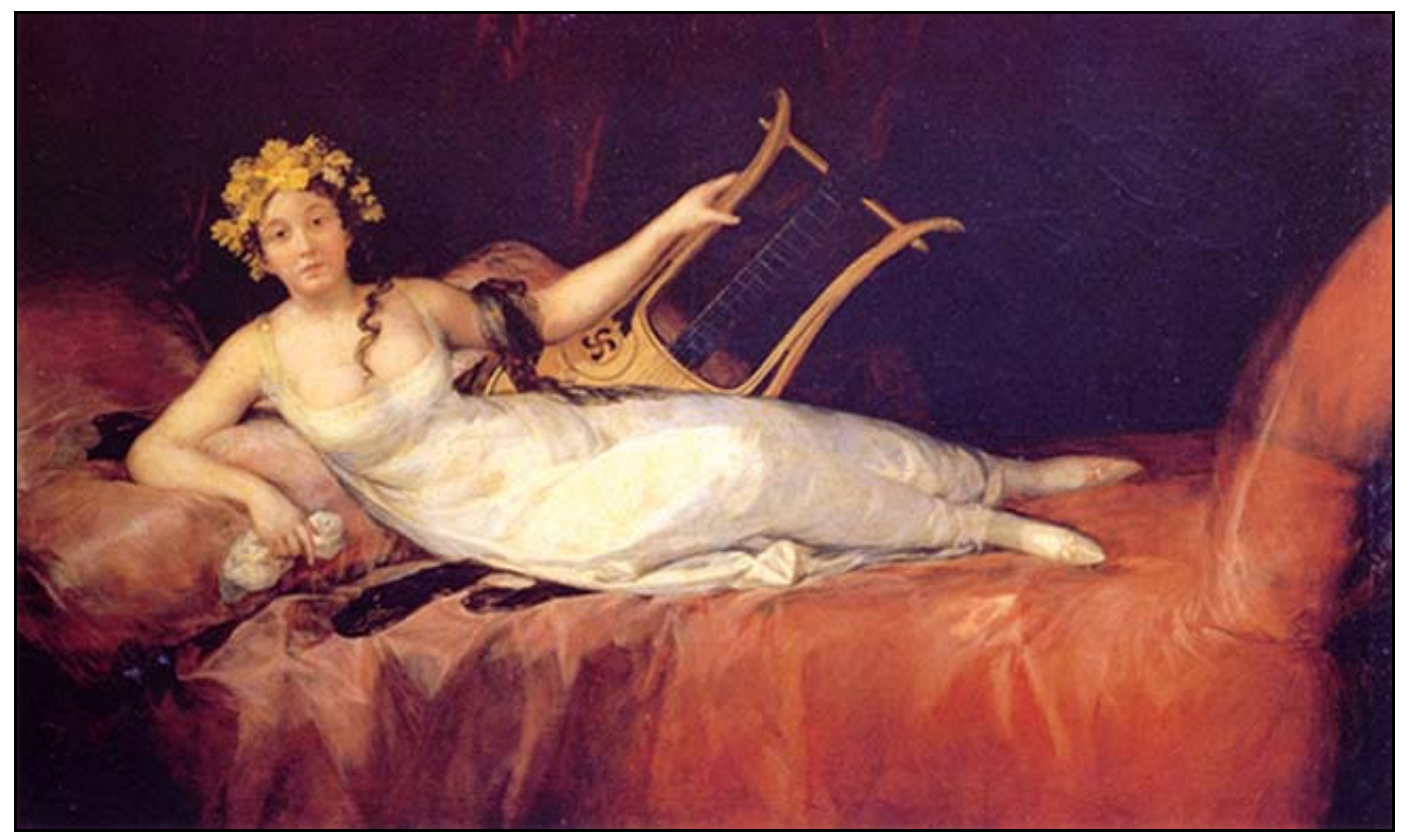

\section{Lámina 5.}

Francisco de Goya y Lucientes:

La Marquesa de Santa Cruz (1805)

Óleo sobre lienzo, Madrid, Museo del Prado.

La tercera de las hijas de los IX Duques de Osuna, Manuela Isidra, condesa de Coguinas $(* 1794-\uparrow 1838)$ se desposó con el Duque de Abrantes. También fue retratada por Goya, en una excelente y colorista obra en la que se evoca su gran afición a la música vocal (Lámina 6). 


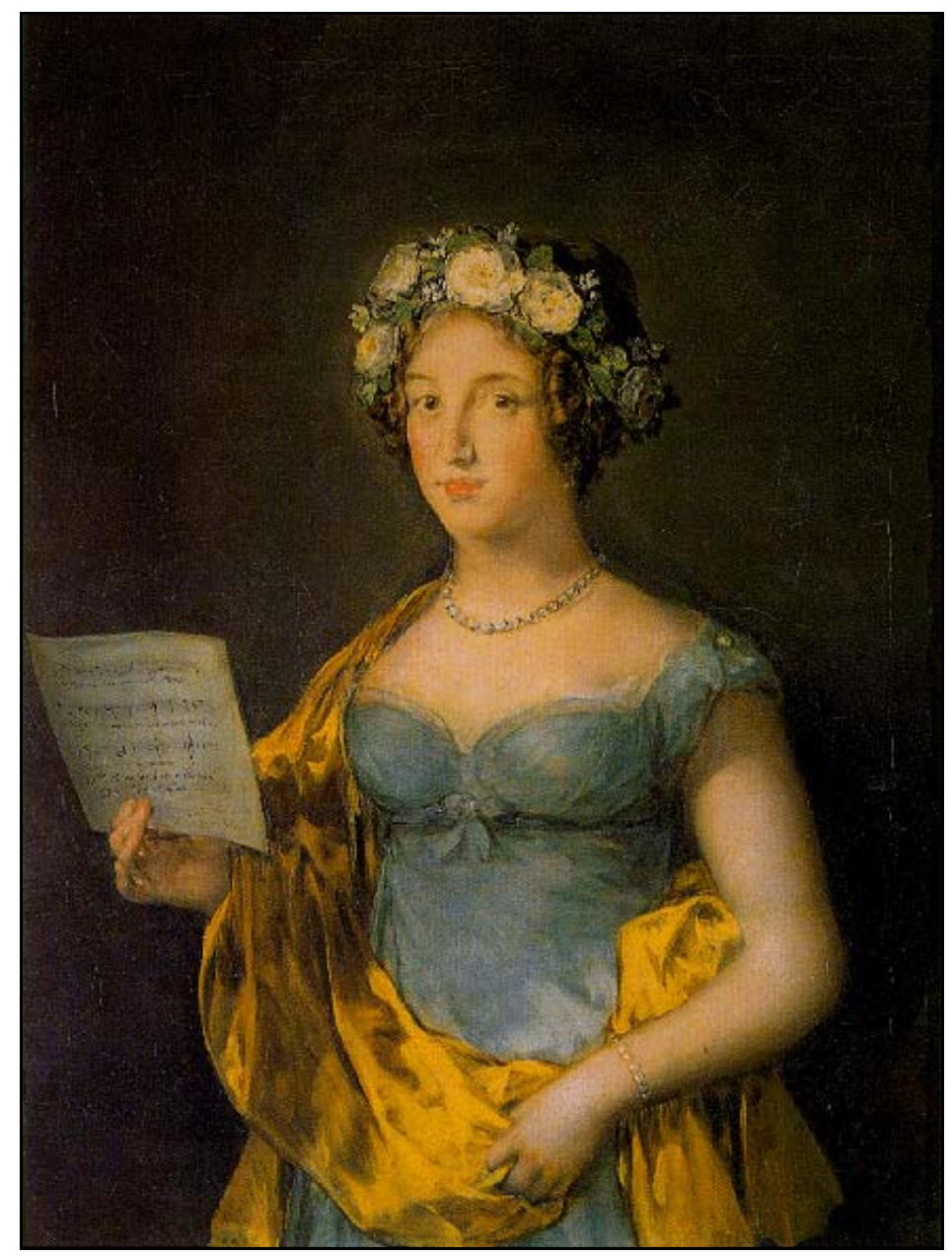

Lámina 6.

Francisco de Goya y Lucientes:

La Duquesa de Abrantes (1816)

Óleo sobre lienzo, Madrid, Museo del Prado.

En cuanto a los hijos varones de los IX Duques de Osuna, el menor de ellos, Pedro de Alcántara $(* 1787-† 1851)$ heredó por vía materna el título de Príncipe de Anglona y ostentó asimismo, el de Marqués de Jabalquinto. Su posición de segundón le dejaba muy pocas posibilidades para heredar los mayorazgos y privilegios de la casa ducal debido al rígido esquema hereditario imperante en la nobleza de la época, por lo que se dedicó intensamente a su carrera militar. Fue Capitán agregado del Regimiento de Infantería de América, 
Teniente Coronel de Dragones de la Reina y en 1808 fue nombrado Coronel del Regimiento de Pavía.

Durante la Guerra de Independencia, el Príncipe de Anglona intervino, entre otras, en las batallas de Bailén, Tamames, Talavera y, Chiclana y fue condecorado por ello con la Gran Cruz de la Real y Militar Orden de San Fernando. En la época del Trienio Liberal ocupó los cargos de Coronel del Primer Regimiento de Reales Guardias de Infantería y Consejero de Estado, lo que le obligó a exilarse tras la vuelta al poder de Fernando VII ${ }^{82}$.

\subsection{Las Casas de Osuna y Benavente desde 1807}

A la muerte de Pedro de Alcántara en 1807, la titularidad de la Casa de Osuna pasó a su hijo varón primogénito Francisco de Borja Bruno Téllez Girón y Alfonso Pimentel $(* 1786-\uparrow 1820)$. De este modo, la administración de la Casa de Osuna se separó de la de Benavente, cuyos títulos continuaron en poder de la Condesa-Duquesa María Josefa hasta su muerte en 1834 (Ver Tabla 3).

Francisco de Borja Téllez Girón, X Duque de Osuna, ocupó los cargos palaciegos de Gentilhombre de Cámara de los reyes Carlos IV y Fernando VII. En su corta vida, desarrolló también una intensa carrera militar como Primer Teniente del Regimiento de Reales Guardias de Infantería Española y Teniente Coronel del Regimiento de Voluntarios de la Corona. En 1802, el X Duque de Osuna contrajo matrimonio con la Condesa Marie-Françoise-Philippine Beaufort-Spontin y Álvarez de Toledo $(* 1785-\uparrow 1830)$, con quien tuvo dos hijos varones que

\footnotetext{
82 Sobre este personaje existe una interesante biografía realizada por su amigo personal Manuel, Pando, Marqués de Miraflores. Manuel Pando Fernández de Prado, Biografía del Excelentísimo Señor Pedro Téllez Girón, Príncipe de Anglona (Madrid: José Rodríguez, 1851).
} 
heredarían sucesivamente la titularidad de la Casa de Osuna.

Tabla 3.

Titulares de las Casas de Osuna y Benavente (1720-1900)

Fuentes: AHN NOBLEZA,OSUNA, leg 450-bis y leg 1953-14. Atienza, Aristocracia y poder...

\begin{tabular}{|c|c|c|}
\hline AÑNOS & CASA DE OSUNA & CASA DE BENAVENTE \\
\hline $1720-1733$ & $\begin{array}{l}\text { José Téllez-Girón } \\
\text { VII Duque de Osuna }\end{array}$ & \multirow[t]{2}{*}{$\begin{array}{l}\text { Antonio Alfonso Pimentel, } \\
\text { XIII Conde-Duque (1709-1743) }\end{array}$} \\
\hline \multirow[t]{2}{*}{$1733-1787$} & \multirow{2}{*}{$\begin{array}{l}\text { Pedro Zoilo Téllez-Girón, } \\
\text { VIII Duque de Osuna }{ }^{83}\end{array}$} & \\
\hline & & $\begin{array}{l}\text { Francisco Alfonso Pimentel } \\
\text { XIV Conde-Duque (1743-1763) }\end{array}$ \\
\hline $1787-1807$ & $\begin{array}{c}\text { Pedro de Alcántara Téllez-Girón y } \\
\text { Pacheco } \\
\text { IX Duque de Osuna }\end{array}$ & \multirow[t]{3}{*}{$\begin{array}{c}\text { María Josefa Alfonso Pimentel } \\
\text { XV Condesa-Duquesa de Benavente } \\
(1763-1834)^{84}\end{array}$} \\
\hline $1807-1820$ & $\begin{array}{c}\text { Francisco de Borja Téllez-Girón } \\
\text { X Duque de Osuna }\end{array}$ & \\
\hline $1820-1834$ & \multirow[t]{2}{*}{$\begin{array}{c}\text { Pedro de Alcántara Téllez-Girón } \\
\text { y Beaufort } \\
\text { XI Duque de Osuna }\end{array}$} & \\
\hline $1834-1844$ & & XVI Conde-Duque de Benavente \\
\hline $1844-1882$ & \multicolumn{2}{|c|}{$\begin{array}{c}\text { Mariano Téllez-Girón y Beaufort } \\
\text { XII Duque de Osuna y XVII Conde-Duque de Benavente }\end{array}$} \\
\hline $1882-1900$ & \multicolumn{2}{|c|}{$\begin{array}{l}\text { Pedro de Alcántara Téllez-Girón y Fernández Santillán } \\
\text { XIII Duque de Osuna y XVIII Conde-Duque de Benavente }\end{array}$} \\
\hline
\end{tabular}

Uno de los momentos de mayor esplendor en la posesión de territorios de la Casa de Osuna tuvo lugar durante la titularidad de Pedro de Alcántara TéllezGirón y Beaufort (*1809-†1844), hijo primogénito y sucesor del X Duque de Osuna (Lámina 7) ${ }^{85}$.

${ }^{83}$ Bajo la tutela de su madre hasta la mayoría de edad.

${ }^{84}$ Ibid.

${ }^{85}$ Pedro de Alcántara Téllez-Girón y Beaufort nació en Cádiz el 10 de septiembre de 1809, y no en 1810 como se cita en muchos de los estudios realizados hasta la fecha. Una copia de su partida de bautismo se conserva en la Biblioteca del Senado (Madrid) bajo la signatura HIS-0326-02. 


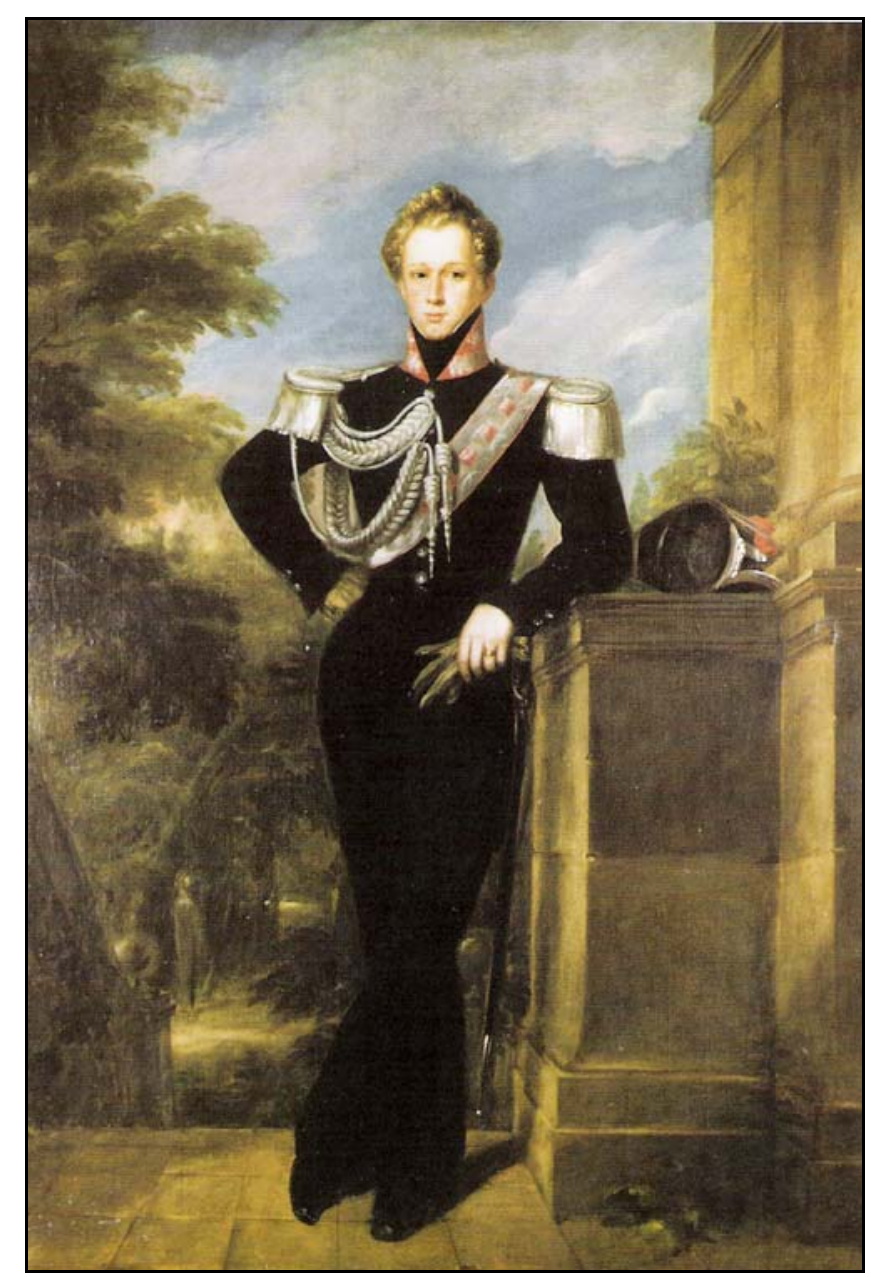

\section{Lámina 7.}

Valentín Carderera

Pedro de Alcántara Téllez Girón (ca.1825)

Óleo sobre lienzo, Madrid, Museo Romántico.

Además de los títulos propios de la Casa de Osuna, Pedro de Alcántara II $^{86}$ heredó en 1834 los de la Casa de Benavente tras la muerte de su abuela paterna la Condesa-Duquesa María Josefa. De este modo se unieron de nuevo las

\footnotetext{
${ }^{86}$ De aquí en adelante me referiré a este personaje como Pedro de Alcántara II para distinguirlo de su abuelo Pedro de Alcántara Téllez Girón y Pacheco, IX Duque de Osuna. Los datos biográficos del XI Duque proceden de Antonio Marichalar, Riesgo y ventura del Duque de Osuna, (Madrid: Espasa Calpe, 1930). Pese a la ampulosidad de su estilo y a la prosa impostada que destila toda la obra, en el prólogo de la edición de 1933 el autor certifica que el contenido de este libro es veraz y "rigurosamente histórico".
} 
administraciones de las Casas de Osuna y Benavente (Ver Tabla 3). Años mas tarde, tras la muerte en 1841 sin herederos directos de su tío abuelo Pedro de Toledo y Salm-Salm, Duque del Infantado ${ }^{87}$, pasaron a la Casa de Osuna los numerosos títulos y propiedades de este ducado, uno de los más importantes de la nobleza española que incluía además los destacados títulos de Duque de Lerma, Medina de Rioseco, Pastrana, y Cenete, entre otros. De este modo Pedro de Alcántara II se convirtió en cuatro veces Grande de España, y la Casa de Osuna amplió sus dominios a gran parte de la Península Ibérica a los que se sumaban las posesiones de Caller y Cagliari en Italia ${ }^{88}$.

En el terreno político, el XI Duque de Osuna fue Senador del Reino en las legislaturas de 1834 y 1836, y estuvo siempre al lado de los moderados, lo que le obligó en 1837 a expatriarse temporalmente en Bélgica e Italia por negarse a jurar la Constitución ${ }^{89}$. Personaje elegante y refinado, una de sus aficiones más notorias fue la hípica. Pedro de Alcántara II, fundó la Sociedad de Fomento de la Cría Caballar y mantuvo en los terrenos de La Alameda una cuadra de caballos ingleses. En los terrenos de este palacio lugar la primera carrera de caballos que se celebró en España ${ }^{90}$.

\footnotetext{
${ }^{87}$ Era el hermano de su abuela materna María Dolores Leopolda de Toledo y Salm-Salm

${ }^{88}$ La extensión de los dominios de las Casas de Osuna en España en esta época puede verse en los mapas elaborados por Ignacio Atienza. Véase Atienza, Aristocracia, pp.390-394.

${ }^{89}$ Marcial Antonio López, Exposición en defensa del Duque de Osuna, contra el decreto de Isabel II de 16 de septiembre que le considera incurso en la pena de Secuestro de bienes por haber salido para país extranjero sin autorización y solicitud de permanencia por tiempo de un año en Bélgica e Italia a favor del mismo.([s.1.]: [s.n], 1836).

${ }^{90}$ El interés por la hípica del XI Duque de Osuna se plasmó en el excelente retrato a caballo que en 1844 realizó Federico de Madrazo, conservado actualmente en una colección privada de Madrid. Una reproducción puede verse en Regueras, Pimentel, p. 123.
} 
Continuando con la tradición familiar, y especialmente con la de su abuela paterna la Condesa-Duquesa de Benavente, con quien se educó y convivió en los primeros años de su vida, Pedro de Alcántara II recibió en su niñez una esmerada educación artística. Fue uno de los personajes habituales de las reuniones aristocráticas de los salones madrileños donde participó como cantante o recitador de poemas, protegió a numerosos artistas plásticos, músicos y literatos, y hasta su muerte en 1844 presidió el Liceo Artístico y Literario de Madrid fundado por iniciativa de un grupo de importantes aristócratas y personajes de la alta sociedad madrileña.

El XI Duque de Osuna murió prematuramente en 1844 de un ataque al corazón. En palabras de Antonio Marichalar fue "el doncel más gallardo de la época; el que, por su donaire, por sus prendas, por sus títulos y hasta por su fortuna constituye [en su época] quizá el mejor partido de Europa"91.

\subsubsection{La titularidad del XII Duque de Osuna. Quiebra y enajenación del patrimonio ducal}

Con la temprana muerte del XI Duque, Pedro de Alcántara II, sin herederos, la titularidad de las Casas de Osuna y Benavente pasó a su hermano Mariano Téllez-Girón y Beaufort-Spontin $(* 1814-\uparrow 1882)^{92}$. Personaje fascinante y calamitoso según Marichalar ${ }^{93}$, el XII Duque heredó la mayor fortuna del país, y fue capaz de dilapidarla despreocupándose de la administración de su patrimonio, lo que unido a una vida de lujo y derroche contribuyó a que la crisis en la que se

\footnotetext{
91 Marichalar, Riesgo y ventura, p.27.

92 Además de XII Duque de Osuna Mariano Téllez Girón fue, entre otros numerosos títulos nobiliarios menores, XVII Conde y XIV Duque de Benavente, XIV Duque de Arcos, XVII de Medina de Rioseco, XVI de Gandía, XIV de Béjar, XIV del Infantado, XII de Lerma.

93 Los datos biográficos del XII Duque proceden de Marichalar, Riesgo y ventura.
} 
veía envuelta desde el siglo XVIII la Casa de Osuna, se acentuase hasta desembocar en su disolución y quiebra definitiva ${ }^{94}$.

El derroche y suntuosidad del estilo de vida del XII Duque de Osuna fue proverbial, especialmente durante en los diez años de su permanencia como ministro plenipotenciario y embajador en Rusia (1856-1866). Su fama de despilfarrador llegó a tal punto que una frase típica del español decimonónico para alguien demasiado ostentoso era: “¡Ni que fuera Osuna!”. En 1866, casó con Maria Leonor Crescencia, princesa de Salm y Salm y del Santo Imperio Romano, y se trasladó a su palacio de Beauraing, en Belgica, donde también poseía títulos y tierras.

Como militar, el XII Duque de Osuna intervino en alguna de las contiendas bélicas más importantes de su época. Participó en la primera guerra civil carlista en el bando de Isabel II, fue Ayudante de Campo del General Espartero y alcanzó el grado de Teniente General en 1863. El XII Duque de Osuna falleció en su palacio de Beuaraing, provincia de Namur (Bélgica) el dos de julio de 1882, sin descendencia directa y arruinado.

La posesión de bienes no fue siempre garantía de gozar de liquidez económica. El dispendio económico de la ostentosa vida de sus titulares, la presión fiscal de la monarquía durante toda la Edad Moderna y los ingentes gastos de administración, contribuyeron a un endeudamiento progresivo que en última instancia desembocó en la quiebra definitiva y la enajenación de las propiedades de las Casas de Osuna y Benavente.

\footnotetext{
94 Sobre las causas de la quiebra de la Casa de Osuna véase Atienza, Aristocracia, pp. 327- 375.
} 
A la muerte del XII Duque se produjo el más impresionante pleito de la historia de España por la división de los cientos de mayorazgos de las casas y que se habían acumulado en su persona. Para hacer frente a las deudas del empréstito hipotecario de noventa millones de reales que el Duque había solicitado en 1863, su viuda y los representantes de testamentaría del Duque iniciaron un complicado proceso judicial que se dilató a lo largo de diez años, y que se cerró en 1894 con un fallo a favor de los acreedores de la Casa de Osuna. Esta sentencia permitió la incautación y enajenación del patrimonio ducal, que pasó a manos de los llamados “Obligacionistas de Osuna”. Los palacios de Madrid se vendieron, y el castillo de Beauraing en Belgica fue incendiado, supuestamente por su viuda para cobrar el seguro $^{95}$.

Con la muerte Mariano Téllez Girón sin descendencia se cierra la etapa de esplendor de las Casas de Osuna y Benavente dos de los linajes más importantes de España desde el siglo XVI. Parte de los títulos más importantes de ambas casas fueron heredados por familias de "nobleza menor", sobrinos del XII Duque. La titularidad de las Casas de Osuna y Benavente pasó a la línea segunda de los Príncipes de Anglona y Marqueses de Jabalquinto. El sucesor fue Pedro de Alcántara Téllez-Girón y Fernández de Santillán $(* 1812-\uparrow 1900)$ que ostentó los títulos de XIII Duque de Osuna, XVIII Conde-Duque de Benavente, Duque de Gandía, Bejar y Pastrana, entre otras numerosas dignidades menores ${ }^{96}$.

\footnotetext{
95 El Banco de Castilla y la Banca Urquijo fueron dos de los más importantes acreedores que se beneficiaron de la quiebra de la Casa de Osuna. Los detalles del proceso del hundimiento económico de la familia Osuna se estudian detalladamente en Ignacio Atienza Hernández y Rafael Mata Olmo, "La Quiebra de la Casa de Osuna”, Moneda y Crédito, 176/3 (1986), pp. 71-95.

96 Era nieto del Pedro de Alcántara, IX Duque de Osuna y de $\mathrm{M}^{\mathrm{a}}$ Josefa Alfonso Pimentel, XV Condesa-Duquesa de Benavente. Véase Apéndice 1.
} 
El desconocimiento de la genealogía de las Casas de Osuna y Benavente durante los siglos XVIII y XIX había dado lugar hasta la fecha a una notable confusión acerca de los titulares de ambas casas nobiliarias, generalizando de forma errónea la expresión "Casa de Benavente-Osuna" para una buena parte del siglo XVIII y todo el siglo XIX ${ }^{97}$. Como hemos visto en los apartados anteriores, a pesar de los lazos familiares existentes entre las familias Téllez-Girón y Pimentel, las Casas de Osuna y Benavente sólo estuvieron unidas entre 1787 y 1807, cuando el matrimonio formado por la XV Condesa-Duquesa de Benavente y el IX Duque de Osuna aunó la administración de ambas casas nobiliarias en una sola, y de nuevo a partir de 1834, momento en el que los títulos de Osuna y Benavente pasaron a ser ostentados por Pedro de Alcántara II $^{98}$.

\footnotetext{
${ }^{97}$ Miguel Ángel Marín afirmó erróneamente que María Faustina Téllez-Girón heredó los títulos de la Casa de Osuna a la muerte de su padre [el VII Duque José Téllez-Girón] y que tras su boda con el XIV Conde-Duque de Benavente (1738) ambas casas se unieron. Desde su fundación la titularidad de la Casa de Osuna sólo se transmitía por la vía del mayorazgo con preferencia de los varones sobre las mujeres, y por tanto la titularidad de esta Casa fue heredada en 1733 por Pedro Zoilo, hijo menor del VII Duque de Osuna. Véase Miguel Ángel Marín "La zarzuela Clementina di Luigi Boccherini”, en Ramón de la Cruz, Clementina, ed. de N. Lepri (Florencia: Collana Secoli d'Oro Alinea, 2003), p. 19. Lothar Siemens, dio a entender que la unión de las Casas de Osuna y Benavente ya se había producido en 1757. (Manalt, Obra Armónica, p.6). En un reciente artículo Judith Ortega, fechó la unión de ambas casas en 1771 tras la boda de la XV Condesa-Duquesa de Benavente con el heredero de la Casa de Osuna. Véase Judith Ortega, "El mecenazgo musical de la Casa de Osuna durante la segunda mitad del siglo XVIII: el entorno musical de Luigi Boccherini en Madrid, RMS, XVII, 2 (2004), p. 645.

${ }^{98}$ Véase Tabla 3.
} 


\subsubsection{Las Casas de Osuna y Benavente en el siglo $X X$}

Tras la muerte sin descendencia masculina del XIII Duque de Osuna y XVIII Conde-Duque de Benavente, el titulo de Osuna volvió a una rama secundaria, la del segundogénito del Príncipe de Anglona, Luis María Téllez Girón y Fernández de Cordoba $(* 1870-\uparrow 1909)$. Este personaje ocupó los cargos de caballero de la Real Maestranza de Sevilla, Gentilhombre de Cámara de Alfonso XIII, y ejerció como diputado en las Cortes por la circunscripción de Talavera de la Reina. El título de Condesa Duquesa de Benavente pasó a María de los Dolores Téllez-Girón, hija del XIII Duque de Osuna que lo ostentó hasta su fallecimiento en $1939^{99}$.

A la muerte del XIV Duque de Osuna le sucedió en la titularidad de esta casa su hermano Mariano Téllez Girón (*1887-†1931), que fue XV Duque de Osuna, XV Duque de Arcos titulado, XVII de Gandía titulado y XIX Conde y XVI Duque de Benavente titulado, ya que por Real Sentencia los ducados de Arcos, Gandía y Benavente seguían siendo posesión efectiva de María de los Dolores Téllez Girón ${ }^{100}$.

Actualmente la titularidad de la Casa de Osuna recae en Angela María Téllez-Girón y Duque de Estrada, hija del XV Duque nacida en 1925, que es la primera mujer titular de la Casa desde su fundación. La XVI Duquesa de Osuna ha recuperado también los títulos de la Casa de Benavente tras la muerte de María de los Dolores Téllez-Girón. Esta dama ostenta además los de Duquesa de Plasencia y Uceda, Marquesa de Jabalquinto, Condesa de Peñaranda de Bracamonte y de Oropesa, entre otros y es cinco veces Grande de España. El

\footnotetext{
${ }^{99}$ Regueras, Pimentel, p. 143.

100 Ibid.
} 
título de Marquesa de Peñafiel, heredera de la Casa de Osuna, recae en la actualidad en Ángela María Solís-Beaumont y Téllez-Girón, XVII Duquesa de Arcos desde 1956, hija mayor de la XVI Duquesa de Osuna, y de su primer esposo Pedro Solís-Beaumont y Lasso de la Vega ${ }^{101}$.

${ }^{101}$ Sobre los actuales titulares de las Casas de Osuna y Benavente véase Vicente Cadenas y Vicent et alt.: Indice nobiliario español (Madrid: Hidalguia, 1956) y Grandezas y títulos del reino. Guía oficial (Madrid: Ministerio de Justicia, 2002). 


\section{Estructura administrativa de las Casas de Osuna y Benavente en los siglos XVIII y XIX}

Uno de los elementos característicos de la alta nobleza española durante la Edad Moderna fue el mantenimiento de una amplia servidumbre que conformaba una compleja "estructura funcionarial" al servicio de los titulares de la casa nobiliaria y de sus familiares. En el caso particular de las Casas de Osuna y Benavente, la importancia que adquirieron algunos personajes de su servidumbre en la educación de los nobles y en la gestión de las actividades culturales, me llevó a considerar la necesidad de conocer las líneas generales de su sistema de administración y los principales cargos de las Casas, antes de abordar el estudio de las actividades del mecenazgo musical.

La organización de la Casa de Osuna mantuvo un esquema bastante uniforme desde sus orígenes, tal y como ha estudiado Ignacio Atienza ${ }^{102}$. La administración de los territorios propiedades de los Duques se delegaba en personas de confianza que se encargaban de los asuntos cotidianos de los señoríos y jurisdicciones, informando periódicamente a los titulares de la Casa. Los cargos de Gobernador, Mayordomo o Secretario Mayor de la Casa se hallaban en la cúspide de una estructura piramidal que comprendía decenas de cargos y oficios. El Gobernador General o Administrador de la Casa ejercía el poder máximo dentro de esta estructura. De él dependían los mayordomos o secretarios de cada uno de los estados de la familia, que contaban además con un administrador local o corregidor elegido directamente por el señor o un delegado suyo en cada una de las villas. Este cargo solía contar con diversos colaboradores locales que se ocupaban de aspectos específicos de la administración como el archivo o la

${ }^{102}$ Atienza, Aristocracia, p.127. 
tesorería.

En el siglo XVIII, la estructura administrativa doméstica de la Casa de Osuna era una auténtica corte jerarquizada que reproducía los usos y costumbres de la monarquía. La llamada "familia de escaleras arriba" conformaba un amplio grupo de empleos para la atención cotidiana de los duques. Con este cordial apelativo se diferenciaba a los empleados de confianza más cercanos a los nobles, algunos de los cuales residían dentro de las dependencias de los palacios y solían acompañar a sus señores en sus desplazamientos. Junto a los administradores y contadores, formaban parte de este selecto grupo los capellanes, empleados de contaduría, archivo, tesorería, abogados, escribanos, médicos, enfermeros, y un largo etcétera que incluye asimismo a los músicos de la casa y a los profesores de dibujo, "primeras letras" y de baile. El resto de la servidumbre que constituía el grupo de criados o familia de "escaleras abajo", desempeñaban aquellos trabajos manuales para los que se requería menor especialización como, por ejemplo, los de mozo de caballeriza, pinche de cocina o lacayo de retretes ${ }^{103}$.

Uno de los empleos más importantes en la estructura doméstica de la casa era el de Gentilhombre, persona de confianza de la corte nobiliaria del Duque, que al menos hasta mediados del siglo XVIII, tenía que superar las pruebas de nobleza de sangre ${ }^{104}$. Este cargo fue desempeñado, entre otros, por el dramaturgo José de Cañizares, que en 1732 figuraba entre los criados al servicio VII Duque José Téllez Girón como "Gentilhombre con el encargo de la letra de la música de

\footnotetext{
${ }^{103}$ Estas denominaciones son comunes para toda la nobleza española. Véase Antonio Morales Moya, Poder político, economía e ideología en el siglo XVIII Español: La Posición de la Nobleza, Tesis doctoral (Madrid: Servicio de Reprografía de la Universidad Complutense, 1983), pp. 11711175.

${ }^{104}$ Yebes, La Condesa-Duquesa, p. 10.
} 
cámara de Su Excelencia” con una asignación de doce reales al día ${ }^{105}$.

Uno de los administradores generales más relevantes de la Casa de las Casas de Osuna en la segunda mitad del siglo XVIII fue Manuel de Ascargorta. Este personaje procedía de un linaje de mayordomos servidores de la Casa de Benavente $^{106} \mathrm{y}$ formaba parte de la nobleza menor como miembro del Estado de Caballeros Hijosdalgos de Madrid ${ }^{107}$. Fue amigo y confidente de la XV CondesaDuquesa de Benavente, que solía encomendarle la resolución de los asuntos domésticos y las gestiones para la contratación de músicos y otros artistas que prestaban sus servicios a los Duques. Otro de los personajes importante dentro de la administración de las familias Osuna y Benavente en las últimas décadas del siglo XVIII fue Manuel de Cubas, que ocupó el cargo de Contador General de la Casa y Estados de la Condesa de Benavente y posteriormente de la unificada Casa de Benavente-Osuna.

Tras la unión efectiva del patrimonio de las Casas de Osuna y Benavente en 1787, se produjo uno de los períodos de mayor esplendor en la estructura administrativa de la Casa. A partir de entonces, las nóminas reflejan la existencia de un amplio aparato de empleados al servicio de los Duques con ocupaciones que van desde las puramente cortesanas como los oficios de Dama y Gentilhombre, a los más domésticos como los de cocina, pasando por una larga relación de empleados de la Secretaría, Archivo o Contaduría. En la categoría de "Criados diferentes" se incluía el "profesor de primeras letras" para los hijos de los duques y aquellos músicos que recibían asignación permanente de la Casa, y que solían

\footnotetext{
105 AHN NOBLEZA, OSUNA-CARTAS, leg 446-1.

$106 \mathrm{Su}$ antepasado Domingo Ascargorta fue el autor de la obra genealógica Origen de los Excelentísimos Condes-Duques de Benavente y su apellido Pimentel. BNE, Ms. 11569.

${ }^{107}$ Yebes, La Condesa-Duquesa, p.24.
} 
encargarse de las principales gestiones para la organización de conciertos y festividades ${ }^{108}$. Además de estos empleos domésticos o administrativos, la Condesa Duquesa de Benavente mantuvo también a su servicio entre 1781 y 1792 a una orquesta de cámara, cuyos miembros recibían una asignación fija mensual de los fondos de la Casa de Benavente ${ }^{109}$.

La hipertrofia en la estructura administrativa de las Casas de Osuna y Benavente se acentuó a finales del siglo XVIII y en los primeros años del siglo XIX, como se observa al examinar las nóminas del personal de la Casa en esos años. En 1794 el número de empleados directos de los IX Duques de Osuna sobrepasaba las doscientas personas que desempeñaban diversos oficios $\mathrm{y}$ ocupaciones clasificadas en quince secciones (Tabla 4). A esta cifra habría que añadir el personal que se mantenía en las administraciones de cada uno de los Estados regidos por las Casas de Osuna y Benavente y las jubilaciones de los criados y de su familia. En las nóminas de gastos mensuales de 1806 se incluían también a los oficiales del Estado de Osuna, empleados de la Secretaría del Regimiento de las Reales Guardias Españolas que comandaba el Duque de Osuna, y a los oficiales del Archivo y Biblioteca ${ }^{110}$.

\footnotetext{
108 Por ejemplo en las nóminas de 1794 figuran los músicos Francisco Basset con 6 reales diarios, y Gaspar Barli con 500 reales al mes. AHN NOBLEZA OSUNA-CARTAS, leg 460.

${ }^{109}$ Véase Capítulo III.

${ }^{110}$ AHN NOBLEZA, OSUNA-CARTAS, leg 452. Nómina de raciones de Abril de 1806.
} 
Tabla 4.

Personal al servicio de los IX Duques de Osuna en 1794

Fuente: AHN NOBLEZA OSUNA-CARTAS, leg 460. Nóminas del mes de mayo de 1794

\begin{tabular}{|c|c|c|}
\hline SECCIÓN & EMPLEO & TOTAL \\
\hline \multirow{8}{*}{ Criados } & Camarera aya de las señoritas & \multirow{8}{*}{13} \\
\hline & Tenienta, aya de las señoritas & \\
\hline & Dama (2) & \\
\hline & Segunda dama (5) & \\
\hline & Portera & \\
\hline & Lavandera y Planchadora & \\
\hline & Encargada del cosido, lavado y planchado de la mantelería & \\
\hline & Cuidadora de la Casa de Aranjuez & \\
\hline \multirow{4}{*}{ Criados mayores } & Capellán & \multirow[b]{4}{*}{6} \\
\hline & Ayo de los señoritos & \\
\hline & Criado del Ayo & \\
\hline & Gentilhombre (3) & \\
\hline \multirow{4}{*}{ Secretaría } & Secretario de Cámara de la Casa & \multirow[b]{4}{*}{10} \\
\hline & Contador del Estado de Osuna & \\
\hline & Oficiales $1^{\circ}$ a $7^{\circ}$ & \\
\hline & Escribiente & \\
\hline \multirow{3}{*}{ Contaduría } & Contador general & \multirow[b]{3}{*}{14} \\
\hline & Oficiales $1^{\circ}$ al $12^{\circ}$ & \\
\hline & Contador de la Casa & \\
\hline \multirow{4}{*}{ Archivo } & Encargado del Archivo de la Casa & \multirow[b]{4}{*}{8} \\
\hline & Oficial mayor & \\
\hline & Oficiales (3) & \\
\hline & Porteros de las oficinas (3) & \\
\hline \multirow[b]{2}{*}{ Abogados } & Primer abogado de Cámara & \multirow[b]{2}{*}{10} \\
\hline & Abogados (9) & \\
\hline \multirow{4}{*}{$\begin{array}{l}\text { Médicos, Cirujanos } \\
\text { y enfermeros }\end{array}$} & Médico del Duque de Osuna & \multirow[b]{4}{*}{9} \\
\hline & Médicos (3) & \\
\hline & Ciujano (4) & \\
\hline & Enfermera & \\
\hline \multirow{12}{*}{ Mayordomía } & Intendente de la Casa & \\
\hline & Veedor de la Casa y Oficios (2) & \\
\hline & Jefe del oficio de tapicería y guardarropa & \\
\hline & Ayudante & \\
\hline & Mozo (2) & \\
\hline & Maestro de bordado de las señoritas & \\
\hline & Carpintero & \\
\hline & Relojero & \\
\hline & Portero de Entradas (4) & \\
\hline & Lavandero & \\
\hline & Peluquero de familia & \\
\hline & Boticario & 17 \\
\hline \multirow{3}{*}{ Repostería } & Jefe & \multirow[b]{3}{*}{8} \\
\hline & Ayudante (4) & \\
\hline & Mozo (3) & \\
\hline
\end{tabular}




\begin{tabular}{|c|c|c|}
\hline \multirow{4}{*}{ Cocina } & Jefe & \multirow[b]{4}{*}{7} \\
\hline & Ayudante (3) & \\
\hline & Mozo (2) & \\
\hline & Comprador & \\
\hline \multirow[b]{2}{*}{ Criados diferentes } & Músicos (2) & \multirow[b]{2}{*}{3} \\
\hline & Maestro de primeras letras & \\
\hline \multirow{4}{*}{ Recámara } & Camarero de Su Excelencia & \multirow[b]{4}{*}{7} \\
\hline & Ayudas de Cámara (3) & \\
\hline & Sangrador & \\
\hline & Mozo de retrete (2) & \\
\hline \multirow{9}{*}{$\begin{array}{l}\text { Casa Huerta de la } \\
\text { Alameda }\end{array}$} & Mayordomo & \multirow{9}{*}{15} \\
\hline & Jardinero & \\
\hline & Mayoral de las vacas y mantequero & \\
\hline & Ayudantes (4) & \\
\hline & Hortelano & \\
\hline & Cuidador de vacas (3) & \\
\hline & Carpintero & \\
\hline & Carretero & \\
\hline & Regalero y Casero (2) & \\
\hline \multirow{17}{*}{ Caballeriza } & Caballerizo (2) & \multirow{17}{*}{35} \\
\hline & Domador & \\
\hline & Portero del zaguán (2) & \\
\hline & Cochero Mayor & \\
\hline & Cochero & \\
\hline & Postillón de Caballos & \\
\hline & Delantero & \\
\hline & Sobresaliente & \\
\hline & Tronquista de mulas & \\
\hline & Cochero de recados (2) & \\
\hline & Lacayo (8) & \\
\hline & Volante & \\
\hline & Farolero & \\
\hline & Lavador de coches & \\
\hline & Mozo de caballos y mulas (8) & \\
\hline & Mayoral del tiro de colleras & \\
\hline & Zagal (2) & \\
\hline \multirow{6}{*}{$\begin{array}{l}\text { Personal al servicio } \\
\text { de [María Faustina } \\
\text { Téllez- Girón] } \\
\text { Condesa Duquesa de } \\
\text { Benavente Madre }\end{array}$} & Familia [Damas de la Condesa-Duquesa y sus criadas] (9) & \multirow{6}{*}{40} \\
\hline & Criados mayores (3) & \\
\hline & Porteros de Estrados y guardarropa (3) & \\
\hline & Repostería & \\
\hline & Cocina (12) & \\
\hline & Caballeriza (12) & \\
\hline TOTAL & & 202 \\
\hline
\end{tabular}


Tras la muerte en 1807 de Pedro de Alcántara, IX Duque de Osuna, comenzó un proceso de supresión de empleos fijos en la hasta entonces unificada Casa de Benavente-Benavente que se separó de nuevo en dos administraciones diferentes. La situación en la Casa de Benavente, regida por María Josefa Alfonso Pimentel, se agravó poco después debido a la Guerra de la Independencia, que supuso un grave perjuicio para la economía de esta casa. La escasez de ingresos durante el período bélico y la falta de liquidez, forzó la supresión de algunos oficios y empleos administrativos. En una carta fechada en enero de 1809, la Condesa-Duquesa María Josefa comunicó a sus contadores la necesidad de suprimir "por el estado de sus intereses" los numerosos empleos innecesarios que se mantenían aún tras la muerte del IX Duque en 1807:

Las extraordinarias y críticas ocurrencias en que nos hallamos y particularmente mi casa, han agravado la triste situación en que quedó al fallecimiento de mi marido y aunque en aquella época debí reformar todo situado puramente gracioso y suprimir dependencias que no fueran absolutamente preciso no lo hice, consultando mi corazón y no mis intereses. En el día a pesar de estos mismos sentimientos no me es posible continuar con más cargas de las de rigurosa justicia y aun estas no sé como satisfacerlas pues me faltan recursos para mi propia subsistencia $[\ldots]^{111}$

Finalizada la Guerra, se volvió paulatinamente al lujo y derroche suntuario que habían caracterizado siempre a las Casas de Osuna y Benavente. Durante la titularidad del XII Duque, Mariano Téllez Girón el despilfarro llegó casi al paroxismo. Según señala Atienza, en 1862 los gastos de administración de la otra

${ }^{111}$ AHN NOBLEZA OSUNA-CARTAS, leg 338-36. 
Casa de Benavente Osuna suponían casi el $62 \%$ de los ingresos ordinarios ${ }^{112}$. Estos gastos eran el resultado de una estructura administrativa desmesurada y el mantenimiento de una serie de empleos anacrónicos, no adecuados a las demandas de una de la sociedad moderna, sobre los que ironizó Mesonero Romanos:

Las ocupaciones de aquellos señores [los empleados de la Casa de Osuna] eran varias: cuál se adiestraba en hacer rúbricas y letras góticas; cuál leía la Gaceta, con los codos sobre el bufete y meneando los labios; quien tomaba el sol cerca de la ventana; quien dormía en su sillón con las manos metidas en los bolsillos del pantalón; y luego los porteros traían sendas botellas y vasos, acompañados de panecillos, con lo cual todos se apresuraban a tomar las once para cobrar nuevas fuerzas con que servir a $\mathrm{Su}$ Excelencia $^{113}$.

Esta administración anquilosada, reflejo último del derroche ostentoso que caracterizó a la Casa de Osuna desde su conformación en el siglo XVI, será una de las causas que propiciaron su quiebra a finales del siglo XIX.

\footnotetext{
112 Atienza, Aristocracia, pp. 96-112.

113 Citado en Marichalar, Riesgo y ventura, pp.36-37.
} 


\section{El mecenazgo artístico de las Casas de Osuna y Benavente entre los siglos XVI y XIX}

El papel que jugó la música en el contexto de las actividades impulsadas por las Casas de Osuna y Benavente no debe considerarse como un fenómeno aislado, sino como una parte de un complejo sistema que caracterizó el ideal de vida de la alta nobleza española en la Edad Moderna. La asunción del protagonismo cultural por parte de la aristocracia propició la utilización de los fenómenos artísticos como un medio para la difusión de una ideología de poder que, junto con la actividad política y militar, contribuyó a la creación de una imagen simbólica que afirmaba los privilegios y el protagonismo de un linaje nobiliario.

El mecenazgo cultural y artístico fue uno de los medios utilizados por las Casas de Osuna y Benavente para reafirmarse como clase dirigente durante el Antiguo Régimen. El estilo de vida noble comportaba gastar mucho en lujos y ostentación, celebrar grandes fiestas pero también tener pretensiones artísticas y literarias ${ }^{114}$. Las actividades musicales promovidas y patrocinadas por las familias Osuna y Benavente se enmarcan dentro de la extensa labor de apoyo de las artes que sus miembros desarrollaron especialmente a partir del siglo XVI.

Juan Téllez Girón, IV Conde Ureña $(* 1494-\uparrow 1558)$, fue el primer exponente importante de la política de protección de las artes de la Casa de Osuna. Hombre de profunda formación humanística, amante de la música y compositor aficionado $^{115}$, fue el artífice de una intensa labor de mecenazgo en la villa de Osuna, que se convirtió en un destacado centro cultural del renacimiento andaluz.

${ }^{114}$ Elinor G Barber, The Bourgeoisie in 18th Century France (New Jersey: Princeton University Press, 1955), pp. 142-143.

${ }^{115}$ Ver el capítulo II. 
En su época se inició un elaborado programa constructivo que dotó a Osuna de varias edificaciones con un marcado carácter simbólico, muestra del cambio de mentalidad en los comportamientos culturales de la aristocracia europea que se estaba produciendo desde los inicios de la Edad Moderna ${ }^{116}$. El IV Conde de Ureña fundó en 1534 la Colegiata de la Asunción de Osuna, uno de los ejemplos más interesantes del renacimiento andaluz, que alberga la Capilla del Santo Sepulcro con el panteón familiar. Años más tarde, en febrero de 1549, este mismo noble obtuvo una bula del Papa Julio III para erigir el Hospital de la Encarnación en Osuna con el privilegio de someterse únicamente a la autoridad del Sumo Pontífice quedando, por tanto, fuera de la jurisdicción del arzobispo ${ }^{117}$. La reforma urbanística de Osuna se completó con la construcción de dos monasterios, uno de dominicos y otro de franciscanos. Para culminar esta empresa artística, el Conde de Ureña y sus sucesores contrataron a los mejores artistas que se hallaban trabajando en Sevilla en la primera mitad del siglo XVI. Asociados a la construcción de la Colegiata aparecen los nombres de Diego de Riaño, Martín Gaínza, Hernando de Esturmio, Roque Balduque, Luis de Morales, Arnao de Vergara y Juan de Zamora $^{118}$.

El segundo de los grandes momentos de esplendor cultural de la Casa de Osuna tuvo lugar en el siglo XVII, coincidiendo con los períodos en que los Duques tuvieron cargos de gobierno en Italia. Durante los virreinatos napolitanos de Pedro Girón de la Cueva, I Duque de Osuna (1582-1586) y de Pedro Téllez

\footnotetext{
116 Jonathan Dewald, The European Noblity, 1400-1800 (Cambridge: Cambridge University Press, 1996), pp. 157-160.

${ }^{117}$ AHN, NOBLEZA OSUNA, leg 7- 9. Citado en Atienza, Aristocracia, p. 177.

118 Sobre la Colegiata de Osuna véase Manuel Rodríguez-Buzón Calle, La Colegiata de Osuna (Sevilla: Diputación Provincial de Sevilla, 1982).
} 
Girón y Velasco, III Duque (1616-1620) ${ }^{119}$ y durante el desempeño del Gobierno de Milán por el quinto titular de la Casa entre 1670 y 1674, los Osuna se convirtieron en auténticos reyes temporales de unos territorios de gran riqueza artística, donde intentaron dejar su impronta. Los Duques de Osuna fomentaron en Italia una política cultural que reflejó sus personales gustos estéticos a través de la promoción de obras de arte y de la protección a escritores y artistas. El cargo de virrey solía ostentarse durante uno o dos trienios a lo sumo, por lo que el mecenazgo de los Osuna se concretó principalmente en el patrocinio del arte suntuario y en la organización de espectáculos festivos en los que se integraban literatura, música, danza, y arquitectura efímera. Todas estas manifestaciones artísticas permitían inmediatamente (y sin grandes dispendios económicos) la afirmación de la imagen simbólica del poder de la Casa de Osuna ${ }^{120}$.

Aunque la tipología de los espectáculos organizados y patrocinados por los Duques de Osuna en los territorios italianos evolucionó a lo largo del siglo XVII, en todos ellos se mantuvo cierta presencia de fusión de distintas artes. En el virreinato del I Duque, Pedro Girón de la Cueva en Nápoles, todavía pervivía la costumbre de organizar fiestas vinculadas a la tradición medieval como los torneos, pero progresivamente adquirieron mayor importancia los espectáculos más elaborados como el ballet, la ópera, o el teatro, en cuya descripción y análisis me detendré en el capítulo siguiente ${ }^{121}$.

El teatro fue otro de los ámbitos de actuación en los que se concretó la política del mecenazgo artístico de las Casas de Osuna y Benavente. La afición de

\footnotetext{
${ }^{119}$ El III Duque de Osuna fue también Virrey de Sicilia entre 1611 y 1615.

120 Martínez del Barrio, Mecenazgo y Politica Cultural, pp.210-290.

121 Ibid.
} 
la familia Téllez-Girón a los espectáculos dramáticos se remonta, al menos, al siglo XVI. El I Duque de Osuna, Pedro Girón de la Cueva, solía incluir en sus fiestas y celebraciones importantes la representación de comedias, como la que se llevó a cabo el 6 de diciembre de 1584 con motivo de la onomástica de su yerno el Conde de Haro. En el siglo XVII, el III Duque, Pedro Téllez-Girón y Velasco, continuó la política de mecenazgo de apoyo a los espectáculos dramáticos, protegiendo a varios grupos teatrales. Durante su estancia como virrey de Sicilia, apoyó la fundación de la Academia degli Agghacciati que se dedicaba a la representación de dramas o comedias al menos dos veces al año. Cuando el III Duque de Osuna se trasladó a Nápoles, los espectáculos teatrales formaron parte de los principales acontecimientos festivos organizados en el palacio virreinal. Para las suntuosas fiestas ducales se solía contratar a las compañías ambulantes que actuaban en las diversas cortes italianas ${ }^{122}$.

La afición al teatro de los titulares de las Casas de Osuna y Benavente les llevó a construir coliseos y a habilitar salas para las representaciones dramáticas dentro de las dependencias de sus palacios

El palacio ene el que residía en Madrid María Remigia Fernández Velasco, VI Duquesa de Osuna, a principios del siglo XVIII, disponía de un fastuoso coliseo o "sala de ópera", cuya descripción conocemos a través de un testimonio anónimo de la época recogido por el Marqués del Saltillo:

Para subir al coliseo había una escalera con ocho estatuas italianas en los macizos, con canastillos de flores y frutas en la cabeza. El corredor de las damas, de balaustres dorados; los pasamanos y basas, blancos; el adorno del mismo consistía en unas repisas o cartelones y unas ninfas doradas que

122 Ibid., pp. 296-305. 
ciñen los canes. Las puertas de comunicación, con pilastras adornadas de flores y frutas, y sobre ellas unas tarjetas doradas. El techo, formado de una comisa de donde arrancaba una escocia de tres pies de ancho, adornada de un friso de talla con unos chicotes de medio cuerpo y cabezas de mascarones muy bien tallados, de yeso, con mucho relieve dorado a sisa. El techo, dividido en tres recuadros; en medio de cada uno, un florón de madera tallado y dorado. El frontis, formado de dos pilastras y dos columnas con basa y capitel dorado y blanco, de treinta pies de alto, y un pabellón de lienzo dorado con cuatro niños sosteniéndolo, y en medio un gran tarjetón con un escudo de armas.

El teatro, compuesto de seis divisiones para las mutaciones, cada una de seis correderas; cinco, de seis bastidores, y la última de] foro, de tres. Hay una mutación de jardín, de bosque, de un salón adornado, una librería, de un castillo y pabellones y de un templo de Diana, con sus correspondientes bambalinas, tramoyas para dichas mutaciones, navíos, peñascos, tornos, escotillones, sogas, hierro y clavazón ${ }^{123}$

También disponía de un teatro privado la residencia madrileña de José Téllez Girón, VII Duque de Osuna situada junto al Convento de Maravillas. Tanto el palacio como el coliseo se destruyeron en un incendio que tuvo lugar el sábado once de septiembre de $1723^{124}$

La familia Pimentel, titular de la Casa de Benavente, también cultivó la afición teatral. Su palacio de Valladolid (en el que residieron los titulares de la Casa durante largos períodos desde su construcción en las primeras del siglo XVI

\footnotetext{
123 Marqués del Saltillo, "Casas madrileñas del Pasado", Revista de la Biblioteca Archivo y Museo, 1945, pp. 91-94. El autor del artículo no cita el documento del que extrajo la información. El coliseo fue propiedad de la VI Duquesa (consorte) de Osuna que lo transmitió a sus hijas, y no de Francisca Bibiana Pérez de Guzmán el Bueno, VII Duquesa (consorte) de Osuna como afirmó Juan José Carerras. Véase Juan José Carreras, “«Terminare a Schiaffoni»: La primera compañía de ópera Italiana en Madrid", Artigrama, 12 (1996-97), p.108.

${ }^{124}$ Lastimoso fuego que se prendió sin saber ciertamente el como, en el Palacio y Coliseo del Excelentísimo Señor Duque de Osuna, el cual pereció sin remedio, por estar mas de seis días ardiendo [..]. sucediò en Madrid este presente año de 1723, (Madrid: [s,1] [s, a]) BNE VC/872/37
} 
hasta su incendio en 1716) contaba con una habitación dedicada a las funciones teatrales denominada "salón de comedias" 125.

Los miembros de las Casas de Osuna y Benavente fueron espectadores habituales de los teatros de la Cruz, el Príncipe y Los Caños del Peral de Madrid, durante el siglo XVIII y XIX, en los cuales mantenían abonos para toda la temporada (Lámina 8) ${ }^{126}$.

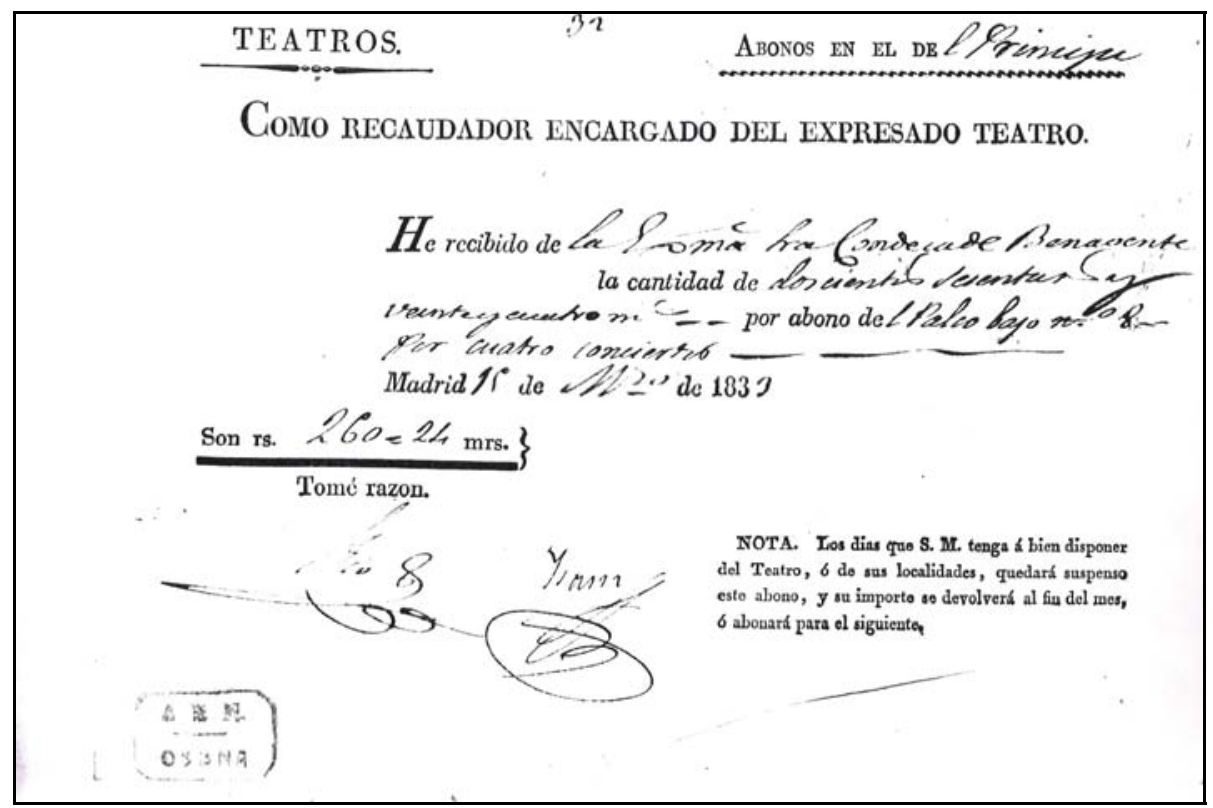

Lámina 8.

Recibo del abono de la XV Condesa-Duquesa de Benavente para la temporada de 1833 en el Teatro del Príncipe de Madrid

AHN NOBLEZA, OSUNA-CARTAS, leg 415-2

A partir de la segunda mitad del siglo XVIII, los titulares de las Casas de Osuna y Benavente, junto con otros personajes de la alta nobleza y la aristocracia residente en Madrid, fueron promotores y accionistas de las empresas de óperas

125 Jesús Urrea, Arquitectura y nobleza: casas y palacios de Valladolid (Valladolid: Consorcio IV Centenario Ciudad de Valladolid, 1996), pp. 41-45.

126 AHN NOBLEZA, OSUNA-CARTAS, leg. 413- 416. 
italianas que actuaron en los Teatros de los Reales Sitios y en el Teatro de los Caños del Peral de Madrid ${ }^{127}$.

$\mathrm{M}^{\mathrm{a}}$ Faustina Téllez Girón, Condesa Duquesa viuda de Benavente ${ }^{128}$, y su hija María Josefa Alfonso Pimentel, fueron dos de las más activas mecenas de actividades teatrales de Madrid. Además de participar en la financiación y gestión de los espectáculos públicos de ópera italiana, organizaron habitualmente funciones particulares en sus palacios y residencias a las que acudían los personajes más destacados de la alta sociedad. En estas representaciones, la música solía jugar un papel fundamental y era habitual que los propios miembros de la familia participasen como actores o cantantes en comedias, zarzuelas o tonadillas, que se encargaban con tal fin o se adaptaban para posibilitar su interpretación por aficionados.

Los actores y sus familias también fueron objeto del apoyo y protección de la familia Benavente-Osuna. Aunque en los capítulos siguientes analizaré detenidamente la relación de mecenazgo de las Casas de Osuna y Benavente con los intérpretes y autores de los géneros dramático-musicales, mencionaré aquí la labor filantrópica y asistencial de los titulares de ambas casas nobiliarias con algunas de las más destacadas figuras del teatro de la segunda mitad del siglo XVIII. Es de subrayar que la importante labor del mecenazgo teatral de los miembros de las Casas de Osuna y Benavente apenas ha recibido la atención de

\footnotetext{
127 Ver Capítulo VI.

128 Este apelativo se utiliza en la documentación administrativa de la Casa a partir de 1763 para distinguir a María Faustina Téllez-Girón de su hija María Josefa que suele aparecer como "Condesa de Benavente hija”, o a partir de 1771 tras su boda con el Marqués de Peñafiel, como Condesa de Benavente "casada" o "Marquesa de Peñafiel". En publicaciones muy recientes continúan confundiéndose ambos personajes. Véase por ejemplo Marín, “La zarzuela”, pp. 15-36.
} 
los investigadores del teatro ${ }^{129}$. Dentro de la documentación administrativa de la Casa de Osuna, se conservan numerosos documentos relacionados con actividades teatrales (protección a compañías de cómicos, recibos por aposentos, carteles de funciones, documentos legislativos, etc.) que aún permanecen inéditos. Su análisis y estudio contribuirá a un mejor conocimiento de la historia del teatro en España entre los siglos XVII al XIX.

Dos de los hijos del actor e intérprete de tonadillas José García Ugalde (apodado "El Redentor”) y de la conocida comediante Mariana Alcázar tuvieron como madrina de bautismo a María Faustina Téllez-Girón ${ }^{130}$. Ésta dama, junto a otras representantes de la aristocracia residente en Madrid, acogió a los hijos de la famosa actriz y cantante María Ladvenant a su muerte, y se encargó de su educación ${ }^{131}$. También recibieron la protección de la Casa de Benavente Margarita Magán y María de la Cruz, viuda e hija, respectivamente, del dramaturgo Ramón de la Cruz, las cuales continuaron recibiendo tras la muerte del escritor los 6 reales diarios que la Condesa Duquesa tenía asignado a este autor teatral ${ }^{132}$. Asimismo Juliana Olivares, viuda del actor y cantante de tonadillas Diego Coronado, recibió (al menos entre 1789 y 1806) una limosna de cuatro reales diarios de la Casa de Osuna ${ }^{133}$.

\footnotetext{
${ }^{129}$ No existe, hasta el momento, un estudio sistemático que analice el papel de esta familia en la promoción de obras literarias y en la protección a comediantes y dramaturgos.

${ }^{130}$ Matías Fernández García, Parroquia Madrileña de San Sebastián. Algunos Personajes de su Archivo (Madrid: Caparrós, 1985), p. 318.

${ }^{131}$ Yebes, La Condesa-Duquesa, p. 67.

${ }^{132}$ Emilio Cotarelo y Mori, Don Ramón de la Cruz y sus obras. Ensayo biográfico y bibliográfico (Madrid: Imprenta de José Perales y Martínez, 1899), pp. 230-231.

${ }^{133}$ AHN NOBLEZA, OSUNA-CARTAS, leg 449 y leg 452.
} 
Las actrices y cantantes de la época se jactaban de la protección que les dispensaba la Casa de Benavente. Así ocurrió, por ejemplo, en 1780 cuando Maria Rosario Fernández "La Tirana" y Josefa Figueras aspiraron al puesto de primera dama de la compañía de Manuel Martínez. "La Tirana” consiguió el contrato, y Josefa Figueras, despechada, dijo que no le importaba dejar el teatro "porque mi señora [la] Condesa de Benavente me contribuiría desde este mismo día con el estipendio que ganaba trabajando, según lo había ejecutado Su Excelencia en otras ocasiones"

La labor de protección a los actores y músicos vinculados al teatro fue continuada por los titulares de las Casas de Osuna y Benavente hasta finales del siglo XIX. Mariano Téllez Girón, XII Duque de Osuna fue también un gran aficionado al teatro musical y protegió a compositores como Francisco Asenjo Barbieri, o Tomás Genovés, entre muchos otros que correspondieron dedicándole sus obras ${ }^{135}$.

Los titulares de las Casas de Osuna y Benavente auxiliaron y apoyaron también a importantes artistas plásticos. El pintor Francisco de Goya realizó diversas obras por encargo del matrimonio formado por Pedro de Alcántara Téllez Girón y María Josefa Alfonso Pimentel. Entre ellas se encuentran varios retratos de los titulares de la casa, como los de Pedro de Alcántara Téllez Girón, IX Duque de Osuna (ca 1798, Nueva Cork, Colección Frick,) y el de su esposa María Josefa, Condesa-Duquesa de Benavente (1785, Madrid, Colección March) ${ }^{136}$ o el

\footnotetext{
${ }^{134}$ Emilio Cotarelo y Mori, Iriarte y su época, citado por Yebes, La Condesa-Duquesa, p.97.

${ }^{135}$ Sobre la protección de Mariano Téllez Girón al teatro musical véase mi artículo, Juan Pablo Fernández-Cortés: "El mecenazgo del Mariano Téllez Girón, XII Duque de Osuna (1844-1882) Revista de Musicología, XVIII/1 (2005), (en prensa).

${ }^{136}$ Ver Láminas 3 y 4 respectivamente.
} 
excepcional retrato colectivo de la familia de los IX Duques de Osuna realizado en 1788, y conservado actualmente en el Museo del Prado (Lámina 9).

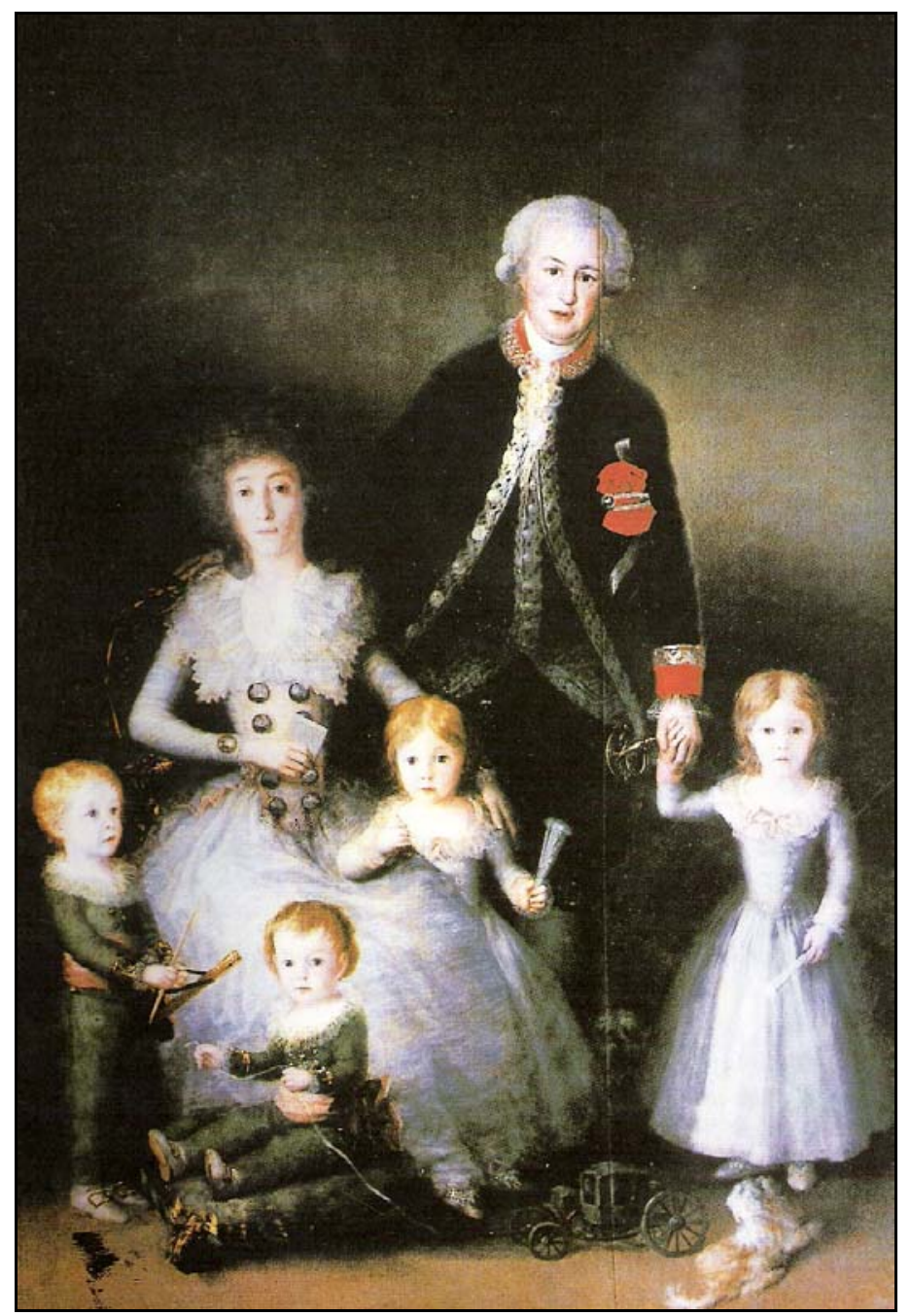

Lámina 9.

Francisco de Goya y Lucientes:

La familia de los Duques de Osuna (1788)

Óleo sobre lienzo, Madrid, Museo del Prado.

En las dos primeras décadas del siglo XVIII Goya pintó los ya descritos retratos de las dos hijas de los IX Duques de Osuna, la Marquesa de Santa Cruz y 
la Duquesa de Abrantes ${ }^{137}$. A finales del siglo XIX, en el momento de la quiebra de la casa ducal, los Osuna tenían una colección de 30 lienzos de Goya sin contar otros cuadros que para entonces ya habían sido vendidos ${ }^{138}$.

Agustín Esteve (*1753-†ca. 1820), colaborador de Goya y pintor de la aristocracia madrileña, fue otro de los artistas protegidos por el IX Duque de Osuna y su esposa. Trabajó como maestro de dibujo de los hijos de los Duques hasta 1808 y pintó por encargo varios retratos de la familia ${ }^{139}$. Otros artistas que recibieron encargos de los IX Duques de Osuna fueron el pintor Alejandro Carnicero, que realizó para la Condesa-Duquesa el famoso lienzo Globo Mongolfier en Aranjuez conservado en el Museo del Prado; y Juan Adán (*1741†1816), Escultor de Cámara de Carlos IV que realizó una Venus para la residencia de recreo de los Osuna, un ejemplo neoclásico fiel a los modelos romanos que aún puede verse en los jardines del Palacio de La Alameda ${ }^{140}$.

La familia Pimentel, titular del condado-ducado de Benavente, ejerció también una importante labor de mecenazgo y coleccionismo artístico, especialmente a partir del siglo XVII. Gracias al reciente estudio de Mercedes Simal $^{141}$, conocemos el interés del VIII Conde de Benavente Juan Alfonso Pimentel, por la pintura y la escultura italiana especialmente desde que ocupó el cargo de virrey de Nápoles entre 1603 y 1609. Durante su estancia en Italia, el VIII Conde conoció la obra de Caravaggio, del cual fue el primer coleccionista de

\footnotetext{
${ }^{137}$ Ver Láminas 5 y 6 respectivamente.

${ }^{138}$. Una síntesis de la amplia bibliografía sobre el mecenazgo de las Casas de Osuna y Benavente con Goya puede verse en Regueras, Pimentel, pp. 89-113.

139 AHN NOBLEZA OSUNA-CARTAS, leg 338-36.

${ }^{140}$ Regueras, Pimentel, pp. 86-87.

${ }^{141}$ Todos los datos sobre el mecenazgo artístico de la Casa de Benavente que figuran de aquí en adelante están tomados de Simal, Los condes-duques., pp. 87-101.
} 
nuestro país, y muy posiblemente el introductor de sus obras en España. El VIII Conde de Benavente consiguió reunir en Italia una importante colección de pintura, escultura y otros objetos artísticos que a su vuelta a España se instalaron en la Fortaleza de Benavente y en la residencia de recreo denominada El Jardín, situada a las afueras de esta localidad zamorana. La importancia de la colección de pintura del VIII Conde de Benavente se conoce por un inventario realizado en 1611 que incluía entre otros objetos 203 pinturas, ocho dípticos, dos cuadros relicario, cerca de 26 estampas y láminas iluminadas. Entre las obras de temática profana recogidas en este inventario figuraba una curiosa colección de veinticuatro "lienzos de músicos diferentes"142.

La colección de pintura de la familia Pimentel se enriqueció con las adquisiciones de obras de artistas de primer orden que realizaron los distintos titulares de la casa a lo largo del siglo XVII. El XII Conde de Benavente, protector del pintor y tratadista Antonio Palomino, fue poseedor (entre otras muchas obras de arte) de varios cuadros de Murillo y de diecisiete bocetos de Rubens para la serie de La Metamorfosis de Ovidio que le había regalado del rey Carlos II.

La colección de escultura instalada en El Jardín se ha considerado uno de los ejemplos más destacados de "jardín anticuario" existentes en España. Al inventariarse en 1612 constaba de doscientas cuarenta y tres esculturas antiguas y modernas entre las que destacaban las de temática mitológica.

Las colecciones de pintura y escultura de la Casa de Benavente comenzaron a dispersarse con los sucesivos cambios de residencia de la familia

142 AHN NOBLEZA, OSUNA, leg 429-50. Transcrito en Simal, Los condes-duques, pp 182-188. 
Pimentel. Cuando en 1619 el VIII Conde de Benavente fue llamado a Madrid para ocupar el cargo de Mayordomo Mayor de la Reina, hizo trasladar a su casa de la Corte varias obras de las que se hallaban en Benavente. Esta costumbre prosiguió con el traslado de la residencia de los Condes Duques a Valladolid en la segunda mitad del siglo XVII. Durante la Guerra de la Independencia, la Fortaleza de Benavente fue incendiada y saqueada, dispersándose o destruyéndose la mayoría de las obras de arte que aún se conservaban en sus salas. De este modo desaparecieron los últimos vestigios de una valiosa colección artística reunida a lo largo de toda la Edad Moderna por los Condes Duques de Benavente en su villa solariega zamorana. 


\title{
Capítulo II
}

\author{
Antecedentes musicales \\ de las Casas de Osuna y Benavente desde \\ desde el siglo XVI hasta 1733
}





\section{La música en las Casas de Ureña y Osuna}

Desde la segunda mitad del siglo XVI, los miembros de la familia TéllezGirón, titular de la Casa de Osuna, desarrollaron una intensa actividad musical en el entorno de sus cortes nobiliarias que se ubicaron fundamentalmente en dos espacios geográficos. El primero fue la España peninsular, y tuvo como escenarios principales la villa sevillana de Osuna y la ciudad de Madrid, lugares de residencia habitual de la familia entre los siglos XVI y XVIII. El segundo ámbito geográfico en el que se desarrolló el mecenazgo de la Casa de Osuna fue los territorios italianos de la corona española de Nápoles, Sicilia y Milán, donde los Duques de Osuna desempeñaron los cargos de Virreyes y Gobernadores en diversos períodos entre los siglos XVI y XVII.

\subsection{La música en las Cortes de los Condes de Ureña y de los Duques de Osuna en la España peninsular (1531-1720)}

\subsubsection{Actividades musicales en la villa de Osuna en los siglos XVI y XVII}

Las primeras referencias directas que he podido documentar sobre las actividades musicales patrocinadas por la familia-Téllez Girón, se sitúan en la villa sevillana del mismo nombre, que a partir de la segunda mitad del siglo XV, vivió uno de sus mayores momentos de esplendor cultural gracias a la labor de Juan Téllez Girón, IV Conde de Ureña, $\left({ }^{*} 1494-\uparrow 1558\right)$. Este personaje que heredó el título en 1531 tras la muerte de sus dos hermanos, transformó la villa de Osuna en un destacado centro cultural. El IV Conde de Ureña, llevó a cabo un ambicioso programa de reformas urbanísticas en Osuna que incluyó la fundación de la Iglesia Colegial (bajo la cual se ubicó la llamada Capilla del Santo Sepulcro, que 
con el tiempo pasó a ser el panteón familiar de los Osuna), la Universidad, y diversos conventos. Todas estas construcciones convirtieron esta pequeña localidad sevillana en el punto de referencia simbólico del linaje de la futura Casa de Osuna.

Juan Téllez Girón fue un hombre culto modelo del noble renacentista preocupado por las artes. Se había formado en las ideas del humanismo y recibió una sólida educación en su infancia, pues como hijo menor de la familia estaba destinado a la carrera eclesiástica. La música jugó un papel fundamental en su formación. La destreza musical adquirida por el futuro IV Conde de Ureña le permitió cantar con facilidad y componer algunas obras, según relató Jerónimo Gudiel en la reseña biográfica que le dedicó en su Compendio de algunas historias de España (1577):

En sus menores años fue criado sin el fausto y autoridad de que suelen gozar los herederos de grandes estados, pues en el faltaba esta razón, siendo el menor de sus hermanos, aunque fue muy regalado de su madre: antes sus padres los encaminaban al estado eclesiástico, haciéndole deprender letras en su niñez, y así le dio a la gramática y música: en las cuales dos disciplinas fue tan aventajado, que cualquier libro escrito en lengua latina de cualesquiera facultades tan claro entendía que los trasladaba en castellano con mucha facilidad, y cualquiera voz por dificultosa que fuese cantaba sueltamente, y con algunos avisos y gracias musicales componía algunas obras que sonaban dulcemente al oído $^{1}$

1 Jerónimo Gudiel, Compendio de algunas historias de España donde se tratan muchas antigüedades dignas de memoria y especialmente se da noticia de la antigua familia de los Girones, y de otros muchos linajes (Alcala de Henares: Juan Iñiguez de Lequerica, 1577), f. 115r. El fragmento citado de Gudiel ha sido parafraseado por distintos autores que desde el siglo XVII, han citado afición musical de este personaje como uno de los rasgos más destacados de su 
Juan Téllez-Girón patrocinó la formación de capillas musicales en las fundaciones religiosas de Osuna ${ }^{2}$. La Iglesia Colegial de la Asunción de Nuestra Señora, conocida como Colegiata de Santa María, estaba terminada en 1539 y tuvo desde sus inicios una capilla musical cuya actividad fue estudiada parcialmente por Inmaculada Cárdenas ${ }^{3}$. La capilla musical de la Colegiata de Osuna contó con el apoyo económico de los Condes de Ureña, y posteriormente de sus herederos los Duques de Osuna. En una fecha cercana a la de la inauguración de esta Colegiata y coincidiendo con el período de máximo esplendor de la villa de Osuna, se construyó el llamado "órgano mayor" que estaba situado entre los dos pilares del coro ${ }^{4}$.

Durante los siglos XVI y XVII, el magisterio de capilla de la Colegiata de Osuna fue desempeñado por una larga nómina de maestros de los que sólo conocemos el nombre y unos pocos datos biográficos. El famoso polifonista Alonso Lobo es uno de los personajes más documentados de los que estuvieron relacionados con la Colegiata de Osuna. Según Inmaculada Cárdenas es probable que Lobo fuera el maestro de capilla de dichaColegiata hacia 1586, antes de

personalidad. Por ejemplo, Robert Stevenson utilizó para documentar la actividad musical de Juan Téllez-Girón un fragmento del Nobiliario genealógico de Alonso López de Haro, publicado en 1622, que glosa el texto citado de Gudiel. Veáse Robert Stevenson: La música en las catedrales españolas en el Siglo de Oro (Madrid: Alianza, 1992), p. 59.

2 El IV Conde de Ureña fue también uno de los mayores benefactores laicos de la catedral de Málaga en la etapa en la que Cristobal Morales trabajaba allí como maestro de capilla. Según recoge Juan Bermudo en su Declaración de instrumentos (1555), Morales compuso una misa de réquiem para este noble. Citado en Stevenson, La música, pp.57- 58.

3 Inmaculada Cárdenas, Música Barroca andaluza en las Colegiatas de Osuna y Olivares. Tesis Doctoral inédita (Sevilla: Universidad de Sevilla, 1980).

4 Manuel Rodríguez-Buzón-Calle, La Colegiata de Osuna (Sevilla: Diputación Provincial de Sevilla, 1982), p. 98. El instrumento sufrió diversas restauraciones durante los siglos XVII y 
ocupar el mismo cargo en las catedrales de Toledo y Sevilla ${ }^{5}$ En 1581 un personaje con este nombre era racionero y secretario del Cabildo de esta Colegiata, y en 1586 figura en las Actas Capitulares como canónigo de esta institución, lo que según Inmaculada Cárdenas justificaría su condición de maestro de capilla. En cualquier caso, la presencia de Alonso Lobo como maestro de capilla en la Colegiata de Osuna, si es que se dio como tal, tuvo que ser anterior a 1591, año en que fue contratado como ayudante de Francisco Guerrero en la catedral de Sevilla ${ }^{6}$.

A partir de la segunda mitad del siglo XVII, la presencia de los duques en su palacio de Osuna fue cada vez menor debido a la frecuente ocupación de cargos militares y palaciegos, que les obligaban a residir junto a la Corte, o en diferentes destinos políticos o militares. Esta circunstancia debió de repercutir notablemente en la atención que los Duques de Osuna prestaron a la actividad musical de la Colegiata, y en el pago de las dotaciones necesarias para su mantenimiento. Según Rodríguez Buzón, la Capilla de la Colegiata de Osuna pasó una época de crisis hasta mediados del siglo XVIII, cuando se reorganizó gracias a la ayuda del VIII Duque de Osuna, que asignó trescientos ducados y una determinada cantidad de trigo para el maestro de capilla ${ }^{7}$.

XVIII, y la caja barroca se amplió hacia 1850 con una cadereta de espalda y dos cuerpos laterales.

${ }^{5}$ Inmaculada Cárdenas Serván, El polifonista Alonso Lobo y su entorno (Santiago de Compostela: Universidad de Santiago de Compostela, 1987), pp. 12-13.

${ }^{6}$ Ibid.

${ }^{7}$ Rodríguez-Buzón, La Colegiata, p.98. Según este autor en 1776 la Capilla estaba compuesta por el maestro de capilla, un organista, tres cantores, tres violines y un bajón, además de diez seises o acólitos. 
En el interior de la Colegiata de Osuna se situaba la llamada Capilla del Santo Sepulcro fundada en 1545 bajo el patronazgo del Conde de Ureña y cuya jurisdicción quedaba al margen del Cabildo de la Colegiata gracias a una bula del papa Paulo III. La Capilla del Santo Sepulcro contaba con nueve capellanías perpetuas cuyos capellanes tenían la obligación de cantar al alba y celebrar misa cantada al menos en las festividades y solemnidades. Un sacristán mayor y dos acólitos completaban la dotación de la Capilla del Santo Sepulcro ${ }^{8}$.

En los estatutos de fundación de la Capilla del Santo Sepulcro, en cuya redacción intervino probablemente el propio Conde de Ureña ${ }^{9}$, se estableció que la capilla musical debía de estar formada por las cuatro voces de tiple, tenor, contralto y contrabajo, dos muchachos de buenas voces, "que sepan canto de órgano aunque poco sea, lo que bastare para ayudar a unas vísperas y a una misa"; un maestro de capilla "que ordene y registre lo que se ha de cantar" y un "tañedor de órganos ${ }^{\text {“10 }}$. En 1545, dos de los cuatro cantores eran capellanes de la propia Capilla del Santo Sepulcro: el contralto Juan Trillo y el tenor Pedro Gallardo. Ambos cobraban una ayuda de costa cuando el maestro de capilla les pedía que

\footnotetext{
${ }^{8}$ Bula de erección de la Capilla del Santo Sepulcro de Osuna. Copia conservada en la Biblioteca General del Consejo Superior de Investigaciones Científicas (Madrid), Archivo Rodríguez Marín, caja 19, doc. 6.1.

${ }^{9}$ Antonio $\mathrm{M}^{\mathrm{a}}$ Ariza y Montero-Coracho, Bosquejo biográfico de D. Juan Téllez Girón, IV Conde de Ureña (Osuna: Eulogio Trujillo, 1890), pp. 20-21 y pp.49-51

${ }^{10}$ Ibid. En la Capilla del Santo Sepulcro se conserva un órgano realejo que, según RodríguezBuzón, es el más antiguo de la provincia. Posee un mueble austero sin decoración. No se conservan los tubos originales pero sí el secreto y los fuelles construidos hacia 1670 por el organista y organero Bonifacio de Rivilla, así como un teclado de 42 teclas. Fue reconstruido en los años 80 del pasado siglo por el organero jerezano Antonio de la Herrán. Rodríguez-Buzón, $L a$ Colegiata, pp. 98-99.
} 
cantasen. El contrabajo Antón Díaz era capellán de coro de la Colegiata y para completar el cuarteto vocal se decidió contratar a un tiple, cuyas características vocales se describieron minuciosamente en los estatutos de fundación de la Capilla del Santo Sepulcro. En el documento se especificó que la persona que ocupase esta plaza no debía de ser castrado, ya que todos ellos "cantan de mala gana", sino un "tiple mudado y que tenga gentil voz y cante de buen aire y se menee con gracia" y que además no tenga "mucho cuerpo de voz ni muy llena, ni voz larga para cantar en veinte puntos”. La dirección de la capilla, se encomendó inicialmente a Cristobal Villarcarbín, del que se dice que dirigía ante el facistol “sin dar codazos ni palmadas en el libro como solían hacer otros maestros de capilla desconcertados y de mal oído" Por su trabajo como maestro de la Capilla musical del Santo Sepulcro se le asignaron 12.000 reales al año ${ }^{11}$.

Los estatutos de fundación de la Capilla musical del Santo Sepulcro, establecían que ésta tenía que actuar en las festividades importantes, donde se cantarían y se tañerían las vísperas y una misa al día siguiente. La capilla intervenía también en las misas de los viernes y los lunes. Los estatutos determinaron también el repertorio de la capilla musical precisando que se debía evitar la interpretación de música extranjera, e incluso sugería los nombres de los compositores cuyas obras debían utilizarse. Entre estos figuran algunos de los autores españoles más importantes de la segunda mitad del siglo XV y primeras

11 Cláusulas de la fundación de la Capilla musical del Santo Sepulcro. Recogidas en Ariza, Bosquejo, pp.49-51. El nombre del maestro de capilla aparece transcrito en Ariza como "Xoval" abreviatura habitual de Cristóbal en la escritura de la época. 
décadas del XVI, como [Pedro Fernández de] Castilleja ${ }^{12,}$ [Pedro Luis de] Pastrana, [Francisco de] Peñalosa, [Pedro de] Escobar, P[edr]o de [O]Porto ${ }^{13}$, [Cristobal de] Morales, [Juan García de] Basurto , junto a otros como Antón Marlete y Motón ${ }^{14 .}$

Del ambiente en el que se desarrollaba la actividad musical de la Colegiata de Santa María y de la Capilla del Santo Sepulcro en la segunda mitad del siglo XVI nos ha quedado el testimonio de primera mano de Jerónimo Gudiel:

Hay en este templo un coro de madera muy bien obrado de talla, a donde se juntan cada día los capellanes, que son perpetuos con su capellán mayor, a celebrar cantando las horas y oficios divinos con tanto reposo y devoción, que mueven mucho los ánimos de los que asisten a la contemplación de Dios [...] Debajo de este templo está otro donde descansan los huesos de los difuntos en los huecos de las paredes y en él hay un coro y un altar, a donde ciertos días de la semana descienden los capellanes a decir misas cantadas ${ }^{15}$.

\footnotetext{
12 Parece muy probable que se trate de este autor el que Ariza transcribe por "Castilaja". Ariza, Bosquejo, p. 51.

${ }^{13}$ Los nombres de "Pedro de Porto" y "Escobar" que aparecen en este documento, se refieren a dos autores diferentes, lo que parece indicar que la identificación de Pedro de Escobar, maestro de capilla de la catedral de Sevilla, con el cantor de la Capilla Real de Isabel la Católica "Pedro de Oporto" no parece tan clara como se ha mantenido hasta la fecha en buena parte de la historiografía. Véase a este respecto Tess Knighton, "Escobar, Pedro”, DMEH, vol. 4, pp. 721-724 ${ }^{14}$ Ariza, Bosquejo, p. 51. Sobre la importancia del repertorio no español en la música religiosa de la época renacentista en España y su visión historiográfica véase Emilio Ros Fábregas, "Historiografía de la Música en las Catedrales Españolas: Nacionalismo y Positivismo en la Investigación Musicológica" CODEXXI, Revista de la Comunicación Audiovisual, I (1998), pp. 68-135.
} 
Es probable que la Universidad de Osuna, fundada por Juan Téllez Girón en 1549 con la idea de emular las enseñanzas de la Universidad de Alcalá de Henares, tuviera a la música como una de sus materias. Quizá se dedicaba a esta disciplina una de las tres cátedras de Arte que tuvo esta institución académica desde su fundación, si bien hasta el momento no ha podido documentarse este hecho ${ }^{16}$. También en 1549 comenzó la actividad de edición de libros de música por la Universidad de Osuna que llevó a cabo el impresor de Sevilla Juan de León ${ }^{17}$. De los talleres de la imprenta universitaria de Osuna salió en dicho año el Libro primero de la declaración de los instrumentos musicales de Juan Bermudo cuya edición se completaría en 1555 con los cinco volúmenes de la Declaración de instrumentos $^{18}$. Del mismo Bermudo se editó en 1550 El Arte Tripharia, obra pedagógica encargada por Isabel Pacheco, superiora del convento de Santa Clara de Montilla y tía de la Duquesa de Arcos, para formar a su sobrina Teresa que iba ingresar en un convento ${ }^{19}$. La imprenta de la Universidad de Osuna publicó también en 1555 los Villancicos y canciones a tres y cuatro de Juan Vázquez ${ }^{20}$.

\subsubsection{La Música en las cortes nobiliarias de los Duques de Osuna (1562-1716)}

El estudio de la actividad musical que se desarrolló en el período comprendido entre la concesión del título ducal de Osuna en 1562 y la muerte del

\footnotetext{
${ }^{15}$ Gudiel, Compendio, f. 117 r.

${ }^{16}$ Véase María Soledad, Rubio Sánchez, El Colegio-Universidad de Osuna (1548-1824), (Sevilla: Caja de Ahorros de San Fernando, 1976).

${ }^{17}$ Cárdenas, El polifonista, p. 11.

18 Stevenson, La música, p. 59.

${ }^{19}$ Ibid., p. 49.

${ }^{20}$ Ibid., p. 59.
} 
VI Duque de Osuna acaecida en 1716, está condicionado por la escasez de las fuentes conservadas. Aunque no se tiene constancia documental de la existencia de una capilla de música estable durante el período de titularidad de los seis primeros Duques es probable que, extrapolando el modelo de la actividad de otras familias nobles de la nobleza andaluza de la época, como los Duques de $\operatorname{Arcos}^{21}$, los titulares de la Casa de Osuna dispusieran de las capillas musicales de la Colegiata de Santa María y la del Santo Sepulcro de Osuna (que estaban bajo su protección) bien para la celebración de fiestas religiosas y profanas o para la interpretación musical en el entorno de su corte palaciega durante los períodos de residencia en Osuna.

La práctica privada de la música por los titulares de la Casa de Osuna y su familia que, como ya vimos anteriormente, tuvo uno de sus primeros ejemplos en la figura del IV Conde de Ureña, continuó durante el siglo XVII. En 1681, las hijas de Gaspar Téllez Girón, V Duque de Osuna, recibían clases periódicas de clavicordio $^{22}$. En la práctica musical participaban también los criados más cercanos de los duques. María Gómez, una de las criadas de la V Duquesa de Osuna que llegó a Madrid desde Navarra en 1681, recibió periódicamente clases de arpa en Madrid del maestro Francisco Fernández. Las clases fueron costeadas por la Duquesa de Osuna, a quien esta criada posiblemente debió de deleitar con sus interpretaciones domésticas (Lámina10).

21 Sobre las actividades musicales de los Duques de Arcos en Marchena (Sevilla) durante los siglos XVI y XVII véase el apartado 3 de este capítulo

22 AHN NOBLEZA OSUNA, CARTAS, leg 389-27. En el documento no figura el nombre del maestro. 


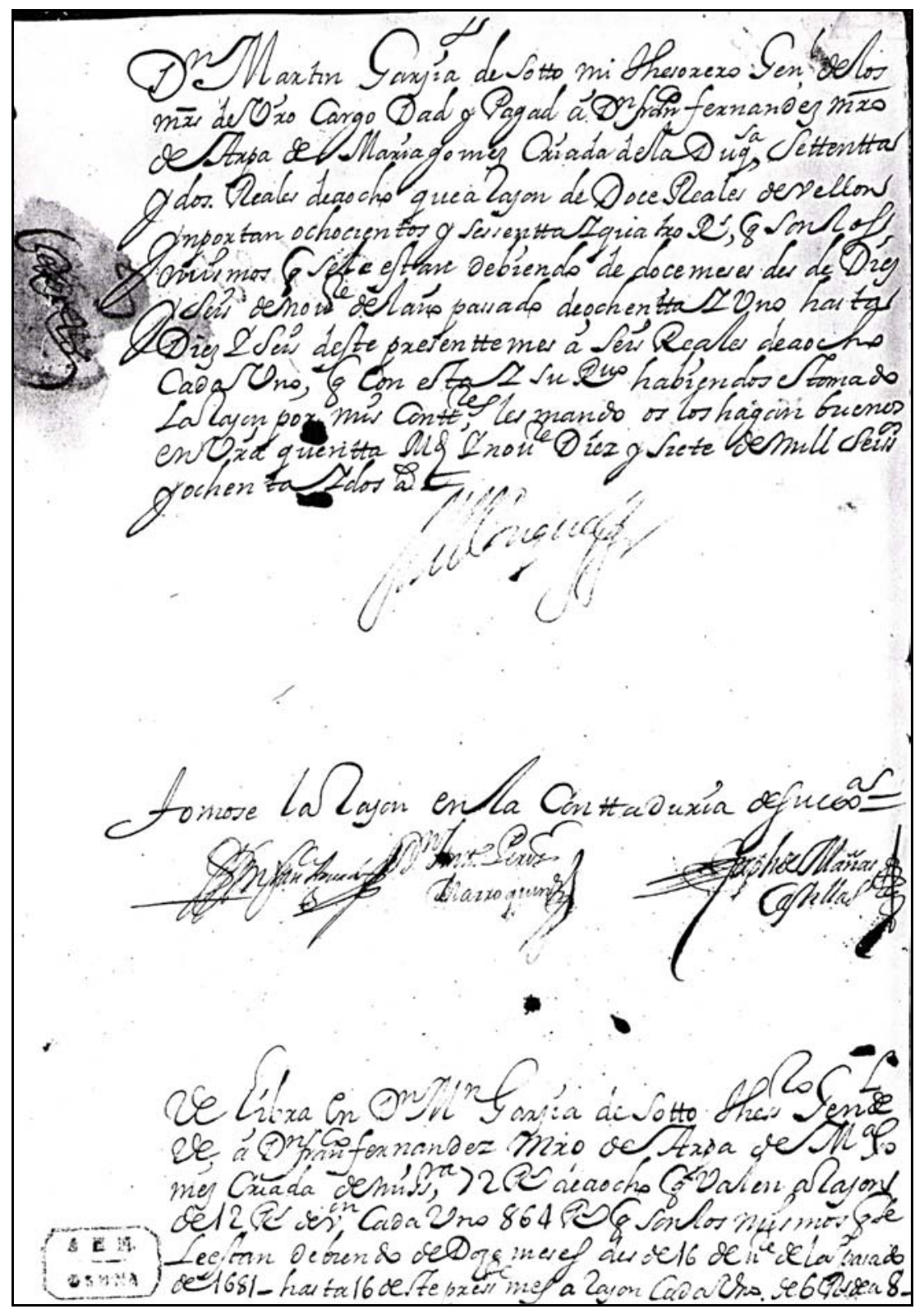

\section{Lámina 10.}

Orden de pago a Francisco Fernández, maestro de arpa, por las clases impartidas a María Gómez criada de Ana Antonia de Benavides, V Duquesa de Osuna (1682)

AHN NOBLEZA OSUNA, CARTAS, leg 389-27

El apoyo económico a determinados compositores fue otra de las constantes en la política del mecenazgo musical de la Casa de Osuna durante la titularidad de los seis primeros Duques de Osuna. Baselga Esteve conjeturó que el 
teórico y músico Pietro Cerone, autor de El melopeo y maestro, se relacionó con el II Duque de Osuna durante su residencia en la Corte española (donde ocupó desde 1593 la plaza de tenor en la Real Capilla):

Ni que decir tiene que Cerone trabó algunas buenas amistades en la Corte española, lo que le facilitaría más tarde buenas plazas y mejores ascensos en el Virreinato de Nápoles. Ejemplo de esto lo tenemos en sus relaciones con don Pedro Téllez-Girón y Guzmán, duque de Osuna" 23

Aunque es probable que sea cierta la relación de Cerone con la Casa de Osuna, hay que subrayar que Baselga confundió a Juan Téllez-Girón y Guzmán, II Duque de Osuna, que ocupó la titularidad de la Casa durante la mayor parte de la estancia de Pietro Cerone en España, con su hijo Pedro Téllez Girón y Velasco, III Duque de Osuna desde 1600, y virrey de Nápoles desde 1616, a cuyo servicio trabajó el compositor en la Real Capilla napolitana.

Ya en el siglo XVIII, Sebastián Durón, maestro de la Real Capilla de Madrid, gozó de la protección de Francisco Ma de Paula Téllez Girón, VI Duque de Osuna. La fidelidad a la monarquía de los Austrias en la Guerra de Sucesión había obligado a Durón a exiliarse a Francia, muy probablemente hacia 1707, después de ser inhabilitado de su cargo de maestro de la Real Capilla en octubre de 1706. Durante su estancia en Francia, Durón residió en Pau, Cambó les Bains y Bayona, donde a partir de 1715 estuvo al servicio de la reina viuda Mariana de

${ }^{23}$ Ramón Baselga Esteve, "Pedro Cerone de Bérgamo, Estudio bio-bibliográfico", Tesoro Sacro Musical, 54 (1971), p.47. 
Neoburgo, con los cargos de Capellán de Honor y Primer Limosnero ${ }^{24}$.

Hasta su muerte en 1716, el VI Duque de Osuna tuvo asignada a Durón una pensión mensual de veinticinco doblones. Así figura en uno de los escritos de su documentación testamentaria fechado en el mes de marzo de 1718, donde se reclaman para los herederos de Durón mil ciento cincuenta doblones que en el momento de su muerte le adeudaba el Duque de Osuna:

[...] Por cuanto en virtud de órdenes especiales que por escrito tuvo del Excelentísmo Señor Duque de Osuna, difunto, estuvo asistiendo y socorriendo a Don Sebastián Durón, también difunto, y maestro que fue de la Real Capilla de Su Majestad con veinticinco doblones de a dos escudos de oro que le señaló en cada mesada dicho Excelentísimo Señor hasta el día en que falleció Su Excelencia' que todas las dichas mesadas dio por pagadas el otorgante al dicho Don Sebastián Durón hasta el día veintisiete de febrero del año pasado de mil setecientos y diez y seis, mediante haberle dado recibo de ellas en confianza, sin embargo de no haber entregádole el importe de mil ciento y cincuenta doblones que se le estaban debiendo al dicho Don Sebastián Durón cuando murió Su Excelencia, y estos corresponden a sus testamentarios $[\ldots]^{25}$

De la lectura de este documento se deduce que, aunque Durón firmó varios recibos como pagados, no se hicieron efectivos por la tesorería del Duque, probablemente debido a la habitual falta de liquidez de la tesorería de la Casa de Osuna que se materializaba en el constante atraso de los pagos durante varios

\footnotetext{
${ }^{24}$ Begoña Lolo, "Consideraciones en torno al legado musical de Sebastián Durón después de su exilio a Francia”, RMS, XV/ 1 (1992), pp.195-208.

25 Archivo Histórico de Protocolos de Madrid. Escribano Blas Hernández Villalpando. leg 13881, fol. 806. Transcrito en Nicolás. A. Solar-Quintes, "Nuevos documentos para la biografía del compositor Sebastián Durón”, AnM, X (1955), p 145.
} 
meses o años ${ }^{26}$. El documento de la testamentaría adjuntó los recibos que se adeudaban a la muerte del Duque, el primero de ellos estaba fechado en marzo de 1712:

Digo yo Don Sebastián Durón que he recibido del Señor Don Juan Tomás de Goyeneche doscientos doblones de a dos escudos de oro, por el importe de ocho mesadas, empezando desde primero de marzo de este presente año, consecutivamente, hasta fin de octubre del mismo año, a razón de veinticinco doblones en cada una de ellas, que de orden del Excelentísimo Señor Duque de Osuna, me los paga, de cuya cantidad, por haberlos recibido a mi satisfacción. Doy este recibo para que pueda acudir a Su Excelencia ${ }^{27}$.

El resto de las cantidades que se debían, pertenecían a los meses de noviembre y diciembre de 1712, y a los años completos de 1713, 1714 y 1715. Aunque no se tiene constancia de la fecha en que se inició la protección económica del Duque de Osuna a Sebastián Durón, es probable que ésta comenzase en 1707, año en que Durón posiblemente se exilió a Francia tras la supresión de su cargo y sueldo en la Real Capilla ${ }^{28}$.

Durón había destacado como defensor del Archiduque de Austria, apoyando su proclamación en Madrid; el VI Duque de Osuna, por el contrario, fue uno de los hombres de confianza de Felipe V y participó en la Guerra de Sucesión en el bando borbónico al frente de una compañía de las Reales Guardias de Corps.

\footnotetext{
${ }^{26}$ Ignacio Atienza Hernández, Aristocracia, poder y riqueza en la España Moderna. La Casa de Osuna, siglos XV-XIX (Madrid: Siglo Veintiuno, 1987), pp. 327-338.

27 Ibid.

28 Sebastián Durón y José de Cañizares, Salir el Amor del mundo, zarzuela en dos jornadas Transcripción y estudio de Antonio Martín Moreno (Málaga: Sociedad Española de Musicología, 1979), p.34.
} 
La relación entre Durón y el Duque de Osuna pudo iniciarse en el entorno de la Corte en una época anterior al conflicto dinástico, quizá cuando el VI Duque de Osuna ocupaba el cargo de Gentilhombre de Cámara durante el reinado de Carlos II. El hecho es que la relación se mantuvo después a pesar de sus divergencias políticas, y se debió de ver favorecida además por las estancias del Duque en Francia, donde falleció en $1716^{29}$.

Sebastián Durón colaboró con el dramaturgo José de Cañizares, en la composición de las zarzuelas Salir el Amor del Mundo, representada probablemente en 1696; Las nuevas Armas de amor, cuyo estreno sitúa Cotarelo y Mori en 1711, y El imposible mayor en Amor le vence Amor ${ }^{30}$. Según Antonio Martín Moreno la relación profesional entre Durón y Cañizares “permite imaginar unos lazos de amistad derivados del servicio común de ambos a la Casa del Duque de Osuna" ${ }^{31}$. Sin embargo, aunque se tiene constancia de que José Cañizares estuvo empleado en la Casa de Osuna durante la titularidad de José Téllez Girón VII Duque de Osuna ${ }^{32}$, no se conoce ningún dato que acredite la relación de servicio de Sebastián Durón con esta casa nobiliaria. Los documentos antes citados (que son los únicos que hasta la fecha han servido para ilustrar la relación de Durón con el Duque de Osuna) sólo especifican que el VI Duque de Osuna “estuvo asistiendo y socorriendo" a Sebastián Durón, lo cual no implica necesariamente que éste trabajase a su servicio.

\footnotetext{
29 AHN NOBLEZA, OSUNA, leg20-18.

30 Sebastián Durón y José de Cañizares, Salir, p. 50.

31 Ibid.

32 AHN NOBLEZA, OSUNA-CARTAS, leg 446-1.
} 


\subsection{El mecenazgo musical de José Téllez Girón, VII Duque de Osuna (1720-} 1733)

A la muerte del VI Duque de Osuna en 1716, se entabló un complejo litigio sucesorio quedando vacante la titularidad de la Casa de Osuna hasta el nombramiento en mayo de 1720 de José Téllez-Girón y Benavides como VII Duque de Osuna ${ }^{33}$. El fallecimiento de su hermano y predecesor en París, la situación política de España, inmersa en el conflicto dinástico, y los problemas en la herencia del título de la Casa de Osuna, pueden ser la causa de la práctica ausencia de referencias sobre actividades musicales en el entorno de los Osuna en las dos primeras décadas del siglo XVIII.

Desde su nombramiento en 1720 hasta su muerte en 1733, José Téllez Girón, desarrolló una intensa labor de apoyo y promoción de la música. Esta política de mecenazgo, que en su gran mayoría no había sido investigada hasta la fecha, se concretó básicamente en la organización y mantenimiento de una capilla musical y en el patrocinio de funciones de teatro musical en español.

\subsubsection{La capilla musical del VII Duque de Osuna}

José Téllez Girón, VII Duque de Osuna mantuvo una importante capilla instrumental en el entorno de su corte nobiliaria que se ubicó en Madrid y en Sevilla (siguiendo los desplazamientos de la Corte Real en el período 1729-1733). De esta capilla formaron parte algunos de los más importantes instrumentistas activos en España durante la primera mitad del siglo XVIII, entre ellos varios

\footnotetext{
33 Véase el Capítulo I.
} 
miembros de la Real Capilla ${ }^{34}$.

Uno de los primeros músicos que gozaron de la protección del recién nombrado VII Duque de Osuna fue Baltasar Caballero, que en 1720 ya trabajaba a su servicio. Caballero había iniciado su vida profesional como segundo músico de la compañía teatral de su padre, Cristóbal Caballero, que actuaba en Valencia. Posteriormente se trasladó a la catedral de Zamora donde trabajó durante varios años como maestro de capilla según los datos que figuran en el manuscrito Genealogía, Origen y Noticia de los Comediantes en España ${ }^{35}$. Sin embargo, de acuerdo con las investigaciones de José López Calo, en esta época era Alonso de Cobaleda el que ocupaba el magisterio de capilla de la catedral zamorana ${ }^{36}$. Baltasar Caballero, figuraba como músico de la capilla catedralicia de Zamora cuando en 1718 se decidió rebajar los salarios de sus integrantes debido a la grave

\footnotetext{
34 Utilizaré la expresión "capilla musical" para referirme a las agrupaciones musicales estables de pequeño tamaño que fueron mantenidas durante el siglo XVIII por los nobles en sus palacios que estaban formadas un conjunto variable de instrumentistas de cuerda y viento, y en las que (a diferencia de las capillas de las instituciones religiosas) no solían figurar cantores. Esta acepción aparece en gran parte de la documentación administrativa de la época y se recoge en el Diccionario de Autoridades de la Real Academia Española de 1729, en donde se define capilla [musical] como "El cuerpo o agregado de varios músicos y ministriles con sus instrumentos mantenidos o asalariados por alguna iglesia, catedral o colegial, convento, príncipe, etc, para celebrar las funciones o fiestas que tienen en el año [...]. Diccionario de la lengua castellana, en que se explica el verdadero sentido de las voces[...] Compuesto por la Real Academia Española. Tomo segundo. Que contiene la letra C. (Madrid: Imprenta de Francisco del Hierro., 1729) p. 144,1. El término "orquesta" con el significado de agrupación musical de varios instrumentos, no fue recogido en los diccionarios de la Real Academia hasta 1803. Véase Diccionario de la lengua castellana compuesto por la Real Academia Española, reducido a un tomo para su más fácil uso. Cuarta edición (Madrid: Viuda de Ibarra, 1803), p. 925, 1.

35 Genealogía, Origen y Noticia de los Comediantes en España. BNE Mss. 12917-12918, t. I, p.179. Publicado con el mismo título en N D. Shergold y J.E Varey (edits.) (Londres: Tamesis Books, 1985).

36 José López-Calo: “Zamora”, DMEH, vol. 10, p.1094.
} 
situación económica de la fábrica de esta catedral ${ }^{37}$. Esta circunstancia fue seguramente la que indujo a Caballero a abandonar su puesto en la Catedral de Salamanca para trasladarse a Madrid, pues en ese mismo año de 1718 se incorporó como “músico" a la compañía de Juan Álvarez que actuaba en los teatros madrileños, en la cual al año siguiente ocupaba el puesto de violón. En 1720, José Téllez-Girón, conocedor de la habilidad musical de Caballero, lo tomó a su servicio con la asignación de trescientos ducados, casa, médico y botica ${ }^{38}$.

Baltasar Caballero debió de incorporarse a una incipiente capilla musical que el Duque fundó posiblemente poco después de asumir la titularidad de la casa y de la cual formaba también parte en 1721 el compositor y violón de la Real Capilla, Antonio Literes Carrión $(* 1673-\uparrow 1747)$. La relación de Antonio Literes con la Casa de Osuna fue dada a conocer por Solar Quintes en $1954^{39}$. El cotejo de las transcripciones de algunos documentos presentados por este autor con los originales que se conservan en el archivo administrativo de la Casa de Osuna evidencian importantes divergencias y la necesidad de una revisión historiográfica sobre la relación de Literes y su familia con la Casa de Osuna.

Antonio Literes estuvo vinculado a la capilla musical del Duque de Osuna al menos desde abril de 1721, según consta en un recibo por el que se le pagó "la música que asistió al miserere del Santísimo Cristo del Desamparo de Recoletos”. Este documento, además de certificar la relación de Antonio Literes con el Duque

\footnotetext{
${ }^{37}$ Ibid., p. 1094.

${ }^{38}$ Genealogía, p. 179.

39 Nicolás A.Solar-Quintes, “Antonio Literes Carrión y sus hijos. Nuevos documentos para su biografía”, AnM IX (1954), pp. 169-189.
} 
en dicha fecha, muestra que la Casa de Osuna tenía a su servicio en ese momento una capilla estable (de la que formaban parte al menos dos violines) que se reforzaba con otros músicos cuando era necesario. Junto a la cantidad consignada por "el punto regular de dicho miserere", es decir por la asistencia de los músicos que habitualmente acudían a tal fiesta religiosa, el Duque pagó a través de Literes (que ejerció aquí como festero o mediador) a tres violines que acudieron como refuerzo ${ }^{40}$.

Dentro de la capilla musical del Duque de Osuna, Antonio Literes debió de desarrollar básicamente una actividad como instrumentista de violón, (instrumento que tocaba en la Real Capilla) pues en documentos del archivo de la Casa de Osuna de 1722 es citado como "músico de mi cámara", y no como maestro o compositor. Esto no excluye que en algunas ocasiones la capilla del Duque interpretase alguna de sus composiciones, como ocurrió en las funciones de celebración de la boda del Duque que se celebraron en Madrid en $1721^{41}$.

Según Solar Quintes, Literes también trabajó para la Casa de Osuna como copista musical. Una lectura detallada de la fuente en que Solar Quintes basó esta afirmación muestra que en realidad las copias de música que se hicieron para la “Academia y Palestra", que tuvieron lugar en los meses de mayo y junio de 1722, fueron realizadas "por orden de Don Antonio Literes" pero no necesariamente por

\footnotetext{
40 AHN NOBLEZA, OSUNA-CARTAS leg 292-1.

${ }^{41}$ Ibid., leg 389-3-4. Este documento aparece transcrito en Solar-Quintes, "Antonio Literes", p. 172 con algunos errores importantes. Donde Solar Quintes transcribe "a lo mismo que su ex ${ }^{a}$ mandó pagar la Bea Nunciat de Don Antonio Literes" el documento original dice claramente "a lo mismo que Su Ex[celenci] a mandó pagar la thea nupcial de Don Antonio Literes", es decir las copias de la música para la tea nupcial o funciones de boda del Duque celebradas en Madrid en 1721, que había sido fue compuesta por el propio Literes.
} 
él mismo ${ }^{42}$. Es muy probable que, Literes, primer violón de la Real Capilla y colaborador habitual de los teatros de Madrid no necesitara realizar este tipo de trabajos, que en ocasiones solía encargar a otras personas de su confianza como Isidro Montalvo, hermano de su segunda mujer ${ }^{43}$.

La relación directa de Antonio Literes Carrión con la Casa de Osuna, finalizó antes de 1732 cuando su hijo José ocupaba la plaza de violón en la capilla musical del Duque, aunque siguió colaborando con la Casa de Osuna, sustituyendo eventualmente a su hijo. Cuando éste viajó en 1732 con la Corte a Sevilla, Literes Carrión cobró doscientos setenta reales que le había dejado "su hijo Don Joseph, músico violón, de su ración de nueve que tiene al día" ${ }^{\prime 44}$. En su testamento Antonio Literes, aclara las circunstancias de esta sustitución:

"Prevengo también que cuando estuvo en Sevilla con la Corte dicho Don Joseph Literes, mi hijo, me cedió el tiempo que se mantuvo en ella las mesadas que le correspondieron por músico del Excelentísimo Señor Duque de Osuna, pero esto fue porque suplí su parte, concurriendo a cumplir por él la obligación que tenía de asistir a tocar en las funciones que se ofrecían en casa de Su Excelencia ${ }^{45}$.

En 1722, la capilla musical del Duque de Osuna contaba entre sus miembros con el joven José de Nebra $(* 1702-\dagger 1768)$ a quien se nombra como "músico de cámara" en un documento de dicho año:

\footnotetext{
42 AHN NOBLEZA, OSUNA-CARTAS, leg 389-3-4.

43 Ibid., leg 414-10.

${ }^{44}$ Ibid., leg 446-1.

45 Archivo de Protocolos de Madrid, Escribano José Collantes Bustamante, leg 18425, f. 35. Publicado en Solar-Quintes, “Antonio Literes Carrión”, p. 175.
} 
Páguense del dinero de mi Tesorería General de esta Corte, un mil ochocientas y ochenta y dos reales y diez y siete maravedíes de vellón; los un mil quinientos y sesenta reales de ellos, Don. Joseph de Nebra, mi músico de cámara por las copias de la ópera Fernán Cortés, de la de Siempre el Amor es vencer, como parece de una memoria que está con este $[\ldots]^{46}$

El joven Nebra, que en esta época trabajaba también como organista en el Real Monasterio de las Descalzas Reales, debía de ser ya un competente instrumentista de tecla para ser admitido en la capilla privada del Duque junto a experimentados y veteranos músicos como Antonio Literes y Baltasar Caballero. Como afirma $\mathrm{M}^{\mathrm{a}}$ Salud Álvarez, el trabajo que desarrolló José de Nebra en la capilla del Duque de Osuna debió de facilitarle el conocimiento de las peculiaridades estilísticas de la música italiana, ya que hacia 1726 se hallaba al frente de esta capilla musical el compositor napolitano Antonio Duni, autor de varias obras teatrales ${ }^{47}$. Este compositor, nacido en los primeros años del siglo XVIII, se había establecido en España antes de $1726^{48}$. José de Nebra pudo coincidir con Antonio Duni durante su permanencia en la capilla del Duque de

${ }^{46}$ AHN NOBLEZA, OSUNA-CARTAS, leg 389-3. Publicado en Solar-Quintes, "Antonio Literes Carrión”, p. 170.

${ }^{47}$ M Salud Álvarez, José de Nebra: vida y obra (Zaragoza: Institución Fernando el Católico, Sección de Música, 1993), pp.17-18.

${ }^{48}$ Emilio Cotarelo y Mori, Historia de la zarzuela, o sea el drama lírico en España, desde su origen a finales del siglo XIX (Madrid: Tipografía de Archivos, 1934), pp. 87-90. Antonio Duni estrenó el 23 de febrero de 1726 en el teatro de la Cruz de Madrid la zarzuela Locuras que hay que dan juicio y sueños que son verdad con texto de Antonio de Zamora, y al año siguiente la comedia de música Santa Inés de Montepoliciano y la música para el auto sacramental de Calderón de la Barca El Maestrazgo del Tusón. Es asimismo autor de la música de Triunfo y error de los celos y el amor, Drama musical al estilo italiano, compuesto a instancias de Antonio Guedes Pereira, enviado extraordinario de su majestad portuguesa en la corte de Madrid para la onomástica de celebración de María Ana Victoria, futura princesa de Brasil. (BNE T-12306). 
Osuna, que finalizó antes de 1732, año en que ninguno de los dos músicos se hallaban ya al servicio de la casa ${ }^{49}$.

La plantilla de músicos asalariados al servicio del Duque en 1732 estaba compuesta por dos violines, un violón, dos oboes, dos bajones, un clarín, y un “músico compositor” que posiblemente debió de ejercer la dirección de la capilla desde el clave (Tabla 5). Esta formación, revela la existencia de una verdadera capilla musical que se reforzaba con otros músicos de fuera cuando era necesario. El Duque contaba en este año también entre sus criados con un "templador de clavicordios" asalariado ${ }^{50}$.

Entre los músicos que formaban parte de la capilla del Duque de Osuna en 1732 se hallaba el clarín Juan Martín Blumen[stengle], que desde 1734 fue trompa de la Capilla Real ${ }^{51}$. El cargo de "músico compositor"fue desempeñado, al menos desde 1732, por Manuel Pradell, que cobraba por esta labor un salario de 22 reales y medio al día. Este personaje, del que no se tenían noticias hasta ahora, todavía prestaba su servicio a la Casa de Osuna en septiembre de 1741, cuando se encargó de pagar a varios músicos por su asistencia a las fiestas de San Pedro y San Zoilo $^{52}$. Siguiendo una política matrimonial endogámica habitual entre los músicos de la época que residían en Madrid, una de las hijas de Manuel Pradell fue la segunda esposa de Domingo Porreti, violonchelista de la Real Capilla ${ }^{53}$. Las

\footnotetext{
49 AHN NOBLEZA, OSUNA-CARTAS, leg 446-1.

50 Ibid.

51 José Subirá, Temas musicales madrileños (Madrid: CSIC, 1971), pp. 222-223.

52 AHN NOBLEZA, OSUNA-CARTAS, leg 389-30.

53 Nicolás Morales, “A la sombra del Poder. Usos sociales y lucrativos de la Comunidad Musical Palaciega en el Siglo XVIII” Campos Interdisciplinares de la Musicología, Actas del V Congreso de la SEdeM, vol. 1, p 74. En los documentos consultados por este autor Manuel Pradell aparece
} 
dos hijas de este matrimonio también se casaron con importantes músicos: la mayor María Joaquina Porreti fue la segunda mujer del violonchelista $y$ compositor Luigi Boccherini; y Maria Teresa Porreti se desposó con Rafael Monreal, violinista de la Real Capilla ${ }^{54}$.

Tabla 5.

Composición de la Capilla musical de José Téllez Girón,

VII Duque de Osuna, en 1732

Fuentes: AHN NOBLEZA, OSUNA-CARTAS leg 446-1.

\begin{tabular}{|c|c|c|}
\hline NOMBRE & $\begin{array}{l}\text { CARGO O } \\
\text { INSTRUMENTO }\end{array}$ & OBSERVACIONES \\
\hline Manuel Pradell & Músico compositor & $\begin{array}{l}\text { Aparece citado también } \\
\text { como "Músico compositor } \\
\text { de Cámara de } \mathrm{Su} \\
\text { Excelencia" }\end{array}$ \\
\hline Juan Francisco Boteri & Violín & \\
\hline José Rocatallata & Violín & \\
\hline José Literes & Violón & $\begin{array}{l}\text { En ocasiones le sustituía su } \\
\text { padre el también violón } \\
\text { Antonio Literes }\end{array}$ \\
\hline Juan López & Oboe & \\
\hline Enrique Michón & Oboe & \\
\hline Juan Martín Blumen[stengle] & Clarín & \\
\hline Pedro Marrogat & Bajón & $\begin{array}{l}\text { Su hijo tocaba el oboe y } \\
\text { colaboraba en ocasiones } \\
\text { con la capilla del Duque. }\end{array}$ \\
\hline Juan Bautista Colón & Bajón & \\
\hline
\end{tabular}

Entre los criados al servicio del VII Duque de Osuna en 1732 se encontraba también el dramaturgo José de Cañizares $(* 1676-\uparrow 1750)$ que aparece citado en las nóminas de la Casa de Osuna como "Gentilhombre con el encargo de 
la letra de la música" o "Gentilhombre encargado de la música de cámara" Según Cayetano Barrera, Cañizares también trabajó como empleado en la contaduría del Duque de Osuna después de obtener su retiro militar ${ }^{56}$. Aunque el empleo de Cañizares al servicio de la Casa de Osuna podría haber cambiado a lo largo de los años, desde un cargo artístico como el de poeta o dramaturgo hasta un puesto de administración, es muy posible que Barrera se equivocara al interpretar la documentación administrativa de la Casa de Osuna, en la que suele aparecer el nombre y la firma de Cañizares en los documentos de pago por copias de obras teatrales junto a la expresión "visto por contaduría"57 . Las nóminas del personal al servicio del Duque en 1732 revelan que, al menos en esta época, el puesto que José Cañizares desempeñaba en la Casa de Osuna tenía una función literariomusical que, seguramente, consistía en la escritura de textos de obras dramáticas y camerísticas, una labor similar a la que a partir de 1736 desempeñó este dramaturgo en la Real Capilla ${ }^{58}$.

\subsubsection{Funciones de teatro musical en español patrocinadas por el VII Duque de Osuna}

El patrocinio y organización de representaciones de teatro musical en español fue otro de los aspectos en que se concretó el mecenazgo musical de José Téllez Girón, VII Duque de Osuna. Al menos hasta 1723, cuando fue destruido

\footnotetext{
${ }^{54}$ Morales, "A la sombra”, p.86.

55 AHN NOBLEZA, OSUNA-CARTAS, leg 446-1.

${ }^{56}$ Cayetano Alberto Barrera y Leirado, Catálogo Bibliográfico y Biográfico del Teatro Antiguo español, (Madrid: M. Rivadeneyra, 1860), p. 68.

${ }^{57}$ Véase, por ejemplo, AHN NOBLEZA, OSUNA-CARTAS, leg 389-5.
} 
por un gran incendio ${ }^{59}$, los Duques de Osuna dispusieron de un teatro particular dentro de las dependencias de su palacio de Madrid, donde se llevaron a cabo diversas funciones teatrales ${ }^{60}$.

En 1721, sólo un año después de obtener la titularidad del ducado de Osuna, el VII Duque de Osuna celebró en su palacio de Madrid unas “funciones de boda" para celebrar su matrimonio con Francisca Bibiana Manuel Alonso Pérez de Guzmán el Bueno. En estas fiestas intervinieron una "compañía de farsantes y "varios músicos" que se debieron sumar a los de su capilla musical ${ }^{61}$. Antonio Literes compuso para esta fiesta la música de la "Tea Nupcial”, cuya partitura no se conserva o al menos no se ha identificado hasta el momento ${ }^{62}$.

El mecenazgo del VII Duque en la producción de espectáculos dramáticomusicales abarcaba desde la gestación de la obra hasta su estreno en los teatros públicos. El proceso comenzaba habitualmente con el encargo de la música y el libreto de la zarzuela o comedia bien a autores que trabajaban a su servicio (como José de Cañizares o Manuel Pradell) o a otros activos en el panorama teatral madrileño de la época. Ocasionalmente, las obras se estrenaban antes en funciones privadas en el teatro del propio Duque con la participación eventual de miembros

\footnotetext{
58 BNE Ms. 14.004.4/ 172 (Papeles Barbieri).

59 Lastimoso fuego que se prendió sin saber ciertamente el como, en el Palacio y Coliseo del Excelentísimo Señor Duque de Osuna, [...] sucedió en Madrid este presente año de 1723, (Madrid: [s,1] [s, a]) BNE VC/1100/23.

60 AHN NOBLEZA, OSUNA-CARTAS, leg 414-10. En 1721 el pintor y escenógrafo Juan Vicente de Ribera realizó varios trabajos en este teatro.

61 AHN NOBLEZA, OSUNA-CARTAS, leg 292-1 y leg 414-10. Por la participación en estas fiestas se realizaron pagos a Antonio de Literes al oboe "Boyen" y a un clarín cuyo nombre no se cita. El oboe podría tratarse de Claudio Boyene, miembro de la Real Capilla al menos desde 1734. Véase Subirá, Temas, pp. 222-223.
} 
de la familia y de sus criados de mayor rango, junto a actores procedentes de los teatros de la Cruz o el Príncipe de Madrid y los músicos de la capilla privada del Duque de Osuna, a los que se añadían los refuerzos pertinentes si la obra así lo requería. Las producciones pasaban después a los teatros públicos, en donde se representaban por los actores y músicos de las compañías estables y algunos miembros de la capilla musical del Duque que reforzaban la plantilla de instrumentistas del teatro.

Tres zarzuelas fechadas entre 1727 y 1733 dan fe de labor de mecenazgo del VII Duque de Osuna en el campo del teatro musical:

1. España vencida triunfa. Zarzuela o "Melodrama" de autores anónimos fechada en 1727. Se representó en el teatro del Duque de Osuna con ocasión de la celebración del cumpleaños de la Duquesa de Medinaceli. Sus intérpretes fueron "la familia de los Excelentísimos Duques de Osuna, sus hermanos", es decir los familiares y miembros de su corte nobiliaria ${ }^{63}$.

2. Templo y Monte de Filis y Demofonte. Zarzuela con libreto de José de Cañizares y música de Francesco Corradini. Se estrenó públicamente el 27 de octubre de 1731 por la Compañía de Manuel de San Miguel en el teatro de la Cruz de Madrid, y duró en cartel veintidós días seguidos ${ }^{64}$. La administración del teatro realizó regalos a los autores de la música y el texto, y a los seis músicos que el Duque de Osuna envió para que tocaran en las funciones que no cobraron salario alguno por su colaboración. La zarzuela fue seguramente encargada por el Duque de

\footnotetext{
${ }^{62}$ AHN NOBLEZA, OSUNA-CARTAS leg 389-3-4. Ver nota 51.

${ }^{63}$ Cotarelo, Historia, p. 88. Se conserva un ejemplar del libreto en BNE T- 24577.

${ }^{64}$ Cotarelo, Historia, p. 92.
} 
Osuna y es probable que se representase en su casa antes de realizarse su presentación pública ${ }^{65}$.

3. Cuerdo delirio es amor. Zarzuela con libreto de José de Cañizares. La música de esta zarzuela atribuida hasta la fecha a Francesco Corradini $^{66}$. fue compuesta, casi con toda seguridad, por Manuel Pradell, maestro compositor de la Capilla del Duque de Osuna en esa fecha, como acredita un documento de pago de febrero de 1733, en el que se especifica que "se sacó la letra para Don Manuel de la zarzuela intitulada Cuerdo Deliro es Amor; para ponerla en música"67. La obra se estrenó el 6 de febrero de 1733 en el teatro de la Cruz de Madrid por la compañía de Juana Orozco, corriendo el Duque de Osuna con todos los gastos de las doce funciones que se dieron. Según Cotarelo, Cañizares sólo recibió unos regalos por parte de la Villa de Madrid por la composición de esta obra y el Duque facilitó siete músicos de su capilla para las representaciones ${ }^{68}$

El interés del VII Duque de Osuna por el teatro musical se enmarca dentro de la política de apoyo a la ópera y zarzuela promovida por personajes de la alta nobleza española en las primeras décadas del siglo XVIII, una política que

\footnotetext{
65 AVM Contaduría leg 4-165. Citado en José Máximo Leza, "Francesco Corradini y la introducción de la ópera en Madrid (1731-1749)", Artigrama, 12 (1996-97), p.134.

${ }^{66}$ Cotarelo, Historia, p. 95. No he localizado la música de esta zarzuela. En la BNE existe una copia manuscrita del libreto bajo la signatura Ms. $14071^{14} \mathrm{y}$ otra impresa en T-26170.

${ }^{67}$ AHN NOBLEZA, OSUNA-CARTAS, 413-40. Memoria de lo que se ha copiado así para los Corrales, como para Casa de. Su Excelencia de orden suya. En este documento figuran también los pagos del Duque por las copias de los libretos y listas de vestuarios enviados "a la Orozco" y un libramiento por la copia de "varios pedazos en la otra Comedia de la Boba discreta" de la cual se sacó una lista de los números musicales "creyendo la pudiese poner [en música] Don Manuel [Pradell]"

${ }^{68}$ Cotarelo, Historia, p. 95.
} 
algunos investigadores han interpretado como una de las causas decisivas que favorecieron la penetración de las óperas o melodramas italianos en la escena madrileña a partir de $1730^{69}$.

Otro de los factores que se han señalado para la introducción del género operístico es la presencia en Madrid de compositores e instrumentistas italianos vinculados a la Real Capilla y a otras actividades de la corte. Sin embargo, hasta el momento no se ha tenido en cuenta el papel que jugó la alta nobleza en este proceso, contratando a compositores italianos a su servicio. Como señalé anteriormente el compositor napolitano Antonio Duni dirigió la Capilla musical del Duque de Osuna hacia 1726, y probablemente gracias a su intercesión, el Duque hizo venir desde Nápoles a España al maestro de capilla napolitano Giovanni Battista Mele (*1701-†después de 1752), tal y como acredita el siguiente documento de pago:

Madrid 23 de noviembre de 1732

Háganse buenos en las cuentas que se dieren del dinero de mi tesorería general de esta corte, tres mil quinientos reales, que se dieron al enviado de Lorena Don Ambrosio Andriani para que en Nápoles se entregaran cincuenta doblones al Maestro de Capilla don Juan Baptista Mele de mi orden para que haga su viaje a esta corte.

El Duque ${ }^{70}$

Mele debió de llegar a Madrid a finales de 1732 o en los primeros días de 1733, posiblemente contratado por el Duque de Osuna para trabajar como profesor de música de su hija María Faustina a quien Mele impartió clases de

\footnotetext{
${ }^{69}$ Véase, por ejemplo, Leza, “Francesco", p. 140.
} 
música al menos entre 1743 y $1744^{71}$. Durante su estancia en España, Mele se convirtió en uno de los compositores más activos de la escena teatral madrileña, participando en la incipiente introducción del melodrama italiano. En enero de 1736 se estrenó en el teatro de la Cruz su ópera o Drama para representar en música, Por amor y lealtad recobrar la majestad. Demetrio en Siria sobre texto de Pietro Metastasio, adaptado al español por Vicente Camacho, y en los años siguientes compuso diversas obras que fueron representadas en las funciones de ópera cortesana del Palacio del Buen Retiro y en los teatros públicos de Madrid $^{72}$.

\subsection{La música en las cortes nobiliarias de los Duques de Osuna en Italia en el siglo XVII}

La política cultural de apoyo a las artes desarrollada por los Duques de Osuna en Nápoles, Sicilia y Milán, incluyó una atención específica hacia la música $^{73}$ : La brevedad del cargo de virrey o gobernador (que no solía extenderse más allá de cuatro años) contribuyó a que la música, arte efímero y temporal por excelencia, fuera potenciada frente a otros proyectos artísticos cuya ejecución requería una mayor planificación.

\footnotetext{
70 AHN NOBLEZA, OSUNA-CARTAS, leg 389-11.

${ }^{71}$ Ver Capítulo III.

72 Emilio Cotarelo y Mori, Orígenes y establecimiento de la Ópera en España hasta 1800, (Madrid: Tipografía de la Revista de Archivos, Bibliotecas y Museos, 1917), p. 72. Ma Salud Álvarez Martínez, "Mele, Giovanni Battista”, DMEH, vol. 7, pp. 412-413. Los principales datos de la biografía de Mele aparecen en el Apéndice 5.

73 Javier Ignacio Martínez del Barrio, Mecenazgo y Política Cultural de la Casa de Osuna en Italia (1568-1694). Tesis doctoral (Madrid: Universidad Complutense, Servicio de Reprografía, 1989).
} 
El apoyo de los Duques de Osuna a la música en sus cortes de Italia se materializó en: 1) contribución al mantenimiento de las Capillas Reales en Nápoles y Sicilia, 2) organización de fiestas y espectáculos con presencia musical y 3) protección a compositores (que a su vez dedicaron ediciones musicales a los Duques de Osuna).

La capilla musical palatina de San Pedro de Palermo, que había sido creada por el virrey Colonna y consolidada en 1587 por su sucesor el Conde de Alba de Liste, estaba a disposición de la corte virreinal y participaba en las fiestas celebradas en los palacios aristocráticos, en el Palacio Real o en las fiestas religiosas y profanas de la ciudad. Durante su virreinato siciliano, Pedro Téllez Girón y Velasco, III Duque de Osuna, contribuyó al sustento de la capilla del palacio virreinal que, según Gregorio Leti, contaba con más de doce músicos [ $d i$ piu di 12 musici $]^{74}$. En una relación aclaratoria del estado de la tesorería del virreinato siciliano que el Duque envió al Rey de España en 1611, figuraban los pagos a los "canónigos y capilla de San Pedro de Palacio y la música que hay en ella" ${ }^{, 75}$. En esta época ocupaba el magisterio de la Capilla de San Pedro de Palermo Fra Vicenzo Gallo, que desempeñaba el mismo puesto en la catedral palermitana $^{76}$.

\footnotetext{
${ }^{74}$ Gregorio Leti, Vita di Don Pietro Giron, Duca d'Ossuna, Vicere di Napoli e di Sicilia, sotto il regno di Filippo Terzo (Amsterdam: Georgio Gallet, 1699), II, libro III, p. 300.

75 AHN, SIMANCAS, ESTADO, leg 1164. Publicado en Martín Fernández Navarrete [et al], Colección de Documentos inéditos para la Historia de España, (Madrid: Viuda de Calero, 1864), vol. 64, p.107.

76 Ottavio Tiby, "La música nella Real Capella Palatina di Palermo", AnM, VII (1952), pp.176192.
} 
Tras su traslado a Nápoles en 1615, el III Duque de Osuna (al igual que ya había hecho su abuelo entre 1582 y 1586) patrocinó las actividades de la Capilla Real napolitana. Cuando el Duque llegó a Nápoles la capilla estaba dirigida por el organista Giovanni María Trabaci y contaba con veinticinco cantores y un conjunto de instrumentistas compuesto por seis violines, un corneto, un trombón (sacabuche), un laúd, un arpa, y dos organistas ${ }^{77}$.

Durante su estancia en Nápoles, los Duques de Osuna solían acudir con frecuencia a los llamados Spassi di Posillipo, entretenimiento cortesano que consistía en pasear en barcas y carrozas por la zona de Posillipo, paraje cercano al mar situado en las afueras de la ciudad que estaba rodeado por numerosos jardines y palacios. Durante el virreinato de Pedro Téllez Girón esta diversión había perdido su condición de simple distracción, y se había convertido en un ejercicio de exhibición suntuosa entre la alta nobleza. En los Spassi di Posillipo se entablaban auténticas pugnas por mostrar la escuadra más numerosa y ostentosa formada por los mejores marineros y músicos ataviados con las mejores galas. En estas veladas se interpretaban canciones italianas y españolas acompañadas por un pequeño conjunto instrumental. Cuando la embarcación del virrey se cruzaba con la de otro noble, los músicos debían guardar silencio como señal de respeto ante la presencia de la máxima autoridad, pero lo habitual era que, salvo en este caso, se entablasen competiciones musicales entre los instrumentistas y cantantes que

\footnotetext{
77 Dinko Fabris, "Nápoles" $D M E H$, vol. 7, p. 957. El personal de la capilla musical incluía también un organero.
} 
acompañaban a los nobles en cada una de las $\operatorname{barcas}^{78}$.

El III Duque de Osuna patrocinó en Italia la celebración de diversos espectáculos festivos con música, una tradición que sería continuada por su nieto durante el gobierno de Milán ${ }^{79}$. En 1620, para celebrar la recuperación de una grave enfermedad del rey Felipe III, el Duque decidió organizar en el palacio virreinal napolitano de La Goletta un fastuoso evento de homenaje al rey. Con este fin encargó la composición de un espectáculo descrito en Breve Racconto della Festa a Ballo. Fantasia in Napoli per l'allegrezza della salute acquistata della Maestá Cattolica di Filippo III d'Austria. Rè delle Spagne. (Nápoles, C. Vitale, 1620). Este libro detalla todos los aspectos de la celebración, un espectáculo integral que puede enmarcarse en el género de la "festa a ballo" o festival cortesano. La edición incluye además de la música que se debía interpretar, y de una explicación detallada con gráficos de todos los movimientos coreográficos, varios discursos de alabanza, una descripción precisa de los trajes y máscaras de la fiesta, y el texto de la historia que actuaba como un simple hilo conductor, sin contenido dramático, y con la única finalidad de unir el movimiento escénico con la sucesión de piezas bailadas y $\operatorname{cantadas}^{80}$. El argumento, inspirado en temas mitológicos, tiene como escenario el citado paraje napolitano de Posillipo. En este lugar se enfrentan los espíritus de los bosques (con el dios Pan a la cabeza) con los representantes marinos dirigidos por Venus

\footnotetext{
${ }^{78}$ Martínez del Barrio, Mecenazgo, pp. 313-315.

79 Ibíd., p. 315. Durante su estancia en Milán el V Duque de Osuna participó con frecuencia en bailes y se hacía representar "comedias de Música"

${ }^{80}$ Martínez del Barrio, Mecenazgo, pp.307-311.
} 
que, finalmente, se reconcilian gracias al amor. En realidad, la trama de la representación no es más que un mero pretexto para alabar al Duque de Osuna y a su política como virrey de Nápoles. El libreto está repleto de constantes alusiones a la persona del Duque y ampulosos epítetos como Hispano Giove o Neptuno del Tirreno, que recuerdan las victorias militares de Pedro Téllez Girón ${ }^{81}$. La música esta Festa a Ballo es una sucesión de recitativos, arias, coros y danzas compuestas por cinco autores diferentes: Giovanni María Trabaci, (maestro de la Capilla Real de Nápoles desde 1614), Francesco Lambardi (organista de la misma capilla desde 1615) Pietro Antonio Giramo, Andrea Ansalone y el coreógrafo Giacomo $\operatorname{Spiardo}^{82 .}$

Del interés por la música que el III Duque de Osuna mostró durante su estancia en Sicilia y Nápoles quedó constancia en las ediciones musicales que le dedicaron importantes compositores italianos que gozaron de su protección. Antonio il Verso (ca.1565- ca.1621), discípulo de Pietro Vinci, y uno de los compositores principales de la escuela polifónica siciliana, dedicó a Pedro Téllez Girón, Il primo libro delle villanelle a tre voci, obra compuesta sobre textos amorosos de Guarini que fue editado por G. Vicenti en Venecia en 1612 (Lámina $11)^{83}$

\footnotetext{
${ }^{81}$ Ibid.

${ }^{82}$ Una selección de estas obras fue editada en Roland Jackson: A Neapolitan festa a ballo and selected instrumental ensemble pieces, (Madison: A-R Editions, 1978).

83 El facsimil completo de esta obra conservado en la Landesbibliothek und Murhardsche Bibliothek der Stadt Kassell se reproduce en Martínez del Barrio, Mecenazgo, pp.1313-1337.
} 


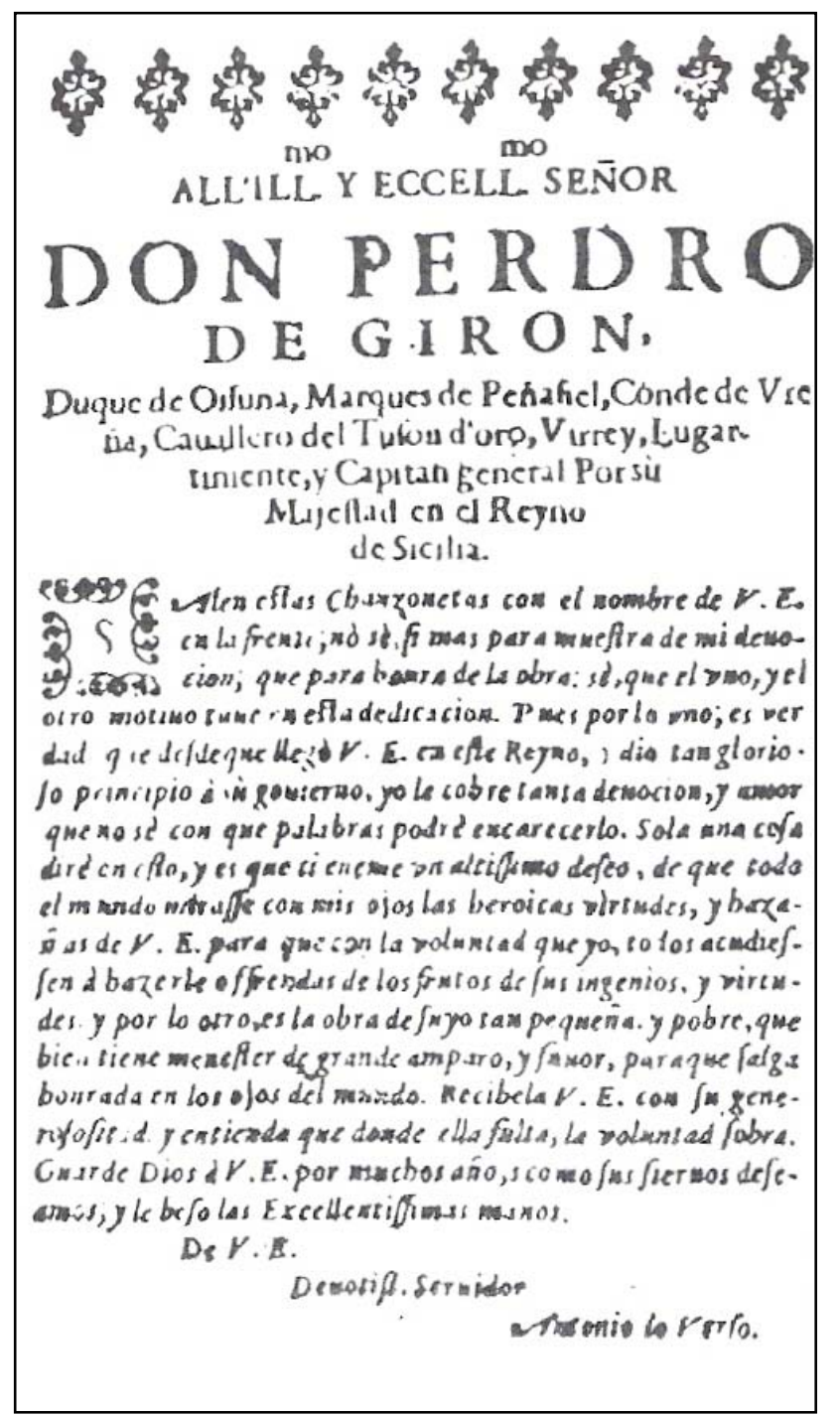

\section{Lámina 11.}

Dedicatoria al III Duque de Osuna de la edición de Il primo libro delle villanelle a tre voci, de Antonio il Verso,

(Venecia: G. Vicenti, 1612)

Giuseppe Palazzotto e Tagliavia, discípulo de Antonio il Verso, también gozó de la protección del III Duque de Osuna. Cuando Pedro Téllez Girón abandonó Sicilia en 1616, este compositor se trasladó con la corte del virrey a 
Nápoles. Nacido hacia 1587y fallecido después de 1633, Palazzotto e Tagliavia dedicó al III Duque de Osuna el primer libro de sus Madrigali a cinque voci editados en 1617 en Nápoles por Costantino Vitale (Lámina 12).

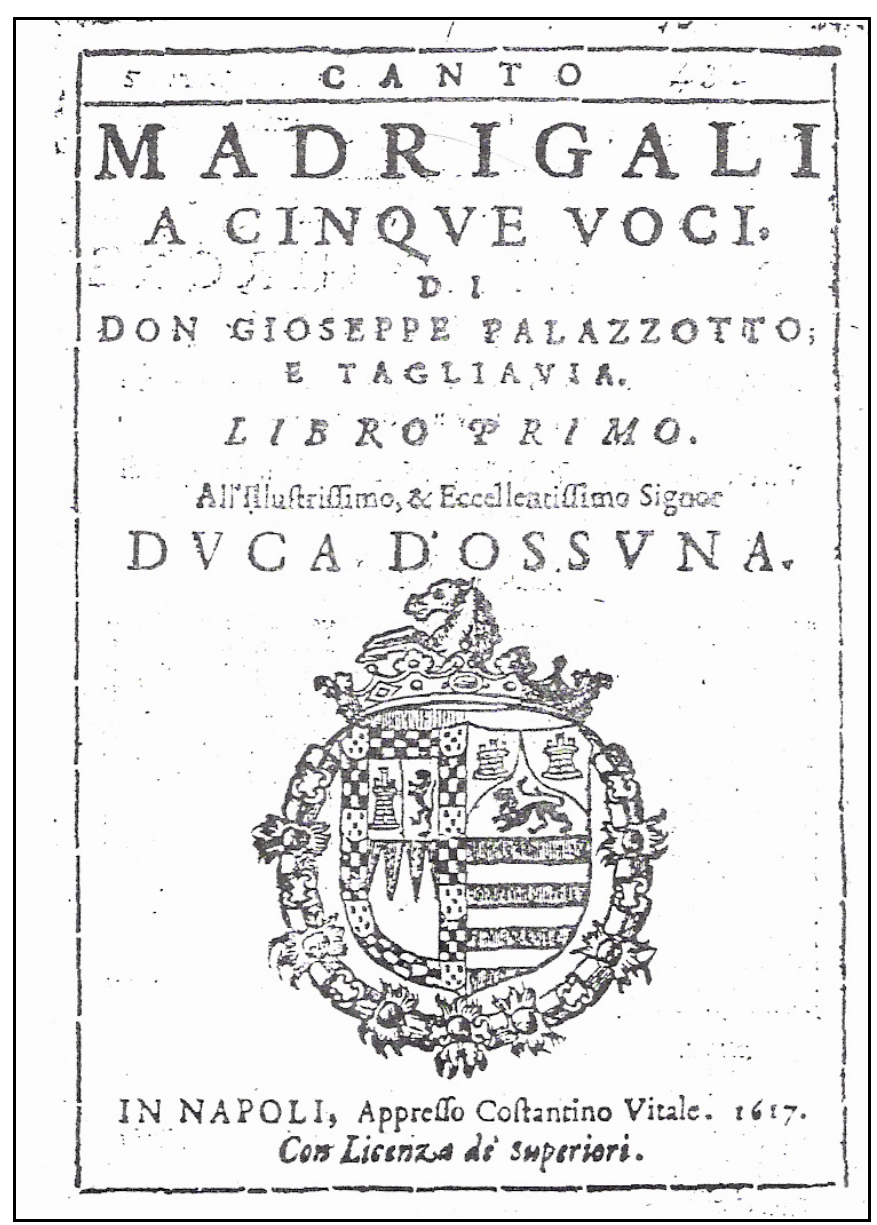

Lámina 12.

Portada de Madrigali a cinque voci: Libro primo de Giuseppe Palazzotto e Tagliavia, (Nápoles: Costantino Vitale, 1617) 
Según expresa el autor en la dedicatoria que abre esta colección de madrigales, la edición incluye algunas piezas que habían sido compuestas por encargo del propio Duque, y otras que eran de su gusto, y que solía escuchar cuando descansaba de sus obligaciones militares (Lámina 13) ${ }^{84}$.

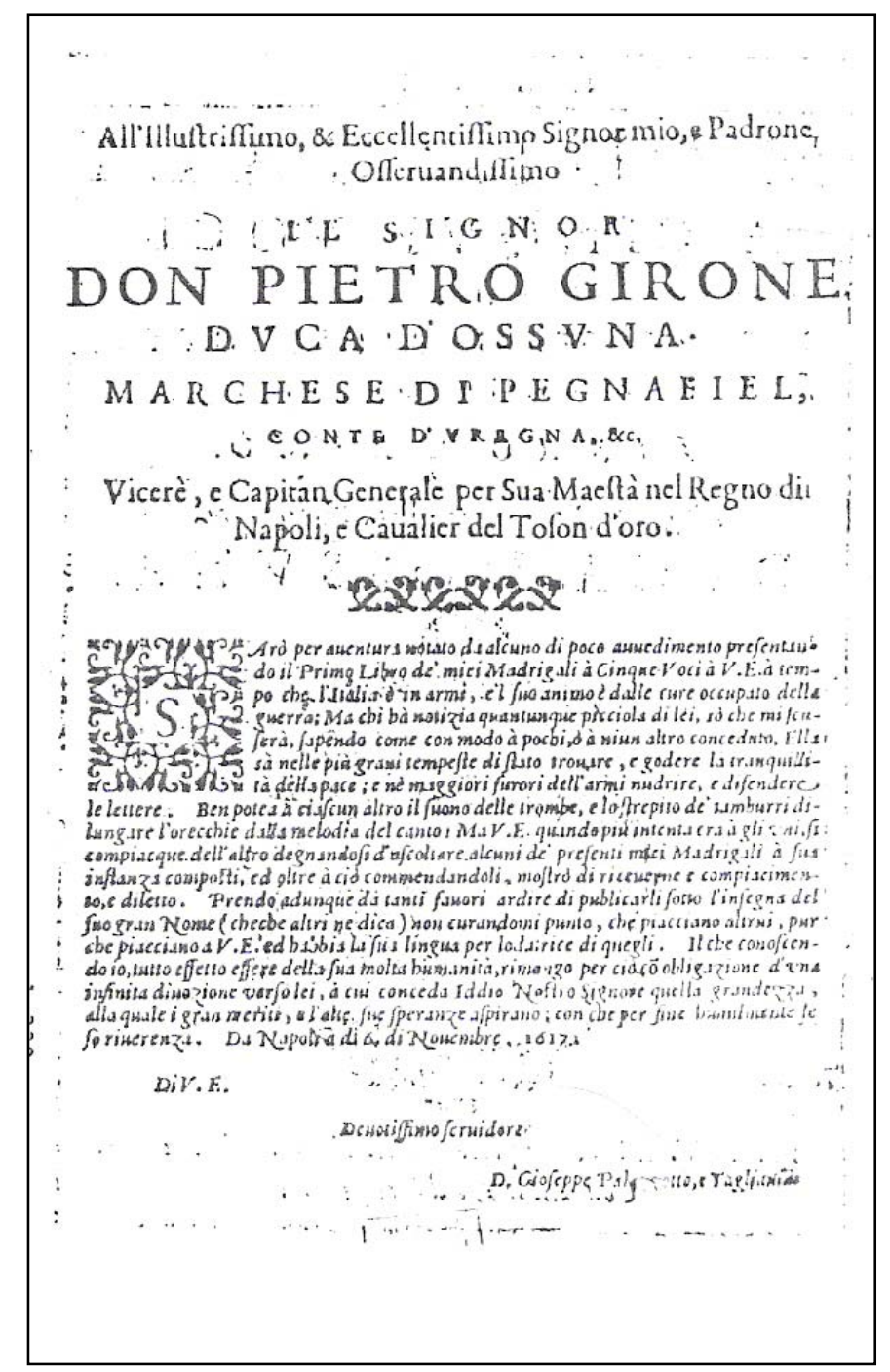

Lámina 13.

Dedicatoria al III Duque de Osuna de la edición

Madrigali a Cinque: Libro primo de Giuseppe Palazzotto e Tagliavia,

(Nápoles: Costantino Vitale, 1617)

84 El facsímil completo conservado en The Euing Music Library (Glasgow University) se reproduce en Martínez del Barrio, Mecenazgo, pp.1337-1397. 
Según Carapezza, los madrigales de Palazzotto constituyen uno de los mejores ejemplos del género en las primeras décadas del siglo XVII, y demuestran las habilidades contrapuntísticas de la escuela de su maestro Antonio il Verso, así como un amplio conocimiento del cromatismo de Carlo Gesualdo y de la seconda prattica de Monteverdi. Cada pieza está concebida como una unidad orgánica de acuerdo con un plan tonal definido y con secciones contrastantes desde el punto de vista rítmico y armónico ${ }^{85}$.

La protección del III Duque de Osuna a algunos músicos de su entorno cortesano se prolongó tras su cese forzoso como virrey de Nápoles. Según Gregorio Leti, biógrafo del III Duque de Osuna, cuando Pedro Girón volvió a Madrid en 1620 le acompañaron un grupo de buenos músicos italianos [un coro di Musici d'Italia nobilísimo] que incluía cuatro capellanes, dos al servicio del Duque y los otros dos al de su mujer ${ }^{86}$. Las difíciles circunstancias políticas, y los sucesivos encarcelamientos a los que se vio sometido el III Duque poco después de su regreso a la Península Ibérica debieron de obstaculizar o al menos limitar las actividades de estos músicos a su servicio de los que, hasta la fecha, no se tiene más noticia.

85 Paolo Emilio Carapezza, “O soave armonia, classicitá, maniera e barocco nella scuola polifonica siciliana, Studi musicali, III (1974), pp. 347-90.

${ }^{86}$ Leti, Vita, libro III, p. 346. 


\section{La música en la corte nobiliaria de los Condes-Duques de Benavente en los siglos XVI y XVII.}

$\mathrm{Al}$ igual que sucede con la gran mayoría de las casas nobiliarias españolas, no contamos hasta la fecha con ningún estudio de la actividad musical de la familia Pimentel, titular del Condado-Ducado de Benavente, antes de su adhesión a la Casa de Osuna en $1787^{87}$. La reconstrucción de la historia de esta familia, en la Edad Moderna se hace especialmente difícil, ya que parte de la documentación administrativa que se guardaba en la Fortaleza de la villa zamorana de Benavente, una de las residencias de los Condes-Duques del mismo nombre hasta el siglo XVII, desapareció tras el incendio que destruyó el archivo familiar durante la Guerra de la Independencia. No obstante, dentro de la documentación administrativa de la Casa de Osuna se conservan algunos documentos que dan fe de que la música estuvo presente en las cortes nobiliarias de los Condes-Duques de Benavente desde finales del siglo XV hasta mediados del siglo XVII.

Entre los criados que trabajaron al servicio de Rodrigo Alfonso Pimentel, IV Conde de Benavente, y su hijo y sucesor Alonso Pimentel en 1499, se hallaban un importante grupo de músicos. Cuando el V Conde de Benavente tomó posesión del título en los primeros meses de 1499, la Casa de Benavente contaba con una capilla musical estructurada compuesta por un maestro de capilla, un grupo de seis cantores, tres niños de coro, dos capellanes, un organista, un arpista, cuatro

\footnotetext{
${ }^{87}$ En su tesis doctoral Roberta Freund Schwartz presentó algunos datos sobre la capilla del IV Conde de Benavente. Véase Roberta Freund Schwartz, En busca de liberalidad. Music and Musicians in the Courts of the Spanish Nobility, 1470-1640. Tesis doctoral (University of Illinois at Urbana-Champaign, 2001), pp. 469-473.
} 
ministriles, y dos sacabuches. La dotación musical de la casa se completaba con un conjunto de músicos "heráldicos" formado por siete trompetas y dos atabales que acompañaban al Conde en sus campañas militares y participaban en los actos representativos organizados por la casa ducal ${ }^{88}$.

El VI Conde de Benavente, Antonio Alfonso Pimentel ("1514- $\uparrow 1575)$, uno de los hombres de confianza del rey Carlos $\mathrm{V}$, tuvo a su servicio una pequeña capilla de músicos esclavos. El 9 de junio de 1554, el Conde compró a Domingo Rodríguez de Albarenga, vecino de la ciudad de Lisboa, seis "esclavos ministriles" con sus instrumentos:

Sepan cuantos esta carta presente vieren como yo Domingo Rodriguez de Albarenga v[ecin]o de la ciudad de Lisboa que es en el reino de Portugal otorgo e conozco por esta carta que vendo al I[lustrísi]mo Señor don Antonio Alfonso Pimentel Conde de Benavente para su señoría e para sus hijos y herederos e antecesores e para quien de ellos obiere titulo e causa conviene saber seis esclavos menestriles que yo tengo, uno que se dice Pedro de Sequera tiple negro de rostro de edad de veinte e tres o veinte e cuatro años poco mas o menos, e el otro Pedro de Magallanes contralto de rostro negro de edad de veinte dos e veinte y tres años poco mas o menos, el otro que se dice Pedro Semon sacabuche moreno de rostro de edad veinte e tres o veinte e cuatro años poco mas o menos e el otro que se dice Fran[cis]co Yeremia negro de rostro de edad de diez e seis o diez e siete años poco mas o menos (ilegible) e el otro que se dice Gaspar sacabuche moreno de rostro de edad de veinte [años] poco mas o menos e el otro que se dice Luis tenor moreno de rostro de edad de veinte y cuatro o veinte e cinco años poco mas o menos" 89 .

\footnotetext{
88 AHN NOBLEZA, OSUNA, leg 418/1, 15-5. Citado en Schwartz, En busca, pp. 469-473.

${ }^{89}$ AHN NOBLEZA, OSUNA, leg 426-15-5. Compra que hizo el Señor Conde Don Antonio el $2^{\circ}$ de seis esclavos menestriles por 1250 Duc[ad]os de oro. Su fecha en 9 de Junio de 1554 ante Luis
} 
El documento certifica la buena conducta y salud de los esclavos de los que se dice "que no son ladrones ni borrachos ni fugitivos" y que no tienen "vicios ni enfermedades encubiertas" $"$.

En la Tabla 6 presento los principales datos de identificación de cada uno de los músicos que formaban parte de este conjunto. Como puede observarse, los seis esclavos todos ellos jóvenes y de raza negra o "morena", formaban un conjunto o capilla autónoma de tres voces (o quizá cuatro si consideramos como cantante a Francisco Yeremía) y dos (o tres) instrumentos de viento, capacitada para la interpretación de gran parte del repertorio polifónico de la época.

Tabla 6.

Músicos esclavos adquiridos por el VI Conde de Benavente en 1554

Fuente: AHN NOBLEZA, OSUNA leg 426-15-5.

\begin{tabular}{|c|c|c|c|}
\hline NOMBRE & $\begin{array}{c}\text { INSTRUMENTO } \\
\text { O VOZ }\end{array}$ & EDAD & $\begin{array}{c}\text { COLOR DEL } \\
\text { ROSTRO }\end{array}$ \\
\hline Pedro de Sequera? & tiple & 23 ó 24 años & Negro \\
\hline Pedro de Magallanes & contralto & 22 ó 23 años & Negro \\
\hline Luis & tenor & 24 ó 25 años & Moreno \\
\hline Gaspar & sacabuche & 20 años & Moreno \\
\hline Pedro Semón & sacabuche & 23 ó 24 años & Moreno \\
\hline Francisco Yeremía & No consta & 16 ó 17 años & Moreno \\
\hline
\end{tabular}

de Carvajal. El estado de conservación en que se encuentra este documento no permite una transcripción completa de su contenido.

${ }^{90}$ Ibid. 
La presencia de músicos esclavos en la Península Ibérica al servicio de la nobleza española durante la Edad Moderna, es un tema prácticamente ignorado hasta fechas muy recientes por la investigación. Roberta Freund Schwartz estudió sucintamente el papel de los esclavos que trabajaban para la nobleza española en los siglos XVI y XVII. El documento más antiguo que Schwartz aportó sobre músicos esclavos de raza negra es posterior al antes citado de 1554. Se trata también de un documento de carácter notarial fechado en 1588 en el monasterio de San Lorenzo [de El Escorial] por el que el Conde de Oropesa adquirió once esclavos negros con sus instrumentos y varios libros de música. Para enseñar a los esclavos a cantar y tañer los instrumentos, el Conde de Oropesa contrató al músico Juan Francisco Ignacio que, además, tenía entre sus obligaciones velar por su salud y buena conducta ${ }^{91}$.

Además existe constancia de que durante la Edad Moderna otras casas nobiliarias españolas también tuvieron esclavos músicos a su servicio. Lucía Gómez Fernández, ha constatado que en el siglo XVII los Duques de Medina Sidonia contaban entre sus criados con varias esclavas dedicadas a la música ${ }^{92 .}$

Las referencias mencionadas parecen evidenciar que la existencia de grupos musicales formados por esclavos debía de ser una práctica común dentro de las cortes nobiliarias españolas de la Península Ibérica durante los siglos XVI y XVII, como parecen acreditar también algunas representaciones iconográficas

\footnotetext{
91 AHN NOBLEZA, FRIAS. leg 1279, 1 -2. Transcritos en Schwartz, En busca, pp.634-638.

92 Lucía Gómez Fernández, Mecenazgo musical de la Casa de Medina Sidonia (1500-1645): Aproximación a las fuentes documentales. Trabajo de investigación inédito. Tutelado y dirigido por Emilio Ros-Fábregas (Granada: Universidad de Granada, 2003), pp. 84-86. Agradezco a la autora de este trabajo su amabilidad al permitirme mencionar este dato.
} 
contemporáneas al caso citado (Lámina 14). Las dimensiones y características de este interesante fenómeno requieren futuros estudios sistemáticos que exceden los objetivos de este trabajo.

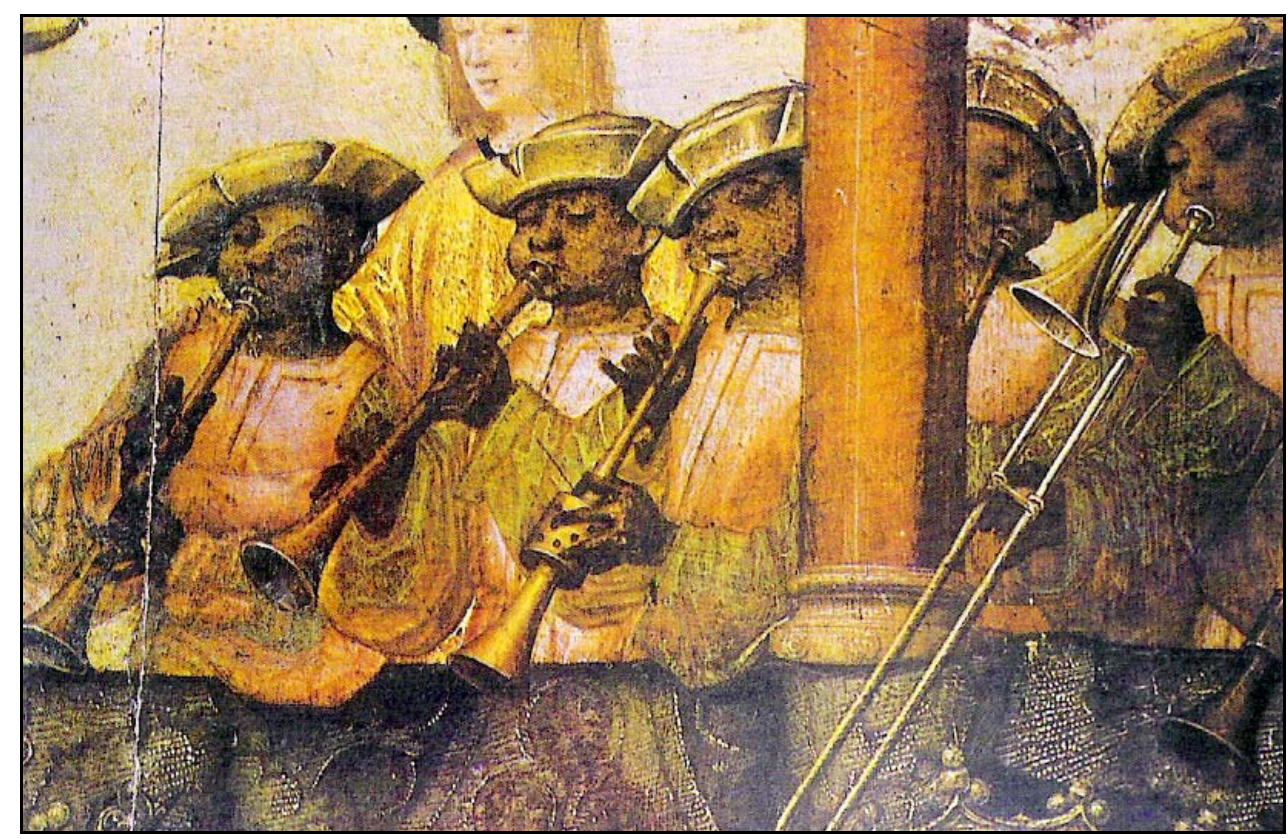

\section{Lámina 14}

Maestro de Ante-altares

Grupo de músicos de color con chirimías, bombarda y sacabuche.

Detalle de una pintura española sobre tabla (ca.1520).

(Museo Nacional de Arte Antiguo de Lisboa, inv. no 597$)^{93}$

Desde los primeros años del siglo XVII, las responsabilidades de los Condes-Duques de Benavente en la Corte les obligaron a trasladar su residencia a Madrid y Valladolid. Comenzó entonces un proceso de desmantelamiento de los bienes de algunos de sus palacios como la fortaleza de la villa de Benavente, que a

93 Fragmento reproducido en Rosario Álvarez y Lothar Siemens, La música en la Sociedad Canaria a través de la Historia, vol I ([Madrid]: Proyecto RALS de Canarias-El Museo Canario y Cosiste, 2005), p. 179. 
partir de entonces fue prácticamente abandonada. Este palacio perdió paulatinamente su función de residencia y sede de la corte nobiliaria de los Condes-Duques de Benavente, y se convirtió en un punto de referencia simbólico para el linaje de la familia Pimentel ${ }^{94}$.

El mobiliario, y también probablemente los instrumentos musicales, que durante el siglo XVI se conservaron en la fortaleza de Benavente, se trasladaron a los palacios de Valladolid y posteriormente a la residencia madrileña de los Condes-Duques. En un inventario de 1655 quedaban aún en la fortaleza de Benavente dos cajas de órganos y un manicordio descompuesto, que dan fe de la actividad musical cortesana que tuvo lugar en la que fue una de las residencia de los Condes-Duques hasta principios del siglo XVII ${ }^{95}$.

\footnotetext{
94 La labor de patronazgo de los Condes-Duques de Benavente en su villa solariega dio lugar también a la fundación del Convento de San Francisco, panteón familiar desde el siglo XV, en cuyo coro, había en el siglo XVIII un órgano con 32 registros y cuatro fuelles. El convento fue abandonado y desapareció definitivamente a consecuencia de la Desamortización de Mendizábal. Véase Mercedes Simal López, Los condes-duques de Benavente en el siglo XVII. Patronos y coleccionistas en su villa solariega (Benavente: Centro de Estudios Benaventanos Ledo del Pozo, 2002), pp. 144-154.

95 AHN NOBLEZA-OSUNA leg 427-8/66. Inventario de los bienes de La Fortaleza de Benavente en 1655. Publicado en Simal, Los condes-duques, pp. 236-239.
} 


\section{La música en las casas nobiliarias de Arcos y Gandía (siglos XVI- XVIII)}

Gran parte de los hábitos privados y comportamientos sociales y culturales de la alta nobleza se fundamentaban en los hechos y privilegios de los vínculos familiares y en las tradiciones del linaje. Cuando las Casas de Osuna y Benavente incorporaron en el siglo XVIII los ducados de Arcos, Béjar y Gandía, y en el siglo XIX los de Medina de Rioseco e Infantado, asumieron también algunas de las prácticas culturales y sociales de estas casas nobiliarias.

La carencia de estudios monográficos sobre el mecenazgo musical de la nobleza española durante la Edad Moderna impide conocer por el momento la trascendencia que tuvo la tradición y el linaje en el conjunto de las actividades musicales patrocinadas por las Casas de Osuna y Benavente. Sin embargo, como veremos a lo largo de este estudio, en los siglos XVIII y XIX los titulares de ambas casas patrocinaron varias prácticas culturales que incluían la música que se basaban en tradiciones fundadas por los anteriores titulares de una determinada dignidad nobiliaria, con los que sólo estaban remotamente emparentados. Por esta razón, antes de entrar a estudiar en detalle el mecenazgo musical de las familias Osuna y Benavente, describiré los principales precedentes de actividades musicales en las casas nobiliarias de Arcos y Gandía, los dos linajes más importantes que se integraron en las Casas de Osuna y Benavente durante la segunda mitad del siglo XVIII ${ }^{96}$.

\footnotetext{
${ }^{96}$ La incorporación de los ducados de Medina de Rioseco y del Infantado se produjo en las décadas centrales del siglo XIX. Véase el Capítulo I.
} 
Como señaló María Ester-Sala, en España, al menos desde el siglo XVI, "donde existe la casa solariega de un gran noble, esto quiere decir con una gran renta anual, amplio prestigio y necesidad de simbolizar un «status», aparece con gran frecuencia, y con más o menos fuerza la presencia de la música" ${ }^{\text {97 }}$. En el caso concreto de las casas ducales de Arcos y Gandía sus actividades musicales entre los siglos XVI y XVIII pueden agruparse en tres grandes bloques: 1) Formación musical y práctica musical de los titulares de las casas nobiliarias, 2) organización y mantenimiento de capillas musicales o plantillas estables de músicos patrocinadas por los nobles, y 3) patrocinio de actividades dramático-musicales.

\subsection{Formación y práctica musical entre los miembros de las casas de Arcos y Gandía}

La educación de la alta nobleza, especialmente desde principios del siglo XVI, se articulaba en dos facetas claramente diferenciadas. La primera, eminentemente práctica y dirigida especialmente a los herederos del título, se centraba en la tradicional formación militar y el aprendizaje de las disciplinas necesarias para la ocupación de importantes cargos administrativos en el gobierno (conocimiento de idiomas, retórica o cuestiones legales). La otra faceta de la formación, menos utilitaria, incluía el aprendizaje de una serie de habilidades destinadas a la vida privada, como la música o el baile, que contribuían a fomentar el uso personal de la experiencia estética como una fuente de conocimiento,

\footnotetext{
97. María Ester-Sala, "El Mecenazgo de la Nobleza en la Música del siglo XVI", Nassarre,. Revista Aragonesa de Musicología, 4/1-2 (1988), p. 48.
} 
sosiego o distracción ${ }^{98}$.

Existe constancia documental de que varios de los titulares de la Casa de Arcos durante el siglo XVI recibieron educación musical como parte de su formación humanística. El compositor Francisco Guerrero, en el prólogo de las Sacrae cantiones de 1555 dedicadas al II Duque de Arcos Luis Cristobal Ponce de León $(* 1512-\uparrow 1573)$, hace alusión a la tradición musical de los miembros de la Casa de Arcos, y menciona que Rodrigo Ponce de León $(* 1488-\uparrow 1530)$, I Duque de Arcos, además de ser un excelente conocedor de la lengua latina y buen aficionado a la música, había aprendido a cantar "de un modo muy aceptable":

Además, reconozco que vuestra familia mantiene la sagrada tradición de deleitarse con los placeres musicales en su tiempo de ocio, puesto que, prescindiendo de la consideración de vuestros antepasados, huelga decir que vuestro padre inculcó en Vuesa Merced desde la más tierna infancia una educación de amplias miras, como corresponde a un príncipe tan noble como Vuesa Merced, honra de nuestros tiempos. Además de valiente guerrero, vuestro padre era un erudito tan consumado que se ocupaba de la narrativa latina, cuyo estilo está por encima de toda censura, por si lo dicho no fuera suficiente disfrutó de la música hasta tal punto que no sólo oía larga y contemplativamente a expertos cantores de excelentes voces, sino que el mismo aprendió a cantar de modo muy aceptable ${ }^{99}$.

Según Francisco Guerrero, el Duque de Arcos solía utilizar la música como medio terapéutico y de distracción:

\footnotetext{
98 Jonathan Dewald, The European Noblity, 1400-1800 (Cambridge: Cambridge University Press, 1996), pp. 150-151.

99 Francisco Guerrero, Sacrae cantiones, (Sevilla: Martín Montesdeoca, 1555). Transcrito en Stevenson, La música, p. 203.
} 
Su afición por la música estaba inspirada en el ejemplo recibido de héroes de la antigüedad de tanto nombre como Aquiles, que reconocía la fuerza curativa de ésta, y de Alejandro, que la utilizaba como una única forma de descansar de sus asuntos de estado ${ }^{100 .}$

Esta afirmación debe interpretarse con una cierta precaución pues era un lugar común que aparece habitualmente en las biografías nobiliarias de la época, y que se remonta a los conceptos de paidia y anapausis (juego y relajación), presentes ya en la Politica aristotélica $^{101}$.

El I Duque de Arcos estuvo casado con María Téllez-Girón Lasso de la Vega, hija de los segundos condes de Ureña, y fue, por tanto, hermano político de otro de los grandes mecenas musicales de la nobleza del siglo XVI: el IV Conde de Ureña, Juan Téllez Girón residente en Osuna, intérprete musical aficionado y compositor. Dada la relativa cercanía entre las villas de Osuna y Marchena, y el vínculo familiar existente parece que fueron frecuentes los intercambios musicales entre las capillas de ambos nobles. En 1541, por ejemplo, se anotó un pago a Pedro Zamorano y otros tres ministriles de la capilla del Conde de Ureña que habían asistido a las fiestas celebradas por el Duque de Arcos el 28 de agosto de ese año ${ }^{102 .}$

\footnotetext{
100 Ibid.

${ }^{101}$ Sobre el valor terapéutico y lúdico de la música en la Antigüedad clásica y su utilización como tópico véase Edward A Lippman, Musical Thought in Ancient Greece, (Nueva York: Columbia University Press, 1964).

102 AHN NOBLEZA OSUNA leg 1613-1.
} 
Contemporáneo del I Duque de Arcos fue Francisco de Borja y Aragón (*1510-†1572), IV Duque de Gandía y marqués de Lombay, canonizado como San Francisco de Borja ${ }^{103}$. Figura esencial en la política y la religión en la España del siglo XVI, Francisco de Borja llegó a ocupar el cargo de Tercer General de la Orden de Jesús, después de una larga carrera al servicio de la monarquía.

Según recogen las declaraciones de sus biógrafos, el IV Duque de Gandía recibió una sólida formación musical que le permitía interpretar tanto música vocal como instrumental de forma competente:

Más porque no bastaban estos empleos a ocupar el tiempo que destinaba a las bizarrías de caballero, aplicó todo el ánimo a la música y a la caza, ejercicios ambos los más decentes, y mas oportunos a su estado y a sus años. Tenía la voz sonora y tan suave, que regalando los afectos blandamente robaba toda la atención, y mucha parte del alma por el oído; y aprendiendo ahora los mas diestros primores de la música, llegó a ser uno de los más celebrados maestros que tuvo España: dulce empleo, que según Tulio, modera los afectos de ánimo y se templan las costumbres al compás de las cuerdas. Jugaba la voz tan armoniosamente que pudiera ser príncipe de aquel arte, pasando la fantasía a la boca, y haciendo acordes con la razón los dedos, con pasar la mano por el instrumento ${ }^{104}$.

\footnotetext{
103 El ducado de Gandía se incorporó a la Casa de Benavente después de la muerte en 1740 sin descendencia de Luis Ignacio Francisco Juan de Borja y Aragón, X Duque de Gandía. La vinculación de San Francisco de Borja con la Casa de Benavente sirvió como excusa para que los titulares de esta casa organizasen en su honor solemnes fiestas religiosas con gran participación musical que se celebraban anualmente en Madrid. Sobre las funciones religiosas de San Francisco de Borja véase el Capítulo V.

104 Álvaro Cienfuegos, La heroica vida, virtudes y milagros del Grande San Francisco de Borja. (Madrid: Juan García Infanzón, 1702), Libro II, p. 50. Esta obra, que debió de tener gran éxito a la vista de las sucesivas ediciones que se repitieron durante el siglo XVIII, recoge y amplia las referencias a la afición musical del Duque de Gandía, que ya habían sido descritas por otros biógrafos anteriores como el jesuita Eusebio Nieremberg (1644).
} 
Como el Duque de Arcos, también Francisco de Borja parece haber disfrutado de los efectos terapéuticos de la música:

Y cuando le fatigaban mucho sus males, especialmente el dolor de gota, cantaba alguna oración a María Santísima de las que usa en la iglesia, y el Regina Coeli laetare con mas frecuencia: o algún verso de un salmo, tomándole a David el arpa de las manos, haciendo punto de la armonía algunos suspiros y músicos también los ojos. No desdeñando nunca esta dulcísima fantasía aun cuando era virrey de Cataluña, pues no se desdeñó Homero de poner en las manos de Hércules un plectro y una lira acabando de arrimar la lanza que sudaba sangre por la punta ${ }^{105}$.

Según Álvaro Cienfuegos, el IV Duque de Gandía compuso varias obras de música litúrgica que tuvieron bastante difusión durante su vida. Entre ellas, una misa, un Magnificat y una versión musical del salmo 118, esta última compuesta cuando convalecía de una grave enfermedad:

Nunca le pudieron vencer los ruegos a que pusiese en música versos profanos con que se hacen cómplices las musas, y los números de algunos afectos que para introducirse al corazón sobornaban los oídos. Los que componía era todo para el culto divino, y a canto de órgano; concertando la devoción con la oreja: siendo tan celebradas sus obras que se cantaban en muchas Iglesias Catedrales buscándolas con ansia los maestros de capilla: la Misa, el Magnificat y otras que llamaron después las obras del Duque de Gandía. Ni olvido del todo este suave ejercicio después de mudar de estado: pues siendo General de la Compañía, en la convalecencia de una enfermedad prolija, que padeció en Roma, puso en admirable música el salmo ciento y diez y ocho que empieza Beati inmaculati in via ${ }^{106}$

\footnotetext{
105 Cienfuegos, La heroica vida..., II, pp.50-51.

${ }^{106}$ Ibid..
} 
Más por tradición que por constancia documental, se atribuyen a Francisco de Borja dos composiciones litúrgicas anónimas: un Ludus Paschalis, que fue publicado por el padre Mariano Baixauli en la revista Razón y Fe en $1902^{107}$, y una misa conocida al menos desde finales del siglo XIX y editada por José Climent en Tesoro Sacro Musical ${ }^{108}$. Otra de las obras musicales que se han atribuido tradicionalmente al IV Duque de Gandía ha sido la Visitatio Sepulchri de Gandía, drama lírico-litúrgico en dos jornadas que representa el entierro y resurrección de Cristo. Esta tradición fue fundada y dotada económicamente por el propio Duque en 1550. Sin embargo, como ha señalado José María Vives Ramiro en un reciente artículo, no se conoce hasta la fecha ningún documento que acredite la autoría musical de esta obra ni que certifique que efectivamente fue compuesta por el Duque de Gandía ${ }^{109}$.

La afición musical de Francisco de Borja se mantuvo hasta el final de su vida y fue transmitida a su hijo Juan de Borja, al que Pietro Cerone alabó como uno de los grandes mecenas musicales de su época ${ }^{110}$.

\subsection{La capilla musical de los Duques de Arcos en los siglos XVI y XVII}

De todos linajes que se incorporaron a la Casa de Osuna entre los siglos XVIII y XIX, sólo la Casa de Arcos ha sido estudiada parcialmente desde el punto

\footnotetext{
107 Mariano Baixauli, “Las obras musicales de San Francisco de Borja conservadas en la Insigne Colegial de Gandía, Razón y Fe, 4 (Septiembre-Diciembre 1902), pp. 154-170 y pp. 273-283

108 José Climent, "Misa de San Francisco de Borja”, Tesoro Sacro Musical, 40 (1973), pp. 15-36.

109 José María Vives Ramiro, "La Pervivencia de la Visitatio Sepulchri de Gandía (Valencia) (1550-2004)", AnM, 59 (2004), p. 27.

110 Schwartz, En busca, pp. 461-465.
} 
de vista musical. Los trabajos de Solar-Quintes, Stevenson, Gómez Pintor y Schwartz analizaron algunos aspectos de la intensa actividad musical que se desarrolló durante los siglos XVI y XVII en torno a la corte nobiliaria de los Duques de Arcos en la villa sevillana de Marchena ${ }^{111}$.

Rodrigo Ponce de León, I Duque de Arcos, fallecido en Rota en $1529^{112}$ mantuvo en su palacio de Marchena una capilla musical de la cual nos han llegado algunas referencias. El Duque de Arcos tuvo a su servicio a un pequeño grupo de cantores, y en 1513 el vihuelista Antonio Ramos trabajaba también para él. Este grupo solía reforzarse para las fiestas religiosas importantes con músicos de la catedral de Sevilla. Rodrigo Ponce de León contaba también entre sus criados con un conjunto de trompetas y tambores que tal vez colaboraran en la interpretación de música cortesana, pero cuya función básica debió de ser representativa y militar, pues se sabe que participaban habitualmente en las campañas bélicas del Duque en Andalucía ${ }^{113}$.

Durante la titularidad de Luis Cristobal Ponce de León, II Duque de Arcos $\left.{ }^{*} 1528-\uparrow 1573\right)$ e hijo de María Téllez Girón de la Casa de Ureña ${ }^{114}$, se vivió uno

\footnotetext{
111 Nicolás. A Solar Quintes, "Morales en Sevilla y Marchena” AnM, VIII (1953), pp. 27-37; Robert Stevenson, La música; María Asunción Gómez Pintor: "Fuentes documentales para el estudio de las Casas de Osuna y Arcos", RMS, XVI/6 (1993), pp. 3459-3475; Schwartz. En busca, pp. 418-435.

112 Gaspar Ibáñez de Segovia, Memorias históricas y genealógicas de la Casa de los Ponces de León, Duques de Arcos, BNE Ms. 3147, f. 352r.

${ }^{113}$ Schwartz, En busca, pp. 418-421.

${ }^{114}$ Y por tanto sobrino de IV Conde de Ureña Juan Téllez Girón, fundador de la Universidad de Osuna y músico aficionado. Sobre la genealogía de la Casa de Arcos además de la citada obra de Gaspar Ibáñez Segovia véase también Pedro Salazar de Mendoza, Chrónico de la excelentisima casa de los Ponces de Leon. BNE Ms. 3462.
} 
de los momentos de mayor esplendor de esta corte nobiliaria y de su capilla musical. Según Solar-Quintes, en la corte nobiliaria del II Duque de Arcos en Marchena se celebraban habitualmente "grandes fiestas religiosas y muchas taurinas, profanas en las que solían actuar músicos, cantores, volatineros, comediantes y conjuntos teatrales según el modo de aquellos tiempos". En algunas de estas actividades participaba también la capilla musical del Duque que, al menos desde 1541, estaba dirigida por el maestro Melchor Téllez ${ }^{115}$.

Siguiendo la tradición de la Casa, el II Duque de Arcos tuvo a servicio un grupo de trompetas o músicos "heráldicos" que intervenían en las contiendas militares ${ }^{116}$. Dos de ellos fueron enviados en 1542 junto con ocho laceros a la frontera de Navarra ${ }^{117}$

Desde 1548, la capilla musical de los Duques de Arcos estuvo dirigida por Cristobal de Morales, que llegó a Marchena tras abandonar el magisterio de capilla de la Catedral de Toledo. En diciembre de 1548, Morales intervino en la compra de un clavicordio para la cámara del Duque ${ }^{118}$. Según Stevenson, el instrumento pudo haberse adquirido para que el mismo Morales lo tocase, posiblemente para deleitar al Duque ${ }^{119}$. En la época en que Morales ocupaba el magisterio de la capilla de los Duques de Arcos figuraban en ella los cantores Juan Gómez, Diego de Villadiego, Nicolás de Velasco, Alonso Verdugo, y el

\footnotetext{
115 Solar-Quintes, “Morales", p.34.

116 AHN NOBLEZA OSUNA, leg 1613-1.

117 Ibíd., leg 160-.4. Citado en Gómez-Pintor, "Fuentes...”, p. 3461

118 AHN NOBLEZA OSUNA-CARTAS, leg 616-27.

119 Stevenson, La música, p. 49.
} 
joven Juan Navarro ${ }^{120}$, cantor tenor, natural de la propia villa de Marchena, que años más tarde ocuparía el puesto de maestro de capilla en las catedrales de Ávila, Salamanca y Palencia, y del cual se conserva una prolífica producción de música $\operatorname{religiosa}^{121}$.

El magisterio de la capilla de los Duques de Arcos quedó vacante en 1551, cuando Cristobal de Morales cesó en este empleo y se trasladó como maestro de capilla a la catedral de Málaga. Aunque no existe constancia documental de quien fue el sucesor de Morales, es posible que se tratase de un personaje llamado Laureano que en 1569 se hallaba al frente de la capilla ${ }^{122}$. A finales del siglo XVI el maestro de capilla del Duque de Arcos era Andrés de Angulo, que abandonó este puesto en octubre de 1599 según consta en una carta de pago donde se le citó como "maestro de capilla que ha sido del Duque mi señor" y se ordenó se le entregasen "doscientos reales para su camino" $" 123$.

Uno de los acontecimientos religiosos más importantes de la Casa de Arcos que contaba con la participación de su capilla musical era la fiesta de la "Limpia Concepción" o la Inmaculada que se celebraba el 8 de diciembre. A través de algunos documentos que se conservan relacionados con esta fiesta

\footnotetext{
120 AHN NOBLEZA, OSUNA-CARTAS leg 1613-8.

121 Asunción Gómez Pintor, "Navarro, Juan”, DMEH, vol. 7, pp. 902-904.

122 AHN NOBLEZA, OSUNA-CARTAS leg 616-36. Citado en Solar-Quintes, "Morales”, p.37.

123 AHN NOBLEZA, OSUNA-CARTAS leg 550-59. Carta de pago fechada en Marchena el 15 de octubre de 1599. La cantidad que se le entregó a Andrés de Angulo debió de cubrir los gastos del viaje de este músico a otra localidad tras haber cesado en su cargo de maestro de capilla del Duque. Gómez Pintor afirma, sin embargo, que esta cantidad se entregó a Angulo "en pago a su labor de dirección y mantenimiento de los cantores" aunque el citado documento no especifica nada al respecto. Véase Gómez Pintor, "Fuentes", p. 3465. Según Roberta Freund Schwartz Angulo fue niño cantor en esa misma capilla hasta 1599. Schwartz. En busca, p.504.
} 
conocemos parte de la actividad religiosa de la capilla musical del duque. En 1569 participaron en la fiesta de la "Limpia Concepción" cinco chirimías, al menos ocho cantores, varios "mozos de coro" más el organista Juan García de Arenas, y el maestro de capilla Laureano ${ }^{124}$. La composición de la capilla musical que participaba en estas fiestas varió a lo largo de los años. En la fiesta de 1636, a la capilla de cantores dirigida por el maestro Carlos Domingo de Rada, se sumaron un grupo de ministriles, y un arpa para acompañar los villancicos y una misa ${ }^{125}$.

\subsection{Espectáculos dramático-musicales promovidos por los Duques de Arcos}

Al menos desde el siglo XVI, los titulares de la casa ducal de Arcos patrocinaron la celebración de espectáculos teatrales en su corte nobiliaria de Marchena (Sevilla). Estas funciones, probablemente contaron con participación musical, como era habitual en la época, aunque en la documentación que se ha conservado sólo se refleja la cantidad global pagada al autor o director de la compañía, que posiblemente incluyera los salarios de los músicos. En 1573 la compañía de Francisco Cornejo interpretó varias comedias en Marchena para los Duques de $\operatorname{Arcos}^{126}$, y en 1620 se pagó por idéntico concepto al autor de Sevilla Juan López ${ }^{127}$.

En el siglo XVIII, los Duques de Arcos patrocinaron varias funciones teatrales con música en los teatros públicos de Madrid. En el carnaval de 1740, se representó en Madrid por la compañía de Antonio Inestrosa la comedia con

\footnotetext{
124 AHN NOBLEZA, OSUNA-CARTAS, leg 616-36. Citado en Solar-Quintes, "Morales", p. 37.

125 AHN NOBLEZA, OSUNA-CARTAS, leg 550-4. Citado en Gómez Pintor, “Fuentes”, p. 3465.

126 AHN NOBLEZA, OSUNA-CARTAS, leg 616-14.
} 
música $2^{a}$ parte de Marta. Según Barbieri, en esta comedia "no se pagó música ni ingenio [libreto] de ella por haberlo costeado el Excelentísimo Señor Duque de Arcos" que además entregó 4000 reales para la compañía ${ }^{128}$. Francisco Ponce de León, IX Duque de Arcos, pagó todos gastos de las funciones públicas de la zarzuela anónima titulada Damne y Eleusipo, que se había representado antes en su casa y que se puso en escena en uno de los dos coliseos públicos de Madrid el 9 de octubre de 1752 por la compañía de José Parra ${ }^{129}$.

La protección de la Casa de Arcos al teatro musical no se limitó a la financiación económica de funciones concretas. El interés por el teatro de esta familia nobiliaria les llevó a financiar una compañía teatral de repertorio español que funcionó, al menos entre 1759 y 1761 en Madrid y Cádiz, bajo el patrocinio del Francisco Ponce de León, X Duque de $\operatorname{Arcos}^{130}$. La compañía estaba dirigida por Juan Doblado y en su elenco, entre otros actores, figuraron Rosalía Planas ${ }^{131}$ y Juan de Ocaña ${ }^{132}$. En 1760 la compañía teatral del Duque de Arcos se trasladó a Cádiz para actuar en la temporada de teatro ${ }^{133}$. Aunque no he podido documentar la totalidad de la plantilla de esta compañía, ni datos concretos sobre las obras que interpretaron, hay constancia de que entre sus miembros hubo algunos instrumentistas (fijos o contratados eventualmente) que se encargaron de

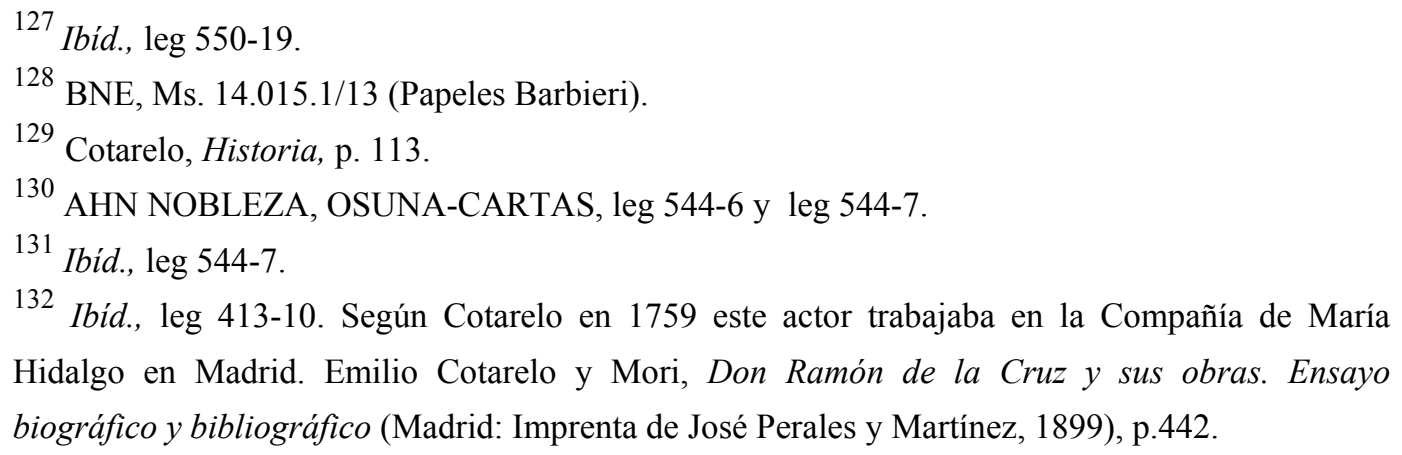


acompañar los números musicales de las comedias, sainetes, y sobre todo de las tonadillas, parte fundamental del repertorio de las compañías teatrales españolas desde la segunda mitad del siglo XVIII. En una carta fechada en Cádiz el 14 de marzo de 1760, Ángela Ronda, comediante de la compañía del Duque de Arcos, se lamentaba de los perjuicios económicos que le suponía la obligación de cantar tres días a la semana en el teatro pues debía "costear por su cuenta un maestro", es decir un músico que le enseñase la tonadilla o el número musical de la comedia o sainete correspondiente; y además "pagar por la copia de papeles" o partes instrumentales de la orquesta que acompañaba sus intervenciones musicales. Estos gastos eran mayores que el salario que la propia actriz recibía, por lo que el Duque de Arcos le concedió una ayuda de $\operatorname{costa}^{134}$.

133 AHN NOBLEZA, OSUNA-CARTAS, leg 544-6.

${ }^{134}$ Ibíd., leg 544-6 bis. 



\section{Capítulo III}

\section{Recursos humanos:}

músicos y maestros de baile

al servicio de las Casas de Osuna y Benavente

(1733-1834) 

Las actividades musicales que se desarrollaron en el entorno doméstico de las familias Osuna y Benavente o que fueron patrocinadas por los miembros de estas casas nobiliarias, requirieron de la participación de numerosos profesionales. Durante el siglo XVIII y en las primeras décadas del XIX, un gran número de instrumentistas, compositores, y profesores de música y baile, miembros de las más prestigiosas instituciones musicales de España trabajaron para las Casas de Osuna y Benavente, bien como músicos asalariados con un sueldo mensual fijo o como colaboradores contratados eventualmente.

Este amplio grupo de profesionales, que constituía los "recursos humanos" sobre los que se asentó la política de mecenazgo musical de la Casa, puede dividirse en dos grandes grupos. En el primero se incluirían los profesores de música y de baile, contratados expresamente para la formación de los miembros de la familia. El segundo grupo estaría formado por los instrumentistas y compositores, fijos o eventuales, cuya actividad principal al servicio de la casa fue la interpretación musical o la composición. Varios miembros de uno u otro grupo desempeñaron además distintas funciones complementarias para sus patronos como las de asesores del repertorio, intermediarios, encargados de contratar a músicos, copistas de música, o responsables del archivo musical de la Casa. 


\section{La formación musical de los miembros de las Casas de Osuna y Benavente: Profesores de música y maestros de baile}

La visión que la historiografía tradicional ha mantenido sobre la formación musical de los miembros de la nobleza durante el siglo XVIII, se ha centrado fundamentalmente en señalar que la educación musical estuvo limitada a las mujeres o que, en los casos en los que se extendió a los hombres, fue una simple cuestión de moda pasajera. Las habilidades de cantar, danzar y tocar un instrumento practicadas por los nobles se han interpretado usualmente bien como meros atributos unidos a la esencia femenina, un "requisito indispensable para completar una educación femenina refinada", o como el resultado de una moda de lujo dieciochesco en imitación de los gustos impuestos por la Casa Real ${ }^{2}$.

Unas coplas publicadas en 1786 y dadas a conocer por Carmen Martín Gaite, reflejan espléndidamente la imagen de la educación musical de los nobles como un artículo de lujo femenino, que desde el siglo XVIII se ha perpetuado en parte de la historiografía:

Las mujeres de mérito y crianza, útiles al Estado y de talento, deben, según del uso la ordenanza saber cantar, tocar un instrumento.

Quien no sabe un minué, una contradanza, bailar con resalado movimiento la decente alemanda con sus muecas, mujercilla será de las Batuecas.

${ }^{1}$ Carmen Martín Gaite, Usos amorosos del siglo XVIII en España (Madrid: Siglo XXI, 1972), p.37. 
Ahora: debe ignorar qué es lino y lana,

en cosas importantes divertida;

no corresponde, no, pasar la vida.

Que es mujer fuerte la mujer que afana

es sentencia de todos recibida;

pero la niña puede, de otra suerte,

con fuerte dote, ser la mujer fuerte.

Ni tener los inútiles cuidados,

casados ya, cuando amanece el día

de dar lo necesario a sus criados

con sabia y con discreta economía ${ }^{3}$.

Las opiniones de los teóricos y preceptistas, que habitualmente se han utilizado para justificar que la enseñanza y práctica de la música entre los nobles del siglo XVIII fue una simple moda, ocultan en realidad una finalidad moralizadora. En muchos de los manuales de buenas costumbres publicados en España en el siglo XVIII se obviaba (o quizá se ocultaba intencionadamente) la evidencia comprobada por otros documentos de que, al menos desde el siglo XVI, la práctica musical era habitual en muchas familias de la aristocracia residentes en la Península Ibérica. El siguiente fragmento de Osorio de la Cadena es un buen ejemplo de las teorías que figuran en muchos de estos manuales acerca de la educación musical:

Bien conoces que, al tomarles el maestro la lección, o al enseñarles ha de estar casi rostro con rostro con las niñas, y esta inmediación ni puede dejar de serles muy perjudicial. ¿A qué han de aprender música? Pues si ninguno

\footnotetext{
${ }^{2}$ Antonio Martín Moreno, Historia de la música española, 4. Siglo XVIII (Madrid: Alianza, 1985), p. 257.

${ }^{3}$ Alejo Dueñas, La crianza mujeril al uso (Pamplona, [s,1], 1786), pp. 9-10. Citado en Martín Gaite, Usos, pp. 36-37.
} 
de nuestros antepasados se ha gloriado de músico, sigamos sus pasos y no los de cuatro que quieren introducir con nombre de moda y habilidad lo que es libertad y relajación de costumbres ${ }^{4}$.

Sin embargo, como vimos en el capítulo anterior, la formación musical que recibieron ciertos miembros de la alta nobleza española llegó a tales niveles de competencia que les permitió incluso componer sus propias obras. La constancia de la participación directa de los miembros de la nobleza en la práctica musical durante los siglos XVI y XVII, apoya la hipótesis de que la enseñanza de la música y el baile que formó parte de la educación de los jóvenes nobles durante los siglos XVIII y XIX respondía a una sólida tradición fundamentada en las prácticas culturales de la alta nobleza española. Aunque es indudable que ciertos factores socioculturales, como la adopción de los gustos franceses e italianos, debieron de influir en la educación musical de los aristócratas durante el siglo XVIII; para ciertas familias de la alta nobleza española, como las titulares de las casas de Arcos, Gandía, Benavente u Osuna, el interés por la música fue una constante que se venía transmitiendo de generación en generación, de forma más o menos regular, al menos desde el siglo $\mathrm{XVI}^{5}$.

\footnotetext{
${ }^{4}$ Antonio Osorio de la Cadena, La virtud en el estrado, (Salamanca: [s,1], 1739). Citado en Martín Gaite, Usos, p.37.

${ }^{5}$ Véase el Capítulo II.
} 


\subsection{Profesores de música}

En el caso concreto de las Casas de Osuna y Benavente, la música y el baile fueron disciplinas fundamentales en la educación de los jóvenes de ambos sexos durante los siglos XVIII y XIX. La afición a la música llegó a calar muy hondo en algunos de los miembros de esta familia como María Faustina Téllez Girón, conocida por el título de Condesa-Duquesa viuda de Benavente, su hija María Josefa Alfonso Pimentel, XV Condesa-Duquesa de Benavente; Pedro de Alcántara, IX Duque de Osuna y sus hijas Joaquina María y Manuela Isidra, o Pedro de Alcántara Téllez Girón, XI Duque de Osuna. Todos ellos recibieron clases de música después de su niñez y algunos llegaron a convertirse en competentes músicos aficionados e intervinieron habitualmente como intérpretes en las academias y funciones que tenían lugar en los salones de sus palacios.

El gran interés que mostraron a lo largo de los siglos XVIII y XIX los titulares de las Casas ducales de Osuna y Benavente por la música tuvo también su reflejo en la elección de algunos de los músicos más destacados de la época para la educación musical de sus hijos. Como veremos en los siguientes apartados, la gran mayoría de los profesores de música que trabajaron al servicio de los Duques de Osuna y de los Condes-Duques de Benavente durante los siglos XVIII y XIX, eran músicos de reconocido prestigio que pertenecían a alguna de las instituciones musicales de la Corte o que trabajaban en los teatros de Madrid como instrumentistas o cantantes. 


\subsubsection{Profesores de música de la Casa de Benavente hasta 1787: G.B.Mele, J.A. Morotti, L. Marescalchi, A.Literes Montalvo, J. Lidón y Blas de Laserna}

A lo largo del siglo XVIII la Casa de Benavente tuvo a su servicio a varios profesores de música que se encargaron de la formación de las esposas e hijas de los herederos y los titulares de la Casa. Entre los maestros que trabajaron en las primeras décadas de dicho siglo para los Benavente se hallaba el compositor Juan Sisí, que al menos entre 1733 y 1734 fue el "maestro de tocar el clavicordio" de la Condesa de Luna, es decir de la esposa del heredero de la Casa de Benavente, Manuel Pimentel, XIV Conde de Luna $(* 1700-\uparrow 1735)^{6}$.

María Faustina Téllez Girón (*1724-†1796), hija del VII Duque de Osuna, tuvo como maestros de música a varios compositores vinculados a la Corte borbónica. Uno de sus primeros profesores fue el napolitano Giovanni Battista Mele, que llegó a Madrid en 1733 apoyado por el Duque de Osuna seguramente para trabajar como profesor de música de su hija ${ }^{7}$. Mele debió de seguir enseñando a la joven dama y es probable que continuase a su servicio tras la boda en 1738 de María Faustina con Francisco Alfonso Pimentel, heredero de la Casa de Benavente. Al menos entre noviembre de 1743 y enero de 1744, Mele estuvo empleado en la Casa de Benavente "con el trabajo de dar lección de cantar a mi señora la Condesa y [a] una dama de Su Excelencia" ${ }^{, 8}$.

\footnotetext{
${ }^{6}$ AHN NOBLEZA, OSUNA-CARTAS, leg 389-27. En los documentos anteriores a este que se conservan en AHN NOBLEZA sólo figuran gastos genéricos por lecciones de música. e

${ }^{7}$ Para la biografía de G.B. Mele véase el Apéndice 5.

${ }^{8}$ AHN NOBLEZA, OSUNA-CARTAS, leg 389-11. Libramientos de pago de 1743 y 1744. En el mismo legajo se conserva un recibo firmado por el propio Mele en 1743 por "el importe de los libros de música que he dado para estudiar [a] Su Excelencia”.
} 
La Condesa-Duquesa María Faustina, continuó su formación musical con José Antonio Morotti ( $\left.{ }^{*} 1709-\uparrow 1771\right)$, que desde 1738 era maestro de estilo italiano en el Real Colegio de Niños Cantores de Madrid, institución vinculada a la Real Capilla. Moroti fue "maestro de música" en la Casa de Benavente, al menos entre el 1 de septiembre de 1749 y el 31 de diciembre de 1751, con un sueldo de seis reales al día ${ }^{9}$. Su sucesor, desde junio de 1760, y con el mismo sueldo fue José de la Torre ${ }^{10}$.

Entre 1767 y 1768 María Faustina Téllez Girón recibió clases de música del compositor italiano Luigi Marescalchi $\left({ }^{*} 1745-\dagger 1812\right)$ que se hallaba en España trabajando como empresario y director de la ópera bufa de los Reales Sitios $^{11}$. El propio Marescalchi recordaba esta relación en una carta que en 1807 dirigió a la XV Condesa-Duquesa de Benavente, hija de María Faustina:

9 AHN NOBLEZA, OSUNA-CARTAS, leg 389-14 y 388-29. Judith Ortega, considera que el "José Moroti" al que se refieren estos documentos es un personaje diferente (probablemente un familiar) de Antonio Morotti maestro de estilo italiano en el Real Colegio de Niños Cantores de Madrid (Véase Judith Ortega, "El mecenazgo musical de la Casa de Osuna durante la segunda mitad del siglo XVIII: el entorno musical de Luigi Boccherini en Madrid, RMS, XVII/2 (2004), p. 651). Sin embargo, en un recibo de la Casa de Benavente de 1763 (AHN NOBLEZA, OSUNACARTAS, leg 389-14) puede verse claramente como el maestro de música de la Casa de Benavente firma como "Joseph Ant[on]io Morotti", lo que indica que se trata de una única persona. Otro dato que apoya esta hipótesis es que el maestro José Antonio Morotti que trabajó para la Casa de Benavente había ya fallecido en 1772 fecha en la que figuran sus herederos y cesonarios como titulares de las cantidades que se le adeudaban a la muerte del XIV Conde-Duque de Benavente (AHN NOBLEZA, OSUNA-CARTAS, leg 506-1.). Para la biografía de Morotti véase el Apéndice 5.

10 AHN NOBLEZA, OSUNA-CARTAS, leg 457. Nóminas de las raciones de "la familia de escaleras arriba” de la Señora Duquesa de Benavente. Por el momento no he podido confirmar si este músico puede identificarse con el "José de la Torre" que fue tenor de la Real Capilla en la época de Fernando VI.

${ }^{11}$ Los principales datos de la biografía de Luigi Marescalchi figuran en el Apéndice 5. 
Memori sempre dell'alti onore e della generosa Protezione, che si degnó accordarmi l'Eccellentisima Madre dell' Eccelenza Vostra como di lei Maestro de Musica quando fui costi primo fondadore delle Opere Buffe a codizzi Siti Reali ${ }^{12}$

La heredera de la Casa de Benavente, María Josefa Alfonso Pimentel ( $\left.{ }^{*} 1751-\uparrow 1834\right)$, también recibió clases de música desde su infancia. Uno de sus primeros maestros fue el organista de la Real Capilla Antonio Literes Montalvo, que le dio clases de clave al menos entre septiembre de 1759 y marzo de $1761^{13}$. Ya en su madurez, la Condesa-Duquesa María Josefa tuvo como profesor a otro miembro de la Real Capilla, el clavecinista y compositor José Lidón como muestra un recibo firmado por este en 1783:

He recibido de Don Manuel de Cubas, Contador General de la Casa y Estados del Excelentísimo Señor Conde de Benavente Un mil ochocientos reales de vellón por la asignación que gozo como maestro de música de la Condesa Duquesa mi Señora de trescientos sesenta reales en cada mes, y por lo correspondiente a los cinco meses contados desde primero de enero de hasta fin de mayo de este año. Madrid 31 de octubre de 1783

Josef Lidón (rúbrica)

Son 1.800 reales de vellón ${ }^{14}$.

\footnotetext{
12 AHN NOBLEZA, OSUNA-CARTAS, leg 387-16. [Mi traducción]: "Recuerdo siempre el alto honor y la generosa protección que se dignó en concederme la Excelentísima madre de $\mathrm{Su}$ Excelencia como su maestro de música cuando fui fundador de la ópera bufa de los Sitios Reales". La estancia de Marescalchi en España y su relación con la Condesa-Duquesa María Faustina no se cita en Richard Macnutt, "Marescalchi, Luigi”, $N G$, vol 15, pp. 845-846.

13 AHN NOBLEZA, OSUNA-CARTAS, leg 457-1.

${ }^{14}$ Ibid., leg 390-8.
} 
El trabajo de José Lidón al servicio de la Condesa-Duquesa de Benavente (que comenzó antes de abril de 1781 y se prolongó hasta mayo de 1792) parece haber tenido básicamente una finalidad pedagógica. Aunque desde las investigaciones de Solar-Quintes ${ }^{15}$ se ha mantenido que Lidón trabajó como director de la orquesta de la Condesa-Duquesa, en los recibos y nóminas conservados su nombre siempre aparece asociado a los empleos de "maestro de música" o "maestro de clave" ". No puede descartarse, no obstante, que como músico asalariado de la Casa, Lidón participase como instrumentista de tecla en las academias o funciones musicales organizadas por la Casa o se hiciera cargo de la dirección de alguna función. Sin embargo, la cantidad de 360 reales de vellón que aparece como pago a Lidón en todas las nóminas de los músicos al servicio de la Condesa-Duquesa de Benavente entre 1781 y 1792 coincide con la que figura en el libramiento arriba transcrito por el que se pagaron sus servicios "como maestro de música de la Condesa Duquesa"17.

José Lidón coincidió al servicio de la Casa de Benavente con el compositor de música teatral Blas de Laserna que, al menos durante el año de

\footnotetext{
${ }^{15}$ Nicolás A. Solar-Quintes, "I. Las relaciones de Haydn con la casa de Benavente. II. Nuevos documentos sobre Luigi Bocherini. III. Manuel García Íntimo ”, AnM, II (1947), pp. 81-104.

${ }^{16}$ Véase el apartado 2 de este capítulo

${ }^{17}$ AHN NOBLEZA OSUNA-CARTAS, leg 390-8. En ocasiones José Lidón cedió la mitad de su salario en la Casa de Benavente a su padre, sacristán y organista de la Iglesia de Santa María la Mayor de Bejar (Salamanca) uno de los territorios que pertenecían a la administración de la Casa de Benavente. Desde las investigaciones de Solar Quintes ("I. Las relaciones", p. 239) se ha mantenido que el padre de José Lidón desempeñaba funciones como tesorero para la Casa de Benavente. Este dato procede de una mala lectura de las nóminas de la orquesta de la CondesaDuquesa en la que se detalla que a Lidón sólo se le pagaba la mitad de su sueldo "a causa de recibir su padre en la Tesorería de la Villa de Bejar la otra mitad. (véase por ejemplo AHN NOBLEZA OSUNA-CARTAS, leg 390-6).
} 
1781, trabajó como "maestro de clave" de la Condesa-Duquesa ${ }^{18}$.

\subsubsection{Manuel Carreras y Gaetano Brunetti, profesores de violín de Pedro de Alcántara Téllez Girón, Marqués de Peñafiel}

La formación musical de los miembros de la nobleza no fue patrimonio exclusivo de las mujeres. Durante los siglos XVIII y XIX, la educación de los futuros titulares varones de la Casa de Osuna incluyó también una formación básica en música y danza.

Pedro de Alcántara Téllez-Girón, Marqués de Peñafiel y futuro IX Duque de Osuna, recibió periódicamente en su juventud clases de violín de dos de los más destacados instrumentistas del Madrid de su época. La formación violinística del Duque debió de iniciarse con Manuel Carreras, violinista de los teatros de la Corte y posteriormente miembro de la Capilla Real, que desde 1773 trabajaba al servicio de la Casa de Osuna con el cargo de "maestro de violín del Marqués, Conde-Duque" con un sueldo de 12 reales al día ${ }^{19}$. Pedro de Alcántara continuó su formación instrumental con uno de los más afamados profesores de violín de Madrid, el italiano Gaetano Brunetti ${ }^{20}$, maestro de violín del Príncipe de Asturias (futuro Carlos IV) y miembro de la Real Capilla que fue contratado por la Casa de Benavente el 1 de abril de 1776 con la asignación de quince reales diarios:

\footnotetext{
18 AHN NOBLEZA OSUNA-CARTAS, leg 390-2 y BNE Ms. 14.016.3/41 (Papeles Barbieri). Blas de Laserna tuvo una estrecha relación con la Casa de Benavente. La Condesa-Duquesa viuda de Benavente fue madrina en el bautizo de una de sus hijas nacida en 1786 que recibió el nombre de María Faustina, en honor a su madrina. Parroquia de San Sebastián de Madrid, Libro de Bautizos 53, fol. 69. Citado en Matías Fernández García, Parroquia Madrileña de San Sebastián. Algunos Personajes de su Archivo (Madrid: Caparrós, 1985), p. 328.

19 AHN NOBLEZA OSUNA-CARTAS, leg 418.

${ }^{20}$ Los principales datos de la biografía de Gaetano Brunetti figuran en el Apéndice 5.
} 
El Marques Conde Duque mi Señor manda que desde el día primero de Noviembre próximo se ponga en las nóminas de la familia de Su Excelencia a Don Cayetano Bruneti, con el sueldo de quince reales diarios por haberle tomado $\mathrm{Su}$ Excelencia por su maestro de violín, pues aunque lo tomó $\mathrm{Su}$ Excelencia desde el día primero del mes de Abril de este año, ya se le ha librado por medio de un libramiento lo devengado desde el día primero del mes de abril hasta fin de este mes, lo que prevengo a vuestra merced para su cumplimiento.

Madrid 25 de Octubre de $1776^{21}$

Brunetti impartió clases de violín a Pedro de Alcántara hasta 1780. Durante este período su nombre aparece en las nóminas de la Casa de Benavente $^{22}$ con el cargo de "Músico del Príncipe [de Asturias] y M[aest]ro de Violín del Marqués Conde Duque [de Benavente]"23. Este dato verifica que su labor pedagógica al servicio del Príncipe de Asturias (y al de otros nobles como el Duque de Alba) era conocida por los miembros de la Casa de Osuna que valoraban como un privilegio el que el heredero de su Casa tuviera el mismo profesor de violín que el futuro rey de España.

La incipiente carrera militar del joven Marqués de Peñafiel, que le obligaba a desplazarse continuamente con su regimiento y a residir largas temporadas fuera de Madrid, debió de suponer una dificultad para que Pedro de Alcántara continuase con su formación musical. En febrero de 1780, Brunetti fue

\footnotetext{
${ }^{21}$ AHN NOBLEZA, OSUNA-CARTAS, leg 473-2.

22 . Desde su matrimonio en 1771 con la Condesa-Duquesa de Benavente, la tesorería del marqués de Peñafiel estaba integrada en la de la Casa de Benavente.

23 AHN NOBLEZA, OSUNA-CARTAS, leg 473-2.
} 
cesado como profesor de violín del Marqués de Peñafiel:

La Condesa Duquesa mi Señora manda quite Vuestra Merced de las nóminas de la familia de Su Excelencia desde el día primero de este mes a Don Cayetano Bruneti, maestro de violín que fue del Marqués mi Señor lo que prevengo a Vuestra Merced para su cumplimiento.

Madrid 10 de febrero de $1780^{24}$.

Después de esta fecha no se tiene constancia documental de que el Marqués de Peñafiel continuase recibiendo clases de música de ningún otro maestro.

\subsection{La educación musical de los hijos de los IX Duques de Osuna: Carlo Marinelli}

Pedro de Alcántara Téllez Girón y María Josefa Alfonso Pimentel, IX Duques de Osuna y Condes-Duques de Benavente transmitieron la afición a la música a sus descendientes y se preocuparon porque todos sus hijos e hijas recibieran desde temprana edad una formación musical como parte de su educación general. Durante su estancia en París en 1799, los hijos de los Duques de Osuna recibieron algunas clases de música de un tal "Monsieur Langlé", nombre que seguramente pueda identificarse con Honoré Langlé, $(* 1741-\uparrow 1807)$, compositor y profesor del Conservatorio de París $^{25}$. personaje que hasta su muerte

\footnotetext{
${ }^{24}$ Ibid.

${ }^{25}$ AHN NOBLEZA, OSUNA-CARTAS, leg 388-29. Los principales datos biográficos de este autor figuran en el Apéndice 5.
} 
en 1807 continuó manteniendo una cordial relación con la Condesa-Duquesa de Benavente $^{26}$.

A su regreso a España en enero de 1800, los Duques contrataron como profesor de música para sus hijos al cantante italiano Carlo Marinelli. Este personaje se hallaba en Madrid al menos desde 1791, trabajando como primer soprano de la Compañía de Ópera del Teatro de los Caños del Peral, en cuya gestión y financiación participaban en esa época varios miembros de las Casas de Osuna y Benavente como accionistas de Asociación para la Representación de Óperas italianas ${ }^{27}$. La contratación de Marinelli inició una relación de protección y mecenazgo con este cantante y profesor de música que se mantuvo hasta su muerte en $1823^{28}$.

Las primeras noticias de la colaboración de Carlo Marinelli con la Casa de Osuna datan de 1800. Desde el mes de febrero de este año, Marinelli impartió clases de música a "los señoritos" de los Osuna cobrando la notable cantidad de ochenta reales por cada lección ${ }^{29}$. El 20 de marzo de 1803, Marinelli se incorporó a la nómina de criados de la Casa de Osuna con el empleo de "maestro de música" y una asignación de 640 reales al mes ${ }^{30}$. En la biblioteca de la Condesa-Duquesa de Benavente se conservaban unas lecciones de solfeo "para Francisco y Pedro Girón y Pimentel" que seguramente fueron parte del material pedagógico utilizado

\footnotetext{
${ }^{26}$ En 1807 Honoré Langlé se encargo de la gestión de la compra de un piano para la CondesaDuquesa en la casa Erard de París. Véase capítulo V.

${ }^{27}$ Ver Capítulo VI.

${ }^{28}$ Sobre este importante cantante véase la biografía del Apéndice 5. Una transcripción de su partida de defunción figura en el Apéndice 6, $\mathrm{n}^{\circ} 47$.

${ }^{29}$ AHN NOBLEZA, OSUNA-CARTAS, leg 392-4.
} 
por Carlo Marinelli en sus clases ${ }^{31}$.

A la muerte del IX Duque de Osuna en 1807, con la consiguiente separación de las Casas de Osuna y Benavente, la comprometida situación económica de la Condesa-Duquesa de Benavente le obligó a reducir notablemente el personal a su servicio. Carlo Marinelli fue cesado en su cargo como maestro de música, una labor que en esta época ya se limitaba a la enseñanza de Manuela Isidra, hija menor de los duques. Aunque Marinelli dejó de pertenecer al servicio de la Casa de Benavente continuó gozando de la protección de la CondesaDuquesa e impartiendo clases a su hija:

\section{Madrid, Aranjuez}

Estimado Marinelli: Nadie mejor que Vuestra Merced conoce y sabe el estado en que ha quedado mi Casa por la muerte del Duque mi marido que esté en gloria. Tampoco ignora Vuestra Merced que desde su fallecimiento no he hecho otra cosa que tratar de estrecharme todo lo posible para poder vivir sin atrasos y libre de los disgustos que son consiguientes a aquellos. En este concepto y hallándose Vuestra Merced perfectamente establecido no puedo menos de decirle que me he visto precisada a mandar se suspenda desde el día $1^{\circ}$ de octubre del año próximo pasado el pago de la consignación mensual que tenía a Vuestra Merced hecha por la enseñanza de mi hija Manuela, pero reservando a Vuestra Merced el uso del cuarto en mi casa y la manutención en las temporadas que venga a Madrid, y además el compensar a Vuestra Merced las lecciones que en ellas pueda a dar a dicha mi hija, que es todo lo que puedo hacer en beneficio de Vuestra Merced.

Siento mucho que mi situación me obligue [a] hacer con Vuestra Merced esta novedad, pero hecho cargo de aquella, como de las actuales circunstancias de mi casa, convendrá en que no puedo otra cosa.

\footnotetext{
${ }^{30}$ AHN NOBLEZA, OSUNA-CARTAS, leg 463. Nómina de raciones de la familia de los Duques de Osuna y Condes Duques de Benavente. Año de 1803

${ }^{31}$ AHN NOBLEZA, OSUNA-CARTAS, leg 392-15.
} 
Deseo a Vuestra Merced las mayores satisfacciones y que Dios guíe su vida muchos años.

A Don Carlos Marinelli ${ }^{32}$.

Madrid, 19 de enero de 1808

La Condesa-Duquesa María Josefa protegió a Marinelli durante la estancia de éste en Cádiz, a donde también se había trasladado (como la propia CondesaDuquesa y su familia) tras la invasión de Madrid por las tropas francesas. En Cádiz, Marinelli continuó dando clases de música a Manuela Isidra al menos hasta finales de $1813^{33}$.

El repertorio didáctico que Marinelli utilizaba para las clases de la hija de los IX Duques de Osuna estaba formado básicamente por obras vocales de género dramático con acompañamiento de piano u orquesta ${ }^{34}$. En las largas listas de la música que se copió por orden de Marinelli para su alumna, figuran numerosas arias, cavatinas y números de conjunto de autores italianos como Ferdinando Paer, Giovanni Paisiello, Bonifacio y Luigi Assioli, Domenico Cimarosa, o Pietro Guglielmi, y Wolfgang Amadeus Mozart (con varios números de la ópera Don Giovanni y uno de Las Bodas de Fígaro). Marinelli también mandó copiar para Manuel Isidra Téllez Girón algunos ejemplos de música religiosa como el Stabat Mater de Pergolessi, el Miserere de Fioravanti, varios motetes de los que no consta el autor, y algunas muestras de música patriótica con texto en español

\footnotetext{
${ }^{32}$ Ibid.

${ }^{33}$ Ibid., leg 392-4.

${ }^{34}$ En el Apéndice 4 presento una catalogación por géneros de las obras musicales que se copiaron para Manuela Isidra Téllez-Girón durante su estancia en Cádiz.
} 
como el Himno Hispano ¡Qué miro, qué escucho! de João Domingos Bontempo ${ }^{35}$

Manuela Isidra seguramente recibió también clases de fortepiano de Carlo Marinelli, pues entre la música que se copió para ella en Cádiz se hallaban algunas obras para fortepiano a dos o a cuatro manos, varios cuadernos de valses y contradanzas y unos Principios de música para fortepiano de Pleyel y Dussek, que seguramente recopilaban estudios fáciles para piano de estos autores.

Marinelli continuó teniendo como discípula a Manuela Isidra en Madrid, después de que ella se casara con Ángel María Carvajal y adoptara el título de Duquesa de Abrantes. En diciembre de 1813, cuando la familia ya había regresado a la capital, la Condesa-Duquesa escribió a Marinelli, que aún se encontraba en Cádiz, para informarle de que su hija, deseaba que viniera "su maestro" y ponía a su disposición el cuarto que Marinelli había ocupado en la residencia madrileña de la Condesa-Duquesa antes de trasladarse a Cádiz ${ }^{36}$.

Aunque los cinco hijos de los IX Duques de Osuna recibieron clases periódicas de Marinelli (y seguramente de otros maestros) no ha quedado constancia de que la actividad musical de los dos varones, Francisco de Borja (futuro X Duque de Osuna) y Pedro de Alcántara (Príncipe de Anglona) se prolongase más allá de la niñez. Por el contrario, las tres mujeres (Josefa Manuela, Marquesa de Camarasa, Joaquina María, Marquesa de Santa Cruz, y la ya citada Manuela Isidra, Duquesa de Abrantes), fueron grandes aficionadas a la música.

\footnotetext{
35 El pianista y compositor portugués João Domingos Bontempo (*1771-1842) fue recomendado en 1806 a la Condesa-Duquesa de Benavente por el político por Charles Maurice de Tayllerand (Apéndice 6, $\mathrm{n}^{\mathrm{o}}$ 44). Sobre Bontempo véase Filipe de Sousa, "Bontempo [Buontempo] João Domingos", $N G, 3$, p. 844.

36 AHN NOBLEZA, OSUNA-CARTAS, leg 392-4.
} 
Durante la estancia en 1799 de la familia Benavente-Osuna en París, Josefa Manuela fue retratada por Jacques-Jean Baptiste Augustin sentada ante un instrumento de teclado con una partitura abierta. El retrato en miniatura fue incrustado en una caja de pastillas (Lámina 15) ${ }^{37}$. Las imágenes de la Marquesa de Santa Cruz y de la Duquesa de Abrantes también han pasado a la historia del arte gracias a los excelentes retratos realizados por Francisco de Goya en los que ambas damas aparecen representadas con motivos iconográficos musicales ${ }^{38}$.

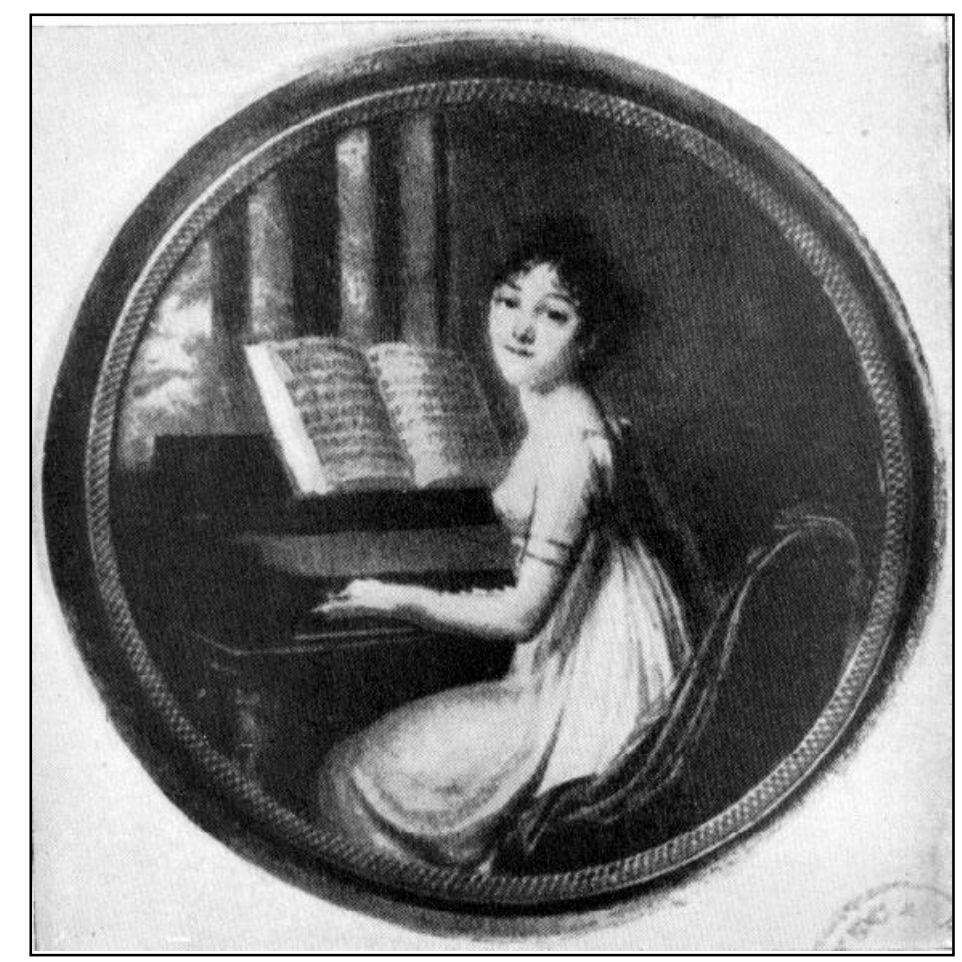

Lámina 15.

Jacques-Jean Baptiste Augustin Josefa Manuela Téllez Girón (1799)

Según Joaquín Ezquerra del Bayo, Retratos, Lamina XIX.

\footnotetext{
37 Joaquín Ezquerra del Bayo, Retratos de la familia Téllez Girón. Novenos duques de Osuna (Madrid: Junta de Iconografía Nacional, 1934), Lamina XIX.

${ }^{38}$ Reproducidas en el Capítulo I. Imágenes 5 y 6 respectivamente.
} 


\subsubsection{Otros profesores de música al servicio de las Casas de Osuna y Benavente en la primera mitad del siglo XIX}

La educación musical de los miembros de las Casas de Osuna y Benavente en las primeras décadas del siglo XIX se centró básicamente en los instrumentos de teclado y en la formación vocal. Siguiendo la tradición familiar, durante la titularidad de Francisco de Borja Téllez Girón, X Duque de Osuna (*1807-†1820), la Casa de Osuna tuvo a su servicio a varios maestros de música que se encargaron de la formación musical de sus hijos y también de su joven esposa Marie-Françoise-Philippine de Beaufort y Toledo (Ver Tabla 7).

Francisco Xavier Gibert, maestro de capilla del Convento de las Descalzas Reales, trabajó como profesor de piano para la Duquesa de Osuna al menos hasta abril de $1818^{39}$. Le sucedió en el puesto Joaquín Martina, que desempeñó el cargo de "maestro de fortepiano de la Casa del Excelentísimo Señor Duque de Osuna" al menos entre mayo de 1818 y mayo de $1820^{40}$. En las nóminas de 1819 de los profesores al servicio de la Casa de Osuna, aparece también Antonio Belbén como "maestro de piano" con un sueldo de 320 reales al mes ${ }^{41}$. Belbén había colaborado esporádicamente con la Casa de Benavente como maestro de clave en $1796^{42}$. Además de estos profesores de piano, al menos entre 1818 y 1819 , la Casa de Osuna tuvo también a su servicio al matrimonio formado por el "maestro de

\footnotetext{
39 AHN NOBLEZA, OSUNA-CARTAS, leg 470. Los principales datos de la biografía de este personaje figuran en el Apéndice 5.

${ }^{40}$ AHN NOBLEZA, OSUNA-CARTAS, leg 470.

${ }^{41}$ Ibid.

${ }^{42}$ Ibid., leg 391-21.
} 
violín” Juan de Menagé y "maestra de arpa" Teresa Edel de Menagé ${ }^{43}$. En el inventario de los libros que se conservaban en los palacios de Madrid de la Casa de Osuna en 1897, figuraban varios métodos y obras sueltas para la enseñanza del arpa que posiblemente fueron utilizados en las lecciones impartidas por esta profesora a la propia Duquesa de Osuna o a algún miembro de su familia ${ }^{44}$.

Pedro de Alcántara II, titular de la Casa de Osuna entre 1820 y 1844 , recibió una esmerada educación musical y en su corta vida se convirtió en uno de los músicos aficionados más destacados de la aristocracia madrileña. En su formación musical intervinieron algunos de los mejores profesores de Madrid. Es muy probable que iniciase sus estudios con Francisco Xavier Gibert o Joaquín Martina, maestros de piano de la Casa de Osuna entre 1818 y 1820 (Tabla 7). Entre 1820 y 1821, Pedro de Alcántara II fue discípulo del famoso cantante y compositor Maríano Rodríguez de Ledesma, miembro de la Real Capilla, y uno de los primeros introductores del romanticismo musical en España ${ }^{45}$. Su formación musical continuó con Ángel Inzenga, profesor de canto del Conservatorio de Madrid, que fue maestro de piano del Duque al menos entre 1826 y 1829. Según Antonio Marichalar, el XI Duque de Osuna recibió también clases de órgano ${ }^{46}$.

\footnotetext{
${ }^{43}$ AHN NOBLEZA, OSUNA-CARTAS, leg 470. Teresa Edel aparece desde las nóminas de enero de 1818. Su marido figura en una nómina fechada el 28 de febrero de 1819. No he podido documentar más datos sobre este matrimonio de músicos.

${ }^{44}$ Véase el Apéndice 3, Inventario $\mathrm{n}^{\mathrm{0}} 5$.

${ }^{45}$ Los principales datos de la biografía de Maríano Rodríguez de Ledesma figuran en el Apéndice 5.

${ }^{46}$ Antonio Marichalar, Riesgo y ventura del Duque de Osuna, (Madrid: Espasa Calpe, 1930), p. 28. Entre la documentación administrativa de la Casa de Osuna se conserva una carta del constructor de órganos Achille Müller fechada en 1840 con las instrucciones de uso de un "órgano expresivo" que debió de pertenecer a Pedro de Alcántara II. AHN NOBLEZA, OSUNA-CARTAS, leg 392-4.
} 
Tabla 7.

Maestros y profesores de música al servicio de la Casa de Osuna (1818-1844)

Fuentes: AHN NOBLEZA,OSUNA-CARTAS, legs 388, 392, 393, 470.

\begin{tabular}{|c|c|c|c|}
\hline NOMBRE & $\begin{array}{l}\text { PUESTO } \\
\text { OCUPADO }\end{array}$ & $\begin{array}{l}\text { FECHAS } \\
\text { DOCUMENTADAS }\end{array}$ & OBSERVACIONES \\
\hline $\begin{array}{l}\text { Francisco Xavier } \\
\text { Gibert }\end{array}$ & $\begin{array}{l}\text { maestro de piano } \\
\text { de la Duquesa de } \\
\text { Osuna }\end{array}$ & enero-abril de 1818 & \\
\hline Joaquín Martina & $\begin{array}{l}\text { maestro de piano } \\
\text { de la Casa del } \\
\text { Excelentísimo } \\
\text { Señor Duque de } \\
\text { Osuna } \\
\end{array}$ & $\begin{array}{l}\text { mayo 1818-mayo } \\
1820\end{array}$ & $\begin{array}{l}\text { Se le pagó también } \\
\text { por la afinación del } \\
\text { piano }\end{array}$ \\
\hline Antonio Belbén & maestro de piano & 1819 & $\begin{array}{l}\text { En un recibo de } 1796 \\
\text { figuraba como } \\
\text { maestro de clave. }\end{array}$ \\
\hline $\begin{array}{l}\text { Teresa Edel de } \\
\text { Menagé }\end{array}$ & maestra de arpa & $1818-1819$ & $\begin{array}{l}\text { Esposa de Juan } \\
\text { Menagé, maestro de } \\
\text { violín }\end{array}$ \\
\hline Juan Menagé & maestro de violín & 1819 & $\begin{array}{l}\text { Esposo de Teresa } \\
\text { Edel, maestra de arpa }\end{array}$ \\
\hline $\begin{array}{l}\text { Maríano Rodríguez } \\
\text { [de] Ledesma }\end{array}$ & $\begin{array}{l}\text { maestro de música } \\
\text { de Su Excelencia }\end{array}$ & $\begin{array}{l}\text { mayo de } 1820- \\
\text { septiembre-1821 }\end{array}$ & \\
\hline Ángel Inzenga & $\begin{array}{l}\text { maestro de piano } \\
\text { de Su Excelencia }\end{array}$ & $1826-1829$ & \\
\hline Modesto Belben & $\begin{array}{l}\text { maestro de } \\
\text { fortepiano }\end{array}$ & $\begin{array}{l}\text { Antes } \\
\text { de } 1840\end{array}$ & $\begin{array}{l}\text { En } 1840 \text { pidió limosna } \\
\text { al Duque para } \\
\text { mantener a su familia } \\
\text { y declaró haber sido, } \\
\text { antiguo maestro de } \\
\text { fortepiano de la } \\
\text { Duquesa y cesante en } \\
\text { la plaza de organista } \\
\text { de la Real Capilla }\end{array}$ \\
\hline
\end{tabular}


Pedro de Alcántara II, cultivó también la música vocal, y tuvo como profesor al cantante y compositor conocido como Valldemosa ${ }^{47}$. Este personaje, cuyo nombre real era Francisco Frontera y Laserra $(* 1807-\uparrow 1891)$, y que adoptó por sobrenombre el de Valldemosa, en honor a su localidad natal, fue uno de los músicos más admirados en Madrid durante el siglo XIX. Ejerció los cargos de Profesor de Canto del Real Conservatorio María Cristina y de la reina Isabel II, y el de Director de la Real Cámara. Valldemosa dedicó a Pedro de Alcántara II un himno que se cantó en el Teatro de Mallorca para celebrar la proclamación de Isabel II (París: Bernard Latte, ¿1843?) ${ }^{48}$.

En su corta vida, Pedro de Alcántara II alcanzó un gran prestigio como intérprete vocal en los círculos privados de la nobleza. Según Baltasar Saldoni "su voz era de barítono o bajo cantante; su escuela era irreprochable y daba gran sentimiento y colorido en todas las frases musicales de la pieza que ejecutaba, según correspondía al género de ella y al carácter del personaje que interpretaba" ${ }^{49}$. El XI Duque de Osuna participaba asiduamente como cantante en las fiestas organizadas en los salones de la nobleza, donde "cantaba apasionados dúos con la que fue prima y novia suya, Encarnación Camarasa, quien al decir de

\footnotetext{
47 Baltasar Saldoni, Diccionario biográfico-bibliográfico de efemérides de músicos españoles (Madrid: Antonio Pérez Dubrull, 1868-1881), vol. III, p. 167. Para la biografía de Valldemosa véase el Apéndice 5.

${ }^{48}$ Francisco F. de VALLDEMOSA, Himno cantado en el Teatro de Mallorca. En ocasión de la Solemne Proclamación de la Reina Doña Isabel II. Compuesto por__ _ y dedicado a su discípulo el Excelentísimo Señor Duque de Osuna. Propieté de l'auteur a Paris, chez Bernard Latte. Citado en José Subirá, La Música en la Casa de Alba: estudios Históricos y Biográficos (Madrid, [Tip: Sucesores de Rivadeneira], 1927), p. 305.

${ }^{49}$ Saldoni, Diccionario, vol. III, p. 167.
} 
todos fue la más linda muchacha y de más bella voz que había en la corte"50.

Pedro de Alcántara II recibió a lo largo de su vida numerosos cargos honoríficos relacionados con la música. En 1831 fue nombrado Adicto de Honor del Real Conservatorio de Música María Cristina de Madrid, en 1833 socio de la Academia Filarmónica Matritense y en 1844 recibió el diploma de socio de la Société des Concerts de Musique vocale, religieuse et classique de París ${ }^{51}$

\subsection{Maestros de baile}

El baile fue una disciplina fundamental en la educación de los jóvenes nobles de la segunda mitad siglo XVIII y primera mitad del siglo XIX. Al igual que la música, el aprendizaje de las danzas de moda era una costumbre arraigada en la nobleza europea, y al menos desde finales del siglo XVII, era habitual que las familias adineradas contasen con un maestro de baile a su servicio ${ }^{52}$.

La importancia que adquirieron para la alta nobleza los bailes de sociedad se acentuó a partir de la segunda mitad del siglo XVIII con la irrupción de los bailes públicos y con la apertura de salones y tertulias organizadas por representantes de la aristocracia en los que la música y el baile eran dos de sus mayores atractivos. Los bailes de máscaras que se reinstauraron en los Coliseos de los Caños del Peral y el Príncipe de Madrid a partir de 1767, fueron uno de los principales acontecimientos sociales en los que los jóvenes miembros de la alta nobleza podían lucir públicamente sus habilidades como bailarines, tal y como

\footnotetext{
${ }^{50}$ Marichalar, Riesgo y ventura, p. 22.

51 AHN NOBLEZA, OSUNA-CARTAS, leg 533.
} 
relataba Luis Coloma en Retratos de antaño:

El concurso de las máscaras se aumenta cada día; el teatro apenas es capaz para las gentes que dicen que bailan, porque hacen unos a vista de otros ciertos movimientos a que hay maestros que presiden e instrumentos de la orquesta que suenan. Suele haber comúnmente dos mil máscaras que generalmente mudan cada baile de vestido en lo que han sobresalido las cuadrillas de Medinaceli, Huescar, Osuna, Benavente, Santiago, etc" ${ }^{53}$.

La asistencia a estos actos permitía exhibir públicamente el dominio de danzas extranjeras que se habían introducido en los salones dieciochescos españoles: la alemanda, el minué y especialmente la contradanza que se convirtió en una de las principales danzas de sociedad ${ }^{54}$.

La participación activa en los bailes públicos debió de estar, no obstante, reservada a la juventud. Cuando en 1796 el capitán José García de Segovia escribió desde Málaga a la Condesa-Duquesa para dedicarle su obra Arte de poner y bailar contradanzas, ésta le respondió que no podía admitir su obsequio por hallarse "en edad y circunstancias que me retiran de tales diversiones propias realmente del tiempo en que Vuestra Merced se acuerda haberme conocido". García de Segovia había sido condiscípulo de la Condesa-Duquesa María Josefa "en el baile bajo la dirección de Don Esteban Mosell, que gustaba de que hiciésemos pareja en las primeras máscaras que hubo en el Teatro del Príncipe y en las funciones que se hicieron en el tiempo de nuestra niñez y aprendizaje ${ }^{55}$

\footnotetext{
52 Jonathan Dewald, The European Noblity, 1400-1800 (Cambridge: Cambridge University Press, 1996), p. 151 y Martín Moreno, Historia, p. 303.

53 Citado en Martín Gaite, Usos, p.47.

54 Ibid.

55 AHN NOBLEZA, OSUNA-CARTAS, leg 388.
} 
Pero el aprendizaje de las danzas de moda, no fue una cuestión de “esencia femenina" como ha mantenido una parte de la historiografía ${ }^{56}$, sino que constituyó una de las disciplinas fundamentales del programa educativo de los jóvenes nobles de ambos sexos. Un buen ejemplo de ello lo encontramos en el extenso y progresista proyecto elaborado hacia 1790 por Diego Clemencín para la educación de los hijos varones de los IX Duques de Osuna. Según Clemencín, la educación de los "señoritos" se debía iniciar a edades tempranas comenzando por "las primeras letras, el baile y el dibujo" disciplinas que se basan en la enseñanza por imitación, en las que sólo había que repetir materialmente "los movimientos que aprendemos de otros por los sentidos"

\footnotetext{
${ }^{56}$ Véase por ejemplo la opinión de Carmen Martín Gaite que resume las ideas de varios teóricos preceptistas del siglo XVIII. Martín Gaite, Usos, p.37.

${ }^{57}$ Diego Clemencin, Proyecto para la educación del Excelentísimo Señor Marqués de Peñafiel y del Señor Príncipe de Anglona. Dirigido a sus padres, los Excelentísimos. Señores Duques de Osuna, Condes-Duques de Benavente. Biblioteca General del CSIC (Madrid), Archivo Rodríguez Marín, caja 78, doc.11. El completo plan de enseñanza elaborado por Clemencín comprendía también "la Lógica, la Metafísica, las Lenguas [extranjeras y clásicas] el Arte de Escribir, la Moral, el Derecho Natural, de Gentes y Público, las Bellas Artes, las Letras Humanas, el Dibujo, la Fortificación, las Matemáticas y la Física, la Religión, la Política y la Económica”. Diego Clemencín (*1765-†1834) ingresó al servicio de la Casa de Osuna como "ayo de los señoritos" en 1788. En febrero de 1798 fue nombrado director de la biblioteca del Duque de Osuna. Fue autor de una edición con prólogo y glosa del Quijote cervantino y ocupó importantes cargos políticos a lo largo de su vida. Sobre este personaje véase Antonio López Ruiz y Eusebio Aranda Muñoz: Diego Clemencin, $2^{\circ}$ edición corregida y ampliada, (Murcia: Real Academia de Alfonso X el Sabio, 1994).
} 


\subsubsection{Maestros de baile al servicio de las Casas de Osuna y Benavente hasta 1787}

Durante el siglo XVIII, las Casas de Osuna y Benavente tuvieron a su servicio a un maestro de baile que se encargaba de impartir clases regularmente a los jóvenes de la familia. En estas clases participaba siempre un instrumentista (habitualmente un violinista) que interpretaba las danzas de moda que debían aprender los nobles. En la relación de maestros de danza o profesores de baile ${ }^{58}$ que trabajaron para ambas casas nobiliarias hasta 1787 figuran algunos de los principales maestros extranjeros que estuvieron al servicio de la corona española.

Entre 1729 y 1731, el "maestro de danzar" de la Casa de Osuna era Sebastián Christiani de Scío [“Christiano Sion"], miembro de una amplia familia de profesores de origen escandinavo que trabajaron para la Casa Real durante el siglo XVIII ${ }^{59}$. Su hermano Carlos Christiani de Scío, que fue maestro de las hijas de Carlos III, también trabajó como maestro de danza de los dos hijos varones del VIII Duque de Osuna al menos hasta finales de julio de 1763 cuando se trasladó temporalmente a Francia ${ }^{60}$. Carlos Christiani sólo se ausentó de la capital española temporalmente. El 30 de noviembre de 1764 falleció en su casa de la calle de Alcalá de Madrid ${ }^{61}$. Un miembro de esta misma familia, llamado también "Carlos Christiani" del cual no se tenían noticias hasta la fecha, comenzó a impartir clases de baile a los dos hijos del Duque de Osuna el 19 de diciembre de 1766 con un

\footnotetext{
${ }^{58}$ En la documentación consultada aparecen ambas denominaciones indistintamente

59 AHN NOBLEZA, OSUNA-CARTAS, leg 388-4. Se conservan 13 recibos por las lecciones impartidas entre marzo de 1729 y febrero de 1730 , y en enero de 1731. Sobre esta familia véase Lothar Siemens Hernández "Sebastián Christiani de Scío y su familia: contribución a los maestros de danzar en la España del siglo XVIII" RMS, XX/1 (1997), pp. 323-329.

${ }^{60}$ AHN NOBLEZA, OSUNA-CARTAS, leg 388-32. Siemens “Sebastián”, p. 328.
} 
sueldo "de 10 reales al día, 5 reales por cada señorito" $"$.

Al menos desde 1742, Miguel Godreau (o Godró) trabajó para la Casa de Benavente con el empleo de "maestro de danzar de la Condesa de Luna",63 es decir de María Faustina Téllez-Giron, esposa de Francisco Alfonso Pimentel, Conde de Luna y heredero de la Casa de Benavente. Godreau fue uno de los más afamados maestros de baile de la primera mitad del siglo XVIII de España, trabajó para la Casa Real hasta su muerte en 1751 y tuvo entre sus alumnos al infante don Luis y al futuro Carlos III $^{64}$. Entre los violinistas que acompañaron a Godreau en las lecciones de baile que impartió a María Faustina Téllez-Girón se hallaban Manuel de Navas (1742), colaborador habitual de la Casa de Benavente ${ }^{65}$, y Juan Félix García $(1746)^{66}$.

María Josefa Alfonso Pimentel, futura Condesa-Duquesa de Benavente, también recibió clases de baile durante su niñez y adolescencia ${ }^{67}$. Uno de sus primeros profesores fue Juan Busquet, que en 1762 era el "maestro de danza de la señorita" con un salario de 10 pesos al mes ${ }^{68}$.

\footnotetext{
${ }^{61}$ Siemens “Sebastián”, p. 328.

62 AHN NOBLEZA, OSUNA-CARTAS, leg 389-30.

${ }^{63}$ Ibid., leg 413-20.

${ }^{64}$ Martín Moreno, Historia, p. 222.

65 AHN NOBLEZA, OSUNA-CARTAS, leg 389-27.

${ }^{66}$ Ibid., leg 389-30.

67 María Josefa Alfonso Pimentel siguió recibiendo clases de baile al menos hasta 1774. En las nóminas de este año figuran pagos de dos reales al día a Francisco Basset, "músico violín que acude a tocar cuando toma lección de baile la Condesa Duquesa actual". AHN NOBLEZA, OSUNA-CARTAS, leg 418.

${ }^{68}$ AHN NOBLEZA, OSUNA-CARTAS, leg 457. Podría tratarse del violinista Juan Busquet que estuvo al servicio de la Casa de Osuna hasta diciembre de 1766. Véase el Apartado 2 de este capítulo.
} 


\subsubsection{Maestros de baile de los hijos de los IX Duques de Osuna: Domenico Rossi, Pierre G. Gardel y Jean Joly}

Los IX Duques de Osuna contrataron como maestros de baile para sus hijos a algunos destacados bailarines europeos que se hallaban en España en las compañías de los teatros y a otros que se trasladaron expresamente desde París para trabajar a su servicio. El primer maestro de baile que tuvieron los hijos de los IX Duques de Osuna fue el italiano Domenico Rossi, una de las figuras más influyentes de la escena madrileña de las dos últimas décadas del siglo XVIII ${ }^{69}$. Rossi comenzó a impartir clases a los "señoritos" en 1788, cuando los cuatro hijos de los Duques tenían menos de cinco años de edad ${ }^{70}$. En 1792 Rossi continuaba trabajando como profesor de baile para la Casa de Osuna. El 31 de mayo de ese año se dirigió por carta a la Condesa-Duquesa de Benavente para comunicarle que esperaba que sus obligaciones en el teatro [de los Caños del Peral] le dejara pronto tiempo libre para poder dar clase a sus hijos:

[...]ansioso aspettando 1'opportunitá de due giorni consecutivi di vacanza in questo teatro per poter aver il piacere di dare lezione a gli amabilissimi teneri degni figli de Vostra Eccelenza como e di mio devere $^{71}$

\footnotetext{
${ }^{69}$ Sobre este bailarín, coreógrafo y empresario teatral italiano véase el Apéndice 5.

70 AHN NOBLEZA, OSUNA-CARTAS, leg 413-20. En una carta fechada el 17 de junio de 1788, la bailarina Ana Binati solicitó al Duque de Osuna su intercesión para enseñar baile a los señores Infantes “y si esto no se verifica a los señoritos y señoritas de la Casa de Osuna". En la respuesta el Duque dice que no puede complacer ninguna de sus peticiones pues los infantes ya tenían maestro y para sus hijos habían dado su palabra a Domenico Rossi.

71 AHN NOBLEZA, OSUNA-CARTAS, leg 387-10. [Mi traducción]: "Esperando ansioso la oportunidad de contar con dos días libres en este teatro para poder tener el placer de dar clase a los amables, delicados y dignos hijos de Vuestra Excelencia como es mi obligación”.
} 
En las lecciones de baile de Domenico Rossi colaboraba el oboísta Gaspar Barli, músico de la Casa de Benavente, que en 1791 cobraba 340 reales "por la consignación mensual que Su Excelencia me tiene hecha para enseñar a bailar a los señoritos"

Las circunstancias políticas, y los traslados de residencia no fueron un obstáculo para que los hijos e hijas de los Duques siguieran recibiendo periódicamente clases de baile. Durante su estancia en París en 1799, los IX Duques contrataron como profesor a Pierre Gabriel Gardel $(* 1758-\dagger 1840)$ famoso coreógrafo y músico, director de la Ecole de Danse y de los ballets de la ópera de París $^{73}$. En la onomástica del IX Duque, en 1799, los cuatro hijos de los duques bailaron para sus padres acompañados de cuatro músicos contratados en París por el propio Gardel:

Vale sesenta pesetas que recibí de Don Juan de Luque para dar a Monsieur Gardel a fin de que este pague [a] 4 músicos que vinieron a tocar una noche que bailaron los señoritos con motivo de ser el cumpleaños de su padre, el 8 de agosto de este presente año. Lo hago de orden verbal de mi Señora la Duquesa, y para que conste lo firmo en París a las once y veinte y dos minutos de la mañana del día 14 de agosto de 1799.

Clemencín $^{74}$

\footnotetext{
72 AHN NOBLEZA, OSUNA-CARTAS, leg 391-31. Basándose en este mismo documento Judith Ortega (Ortega, "El mecenazgo", p. 651) afirma que Gaspar Barli fue el maestro de baile en la Casa de Osuna entre 1781 y 1792. El citado documento sólo acredita el pago a Barli en 1791. La expresión"para enseñar a bailar a los señoritos" que figura en este recibo se refiere a la participación de Barli como músico para las lecciones que les impartía el bailarín Domenico Rossi, maestro de baile de los hijos de los Duques al menos entre 1788 y 1792.

${ }^{73}$ AHN NOBLEZA, OSUNA-CARTAS, leg 391-31. Para la biografía de este personaje véase el Apéndice 5.

${ }^{74}$ AHN NOBLEZA, OSUNA-CARTAS, leg 391-31.
} 
Tener un maestro de danza francés se consideraba en la época una muestra de elegancia a la que los Osuna no renunciaron. A su regreso a España en 1799, el bailarín francés Louis Moreau fue contratado como profesor de baile de los hijos del Duque. Moreau y su mujer, la también bailarina Achille Monroy, habían llegado a España con la protección de la Condesa-Duquesa María Josefa para trabajar en el Teatro de los Caños del Peral, dirigido por entonces por el empresario Santiago Panati. Tras el regreso a Francia de estos bailarines por los problemas económicos de la empresa de Panati, los Duques de Osuna contrataron en París al bailarín francés Jean Joly gracias a la mediación de Pierre Gabriel Gardel. En una carta enviada en París, Joly expresó su agradecimiento a la Condesa-Duquesa y a Gardel por su nombramiento:

[...] je vois que Monsieur Gardel a bien voulu me recommander a Madame la Duchesse d'une manière distinguée, je redoublerai d'activité pour que à Madame la Duchesse et Monsieur Gardel, ne se repentir pas de la confiance dout ils veulent bien $\mathrm{m}^{\prime}$ honorer. ${ }^{75}$

En diciembre de 1801 Jean Joly entró al servicio de la Casa de Osuna como "maestro de baile de los señoritos y la señorita" (es decir de los tres hijos menores de los Duques). Por su trabajo Joly cobraba un sueldo de 8 reales al día y tenía la obligación de seguir a la Condesa-Duquesa "a todas las partes"76.

\footnotetext{
75 AHN NOBLEZA, OSUNA-CARTAS, leg 274-1. Carta fechada el 1 de noviembre de 1801. [Mi traducción]: "Como el Señor Gardel ha tenido a bien recomendarme a la Señora Duquesa de una manera distinguida, yo trabajaré para que la Señora Duquesa y el Señor Gardel no se arrepientan de la confianza con la que me han honrado"

${ }^{76}$ AHN NOBLEZA, OSUNA-CARTAS, leg 462-467.
} 
Tras la muerte de su marido en enero de 1807, la Condesa-Duquesa redujo gran parte del personal a su servicio. Jean Joly fue despedido, pero recibió una ayuda de 3000 reales para sufragar los gastos de su regreso y el de su "dilatada familia a París"

Joly continuó solicitando desde París la protección e intercesión de la Condesa-Duquesa para conseguir trabajo ${ }^{78}$. En 1814, el bailarín pasaba por graves apuros económicos y solicitó la ayuda de la Condesa-Duquesa para volver a España. El viaje no debió de verificarse, ya que la Condesa-Duquesa le respondió que, aunque era sensible a sus problemas no podía remediarlos ni prestarle protección porque ya no tenía hijos en edad para aprender a bailar. Su consejo fue claro: "haría usted muy mal de venirse a España confiado sólo con mi apoyo pues le repito que por mi situación y circunstancias no puedo dispensarle [mi protección]"79.

\subsubsection{Otros maestros de baile al servicio de las Casas de Osuna y Benavente en la primera mitad del siglo XIX}

Los jóvenes de la Casa de Osuna continuaron recibiendo clases periódicas de baile al menos hasta la época de titularidad del XI Duque. Durante su infancia Pedro de Alcántara II, tuvo como maestro a Francisco Loli que en 1821 figura en la documentación de la Casa con el cargo de "maestro de baile del señorito Don Pedro" ${ }^{„ 80}$. Al año siguiente ocupaba este empleo Andrés Belluzi con un sueldo de 220 reales mensuales (que incluían los 60 que cobraba el músico que asistía a las

\footnotetext{
77 AHN NOBLEZA, OSUNA-CARTAS, leg 388-6.

${ }^{78}$ Ibid., leg 274-1 y leg 277-4.

${ }^{79}$ Ibid., leg 617-38.
} 
lecciones) y en 1832, un personaje apellidado "Volet" cobró de la Casa de Osuna tres lecciones de baile, que seguramente impartió a Pedro de Alcántara II, o a su hermano menor, sucesor en las Casas de Osuna y Benavente, Maríano Téllez Girón $^{81}$.

\footnotetext{
${ }^{80}$ Ibid., leg 388-27.
}

${ }^{81}$ Ibid., leg 388-26. 


\section{Instrumentistas y compositores al servicio de los Duques de Osuna y de los Condes-Duques de Benavente}

La formación y la práctica musical privada de los miembros de las familias Osuna y Benavente, y los antecedentes musicales de ambas familias, estudiados en los capítulos anteriores fueron, sin duda, factores decisivos para que a lo largo de todo el siglo XVIII y en las primeras décadas del siglo XIX, la música se convirtiera en una de las actividades centrales del mecenazgo cultural de estas dos casas nobiliarias.

Una de las formas en que se materializó la política de apoyo a la música que desarrollaron los Duques de Osuna y los Condes-Duques de Benavente fue la creación y patrocinio de pequeñas capillas musicales $\mathrm{u}$ orquestas privadas formadas por selectos grupos de músicos (asalariados o colaboradores eventuales) que fueron seleccionados entre los instrumentistas y compositores más competentes de su época. Estas capillas o agrupaciones musicales tuvieron una gran versatilidad, y cumplieron variadas funciones como las de amenizar bailes y fiestas organizadas por los nobles en sus residencias, intervenir en funciones teatrales, tomar parte de las academias donde se presentaban las novedades de la música instrumental europea, o participar en las conmemoraciones familiares y en las grandes fiestas religiosas patrocinadas por la familia.

Este amplio apartado está dividido en cuatro puntos, en los que estudiaré desde el punto de vista diacrónico las trayectorias de los músicos y de las formaciones musicales que trabajaron al servicio de los Duques de Osuna y los Condes-Duques de Benavente entre 1733 y 1834. En el primer punto abordaré el estudio de las capillas y músicos que trabajaron al servicio de las Casas de Osuna entre 1733 y 1787 , período en que ocupó la titularidad de esta casa nobiliaria el 
VIII Duque Pedro Zoilo Téllez-Girón. En este apartado incluyo también una breve reseña sobre los músicos que trabajaron para la Casa de Benavente desde 1743 año en que asumió la titularidad de esta casa Francisco Alfonso Pimentel (XIV Conde y XI Duque de Benavente) hasta finales de 1771 cuando María Josefa Alfonso Pimentel se desposó con el heredero de la Casa de Osuna y comenzó a ocuparse de la administración de la Casa de Benavente. El segundo punto se dedica al análisis de la estructura y el funcionamiento de la orquesta o grupo instrumental que María Josefa Alfonso Pimentel, XV Condesa-Duquesa de Benavente mantuvo entre 1781 y 1792, una formación cuya existencia se conocía pero que no había sido objeto de una investigación sistemática hasta la fecha. En los dos puntos finales se estudian las formaciones instrumentales y los músicos que trabajaron al servicio de las Casas de Osuna y Benavente desde la disolución de la orquesta de la Condesa-Duquesa en mayo de 1792 hasta la muerte de ésta en 1834.

Aunque una parte de los datos que presentaré en este apartado eran ya conocidos por los trabajos de Solar-Quintes y Gómez Pintor (ver introducción), en mi investigación he localizado importante información que amplía y precisa notablemente la visión que hasta ahora teníamos sobre la actividad musical de los Benavente y los Osuna en este período. En los puntos subsiguientes presentaré por primera vez una visión sistematizada y renovada de las capillas, orquestas y músicos que trabajaron al servicio de las Casas de Osuna y Benavente a lo largo de un siglo. 
2.1. Músicos al servicio de las Casas de Osuna y Benavente entre 1733 y 1787

\subsubsection{Músicos al servicio de la Casa de Osuna}

Cuando en 1734 falleció José Téllez Girón, VII Duque de Osuna, la titularidad de esta casa nobiliaria fue heredada por su hijo Pedro Zoilo que sólo era un niño de cinco años de edad. Su madre, Francisca Bibiana Pérez de Guzmán el Bueno, tuvo que hacerse cargo entonces de la tutela de su hijo y de la administración de la casa ducal hasta su mayoría de edad. Este hecho contribuyó a prorrogar las líneas principales de la política del mecenazgo musical del VII Duque y el funcionamiento de su capilla musical hasta la muerte de la Duquesa viuda Francisca Bibiana en 1748.

Tras la muerte del VII Duque en 1733, la capilla musical de la Casa de Osuna continuó funcionando bajo la administración de su esposa la Duquesa viuda Francisca Bibiana. En 1732, integraban la capilla musical de la Casa de Osuna dos violines, un violón, dos oboes, dos bajones, un clarín y un "músico compositor" ${ }^{82}$. Además de estos músicos, la Casa de Osuna contaba a su servicio con un escritor "con el encargo de la letra de la música" y un afinador o templador de clavicordios. Es muy probable que esta estructura con gran parte de sus miembros se mantuviese al menos hasta 1748, cuando Pedro Zoilo se hizo cargo de la administración de la Casa tras el fallecimiento de su madre, ya que varios músicos que trabajaron para José Téllez Girón, seguían al servicio de la Casa de Osuna después de su muerte. Uno de ellos era el violón José Literes que continuó trabajando para la Duquesa viuda de Osuna al menos hasta febrero de 1737, 
cuando la Duquesa le adelantó parte de su sueldo de la Real Capilla:

He recibido del Señor Don Manuel de Angulo tesorero de la Excelentísima Señora Duquesa de Osuna mi señora, doscientos y setenta y cinco reales de vellón en virtud de la orden de Su Excelencia por lo correspondiente en esta presente mesada del sueldo que tengo señalado por músico de la Real Capilla de que fíe de dar recibo correspondiente a favor de la Tesorería de Su Excelencia por la buena obra que en esto me hace. Madrid 28 de febrero de 1737.

Son 275 reales de vellón

Joseph Líteres [rúbrica] ${ }^{83}$

En 1741 también continuaba al servicio de la Casa de Osuna el "maestro compositor" Manuel Pradell. En julio de ese año, Pradell cobró 1020 reales por la contratación de músicos para "acompañar a los de la casa” y otros gastos relacionados con la celebración de la onomástica de Pedro Zoilo, VIII Duque de Osuna (Lámina 16). El documento contable que recoge los gastos de estas fiestas además de verificar la permanencia de Manuel Pradell al servicio de la Casa de Osuna tras la muerte del VII Duque muestra que en 1741 seguía existiendo un grupo estable de músicos al servicio de la Duquesa viuda de Osuna que se reforzaba con músicos de fuera en aquellas ocasiones en las que se consideraba necesario.

\footnotetext{
${ }^{82}$ Véase Capítulo II.

${ }^{83}$ AHN NOBLEZA OSUNA-CARTAS, leg 389-30.
} 
Lámina 16.

Memoria de gastos por la contratación de instrumentistas para reforzar la capilla musical de la Casa de Osuna en las fiestas de la onomástica del VIII Duque en 1741 AHN NOBLEZA OSUNA-CARTAS leg 389-30.

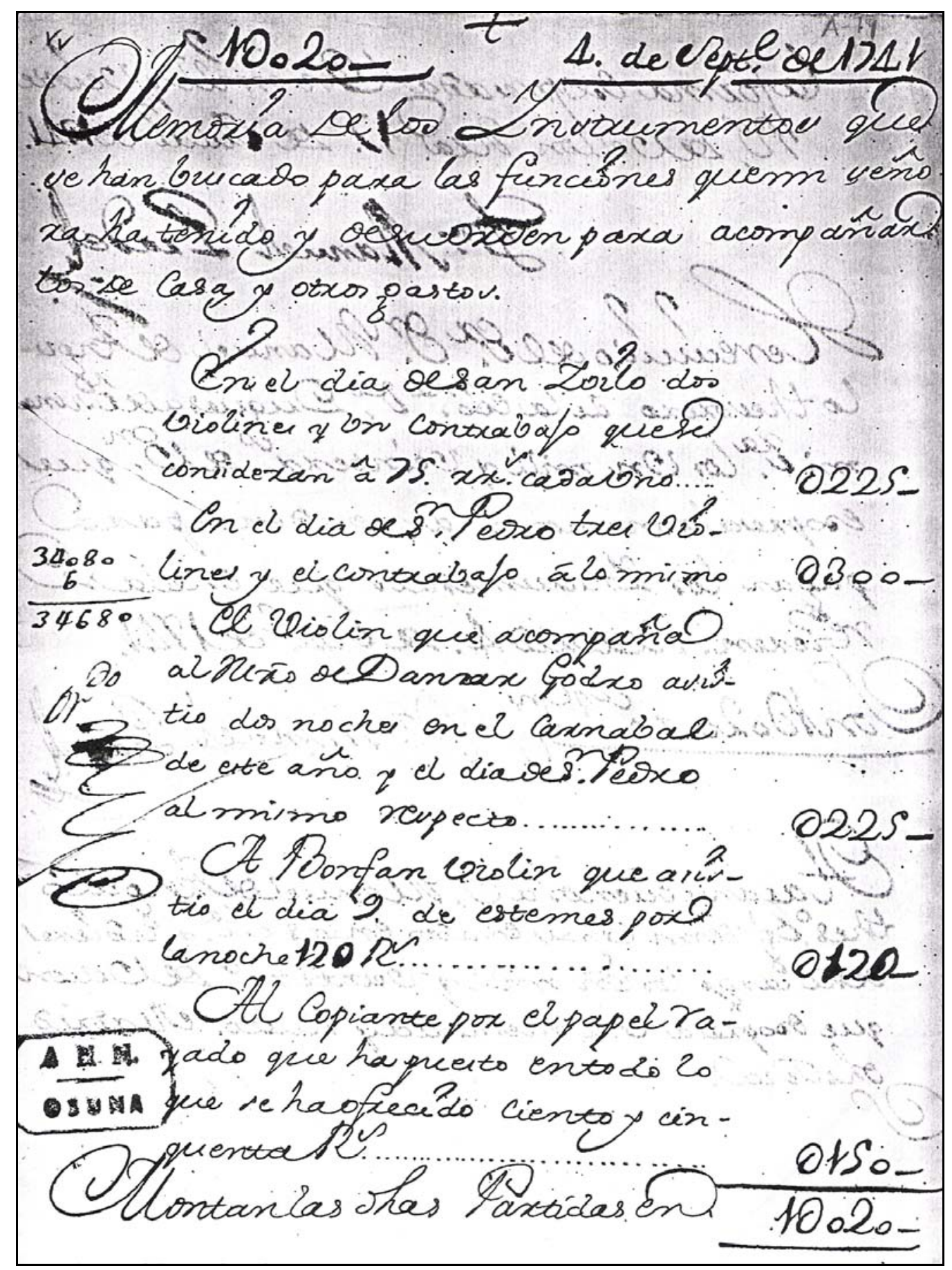




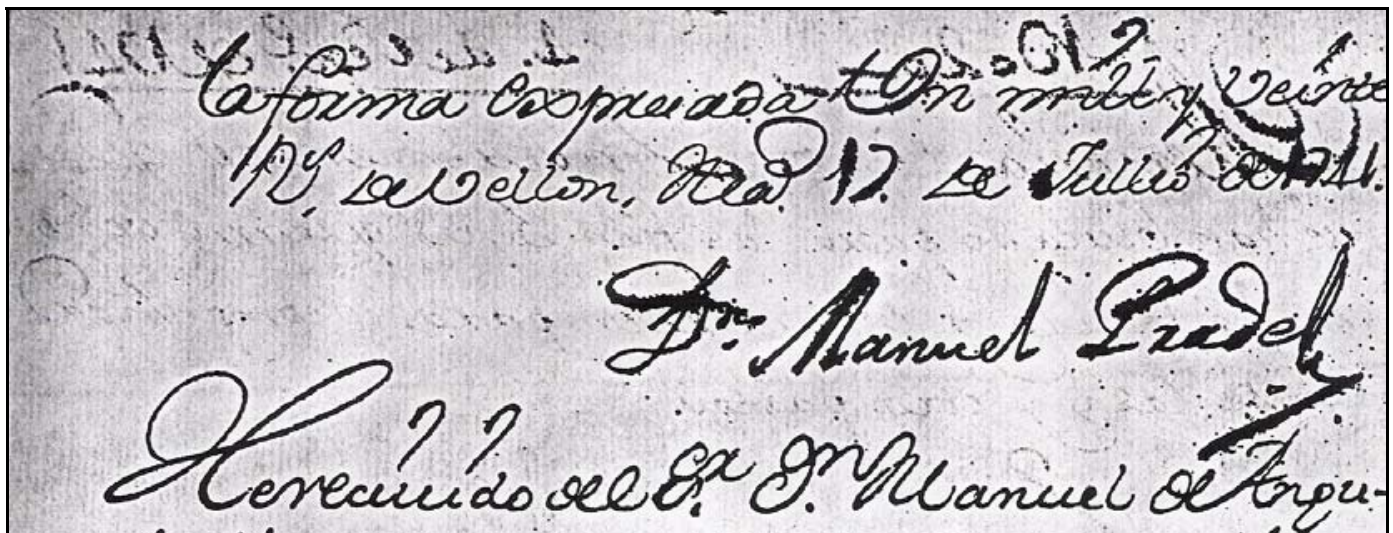
lo thevoxexo. de la exima ga Onqueradionng mita los $0 n$ mill y veintexx. selo, que esopreialamemoxia anteres entep aria papax los Initumentor que enellale

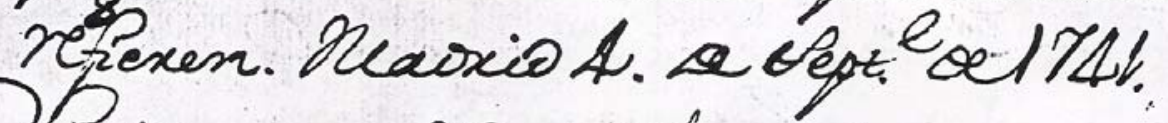

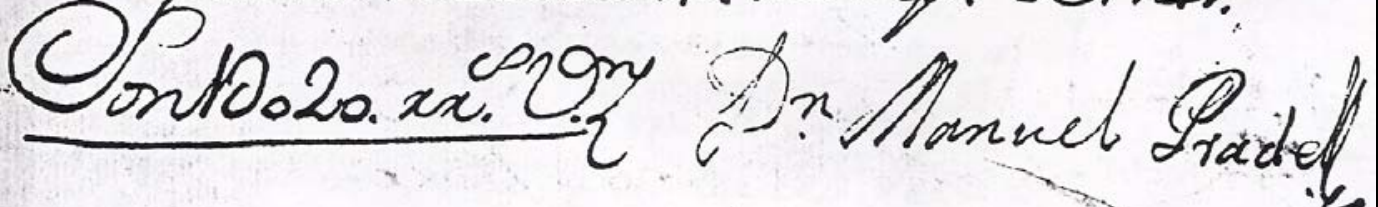

Ota

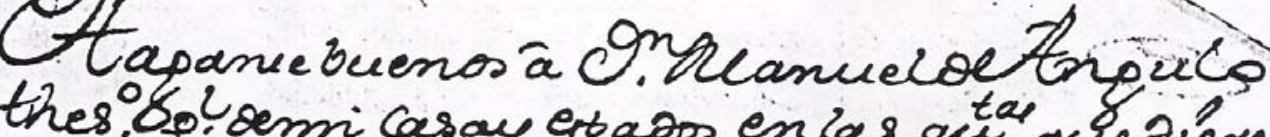
bet o drmi casay ertados entas qui queviexel

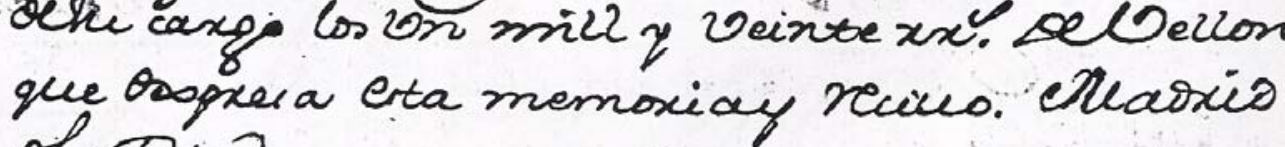
oho Dia.

(C)

11 a on muest

191 


\section{Músicos de la Real Capilla}

La presencia de músicos ligados a la Real Capilla en las capillas musicales y orquestas de la Casa de Osuna fue una constante a lo largo de todo el siglo XVIII. Como puede observarse al examinar la Tabla 8, en los 54 años de titularidad del VIII Duque de Osuna (que incluyen la tutela de su madre hasta 1748) un importante número de instrumentistas de la capilla musical de la Casa de Osuna trabajaron simultáneamente en la Real Capilla, colaboraron con ella o formaron parte de otras instituciones musicales ligadas a la monarquía como la orquesta del Real Coliseo del Buen Retiro o la capilla del Real Convento de la Encarnación de Madrid $^{84}$.

Esta circunstancia pone en entredicho la efectividad de las distintas normas dictadas desde la época de los Austrias para que los músicos de la Real Capilla tuvieran una dedicación exclusiva al servicio de la monarquía. Uno de los puntos del reglamento de la Real Capilla de 1749 prohibía expresamente a sus componentes asistir a "otras funciones de fuera de ella, excepto en las fiestas que se dignare $\mathrm{Su}$ Majestad dar especial permiso para ello"85. Asimismo, en las Nuevas Constituciones de la Real Capilla establecidas por Fernando VI en 1757, la norma se concretó más ya que se especificó que los músicos de esa institución no debían asistir sin autorización expresa para ello a ninguna función religiosa

\footnotetext{
${ }^{84}$ Gran parte de los músicos de la orquesta de la Condesa Duquesa de Benavente que funcionó entre $c a$. 1781 y 1792 también pertenecieron a la Real Capilla. Véase el punto 2.2.3 de este capítulo.

${ }^{85}$ Reglamento de la Real Capilla de 1749. Epígrafe n 16 . Citado en Germán Labrador López de Azcona, "Música, poder e institución: La Real Capilla de Carlos IV”, RMS, XXVI/1 (2003), pp. 243-244.
} 
pública "ni a las casas, por distinguidas que sean" "86. A pesar de estas prohibiciones, como veremos a continuación, la gran mayoría de los violinistas que trabajaron para el VIII Duque de Osuna como músicos asalariados pertenecían a la Real Capilla o a su entorno más cercano, o ingresaron en dicha institución durante su permanencia al servicio de la Casa de Osuna.

El violinista de origen boloñés Francisco Landini, miembro de la Real Capilla desde 1742, trabajó para la Casa de Osuna al menos desde mayo de 1745 hasta diciembre de $1747^{87}$. Landini coincidió en la Capilla de los Osuna con Francisco Manalt (miembro de la Real Capilla desde 1737) que ingresó al servicio de los Osuna antes de enero de 1745 con un salario de 9 reales diarios como “músico violín” de la Duquesa viuda de Osuna a la que sirvió hasta fin de Diciembre de $1747^{88}$. Según Lothar Siemens, Manalt seguía al servicio de la Casa de Osuna en 1757, fecha de edición de su Obra armónica de Seis Sonatas de Cámara de Violín y bajo solo dedicadas al Duque de Osuna de quien dice ser su "menor criado" y a quien trata de "mi dueño" 89 .

\footnotetext{
${ }^{86}$ BNE, Ms. 14017-14 (Papeles Barbieri).

87 AHN NOBLEZA, OSUNA-CARTAS, leg 390-4-2. Para la biografía de Landini véase el Apéndice 5.

88 AHN NOBLEZA, OSUNA-CARTAS, leg 389-28. Este dato viene corroborado por un documento de la testamentaria de la VII Duquesa viuda de Osuna donde figuran la cantidad de 9738 reales con 22 maravedíes de vellón que se le adeudaban a Manalt en diciembre de 1747. Considerando que su sueldo era de de nueve reales diarios resulta un total de 36 meses completos al servicio de la Casa de Osuna. Para la biografía de Manalt véase el Apéndice 5.

${ }^{89}$ Francisco Manalt, Obra Armónica en seis Sonatas de Cámara de violín y bajo solo. Edición de Lothar Siemens, (Madrid: Sociedad Española de Musicología, 2001), p. 6.
} 
Tabla 8.

Músicos al servicio de Pedro Zoilo Téllez Girón,

VIII Duque de Osuna (1733-1787)

Fuentes: AHN NOBLEZA, OSUNA-CARTAS, legs. 388, 392, 393, 447-453.

BNE Mss 14.015-2²/ 18 (Papeles Barbieri); Subirá, "Necrologías musicales madrileñas”; Siemens,

"Los violinistas compositores"

\begin{tabular}{|c|c|c|c|c|}
\hline NOMBRE & $\begin{array}{l}\text { INSTRUMENTO } \\
\text { O CARGO } \\
\end{array}$ & INCORPORACIÓN & BAJA & $\begin{array}{c}\text { OTROS } \\
\text { EMPLEOS } \\
\end{array}$ \\
\hline José Bonfanti & violín & 1 de Enero de 1748 & $\begin{array}{c}\text { Después de } \\
\text { agosto de } \\
1748\end{array}$ & $\begin{array}{c}\text { Violín de la Real } \\
\text { Capilla desde } 1747\end{array}$ \\
\hline Juan Busquet[s] & violín & Se desconoce & $10 / 12 / 1766$ & $\begin{array}{c}\text { Violín en la orquesta } \\
\text { del Real Coliseo del } \\
\text { Buen Retiro } \\
\text { (Antes de 1758) }\end{array}$ \\
\hline Pablo Esteve & $\begin{array}{l}\text { maestro de capilla y } \\
\text { de la casa del Duque }\end{array}$ & $\begin{array}{c}\text { Antes } \\
\text { de } 1765\end{array}$ & $\begin{array}{c}\text { Antes } \\
\text { de } 1772\end{array}$ & $\begin{array}{c}\text { Músico del Marqués } \\
\text { de Mortara (1774) } \\
\text { Compositor de la } \\
\text { Compañía de } \\
\text { Manuel Martínez } \\
(1777-1790\end{array}$ \\
\hline Pablo Font & trompa & Se desconoce & \begin{tabular}{|c|} 
Después de \\
Julio de 1767 \\
\end{tabular} & Se desconoce \\
\hline Francisco Landini & violín & Antes de mayo de 1745 & $\begin{array}{c}\text { Después de } \\
\text { diciembre de } \\
1747 \\
\end{array}$ & $\begin{array}{c}\text { Violín de la Real } \\
\text { Capilla desde } 1742\end{array}$ \\
\hline José Literes & violón & Antes de 1732 & $\begin{array}{c}\text { Después de } \\
\text { febrero de } \\
1737 \\
\end{array}$ & $\begin{array}{c}\text { Violón de la Real } \\
\text { Capilla desde } 1734\end{array}$ \\
\hline Francisco Manalt & violín & $\begin{array}{c}\text { Antes de diciembre de } \\
1745\end{array}$ & $\begin{array}{l}\text { Después de } \\
1757\end{array}$ & $\begin{array}{c}\text { Violín de la Real } \\
\text { Capilla desde } 1737\end{array}$ \\
\hline Juan Miserachs & fagot & $1 / 4 / 1753$ & Se desconoce & Se desconoce \\
\hline Juan Orri & violón & Antes de 1747 & $\begin{array}{l}\text { Después de } \\
\text { agosto de } \\
1748\end{array}$ & $\begin{array}{c}\text { Violón de la Real } \\
\text { Capilla antes de } \\
1756\end{array}$ \\
\hline Manuel Pradell & $\begin{array}{l}\text { músico } \\
\text { compositor }\end{array}$ & $\begin{array}{c}\text { Antes } \\
\text { de } 1732\end{array}$ & $\begin{array}{c}\text { Después de } \\
1741\end{array}$ & Se desconoce \\
\hline Salvador Rexach & violín & $1 / 4 / 1753$ & $\begin{array}{l}\text { Después de } \\
1775\end{array}$ & $\begin{array}{c}\text { Primer violín de la } \\
\text { capilla del Colegio } \\
\text { Imperial de la Corte } \\
(1760) \text {. Violín en la } \\
\text { Real Capilla desde } \\
1768\end{array}$ \\
\hline Francisco Torner & contrabajo & $1 / 4 / 1753$ & $(† 25 / 7 / 1767)$ & $\begin{array}{l}\text { Contrabajo en la } \\
\text { orquesta de la } \\
\text { compañía teatral de } \\
\text { María Hidalgo al } \\
\text { menos desde } 1758\end{array}$ \\
\hline Pablo Vidal & violón & $1 / 4 / 1753$ & $\begin{array}{c}\text { Permanece en } \\
\text { las nóminas } \\
\text { de la Casa de } \\
\text { Osuna hasta } \\
\text { su muerte en } \\
1808 . \\
\end{array}$ & $\begin{array}{l}\text { Primer Violón en la } \\
\text { Real Capilla del } \\
\text { Convento de la } \\
\text { Encarnación de } \\
\text { Madrid }\end{array}$ \\
\hline
\end{tabular}


La introducción de Lothar Siemens a su edición de la citada obra de Manalt contiene algunos datos dudosos que es necesario precisar, una vez que se ha establecido la cronología y genealogía de las casas nobiliarias de Osuna y Benavente. Según Lothar Siemens, Francisco Manalt “debió complementar su salario [en la Real Capilla] acudiendo como maestro y músico de cámara a casas de la nobleza madrileña, especialmente a la del Duque de Osuna, y su esposa la Condesa de Benavente, a los que siempre se sintió especialmente vinculado" Siemens mantiene que Manalt coincidió en los conciertos y academias musicales de los “Osuna-Benavente" con José Herrando, violinista de la Encarnación, adscrito a la órbita de los Duques de Alba ${ }^{90}$.

Francisco Manalt falleció en 1759, y por consiguiente, estuvo necesariamente al servicio de Pedro Zoilo Téllez Girón, VIII Duque de Osuna (*1728-†1787), casado desde 1753 con $\mathrm{M}^{\mathrm{a}}$ Vicenta Pacheco, que no tenía ninguna relación directa con la Casa de Benavente. Siemens confunde, por tanto, al VIII Duque con su hijo Pedro de Alcántara Téllez Girón, casado desde diciembre de 1771 con María Josefa Alfonso Pimentel, XV Condesa-Duquesa de Benavente. La Obra armónica de Manalt está dedicada, por consiguiente, a Pedro Zoilo Téllez Girón (VIII Duque de Osuna) con el cual no se conoce que tuviese relación alguna José Herrando, violinista que sí colaboró habitualmente con la Casa de Benavente $^{91}$.

\footnotetext{
${ }^{90}$ Francisco Manalt, Obra armónica... pp. 5-6.

${ }^{91}$ Sobre la relación de José Herrando con la Casa de Benavente véase el apartado 2.1.2 de este capítulo.
} 
José Bonfanti fue otro de los violinistas de la Real Capilla que trabajaron para los Osuna en esta época. Bonfanti (que fue miembro de la institución monárquica desde 1747$)^{92}$ colaboró con la Casa de Osuna al menos desde 1741, como músico de refuerzo en las funciones organizadas por la Duquesa viuda de Osuna $^{93}$, y se incorporó como miembro asalariado al servicio de la capilla ducal en enero de 1748 en la cual permaneció hasta agosto del mismo año ${ }^{94}$.

Antes de la muerte de la Duquesa viuda en 1748, ocuparon los atriles de la cuerda grave de la capilla musical de los Osuna otros dos músicos de la Real Capilla: José Literes que era violón de la Capilla desde la época del VII Duque de Osuna, y que permanecía en este puesto en febrero de $1737^{95}$, y el que probablemente fuera su sucesor Juan Orri que trabajó como músico asalariado de la Casa de Osuna al menos entre enero de 1747 y agosto de 1748 , fecha en la que se le adeudaban 6.065 reales de vellón ${ }^{96}$.

Dos violinistas que trabajaron al servicio del VIII Duque de Osuna se presentaron a las oposiciones de la Real Capilla con diferentes resultados. Salvador Rexach (músico de la Casa de Osuna desde 1753), logró ingresar como

\footnotetext{
92 Los principales datos biográficos de José Bonfanti figuran en el Apéndice 5.

93 AHN NOBLEZA, OSUNA-CARTAS, leg 390-3-4. Identifico a José Bonfanti con el violinista de nombre "Bonfan" que aparece entre los instrumentos contratados para reforzar la capilla de la Duquesa en las fiestas de 1741.

94 AHN NOBLEZA OSUNA-CARTAS, leg 390-4-5. Carta de Pago otorgada ante Don Cosme Damián de los Reyes por la testamentaría de la Duquesa de Osuna a favor de José Bonfanti como músico violón que sirvió en su casa desde el uno de enero de 1748 hasta fin de agosto del mismo año de 1748 .

${ }^{95}$ AHN NOBLEZA OSUNA-CARTAS, leg 389-30.

${ }^{96}$ Ibid., leg 390-4-4.
} 
violinista en la Real Capilla en $1768^{97}$. A pesar de obtener esta plaza, Rexach continuó al servicio del Duque de Osuna al menos hasta $1775^{98}$. Juan Busquet o Busquets, que trabajaba para la Casa de Osuna en 1766, había sido violinista de la orquesta del Real Coliseo del Buen Retiro y primer violín suplente en la Real Capilla. En junio de 1760 se presentó a las oposiciones para la Real Capilla donde compitió con Salvador Rexach, Ramón Palaudarias, Domingo Rodil, Cayetano Brunetti, Juan Bautista Isnar, Antonio López y José Herrando que fue quien finalmente obtuvo la plaza. Según el informe que elaboró el maestro de la capilla Francisco Courcelle, Busquet no estuvo muy acertado el día de su oposición:

Ha sido uno de los violines de la Real Orquesta del Coliseo y ha servido de primero violín en las funciones de la Real Capilla de Su Majestad durante las ausencias de sus individuos violinistas. Este sujeto, en el examen ha tenido la desgracia de hallarse comprimido por el miedo de modo que no pudo contener el pulso, por cuyo motivo no ejecutó con acierto su tocada propia, y mucho menos la de oposición; pero habiéndose algo serenado, desempeñó mejor los asuntos de capilla 99

Busquet no llegó nunca a ingresar en la Real Capilla, por lo que continuó presentándose a otras oposiciones, buscando un empleo estable en una institución que le reportase unos ingresos fijos. El 10 de diciembre de 1766 Busquet renunció a su trabajo como violinista en a Casa de Osuna y se trasladó a Córdoba donde

\footnotetext{
97 Lothar Siemens Hernández, "Los violinistas compositores en la Corte Española durante el período central del siglo XVIII", $R M S$, XI/ 3 (1988), pp. 728. Sobre la biografía de Rexaxh véase el Apéndice 5.

98 AHN NOBLEZA, OSUNA CARTAS, leg 448-1. En 1775 Salvador Rexach continuaba figurando en las nóminas de la Casa Osuna con el mismo sueldo de 9 reales con el que había comenzado a servir en 1753.

99 APR, Real Capilla cajas 119 y 138. Citado en Siemens, "Los violinistas”, pp. 755.
} 
había ganado la plaza de primer violín en su catedral ${ }^{100}$.

\section{Músicos catalanes al servicio del VIII Duque de Osuna: Manalt, Rexach, Vidal, Esteve y otros}

Las posibilidades profesionales que ofrecía la vida de la Corte durante la segunda mitad del siglo XVIII propició una notable afluencia a Madrid de músicos de todas las regiones que intentaban buscar algún puesto estable en las instituciones de la Corte, en los teatros, o en las numerosas capillas que funcionaron en la capital mantenidas por instituciones religiosas o por los miembros de la alta nobleza. En la mayoría de las ocasiones la pertenencia a la capilla musical de una casa nobiliaria no implicaba la exclusividad en el servicio, y suponía una situación de prestigio que los músicos aprovechaban para obtener otras plazas estables mejor remunerados que compatibilizaban con su trabajo al servicio de los nobles.

En el caso concreto de la Casa de Osuna, los altos cargos militares y cortesanos que desempeñaron sus titulares durante el siglo XVIII les obligó a residir durante largos períodos en diversos lugares de la geografía española o europea, aunque (como el resto de la nobleza titulada) su residencia permanente estuviera situada en Madrid y sus alrededores, siempre cerca de la Corte Real. Los destinos militares que desempeñaron los titulares de la Casa de Osuna durante el siglo XVIII podrían explicar la presencia de un buen número de músicos

\footnotetext{
100 AHN NOBLEZA OSUNA CARTAS, leg 389-30. Juan Busquet fue con Gabriel Terri (músico de la Real Capilla) uno de los albaceas en el testamento firmado en 1750 por Francisco Manalt, otro de los músicos de la Casa de Osuna (AHPM, leg 19142. Escribano Manuel Fernández Sánchez. Transcrito en Siemens. "Los violinistas”, p. 748).
} 
catalanes en sus capillas musicales.

Es bastante probable que José Téllez Girón, VII Duque de Osuna, que fue Teniente General de los Reales Ejércitos y Coronel del Regimiento de la Guardia de Corps fuera destinado una temporada con su regimiento a Cataluña. En 1732 trabajaban en la capilla musical de la Casa de Osuna varios músicos con apellidos catalanes como Manuel Pradell o Pedro Marrogat, que podrían haber seguido al Duque en su posible traslado de residencia a Madrid.

Uno de los primeros músicos catalanes que se incorporó al servicio de Pedro Zoilo Téllez Girón, VIII Duque de Osuna fue Francisco Manalt, quien al menos desde 1735 se hallaba ya en Madrid ${ }^{101}$. Manalt ingresó al servicio de la Casa de Osuna antes de 1745 (Tabla 8) y según Lothar Siemens (que cita investigaciones no publicadas de María Ester-Sala) había trabajado antes en Barcelona como miembro de la Capilla del Palau, una institución que hacia 1730 gozaba de la protección de los Duques de Osuna:

Gracias a las investigaciones de nuestra malograda amiga María Ester Sala, sabemos que desde principio de los años treinta del siglo estuvo Manalt adscrito como violinista a la capilla del Palau de Barcelona, bajo el gobierno de los duques de Osuna a los que nuestro músico se sintió siempre vinculado. Esta presencia de Osuna en Barcelona, cuya capilla del Palau era una verdadera escuela violinística desde la época de la guerra de Sucesión española en la que el pretendiente Carlos de Austria residió allí y dotó a su capilla con refuerzos de músicos, y nuevos estilos importados de Italia, supuso durante la primera mitad del siglo XVIII un impulso innovador que favoreció el trasvase de músicos catalanes a Madrid, con lo que encontramos en aquel siglo no pocos maestros venidos a Madrid desde Barcelona de la

101 Sobre la capilla del VII Duque véase el Capítulo 2. 
mano de Osuna y que ocuparon plazas musicales de privilegio en la Real Capilla: los Dalp, Terri, Rexach, Palaudarias, Misón, el propio Manalt, etc. Y también italianos, como fue el caso del violonchelista Porretti que estuvo en el Palau antes de trasladarse a Madrid ${ }^{102}$.

De todos los músicos que cita Siemens sólo está probada la pertenencia al servicio de la Casa de Osuna de Francisco Manalt y Salvador Rexach. No obstante, de confirmarse la interesante hipótesis de María Ester Sala citada por Siemens se demostraría la importancia del mecenazgo de los Osuna en la circulación de músicos de origen catalán que después ocuparían importantes plazas en las instituciones musicales de la monarquía.

La capilla musical de la Casa de Osuna sufrió una importante renovación en 1753, coincidiendo con el matrimonio del VIII Duque con María Vicenta Pacheco, hermana del Duque de Uceda ${ }^{103}$. En abril de ese año se incorporaron al servicio del Duque de Osuna cuatro músicos de origen catalán con el sueldo de nueve reales diarios: el violinista y compositor Salvador Rexach, el violón Pablo Vidal, el contrabajo Francisco Torner y el fagotista Juan de Miserachs ${ }^{104}$. Estos cuatro músicos procedían de la orquesta de la compañía de ópera italiana de

\footnotetext{
${ }^{102}$ Manalt, Obra armónica, p. 5. Para la biografía de Manalt véase el Apéndice 5.

103 AHN NOBLEZA OSUNA-CARTAS, leg 450-65 bis. La boda se celebró el 28 de febrero de 1753 en la Iglesia de San Martín de Madrid.

104 AHN NOBLEZA OSUNA-CARTAS, 389-30. Judith Ortega interpreta erróneamente este documento en el que sólo aparece una referencia al "Duque" y afirma que estos cuatro músicos fueron contratados por "el duque de Benavente". Los titulares de la Casa de Benavente nunca utilizaron esta dignidad nobiliaria y se hacían nombrar siempre como "Conde-Duque" o simplemente "Conde". La pertenencia de estos cuatro instrumentistas al servicio de los Osuna queda probada además por otros documentos citados en este apartado en los que se declaraban músicos del "Duque de Osuna" [=Pedro Zoilo Téllez Girón] y no del "Conde-Duque de Benavente". Véase Ortega, "El mecenazgo musical", p. 664.
} 
Nicola Setaro, que había actuado en el Teatro de la Santa Cruz de Barcelona hasta el 7 de marzo del mismo año ${ }^{105}$. Salvador Rexach era el segundo violín (principal) de la orquesta y también realizaba funciones de copista musical; Pablo Vida[1] figura como "biola" de la cuerda de bajos [= ¿viola de gamba? junto al contrabajo Francisco Torner. El fagotista Juan de Miserachs que fue contratado por el Duque en esta misma fecha es muy probable que sea el instrumentista de oboe que aparece en la lista de la plantilla de la orquesta como“Juan Suirach", y del que no he podido documentar ningún otro dato ${ }^{106}$.

El Regimiento de las Reales Guardias de Infantería Española, al que pertenecía el Duque de Osuna, estuvo destinado en Barcelona en la época en que la Compañía de Nicola Setaro trabajó en el teatro de la Santa Cruz (1751-1753). Sus oficiales (al igual que los de la mayoría de los regimientos militares destinados en la Ciudad Condal) tenían abonos para toda la temporada de ópera, y eran los principales promotores de este espectáculo ${ }^{107}$. Como miembro de la oficialidad militar destinada en Barcelona, el joven Duque de Osuna debió de asistir a los espectáculos operísticos de dicho teatro, y en este contexto conoció seguramente a los cuatro músicos catalanes que contrató para su capilla musical de Madrid cuando cesaron las funciones de la Compañía de Setaro. A lo largo de

\footnotetext{
105 Sobre la actividad de esta compañía de ópera en España véase María del Carmen Rodríguez Suso, "La trastienda de la ilustración: El empresario Nicola Setaro y la Ópera Italiana en España, $I l$ Saggiatore Musicale, Revista Semestrale di Musicología, 5/2 (1998), pp. 245-268.

106 Archivo Hospital de la Santa Cruz (Barcelona), Teatre, Carpeta $6^{\mathrm{a}} \mathrm{n}^{\mathrm{o}} 5$. Cuentas de 1750-1759. Transcrito en Roger Alier, $L^{\prime}$ òpera a Barcelona : origens, desenvolupament $i$ consolidació de l'ópera com a espectacle teatral a la Barcelona del segle XVIII, (Barcelona: Institut d'Estudis Catalans, Societat Catalana de Musicología, 1990), pp. 519-526.

107 Alier, L' òpera, pp.116-134.
} 
su vida, Pedro Zoilo Téllez-Girón continuó teniendo relación militar con Cataluña, y seguramente residió allí en algún otro período a lo largo de su vida. En uno de los panegíricos que se realizaron a su muerte en 1787 se citaba que el Duque mantuvo en Barcelona "a cincuenta soldados de su cuerpo" que se habían retirado del servicio por inválidos ${ }^{108}$.

Tras su llegada a Madrid, el violinista Salvador Rexach $(* 1725-\dagger 1780)$ compatibilizó su trabajo al servicio de la Casa de Osuna con diversos empleos, algo necesario para completar el insuficiente salario que obtenía como músico al servicio del Duque. En 1760 Rexach ocupaba la plaza de primer violín de la capilla del Colegio Imperial ${ }^{109}$, y al menos entre 1762 y 1768, formó parte de la orquesta de la compañía teatral de María Hidalgo, que actuaba en los teatros madrileños de La Cruz y el Príncipe ${ }^{110}$. Este trabajo le reportaba unos ingresos económicos muy superiores a los de la Casa de Osuna, sin duda insuficientes para mantener un adecuado nivel de vida. Rexach debió de abandonar su empleo en la orquesta de la compañía de María Hidalgo cuando ingresó en la Real Capilla en

\footnotetext{
108 Correo de Madrid, 5 de Mayo de 1787, nº 56 p.239.

109 Aunque algunos autores como Lothar Siemens han dudado de la existencia de esta institución (Siemens, "Los violinistas", p.725) en la documentación administrativa de la Casa de Osuna figura un recibo que acredita su funcionamiento. El documento firmado por Sebastián Moneva, "festero de la capilla del Colegio Imperial"'refleja el pago por la asistencia de varios músicos de esta capilla a las vísperas, misa, siesta y Te Deum organizada en 1755 por el Conde Duque de Benavente en honor de San Francisco de Borja. AHN NOBLEZA, OSUNA-CARTAS, leg 389-16.

110 BNE. Mss 14.016.1 (Papeles Barbieri). En 1762 ya aparece un "Salvador" entre los violines primeros de la compañía de María Hidalgo con la asignación de 20 reales diarios. En otro documento que detalla los sueldos que se les pagó a los miembros de la orquesta de esta compañía hasta el 30 de abril de 1768 figura Salvador Rexach con la misma asignación.
} 
Octubre de $1768^{111}$, pero continuó trabajando al servicio del Duque de Osuna al menos hasta $1775^{112}$. Paralelamente a su trabajo en la Casa de Osuna, Rexach colaboró también en algunas veladas musicales organizadas por María Faustina Téllez-Girón Condesa-Duquesa de Benavente y hermana del VIII Duque de Osuna $^{113}$.

El compositor y violón Pablo [Pau] Vidal, gozó de la protección de la Casa de Osuna durante gran parte de su vida. Debía de ser muy joven cuando en 1753 se incorporó a la capilla musical del VIII Duque y permaneció al servicio de esta casa nobiliaria hasta su muerte en $1807^{114}$. Entre 1781 y 1792 fue miembro de la orquesta de la Condesa-Duquesa de Benavente, y al menos desde 1775 fue primer violón en la Real Capilla del Convento de la Encarnación de Madrid ${ }^{115}$.

Al margen de su labor como instrumentista, Pablo Vidal mostró también interés por la pedagogía del violonchelo. Uno de sus discípulos fue seguramente su propio hijo el violonchelista José Vidal que colaboraba como músico de refuerzo en las fiestas organizadas por la Condesa-Duquesa María Josefa ${ }^{116}$. Fruto de este interés por la enseñanza son dos obras pedagógicas que muestran la gran

\footnotetext{
111 Siemens, Los violinistas, p.728.

112 AHN NOBLEZA, OSUNA CARTAS, leg 448-1. En 1775 Salvador Rexach continuaba trabajando para la Casa de Osuna con el mismo sueldo de 9 reales con el que comenzó a servir en 1753.

113 AHN NOBLEZA, OSUNA CARTAS, leg 389-21. Libramiento para pagar los trajes encargados por la Condesa-Duquesa de Benavente para Salvador Rexach, Pablo Vidal y Pablo Esteve.

114 AHN NOBLEZA, OSUNA CARTAS, leg 452. Pablo Vidal figuraba en 1806 en el apartado de personal jubilado de la Casa de Osuna como“músico que fue de la casa de Su Excelencia” con el mismo sueldo de nueve reales diarios con el que fue admitido en 1753.

115 Para la biografía de Pablo Vidal véase el Apéndice 5.

116 AHN NOBLEZA, OSUNA CARTAS, leg 389-30.
} 
competencia técnica de Vidal en su instrumento. La primera de ellas lleva por título Arpegio Armónico de Violonchelo y Bajo, de buen gusto y arte, según el moderno estilo, utilísimo para perfeccionarse en dicho instrumento, su tema: ut, re, mi, fa, sol, la. Según Emilio Moreno "se trata de un cuaderno manuscrito de once páginas, una de portada y diez de música, conteniendo unas difíciles lecciones para violonchelo y «violón o viola» en el bajo"117. En la Biblioteca Nacional de España (Madrid) se conserva un ejemplar de la segunda de las obras pedagógicas de Vidal conocidas hasta la fecha que lleva por título Arte y Escuela de violonchelo, (Lámina 17); un breve método progresivo que va desde las bases del aprendizaje técnico del instrumento, hasta un complejo estudio destinado a los discípulos más adelantados que recorre gran parte del diapasón ${ }^{118}$.

Pablo Vidal fue también autor de otras obras que no se han localizado hasta la fecha como un concierto para violonchelo fechado 1796. Asimismo se le atribuyen varias piezas para voz y guitarra que se anunciaban en el Diario Noticioso de Madrid en los primeros años del siglo XIX ${ }^{119}$.

\footnotetext{
117 Emilio Moreno, “Aspectos técnicos del tratado de violín de José Herrando (1756): El violín español en el contexto europeo de mediados del siglo XVIII”, RMS, XI/3 (1988), p.563.

118 BNE MC/5307/70.

119 Judith Ortega, Pablo Vidal, DMEH, 10, pp.864-865.
} 


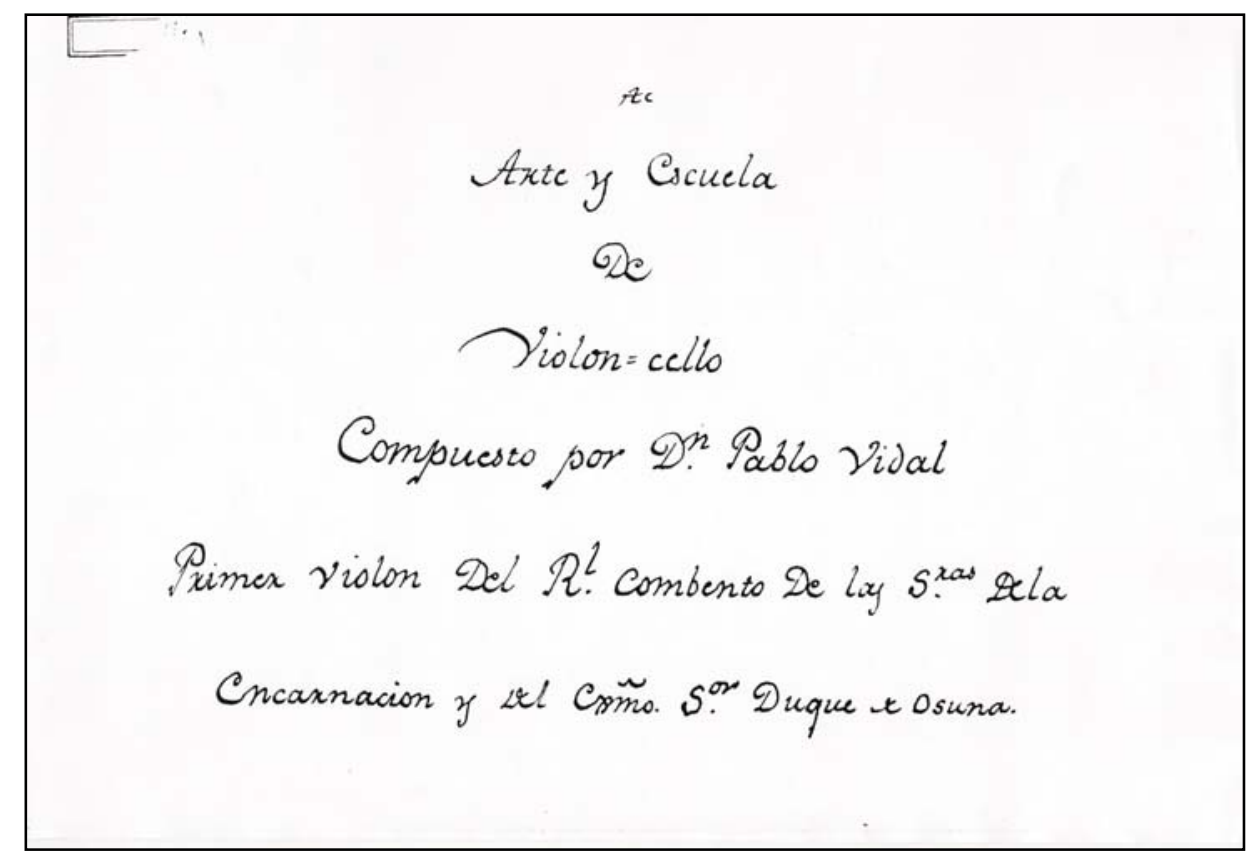

Lámina 17.

Portada de Arte y Escuela de violonchelo de Pablo Vidal

$\mathrm{BNE} \mathrm{MC} / 5307 / 70$.

El contrabajo Francisco Torner, otro de los músicos catalanes de cuerda que se incorporó en abril de 1753 a la capilla del Duque de Osuna, era natural de Villafranca del Penedés (Barcelona) ${ }^{120}$. Al menos entre 1758 y 1765 Torner fue también contrabajista en la orquesta de la compañía de María Hidalgo, donde coincidió con Salvador Rexach ${ }^{121}$. Siguió trabajando para los Osuna hasta su muerte que tuvo lugar el 25 de julio de 1767. Sus albaceas testamentarios fueron el carmelita fray José Flores y "don Salvador Rexach y don Pablo Font, músicos de dicho Excelentísimo Señor [Duque de Osuna]"122.

\footnotetext{
120 José Subirá, "Necrologías musicales madrileñas", AnM, XIII (1958), p.216.

121 BNE, Ms.14.015 y Ms. 14.016 (Papeles Barbieri).

122 Subirá "Necrologías", p.216.
} 
Además de los instrumentistas ya citados, al menos otros dos músicos del VIII Duque de Osuna eran de origen catalán, Pablo Font y Pablo[Pau] Esteve y Grimau, ambos nacidos en Barcelona.

Pablo Font trabajaba ya como músico al servicio del Duque de Osuna en $1767^{123}$. No debe confundirse a este personaje con su sobrino del mismo nombre, hijo de su hermano Francisco Font, que fue uno de los músicos del Infante don Luis $^{124}$. Antes de su llegada a Madrid, Pablo Font había trabajado en Barcelona como trompa de la orquesta de la compañía de ópera de Nicola Setaro al menos durante la temporada de 1752-1753. En la plantilla de esta orquesta también se hallaba su hermano Francisco y los citados músicos de la Casa de Osuna Vidal, Rexach, Torner ${ }^{125}$, quienes seguramente debieron de influir para que Font se trasladase a Madrid y comenzase a trabajar al servicio de dicha casa ducal. La última noticia conocida de Pablo Font es de 1789. El 30 de marzo de ese año firmó una declaración testamentaria de pobre con su hermano Francisco y su cuñada Teresa Marimom. Por este documento se conoce que era natural de Barcelona y que estaba viudo de Ramona Manalt, probable pariente del también músico de los Osuna, Francisco Manalt ${ }^{126}$.

\footnotetext{
${ }^{123}$ Ibid.

124 Jaime Tortella, Boccherini, un músico italiano en la España Ilustrada, (Madrid: Sociedad Española de Musicología, 2002), pp.248-249.

${ }^{125}$ Archivo Hospital de la Santa Cruz (Barcelona), Teatre, Carpeta $6^{\mathrm{a}} \mathrm{n}^{\mathrm{o}} 5$. Cuentas de 1750-1759. Cuentas de la compañía de ópera de Nicola Setaro en la temporada de 1752 1753. Transcrito en r Alier, $L^{\prime}$ òpera, , pp. 519-526.

126 AHPM, Protocolo 20909, fol. 82. Escribano A Martínez Llorente. Citado en Tortella, Boccherini, pp. 248-249.
} 
En la década de los años 60 del siglo XVIII la dirección de la capilla musical del VIII Duque de Osuna estuvo a cargo del prolífico compositor catalán Pablo Esteve y Grimau, una las de las figuras centrales de la música teatral española de la segunda mitad del siglo XVIII ${ }^{127}$.

Pablo Esteve y Grimau nació en Barcelona hacia 1730 y era hijo de Pablo Esteve y de Josefa Grimau. Murió soltero el 4 de junio de 1794, dejando como heredera de sus bienes a Ramona María de la Soledad, su hija natural de 9 años de edad, que quedó bajo la custodia de Doña María de Vera y Córdoba. Los restos mortales de Esteve fueron enterrados en la capilla de Nuestra Señora de la Novena de Madrid, patrona de los comediantes, a cuya congregación había pertenecido el músico en vida ${ }^{128}$.

La trayectoria de Esteve durante las dos primeras décadas de su existencia permanece todavía desconocida. No sabemos nada de su período de formación, aunque él mismo se jactaba de haber estudiado "metódica y formalmente la composición con los “más acreditados Maestros de España ${ }^{129}$ "

\footnotetext{
${ }^{127}$ Una visión más amplia de la trayectoria biográfica de Esteve puede verse en el estudio introductorio de mi edición de la zarzuela Los Jardineros de Aranjuez. Pablo Esteve y Grimau, Los Jardineros de Aranjuez (1768) Zarzuela en dos actos. Estudio y edición crítica de Juan Pablo Fernández Cortés (Granada: Universidad de Granada, 2005), pp. XXV- XXII.

${ }^{128}$ En su partida de defunción se detalla que es "soltero" y "como de 60 años" Parroquia de San Sebastián de Madrid, Libro 37 de difuntos, fol. $307 \mathrm{v}$.

${ }^{129}$ Letras de la música que se canta en la ópera cómico- bufo-dramática intitulada "También de amor los rigores sacan fruto de las flores" por otro título: Los jardineros de Aranjuez (Madrid: Imprenta de Manuel Martínez, 1768), Prólogo.
} 
Hacia 1758 Pablo Esteve estaba ya en Madrid trabajando en los "teatros de la corte" ${ }^{\prime 130}$, donde estrenó en 1761 la tonadilla a dúo El pozo $\left(1^{a} \text { parte }\right)^{131}$. No he podido documentar más datos sobre la vinculación que tuvo Pablo Esteve a las compañías de los teatros de Madrid en la primera parte de su carrera, pero es probable que además de colaborar en la producción de los espectáculos dramáticomusicales en español, componiendo la música para sainetes y tonadillas, Esteve trabajase en estos años como maestro repetidor para enseñar la música a los actores $^{132}$.

Aunque en esta etapa la composición de música teatral fue una actividad importante para Pablo Esteve, es muy probable que su traslado desde Barcelona a Madrid no estuviera motivado por el deseo de abrirse paso como autor de música dramática, sino con su contratación como maestro de capilla del VIII Duque de Osuna, un empleo estable que podía ser completado con las colaboraciones como compositor en los coliseos madrileños.

Pablo Esteve trabajó al servicio del Duque de Osuna al menos desde 1765. El 8 de noviembre de ese año dedicó al Duque la edición de las partes cantadas de de La buona figliola, zarzuela en castellano sobre un original de Goldoni y Piccini, a la que Esteve añadió algunos números de su composición para su puesta

\footnotetext{
${ }^{130}$ En la introducción del libreto de la comedia No hay en amor fineza más constante, publicada en 1766, Esteve declaró llevar "ocho años de ejercicio en los Teatros de la Corte". La transcripción completa de este texto figura en Esteve, Los Jardineros, pp. XLIII-XLIV.

${ }^{131}$ BHM Mus 184-1.

${ }^{132}$ El compositor José Castel se hallaba también en Madrid en estos mismos años en una situación análoga. Sobre este autor puede consultarse mi artículo Juan Pablo Fernández-Cortés, "José Castel (1728-1807) un tonadillero maestro de capilla", RMS, XXIV/1-2, 2001, pp. 115-134; así como Beatriz Gurbindo, "José Castel y la tonadilla entre Tudela y Madrid", Nassarre, XVII/1-2, 2001, pp. 243-304.
} 
en escena en el Coliseo de la Cruz de Madrid por la Compañía de María Hidalgo:

Al Excelentísimo Señor Don Pedro Zoilo Tellez Girón Duque de Osuna, mi Señor, etc.

Excelentísimo Señor.

En el concepto de que mi obligación es sacrificar a Vuestra Excelencia, como a mi principal Dueño, hasta el mas mínimo producto de las cortas facultades de mi suficiencia, se atreve mi humildad a poner a los pies de Vuestra Excelencia este pequeño trabajo, para que por la parte en que puede llamarse mío, se verifique subordinado a quien debe estar siempre rendido,: con cuya sombra no dudo tenga el sagrado que necesita, para que no sea (sino por el contexto) en el impulso de darle a la luz, perseguido de los que solo viven de lo que matan: y aunque de éstos no faltará quien acuse mi resolución por lo insustancial del asunto, con todo, si mis débiles tareas no manifiestan el cumplimiento a que estoy obligado, ¿cuándo alcanzaría mi pobre talento a verificar esta satisfacción? Acredíteme lo posible de mi reconocido, y cúlpeme la mordacidad de osado; que para ser el corazón correspondiente no necesita serlo en lo más digno, si no le es factible: baste solo que lo explique en la parte que es permitida á su proporción, y mas cuando carezco del conocimiento de que para obsequio de Vuestra Excelencia muy venial este tributo, pero nadie podrá negarme, que ni yo puedo jamás tener obra que sea proporcionada á sus merecimientos, ni que las ofrendas se debe atender á la entidad del impulso, y no a lo equivalente de su validación; con que así espero que Vuestra Excelencia dispense por el espíritu de aquel aliento la futilidad de este holocausto: que si se mira como feudo obligatorio, ya con lo que tiene de alentado, consigue la formalidad de cumplido. Nuestro Señor prospere la vida de Vuestra Excelencia los muchos años, que necesitamos sus referentes criados. Madrid 8 de Noviembre de 1765.

Excelentísimo Señor

Besa los Pies de Vuestra Excelencia su mas humilde criado Pablo Esteve y Grimau ${ }^{133}$.

133 Pablo Esteve y Grimau, Letra de la música contenida en la zarzuela intitulada en idioma italiano "La buona figliola" y en castellano "La buena muchacha compuesta por el insigne Nicolao Piccini a excepción de la que se nota con unas xxx que lo es por Don.Pablo Esteve y 
En los años siguientes las publicaciones de Esteve que se conservan, fueron siempre dedicadas al VIII Duque de Osunar. En 1766 Esteve dedicó al Duque el libreto de las piezas cantadas de la comedia No hay en amor fineza más constante, que dejar por Amor su mismo amante cuya música había sido escrita por Esteve. La dedicatoria esta llena de dobles sentidos con significado musical que demuestran la competencia literaria de Esteve:

Al Excelentísimo Señor Don Pedro Zoilo Tellez, Giron, etc. Duque De Osuna, mi Señor.

Excelentísimo Señor

No el arbitrio me conduce a los pies de Vuestra Excelencia, la obligación de mi respeto me guía, para que cumpliendo con la ley del agradecimiento, verifique, dedicando cuanto debo, correspondiendo. Corta es la Obra; pero cuándo las de los compositores de música no fueron mínimas y breves? No está la clave de los procedimientos en lo máximo; lo acorde se cifra, en que sean de la humildad sostenidos, y por nota de la gratitud decantados; por lo que en el debido tono, que puede suplicaros mi pequeñez, con la pauta de la mayor sumisión, espero, que al compás de vuestra Grandeza, me patrocine su liberalidad, deseando, como siempre que en compañía de la Excelentísima Señora mi Ama, e inestimable familia, prospere nuestro Señor a Vuestra Excelencia en el auge de su gracia los años que sus Criados le pedimos, etc.” Excelentísimo Señor,

Señor, Besa Los Pies de Vuestra Excelencia su mas humilde Criado Pablo Esteve y Grimau ${ }^{134}$.

Una de las funciones de Pablo Esteve como maestro de capilla de la Casa de Osuna fue la de conseguir para el Duque la música de otros autores que se

Grimau, quien la dedica al Excelentísimo Señor Duque de Osuna ([s.1, s.n], 1765). El texto es una adaptación de Cecchina ossia la buona figliola de Carlo Goldoni BNE T/22.325.

${ }^{134}$ Esteve, Letras que se cantan, [prólogo]. Una transcripción de este texto figura en Esteve, Los Jardineros, pp. XLIII-XLIV. 
representaron en los teatros públicos, seguramente para que fuera interpretada en el ámbito doméstico de los Osuna. El 24 de Julio de 1766, Esteve recibió un pago de 300 reales "por la música de la ópera intitulada el Bobo de Antona que Su

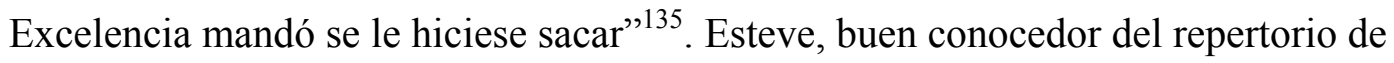
teatro musical europeo, influyó seguramente en la elección de este drama jocoso con música de Tomaso Traetta, estrenado en Madrid ese mismo año con poco éxito pero que Esteve consideraba que tenía "una música excelente",136.

La última referencia que he localizado sobre la relación de Pablo Esteve con la Casa de Osuna es del mes de junio de 1768, fecha de la dedicatoria al VIII Duque de la edición del libreto de la zarzuela Los jardineros de Aranjuez, en cuya portada Esteve se denomina "Maestro de Capilla catalán y de casa del Excelentísimo Señor Don Pedro Zoilo Téllez Girón, Duque de Osuna, mi Señor" ${ }^{137}$.

Al igual que hicieron otro músicos vinculados a la Casa de Osuna, Pablo Esteve también intentó mejorar su situación profesional, en su caso presentándose a las oposiciones a maestro de capilla del Monasterio de las Descalzas Reales de Madrid. En un informe realizado en 1780 por José Castel, compañero de Esteve en las labores teatrales y a la sazón maestro de capilla en la Catedral de Tudela (Navarra), sobre los candidatos más adecuados para ocupar un puesto vacante en

\footnotetext{
${ }^{135}$ AHN NOBLEZA, OSUNA-CARTAS, leg 452.

136 Esteve, Letras que se cantan.

${ }^{137}$ Pablo Esteve y Grimau, Letras de la música que se canta en la ópera cómica bufo dramática intitulada "También de amor los rigores sacan fruto de las flores" por otro título los jardineros de Aranjuez. (Madrid: Imprenta de Manuel Martínez, 1768). Un ejemplar de este libreto se conserva en la Biblioteca del Institut del Teatre de Barcelona bajo la signatura 46258. La portada se reproduce en el Capítulo 6. Lámina 30.
} 
el magisterio de la catedral de Burgos, Castel propuso entre otros a Pablo Estebet [sic], compositor de uno de los Coliseos de Madrid al que "vio hacer oposición al magisterio de las Descalzas Reales, en la que se desempeñó muy bien"138.

Como hemos visto hasta aquí, todos los datos documentados que relacionan a Pablo Esteve con la Casa de Osuna, se refieren a la composición o copia de obras de música teatral. La labor más importante de Esteve como maestro de capilla del VIII Duque de Osuna parece haber sido, por tanto, la composición e interpretación de obras dramático-musicales, campo en el que se desarrolló su carrera profesional especialmente a partir de 1778 cuando fue nombrado compositor en la compañía teatral madrileña de Manuel Martínez ${ }^{139}$. La hipótesis planteada por Antonio Martín Moreno acerca de la posibilidad de que Esteve hubiera contribuido con "obras puramente instrumentales" a las academias del Duque de Osuna no puede avalarse documentalmente. Hasta la fecha no se conoce ninguna obra instrumental de Esteve que no esté vinculada al género teatral ni se ha descubierto ningún dato que confirme que entre las obligaciones de Esteve al servicio de los Osuna se hallase la de proveer al Duque de música instrumental pura ${ }^{140}$.

La relación de servicio de Pablo Esteve con el Duque de Osuna finalizó

\footnotetext{
138 José López-Calo, La música en la catedral de Burgos (Burgos: Caja de Ahorros del Círculo Católico de Burgos, 1996), vol. VII, p. 38. Estas oposiciones debieron ser las celebradas en 1769 que ganó Manuel Mencía.

${ }^{139}$ Sobre las obligaciones de Pablo Esteve como “compositor de compañía” véase José Subirá, $L a$ Tonadilla Escénica (Madrid: Tipografía de la Revista de Archivos, Bibliotecas y Museos, 19281930), vol. I, p. 171.

${ }^{140}$ Martín Moreno, Historia, pp. 265.
} 
antes de enero de 1772. En las extensas nóminas del personal al servicio de la casa ducal de este año y en los años inmediatamente posteriores no figura Pablo Esteve, y sólo quedan como músicos asalariados dos de los componentes de la capilla: el "músico violín del duque" Salvador Rexach, y el violón Pablo Vidal ${ }^{141}$. La capilla musical de la Casa de Osuna parece haberse disuelto después de 1768 y antes de $1771^{142}$, lo cual probablemente obligó a Esteve a buscarse un nuevo empleo en otra casa nobiliaria. En 1774 Pablo Esteve trabajaba como músico para el Marqués de Mortara, otro importante mecenas musical de la nobleza urbana que en esa misma época contaba entre el personal al servicio de su casa con el músico Blas de Laserna y el dramaturgo Luciano Francisco Comella ${ }^{143}$.

Tras la boda de su hijo Pedro de Alcántara, Marqués de Peñafiel y futuro Duque de Osuna en diciembre de 1771, las actividades musicales de la Casa de Osuna parecen eclipsadas por la importante labor de María Josefa Alfonso Pimentel, XV Condesa Duquesa de Benavente y nuera del VIII Duque de Osuna. Esta dama tomará el relevo definitivo en el protagonismo del mecenazgo musical de la unificada Casa de Benavente-Osuna, tras la muerte en 1787 del VIII Duque de Osuna ${ }^{144}$

\footnotetext{
${ }^{141}$ AHN NOBLEZA, OSUNA-CARTAS, leg 447-1..

${ }^{142}$ No he podido documentar las circunstancias ni la fecha concreta de la disolución de la capilla musical del VIII Duque, pues en la documentación administrativa del Archivo de la Casa de Osuna no se conservan nóminas ni documentos de pago a músicos entre 1766 y 1771.

${ }^{143}$ Esteve, Los jardineros, p. XIX.

144 El VIII Duque de Osuna financió algunas actividades musicales de su nuera. En 1778 el violinista Francisco Basset, recibió un pago del Duque por la asistencia de 26 músicos en los tres bailes [de carnaval] "que ha tenido mi hija la Marquesa Condesa" AHN NOBLEZA, OSUNACARTAS, leg 390-1.
} 


\subsubsection{Músicos al servicio de la Casa de Benavente}

Durante la titularidad de Francisco Alfonso Pimentel, XIV Conde de Benavente y de su segunda esposa María Faustina Téllez Girón (que comenzó en 1743 y finalizó en 1763 a la muerte del Conde), la Casa de Benavente tuvo a su servicio a diversos músicos que formaron parte de la plantilla fija de la Casa o fueron contratados eventualmente para las fiestas y actos organizados por la familia.

Entre los músicos contratados para las funciones profanas y bailes organizados por la Casa de Benavente entre 1746 y 1752 figuran los violinistas Manuel Palomino que acudió en 1746 a tocar "diferentes serenatas y minuetos" en el cumpleaños del Conde-Duque, y Vicente Juan Amat, que participó en los numerosos bailes organizados por la Condesa de Benavente entre 1748 y 1750 .

Una curiosa formación instrumental integrada por el violinista Carlos Dimas y sus "consortes músicos ciegos" fue contratada por la Casa de Benavente para las fiestas que se celebraron en las onomásticas del Conde-Duque y su hija, y para distintos bailes y funciones que se organizaron "dentro y fuera de Madrid" por la Condesa-Duquesa María Faustina y su hija María Josefa entre 1753 y $1765^{145}$

Al menos entre 1753 y 1756 también colaboró con la Casa de Benavente el compositor y violinista José Herrando, miembro de la Real Capilla que trabajo habitualmente para la alta nobleza residente en Madrid. Herrando fue profesor de violín del Duque de Huescar, primogénito y heredero de la Casa de Alba, y del

\footnotetext{
145 AHN NOBLEZA, OSUNA-CARTAS, leg 389-30.
} 
Duque de Arcos Francisco Ponce de León a quien dedicó su tratado de violín ${ }^{146}$.

La relación que José Herrando estableció con la Casa de Benavente (conocida a través de las investigaciones de Lothar Siemens ${ }^{147}$ ) parece deberse a su condición de primer violín de la Real Capilla del Convento de la Encarnación de Madrid. Herrando trabajó también como festero (al menos eventualmente) proporcionando a los Condes-Duques de Benavente los músicos necesarios para reforzar su capilla musical, una formación de la que apenas nos ha quedado constancia en esa etapa.

En diciembre de 1753, Herrando que aparece nombrado como "músico de la Capilla Real de la Encarnación" cobró un libramiento de la Casa de Benavente por las dos trompas y "otros violines" que se contrataron para las fiestas celebradas el día de San Francisco de Borja, en los "años de la señorita" es decir en el cumpleaños de María Josefa, futura XV Condesa-Duquesa de Benavente, y para "otro día en el cuarto del señorito" (Antonio Alfonso Faustino primogénito de la Casa de Benavente, que fallecería siendo niño) ${ }^{148}$.

La existencia de una capilla estable con músicos asalariados al servicio de los XIV Condes de Benavente aparece documentada en una relación de los instrumentos que fueron contratados a través de José Herrando para la Salve que se cantó en la residencia de los Benavente en 1755. Para esta ocasión Herrando se encargó de llamar a un violón, dos violas, dos trompas y a [José] Bonfanti, violinista de la Real Capilla cuya asignación se igualó “a los músicos de paga”, lo

\footnotetext{
${ }^{146}$ Lothar Siemens, "Herrando, José”, DMEH, 6, pp.268-269.

${ }^{147}$ Lotear Siemens Hernández: "Los violinistas compositores en la Corte Española durante el período central del siglo XVIII". RMS, XI/3 (1988), pp.657-765.

148 AHN NOBLEZA, OSUNA-CARTAS, leg 389-30
} 
cual da a entender que existía una plantilla de músicos fijos de la casa que se reforzaba cuando era necesario con instrumentistas de otras instituciones:

Cuenta de los instrumentos avisados por parte de Herrando para la Salve que se cantó en Casa del Excelentísimo Señor Conde de Benavente, en el año 1755

$\underline{\text { Reales de vellón }}$

Rio, violón, un ensayo y dos días de Salve 150

Viola Burriel lo mismo

Guerra, viola que sólo asistió a las dos noches

Las dos trompas son

Bonfanti que asistió dos noches según mando Su Excelencia se igualase con los de paga

Importa

Pagados según práctica dos pesos los ensayos y a doblón cada día de función habiendo habido un ensayo y dos noches de Salve.

Don Joseph [Her]rando

Despachado en 30 de Agosto de 1755 Visto: Puebla ${ }^{149}$

José Herrando colaboró también con la Casa de Benavente aportando música dramática, para las "fiestas organizadas en el palacio de los CondesDuquesa. El 10 de noviembre de 1755 se pagó a Herrando un recibo por la copia de la música y letra, impresión y encuadernación de libros de la Serenata de Indimión y Diana, [sic] realizada para "la Excelentísima Señora Condesa de Benavente" es decir para María Faustina Téllez Girón, que actuó como mecenas y promotora de esta obra ${ }^{150}$.

\footnotetext{
149 AHN NOBLEZA, OSUNA-CARTAS, leg 389-29.

150 Ibíd. Sobre esta obra véase el Capítulo VI.
} 


\subsection{La orquesta de María Josefa Alfonso Pimentel, XV Condesa-Duquesa de Benavente (ca. 1781-1792)}

Uno de los aspectos más conocidos y glosados del mecenazgo musical de la Casa de Benavente durante la segunda mitad del siglo XVIII es que la XV Condesa-Duquesa de Benavente fundó y mantuvo una pequeña orquesta privada de la cual formaron parte algunos de los músicos más importantes del panorama español de su época. Las investigaciones de Joaquín Ezquerra del Bayo, apenas conocidas en el ámbito musicológico ${ }^{151}$, fueron el punto de partida para los trabajos de Nicolas A. Solar Quintés ${ }^{152}$, autor que se ha considerado uno de los pioneros en la investigación sobre el mecenazgo musical de las Casas de Osuna y Benavente..

Aunque las aportaciones de ambos autores poseen un valor indiscutible, han de ser revisadas a partir de los nuevos documentos que he consultado, y del conocimiento de la genealogía de las Casas de Osuna y Benavente que he reconstruido para esta investigación. Un primer punto a aclarar es que la dama que promovió la mencionada orquesta fue María Josefa Alfonso Pimentel, XV Condesa-Duquesa de Benavente que ostentaba dicho título desde la muerte de su padre en 1763, y no su madre María Faustina Téllez Girón como se ha dado a entender recientemente. En una publicación de 2003, Miguel Ángel Marín atribuye erróneamente la fundación y mantenimiento de esta orquesta a María Faustina Téllez Girón, Condesa-Duquesa viuda de Benavente:

\footnotetext{
${ }^{151}$ Ezquerra, Retratos.

152 Solar-Quintes: "I. Las relaciones".
} 
La Contessa [María Faustina Téllez Girón $(* 1724-\uparrow 1797)]$ non fu come vedremo, soltanto una assidua frequentatrice dei teatri pubblici di Madrid, ma promosse anche una notevole attività musicale, creando una sua orchestra privata per alietare le riunioni e i balli nel suo palazzo e patrocinio l'acquisto delle partiture dei piu importanti compositori del momento. A lei si debe, per esempio, la tempestiva ricezione a Madrid della musica di Joseph Haydn"153

Los documentos contables relacionados con la orquesta mencionan siempre a la "Condesa Duquesa de Benavente, Bejar Gandía y Arcos" (títulos que sólo ostentó la XV Condesa-Duquesa) o a la "Marquesa de Peñafiel". Este último título nobiliario, propio de los herederos de la Casa de Osuna, lo utilizó María Josefa como consorte de Pedro de Alcántara, futuro Duque de Osuna y no la Condesa-Duquesa viuda de Benavente como afirma Marín ${ }^{154}$. Además, la firma de María FaustinaTéllez-Girón, Condesa-Duquesa viuda de Benavente (Lámina 18) que aparece en los documentos administrativos desde la muerte de su marido en 1763, se diferencia claramente de la de su hija María Josefa Alfonso Pimentel (Lámina 19) que es la que figura siempre en los recibos de la orquesta y en otras

\footnotetext{
153 Miguel Ángel Marín "La zarzuela Clementina di Luigi Boccherini”, Ramón de la Cruz, Clementina, ed. de N. Lepri (Florencia: Collana Secoli d'Oro Alinea, 2003), p. 19. [Mi traducción]: "La Condesa [María Faustina Téllez Girón $(* 1724-\uparrow 1797)]$ no fue sólo, como veremos, una habitual espectadora de los teatros públicos de Madrid, sino que también llevó a cabo una importante actividad musical, creando una orquesta privada para amenizar las reuniones y los bailes en su palacio y patrocinó la adquisición de las partituras de los compositores más importantes del momento. A ella se debe, por ejemplo, la temprana recepción en Madrid de la música de Joseph Haydn".

${ }^{154}$ Marín, "La zarzuela", p. 25.
} 
muchas cartas y documentos administrativos de la Casa de Benavente después de la muerte de la Condesa-Duquesa viuda de Benavente.

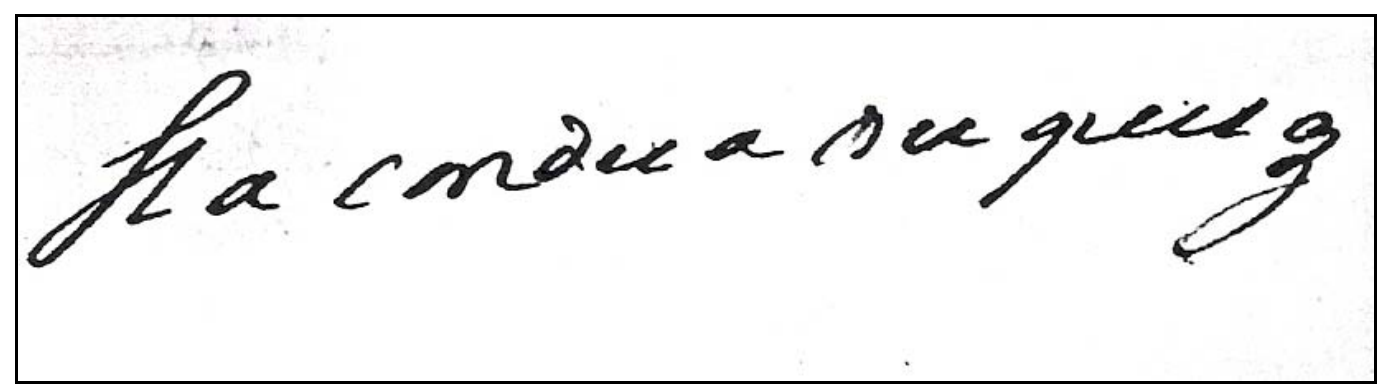

Lámina 18.

Firma de María Faustina Téllez Girón, Condesa-Duquesa viuda de Benavente en un documento de 1764

AHN NOBLEZA, OSUNA-CARTAS, leg 389-30

La orquesta de la Condesa-Duquesa de Benavente estuvo activa al menos desde abril de 1781 y se disolvió en mayo de 1792, probablemente debido a los elevados costes de mantenimiento y la dificultad para pagar las nóminas mensuales de sus componentes ${ }^{155}$, en una etapa de falta de liquidez y progresivo endeudamiento de la Casa de Benavente-Osuna ${ }^{156}$. En septiembre de 1794, la Condesa-Duquesa aún adeudaba a los músicos gran parte de las asignaciones de los años 1790 a 1792 (Véase Lámina 19)

\footnotetext{
155 AHN NOBLEZA, OSUNA-CARTAS, leg 390-2 y leg 390-15.

${ }^{156}$ Sobre los problemas de liquidez de la Casa de Osuna véase Ignacio Atienza Hernández, Aristocracia, poder y riqueza en la España Moderna. La Casa de Osuna, siglos XV-XIX, (Madrid: Siglo Veintiuno, 1987), pp. 327-353.
} 


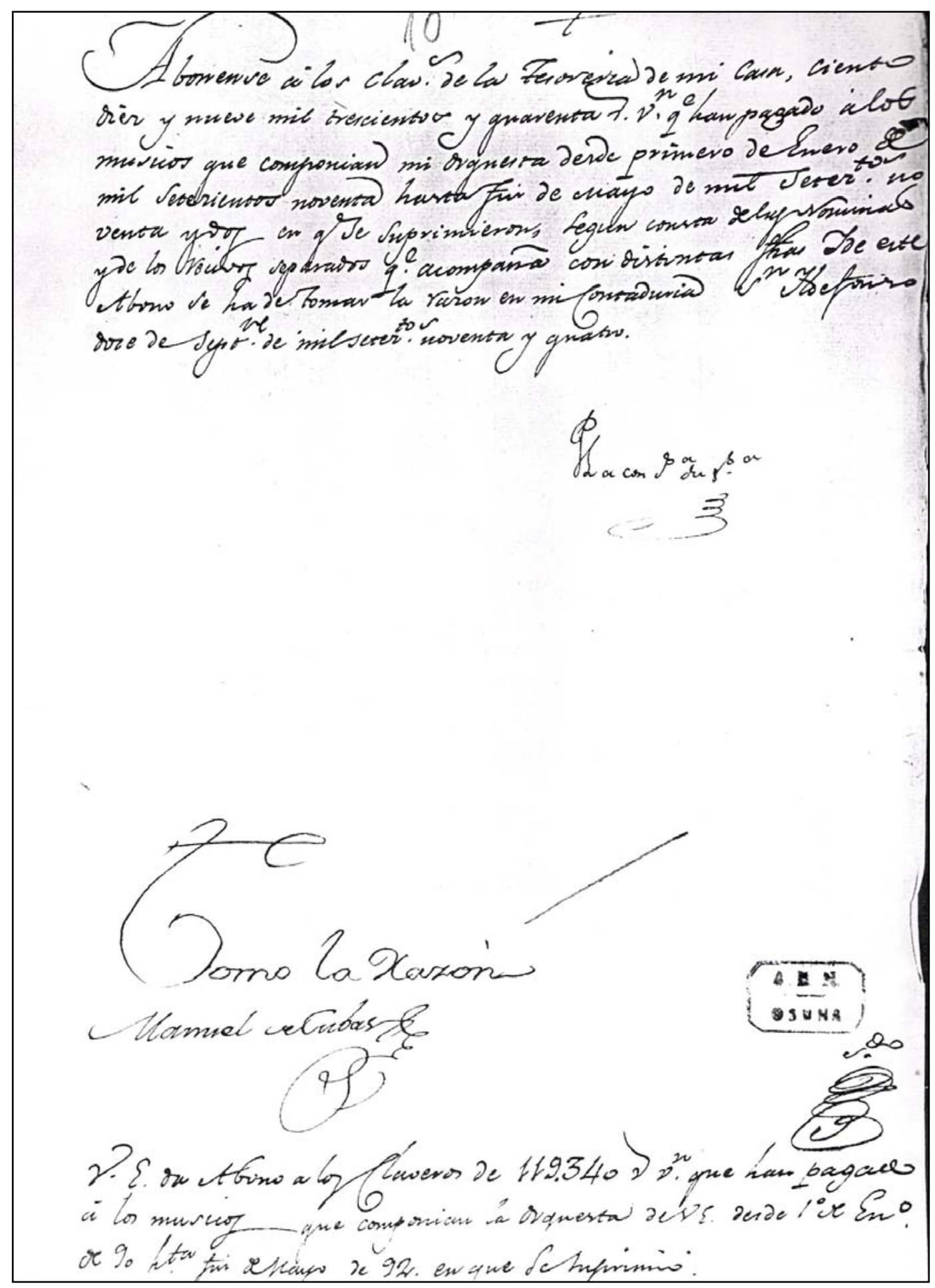

Lámina 19.

Orden de pago de los salarios adeudados

a los músicos de la orquesta de la Condesa-Duquesa de Benavente (1794)

AHN NOBLEZA, OSUNA-CARTAS, leg 390-1. 


\subsubsection{Estructura y funcionamiento de la orquesta. Músicos asalariados e instrumentistas de refuerzo}

En los once años en que está documentado el funcionamiento de la orquesta de la Condesa-Duquesa, su formación no mantuvo una estructura estable, tal y como se ha dado a entender hasta ahora repitiendo la plantilla que publicó Solar Quintes y que corresponde sólo al año de 1787. La primera nómina conservada en la que aparecen un grupo de músicos asalariados al servicio de la Condesa-Duquesa María Josefa es de abril de $1781^{157}$ y refleja un conjunto de 17 músicos: una flauta, dos oboes, dos trompas, dos fagotes, cuatro violines (uno de ellos con la función de "primer violín de la orquesta"), una viola, un violón, dos contrabajos, y dos "maestros de clave", mas un encargado de la afinación del clave:

Nomina de las Raciones que la Excelentísima Señora Condesa de Benavente, Bejar Arcos y Gandía, mi Señora da de su bolsillo a sus maestros y músicos, perteneciente a este mes de abril de este año de 1781

A Don Joseph Lidon, Maestro de Clave, doce reales al día

$$
\text { y al mes }
$$

Joseph Lidon [rúbrica]

A Don Blas Laserna, Maestro de Clave, diez reales al día

$$
\mathrm{y} \text { al mes }
$$

Laserna [rúbrica]

A Don Bonifacio Zlotek, primer violin de la orquesta, quince reales al día y al mes

Bonifacio Zlotek [rúbrica]

\footnotetext{
157 Judith Ortega retrasa el inicio de funcionamiento de la orquesta al mes de noviembre de este año. Véase Ortega, "El mecenazgo", p. 665.
} 
Don Christoval Andreosi ${ }^{158}$ segundo violin de primeros, ocho reales al día y al mes

Antonio de Jaúregui [rúbrica]

Don Manuel Carril, segundo violín seis reales al día y al mes

Carril [rúbrica] ${ }^{159}$

Don Francisco Basset, segundo violín cuatro reales al día y al mes

Basset [rúbrica]

Don Pascual Juan Carril, otro segundo violin seis reales al día y al mes

Carril [rúbrica]

Don Raphael García, viola, goza al día seis reales y al mes 180 Rafael García [rúbrica]

Don. Ramon Monroy, contrabajo, goza al día doce reales

$$
\mathrm{y} \text { al mes }
$$

Ramon Monroy [rúbrica]

Don Pedro Sebastian, otro contrabajo goza al día ocho reales $\mathrm{y}$ al mes

Pedro Sebastian [rúbrica]

Don Pablo Vidal, violón, goza al día seis reales y al mes Pablo Vidal [rúbrica]

Don Gaspar Barly, oboe, goza al día treinta y dos reales $\mathrm{y}$ al mes

Gaspard Barly [rúbrica]

Don Manuel Julián, oboe goza al día siete reales y al mes Manuel Julian [rúbrica]

Don Jerónimo German, trompa primero con 9 reales desde el día 13 de mayo

Don Cayetano Canaut, otro trompa, goza al día siete reales y al mes

Caietano Canaut [rúbrica]

\footnotetext{
158 Tachado "Antonio de Jaúregui"

${ }^{159}$ En nota al margen " 8 reales desde el 13 de mayo"
} 
Don Joaquín Garisuain, Fabot [sic], con 10 reales diarios

desde el día 13 de mayo

Don Ramon Herrero y Sessé templador de clave, a razón de tres reales diario]s

Sesse [rúbrica]

Suman todas estas partidas cuatro mil trescientos y veinte reales de vellón. Madrid 30 de abril de 1781 Juan de Gamboa ${ }^{160}$

Si bien, el conjunto de músicos que figura en esta nómina podría verse como una orquesta clásica reducida, me parece importante señalar que una de las funciones principales de los músicos asalariados de la Condesa-Duquesa fue la interpretación de música de cámara y de baile escrita para formaciones instrumentales reducidas y no de repertorio "sinfónico" propiamente dicho. La llamada "orquesta" de la Condesa-Duquesa ${ }^{161}$ fue, de hecho, una formación de solistas versátil que se adaptaba a la funcionalidad de cada una de las situaciones en las que intervenía. En las academias se interpretaba música de cámara sin que a ellas concurrieran todos los músicos asalariados; y en cambio en las grandes fiestas religiosas o bailes la orquesta se reforzaba notablemente ${ }^{162}$.

\footnotetext{
160 AHN NOBLEZA, OSUNA-CARTAS, leg 390-2.

161 El término "orquesta" aparece en sucesivas nóminas de los músicos contratados por la Casa de Benavente pero, debe tenerse en cuenta que en la época se utilizaba para referirse a cualquier “conjunto de músicos de varios instrumentos” lo que incluía a las agrupaciones de cámara. Véase Diccionario de la lengua castellana compuesto por la Real Academia Española, reducido a un tomo para su más fácil uso. Cuarta edición (Madrid: Viuda de Ibarra, 1803), p. 925, 1.
} 
Al comentar una nómina de la orquesta fechada de 1787 (publicada por Solar Quintes) Antonio Martín Moreno, afirma que en esta formación “extraña la falta de violas (tal vez estarían englobados bajo el término de violines y tal lo fuese Pedro Vidal) y la falta todavía de clarinetes"163. Sin embargo Rafael García, que era violista de la Real Capilla, se encargó de tocar la viola entre 1781 y 1787. Además, es muy probable que los violinistas Manuel Carriles y su hijastro Pascual Juan Carriles tocasen la viola cuando fuera necesario, ya que ambos se consideraban lo suficientemente diestros con este instrumento como para presentarse a unas oposiciones en la Real Capilla ${ }^{164}$. El Pedro Vidal que menciona Martín Moreno como posible viola de la formación reproduce una errata de Solar Quintes que confundió el nombre del violón Pablo Vidal. En cuanto a los clarinetes, que no formaron parte de las plantillas habituales de las orquestas españolas hasta las últimas décadas del siglo XVIII (aunque si de las formaciones militares) ${ }^{165}$, se contrataban cuando eran necesarios como refuerzo, especialmente

\footnotetext{
162 Véase los Capítulos V-VII.

${ }^{163}$ Martín Moreno, Historia, p.278.

${ }^{164}$ Para las biografías de Manuel y Pascual Juan Carriles véase el Apéndice 5.

165 La introducción y difusión del clarinete en España se halla aún a falta de un estudio sistemático. Según Albert R. Rice, el clarinete llegó a España en la década de 1770. Sin embargo su presencia en el ámbito militar debió de ser anterior, pues ya aparece una alusión a los clarinetes en las Ordenanzas Militares de 1768, que se plasma en la segunda recopilación de los Toques de Guerra de Manuel Espinosa. Desde 1787 los clarinetes estuvieron presentes en la Orquesta del Teatro de los Caños del Peral. Agradezco estas informaciones a Francisco J. Fernández Vicedo, profesor de clarinete del Conservatorio Profesional de Música de Granada e investigador de la historia del clarinete en España. Sobre la presencia del clarinete en España véase Ricardo Fernández de Latorre, Historia de la música militar de España (Madrid: Ministerio de Defensa, Secretaría General Técnica, 2000), p 120. José Máximo Leza, "Las orquestas de Ópera en Madrid entre los siglos XVIII y XIX”, Campos interdisciplinares de la musicología. Actas del V Congreso de la Sociedad Española de Musicología (Madrid: SEdeM, 2001), p. 122 y Albert R. Rice: The Clarinet in the Classical Period, (New York: Oxford University Press, 2003).
} 
en las grandes fiestas y celebraciones. Así ocurrió, por ejemplo en la fiesta organizada por los Duques de Osuna en 1789 con ocasión de la coronación de Carlos IV para la que se contrataron dos clarinetes para cada una de las dos orquestas que intervinieron en los bailes ${ }^{166}$.

Por otra parte, la distinción terminológica entre "maestros" y "músicos" que figura en los documentos de pago conservados, parece dar a entender que en las nóminas se incluía a todo el personal relacionado con la música que estaba al servicio de la casa, lo que no implicaba necesariamente su pertenencia a la orquesta. Es probable que las dos plazas de "maestro de clave" que aparecen en las nóminas de los músicos al servicio de la Condesa-Duquesa y que desempeñaban José Lidón y Blas de Laserna tuvieran una función principalmente didáctica, si bien no puede descartarse su participación en las sesiones musicales organizadas en el ámbito doméstico.

Aunque una parte de los músicos que aparecen en la nómina de abril de 1781 permanecieron en la orquesta de la Condesa-Duquesa hasta su disolución en 1792, la plantilla de la formación sufrió cambios notables. Hubo diversas bajas e incorporaciones de nuevos instrumentistas, algunos de los que ya formaban parte de ella pasaron a tocar otro instrumento, y otros adquirieron mayor protagonismo dentro de la formación, tal y como puede verse en la Tabla $9^{167}$.

\footnotetext{
166 AHN NOBLEZA, OSUNA-CARTAS, leg 391-15. Sobre esta fiesta véase el Capítulo VII.

${ }^{167}$ No se conservan ninguna nómina de pagos a los músicos de la orquesta del año 1782, pero si varios recibos de pagos de atrasos a algunos de sus miembros, lo que da a entender que en este año y durante la residencia de la Condesa-Duquesa de Benavente en Barcelona en la primera mitad de 1783, la orquesta mantuvo una estructura similar a la que tenía a finales del año 1781.
} 
Tabla 9.

Plantilla de la orquesta de la XV Condesa-Duquesa de Benavente (1781-1792)

Fuentes: AHN NOBLEZA, OSUNA-CARTAS, legs. 390, 391, 489-4.

BNE Mss 14.016.3/25; 14.016.3/27; 14.016.3/65 (Papeles Barbieri)

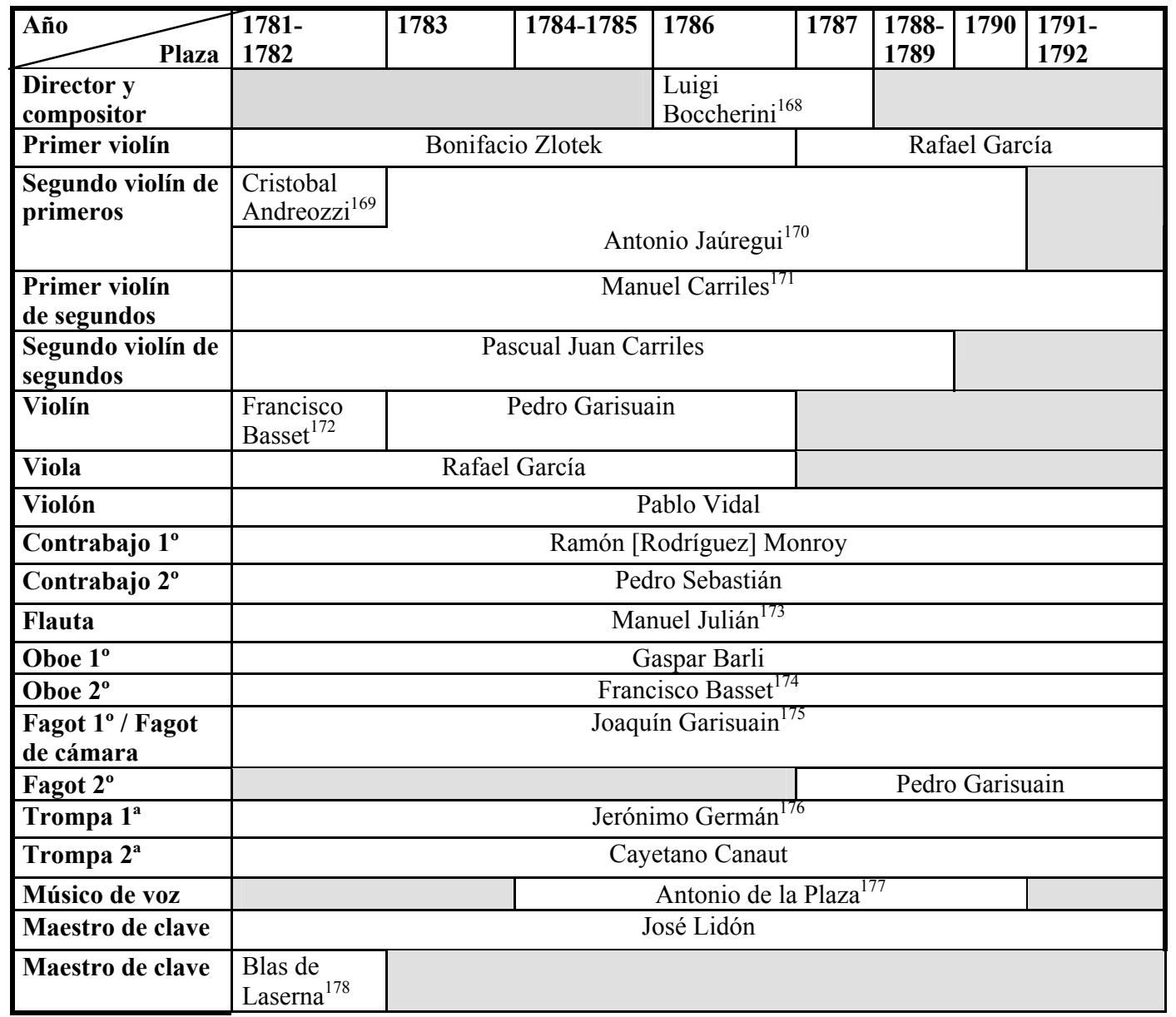

${ }^{168}$ Desde marzo de 1786 hasta diciembre de 1787.

${ }^{169}$ Le sustituye Antonio Jaúregui desde diciembre de 1781.

${ }^{170}$ Permanecerá en la orquesta hasta diciembre de 1790

${ }^{171}$ Se incorpora a la orquesta el 13 de mayo de 1781.

172 Pasa a segundo oboe en la nómina de agosto de 1781 .

${ }^{173}$ En la nómina de abril de 1781 Manuel Julián aparece como oboe y no existe plaza de flauta.

${ }^{174}$ Segundo oboe desde la nómina de agosto de 1781 .

${ }^{175}$ Se incorpora a la orquesta el 13 de mayo de 1781 .

${ }^{176}$ Ibid.

${ }^{177}$ Fallece en septiembre de 1791. Ver Apéndice 5.

${ }^{178}$ Documentado entre abril y agosto de 1781. 
Varios músicos de la orquesta de la Condesa-Duquesa tocaban más de un instrumento, lo que les permitió mejorar su posición dentro de la formación. Así, Francisco Basset, que en las primeras nóminas aparece en la última plaza de violines, ocupó la plaza de oboe segundo a partir de agosto de 1781. La plaza de violín que dejó vacante Basset fue ocupada por Pedro Garisuain hasta 1787 cuando este último, paso a desempeñar el puesto de segundo fagot compartiendo atril con su hermano Joaquín. Rafael García de Sena, que comenzó como viola, fue a partir de 1787 el primer violín de la orquesta.

En 1784 se incorporó a la plantilla de músicos asalariados el cantante o “músico de voz" Antonio de la Plaza, que trabajaba para la Casa de Benavente al menos desde $1781^{179}$. Es también probable que el compositor y violonchelista Luigi Boccherini (que desempeñó el cargo de "director y compositor de la orquesta" entre marzo de 1786 y diciembre de 1787) ${ }^{180}$ participase como instrumentista con algunos músicos de la formación, al menos en las "academias" en las que se interpretaba su propia música y para las cuales eran contratados algunos de sus compañeros más cercanos como el violinista Francisco Font ${ }^{181}$.

La orquesta de la Condesa-Duquesa parece haber vivido su mayor momento de esplendor entre 1784 y 1790 cuando disponía de una formación de

\footnotetext{
${ }^{179}$ BNE. Ms.14.016.3/44 (Papeles Barbieri).

${ }^{180}$ Ver el punto siguiente de este Capítulo.

181 AHN NOBLEZA, OSUNA-CARTAS, leg 390-6. Antonio Martín Moreno (cita este mismo documento que reproduce Solar Quintes para explicar que las academias y ensayos patrocinados por la Condesa-Duquesa de Benavente "tenían lugar también en la casa de la Marquesa de Peñafiel". Esta dama era la propia María Josefa, Condesa-Duquesa de Benavente nombrada con el título que ostentaba su marido como heredero de la Casa de Osuna. Martín Moreno, Historia, p. 279.
} 
cuerda y viento equilibrada. En los últimos años de funcionamiento, la plantilla de músicos asalariados al servicio de la Condesa-Duquesa de Benavente carecía del equilibrio suficiente en la sección de cuerdas para la interpretación de gran parte del repertorio orquestal, pues sólo contaba con dos violines y carecía de violas (Tabla 9).

La contratación de instrumentistas ajenos al servicio de la casa fue una práctica habitual en la orquesta de la Condesa-Duquesa, bien para suplir las ausencias de los músicos asalariados o para completar o incrementar su plantilla cuando esta comenzó a decrecer o en ocasiones especiales, como en las grandes funciones religiosas, conmemoraciones familiares o en los bailes de carnaval que anualmente organizaba dicha dama. Por ejemplo, en los bailes de carnaval que se celebraron en 1786 la orquesta se reforzó con 17 músicos (ocho violines, dos oboes, dos fagotes, tres trompas, un contrabajo y un violón que actuaron en diferentes días), y para los que del año siguiente fueron contratados como refuerzo un número variable de entre once y quince músicos ${ }^{182}$. Para estas suplencias o refuerzos se contaba preferentemente con los familiares de los músicos de la casa o de su entorno cercano, lo que demuestra la importancia de las relaciones gremiales y familiares entre los músicos de Madrid. Un ejemplo de esta práctica, puede verse en la relación de músicos de refuerzo que se contrataron para los bailes de carnaval de 1784 en la que figuraban los violinistas Salvador Feixas [“Salvadoret"] (que colaboraba como copista de música de la Condesa-Duquesa), [Francisco] Rexach (hijo de Salvador Rexach, que había sido violinista del VIII Duque de Osuna), y Cayetano Vidal (hijo del violón de la orquesta Pablo Vidal). 
Como violón se contrató al "hijo de Pau [Vidal]" (es decir a José Vidal), como contrabajo a Andrés Julián (citado como "el hermano de [Manuel] Julian”) y como trompa al "hermano de Canaut". También fueron contratados para dicho bailes los violinistas Ramón Montejano, y uno apodado "el gordito" "183. Otro de los colaboradores habituales de la orquesta fue el violinista Francisco Javier Moreno, que en 1786 trabajaba como músico para María Faustina Téllez Girón, la Condesa-Duquesa viuda de Benavente ${ }^{184}$

\subsubsection{La dirección de la orquesta: Bonifacio Zlotek, Luigi Boccherini y Rafael García de Sena}

Otra de las cuestiones que ha de ser revisada a la luz del estudio de la documentación de la Casa de Osuna, es la de la figura del director de la orquesta de la Condesa-Duquesa. Desde las investigaciones de Solar-Quintes ${ }^{185}$, se ha mantenido casi invariablemente que el clavecinista y compositor José Lidón dirigió la formación al menos hasta la incorporación de Luigi Bocherinni en $1786^{186}$. Aunque, en ninguna de las nóminas de la Casa de Osuna aparece José Lidón con el empleo de director, Solar Quintes supuso que el cargo de "maestro de clave" incluía la dirección del conjunto, quizá apoyándose en que era una práctica habitual en la época que un clavecinista o instrumentista de tecla fuera el encargado de dirigir una formación instrumental. Sin embargo, en un momento en

\footnotetext{
182 AHN NOBLEZA OSUNA-CARTAS, leg 390-1.

183 Ibíd.

184 AHN NOBLEZA OSUNA-CARTAS, leg 390-21.

185 Solar-Quintes: “I. Las relaciones”, pp. 81-104.

${ }^{186}$ Miguel Ángel Marín también ha cuestionado recientemente que José Lidón ocupase el puesto de director de la orquesta de la Condesa-Duquesa de Benavente. Marín,"La zarzuela”, p. 20.
} 
que el repertorio musical se independizaba de la supremacía del bajo continuo, la figura del clavecinista-director empezaba a entrar en decadencia, especialmente en las formaciones más reducidas, donde la labor de dirección o codirección de la orquesta por un violinista competente y experimentado comenzó a ser una práctica habitual al menos desde las últimas décadas del siglo XVIII ${ }^{187}$.

En las nóminas de la orquesta de la Condesa-Duquesa, el violinista Bonifacio Zlotek aparece siempre diferenciado del resto de los instrumentistas con el cargo de "primer violín de la orquesta", por lo que es muy posible que al menos en el repertorio instrumental profano la dirección del conjunto estuviera a su cargo. Este músico apodado "el Polaco" por su origen, era uno de los más afamados instrumentistas de cuerda de su época, y fue miembro de la Real Capilla desde 1770 hasta su muerte en $1787^{188}$.

La importancia de Zlotek en la orquesta de la Condesa-Duquesa, queda constatada por el salario que percibía (450 reales mensuales una cantidad notablemente superior a los 360 reales que percibía el "maestro de clave" José Lidón). El sueldo de Zlotek fue uno de los más altos de los músicos de la orquesta y sólo era superado por el del oboísta Gaspar Barli, auténtico virtuoso del instrumento que siempre gozó de la protección especial de la Condesa-Duquesa, y por el de Luigi Boccherini ${ }^{189}$.

\footnotetext{
${ }^{187}$ Robin Stowell "Good execution and other necessary skills. The role of the concermaster in the late $18^{\text {th }}$ century", Early Music, XVI (1988), pp. 21-33.

188 Judith Ortega, "La Real Capilla de Carlos III: los músicos instrumentistas y la provisión de sus plazas", RMS , XXIII, 2 (2000), pp. 433-437.

${ }^{189}$ Sobre los sueldos de los músicos de la orquesta véase la Tabla 10
} 
En enero de 1783, Bonifacio Zlotek viajó a Barcelona con un selecto grupo de músicos de la orquesta para servir a la Condesa-Duquesa María Josefa que se había desplazado allí para reunirse con su esposo el Marqués de Peñafiel destinado con su regimiento militar en la Ciudad Condal. La Condesa-Duquesa eligió a los músicos más apreciados de la formación para que pasaran a servirla a Barcelona, pues junto a Zlotek viajaron el oboísta Gaspar Barli, que en esa época era el músico mejor remunerado de la formación, y el versátil Francisco Basset, oboísta y violinista que además de ser miembro de la orquesta tenía el cargo de "músico de la casa"190.

Otro dato que verifica que la labor de Zlotek dentro de la orquesta de la Condesa-Duquesa fue seguramente la de "concertino-director", es la diferente indumentaria que se le proporcionó como atuendo o uniforme de la orquesta. Cuando en marzo de 1786, la Condesa-Duquesa encargó la confección de trajes para sus músicos, eligió para todos trajes de "paño de Guadalajara", a excepción de los que se fabricaron para Luigi Boccherini que fue elaborado con "rizo piñuela de Francia" y el de Bonifacio Zlotek que era "más fino que los de los otros [y confeccionado con] paño de abrebila"191 . “

\footnotetext{
190 AHN NOBLEZA, OSUNA-CARTAS, leg 389-24 y leg 390-1. Zlotek estuvo en Barcelona con su familia al menos entre el 16 y el 20 de febrero de 1783 según figura en la cuenta de gastos de fonda del violinista Bonifacio Zlotek y su familia. La Condesa de Yebes interpretó erróneamente este documento, y transformó al violinista Bonifacio Zlotek en un hotelero usurero que se encargó de alojar a la Condesa Duquesa: "En julio de 1782, [La condesa-Duquesa] ya repuesta la quebrantada salud parte camino de Barcelona. Allí se hospeda en la fonda de Bonifacio Zloteck. El buen hotelero hacía pingües negocios, pues al decir de la Condesa-Duquesa, cobraba por «una botella de rosalí de ratafia» nada menos que cuatro reales de vellón (...)." Yebes, La CondesaDuquesa de Benavente. Una vida en unas cartas (Madrid: Espasa Calpe, 1958), p.23.

${ }^{191}$ AHN NOBLEZA OSUNA-CARTAS leg 391.20. Este documento fue transcrito parcialmente y con algunos errores en Solar-Quintes: "I. Las relaciones” p. 93.
} 
El lujoso traje encargado para Boccherini, está relacionado con su reciente incorporación al servicio de la Casa de Benavente (el mismo mes de marzo de 1786) con el cargo de "director de la orquesta y compositor" 192 . Por el desempeño de este puesto, Boccherini recibió el importante salario de 1000 reales mensuales

Los claveros del Arca de la Tesorería de mi casa pagarán en virtud de este y de recibo a D. Luis Boquerini, músico Director de mi orquesta 10.000 reales de vellón importe de los diez meses contados desde Marzo de 1786 en que le admití con el sueldo de un mil reales en cada uno, hasta fin de Diciembre del mismo año; tomándose la razón en mi contaduría Madrid, 30 de abril 1787

La Condesa-Duquesa ${ }^{193}$

Boccherini comenzó a trabajar para la Condesa-Duquesa de Benavente en marzo de 1786, y terminó su vinculación contractual con esta dama después de finalizar el mes de diciembre de $1787^{194}$. El descubrimiento de este dato amplía la certeza de que Boccherini estuvo al servicio de la Casa de Benavente al menos hasta el final del año 1787 y no hasta enero o abril del mismo año como se ha mantenido hasta la fecha ${ }^{195}$. Por consiguiente, Boccherini se hallaba aún al servicio de la Condesa-Duquesa el 29 de diciembre de 1787 cuando participó, por deseo expreso de esta dama, en una fiesta que se celebró en Madrid en casa del

\footnotetext{
192 Con este cargo aparece en la nómina de la orquesta de enero de 1787. AHN NOBLEZA OSUNA-CARTAS, leg 390-5.

193 AHN NOBLEZA OSUNA-CARTAS, leg 390-1. Publicado en Solar-Quintes: "I. Las relaciones", p.93.

194 AHN NOBLEZA, OSUNA-CARTAS, leg 489-4. Data del Arca del año 1787 "A Don Luis Boccherini por la consignación de 1000 reales mensuales hasta fin de diciembre de [17]87"

${ }^{195}$ Véase por ejemplo el reciente artículo de Judith Ortega. Ortega,"El mecenazgo", p. 651.
} 
portugués Juan Pereira Pacheco, ministro de Hacienda de su país, según relató el viajero inglés William Beckford ${ }^{196}$.

El nombre de Boccherini no aparece en las nóminas de la orquesta de la Condesa-Duquesa a partir del año 1788, ni en ningún otro documento administrativo, por lo que todo parece indicar que su relación de servicio con la Casa de Benavente finalizó en los últimos días de $1787^{197}$.

Boccherini fue el único músico que desempeñó el cargo específico de director de la orquesta de la Condesa-Duquesa. Desde 1788 y hasta la disolución de la orquesta en 1792, no figura ningún nombre asociado a este puesto en la documentación administrativa conservada. Tras la muerte de Bonifacio Zlotek a principios de 1787, el viola Rafael García de Sena pasó a ocupar el puesto de primer violín de la orquesta y se le ascendió el sueldo de 180 a 300 reales al mes. Es muy probable que tras la dimisión o cese de Boccherini, García de Sena se encargase de la dirección del conjunto desde el primer atril de la orquesta en aquellas ocasiones en las que fuera necesario, compatibilizando esta labor con la

\footnotetext{
${ }^{196}$ William Beckford, Italy; with sketches of Spain and Portugal (Londres: R. Bentley, 1834), vol II, p.333. La fecha concreta de la fiesta en casa del portugués Pacheco, que ha hecho dudar a algunos autores sobre la veracidad de esta anécdota, fue el 29 de diciembre de 1787, tal y como aparece en el diario del propio Beckford. William Beckford: The Journal of William Beckford in Portugal and Spain. Edición y notas de Alexander Boyd (Londres: Rupert-Hart Davis, 1954), pp.305-306.

${ }^{197}$ La hipótesis de Jaime Tortella que extiende hasta 1798 la relación de Boccherini con la Condesa-Duquesa de Benavente no se ha constatado documentalmente. El análisis que este autor presenta en su libro para rebatir el mito de la pobreza de Boccherini debe revisarse pues basa parte de su argumentación en la suposición de que la Casa de Benavente continuó pagando a Boccherini 1000 reales mensuales hasta la partida de los Duques a París en 1799. Véase Tortella, Boccherini, pp. $430-431$.
} 
de encargado del archivo o "papelera" de música de la Condesa-Duquesa, cargo en el que continuó incluso después de la disolución de la orquesta ${ }^{198}$.

\subsubsection{Músicos de la Real Capilla y de otras agrupaciones estables en la orquesta de la Condesa-Duquesa}

Los instrumentistas asalariados de la orquesta de la Condesa-Duquesa de Benavente compatibilizaron su trabajo en esta agrupación, que no les exigía una exclusividad, con un empleo estable en otras importantes instituciones musicales madrileñas. Es particularmente interesante observar que casi la mitad de los músicos de la orquesta de la Condesa-Duquesa fueron miembros de la Real Capilla, institución que contaba con algunos de los mejores instrumentistas y compositores del momento o de otras instituciones musicales monárquicas. Como puede verse en la Tabla 10 (en la que figuran los principales empleos de los músicos de la orquesta y sus salarios) pertenecieron a la Real Capilla: el violinista Bonifacio Zlotek, el violista y violinista Rafael García de Sena (que ingresó en la cuarta plaza de violas en 1781), el contrabajista Ramón [Rodríguez] Monroy (que desde 1780 ocupaba una plaza de violón en la Real Capilla), el oboe Gaspar Barli, (que ganó la oposición de fagot en 1784), el fagot Joaquín Garisuain (que ingresó en la Real Capilla en 1775 como tercer bajonista), su hermano Pedro Garisuain (fagot de la Real Capilla desde 1790), y el trompa Jerónimo Germán, que era segundo clarín en la orquesta palatina ${ }^{199}$.

\footnotetext{
${ }^{198}$ AHN NOBLEZA, OSUNA-CARTAS, leg 387-7. Sobre la biografía de García de Sena véase el Apéndice 5.

${ }^{199}$ Para las plantillas de los músicos de la Real Capilla en la época de Carlos III véase Ortega "La Real Capilla".
} 
Tabla 10.

Salario mensual y ocupación principal de los músicos de la orquesta de la

XVCondesa-Duquesa de Benavente (1781-1792)

Fuentes: AHN NOBLEZA OSUNA-CARTAS, 390, 391,489-4.

BNE Ms 14.016-3 (Papeles Barbieri), Cotarelo y Mori, Orígenes; Ortega: "La capilla Real",

Subirá, La tonadilla escénica

\begin{tabular}{|c|c|c|c|}
\hline Nombre & $\begin{array}{l}\text { Plaza en la Orquesta de la } \\
\text { Condesa-Duquesa }\end{array}$ & $\begin{array}{l}\text { Salario/mes en } \\
\text { la orquesta } \\
\text { (reales de vellón) }\end{array}$ & $\begin{array}{l}\text { Ocupación Principal } \\
\text { (localizada en Madrid si no } \\
\text { se indica lo contrario) }\end{array}$ \\
\hline Luigi Bocherinni & $\begin{array}{l}\text { Director de la orquesta y } \\
\text { compositor }\end{array}$ & 1000 & $\begin{array}{l}\text { Pensión real y contrato } \\
\text { con el rey de Prusia. }\end{array}$ \\
\hline Gaspar Barli & Oboe primero & 960 & $\begin{array}{l}\text { Fagot de la Real Capilla } \\
\text { desde } 1784 \text { y oboe desde } \\
\text { finales de } 1790\end{array}$ \\
\hline Bonifacio Zlotek & Primer violín de la orquesta & 450 & Violín de la Real Capilla \\
\hline Antonio Plaza & Músico de voz & 360 & $\begin{array}{l}\text { Maestro de rudimentos del } \\
\text { Real Colegio de Niños } \\
\text { Cantores desde } 1783\end{array}$ \\
\hline $\begin{array}{l}\text { Ramón[Rodríguez] } \\
\text { Monroy }\end{array}$ & Contrabajo primero & 360 & Violón de la Real Capilla \\
\hline \multirow[t]{2}{*}{ Rafael García } & Primer violín de la orquesta & 300 & \multirow{2}{*}{$\begin{array}{l}\text { Viola de la Real Capilla } \\
\text { desde noviembre de } 1781\end{array}$} \\
\hline & Viola & 180 & \\
\hline Joaquín Garisuain & fagot / fagot de cámara & 300 & Bajón de la Real Capilla \\
\hline Jerónimo Germán & Trompa primero & 270 & Clarín de la Real Capilla \\
\hline Antonio Jaúregui & Segundo violín de primeros & 240 & $\begin{array}{l}\text { ¿Orquesta de los Teatros } \\
\text { de la Cruz y el Príncipe? }\end{array}$ \\
\hline $\begin{array}{l}\text { Cristobal } \\
\text { Andreozzi }\end{array}$ & Segundo violín de primeros & 240 & $\begin{array}{l}\text { Maestro de música en los } \\
\text { teatros de la Cruz y el } \\
\text { Príncipe }\end{array}$ \\
\hline Manuel Carriles & Primer violín de segundos & 240 & $\begin{array}{l}\text { Violín en la orquesta del } \\
\text { Teatro de la Cruz }\end{array}$ \\
\hline Pedro Sebastián & Contrabajo segundo & 240 & $\begin{array}{l}\text { Contrabajo de la Orquesta } \\
\text { del Teatro de la Cruz }\end{array}$ \\
\hline Manuel Julián & Flauta & 210 & $\begin{array}{l}\text { Flauta en la orquesta del } \\
\text { Teatro de los Caños del } \\
\text { Peral }\end{array}$ \\
\hline Cayetano Canaut & Trompa segundo & 210 & $\begin{array}{l}\text { Músico en las Reales } \\
\text { Caballerizas. ¿Trompa en } \\
\text { orquesta de los Teatros de } \\
\text { la Cruz y el Príncipe? }\end{array}$ \\
\hline $\begin{array}{l}\text { Pascual Juan } \\
\text { Carriles }\end{array}$ & Segundo violín de segundos & 180 & $\begin{array}{l}\text { Violín en la capilla de las } \\
\text { Descalzas Reales y en el } \\
\text { Teatro de los Caños del } \\
\text { Peral }\end{array}$ \\
\hline Pablo Vidal & violón & 180 & $\begin{array}{l}\text { Primer Violón en la Real } \\
\text { Capilla del Convento de la } \\
\text { Encarnación de Madrid }\end{array}$ \\
\hline \multirow[t]{2}{*}{ Pedro Garisuain } & violín & 180 & \multirow{2}{*}{$\begin{array}{l}\text { Primer violín en el Teatro } \\
\text { de los Caños del Peral } \\
\text { Fagot de la Real Capilla } \\
\text { desde } 1790\end{array}$} \\
\hline & Fagot segundo & 180 & \\
\hline Francisco Basset & Violín/ oboe segundo & 120 & $\begin{array}{l}\text { ¿Músico de la Capilla de } \\
\text { San Cayetano? }\end{array}$ \\
\hline
\end{tabular}


También estuvieron vinculados a las instituciones musicales de la monarquía el cantante Antonio Plaza, que por intercesión de la Condesa-Duquesa María Josefa obtuvo en 1783 la plaza de "maestro de rudimentos" (es decir de teoría musical y solfeo) en el Real Colegio de Niños Cantores ${ }^{200}$, el trompa Cayetano Canaut, que formaba parte de las Reales Caballerizas, y el director y compositor Luigi Boccherini, que tras la muerte del Infante Don Luis en agosto de 1785 cobraba una pensión de la Casa Real, aunque sin ocupar un puesto en la Real Capilla $^{201}$.

La calidad de los instrumentistas que pertenecían a la Real Capilla, debió de compensar los inconvenientes que surgían en la Casa de Benavente cuando al coincidir actos en ambas instituciones era preciso sustituirlos contratando a otros músicos. En un documento fechado en 1782, se justifica la contratación de varios instrumentistas "de fuera" para suplir las ausencias de los músicos de la orquesta de la Condesa-Duquesa "por impedirles la asistencia a algunos de éstos su destino en la Capilla Real",202.

Estas evidencias contrastan con las afirmaciones de Germán Labrador López de Azcona que sostuvo en un reciente artículo que en la orquesta de la Condesa-Duquesa apenas había instrumentistas de la Real Capilla porque se lo impedía el reglamento de la institución:

[...] resulta llamativo comprobar cómo los miembros de las orquestas de los teatros de Madrid o de ciertos personajes, como la Duquesa de Benavente

\footnotetext{
200 AHN NOBLEZA, OSUNA-CARTAS, leg 391-26.

201 Jaime Tortella, Boccherini, p.234.

202 AHN NOBLEZA, OSUNA-CARTAS, leg 390-1.
} 
[sic], proceden de ámbitos ajenos a la [Real] Capilla. En este último caso, el de la Duquesa [sic], la circunstancia es especialmente llamativa, habida cuenta de lo principal de su apellido y de la buena remuneración que obtenían sus instrumentistas. De esta manera se crea una diferencia fundamental entre los músicos adscritos al teatro y a las orquestas privadas, que se moverán en un ámbito propio, al que no acceden los de la [Real] Capilla por cuestiones reglamentarias ${ }^{203}$.

Aunque la pertenencia a la plantilla de la Real Capilla era en teoría un obstáculo para poder participar en otras agrupaciones musicales privadas, la presencia de un gran número de músicos de la institución real en la orquesta de la Condesa-Duquesa de Benavente demuestra que las normas o reglamentos que regulaban el funcionamiento de la institución real no se respetaban en la práctica. Consecuentemente, no puede mantenerse, tal y como afirma Labrador López de Azcona, que los músicos pertenecientes a las orquestas privadas fueran ajenos a la Real Capilla ya que durante todo el siglo XVIII, la Casa de Osuna tuvo a su servicio a un importante número de músicos asalariados que pertenecieron simultáneamente a dicha institución palatina ${ }^{204}$.

El resto de los músicos de la orquesta de la Condesa-Duquesa, fueron miembros de destacadas capillas religiosas o de las orquestas de los teatros madrileños. Pablo Vidal trabajó como violón en la capilla musical del Convento de la Encarnación; el violinista Pascual Juan Carriles en la de las Descalzas Reales ambas de Madrid. Adscritos a los teatros madrileños estuvieron Manuel Carriles y

\footnotetext{
${ }^{203}$ Germán Labrador López de Azcona, "Música poder e institución: La Real Capilla de Carlos IV, RMS, XXVI/1 (2003), p.242. En la nota 25 de la misma página Labrador mantiene asimismo que los únicos músicos de la Real Capilla que en 1781 pertenecían a la orquesta de la Condesaduquesa eran Bonifacio Zlotek y José Lidón.

${ }^{204}$ Véase el punto 2.1.1.de este capítulo.
} 
Pedro Sebastián, miembros de la orquesta del Teatro de la Cruz ${ }^{205}$; Pascual Juan Carriles, Manuel Julián y Pedro Garisuain (que formaban parte de la orquesta del Teatro de los Caños del Peral) y Cristobal Andreozzi que fue maestro de música en los teatros públicos madrileños desde 1789 y director y empresario en los Teatros de los Reales Sitios a finales del siglo XIX ${ }^{206}$.

\subsubsection{La protección de la Condesa-Duquesa a los músicos de su orquesta}

La Condesa-Duquesa María Josefa protegió decididamente a los músicos de su casa concediéndoles apoyo económico y ayudas para gastos de estancia y manutención, y mediando ante las autoridades pertinentes para conseguir que promocionasen profesionalmente ${ }^{207}$.

Al menos en cuatro ocasiones, la Condesa-Duquesa de Benavente, trató de que alguno de sus músicos lograse una plaza al servicio de la Casa Real. En 1783, la Condesa-Duquesa, se dirigió al Patriarca de las Indias, máxima autoridad en el gobierno de la Real Capilla para recomendar al violón Pablo Vidal en las oposiciones a una plaza de ese instrumento:

\footnotetext{
205 BNE Ms. 14.016.3/ 3 (Papeles Barbieri). "Se confirió la plaza de contrabajo del coliseo de la Cruz en Don Pedro Sebastián siendo corregidor de esta villa el Señor Don Antonio Armona en el año de 1780, en 8 de abril, habiendo igualmente admitido a su hijo Don Diego Sebastián de supernumerario de violón de las dos orquestas de la Cruz y el Príncipe, la Junta de dirección en 16 de Julio de 1801 en atención a su desempeño y méritos del dicho su padre en 21 años".

${ }^{206}$ BNE Ms. 14.016.3/358 (Papeles Barbieri).

${ }^{207}$ Por ejemplo en 1782, la Condesa-Duquesa pagaba el alojamiento al oista Gaspar Barli. BNE Ms. 14.016.3/65 (Papeles Barbieri).
} 


\section{Excelentísimo Señor}

Muy Señor mío.

Don Pablo Vidal piensa oponerse a la plaza de violón que se halla vacante en la Real Capilla y con este motivo me ha pedido suplique a Vuestra Excelencia, como lo ejecuto con todo encarecimiento, que si sus ejercicios no lo desmerecieren como espero, se digne su bondad proporcionarle dicha vacante. $\mathrm{Su}$ habilidad es notoria, como su irreprehensible conducta, acreditadas muchos años hace en la Real Capilla de la Encarnación, por lo que me tomo la libertad de molestar a Vuestra Excelencia con esta súplica considerando muy digno al pretendiente de que la justificación de Vuestra Excelencia le proteja.

Con más razón debo rogar a Vuestra Excelencia me disimule esta confianza, y que ejecute mi pronta voluntad y afecto en cuanto sea de su agrado.

Nuestro Señor que a Vuestra Excelencia guarde muchos años

Madrid 21 de agosto de 1783 Excelentísimo Señor Patriarca de las Indias ${ }^{208}$

La intercesión de la Condesa-Duquesa no tuvo los efectos esperados. Pablo Vidal no consiguió ingresar en la Real Capilla y la plaza fue concedida a Joaquín Samaranch ${ }^{209}$. Si tuvo efecto, en cambio, su intercesión ante el Patriarca de las Indias, para que Antonio Plaza, músico vinculado al servicio de la Casa de Benavente desde 1781, ocupase en 1783 el "magisterio de rudimentos del Real Colegio de niños músicos”, institución asociada a la Real Capilla ${ }^{210}$ :

En 1785 la Condesa-Duquesa se dirigió de nuevo al Patriarca de las Indias, para pedir que se le adjudicara una plaza de viola en la Real Capilla a Manuel

\footnotetext{
208 AHN NOBLEZA OSUNA-CARTAS leg 389-23.

209 Ortega, "La Real Capilla”, p. 436.
} 
Carril (o Carriles), violinista de la orquesta de la Condesa-Duquesa, que ya se había presentado en diversas ocasiones a las oposiciones para violín y viola en la citada institución:

[Madrid, 24 de noviembre de 1785]

Muy Señor mío:

Noticiosa del lucimiento con que ha quedado don Manuel Carriles con la oposición que ha hecho a la plaza de viola vacante de la Real Capilla, y respecto que en la última anterior mereció la bondad de Vuestra Excelencia, le asegurase que lograría la primera si mereciese buen lugar, cuya circunstancia presumo se verifique ahora, me tomo la confianza de suplicar a Vuestra Excelencia que en atención a todo se digne preferirle para la citada plaza, que seguramente no desmerece por su conducta y demás buenas prendas que le acompañan. Disimúleme Vuestra Excelencia esta satisfacción $\mathrm{y}$ espero que asegurado de mi gratitud y fina voluntad me proporcione Vuestra Excelencia frecuentes ocasiones de complacerle.

Excelentísimo Señor

Besa la mano de Vuestra Excelencia su mayor servidora La Condesa- Duquesa Excelentísimo Señor Cardenal Patriarca ${ }^{211}$

En esta ocasión la mediación de la Condesa-Duquesa no tuvo los resultados esperados ya que Manuel Carriles no consiguió ingresar en la Real Capilla hasta las oposiciones que se celebraron en $1789^{212}$.

\footnotetext{
210 AHN NOBLEZA OSUNA-CARTAS, leg 391-26.

211 Ibid., leg 391-29.

212 Guy Bourligueux, "El violinista Pascual Juan Carriles”, p.196.
} 
En 1788, la petición de intercesión de la Condesa-Duquesa se dirigió a Gaetano Brunetti, violinista de la Real Capilla, y a la sazón encargado de la dirección de la "orquesta de parejas" del Príncipe de Asturias. La Condesa Duquesa, conocía bien a Brunetti (que había sido profesor de violín de su marido) y se dirigió a él para solicitarle la plaza de fagot vacante en dicha orquesta para Pedro Garisuain, violinista y fagotista de su orquesta:

Muy Señor mío:

Con noticia de que por haber pasado Don Andrés Julián a servir en la orquesta de parejas la plaza de timbalero que servía Don Eustaquio de León, queda vacante la de fagot que tenía en dicha orquesta Don Andrés Julián, no puedo dejar de interesarme por Don Pedro Garisuain para que sea admitido en esta. Nadie como Vuestra Merced conoce su desempeño; y esta circunstancia me hace no dudar que le proporcionará la expresada plaza, como le ruego con la confianza de que cuando recomiendo a Vuestra Merced un criado mío de conocida habilidad para lo mismo en que desea servir, no ha de dejar Vuestra Merced de atenderle, como que tanto desea que $\mathrm{Su}$ Alteza esté bien servido.

Quedo para servir a Vuestra Merced con el mayor afecto; y ruego a Dios le guarde muchos años. Madrid 20 de septiembre de 1788

Besa la mano suya

La Condesa- Duquesa

Señor Don Cayetano Brunetti ${ }^{213}$

La orquesta a la que se alude en esta carta era la encargada de amenizar la llamada “diversión de Parejas”, un espectáculo hípico cortesano que en las últimas décadas del siglo XVIII se representaba durante las estancias primaverales de la

\footnotetext{
213 AHN NOBLEZA, OSUNA-CARTAS, leg 391-25. No consta si finalmente Garisuian consiguió el puesto solicitado.
} 
Corte en Aranjuez, y que solía estar organizado por el Príncipe de Asturias, el futuro Carlos IV, o por algún representante de la alta nobleza ${ }^{214}$. El empleo que solicitó la Condesa para Pedro Garisuain no está relacionado, por consiguiente, con la orquesta del Teatro del Príncipe, como afirma Miguel Ángel Marín, sino con la agrupación musical que intervenía en "Las Parejas", y que estaba coordinada por Gaetano Brunetti ${ }^{215}$.

A finales del siglo XVIII, la representación de "Las Parejas" consistía en un desfile de cuatro grupos de doce jinetes cada uno, elegidos entre los miembros de la alta nobleza, que ejecutaban movimientos coreográficos acompañados por una orquesta de viento y percusión ${ }^{216}$. El ambiente festivo de este espectáculo quedó magistralmente reflejado en el cuadro "Las Parejas Reales" de Luis Paret y Alcázar (1770) en el que aparece representado el grupo instrumental que participaba en estas funciones ${ }^{217} \mathrm{y}$ en un libro que se editó en 1781 y que fue realizado bajo la dirección del músico, bailarín y empresario teatral Domenico

\footnotetext{
${ }^{214}$ Por ejemplo en 1765 se celebró una "Función de Parejas", para festejar la boda del Príncipe de Asturias, costeada por el Duque de Medinaceli. En la Biblioteca Nacional de Madrid se conserva un manuscrito (procedente de la Biblioteca del Duque de Osuna) con la relación de gastos y varios dibujos de esta función entre los que figura una representación del grupo de clarines y timbales que intervino en esta función. Véase Libro en donde consta el por menor de los gastos causados con motivo de la Función de Parejas que se corrieron el día 12 de diciembre de 1765 en celebridad del casamiento del Serenísimo Príncipe de Asturias. BNE Ms. 10354.

${ }^{215}$ Marín, "La zarzuela", p. 25, nota 22.

${ }^{216}$ Pedro de Alcántara Téllez Girón, futuro IX Duque de Osuna, era uno de los nobles invitado asiduamente por el Príncipe de Asturias a participar en estas diversiones. AHN NOBLEZA OSUNA-CARTAS, leg. 309-14; leg 538 y leg 594.

${ }^{217}$ En este cuadro que se conserva en el Museo del Prado de Madrid, se representa la función de Parejas que se celebró en la plazuela del palacio del Real Sitio de Aranjuez el 6 de junio de 1770. Sobre este cuadro véase José Luis Morales y Marín, Luis Paret: vida y obra (Zaragoza: Aneto, 1997), pp. 113.
} 
Rossi. Esta obra contiene 36 láminas con los dibujos esquemáticos de los desfiles ecuestres, y la música escrita por el compositor Luigi Marescalchi para el espectáculo $^{218}$

\subsection{La Capilla del Duque de Osuna según el Allgemeine musikalische Zeitung (Leipzig, 1799)}

Tras la disolución de la orquesta de la Condesa-Duquesa María Josefa en mayo de 1792, no existe constancia documental de la existencia de un conjunto musical estable al servicio de la unificada Casa de Benavente-Osuna. La falta de liquidez y el progresivo endeudamiento a los que se vio sometida la administración de la casa ducal, fueron probablemente las causas que llevaron a prescindir de los onerosos gastos que suponía el mantenimiento de una plantilla fija de músicos asalariados. La actividad musical de los Duques de Osuna y Condes-Duques de Benavente se vio afectada también por su traslado a París en 1799 y especialmente por la crisis económica que atravesó la Casa de Benavente tras la muerte del IX Duque en 1807 (que provocó la separación de la administración de la Casas ducales de Osuna) y que se agravó con el traslado forzoso de la familia a Sevilla y Cádiz durante la Guerra de la Independencia (1808-1814). Según Antonio Cordero y Fernández tras la invasión francesa quedaron desorganizadas la mayoría de las capillas musicales mantenidas por las

\footnotetext{
${ }^{218}$ El original de este libro se conserva en la Biblioteca del Palacio Real. Existe una edición facsímil moderna. Matilde López Serrano (Edición y estudio preliminar) Las Parejas. Juego hípico del siglo XVIII, Manuscrito de Domenico Rossi, Editorial Patrimonio Nacional, Madrid, 1987.
} 
familias de la alta nobleza además de la mayoría de las capillas religiosas que funcionaban en los conventos de Madrid ${ }^{219}$.

A partir de 1793, los titulares de las Casas de Osuna y Benavente parecen haber optado por contratar músicos sólo cuando se necesitaban sus servicios. Este sistema suponía un notable ahorro respecto a la época en que funcionó la orquesta de la Condesa-Duquesa, cuando además del sueldo fijo de los músicos asalariados había que pagar a otros instrumentistas para reforzar la plantilla fija o para sustituir a aquellos a los que sus obligaciones en la Real Capilla o en otras instituciones les impedía la asistencia a los actos organizados por la familia ${ }^{220}$. Para las funciones religiosas que patrocinaron a partir de 1793, los Duques contrataron algunas de las capillas musicales estables que funcionaban en las iglesias y conventos de Madrid, como la de San Cayetano o la de las Descalzas Reales, reforzadas con otros instrumentistas contratados para la ocasión (Ver Capítulo V). En los bailes y academias musicales organizados por los BenaventeOsuna en la última década del siglo XVIII, uno de los músicos de plantilla de la casa se encargaba de contratar a los instrumentistas necesarios que solían ser reconocidos miembros de las orquestas de los teatros de Madrid, de las formaciones militares o de algunas de las capillas musicales religiosas. En 1796 y 1797, por ejemplo Francisco Basset buscó a los instrumentistas que actuaron en diversos bailes y academias organizados por la Condesa-Duquesa en su palacio de Madrid, y en su residencia de recreo de la Alameda, situada a las afueras de

\footnotetext{
219 Citado en Antonio Gallego, La música en tiempos de Carlos III (Madrid: Alianza, 1988), p.162.

${ }^{220}$ Véase, por ejemplo, la relación de los músicos contratados "a mas de los criados músicos de $\mathrm{Su}$ Excelencia" para los bailes de Carnaval de 1787. AHN NOBLEZA, OSUNA-CARTAS, leg 390-3.
} 
Madrid. Las plantillas reunidas eran de cuarteto de cuerda para las academias y de orquesta clásica para los bailes (Ver Tabla 11)

A excepción de Francisco Basset los instrumentistas que actuaron en estas funciones no figuran en las nóminas del personal al servicio de la casa, ni en ningún otro documento contable de la misma, lo que da a entender que no eran músicos asalariados. A todos ellos se les pagaba la cantidad de 80 reales por su asistencia a bailes y 40 por las academias sin distinción del instrumento, ni del puesto ocupado en la orquesta.

Entre los músicos que se contrataron para las funciones profanas había también algunos que sirvieron con asiduidad a la casa de Benavente-Osuna en los últimos años del siglo XVIII. Además de Francisco Basset, participaron habitualmente en estas funciones el violinista Salvador Feixas (copista de música de la familia Benavente) el contrabajo Pedro Sebastián (que había sido miembro de la orquesta de la Condesa-Duquesa hasta su disolución), los oboístas Gaspar Barli (que pertenecía al servicio de la casa desde 1781) y José Rafael Álvarez ["Pepito"] (protegido de la Condesa-Duquesa María Josefa); y el clarinete Esteban François (músico del Regimiento de América del que Pedro de Alcántara Téllez Girón era coronel y que en 1786 ya figuraba al servicio de la Casa de Osuna) ${ }^{221}$.

\footnotetext{
221 AHN NOBLEZA, OSUNA-CARTAS, leg 391-16. El futuro Duque de Osuna debió de mantener a este músico militar con sus propios medios como era habitual en los regimientos militares. Desde 1793 tuvo también a su servicio al fagotista Lorenzo Geisel para que le acompañase en sus campañas militares. Sobre estos y otros músicos que trabajaron para las Casas de Osuna y Benavente a finales del siglo XVIII véase el apartado subsiguiente de este capítulo.
} 
Tabla 11

Músicos que asistieron a las academias y bailes organizados por la CondesaDuquesa de Benavente entre el 28 de junio de 1796 y el 4 de enero de 1797

Fuente: AHN NOBLEZA, OSUNA-CARTAS, leg 390-1

\begin{tabular}{|c|c|c|}
\hline Acontecimiento y fecha & Instrumento & Músico \\
\hline \multirow{4}{*}{$\begin{array}{l}\text { Cuartetos } \\
28 \text { de Junio de } 1796 \\
\text { y } 20 \text { de octubre }\end{array}$} & Violín $1^{\mathrm{o}}$ & Juan Balado \\
\hline & Violín 2 & ${\text { [Francisco Basset }]^{223}}$ \\
\hline & [Viola] & Marcos Balado \\
\hline & Violón & Francisco Rosquillas \\
\hline \multirow{16}{*}{$\begin{array}{l}\text { Baile } \\
19 \text { de octubre de } 1796^{224}\end{array}$} & \multirow[t]{6}{*}{ Violines } & Eustaquio León \\
\hline & & Juan Balado \\
\hline & & Joaquín León \\
\hline & & Bacarela \\
\hline & & Francisco Basset \\
\hline & & Salvador Feixas \\
\hline & \multirow[t]{2}{*}{ Violas } & Marcos Balado \\
\hline & & Manuel Maccia \\
\hline & Violón & Francisco Rosquillas \\
\hline & Contrabajo & Pedro Sebastián \\
\hline & \multirow[t]{2}{*}{ Oboes } & Pepito [José Rafael Álvarez García] \\
\hline & & Eugenio Laserna \\
\hline & \multirow[t]{2}{*}{ Fagotes } & Monsieur Fransua [Esteban François] \\
\hline & & Monsieur Maus \\
\hline & \multirow[t]{2}{*}{ Trompas } & Conrado Pensiel \\
\hline & & Monsieur Nicolás \\
\hline
\end{tabular}

${ }^{222}$ La academia del 20 de octubre se celebró en el Palacio de La Alameda situado a las afueras de Madrid.

223 Aunque la documentación manejada no menciona a Francisco Basset como el violín $2^{\circ}$, deduzco que fue él porque era el encargado de contratar a los músicos, y como tal recibía un sueldo fijo de la casa. El nombre de Basset aparece siempre tachado en el documento de las relaciones de músicos contratados para los bailes que fue redactado por el propio Basset.

${ }^{224}$ Se celebró en el Palacio de La Alameda. 


\begin{tabular}{|c|c|c|}
\hline Acontecimiento y Fecha & Instrumento & Músico \\
\hline \multirow{15}{*}{$\begin{array}{l}\text { Baile } \\
26 \text { de octubre de } 1796^{225}\end{array}$} & \multirow[t]{4}{*}{ Violines } & Juan Balado \\
\hline & & Sebastián Dimas \\
\hline & & Francisco Basset \\
\hline & & Salvador Feixas \\
\hline & \multirow[t]{2}{*}{ Violas } & Marcos Balado \\
\hline & & Manuel Marcia \\
\hline & Violón & Francisco Rosquillas [Rosquellas] \\
\hline & Contrabajo & Pedro Sebastián \\
\hline & Oboe & Pepito [José Rafael Álvarez García] \\
\hline & \multirow[t]{2}{*}{ Clarinetes } & Bis [Wisse] \\
\hline & & Paco \\
\hline & \multirow[t]{2}{*}{ Fagotes } & Fransua [Esteban François] \\
\hline & & Maus \\
\hline & \multirow[t]{2}{*}{ Trompas } & [Conrado] Pensiel \\
\hline & & Manfredi \\
\hline \multirow{12}{*}{$\begin{array}{l}\text { Baile } \\
24 \text { de diciembre de } 1796\end{array}$} & \multirow[t]{4}{*}{ Violines } & Joaquín León \\
\hline & & Sebastián Dimas \\
\hline & & Francisco Basset \\
\hline & & Salvador Feixas \\
\hline & \multirow[t]{2}{*}{ Violas } & Manuel Macia \\
\hline & & Juan Balado \\
\hline & Violón & Manuel Martínez \\
\hline & & Juan Antonio Gamarra \\
\hline & \multirow[t]{2}{*}{ Clarinetes } & Bis [Wisse] \\
\hline & & Paco \\
\hline & \multirow[t]{2}{*}{ Trompas } & Monsieur Nicolás \\
\hline & & Manfredi \\
\hline \multirow{12}{*}{$\begin{array}{l}\text { Baile } \\
31 \text { de diciembre de } 1796\end{array}$} & \multirow[t]{4}{*}{ Violines } & Joaquin León \\
\hline & & Andrés Monjui \\
\hline & & Ramón Montejano \\
\hline & & Francisco Basset \\
\hline & \multirow[t]{2}{*}{ Violas } & Juan Balado \\
\hline & & Pablo del Moral \\
\hline & Violón & José Alarcón \\
\hline & Contrabajo & Juan Antonio Gamarra \\
\hline & \multirow{2}{*}{ Oboes } & Vicente Julia \\
\hline & & \begin{tabular}{|l|} 
Eugenio Laserna \\
\end{tabular} \\
\hline & \multirow[t]{2}{*}{ Trompas } & \begin{tabular}{|l|} 
Francisco Isabela \\
\end{tabular} \\
\hline & & \begin{tabular}{|l} 
José Trota \\
\end{tabular} \\
\hline
\end{tabular}

225 Ibíd. 


\begin{tabular}{|c|c|c|}
\hline \multirow{18}{*}{$\begin{array}{l}\text { Baile } \\
4 \text { de Enero de } 1797\end{array}$} & \multirow[t]{6}{*}{ Violines } & Eustaquio León \\
\hline & & Joaquín León \\
\hline & & Salvador Feixas \\
\hline & & Bacarela \\
\hline & & Francisco Basset \\
\hline & & El hijo de León \\
\hline & \multirow[t]{2}{*}{ Violas } & Pablo del Moral \\
\hline & & Joaquinito \\
\hline & [Violón] & Francisco Rosquillas \\
\hline & \multirow{2}{*}{ Contrabajos } & Pedro Sebastián \\
\hline & & Juan Antonio Gamarra \\
\hline & Oboe & Pepito [José Rafael Álvarez García] \\
\hline & \multirow[t]{2}{*}{ Clarinetes } & Bis [Wisse] \\
\hline & & Paco \\
\hline & \multirow[t]{2}{*}{ Fagotes } & Monsieur Fransua [Esteban François] \\
\hline & & Maus \\
\hline & \multirow[t]{2}{*}{ Trompas } & Francisco Isabela \\
\hline & & José Trota \\
\hline
\end{tabular}

La formación instrumental que trabajó a finales del siglo XVIII para los Duques de Osuna fue considerada como una de las mejores agrupaciones musicales privadas de España, a pesar de la eventualidad y rotación de sus músicos. En marzo de 1799 un personaje que firmó como "B...n" dedicó un amplio artículo en el Allgemeine Musikalische Zeitung (Leipzig: Breitkopf und Härtel) a la situación de la música en España que había conocido en un reciente viaje $^{226}$. Este anónimo informante señaló que la "Capilla del Duque de Osuna" [der Kapelle von Herzogs von Osuna] era la mejor de España y alabó la calidad individual de sus componentes que, según su opinión, era superior a la de los músicos de la Capilla del Duque de Alba y superaba incluso a los de la Real Capilla:

${ }^{226}$ B...n., "Etwas uber den jetzigen Zustand der Musik in Spanien (Beschluss)", Allgemeine Musikalische Zeitung, 26 (27 de Marzo de 1799), pp. 402-405. 
Ich brauche jetz wohl nicht mehr zu bemerken, dass die Kapelle dieses Herzorgs [von Osuna] die beste in Spanien ist. Die des Herzogs von Alba ist zwar auch gut, hat aber keine ausgezeichneten Musiker aufzuweisen. Die Kapelle des Königs ist wie ich vorhin schon gesagt habe, im Ganzen die unbedeutendste, hat aber an ihres Spitze einen Boccherini, Barly, und einen vortreflichen Violoncellisten an dessen Namen ich mich nicht mehr erinnern $\operatorname{kann}^{227}$.

En su artículo, el cronista del Allgemeine Musikalische Zeitung (AMZ) dedica un amplio apartado a alabar la calidad de los instrumentistas de viento del Duque de Osuna ${ }^{228}$. De Gaspar Barli, primer oboísta de la formación, al que (según este articulista) los madrileños adoraban como un "semidios" [wie einem Halbgott] ensalza su sorprendente agilidad, destreza y la delicada sensibilidad de sus interpretaciones [bläst mit ungemeiner Leichtigkeit, Fertigkeit und mit seinem Gefuh]. Otra de las cualidades interpretativas de Barli era su sonido pletórico, cálido y redondo con el que era capaz de realizar los efectos de "echo piano" mas lejanos. Barli componía también sus propias obras al estilo de Pleyel.

El primer clarinete de la capilla musical del Duque de Osuna en los últimos años del siglo XVIII era Wisse, un músico de origen alemán que se apellida originalmente Weiss. De este instrumentista que poseía de un excelente sonido, el cronista del $A M Z$ sólo critica su costumbre de atacar los sonidos con la

227 B...n., “Etwas”, pp. 403-404. [Mi traducción]: "No he de dejar de señalar que la Capilla de este Duque es la mejor de España. La del Duque de Alba es también buena pero sus músicos no tienen la misma calidad. La Capilla Real es, como ya he comentado, la mas insignificante aunque tiene entre su plantilla a Boccherini, Barli y otro excelente violonchelista, cuyo nombre ahora no recuerdo.

228 Todos los datos que figuran a continuación proceden del citado artículo del Allgemeine Musikalische Zeitung, Para las biografías de estos músicos véase el Apéndice 5. 
garganta en lugar de con la lengua. Esta técnica molestaba la audición a una distancia cercana. En el momento de redactarse la noticia del $A M Z$ (1799) Wisse se encontraba en Lisboa.

Los dos fagotistas de la Capilla del Duque de Osuna eran los mismos que trabajaban en la orquesta del Teatro de los Caños del Peral de Madrid. El primer fagot era el ya citado [Esteban] François, un francés que, según el cronista del $A M Z$ poseía un sonido inigualable y tocaba con pulcritud, gracia y mucho sentimiento [bläst nicht schwer, aber rein, nett, und mit vielem Ausdruck]. El segundo fagotista era Maus, un alsaciano, que aunque no tenía la calidad de François, poseía un absoluto dominio del instrumento en toda su tesitura.

El cronista del $A M Z$ alabó también extensamente las cualidades técnicas e interpretativas de Bardin, un músico de origen francés, que tocó el serpentón en la capilla del Duque de Osuna y que ya había fallecido en el momento de redactarse la noticia. Bardin solía interpretar con el serpentón los conciertos para trompa de [Giovanni] Punto y [Antón] Rosetti:

Bardin, ein Franzos, Serpentist des Herzogs von Osuna. Ich habe zwar in Frankreich viele gute Serpentisten gehört, aber nie einen Bardin. Er blies mit der großten Leichtihkeit Puntoische und Rosettische Waldhornnconcerte; ja, sie gewannen sogar auf seinem Instrument sehr viel dadurch, da $\beta$ er diejenigen Tone, die auf dem Waldhorn gesteckt warden müssen, und die daher im Verhältnis mit den übrigen, auch bei den besten Waldhornisten etwas dumpfer klingen, sehr rein, voll, und ganz den andern gleich heraus brachte. Hierbei mu $\beta$ das er wenn obligate blies, sich nie des Serpent, sondern des Waldhorn-Mundstücks bediente, weil er mit diesem leichter und 
delicater in die Höhe blasen konnte. Übringens vermißte man leider!. Er ist jetz todt. Ach die spanischen Weine und die spanischen Mädchen ${ }^{229}$.

\subsection{Otros músicos al servicio de las Casas de Osuna y Benavente entre 1793 y 1834.}

Tras la disolución de la orquesta de la Condesa-Duquesa de Benavente algunos de sus miembros siguieron vinculados al servicio de sus señores compatibilizando su labor de intérprete con la gestión musical.

En enero de 1793 el único músico que poseía una asignación fija de la Casa de Osuna era el oboísta y violinista Francisco Basset. Este personaje, que al menos desde 1775 era "músico de la casa" del futuro IX Duque de Osuna y de su esposa la Condesa-Duquesa de Benavente, continuó ocupándose hasta su muerte (1808) de la organización y contratación de músicos para las funciones religiosas y bailes organizados en la Casa de Benavente-Osuna ${ }^{230}$, siendo el "encargado por $\mathrm{Su}$ Excelencia [El Duque de Osuna] para todo lo relativo a la música"231. Este empleo comprendía una serie de obligaciones similares a las desempeñadas por el festero de las capillas religiosas en la misma época. Más propiamente podría

\footnotetext{
${ }^{229}$ B....n., "Etwas", pp. 403-404. [Mi traducción]: "Bardin, [es] un francés, serpentón del Duque de Osuna. He escuchado a muchos y buenos serpentones en Francia, pero a ninguno como Bardin. Toca los conciertos para trompa natural de Punto y Rosetti con gran destreza e incluso los conciertos ganan en calidad cuando son interpretados por él, siendo capaz de igualar los sonidos que en la trompa han de amortiguarse, y que incluso en los trompas más hábiles suenan apagados, haciéndolos sonar puros, llenos e igualados a los otros. He de hacer notar que cuando tiene que tocar un obligato, no lo hace con la boquilla de un serpentón sino con la boquilla de la trompa de caza, puesto que con esta puede tocar en la tesitura aguda de manera más delicada. ¡Lo cual se echaba en falta! Ahora ya está muerto. ¡Ah, el vino español y las mujeres!”

${ }^{230}$ Los principales datos biográficos de Basset figuran en el Apéndice 5

${ }^{231}$ AHN NOBLEZA, OSUNA-CARTAS, leg 390-1.
} 
hablarse de un gestor o, según la terminología de Antonio Gallego, de un "festeroavisador" o "festero intermediario" cuya principal labor consistía buscar músicos de distintas instituciones para participar en las fiestas musicales religiosas o $\operatorname{profanas}^{232}$.

El violinista y director boloñés Melchor Ronzi, fue otro de los músicos que desempeñó la función de gestor o "festero-avisador" para la Casa de BenaventeOsuna a finales del siglo XVIII ${ }^{233}$. Ronzi buscó varios instrumentistas para los bailes que organizaron los Duques de Osuna en $1797^{234}$ y para las funciones religiosas de San Francisco de Borja y Nuestra Señora del Pilar de $1798^{235}$.

Aunque Ronzi no figura en las nóminas de la casa, en estos años su relación con la Condesa-Duquesa de Benavente parece haber sido muy estrecha como se deduce de una carta que dirigió a esta dama en junio de 1797, en la que le solicitaba su aprobación antes de firmar el contrato que le había ofrecido la empresa de los “Teatros Españoles” de Madrid, es decir de los teatros del Príncipe y de la Cruz.:

\section{Excelentísima Señora}

En cumplimiento de mi obligación y reconocimiento debido hago presente a Vuestra Excelencia que habiéndoseme hecho varias proposiciones sobre el modo y forma que debía quedar en los Teatros Españoles, han sido las mas proporcionadas una darme 15.000 reales anuales y el teatro por diez años para ejecutar conciertos en las cuaresmas, y otra doce mil con la

\footnotetext{
${ }^{232}$ Antonio Gallego, "Breve nota sobre el festero y la festería", Nassarre, V/1 (1988), pp. 35-38.

${ }^{233}$ Para la biografía de Ronzi véase el Apéndice 5

${ }^{234}$ AHN NOBLEZA, OSUNA-CARTAS, leg 391-34.

${ }^{235}$ Ibid., leg 391-26 y leg 391-30..
} 
obligación de asistir y tocar seis óperas que ejecútense o no, he de percibir; y 2000 reales por cada una de las que se hagan, además de aquellas, con el uso del teatro por los diez años, y habiéndolas examinado con reflexión me parece convenirme la de los 12000 pues a pesar de la corta diferencia que resulta en los intereses, logro el beneficio de muchos meses de descanso en los cuales ningún motivo me puede impedir el estar pronto a las órdenes de Vuestra Excelencia, restando sólo para finalizar el asunto su aprobación, cuya circunstancia me servirá de la mayor satisfacción.

Espero se digne Vuestra Excelencia dispensarme sus preceptos que cumpliré gustoso, y en el ínterin pido a Dios me guie su vida muchos años.

Madrid 8 de junio de 1797.

Besa los pies de Vuestra Excelencia su más humilde criado

Melchor Ronzi. ${ }^{236}$

Tras la muerte de Basset en septiembre de 1808, la labor de "festeroavisador" para la Condesa de Benavente fue desempeñada (al menos eventualmente) por el director, compositor y cantante Maríano Rodriguez Ledesma, cuyo "visto bueno" aparece estampado en varios documentos de pago a músicos y cantantes por su asistencia a las funciones religiosas organizadas por la Casa de Benavente ${ }^{237}$. La relación de Rodríguez Ledesma con la CondesaDuquesa María Josefa queda constatada además por una carta fechada en 1815 en Londres en la que Ledesma, anunciaba su próximo regreso a Madrid para ocupar el puesto de profesor de música de la Real Cámara y pretendía ganarse de nuevo la protección de la Condesa-Duquesa, tras una relación de servicio que, a tenor de lo expresado por Ledesma, parece que no tuvo un buen fin:

\footnotetext{
236 AHN NOBLEZA, OSUNA-CARTAS, leg 413-7. Según figura en la anotación al margen, la Condesa-Duquesa le respondió que a ella también le parecía más acertado aceptar la segunda propuesta y que tenía "su permiso para cerrar la contrata".
} 
Londres 18 de Julio de 1815

Excelentísima Señora

Muy señora mía: No habiendo olvidado nunca, que hubo un tiempo en que Vuestra Excelencia me dispensaba su gracia, y que los hombres sin mundo obran a las veces de un modo contrario a sus intereses, no por maldad de su corazón sino por atolondramiento; ha llegado el tiempo en que conociendo que no debía jamás haberme indispuesto con Vuestra Excelencia la suplique se digne volverme a su gracia, y me permita ofrezca a su pies el destino de Músico de Cámara con que Su Majestad me ha agraciado últimamente como así mismo cuanto dependa de mi para el agrado de Vuestra Excelencia.

Pienso ponerme en camino por París para esa, luego que arregle mis cosas que siempre se tardará un mes o mes y medio; si entre tanto quiere Vuestra Excelencia dispensarme sus órdenes tendrá el honor en cumplirlas su seguro servidor que sus pies besa

Maríano de Ledesma

Excelentísima Señora Duquesa Condesa de Benavente, etc. ${ }^{238}$

La función de "festero-avisador" de la Casa de Osuna fue también ejercida por el cantante y profesor Carlo Marinelli, que después de haber pertenecido al servicio de la Casa de Osuna como profesor de los hijos de los Duques de Osuna (entre 1800 y 1813) continuó colaborando, al menos hasta 1820, con la CondesaDuquesa María Josefa, encargándose de la gestión o supervisión de la contratación de músicos para las fiestas religiosas y profanas ${ }^{239}$.

El violinista Francisco Bocolo fue entre 1827 y 1829 el encargado de buscar los músicos para los bailes organizados por la Condesa-Duquesa de

\footnotetext{
${ }^{237}$ AHN NOBLEZA, OSUNA-CARTAS, leg 392-7.

${ }^{238}$ Ibid., leg 392.-8.

${ }^{239}$ Ibid., leg 413-48.
} 
Benavente $^{240}$ Bocolo realizaba también la copia de la música y los arreglos e instrumentación del repertorio que se interpretaba en estos bailes que estaba formado principalmente por contradanzas y valses ${ }^{241}$. La plantilla de músicos que intervenía en estas fiestas solía estar formada por un pequeño grupo de instrumentos de cuerda a los que se añadía alguno de viento (habitualmente flauta o clarinete) y de percusión. Los bailes de Carnaval que se celebraron en 1828 en el palacio de la Condesa-Duquesa estuvieron amenizados por un conjunto instrumental formado por tres violines primeros, dos violines segundos, un violonchelo, un contrabajo, una flauta, un clarinete y un triángulo ${ }^{242}$..

Además de los citados músicos que ejercieron labores de gestión para las Casas de Osuna y Benavente, en la última década del siglo XVIII y en las dos primeras del XIX estuvieron vinculados al servicio de la Casa otros músicos con funciones diversas. El fagotista Lorenzo Geisel, fue nombrado "músico de la Casa" el 1 de Febrero de 1794 con efecto retroactivo desde el 17 de diciembre de 1793. Las obligaciones de Geisel como músico al servicio de los Osuna estaban relacionadas con el ejército. Debía de tocar el fagot con los músicos del Regimiento de Reales Guardias Españolas de Infantería al que pertenecía el Duque de Osuna, y acompañar a su señor en las campañas militares y en las ocasiones en las que éste considerase conveniente. Por todo ello Geisel recibiría un sueldo de nueve reales diarios mientras residiese en Madrid y además "cuarto

\footnotetext{
${ }^{240}$ En 1831 Francisco Bocolo era uno de los violinistas del teatro de la ópera de Madrid y cursó una solicitud para pasarse a la orquesta "de los teatros de comedia". AVM, Corregimiento, Sección 2 leg 472-62.

${ }^{241}$ AHN NOBLEZA, OSUNA-CARTAS, leg 392.-27.

${ }^{242}$ Ibíd.
} 
material en que dormir, si le quisiese". En los períodos en que saliese "a campaña" Geisel cobraría diez reales al día siendo de cuenta del Duque su manutención ${ }^{243}$. En 1802 Lorenzo Geisel consiguió una plaza de músico de la Real Capilla, pero siguió trabajando para el Duque de Osuna. El 1 de junio de este año, tras su incorporación a la institución monárquica, el Duque redujo la consignación diaria de Geisel a 5 reales diarios y le concedió una ayuda de costa de seiscientos cuarenta reales para hacerse el uniforme de músico de la institución palatina $^{244}$.

El virtuoso oboísta Gaspar Barli, uno de los músicos mejor pagados de la orquesta de la Condesa-Duquesa, fue uno de los "criados diferentes" de los Osuna entre mayo de 1793 y enero de 1807 con el interesante sueldo de 500 reales de vellón al mes ${ }^{245}$. Las obligaciones de Barli al servicio de los Osuna, incluyeron seguramente la formación musical de José Rafael Álvarez García, hijo de Joaquín Álvarez (criado de la Casa de Benavente) que fue protegido de la CondesaDuquesa y discípulo de Barli ${ }^{246}$.

José Rafael Álvarez García (que aparece habitualmente nombrado como "Pepito") estaba en Cádiz en diciembre de 1813 acompañando a su maestro Gaspar Barli. El cantante y profesor de música Carlo Marinelli relataba a la Condesa-Duquesa los incidentes ocurridos para la preparación de un concierto

\footnotetext{
243 Ibíd. En este mismo año y con motivo de la Guerra de la Convención Francesa, el IX Duque de Osuna, creó seis compañías de cazadores artilleros de Reales Guardias Españolas de Infantería que fueron mantenidas a su costa. Véase Emilio Becerra de Becerra, "El ejercito Español desde 1788 hasta 1802", Revista de Historia Militar, 56 (1984), p. 108

${ }^{244}$ AHN NOBLEZA, OSUNA-CARTAS, leg 392-31.

${ }^{245}$ Ibid., legs.459-468.

${ }^{246}$ Para la biografía de este músico véase el Apéndice 5.
} 
dado en Cádiz por Barli con su hija "Mariquita" y la "desagradable" actitud de el joven oboísta que se negó a tocar en este acto a pesar de haber sido invitado por Barli:

Excelentísima Señora:

Muy Señora mía de mi mayor veneración y respeto:

Tengo el honor de participar a Vuestra Excelencia que al fin Barli dio su concierto el día 10 del corriente [diciembre de 1813] a pesar de los muchos obstáculos, que a cada instante se presentaban. En efecto llegamos a creer que al fin no se daría; mas no sólo le ha dado, sino que estuvo muy concurrido de gente lúcida, y mereció el mayor agrado del público. Fue en casa de Bachicha a dos duros la entrada, y se despacharon doscientos billetes destinados al efecto sin haber sobrado uno. Mariquita gustó infinito como era de esperar, y Barli entusiasmó con su concierto de oboe; yo he tenido suma satisfacción, y se que Vuestra Excelencia la tendrá igualmente, pues siempre se ha tomado tanto interés en la suerte de esta buena familia.

En medio de esto es desagradable lo que ha ocurrido con Pepito, quien se ha conducido con su maestro de un modo horroroso. Desde luego le envió a decir de una manera muy chocante, que no contase con él para el concierto, porque no asistiría, y aunque Barli no obstante le convidó, él cumplió su palabra, llegando al extremo de decir que no había sido convidado. Viendo que a pesar de todo se verificaba el concierto, los enemigos de Barli urdieron la cosa de tal modo que el día antes de darse, influyeron para que en el teatro se diese ópera, a pesar de ser viernes, en cuyo día jamás se acostumbraba a dar óperas, con lo cual los músicos que debían asistir no podían hacerlo. Así es que Barli se halló en el mayor apuro y la orquesta no estuvo tan bien servido [sic], como era de desear.

Creo justo participar a Vuestra Excelencia esta ocurrencia, que no podrá menos de producirle disgusto pues la conducta de Barli no merecía este pago.

Disimule Vuestra Excelencia la libertad que me tomo, y con esta ocasión me ofrezco de nuevo a las órdenes de Vuestra Excelencia a quien deseo las mayores prosperidades, especialmente en las próximas Pascuas de Navidad. 
Excelentísima Señora

Besa los pies de Vuestra Excelencia

Carlos Marinelli

Cádiz, 14 de diciembre de $1813^{247}$

Los músicos Barli, Basset, Marinelli y acaso Ronzi, pudieron coincidir al servicio de la Casa de Benavente-Osuna con el compositor catalán José Nonó, que, según Baltasar Saldoni, fue desde 1802 "maestro compositor de la casa del Duque de Osuna para el cual compuso más de treinta óperas, algunas de ellas por indicación de la duquesa"248. La noticia publicada por Saldoni es la única referencia que relaciona a Nonó con el Duque de Osuna. No he localizado a este músico en ninguno de los documentos administrativos del personal de la casa consultados de los años 1802 a 1808, en los que si aparecen otros músicos y profesores de danza y baile. Las obras de este autor, a las que alude Saldoni, tampoco figuran en ninguno de los inventarios de los archivos de música de las Casas de Osuna y Benavente elaborados a lo largo del siglo XIX ${ }^{249}$.

\footnotetext{
${ }^{247}$ AHN NOBLEZA, OSUNA-CARTAS, leg 392-4. También se conserva una carta más breve de Barli dirigida a la Condesa-Duquesa con un contenido muy similar en AHN NOBLEZA, OSUNA-CARTAS, leg 387-8.

${ }^{248}$ Saldoni, Diccionario, vol. III, p. 394.

${ }^{249}$ Véase Apéndice 3.
} 


\title{
Capítulo IV
}

\author{
Recursos materiales: archivos de música e \\ instrumentos musicales de las familias Osuna \\ y Benavente en los siglos XVIII y XIX
}





\section{Fondos musicales de las Casas de Osuna y Benavente}

\subsection{La formación del repertorio musical de las Casas de Osuna y Benavente}

El interés por conseguir un repertorio novedoso o exclusivo para ser presentado como primicia en los actos sociales y religiosos, impulsó a los miembros de las Casas de Osuna y Benavente a adquirir obras musicales de los más destacados autores del panorama español y europeo. En el período estudiado las formulas de adquisición de este repertorio fueron muy variadas como describiré en los apartados siguientes.

\subsubsection{Dedicatorias y regalos}

La dedicatoria de obras a un personaje de la nobleza fue uno de los procedimientos habituales utilizados por los creadores de todas las épocas para conseguir publicidad y prestigio para su producción. En el caso de los compositores o instrumentistas vinculados al servicio de las Casas de Osuna y Benavente, la dedicatoria refleja, en la mayoría de los casos, una muestra de agradecimiento del músico hacia sus señores por el empleo y protección que recibían de ellos. A este grupo pertenecen, entre otras, las dedicatorias a Pedro Zoilo Téllez Girón, VIII Duque de Osuna, de las obras dramático-musicales de Pablo Esteve y Grimau ${ }^{1}$ o la de la Obra armónica en Seis Sonatas de Cámara de violín y bajo Solo de Francisco Manalt, en cuyo texto puede apreciarse el carácter formal o "protocolario" que tenían siempre este tipo de dedicatorias:

\footnotetext{
${ }^{1}$ Ver Capítulo 3.
} 
Excelentísimo Señor:

A la benéfica Sombra de Vuestra Excelencia se acoge la pequeñez de este libro. Mi obligación le sacrifica a Vuestra Excelencia sintiendo la cortedad del tributo y la nimiedad del sacrificio, pero siempre será sacrificio y tributo, y siempre será el respeto y la humildad la que guíe la víctima.

Para su defensa no bastará menor mecenas, ni otra protección temiera la envidia. El afecto es el que ofrezco a Vuestra Excelencia, que siendo Vuestra Excelencia mi dueño, lo es también de mis laboriosas tareas, y así recibiéndolas Vuestra Excelencia no le queda a mi lealtad que apetecer; ni a otra gloria que aspirar

Espero de la bondad de Vuestra Excelencia esta dicha. Pasándome en cuenta de lo rendido, por cuya gracia y benignidad, quedaré eternamente pidiendo a Dios guarde la persona de Vuestra Excelencia en su grandeza. Madrid, año de 1757.

Excelentísimo Señor, mi Señor Besa los pies de Vuestra Excelencia, su menor criado

Don Francisco Manalt ${ }^{2}$

Algunos compositores que no mantuvieron relaciones de servicio con las Casas de Osuna o de Benavente también trataron de que sus obras se incorporasen al repertorio musical de estas casas nobiliarias o fueran publicadas con la dedicatoria a uno de los personajes de la familia. De este modo autores principiantes o fuera de los circuitos habituales de producción musical intentaban dar publicidad a sus obras y, además, conseguir una gratificación económica. Expondré a continuación algunos ejemplos de esta práctica.

\footnotetext{
${ }^{2}$ Francisco Manalt, Obra Armónica en seis Sonatas de Cámara de violín y bajo solo. Ejemplar conservado en la BNE M 1703. Editadas en Francisco Manalt, Obra armónica en seis sonatas de cámara de violín y bajo solo (1757); edición de Lothar Siemens y Lourdes Bonnet, (Madrid: Sociedad Española de Musicología, 2001.
} 
En febrero de 1783 Angel Valli, “copista” del teatro de Barcelona, envió a la Condesa-Duquesa María Josefa, varias arias con oboe y fagot obligados. En la minuta de contestación del 5 de marzo la Condesa-Duquesa le agradeció el envío pero le advirtió que en lo sucesivo no había necesidad de que se molestase en hacerlo pues ella era propietaria de "mucha y excelente música"3. José Fiori Spontoni, también residente en Barcelona, envió en enero de 1784 a la CondesaDuquesa María Josefa una colección de música de baile que había compuesto para que fuera utilizada por esta dama en "beneficio propio"(es decir para uso privado) en uno de los habituales bailes de carnaval que organizaba anualmente la Casa de Benavente y en los que participaban los músicos asalariados de la Casa. En la carta que acompañó al envío, Spontoni describía además las necesidades económicas de él y de su familia y solicitaba a la Condesa-Duquesa que le diera “ocasión de servirla”. La Condesa-Duquesa confirmó que había recibido las obras pero no le entregó ninguna ayuda económica ${ }^{4}$.

Años más tarde, en 1796 el capitán José García de Segovia, escribió desde Málaga a la Condesa Duquesa María Josefa solicitando permiso para dedicarle su Arte de bailar y poner contradanzas. Este militar había sido una de las parejas de baile de la Condesa- Duquesa en los bailes de máscaras realizados "bajo la dirección de Don Esteban Mosell” y en otras funciones que tuvieron lugar en la época de su "niñez y aprendizaje". La Condesa-Duquesa agradeció la intención

\footnotetext{
${ }^{3}$ AHN NOBLEZA OSUNA-CARTAS leg 391-18.

${ }^{4}$ Ibid, leg 391-1.

${ }^{5}$ Ibid., leg 388-1. Este dato apareció citado por primera vez de forma parcial en Yebes, $L a$ Condesa-Duquesa de Benavente. Una vida en unas cartas (Madrid: Espasa Calpe, 1958), pp.116117.
} 
de García de Segovia pero no aceptó su dedicatoria alegando la excusa de hallarse "en edad y circunstancias que me retiran de tales diversiones propias realmente del tiempo en que Vuestra Merced se acuerda haberme conocido"6.

\subsubsection{Contratos de adquisición de música y obras de compositores al servicio de la Casa.}

El 20 de octubre de 1783, la Condesa-Duquesa María Josefa firmó en Viena a través de su corresponsal Carlos Alejandro de Lelis, un contrato con Franz Joseph Haydn, por el que éste se obligaba a enviarle todas sus composiciones musicales, “exceptuándose solamente las que fuesen encargadas por otros para su uso privado". Con este contrato, que fue revisado en 1785, la Condesa Duquesa trataba de hacerse con las nuevas obras de Haydn, que serían presentadas como primicia en España. El acuerdo a que el compositor vienés llegó con la Condesa-Duquesa de Benavente le obligaba a enviarle un mínimo de doce obras al año, que debían ser principalmente instrumentales: sinfonías, cuartetos, quintetos, sextetos y conciertos ${ }^{7}$. Los detalles de este contrato han sido ampliamente comentados desde que fueron dados a conocer por primera vez por Joaquín Ezquerra del Bayo en 1934, y por Nicolas A. Solar Quintes en $1947^{8}$. El

${ }^{6}$ AHN NOBLEZA OSUNA-CARTAS leg 388-1. Este dato fue citado por primera vez de forma parcial en Yebes, La Condesa-Duquesa, pp.116-117.

${ }^{7}$ Haydn también envió otras obras no instrumentales, entre ellas dos misas que fueron estrenadas en las funciones de San Francisco de Borja, y la ópera Orlando y Palatino. Véase el Capítulo V.

${ }^{8}$ AHN NOBLEZA OSUNA-CARTAS leg 391-1 y 391-2. Joaquín Ezquerra del Bayo, Retratos de la familia Téllez Girón. Novenos duques de Osuna (Madrid: Junta de Iconografía Nacional, 1934), pp.24-25. Nicolás A. Solar-Quintes, "I. Las relaciones de Haydn con la casa de Benavente. II. Nuevos documentos sobre Luigi Bocherini. III. Manuel García Íntimo ”, AnM, II (1947) pp. 81104. 
contrató finalizó seguramente antes de diciembre de 1790 cuando Haydn abandonó Viena tras la muerte de su protector el Príncipe Nicolás de Esterhàzy para trasladarse a Londres ${ }^{9}$.

Coincidiendo con el período de vigencia del contrato con Haydn, la Condesa-Duquesa de Benavente empleó a Luigi Boccherini, como compositor y director de su orquesta ${ }^{10}$. El hecho de que Boccherini figure en las nóminas de la Casa como compositor, además de director, delata un interés por conseguir nuevas obras de este autor para la orquesta y los grupos de cámara formados por los músicos asalariados de la Casa. Además de las obras que Boccherini compuso expresamente para la Condesa-Duquesa, durante el breve período que este compositor permaneció al servicio de la Casa de Benavente se copiaron varias sinfonías, juegos de minuetos, conciertos y otras obras de cámara suyas, que se incorporaron al repertorio de la casa ${ }^{11}$.

Algunos instrumentistas y maestros de música que trabajaron al servicio de las familias Osuna y Benavente contribuyeron también a ampliar el repertorio musical. En los archivos de música de la Condesa-Duquesa de Benavente figuraban varias obras de instrumentistas y profesores de música de la familia como los sextetos y sinfonías de Ramón Rodríguez Monroy, contrabajista de la orquesta de la Condesa-Duquesa, o los quintetos y canciones de Giuseppe

9 AHN NOBLEZA OSUNA-CARTAS leg 391-1 y 391-2. La documentación conservada en el archivo administrativo de la Casa de Osuna no permite conocer si la relación contractual con Haydn se prolongó mas allá del mes de junio 1789, fecha del último documento de pago de Tomás de Iriarte, (intermediario en España de la Condesa-Duquesa) al comisionado Carlos Alejandro de Lelis.

${ }^{10}$ Boccherini estuvo al servicio de la Casa de Benavente desde marzo de $1786 \mathrm{y}$ al menos hasta el mes de diciembre de 1787. Véase el Capítulo III. 
Ponzo $^{12}$. Ángelo Inzenga (maestro de música de la Casa de Osuna) compuso expresamente para su discípulo Pedro de Alcantara II, XI Duque de Osuna, la arietta para bajo y piano La tomba ${ }^{13}$.

\subsubsection{Encargos de obras}

Los miembros de las Casas de Osuna y Benavente encargaron habitualmente la composición de misas y juegos de vísperas para las fiestas religiosas celebradas anualmente en Madrid bajo su patrocinio. Las obras se encargaban preferentemente a los músicos que trabajaban en el entorno de la Corte o de los teatros de Madrid. Como resultado de estos encargos, importantes autores como José Lidón, Antonio Rosetti, João Pedro Almeida Motta o Saverio Mercadante, entre otros, compusieron varias obras que fueron estrenadas por los conjuntos instrumentales de la Casa y las capillas musicales contratadas al efecto $^{14}$

\subsubsection{Compras a proveedores españoles y europeos}

Al menos desde la última década del siglo XVIII, y especialmente a lo largo de todo el siglo XIX, la compra de partituras y materiales musicales impresos y manuscritos a almacenistas, editores y otros proveedores españoles y europeos fue uno de los principales sistemas utilizados por los titulares de las Casas de Osuna y Benavente para conseguir las novedades del repertorio europeo.

\footnotetext{
${ }^{11}$ Véase el Capítulo VII.

12 Ver Apéndices 3 y 4.

13 Sobre esta obra véase el Capítulo VII.

${ }^{14}$ Sobre los encargos de obras para las funciones religiosas véase el Capítulo V.
} 
Como puede observarse en la Tabla 12, desde la última década del siglo XVIII, los miembros de la familia Osuna y Benavente adquirieron habitualmente materiales musicales a algunos de los principales proveedores europeos.

Tabla 12.

Principales proveedores de música españoles y europeos de las Casas de Osuna y Benavente (1790-1840)

Fuentes: AHN NOBLEZA, OSUNA-CARTAS legs. 274-2, 387-7, 392-12, 392-22.

\begin{tabular}{|c|c|c|c|c|}
\hline PROVEEDOR & LOCALIDAD & FECHA & $\begin{array}{c}\text { GÉNEROS DE } \\
\text { LAS OBRAS } \\
\text { ADQUIRIDAS }\end{array}$ & $\begin{array}{c}\text { PRINCIPALES } \\
\text { AUTORES DE LA } \\
\text { MÚSICA } \\
\text { ADQUIRIDA }\end{array}$ \\
\hline \multirow[t]{2}{*}{ Gabriel de Sancha } & \multirow[t]{2}{*}{ Madrid } & \multirow[t]{2}{*}{1790} & \multirow{2}{*}{$\begin{array}{c}\text { Música } \\
\text { instrumental } \\
\text { para orquesta y } \\
\text { grupos de cámara }\end{array}$} & I Pleyel \\
\hline & & & & F.J. Haydn \\
\hline Jean Jérôme Imbault & París & $1800-1806$ & $\begin{array}{l}\text { Ópera y Opereta } \\
\text { francesa }\end{array}$ & Ver Tabla 14 \\
\hline Juan Bautista Ricci & Génova & $1818-1819$ & Ópera y ballet & No consta \\
\hline \multirow[t]{2}{*}{ Chez Pacini } & \multirow[t]{2}{*}{ París } & \multirow[t]{2}{*}{1838} & \multirow[t]{2}{*}{ Ópera italiana } & G. Rossini \\
\hline & & & & V. Bellini \\
\hline Maurice Schlesinger & París & 1840 & $\begin{array}{c}\text { Música } \\
\text { instrumental }\end{array}$ & J. Strauss I \\
\hline Tobias Haslinger & Viena & 1840 & $\begin{array}{c}\text { Música } \\
\text { instrumental }\end{array}$ & J. Strauss I \\
\hline
\end{tabular}

El editor, impresor y almacenista de libros Gabriel de Sancha (*1746$\dagger 1820$ ), hijo y sucesor del conocido editor y encuadernador Antonio de Sancha, fue uno de los proveedores españoles de música de la Casa de Benavente-Osuna. El establecimiento de la familia Sancha era uno de los lugares de Madrid en los que se podía adquirir las novedades musicales de los principales compositores 
europeos. $^{15}$. En 1790, Rafael García violinista de la orquesta y "encargado de la custodia de los papeles de música de la Condesa-Duquesa de Benavente"16 adquirió en el almacén de Gabriel de Sancha varias partituras de música instrumental. Este lote, destinado seguramente a su interpretación por los músicos asalariados de la Condesa-Duquesa de Benavente, estaba compuesto por 2 sinfonías, 21 cuartetos y 6 quintetos de [Ignace] Pleyel y tres cuartetos de [Franz Joseph] Haydn ${ }^{17}$

Uno de los proveedores de música más importantes de la Casa de Benavente-Osuna durante la primera década del siglo XIX fue el francés Jean Jérôme Imbault $(* 1753-\uparrow 1832)$. Este violinista, editor y distribuidor de música, era el propietario de un próspero negocio de edición musical en Francia que dirigió desde las últimas décadas finales del siglo XVIII hasta 1812, fecha en que vendió su empresa ${ }^{18}$. La Condesa-Duquesa de Benavente debió de conocer la empresa de Imbault durante su residencia en París en el año 1799. Tras el regreso a España de los Duques de Osuna a principios del año 1800, Imbault comenzó a enviar periódicamente a Madrid las partituras, libretos y partes instrumentales y vocales de óperas y operetas francesas (opéra comique) e italianas que la Condesa-Duquesa le solicitaba. Esta relación comercial se extendió al menos

\footnotetext{
15 Miguel Ángel Marín, "Music Selling in Boccherini's Madrid", Early Music, XXXIII/ 2 (2005), p. 169.

${ }^{16}$ AHN NOBLEZA OSUNA-CARTAS leg 387-7.

17 Ibíd.,leg 387-7 y leg 417. El pago de la cuenta no se verificó hasta febrero de 1794. Sobre Antonio de Sancha véase Antonio de Sancha, 1720-1790, reinventor de lecturas y hacedor de libros, (Madrid: Calcografía Nacional, 1997)

18 Sobre este editor personaje véase Rita Benton, “Imbault, Jean-Jérôme”, NG, vol. 10, pp. 87-88.
} 
hasta $1806^{19}$. Los pedidos de música de la Condesa-Duquesa eran remitidos por Imbault hasta la frontera de Bayona. Desde allí personaje llamado Jean Julian se encargaba de enviarlos a Madrid. El pago se verificaba a través de letras de cambio.

Jean Jerôme Imbault mantenía informada a la Condesa-Duquesa de las nuevas partituras de ópera, impresas o manuscritas, que se editaban o estaban a la venta en su negocio parisino. En 1801, Imbault notificó a la Condesa-Duquesa la inminente aparición de su edición de la ópera Il Matrimonio Secreto de Domenico Cimarosa:

Je gravé maintenant la partition de Matrimonio Secreto, musique de Cimarosa, paroles italiennes et françaises, elle sera prête dans un mois. Il n'y a pas d'autres nouveautés dans le moment ${ }^{20}$.

En algunas ocasiones los materiales musicales que solicitaba la CondesaDuquesa no se habían impreso aún e Imbault, para complacer a su cliente, se encargaba de pedir los originales a los propios autores o de buscarlos en alguna de las bibliotecas públicas parisinas para realizar las copias manuscritas que se enviaban a Madrid:

\footnotetext{
${ }^{19}$ AHN NOBLEZA OSUNA-CARTAS leg 274-2, leg 392-41. Todos los datos y documentos que se presentan a continuación proceden de las correspondencia entre Jerome Imbault y la CondesaDuquesa de Benavente. El primer documento que he hallado, es una carta fechada el 25 de abril de 1801 pero hace referencia a un pedido realizado varios meses antes, probablemente a finales de 1800. La última es de febrero de 1806.

${ }^{20}$ AHN NOBLEZA OSUNA-CARTAS leg 274-2. [Mi traducción]: "Recientemente he grabado la partitura del Matrimonio Secreto, música de Cimarosa, texto italiano y francés, y estará disponible en un mes. Por el momento no hay más novedades".
} 
Madame

J'ai l'honneur de vous prévenir que j'ai adresse ce jour par la diligence a Monsieur Jean Julian Dab[..] n l'aîné á Bayonne une caisse contenant les articles que vous avais demandés et sout la note est- ci joute.

Observations

La partition des Promesses de Mariage n'existe plus, j'ai pût retrouver que 1'exemplaire qui j'ai l'honneur de vous envoyer et pour le compléter il a fallu avoir recours a la bibliothèque du Roy .

La partition des curieux punis n'existe plu. J'ai en beaucoup de recherches à faire pour me procurer l'exemplaire que vous recevrais. La totalité des paroles dans la partition il n'y a plus de poème.

Les 2 hermites, ne faut no gravés, ni imprimes, il faut s'adresser aux auteurs pour les faire copier.

Le 30 et 40 est dans le même cas.

Elisca ou l'amour maternel n'est pas gravée, il faut demander une copie a 1'auteur. Vous avis le poème la Petite Nanette de même

Montano et Stephanie n'a pas de poème a part, mais il est dans la partition

Nourjahad et Chéredin espèce de pantomime, il n'y a rien d'imprimé il faut faire copier.

La belle fermière, il faut faire copier les morceaux de chant. Blanche et Moucasin se vend chez l'auteur, mais il est a la campagne et l'on $\mathrm{n}^{\prime \prime}$ a pas pu en avoir en son absence. Le reste de votre commande, Madame, est entièrement conforme a vos ordres, $j^{\prime}$ aurais pû copier les articles qui manquent. mais outre que cela aurait considérablement retardé votre envoi.

J'ai crû devoir attendre vos ordres ultérieurs; les frais de copie de ce genre surpassant de beaucoup, aux de la gravure.

J'ai l'honneur d'être avec le plus profond respect.

Madame. Votre très humble et très obéissent serviteur

Imbault. Ce 11 Auguste $1801^{21}$

${ }^{21}$ AHN NOBLEZA OSUNA-CARTAS leg 274-2. 
[Mi traducción]:

Estimada Señora.

Tengo el honor de anunciaros que hoy mismo os he enviado por diligencia a través del señor Jean Julian Dab[...] n el viejo, de Bayona una caja que contiene los artículos que me habíais solicitado según la nota adjunta.

Observaciones.

La partitura de Promesses de Mariage está agotada, he podido conseguir el ejemplar que os he enviado y para completarlo ha sido necesario recurrir a la Biblioteca del Rey.

La partitura de Curieux Punis está agotada y después de muchas investigaciones he podido conseguir el ejemplar que recibiréis. Todo el texto está en la partitura y no hay libreto.

Les 2 hermites, no está grabado, ni impreso, y hay que dirigirse a los autores para hacer una copia. El 30 y 40 está en el mismo caso.

Elisca ou l'amour maternel no está grabado y debe solicitarse una copia al autor.

De Montano et Stephanie no hay libreto separado, pero está todo el texto en la partitura. Nourjahad et Chéredin especie de pantomima, no está impreso y hay que mandarlo copiar.

De La belle fermière, deben copiarse las piezas de canto. Blanche et Moucasin se vende en casa del autor, pero él se encuentra en el campo y no se ha podido conseguir en su ausencia. El resto de vuestro encargo, Señora, está todo conforme a vuestras órdenes. Podía haber hecho copiar los artículos que faltaban, pero esto hubiera retrasado mucho vuestro envío. He preferido esperar vuestras órdenes, pues los gastos de este tipo de copias son mayores que los de su grabado. Tengo el honor de mostraros mi más profundo respeto. Señora-. Vuestro más humilde y obediente servidor.

Imbault, 11 de agosto de 1801.

En mayo de 1805, junto con la partitura y las partes de la ópera $L$ 'Intrigue aux fenêtres de Nicolo Isouard, Imbault envió a la Condesa-Duquesa un catálogo y una nota en la que incluía las nuevas óperas francesas que vendía en su tienda. La Condesa-Duquesa encargó las partituras de todas las óperas que Imbault le 
había ofrecido, especificando que no le fuesen enviadas "las partes separadas", probablemente porque encarecían notablemente el envío y su copia podía realizarse con facilidad en Madrid si era preciso.

En los encargos que la Condesa-Duquesa realizó a Imbault predominan las óperas cómicas en francés, género que vivió su máximo apogeo en Madrid a partir del año 1800. La Real Orden de 1799, que se prolongó hasta enero de 1808, prohibió la interpretación de obras teatrales en otro idioma distinto al español, y obligó a que éstas fueran interpretadas por actores y actrices españoles o residentes en España. La escasez de un repertorio nuevo de teatro musical en español propició la realización de adaptaciones musicales y literarias de óperas cómicas francesas que se presentaron en traducción española en los teatros públicos de Madrid ${ }^{22}$.

La Condesa-Duquesa María Josefa debió de conocer el género de la Opéra Comique francesa durante su residencia en París en 1799, y es posible que a su regreso a España en 1800 influyera en la programación de este repertorio en el Teatro de los Caños del Peral de Madrid, que desde los primeros años del siglo XIX estaba dirigido por el violinista y empresario Melchor Ronzi, uno de los músicos que gozaba de su protección ${ }^{23}$. Al menos seis de las óperas que fueron encargadas por la Condesa-Duquesa a Imbault se estrenaron en versión española

\footnotetext{
22 Emilio Cotarelo y Mori, Historia de la zarzuela, o sea el drama lírico en España, desde su origen a finales del siglo XIX (Madrid: Tipografía de Archivos, 1934), p.158. Cotarelo recoge los títulos en castellano de varias de estas óperas francesas que se pusieron en escena en el Teatro de los Caños del Peral de Madrid a partir de 1800 pero no precisa la fecha concreta de su presentación. Véase también Luis Carmena y Millán, Crónica de la Ópera Italiana en Madrid desde 1738 hasta nuestros días, (Madrid: Manuel Minuesa de los Ríos, 1878), pp. 39 a 45

23 Para la biografía de Melchor Ronzi véase el Apéndice 5.
} 
en el Teatro de los Caños del Peral poco después del envío de sus materiales musicales y literarios desde París (Tabla 13) ${ }^{24}$.

Los pedidos de música a proveedores de Europa continuaron siendo habituales tras la muerte de la XV Condesa-Duquesa de Benavente. Durante la titularidad de su nieto Pedro de Alcantara II, XI Duque de Osuna, los fondos musicales de la unificada Casa de Benavente-Osuna se incrementaron con la compra de partituras de óperas y música instrumental a varios proveedores de París y Viena. En 1838, el Duque adquirió al editor Pacini de París las partituras de las óperas Il Maometto, Guillermo Tell y La Donna del lago de Gioacchino Rossini y la de I Puritani de Vicenzo Bellini ${ }^{25}$ En 1840, el editor Maurice Schlesinger de París sirvió a la Casa de Benavente-Osuna un pedido de música para orquesta que incluía 6 valses "de Strauss", y otras 7 obras o juegos de obras instrumentales entre los cuales figura una sinfonía para orquesta y otras obras de autor anónimo que a tenor de sus títulos (Le comique, Le lion o l'enfant trouve) pudieron haber sido piezas características de baile ${ }^{26}$. En este mismo año de 1840 la editorial Haslinger de Viena envió al Duque de Osuna un lote con varios álbumes de valses para orquesta de Johann Strauss I que posiblemente escucharon por primera vez en España en los bailes de sociedad organizados que este noble organizaba en sus palacios de Madrid $^{27}$.

\footnotetext{
${ }^{24}$ No es posible identificar todos los títulos de las óperas francesas que se estrenaron en Madrid en dicho período con las enviadas por Imbault, puesto que era habitual que las adaptaciones en castellano se presentasen con otros títulos diferentes.

${ }^{25}$ AHN NOBLEZA OSUNA-CARTAS 392-22.

${ }^{26}$ Ibid.

${ }^{27}$ Ibíd.
} 
Tabla 13.

Óperas francesas e italianas encargadas por la Condesa-Duquesa de Benavente al editor y almacenista de música de París Jean Jerome Imbault (1801-1806)

Fuentes: AHN NOBLEZA, OSUNA-CARTAS, leg 274-2; Carmena y Millán, Crónica de la Ópera Italiana en Madrid; Cotarelo y Mori, Isidoro Maíquez y el teatro de su tiempo ${ }^{28}$.

\begin{tabular}{|c|c|c|c|}
\hline $\begin{array}{l}\text { AÑO } \\
\text { ENCARGO }\end{array}$ & TÍTULO & COMPOSITOR & $\begin{array}{l}\text { REPRESENTACIÖN } \\
\text { EN LOS CAÑOS DEL } \\
\text { PERAL DE MADRID }\end{array}$ \\
\hline 1801 & Ariodant & [Étienne Méhul] & \\
\hline 1801 & L'Erato & No consta & \\
\hline 1801 & Médée la plus belle & [Luigi] Cherubini & 1801 \\
\hline 1801 & Zoé [ou la Pauvre petite] & [Plantade] & \\
\hline 1805 & Aline & [Henri] Berton & \\
\hline 1805 & $\begin{array}{l}\text { Anacréon ou l'amour } \\
\text { fugitif }\end{array}$ & [Luigi ]Cherubini & \\
\hline 1805 & Cigisbe & [Nicolo] Piccini & \\
\hline 1801 & Jockey & No consta & A partir de 1800 \\
\hline 1805 & L'Amour Romanesque & [Joseph]Wöelfl & \\
\hline 1805 & $\begin{array}{l}L \text { 'habit du Chevalier de } \\
\text { Gramont }\end{array}$ & Cler & \\
\hline 1805 & L'Intrigue aux fenêtres & [Nicolo Isouard] & 10 de abril de 1806 \\
\hline 1805 & La Boucle de cheveux & $\begin{array}{l}\text { [Nicolas-Marie] } \\
\text { Dalayrac }\end{array}$ & \\
\hline 1805 & La Romance & [Henri] Berton & \\
\hline 1805 & Le Bouffe et le Tailleur & [Pierre]Gaveaux & \\
\hline 1805 & Le diable en vacance & [Pierre]Gaveaux & \\
\hline 1805 & Le Jeune prude & $\begin{array}{l}\text { [Nicolas-Marie] } \\
\text { Dalayrac }\end{array}$ & \\
\hline 1805 & Le Médecin Turc & Nicolo Isouar[d] & 14 de abril de 1805 \\
\hline 1805 & Le Petit Page & $\begin{array}{l}\text { [Rodolphe] } \\
\text { Kreutzer- Nicolo } \\
\text { [Isouard] }\end{array}$ & \\
\hline 1805 & Milton & $\begin{array}{l}\text { [Gaspare] } \\
\text { Spontini }\end{array}$ & 4 de noviembre de 1805 \\
\hline 1805 & Ossian ou les Bardes & $\begin{array}{l}\text { [Jean-François] } \\
\text { Lesueur }\end{array}$ & \\
\hline 1805 & $\begin{array}{l}\text { Un quart d'heure de } \\
\text { silence. }\end{array}$ & [Pierre]Gaveaux & 30 de mayo de 1806 \\
\hline 1805 & Vivat in aeternum & L. Rose & \\
\hline
\end{tabular}

${ }^{28}$ Todos los datos que figuran en esta tabla proceden del citado legajo del archivo administrativo de la Casa de Osuna a excepción de las fechas de las representaciones que he tomado de las citadas obras de Cotarelo y Mori y Carmena y Millán. 


\subsubsection{Copias de música}

Los numerosos recibos y cuentas de gastos por copias de música que se conservan en la documentación administrativa de la Casa de Osuna muestran la importancia que tuvo la copia musical manuscrita para la ampliación del repertorio musical en las Casas de Osuna y Benavente durante todo el siglo XVIII y una buena parte del siglo XIX. Las copias que se efectuaban solían tener como objetivo la reproducción de las partituras o la realización de las partes instrumentales o vocales tanto para su interpretación como para su conservación en los archivos musicales de la familia. La copia manuscrita sirvió también en ocasiones para realizar recopilaciones o antologías de un género determinados como el Libro de arias y cantatas italianas de la Duquesa de Osuna que se elaboró en la primera mitad del siglo XVIII ${ }^{29}$.

A lo largo de todo el siglo XVIII numerosos copistas musicales colaboraron con las Casas de Osuna y Benavente. Uno de los más importantes parece haber sido el violinista Salvador Feixas que aparece con frecuencia como copista en la documentación administrativa de la Casa de Benavente en las dos últimas décadas del siglo XVIII y en los primeros años del XIX. Su colaboración coincidió con el período de funcionamiento de la orquesta de la Condesa-Duquesa de Benavente (1781-1792) por lo que la mayor parte de las obras copiadas por Feixas en estos años fueron piezas instrumentales o arias con acompañamiento de orquesta. Por ejemplo en 1786, Feixas copió varias sinfonías y obras de cámara principalmente de autores que trabajaban para la Casa de Benavente como Luigi

${ }^{29}$ BNE M-2245. Sobre esta colección véase el Capítulo VII . 
Boccherini o Ramón Rodríguez Monroy, o que mantenían relaciones contractuales con la Condesa-Duquesa, como Joseph Haydn (Tabla 14).

Tabla 14

Música copiada por Salvador Feixas

para la Casa de Benavente en 1786

Fuente: AHN NOBLEZA OSUNA-CARTAS legs. 389-22; 391-21; 414.

\begin{tabular}{|c|c|c|}
\hline AUTOR & OBRA & OBSERVACIONES \\
\hline ¿Ansani, [Giovanni]? & Aria & $\begin{array}{l}\text { El tenor Giovanni Ansani fue } \\
\text { posiblemente el intérprete y } \\
\text { no el compositor de las } \\
\text { obras. Se conservan otros } \\
\text { pagos por copias de música } \\
\text { realizadas para sus } \\
\text { actuaciones }\end{array}$ \\
\hline Aspelmayer, [Franz] & Minuetes y contradanzas & Se copiaron "duplicados" \\
\hline \multirow{6}{*}{ Boccherini, [Luigi] } & Concierto de todos instrumentos & \\
\hline & Seis Sinfonías & Fechadas en el año 1782 \\
\hline & Minuetes & \\
\hline & Sinfonía cuarta & \\
\hline & Sinfonía quinta & \\
\hline & Sinfonía sexta & $\begin{array}{l}\text { Se copiaron "duplicados" a } \\
\text { partir de la partitura impresa }\end{array}$ \\
\hline \multirow{5}{*}{ Haydn, [Franz Joseph] } & Dos Divertimentos de clave & \\
\hline & Dos Sinfonías nuevas & $\begin{array}{l}\text { Se copió la partitura "con sus } \\
\text { duplicados" }\end{array}$ \\
\hline & Minuetes & Se copiaron "duplicados" \\
\hline & Dos Sinfonías nuevas & \\
\hline & Seis trios con flauta & \\
\hline \multirow{4}{*}{$\begin{array}{l}\text { Monroy [Ramón Rodríguez] } \\
\text { ] }\end{array}$} & Contradanzas & \\
\hline & Sinfonía cuarta & \\
\hline & Sinfonía quinta & \\
\hline & Sinfonía sexta & Se copiaron "duplicados" \\
\hline Ponzo [Giuseppe] & Dos Quintetos & \\
\hline [No consta] & Tres arias & "Con sus duplicados" \\
\hline [No consta] & Rondó se da voi non discaciata & $\begin{array}{l}\text { Se copiaron las partes } \\
\text { instrumentales }\end{array}$ \\
\hline
\end{tabular}

30 BNE Mss.14016.3/192 (Papeles Barbieri). Pago a Conrado Appenceller fechado el 2 de julio de 1787 por tres arias, una escena, un dueto y un terceto la música que se copiaron para la "función cuando cantó el Señor Ansani con su coñata [cuñada]” 
Gran parte de las obras copiadas por Salvador Feixas que aparecen en la anterior se incorporaron al archivo musical de la Condesa-Duquesa de Benavente y aparecen recogidas en los inventarios de dicho archivo realizados en $1824 \mathrm{y}$ ca. $1838^{31}$.

\subsection{Inventarios de los archivos y bibliotecas de las Casas de Osuna y Benavente}

La intensa actividad de mecenazgo musical que llevaron a cabo los miembros de las familias Osuna y Benavente dio lugar a formación de varios archivos de música que, a la luz de la documentación consultada, parecen haber tenido su momento de mayor esplendor en las dos últimas décadas del siglo XVIII y en las tres primeras del XIX, coincidiendo con la titularidad de María Josefa Pimentel en la Casa de Benavente y de su marido Pedro de Alcántara en la Casa de Osuna.

Los contenidos de los fondos que formaron parte de los archivos de las Casas de Osuna y Benavente durante los siglos XVIII y XIX pueden reconstruirse parcialmente a través de varios inventarios, catálogos y documentos de copia de música, que han llegado a nuestros días y a cuyo estudio dedico los siguientes apartados.

\footnotetext{
${ }^{31}$ Ver Apéndices 3 y 4.
} 


\subsubsection{Materiales musicales propiedad de las Casas de Osuna y Benavente hasta 1781}

La primera referencia que he podido documentar sobre la existencia de un archivo propiedad de los miembros de las Casas de Osuna o Benavente es de 1791, cuando se realizó el primer inventario de la papelera de música de María Josefa Alfonso Pimentel, XV Condesa-Duquesa de Benavente ${ }^{32}$. Sin embargo, dada la importante actividad musical doméstica que se desarrolló en el entorno de las Casas de Osuna y Benavente durante todo el siglo XVIII (a cargo de los miembros de ambas familias y sus allegados, de los músicos de la Casa o de otros músicos contratados), es probable que antes de dicho año ya existiera en las residencias de ambas familias un archivo de música o al menos un armario para guardar los materiales musicales que se copiaron en esta época.

Entre 1721 y 1733, José Téllez Girón, VII Duque de Osuna, ordenó realizar "para su casa" varias copias de las zarzuelas y óperas que se representaron en los teatros de Madrid, lo que sugiere la existencia de un mínimo archivo de música que sería utilizado por su capilla musical ${ }^{33}$. Su hija, María Faustina Téllez Girón, futura esposa del XIV Conde-Duque de Benavente, fue propietaria desde su juventud de varios libros de música que utilizó para su aprendizaje y probablemente también para la práctica musical doméstica. En 1743 su maestro de canto Giovanni Battista Mele, le proporcionó varios "libros de música [...] para estudiar" ${ }^{\text {34 }}$. Años más tarde la Condesa-Duquesa María Faustina poseía cuatro

\footnotetext{
32 AHN NOBLEZA, OSUNA-CARTAS, leg 392-15. Ver Apéndice 3, registro [3/363].

33 AHN NOBLEZA, OSUNA-CARTAS, 413-40.

${ }^{34}$ Ibid., leg 389-11.
} 
libros de música que contenían "diversas arias e instrumentos” y que habían sido un regalo de [Giovanni] Manzuoli, famoso soprano castrato de fama internacional que trabajó en los teatros de Madrid entre 1749 y $1754^{35}$. Estos libros, de los cuales no se tiene constancia de su conservación en la actualidad, debían de contener música de estimable valor, pues en 1754 la Condesa-Duquesa encargó realizar una lujosa copia encuadernada al estilo de la "Real Música de Cámara" para regalársela a la hija un Ministro de Castilla apellidado Adorno:

\section{Señor Andrés Merlo}

Participo a Vuestra merced de orden de la Condesa, y de cuenta del Conde mi Señor, y para hacer un regalo a un señorita, hija de uno de los Señores Ministros de Castilla, se han mandado copiar los cuatro libros de Música que Su Excelencia tiene, y le regalo Manzoli, con diversas arias e instrumentos; los cuales han tenido un coste de ochocientos ochenta y cuatro reales de vellón en esta manera, sesenta reales por el papel fino de marca mayor. Los cuatrocientos sesenta y cuatro pagados a Don Nicolás de San Andrés por copiar los cincuenta y ocho pliegos útiles de música, según y como los libros de la Real Música de Cámara, y sesenta a Alfonso de Fuente el Saz, encuadernador de libros, por los cuatro que a encuadernado en pasta con tafilete encarnado, dorados y floreteado, a razón de noventa reales cada uno, de cuya cantidad se servirá Vuestra Merced providenciar el libramiento correspondiente. Madrid, 11 de Marzo de 1754

Ignacio Berdún de Espinosa [rúbrica] ${ }^{36}$

\footnotetext{
${ }^{35}$ El castrato florentino Giovanni Manzuoli, (ca. 1720- 1782) fue uno de los principales cantantes de la escena europea en las décadas de los 50 a 70 del siglo XVIII. Trabajó en varias funciones operísticas de Madrid entre 1749 y 1754, y en las representaciones cortesanas organizadas por Farinelli. Sobre Manzuoli véase Emilio Cotarelo y Mori, Orígenes y establecimiento de la Ópera en España hasta 1800, (Madrid: Tipografía de la Revista de Archivos, Bibliotecas y Museos, 1917), especialmente las pp. 140-142 y Kathleen Kuzmick Hansell, "Manzuoli, Giovanni” NG, vol 15, pp.792-793.

36 AHN NOBLEZA, OSUNA-CARTAS, leg 389-27.
} 
María Faustina Téllez Girón encargó frecuentemente la realización de numerosas copias de arias y música italiana para su uso personal que, seguramente se conservaron en las dependencias de su palacio. Un ejemplo de la gran cantidad de copias manuscritas que tuvo la Condesa- Duquesa María Faustina puede verse en la relación que el copista de música José Alaguero presentó en 1763 para requerir el pago de "diferentes arias y otras obras de música" que había encargado copiar esta dama para su uso personal. En dicha relación figuraban los títulos de más de sesenta arias y otras piezas vocales en italiano, la mayoría de ellas anónimas y otras de [Nicolo] Piccinni y Francesco di Majo (Ver Lámina 20) ${ }^{37}$.

Pedro Zoilo Téllez-Girón, VIII Duque de Osuna, y hermano de la Condesa-Duquesa María Faustina, también ordenó realizar en diversas ocasiones copias de varias obras musicales que se estrenaban en los teatros de Madrid, bien para su uso personal o para el de sus músicos, y que probablemente se guardasen en las dependencias de su palacio de Madrid. En 1766, el Duque de Osuna encargó a Pablo Esteve, su maestro de capilla y compositor, la copia de la ópera El Bobo de Antona (con música original de Tommaso Traetta y libreto de Carlo Goldoni) que se había estrenado en ese mismo año en Madrid ${ }^{38}$

\footnotetext{
${ }^{37}$ AHN NOBLEZA, OSUNA-CARTAS, leg 389-27. No es posible precisar el número exacto de obras que aparecen en esta relación, pues varios títulos están repetidos, y podrían corresponder tanto a obras diferentes con el mismo título como a copias de la misma obra.

${ }^{38}$ AHN NOBLEZA, OSUNA-CARTAS, leg 452.
} 


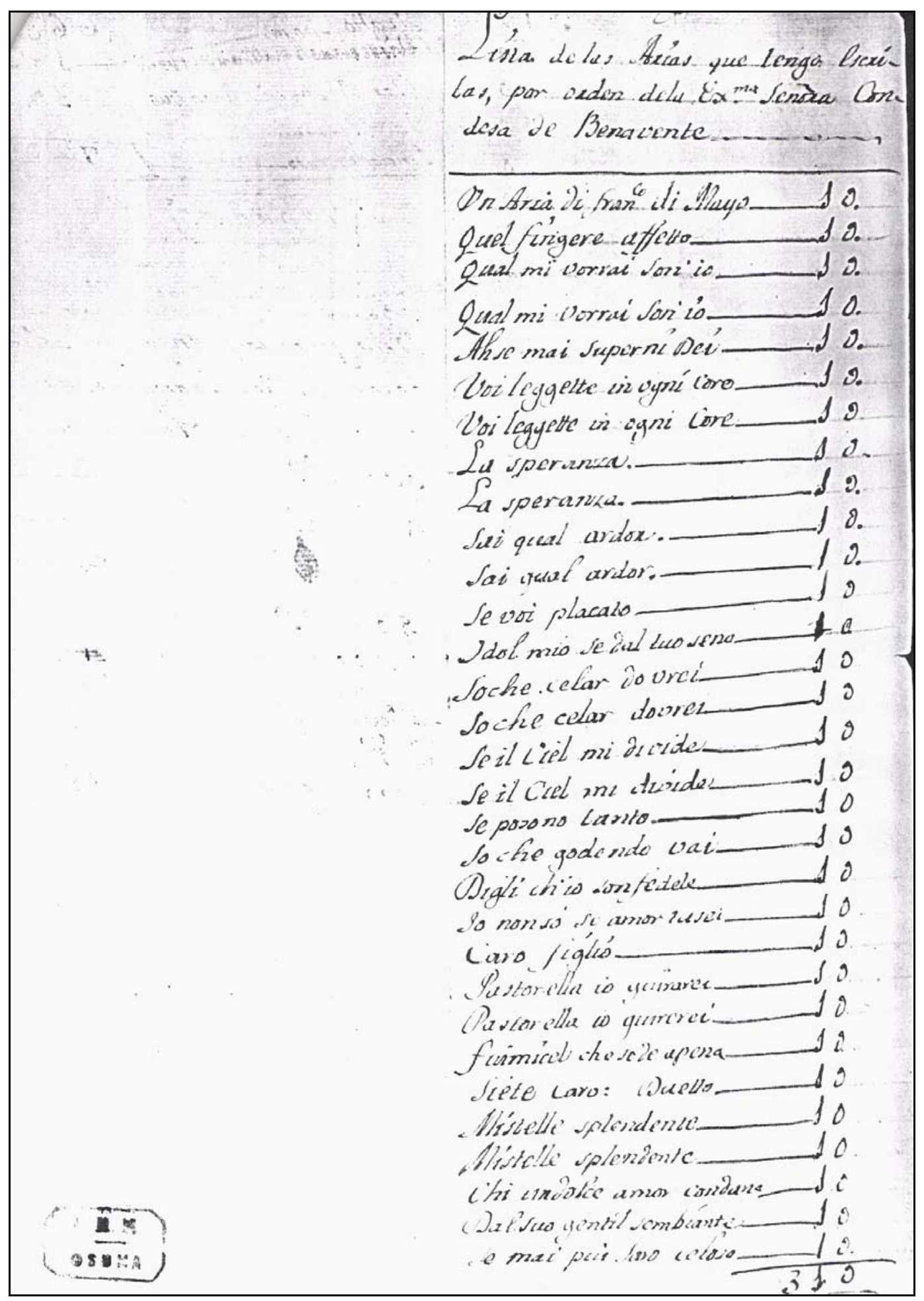

Lámina 20.

Primera página de la relación de arias copiadas por José Alagueró

para María Faustina Téllez Girón (1763)

AHN NOBLEZA OSUNA, CARTAS, leg 389-27. 
Otro ejemplo de las copias de música que se realizaron para el VIII Duque de Osuna figura en un documento de pago fechado en 1782, por el que Manuel de León cobró 194 reales por las copias de cinco piezas de música teatral “intituladas: La Buena Esposa, Efectos de la Virtud y consecuencias del Vicio, El Amor filial , La Matilde y la Zarzuela el Puerto de Flandes con su música”39.

\subsubsection{La papelera de música de la XV Condesa-Duquesa de Benavente. Los inventarios de 1824 y ca. 1838}

La XV Condesa-Duquesa de Benavente María Josefa Alonso Pimentel fue la propietaria del primer archivo musical de las Casas de Osuna y Benavente del cual poseemos una amplia información. Este archivo o "papelera de música" ya estaba organizado en 1791, cuando se elaboró un Índice de la papelera de música de la Excelentísima Señora Duquesa de Osuna cuyo paradero se desconoce en la actualidad, pero que aparece citado dentro del inventario que se realizó en $1824^{40}$. Este último documento titulado "Índice de las obras custodiadas en dos armarios que componen la papelera de Música vocal e instrumental de la Excelentísima Señora Duquesa Condesa [sic] de Benavente. Año de 1824” (Lámina 21) fue publicado en francés por Nicolás A. Solar Quintés e Yves Geràrd en 1963, en una versión resumida, que contiene diversos errores y omite muchos de los datos que

\footnotetext{
${ }^{39}$ Ibid., leg 414-8.

40 Ibíd., leg 392-15. María Josefa Alfonso Pimentel utilizó también el título de Duquesa de Osuna desde 1787 cuando su marido Pedro de Alcántara heredó dicho título a la muerte de su padre, aunque en ningún momento llegó a ser titular de esta Casa.
} 
contiene el original ${ }^{41}$. En el Apéndice 3 presento una transcripción íntegra y ordenada de este documento.

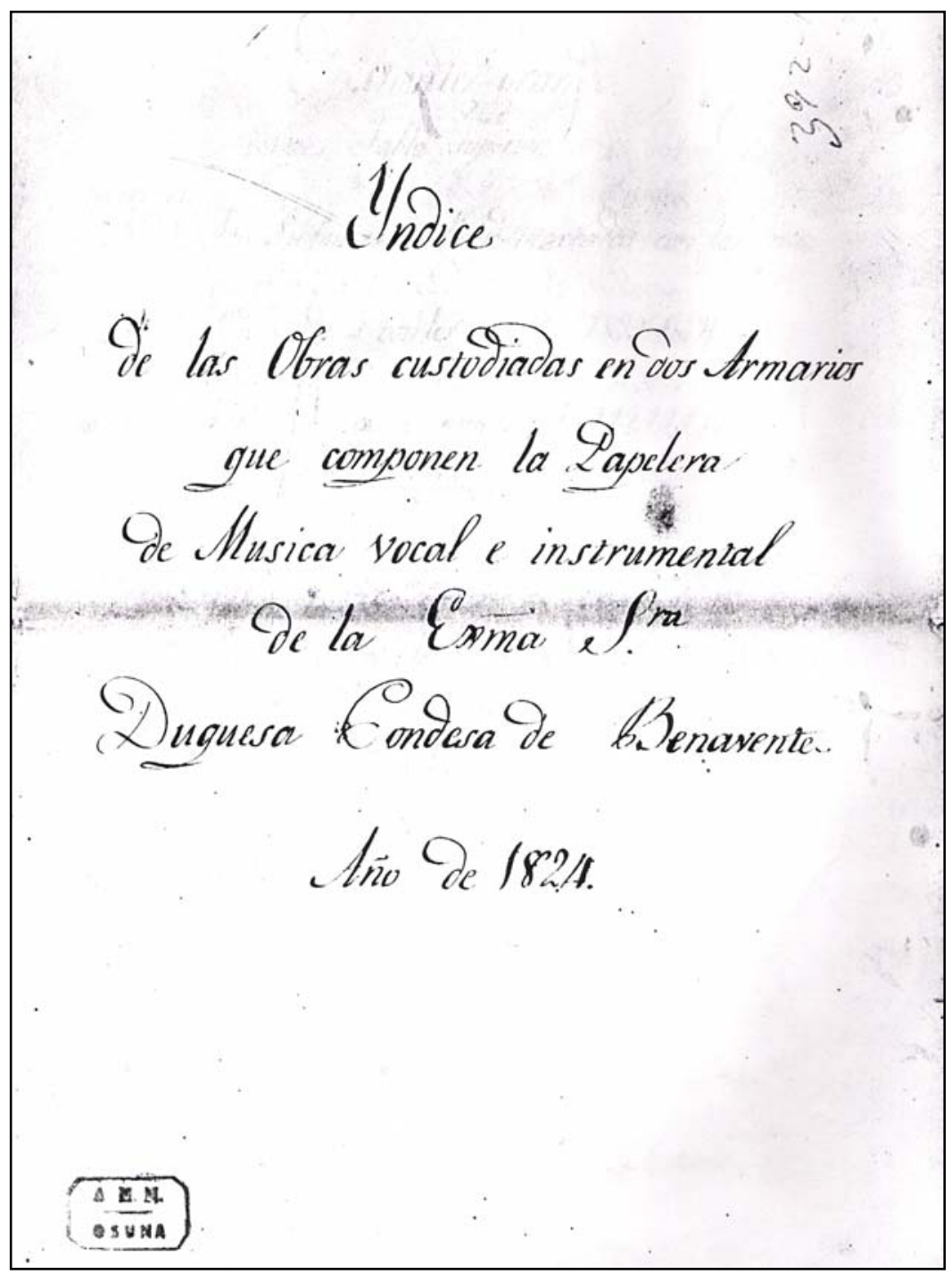

\section{Lámina 21.}

Portada del Inventario del archivo de música de la XV Condesa-Duquesa de Benavente (1824)

AHN NOBLEZA, OSUNA-CARTAS, leg 392-15.

${ }^{41}$ SOLAR-QUINTES, Nicolás, A y GÉRARD, Yves: "La bibliothèque musicale d'un amateur éclairé de Madrid: La Duchesse-Comtesse de Benavente, Duchesse de Ossuna (1752-1834) , en: Recherches sur la Musique française classique, III, 1963, Picard, Paris, pp.179-188. 
Por el inventario de 1824 sabemos que el archivo de música de la Condesa-Duquesa estaba ubicado en dos armarios con varios estantes y cajones que se debían de conservar en las dependencias del Palacio de la Puerta de la Vega de Madrid. Los materiales se guardaban agrupados en legajos y libros, algunos de ellos encuadernados lujosamente ${ }^{42}$, y estaban colocados en diversos estantes (Lámina 22). La música religiosa se conservaba en un cajón aparte separada de la vocal profana y de la instrumental.

La música que se conservaba en el archivo de la Condesa Duquesa es el reflejo de la actividad de mecenazgo y la práctica musical doméstica de las familias Osuna y Benavente desde ca. 1780 hasta la muerte de la CondesaDuquesa en 1834.

La música instrumental de este fondo constituyó la base del repertorio de las orquestas y grupos de cámara mantenidos por la Casa de Benavente-Osuna en las últimas décadas del siglo XVIII y de los conjuntos contratados para las fiestas y academias organizadas por los miembros de la Casa de Benavente en las primeras décadas del siglo $\mathrm{XIX}^{43}$.

42 AHN NOBLEZA, OSUNA-CARTAS, leg 418-1. Gastos por encuadernaciones de libros de música hechos para la Condesa- Duquesa de Benavente en 1804 y 1827.

${ }^{43}$ Véase Capítulo VII. 
lepajos.

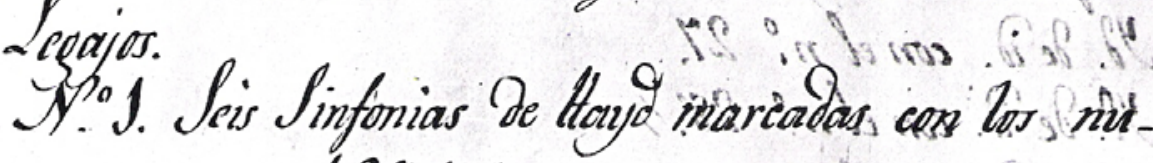
meros 1.2.3. A.5.6.

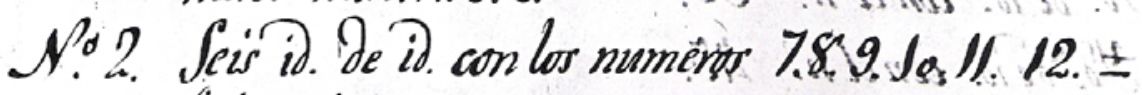
faltan lov 9. Jo.'12.

M. 3. Seis 2. de id. con los numeros 13.14.15:16.1\%18.

N. 4. Seis id de id con los numeros 19.20.21.22.23.2\%= faltan la 20. 21: 22.

H. G. Seis id de id con los mumens 31.32.33.341.35.36= faltan 20.35 .36

N. F. Seis id de id con lo numperos 37.38.39.410.111. $112=$

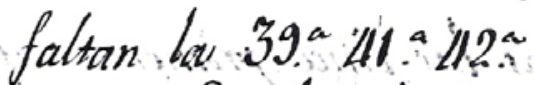

No. Jo. Seis -id. De Kuzeluich.

No II. Seis id. De Monroy.

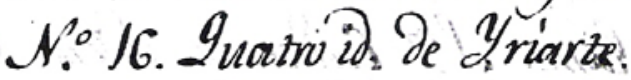

Y.' 2. Seis Q quartettor de Hailont.

S. $31 . D_{0}$ id. . de 2 .

Y.: Ht. Seis id. De Huber.

N. 13 . Sais id. De Hay orn.

No 116 . Seis Frive Yé Haydn.

No 5a. Cinco Quintettos de 20 ongo,

Lcajo sin m." Minnetes y Contraldes de varios Atutores.

Lámina 22.

Primera página del Inventario del archivo de música de la XV Condesa-Duquesa de Benavente (1824)

AHN NOBLEZA, OSUNA-CARTAS, leg 392-15. 
La música religiosa procedía en su gran mayoría de las funciones de Iglesia patrocinadas por la Condesa-Duquesa de Benavente y su familia, y la música teatral está relacionada, básicamente, con la labor del mecenazgo de espectáculos teatrales (públicos o privados) que desarrollaron los miembros de ambas familias en la segunda mitad del siglo XVIII y en las primeras décadas del siglo XIX ${ }^{44}$.

Hacia 1838 se realizó un segundo inventario de la que fue la papelera de música de la Condesa-Duquesa de Benavente. La fecha concreta de redacción de este inventario no puede conocerse con certeza, pues aunque está realizado en varios pliegos de papel timbrado oficial que llevan un "sello de pobres" y "el sello de oficio" del año de 1838 correspondiente al reinado de Isabel II, es muy probable que se elaborase en una fecha posterior a dicho año utilizando un papel oficial cuya validez había ya caducado ${ }^{45}$. Este inventario, cuyo contenido se desconocía hasta la fecha, no tiene título y en su realización intervinieron dos copistas diferentes. Su redacción es menos precisa que el inventario de 1824, y se omiten detalles sobre la encuadernación de los libros o la ubicación física de los materiales, por lo que no es posible saber si éstos seguían conservándose en los dos armarios que se citan en el inventario anterior o se habían trasladado a otro lugar. En el Apéndice 3 presento una transcripción íntegra de este documento.

Al menos entre 1792 y 1795, el responsable de este archivo de música o "encargado de la custodia de los papeles de música" fue Rafael García de Sena, instrumentista de viola y violín de la orquesta de la Condesa-Duquesa y miembro

\footnotetext{
${ }^{44}$ Véase Capítulo V.

45 AHN NOBLEZA, OSUNA-CARTAS, leg 392-16.
} 
de la Real Capilla ${ }^{46}$. García de Sena atendía las numerosas peticiones de préstamos de material musical que se hacían a la Condesa-Duquesa y al Duque de Osuna. La riqueza de los fondos del archivo musical de las Casas de Osuna y Benavente era conocida no sólo en el entorno de Madrid, sino en toda España. Los músicos que trabajaban en los estados de los Osuna y Benavente u otras personas vinculadas al servicio de la Casa, solicitaron habitualmente a los IX Duques de Osuna copias de materiales de todos los géneros musicales para interpretarlos en teatros, iglesias o academias privadas como puede observarse en los ejemplos subsiguientes.

En 1792, el bailarín y empresario de ópera Domenico Rossi, solicitó a la Condesa-Duquesa de Benavente el préstamo de la partitura de la “ópera della Molinarella" que [el cantante Esteban] Manzini quería poner en escena" en el Teatro de los Caños del Peral de Madrid. En esta ocasión gracias al archivo musical de la Casa de Benavente se facilitó la producción de una ópera cuyos materiales musicales no debían de ser fáciles de conseguir en España ${ }^{47}$.

La música vocal de cámara que se conservaba en el archivo de la Casa de Benavente fue también solicitada en ocasiones. En 1816 Anselmo Clavijo, maestro de capilla de la localidad de Marchena (Sevilla), escribió a la CondesaDuquesa María Josefa para recordarle que la Duquesa de Abrantes (hija menor de la Condesa-Duquesa), le había ofrecido enviarle una copia de los 24 dúos de

\footnotetext{
${ }^{46}$ Ibid., AHN NOBLEZA, OSUNA-CARTAS, leg 387-7.

${ }^{47}$ Ibíd., leg 392-15. La partitura solicitada fue seguramente la de la ópera la Molinera astuta de Giovanni Paisiello que se representó en este año en el Teatro de los Caños del Peral de Madrid bajo la dirección de Domenico Rossi y el patrocinio de la Asociación de Óperas. Véase Cotarelo, Orígenes, pp. 342-344.
} 
Asioli que tenían en su archivo y que aún no los había recibido. El destino de esta música era su interpretación en la "academia de música" que organizaban en dicha localidad y para la que disponían de "un clave inglés famoso"48.

El repertorio de música religiosa europea que se conservaba en el archivo de la Condesa-Duquesa también era requerido en ocasiones por otros centros musicales de España. En julio de 1803, Francisco Prieto Torres, presbítero Canónigo de la Catedral de Salamanca, que había sido anteriormente capellán del Duque de Osuna, transmitió a éste el deseo de "algunos individuos profesores de música de la Catedral [de Salamanca]" de conseguir varias obras religiosas que poseía la papelera de música del Duque para utilizarlas en las "principales festividades que hace la Capilla de Música de aquella Santa Iglesia"49. En la misma carta, Prieto mostró al Duque su interés por poseer las “misas últimas de Haydn y Pleyel con el Dixit Dominus de tiple y bajo de este último",50

El envío que realizó el Duque de Osuna a Francisco Prieto se verificó en el mes de agosto de 1803. Contenía la copia de una "misa de Haydn" y dos salmos de vísperas, uno de ellos del italiano Giuseppe Gazzaniga. Asimismo, en diciembre de este mismo año, el Duque envió a Salamanca dos misas de

\footnotetext{
48 AHN NOBLEZA, OSUNA-CARTAS, leg 392-10. La localidad de Marchena pertenecía a la Casa de Arcos, uno de los estados andaluces de la Casa de Benavente desde el siglo XVIII. Anselmo Clavijo fue contralto en la catedral de Cádiz entre 1796 y 1798, y ya en 1807 se encontraba en Marchena. Sobre este personaje véase Marcelino Díez Martínez La música en Cádiz, la catedral y su proyección urbana durante el siglo XVIII (Cádiz: Universidad de Cádiz, Servicio de Publicaciones, 2004), vol. 3, p.14.

${ }^{49}$ AHN NOBLEZA, OSUNA-CARTAS, leg 389-5.

${ }^{50}$ Ibid.
} 
[Antonio] Rosetti, y en agosto de 1804, un lote con tres misas de [Ferdinando] P[a]er, [Gaetano Brunetti] y otra de [João Pedro] Almeida ${ }^{51}$.

Francisco Prieto decidió depositar las obras enviadas por el Duque en el Colegio de Música de la Catedral de Salamanca, que se había creado recientemente, y de cuyo funcionamiento da abundante información en una carta dirigida al Duque de Osuna el 11 de enero de 1804. Prieto agradeció al Duque el envío de las misas de Antonio Rosetti y le solicitó su protección para el Colegio:

[...] Unos papeles tan exquisitos, y tan poco comunes como son todos los que tiene la papelera de Vuestra Excelencia merecen un destino que los haga estimables a los profesores de la música; con este objeto he entregado estas dos misas al Colegio de Música que acaba de establecerse en la Catedral de Salamanca para la educación de los jóvenes que se dediquen a la música eclesiástica. Como Vuestra Excelencia es tan amante de esta arte encantadora, y ha protegido tan generosamente a sus profesores, me disimulará benignamente que haga una digresión para informarle de este colegio. Tiene por ahora seis colegiales, rector sacerdote, compositor, y organista; con un pasante de música. A los dos meses cantaron los colegialitos con la Capilla un Psalmo y cantarán un día de estos perfectamente bien el Laudate Pueri Dominum del Maestro Gazániga [sic] que Vuestra Excelencia me dio. Se está formando ahora el Archivo de música de este colegio, y yo como muy interesado en la prosperidad de esta casa para que se entienda el buen gusto desde los principios, deseo ardientemente que dicho archivo está enriquecido con obras magistrales del gusto del día así de instrumental como de vocal. Si Vuestra Excelencia se digna a extender su protección sobre este colegio, se hará sin duda el más interesante en España en esta clase, una protección de esta naturaleza contribuye en los principios a

${ }^{51}$ Ibíd. 
la mayor prosperidad y los individuos de esta casa bendecirán eternamente a Vuestra excelencia, a su piadosa esposa, y amable familia ${ }^{52}$.

La exclusividad de las obras que se conservaban en el archivo de la Condesa-Duquesa llevó también a algunos músicos a solicitar su préstamo para tomarlas como modelo para sus composiciones. En 1795, Juan Moliner, Presbítero y Capellán del Real Convento de la Encarnación de Madrid pidió a la Condesa-Duquesa María Josefa una de las obras de Franz Joseph Haydn que se hallaban en su archivo. Moliner había cantado "varias veces en su casa y en [el Convento de] la Encarnación" el Stabat Mater compuesto por el Conde de Fernán Núñez, y había escrito el texto de "una obrita en verso análoga a la muerte",53. Antes de empezar a componer la música y "para no incurrir en algunos defectos que se incurren por falta de aplicación”, Moliner solicitó la partitura de Orlando y Paladino del Señor Haydn" es decir la ópera o "dramma eroicocómico" Orlando paladino que Joseph Haydn había enviado a la Condesa Duquesa en $1783^{54}$. Seguramente la variedad del pathos de la música y el argumento de esta obra, que alterna pasajes cómicos con otros de intenso patetismo como las arias de Angelica y Medoro del segundo acto, debieron alentar la inspiración de Juan Moliner para la composición de su obra ${ }^{55}$.

\footnotetext{
52 Ibid.

${ }^{53}$ Ibid., leg 387-7

${ }^{54}$ Ibid.

${ }^{55}$ F. J. Haydn, Orlando Paladino dramma eroicomico. K. Geiringer (ed.) (Munich: Duisburg G.. Henle-Verlag, 1972).
} 
Al menos una parte de los fondos que integraron el archivo musical de la XV Condesa-Duquesa de Benavente durante los siglos XVIII y XIX, y que fueron descritos en los inventarios de 1824 y ca. 1838 se dispersaron progresivamente. Varias obras que se conservaban en el archivo en 1824 no se recogen ya en el inventario realizado hacia $1838^{56}$, y es posible que el resto de los materiales se vendiese en las subastas públicas que tuvieron lugar durante el proceso de enajenación del patrimonio de la Casa de Osuna a finales del siglo $\mathrm{XIX}^{57}$. En cualquier caso, la venta debió de ser anterior a 1897, ya que en el catálogo que se realizó en este año para la subasta de los fondos bibliográficos de los Palacios de La Alameda, Aranjuez y Madrid, sólo figuran dos obras que podrían identificarse con las que figuraron en la biblioteca musical de la Condesa-Duquesa de Benavente. Se trata de la partitura de la ópera Il Crociato in Egitto de G. Meyerbeer (en reducción para voz y piano editada por M. Schlesinger) [5/19] y de la versión para piano solo de la ópera de G. Rossini, La donna del lago (editada por la casa Ricordi de Milán) $[5 / 21]^{58}$. No obstante, es bastante probable que los ejemplares que aparecen recogidos en este catálogo sean otros distintos de los que pertenecieron a la Condesa-Duquesa de Benavente.

\footnotetext{
56 Véase el Apéndice 3.

${ }^{57}$ Los actuales titulares de la Casa de Benavente guardan silencio sobre el paradero y la posible venta de fondos musicales de su propiedad durante el siglo XX. En septiembre de 2004 escribí una carta a Ángela María Téllez Girón actual titular de las Casas de Benavente y Osuna solicitándole información sobre la conservación de fondos musicales entre sus propiedades pero no he recIbído respuesta hasta la fecha [noviembre de 2005].

58 De aquí en adelante la numeración que figura junto a las obras musicales hace referencia a los inventarios de los libros de música y partituras de las Casas de Osuna y Benavente que recojo en el Apéndice 3.
} 
En 1989, los autores del Catálogo de Impresos musicales del siglo XVIII de la Biblioteca Nacional plantearon la posibilidad de que parte de las obras musicales impresas del siglo XVIII que se conservan actualmente en la Biblioteca Nacional de España (BNE) procedan del archivo de música de la CondesaDuquesa $^{59}$. Sin embargo, en el inventario que se elaboró en 1886 cuando el Estado español adquirió la Biblioteca de la Casa de Osuna, no se recogen materiales musicales $^{60}$.

La progresiva dispersión del archivo musical de las Casas de Osuna y Benavente debió de poner en manos de particulares una buena parte de sus fondos Algunas obras musicales que pertenecieron al archivo de las Casas de Osuna y Benavente se conservan actualmente en colecciones particulares de miembros de la oligarquía empresarial vasca que han ocultado su posesión y no permiten su consulta a los investigadores. Una anécdota relatada recientemente por el periodista Gregorio Morán da muestra del cuidado que han puesto sus propietarios en que no se difundiera la propiedad y conservación de estos fondos:

Para mí, Boccherini es también una historia personal. Estaba yo pasándolas canutas y tratando de adentrarme en el mundo vasco de Neguri, el de la oligarquía impermeable y decisoria, cuando supe que en una mansión a la vera de Bilbao, una de las grandes familias, ya muy ajadas y sin embargo ricas, tenían a gala con ocasión del fin de año, sacar sus partituras, procedentes de la subasta mítica de la casa Benavente-Osuna, y tocar en familia su música.

59 Catálogo de impresos musicales del s. XVIII en la Biblioteca Nacional (Madrid: Dirección General del Libro y Bibliotecas, 1989), Introducción.

${ }^{60}$ Véase Catálogo alfabético de las obras impresas pertenecientes a la Biblioteca del Duque de Osuna adquiridas en 1886, BNE Ms. 18953. 
Eran dos cuartetos, ambos inéditos, uno de Haydn y el otro de Boccherini, interpretados en una gama de instrumentos de época, incluido un Guarnerius. Después de charlar ampliamente, el patriarca, con un tono capaz de atravesarme allí mismo, me rogó que este fuera un asunto que quedara entre nosotros ${ }^{61}$.

Según Robert Stevenson, "un coleccionista de Bilbao" compró en 1957 seis cuartetos de Mederitsch-Gallus procedentes del archivo de la CondesaDuquesa de Benavente. Stevenson mantiene que dichos cuartetos eran los mismos que figuran en el catálogo de F. J. Haydn dentro de las obras de autoría dudosa, concretamente los que aparecen catalogados como Grupe III. B4, G5, C5. F2, D2, $\mathrm{g} 1)^{62}$. Estos seis cuartetos fueron adquiridos por el financiero vasco Luis Lezama Leguizamón a los herederos de la familia Osuna en los años 50 del pasado siglo ${ }^{63}$.

\subsubsection{Libros de música y partituras de los palacios de los Osuna subastados en 1897}

La llamada Comisión Ejecutiva de obligacionistas de Osuna, encargada de liquidar el patrimonio de la antigua Casa Ducal para hacer frente a sus deudas, subastó en 1897 todo el mobiliario y objetos de valor que aún se conservaban en los palacios madrileños de La Alameda, Aranjuez y Madrid que habían sido propiedad de las familias Osuna y Benavente Con este motivo se editó un

\footnotetext{
61 Gregorio Morán, “El caso Boccherini”, La Vanguardia, 28 de Mayo de 2005, p. 24

62 Robert Stevenson, "Los Contactos de Haydn con el Mundo Ibérico", Revista Musical Chilena, 157 (Enero-Junio 1982), p.18. Las obras que cita Stevenson son los 6 cuartetos que figuran en el catálogo Hoboken como Grupe III (B4, G5, C5. F2, D2, g1).

63 Anthony van Hoboken, J. Haydn, Thematisch-bibliographisches Werkverzeichnis, (Mainz: B. Schott's Schone, 1957-.71), vol. I, p. 458.
} 
catálogo de los libros que en dicha fecha aún permanecían en las dependencias de los palacios madrileños de los Duques de Osuna (Lámina 23). Las obras que figuran en dicho catálogo pertenecían a la biblioteca particular de los titulares de las Casas de Osuna y Benavente, pues se hallaban ubicadas en un lugar distinto al de la llamada "Biblioteca del Duque de Osuna" que estuvo abierta al público en la calle Leganitos y cuyo fondo habían sido ya vendidos en la década anterior al Estado $^{64}$.

El catálogo de 1897, que hasta la fecha no había sido estudiado recoge un total de 1249 referencias que corresponden a cerca de 2000 volúmenes, entre las que predominan las obras de temática militar, genealogía e historia ${ }^{65}$. En este fondo figuraban asimismo varias colecciones con los textos de obras dramáticomusicales como los 10 volúmenes de Teatro o colección de los sainetes y demás obras dramáticas de Ramón de la Cruz, que fueron editados en el siglo XVIII con el apoyo de varios miembros de las Casas de Osuna y Benavente y de otros personajes de la nobleza y la aristocracia ${ }^{66}$; y una colección de dramas, comedias y zarzuelas de diferentes autores, titulada Magasín théatral ${ }^{67}$.

\footnotetext{
${ }^{64}$ Véase Capítulo I.

${ }^{65}$ Catálogo de libros procedentes de los palacios de La Alameda, Aranjuez y Madrid. Precede al título Comisión Ejecutiva de Obligacionistas de Osuna, Venta en Pública subasta del mobiliario del Palacio de Osuna, (Madrid: Est. Tip. de la Viuda e hijos de M. Tello, 1897)

${ }^{66}$ Catálogo, p. 36. Sobre esta colección véase el Capítulo VI.

${ }^{67}$ Catálogo, p.88.
} 


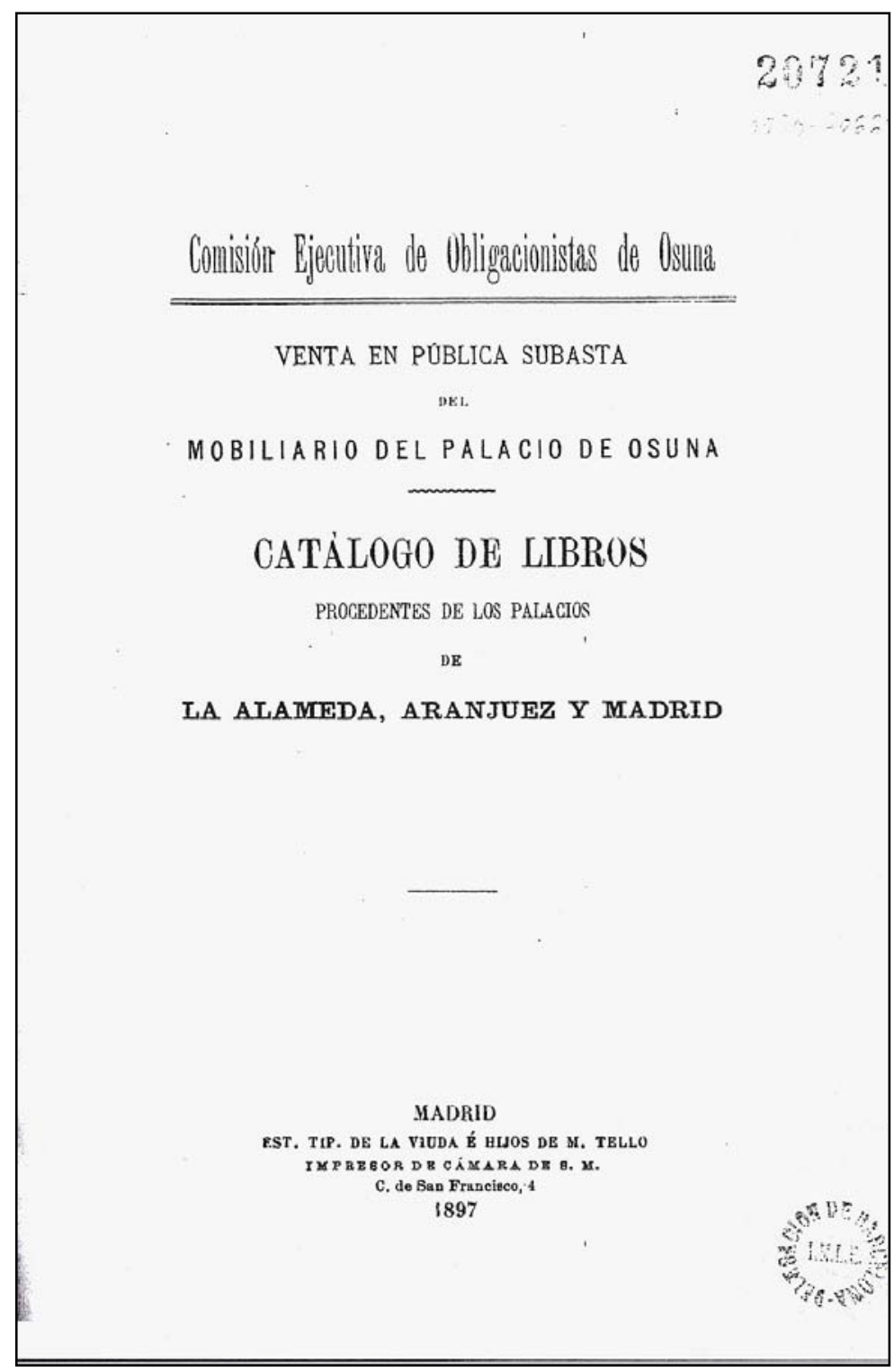

Lámina 23.

Portada del catálogo de libros subastados en Madrid en 1897 procedentes de los palacios de los Duques de Osuna (Madrid: Est. Tip de la viuda e hijos de M. Tello, 1897)

Entre las obras que se recogen en este amplio catálogo figuran varios libros de música y partituras editados o compuestos en su mayoría en el siglo XIX, lo que lleva que indica que seguramente fueron parte de la biblioteca personal de Pedro de Alcántara II, XI Duque de Osuna y de su hermano, Mariano, 
XII Duque de Osuna (Ver Apéndice 3) ${ }^{68}$.

Las obras didácticas que aparecen en el catálogo de 1897 dan fe del nivel musical que llegaron a alcanzar en el siglo XIX algunos miembros de la dinastía Benavente-Osuna cuya formación superó el mero aprendizaje de los rudimentos musicales $^{69}$. Además del método de solfeo Principes élémentaires de musique, arrêtes par les membres du Conservatoire (París, 1816) [5/20], en el catálogo de 1897 figuran dos tratados teóricos: el Manual de Armonía de Antoine Elwart $[5 / 1]^{70}$, y la Cartilla harmónica ó el contrapunto, explicado en seis lecciones, del musicógrafo gaditano José Joaquín Virués Spínola (Madrid 1825) [5/27].

Los métodos de piano de Louis Adam ([5/3], [5/4]), José Sobejano Ayala [5/25], un anónimo Méthode (Nouvelle) de toucher le piano forte [5/18], y el Nouvelle méthode de harpe de Gatayes [5/11] fueron seguramente parte del repertorio didáctico utilizado en las primeras décadas del siglo XIX para la enseñanza instrumental de los miembros de las Casas de Osuna y Benavente ${ }^{71}$.

En el catálogo de 1897 se recogen también cuatro misas de Luis Vicente Arche, Antonio Merce Fondevilla, Tomás Genovés y Mariano Rodríguez de Ledesma, relacionadas con la celebración de las funciones religiosas en honor a San Francisco de Borja, una tradición de la Casa de Benavente que se remonta al

\footnotetext{
${ }^{68}$ Sobre las actividades musicales del XII Duque véase mi artículo Juan Pablo Fernández-Cortés: “El Mecenazgo musical de Mariano Téllez Girón, (1844-1882) Actas del VI Congreso de la Sociedad Española de Musicología. Oviedo 2004, RMS, XVIII/1 (2005), en prensa.

${ }^{69}$ De aquí en adelante, la numeración que figura junto a las obras musicales se refiere al inventario del Apéndice 3 realizado a partir de las obras del citado catálogo

70 Se trata de una traducción española realizada por Francisco F. Valldemosa del Petit manuel d'harmonie, d'accompagnement de la basse chiffrée de Elwart.

71 Véase el Capítulo III.
} 
menos a $1740^{72}$. La Misa a grande orquesta en honor de San Francisco de Borja de Rodríguez de Ledesma [5/16] estaba dedicada al XI Duque de Osuna y fue estrenada, en las funciones en honor a dicho santo celebradas en 1852, junto a la Misa en mi bemol a cuatro voces y coro con orquesta de Tomás Genovés [5/12 $]^{73}$. Antonio Mercé Fondevilla dedicó al Duque una "Misa a toda orquesta" para que fuera interpretada en las funciones de San Francisco de Borja de $1852^{74}$. Esta obra debía de ser la misma que figuraba en el catálogo de 1897 con el título Misa a cuatro voces con grande orquesta [5/17].

Una importante parte de las obras musicales que se recogen en el catálogo de 1897 están relacionadas con la práctica musical doméstica: música de baile para piano solo o piano y otros instrumentos y reducciones para piano o voz y piano de óperas completas o fragmentos de óperas de Rossini [5/21] y Meyerbeer [5/22] entre otros. Este repertorio de salón se utilizó seguramente en las reuniones sociales de la familia Osuna y Benavente durante la titularidad del XI y XII Duque de Osuna. La colección de música impresa para arpa que figura en el catálogo ([5/28] y [5/29]) posiblemente perteneció a alguno de los miembros de la Casa de Osuna que recibieron lecciones de este instrumento en la segunda década del siglo XIX. El repertorio de música vocal de cámara (otro de los géneros habituales en los salones de las Casas de Osuna y Benavente) aparece representado en este inventario por los cinco volúmenes de Chansons choisies,

\footnotetext{
72 Sobre las funciones religiosas en honor a San Francisco de Borja véase el capítulo V.

73 AHN NOBLEZA OSUNA-CARTAS leg 422-52.

${ }^{74}$ Ibid.
} 
[avec les airs notés] antología publicada en Londres entre 1783 y $1785[5 / 2]^{75}$.

\subsection{Fondos de interés musical procedentes de la Casa de Osuna conservados en la Biblioteca Nacional de España (Madrid)}

Antes de la enajenación y dispersión de su patrimonio a finales del siglo XIX, la Casa de Osuna poseía una de las bibliotecas públicas más importantes de España y una de las más ricas de la nobleza europea, que se incrementó aún más tras la incorporación en 1841 de las bibliotecas procedentes del Ducado del Infantado y sus títulos menores a la Casa de Osuna ${ }^{76}$.

Cuando en 1886 los fondos de la biblioteca pública del Duque de Osuna pasaron al Estado, gran parte de ellos fueron incorporados a la Biblioteca Nacional de España (BNE). Con este motivo se realizó un catálogo alfabético de las obras impresas que pasaron a la BNE en el que, como hemos señalado anteriormente, no aparece ninguna obra de música ${ }^{77}$ lo cual nos lleva a suponer que en la época de enajenación de este fondo los materiales musicales impresos que pudieran existir en esta biblioteca debían de conservarse ya en otro lugar diferente ${ }^{78}$

\footnotetext{
75 Sobre esta colección véase RISM B/II, (=Lesure, François: Recueils imprimés, XVIIIe siècle. München, Henle, 1961), p. 127.

${ }^{76}$ Ignacio Atienza Hernández, Aristocracia, poder y riqueza en la España Moderna. La Casa de Osuna, siglos XV-XIX (Madrid: Siglo Veintiuno, 1987), p. 278.

${ }^{77}$ Catálogo alfabético de las obras impresas pertenecientes a la Biblioteca del Duque de Osuna adquiridas en 1886 con destino a esta Biblioteca Nacional, contiene 11100 volúmenes impresos, 144 mapas y planos y 67 estampas. BNE Ms 18953.

${ }^{78}$ Como hemos visto en el apartado anterior, al menos una parte de los materiales musicales propiedad de las Casas de Osuna y Benavente, se conservó en las residencias particulares de Madrid hasta finales del siglo XIX.
} 
En la BNE se conserva también otro catálogo alfabético en 26 volúmenes de toda la biblioteca del Duque de Osuna elaborado a finales del siglo XVIII y actualizado durante las primeras décadas del $\mathrm{XIX}^{79}$. El estudio de los contenidos de este catálogo merece un trabajo monográfico que excede los planteamientos metodológicos de esta Tesis Doctoral. No obstante con el fin de evaluar la probable presencia de libros de música o de materiales de interés musical en la Biblioteca de los Duques de Osuna, he analizado los cinco primeros volúmenes del citado catálogo de la biblioteca ${ }^{80}$. En las más de 1600 fichas catalográficas examinadas, sólo he hallado una traducción al francés con comentarios de la obra De musica del Pseudo Plutarco realizada por M. Burette ${ }^{81}$.

En los fondos bibliográficos públicos de los Duques de Osuna había también una importante colección de obras teatrales manuscritas e impresas, que incluían los libretos y textos de varias obras dramático-musicales. En el inventario de los manuscritos de la biblioteca del Duque de Osuna realizado en 1882 aparecen 1182 referencias bajo el epígrafe de "comedias manuscritas" incluían varios libretos y textos de zarzuelas, entremeses, mojigangas, bailes y fines de fiesta de autores españoles de los siglos XVI al XVIII, como Lope de Vega, [José de] Cañizares, o [Francisco] Bances de Cándamo ${ }^{83}$.

\footnotetext{
79 BNE Mss. 10958-10983. Catálogo alfabético de la Biblioteca del Duque de Osuna. Existen otros inventarios y catálogos de la Biblioteca del Duque de Osuna en la British Library de Londres (Mss. Add. 17464) y en AHN NOBLEZA-OSUNA, leg 3521.

${ }^{80}$ BNE Mss, 10 958-10962.

${ }^{81}$ Ibid., Ms. 10961 [s.f].

82 José María Rocamora, Catálogo abreviado de los manuscritos de la biblioteca del Señor Duque de Osuna e Infantado (Madrid: Imprenta de Fortanet, 1882).

83 Véase Inventario General de Manuscritos de la Biblioteca Nacional (Madrid: Biblioteca Nacional de España, 1953-2001), 15 vols. [Mss. 1 a 11000].
} 
Los valiosos fondos de obras teatrales de esta biblioteca eran requeridos por los investigadores y eruditos de la época. En 1804 el dramaturgo Leandro Fernández de Moratín solicitó a la Condesa-Duquesa de Benavente un “ejemplar único" del Cancionero de Juan del Encina que se conservaba en su biblioteca "a fin de copiar algunas piezas para la formación de una historia sobre el origen del Teatro Español” en la que estaba trabajando, y que se publicó póstumamente en $1838^{84}$.

Según el catálogo realizado por Higinio Anglés y José Subirá ${ }^{85}$ la Biblioteca Nacional de España sólo conserva dos obras musicales del siglo XVIII y de las primeras décadas del siglo XIX, que proceden directamente de la Biblioteca de los Duques de Osuna. La más antigua es la ópera en dos actos Didone abbandonata del compositor italiano Giovanni Battista Lampugnani $(* 1706-\uparrow 1781)^{86}$. La segunda obra es una recopilación manuscrita titulada Colecçao de modinhas portuguesas que contiene modinhas a sólo y a dúo compuestas a principios del siglo XIX por el compositor español residente en Portugal José Palomino, el brasileño Joaquim Manoel, y el portugués Antonio Claudio Pereira ${ }^{87}$.

\footnotetext{
${ }^{84}$ AHN NOBLEZA OSUNA-CARTAS leg 417-7. La obra a la que hace referencia la carta de Moratín fue publicada póstumamente. Leandro Fernández de Moratín, Orígenes del Teatro Español, seguidos de una colección escogida de piezas dramáticas anteriores a Lope de Vega (París: Librería Europea de Baudry, 1838).

${ }^{85}$ Higinio Anglés y José Subirá, Catálogo musical de la Biblioteca Nacional de Madrid, (Barcelona: CSIC. Instituto Español de Musicología, 1946-1951).

${ }^{86}$ BNE M. 2369 y M. 2370. Ejemplar manuscrito dividido en dos volúmenes encuadernados en pergamino con caligrafía de la segunda mitad del siglo XVIII. Para la descripción de esta obra véase Anglés y Subirá, Catálogo, vol. I, p. 376.

${ }^{87}$ Sobre esta colección véase el Capítulo VII.
} 


\section{Los instrumentos musicales de los Duques de Osuna y de la Condesa- Duquesa de Benavente}

La formación musical que recibieron los jóvenes de las Casas de Osuna y Benavente, y las orquestas y conjuntos instrumentales que funcionaron bajo su mecenazgo hizo necesaria la compra y mantenimiento de numerosos instrumentos musicales que se ubicaron en sus palacios urbanos y residencias de recreo. Existe constancia documental de que a lo largo de los siglos XVIII y XIX los titulares de las Casas de Osuna y Benavente adquirieron numerosos instrumentos musicales. Al menos una parte de los instrumentos que se compraron durante el siglo XVIII desapareció durante la Guerra de la Independencia. El Palacio de la Alameda de Madrid, residencia de recreo de las familias Osuna y Benavente, fue saqueado por las tropas francesas y entre los numerosos objetos de valor que desaparecieron se perdieron dos fortepianos ${ }^{88}$.

La crisis económica de la Casa de Osuna, que desembocó en la hipoteca de gran parte de sus bienes y la posterior quiebra y enajenación del patrimonio ducal a finales del siglo XIX, contribuyó a la dispersión de los instrumentos musicales que los Duques de Osuna conservaron hasta las últimas décadas del siglo XIX en sus residencias. Los instrumentos musicales (al igual que la biblioteca, las armas, los cuadros y esculturas o el mobiliario) formaron parte de la garantía hipotecaria que la Casa de Osuna suscribió a favor de Estanislao Urquijo y otros miembros de la burguesía empresarial de Madrid para paliar la apurada situación presupuestaria de su administración. Tras la muerte en 1882 de Mariano Téllez Girón, XII Duque

\footnotetext{
88 Joaquín Ezquerra del Bayo, Retratos de la familia Téllez Girón. Novenos duques de Osuna (Madrid: Junta de Iconografía Nacional, 1934), p.44.
} 
de Osuna y XVII Conde-Duque de Benavente, los acreedores iniciaron un pleito que desembocó en la enajenación de todos los objetos de valor de la Casa Ducal ${ }^{89}$. Entre los últimos cuadros y objetos de arte del patrimonio de los Osuna que se expusieron para ser subastados en el Palacio de la Industria y las Artes de Madrid en 1896 figuraba un piano que se valoró en mil pesetas ${ }^{90}$.

\subsection{Instrumentos de teclado}

\subsubsection{Los clavicémbalos y clavicordios del VII Duque de Osuna y de la Duquesa viuda de Osuna (ca. 1733-1745)}

En el amplio inventario de bienes realizado en 1733 a la muerte de José Téllez Girón, VII Duque de Osuna, figuraban varios instrumentos musicales que formaron parte del patrimonio personal del Duque. En la tasación de los instrumentos del Duque de Osuna realizada por Manuel Pradell el 8 de junio de 1733, se incluyeron dos "clavicembalos": uno valorado en 900 reales de vellón del cual no aparece ningún detalle y otro lujoso instrumento "con teclas de cristal con su pie tallado y dorado y conchas de charol" que fue tasado en 3000 reales ${ }^{91}$. Ambos clavicembalos fueron seguramente tocados por el propio Manuel Pradell, que al menos desde 1732 desempeñó el cargo de "músico compositor" al servicio del VII Duque de Osuna ${ }^{92}$.

Es probable que el primero de los clavicémbalos citados fuera el mismo

\footnotetext{
89 Sobre la quiebra definitiva de la Casa de Osuna y el desmantelamiento de la propiedad ducal véase Ignacio Atienza Hernández, Aristocracia, poder y riqueza en la España Moderna. La Casa de Osuna, siglos XV-XIX (Madrid: Siglo Veintiuno, 1987), pp. 366- 375.

${ }^{90}$ Exposición y venta de los cuadros y demás objetos de arte de la Casa Ducal de Osuna (Madrid: Viuda e hijos de M. Tello 1896), p. 31.

91 AHN NOBLEZA, OSUNA, leg 48-1.
} 
que diez años después de la muerte del Duque se reparó por encargo de Francisca Bibiana Pérez de Guzmán el Bueno, Duquesa viuda de Osuna. En 1743 y 1744, el conocido constructor Diego José Fernández, uno de los principales proveedores de instrumentos de tecla de la reina María Bárbara de Braganza" a3 arregló "un clavicordio" de la Casa de Osuna ${ }^{94}$. Gracias a la precisión que puso Fernández en la factura de estas reparaciones podemos conocer algunas de las características organólogicas de este instrumento, al que se colocaron "ciento doce martinetes de peral" y una encordadura con ciento doce cuerdas. El teclado era "de cedro, cubierto y embutido de ébano y hueso, con cincuenta y seis teclas” que Fernández sustituyó en 1743 y 1744, seguramente debido al desgaste de su uso habitual. El clavicémbalo poseía además dos registros que se cambiaron en ambas reparaciones y que llevaban "dos guías de peral con pies derechos y molduras debajo de ellos". En 1744 se sustituyó además "la cabeza del clavicordio" para colocar el teclado y se ajustó la afinación al “diapasón para el tono de capilla".

\subsubsection{Un clavicordio importado de Inglaterra para Pedro Zoilo Téllez Girón, VIII Duque de Osuna}

En 1772 Pedro Zoilo Téllez Girón, VIII Duque de Osuna, hizo traer desde Inglaterra un clavicordio. El "coste y gastos de conducción” desde Londres del instrumento ascendió a 2390 reales que fueron pagados por el Duque a Matías de

\footnotetext{
92 AHN NOBLEZA, OSUNA-CARTAS, leg 446-1.

93 Véase el apartado 1.5 de este capítulo.

94 Aunque en el documento contable que refleja las reparaciones se alude a la reparación de un "clavicordio", se trataba en realidad de un clavicémbalo como puede verse por las reparaciones realizadas.
} 
Sobrevilla. En el documento del que se extrae esta información no figuran más datos sobre el instrumento ${ }^{95}$.

\subsubsection{Los instrumentos de teclado de la XV Condesa-Duquesa de Benavente}

Los instrumentos de teclado también estuvieron presentes en el ambiente cotidiano de María Josefa Alfonso Pimentel (XV Condesa-Duquesa de Benavente) desde su niñez. La futura heredera de la Casa de Benavente recibió clases de clave de destacados músicos del entorno de la corte, como Antonio Literes Montalvo, organista de la Real Capilla (que fue uno de sus primeros maestros de música) y de José Lidón, compositor e intérprete de teclado, que al menos desde 1783 trabajó como "maestro de clave de la Condesa Duquesa"96. El aprendizaje de los instrumentos de teclado constituyó también el centro de la formación musical de los hijos y nietos de la Condesa-Duquesa de Benavente. Algunos de los miembros de la familia Benavente-Osuna, como la hija menor de la Condesa-Duquesa, María Manuela Isidra, y su nieto Pedro de Alcántara II, futuro XI Duque de Osuna, fueron intérpretes aficionados de instrumentos de tecla ${ }^{97}$

\footnotetext{
95 AHN NOBLEZA, OSUNA-CARTAS, leg 389-25. Este testimonio de la importación de instrumentos desde Inglaterra por parte de la Casa de Osuna, fue dado a conocer por la Condesa de Yebes que atribuyó erróneamente la adquisición de este instrumento al joven Pedro de Alcántara, futuro IX Duque de Osuna. Aunque esta autora no cita la fuente de la información, el dato procede extraído del documento contable citado fechado el 28 de Julio de 1772 que se conserva en el archivo de la Casa de Osuna y que aparece firmado por "El Duque [de Osuna]" título que ostentó Pedro Zoilo Téllez Girón hasta su muerte en 1787. Condesa de Yebes, La Condesa-Duquesa de Benavente. Una vida en unas cartas (Madrid: Espasa Calpe, 1958), p. 87.

${ }^{96}$ Ver Capítulo 3.
} 
Para la enseñanza musical, la práctica en el entorno doméstico de los miembros de la familia y la celebración de "academias", fiestas, y otros eventos musicales, la XV Condesa-Duquesa de Benavente adquirió varios instrumentos de teclado a los principales constructores europeos de su época. En 1781 la CondesaDuquesa adquirió por 3.300 reales de vellón un fortepiano a Adam Miller ${ }^{98}$ constructor de origen alemán que trabajó en Madrid en las últimas décadas del siglo XVIII cuyos instrumentos seguían las tipologías de construcción de la escuela inglesa $^{99}$. Este fortepiano podría ser el mismo para el que Antonio Plaza (uno de los músicos que trabajaba al servicio de la Casa de Benavente) compró cuerdas al año siguiente ${ }^{100}$, y posiblemente fuera también el instrumento de Adam Miller que Francisco Flórez reparó en $1797^{101}$.

Además de reparar los instrumentos de teclado de las Casas de Osuna y Benavente, el constructor murciano Francisco Flórez (†1824) construyó al menos tres instrumentos por encargo de la Condesa-Duquesa de Benavente ${ }^{102}$. El primero de ellos fue un clave por el que se pagó el 16 de abril de 1787, 4500 reales de vellón ${ }^{103}$.

\footnotetext{
${ }^{97}$ Ver Capítulo 3.

${ }^{98}$ BNE Ms. 14.016.3/45 (Papeles Barbieri)

99 Beril Kenyon de Pascual: "Piano", DMEH, vol.8, pp.754-758.
}

100 BNE Ms. 14.016.3/65 (Papeles Barbieri). Recibo fechado el 19 de abril de 1782 por el que Antonio Plaza cobró 120 reales por la compra de "cuerdas para el fuertepiano" [sic] y compostura de este"

101 AHN NOBLEZA, OSUNA-CARTAS, leg 391-2.

102 Sobre este constructor véase Beril Kenyon de Pascual "Flórez, Francisco", DMEH, vol. 5, pp.175-176 y Cristina Bordas, "Dos constructores de pianos en Madrid: F. Flórez y F. Fernández", RMS, XI 3 (1988), pp.-807-851.

103 AHN NOBLEZA, OSUNA-CARTAS, leg 389-25. Bordas, "Dos constructores", p.813. En el resumen de cuentas anuales de la Casa de Benavente de 1787 se detalla el pago de dicha partida 
Según Robert Stevenson, el 24 de marzo de 1785 el compositor Joseph Haydn dirigió a la Condesa-Duquesa de Benavente una carta en la que se mencionaba al constructor de pianos Francisco Flórez, lo que le da pie a suponer que la relación de Flórez con la Condesa-Duquesa de Benavente comenzó antes de 1787. Sin embargo el documento en el que basa su afirmación el profesor Stevenson sólo se menciona una carta enviada por Carlos Alejandro de Lelis para el "Señor Flores", y no se hace ninguna otra alusión a la construcción de instrumentos, ni a la relación de este con Haydn ${ }^{104}$.

Francisco Flórez construyo en 1797 un "fortepiano de nueva estructura" para la Condesa-Duquesa que tenía “toda la extensión" aunque era "de lo más pequeño que se ha visto". Los materiales con los que estaba elaborado no debían de ser los habituales con los que se construían los instrumentos de teclado en España, pues Flórez especificó en la cuenta de pago que "las maderas que lleva, no se conocen por aquí pues dicha madera sólo la conocen los ingleses y es de

\footnotetext{
“al Maestro de claves Francisco Flores [sic] por el coste de uno que ha hecho para mí". Véase AHN NOBLEZA, OSUNA-CARTAS, leg 489-4. Data del arca del año 1787.

104 Robert Stevenson: "Los Contactos de Haydn con el Mundo Ibérico" Revista Musical Chilena 157, (Enero-Junio 1982), pp.3-39. El profesor Stevenson apoyaba esta afirmación en un documento que se conserva en el archivo administrativo de la Casa de Osuna y que fue publicado por Solar-Quintes en 1947. Dicho documento (AHN NOBLEZA OSUNA-CARTAS, 391), es en realidad una carta que Carlos Alejandro de Lelis (intermediario de la Condesa-Duquesa ante Joseph Haydn) envió a Tomás de Iriarte para informarle de las gestiones realizadas en Viena para que Joseph Haydn cumpliera el contrato que había firmado con la Condesa-Duquesa de Benavente. En un párrafo de esta carta Carlos Alejandro de Lelis dice haber remitido a Iriarte una sinfonía "con fecha 16 de febrero unidamente al Libro de Orlando y una carta para el Señor Flores". Este único dato sirvió a Stevenson para identificar a "Señor Flores" que se cita en la carta de Lelis a Iriarte, con el constructor de pianos Francisco Flórez, y relacionarlo con Haydn y la Condesa-Duquesa de Benavente. La afirmación de Stevenson fue también cuestionada por Cristina Bordas. Véase Bordas, "Dos constructores”, p. 813, nota 8.
} 
mucho valor". El fortepiano estaba profusamente adornado con colgantes dorados, impostas y cornisitas y camafeos con sus cercos dorados a fuego. El instrumento costó 6100 reales de vellón ${ }^{105}$.

En 1802, Francisco Flórez construyó un nuevo fortepiano por encargo de la Condesa-Duquesa, probablemente para que fuera utilizado en la formación musical de la menor de sus hijas María Manuela. El instrumento se fabricó con un "teclado reducido" y una extensión de 5 octavas (de el "fa a el fa") según las instrucciones que "el profesor" había dado para su construcción:

Cuenta que yo Don Francisco Flórez, constructor de fortespianos [sic] de Cámara de Su Majestad he construido para la Excelentísima Señora Duquesa de Osuna”, con las cualidades y condiciones siguientes:

Está dicho fortepiano construido a la moderna, es decir, con los ángulos ochavados, ser su construcción de caoba, llevar la maquinaria doble, o dobles mazos; ser de un teclado reducido y alcanzar del fa a el fa según manda el profesor. Importan los materiales y manufacturas que lleva cuatro mil reales de vellón. Madrid y mayo, 4 de 1802.

Visto Juan de Gamboa.

Recibí el importe de esta cuenta en un libramiento que despachó Su Excelencia contra el pagador de la Casa con fecha de 8 de Junio de 1802. Madrid dicho día.

Por mi tío Don Francisco Flórez: Bruno García Celdrán? ${ }^{106}$

\footnotetext{
105 AHN NOBLEZA, OSUNA-CARTAS, legs 391-2, 391-13, y 515-8 tris-21. El importe de la factura de Flórez fue de 6300 reales e incluía otros 200 reales por "una compostura" realizada a un fortepiano de Adam Miller.

${ }^{106}$ AHN NOBLEZA, OSUNA-CARTAS, leg 392-38. Transcrito en Bordas, "Dos constructores", p. 821 .
} 
El profesor al que se refiere este documento debió de ser el cantante Carlo Marinelli, que desde 1800 impartió clases de música a los hijos del Duque de Osuna y la Condesa-Duquesa de Benavente, y que desde 1803 formó parte del personal al servicio de la Casa de Benavente-Osuna ${ }^{107}$.

Los dos fortepianos construidos en 1797 y 1802 no fueron pagados a Francisco Flórez hasta enero de $1806^{108}$. La falta de liquidez que caracterizó a la gestión económica de la Casa de Benavente-Osuna en las últimas décadas del siglo XVIII y a principios del siglo XIX, originaba graves retrasos en los pagos a los proveedores y artistas quienes, aún conociendo que el abono de su facturas podían dilatarse varios años, raramente rechazaban los encargos que procedían de los personajes de la alta nobleza, cuyo prestigio e influencias eran necesarios a la hora de conseguir otros trabajos o favores particulares ${ }^{109}$.

Además de los instrumentos encargados a Flórez y Miller, la CondesaDuquesa, encargó en 1807 a Honoré de Langlé (compositor que había trabajado como profesor de música de sus hijos durante su estancia en París en 1799) que adquiriera un nuevo piano de la próspera empresa de los hermanos Eràrd de París. El nuevo instrumento llegó a Madrid antes del 19 de noviembre de 1807 y costó 2000 francos que la Condesa se comprometió a pagar a través de una letra de

\footnotetext{
${ }^{107}$ Ver Capítulo 3.

108 AHN NOBLEZA, OSUNA-CARTAS, leg 391-2.

109 AHN NOBLEZA, OSUNA-CARTAS, leg 515-8 tris. Por ejemplo en el "Indice de los Acreedores posteriores al año 1797 hasta 1804" de la Casa de Benavente-Osuna además de la deuda pendiente con Francisco Flórez, figuran varias cantidades que se debían a otros artistas que habían realizado obras por encargo de la Casa, como los pintores Francisco de Goya y Agustín Esteve.
} 
cambio $^{110}$. Este fortepiano es muy probable que fuera el mismo que se conservaba en las primeras décadas del siglo XIX en el Palacio de la Alameda, finca de recreo de la familia situada a las afueras de Madrid, y que fue descrito en un inventario que se realizó hacia 1814 como "un piano de caoba y adornos de bronce hecho en París con 4 registros valorado en 2660 reales" que se hallaba ubicado en la llamada "Sala de compañías" de dicho palacio ${ }^{111}$.

\subsubsection{Otros instrumentos de tecla propiedad de la familia Benavente-Osuna en la primera mitad del siglo XIX.}

Manuela Isidra Téllez Girón, la hija menor de los IX Duques de Osuna, fue propietaria de un "clave inglés de Clementi con bronces valorado en seis mil reales", que aportó como dote en su matrimonio con el Duque de Abrantes, Angel María Carvajal Fernández de Córdoba. Dicho instrumento aparece inventariado en el apartado de "muebles de caoba" en las capitulaciones matrimoniales fechadas en Cádiz el 31 de diciembre de $1812^{112}$. Había sido fabricado por la importante firma inglesa Clementi \& Company de la que fue uno de los principales accionistas el compositor y pianista Muzio Clementi ${ }^{13}$.

En 1823 el Duque de Osuna adquirió un piano de la marca Schanty a Pietro Tespiani ${ }^{114}$. Este u otro piano de cola que se conservaba en las dependencias personales del palacio de los Osuna fue reparado y afinado por Juan

\footnotetext{
110 AHN NOBLEZA, OSUNA-CARTAS, leg 277-11. Según figura en una anotación autógrafa de la Condesa-Duquesa de Benavente en la carta enviada por los hermanos Eràrd el 5 de diciembre de 1807.

111 AHN NOBLEZA, OSUNA-CARTAS, leg 519-3.

112 AHN NOBLEZA, OSUNA', leg 450-5 bis.

113 León Plantinga y Alan Tyson, "Clementi, Muzio", NG, vol. 6, p. 3946.
} 
Salinas a finales de 1831 por encargo del XI Duque de Osuna:

He recibido del mayordomo del Excelentísimo Señor Duque de Osuna por componer el piano de cola del despacho ochenta reales y mas por dos meses de afinación, noviembre y diciembre a treinta reales cada uno son sesenta, que todo hace la cantidad de ciento cuarenta reales [de] vellón.

Madrid 31 de diciembre 1831

Juan Salinas [rúbrica] ${ }^{115}$

El XI Duque de Osuna, Pedro de Alcántara II, fue un competente músico aficionado que, en su corta vida actuó frecuentemente como cantante en los salones de la nobleza madrileña. Según Antonio de Marichalar, Pedro de Alcántara II recibió también clases de órgano y es posible que tuviera un órgano de su propiedad. En el archivo administrativo de la Casa de Osuna se conserva un documento fechado en 1840 y firmado por Achille Muller, constructor de "órganos expresivos" de París donde se explican extensamente los detalles del funcionamiento de un órgano que es muy probable que fuera propiedad del XI Duque de Osuna $^{116}$.

\subsubsection{Templadores de claves y "pianistas" al servicio de las Casas de Osuna-y Benavente (siglos XVIII y XIX)}

La conservación y mantenimiento de los numerosos instrumentos de teclado que pertenecieron a los miembros de las familias Osuna y Benavente

\footnotetext{
114 AHN NOBLEZA, OSUNA-CARTAS, leg 541.

115 Ibíd., leg 392-45.

116 AHN NOBLEZA, OSUNA-CARTAS, leg 392-22. Documento fechado el 14 de abril de 1840 con membrete del fabricante de Achille Muller fabricante de órganos expresivos y de pianos. No figura el destinatario.
} 
durante los siglos XVIII y XIX fue confiada a los más prestigiosos constructores de la época. Los titulares de ambas casas nobiliarias ocuparon diversos puestos en la Corte, lo que les permitió conocer de cerca a los principales proveedores y constructores de instrumentos de teclado que trabajaron para la Casa Real ${ }^{117}$.

Diego José Fernández [Caparrós] $(* 1703-\uparrow 1775)$, fue uno de los más importantes constructores de instrumentos de tecla que trabajó en Madrid durante los reinados de Fernando VI y Carlos III. Construyó al menos dos claves de 61 teclas para la reina María Bárbara de Braganza y uno de los tres instrumentos que se llevó Farinelli a Italia legados por la reina tal y como describe el viajero Charles Burney ${ }^{118}$. Entre 1743 y 1744, Diego José Fernández realizó al menos dos trabajos de reparación y conservación de un clavicembalo propiedad de la Duquesa viuda de Osuna. En las facturas de estas reparaciones Fernández se refiere a la Duquesa viuda de Osuna como "mi señora" lo que sugiere la existencia de una relación de servicio estable de este constructor con la Casa de Osuna $^{119}$.

La Condesa-Duquesa de Benavente, María Josefa Alfonso Pimentel, también encargó la conservación de sus instrumentos de tecla a constructores y "pianistas" que trabajaron habitualmente para la Casa Real. Entre ellos se hallaban el ya citado Francisco Flórez, constructor de órganos y claves de la Real Cámara de Carlos IV, que reparó y construyó varios instrumentos de tecla por encargo de

\footnotetext{
117 Ver Capítulo I.

118 Beryl Kenyon de Pascual: "Diego Fernández-Harpsichord Maker to the Spanish Royal Family from 1722 to 1755 and his nephew Julián Fernández", The Galpin Society Journal, XXXVIII, 1985 , pp.35-47.

119 AHN NOBLEZA, OSUNA-CARTAS, leg 389-28.
} 
la Condesa-Duquesa, y Francisco Fernández $(* 1766-\uparrow 1852)$, que fue nombrado constructor honorario de pianos de la Real Cámara de Carlos IV en el mes de marzo de 1806, y ocupó la misma plaza de forma efectiva desde diciembre de 1816. En 1807, Francisco Fernández reparó y afinó tres pianos, uno de ellos inglés, para la Casa de Benavente-Osuna ${ }^{120}$. Fernández continuaba colaborando con los Osuna en abril de 1816 cuando realizó varias reparaciones a los pianos de la Casa por importe de 1620 reales $^{121}$.

Para la afinación de los instrumentos de tecla, los titulares de las Casas de Osuna y Benavente tuvieron a su servicio un afinador o "templador de clavicordios" que formaba parte del personal asalariado de la Casa, lo que evidencia la importancia que la música tuvo siempre en el entorno doméstico de los Osuna y Benavente durante los siglos XVIII y XIX ${ }^{122}$.

Entre los criados que aparecen en las nóminas del año de 1732 al servicio de José Téllez Girón, VII Duque de Osuna, figuraba Manuel Calleja con el empleo de "templador de clavicordios" ${ }^{123}$. Para María Faustina Téllez Girón, hija del VII Duque, y esposa del XIV Conde-Duque de Beanvente trabajaron los templadores de clave Fernando Sánchez (ca. 1755-1759) y José Manzón que se

\footnotetext{
120 Ibid, AHN NOBLEZA, OSUNA-CARTAS, leg 392-32. Bordas, "Dos constructores”, p. 831.

${ }^{121}$ AHN NOBLEZA, OSUNA-CARTAS, leg 515-8 tris 2.

${ }^{122}$ Además de estos "templadores" asalariados, los titulares de las Casas de Osuna y Benavente contrataban eventualmente a otros afinadores cuando se hallaban fuera de Madrid. Véase por ejemplo los pagos realizados en Aranjuez en 1788 "al templador de claves Castaneda" (AHN NOBLEZA, OSUNA-CARTAS, leg 392-40) o en Cádiz en 1812 a José Tudela "por haber templado el clave de la señorita Condesa de Coquinas" [Manuela Isidra Téllez Girón, hija menor de los Duques de Osuna] en enero y febrero de 1812. (Ibíd., leg 489).

${ }^{123}$ AHN NOBLEZA, OSUNA-CARTAS, leg 446-1.
} 
hallaba al servicio de la Casa de Benavente en $1761^{124}$. María Faustina TéllezGirón tuvo también a su servicio a Juan García Culebro que trabajó como “templador de los claves de la Condesa-Duquesa viuda" al menos desde $1783^{125}$, y que en 1802 seguía cobrando dos reales diarios de pensión de jubilación de la Casa de Benavente-Osuna ${ }^{126}$.

Ramón Herrero Sessé trabajó al servicio de la Casa de Benavente como templador de claves entre 1781 y 1792 con un sueldo de tres reales diarios. Este puesto estuvo vinculado al funcionamiento de la orquesta mantenida por la Condesa-Duquesa de Benavente, y fue suprimido cuando el conjunto se disolvió. Herrero y Sessé falleció antes de $1802^{127}$.

En la relación de afinadores o templadores que mantuvieron una relación de servicio permanente con las Casas de Osuna y Benavente en la primera mitad del siglo XIX, figuran otros muchos nombres. Desde enero de 1800, desempeñó el cargo de "templador de claves de los Duques de Osuna y Condes de Benavente" Juan García Vergara, que mantuvo el mismo sueldo de tres reales diarios, que había cobrado su antecesor Ramón Herrero Sessé. García Vergara trabajó al servicio de la Casa de Benavente-Osuna al menos hasta finales de $1808^{128}$.

El constructor de origen holandes Jan [Juan] Hosseschrueders (17791850), fundador de la marca de pianos del mismo nombre (actualmente Hazen)

\footnotetext{
124 Ibid., leg 457.

125 Ibid., leg 489.

126 Ibid., leg 462.

127 AHN NOBLEZA, OSUNA-CARTAS, leg 462. Su viuda, María Marzal, continuó cobrando la pensión de jubilación que la Casa de Benavente hasta 1802.

128 AHN NOBLEZA, OSUNA-CARTAS, leg 461-468.
} 
llegó a España en 1802 y desde 1814 regentó un taller de construcción de pianos en Madrid ${ }^{129}$. En 1818 trabajaba al servicio de Marie-Françoise-Philippine de Beaufort-Spontin, X Duquesa de Osuna como "pianista" y templador con un sueldo de ochenta reales al mes ${ }^{130}$. Para esta misma dama trabajaba en 1829 Marcos Latronde como "templador" de pianos ${ }^{131}$

\section{2. Instrumentos de cuerda y viento}

Los instrumentos de teclado no fueron los únicos adquiridos por los titulares de las Casas de Osuna y Benavente a lo largo de los siglos XVIII y XIX. Algunos instrumentos de cuerda o viento también formaron parte del patrimonio de las Casas de Osuna y Benavente y seguramente fueron adquiridos para los músicos que trabajaban a su servicio.

Dentro de las pertenencias que se tasaron a la muerte del VII Duque de Osuna en 1733 figuraban dos "trompas de caza" que fueron valoradas por Manuel Pradell en 100 reales, y una "guitarra grande de marca regular, llana sin calado ni sobrepuesto algunos" que se valoró en 30 reales $^{132}$. Este último instrumento es seguramente el mismo que se había adquirido en 1721 al "guitarrista" José Jiménez por 18 pesos "más cuatro que costó una caja para guardarla" y que se

\footnotetext{
${ }^{129}$ Sobre los orígenes de esta casa comercial véase Cristina Bordas, Hazen y el piano en España. 175 años (Madrid: Hazen, 1989).

${ }^{130}$ AHN NOBLEZA, OSUNA-CARTAS, leg 470. Nóminas de "los maestros de leer, escribir, música [...] que disfrutan asignación por la Señora Duquesa de Osuna.

${ }^{131}$ Ibid.

${ }^{132}$ AHN NOBLEZA, OSUNA-CARTAS, leg 48.
} 
utilizó en las fiestas de celebración ("Tea Nupcial”) de la boda del Duque ${ }^{133}$.

El 27 de septiembre de 1781, el músico Antonio Plaza recibió 660 reales de la tesorería de la Casa de Benavente "para comprar una vihuela"134. Esta información de la compra de un instrumento obsoleto a finales del siglo XVIII, se presta a diversas interpretaciones. Aunque podría tratarse de una vihuela de arco, término empleado en España para designar a la familia de las violas de gamba que se usaron tanto en la música religiosa como profana hasta finales del siglo $\mathrm{XVII}^{135}$, lo mas probable es que fuera sencillamente una guitarra, pues en las últimas décadas del siglo XVIII los términos "vihuela" y "guitarra" eran sinónimos en España ${ }^{136}$. Se tratase de uno u otro instrumento, la "vihuela" comprada por Antonio Plaza debió de tener una funcionalidad muy específica, pues no se conoce ningún músico de cuerda pulsada al servicio de las Casas de Osuna y Benavente en los siglos XVIII y XIX. Es posible que fuera adquirido para utilizarse en alguna de las producciones de teatro musical que se representaban en el palacio de los Benavente y en las que solía colaborar como intérprete Antonio Plaza.

\footnotetext{
133 AHN NOBLEZA, OSUNA-CARTAS, leg 292-1. El constructor de guitarras José Jiménez trabajó en Madrid al menos desde 1685, año en el que participó como tribunal examinador para la maestría. En 1723 tomo parte en la reunión de violeros que se celebro en el Convento de San Felipe el Real véase José Luís Romanillos Vega, y Marian Harris Winspear, The vihuela de mano \& The Spanish Guitar (Guijosa: The Sanguino Press, 2002), p. 197.

134 BNE Ms. 14.016.3/44 (Papeles Barbieri).

135 John GRIFFITHS, "Vihuela", DMEH, vol.10, pp. 878-883.

${ }^{136}$ Véase, por ejemplo, la definición de "vihuela" en el Diccionario de la Real Academia Española de 1780. Diccionario de la lengua castellana compuesto por la Real Academia Española, reducido a un tomo para su más fácil uso (Madrid: Joachín Ibarra, 1780), pp. 930.
} 



\section{Capítulo V}

\section{La música de Iglesia}

en las Casas de Osuna y Benavente

(ca. 1740-1844) 

La música de Iglesia fue uno de los principales géneros en los que se concretó la política del mecenazgo de las Casas de Osuna y Benavente durante la segunda mitad del siglo XVIII y las primeras décadas del siglo XIX. Los titulares de ambas casas nobiliarias, interesados en perpetuar las tradiciones de su linaje, desarrollaron una amplia labor de protección a las instituciones y tradiciones religiosas de sus antepasados que se centraron básicamente en dos ámbitos de producción: 1) Las capillas musicales de las fundaciones religiosas de la villa de Osuna (Sevilla) centro de gran valor simbólico para la familia Téllez-Girón como punto de referencia de su linaje y 2) Las fiestas y actos religiosos patrocinados por las Casas de Osuna y Benavente que se desarrollaron fundamentalmente en Madrid, principal ciudad de residencia de los titulares de ambas familias nobiliarias durante los siglos XVIII y XIX .

\section{El mecenazgo de los Duques de Osuna en la Colegiata de Santa María y la Capilla del Santo Sepulcro de Osuna, Sevilla (ca. 1750-1844)}

Los Duques de Osuna mantuvieron dos capillas musicales en la villa sevillana de Osuna: la situada en la Iglesia Colegial de la Asunción de Nuestra Señora, también llamada Colegiata de Santa María, y la adscrita a la Capilla del Santo Sepulcro, panteón oficial de la Casa de Osuna ubicado en el interior de esta Colegiata. Ambas capillas musicales habían sido fundadas en el siglo XVI por Juan Téllez Girón, IV Conde de Ureña ${ }^{1}$.

\footnotetext{
${ }^{1}$ Sobre la fundación de estas capillas musicales y su actividad durante los siglos XVI y XVII véase el Capítulo II.
} 
La actividad musical de las capillas musicales del Santo Sepulcro y de la Colegiata hasta la segunda mitad del siglo XVIII fue estudiada parcialmente por Inmaculada Cárdenas en su Tesis Doctoral ${ }^{2}$. Otra aportación interesante para el estudio de estas dos capillas musicales es la monografía de Manuel Rodríguez Buzón sobre la Colegiata de Osuna, en la que se presentan algunos aspectos concretos sobre el funcionamiento de las dos instituciones ${ }^{3}$.Sin embargo, en ninguno de estos dos trabajos se ha abordado en detalle la importancia que tuvo el mecenazgo de la Casa de Osuna para ambas fundaciones religiosas.

Los fondos del archivo administrativo de la Casa de Osuna (que no fueron analizados en los trabajos de Cárdenas y Rodríguez Buzón) conservan una interesante documentación que revela aspectos desconocidos hasta la fecha sobre la actividad musical de las dos instituciones musicales religiosas de la villa de Osuna que gozaron de la protección de la Casa de Osuna en la última década del siglo XVIII y primera mitad del siglo XIX. En este apartado analizaré dichos documentos y la información que proporcionan.

\subsection{El mecenazgo musical de los Duques de Osuna en la Colegiata de Santa María de Osuna hasta 1813}

La familia Téllez-Girón venía patrocinando la Capilla de la Colegiata de Osuna desde su origen en el siglo XVI. En la segunda mitad del siglo XVIII, la

\footnotetext{
2 Inmaculada Cárdenas, Música Barroca andaluza en las Colegiatas de Osuna y Olivares. Tesis Doctoral inédita, (Sevilla: Universidad de Sevilla, 1980).

3 Manuel Rodríguez-.Buzón Calle, La Colegiata de Osuna, (Sevilla: Diputación Provincial de Sevilla, 1982).
} 
Capilla se hallaba sumida en una crisis, por lo que el Cabildo de la Colegiata solicitó al VIII Duque de Osuna, Pedro Zoilo Téllez Girón, el aumento de las rentas para reorganizar su capilla musical. En 1761 la capilla de la Colegiata de Osuna tenía un presupuesto de trescientos ducados anuales y una cantidad de trigo para todos sus componentes. La Casa de Osuna se hacía cargo del pago de dos tercios de dichas cantidades y el resto era asumido por la Fábrica de la Colegiata que dependía del obispado sevillano. El mencionado presupuesto permitía mantener una modesta capilla que, según Rodríguez Buzón, en 1761 estaba formada por tres voces y tres o cuatro músicos instrumentistas (en 1776 eran tres violines y un bajo $)^{4}$. Existía además un puesto de organista por el que pasaron al menos 5 músicos a lo largo del siglo XVIII (Tabla 15)

Tabla 15.

Organistas de la Colegiata de Santa María de Osuna durante el siglo XVIII Fuente: Cárdenas, Música Barroca; Rodríguez Buzón, La Colegiata

\begin{tabular}{|l|l|l|}
\hline Nombre & Años en el puesto & Observaciones \\
\hline Bonifacio de Rivilla & Antes de 1716 & También era organero \\
\hline Juan de los Reyes & $1716-\uparrow 1720$ & \\
\hline Francisco de Madroñal & $1720-\uparrow 1762$ & confirmado por el \\
\hline Juan Guitarte & $1766 ?-\uparrow 1785$ & $\begin{array}{l}\text { Fue } \\
\text { Duque en su cargo en 1766. }\end{array}$ \\
\hline Francisco González & 1785 & $\begin{array}{l}\text { Accedió al cargo por } \\
\text { oposiciones. Era natural de } \\
\text { la localidad sevillana de } \\
\text { Cañete }\end{array}$ \\
\hline
\end{tabular}

4 Rodríguez Buzón, La Colegiata, pp.94-98. Según Inmaculada Cárdenas eran tres músicos más bajón y violín. Citado en Antonio Martín Moreno, Historia de la música española, 4. Siglo XVII, (Madrid: Alianza, 1985), pp.191-192. 
El 1lamado "órgano mayor" de la Colegiata, restaurado en 1725 por el organero Juan Antonio Hinojosa y el carpintero José Hormigo, debía de estar bastante deteriorado en la segunda mitad del siglo XVIII. El Cabildo en su reunión del 17 de julio de 1777 decidió que el organero de la catedral de Sevilla José Echevarría, que había acudido a Osuna para reparar el órgano antiguo, presentase un proyecto para construir un nuevo instrumento. Éste fue finalmente encargado a José Antón, organero que también trabajó en la catedral de Sevilla. En abril de 1782, Antón presentó un proyecto que se basaba en la restauración del órgano antiguo de la Colegiata, con un coste de 15.450 reales de vellón. Se tiene constancia de que en septiembre de 1783 el órgano estaba ya colocado en el coro ${ }^{5}$.

El nombramiento del maestro de capilla de la Colegiata de Osuna fue siempre supervisado por los titulares de la Casa de Osuna, que eran los encargados en última instancia de otorgar la plaza, ya que la Colegiata funcionaba como un patronato ducal. Desde 1703 desempeñó el puesto de maestro de capilla de la Colegiata Andrés González de Araujo, que falleció en 1761. El siguiente maestro de capilla de la Colegiata de Osuna fue Antonio Moy, quien ocupó el cargo hasta su fallecimiento en $1778^{6}$. Tras la muerte de Moy, el magisterio de capilla estuvo vacante durante nueve años, probablemente por el poco interés que debía despertar entre los profesionales esta plaza cuya escasa dotación económica

\footnotetext{
${ }^{5}$ Rodríguez-Buzón, La Colegiata, pp.97-98.

6 Según Rodríguez Buzón ocuparon también el cargo de maestro de Capilla de la Colegiata de Santa María de Osuna José de Salazar hacia 1708, José González de Araujo en 1726 y Martín Sánchez Calvo en 1768. Rodríguez-Buzón, La Colegiata, pp.94-98.
} 
es seguro que no superaba los 60 ducados anuales y 24 fanegas de trigo que cobraba en 1813 el maestro de la Capilla Musical de la Colegiata ${ }^{7}$.

Debido a la falta de candidatos para cubrir las plazas que quedaban libres, al menos desde mediados del siglo XVIII, los músicos de la Capilla de Música de la Colegiata de Osuna promocionaban por orden de antigüedad a las vacantes que se producían hasta llegar a ostentar la plaza de maestro de capilla. Esta norma práctica no estaba fijada en ningún documento, pero se convirtió en el modelo de adjudicación de las plazas hasta 1814. Francisco de Borja Téllez Girón, X Duque de Osuna modificó en dicho año el sistema de promoción de músicos tras recibir un escrito de Antonio Palacios, su administrador del Estado de Osuna, en el que le informaba de que los músicos disfrutaban de las vacantes de la Capilla "por derecho de acrecer según costumbre observada de muy antiguo" y que esta costumbre se había "introducido por un abuso" $"$

Acogiéndose a este derecho consuetudinario, el bajonista de la Colegiata José Picó solicitó la plaza vacante de maestro de capilla, que le fue concedida por el Duque en $1787^{9}$. José Picó debió de desempeñar el cargo hasta su muerte que tuvo lugar antes de $1813^{10}$.

En julio de 1813, tras la retirada de las tropas francesas, el músico Juan Sánchez escribió al Duque de Osuna que se encontraba de paso en Sevilla. En su carta Juan Sánchez, que afirmaba ser el "maestro de [1a] Capilla de Música de la

\footnotetext{
${ }^{7}$ Véase la Tabla 16.

${ }^{8}$ AHN NOBLEZA, OSUNA-CARTAS leg 486-8.

${ }^{9}$ Este personaje es el mismo al que Inmaculada Cárdenas y Antonio Martín Moreno mencionan como "José Pisó". En toda la documentación administrativa del archivo de la Casa de Osuna, figura claramente el apellido "Pico" tanto para él como para su hijo Jerónimo.
} 
Insigne Iglesia Colegial de la villa de Osuna", le comunicó al Duque el precario estado económico en que se hallaba la institución y de sus músicos después de varios meses sin cobrar sus sueldos:

Excelentísimo Señor Duque de Osuna:

El maestro de [la] Capilla de Música de la Insigne Iglesia Colegial de la villa de Osuna por si y a nombre de todos sus individuos a Vuestra Excelencia con la mayor sumisión dice que hace año y medio que no se les ha satisfecho por aquella Fábrica la cuota de sus sueldos, ni menos se ha verificado el señalado por Vuestra Excelencia desde que los franceses invadieron dicha villa, por cuyo motivo se ven en la precisión de elevarlo a Vuestra Excelencia con la mayor sumisión pues no teniendo mas establecimiento que asegure su subsistencia y la de sus familias se ven pereciendo y cargados de créditos contra si, y conociendo que la satisfacción de Vuestra Excelencia protegerá en un todo tan urgente necesidad para la conservación de su piadoso fin a que se estableció la música; por tanto: A Vuestra Excelencia suplica que informado de esta aserción y de que si no han cobrado no ha sido por falta de diligencias; por un efecto de su grande benevolencia se digne dar las competentes órdenes para que se les satisfaga sus vencidos alcances continuando en lo sucesivo con el pago correspondiente a cada individuo, pues si así no se verifican padecerán los perjuicios que serán insoportables; así lo esperan de la piedad de Vuestra Excelencia. Sevilla y julio 8 de 1813.

Excelentísimo Señor

Juan Sánchez" ${ }^{\prime 1}$

\footnotetext{
${ }^{10}$ AHN NOBLEZA, OSUNA-CARTAS leg 486-8.

${ }^{11}$ Ibíd., AHN NOBLEZA, OSUNA-CARTAS leg 486-8. Juan Sánchez seguramente desempeñaba dicho cargo de forma interina por ser el músico más antiguo, y apoyándose en el citado "derecho de acrecer" En la "nota del situado anual que paga la hacienda a la capilla de música" que el administrador Antonio Palacio remitió al Duque de Osuna a principios del año siguiente, y que se conserva en este mismo legajo, la plaza de maestro de capilla figuraba como vacante, y Juan Sánchez aparecía entre los miembros de la Capilla.
} 
El Duque de Osuna ordenó que se pagasen de inmediato a todos los músicos los atrasos solicitados "haciéndose cargo la hacienda [ducal] de los [sueldos] que antes pagaba la Fábrica [de la Colegiata]"12. La Casa de Osuna se ocuparía en adelante de pagar los sueldos de la Capilla Musical de la Colegiata con la condición de que sus miembros se desligasen a partir de entonces del servicio de esta institución y, quedasen adscritos en exclusiva a la Capilla del Santo Sepulcro. Los músicos pasaron a partir de entonces a estar al servicio directo del Duque de Osuna y quedaron bajo las órdenes del Capellán Mayor de la Capilla del Santo Sepulcro. La administración de esta capilla se mantenía al margen de las decisiones del cabildo de la Colegiata gracias a la bula papal que se le concedió en su fundación (1545). En la respuesta del Duque a los requerimientos de Juan Sánchez figuraban las nuevas condiciones que debían aceptar los músicos:

[...]Todo con la precisa condición de separarse en un todo de la Colegiata, no perteneciendo ya a ella y siendo ya unos criados míos asistiendo a las funciones que mi Casa les mande estando a las órdenes y disposición del Capellán Mayor del Santo Sepulcro para todas las funciones que dicha mi Capilla hace en obsequio de mi casa o en las que determine dicho Capellán Mayor su asistencia.

De la contravención de este mi Decreto queda sin efecto dicha gracia ${ }^{13}$.

Este decreto de 1813 puso fin al mecenazgo de la Casa de Osuna sobre la Capilla Musical de la Colegiata de Santa María que posiblemente dejó de

\footnotetext{
12 AHN NOBLEZA, OSUNA-CARTAS, leg 486-8.

${ }^{13}$ Ibid.
} 
funcionar después suprimirse la dotación económica de la Casa de Osuna y de quedarse sin músicos asalariados. Aunque la actividad musical de la Colegiata de Osuna debió de reducirse a partir de entonces, sabemos que, al menos durante la primera mitad del siglo XIX, esta institución siguió contando con una plaza fija de organista. Este cargo fue ocupado durante el siglo XIX por Francisco Cañete (que desempeñaba este cargo a principios del siglo), Pedro Regalado Salgado (que ocupó la plaza "casi medio siglo") y Francisco del Real que aún ocupaba dicho puesto en enero $1857^{14}$.

\subsection{La Capilla Musical del Santo Sepulcro de Osuna}

La antigua Capilla Musical de la Colegiata de Osuna que, desde julio de 1813, pasó al servicio de la Capilla del Santo Sepulcro, estaba formada por un maestro de capilla, un violín y otros tres músicos cuya especialidad desconocemos Hasta esa fecha la financiación de esta institución musical había sido compartida por la administración de la Casa de Osuna y por la Fábrica de la Colegiata. La dotación de las plazas de la Capilla de la Colegiata era bastante exigua, por lo que la vacante de maestro de capilla, que tenía una renta de 60 ducados anuales y 24 fanegas de trigo, sólo debía de interesar a los propios músicos de la capilla o a otros músicos locales (Tabla 16).

\footnotetext{
${ }^{14}$ Rodríguez-Buzón, La Colegiata, pp.97-98. AHN NOBLEZA, OSUNA-CARTAS, leg 486-8.
} 
Tabla 16.

Composición y salarios anuales de la capilla musical de la Colegiata de Santa María de Osuna

cuando pasó al servicio de la Capilla del Santo Sepulcro en julio de 1813

Fuente: AHN NOBLEZA, OSUNA-CARTAS leg 486-8-1.

\begin{tabular}{|l|l|l|l|l|l|}
\hline Nombre & Puesto & \multicolumn{3}{|l|}{$\begin{array}{l}\text { Renta pagada por la } \\
\text { Casa de Osuna hasta } \\
\text { julio de 1813 }\end{array}$} & $\begin{array}{l}\text { Renta pagada por la } \\
\text { Fábrica de la Colegiata } \\
\text { hasta julio de 1813 }\end{array}$ \\
\cline { 3 - 6 } & & $\begin{array}{l}\text { Trigo } \\
\text { (fanegas) }\end{array}$ & Ducados & $\begin{array}{l}\text { Trigo } \\
\text { (fanegas) }\end{array}$ & Ducados \\
\hline [Vacante] & $\begin{array}{l}\text { Maestro } \\
\text { de capilla }\end{array}$ & 14 & 40 & 10 & 20 \\
\hline Jerónimo Pico & $\begin{array}{l}\text { Músico } \\
\text { [violín] }\end{array}$ & 4 & 32 & 8 & 16 \\
\hline Miguel Cedillo & No consta & 4 & 32 & 8 & 16 \\
\hline Francisco de Reina & No consta & 4 & 32 & 8 & 16 \\
\hline Juan Sánchez & No consta & 4 & 32 & 8 & 16 \\
\hline
\end{tabular}

En noviembre de 1813 Jerónimo Picó, hijo de José Picó (anterior maestro de capilla, ya fallecido) que había sido primer violín de la Capilla de la Colegiata, solicitó la plaza vacante del magisterio de la Capilla Musical del Santo Sepulcro. Jerónimo Picó decía haber servido al Duque desde su infancia "más de cuarenta años" (lo que da una idea de su edad) tener escasos medios para su subsistencia y alegaba en su favor "existir todos los papeles de música [de la capilla] en su poder", seguramente heredados de su padre ${ }^{15}$.

En los informes que Antonio Palacios, el administrador de la Casa ducal en Osuna, remitió al Duque declaró que "el Jerónimo es un músico de una muy regular habilidad con superioridad a todos sus compañeros" y que había servido muchos años como "primer violín de la Capilla de Música que era de la Insigne

${ }^{15}$ AHN NOBLEZA, OSUNA-CARTAS, leg 486-8. 
Iglesia Colegial y fue destinada por orden de Vuestra Excelencia a la del Santo Sepulcro de la misma". Enterado de que la provisión de la plaza era indispensable para el funcionamiento de la Capilla Musical del Santo Sepulcro, el Duque de Osuna nombró el 17 de febrero de 1814 a Jerónimo Picó maestro de la Capilla del Santo Sepulcro ${ }^{16}$.

La actividad musical de la Capilla del Santo Sepulcro prosiguió a lo largo del siglo XIX. Al menos hasta 1857 este patronato ducal contó con un organista nombrado directamente por el Duque. Cuando el 23 de enero de 1857 falleció Cayetano Saá, que había sido hasta entonces organista de esta capilla, varios músicos locales se dirigieron al XII Duque de Osuna para solicitarle la plaza ${ }^{17}$. La plaza de organista de la Capilla del Santo Sepulcro de Osuna fue otorgada finalmente a Tomás Holgado, hijo del sacristán segundo de la Iglesia Colegial de Santa María de Osuna, que había ejercido como organista "en la misma Capilla por el tiempo de tres o cuatro años en las enfermedades de Saá sin retribución alguna"18

\footnotetext{
${ }^{16}$ Ibid.

${ }^{17}$ Ibid. Se conservan las solicitudes para dicha plaza de Antonio María del Real, Antonio de Ayala, Miguel Navarro y Holgado, José María Gordillo y Tomás Holgado

${ }^{18}$ AHN NOBLEZA, OSUNA-CARTAS, leg 486-8.
} 


\section{Música y ceremonial en las fiestas religiosas relacionadas con las Casas de Osuna y Benavente}

La fiesta, tanto en su vertiente religiosa como profana, vinculada al calendario litúrgico o como resultado de circunstancias y acontecimientos diversos, no es sólo el resultado de las necesidades lúdicas del ser humano. En las sociedades organizadas política y socialmente la fiesta está íntimamente relacionada con una determinada visión del poder.

Durante la Edad Moderna, la alta nobleza española siguiendo de cerca las costumbres de la monarquía, utilizó los acontecimientos festivos para hacer ostentación de su supremacía económica y social. Los bautismos, matrimonios o funerales de los miembros de una familia nobiliaria, las victorias militares, la coronación de los reyes, el carnaval o la celebración de las fiestas de los patronos religiosos de la casa, entre muchas otras efemérides, se convirtieron en suntuosas celebraciones que permitían exhibir la pujanza económica y los privilegios obtenidos. Estos acontecimientos festivos se plasmaban en distintas manifestaciones artísticas con frecuencia entremezcladas como la literatura, la música, el baile, la pintura, la escenografía o la arquitectura efímera.

Para entender el papel que desempeñó la música en estas celebraciones festivas es necesario, por tanto, conocer las líneas generales del ceremonial que se desarrollaba en cada uno de estos actos y las peculiaridades del resto de expresiones artísticas que formaban parte de ellos ${ }^{19}$.

\footnotetext{
${ }^{19}$ Hasta el momento apenas unos pocos estudios han abordado la importancia del ceremonial para la comprensión de los fenómenos musicales de las fiestas realizadas en España en el siglo XVIII. Entre ellos destaca la recopilación bibliográfica de Margarita Torrione y la reciente Tesis Doctoral
} 
Entre los acontecimientos festivos urbanos que se celebraban durante la Edad Moderna en España en los que se combinaban distintos fenómenos artísticos se hallaban las llamadas funciones de iglesia o fiestas religiosas, que solían organizarse por los gremios profesionales, las congregaciones religiosas, las casas nobiliarias o la familia real, para honrar a sus patronos o antepasados, conmemorar una victoria militar o celebrar cualquier otro acontecimiento que requiriese una cierta solemnidad.

Las fiestas religiosas seguían un complejo ceremonial perfectamente organizado que se desarrollaba en una o varias sesiones. Las funciones constaban de diversos actos litúrgicos en los que intervenían predicadores que eran anunciados en carteles y en la prensa con el fin de atraer al público, y cuyos sermones, cuando se trataba de oradores afamados, llegaban a convertirse en auténticos espectáculos a los que asistían un gran número de fieles. La música de estas fiestas era interpretada por las principales capillas de música adscritas a instituciones religiosas, o por grupos de músicos y cantores formados para la ocasión.

La prensa de la época anunciaba habitualmente las funciones de iglesia con todo lujo de detalles sobre su organización y celebración. Un ejemplo, seleccionado entre los numerosos que aparecen en la prensa de la época, es el anuncio que se insertó el 22 de noviembre de 1797 en el Diario de Madrid

de María José de la Torre. Véase Margarita Torrione (ed.), Crónica festiva de dos reinados en la Gaceta de Madrid (1700-1759) ([Toulouse]: CRIC \& Ophrys, 1998); y María José de la Torre, Música y ceremonial en las Fiestas Reales de proclamación de España e Hispanoamérica (17461814), Tesis doctoral (Granada: Universidad de Granada, 2004). 
avisando con todo detalle de la celebración de la fiesta en honor de Santa Cecilia patrona de los músicos. En la función participó la Capilla de Música de Santa Cecilia a la que se unieron otros "profesores devotos de la Santa":

Solemne fiesta en honor y culto de la Patrona y protectora del noble arte de la música la Gloriosa y esclarecida Virgen y Martir Santa Cecilia, [que] ofrecen y dedican a expensas anualmente los individuos de su propia Capilla en la Iglesia del Real Convento de Nuestra Señora de los Ángeles del orden de Nuestro Padre San Francisco de esta Corte en su propio día 22 del presente mes de noviembre de 1797 dando principio a la festividad del día 21 con Solemnes Vísperas y el [día] de la Santa habrá Misa, Completas e intermedios por mañana y tarde. Será Panegirista de las Virtudes, Glorias y Excelencias de la Santa el Muy Reverendo Padre Fray isidro Ceballos, Bibliotecario y Predicador de Corte en el Real Monasterio de San Jerónimo. Autorizará este Sagrado culto la Real presencia de Jesucristo sacramentado mañana y tarde, y acabada la Misa Mayor velarán a su Divina Majestad los expresados individuos hasta la hora de completas. A cuya festividad de vísperas Solemnes, Misa, completas e intermedios de mañana y tarde de dicho día 22 asistirá con todo el lleno de voces e instrumentos la Capilla de Música dedicada a dicha santa, asociada de unos profesores devotos de la $\operatorname{Santa}^{20}$.

Las Casas de Osuna y Benavente patrocinaron la celebración de fiestas religiosas en los principales templos de las ciudades donde residieron, bien para honrar a sus santos patronos, o para celebrar cualquier acontecimiento privado o político. La música fue uno de los elementos fundamentales de estas celebraciones que, obviando su supuesta función litúrgica, llegaban a convertirse en un espectáculo de características teatrales, como relataba el Barón de Maldá a

\footnotetext{
${ }^{20}$ Diario de Madrid, 22 de Noviembre de 1797, p.1398.
} 
propósito de una función de gracias celebrada por la Condesa-Duquesa María Josefa a su llegada a Barcelona en 1783:

Dicha función [celebrada] en la iglesia de los Trinitarios supo más a teatro que a iglesia, por los músicos y cantores que entraban en la orquesta, puesto que cantó Tenucci, de la Ópera, causando todo aquel aparato festivo y reunión a más de la confusión, devoción poca o ninguna ${ }^{21}$.

Al igual que el resto de la alta nobleza, los titulares de las Casas de Osuna y Benavente utilizaron las fiestas religiosas para mostrar públicamente su superioridad económica y cultural. Desde el punto de vista musical, esta superioridad se concretó en un especial interés por presentar en estos actos religiosos un repertorio musical de calidad, compuesto por misas, motetes y otras obras religiosas de los más destacados compositores del momento que se encargaban expresamente para ser estrenadas en estas fiestas, o se adquirían en distintos lugares de Europa para presentarse como primicia en España. La interpretación de las obras corría a cargo de las principales capillas musicales adscritas a instituciones religiosas de la ciudad, de los músicos que trabajaban al servicio de la familia o de grupos instrumentales y vocales que se formaban para la ocasión con destacados profesionales de otras formaciones.

21 Barón de Maldá, Calaix de Sastre. Citado en Condesa de Yebes, La Condesa-Duquesa de Benavente. Una vida en unas cartas (Madrid: Espasa Calpe, 1958), p. 28. 


\subsection{Principales celebraciones}

\subsubsection{Funciones en honor a San Francisco de Borja y a laVirgen del Pilar}

El concepto de linaje en el que se apoyan gran parte de las tradiciones de la nobleza, comportaba la responsabilidad de asumir como propias las tradiciones de los títulos nobiliarios que, a través de complejos procesos administrativos, se incorporaron a las Casas de Osuna y Benavente a lo largo del siglo XVIII y XIX.

La fiesta religiosa más importante patrocinada por la Casa de Benavente fue la dedicada a San Francisco de Borja, patrón de la Casa de Gandía. Este personaje de notorias aficiones musicales, fue reivindicado como un antepasado de la Casa de Benavente a partir de 1740 cuando tras la muerte sin descendencia de Luis Ignacio de Borja, Duque de Gandía, la titularidad de este ducado y todas sus posesiones se incorporaron al patrimonio de los Benavente.

Todos los años, entre los meses de septiembre y octubre, la Casa de Benavente organizaba en el Real Oratorio de San Felipe Neri de Madrid, una serie de actos religiosos solemnes para honrar la memoria de San Francisco de Borja, a quien consideraban "su abuelo", más por cuestiones de linaje que por una verdadera consanguinidad ${ }^{22}$.

El Real Oratorio de San Felipe Neri, donde se custodiaban los restos de San Francisco de Borja, fue la "Casa Profesa" de la Compañía de Jesús en Madrid hasta su expulsión en 1767. El edificio fue entregado a los Padres de San Felipe

\footnotetext{
22 Otras casas nobiliarias como la de Medinaceli o Lerma también declaraban ser herederas de San Francisco de Borja y participaban en la celebración de estas fiestas, patrocinando alguno de los actos.
} 
Neri, quienes mantuvieron la advocación del templo a San Francisco y sus reliquias que estaban situadas en el altar mayor ${ }^{23}$.

La música formaba parte del ceremonial de celebración de las fiestas de San Francisco de Borja antes de que estas comenzaran a ser patrocinadas por la Casa de Benavente. En 1733 y 1734, el Duque de Gandía organizó una función en honor a San Francisco de Borja que comenzó en las vísperas del día 30 de septiembre y finalizó el primero de octubre al caer el día. A esta función asistió “toda la música con tres violines y un oboe ${ }^{24 "}$. Asimismo, en las fiestas de 1738, se contrataron "clarines, timbales, trompas de caza y contrabajos" que se unieron a "los músicos" lo cual parece dar a entender que el Duque de Gandía tenía una capilla de música o grupo de músicos asalariados a su servicio a los que se unían otros músicos de refuerzo en las grandes solemnidades ${ }^{25}$.

Cuando a partir de 1740 la organización de las fiestas de San Francisco de Borja fue asumida por la Casa de Benavente, la música continuó siendo uno de los elementos fundamentales del ceremonial de estas celebraciones. En 1745, el “compositor de música” Juan Bautista Mele recibió ochocientos setenta reales para pagar a los músicos por asistir a la función del día de San Francisco de Borja

\footnotetext{
23 El cuerpo de San Francisco de Borja se trajo a España y se entregó a la Compañía de Jesús en 1617 gracias a Francisco Gómez de Sandoval, Duque de Lerma y primer ministro de Felipe III. En 1627, las reliquias se trasladaron a la casa que la orden jesuita tenía en la Plazuela de los Herradores de Madrid en donde se inició la construcción de la Iglesia que se concluyó a finales del siglo XVII. Josef Antonio Álvarez y Baena, Compendio Histórico de las Grandezas de la Coronada Villa de Madrid, Corte de la Monarquía de España, (Madrid: Antonio de Sancha, 1786), pp.28-29 у p.172.

24 AHN NOBLEZA, OSUNA-CARTAS, leg 389-17.

25 Ibíd, leg 350.
} 
y su víspera del año 1744 "que fueron cuatro violines, dos oboes, dos trompas y dos bajos (el día del santo) y la víspera dos violines y dos bajos"26.

Durante la etapa en que la Casa de Benavente estuvo regida por María Faustina Téllez-Girón, Condesa-Duquesa viuda y por su hija María Josefa (17631834), las funciones de San Francisco de Borja se convirtieron en un acontecimiento social de primer orden en Madrid y fueron utilizadas para hacer ostentación del poder económico de la familia y de su prestigio social. Entre los invitados que asistían habitualmente a estas funciones figuraban los representantes de las principales casas nobiliarias de España, embajadores y otros relevantes personajes de la política y la cultura del momento, como Tomás y Bernardo de Iriarte, Francisco de Sabatini o el Corregidor de la Villa de Madrid José Antonio de Armona $^{27}$.

A lo largo de la segunda mitad del siglo XVIII y en las primeras décadas del siglo XIX, las fiestas de San Francisco de Borja, se consolidaron como una de las tradiciones religiosas más importantes de la Casa de Benavente. Su celebración anual sólo debió de interrumpirse por motivos forzosos durante la invasión francesa cuando la familia se trasladó a Cádiz. No obstante es posible que, al menos en 1812 , se celebrasen en dicha ciudad andaluza una o varias funciones de iglesia en honor a San Francisco de Borja patrocinadas por la Casa

\footnotetext{
${ }^{26}$ Ibid., leg 414-11-1.
}

27 AHN NOBLEZA, OSUNA-CARTAS, leg 350-8. Relación de invitados a las fiestas de San Francisco de Borja de 1779. 
de Benavente. Varias misas y motetes de Mozart, Kraft, y Tomás Abril ${ }^{28}$ fueron copiados por encargo de la Condesa-Duquesa en octubre de ese año, mes en que solían celebrarse las funciones en honor de San Francisco de Borja ${ }^{29}$.

A finales de 1813, después de que la familia Benavente-Osuna regresase a Madrid, la Condesa-Duquesa María Josefa inició las gestiones para restaurar la costumbre de celebrar las fiestas de San Francisco de Borja. Comenzó poniéndose al corriente del estado en el que había quedado el Real Oratorio de San Felipe Neri y los restos del santo. El 26 de noviembre de este año, la Condesa-Duquesa escribió al Duque de Medinaceli para comunicarle que el arca con los restos de San Francisco de Borja no había sido profanada por las tropas francesas y se hallaba oculta en una "capilla oscura" de la Iglesia del Salvador en la Calle Ancha de San Bernardo de Madrid. A principios de octubre de 1814, la Condesa Duquesa María Josefa solicitó al Arzobispo de Toledo la pertinente autorización para restablecer la celebración de las fiestas que comenzarían el día 10, una vez finalizadas las obras de restauración del Oratorio de San Felipe Neri e instaladas en él las reliquias de San Francisco de Borja para que pudieran venerarse públicamente $^{30}$. El comienzo de las fiestas se retrasó finalmente hasta el día 23 de

\footnotetext{
28 Según Saldoni Tomás Abril falleció en 1796, y era Director de música en el teatro de Cádiz en 1790. Baltasar Saldoni, Diccionario biográfico-bibliográfico de efemérides de músicos españoles (Madrid: Antonio Pérez Dubrull, 1868-1881), vol. I, p. 332.

29 AHN NOBLEZA, OSUNA-CARTAS, leg 392-4. En este documento, en el que figura el visto bueno de Carlo Marinelli, consta el pago de la copia en partitura de una misa a cuatro voces de W.A Mozart, otra misa a cuatro voces y el motete "O salutaris hostia" del "Signor Kraftt" y la partitura de la Misa a tres voces de "Don Tomas Abril". Las dos últimas figuraban en los inventarios de la papelera de música de la Condesa Duquesa que se redactaron en 1824 y 1838. Ver Apéndices 3 y 4.

${ }^{30}$ AHN NOBLEZA, OSUNA-CARTAS, leg 570.
} 
octubre de 1814 posiblemente debido a una demora en la finalización de las obras del Oratorio de San Felipe Neri ${ }^{31}$.

Después de la muerte de la XV Condesa-Duquesa de Benavente en 1834, la tradición de celebrar solemnemente la fiesta de San Francisco de Borja fue continuada por sus dos nietos, los Duques de Osuna y Condes-Duques de Benavente Pedro de Alcántara II y Mariano Téllez Girón. Este último perpetuó la tradición familiar de las fiestas religiosas de San Francisco de Borja al menos hasta $1858^{32}$.

Las funciones o fiestas en honor de San Francisco de Borja organizadas en Madrid por la Casa de Benavente durante los siglos XVIII y XIX se extendían a lo largo de varios días. Solían comenzar con las Vísperas de la tarde del día 30 de septiembre y finalizaban habitualmente hacia el 10 de octubre. Los principales actos tenían lugar los días 1 de octubre (con la inauguración de las fiestas) y el día 10, festividad del santo. En las funciones participaba un conocido predicador, y un amplio conjunto instrumental y vocal, que se encargaba de interpretar un programa de obras completas o fragmentos de música religiosa, que en muchas ocasiones se habían encargado expresamente para la ocasión.

Aunque la promotora y organizadora de las fiestas de San Francisco de Borja era la Condesa-Duquesa de Benavente como titular del Ducado de Gandía, cada una de las funciones solía estar patrocinada por alguno de sus familiares

\footnotetext{
${ }^{31}$.Ibíd. leg 3908.

32 AHN NOBLEZA, OSUNA leg 3908. La última referencia que he localizado de la celebración de las fiestas de San Francisco de Borja en Madrid es un cartel de anuncio de 1858. En esta ocasión la música estuvo a cargo de un conjunto de "voces escogidas" y una "brillante orquesta dirigida por el profesor y director de música de la Casa de Su Excelencia Don Victoriano Daroca”.
} 
directos (como su marido, el IX Duque de Osuna o sus hijos), un miembro de la familia real o por un representante de la alta nobleza vinculado a la memoria de San Francisco de Borja.

Un ejemplo del amplio programa de estos actos puede verse en el cartel de anuncio de las fiestas celebradas en 1818 (Lámina 24). Las funciones comenzaron el día 30 de septiembre con la celebración de las vísperas cuyos gastos corrieron a cargo de la Condesa-Duquesa María Josefa que también patrocinó la función del día 1 de octubre. Las fiestas de los tres días siguientes fueron sufragadas por miembros de la Casa Real (el Rey, la Reina y el infante Don Carlos respectivamente) y el día 5 la fiesta fue patrocinada por el Real Consejo de Órdenes. Los días 6 al 9 costearon las funciones miembros de las más importantes casas nobiliarias españolas: el día 6 patrocinó la fiesta el Duque de Medinaceli, los días 7 y 8 la función se hizo en memoria de la Duquesa del Infantado, y el día 9 corrió a cargo del Duque de Medina Sidonia. La función del 10 de octubre fue patrocinada por la Condesa Duquesa de Benavente María Josefa a devoción de “su difunta madre la Excelentísima Señora Condesa Duquesa viuda de Benavente" puso fin a las funciones de 1818. 


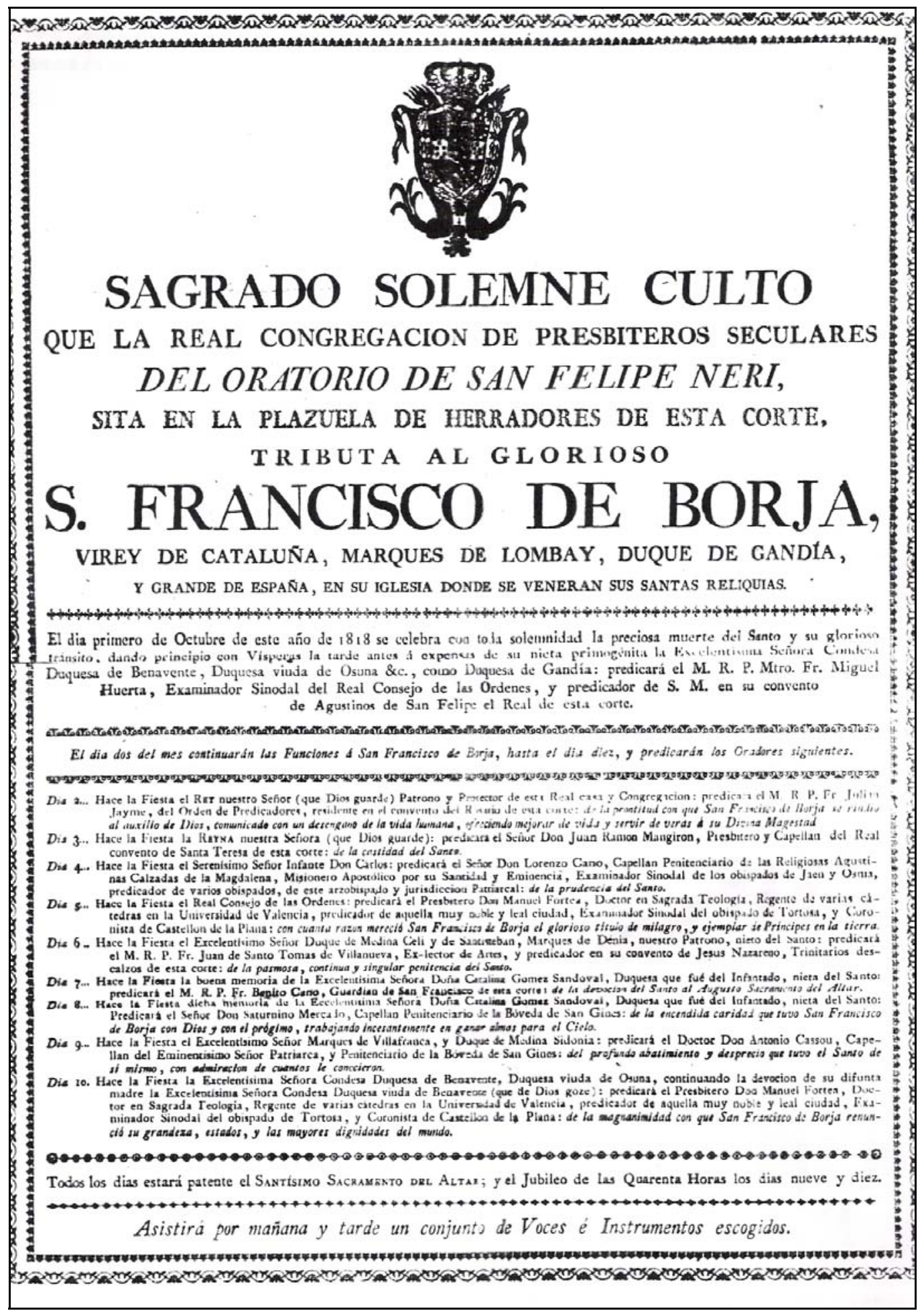

\section{Lámina 24.}

Cartel de las fiestas en honor de San Francisco de Borja que se celebraron en el oratorio de San Felipe Neri de Madrid en 1818

AHN NOBLEZA, OSUNA-CARTAS, leg 570. 
En la segunda década del siglo XIX, la intervención de las Casas de Osuna y Benavente en el patrocinio de las funciones de San Francisco de Borja sufrió una notable merma respecto a las décadas anteriores. Si a finales del siglo XVIII y en los primeros años del siglo XIX, los miembros de la familia Benavente-Osuna solían patrocinar al menos 7 u 8 de las funciones ${ }^{33}$, tras la restitución de las fiestas después de la invasión francesa su participación se redujo notablemente. En 1818, la Condesa-Duquesa de Benavente sólo patrocinó las vísperas y dos de las fiestas de San Francisco de Borja (Lámina 24). Entre 1825 y 1830 la Casa de Benavente patrocinó las Vísperas del día 30 de septiembre y la misa del 1 de octubre (en ambos días con la participación de un amplio grupo vocal y una orquesta), y en otro de los días se costeaba la celebración de una misa "a canto llano" en los que intervenía un coro de 8 salmistas, más un bajón y un organista ${ }^{34}$.

Al menos desde 1786, la Casa de Benavente patrocinó también las funciones en honor a la Virgen del Pilar, que se celebraban en Madrid a partir del día 12 de octubre en el Convento de las Madres Capuchinas de Madrid. En ellas solían particpar los mismos efectivos musicales contratados para las funciones de San Francisco de Borja, que tenían lugar siempre en los días precedentes de los meses de septiembre y octubre.

\footnotetext{
33 AHN NOBLEZA, OSUNA-CARTAS, leg 390-1.

${ }^{34}$ Ibíd.. Véase Apéndice 6, documentos n 12,13 y 14.
} 


\subsubsection{Otras funciones religiosas con participación musical}

Además de las funciones en honor a San Francisco de Borja y a la Virgen del Pilar, la Casa de Benavente patrocinó en Madrid otras fiestas religiosas que contaron con una importante participación musical. Una de las más destacadas fue la dedicada a la memoria de Santo Toribio Alfonso de Mogrovejo. (*1538†1606), patrón de la villa de Mayorga (Valladolid), un territorio que pertenecía a la administración de la familia Pimentel desde su fundación. Santo Toribio era considerado uno de los santos patrones de la Casa de Benavente ${ }^{35}$., y por ello se le honraba periódicamente con funciones religiosas en Madrid que se celebraban durante el mes de abril en la Iglesia de Nuestra Señora de Porta-Coeli [Portaceli] situada en la calle de la Luna o en el Convento de la Trinidad de religiosos Calzados de la calle Atocha ${ }^{36}$

Los titulares de la Casa de Osuna, mantuvieron durante el siglo XVIII la tradición de patrocinar al menos una de las novenas religiosas en honor a San Pascual Bailón que se celebraban anualmente en Convento de Madrid del mismo

35 Santo Toribio fue el segundo Arzobispo de Lima y se hizo célebre por su labor de evangelización en los territorios americanos que se caracterizó por el respeto y la protección de la población indígena. Fundó varios hospitales y escuelas en el Perú y redactó un catecismo en castellano, quechua y aymara que también se tradujo a otras lenguas indígenas. Fue beatificado en 1679 y canonizado en 1726. Sobre este personaje véase Ángela Polo Barrera, Santo Toribio de Mogrovejo: hijo y patrono de Mayorga, ([Valladolid]: Diputación Provincial de Valladolid, 2002). María Gembero ha documentado también una fiesta en honor a este santo que se celebró en 1732 en la Parroquia de San Nicolás de Pamplona por un miembro cercano a la nobleza. María Gembero Ustárroz, "El patronazgo ciudadano en la gestión de la música eclesiástica: la Parroquia de San Nicolás de Pamplona (1700-1800)", Nassarre XIV/1 (1998), pp. 312-313 y 358-359.

36 AHN NOBLEZA, OSUNA-CARTAS legs 389-9 y 389-28. Sobre la fundación de estos conventos véase Álvarez y Baena, Compendio, pp.163-164 y pp. 119-120 respectivamente. 
nombre habitado por monjas Franciscanas Descalzas ${ }^{37}$. Para solemnizar estas novenas los miembros de la Casa de Osuna solían contratar a alguna de las capillas musicales estables de Madrid, o a conjuntos musicales que se formaban para la ocasión ${ }^{38}$.

\subsection{La música en las celebraciones religiosas familiares}

La forma de vida de la alta nobleza española durante la Edad Moderna, estuvo dominada por un ideal de exhibición y apariencia que tenía como propósito señalar su pertenencia al grupo social privilegiado. La ostentación que presidía la vida cotidiana de las Casas de Osuna y Benavente llegó a uno de sus máximos niveles en la celebración de los acontecimientos religiosos familiares. En los bautizos, bodas o funerales de los miembros de la familia, la música fue uno de los elementos indispensables de un ceremonial que pretendía mostrar públicamente el poder económico del linaje.

El análisis de la documentación contable de la Casa de Osuna confirma la importancia que tuvo la música dentro de las celebraciones familiares de esta familia nobiliaria. Aunque los documentos conservados en este fondo no permiten abordar un estudio sistemático del ceremonial, la abundancia de recibos y

\footnotetext{
${ }^{37}$ El convento donde se desarrollaba estas funciones situado cerca del Paseo del Prado estaba habitado por monjas franciscanas, y no por monjes como afirma Judith Ortega. Judith Ortega, "El mecenazgo musical de la Casa de Osuna durante la segunda mitad del siglo XVIII: el entorno musical de Luigi Boccherini en Madrid, RMS, XVII/2 (2004), p. 654. Sobre la fundación de este convento véase Álvarez y Baena, Compendio, pp.175-176.

${ }^{38}$ En las funciones de San Pascual Bailón de 1740 intervino la Capilla de música de las Descalzas Reales; en 1758 y 1760 participó "un coro de voces" y "una orquesta de música”, y en 1775 la Capilla de Música de la Encarnación. AHN NOBLEZA, OSUNA, leg 3908 y AHN NOBLEZA, OSUNA-CARTAS, leg 389-12 y 389-30.
} 
libramientos de pagos realizados a instrumentistas y cantores confirma la presencia de la música como una constante en todas las celebraciones religiosas familiares de las Casas de Osuna y Benavente desde la segunda mitad del siglo XVIII hasta mediados del siglo XIX.

Este apartado está dividido en dos puntos. En el primero estudio un caso paradigmático de celebración religiosa familiar, las exequias del VIII Duque de Osuna celebradas en 1787 en Madrid. En el segundo incluyo diversas noticias sobre otras fiestas religiosas familiares en las que la música tuvo una destacada presencia.

\subsubsection{Música y ceremonial en los funerales del VIII Duque de Osuna.}

A finales del siglo XVIII los funerales de la alta nobleza española seguían un modelo ceremonial que, en líneas generales, preservaba la teatralidad característica del Barroco. Este modelo, que había tenido sus máximos exponentes en los grandes funerales de Estado realizados a la muerte de los monarcas de las Casas de Austria y de los primeros Borbones, respondía a un complejo sistema simbólico-escenográfico, cuya función primordial era mostrar las relaciones políticas y sociales de la persona fallecida ${ }^{39}$. La plasmación de este programa ideológico entrañaba la colaboración de diferentes disciplinas artísticas: la escultura y la arquitectura de carácter efímero, la escenografía, la pintura, la literatura y la música.

39 Sobre este tema véase Javier Varela, La muerte del rey. El ceremonial funerario de la monarquía española (1500-1885) (Madrid: Turner, 1990). 
Las honras fúnebres que se celebraron en 1787 cuando falleció Pedro Zoilo Téllez Girón, VIII Duque de Osuna, constituyen un notable ejemplo del complejo ceremonial que rodeaba a la muerte de un personaje de la alta nobleza. A través de fuentes literarias, iconográficas y administrativas he podido reconstruir los principales actos fúnebres que se celebraron en Madrid para honrar el alma del Duque tras su muerte, y el importante papel que tuvo la música en dichos actos.

Pedro Zoilo Téllez Girón falleció el 2 de abril de 1787 a los cincuenta y ocho años de edad. Las honras funerarias comenzaron el día 5 del mismo mes con el depósito del cadáver y la urna de su sepulcro en el convento de San Francisco de Paula de Madrid. Según su panegirista, Tomás Fernández de Mendoza, autor contemporáneo a los hechos, esta ceremonia tuvo lugar "con toda la pompa fúnebre, política y militar" que correspondía a la "grandeza, carácter y ministerios" del Duque de Osuna ${ }^{40}$. El día 30 de abril se celebraron en la iglesia de San Francisco de Paula unas exequias a cargo de los oficiales del Regimiento de Reales Guardias Españolas de Infantería que había sido dirigido por el Duque $^{41}$.

Las honras fúnebres continuaron en el mes de mayo con un novenario celebrado la Real Iglesia Oratorio de San Felipe Neri de Madrid que fue

\footnotetext{
40 Tomás Fernández de Mendoza, Elogio fúnebre en que se da una idea cabal, de las circunstancias virtudes y premios del Excelentísimo Señor Don Pedro Zoilo Téllez Girón, $8^{\circ}$ Duque de Osuna (1787). BNE Ms. 10494, f. 38 v.

${ }^{41}$ Pedro Silva y Sarmiento, Oración fúnebre en las honras, exequias que celebraron los oficiales del Regimiento de Reales Guardias Españolas de Infanteria por el alma del Excelentísimo Señor Duque de Osuna el día 30 de Abril de 1787, en la Iglesia de Padres mínimos de San Francisco de Paula de esta Corte, (Madrid: Viuda de Ibarra, Hijos y Compañía).
} 
organizado por la Condesa-Duquesa de Benavente, hija política del fallecido. Los actos religiosos comenzaron el día 12 de mayo y finalizaron el día 20 del mismo mes. Hasta el día 15 de mayo se habían celebrado 473 misas en los diferentes altares de la iglesia, en turnos de 9 a 12 horas y de 5 a 9 de la tarde ${ }^{42}$.

En los nueve días que duraron las misas, la música estuvo a cargo de un conjunto vocal perteneciente a la Capilla de las Descalzas Reales que, en ese momento, colaboraba habitualmente con la Casa de Benavente en la celebración de las funciones religiosas ${ }^{43}$. Joaquín Agramuntell, festero de dicha Capilla fue el encargado de cobrar los 5620 reales de vellón que recibieron los músicos por su asistencia a este novenario $^{44}$

El novenario finalizó el día 20 de mayo de 1787 con una solemne vigilia, misa y responso en los que participaron cantores de las Descalzas Reales, y la orquesta de la Condesa-Duquesa María Josefa que fue reforzada con varios músicos como era habitual en las fiestas importantes, tanto religiosas como profanas que organizaba la Casa de Benavente:

Los claveros del arca de la tesorería de mi Casa entregarán en virtud de este y de recibo a Don Francisco Basset cuatrocientos reales de vellón para pagar a los músicos que han asistido a la Vigilia, misa y responso del último día del novenario que se celebró en la Real Iglesia Oratorio de San Felipe Neri, por el alma del Excelentísimo Señor Duque de Osuna mi padre y señor, que santa gloria haya, además de los que tengo asalariados. Tomándose la

\footnotetext{
42 AHN NOBLEZA, OSUNA-CARTAS, leg 317-6.

${ }^{43}$ Véase el apartado 2.3.5. de este capítulo.

44 AHN NOBLEZA, OSUNA-CARTAS, leg 317-6.
} 
razón en mi contaduría. Madrid seis de julio de mil setecientos ochenta y siete.

La Condesa Duquesa

Tomo la razón

Manuel de Cubas ${ }^{45}$

Los actos anteriores sirvieron de prólogo para el gran funeral público, que tuvo lugar el 5 de julio del mismo año en la Iglesia del Convento de San Hermenegildo de la orden de los Carmelitas Descalzos de Madrid, organizado por María Faustina Téllez Girón, Condesa-Duquesa viuda de Benavente y hermana del fallecido "con la pompa y grandeza propias de su acostumbrada

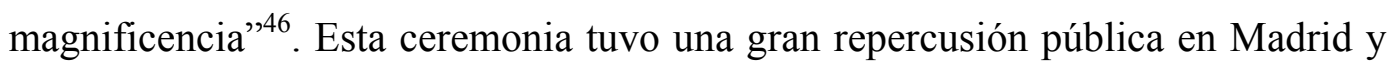
generó una abundante literatura que permite conocer con detalle el espléndido montaje escenográfico en el que se integró la música.

La iglesia de los Carmelitas Descalzos fue decorada desde las cornisas hasta el suelo con bayetas negras como señal de luto sobre las cuales se colocó una gasa de plata que simulaba cenefas. El templo fue iluminado con antorchas dispuestas de forma simétrica desde la cabecera hasta los pies de la iglesia. Juan José Benito describió poéticamente la iluminación de la iglesia con los siguientes versos:

45 Ibíd., leg 390-3. La iglesia se conserva todavía en la actualidad con el nombre de Parroquia de San José (C/ Alcalá, 43)

46 Mientras no se indique lo contrario, los datos del ceremonial del funeral del VIII Duque que figuran en este apartado proceden de la noticia anónima publicada en el Correo de Madrid, $\mathrm{n}^{\circ}$ 81, 28 Julio 1787, pp.349-352. 
En distancias, con bella simetría,

se miran repartidas ciertas luces,

y tanto mas y más sobresalía,

cuanto eran más obscuros sus capuces:

si entre ellas otra cosa se veía

era solo señal de algunas cruces,

porque para morir el más amado

con Christo ha de morir crucificado.

Por el Altar mayor y las Capillas

multitudes de antorchas se notaron,

pues aunque todas eran amarillas,

fue porque igual dolor manifestaron:

portentos son del arte y maravillas

los que en toda la Iglesia figuraron

el más lucido aspecto triste y serio,

propio del melancólico misterio ${ }^{47}$..

El monumento funerario estaba situado en medio del crucero y se levantaba sobre una tarima que imitaba al mármol (Lámina 25). Sobre ella se colocó el catafalco o urna sepulcral que estaba realizada "al gusto griego" con un color que imitaba al pórfido (es decir púrpura y salpicado con pintas de varios colores). La urna se cubrió con el manto de la Real Orden de Carlos III, las insignias de General y las armas del difunto.

47 Juan José Benito García, Afectos del más tierno amor fraternal con el que la Excelentísima Señora Condesa Viuda de Benavente celebró las exequias de su difunto hermano el señor Duque de Osuna [...] Descripción del monumento erigido con este motivo en aquel templo. (Madrid: Manuel González, 1787). 


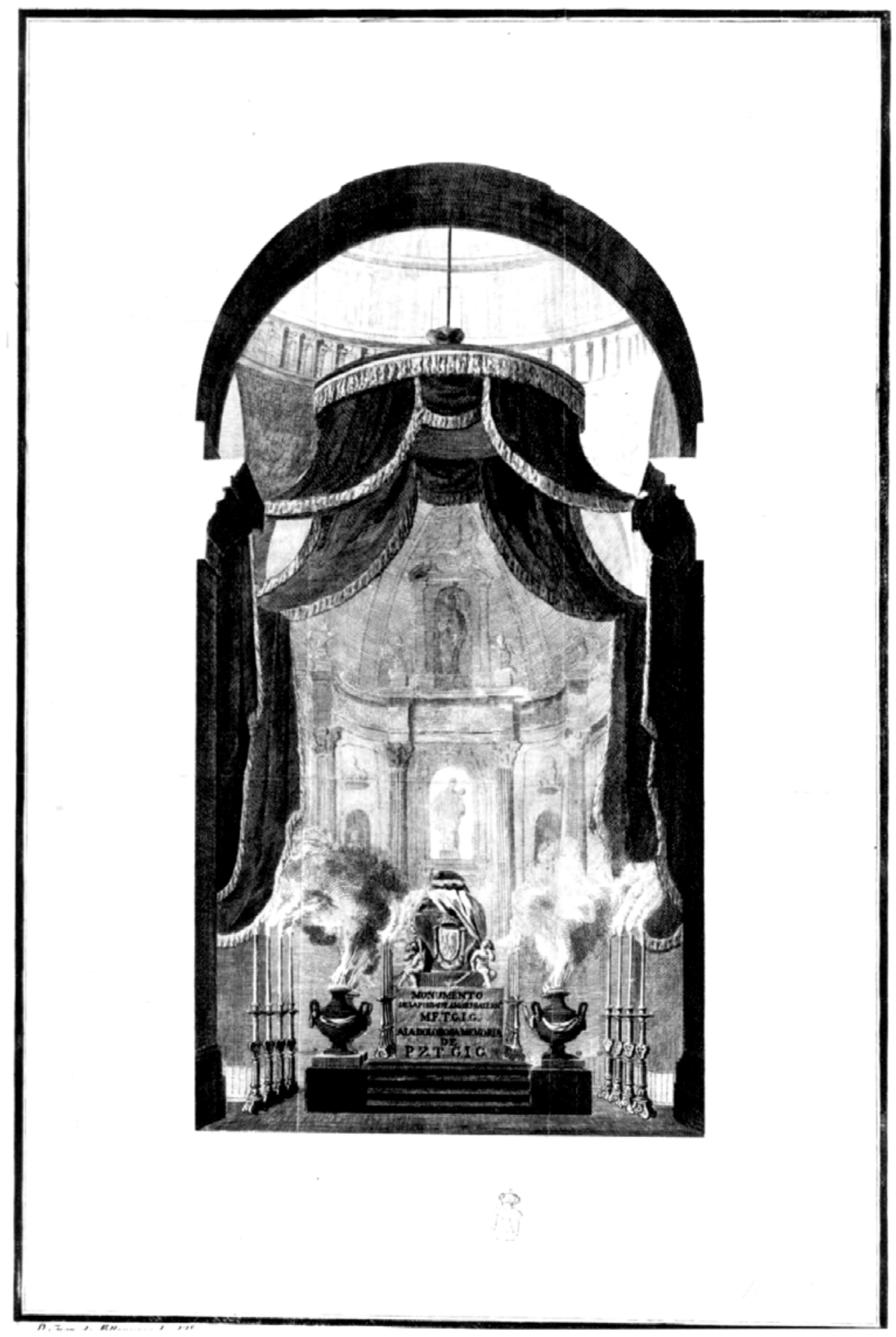

Lámina 25.

Juan de Villanueva (dibujo) y José Jimeno (grabado)

Monumento sepulcral del VIII Duque de Osuna

Grabado calcográfico, (Madrid: s.n, 1787)

(BNE INV 14978) 
En los extremos de la urna funeraria se habían colocado cuatro esculturas de niños llorando:

Cuatro niños llorando en las esquinas

prestaban ocasión de acompañarlos,

en acciones tan propias y tan finas,

que por vivos pudiera admirarlos:

acércate, mortal si determinas

con tanto justo motivo consolarlos,

que, aunque sin alma, alumbran con las teas,

que son del funeral propias preseas ${ }^{48}$.

La base sobre la que estaba situada la urna funeraria tenía dos inscripciones. En el tablero situado frente al altar mayor figuraba un epigrama en latín alusivo al amor fraternal que la Condesa-Duquesa viuda de Benavente profesaba a su hermano:

PETR.ZOIL.TELL.GIR.

DUC.URSAONENS

FRAT. DULCISIM.

MOESTISSIM.SOR.

MAR. FAUSTIN. TELL.GIR.

HOC. PIETAT. ET. AMOR.

MON P.

ANN. MDCCLXXXVII

En el lado opuesto se podía leer una inscripción en castellano de contenido muy similar: 


MONUMENTO
DE LA PIEDAD Y DEL AMOR FRATERNAL
M.F.T.G.G
A LA DOLOROSA MEMORIA
DE
P.Z.T.G.G

Junto a la plataforma del sepulcro se colocaron sobre una basa azulada cuatro jarrones del mismo color que la urna funeraria que fueron cubiertos con una banda de gasa de oro. El sepulcro estaba alumbrado por las llamas que salían de cada uno de los jarrones y por las doce velas que estaban situadas en altos candelabros de plata. Todo este aparato escénico se cubrió con un gran dosel negro orlado con gasas de plata que pendía de la cúpula.

El público asistente a las exequias estaba formado por los principales personajes de la aristocracia y la nobleza residente en Madrid. En un estrado colocado a la derecha del crucero se sentó María Faustina Téllez Girón, la Condesa viuda de Benavente, acompañada de las damas de las principales casas nobiliarias:
En el lado siniestro en un estrado
bien vestido, si bien de sombras lleno,
lamentando la muerte de su amado
estaba la Condesa: ¿quién sereno
podrá mirarla aquí, sin que a su lado
se ponga a consolarla? No ha veneno,
no tósigo más fuerte a dar muerte
que ver y padecer de aquesta suerte.

\footnotetext{
${ }^{48}$ García, Afectos, s.f.

49 Monumento de la Piedad y del Amor Fraternal [que] María Faustina Tellez Girón y Guzmán [dedica] a la dolorosa memoria de Pedro Zoilo Téllez Girón y Guzmán.
} 
Pero porque no acabe esta Señora

al rigor de la pena y sentimiento,

acompañada estaba en esta hora

de otras del mas excelso nacimiento:

con ellas la piedad de Dios implora;

el sacrificio ofrecen incruento,

como sangriento le ofreció María

cuando a su Hijo vio que se moría ${ }^{50}$.

La suntuosidad que proporcionaba este ampuloso marco escénico se vio reforzada por la intervención musical. En este solemne funeral participaron un nutrido coro y un conjunto de "profesores escogidos" dirigidos todos por Cristobal Andreozzi ${ }^{51}$. El grupo vocal estaba dividido en dos coros, el primero formado por nueve cantantes y el segundo por once (Ver Tabla 17).

${ }^{50}$ García, Afectos, s.f.

${ }^{51}$ BNE Ms 14.016.3/188 (Papeles Barbieri). Este documento es una relación de instrumentistas y cantantes con el encabezamiento "Oficio de Difunto[s] que se ha celebrado en la Iglesia de Carmelitos Descalzos de esta Corte el día 5 de Julio de 87". Aunque en ningún punto del documento se menciona al Duque de Osuna, la fecha y lugar de celebración del acto, y el hecho de que Cristóbal Andreozzi figure como director de la función (que aparece también documentado en la citada noticia del Correo de Madrid) lo vinculan, indudablemente, a esta ceremonia. 
Tabla 17.

Miembros del coro y orquesta que solemnizaron los funerales del VIII Duque de Osuna celebrados el 5 de Julio de 1787 en la Iglesia del Convento de San Hermenegildo de Madrid Fuente: BNE Ms 14.016.3/188 (Papeles Barbieri)

\begin{tabular}{|c|c|c|}
\hline \multirow{20}{*}{ CORO } & \multirow{9}{*}{ [Coro 1] } & Ramírez \\
\hline & & Aguirre \\
\hline & & Juan de Dios \\
\hline & & Ant[onio] Bosques \\
\hline & & Roque Ibáñez \\
\hline & & Tomás Isasi \\
\hline & & Fajardo \\
\hline & & Blas Gil \\
\hline & & Ramón Bioscas \\
\hline & \multirow{11}{*}{ [Coro 2] } & Martin Yhavar \\
\hline & & Liborio Fernández \\
\hline & & Josef Inojes \\
\hline & & Josef Pendon \\
\hline & & Antonio Bosques \\
\hline & & Francisco Gómez \\
\hline & & Julián Galindo \\
\hline & & Andrés Jiménez \\
\hline & & Julián Mollinedo \\
\hline & & Dámaso Santos \\
\hline & & Feliz Ramos \\
\hline & Maestro [de coro] & Asero [¿Bernardo Álvarez Acero?] \\
\hline & Avisador & Arse [Arche] \\
\hline
\end{tabular}




\begin{tabular}{|c|c|c|}
\hline \multirow{23}{*}{ ORQUESTA } & \multirow{11}{*}{ [Violines] } & [Antonio] Jaúregui \\
\hline & & Manuel Carriles \\
\hline & & [Pascual Juan] Carriles \\
\hline & & Cruz \\
\hline & & Eustasio León [Eustaquio León] \\
\hline & & [José] Vidal \\
\hline & & Dimas \\
\hline & & Bala[do] \\
\hline & & [Cristobal de] Ronda \\
\hline & & Pepe León \\
\hline & & Terzi \\
\hline & \multirow[t]{2}{*}{ Violas } & Balado \\
\hline & & Balado \\
\hline & \multirow[t]{2}{*}{ Violones } & [Pablo] Vidal \\
\hline & & [Cayetano] Vidal \\
\hline & \multirow[t]{2}{*}{ Contrabajo } & Blas López \\
\hline & & Perico [Pedro Sebastián] \\
\hline & \multirow[t]{2}{*}{ Oboes } & García \\
\hline & & García \\
\hline & \multirow[t]{2}{*}{ Fagotes } & Fransua [Esteban François] \\
\hline & & Gerisuan [Joaquín Garisuain] \\
\hline & \multirow[t]{2}{*}{ Trompas } & Canado [Cayetano Canaut] \\
\hline & & Canado [Canaut] \\
\hline \multicolumn{2}{|c|}{ Director [del coro y la orquesta] } & Cristobal Andreozzi \\
\hline
\end{tabular}

La división del conjunto vocal en dos grupos se menciona también en el poema de Juan José Benito García:

Formados así el objeto lastimoso,

que la muerte de OSUNA representa,

se comenzó el sufragio mas piadoso,

que acaso en muchos siglos se nos cuenta:

un concierto de música armonioso

dulcifica la voz, que se lamenta 
en alternados coros, con tal arte,

que no se vio mejor en otra parte ${ }^{52}$

Como "maestro" del grupo vocal actuó un tal "Asero", nombre que puede identificarse con Bernardo Álvarez Acero, clavecinista en la orquesta del teatro de los Caños del Peral. Como avisador de los cantores figura "Arse", es decir alguno de los dos miembros de la familia de festeros apellidados Arche que trabajaban en Madrid en esta época (Baltasar o Antonio). La orquesta estaba compuesta por un total de veintitrés músicos: once violines, dos violas, dos violones y dos contrabajos, dos oboes, dos fagotes, y dos trompas ${ }^{53}$. Entre ellos figuraban algunos miembros de la orquesta de la Condesa-Duquesa Maria Josefa, como los violinistas Antonio Jaúregui, Manuel y Pascual Juan Carriles, el violón [Pablo] Vidal, el contrabajo "Perico" [Pedro Sebastián], el fagot Joaquín Garisuiain o el trompa [Cayetano] Canaut. Entre los restantes instrumentistas había algunos de los colaboradores habituales de las Casas de Benavente y Osuna como los hijos de Pablo Vidal (Cayetano y José) o el fagot Fransua [Esteban François], músico del Regimiento de América que dirigía el IX Duque de Osuna.

Aunque no ha quedado constancia de la música que se interpretó durante el funeral del VIII Duque de Osuna, en el extenso inventario de la biblioteca musical de la Condesa-Duquesa de 1824 figuran dos obras de temática fúnebre que, dada su fecha de composición, podrían haberse escuchado en estas exequias: un

\footnotetext{
52 García, Afectos, s.f.

53 BNE Ms 14.016.3/188(Papeles Barbieri).
} 
Responsorio de difuntos del napolitano Davide Pérez y un Oficio de difuntos a 8 voces de Manuel Doyagüe ${ }^{54}$.

Las solemnes exequias por el VIII Duque de Osuna concluyeron con el elogio fúnebre expuesto por Antonio Tavira de la orden de Santiago "55 “un orador bien conocido por su talento, erudición y elocuencia" que ostentaba el cargo del Capellán de Honor y Predicador del rey ${ }^{56}$.

La reconstrucción de los actos religiosos y las exequias fúnebres que tuvieron lugar a la muerte del VIII Duque de Osuna muestra que aún en las últimas décadas del siglo XVIII la alta nobleza seguía manteniendo en sus actos públicos un modelo ceremonial heredero de la artificiosidad barroca y en el cual la música se integraba como un elemento más de un "espectáculo" en los límites entre la realidad y la ilusión teatral.

\subsubsection{Otras celebraciones religiosas familiares con participación musical}

Al menos desde la segunda mitad del siglo XVIII, la música estuvo presente en la gran mayoría de acontecimientos religiosos familiares de las Casas de Osuna y Benavente como queda acreditado por los documentos conservados en

\footnotetext{
54 Véase Apéndices 3 y 4.

55 Oración fúnebre que en las solemnes exequias del Señor Don Pedro Zoylo Tellez Girón y Guzmán, Duque de Osuna, etc. mandadas celebrar por su hermana la Condesa Duquesa Viuda de Benavente y Gandía, etc. en la Iglesia de San Hermenegildo de [los] Padres Carmelitas Descalzos de Madrid el día 5 de Julio de 1787 dijo Antonio Tavira, del Orden de Santiago... (Madrid: Viuda de Ibarra, Hijos y Compañia, [1787]).

${ }^{56}$ Correo de Madrid, p. 352.
} 
el archivo administrativo de los Osuna y en diversas fuentes literarias. Citaré a continuación varios ejemplos significativos:

a) Bautizos

El 18 de agosto de 1783 se celebró en la Catedral de Barcelona el bautizo de Josefa Manuela, la primogénita de los Condes-Duques de Benavente y futuros IX Duques de Osuna. El Barón de Maldá en su Calaix de Sastre, da fe de la suntuosidad con la que se celebró este acto. La catedral se adornó “con colgaduras [de las] que se ponen en muchas festividades del año. Concurrió mucha gente, la más pueblo, para ver el bautizo y ver a las señoras invitadas. La música [corrió a cargo de los miembros] del Regimiento de América"57, del cual era en esa época coronel el Marqués de Peñafiel.

También hubo una importante presencia musical en el bautizo del nieto de la Condesa-Duquesa de Benavente e hijo primogénito de la Marquesa de Santa Cruz que tuvo lugar en Madrid en 1804. En este acto intervino una orquesta cuyos músicos fueron reunidos por el violinista Melchor Ronzi que posiblemente ejerció también como director musical ${ }^{58}$.

b) Consagración musical del Obispo Joaquín Company.

Otro acontecimiento familiar que tuvo una importante participación musical fue la función organizada en 1798 por los Duques de Osuna para celebrar

${ }^{57}$ Barón de Maldá, Calaix de Sastre, citado en Yebes, p.30.

58 AHN NOBLEZA, OSUNA-CARTAS, leg 535-40. 
la consagración de Joaquín Company, obispo de la Orden Franciscana que fue elegido arzobispo de Zaragoza en junio de $1797^{59}$.

La función de consagración sufragada por el Duque de Osuna tuvo lugar el 4 de marzo de 1798 en la iglesia de San Francisco el Grande de Madrid, templo muy próximo al palacio de los IX Duques de Osuna ${ }^{60}$. Por la mañana los Duques ofrecieron un desayuno "con ramilletes, flores [y] dulces de confitería" que se llevó desde su palacio hasta la iglesia. Durante la misa se interpretó un Te deum y un Venite creator cuyos autores no aparecen en la documentación consultada. Los intérpretes de estas obras fueron miembros de la Real Capilla de Música de San Cayetano, encargada de solemnizar las fiestas religiosas de la familia, y una amplia orquesta formada para la ocasión.

La Capilla de San Cayetano aportó a esta fiesta tres tiples, tres contraltos, seis tenores y cinco bajos, más dos bajones y un organista, reunidos por el festero Antonio de Arche. Francisco Basset, músico de la Casa de Benavente-Osuna, fue el encargado de contratar a los instrumentistas de la orquesta, que estaba formada por once violines, dos violas, dos violones y tres contrabajos, dos oboes, dos fagotes, dos trompas y dos clarines.

\footnotetext{
${ }^{59}$ Fernando Regueras Grande, Pimentel, fragmentos de una iconografia (Benavente: Centro de Estudios Benaventanos Ledo del Pozo, 1998) p. 104.

${ }^{60}$ Los datos sobre este acto que se citan de aquí en adelante proceden de AHN NOBLEZA, OSUNA-CARTAS, leg 350-5.
} 
c) Exequias varias.

Los funerales de los miembros de la familia fueron momentos de máxima ostentación para el linaje de los Osuna y Benavente. Las exequias que se realizaron a la muerte de los titulares de la Casa debieron contar siempre con una amplia participación musical como vimos en el caso paradigmático del funeral del VIII Duque de Osuna (ver punto 2.2.1. de este capítulo) ${ }^{61}$..

Los funerales de Josefa Manuel Téllez Girón, Marquesa de Camarasa e hija primogénita de los IX Duques de Osuna, que tuvieron lugar el 11 de diciembre de 1817 en la Iglesia de San Felipe Neri de Madrid, fueron solemnizados con un nutrido grupo vocal e instrumental. Francisco Gómez (uno de los músicos que colaboraban con la Casa de Benavente en esta época) reunió por orden de la Condesa-Duquesa María Josefa (madre de la fallecida) un coro formado por 22 cantores y una orquesta de 26 profesores: 8 violines, 2 violas, violón, 2 contrabajos, 2 oboes, 2 clarinetes, 2 fagotes, 2 trompas, 2 trombones, 2 bajones y timbal ${ }^{62}$

También hubo una importante presencia musical en las exequias que se celebraron a la muerte de Pedro de Alcántara II, XI Duque de Osuna, el 29 de octubre de 1844 en la Iglesia de Santo Tomás de Madrid. Según Baltasar Saldoni

\footnotetext{
61 Aunque no he localizado ningún documento que confirme la presencia de la música en los funerales del IX Duque de Osuna, es muy probable que ésta formara parte del solemne ceremonial de las exequias que se celebraron por su alma en la Colegiata de San Isidro el Real de Madrid en 1807. Para este acto el arquitecto Antonio Aguado, construyó un imponente catafalco de inspiración neoclásica, que se conoce a través de un grabado dibujado por él mismo (BNE INV 14921). Sobre los funerales del IX Duque, véase también Yebes, La condesa-duquesa, pp. 219220 .

${ }^{62}$ AHN NOBLEZA, OSUNA-CARTAS, leg. 392-4.Apéndice 6, nº 11.
} 
en este acto intervino una orquesta con 200 profesores que fueron dirigidos por Victoriano Daroca El repertorio que se interpretó en este funeral incluía un versículo del responso Tremens Factus Sum ego compuesto por el propio Saldoni e interpretado por su discípula Encarnación Lama ${ }^{63}$ y un Oficio de difuntos de Jaime Nadal $^{64}$

\subsection{Conjuntos contratados para las funciones religiosas. Capillas musicales y festería}

Las funciones religiosas patrocinadas por la alta nobleza poseían un gran valor simbólico y, más allá de su funcionalidad litúrgica, eran un espejo en el que mostrar públicamente el poder económico y la supremacía cultural de un linaje. Desde el punto de vista musical, esta posición de superioridad se concretó en la cuidadosa elección de las capillas y conjuntos que se encargaban de interpretar la música en estas funciones, conjuntos que solían estar vinculados a importantes instituciones de la corona o a fundaciones religiosas con una amplia trayectoria musical.

El estudio realizado sobre las fiestas religiosas patrocinadas por las Casas de Osuna y Benavente revela datos desconocidos hasta ahora sobre la actividad de varias capillas musicales adscritas a instituciones religiosas que funcionaron en Madrid hasta la primera década del siglo XIX, y sobre el funcionamiento de la festería, actividad que fue uno de los principales medios de completar los ingresos

\footnotetext{
63 Saldoni, Diccionario, vol. II, p. 146.

64 Emilio Casares Rodicio, "Nadal Acero, Jaime”, DMEH, vol. 7, p. 945. Según este autor el funeral se celebró en 1845 .
} 
fijos de los músicos españoles durante el Antiguo Régimen ${ }^{65}$. Asimismo el conocimiento de los efectivos musicales que participaron en las funciones religiosas organizadas por las Casas de Osuna y Benavente, en los siglos XVIII y XIX, permite conocer algunos detalles interesantes sobre las prácticas de interpretación de la música religiosa en un contexto muy diferente al de las celebraciones de las grandes capillas catedralicias.

La contratación de las capillas de música estables para las funciones religiosas, que fue habitual hasta los primeros años del siglo XIX, dio paso a la formación de grupos a cargo de un festero-avisador o persona de confianza de los titulares de la casa para las cuestiones musicales. Esta labor fue desempeñada hasta su muerte en 1808 principalmente por Francisco Basset, y posteriormente por otras personas relacionadas con las Casas de Osuna y Benavente como Carlo Marinelli, profesor de música de los hijos de la Condesa-Duquesa María Josefa o el cantante Francisco Gómez.

En los siguientes puntos estudiaré las principales capillas y conjuntos musicales que fueron contratados para las funciones religiosas patrocinadas por las Casas de Osuna y Benavente entre 1739 y 1828.

\subsubsection{Real Capilla}

La contratación de la Real Capilla, una de las más importantes instituciones musicales de España, afirmaba el prestigio del promotor y otorgaba

\footnotetext{
65 Sobre la actividad de la festería véase Antonio Gallego, La música en tiempos de Carlos III (Madrid, Alianza, 1988), pp.157-164, Idem, “Breve nota sobre el Festero y la Festería”, Nassarre, V/1 (1989), pp .27-57; y Nicolás Morales, "Real Capilla y festería en el Siglo XVIII: Nuevas aportaciones para la historia de la Institución Musical Palatina”, RMS, XXII/1 (1999), pp. 175-208.
} 
una solemnidad cortesana a los actos religiosos. Conscientes de esta importancia, la Casa de Osuna empleó los servicios de la Real Capilla en diversas ocasiones para sus funciones religiosas. El primer ejemplo que he podido documentar data de 1739, cuando Casiano López, contralto y festero de la Real Capilla entre 1734 y $1740^{66}$ cobró trescientos noventa y dos reales de vellón por la asistencia de los músicos de la institución monárquica a la fiesta de San Pascual Bailón que se celebró por orden de la Francisca Bibiana Pérez de Guzmán el Bueno, Duquesa viuda de Osuna, el día 17 de mayo de 1738 en el Convento de San Pascual (o Convento del Almirante) de Madrid $^{67}$

La Real Capilla fue contratada también en 1742 para celebrar la beatificación de Camilo de Lelis, ${ }^{68}$ y entre 1744 y 1748, la Duquesa viuda de Osuna volvió a contar con sus servicios para solemnizar las fiestas de San Pascual Bailón $^{69}$. En este período ejercía como festero de la institución el violón Bernardo Alberich. El pago de los honorarios por estas y otras asistencias que hizo la Real Capilla para la Casa de Osuna, se dilató a lo largo de los años y en 1761 el titular de la Casa Pedro Zoilo Téllez Girón, VIII Duque de Osuna, tuvo que hacerse cargo de la deuda que la administración de la casa ducal tenía con la Real Capilla y comprometerse a abonarla:

[...] se quedaron debiendo por Su Excelencia [La Duquesa viuda de Osuna] a la Real Capilla de Música de Su Majestad y en su nombre al otorgante [Bernardo Alberich] como festero que fue de ella, mil ciento sesenta reales de vellón por las asistencias que tuvieron de la música en las

\footnotetext{
66 Morales, "Real Capilla”, p. 182.

67 AHN NOBLEZA, OSUNA-CARTAS, leg 389-30.

68 Ibid.

69 AHN NOBLEZA, OSUNA-CARTAS, leg 392-15 bis.
} 
festividades que a devoción de la propia Excelentísima Señora se hicieron en la Iglesia de Religiosas del Convento de San Pascual Bailón desde el año de mil setecientos cuarenta y cuatro hasta el de mil setecientos cuarenta y ocho, como también por la asistencia a la profesión en el convento de capuchinas de esta corte de Doña Manuela Pareja, Dama que fue de Su Excelencia el día veinte y nueve de junio de mil setecientos cuarenta y seis $(. . .)^{70}$.

El documento anterior revela también que parte de los ingresos extraoficiales que percibían los músicos de la Real Capilla por su labor de festería, no siempre se materializaban de forma inmediata. Los miembros de las Casas de Osuna y Benavente, como otros personajes de la alta nobleza urbana, demoraron con frecuencia los pagos a los músicos de su casa. Las deudas contraídas con sus proveedores o colaboradores (incluidos artistas de renombre como Goya) se prolongaban durante varios años ${ }^{71}$. Esta circunstancia pone en duda la supuesta prosperidad económica que, según Nicolas Morales, gozaban los músicos al servicio de la Casa Real gracias a los ingresos que obtenían por su participación en las fiestas privadas ${ }^{72}$.

\subsubsection{Capilla de Música del Colegio Imperial de Madrid}

De esta capilla, adscrita a una de los más relevantes establecimientos educativos de Madrid regentado por los jesuitas, apenas se tenía noticia alguna hasta el momento. En la documentación de la Casa de Osuna se conservan varios documentos que acreditan que en 1755 la Capilla de Música del Colegio Imperial

\footnotetext{
70 Ibid.

${ }^{71}$ Véase el Capítulo I.

72 Morales, “Real Capilla”, p. 182.
} 
de Madrid funcionaba con una estructura estable, y que en dicha fecha tenía como festero a Sebastián Moneva ${ }^{73}$.

Los días 9 y 10 de agosto de 1755, la Capilla del Colegio Imperial participó “con voces e instrumentos" en las funciones de acción de gracias en honor de San Francisco de Borja que el XIV Conde-Duque de Benavente celebró en Madrid seguramente para festejar el reciente éxito obtenido en el pleito por la posesión del estado de Gandía ${ }^{74}$ :

Como festero, que soy de la Capilla del Colegio Imperial de esta Corte certifico, cómo de orden del Excelentísimo Señor Conde Duque de Benavente, mi Señor, asistió dicha Capilla a la festividad que su Excelencia celebró en acción de Gracias al Señor San Francisco de Borja en Vísperas, Misa, Siesta y Te Deum en la Iglesia de la Casa Profesa de Padres Jesuitas de esta corte el día nueve y diez del corriente con seis violines, dos oboes, fagot y contrabajo, trompas y demás instrumentos adherentes a Capilla, cuyo importe de la expresada función [es de] tres mil trescientos reales de vellón y por ser verdad lo firmé. Madrid y agosto 14 de 1755.

Don Sebastián Moneva ${ }^{75}$

\footnotetext{
${ }^{73}$ Lothar Siemens atribuye erróneamente la organización de esta fiesta al Duque de Osuna. Lothar Siemens, "Rexach, Salvador", DMEH, vol. 9, p.149.

74 AHN NOBLEZA, OSUNA-CARTAS, leg 389-16. El 28 de julio del mismo año se había celebrado un Te Deum y una Salve Regina a Nuestra Señora de la Soledad para celebrar “el éxito obtenido en la tenuta de mi estado de Gandía" en el que participó la misma capilla.

75 AHN NOBLEZA, OSUNA-CARTAS, leg 389-16. Como puede verse en este documento y en los casos que citaré en los siguientes apartados, las capillas musicales que participaron en las funciones religiosas de las Casas de Osuna y Benavente en los siglos XVIII y XIX incluyeron en muchas ocasiones instrumentistas y no sólo "voces, bajones y organista" como ha afirmado recientemente Judith Ortega. Véase Ortega, “El mecenazgo”, p. 655.
} 
La función constó de "vísperas, intermedios, misa y siestas", y su solemnidad quedó patente por el importante grupo de músicos que se contrató para la ocasión. Los "instrumentos adherentes a capilla" a los que se refiere el documento transcrito, seguramente serían el órgano, el bajón y acaso el arpa, habituales en la música de iglesia en España a lo largo de la segunda mitad del siglo XVIII ${ }^{76}$.

Además de los músicos de la Capilla del Colegio Imperial, en esta función participaron otros instrumentistas contratados para la ocasión. El conjunto quedó formado por 8 violines, 4 oboes, 2 trompas, 3 "bajos" (seguramente violón, contrabajo y fagot) y un timbalero, a los que se añadieron el resto de instrumentos “de capilla" y un conjunto vocal cuyas dimensiones desconocemos ${ }^{77}$.

\subsubsection{Capilla de Música del Real Oratorio de San Felipe Neri.}

Este conjunto fue el encargado de la música que se interpretó en las fiestas de San Francisco de Borja al menos entre los años 1773 y 1777. Los servicios de la Capilla de Música del Oratorio de San Felipe Neri se incluían dentro del contrato que los Condes-Duques de Benavente y Marqueses de Peñafiel habían firmado con la congregación del mismo nombre, en cuya iglesia tenía lugar la celebración, para que se encargasen de todo el ceremonial. El coste de la fiesta principal que se realizaba el primer día "estaba arreglado por la Casa de la

\footnotetext{
${ }^{76}$ Sobre los instrumentos habituales en las iglesias en la segunda mitad del siglo XVIII véase, por ejemplo la descripción de Iriarte. Tomás Iriarte, La música (Madrid: Imprenta Real de la Gaceta, 1779), Canto Tercero, VII, p. 61.

${ }^{77}$ AHN NOBLEZA, OSUNA-CARTAS, leg 389-16. Véase Apéndice 6. nº 1.
} 
Congregación de Padres de San Felipe Neri en tres mil trescientos reales; y el de cada una de las demás fiestas en mil y ciento”. En esta cantidad se incluían, además de otros gastos menores, el pago a los predicadores de la propia institución religiosa y a su capilla musical que debía de asistir a todas las funciones y a las vísperas del día 30 de septiembre ${ }^{78}$.

La Capilla Musical de San Felipe Neri se reforzaba con otras voces e instrumentos que eran contratados a través de un festero. Entre 1773 y 1777 ocupaba este cargo Baltasar de Arche, miembro de la conocida familia de festeros y músicos de iglesia que desarrollaron su actividad en Madrid en los siglos XVIII y XIX. Arche fue recompensado en 1777 "por la puntualidad y esmero" que había tenido "en las disposiciones de orquesta y demás incidentes"79 . Estos "incidentes" parecen ser la causa por la que la Condesa-Duquesa de Benavente decidió prescindir de los servicios de la Capilla de música de San Felipe Neri después de la celebración de las fiestas de este año. La Condesa-Duquesa había quedado “sumamente disgustada del desempeño de la capilla de San Felipe Neri en la fiesta [en honor de San Francisco de Borja] del día primero de este mes”, y por esta razón para la celebración de las fiestas de Nuestra Señora del Pilar de 1777 la Condesa ordenó a su secretario de cámara Manuel de Ascargorta

[...] que [Baltasar] Arche se encargue del desempeño de esta fiesta, en el precio que hablamos, buscando las voces e instrumentos que convenga para hacer una fiesta solemnísima y lucida, sin atender las políticas de gobierno interior de las capillas, ni las que rigen unas con otras bajo el supuesto de

\footnotetext{
78 AHN NOBLEZA, OSUNA, leg 1516-252.

${ }^{79}$ AHN NOBLEZA, OSUNA-CARTAS, leg 389-12.
} 
cualquier falta ha de ser Vuestra Merced el único responsable, pues puede evitarla valiéndose de sujetos diestros una vez que Su Excelencia le libra de sujeciones y lo deja a su arbitrio ${ }^{80}$.

Esta carta, escrita poco después de las celebraciones de las funciones de 1777, muestra cómo la rigidez de los estatutos y normas que regían el funcionamiento de las capillas musicales eran causa frecuente de conflictos y problemas que repercutían directamente en la interpretación musical. En esta ocasión la Condesa-Duquesa María Josefa intentó evitar tales problemas terminando su relación contractual con la Capilla de San Felipe Neri y reemplazándola por un conjunto de voces e instrumentos seleccionados por el festero Baltasar de Arche.

\subsubsection{Capilla Musical del Real Convento de la Encarnación}

A lo largo del siglo XVIII, la Capilla Musical del Real Convento de la Encarnación de Madrid desarrolló una intensa actividad de festería colaborando en varias funciones religiosas patrocinadas por las Casas de Osuna y Benavente ${ }^{81}$. La referencia más antigua que he podido documentar que relaciona a esta institución con la Casa de Osuna es de 1729. En este año el VII Duque de Osuna, contrató los músicos del Convento de la Encarnación para el Miserere dedicado al Santísimo Cristo de la Salud que tuvo lugar en la Iglesia de San Andrés de Madrid. Las gestiones fueron realizadas por el bajonista Joaquín Ferrer, festero de

\footnotetext{
${ }^{80}$ Ibid., leg 331-1.

${ }^{81}$ Una lista parcial de los festeros de la Real Capilla de la Encarnación figura en Morales, "Real Capilla”, pp. 186-187. Sobre esta capilla véase también Paulino Capdepón, La música en el Monasterio de la Encarnación (Siglo XVIII) (Madrid: Alpuerto, 1997).
} 
la capilla ${ }^{82}$. Durante la titularidad del VIII Duque Pedro Zoilo Téllez Girón, la Casa de Osuna contrató de nuevo a la Capilla musical del Convento de la Encarnación para solemnizar una de las novenas a San Pascual Bailón que se celebraron en 1775 en el Convento de las Religiosas Franciscanas de Madrid. En este año ejercía como festero de esta institución Francisco Gutierrez ${ }^{83}$.

La Casa de Benavente mantuvo también una estrecha relación con la Capilla musical del Convento de la Encarnación, que fue contratada en numerosas festividades y actos religiosos organizados por esta Casa. Al menos desde 1753 algunos músicos de la Encarnación colaboraron como refuerzo en las fiestas de San Francisco de Borja que patrocinaba anualmente la Casa de Benavente ${ }^{84}$.

En 1754 ejercía como festero de la Capilla de la Encarnación Juan Antonio Castellano, que fue el encargado de gestionar la contratación de músicos en las tres funciones religiosas que el Conde-Duque de Benavente organizó en Madrid por la salud de su hijo. La primera de ellas se celebró en honor a Nuestra Señora de la Soledad en la Iglesia de San Pedro, la segunda se dedicó a San Antonio de Padua en la llamada Iglesia de los Portugueses y la tercera fue una devoción "al Niño Perdido que se venera en el convento de San Juan de Alarcón"85. Juan Antonio Castellano también actuó como festero de la Capilla de la Encarnación en la función que se celebró en la Parroquia de San Pedro para celebrar el "voto

\footnotetext{
82 AHN NOBLEZA, OSUNA-CARTAS, leg 389-17.

${ }^{83}$ Ibíd., leg 389-12.

${ }^{84}$ Ibid., leg 389-30.

${ }^{85}$ Ibid., leg 390-3.
} 
favorable obtenido en el pleito por la titularidad del Estado de Gandía" a favor del Conde-Duque de Benavente ${ }^{86}$.

Al menos entre 1778 y 1783 la Capilla Musical del Real Convento de la Encarnación solemnizó las funciones de San Francisco de Borja, celebradas anualmente por la Casa de Benavente. Como era habitual, los servicios de la capilla fueron contratados a través del festero de la misma, que en el año 1783 era Pedro Ochoa ${ }^{87}$. En 1778 y 1779 la Capilla Musical de la Encarnación concurrió a estas fiestas con ocho voces ${ }^{88}$, y en 1783 volvió a ser llamada "para que concurriese a cantar dichas vísperas y misas según lo había ejecutado en el año último y en algunos otros años anteriores" ${ }^{, 89}$, lo que da a entender que este conjunto participó también en las funciones de San Francisco de Borja del año 1782.

En las funciones de San Francisco de Borja de 1778, el coro de la Capilla Musical del Real Convento de la Encarnación fue dirigido por el "maestro de capilla” Giuseppe [Joseph] Ponzo. El “Conde-Duque”(es decir Pedro de Alcántara Téllez-Girón, futuro IX Duque de Osuna) entregó a Ponzo 3840 reales para que los distribuyera entre todos los instrumentistas y cantores que participaron "en las vísperas, fiesta y dos pruebas que antes se hicieron" 90 .

Las voces e instrumentos que proporcionaba la Capilla de la Encarnación para las funciones de San Francisco de Borja se unían al resto de instrumentistas

\footnotetext{
${ }^{86}$ Ibid., leg 389-16.

${ }^{87}$ Ibid., leg 390-3.

88 Ibid., leg 389-30.

${ }^{89}$ Ibid.

90 Ibíd., leg 350. Sobre Giuseppe Ponzo véase el Apéndice 5.
} 
asalariados y a los que se contrataba para la ocasión. Por ejemplo, en las fiestas de 1779, además de ocho voces de la Capilla de la Encarnación, intervinieron cuatro violines, dos violas, un oboe y un bajo reunidos por el músico de la Casa de Benavente Francisco Basset ${ }^{91}$.

Al menos desde 1781, las voces de la Capilla de la Encarnación estuvieron acompañadas por un grupo de instrumentistas pertenecientes a la orquesta de la Condesa-Duquesa de Benavente que se incrementaba "con el correspondiente lleno de instrumentos y demás circunstancias de solemnidad”. Para las fiestas de 1781, la Condesa-Duquesa ordenó que

[...] se llamasen varios músicos instrumentistas (a mas de los que están asalariados por Su Excelencia), los cuales concurrieron con efecto, seis a la prueba de música que se hizo en casa de Su Excelencia el día 28 de septiembre, ocho a las vísperas el día 30 del mismo, y los mismos a las misas de los días $1^{\circ}$ y $5^{\circ}$ de Octubre, cuyas pagas al respecto de 20 reales cada uno por dichas asistencias (conforme a lo que Su Excelencia arregló, y dispuso en año anterior para los sucesivos) importan seiscientos reales según la razón adjunta que con fecha 12 del corriente me ha entregado Don Francisco Basset, encargado por Su Excelencia del cobro y distribución de estas pagas" $" 92$

Además de los músicos de refuerzo, en ocasiones se contrataba a otros instrumentistas con el fin de suplir las ausencias de los músicos asalariados pertenecientes a la orquesta de la Condesa-Duquesa, que por enfermedad o por cumplir otras obligaciones, como la asistencia a los servicios de la Real Capilla,

\footnotetext{
91 AHN NOBLEZA, OSUNA-CARTAS, leg 389-30.

92 Ibíd., leg 390-1. Véase también Apéndice 6, documentos 3-6.
} 
no podían concurrir a las funciones de San Francisco de Borja. En 1782 los músicos contratados "a mas de los de Su Excelencia" fueron dos violines, dos violas, un fagot, una trompa y un contrabajo, y al año siguiente dos violines, dos violas, y una trompa ${ }^{93}$.

La contratación de músicos para estas fiestas respondía, por consiguiente, tanto a razones de tipo laboral (sustitución de los músicos asalariados enfermos o ausentes) como a la necesidad de reforzar algunas secciones de la orquesta de la Condesa-Duquesa que carecían del suficiente número de instrumentistas para interpretar ciertas obras. Por esta razón, y dada la carencia de listas completas de instrumentistas, no puede conocerse con exactitud la plantilla exacta de la orquesta o grupo instrumental que intervino en las fiestas de San Francisco de Borja acompañando a las voces de la Capilla de la Encarnación, plantilla que, varió constantemente dependiendo de la instrumentación de las obras que se interpretaban.

\subsubsection{Capilla Musical del Convento de las Descalzas Reales}

Esta importante institución musical vinculada a la corona, fue contratada por los titulares de la Casa de Osuna y Benavente en diversas ocasiones a lo largo del siglo XVIII para solemnizar sus funciones religiosas. El 17 de mayo de 1740, la "Real Capilla de las Señoras Descalzas" participó en la función a San Pascual Bailón que se celebró en Madrid bajo el patrocinio de Francisca Bibiana Pérez de

${ }^{93}$ AHN NOBLEZA, OSUNA-CARTAS, leg 390-3. 
Guzmán el Bueno, VII Duquesa de Osuna ${ }^{94}$.

Al menos entre 1780 y 1788 la Casa de Benavente contrató de nuevo a la Capilla Musical de las Descalzas para solemnizar las fiestas en honor a Santo Toribio de Mogrovejo ${ }^{95}$. Esta capilla musical participó también en las funciones en honor de San Francisco de Borja y de Nuestra Señora del Pilar que celebró la familia Benavente entre 1784 y $1789^{96}$. En las funciones de San Francisco de Borja la Capilla de las Descalzas Reales proporcionó seguramente un conjunto de ocho voces, el mismo número de cantores que la Capilla de la Encarnación había aportado en años anteriores, mas un bajonista y un organista ${ }^{97}$. En este último período ocupaba el cargo de festero y tesorero de la Capilla de las Descalzas el presbítero Joaquín Agramuntell ${ }^{98}$.

${ }^{94}$ Ibíd, leg 389-30. No figura la iglesia en la que se celebró. El libramiento está firmado por Manuel García Durón, que posiblemente fuera el festero de la capilla en dicho año.

95 AHN NOBLEZA, OSUNA-CARTAS, leg 331-1. Sobre esta institución véase José Subirá, "La música en la Capilla y Monasterio de las Descalzas Reales de Madrid”, AnM, XII (1957), pp. 147166 y Paulino Capdepón La música en el Monasterio de las Descalzas Reales (Siglo XVIII) (Madrid: Alpuerto, 1999).

${ }^{96}$ Este es el período que puede datarse con certeza a partir del estudio de la documentación del archivo administrativo de la Casa de Osuna. No obstante, es posible que la Capilla Musical del Convento de las Descalzas Reales de Madrid continuase solemnizando las funciones de San Francisco de Borja organizadas por la Casa de Benavente hasta 1792, cuando fue sustituida por la Capilla de San Cayetano.

${ }^{97}$ AHN NOBLEZA, OSUNA-CARTAS, leg 390-3. Esta estructura es la misma que aportó a partir de 1792 la Real Capilla de San Cayetano para las funciones de San Francisco de Borja. Véase Apéndice $6, \mathrm{n}^{\circ} 7$.

98 AHN NOBLEZA, OSUNA-CARTAS, leg 389-18; leg 391-28. Joaquín Agramuntell era natural de Chinchtorrer, obispado de Tortosa. Falleció el 11 de agosto de 1804. José Subirá, “Necrologías musicales madrileñas" AnM, XIII (1958), p. 222. 
El conjunto instrumental que acompañaba a la Capilla de las Descalzas Reales variaba en función de la solemnidad que se pretendiera dar a cada uno de los actos religiosos. En las fiestas de San Francisco de Borja se contaba siempre con un amplio grupo que tenía como base la orquesta de músicos asalariados de la Condesa-Duquesa María Josefa. La plantilla de la orquesta se reforzaba con otros músicos que se encargaba de buscar Francisco Basset ${ }^{99}$. En algunas ocasiones la la Capilla de las Descalzas también aportaba instrumentistas. Por ejemplo, en las fiestas de Nuestra Señora del Pilar de 1788, se pagó al festero de esta capilla 600 reales "por [la] misa con capilla, orquesta y organillo"100.

\subsubsection{Real Capilla de San Cayetano}

La Real Capilla de San Cayetano era una institución musical adscrita al convento o Casa Real de Nuestra Señora del Favor de clérigos reglares de San Cayetano situado en la calle del Oso de Madrid que tenía como patrono al Real Consejo de Hacienda ${ }^{101}$. Esta capilla musical, que hasta la fecha no ha sido objeto de ninguna investigación, colaboró con la Casa de Osuna al menos desde 1790 participando en las funciones de Santo Toribio de Mogrovejo y en otras celebraciones familiares ${ }^{102}$. Desde 1792 está documentada su participación en las fiestas de San Francisco de Borja y Nuestra Señora del Pilar ${ }^{103}$. La última colaboración de la Capilla de San Cayetano con la familia Benavente-Osuna que

\footnotetext{
99 AHN NOBLEZA, OSUNA-CARTAS, leg 390-3.

100 Ibid., leg 389-18.

101 Álvarez y Baena, Compendio, pp.167.

102 AHN NOBLEZA, OSUNA-CARTAS, leg 390-1.

103 Ibíd.
} 
he podido documentar fue la función en honor de Santo Toribio de Mogrovejo que se celebró los días 26 y 27 de Abril de 1806 en la Iglesia de los Padres Trinitarios Descalzos de Madrid por orden del "Duque de Osuna, Arcos y Bejar

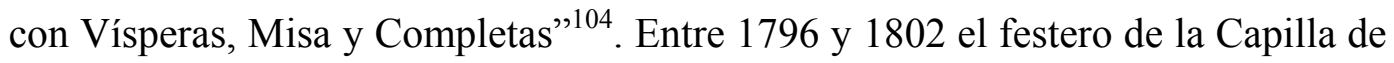
San Cayetano fue Antonio de Arche.

La Capilla de San Cayetano aportaba a todas las fiestas, las voces, el bajón, el organista, más algunos instrumentistas cuya especialidad no aparece en los documentos consultados. Tras la disolución de la orquesta de la CondesaDuquesa en 1792, Francisco Basset se encargó de organizar el conjunto instrumental que intervenía en las funciones religiosas patrocinadas por la familia Benavente. Este conjunto se formaba con instrumentistas de la propia capilla de San Cayetano a los que se unían los de otras capillas tal y como se detalla en una carta que Manuel de Ascargorta, secretario de la Condesa-Duquesa de Benavente, dirigió al tesorero de la Casa en diciembre de 1800:

Muy Señor mío:

La Condesa Duquesa Mi Señora, se sirvió disponer que la Capilla Música de San Cayetano de esta Corte y el competente número de instrumentos así individuos de la misma capilla como de otras asistiesen, como lo ejecutaron, a las solemnes vísperas y fiestas celebradas en obsequio de su glorioso abuelo San Francisco de Borja en los días 30 de Septiembre y 1, 8, 9, 10, 11, 13, 15 y 16 de octubre de este año en la Real Iglesia de San Felipe Neri según expresó a Vuestra Merced individualmente en otro oficio de esta fecha.

\footnotetext{
104 AHN NOBLEZA, OSUNA leg 1516-284-85. Cuenta de Tiburcio García Tesorero de la Real Capilla de San Cayetano por mil trescientos cuarenta reales de vellón "en los mismos términos que en los años anteriores".
} 
La asistencia de los músicos instrumentistas, incluyendo el importe de la asistencia a cinco ensayos o pruebas de misas, es seis mil doscientos y noventa reales, según resulta de la cuenta que acompaño de Don Francisco Basset quien, según costumbre, ha cuidado de las disposiciones relativas a la música, así como también se halla habilitado para el percibo y distribución de dichos seis mil doscientos noventa reales, por lo que se servirá Vuestra Merced poner a la firma del Duque, mi señor el correspondiente libramiento de dicha cantidad a favor del referido don Francisco Basset.

Nuestro Señor guarde a Vuestra Merced muchos años.

Madrid a 4 de diciembre de 1800

Besa la mano de Vuestra Merced, su mas afecto servidor y amigo Manuel de Ascargorta ${ }^{105}$.

La plantilla instrumental que intervino en las funciones patrocinadas por la Casa de Benavente a finales del siglo XVIII y en los primeros años del siglo XIX junto a las voces e instrumentos de la Capilla de San Cayetano, estuvo obviamente condicionada por el repertorio interpretado. Como puede apreciarse en las Tablas 18 y 19, la formación instrumental que participó en las funciones de San Francisco de Borja y Nuestra Señora del Pilar de 1798 y 1800 tenía la estructura habitual de la orquesta clásica, con una base de once o doce instrumentos de cuerda, dos trompas y dos oboes a los que se sumaban los instrumentos de vientomadera (flautas o clarinetes) y viento-metal (clarines) que precisaban alguna de las obras interpretadas.

105 AHN NOBLEZA, OSUNA-CARTAS, leg 390-1. Véase también Apéndice 6, nº 9. 
Tabla 18.

Plantilla de la orquesta y repertorio interpretado en las fiestas de San Francisco de Borja y Nuestra Señora del Pilar patrocinadas por la Casa de Benavente en 1798 Fuente: AHN NOBLEZA, OSUNA-CARTAS, leg 390-1.

\begin{tabular}{|c|c|c|}
\hline Fecha y función & $\begin{array}{l}\text { Obras } \\
\text { interpretada }\end{array}$ & Plantilla \\
\hline \multirow{8}{*}{$\begin{array}{l}30 \text { de septiembre } \\
\text { Vísperas a San Francisco } \\
\text { de Borja }\end{array}$} & \multirow[t]{8}{*}{ No consta } & 7 violines \\
\hline & & 1 viola \\
\hline & & 1 violón \\
\hline & & 2 contrabajos \\
\hline & & 1 flauta \\
\hline & & 2 oboes \\
\hline & & 2 fagotes \\
\hline & & 2 trompas \\
\hline $\begin{array}{l}1 \text { de Octubre } \\
\text { San Francisco de Borja }\end{array}$ & \begin{tabular}{|l} 
Misa nueva de \\
[Ferdinando] Paer
\end{tabular} & $\begin{array}{l}\text { La misma plantilla que el día } 30 \\
\text { más dos clarines y una flauta } 2^{\mathrm{a}}\end{array}$ \\
\hline $\begin{array}{l}8 \text { de Octubre } \\
\text { San Francisco de Borja }\end{array}$ & $\begin{array}{l}\text { Misa chica de } \\
\text { [Joseph ] Haydn }\end{array}$ & La misma plantilla que el día 30 \\
\hline $\begin{array}{l}9 \text { de Octubre } \\
\text { San Francisco de Borja } \\
\end{array}$ & $\begin{array}{l}\text { Misa nueva de } \\
\text { [Ferdinando] Paer }\end{array}$ & La misma plantilla que el 1 \\
\hline $\begin{array}{l}10 \text { de Octubre } \\
\text { San Francisco de Borja }\end{array}$ & $\begin{array}{l}\text { Misa de [Giuseppe] } \\
\text { Nicolini }\end{array}$ & $\begin{array}{l}\text { La misma plantilla que el día } 30 \\
\text { más dos clarines y dos clarinetes }\end{array}$ \\
\hline $\begin{array}{l}11 \text { de Octubre } \\
\text { San Francisco de Borja }\end{array}$ & $\begin{array}{l}\text { Misa de [Gaetano] } \\
\text { Brunetti }\end{array}$ & La misma plantilla que el día 30. \\
\hline $\begin{array}{l}12 \text { de Octubre } \\
\text { Nuestra Señora del Pilar }\end{array}$ & $\begin{array}{l}\text { Misa chica de } \\
\text { [Joseph ] Haydn }\end{array}$ & La misma plantilla que el día 30 \\
\hline $\begin{array}{l}13 \text { de Octubre } \\
\text { San Francisco de Borja }\end{array}$ & $\begin{array}{l}\text { Misa nueva de } \\
\text { [Ferdinando] Paer }\end{array}$ & La misma plantilla que el día 30 \\
\hline $\begin{array}{l}15 \text { de Octubre } \\
\text { San Francisco de Borja }\end{array}$ & $\begin{array}{l}\text { Misa chica de } \\
\text { [Antonio] Rosetti }\end{array}$ & $\begin{array}{l}\text { La misma plantilla que el día } 30 \\
\text { más dos clarines y una flauta } 2^{\mathrm{a}}\end{array}$ \\
\hline
\end{tabular}


Tabla 19

Plantilla de la orquesta y repertorio interpretado en las fiestas de San Francisco de

Borja y Nuestra Señora del Pilar patrocinadas por la Casa de Benavente en 1800

Fuente: AHN NOBLEZA, OSUNA-CARTAS, leg 390-1

\begin{tabular}{|c|c|c|}
\hline Fecha y función & Obras interpretada & Plantilla \\
\hline \multirow{7}{*}{$\begin{array}{l}30 \text { de septiembre } \\
\text { Vísperas a San Francisco } \\
\text { de Borja }\end{array}$} & \multirow[t]{7}{*}{ No consta } & 7 violines \\
\hline & & 2 violas \\
\hline & & 1 violón \\
\hline & & 2 contrabajos \\
\hline & & 2 oboes \\
\hline & & 2 fagotes \\
\hline & & 2 trompas \\
\hline $\begin{array}{l}1 \text { de Octubre } \\
\text { San Francisco de Borja }\end{array}$ & $\begin{array}{l}\text { Misa nueva de } \\
\text { [Antonio] Rosetti }\end{array}$ & $\begin{array}{l}\text { La misma plantilla que el día } 30 \\
\text { más dos flautas y dos clarinetes }\end{array}$ \\
\hline $\begin{array}{l}8 \text { de Octubre } \\
\text { San Francisco de Borja }\end{array}$ & $\begin{array}{l}\text { Misa de [Giuseppe] } \\
\text { Nicolini }\end{array}$ & $\begin{array}{l}\text { La misma plantilla que el día } 30 \\
\text { más dos flautas y dos clarinetes }\end{array}$ \\
\hline $\begin{array}{l}9 \text { de Octubre } \\
\text { San Francisco de Borja }\end{array}$ & $\begin{array}{l}\text { Misa de [Gaetano] } \\
\text { Brunetti }\end{array}$ & $\begin{array}{l}\text { La misma plantilla que el } 30 \text { de } \\
\text { octubre más una flauta "para la } \\
\text { obertura" }\end{array}$ \\
\hline $\begin{array}{l}10 \text { de Octubre } \\
\text { San Francisco de Borja }\end{array}$ & $\begin{array}{l}\text { Misa de [Antonio] } \\
\text { Rosetti }\end{array}$ & $\begin{array}{l}\text { La misma plantilla que el día } 30 \\
\text { más dos flautas y dos clarinetes }\end{array}$ \\
\hline $\begin{array}{l}11 \text { de Octubre } \\
\text { Francisco de Borja }\end{array}$ & $\begin{array}{l}\text { Misa chica de } \\
\text { [Joseph ] Haydn }\end{array}$ & $\begin{array}{l}\text { La misma plantilla que el día } 30 \\
\text { más una flauta y dos clarinetes } \\
\text { "para la obertura" y dos } \\
\text { clarines. }\end{array}$ \\
\hline $\begin{array}{l}12 \text { de Octubre } \\
\text { Nuestra Señora del Pilar }\end{array}$ & $\begin{array}{l}\text { Misa de Gaetano } \\
\text { Brunetti }\end{array}$ & $\begin{array}{l}\text { La misma plantilla que el } 30 \mathrm{de} \\
\text { octubre }\end{array}$ \\
\hline $\begin{array}{l}13 \text { de Octubre } \\
\text { San Francisco de Borja }\end{array}$ & $\begin{array}{l}\text { Misa de } \\
{[\text { Ferdinando }] \mathrm{P}[\mathrm{a}] \mathrm{er}} \\
\end{array}$ & $\begin{array}{l}\text { La misma plantilla que el día } 30 \\
\text { más dos flautas y dos clarines }\end{array}$ \\
\hline $\begin{array}{l}14 \text { de Octubre } \\
\text { San Francisco de Borja }\end{array}$ & $\begin{array}{l}\text { Misa chica de } \\
\text { [Joseph] Haydn }\end{array}$ & $\begin{array}{l}\text { La misma plantilla que el día } 30 \\
\text { más dos flautas }\end{array}$ \\
\hline $\begin{array}{l}15 \text { de Octubre } \\
\text { San Francisco de Borja }\end{array}$ & $\begin{array}{l}\text { Misa nueva de } \\
\text { [Ignaz Josef] Pleyel }\end{array}$ & $\begin{array}{l}\text { La misma plantilla que el día } 30 \\
\text { más dos flautas, dos clarinetes y } \\
\text { dos clarines. }\end{array}$ \\
\hline
\end{tabular}


En las funciones de San Francisco de Borja de 1802 intervino como "maestro de capilla" Eugenio Castel hijo del compositor de música escénica y maestro de capilla José Castel $(* 1737-1807)^{106}$. Por su buen hacer en dichas funciones religiosas, la Condesa-Duquesa María Josefa gratificó a Eugenio Castel con 160 reales ${ }^{107}$. Al menos en los años 1796, 1800 y 1802, la dirección musical de las funciones de San Francisco de Borja corrió a cargo del violinista y director de origen italiano Melchor Ronzi, en cuya casa solían realizarse los ensayos. Por ejemplo, el día 9 de octubre de 1802 tuvo lugar la "prueba" o ensayo de la "misa nueva" de João Pedro Almeida Motta [“Juan de Almeida"] en casa de Melchor Ronzi. "para la inteligencia de ella y comprobación de los papeles". La obra se estrenó al día siguiente, al parecer con esa única puesta en común ${ }^{108}$. Este régimen de trabajo se repite de forma similar en las funciones de otros años y demuestra la alta profesionalidad de los músicos que intervenían en estas fiestas que en un período de quince días debían interpretar hasta siete obras diferentes, muchas de ellas de estreno, con un único ensayo de conjunto.

\subsubsection{Otras agrupaciones no estables}

A partir de 1806 el conjunto sufragado por las Casas de Osuna y Benavente para las fiestas de San Francisco de Borja y Nuestra Señora del Pilar

\footnotetext{
106 Sobre José Castel véase Juan Pablo Fernández-Cortés, “José Castel (1737?-1807) un tonadillero maestro de capilla, RMS, XXIV/1-2, 2001, pp. 115-134 y Beatriz Gurbindo, “José Castel y la tonadilla entre Tudela y Madrid", Nassarre, XVII/ 1-2 (2001), pp. 243304.

${ }^{107}$ AHN NOBLEZA, OSUNA-CARTAS, leg 390-1.

${ }^{108}$ Ibid.
} 
apareció anunciado en los carteles como "conjunto de voces e instrumentos escogidos". Por el momento, no se conoce si a partir de 1806 la Condesa-Duquesa prescindió de la colaboración de la Capilla de San Cayetano o si esta se había disuelto previamente. Según Antonio Cordero Fernández, la mayoría de las capillas que funcionaban en Madrid antes de la invasión francesa sufrieron a raíz de ésta una crisis provocada por la progresiva merma de sus dotaciones que obligó a reducir la ostentación en el culto. El mismo autor subraya que después de la guerra napoleónica quedaron desorganizadas gran parte de las capillas musicales adscritas a instituciones religiosas que funcionaban en Madrid, entre ellas las de "Santa María, de las Descalzas Reales, de la Encarnación, de la Soledad, de San Cayetano y de Santa Cecilia y otras" ${ }^{\text {"109. }}$

La plantilla musical empleada en las fiestas de San Francisco de Borja de 1807 fue, no obstante, similar a la de años anteriores cuando se contrató a la Capilla de San Cayetano. En las funciones patrocinadas el X Duque de Osuna en 1807, que se celebraron los días 7, 10, 13 y 16 de octubre, intervinieron doce voces masculinas divididas en dos coros. El primero estaba formado por un grupo de solistas vocales (dos tiples, contralto, tenor, y bajo) que cobraban 40 reales cada uno por cada función y en el que se incluyo a [Eugenio] Castel "para regir". El segundo coro lo formaban un tiple, dos contraltos, dos tenores y dos bajos, más

\footnotetext{
109 Antonio Cordero y Fernández, "De los festeros y su industria" Revista y Gaceta Musical, Semanario de crítica, literatura, historia, biografía y bibliografia de la música, I/11 (1867). Citado en Gallego, "Breve nota", pp. 35-36.
} 
un organista, un bajonista y un entonador (o encargado de los fuelles) para el órgano ${ }^{110}$. Los miembros de este segundo coro cobraron 20 reales cada uno.

La orquesta que intervino en esta función tenia una plantilla muy similar a la que participó en las fiestas de 1798 y 1800 (Tablas 18 y 19 respectivamente). La base era la cuerda, y en ella destaca el sueldo del primer violín (50 reales frente a los 20 que recibieron el resto de violines) que probablemente se encargó de la dirección del grupo instrumental. Los clarinetes y las flautas aparecen ya como instrumentos de la plantilla de la orquesta, y se contó también con un timbalero para el Credo de la misa que se interpretó el día $10^{111}$.

En las funciones de San Francisco de Borja patrocinadas por el X Duque de Osuna que se celebraron los días 4, 8, 10, y 11 de octubre de 1808, la orquesta formada para la ocasión mantenía la estructura de orquesta clásica. La plantilla vocal estaba formada por un grupo de cuatro solistas masculinos (tiple, contralto, tenor y bajo) y un coro de ocho voces ( 2 tiples, 2 contraltos, 2 tenores y 2 bajos). Las funciones fueron dirigidas por Mariano Rodríguez de Ledesma (que además cantó como tenor solista). En esta época Rodríguez de Ledesma debía de trabajar al servicio de la Casa de Benavente o al menos gozar de la protección de esta familia, pues al igual que el oboe José Álvarez, que pertenecía "a la Casa de $\mathrm{Su}$ Excelencia” renunció a cobrar la cantidad que le correspondía por su participación en dichas funciones ${ }^{112}$.

\footnotetext{
${ }^{110}$ AHN NOBLEZA, OSUNA-CARTAS leg 390-1.

111 Ibíd. En estas funciones se interpretaron misas de Guglielmi, Nicolini y Rosetti, pero el documento no especifica que obras se interpretaron en cada uno de los días.

112 AHN NOBLEZA, OSUNA-CARTAS, legs. 392-37 y 570. Ver Apéndice 6, nº 10.
} 
Cuando la Casa de Benavente reanudó la celebración de las fiestas religiosas tras el paréntesis de la invasión francesa, las funciones continuaron celebrándose con la intervención de conjuntos musicales que se reunían para la ocasión $^{113}$. Varios de los instrumentistas que participaron en las funciones de San Francisco de Borja y de Nuestra Señora del Pilar celebradas entre 1825 y 1830 pertenecían a formaciones estables como las orquestas de los teatros de Madrid ${ }^{114}$. Entre los músicos que intervinieron en dichas funciones estaban algunos de los protegidos o colaboradores de la Condesa-Duquesa María Josefa como el tenor Leandro Valencia (que tuvo siempre un sueldo mayor que el resto de los cantantes solistas) ${ }^{115}$, el violinista Francisco Bocolo (encargado de la música en los bailes que organizaba la Condesa-Duquesa en sus palacios) y Angel Inzenga, (maestro de piano de la Casa de Osuna que se encargó de la dirección de las funciones al menos entre 1828 y 1830). También formaba parte de la orquesta el violista Victoriano Daroca, festero y director musical de las fiestas de San Francisco de Borja durante la titularidad de Mariano Téllez Girón en las Casas de Osuna y Benavente, que en 1858 ejercía el cargo de "director de música" de la Casa del Duque $^{116}$.

\footnotetext{
${ }^{113}$ Ver Apéndice 6, documentos $\mathrm{n}^{\mathrm{o}} 12$ a 14.

${ }^{114}$ Hasta el momento no existe un estudio sobre las plantillas de las orquestas de los teatros de Madrid en la primera mitad del siglo XIX. Por algunos documentos conservados en el Archivo de la Villa de Madrid he podido documentar que, al menos los violinistas Francisco Bocolo, José León, Antonio Cruz y Victoriano Daroca y el flautista y clarinetista Magín Jardín, pertenecían en esa época a las orquestas de los teatros municipales de Madrid. AVM Corregimiento, secciones 2 y 3.

${ }^{115}$ Leandro Valencia fue primer tenor de los teatros de Madrid. Entre 1830 y 1832 actúo en Italia adónde se trasladó con el apoyo de la Casa de Benavente-Osuna. Véase Capítulo VI..

${ }^{116}$ AHN NOBLEZA, OSUNA leg 3908.
} 


\subsection{Repertorio musical}

El estudio de las funciones religiosas patrocinadas durante los siglos XVIII y XIX por las Casas de Osuna y Benavente revela interesantes datos, desconocidos hasta ahora, sobre el repertorio musical que se interpretaba en este tipo de celebraciones.

El prestigio social y económico de los patrocinadores de las funciones religiosas se plasmaba también en la cuidadosa elección del repertorio musical que era encargado a los principales compositores que trabajaban en Madrid, o adquirido a proveedores de diversos lugares de Europa, especialmente de Italia. La Condesa-Duquesa María Josefa controló directamente la elección de los compositores que se elegían para encargarles las obras religiosas que se estrenaban en las funciones patrocinadas por su familia, imponiendo sus preferencias estéticas, lo que le llevó en ciertas ocasiones a rechazar obras que se habían compuesto sin su consentimiento con el objeto de ganarse su favor. En 1796 el violinista y director Melchor Ronzi, encargó al compositor portugués Antonio Leal Moreira, "maestro de música del Regio Seminario de Su Majestad" la composición de un juego de vísperas y una misa. El encargo de Ronzi a Leal Moreira no fue del agrado de la Condesa-Duquesa que rechazó la oferta de estas obras y su adquisición debido al excesivo importe que pretendía cobrar por ellas su autor, y especialmente porque Ronzi se había tomado la libertad de ordenar su composición sin consultarla previamente. La Condesa-Duquesa escribió a Leal Moreira, y dejó claro que no solía admitir la dedicatoria de aquellas obras que no habían sido encargadas por ella misma: 
Muy Señor mío:

Me han sorprendido ciertamente dos cartas que he recibido de Vuestra Merced, ambas sin fecha, remitiéndome parte de la música de una misa, que dice haber compuesto para mí por encargo de Melchor Ronzi. Éste no ha tenido orden alguna mía para hacer a Vuestra Merced tal encargo, y ha tomado mi nombre indebidamente, lo cual le he hecho entender a vista de las cartas de Vuestra Merced; y aunque ha pretendido satisfacerme a esto exponiendo que encargó a Vuestra Merced las vísperas y la misa con ánimo de hacerme él un obsequió con estas obras, no ha podido satisfacerme con esta excusa, porque sabe y es notorio que no admito de nadie regalos de esta clase, y por lo mismo no podía lisonjearse de que de él le admitiese.

Sea como quiera y con esta inteligencia devuelvo a Vuestra Merced la música que me ha remitido de la misa para que haga de ella el uso que fuere servido, como de las vísperas que en carta posterior de 12 de este mes me dice que está trabajando: pues aun cuando hubiera yo pensado en satisfacer a Vuestra Merced su trabajo, único modo de que yo me sirviese de estas obras, no puede verificarse habiéndome dicho el mismo Ronzi que Vuestra Merced las estima en treinta y dos mil reales, cuando estoy acostumbrada a que las vísperas y misas que han hecho por encargo mío los mejores Maestros de esta corte, que están en actual servicio de Su Majestad Católica, no me hayan pasado de seis mil reales.

Siento que el haberse tomado indebidamente mi nombre, haya ocasionado a Vuestra Merced la molestia de hacer este trabajo inútilmente; pero a esto sólo puede satisfacer Vuestra Merced Don Melchor Ronzi, que se tomó la libertad de hacerle este encargo sin haberme dado la menor noticia hasta que por las cartas de Vuestra Merced me vi en el caso de reconvenirle. Nuestro Señor guarde a Vuestra Merced muchos años:

Madrid, 22 de septiembre de 1796

Señor Antonio Leal Moreira ${ }^{117}$

117 AHN NOBLEZA, OSUNA-CARTAS, leg 391-11. 
Es una tarea ardua identificar con precisión las obras que formaban parte del repertorio religioso de las Casas de Osuna y Benavente. La paulatina dispersión y posterior desaparición de los archivos de música de la familia, y los escasos datos sobre las composiciones que aporta la documentación administrativa conservada no permiten saber, en la mayoría de los casos, si las misas, salmos de vísperas o motetes que se interpretaron en los actos religiosos de las Casas de Osuna y Benavente fueron las obras que se conservan actualmente. La labor de identificación se complica aún más en aquellos autores de los que (a pesar de su importancia) no se ha realizado aún un catálogo sistemático de su obra, o de los que hasta el momento apenas disponemos de datos biográficos.

\subsubsection{Música de compositores españoles}

La música religiosa de autores españoles estuvo presente en el repertorio de las fiestas y funciones religiosas patrocinadas por las Casas de Benavente y Osuna durante la titularidad de la Condesa Duquesa María Josefa. De las 40 obras con autor identificado que figuran en los inventarios del archivo musical de la Condesa-Duquesa de 1824 y ca.1838, 11 son indudablemente de compositores españoles $^{118}$. Varias de estas obras fueron encargadas directamente por los miembros de las Casas de Osuna y Benavente para ser estrenadas en alguna de sus funciones religiosas.

\footnotetext{
${ }^{118}$ Ver Apéndice 3. Es muy probable que también sean de autores españoles las obras de Ortellez [ $=i$ Antonio Teodoro Ortells? $(* c a .1650-\dagger 1706)]$, Pacheco y Medina, que se conservaban en el archivo de la Condesa-Duquesa.
} 
En 1780, la Condesa Duquesa María Josefa encargó a José Lidón, la composición de un juego de vísperas y una misa para las funciones de San Francisco de Borja que se celebraron los días 30 de septiembre y 1 de octubre de dicho año:

Muy Señor mío:

Para mayor solemnidad de la fiesta que a expensas de la CondesaDuquesa Mi Señora había de celebrarse, y se celebró con efecto, en obsequio de San Francisco de Borja en la Real Casa Oratorio de San Felipe Neri de esta corte el día primero del corriente, dispuso la Condesa-Duquesa mi señora que Joseph Lidón maestro de estilo en el Real Colegio de Músicos, compusiese nueva música para las vísperas que se cantaron en la tarde del 30 de septiembre, y para la misa que se cantó el día $1^{\circ}$ del corriente; y habiéndolo practicado así dicho Don Joseph encargó la copia de dicha nueva música a Don Jerónimo Sánchez quien parece la hizo y en su consecuencia me ha presentado una razón del importe de dicha copia que asciende a setecientos setenta y cuatro reales de vellón, la que reconocida por Don Francisco Basset me ha dicho este haberla cotejado con la misma copia y estar arreglada. En cuya consecuencia y de la orden que me dejó la CondesaDuquesa mi Señora para que a dicho Don Jerónimo se le pagase su trabajo, se hace preciso que Vuestra Merced se sirva de extender y poner a la firma de los apoderados de Su Excelencia el correspondiente libramiento de la citada cantidad a favor del mismo Don Jerónimo Sánchez.

Me repito con todo afecto a la disposición de Vuestra Merced cuya vida guarde Dios muchos años. Madrid 30 de octubre de 1780.

Besa la mano de Vuestra Merced Manuel de Ascargorta

Don Francisco Grande Torrejón ${ }^{119}$

119 AHN NOBLEZA, OSUNA-CARTAS, leg 389-27. 
La misa de José Lidón que se cita en este documento es seguramente la misma que aparece en los inventarios del archivo de música de la CondesaDuquesa María Josefa [3/327], [4/64] $]^{120}$. El Responsorio para el Santo Sacramento a 8 de Lidón que figuraba en dicho archivo [3/334], debió de formar parte del juego de vísperas compuesto para las funciones de San Francisco de Borja de 1780. La fecha de composición de estas obras no coincide con la de ninguna de las misas o juegos de vísperas de José Lidón que se conocen en la $\operatorname{actualidad}^{121}$.

En el archivo de la Condesa-Duquesa también se conservaban otras dos obras dedicadas a los miembros de las Casas de Osuna y Benavente compuestas por autores supuestamente españoles: un Stabat mater a cuatro voces de Delgado, “dedicado a la Excelentísima Señora Condesa de Benavente" [3/316] y [4/73] que podría ser una obra de Francisco Delgado (*1719- $\uparrow 1792)$, maestro de capilla de la catedral de Cádiz) natural de Arcos de la Frontera, uno de los territorios de los estados andaluces de los Osuna ${ }^{122}$; y una Misa "dedicada a la Excelentísima Señora Duquesa de Osuna" de Capmany [3/317], [4/57] ${ }^{123}$.

\footnotetext{
${ }^{120}$ La numeración que figura junto a los títulos de las obras, corresponde a mi transcripción de los inventarios de 1824 y ca. 1838 del archivo de música de la Condesa-Duquesa (Apéndice 3).

${ }^{121}$ Una primera aproximación al catálogo de la obra de Lidón puede verse en José Lidón, Música para teclado, estudio y transcripción de Dámaso García Fraile, (Madrid: Sociedad Española de Musicología, 2002) vol I, pp. 34-36 y en María Gembero Ustárroz, "Lidón Blázquez José”, $N G$, vol. 14, pp. 657-659.

122 Sobre este autor véase Marcelino Díez Martínez, La música en Cádiz: la catedral y su proyección urbana durante el siglo XVIII, (Cádiz: Universidad de Cádiz, Servicio de Publicaciones, 2004), vol. I, pp. 381-401.

${ }^{123}$ No he podido documentar ningún dato biográfico sobre este compositor. En el archivo musical de la Condesa-Duquesa se conservaba también la zarzuela Lorenza la incluserita de Francisco Capmany dedicada al "Excelentísimo Señor Don Pedro Girón Duque de Osuna" [3/289], [4/43]
} 
Además de las citadas obras, que fueron compuestas expresamente para la Condesa-Duquesa de Benavente, en las funciones religiosas de las Casas de Osuna y Benavente se interpretaron otras composiciones de autores españoles. En la primera década del siglo XIX, se copió para la Condesa-Duquesa una misa del "Maestro Don Narciso Sors" (compositor y director de orquesta en el Teatro de los Caños del Peral) que fue interpretada en la fiesta de San Francisco de Borja de un 15 de octubre, probablemente de $1807^{124}$. En el archivo de la CondesaDuquesa se conservaban también varias misas y obras religiosas para coro o coro y orquesta de otros autores españoles de los siglos XVIII y XIX como [¿Sebastián?] Durón, [Tomás] Abril, Ramón [Rodríguez] Monroy (contrabajista de la Orquesta de la Condesa-Duquesa), Fray Ignacio Ramoneda o [Manuel] Doyagüe que, posiblemente fueran interpretadas en alguna de las funciones religiosas patrocinadas por las familias Osuna y Benavente (Ver Apéndice 4). Los escasos datos que aportan las fuentes administrativas de la Casa de Osuna, no permiten la identificación de ninguna de estas obras.

En el archivo de música de la Condesa-Duquesa de Benavente se conservaban también dos colecciones de versos para órgano compuestas por Pedro Carrera Lanchares, organista del Real Convento del Carmen Calzado de

\footnotetext{
124 En AHN NOBLEZA, OSUNA-CARTAS, leg 392-7 figuran dos documentos sin fecha en los se hace referencia a esta misa de Sors o "Sort". El primero de ellos es el recibo por la copia de la obra realizada por Salvador Feixas en la que aparece el visto bueno de Carlo Marinelli. El segundo es una relación de obras de música con el día de su interpretación (pero sin año) que coinciden con las interpretadas en las fiestas de San Francisco de Borja de 1807 patrocinadas por el Duque de Osuna que figuran en AHN NOBLEZA, OSUNA-CARTAS, leg 390-1.
} 
Madrid $^{125}$. Una de ellas era la Salmodia Orgánica: Juego de versos de todos los tonos, publicada en Madrid en 1792 "por un apasionado del autor” [3/78], [4/218] (Lámina 26), una colección que contiene dieciocho versos para órgano, diez breves, de duración regular para los días de ordinario y ocho versos más largos, compuestos en un lenguaje galante ${ }^{126}$.

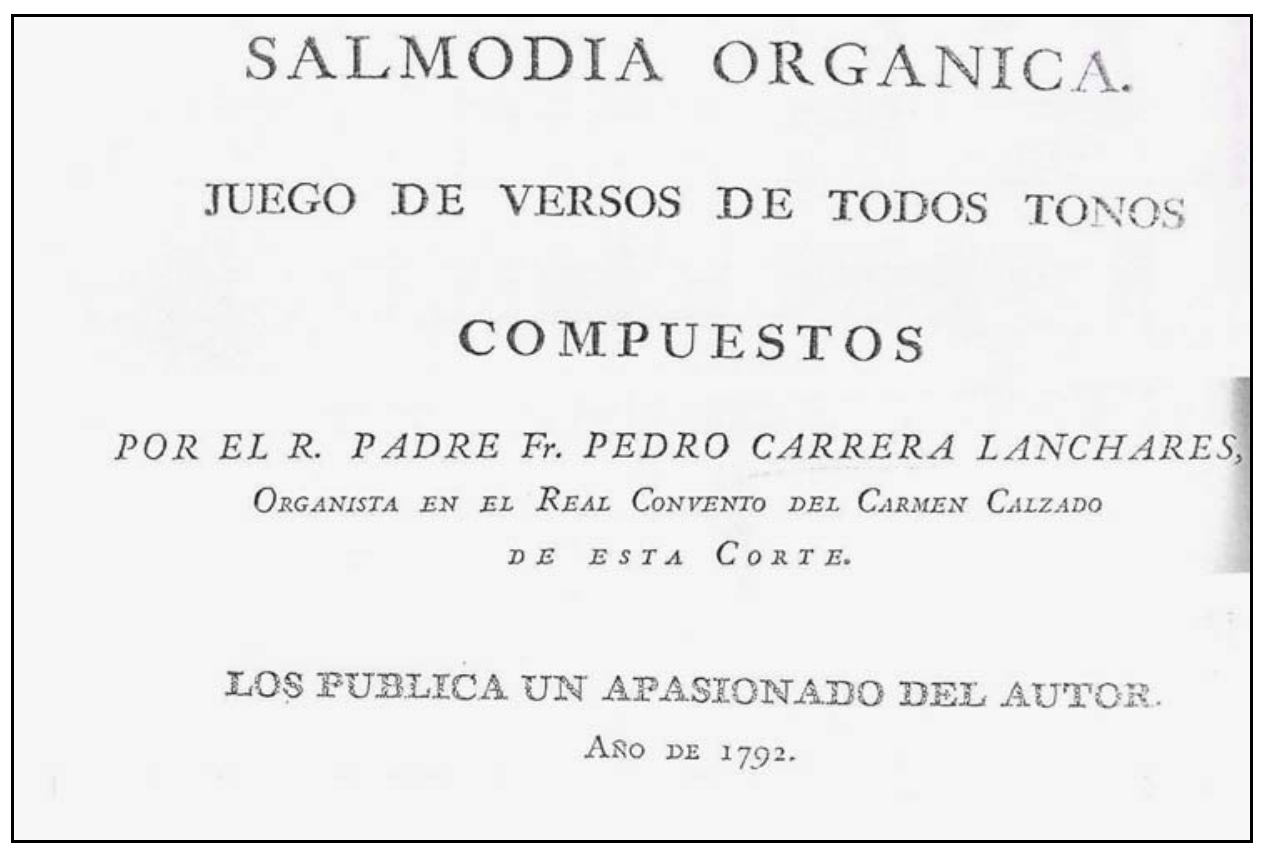

Lámina 26.

Portada de la edición de Salmodia orgánica de Pedro Carrera y Lanchares (Madrid: 1792) (BNE M 2739)

\footnotetext{
${ }^{125}$ Sobre este compositor véase Javier Garbayo, “Carrera Lanchares, Pedro”, DMEH, vol. 3, pp. 243-244.

${ }^{126}$ Pedro Carrrera Lanchares, Salmodia Organica Juego de versos de todos tonos [....], .([Madrid]: [s.n.], 1792). Ejemplar conservado en BNE M 2739.
} 
En el prólogo a Salmodia Orgánica, Carrera y Lanchares se declara discípulo de "su dignísimo maestro Don Joseph Lidón, organista de primero de la Real Capilla de Su Majestad Católica" y dice publicar esta obra para "facilitar a los jóvenes dedicados al ejercicio del órgano, y destituidos de ejemplares que seguir en el modo y en la sustancia, una colección de pensamientos para coadyuvar al desempeño de su ministerio"127.

En el archivo de la Condesa-Duquesa se conservaba también la segunda colección de versos de órgano de Carrera y Lanchares que se publicó en 1814 bajo el título de Adiciones a la Salmodia Orgánica: Versos de los tonos primero, sexto y cuarto punto bajo, y los del último con extensión en forma de Sonatas [3/78] y [4/218].

\subsubsection{Música de compositores italianos y centroeuropeos}

Las fiestas religiosas organizadas por la Casa de Benavente-Osuna fueron un importante medio de difusión del repertorio musical de autores europeos en España. Gran parte de las obras musicales que se interpretaron durante las funciones religiosas de San Francisco de Borja y Nuestra Señora del Pilar en el período de titularidad de la Condesa-Duquesa María Josefa fueron adquiridas en diversos lugares de Europa, especialmente en Italia, o encargadas a compositores europeos residentes en España

\footnotetext{
127 Carrera, Salmodia, [Prólogo de] el editor, [s.f
} 


\section{Música de autores italianos}

Durante la titularidad de María Josefa Alfonso Pimentel la música religiosa de autores italianos fue uno de los pilares básicos del repertorio de las fiestas y funciones religiosas patrocinadas por la Casa de Benavente. De las 40 obras con autor identificado que figuran en los inventarios del archivo musical de esta dama, 13 están compuestas por autores italianos ${ }^{128}$. La gran mayoría de ellas fueron escritas por compositores que trabajaron en las últimas décadas del siglo XVIII y en las primeras del siglo XIX, aunque también se conservaban algunas de autores anteriores (quizá en copias o impresos del siglo XIX) como unos Ofertorios a cinco "para las Dominicas de Septuagesima, $1^{\mathrm{a}}, 2^{\mathrm{a}}, 3^{\mathrm{a}}, 4^{\mathrm{a}}$ de Cuaresma, In Passione y Miércoles Santo” de G.P da Palestrina (*1525-†1594) [3/355], [4/63], pertenecientes a la colección de ofertorios a cinco voces para todo el año publicados en Roma en $1593^{129}$; una Misa a due cori [3/322], [4/72] y el Stabat mater de Giovanni Battista Pergolessi $(* 1710-\uparrow 1736)$ [3/348]; y un Responsorio de Difuntos del napolitano Davide Pérez (*1711-†1778)[3/323], $[4 / 71]$.

Una importante parte del repertorio italiano de música sacra de los Osuna y Benavente fue el resultado de encargos realizados a compositores que trabajaban en Madrid en puestos relacionados con la Corte o en los teatros. Citaré a continuación algunos ejemplos significativos.

\footnotetext{
${ }^{128}$ Ver Apéndices 3 y 4.

${ }^{129}$ Lemus Lockwood, Noel Regan, y Jessie Ann Owens, "Palestrina,. Giovanni Pierluigi da", $N G$, vol 18, pp. 937-957.
} 
Para las funciones de San Francisco de Borja celebradas en 1800, la Casa de Benavente encargó al milanés Antonio Rosetti la composición de una misa por la que recibió 3.000 reales ${ }^{130}$. Rosetti era ya conocido por la Condesa-Duquesa, pues en la década anterior había trabajado como compositor y director musical de la Compañía de Ópera del Teatro de los Caños del Peral dirigida por Domenico Rossi y gestionada por la Asociación para la Representación de Óperas Italianas de la que formaron parte la propia Condesa-Duquesa y otros miembros de la familias Osuna y Benavente ${ }^{131}$.

El compositor italiano Saverio Mercadante, que en la temporada de 18261827 se encontraba en Madrid dirigiendo las temporadas de ópera de los teatros de la Cruz y el Príncipe, compuso en 1827 para la Condesa-Duquesa de Benavente una misa y un juego de vísperas, que se debieron de interpretarse en alguna de las fiestas religiosas patrocinadas por esta dama. En este mismo año se copiaron las partes instrumentales de una misa puesta que había sido "puesta en música y dedicada a la Excelentísima Señora Duquesa de Benavente" por Saverio Mercadante y Angelo Inzenga. Mercadante había compuesto el Kyrie y el Gloria e Inzenga el Credo, el Sanctus, y el Agnus Dei ${ }^{132}$. Esta obra podría ser la misma

\footnotetext{
${ }^{130}$ AHN NOBLEZA, OSUNA-CARTAS, leg 392-2. Antonio Rosetti escribió dos misas, una “en sol" y otra "en fa" que fueron estrenadas en las funciones de San Francisco de Borja (AHN NOBLEZA, OSUNA-CARTAS, leg 392-7).

131 Véase el Capítulo VI.

132 AHN NOBLEZA, OSUNA-CARTAS, leg 392-35. Nicolás A. Solar-Quintes, "Saverio Mercadante en España y Portugal. Su correspondencia con la condesa de Benavente" AnM, VII, 1952, p 202.
} 
que se interpretó en 1828 en las fiestas de San Francisco de Borja dirigidas por el propio Angelo Inzenga ${ }^{133}$.

Parte de las obras de música sacra de autores italianos que se interpretaron en las funciones religiosas patrocinadas por las familias Osuna y Benavente en las primeras décadas del siglo XIX, llegó a España a través de encargos realizados a corresponsales o a personas de confianza de la casa que residían en Italia. Un ejemplo de esta práctica es el lote de obras de música religiosa que, en el mes de agosto de 1807, se enviaron desde Roma para la Condesa-Duquesa María Josefa. En dicho envío figuraban obras de autores italianos consagrados como [Pietro Carlo] Guglielmi ${ }^{134}$, Baldassare Galuppi [“Buranello"], [Pasquale] Anfossi, entre otros y varias obras de Giovanni Paisiello (que no se especifican) entre las cuales seguramente se hallaba la misa y el Dixit Dominus de dicho autor que fueron copiados por Salvador Feixas en los meses de septiembre y octubre de 1807 (Tabla 20).

\footnotetext{
133 AHN NOBLEZA, OSUNA-CARTAS, leg 392-20. Apéndice 6, nº 13.

134 Aunque cabe la posibilidad de que el autor de las obras enviadas fuera Pietro Alessandro Guglielmi $\left({ }^{*} 1728-\dagger 1804\right)$, es mas probable que fueran de su hijo Pietro Carlo $\left({ }^{*} c a .1763-\dagger 1817\right)$, que trabajado en 1793 en la compañía de Ópera del Teatro de los Caños del Peral de Madrid, antes de dedicarse extensamente a la música religiosa. Sobre este autor véase Emilio Cotarelo y Mori, Orígenes y establecimiento de la Ópera en España hasta 1800, (Madrid: Tipografía de la Revista de Archivos, Bibliotecas y Museos, 1917), p. 358.
} 
Tabla 20.

Música sacra de autores italianos adquirida en Italia o copiada para la XV Condesa-Duquesa de Benavente entre agosto y octubre de 1807 Fuente: AHN NOBLEZA, OSUNA-CARTAS leg 392-7.

\begin{tabular}{|l|l|l|}
\hline Autor & Obra & Observaciones \\
\hline Anfossi, Pasquale & Confitebor [tibi domine] & Enviada desde Roma \\
\hline Galuppi, Baldassare & Credo & Enviada desde Roma \\
\hline Guglielmi,[Pietro Carlo] & Misa & $\begin{array}{l}\text { Ambas obras fueron se } \\
\text { enviaron desde Roma y } \\
\text { fueron copiadas por Feixas } \\
\text { en 1807 }\end{array}$ \\
\cline { 2 - 3 } & Beatus vir & Enviada desde Roma \\
\hline Masi & Dixit Dominus & $\begin{array}{l}\text { Copiada por Feixas en } \\
\text { 1807. Posiblemente fue } \\
\text { enviada desde Roma. }\end{array}$ \\
\hline Zingarelli,[Niccolò Antonio] & Bixit Dominus & $\begin{array}{l}\text { Copiada por Feixas en } \\
\text { 1807. Posiblemente fue } \\
\text { enviada desde Roma. }\end{array}$ \\
\cline { 2 - 3 } & Misa vir & Enviada desde Roma \\
\hline
\end{tabular}

Varias de las obras de música sacra italiana que fueron enviadas en el año 1807 se incorporaron al repertorio musical de las fiestas religiosas patrocinadas por las Casas de Osuna y Benavente. La misa de Guglielmi, se interpretó en una de las funciones de San Francisco de Borja 1807 patrocinada por el X Duque de Osuna $^{135}$, y la misa de Giovanni Paisiello era seguramente la misma que figuraba en los archivos de música de la Condesa-Duquesa de Benavente ([3/330], [3/341], [4/66]] y que fue interpretada en las funciones de San Francisco de Borja de 1808 dirigidas por Mariano Rodríguez de Ledesma ${ }^{136}$.

\footnotetext{
${ }^{135}$ AHN NOBLEZA, OSUNA-CARTAS, leg 390-1.

${ }^{136}$ Ibíd.
} 
Según el catálogo realizado por Michael F. Robinson, Paisiello compuso al menos cinco misas para doble coro antes de 1807, por lo que, con los escasos datos que proporciona la documentación administrativa, no es posible saber si alguna de las misas que figuran en este catálogo fue la que tuvo en su archivo la Condesa-Duquesa María Josefa ${ }^{137}$.

El Beatus vir de Giuseppe Gazzaniga $(* 1743 \dagger 1818)^{138}$ que se conservaba en el archivo de música de la Condesa-Duquesa formando un juego de vísperas con otros cuatro salmos de Pacheco, Doyagüe y Bonfichi ${ }^{139}$ es posible que se trate de uno de los dos Beautus vir de Gazzaniga que actualmente se hallan en la Biblioteca del Conservatorio Giuseppe Verdi de Milán. Como ejemplo de este tipo de repertorio comentaré uno de ellos, el Beatus vir a 4 voci concertato con tutti li strumenti ${ }^{140}$, cuya plantilla orquestal (dos oboes, dos trompas, cuerda, y órgano) coincide con la que se empleaba habitualmente en las funciones religiosas realizadas por las Casas de Osuna y Benavente en los primeros años del siglo $\mathrm{XIX}^{141}$

El Beatus vir de Giuseppe Gazzzaniga, revela una notable influencia de la música teatral en la que se concentró gran parte de la actividad creadora de este

\footnotetext{
${ }^{137}$ Michael F. Robinson, Giovanni Paisiello (1740-1816) a thematic catalogue of his works. (New York:, Pendragon Press, 1994), vol II, pp.109-127.

138 Sobre este compositor véase Rudolf Angermüller, Mary Hunter y Caryl L. Clark "Gazzaniga, Giuseppe", $N G$, vol. 9, pp. 610-612.

${ }^{139}$ Ver Apéndices 3 y 4.

140 Biblioteca del Conservatorio Giuseppe Verdi de Milán M. S. Mss. 106-1. En el mismo archivo se conserva otro Beatus Vir de Gazzaniga para cuatro voces, dos oboes, dos trompas, violines y bajo (M.S Mss 106-2.).

${ }^{141}$ Véase, por ejemplo la plantilla de músicos que actuaron en las funciones de San Francisco de Borja en 1808. Apéndice 6, $\mathrm{n}^{\circ} 10$.
} 
compositor antes de aceptar en 1791 el cargo de maestro de capilla de la catedral de Crema (Italia) ${ }^{142}$. La obra está dividida en 5 números y utiliza un lenguaje plenamente clásico en el que predominan las frases simétricas y la polaridad tónica-dominante como elemento articulador de una estructura presidida por la simetría.

El esquema general de la obra (Tabla 21) revela un equilibrio tanto en la disposición de los tiempos lentos y rápidos como en la distribución de las partes concertantes. La sensación de simetría y equilibrio a gran escala viene apoyado por la alternancia de números en los que predomina la textura homofónica y la utilización de la plantilla orquestal completa (1, 3 y 5), con otros en los que prevalece la melodía acompañada con una voz solista acompañada por un pequeño grupo instrumental (2 y 4). Es precisamente en estos dos números donde se aprecia con mayor nitidez la notable influencia de la música teatral en esta obra.

142 Angermüller, "Gazzaniga" 
Tabla 21.

Estructura del Beatus vir a 4 voci concertato con tutti li strumenti de Giuseppe Gazzaniga

Fuente: Biblioteca del Conservatorio Giuseppe Verdi de Milán. M. S. Ms .106-1.

\begin{tabular}{|c|c|c|c|c|}
\hline $\mathrm{N}^{0}$ & Tempo & Incipit Secciones & Textura principal & Plantilla \\
\hline \multirow[t]{8}{*}{ [1] } & \multirow[t]{8}{*}{ Allegretto } & [Introducción orquestal] & Melodía acompañada & \multirow{8}{*}{\begin{tabular}{|l} 
Orquesta y \\
Coro con voces \\
concertantes
\end{tabular}} \\
\hline & & Beatus vir & Homofónica & \\
\hline & & Potens in terra & $\begin{array}{l}\text { Melodía acompañada } \\
\text { Tiple concertante. }\end{array}$ & \\
\hline & & Beatus vir & Homofónica & \\
\hline & & Exortum est & $\begin{array}{l}\text { Melodía acompañada. } \\
\text { Bajo concertante. }\end{array}$ & \\
\hline & & Jucundus homo & Homofónica & \\
\hline & & Quia in eternum & $\begin{array}{l}\text { Homofónica } \\
\text { Contrapuntística }\end{array}$ & \\
\hline & & Beatus vir & Homofónica & \\
\hline \multirow[t]{2}{*}{ [2] } & $\begin{array}{l}\text { Andante } \\
\text { sostenuto }\end{array}$ & $\begin{array}{l}\text { In memoria eterna } \\
\text { [Recitativo] }\end{array}$ & Melodía acompañada & $\begin{array}{l}\text { Soprano, violas, } \\
\text { violines y bajo, }\end{array}$ \\
\hline & Allegro & Dispersit [aria] & $\begin{array}{l}\text { Melodía acompañada } \\
\text { +contrapunto imitativo }\end{array}$ & $\begin{array}{l}\text { Soprano, oboe } \\
\text { solo, violas, } \\
\text { violines y bajo, }\end{array}$ \\
\hline \multirow[t]{2}{*}{ [3] } & \multirow[t]{2}{*}{ Andante } & Peccator videbit & \multirow[t]{2}{*}{ Homofónica } & \multirow{2}{*}{$\begin{array}{l}\text { Orquesta y } \\
\text { Coro con voces } \\
\text { concertantes }\end{array}$} \\
\hline & & Desideriumn pecatorum & & \\
\hline [4] & $\begin{array}{l}\text { Andante } \\
\text { cantaile }\end{array}$ & Gloria Patri & Melodía acompañada & $\begin{array}{l}\text { Tenor, violas, } \\
\text { violines y bajo, }\end{array}$ \\
\hline \multirow[t]{2}{*}[5]{} & Allegro & Sicut erat & \multirow[t]{2}{*}{ Homofónica } & \multirow[t]{2}{*}{$\begin{array}{l}\text { Orquesta y } \\
\text { Coro con voces } \\
\text { concertantes }\end{array}$} \\
\hline & Larguetto & Beatus vir & & \\
\hline
\end{tabular}

El carácter claramente dramático del segundo número del Beatus vir de Gazzaniga lo asemeja al de una aria de concierto teatral. El número se abre con un recitativo acompañado para soprano, violas, dos violines y bajo. Este fragmento introductorio enlaza sin interrupción con un aria que evidencia su clara inspiración dramática en los amplios pasajes de coloratura del soprano (que llega a alcanzar un Si 4). La parte vocal es apoyada y complementada por un oboe solista, que se suma a los instrumentos que habían intervenido en el recitativo (véase el Ejemplo musical 1). 


\section{Ejemplo musical 1.}

Fig. XX. Giuseppe Gazzaniga. Beatus vir a4 voci concertato

$\mathrm{N}^{\mathrm{o}} 2$. Recitativo y aria. cc. $80-109$

[Biblioteca del Conservatorio de Milán M.S. ms 106-1]
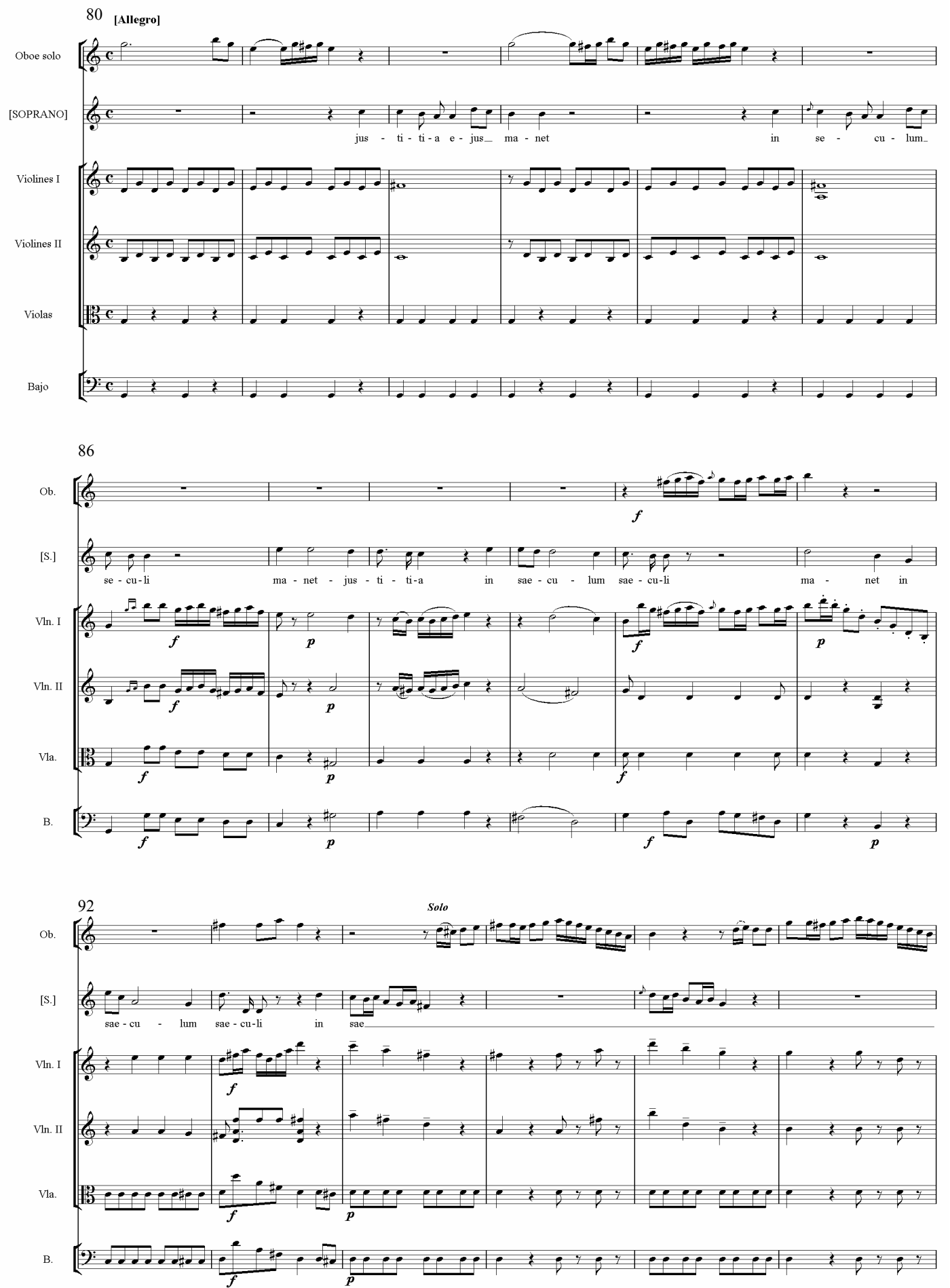

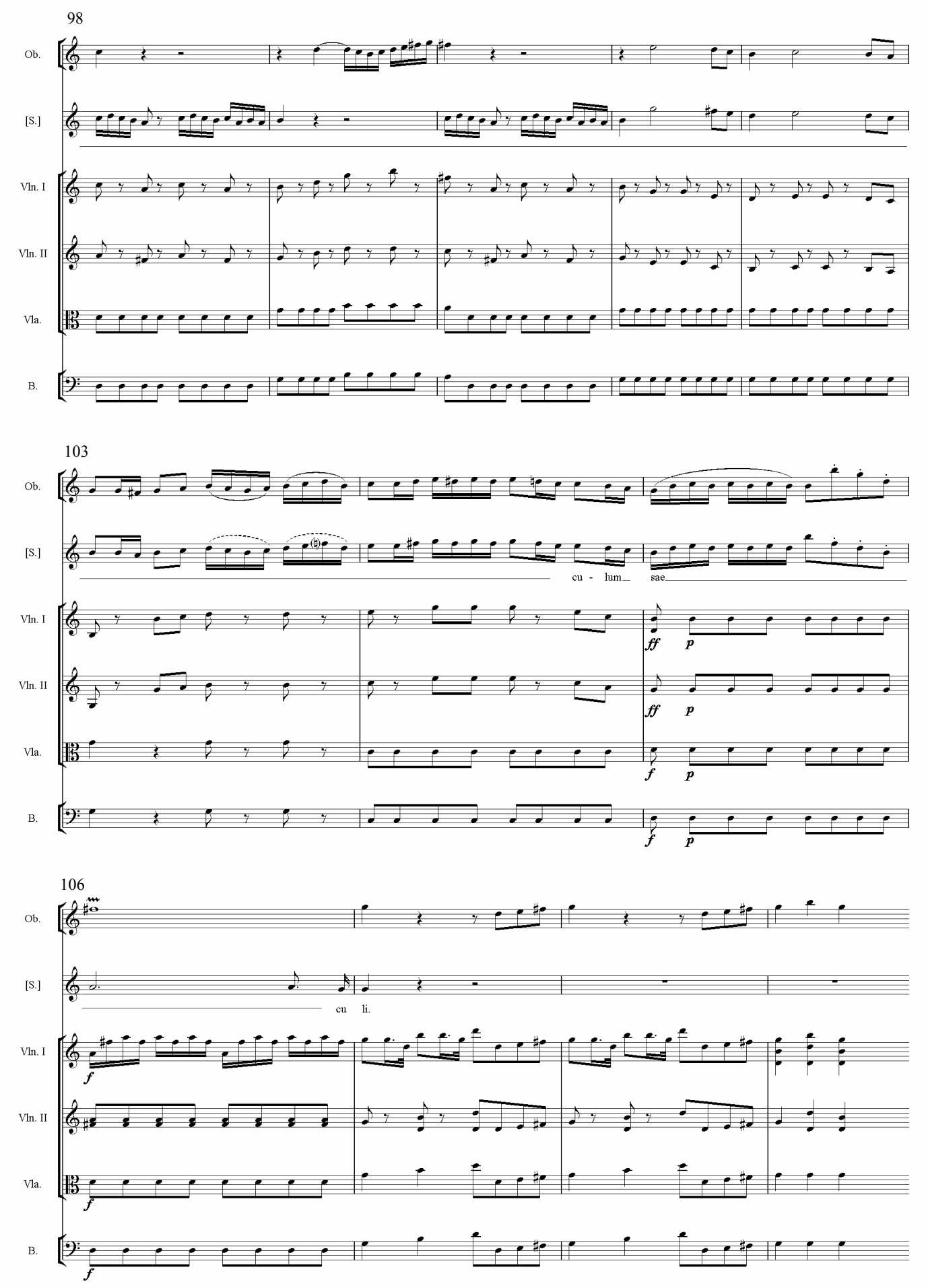
Junto al Beatus vir de Gazzaniga, en el archivo de música de la CondesaDuquesa de Benavente se conservaba el Salmo a 4 Laudate pueri de [Paolo] Bonfichi $(* 1769-\dagger 1840)$ [3/358] compositor que trabajó en Milán y su zona de influencia en las primeras décadas del siglo $\mathrm{XIX}^{143}$. La única obra que he podido localizar con similares características se conserva en la Biblioteca del Conservatorio Giuseppe Verdi de Milán, y además de las cuatro partes vocales tiene una amplia plantilla orquestal con maderas a dos (flautas, oboes y clarinetes) metales (dos trompetas, dos trompas y trombón), timbales cuerda y órgano ${ }^{144}$.

En las fiestas de San Francisco de Borja y Nuestra Señora del Pilar patrocinadas por la Casa de Benavente se interpretaron también otras obras de autores italianos: una misa de [Gaetano] Brunetti, dos misas de Ferdinando Paer, (interpretadas ambas en 1798 y 1800) ${ }^{145}$ y un Credo de Boccherini (ca. 1805) ${ }^{146}$. La misa de Brunetti, es posible que fuera la misma que figuraba en el inventario del archivo musical de la XV Condesa-Duquesa de Benavente realizado en 1824 $[3 / 343]$.

\section{Música de autores centroeuropeos}

Gracias a las investigaciones de Solar-Quintes conocemos el papel que jugó María Josefa Alfonso Pimentel, XV Condesa-Duquesa de Benavente en la

\footnotetext{
143 Denis Libby: “Bonfichi, Paolo”, NG, 3, pp. 856-857.

144 Biblioteca del Conservatorio Giuseppe Verdi de Milán. M. S. Mss .60-1.

145 Ver Tablas 19 y 20.

146 AHN NOBLEZA, OSUNA-CARTAS, leg 390-1..
} 
temprana recepción de la música instrumental de Joseph Haydn en España ${ }^{147}$, sin embargo hasta la fecha no se ha tenido en cuenta la importancia que tuvo la relación contractual que dicha dama estableció con el compositor vienés para la recepción de su música religiosa en España.

El contrato que firmó la Condesa-Duquesa con Haydn en 1783, obligaba al compositor a enviarle todas las obras que hubiera compuesto a lo largo del año exceptuando solamente las que fueran encargadas por otros para su uso privado. Entre las obras que Haydn envió a la Condesa-Duquesa antes de 1785, figuraban varias misas, según relataba Carlos Alejandro de Lellis en una carta dirigió a Tomás de Iriarte:

[Franz Joseph Haydn] añadió que envió las misas porque yo le había manifestado que las deseaban, y porque creyó poder agradar si las dejaba entrar en cuenta de la contrata sin hacerlas pagar separadamente, y porque ya naturalmente debía comprenderse bajo la palabra toda la música ${ }^{148}$.

Las misas que se citan en esta carta eran seguramente las mismas que se interpretaron en las funciones de San Francisco de Borja de 1784 y 1785, a las que también se refieren sendos recibos firmados por Francisco Basset, músico de la Casa de Benavente. El primero de ellos está fechado en noviembre de 1784, y hace referencia a las funciones de San Francisco de Borja de dicho año:

\footnotetext{
${ }^{147}$ Nicolás A. Solar-Quintes, "I. Las relaciones de Haydn con la casa de Benavente. II. Nuevos documentos sobre Luigi Bocherini. III. Manuel García Íntimo ”, AnM, II (1947), pp. 81-104.

148 AHN NOBLEZA, OSUNA-CARTAS, leg 391-2. Solar-Quintes: “I. Las relaciones”, p. 83. Las cursivas están en el original.
} 
Madrid 6 de noviembre de 1784

Razón del gasto de copia para el segundo coro que se ha puesto a la Misa de Hayden [sic]: Consta de 9 cuadernos y estos de 16 pliegos que a razón de 8 reales el pliego por trabajo y papel son 132 [reales]

Un violín que puse en la primera función de víspera y misa de último y primero de septiembre por estar malo Don Pedro Garisuain en dichas dos funciones a razón de 20 reales por cada función como es costumbre en otros años 40

Para las funciones de 1785 se copió por orden de la Condesa-Duquesa "una misa de Hayden que había de servir, y sirvió en las mismas fiestas"150. Esta misa es la misma a la que se alude en un recibo de Francisco Basset del año 1785 como "misa nueva de Hayden":

Razón del importe de la copia de la misa nueva de Hayden que se ha cantado en la función del día primero de setiembre en la iglesia de San Felipe Neri este año de la fecha.

Consta dicha misa de 82 pliegos de papel escritos a 5 reales el pliego con papel aparte

Madrid 27 de octubre de 1785

149 AHN NOBLEZA, OSUNA-CARTAS, leg 390-1.

${ }^{150}$ Ibid. leg 390-5.

${ }^{151}$ AHN NOBLEZA, OSUNA-CARTAS, leg 390-1. 
Las dos misas que Haydn envió a la Condesa-Duquesa de Benavente eran probablemente las mismas que se conservaban en el archivo musical de esta dama. La primera de ellas que aparece catalogada como Misa a cuatro por José Haydn [3/345], [4/72] es probablemente la primera de las dos misas enviadas por Haydn desde Viena. Esta obra sería la misma que se denomina Misa chica de Haydn en la documentación contable y que fue una de las piezas de referencia del repertorio de las fiestas de San Francisco de Borja y Nuestra Señora del Pilar. Después de su primera audición en 1785, la llamada Misa chica de Haydn se repuso en las funciones de 1798 (8 y 12 de octubre), 1800 (11 y 15 de octubre), 1802 (8 y 15 de octubre), y 1808 (11 de octubre $)^{152}$. Al menos en algunas funciones la Misa chica de Haydn se interpretó en un arreglo que añadía un segundo coro a la partitura original para preservar la policoralidad habitual en los grandes acontecimientos religiosos de la música española ${ }^{153}$.

La segunda de las misas enviadas por Joseph Haydn a la Condesa-Duquesa de Benavente antes de 1785 se interpretó por primera vez en las fiestas de San Francisco de Borja, pues se la denomina “misa nueva” en la documentación de las funciones de 1785. Esta obra fue seguramente la misma que se repitió en 1807 bajo el título de "Misa grande de Haydn" con una plantilla, de solistas vocales, coro y orquesta lo que permite relacionarla con la otra misa de Joseph Haydn que figura en el inventario del archivo musical de la Casa de Benavente-Osuna de $c a$. 1838 con el título de Misa a cuatro y a ocho [4/62 $]^{154}$.

\footnotetext{
152 Ibíd.

153 Ibid.

154 AHN NOBLEZA, OSUNA-CARTAS, leg 392-16.
} 
La escasez de datos que presentan las fuentes administrativas de la Casa de Osuna impide identificar las dos misas que envió F.J. Haydn con alguna de las que figuran en el catálogo de su música religiosa ${ }^{155}$. Las claúsulas del contrato que el compositor vienés había firmado con la Condesa-Duquesa le obligaba a enviar toda la música compuesta durante el año, pero ninguna de las misas de Haydn que se conocen en la actualidad ninguna fue compuesta entre 1783 y 1785 , fechas en las que la Condesa-Duquesa recibió estas obras ${ }^{156}$. Por consiguiente, es posible que las dos misas que Haydn envió a España sean obras distintas a las que actualmente conocemos o que, lo que parece más probable, que el compositor no cumpliera las cláusulas del contrato y mandase alguna misa de las que había compuesto en los años inmediatamente precedentes al envío.

El conocimiento de la obra religiosa de Franz Joseph Haydn, alentó la adquisición de una misa de su hermano Michael Haydn. En 1789, Carlos Alejandro de Lelis, adquirió en Viena para la Condesa-Duquesa la partitura de una misa de este autor por 40 ducados. Lelis se encargó de escuchar la misa de Michael Haydn para evaluar su calidad organizando una audición por unos aficionados y la envió a Tomás de Iriarte con una remesa que incluía otras partituras de Joseph Haydn y [Johann Mederitsch-] Gallus ${ }^{157}$. La misa de Michael Haydn se interpretó seguramente en alguna de las funciones religiosas patrocinadas por la Condesa-Duquesa o algún miembro de su familia, pues fue

\footnotetext{
${ }^{155}$ Anthony van Hoboken J. Haydn, Thematisch-bibliographisches Werkverzeichnis, Mainz: B. Schott's Schone, 1957, 3 vols.

${ }^{156}$ Véase Hoboken, Thematisch-bibliographisches

157 AHN NOBLEZA, OSUNA-CARTAS, leg 391-2. Solar-Quintes: “I. Las relaciones”, p. 834
} 
copiada en el mismo año de 1789 por el copista Salvador Feixas ${ }^{158}$. Esta obra es probablemente la misma que hasta 1838 se conservó en el archivo musical de la Casa de Benavente [3/322], [4/72].

Entre las partituras de autores centroeuropeos que formaron parte del repertorio de música sacra de las Casas de Osuna y Benavente había varias obras de otros compositores del entorno vienés. Una misa de [Ignaz Josef] Pleyel se interpretó en las funciones en honor de San Francisco de Borja que se celebraron en Madrid en $1800^{159}$. En el archivo de música de la Condesa-Duquesa de Benavente se conservaban también una Misa a ocho [3/331] y el motete $O$ salutaris ostia del checo [Antón] Kraft, violonchelista de la orquesta del príncipe Esterhàzy y discípulo de F.J.Haydn [3/352], [4/82 $]^{160}$.

\footnotetext{
158 AHN NOBLEZA, OSUNA-CARTAS, leg 391-2.

${ }^{159}$ Ibid. 390-1.

${ }^{160}$ Sobre este autor véase Die Musik in Geschichte und Gegenwart: Allgemeine Enzyklopädie der Musik, Ludwig Finscher (ed.) (Basel : Bärenreiter ; Stuttgart : Metzler 1994-2005), Personenteil, 10, pp.606.
} 



\section{Capítulo VI}

\section{EI teatro musical en las}

Casas de Osuna y Benavente (1738-1834) 

El papel que jugó la alta nobleza como clase social promotora de los espectáculos dramático-musicales en España durante los siglos XVIII y XIX, no ha recibido la atención específica de los investigadores hasta la fecha. Aunque en algunos de los trabajos publicados sobre el mecenazgo de las grandes casas nobiliarias españolas, y en las extensas monografías sobre el teatro musical en España de Emilio Cotarelo y Mori, José Subirá y Luis Carmena y Millán se presentan datos concretos sobre el patrocinio por la nobleza y la aristocracia de algunos espectáculos de ópera, zarzuela y tonadilla, no se ha llevado a cabo hasta el momento ningún estudio sistemático que valore desde el punto de vista estructural la contribución de la nobleza titulada al desarrollo del teatro musical en España ${ }^{1}$.

Una de las principales líneas de la política de mecenazgo de la Casa de Osuna desde el siglo XVII se centró en el apoyo y fomento del teatro musical. Siguiendo las tradiciones de su linaje, los titulares de esta casa y sus familiares desarrollaron una intensa labor de promoción de los distintos géneros dramáticomusicales y de apoyo a sus empresarios, creadores e intérpretes ${ }^{2}$. Tras la boda en 1738 de María Faustina Téllez-Girón (primogénita del VII Duque de Osuna) con

\footnotetext{
${ }^{1}$ Luis Carmena y Millán, Crónica de la ópera Italiana en Madrid desde 1738 hasta nuestros días, (Madrid: Manuel Minuesa de los Ríos, 1878); Emilio Cotarelo y Mori, Orígenes y establecimiento de la ópera en España hasta 1800 (Madrid: Tipografía de la Revista de Archivos, Bibliotecas y Museos, 1917); Idem, Historia de la zarzuela, o sea el drama lírico en España, desde su origen a finales del siglo XIX (Madrid: Tipografía de Archivos, 1934); José Subirá, La Música en la Casa de Alba: Estudios Históricos y Biográficos (Madrid, Tip. Sucesores de Rivadeneira, 1927); Idem La tonadilla escénica (Madrid: Tipografía de la Revista de Archivos, Bibliotecas y Museos, 19281930), 3. vols.; Miguel Ángel Marín, "La Zarzuela Clementina, di Luigi Boccherini” en Ramón de la Cruz, Clementina, introducción de María Grazia Profeti y Miguel Ángel Marín, texto crítico, traducción y notas de Nicoletta Lepri, (Firenze: Alinea Editrice, 2003), pp. 15-36.
} 
el heredero de la Casa de Benavente, el teatro musical se incorporó también a las prácticas culturales y a la política de mecenazgo de esta casa nobiliaria.

Durante todo el siglo XVIII y una buena parte del siglo XIX, los miembros de las Casas de Osuna y Benavente participaron en la financiación de empresas cortesanas o públicas de música teatral, apoyaron los estrenos de las óperas, zarzuelas y tonadillas de compositores y libretistas que trabajaban a su servicio y fueron los promotores financieros y artísticos de funciones privadas de teatro musical $^{3}$.

En este capítulo estudiaré la ingente labor de gestión, producción y fomento de espectáculos públicos y privados de teatro musical, que llevaron a cabo entre 1738 y 1834 las Casas de Osuna y Benavente en Madrid (en los teatros de los Caños del Peral, de la Cruz y del Príncipe, y en los escenarios privados de los palacios de la Casa de Benavente) y en el ámbito cortesano de los Reales Sitios (Aranjuez, San Lorenzo del Escorial, San Ildefonso y El Pardo). Así mismo me detendré en la descripción y análisis de las principales obras de música teatral que fueron compuestas o estrenadas entre el citado período gracias al mecenazgo de las Casas de Osuna y Benavente.

\footnotetext{
${ }^{2}$ Ver Capítulo II.

3 Para la segunda mitad del siglo XIX véase mi artículo Juan Pablo Fernández-Cortés, "El mecenazgo musical de Maríano Téllez Girón, XII Duque de Osuna (1844-1882)". Actas del VI Congreso de la Sociedad Española de Musicología. Oviedo 2004, RMS, XVIII/1 (2005), en prensa.
} 


\section{El mecenazgo de las Casas de Osuna y Benavente en las compañías públicas de ópera de Madrid (1738-1834)}

Desde la instauración de los primeros espectáculos de ópera pública en Madrid en 1738 y al menos hasta 1834, varios miembros de las Casas de Osuna y Benavente participaron en la gestión y financiación de las temporadas de ópera que se desarrollaron en los Teatros de los Caños del Peral, de la Cruz y del Príncipe de Madrid y apoyaron a destacados cantantes, bailarines y compositores que trabajaron en dichos teatros.

\subsection{La VII Duquesa viuda de Osuna y la Compañía de ópera italiana del Teatro de los Caños del Peral de Madrid (1738-1739)}

Francisca Bibiana Pérez de Guzmán el Bueno, VII Duquesa viuda de Osuna fue, al igual que su marido José Téllez Girón una gran aficionada al teatro musical. La Duquesa asistía habitualmente a las funciones operísticas italianas del Teatro de los Caños del Peral de Madrid como lo acreditan los numerosos recibos por pagos por abonos y aposentos para ella y su familia que se conservan entre la documentación administrativa de la Casa de Osuna ${ }^{4}$.

La primera temporada comercial de ópera italiana del Teatro de los Caños del Peral comenzó en febrero de 1738. Este coliseo había sido reconstruido previamente por orden del Rey Felipe V, que posiblemente apoyó también la

\footnotetext{
${ }^{4}$ AHN NOBLEZA OSUNA-CARTAS, legs. 413-37, 413-45 y 413-46. En gran parte de estos documentos aparecen los títulos y fechas de las óperas representadas. El análisis sistemático de estos legajos revelará nuevos datos sobre el repertorio de las temporadas de ópera italiana en Madrid durante la primera mitad del siglo XVIII.
} 
llegada a Madrid de la compañía de cantantes italianos que actuó en dicho teatro hasta 1739 bajo la dirección de los empresarios Giovanni María Pieracini y Juan María Mazza. Como ha estudiado Juan José Carreras, la compañía de ópera italiana que actuó en Madrid entre 1738 y 1739, si bien contó con el decisivo apoyo de la Corte (a través de la supervisión del Marqués de Scotti) respondía en realidad al modelo de una empresa capitalista que buscaba la obtención de beneficios económicos ${ }^{5}$. En el otoño de 1738 y para intentar resolver la crisis en la que se hallaba sumida la compañía dirigida hasta entonces por Pieracini, se hizo cargo de la dirección Giovanni María Mazza, violinista de la orquesta, que llevó a cabo una operación que tenía "todos los visos de ser una solución de emergencia" ${ }^{\prime 6}$.

Poco después de asumir la dirección de la empresa, Mazza, dedicó a la Duquesa viuda de Osuna la edición del libreto de los intermezzi o entremeses Don Tabarano, que se representaron en los últimos meses de 1738 en el Teatro de los Caños del Peral. Esta dedicatoria, evidencia que entre los objetivos de Mazza como nuevo "empresario" se hallaba el de conseguir la atención de un personaje de la alta nobleza que respaldase, económica o institucionalmente, las representaciones de ópera italiana y que, de paso, le ayudase a darse a conocer ante el público:

5 Sobre esta compañía de ópera véase Cotarelo, Orígenes, pp.79-93 y Juan José Carreras. “Terminare a schiaffoni: La primera compañía de ópera italiana en Madrid (1738/39)", Artigrama, 12 (1996-1997), pp.99-121. 


\section{Excelentísima Señora}

El generoso agrado con que Vuestra Excelencia ha sido servida admitir en todo tiempo las señales de mi profundo respeto, me incita a poner a sus pies este pequeño tributo de veneración y obsequio, confiando, que sin embargo de su pequeñez, merecerá de Vuestra Excelencia la misma feliz suerte, y me dará el honor de hacerme conocer.

A los pies de Vuestra Excelencia

Su más humilde servidor,

Juan María Maza

Impresario $[\mathrm{sic}]^{7}$

Los dos intermezzi que Giovanni María Mazza dedicó a la Duquesa viuda de Osuna habían sido estrenados en Nápoles en 1728 en las representaciones de $I l$ Clitarco de Pietro Scarlatti. La música era de Johann Adolf Hasse, y el autor del texto, que hasta épocas muy recientes había sido atribuido a Andrea Belmuro, es Bernardo Saddumene ${ }^{8}$

La Duquesa viuda de Osuna mantuvo también una estrecha relación con los artistas de la compañía de ópera italiana que trabajó en el Teatro de los Caños del Peral entre 1738 y 1739. Al igual que hicieron otros nobles residentes en Madrid y los propios monarcas ${ }^{9}$, la Duquesa Francisca Bibiana contrató en varias ocasiones a los miembros del elenco de la compañía de ópera para que amenizasen distintas fiestas y funciones particulares. Las tiples Rosa Mancini y

\footnotetext{
${ }^{6}$ Carreras, "Terminare”, p.114.

7 Don Tabarano. Entremeses que se han de representar en el nuevo Real Teatro de los Caños del Peral este presente año de 1738 (Madrid: [s.1], 1738), BNE T-24553.

${ }^{8}$ Ulrich Schreiber, Opernführer für Fortgeschrittene 1.Die Geschichte des Musiktheaters. von den Anfängen bis zur Französischen Revolution (Kassel: Bärenreiter, 2002), p. 243.

${ }^{9}$ Carreras, "Terminare”, pp.112-114.
} 
Jacinta Forcellini, la cantante bufa Santa Marchesinni (que en la documentación de la Casa de Osuna aparece bajo el seudónimo de "La Marchesina") y el tenor Anibal Pio Fabri ("Il Anibalino") participaron en varios actos musicales privados que fueron patrocinados por la Duquesa viuda de Osuna en 1738 y $1739^{10}$.

\section{2. Ópera italiana en los Teatros del Príncipe y de la Cruz de Madrid patrocinada por la Casa de Benavente (1783-1787)}

Durante la década de 1780, la Casa de Benavente participó en la producción de una serie de óperas que se interpretaron en su versión original italiana por las compañías españolas que actuaban en los teatros del Príncipe y de la Cruz de Madrid. La intervención de María Faustina Téllez Girón, CondesaDuquesa viuda de Benavente y de su hija María Josefa en la programación de los teatros públicos ilustra la influencia que, desde su posición social privilegiada, tuvo la familia Benavente en la imposición de sus gustos musicales y en la difusión de la ópera italiana en España en las últimas décadas del siglo XVIII.

La noticia de la celebración de estas funciones de ópera italiana a cargo de los intérpretes de las compañías de teatro español fue dada a conocer por Emilio Cotarelo y Mori. Gracias a este autor conocemos que los cronistas de la época elogiaron la gran calidad de los cantantes españoles que intervinieron en dichas funciones y su habilidad a la hora de interpretar las óperas en su lengua original. Cotarelo señaló asimismo algunos de los títulos de las óperas italianas que fueron

${ }^{10}$ AHN NOBLEZA, OSUNA-CARTAS, leg 413-37 y leg 413-44. 
representadas en dicho período por los cómicos españoles ${ }^{11}$. Sin embargo, hasta ahora no se conocía ningún detalle de los aspectos administrativos o económicos de estas representaciones, ni de las razones que llevaron a que una compañía de repertorio español se involucrase en la puesta en escena de óperas en italiano.

Cuando en 1777 se cerraron definitivamente los Teatros de los Reales Sitios y se disolvieron sus compañías, la nobleza residente en Madrid se vio privada de las funciones de ópera, uno de sus entretenimientos más preciados ${ }^{12}$. La ausencia de una compañía comercial de ópera italiana en la capital fue seguramente una de las razones que apoyó el intento de restituir las funciones operísticas en los teatros de la Cruz y el Príncipe de Madrid durante las temporadas de 1783 a 1787. En estas representaciones jugó un papel fundamental la iniciativa privada como demuestra la importante intervención de la Casa de Benavente en este intento de restaurar la ópera italiana en la capital.

El 27 de septiembre de 1783, la compañía de Eusebio Ribera representó en el Coliseo del Príncipe de Madrid la ópera bufa en tres actos I Visionari [Los

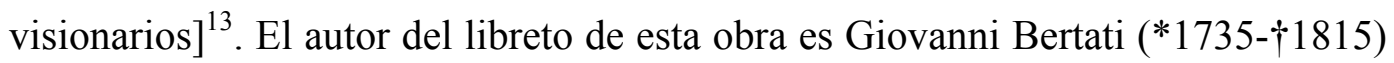
y es posible que se presentase en la versión musical de Gennaro Astarita (*1745-

11 Cotarelo, Orígenes, pp. 291-293. Cotarelo sólo documenta las representaciones de La Frasquetana (1782), I Visionari (1783), L'italiana en Londra (1785) y La serva padrona (1786).

12 Sobre la compañía de ópera de los Reales Sitios véase el apartado 3 de este capítulo.

13 [Giovanni Bertati], Los visionarios, opera bufa que ha de recitar la compañía española de Eusebio Ribera en el Coliseo del Príncipe el día 27 de septiembre de 1783. (Madrid: Antonio de Sancha, 1783) BNE T- 22281. Libreto bilingüe. En este libreto no figuran los autores del texto ni de la música. 
$\dagger 1805$ ) que se había estrenado en Venecia en $1772^{14}$. Su interpretación corrió a cargo de los principales actores de la compañía de Ribera: Catalina Tordesillas, María Pulpillo, Polonia Rochel, José Ordóñez, Sebastián Briñoli, Manuel García y Tadeo Palomino.

La Casa de Benavente se hizo cargo del pago de las copias que se hicieron del libreto de I Visionari para que fueran enviadas a los jueces censores, lo que evidencia que la producción de la ópera contó con el mecenazgo de algún miembro de esta casa nobiliaria. Los cómicos españoles insertaron en los entreactos de esta ópera una tonadilla a 5 siguiendo las prácticas interpretativas habituales en esta época para las funciones de teatro en castellano, como muestra el siguiente documento contable:

Importe del escrito de la ópera: Los visionarios

2 copias juntas una en italiano, y otra en castellano $\quad 60$

Otra copia en castellano para las censuras. 30

Otra en italiano con guión y repeticiones $\quad 45$

Letra de la tonadilla a 5 que se cantó en la misma ópera $\quad 04$

Importe 139

Cuyo importe he recibido del señor Don Juan de Gamboa hoy día de la fecha, y por ser verdad lo firmo en Madrid a 3 de Noviembre de 1783

Julián de Parga [rúbrica] ${ }^{15}$

\footnotetext{
${ }^{14}$ Claudio Sartori (ed.), I libretti italiani a stampa dalle origini al 1800, (Cunneo: Bertola \& Locatelli, 1990), vol. V., pp. 506-507.

15 AHN NOBLEZA, OSUNA-CARTAS, leg 389-30. María Asunción Gómez Pintor transcribió parcialmente este documento y atribuyó la composición de la música de esta obra a Pasquale Anfossi. Véase María Asunción Gómez Pintor, "Fuentes documentales para el estudio de las Casas de Osuna y Arcos", RMS, XVI/6 (1993), p. 3468.
} 
El 28 de septiembre de 1786, la compañía de cómicos españoles puso en escena La Serva Padrona, "Composición dramática en dos actos puesta en música por el célebre Paisiello, maestro de capilla napolitano”. La ópera fue interpretada por Catalina Tordesillas, Sebastián Briñole y Maríano Querol ${ }^{16}$. Para estas funciones, la Condesa-Duquesa de Benavente encargó a la Imprenta Real una edición de 1500 ejemplares del libreto que se imprimió “en papel prolongado". La amplia tirada de este libreto se corresponde con el aforo de un teatro público, lo que demuestra que la Condesa-Duquesa participó directamente en la financiación de esta producción pagando, al menos, los libretos y las “esquelas del convite" es decir las invitaciones para asistir a la ópera ${ }^{17}$.

María Faustina Téllez-Girón, Condesa-Duquesa viuda de Benavente, encargó en 1787 una copia de la "ópera tragica" Alceste ${ }^{18}$, seguramente pensando en la posibilidad de presentarla públicamente en las funciones de ópera italiana realizadas por los cómicos españoles en los teatros del Príncipe y de la Cruz. El proyecto se abandonó después de ensayarse el primer acto que no fue del agrado de la Condesa-Duquesa ${ }^{19}$.

La intercesión de la Casa de Benavente posibilitó también que algunas de las novedades del repertorio operístico presentadas en Barcelona llegaran a

\footnotetext{
${ }^{16}$ BNE T-12173 y T-22347.

${ }^{17}$ BNE Ms. 14.016.3/193 (Papeles Barbieri).

18 Podría tratarse de la ópera del mismo nombre de Cristoph W. Gluck de cuya presentación en Madrid durante el siglo XVIII no se tienen noticias.

${ }^{19}$ BNE Ms. 14.016.3/191 (Papeles Barbieri). En el mismo documento figura el pago de "un aria con todos [los] instrumentos" posiblemente de esta misma obra que fue traducida o "trovada la letra por Don Ramón de la Cruz" y arreglada por Don José Lidon de orden de Su Excelencia [la Condesa-Duquesa viuda de Benavente] "para que la Nicolasa [Palomera] la cantase en el teatro".
} 
Madrid. A finales de 1787 la Condesa-Duquesa de Benavente encargó que se trajeran desde Barcelona los materiales musicales de El Barbero de Sevilla ${ }^{20}$. Esta ópera con música de Giovanni Paisiello y texto de Giuseppe Petrosellini (sobre un texto original de Beaumarchais) se había estrenado en el Teatro de la Santa Cruz de Barcelona el 25 o 26 de octubre de 1787 y fue el último título que se puso en escena antes del incendio que destruyó dicho teatro ${ }^{21}$. En Madrid se estrenó en el Teatro del Príncipe el 3 de diciembre del mismo año ${ }^{22}$.

\subsection{Las Casas de Osuna y Benavente accionistas en la Asociación de Óperas italianas del Teatro de los Caños del Peral de Madrid (1790-1795)}

El Teatro de los Caños del Peral, fue el principal escenario público de ópera de Madrid desde sus orígenes a principios del siglo XVIII hasta la finalización de las temporadas en 1810. El modelo de gestión empresarial de este coliseo sufrió distintos avatares pero siempre estuvo sometido a un importante intervencionismo por parte de la administración. En 1786 comenzó una nueva etapa en la gestión del teatro de los Caños del Peral. Con la aprobación del rey Carlos III, la Junta de Hospitales de Madrid arrendó el Teatro para organizar representaciones de ópera italiana con el fin de recaudar fondos con fines

\footnotetext{
20 AHN NOBLEZA, OSUNA-CARTAS, leg 391-31. El recibo por el pago de esta ópera está fechado el 11 de febrero de 1788, pero el encargo seguramente fue anterior. Lo firmó Antonio de la Plaza, cantante que trabaja al servicio de la Casa de Benavente al menos desde 1781.

21 Roger Alier, $L$ ' òpera a Barcelona: orígens, desenvolupament $i$ consolidació de l'ópera com a espectacle teatral a la Barcelona del segle XVIII (Barcelona: Institut d'Estudis Catalans, Societat Catalana de Musicología, 1990), p. 370.

22 René Andioc y Mireille Coulon. Cartelera teatral madrileña del siglo XVIII (1708-1808) (Toulouse: Presses Universitaires, 1996), vol II, p. 636.
} 
asistenciales $^{23}$. Los primeros responsables de la empresa fueron los italianos Felipe Bartolomei y Juan Bautista Montaldi a quienes la Junta de Hospitales encargó la organización de la temporada en julio de 1786. La efímera empresa de estos dos personajes inició sus representaciones en enero de 1787. Uno de los abonados a esta temporada de ópera fue María Vicenta Pacheco, VIII Duquesa de Osuna, que pago 7.500 reales por un palco de primera fila para las 150 representaciones que se preveían realizar (Lámina 27).

Antes del verano de 1787, la empresa de Montaldi y Bartolomei decidió rescindir su contrato quedando de nuevo la gestión del teatro en manos de la propia Junta de Hospitales que encargó la dirección y organización de las compañías a distintos profesionales como Domenico Rossi (1788 y 1789) y Santiago Panati $(1790)^{24}$

23 Sobre los orígenes, la historia y la gestión del Teatro de los Caños del Peral de Madrid durante la segunda mitad del siglo XVIII véase Cotarelo, Orígenes;John E. Varey y Charles Davis: Los corrales de comedias y los hospitales de Madrid: 1615-1849 (Londres: Tamesis Books, 1997); Michael F. Robinson, “Aspectos financieros de la gestión del teatro de Los caños del Peral 17861799”, en Malcolm Boyd y Juan José Carreras (eds.) La música en España en el siglo XVII (Madrid: Cambridge University Press, 2000), pp.41-66. José Máximo Leza, “Aspectos productivos de la ópera en los teatros públicos de Madrid (1730-1799), en Emilio Casares Rodicio y Álvaro Torrente (eds.): La ópera en España e Hispanoamérica, (Madrid: ICCMU, 2001) vol. 1. 231-262. ${ }^{24}$ Cotarelo, Orígenes, pp. 305-323. 


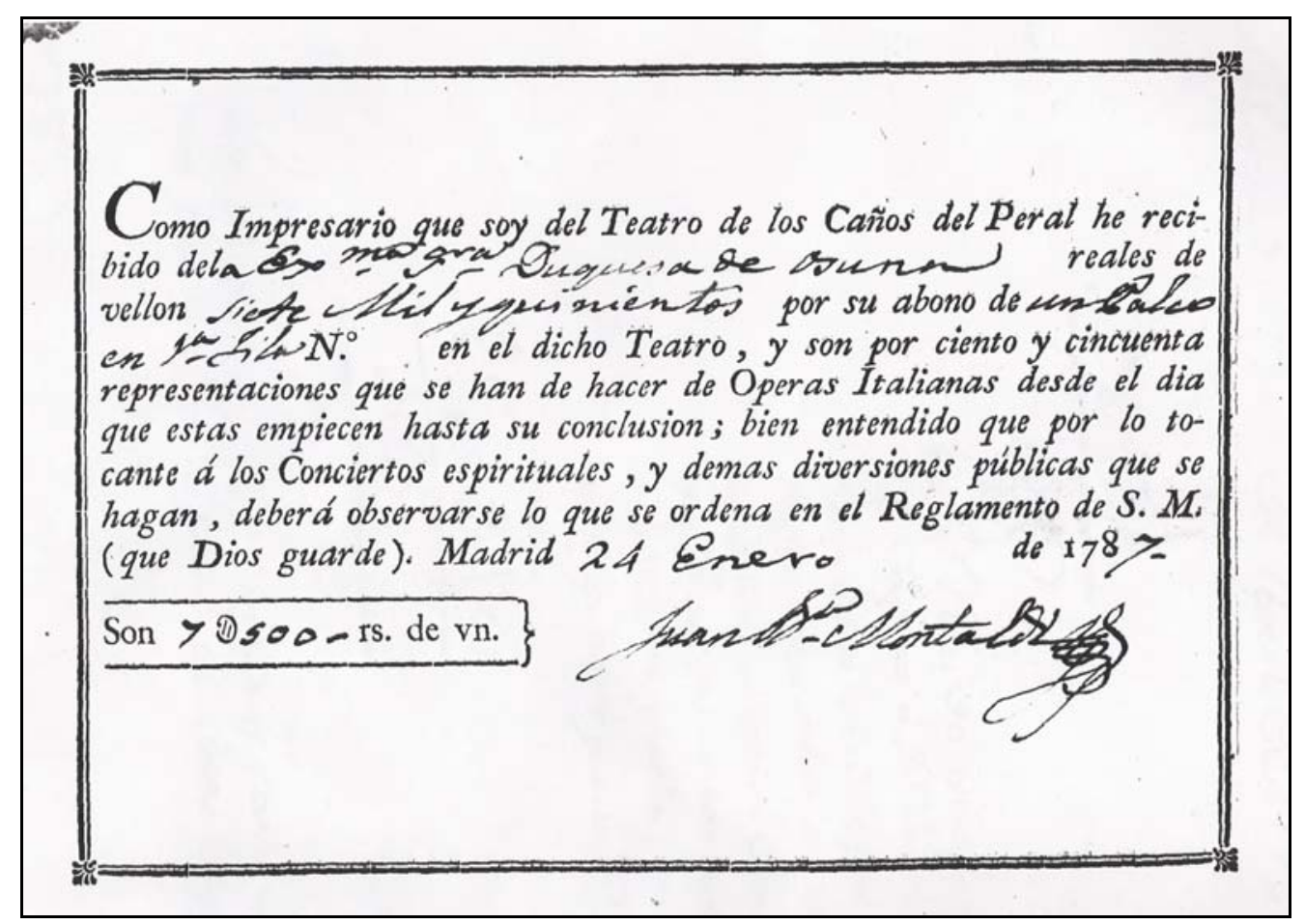

\section{Lámina 27.}

Recibo del abono de la VIII Duquesa de Osuna a la temporada de ópera de 1787 del Teatro de los Caños del Peral de Madrid. (AHN NOBLEZA, OSUNA-CARTAS, leg 416)

Según Cotarelo, la idea de organizar una alternativa a la gestión directa del teatro por parte de la Junta de Hospitales partió de Felipe Marescalchi ${ }^{25}$. Este personaje del que se desconoce aún gran parte de su trayectoria, era posiblemente hijo del músico Luigi Marescalchi, empresario de la Compañía de Ópera de los Teatros de los Reales Sitios hasta 1769 y maestro de música de María Faustina Téllez Girón, XIV Condesa-Duquesa viuda de Benavente ${ }^{26}$.

\footnotetext{
25 Ibid., p. 332.

${ }^{26}$ Los principales datos de la biografía de Luigi y Felipe Marescalchi se recogen en el Apéndice 5.
} 
En 1790 Felipe Marescalchi propuso a la Junta de Hospitales la creación de un modelo de gestión privada para la representación de óperas italianas en el Teatro de los Caños del Peral que generaría un beneficio público para los hospitales de Madrid. Con este fin consiguió la protección de destacados personajes de la alta nobleza y la aristocracia madrileña "que formaron una Sociedad que tomó el nombre de Asociación para la Representación de Óperas italianas, 27 .

Emilio Cotarelo y Mori y Michael F. Robinson, han sido hasta ahora los principales investigadores que han abordado el estudio de la actividad de la Asociación que se hizo cargo de las representaciones de ópera italiana en Madrid entre 1791 y $1795^{28}$. El análisis de la documentación administrativa de la Casa de Osuna, revela nuevos datos de este proyecto empresarial privado de producción de ópera italiana, que fue financiado por la aristocracia y la alta nobleza y en el que siempre estuvieron presentes como socios mayoritarios varios miembros de las casas de Osuna y Benavente.

La gestión administrativa de la Asociación pasó por dos etapas claramente diferenciadas que hasta el momento no se conocían. La primera comenzó en 1790 y finalizó en marzo de 1793. Este período se caracterizó por la participación de un amplio grupo de personajes de la alta nobleza y la aristocracia que apoyaron

\footnotetext{
${ }^{27}$ Cotarelo, Orígenes, p. 332. De aquí en adelante me referiré a esta sociedad como la Asociación. ${ }^{28}$ Véanse Cotarelo, Orígenes y Robinson, "Aspectos". La obra de Cotarelo se centra básicamente en la descripción de las compañías de ópera y del repertorio interpretado durante el período de administración de la Asociación. El artículo de Michael F. Robinson presenta un análisis sobre la gestión económica del teatro desde la reanudación de las temporadas de ópera italiana en 1786 hasta la clausura de las funciones en 1799.
} 
económicamente a Felipe Marescalchi, convirtiéndose en accionistas de la empresa. En la segunda etapa (abril 1793-febrero de 1795) los accionistas de la Asociación se redujeron a ocho, que formaron la llamada Asociación de los ocho señores, en la cual participaron el IX Duque de Osuna y su mujer la CondesaDuquesa de Benavente, con una acción cada uno, lo que supuso el control por parte de la Casa de Benavente-Osuna del 25\% del capital de la empresa. En febrero 1795 se disolvió definitivamente la Asociación. Tras un breve período de gestión a cargo de empresarios privados, como Domenico Rossi, las funciones de ópera italiana de Madrid fueron clausuradas. La Real Orden de 28 de diciembre de 1799, inspirada probablemente por Godoy, prohibió las representaciones de ópera en otro idioma distinto del español, y obligó a que las funciones teatrales (con o sin música) fueran siempre representadas "por actores del país"29.

\subsubsection{Primera etapa (primavera de 1790 - marzo de1793)}

Los datos conocidos hasta la fecha sobre los orígenes de la Asociación atribuyen a Felipe Marescalchi la iniciativa de crear una empresa privada con el apoyo de personajes de la alta nobleza y la aristocracia para financiar la representación de óperas italianas en el Teatro de los Caños del Peral de Madrid. Según Cotarelo y Mori, fue el propio Marescalchi quien, después de trabajar en varios teatros, trató de que apoyasen su idea algunos personajes de la alta aristocracia que realizaron las aportaciones económicas necesarias para poner en marcha la empresa. Las gestiones de Marescalchi, dieron su fruto y así consiguió que "apadrinasen su idea"

${ }^{29}$ Cotarelo, Orígenes, pp.401-403. 
el Príncipe de Castelfranco, Don Pablo Sangro, teniente general; el Marqués de Astorga, el Príncipe de Masserano, el Duque del Infantado, el de Aliaga, la Condesa viuda de Benavente, el Conde de Jaruco, don Jerónimo de Mendinueta y otros personajes de cuenta, que formaron una Sociedad que tomó el nombre de "Asociación para la representación de óperas italianas" y nombró a Marescalchi su representante. ${ }^{30}$

Después de conseguir el apoyo de estos personajes, el 17 de abril de 1790 Marescalchi solicitó a la Junta de Hospitales el arriendo del Teatro de los Caños del Peral por cuatro años "dos forzosos y dos voluntarios a contar desde el próximo venidero de $1791^{\text {"31 }}$. La escritura de arrendamiento se firmó finalmente a nombre de Pablo Sangro, Príncipe de Castelfranco y de Jerónimo de Mendinueta, que actuaron como comisionados de la Asociación y la gestión fue cedida a Felipe Marescalchi $^{32}$. Los Hospitales de Madrid recibirían por el alquiler 57.000 reales anuales que se pagarían en dos plazos a partir del comienzo de la temporada ${ }^{33}$.

\footnotetext{
30 Ibid., p.332.

31 Ibid., pp.332.-333.
}

32 AHN NOBLEZA, OSUNA- CARTAS, leg 414-12. Pablo Sangro [Príncipe de Castelfranco] y Jerónimo Mendinueta, fueron nombrados representantes de la Asociación en la Junta que se celebró el 3 de septiembre de 1790. En el acta de dicha reunión se especificó que Felipe Marescalchi debía acordar "con estos señores las disposiciones relativas a dicha empresa". Una vez aceptada la propuesta por la Real Junta de Hospitales, y recogidas las cantidades de los fondos de las acciones, Marescalchi se encargaría, de acuerdo con los comisionados protectores "de la formación de la compañía, ajustes de partes y demás funciones propias de su encargo". Véase Apéndice 6, $\mathrm{n}^{\circ} 16$.

33 Cotarelo, Orígenes, pp.332-333. La temporada teatral de ópera comenzaba siempre después del domingo de Pascua y terminaba en Carnaval. Desde 1787 durante la Cuaresma se interpretaron conciertos instrumentales y vocales a cargo de los miembros de la Compañía y de otros músicos y cantantes. 
Aunque Cotarelo y Mori presentó a Marescalchi como promotor y "alma mater" de esta empresa, la fundación y gestión de la Asociación que se encargó de las temporadas de ópera italiana en Madrid entre 1791 y 1795 surgió realmente gracias al apoyo de la alta nobleza y la aristocracia residente en Madrid.

La correspondencia que la Condesa-Duquesa María Josefa mantuvo con Felipe Marescalchi en 1790 da fe de la importancia que tuvieron los miembros de las Casas ducales de Benavente y de Osuna en la constitución de la Asociación. Antes de la firma del arrendamiento del teatro, Marescalchi se dirigió al menos en tres ocasiones a la Condesa-Duquesa para informarle de las deliberaciones de la Junta que se constituyó para la creación de la Asociación. La Condesa-Duquesa María Josefa apoyó firmemente desde sus inicios la constitución de la empresa de óperas. Su amplio conocimiento de la gestión teatral se evidencia en una carta dirigida a Marescalchi el 30 de agosto de 1790, en la que reitera que la empresa de óperas podría funcionar como un negocio rentable. Para convencer a la Junta constituyente de la Asociación de la viabilidad y rentabilidad del proyecto, la Condesa-Duquesa repasó la situación económica que había tenido la ópera italiana en Madrid en los años precedentes, y planteó las directrices económicas que debía seguir la empresa para que la ópera italiana pudiera mantenerse en la capital como un negocio rentable. Para evitar las previsibles pérdidas económicas, la CondesaDuquesa propuso renunciar a la contratación de cantantes que exigían honorarios excesivos y formar una compañía con un reparto común para la ópera bufa y la seria, con la única excepción de un soprano que sería contratado para las representaciones de ópera seria: 
Las entradas de la ópera en el año de [17]88 correspondieron a mucho mas de 5500 reales siendo así que por la muerte del Rey cesaron las representaciones al principio de la temporada más favorable. En [17]89 excedieron también de los 5500 y si no me engaño lo mismo ha sucedido en los anteriores. Decir que la venida de tanto forastero a las fiestas es la causa de que en el año pasado llegasen las entradas a lo que digo, ni lo negaré ni lo concederé abiertamente, pero si diré que precisamente en el tiempo que había más gente de fuera se hicieron menos representaciones lo que se extrañó por algunos, y además las fiestas particulares quitaron muchos días de ópera. En el año presente salen las representaciones hechas a mayor cantidad de la que no se quiso conceder en la Junta por algunos accionistas, y falta el mejor tiempo para que concurra la gente. Estos hechos y la multitud de consideraciones perjudiciales de estos años comparados con las que ofrece ventajosas a nuestra empresa la mejora de partes, ahorros de gastos inútiles y demás cosas que omito, debe lisonjearnos de que merecerá el teatro más aceptación, y así no sólo se disipa en mi opinión toda idea de pérdida, sino que aún me prometo ganancias aunque por cortas no merezcan considerarse tales; y juzgo que subsistirá la ópera y que puede sostenerse, no pretendiendo traer a actores que cuesten 60 mil reales, ni duplicando partes a título de la ópera seria, pues están en mi concepto no debe aumentar el gasto mas que en la paga de un soprano y vestuario pues todas las demás personas deben ser para bufo y serio ${ }^{34}$.

A pesar del apoyo entusiasta que la Condesa-Duquesa María Josefa mostraba por la incipiente Asociación, en las reuniones previas a la firma del contrato de arrendamiento del teatro se demostró que no era fácil encontrar el número suficiente de accionistas que aportaran los 180.000 reales necesarios para comenzar la empresa. Muchos de los nobles y aristócratas que en principio se comprometieron a apoyar la empresa se retiraron finalmente de la Junta

\footnotetext{
${ }^{34}$ AHN NOBLEZA, OSUNA- CARTAS, leg 414-12-5.
} 
constituyente. Para evitar la falta de fondos que parecía abocar a la disolución de la Asociación, la Condesa-Duquesa comunicó el 13 de septiembre de 1790 a Felipe Marescalchi que estaba dispuesta, si fuera preciso, a adelantar el importe de las dos acciones del primer año (una por ella y otra por su marido el Duque de Osuna) y las dos del segundo:

[...] y así por mi parte decididamente voto que se sostenga la asociación, y que se abrace la empresa aunque no quede más que una tercera parte de los accionistas, pues todo es admisible antes que hacer una figura poco decorosa con el público, como ver no se verifica una cosa en que han echado su firma unas personas de las circunstancias que formamos la Asociación, y en este supuesto estoy pronta a dar desde ahora el importe de mis dos acciones para el primer año y el de las que corresponden al segundo ${ }^{35}$.

La Asociación quedó constituida finalmente por 19 familias o casas nobiliarias que se hicieron cargo de 25 acciones por un valor de 6.000 reales cada una. Faltaban 5 accionistas para completar la cantidad de 180.000 reales en que se había presupuestado el capital necesario para la puesta en marcha de la empresa de óperas. La Casa de Benavente-Osuna cubrió parte de este déficit a través de la Condesa-Duquesa María Josefa, que adelantó finalmente el importe de las dos acciones del llamado"depósito de pérdidas"36.

Como puede apreciarse en la Tabla 22, en la primera etapa de la Asociación participaron numerosos representantes de las grandes casas nobiliarias

\footnotetext{
${ }^{35}$ Ibid.

${ }^{36}$ Ibid., leg 414-12.
} 
españolas o vinculadas a nuestro país como la Casa de Alba, la de Frías y Uceda o la de Berwick, junto a otros personajes que ocupaban importantes cargos administrativos oficiales o militares. La unificada casa de Benavente-Osuna fue la mayor accionista de la empresa y llegó a controlar el 16\% del capital de la Asociación. Además de las dos acciones que correspondían al matrimonio de los IX Duques de Osuna también procedían de la tesorería de los Benavente-Osuna las acciones de María Faustina Téllez Girón, Condesa-Duquesa viuda de Benavente, y María Vicenta Pacheco, Duquesa viuda de Osuna ${ }^{37}$.

Desde los inicios de la formación de la empresa de óperas, la CondesaDuquesa María Josefa apoyó a Felipe Marescalchi para que ocupase el cargo de Director del Teatro, proponiendo a la Junta constituyente que se le asignase un sueldo de 12.000 reales anuales y un porcentaje en las ganancias de la empresa ${ }^{38}$. La confianza que la Condesa-Duquesa mostraba hacia Marescalchi no era compartida por algunos miembros de la Asociación, que debían de tener otro candidato para ocupar dicho cargo, según expresaba la propia Condesa-Duquesa en una carta fechada en septiembre de 1790:

Si por cualquier motivo no quedase de Director Don Felipe Marescalchi, y se pone otro en su lugar me considero fuera y sin obligación alguna de las firmadas ni modificadas en este papel mientras no se me dé noticia de quien sea el sujeto elegido y yo en consecuencia me conforme o no conque se le confíe la dirección ${ }^{39}$.

\footnotetext{
${ }^{37}$ La administración de las Casas de Osuna y Benavente se unificó a partir de abril de 1787, tras la muerte del VIII Duque de Osuna. El presupuesto de la Condesa-Duquesa viuda de Benavente y el de la Duquesa viuda de Osuna procedían de la tesorería única de la Casa de Benavente-Osuna.

38 AHN NOBLEZA, OSUNA- CARTAS, leg 414-12/5.

39 Ibid.
} 
Tabla 22.

Accionistas de la Asociación de Óperas Italianas

del Teatro de los Caños del Peral de Madrid (1791-1793)

Fuente: AHN NOBLEZA OSUNA-CARTAS, 414-12

\begin{tabular}{|c|c|c|}
\hline Título o Casa Nobiliaria & $\begin{array}{l}\mathrm{N}^{\mathbf{0}} \text { de } \\
\text { acciones }\end{array}$ & Observaciones \\
\hline Casa de Benavente-Osuna & 4 & $\begin{array}{l}\text { Los titulares de las acciones eran los } \\
\text { Duques de Osuna (2) y sus respectivas } \\
\text { madres, la Condesa-Duquesa viuda de } \\
\text { Benavente, y la Duquesa viuda de } \\
\text { Osuna }\end{array}$ \\
\hline Príncipes de Castelfranco & 2 & $\begin{array}{l}\text { El Titular de esta dignidad nobiliaria } \\
\text { era Pablo Sangro, Fue uno de los } \\
\text { comisionados de la empresa }\end{array}$ \\
\hline Duques de Abrantes & 2 & \\
\hline Duques de Berwick & 2 & \\
\hline Príncipe de Masserano & 1 & \\
\hline Príncipe de Raffadale & 1 & \\
\hline Duque de Frías y Uceda & 1 & \\
\hline Duquesa de Alba & 1 & \\
\hline Conde de Casamontalvo & 1 & \\
\hline Conde de la Cimera & 1 & $\begin{array}{l}\text { El titular de esta dignidad era } \\
\text { Jerónimo Mendinueta. Fue uno de los } \\
\text { comisionados de la empresa }\end{array}$ \\
\hline Conde de San Juan de Jaruco & 1 & $\begin{array}{l}\text { El titular de esta dignidad era Joaquín } \\
\text { Santa Cruz y Cárdenas }(* 1769-1807) \text {, } \\
\text { miembro de la nobleza criolla } \\
\end{array}$ \\
\hline Conde de Vistaflorida & 1 & \\
\hline Condesa del Campo de Alange & 1 & \\
\hline Marqués de Castrillo & 1 & \\
\hline Marqués de Oira & 1 & \\
\hline Marqués de Pontejos & 1 & \\
\hline Marques del Vado & 1 & \\
\hline Fernando José Mangino & 1 & $\begin{array}{l}\text { Superintendente de la Casa de la } \\
\text { Moneda }\end{array}$ \\
\hline Antonio Valdés [Fernández-Bazán] & 1 & Capitán General de la Armada \\
\hline
\end{tabular}


Aunque en la "Junta de accionistas de las óperas italianas" del 3 de septiembre de 1790 se acordó que Felipe Marescalchi se encargara "de la formación de la compañía, ajustes de partes y demás funciones propias de su encargo" ${ }^{40}$, la primera temporada de ópera patrocinada por la Asociación comenzó bajo la dirección del bailarín y coreógrafo italiano Domenico Rossi que se hizo cargo de la dirección artística del teatro hasta $1793^{41}$.

La Asociación se planteó en sus orígenes como un grupo de accionistas que aportaban un capital económico y tenían derecho a participar en las decisiones administrativas y artísticas de la empresa. Sin embargo, la gestión de los comisionados Jerónimo Mendinueta y Pablo Sangro en la primera etapa de la Asociación impidió que los accionistas intervinieran en los aspectos artísticos. Así lo expresaba la Condesa-Duquesa María Josefa en una carta que envió en enero de 1791 a su protegida la bailarina María Medina Viganò que había solicitado su intercesión para volver a actuar en Madrid:

[...] Mariquita, yo de teatro no sé nada, Mendinueta y Sangro dirigen todo como quieren, dicen a los que hemos dado nuestro dinero lo que se les antoja, y por último a pesar de lo que deseo volvieras aquí no puedo hacer

\footnotetext{
40 Ibid.

41 En la lista de la compañía para la temporada de ópera de 1791-1792 que se publicó en el Diario de Madrid el 23 de abril de 1791, figura Domingo Rossi como Director del Teatro. Véase Cotarelo, Orígenes, pp 335-336. Sobre las actividades de Rossi en España véase Xoan María Carreira, "Ballet performed at the Teatro de los Caños del Peral de Madrid, and other Spanish Theaters 1787-1799", The Origins of the Bolero School, Studies on Dance History, IV/I, (Pennington: The Journal of the Society of Dance History Scholars, 1993).
} 
nada en este punto pero si protegerte en cualquier destino que te halles, lo mismo a Viganó ${ }^{42}$.

Las optimistas previsiones sobre la rentabilidad de la empresa de óperas no se correspondieron con la realidad. La primera temporada bajo el patrocinio de la Asociación (1791-1792) finalizó con notables pérdidas a pesar de que la asistencia del público se había incrementado respecto a los años anteriores ${ }^{43}$. Según Michael F. Robinson, una de las causas de este déficit fue que las previsiones de recaudación por venta de entradas no se cumplieron, ya que "al menos hasta 1794, la compañía [del Teatro de los Caños del Peral] actuaba para un aforo a media entrada"44. Los gestores de la empresa atribuyeron las pérdidas de la primera temporada a "los gastos extraordinarios que las circunstancias del tiempo, y el mal estado de la Ópera cuando la administraba el Hospital exigían”,45. Antes de comenzar la temporada siguiente, la Asociación tuvo que asumir unos gastos imprevistos de 140.000 reales "en viajes de actores, obras del coliseo, e importe del arrendamiento [del Teatro]”. A estas cantidades había que sumar la pérdida por los conciertos de la Cuaresma que no se pudieron celebrar por acondicionamiento del teatro y las cantidades que se dejaron de ingresar por lo que "hubieran producido las representaciones desde Pascua hasta el cinco de mayo, que se abrió el teatro", lo que supuso “a lo menos 220.000 reales de gastos

\footnotetext{
42 AHN NOBLEZA, OSUNA- CARTAS, leg 388-13. Véase también la carta de la CondesaDuquesa a María Viganó el 23 de septiembre de 1790. Apéndice 6, n⿳0 25.

43 AHN NOBLEZA, OSUNA-CARTAS, leg 414-12/7.Véase Apéndice 6, nº 17.

${ }^{44}$ Robinson, Aspectos, p. 51

45 AHN NOBLEZA, OSUNA-CARTAS, leg 414-12/7.
} 
o perjuicios, que no se han podido evitar en este primer año" ${ }^{, 46}$. Esta cantidad tuvo que ser sufragada con las aportaciones de los miembros de la Asociación.

En la temporada de 1792-1793 los comisionados del teatro trataron de evitar que se repitiesen las pérdidas, "tomando las providencias mas convenientes, a fin de queden mejoradas las compañías; para hacer todas las economías posibles; y aprovechando la Cuaresma con conciertos, abrir el Teatro por Pascua" ${ }^{\text {47 }}$. De nuevo las previsiones de los gestores del teatro no se cumplieron, y la primera etapa de la empresa de óperas patrocinada por la Asociación finalizó con un importante déficit de 75.018 reales y dos maravedíes que fue asumido proporcionalmente por los 25 miembros de la Asociación $^{48}$. Estas pérdidas debieron de convencer a gran parte de la alta nobleza de la escasa rentabilidad del negocio de la ópera italiana en Madrid. La gran mayoría de los accionistas abandonaron la empresa, y la Asociación tuvo que enfrentarse a una importante reorganización para poder hacerse cargo de la gestión del teatro a partir de la temporada de 1793-1794.

\subsubsection{La Asociación de los ocho señores (abril de 1793-febrero de 1795)}

El modelo de gestión del Teatro de los Caños del Peral, sufrió una importante reestructuración a partir de la temporada que se inició después de la Semana Santa de 1793. Aunque la empresa de óperas siguió funcionando bajo los auspicios de la Asociación, la gran mayoría de los nobles y aristócratas se

\footnotetext{
${ }^{46}$ Ibid.

${ }^{47}$ Ibid.

${ }^{48}$ AHN NOBLEZA, OSUNA-CARTAS, leg 414-12-6.
} 
desligaron de ella al finalizar los dos primeros años de compromiso obligatorios. En la segunda etapa, la institución se convirtió en la Asociación de los ocho señores, que estuvo al frente del teatro durante las temporadas de 1793-1794 y 1794-1795. En nueva andadura participaron los miembros más activos de la anterior etapa de la Asociación como los comisionados Jerónimo de Mendinueta (Conde de la Cimera), Pablo Sangro (Príncipe de Castelfranco), y la CondesaDuquesa de Benavente (que representaba también la acción de su marido el Duque de Osuna). La lista de accionistas se completaba con el Conde de San Juan de Jaruco, el Príncipe de Masserano, el Duque del Infantado y Joaquín Osorio de Moscoso, XV Marqués de Astorga. Este último se convirtió en uno de los principales gestores de la Asociación $^{49}$.

A partir de 1793 los miembros de la Asociación se preocuparon principalmente por contratar buenos artistas internacionales para obtener una mayor aceptación del público. Por esta razón se decidió prescindir de los servicios de Domenico Rossi, que fue el director artístico del teatro durante las temporadas de 1791-1792 y 1792-1793, “y entregó el teatro en una especie de subarriendo a un don Antonio Sattini que sólo se mantuvo unos meses en el puesto",50.

El 7 marzo de 1793, Antonio Sattini ya figuraba como "encargado del teatro de óperas, y [de] su dirección por la sociedad de ellas, por dos años de mil setecientos noventa y tres y mil setecientos noventa y cuatro". Al comienzo de su gestión, Sattini solicitó a cada uno de los ocho accionistas de la Asociación que

\footnotetext{
49 AHN NOBLEZA, OSUNA-CARTAS, leg 414-12.

${ }^{50}$ Cotarelo, Orígenes, p. 351.
} 
aportasen 20.000 reales de vellón, para que cubriesen los fondos necesarios para comenzar la temporada de $1793-1794^{51}$.

Sattini consiguió traer a España algunos de los cantantes más aclamados en los teatros europeos de la época como las sopranos italianas Brigida Banti y Ana Morichelli, o el barítono bufo Francisco Albertarelli ${ }^{52}$. Los accionistas de la Asociación no debían de estar demasiado satisfechos con la labor desarrollada por este gestor, pues pocos meses después de su nombramiento decidieron hacerse cargo directamente de la gestión y dirección artística del Teatro de los Caños del Peral. En septiembre de 1793 con el fin de "destruir la anarquía que se experimentaba en el teatro" elaboraron un reglamento de funcionamiento interno $^{53}$. El texto de este reglamento, que no había sido estudiado hasta la fecha es de una sustancial importancia para el estudio de la gestión empresarial de la ópera italiana en España. Su lectura pone de manifiesto la destacada labor emprendida por un grupo de la alta nobleza urbana en el mantenimiento de la ópera italiana en Madrid. El modelo empresarial que se reflejó en el reglamento elaborado por la Asociación de los ocho señores en 1793, implicó directamente a todos los accionistas en la gestión artística y administrativa del teatro

A partir de septiembre de 1793, cada uno de los nobles que formaban parte de la Asociación se responsabilizó de uno de los "ramos" o departamentos de la empresa (Tabla 23). En el reglamento interno se estableció además que todos los

\footnotetext{
51 AHN NOBLEZA, OSUNA-CARTAS, leg 414-12/8.

52 Cotarelo, Orígenes, p. 351.

53 BNE Ms. 14.052-3 y Ms. 14.052-5 (Papeles Barbieri). El reglamento se firmó el 23 de septiembre de 1793 y se amplió el 24 de diciembre del mismo año.
} 
viernes se celebraría una junta semanal en la casa de la Condesa-Duquesa de Benavente y que uno de los siete socios estaría siempre presente en el teatro a lo largo de la semana para resolver cualquier novedad que se ofreciera durante las representaciones si no se encontraba allí el responsable del ramo correspondiente. El "encargado de semana" debería también observar que los actores interpretasen todas las piezas de la obra, tal y como se había estrenado el primer día, a no ser que hubiera algún "motivo legítimo" que lo impidiera; además se encargaría de controlar la asistencia de todos los miembros de la orquesta, y de que se cumpliera el orden público en el teatro.

Tabla 23

Departamentos administrativos de la empresa de ópera del Teatro de los Caños del Peral de Madrid creados en diciembre de 1793

Fuentes: AHN NOBLEZA, OSUNA-CARTAS, leg 414-12; BNE Ms. 14.052-3 y Ms. 14.052-5 (Papeles Barbieri).

\begin{tabular}{|l|l|l|}
\hline Departamento & Responsable & Funciones \\
\hline Compañía de cantantes & $\begin{array}{l}\text { Conde de San Juan } \\
\text { de Jaruco }\end{array}$ & $\begin{array}{l}\text { Responsable del personal de la } \\
\text { Compañía de ópera }\end{array}$ \\
\hline Compañía de bailarines & Conde de la Cimera & $\begin{array}{l}\text { Responsable del personal de la } \\
\text { Compañía de ballet }\end{array}$ \\
\hline Correspondencia General & $\begin{array}{l}\text { Condesa-Duquesa de } \\
\text { Benavente }\end{array}$ & $\begin{array}{l}\text { Gestión de las solicitudes de artistas } \\
\text { y todos los documentos recibidos } \\
\text { que debían presentarse en las } \\
\text { juntas semanales }\end{array}$ \\
\hline Escenario y alumbrado & $\begin{array}{l}\text { Príncipe de } \\
\text { Masserano }\end{array}$ & $\begin{array}{l}\text { Velar por el buen estado del interior } \\
\text { del teatro }\end{array}$ \\
\hline Policía de telones & $\begin{array}{l}\text { Príncipe de } \\
\text { Castelfranco }\end{array}$ & Control de taquillaje y cobradores. \\
\hline Tesorería & Marqués de Astorga & Gestión económica. \\
\hline Orquesta & Duque del Infantado & Jefe de personal de la orquesta \\
\hline
\end{tabular}

La Condesa-Duquesa de Benavente aprovechó el período en que los accionistas se involucraron directamente en la administración y gestión del teatro para intentar que se contratase a alguno de los artistas que gozaban de su 
protección. Gracias a la mediación de la Condesa-Duquesa se consiguió contratar a la famosa mezzosoprano portuguesa Luisa Rosa de Aguiar, conocida en España como Luisa Todi $(* 1753-\uparrow 1833)$ para la temporada de ópera de $1794^{54}$. La Todi fue una de las cantantes preferidas del público de Madrid que la dedicó numerosos elogios (Ver Lámina 28).

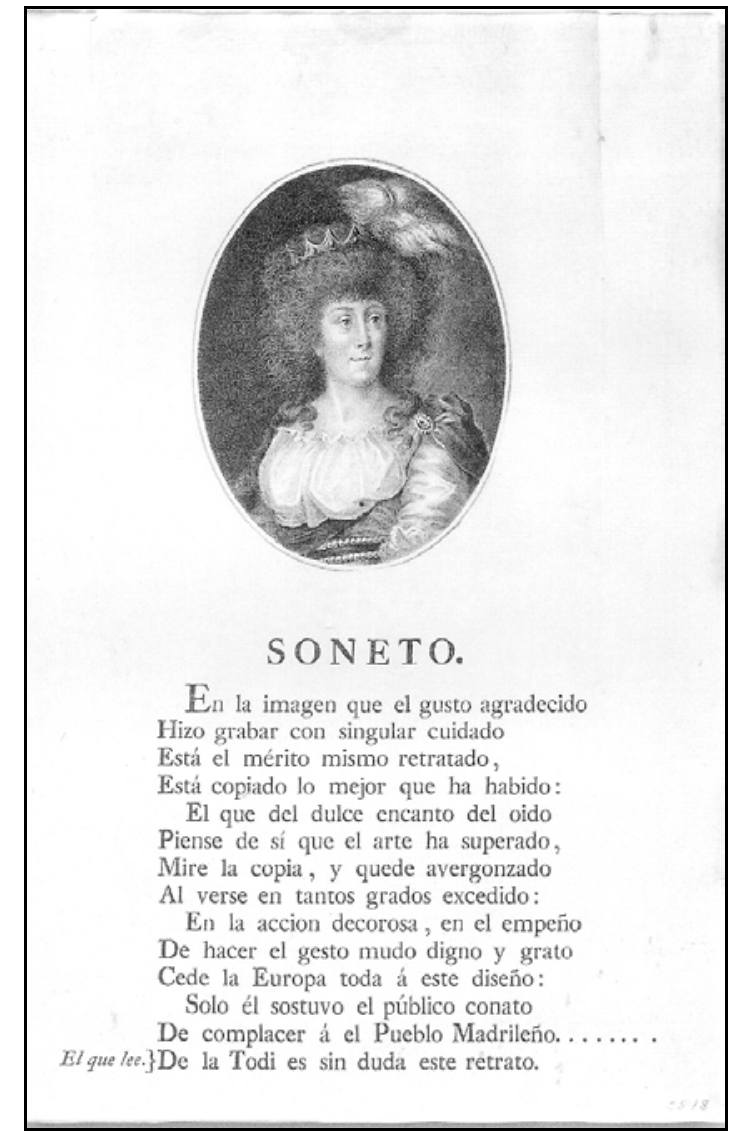

Lámina 28.

Anónimo: [Retrato y Soneto a Luisa Todi]

Aguafuerte y Buril. [S.1.: s.n., después de 1777]

(BNE ICONOGRAFÍA HISPANA 9228-2)

54 Sobre esta cantante véase Mario Moreuau, Luísa Todi, (1753-1833) (Lisboa: Hugin, 2002). En el Apéndice 6, documentos $n^{\circ}$ 28-33, presento una selección de la correspondencia entre la Todi y la Condesa-Duquesa de Benavente. 
Los pormenores del contrato de la Todi, han quedado reflejados en una carta que los miembros de la Asociación dirigieron a la Condesa-Duquesa en noviembre de 1793:

\section{Excelentísima Señora}

Muy Señora nuestra: En consecuencia de la carta de Vuestra Excelencia de 14 del presente hemos extendido y firmado la escritura a favor de la Todi, en los mismos términos que propusimos a Vuestra Excelencia en el plan $\mathrm{n}^{\circ}$ 1, el que ha parecido muy bien a Vuestra Excelencia según nos asegura; de lo que hemos quedado muy satisfechos por haber acertado en su opinión. Hemos agregado a las escrituras como Vuestra Excelencia verá, la casa, siguiendo en esto la idea que Vuestra Excelencia nos propone adelantar alguna cosa mas a los 100.000 reales y el beneficio. Adjunta la encontrará Vuestra Excelencia firmada por todos nosotros para que se sirva hacer lo mismo pues esto animará a la Todi a no desairarla por la mucha estimación que hace su persona. Vuestra Excelencia nos devolverá a vuelta de parte para dirigirla con seguridad en el primer correo a Lisboa. $[\ldots]^{55}$

La Condesa-Duquesa y la soprano Luisa Todi establecieron una estrecha relación de amistad durante la estancia de esta última en Madrid. Aunque las cláusulas del contrato firmado entre la Asociación y la Todi se incluía el pago del alquiler de su residencia en Madrid, la Condesa-Duquesa la alojó en su propia casa durante cuatro meses, tal y como relató en la carta de recomendación que en 1796 dirigió al Conde de Valparaiso, “ministro plenipotenciario de Su Majestad Católica en la Corte de Parma" para que protegiera y favoreciera a la Todi durante su estancia en Nápoles:

\footnotetext{
${ }^{55}$ AHN NOBLEZA, OSUNA-CARTAS, leg 387-18.
} 
Muy Señor mío y mi favorecedor:

Tendrá el honor de poner esta en manos de Vuestra Señoría la Señora Luisa Todi, célebre actriz de la ópera italiana, que pasa al teatro de Nápoles, cuyo extraordinario mérito en el canto es la menor de sus apreciables prendas, que he experimentado muy de cerca, teniéndola en mi casa cuatro meses. Por todo se ha merecido singular estimación mía, y que no pudiendo dejar de contribuir a cuanto sea de su satisfacción, me tomé la liberta de recomendarla eficazmente a Vuestra Señoría de quien espero se servirá protegerla y atenderla en lo que se la ofreciere en esa capital; dispensando la bondad de Vuestra Señoría esta confianza a su más grata servidora que su mano besa. Madrid, 18 de Abril de 1796

Señor Conde de Valparaiso. Ministro Plenipotenciario de Su Majestad Católica. en la Corte de Parma ${ }^{56}$

El control directo del Teatro de los Caños del Peral por la Asociación de los ocho señores, no solucionó los problemas económicos de la etapa anterior, y la empresa de óperas siguió presentando pérdidas constantes que se suplían con las aportaciones extraordinarias de los accionistas. Durante la temporada de 17931794, la Casa de Benavente-Osuna, titular del 25\% del capital de la empresa, aportó en sucesivos pagos un total de 104.000 reales de vellón ${ }^{57}$. Según Robinson, a estas cantidades habría que añadir otros gastos menores que en total ascendían a 54.054 reales de vellón por cada accionista ${ }^{58}$. En la siguiente temporada (1794-

\footnotetext{
${ }^{56}$ AHN NOBLEZA, OSUNA-CARTAS, leg 387-26. La Condesa-Duquesa se preocupó incluso de que el viaje de Luisa Todi a Nápoles fuera lo más cómodo posible. Con este fin se dirigió a Francisco de Partearroyo (Contador General de Correos de Cataluña) y al coronel Agustín Lancaster para que se encargasen de su embarco en Barcelona. Véase Apéndice 6, n⿳⺈ 30 y 31.

${ }^{57}$ AHN NOBLEZA, OSUNA-CARTAS, leg 414-12.

${ }^{58}$ Robinson, “Aspectos”, p. 56.
} 
1795) la situación fue similar y las aportaciones de las Casas de Osuna y Benavente ascendieron a 100.000 reales de vellón ${ }^{59}$.

La mala situación financiera de la empresa y los constantes requerimientos económicos por parte de sus administradores debieron de ser influir decisivamente para que en julio de 1794, sólo unos meses después de comenzar la temporada, la Condesa-Duquesa de Benavente y su marido el Duque de Osuna comunicasen al resto de accionistas de la Asociación su intención de abandonar la empresa al finalizar dicha temporada:

Excelentísimos Señores:

Muy Señores míos:

Teniendo muy presente que los individuos de la empresa de la Asociación de Óperas de los Caños del Peral debemos avisar seis meses antes de concluirse los dos años fijos de asociación si queremos continuar en los otros dos condicionales, y que ya está muy próximo este plazo, manifiesto a Vuestras Excelencias tanto por lo que respecta a mi como al Duque mi marido, que uno y otro hemos resuelto no continuar en la asociación sino hasta fin del presente año cómico que concluirá en Carnaval de 1795, aun cuando los demás señores asociados determinen continuar con el teatro por más tiempo $[\ldots]^{60}$.

\footnotetext{
${ }^{59}$ AHN NOBLEZA, OSUNA-CARTAS, leg 414-12/3. El 21 de julio de 1794 se pagaron sendos recibos de 20.000 reales para suplir "la imposibilidad de pagar las nóminas del mes de junio y otras cuentas pendientes" En la Junta de 4 de noviembre se estableció una nueva aportación de 15.000 reales por cada acciónista y el 7 de febrero de 1795 se pagó otra aportación de 15.000 reales por acción.

60 AHN NOBLEZA, OSUNA-CARTAS, leg 414-12/4. Borrador de la carta que la CondesaDuquesa de Benavente dirigió a los miembros de la Asociacion el 11 de julio de 1794.
} 
La determinación de los titulares de las Casas de Osuna y-Benavente de no seguir apoyando económicamente la empresa de óperas italianas del Teatro de los Caños del Peral, contribuyó a la disolución de la Asociación, que, a partir de ese momento, se vio privada del $25 \%$ de sus recursos.

La decadencia del proyecto empresarial de la Asociación se enmarca dentro de la crisis que afectó a las empresas de ópera en Madrid a finales del siglo XVIII. Según Robinson, hubo tres factores decisivos que precipitaron esta crisis: 1) la inflación que afectaba a España en la década de 1790 debida al aumento de los precios de consumo, 2) la emisión de documentos de deuda pública que se utilizaban como papel moneda y que se fueron depreciando paulatinamente y 3) la escasez de asistencia del público que "en general al menos hasta 1794" apenas cubría la mitad del aforo del teatro ${ }^{61}$. Además de estas tres causas, en la crisis económica que llevó a la disolución de la Asociacion habría que tener en cuenta también los frecuentes retrasos e impagos de las cantidades que habían de aportar los accionistas. Después de abandonar la empresa en 1795, los nuevos administradores del Teatro de los Caños del Peral solicitaron en numerosas ocasiones a los titulares de las Casas de Osuna y Benavente, diversas cantidades que adeudaban del período en que los miembros de su familia participaron en la Asociación.

En 1799 Antonio Santidrián, Tesorero del Teatro de los Caños del Peral reclamó a la Condesa-Duquesa de Benavente, el pago de una deuda pendiente de 10.811 reales de vellón y doce maravedíes por cada una de las dos acciones que

\footnotetext{
61 Robinson, “Aspectos”, pp 51-56.
} 
había tenido como miembro de la Asociación. Desde París, la Condesa-Duquesa contestó a Santidrián que todas sus posibles deudas con la Asociación ya habían sido pagadas anteriormente

con la cantidad de 6000 y tantos reales habiendo dicho a la persona que se la entregué que este pago se entendiese por todo lo que yo podía deber; y que en ningún tiempo, ni bajo cualquier pretexto se me tenía que pedir dinero alguno por esta asociación pues había contribuido sobradamente para la satisfacción de cuanto podía estarse debiendo ${ }^{62}$.

Los argumentos de la Condesa-Duquesa no debieron de convencer a los administradores del Teatro de los Caños del Peral. En 1806, Santidrián pidió de nuevo a la Condesa-Duquesa de Benavente que efectuara el pago de las cantidades que ella y su marido debían a los administradores del teatro alegando que los deudores reclamaban constantemente su abono "siendo la mayor deuda la del Hospital General y que a todos es de justicia su pago"63.

Pero la cantidad anterior no fue la única que la Casa de Benavente-Osuna debía a los administradores del Teatro de los Caños del Peral después de la disolución de la Asociación. En 1801, tres años después de la muerte de María Faustina Téllez Girón, Condesa-Duquesa viuda de Benavente, aún se adeudaban a la empresa de óperas 6032 reales que correspondían a la participación de esta dama como accionista en las dos primeras temporadas de ópera patrocinadas por

\footnotetext{
${ }^{62}$ AHN NOBLEZA, OSUNA-CARTAS, leg 414-12/3.

${ }^{63}$ Ibid.
} 
la Asociación. La Condesa-Duquesa María Josefa, titular de la Casa de Benavente, tuvo también que asumir la deuda de su madre ${ }^{64}$.

La pionera iniciativa empresarial de la Asociación para mantener los espectáculos de ópera italiana en Madrid finalizó con importantes pérdidas que demostraban la escasa rentabilidad económica de la ópera italiana, espectáculo elitista que ni siquiera el potencial económico de la aristocracia y la alta nobleza fue capaz de mantener ${ }^{65}$.

\subsection{La relación de la Condesa-Duquesa María Josefa con las Compañías de Ópera de los teatros públicos de Madrid (1796-1834)}

La fracasada iniciativa empresarial de la Asociación no puso fin a las relaciones de las Casas de Osuna y Benavente con las Compañías de los teatros públicos de Madrid. A pesar de los problemas económicos y las disensiones entre sus miembros con los que terminó en 1795 la temporada de ópera patrocinada por la Asociación, la Condesa-Duquesa de Benavente continuó abonada a las funciones del Teatro de los Caños del Peral de Madrid en las temporadas siguientes (Lámina 29), y siguió vinculada a la gestión del Teatro de los Caños del Peral encargándose, al menos, de la adquisición de los materiales musicales de

\footnotetext{
64 Ibid.

65 En 1795, según Cotarelo, las pérdidas de la Asociación ascendieron a 534.038 reales de vellón. Esta cantidad tuvo que ser asumida sólo por los miembros de las siete familias de la alta nobleza que formaban parte de la Asociación en el momento de su disolución y no "por toda la aristocracia española” como de forma hiperbólica afirmó Cotarelo. Véase Cotarelo, Orígenes, p. 374.
} 
algunas óperas y ballets que se pusieron en escena en este teatro en las dos primeras décadas del siglo XIX.

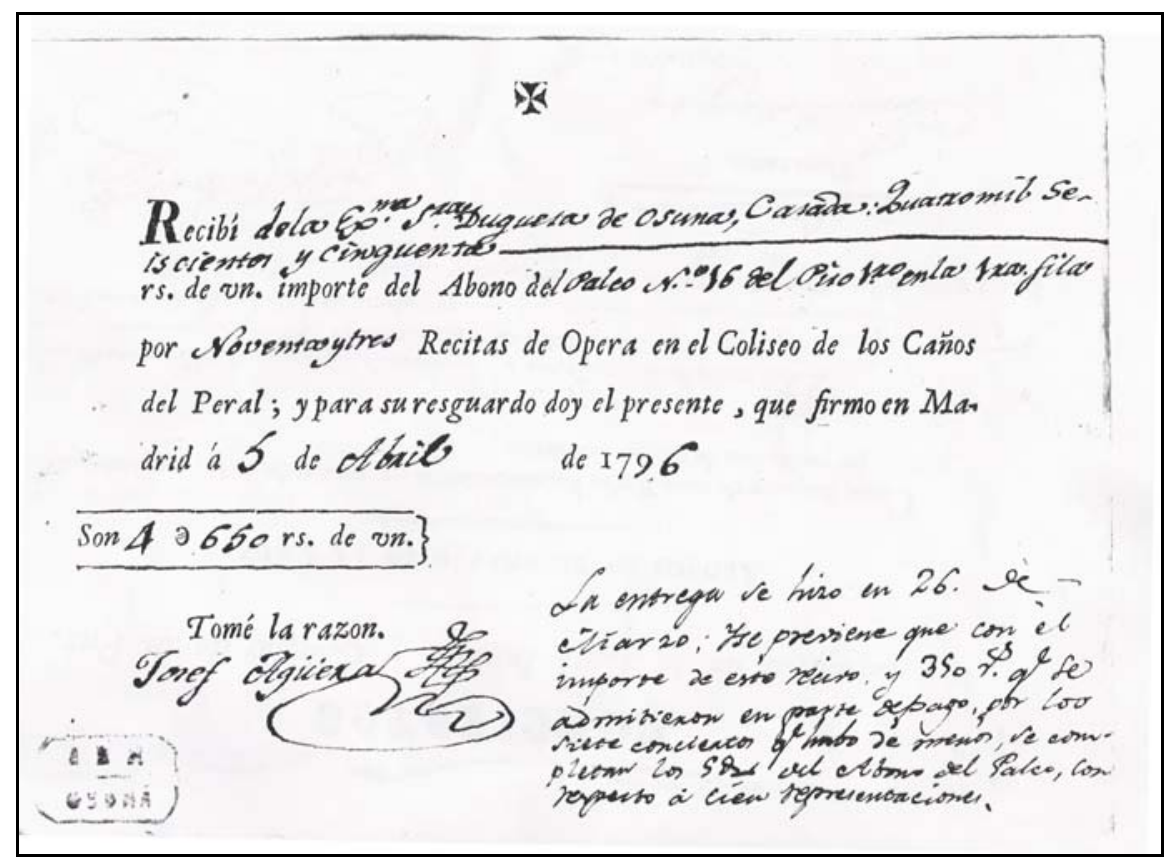

Lámina 29.

Recibo del abono de la XV Condesa-Duquesa de Benavente a la temporada de ópera de 1796 del Teatro de los Caños del Peral de Madrid.

(AHN NOBLEZA, OSUNA-CARTAS, leg 416)

Hasta los últimos años de su vida, la Condesa-Duquesa continuó también protegiendo a algunos compositores, bailarines y cantantes que solicitaron su intercesión para ser contratados en las compañías de los teatros públicos de Madrid. 


\subsubsection{Adquisición de partituras}

La carencia de un estudio sistemático sobre los aspectos de gestión de las temporadas de ópera de Madrid a partir de 1800 impide conocer el papel que jugó la alta nobleza después de la disolución de la Asociación (1795). A la luz de la documentación consultada, parece probable que la Casa de Benavente, a través de su titular la Condesa-Duquesa María Josefa, continuara teniendo un papel importante en la gestión de las temporadas de ópera que tuvieron lugar en las primeras décadas del siglo XIX en Madrid. Al menos entre 1800 y 1818, la Condesa-Duquesa de Benavente parece haber sido una de las personas encargadas de adquirir el repertorio operístico para las temporadas públicas de Madrid.

Es posible que gran parte de las partituras de óperas francesas que adquirió la Condesa-Duquesa entre 1801 y 1806 al editor y almacenista francés Jean Jerome Imbault fueran destinadas a las funciones públicas de los teatros de Madrid. Varias de las óperas que envió Imbault a la Condesa-Duquesa se estrenaron en el Teatro de los Caños del Peral de Madrid, adaptadas al castellano, sólo unos meses después de que la Condesa-Duquesa las recibiese en Madrid ${ }^{66}$. Entre 1818 y 1819 la Condesa-Duquesa de Benavente seguía ocupándose de la compra de las partituras de óperas y bailes para los teatros de Madrid como demuestra la correspondencia mantenida con Juan Bautista Ricci almacenista de música de Génova, en donde se detalla que las partituras de óperas que enviaba

\footnotetext{
${ }^{66}$ Véase Capítulo IV.
} 
este proveedor a la Condesa-Duquesa tenían como destino "los teatros [públicos] de Madrid"67

\subsubsection{Protección de cantantes y compositores de ópera}

Dentro de la copiosa documentación epistolar que se conserva en el archivo administrativo de la Casa de Osuna, figuran un gran número de cartas que dan fe de la intensa labor de mecenazgo y protección que María Josefa Alfonso Pimentel, Condesa-Duquesa de Benavente, desarrolló a lo largo de su vida con un gran número de artistas del mundo del teatro musical. Gran parte de esta correspondencia ha sido editada y estudiada por distintos autores que, básicamente, se han centrado en la recopilación antológica o en la descripción de los documentos ${ }^{68}$. Una excepción es el reciente artículo de Marc Heilbron en el que se presenta una clasificación de los principales tipos de solicitudes que los artistas dirigían a la Condesa-Duquesa de Benavente ${ }^{69}$.

Después de la disolución de la Asociación (1795), la Condesa-Duquesa continuó protegiendo a algunos músicos cantantes y bailarines que actuaron en las óperas y conciertos del Teatro de los Caños del Peral en los últimos años del siglo

\footnotetext{
${ }^{67}$ AHN NOBLEZA, OSUNA-CARTAS, legs. 392-12 y 392-13.

${ }^{68}$ Nicolás A. Solar Quintes. "I. Las relaciones de Haydn con la casa de Benavente. II. Nuevos documentos sobre Luigi Bocherini. III. Manuel García Íntimo”, AnM, II (1947), pp. 81-104.; Idem "Saverio Mercadante en España y Portugal. Su correspondencia con la condesa de Benavente", en: AnM, VII (1952), pp 201-208; “Virtuose. Viaggi e Stagioni Nell'Ultimo Decennio del Settecento, (Madrid: Istituto Italiano di Cultura, 1979); James Radomski: Chronicle of the Life of a bel canto Tenor at the Dawn of Romanticism (Oxford: Oxford University Press, 2000). Versión Española: Manuel Garcia (1775-1832), Maestro del Bel Canto y Compositor, (Madrid: ICCMU, 2002).

69 Marc Heilbron, "Umilissimi, devotissimi servi, Correspondencia de cantantes de ópera italiana con la Duquesa de Osuna." AnM, 57, (2002), pp. 199-227.
} 
XVII y en los primeros del XIX. Entre ellos se encontraba la anteriormente citada Luisa Todi, una de las artistas más apreciadas por la Condesa-Duquesa, con quien mantuvo una cordial relación durante su residencia en España y a la que continuó protegiendo durante varios años ${ }^{70}$; la violinista y cantante Luisa Gerbini que fue recomendada a la Condesa-Duquesa por el Conde de Valdeparaiso ${ }^{71}$ o el matrimonio de bailarines franceses formado por Louis Moreau y Achille Monroy que fueron contratados en París para la temporada de ballet de Madrid de 1799 gracias a las gestiones de la Condesa-Duquesa. A su llegada a España estos bailarines tuvieron diversos problemas con Santiago Panati, a la sazón empresario del Teatro de los Caños del Peral, que se negaba a pagarles lo estipulado. La Condesa-Duquesa, a través de sus abogados intervino para resolver el conflicto ${ }^{72}$.

La situación de crisis en la que se vio envuelta la administración de la Casa ducal de Benavente tras la muerte del Duque de Osuna en 1807, paralizó la generosa concesión de cantidades económicas que se había verificado en otras épocas. En este mismo año el tenor y compositor Manuel García, que había trabajado en los primeros años del siglo en Madrid, solicitó insistentemente desde su exilio francés la ayuda económica de la Condesa-Duquesa de Benavente. Las difíciles circunstancias que atravesaba la Tesorería de la Casa de Benavente en esa

\footnotetext{
${ }^{70}$ Véase Apéndice 6, documentos $n^{\circ}$ 28-33.

${ }^{71}$ Véase Apéndice 6, $\mathrm{n}^{\circ} 37$.

72 AHN NOBLEZA, OSUNA-CARTAS, leg 388- 8. En BNE. Ms 13994.2/51 (Papeles Barbieri) se conserva el contrato de la bailarina Achille Monroy para la compañía de Santiago Panati de Madrid firmado en París, el 11 de agosto de 1799. Sobre la protección de la Condesa-Duquesa al matrimonio Moreau/Monroy véase también la carta de A. Monroy a la Condesa-Duquesa recogida en el Apéndice 6, nº 43.
} 
época no permitían proteger "como en otro tiempo a los artistas" y lo único que la Condesa-Duquesa ofreció a García fue una ayuda de costa por una sola vez "en caso de necesidad extrema". Según James Radomski la falta de apoyo de la Condesa-Duquesa fue decisiva para que Manuel García abandonase definitivamente su papel de representante de la música española en el extranjero, y se decidiese a "dejar a un lado sus raíces y abandonar su país natal para siempre",73.

A pesar de las citadas dificultades económicas, María Josefa Alfonso Pimentel continuó protegiendo a algunos artistas relacionados con la música teatral durante las tres primeras décadas del siglo XIX. Entre ellos se hallaba Lorenza Correa, una de las sopranos españolas más afamadas de la primera mitad del siglo XIX, que desarrolló gran parte de su carrera en los principales teatros de Europa. La correspondencia que mantuvo la Correa con la Condesa-Duquesa María Josefa, ha sido dada a conocer recientemente por Marc Heilbron, y muestra la estrecha relación de protección y amistad que esta artista mantuvo con la Casa de Benavente ${ }^{74}$.

En los períodos en que Lorenza Correa se encontraba en España, la Condesa-Duquesa solía invitarla a participar en los conciertos privados que tenían lugar en su casa. La generosidad de la Condesa-Duquesa hacia la cantante

\footnotetext{
73 AHN NOBLEZA, OSUNA-CARTAS, leg 413-24. De la relación epistolar entre Manuel García y la Condesa-Duquesa de Benavente se conservan seis cartas que fueron publicadas por SolarQuintes, y han sido analizadas de nuevo actualizando algunos datos desconocidos por James Radomski. Véase Solar Quintes “I. Las relaciones”, pp. 98-104. y Radomski, Manuel García, pp. 99-103.

${ }^{74}$ Heilbron, “Umilissimi”, pp.223-226.
} 
queda patente en los importantes regalos y pagos con que gratificó su colaboración en esas veladas. En 1818 la Condesa-Duquesa regaló a la Correa un par de pendientes de brillantes, un medallón y una cadena de oro como pago por su colaboración en uno de los $\operatorname{conciertos}^{75}$. En otras ocasiones la CondesaDuquesa agradeció a la soprano la participación en sus fiestas con una retribución económica. Por ejemplo, para agradecer la intervención de Lorenza Correa en un concierto que se celebró en junio de 1827, la Condesa-Duquesa entregó a la cantante la importante cifra de 3.000 reales $^{76}$.

Las noticias de la eficacia de las recomendaciones de la Condesa-Duquesa María Josefa a la hora de conseguir un empleo en los teatros de Madrid traspasaron las fronteras españolas, y muchos artistas franceses e italianos que querían trabajar en la capital española intentaron conseguir un trato de favor gracias a la intercesión de la Condesa-Duquesa. La trascendencia de la protección que la Condesa-Duquesa dispensaba a los artistas del mundo del teatro queda patente en la carta que en 1807 Stefano Vestris ${ }^{77}$ escribió desde París a la Condesa-Duquesa para solicitar un puesto en la compañía de baile del Teatro de los Caños del Peral de Madrid:

\footnotetext{
75 AHN NOBLEZA, OSUNA-CARTAS, leg 413-47.

76 Ibid., leg 413-37/3. Este dato contradice la opinión de Marc Heilbron quien afirmó que los cantantes que tomaban parte en las academias organizadas en la casa de la Condesa-Duquesa no recibían una gratificación económica sino un regalo, un detalle que se consideraba "de mejor gusto que el pago en metálico”. Heilbron, “Umilissimi”, pp.219.

77 Stefano Vestris era primo del famoso bailarín y maestro de danza Armand Vestris Sobre la familia Vestris véase Ivor Guest, "Vestris" NG, vol 20, p. 509.
} 
Señora Duquesa

Aunque no tengo el honor de conocer personalmente a Vuestra Excelencia, las bondades con que ha tenido a bien honrarme, concediendo su aprecio a mi hijo menor Carlos Vestris el año último cuando estuvo en Madrid, me enardecen para implorar su protección en estos momentos.

Vuestra Excelencia estará probablemente informada que desde la salida del Príncipe y la entrada de los franceses aquí, nuestro teatro ha padecido tanto, que no solamente se deben a los artistas tres meses de sus sueldos, sino que se ignora como podrá subsistir. Mi primo Armand Vestris que se hallaba aquí y que Vuestra Excelencia conoce muy bien, tiene el valor de aventurarse a esperar los sucesos: pero yo que estoy convencido de que las artes no prosperan entre el estruendo de las armas, no he querido seguir su proyecto: he reflexionado que no habiendo disgustado este niño en Madrid, no sería acaso fuera de propósito colocarle en la compañía de baile de esa Corte, tanto más cuanto Monsieur. Lefebre lo conoce y compuso un baile para él, intitulado La insurreción de Citheres en nuestro paso por Marsella He pensado que la mediación de Vuestra Excelencia podría acabar la obra.

Vuestra Excelencia ha honrado siempre con sus bondades a los artistas, y particularmente a mi familia. No tengo necesidad de indicar a Vuestra Excelencia los medios, pues sé que una sola palabra de Vuestra Excelencia puede hacer llamar a mi hijo a esa capital, y mi corazón me anuncia que no seré el único que no haya logrado los efectos de su protección generosa. Tengo el honor de ser con el más profundo respeto el más humilde y obediente servidor

Stefano Vestris

Lisboa 30 de Diciembre de $1807^{78}$.

${ }^{78}$ AHN NOBLEZA, OSUNA-CARTAS, leg 388-30. 
La Condesa-Duquesa remitió la carta anterior al Marqués de Perales, que prometió hacer lo posible para complacerla, y pidió que solicitase a Stefano Vestris información sobre las condiciones en que su hijo estaría dispuesto a venir a Madrid ${ }^{79}$.

La protección que la Condesa-Duquesa de Benavente dispensó a cantantes y bailarines se mantuvo hasta los últimos años de su vida. El tenor Leandro Valencia que pertenecía a la compañía de los teatros municipales de Madrid ${ }^{80}$ fue protegido por la Condesa-Duquesa desde los comienzos de su carrera ${ }^{81}$. Cuando Leandro Valencia se trasladó en 1830 a Italia la Condesa-Duquesa lo recomendó a varios aristócratas y a otros influyentes personajes de la nobleza como el Conde Pacta (residente en Milán), el Marqués de Bassecourt que vivía entonces en Nápoles $^{82}$ y a F.B Ricci a quien la Condesa-Duquesa le pidió encarecidamente que facilitase "colocarse en alguno de los [teatros] de ese país mediante ser un buen profesor de música" ${ }^{\natural 3}$

La cantante Isabella Fabrica Montresor, que actuó en las temporadas de ópera de Madrid hacia $1827^{84}$, también gozó de la protección de la CondesaDuquesa durante su estancia en España. La relación entre las dos mujeres,

\footnotetext{
79 No he podido documentar si finalmente Carlos Vestris fue contratado en alguno de los teatros de Madrid.

80 AVM, Corregimiento, Secc 2 leg 471-48. En 1828 era “profesor de música y tenor” en los teatros municipales de Madrid

81 AHN NOBLEZA, OSUNA-CARTAS, leg 387-19. En una carta desde Milán, Leandro Valencia agradeció la protección de la Condesa-Duquesa que era la única que había tenido desde que comenzó su carrera.

82 AHN NOBLEZA, OSUNA-CARTAS, leg 387-19. Heilbron, “Umilissimi”, pp.221.

83 AHN NOBLEZA, OSUNA-CARTAS, leg 413-36.

${ }^{84}$ Ibíd, leg 413-37-14.
} 
desconocida hasta la fecha, se prolongó durante varios años a través de una intensa correspondencia. Después de regresar a Italia, la Montresor continuó escribiendo regularmente a la Condesa-Duquesa. En sus cartas, además de agradecer la protección que ésta le había dispensado durante su estancia en Madrid, e informarle de sus éxitos y proyectos profesionales, la Montresor, expresaba sus deseos de volver a actuar en España, para lo cual esperaba contar de nuevo con la protección y mediación de la Condesa-Duquesa:

Milán, 28 de octubre de 1829

Excelentísima Señora:

Creo cumplir con lo que mi deber me impone hacia Vuestra Excelencia como a la persona de quien tantos favores he recibido, y por la protección que siempre se ha dignado dispensarme haciendo conocer todo lo que me ocurre en mi profesión, persuadida que Vuestra Excelencia lo sabrá con aquel placer, que en otras mil ocasiones ha manifestado por todo lo que puede serme satisfactorio.

Sabrá Vuestra Excelencia que en unión con mi esposo tuve el honor de ser llamada a Turín por el Señor Marqués de Bassecourt, para cantar en un gran concierto que dio a la nueva reina de España, a sus augustos padres y al rey de Cerdeña. No diré a Vuestra Excelencia, si hemos correspondido dignamente a la gran ocasión, por la cual hemos sido llamados. El caballero Gavira Secretario de la Embajada Extraordinaria cerca del Rey de las Dos Sicilias, que se hallaba presente, y que quiso pusiese por escrito mi solicitud para ir a Madrid podrá informar por menor a Vuestra Excelencia de todo. Yo solamente diré a Vuestra Excelencia que la función no pudo ser más magnífica, y que se dio verdaderamente con toda la esplendidez española. Fueron tantos los obsequios que recibimos así del Señor Marqués de Bassecourt, como de su digna esposa la señora Marquesa, que viéndolos no puedo menos de creer pertenezcan a la ilustre familia de Vuestra Excelencia.

Este Carnaval iremos a Roma, y desde allí cumpliré con el deber de dar a Vuestra Excelencia noticias mías, así como ruego a Vuestra Excelencia no me prive de las suyas. Todo me hace esperar que no puede estar lejos el 
instante, en que verbalmente pueda renovar a Vuestra Excelencia mi eterno reconocimiento. Una sola palabra que Vuestra Excelencia se dignase proferir en mi favor, estoy bien persuadida que bastaría para que aquello se ejecutase más fácilmente. No quiero sin embargo importunar a Vuestra Excelencia con exigir demasiado de su experimentada bondad. Ruego a Vuestra Excelencia se digne a hacer presente mis respetos a toda su respetable familia, protestándome yo eternamente de Vuestra Excelencia Ilustrísima.

Isabella Fabricca Montresor ${ }^{85}$

En los últimos años de su vida, la Condesa-Duquesa no tuvo las mismas influencias sobre los responsables de las compañías de ópera de Madrid que en épocas anteriores, tal y como expresó en la carta de respuesta a Isabella Fabrica Montresor. La Condesa-Duquesa lamentó no poder hacer nada para conseguir que la cantante actuase de nuevo en Madrid pues no conocía al empresario ni a nadie que pudiera ayudarla en ese tema ${ }^{86}$.

${ }^{85}$ AHN NOBLEZA, OSUNA-CARTAS, leg 617-49. Transcribo la traducción que se conserva en el mismo legajo junto a la carta original en italiano.

${ }^{86}$ AHN NOBLEZA, OSUNA-CARTAS, leg 617-49. Una respuesta similar recibió el compositor Saverio Mercadante cuando solicitó en este mismo año de 1829 la intercesión de la CondesaDuquesa para que su compañía de ópera que estaba actuando en Cádiz pudiese debutar en Madrid. Véase Solar-Quintes "Saverio", p. 206. 


\section{Música teatral de Pablo Esteve Grimau dedicada al VIII Duque de Osuna estrenada en los teatros públicos de Madrid.}

El compositor catalán Pablo Esteve y Grimau (ca. 1730-†1794) es, sin duda alguna, uno de los compositores españoles de música teatral más prolíficos de su época ${ }^{87}$. En el amplio catálogo de Esteve, que hasta la fecha no ha sido estudiado sistemáticamente ${ }^{88}$, figuran tres obras dramático-musicales dedicadas a Pedro Zoilo Téllez Girón, VIII Duque de Osuna, para quien Esteve trabajó al menos entre 1765 y 1768 . En los apartados siguientes me detendré en el análisis de dichas obras que muestran la evolución estética de este autor en el proceso de asimilación de los modelos italianos de la ópera bufa y su incorporación a los géneros teatrales cantados en español.

\subsection{La buena muchacha, adaptación de Cecchina o La buona figlioula de Carlo} Goldoni y Niccolò Piccinni (1765)

En noviembre de 1765, Pablo Esteve dedicó al Duque de Osuna la edición de la Letra de la música contenida en la zarzuela intitulada en idioma italiano "La buona figlioula" y en castellano "La buena muchacha" que se representó en el Coliseo de la Cruz por la compañía de María Hidalgo ${ }^{89}$. El texto de esta obra es

\footnotetext{
${ }^{87}$ Sobre la biografía de Esteve y su relación de servicio con la Casa de Osuna véase el Capítulo III.

${ }^{88}$ Una primera aproximación al catálogo de Esteve figura en Fernando J. Cabañas Alamán, "Pablo Esteve y Grimau", DMEH, vol.4, pp. 817-819.

${ }^{89}$ Letra de la música contenida en la zarzuela intitulada en idioma italiano "La buona figliuola" y en castellano "La buena muchacha" la cual se representa por la Compañia de María Hidalgo en el Coliseo de la Cruz compuesta por el insigne Nicolao Piccinni a excepción de la que se nota
} 
una adaptación al castellano de la ópera bufa o dramma giocoso Cecchina ossia la buona figliuola con libreto de Carlo Goldoni y música de Niccolò Piccinni que se había estrenado en 1760 en Roma ${ }^{90}$. La buona figliuola obtuvo un gran éxito tras su estreno y se difundió rápidamente por toda Europa con adaptaciones a diversos idiomas, como relató el famoso viajero Charles Burney:

[La buona figliuola] had a success that no musical drama could boast before It was no heard at Rome than copies were multiplied, and there was no musical theatre in Europe where this burletta was not frequently performed, in some language or other during many years ${ }^{91}$

Al igual que en otras capitales europeas, como en Londres donde se estrenó en 1767 con diálogos en ingles ${ }^{92}$, la presentación en España de La buona figliuola de Goldoni/Piccini se realizó en versión de zarzuela, sustituyendo los

con unas xxx que lo es por D. Pablo Esteve y Grimau, quien la dedica al Excelentísimo Señor Duque de Osuna ([s.l]: [s.n], 1765). Una copia de este libreto se conserva en BNE T/22.325.

90 El libreto de Goldoni es una adaptación teatral de la novela Pamela: or virtue rewarded del escritor Samuel Richardson. La partitura de la ópera original de Piccinni está editada en Niccoló Piccinni, La Cecchina, ossia, La buona figliuola; introducción de Eric Weimer (Garland: New York, 1983).

91 Citado en William C. Holmes, "Pamela Tranformed", Musical Quarterly 38 (1952), p.591. [Mi traducción]: “La buona figliuola tuvo el mayor éxito alcanzado por un drama musical hasta la fecha. Poco después de estrenarse en Roma fue copiada extensamente, y no hubo teatro musical de Europa en el que no se representase frecuentemente esta burletta en uno u otro idioma durante muchos años"

92 Holmes, "Pamela", p. 591. 
recitativos por diálogos en castellano y añadiendo al original varios números musicales escritos para la ocasión por Pablo Esteve y Grimau ${ }^{93}$.

La participación de Pablo Esteve en la adaptación de la obra de Piccinni se enmarca en el proceso de asimilación de los drammi giocosi por los dramaturgos y compositores españoles $^{94}$. Las primeras traducciones de obras de Goldoni al castellano, anónimas en su mayoría o de autores como Ramón de la Cruz, Antonio Valladares o Luis Moncín, se presentaron en los escenarios en forma de zarzuela, con la música original de los compositores italianos, a la que ocasionalmente se añadían números enteros o secciones de autores españoles para adecuar los contenidos y personajes a las peculiaridades de la escena española.

Los libretistas españoles eliminaron paulatinamente todas las referencias políticas o sociales que no interesaban en nuestro país y omitieron algunas escenas e incluso actos completos de una misma obra, conformando así el modelo típico de zarzuela en dos actos o jornadas ${ }^{95}$. Este proceso de adaptación del texto dramático propició la asimilación por los compositores españoles de los modelos formales vigentes en la ópera bufa. Las adaptaciones literarias obligaban a la transformación de algunos fragmentos musicales y a crear nuevos números que se

\footnotetext{
93 En el verano de 1767 La buona figlioula se representó en el Real Sitio de San Ildefonso por la compañía de ópera de los Reales Sitios en la versión original en italiano con tres arias añadidas por Luigi Marescalchi. Cotarelo, Orígenes, pp.198-199.

94 Para la influencia de los dramas goldonianos en la gestación de la zarzuela costumbrista dieciochesca véase Pablo Esteve y Grimau, Los Jardineros de Aranjuez (1768) Zarzuela en dos actos. Estudio y edición crítica de Juan Pablo Fernández Cortés (Granada: Universidad de Granada, 2005), pp. 21-25.

95 Antonieta Calderone y Victor Pagán, "Carlo Goldoni, La comedia y el drama jocoso", en Francisco Lafaga (ed.), El teatro europeo en la España del siglo XVIII, (Lleida: Universidad de Lleida, 1997), p. 193.
} 
encargaban a los compositores que trabajan en España. No se trataba de crear obras nuevas, sino de acomodar las obras originales a las características vocales y dramáticas de los intérpretes españoles, sin olvidar la utilización de recursos habituales en la música nacional. Los compositores, de paso, se ejercitaban en el estilo italiano, tal y como aclaró Pablo Esteve en el prólogo de La buena muchacha:

[...] Lo he dispuesto, porque habiendo sido forzoso ajustar á las voces, y facultades de los Actores [a] la Música del Autor originario por haberla éste compuesto para sujetos determinados, mejor que echar a perder lo bueno, he querido aventurarme á imitarlo según mi corta ingeniatura, para con su buen estilo, y erudita composición ejercitar el documento, y aprovechar la ocasión del estudio, que ofrece tan grande armonía; y asegurar con esta idea, he tenido infinito que adelantar con su especulación, por lo que no me he atrevido a privar al público de más que aquello forzosamente necesario para cumplir con el motivo; y así, lo que toca á la segunda parte de las Arias, tampoco me ha parecido que se omita, aunque abreviase la Zarzuela, porque quedaba defectuosa la modulación de los caprichos, que los inteligentes saben son de mucho arte, cuando los preceptos de este se explayan desde la primera a la segunda parte de las Arias. ${ }^{96}$

En este texto, Pablo Esteve muestra que los modelos formales italianos fueron aceptados por los compositores españoles que participaron en el proceso de renovación de la zarzuela como un medio seguro para mantener la coherencia estructural de la obra. La referencia a "la segunda parte de las Arias" revela el

\footnotetext{
${ }^{96}$ Letra de la música, Prólogo, [s.p].
} 
proceso de evolución formal del aria da capo que se estaba gestando en la ópera bufa y que fue asimilada por los compositores españoles.

El trabajo de adaptación y composición de nuevos números para la versión española de esta obra en forma de zarzuela, debió de ser para Esteve una excelente ocasión de presentar públicamente su conocimiento de los elementos estilísticos y los presupuestos formales del género dramático italiano. Pocos años después, estos elementos aparecerán hábilmente fusionados con los propios de la tradición española en obras originales de Esteve, como la zarzuela Los jardineros de Aranjuez.

\subsection{No hay en amor fineza mas constante. Comedia con música (1766)}

Pablo Esteve también dejó constancia de su interés por la renovación de la música teatral en él prólogo del libreto de la comedia No hay en amor fineza más constante, que dejar por Amor su mismo amante, obra dedicada al VIII Duque de Osuna, que se representó en 1766 en el Teatro de La Cruz de Madrid ${ }^{97}$.

En el mencionado prólogo, Esteve mostró un talante progresista y proclive a la introducción de novedades en la música teatral. Como se vio en el apartado anterior, la utilización de nuevos modelos de estructuración formal para las arias era una de las cuestiones que centraban la especulación teórica de Pablo Esteve en

\footnotetext{
${ }^{97}$ Pablo Esteve y Grimau (ed.), Letras que se cantan en la Comedia de no hay en amor fineza más constante, que dejar por Amor su mismo amante: Inclusas las tonadillas, que se cantan igualmente en los Sainetes de esta Fiesta en el Coliseo de la Cruz. Año de 1766 Dadas a la luz por don Pablo Esteve y Grimau, compositor de música en esta Corte. Las dedica al Exc. Señor Duque de Ossuna \&c. (Madrid: Imprenta de Manuel Martín, 1766) Prólogo. Se conserva un ejemplar en BNE T-22.389.
} 
esta época. El compositor argumentó que la "disposición de las arias" y otras reglas vigentes en la composición para la música teatral se apoyaban más en la tradición que en la teoría musical. Esteve apoyó sus afirmaciones remitiéndose a la autoridad de autores como San Agustín, y Tomás Vicente Tosca, entre otros:

[...] Y pasando a lo principal de mi escrúpulo, digo, que con la experiencia de ocho años de ejercicio en los teatros de la Corte, he advertido el gusto que más predomina entre los apasionados de ésta diversión, y que su genio vivo, y nunca pagado de mas artificios, que los que bastan para divertir las fatigas de sus labores, no desmerece el desvelo de buscar novedades, que se conformen con su parecer, y no vicien el arreglo de la Facultad: en cuyo supuesto he discurrido que la disposición de las arias no sigan aquel orden común que las suele hacer prolijas, venerando el que han usado los primeros Ingenios de éste inestimable Arte de la Música: pues además de que éste no prescribe preceptos para no variarle; si acertase yo á complacerle con la extrañeza, no es, no, regular culpes el pensamiento de la traza. Entre mas de cuarenta autores que he leído de ésta ciencia, así italianos, como franceses y españoles, no he visto uno que trate de reglas invariables para escribir en los teatros, y menos á los de nuestra patria; con que siendo la música, según San Agustín [D. August. lib. I. cap. 3] Ciencia bien modulada; y según otros Autores, [Tosca, cap I. \& 3. D. Blas Comp. Music, cap. I] Ciencia que en números, proporciones, consonancias, medidas é igualdades consiste , podrás advertir si me aparto de ésta definición en la Obra que te presento; y si arreglado à ella cumpliese con el bien que dice San Agustín, haz cuenta, que puedo prometerme, sin lisonja, la mayor estimación de tu agradecimiento, pues logré la palma de las dificultades ${ }^{98}$.

Esteve mencionó también los fracasos de cuatro de los más importantes compositores de música escénica de su época, que a pesar de la calidad de sus

98 Esteve, Letras, Prólogo, [s.p]. 
obras no recibieron los beneplácitos del público: el catalán Domenico Terradellas (*1711?-†1751) en Roma, el alemán Johann Adolf Hasse, (*1699-†1783) apodado il Sassone en Nápoles, el italiano residente en Munich Giovanni Battista Ferrandini $(* 1710-\uparrow 1791)$ en Barcelona, y Tomaso Traetta $(* 1727-\dagger 1771)$ autor del drama jocoso Il Buovo de Antona que en su presentación en Madrid no gozó de mucho éxito de público. El fracaso de la última obra citada llevó a Esteve a una reflexión sobre las innovaciones que debían introducirse en la música teatral con el fin de conseguir agradar al público español:

Si eres inteligente, no la novedad, siendo acertada, te cause envidia; si no entiendes el punto de la diferencia que no te desagrada, no publiques tu ignorancia; y si lo primero, ni lo segundo tuvieres, conténtate en no meter tu cucharada (si puedes) en lo que no sabes, y déjate de historias que no alcanzas. Pero si por mi desgracia no consigo acreditar el conocimiento de tu gusto, y desempeño de tu diversión, recibe la buena voluntad, que no te ofende; y ten lástima de los que exponen al público sus obras, que por mas acertadas que sean en el mérito, suelen padecer el desaire de no ser conocidas, y verse despreciadas: así les ha sucedido al Gran Terradellas en Roma con la Opera del Sesostre. Al Sasone en Napoles. A Ferradini en Barcelona, los cuales me servirán, si no de consuelo (porque aunque tonto, no el mal de muchos me repara el mío) sí de conformidad para conocer mis pocas facultades. El Bobo de Antona del año presente, no gustó en Madrid, y su música era excelente: la causa, es el motivo que yo tengo para ésta invención, con que si no lo acierto, paciencia, y váyase éste chasco por el logro de haberte servido à tu satisfacción en Los portentosos Efectos de Naturaleza, donde oíste sin desazón varias composiciones mías, bien que guarecidas de la mejor armonía del compositor Originario, y artificioso capricho de su tarde, ó nunca bien conocido Traductor [...] ${ }^{99}$ 
La música que Esteve realizó para la comedia No hay en amor fineza mas constante no se ha localizado hasta la fecha, lo que nos impide conocer con detalle cómo materializó este compositor desde el punto de vista musical las innovaciones que propone en el prólogo del libreto. No obstante, a través del análisis del texto literario pueden deducirse algunas de las novedades musicales que Esteve introdujo en esta obra

En la Tabla 24 presento la distribución de las piezas con música dentro de esta función. Las habituales arias se sustituyeron por breves cavatinas en las que seguramente se prescindió de las continuas repeticiones del ritornello. En el libreto de No hay en amor fineza más constante se refleja también el eclecticismo de estilos y géneros que caracterizaban a las funciones de teatro español de la segunda mitad del siglo XVIII. Los dos intermedios de dicha comedia fueron amenizados con sendas tonadillas del propio Esteve. En el primer entreacto se puso en escena la tonadilla a cuatro El pintor y la vieja ${ }^{100}$ y entre las jornadas segunda y tercera se representó un sainete que contenía unas seguidillas para ser bailadas (seguramente también compuestas por Esteve) y la tonadilla a tres $L a$ Avellanera y los franceses ${ }^{101}$.

\footnotetext{
99 Ibíd.

${ }^{100}$ Una copia de los materiales musicales de esta tonadilla se conservan en la BMM Mus 150-11

101 Ibid., BMM Mus 164-11.
} 
Tabla 24

Distribución de las piezas musicales compuestas por Pablo Esteve

para la comedia No hay en amor fineza más constante (1766)

Fuente: BNE T- 22389

\begin{tabular}{|c|c|}
\hline $\begin{array}{c}\text { Comedia } \\
\text { No hay en amor... } \\
\text { JORNADA } \\
\text { PRIMERA }\end{array}$ & $\begin{array}{l}\text { Coro } \\
\text { Cavatina } \\
\text { Cavatina } \\
\text { Dúo } \\
\text { Recitado } \\
\text { Cavatina } \\
\text { Coro } \\
\end{array}$ \\
\hline [ENTREACTO 1] & Tonadilla El pintor y la vieja \\
\hline $\begin{array}{c}\text { Comedia } \\
\text { No hay en amor... } \\
\text { JORNADA } \\
\text { SEGUNDA }\end{array}$ & $\begin{array}{l}\text { Cavatina } \\
\text { Cavatina } \\
\text { Recitado } \\
\text { Cavatina } \\
\text { Recitado } \\
\text { Cavatina } \\
\text { Coro Triste }\end{array}$ \\
\hline \multirow{2}{*}{ [ENTREACTO II] } & $\begin{array}{l}\text { Sainete El simple discreto } \\
\text { Contiene las seguidillas tituladas Ay madre, } \\
\text { que en el pecho tengo un gusano }\end{array}$ \\
\hline & Tonadilla La avellanera y los franceses \\
\hline $\begin{array}{c}\text { Comedia } \\
\text { No hay en amor... } \\
\text { JORNADA } \\
\text { TERCERA }\end{array}$ & $\begin{array}{l}\text { Cavatina } \\
\text { Dúo } \\
\text { Cavatina } \\
\text { Coro y Todos }\end{array}$ \\
\hline
\end{tabular}

Las cavatinas y recitados convivían en un mismo espectáculo con las tonadillas y las seguidillas bailadas. Esta fusión entre los géneros populares y cultos será una de las características en las que se apoyará la zarzuela renovada de temática costumbrista, uno de cuyos primeros ejemplos será la opera cómico-bufo dramática o zarzuela en dos actos Los jardineros de Aranjuez de Pablo Esteve a cuyo estudio dedico el siguiente apartado. 


\subsection{Los jardineros de Aranjuez (1768)}

Estrenada en el Teatro del Príncipe de Madrid en las funciones de Navidad de 1768, la zarzuela Tambien de Amor los rigores sacan fruto entre las flores o los jardineros de Aranjuez con música y libreto de Pablo Esteve y Grimau es una de las primeras zarzuelas costumbristas que se presentaron en los escenarios españoles ${ }^{102}$. Recientemente he realizado la primera edición crítica de esta obra que va precedida de un estudio preliminar al que remito para los detalles sobre las fuentes de esta obra y su contexto de producción ${ }^{103}$. En este apartado me limitaré a presentar los rasgos esenciales de la zarzuela y me centraré especialmente en estudiar los aspectos que no fueron analizados en dicha publicación.

Pablo Esteve dedicó la zarzuela Los jardineros de Aranjuez al que por entonces era su señor, Pedro Zoilo Téllez Girón, VIII Duque de Osuna, para el que trabajó al menos desde 1765 (Lámina 30). Según el autor, la obra debió haberse estrenado en "la estación en que fue concebida" 104 , es decir durante la primavera del mismo año, momento en que se desarrolla la acción de la obra y que coincidía con la estancia anual de la Corte en el Real Palacio de Aranjuez. La composición de Los jardineros fur, por tanto, anterior a Las Segadoras de Vallecas, zarzuela de Rodríguez de Hita y Ramón de la Cruz (1768), que desde las

\footnotetext{
${ }^{102}$ Se estreno el 25 de diciembre de 1768 y se representó diariamente hasta el 7 de Enero de 1769. Andioc y Coulon, Cartelera, , vol I, p.286.

${ }^{103}$ Esteve, Los jardineros, pp. XV-XLVIII.

${ }^{104}$ Véase Esteve, Los jardineros, p. XL.
} 
investigaciones de Cotarelo, se ha considerado la pionera en la introducción de los elementos populares en el género ${ }^{105}$.

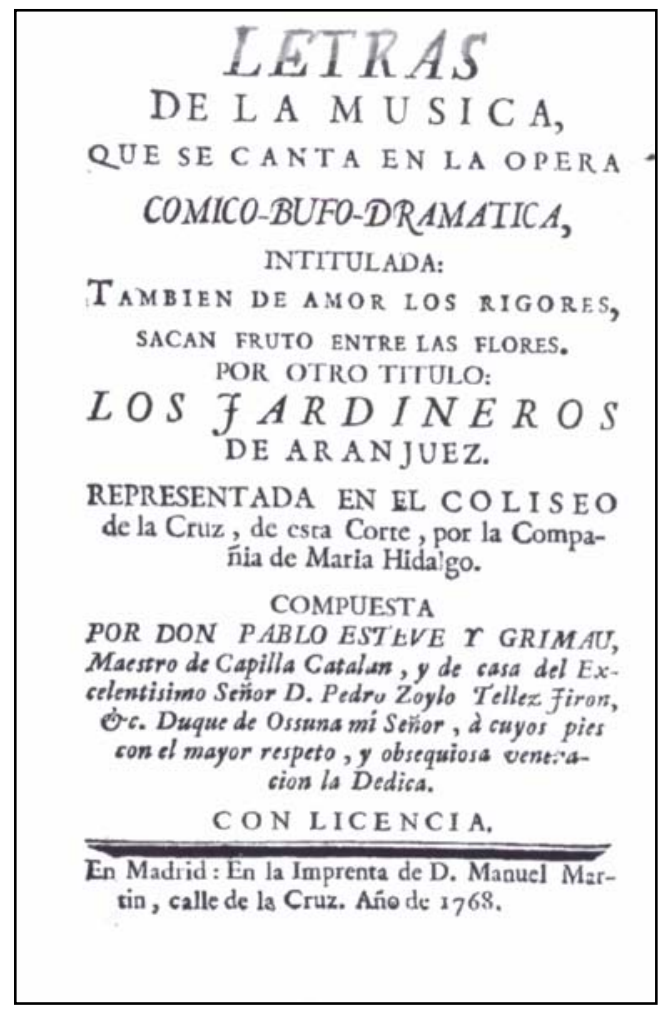

\section{Lámina 30.}

Pablo Esteve y Grimau, Los jardineros de Aranjuez.

Portada del libreto publicado con motivo del estreno de la obra

(Madrid: Imprenta de Manuel Martín, 1768)

(ITB $\left.n^{\circ} 46258\right)$

Los papeles protagonistas de las funciones del estreno Los jardineros fueron interpretados por los principales actores de la compañía de María Hidalgo, y según Cotarelo la obra gustó al público ${ }^{106}$. La zarzuela se volvió a representar al

105 Rainer Kleinertz ha señalado también la importancia de algunos elementos populares que aparecen en esta zarzuela. Véase Rainer Kleinertz, Grundzüge des Spanischen Musiktheaters im 18 Jahrundert. Opera, comedia und Zarzuela (Kassel, Reichenberger, 2003), vol. I, pp. 157-170. 106 Cotarelo, Historia, p. 143. 
menos una vez más entre 1773 y 1782, pues en los materiales musicales conservados aparecen asociados a las arias los nombres o apellidos de distintos miembros de la compañía de Manuel Martínez activos durante ese período. (Ver Tabla 25) ${ }^{107}$.

Tabla 25.

Intérpretes que participaron en el estreno de Los jardineros de Aranjuez en 1768 y en la reposición que se realizó entre 1773 y 1782

Fuente: BMM Mus 58-10 (ITB no 46258)

\begin{tabular}{|l|l|l|}
\hline Papel & $\begin{array}{l}\text { Intérprete del estreno } \\
\text { por la Compañía } \\
\text { de María Hidalgo }\end{array}$ & $\begin{array}{l}\text { Intérprete en la reposición } \\
\text { que se realizó entre 1773 y } \\
\mathbf{1 7 8 2} \text { por la compañía de } \\
\text { Manuel Martínez }\end{array}$ \\
\hline Isabela & María La Chica & Nicolasa [Palomera] \\
\hline Isidoro & María Mayor & {$[$ Maríana] Raboso } \\
\hline Lorenzo & Diego Coronado & {$[$ Miguel] Garrido } \\
\hline Luisito & Gertrudis Cortinas & No consta \\
\hline Marcos & Ambrosio de Fuentes & Ambrosio [de Fuentes] \\
\hline Patricio & Josefa Guzmán & No consta \\
\hline Robertina & Teresa Segura & No consta \\
\hline & \multicolumn{2}{|l}{} \\
\hline
\end{tabular}

Es probable que alguna de las funciones de estreno o en su reposición se realizase dentro de la temporada de ópera de los Teatros de los Reales Sitios o en alguna de las fiestas que se realizaban para el entretenimiento de la Corte en el Real Sitio de Aranjuez en las que solían participar los mejores intérpretes de las compañías de los coliseos de Madrid. En los ejemplares manuscritos del libreto figura "otro final por si acaso acomodase mejor" adaptado para su representación

\footnotetext{
${ }^{107}$ BMM Mus 58-10. Para los listados de las compañías de teatro en español que actuaron en los coliseos del Príncipe y de la Cruz de Madrid entre 1757 a 1794 véase Emilio Cotarelo y Mori, Don Ramón de la Cruz y sus obras. Ensayo biográfico y bibliográfico (Madrid: Imprenta. de José Perales y Martínez, 1899), pp. 440-472.
} 
con un gran aparato escénico en los exteriores del Palacio de Aranjuez, que cierra el espectáculo con alabanzas al rey Carlos III y a sus hijos ${ }^{108}$

La orquesta que Esteve utilizó en esta zarzuela refleja la composición más habitual de las plantillas instrumentales de los teatros de Madrid en esta época ${ }^{109}$ : 2 oboes y 2 flautas (que tocaban los mismos intérpretes), 2 trompas (sustituidas en algunos números por clarines), violines primeros y segundos, viola obligada, y el dispositivo de bajo con violonchelo o violón, contrabajo, y clave.

Etiquetada por el propio Esteve como "ópera cómico bufo dramática", Los jardineros de Aranjuez es una muestra de la recepción de las innovaciones estructurales que, a través de las adaptaciones de las óperas bufas italianas, se incorporaron a la zarzuela española y contribuyeron al abandono definitivo del estatismo de los modelos barrocos ${ }^{110}$. La estructuración en dos actos, el equilibrio entre las secciones habladas y cantadas y la diversificación de metros y tipologías poéticas, son rasgos que contribuyeron a la modernización del género zarzuelístico y que ya se hallan presentes en Los jardineros. Las partes habladas presentan cierta homogeneidad gracias al uso preferente del verso octosílabo que contrasta con la gran variedad métrica de los versos utilizados piezas musicales. En las arias, cavatinas, dúos y números de conjunto, no se utiliza ningún modelo de versificación preferente, y pueden encontrarse versos pentasílabos, hexasílabos, heptasílabos, octosílabos y hasta dodecasílabos.

\footnotetext{
108 Véase Esteve, Los jardineros, p. XCIX.

109 BNE Mss 14.016.1/ 65; 14.016.1/ 72 (Papeles Barbieri).

110 Sobre el contexto de producción de esta obra zarzuela véase Esteve, Los jardineros, pp.-XVXLVIII.
} 
La síntesis entre las influencias de la ópera bufa italiana y la tradición de la zarzuela española puede observarse especialmente en la variedad de tipos formales que aparecen en el libreto de Los jardineros y que configuran la organización formal de los números musicales. El uso de coros en los números de presentación y despedida de la obra, y la utilización de formas estróficas son elementos que remiten a la tradición de la música teatral española. Estos elementos se fusionan con otros que evidencian influencias de la ópera bufa italiana, como la incorporación de amplios números concertantes en el penúltimo número de cada uno de los actos, o la utilización de las arias y cavatinas como elemento articulador de la estructura de la zarzuela.

El recitativo y aria de Patricio que abre musicalmente el segundo acto de la obra es un ejemplo de la incorporación a la zarzuela de los procedimientos compositivos de la ópera bufa italiana. El número comienza con un amplio recitativo acompañado que se caracteriza por los sucesivos cambios agógicos y un fuerte contraste armónico que representa musicalmente la angustia del personaje. (Ejemplo musical 2). La constante traslación de regiones tonales que se produce entre los compases 12 y 23 evoca la impaciencia de Patricio, que amenaza con suicidarse si no halla a su amada. Esteve plasma musicalmente el pathos del personaje con un procedimiento de enlace de áreas tonales con relación de mediante. Partiendo de la tonalidad de si bemol mayor (c.12) pasa sucesivamente por sol menor y mi menor para llegar finalmente a do mayor (c. 23). 


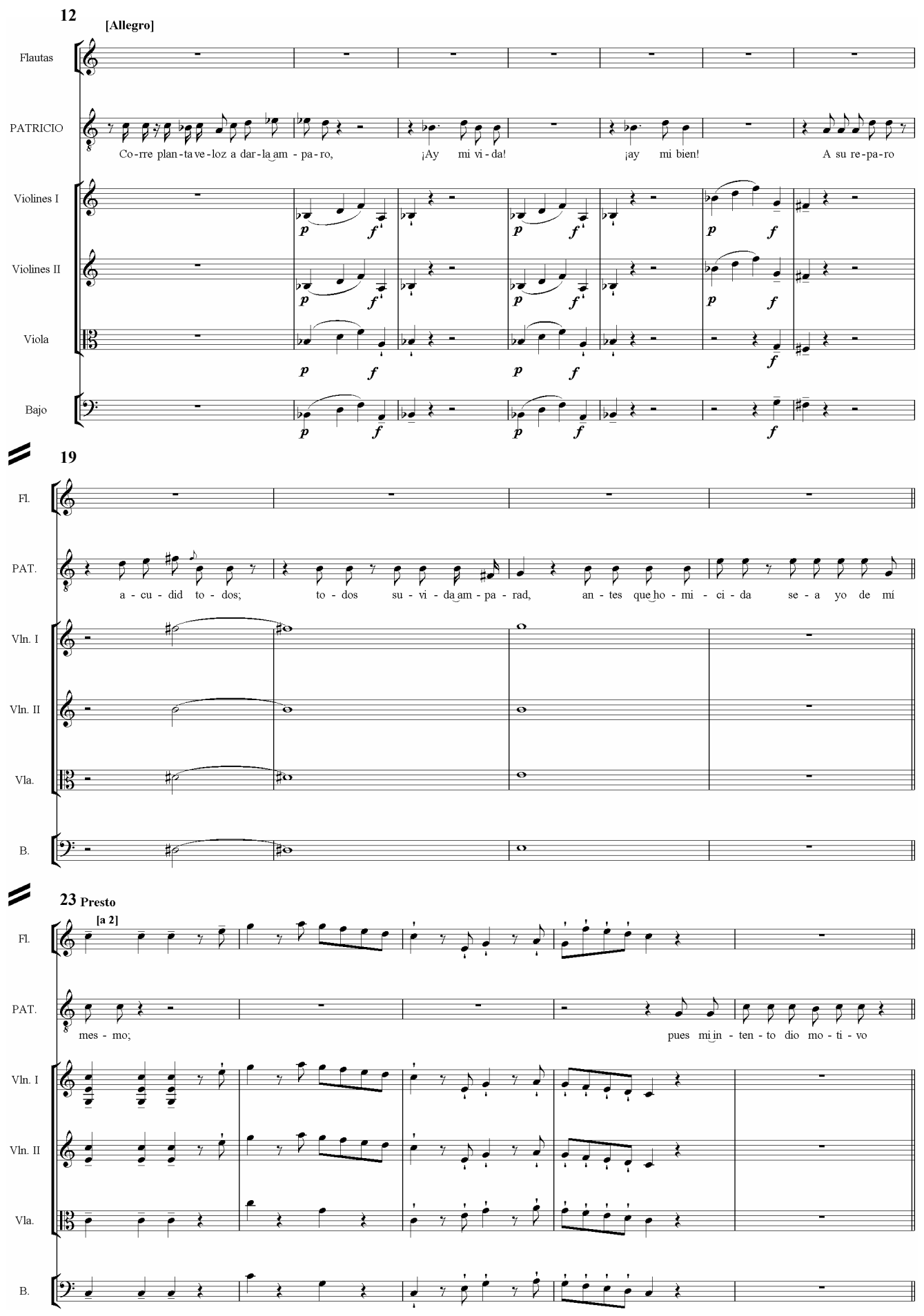

Ejemplo musical 2.

Pablo Esteve: Los jardineros de Aranjuez

Edición de Juan Pablo Fernández-Cortés, pp. 198-199.

15. Recitado (cc.12-27) 
La impaciencia y el desasosiego de Patricio se describen con valores rítmicos más breves y una aceleración del tempo. En los compases 28 al 33, del recitativo, Esteve representa musicalmente el texto iPresto, corred Presto volad! con un cambio de tempo (de Andante a Allegro) y el uso de rápidos grupos de seisillos de semicorcheas (Ejemplo musical 3)
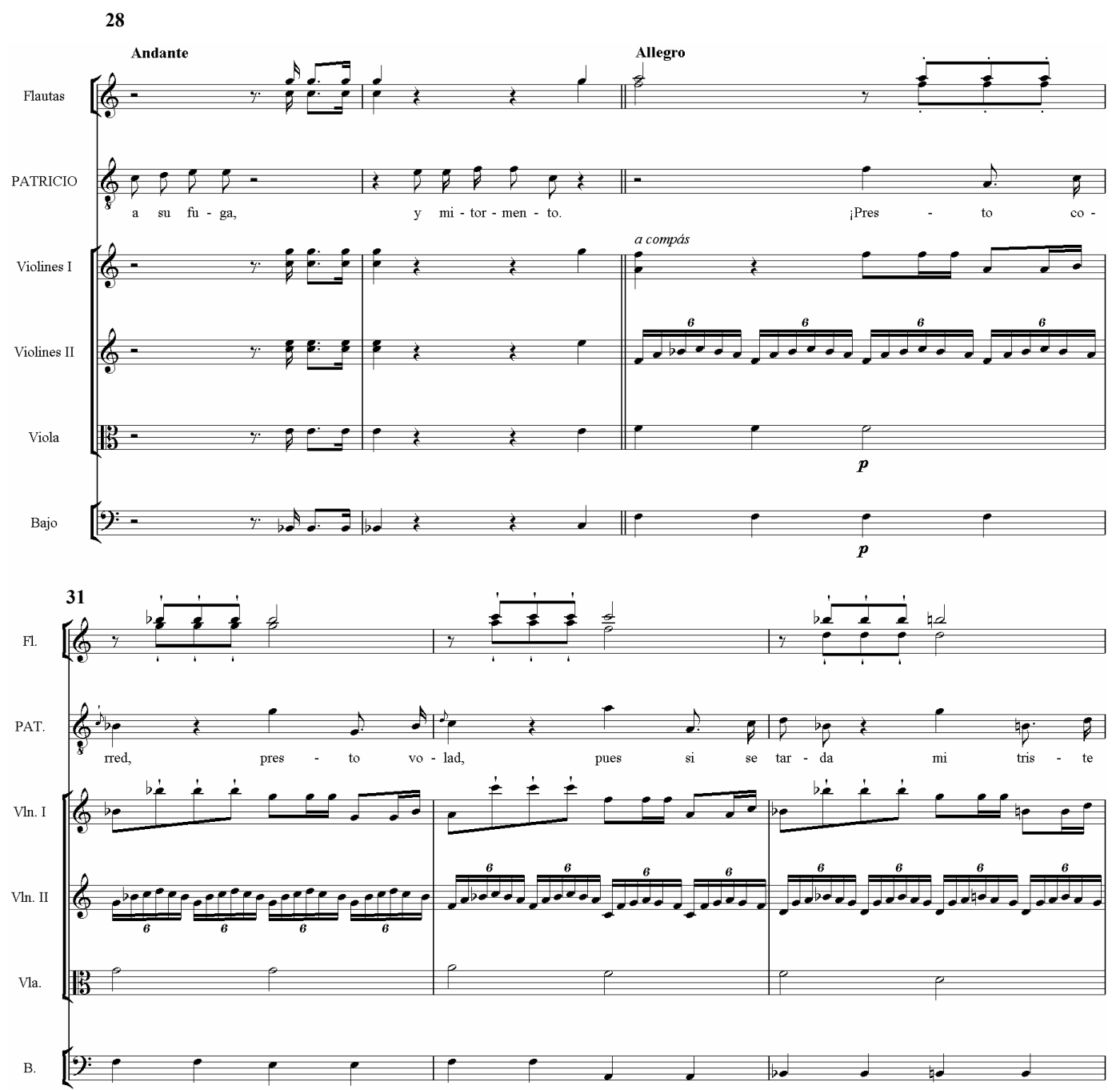

Ejemplo musical 3.

Pablo Esteve: Los jardineros de Aranjuez

Edición de Juan Pablo Fernández-Cortés, pp. 199-201 .

15. Recitativo (cc.28-33) 
El recitativo enlaza sin solución de continuidad con una extensa aria de estructura $\mathrm{ABA}$ 'B' en la que aparecen dos temas claramente contrastados en ritmo y carácter ${ }^{111}$. Este esquema formal muestra el interés de Esteve por la renovación de la estructura del aria y su deseo de abandonar definitivamente el esquema estático del aria da capo. El aria es también un ejemplo de la asimilación de recursos compositivos del estilo galante. Véase, por ejemplo, la destreza en la construcción de frases periódicas que aparecen articuladas con la enfatización de la polaridad tónica-dominante en las dos primeras frases vocales del aria (Ejemplo musical 4).

Una muestra de la presencia de elementos populares en Los jardineros de Aranjuez son las Coplas que interpreta el jardinero Lorenzo en el segundo acto En este número se alternan las partes habladas con un estribillo cantado Esteve refuerza la simplicidad de la elemental estructura estrófica instrumentando el estribillo con sólo dos flautas que doblan la melodía cantada, mientras que los instrumentos de cuerda realizan un largo pedal de tónica que afirman el carácter rústico del número (Ejemplo musical 5).

\footnotetext{
111 Véase Esteve, Los jardineros, pp.207-224.
} 


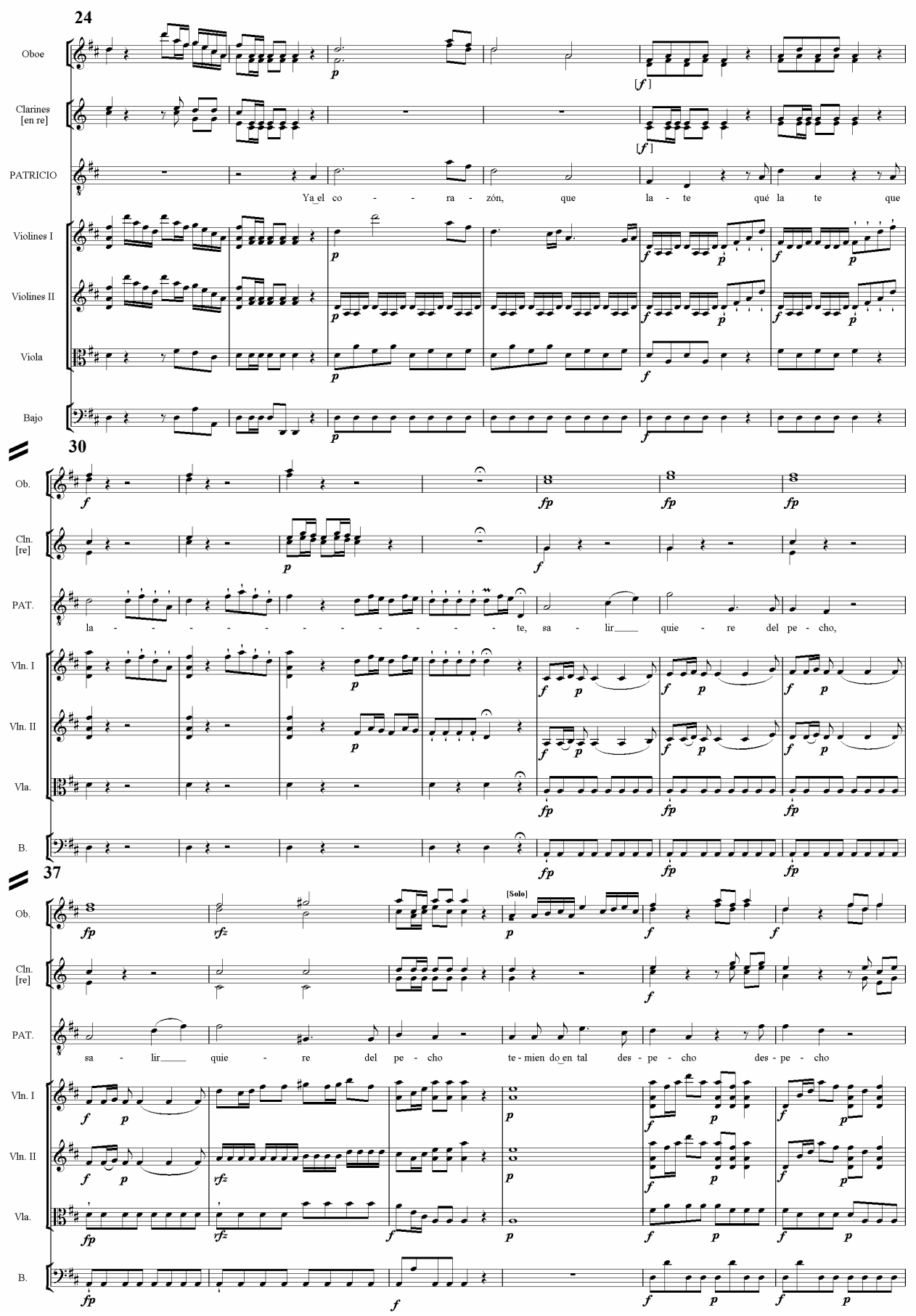

Ejemplo musical 4.

Pablo Esteve: Los jardineros de Aranjuez

Edición de Juan Pablo Fernández-Cortés, pp. 209-211 .

15. Aria (cc 24-42) 
20. COPLAS

Lorenzo
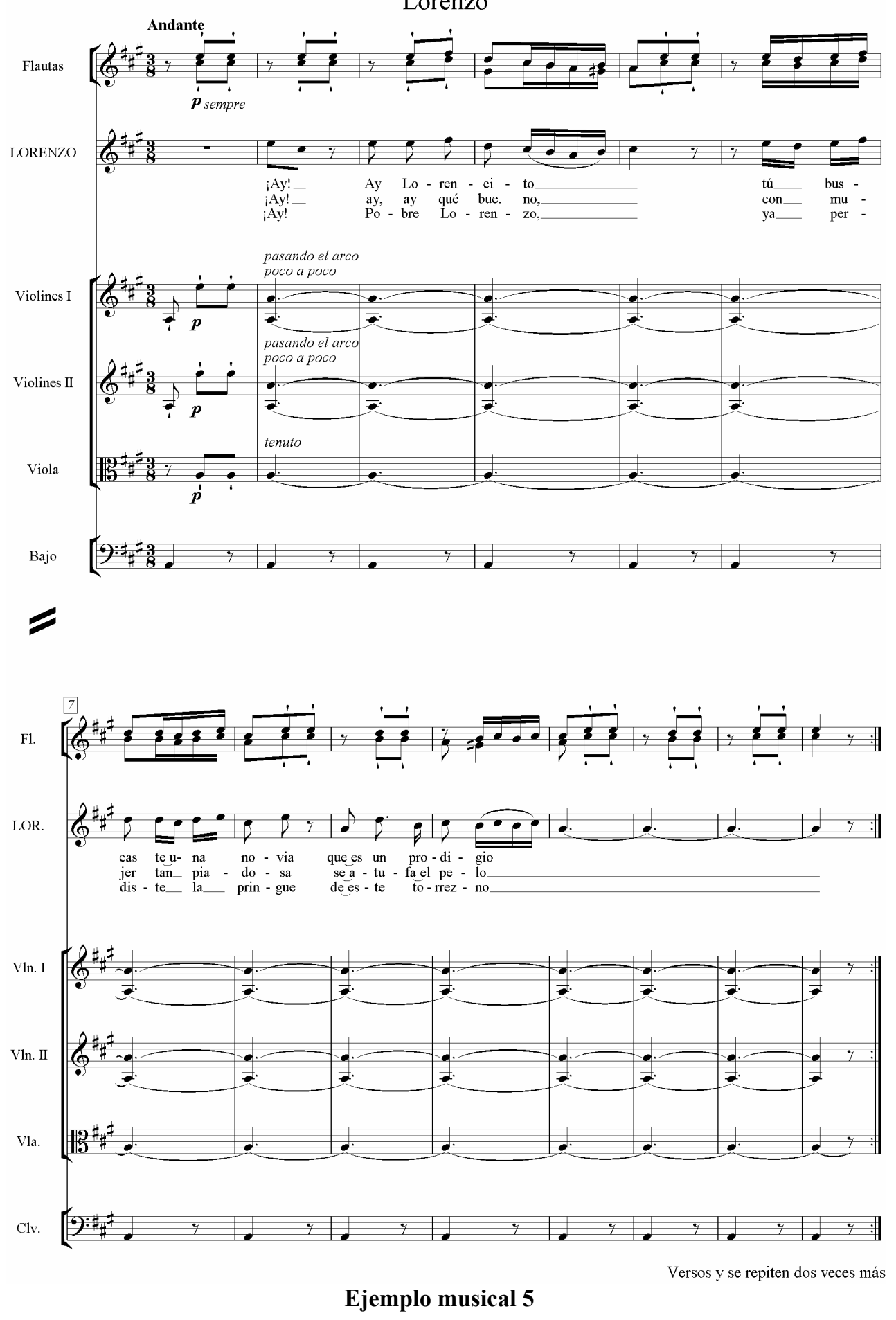

Pablo Esteve: Los jardineros de Aranjuez

Edición de Juan Pablo Fernández-Cortés, p. 255 .

20. Coplas 
El sincretismo entre los elementos italianizantes y los de origen popular (presentes en la ópera bufa pero también en la tradición barroca española), la utilización de una estructuración formal que recoge las novedades de la música europea de su tiempo, y la precursora introducción de la temática popular en el argumento, son aspectos que contribuyen a que Los jardineros de Aranjuez de Pablo Esteve deba considerarse como una de las obras más representativas de la zarzuela costumbrista de la segunda mitad del siglo XVIII.

\section{EI mecenazgo de las Casas de Osuna y Benavente en las compañías de ópera de los Teatros de los Reales Sitios (1767-1776)}

La llegada a la presidencia del Consejo de Castilla en 1766 de Pedro Abarca de Bolea, X Conde de Aranda, supuso el inicio de un período de cambios sociales y la imposición en España de una política cultural de corte ilustrado. Aranda promovió una importante reforma de las diversiones públicas, y en especial del teatro, que se hallaba anclado en modelos dramatúrgicos alejados de las innovaciones europeas más progresistas. La reforma comenzó con la renovación de los teatros adscritos a la Corte. El Conde de Aranda, prescindió de la utilización del Teatro del Buen Retiro (que hasta entonces había sido el escenario principal de las representaciones operísticas cortesanas), y decidió centrar su interés en la organización de espectáculos teatrales en los escenarios de los Reales Sitios (Aranjuez, San Ildefonso, El Escorial y El Pardo), lugares donde residía la Corte gran parte del año. 
La estancia del rey y su séquito en los Reales Sitios implicaba también el traslado de la Corte como institución, lo que conllevaba el movimiento de un gran número de personas a las que había que proporcionar medios de diversión. Ministros, secretarios, miembros del aparato administrativo del Estado, militares y familias de la alta nobleza, residían en sus casas de recreo en los Reales Sitios o las alquilaban para acompañar al rey en sus desplazamientos estacionales. El plan de reformas del Conde de Aranda para los teatros de los Reales Sitios se centró en la construcción y rehabilitación de los espacios escénicos y en la fundación de dos compañías teatrales, una de ópera italiana y baile (que funcionó entre 1767 y 1776) y una compañía de teatro hablado que a partir de 1770 representó tragedias y comedias francesas en versión castellana ${ }^{112}$.

Tal y como ha señalado recientemente Gian Giacomo Stiffoni, el período de funcionamiento de las compañías de ópera y baile de los Reales Sitios adquiere una especial relevancia por la orientación de su repertorio. Como resultado de la política ilustrada del Conde de Aranda, una importante parte de las obras representadas durante la actividad de dichas compañías pertenecían al género de la ópera bufa o drammi giocosi per musica ${ }^{113}$, un tipo de repertorio que tuvo un gran peso en la renovación del lenguaje dramático-musical en España durante la segunda mitad del siglo XVIII ${ }^{114}$.

\footnotetext{
112 Sobre las reformas teatrales del Conde de Aranda véase Jesús Rubio Jiménez, El conde de Aranda y el teatro, (Ibercaja: Zaragoza, 1998).

113 Gian Giacomo Stiffoni, "La opera de Corte en tiempos de Carlos III (1759-1788)", en Álvaro Torrente y Emilio Casares Rodicio (eds.), La ópera en España e Hispanoamérica, (Madrid: ICCMU, 2001), vol.1, pp. 317-341.

${ }^{114}$ Esteve, Los jardineros, pp. XXI- XXV.
} 
Las investigaciones realizadas hasta la fecha sobre la actividad operística en los teatros de los Reales Sitios se han centrado en la reconstrucción del repertorio representado y de su elenco artístico. Emilio Cotarelo y Mori, y más recientemente Gian Giacomo Stiffoni, basaron sus investigaciones en el análisis de los libretos que se imprimieron para las funciones de las compañías de ópera que actuaron en los Reales Sitios entre 1767 y 1776 conservados en la Biblioteca Nacional de España (Madrid). Las limitaciones de este fondo de libretos y el desconocimiento de los documentos administrativos de las compañías de ópera de los Reales Sitios, sólo permitían una reconstrucción parcial de los hechos, algo sobre lo que ya llamó la atención el propio Cotarelo:

No conocemos al día las representaciones que dieron las compañías de los Reales Sitios, pues los papeles administrativos, si por ventura los hubo, se habrán perdido; pero existen unos cuantos libretos de las piezas cantadas, con ayuda de los cuales procuraremos esbozar una relación que tenga algo de histórica del hecho ${ }^{115}$.

En el archivo de la Casa de Osuna se conservan varios documentos administrativos que relacionan a los miembros de las Casas de Osuna y Benavente con el funcionamiento de las compañías de ópera de los Reales Sitios. El estudio de estas fuentes, desconocidas hasta ahora, me ha permitido completar algunos datos y revisar algunas hipótesis que se han mantenido hasta nuestros días acerca de la actividad y financiación de dichas compañías de ópera cortesana, que presentaré en los apartados subsiguientes.

\footnotetext{
115 Cotarelo, Orígenes, p.197.
} 


\subsection{La Compañía de los Reales Sitios en Valencia. La relación de Luigi Marescalchi con la Casa de Benavente y Gandía.}

El compositor de origen boloñés Luigi Marescalchi fue uno de los personajes centrales en la fundación de la primera compañía de ópera que actuó en los teatros de los Reales Sitios. Según Cotarelo es probable que Marescalchi fuera uno de los empresarios o directores de esta compañía en su etapa inicial cuando se pusieron en escena varias obras con música suya. En el verano de 1767 se representaron en el Real Sitio de San Ildefonso Il Ciarlone, ópera bufa en tres actos a la que había puesto música Marescalchi y La buona figliuola ópera bufa con libreto de Carlo Goldoni que tenía música de Niccolò Piccinni y para la cual Marescalchi compuso tres arias. En la primavera del año siguiente se representó en el mismo escenario la ópera seria $L^{\prime}$ Almeria con música original del napolitano Gian Francesco di Majo, a la que Marescalchi añadió varias arias, la sinfonía y los recitativos instrumentales ${ }^{116}$.

Si bien la interpretación de estas obras no es una prueba suficiente para probar que Luigi Marescalchi fuera el director, el empresario (o ambas cosas) de la compañía de ópera de los Reales Sitios, su labor en la empresa fue decisiva pues en una carta que el músico dirigió en 1807 a la XV Condesa-Duquesa de Benavente, Marescalchi declaraba haber sido el "Primo fondatore delle Opere Buffe" en los Reales Sitios ${ }^{117}$. Este dato apoya la hipótesis planteada por Cotarelo, y recogida también por Stiffoni $^{118}$, sobre la importancia decisiva de Luigi

\footnotetext{
116 Ibíd., pp.198-199.

117 AHN NOBLEZA, OSUNA-CARTAS, leg 387-16.

118 Stiffoni, "La ópera”, p. 324.
} 
Marescalchi en la gestión y dirección artística de la compañía de ópera de los Reales Sitios en los primeros años de su funcionamiento.

Al menos en las temporadas de 1768 y 1769, en la dirección de la compañía figuraba también el empresario catalán Francisco Creus ${ }^{119}$. En los inviernos de 1768 y 1769, la compañía de ópera y baile de los Reales Sitios, con Creus al frente, se trasladó a Valencia para ofrecer varias funciones. La carencia de un teatro adecuado para la representación de estos espectáculos obligó al empresario a buscar espacios alternativos. Las representaciones de ópera tuvieron lugar finalmente en una sala del antiguo palacio de los Duques de Gandía, que fue habilitado por el arquitecto y pintor italiano Felipe Fontana ${ }^{120}$, y cedida "a los empresarios Francisco Creus y Luigi Marescalchi”. ${ }^{121}$. El citado palacio era propiedad de la Casa de Benavente, entre cuyos títulos nobiliarios figuraba desde 1740 el ducado de Gandía $^{122}$. La utilización de este palacio para las representaciones operísticas de Valencia tuvo que ser autorizada por María Faustina Téllez Girón, Condesa-Duquesa viuda de Benavente, que en ese momento era alumna del compositor y empresario de la compañía Luigi

\footnotetext{
${ }^{119}$ Ibid., pp. 324-325. Creus había estado al frente de una compañía de ópera en el teatro de Palma de Mallorca.

${ }^{120}$ Cotarelo, Orígenes, p. 271.

121. Cuando en octubre de 1768 Francisco Creus solicitó permiso a los responsables municipales de Valencia para representar funciones de ópera con la compañía de los Reales Sitios, declaró que con dicha finalidad se le había "franqueado la sala de los Eximios [sic por Excelentísimos] Duques de Gandía" Archivo Municipal de Valencia, sección Libros Capitulares y Actas. Libro de instrumentos ordinarios del año 1768, f.452. Citado en Stiffoni, "La ópera", p.325.

${ }^{122}$ Los Condes-Duques de Benavente prestaron en diversas ocasiones sus casas o palacios del Ducado de Gandía para que sirviesen como escenario de representaciones teatrales. Véase, por ejemplo, AHN NOBLEZA OSUNA-CARTAS, leg 310.
} 
Marescalchi $^{123}$. La relación entre Marescalchi y la Condesa-Duquesa viuda de Benavente favoreció el traslado de la compañía de los Reales Sitios a Valencia durante los períodos invernales de 1768 y 1769, y la consiguiente puesta en escena en dicha ciudad de las óperas que se habían representado anteriormente en los escenarios cortesanos.

\subsection{Financiación y funcionamiento de la Compañía de ópera de los Reales Sitios (1770-1777)}

El proyecto del Conde de Aranda de llevar la ópera a los Reales Sitios, contó con el apoyo económico de la alta nobleza. Desde julio de 1770, la compañía de ópera y ballet de los Reales Sitios funcionó como una empresa financiada, total o parcialmente, por accionistas, entre los que se encontraba el VIII Duque de Osuna.

Baltasar Saldoni dio a conocer a finales del siglo XIX algunos datos sobre la financiación de la compañía de los Reales Sitios que han sido obviados por todos los investigadores posteriores. En una noticia publicada en el Diario curioso, erudito, económico y comercial del 17 de Enero de 1787 reproducida por Saldoni se detalla que, tras una primera etapa a cargo de "empresarios particulares" (entre los que se encontrarían Luigi Marescalchi y Francisco Creus), los espectáculos de ópera de los Reales Sitios contaron con el apoyo financiero de "varios señores de la corte", es decir de los miembros de la aristocracia y la nobleza residentes en Madrid:

123 AHN NOBLEZA OSUNA-CARTAS, leg 387-16. 
En el presente reinado [de Carlos III] sólo se han efectuado óperas en los teatros de los Reales Sitios corriendo esta empresa primeramente uno o dos años a cargo de empresarios particulares, hasta que en julio de 1770 se encargó de la dirección a aquellos a Don Joseph Clavijo y cesaron estos de correr con los gastos de la ópera. Renovose en aquel año por medio de acciones que varios señores de la corte tomaron para sostener los gastos; pero se cerraron los coliseos en el año de 1777 de orden del rey y por esta causa finalizó también la Ópera ${ }^{124}$

Uno de los accionistas de la empresa de ópera de los Reales Sitios fue Pedro Zoilo Téllez-Girón, VIII Duque de Osuna, que como gran parte de los miembros de la alta nobleza, ostentó cargos cortesanos que le obligaban a acompañar al rey en sus desplazamientos estacionales, y a residir largos períodos fuera de Madrid. Durante las estancias en los Reales Sitios, los espectáculos teatrales eran una de las principales diversiones de la Corte y la familia Osuna asistía frecuentemente a estas funciones ${ }^{125}$. En noviembre de 1773 el Duque de Osuna dobló su aportación económica como accionista de la compañía de ópera de los Reales Sitios, lo que revela que antes de esa fecha ya participaba en la financiación de la misma:

Háganse buenos a Don Lucas de la Peña y Pacheco, mi Tesorero General en las cuentas de su cargo: siete mil quinientos y veintinueve reales y catorce maravedíes de vellón que ha entregado por mano de Don Jerónimo Pareja, mayordomo de mi casa, a Don Jorge Tangasi para doblar el fondo de la

\footnotetext{
124 Diario curioso, erudito, económico y comercial, 17 de Enero de 1787, p. 70 y siguientes. Transcrita en Baltasar Saldoni, Diccionario biográfico-bibliográfico de efemérides de músicos españoles (Madrid: Antonio Pérez Dubrull, 1868-1881), vol IV, p. 395.

125 AHN NOBLEZA, OSUNA-CARTAS, leg 413-46/3 y leg 416-2. Alquileres de aposentos y asientos en los teatros de los sitios de San Lorenzo, La Granja, y el Coliseo del Pardo.
} 
acción que tengo en la empresa de óperas de los Sitios Reales visto que ha dado recibo en éste a diez y seis del presente mes cuyo original queda recogido en mi Contaduría donde se ha de tomar la razón de este abono. San Lorenzo veintitrés de noviembre de mil setecientos setenta y tres

El Duque [rúbrica]

Tomo la razón

Andrés Merlo ${ }^{126}$

El Duque de Osuna continuó participando en la financiación de la empresa de ópera de los Reales Sitios entre 1774 y 1776 con una aportación de 15.000 reales por temporada ${ }^{127}$.

La falta de estudios sobre el mecenazgo musical de las grandes familias nobiliarias españolas en esta época no permite extraer, por el momento, conclusiones definitivas sobre la importancia que tuvo el apoyo económico de alta nobleza en compañía de ópera de los Reales Sitios entre 1770 y 1777. Es muy probable que entre los "señores de la corte" que participaron en la financiación de esta compañía, según la citada noticia del Diario curioso, se hallaran los miembros de alguna de las principales familias de la nobleza titulada española que acompañaban al Rey en sus desplazamientos a los Reales Sitios.

La documentación de la Casa de Osuna, aporta también datos interesantes sobre el funcionamiento de la compañía de ópera en los Reales Sitios, la duración de las temporadas y su distribución en los distintos teatros cortesanos. Las

\footnotetext{
${ }^{126}$ AHN NOBLEZA OSUNA-CARTAS, 414-12/1.

${ }^{127}$ Ibid.
} 
investigaciones más recientes han insistido en señalar que las temporadas de ópera tuvieron lugar principalmente en los teatros de San Ildefonso y Aranjuez. Stiffoni afirmó que al menos entre 1767 y 1769, la temporada de ópera de los Reales Sitios

se desarrollaba durante la primavera y el verano respectivamente en los Sitios de S. Idelfonso [sic por Ildefonso] de la Granja y de Aranjuez. En 1769, con la construcción del nuevo teatro de Aranjuez, se suspendieron las óperas en S. Idelfonso $[\mathrm{sic}]$. No hay sin embargo que descartar como hipótesis que ya en 1771, después del año sin estrenos operísticos, se reanudaran en este último teatro algunas representaciones operísticas. La indicación presente en las portadas de los libretos impresos, donde se indica como sede un general "nei Teatri de Siti Reali", es en efecto lo suficientemente vaga para dejarnos en la duda ${ }^{128}$.

En el párrafo anterior Stiffoni confunde el itinerario estacional de la corte $\mathrm{y}$, en consecuencia, los meses en los que se desarrollaron las representaciones en cada uno de los escenarios de los Reales Sitios. Como fue narrado con detalle por el Conde de Fernán Núñez, biógrafo de Carlos III, la estancia en Aranjuez tenía lugar siempre durante la primavera, y la del Sitio de San Ildefonso en el verano (y no viceversa):

Pasaba [el Rey Carlos III] en el Sitio de El Pardo desde el 7 de Enero hasta el sábado de Ramos, que volvía a Madrid. Allí estaba diez días, y el miércoles, después de Pascua, por la mañana a las siete, salía para Aranjuez, donde permanecía hasta últimos de junio, días más o menos. Pasaba en Madrid desde este día hasta el 17 o 18 de julio que marchaba a comer, cazar 
y dormir a El Escorial, y de allí, al día siguiente, al Sitio de San Ildefonso. Allí se detenía hasta el 7 o el 8 de octubre, que bajaba a El Escorial, de donde se restituía a Madrid entre el 30 de Noviembre y el 2 de Diciembre ${ }^{129}$.

A estos desplazamientos citados por Fernán Núñez habría que añadir la llamada "jornadilla" que tenía lugar en el mes de diciembre, cuando la Corte se trasladaba de Madrid a Aranjuez durante unos días ${ }^{130}$.

Gracias a los documentos administrativos de la Casa de Osuna tenemos constancia de que, al menos en los últimos años de su funcionamiento, la compañía de los Reales Sitios también desarrolló su actividad en los pequeños teatros de El Escorial y de El Pardo, lugares en los que los reyes pasaban gran parte del invierno ${ }^{131}$

El Coliseo de El Pardo era un teatro de pequeñas dimensiones que se construyó a partir de 1771 dentro de la reforma del Palacio del Pardo proyectada por Francisco Sabatini. Estaba situado en el lado opuesto del llamado "Cuarto Principal" y tenía acceso directo desde la fachada norte del Palacio. En la denominada "Jornada de El Pardo", que coincidía con las grandes fiestas de Carnaval que la Corte celebraba anualmente, se celebraban diversas funciones con

\footnotetext{
128 Stiffoni, “La ópera”, p. 326.

129 Fernán- Núñez, Carlos Gutiérrez de los Ríos, Conde de. Vida de Carlos III escrita por el Conde de Fernán-Núñez; publicada con la biografía del autor, apéndices y notas por A. MorelFatio y A. Paz y Meliá y un prólogo de Juan Valera (Madrid: Librería de Fernando Fé, 1898), Tomo II, pp.42-43.

130 José Luis Sancho, El Palacio de Carlos III de El Pardo, ([Madrid]: Fundación de Apoyo a la Historia del Arte Hispánico, 2002), p. 49.

131 Gian Giacomo Stiffoni duda de que en estos escenarios hubiese representaciones operísticas. Stiffoni, "La ópera", p. 326, nota 38.
} 
música en las que solían participar los instrumentistas de la Real Capilla ${ }^{132}$. Este coliseo albergó espectáculos teatrales al menos desde la temporada de 1772-1773. En este último año la tesorería de la Casa de Osuna abonó a Jorge Tangasi “empresario de los Coliseos de los Sitios Reales" un recibo por los cuatro asientos de galería en dicho teatro para "la temporada que cumplió el 23 del presente mes [de febrero]"133.

En 1774 y 1775 hubo representaciones de ópera en el teatro de El Pardo a cargo de la compañía de los Reales Sitios. Así se deduce de documentos contables de la Casa de Osuna, que reflejan las aportaciones realizadas por el Duque de Osuna como accionista de dicha empresa. Las actuaciones comenzaban el mes de abril en el teatro de Aranjuez y concluían en el carnaval "al año siguiente en el del Pardo" ${ }^{\text {134 }}$. Estos documentos ponen en cuestión algunas afirmaciones de Cotarelo y Mori, según el cual la temporada de ópera de la Compañía de los Reales Sitios finalizaba en El Escorial, y durante estancia invernal de la corte en el palacio de El Pardo no había representaciones operísticas:

La temporada de El Escorial terminaba en diciembre. Luego se iba el Rey a El Pardo, en donde pasaba el resto del invierno. Y como allí no había teatro ni acomodo suficiente, claro es que los cantantes tenían que aguardar en Madrid la venida de la primavera y el traslado consiguiente a Aranjuez ${ }^{135}$.

\footnotetext{
${ }^{132}$ En el Archivo General del Palacio Real de Madrid se conservan numerosos documentos de interés musical sobre estas fiestas que merecerían un estudio pormenorizado. AGP, Carlos III, legs. 38,48 y 50 .

133 AHN NOBLEZA OSUNA-CARTAS, leg 416-2.

${ }^{134}$ Ibid., leg 414-12/10.
} 
Los documentos de la Casa de Osuna también confirman que la Compañía de Ópera de los Reales Sitios no interrumpió sus actuaciones después en 1771, para reanudarlas en 1776 como se había mantenido hasta el momento. La hipótesis de esta supuesta suspensión de las representaciones fue formulada por Cotarelo y Mori $^{136}$ y asumida mas recientemente por Stiffoni, basándose en la inexistencia de libretos que acreditasen las representaciones después de 1771:

La representación de ópera italiana en los Reales Sitios parece interrumpirse por cinco años a partir de 1771. No hay documentos ni libretos que nos confirmen ninguna puesta en escena durante estos años. Sin embargo en 1776 se estrena un nuevo dramma giocoso, La sposa fedele. El libreto impreso nos señala a Pietro Guglielmi como autor de la música ${ }^{137}$.

La participación del Duque de Osuna como accionista en las temporadas de ópera de los Reales Sitios entre 1773 y 1776 demuestra que, aunque por el momento no dispongamos de datos sobre el repertorio que se interpretó en esas temporadas, la compañía de los Teatros de los Reales Sitios continuó funcionando regularmente al menos hasta el final de la temporada de 1776.

\footnotetext{
135 Cotarelo, Orígenes, p. 207.nota 1.

136 Ibid., pp. 204-205.

${ }^{137}$ Stiffoni, "La ópera”, p. 333.
} 


\section{Teatro musical en los palacios de la Casa de Benavente (1744-1790)}

María Faustina Téllez Girón $(* 1724-\uparrow 1797)$, hija primogénita del VII Duque de Osuna, casada desde 1738 con Francisco Alfonso Pimentel, ha pasado a la historia con el título de Condesa-Duquesa (viuda) de Benavente dignidad que ostentó como consorte a partir de 1743, cuando su marido fue titulado XIV Conde y XI Duque de Benavente. Su afición a la música, y su interés por los espectáculos teatrales fueron una lógica continuación deudora de la tradición del linaje de los Osuna, que ella recibió a través de su padre José Téllez Girón ${ }^{138}$.

La Condesa-Duquesa María Faustina se formó musicalmente con destacados maestros de origen italiano como Giovanni Battista Mele, José Antonio Moroti o Luigi Marescalchi ${ }^{139}$. Esta formación italianizante debió de influir notablemente en sus preferencias estéticas, y en su política de mecenazgo musical que, tuvo como actividad central la producción de espectáculos de teatrales para una minoría selecta que acudía las funciones que tenían lugar en su palacio de Madrid.

Las representaciones teatrales organizadas por María Faustina Téllez Girón se desarrollaban en el llamado teatro o coliseo de su palacio de Madrid que estaba ubicado en la calle de Segovia muy cerca del Palacio Real, y que ocupaba

\footnotetext{
${ }^{138}$ Sobre las funciones teatrales domésticas véase Pablo Jauralde Pou. "El Teatro en los Palacios", Teatro. Revista de Estudios Teatrales 1 (1992), pp. 33-56.

${ }^{139}$ Véase el Capítulo III.
} 
la manzana $n^{\circ} 132$ según la numeración de la planimetría geométrica de Tomás López de 1785 (Lámina 31) ${ }^{140}$.

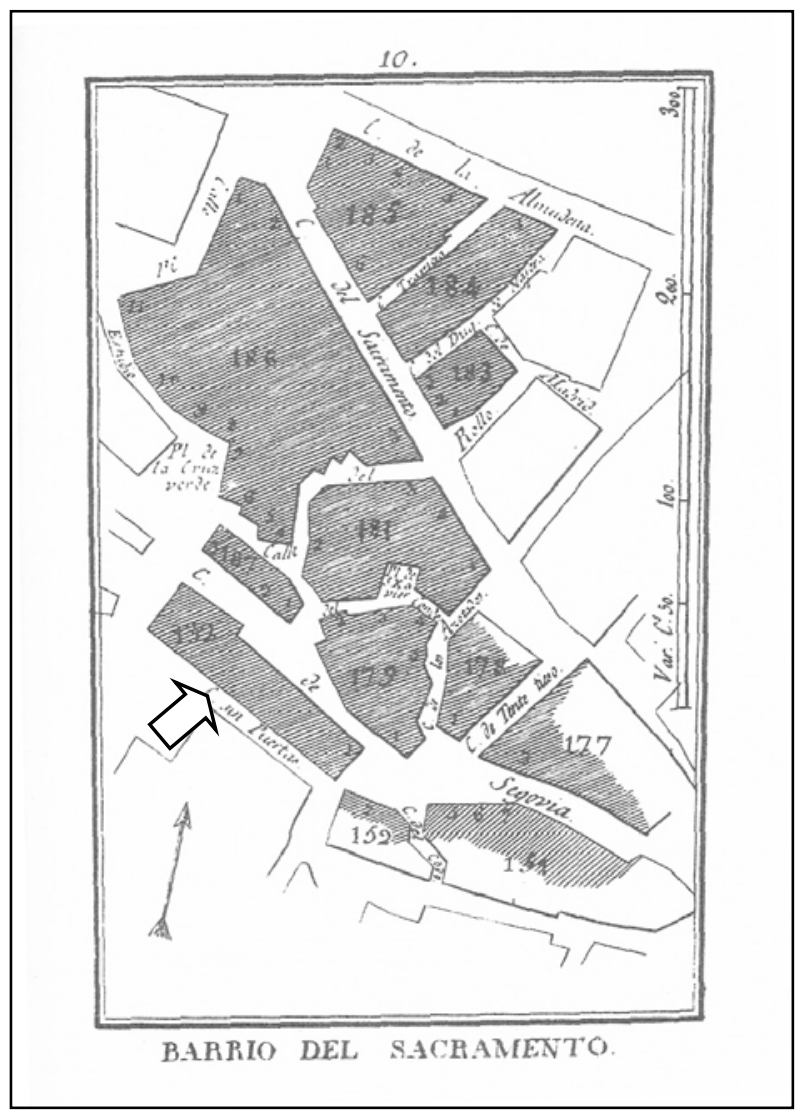

Lámina 31.

Situación del Palacio de los Condes-Duques de Benavente en la calle Segovia de Madrid. ${ }^{141}$

140 Tomás López, Plano geométrico de Madrid dedicado y presentado al rey nuestro señor Don Carlos III por mano del Excelentísimo señor Conde de Floridablanca (Madrid [s.1], 1785). Sobre la situación de los Palacios de las Casas de Osuna y Benavente véase también Planos de Madrid de los siglos XVII y XVIII, introducción, reseña y estudio por Miguel Molina Campuzano (Madrid: Instituto de Estudios de Administración Local, 1960), pp.775, 783-784.

${ }^{141}$ Para una mayor claridad en la ubicación del palacio he tomado la imagen del plano de Fausto Martínez de la Torre y Josef Asensio realizado en 1800 en el que se mantiene la numeración de manzanas y ubicación de los edificios de la planimetría geométrica de Tomás López. Véase Fausto Martínez de la Torre y Josef Asensio, Plano de la villa y corte de Madrid (Madrid: Imprenta de don Joseph Doblado, 1800), Lámina 10. 
El supuesto teatro privado de la Condesa-Duquesa viuda de Benavente, al que se ha venido aludiendo hasta la fecha, era en realidad una sala de su palacio de la calle Segovia acondicionada con un escenario provisional y decorada convenientemente para cada representación. La construcción de los "tablados" o escenarios se encargaba a los tramoyistas y escenógrafos que trabajaban en ese momento en los teatros públicos de Madrid.

Los abundantes recibos conservados por gastos de construcción de “teatricos", y "tablados" en el palacio de la Condesa-Duquesa viuda de Benavente demuestran que no existía un teatro particular permanente como han mantenido algunos investigadores. Miguel Angel Marín señalaba recientemente que el teatro de la Condesa-Duquesa fue construido en $1771^{142}$, pero el documento que cita como fuente, no es más que uno de los muchos que figuran en el archivo administrativo de la Casa de Osuna que reflejan la construcción de un teatro provisional para unas funciones celebradas en ese año.

Mencionaré a continuación algunos ejemplos, de entre los muchos que podrían citarse, que ponen en duda la existencia de un teatro estable en la residencia madrileña de la Condesa-Duquesa de Benavente María Faustina.

En 1759, M ${ }^{\mathrm{a}}$ Faustina Téllez Girón, contrató al "maestro teatrista". Manuel Avecilla para construir un "teatrico" que se acomodase en un salón de su casa. Este pequeño escenario contaba con "un vestuario que se hizo a un lado con un cerco de maderos" y "una escalera portátil para bajar de la altura del tablado".

\footnotetext{
142 Miguel Ángel Marín, “La zarzuela Clementina di Luigi Boccherini”, en Ramón de la Cruz: Clementina, introducción de María Grazia Profeti y Miguel Ángel Marín, texto crítico, tradución y notas de Nicoletta Lepri (Firenze: Alinea Editrice,: 2003), p. 22.
} 
El teatro se conservó al menos hasta 1763 cuando se encargó al mismo maestro una remodelación ${ }^{143}$.

Gerónimo Avecilla (probablemente familiar de Manuel Avecilla) que era tramoyista de los Coliseos de la Corte, recibió en 1771 el encargo por parte de "la Condesa-Duquesa de Benavente viuda", es decir de María Faustina Téllez Girón, de construir un teatro "para que sirviese en el cuarto bajo de su casa "en la Tragedia titulada la Zayda, que se representó en ella el mes de abril de este año”. La Condesa-Duquesa pagó también los jornales de los mozos que asistieron como tramoyistas "en las noches de los ensayos y diferentes noches en que se repitió [la función]"144. Este recibo fue el que citó Miguel Ángel Marín para justificar la construcción del teatro. ${ }^{145}$

Las funciones organizadas por la Condesa-Duquesa viuda de Benavente en la segunda mitad del siglo XVIII eran célebres en Madrid por la riqueza de los materiales empleados y por la asistencia de los personajes principales de la alta sociedad madrileña, como señalaba Ramón de la Cruz:

La magnificencia de dicha Señora Excelentísima en sus funciones, y la numerosa concurrencia a ellas de todos los cuerpos más ilustres, más elevados y más instruidos, nacionales y extranjeras son bien notorias ${ }^{146}$.

\footnotetext{
143 AHN NOBLEZA, OSUNA-CARTAS leg 1516-5.

144 AHN NOBLEZA, OSUNA-CARTAS, leg 413-27. La condesa de Yebes, interpretó erróneamente este documento, y citó como tramoyista a Francisco Antonio González de Miranda, Tesorero General de la Condesa-Duquesa. Véase Condesa de Yebes, La Condesa-Duquesa de Benavente. Una vida en unas cartas (Madrid: Espasa Calpe, 1958), p. 98.

145 Marín, "La zarzuela", p. 22.

146 Ramón de la Cruz, Teatro o colección de los sainetes y demás obras dramáticas (Madrid: Imprenta Real, 1786-1791), vol. V, pp. IV-V.
} 
La música solía ocupar un papel fundamental en las funciones domésticas de la Condesa-Duquesa. Los propios miembros de la "familia"147 participaron habitualmente como actores y cantantes en comedias, zarzuelas o tonadillas que se encargaban expresamente para ser estrenadas en estas funciones domésticas o se adaptaban del repertorio de los teatros públicos para facilitar su representación palaciega por aficionados.

\subsection{Teatro musical en el Palacio de los Condes-Duques de Benavente entre} 1744 y 1756

Las escasas fuentes de interés musical de la primera mitad del siglo XVIII relacionadas con la Casa de Benavente que se conservan en la documentación administrativa de la Casa de Osuna, impiden una evaluación objetiva de la importancia que tuvieron los espectáculos de teatro musical privados organizados por esta familia en sus palacios antes de 1780. Algunos documentos del archivo muestran, sin embargo, que desde los primeros años en que María Faustina Téllez Girón y su marido ocuparon la titularidad de la Casa de Benavente se representaron en sus palacios varias obras de teatro musical bajo su patrocinio.

La primera noticia que he podido documentar de la realización de un espectáculo de teatro musical en la residencia de los Benavente durante el siglo XVIII es la representación de la zarzuela Las Nuevas Armas de Amor, que fue puesta en escena el 19 de abril de 1744. Juan Bautista Mele, "maestro

\footnotetext{
147 La familia de la casa incluían además de los propios nobles y de sus familiares directos, las damas de compañía, gentilhombres, mayordomos y otros personajes allegados a la noble en cuestión.
} 
compositor", que trabajaba al servicio de la Casa de Benavente como profesor de música de la Condesa-Duquesa María Faustina, se encargó de cobrar los gastos de esta función, pero no consta quienes fueron los autores de la música ni del texto $^{148}$.

El 10 de noviembre de 1755 se pagó al violinista y compositor José Herrando la copia de la música y letra, impresión y encuadernación de libros de la Serenata de Indimión y Diana, [sic] realizada para "la Excelentísima Señora Condesa de Benavente" es decir para María Faustina Téllez Girón, que actuó como mecenas y productora de esta obra. A la citada Serenata que se representó en fecha posterior al documento de pago en el palacio de los Condes-Duques de Benavente, debió de asistir abundante público a tenor de los trescientos ejemplares de la letra que se imprimieron "en papel fino" y se encuadernaron "en papel dorado" $"$. La obra en cuestión, cuyo título correcto es Endimión y Diana, podría ser la Serenata del mismo título que se cantó en el Real Coliseo del Buen Retiro en 1749 por Ana Peruzzi, Francisco Giovannini, Isabel Uittini y María Heras, y cuya música había sido compuesta por Juan Bautista Mele, músico vinculado a la Casa de Benavente ${ }^{150}$.

La serenata Endimión y Diana que se representó en 1755 en el palacio de los Condes-Duques de Benavente fue interpretada en sus papeles vocales al menos por cuatro mujeres y constaba de una obertura y varios recitados y arias. La parte

\footnotetext{
148 AHN NOBLEZA, OSUNA-CARTAS leg 414-11/1. Según Cotarelo una zarzuela en dos jornadas con este mismo título se estrenó en 1711. Tenía texto de José de Cañizares y música Sebastian Durón. Cotarelo, Historia, p.886.

149 AHN NOBLEZA, OSUNA-CARTAS leg 389-29. Recibo del 27 de Octubre de 1756.

${ }^{150}$ Cotarelo, Origenes, p. 140.
} 
instrumental contó con cuatro violines, dos oboes, dos trompas, viola, bajo y dos claves. Uno de los dos clavecinistas parece que hizo de director pues se encargó para él una copia de "toda la fiesta en partitura con todos los instrumentos y obertura" 151

Esta misma obra u otra similar también calificada como "Serenata" se representó en el palacio de los Condes-Duques de Benavente el día 16 de octubre de 1756. El violinista José Herrando cobró de la tesorería de la Casa 527 reales de vellón que distribuyó entre los músicos que concurrieron a tocar en dicha función ${ }^{152}$.

\subsection{Obras de teatro musical en español escritas para las funciones privadas organizadas por María Faustina Téllez Girón (1781-1787)}

La producción de espectáculos dramático-musicales privados patrocinados por la Casa de Benavente tuvo una de sus épocas más prolíficas en la década de 1780. En este período se representaron en el palacio de la Condesa-Duquesa viuda de Benavente varias obras musicales con texto en español que se habían encargado expresamente para las funciones o se adaptaron del repertorio de los teatros públicos. Para estas representaciones dramático-musicales Ramón de la Cruz escribió, al menos, tres obras: la comedia El día de campo, cuya música fue compuesta por Blas de Laserna, la zarzuela o "comedia con música" en dos actos El Extranjero con partitura el italiano Giuseppe Ponzo y la comedia o zarzuela Clementina con música de Luigi Boccherini. El dramaturgo Leandro Fernández de

\footnotetext{
${ }^{151}$ AHN NOBLEZA, OSUNA-CARTAS leg 389-28. Ver Apéndice 6, nº 15. ${ }^{152}$ Ibid.
} 
Moratín, escribió también para las funciones para la Condesa-Duquesa viuda de Benavente la zarzuela El Barón que fue puesta en música por José Lidón. Esta obra no llegó nunca a representarse en su versión musical, y posteriormente fue reelaborada por Moratín para ser estrenada como comedia.

El dramaturgo Ramón de la Cruz $(* 1731-\dagger 1794)$, fue uno de los principales introductores de la temática popular en el teatro en español de la segunda mitad del siglo XVIII. El estudio de su prolífica obra es fundamental para el conocimiento de la evolución de los géneros dramático-musicales en español. En una buena parte de sus obras dramáticas la música juega un papel fundamental. Los sainetes, que contienen abundante música incidental, las comedias con música o las zarzuelas, presentaban una alternativa a la ópera italiana seria y al alambicado gusto neoclásico.

Aunque sus obras fueron descalificadas por los dramaturgos neoclásicos por su carácter costumbrista y populachero, Ramón de la Cruz siempre gozó de la protección de destacados personajes de la aristocracia, que defendían un acercamiento al género popular. La Condesa-Duquesa viuda de Benavente y su hija María Josefa estuvieron entre sus principales mecenas y, al menos en los últimos años de su vida, Ramón de la Cruz recibió un sueldo de 6 reales al día de la Casa de Benavente. Después de la muerte del dramaturgo en 1794 su viuda Margarita Magán y su hija María de la Cruz continuaron percibiendo esta cantidad en concepto de limosna ${ }^{153}$.

153 AHN NOBLEZA, OSUNA-CARTAS leg 413-18, 462 y 467. Véase también Cotarelo, Don Ramón, pp. 212-213 y pp. 230-231. 
Cuando en 1784 Ramón de la Cruz decidió iniciar la publicación de los diez tomos de su Teatro o colección de los sainetes y demás obras dramáticas los principales subscriptores fueron miembros de las Casas de Osuna y Benavente que se quedaron con una importante parte de la tirada de la obra ${ }^{154}$.

Como fruto de la relación de mecenazgo de Ramón de la Cruz con la Casa de Benavente nacieron diversas obras teatrales que se representaron en la Casa de la Condesa-Duquesa viuda de Benavente. Algunas de ellas eran tan breves y divertidas como el siguiente juguete dramático que el dramaturgo compuso para que fuera interpretado por los dos nietos de la Condesa-Duquesa:

Comedia escrita por DON RAMÓN DE LA CRUZ CANO Y OLMEDILLA (entre los Arcades de Roma Larisio Dianeo), para que la representen el Excelentísmo Señor Marqués de Peñafiel y su hermano el Príncipe de Anglona, en presencia de su abuela materna la Excelentísima Señora Condesa viuda de Benavente y Gandía, siendo dichos señores de tierna edad.

Loa

$1^{\circ}$ Noble y discreto auditorio oid una función muy larga.

$2^{\circ}$ Pero que tampoco es buena.

$1^{\circ} \mathrm{Y}$ basta de loa.

$2^{\circ}$ Basta.

Comedia. Jornada $1^{a}$

$1^{\circ}$ ¿Juanillo?

$2^{\circ}$ ¿Qué me mandáis?

\footnotetext{
${ }^{154}$ De la Cruz, Teatro, vol I, pp. VII-XX. En la relación de subscriptores figuran (además de otros personajes de la alta nobleza) la Condesa-Duquesa viuda de Benavente y su hermano el VIII Duque de Osuna con sendas subscripciones por 12 ejemplares; los Condes- Duques de Benavente, y Marqueses de Peñafiel (María Josefa y Pedro de Alcántara) con doce ejemplares cada uno y la Duquesa de Osuna con 4 ejemplares. También se suscribieron a un volumen los mayordomos de la Casa de Benavente Juan de Gamboa y Antonio Azpeitia.
} 
$1^{\circ}$ Ya no me acuerdo de nada.

$2^{\circ}$ Pues después me lo diréis, en la segunda jornada.

Jornada $2^{a}$

$2^{\circ}$ ¿Os acordáis ya de aquello?

$1^{\circ}$ Tengo la memoria flaca.

$2^{\circ}$ ¿Y las piernas?

$1^{\circ}$ No.

$2^{\circ}$ Pues vamos a darnos cuatro patadas.

\section{Jornada $3^{a}$}

$1^{\circ}$ ¿Qué hora será?

$2^{\circ}$ Media noche.

$1^{\circ}$ Pues vámonos a la cama.

$2^{\circ} \mathrm{Y}$ aquí acaba la comedia.

\section{LOS DOS}

Perdonad sus muchas faltas ${ }^{155}$

Además de estos pequeños entretenimientos domésticos, la protección de la familia Benavente a Ramón de la Cruz se materializó en el encargo de los textos de tres obras musicales que fueron producidas y escenificadas en la residencia de la Condesa-Duquesa viuda de Benavente.

\subsubsection{El día de Campo de R. de la Cruz y Blas de Laserna (1781)}

En agosto de 1781, María Faustina Téllez-Girón organizó en su palacio una función para celebrar el cumpleaños de su hermano Pedro Zoilo, VIII Duque de Osuna. Para esta ocasión Ramón de la Cruz adaptó su comedia en dos actos $E l$ día de campo para que fuera representada por "las damas y familia de $\mathrm{Su}$

\footnotetext{
${ }^{155}$ Original conservado en la BNE (Papeles Barbieri). Citado en Cotarelo, Don Ramón, pp.213.
} 
Excelencia [la Condesa-Duquesa viuda de Benavente y Gandía] que la desempeñaron con la mayor gracia, viveza y propiedad"156. La comedia se había estrenado el 9 de julio de 1781 en el Teatro del Príncipe de Madrid por la compañía de Joaquín Palomino $^{157}$. Algunos de los intérpretes que figuran en el reparto de esta función doméstica pueden identificarse con la familia y los miembros de la corte y la administración de la Casa de Benavente: como [Manuel de] Ascargorta, administrador general de la Casa, las damas de la CondesaDuquesa Pabla [Paula Gozani], Dionisia [Ruiz] y Pedro [Gil de Tejada] un personaje habitual en las tertulias de los Benavente, que fue retratado por Goya ${ }^{158}$. Una copia de los materiales musicales de El día de campo se conserva en la Biblioteca Histórica Municipal de Madrid $^{159}$. La música de esta comedia es de Blas de Laserna, músico que en esos años trabajaba al servicio de la Condesa-

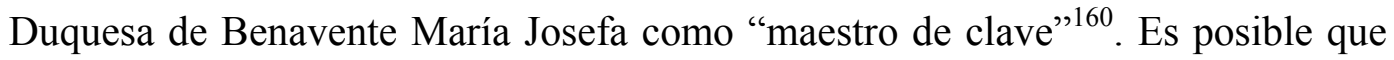
en las representaciones de El día de campo se incluyeran también las tonadillas de Laserna La Beata y la que comienza con los verso Quien me dará un remedio que en una fecha muy cercana a dicha función doméstica se copiaron transportadas a una altura más grave para facilitar su interpretación por aficionados $^{161}$.

\footnotetext{
${ }^{156}$ De la Cruz, Teatro, vol I, pp.265.

${ }^{157}$ BMM Tea 1-164/18. Citado en Cotarelo, Don Ramón, p. 263.

${ }^{158}$ Ibíd.

159 BMM Mus 69-10.

${ }^{160}$ Ver Capítulo III.

${ }^{161}$ BNE Ms 14.016.3/26 (Papeles Barbieri). Recibo de 1 de Noviembre de 1781. Citado en Subirá, La Tonadilla, vol. I, p.265.
} 
Aunque José Subirá calificó El día de campo como "zarzuela"162, dado el predominio de las escenas habladas sobre los números musicales parece más adecuado considerarla como una comedia con música. El primer acto sólo tiene cuatro intervenciones musicales, dos números individuales a modo de aria o cavatina, un dúo y un baile con "un solo de violín que toca el Guarda" y en el que cuatro personajes bailaban seguidillas mientras uno cantaba y tocaba la guitarra. En el segundo acto las intervenciones musicales se limitan a un dúo, un terceto y al coro final que cierra la obra con unos versos alusivos a la celebración de la onomástica del Duque de Osuna ${ }^{163}$.

\subsubsection{El extranjero de Ramón de la Cruz y Giuseppe Ponzo (1785)}

Ramón de la Cruz escribió también para la Condesa-Duquesa viuda de Benavente el libreto de la "comedia con música en dos actos" El extranjero, que se representó "varias veces en el teatro de casa de Su Excelencia [la CondesaDuquesa viuda de Benavente] por su familia, y después en el Coliseo del Príncipe por los cómicos de la compañía de Eusebio Ribera"164. Según Cotarelo, las funciones públicas de $\mathrm{El}$ extranjero fueron interpretadas por las mujeres de la compañía de Ribera entre el 28 de enero y el 9 de febrero de 1786, corriendo todos los gastos por cuenta de la Condesa-Duquesa viuda de Benavente ${ }^{165}$.

\footnotetext{
162 Subirá, La Tonadilla, vol. I, pp. 264-265.

163 Cotarelo, Don Ramón, p. 263

164 De la Cruz, Teatro, vol II, p..234.

165 Cotarelo, Don Ramón, p. 268.
} 
En las representaciones domésticas de El extranjero también participaron, como era habitual, los miembros de la "familia" de la Casa de Benavente. Algunos nombres que figuran en los materiales literarios pueden identificarse con los miembros de la corte nobiliaria y la administración de la Casa (Tabla 26) ${ }^{166}$.

Tabla 26.

Intérpretes de la zarzuela El Extranjero en las funciones celebradas en el palacio de la Condesa-Duquesa viuda de Benavente (1786)

Fuentes: BMM: Mus 48-2 y Tea 1-110/8

\begin{tabular}{|l|l|}
\hline \multicolumn{1}{|c|}{ PERSONAJE } & \multicolumn{1}{c|}{ INTÉRPRETE } \\
\hline Doña Leonor, & María \\
\hline Doña Pascuala, su cuñada & Paula [Gozani] \\
\hline Paquilla. & Dionisia [Ruiz] \\
\hline Rosa & Lucía [Gilabert] \\
\hline Don Alberto & [Manuel de] Ascargorta \\
\hline Don Plácido & Juan Marcolini \\
\hline Don Rodolfo & Francisco “Portugués” \\
\hline Don Rodrigo & Bernabé \\
\hline Pepín & Antonio [¿Plaza?] \\
\hline Un escribano & No consta \\
\hline
\end{tabular}

Según figura en la edición del Teatro o colección de los sainetes de Ramón de la Cruz, el autor de la música de El extranjero fue el "célebre maestro Don Antonio Ponzo, siciliano" Sin embargo en los materiales musicales y

\footnotetext{
${ }^{166}$ La relación de personajes que cita Miguel Angel Marín es incompleta. Al utilizar únicamente la fuente musical olvida incluir aquellos papeles que sólo eran representados. Véase Marín, Clementina, p.28.
} 
literarios de esta obra que se conservan en la Biblioteca Histórica Municipal de Madrid, aparece como compositor José Ponzo ${ }^{167}$. Ambos nombres parecen corresponder al compositor de origen napolitano Giuseppe Ponzo, que mantuvo una estrecha vinculación con la Casa de Benavente durante su estancia en España $^{168}$.

Aunque la zarzuela El extranjero aparece con el subtítulo de "comedia con música" en la edición de Ramón de la Cruz, se trata de una obra que posee todas las características de la zarzuela costumbrista de la segunda mitad del siglo XVIII, y como tal fue clasificada por Emilio Cotarelo y Mori ${ }^{169}$. Esta variabilidad en la terminología es un ejemplo más de la habitual indefinición con que se han clasificado las obras escénicas en español que alternan partes cantadas y habladas, especialmente en las obras escritas entre último tercio del siglo XVIII y la primera mitad del siglo XIX.

El primer acto de El extranjero comienza y finaliza con un número de conjunto musical como es habitual en la zarzuela costumbrista (un coro inicial y un final a 5 respectivamente). El resto del acto se completa con las habituales arias y cavatinas de cada uno de los personajes y dos dúos. El segundo acto continúa con la sucesión de números individuales y se cierra con el coro final en el que intervienen todos los personajes característico también de la zarzuela española.

\footnotetext{
167 BMM Mus 48-2 y BMM Tea 1-110-8. De estas dos fuentes proceden todos los ejemplos musicales y literarios de El extranjero obra que se transcriben en reproducen en als siguientes a continuación.

168 Los principales datos biográficos de Giuseppe Ponzo se recogen en el Apéndice 5.

${ }^{169}$ Cotarelo, Historia, p.149.
} 
La obra tiene varios números de estimable calidad musical. Entre ellos destaca la interesante aria con violín obligado, Oíd los trinos suaves que canta el personaje Don Plácido en la Escena V del Acto Segundo. Este número requiere un intérprete excepcional capaz de cantar un aria que incluye en recitativo acompañado, y de tocar varios pasajes para violín solista de una considerable complicación técnica. A la hora de escribir este número tanto Ramón de la Cruz como Giuseppe Ponzo debieron de tener en mente a Juan Marcolini, violinista de la Real Capilla, que interpretó el papel de Don Plácido en las funciones realizadas en el palacio de la Condesa-Duquesa.

Antes de comenzar el aria, y para entretener a Doña Leonor, mientras espera a su hermano, Don Plácido toca un "capricho" para violín solo que dice haber compuesto en la noche anterior:

DOÑA LEONOR

Señor Don Plácido, si me enfada hasta el hablar.

\section{DON PLÁCIDO}

Pues no habléis

y dormid si os da la gana

que yo para entreteneros

a que estéis acompañada

voy a estudiar un capricho

que desvelado en la cama

me ocurrió esta noche solo

por no alborotar la casa

no pedí luz y en camisa

lo escribí sobre la marcha oid, o no le oigáis, por eso

no me pongáis una cara

que siendo linda parece

que se la pedís prestada

a una fea para mí.

DOÑA LEONORA

La aprensión es bien extraña

(se sonrie)

Qué loco sois.

DON PLACIDO

Venturosa mi locura, si lograra

calmar vuestras pasiones

por el oído las ansias. 
Después de estos versos, Don Plácido comienza a tocar el citado “capricho", una pieza para violín solo que fue compuesta para lucimiento de Juan Marcolini ${ }^{170}$. Una vez finalizado el solo de violín, se inicia un aria en la que alternan las intervenciones cantadas de Don Plácido con evocaciones descriptivas interpretadas por el propio personaje con el violín. El aria se abre con los siguientes versos:
Oíd los trinos suaves
que imitan de las aves
al descubrir el día
la dulce algarabía
y el gozo universal.

Tras esta estrofa, Don Plácido interpreta en el violín un pasaje en el que se evoca el canto de los pájaros al amanecer con una melodía en la región más aguda del violín (Ejemplo musical 6).

\footnotetext{
${ }^{170}$ En el guión musical de El extranjero (BMM Mus 48-2) figura también otra pieza para violín solo de una dificultad técnica menor que posiblemente fuera interpretada en alguna de las funciones públicas de esta obra.
} 


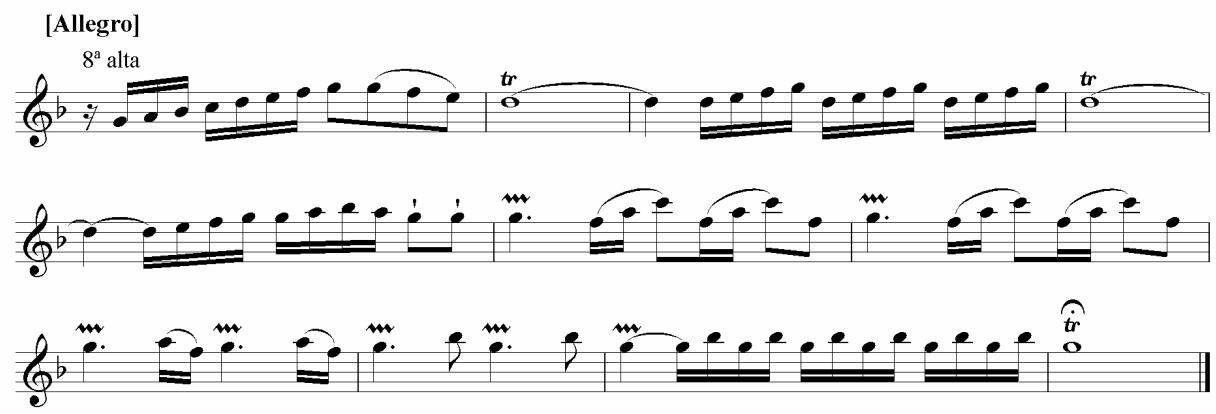

Ejemplo musical 6.

Giuseppe Ponzo, El extranjero.

Fragmento del aria de Don Plácido Oíd los trinos suaves.

Segundo Acto. Escena quinta. cc. 82-93.

(BMM Mus 48-2)

Cuando Don Plácido finaliza esta intervención, y en vista de que Doña Leonor no se ha animado aún, decide continuar con otra evocación musical de carácter bucólico:

(representado)

Decid Leonor qué tal.

¿Aún no se alivia el mal?

(Canta)

Oíd cual finge el río

el instrumento mío

corred precipitado

y lento ya en el prado

seguir con paso igual.

El fluir del río al que alude el texto se representa musicalmente con un pasaje rápido en semicorcheas y enlaza con otro con valores más largos que evoca la llegada del río al prado, donde su cauce se desliza con mayor sosiego (Ejemplo musical 7 ). 

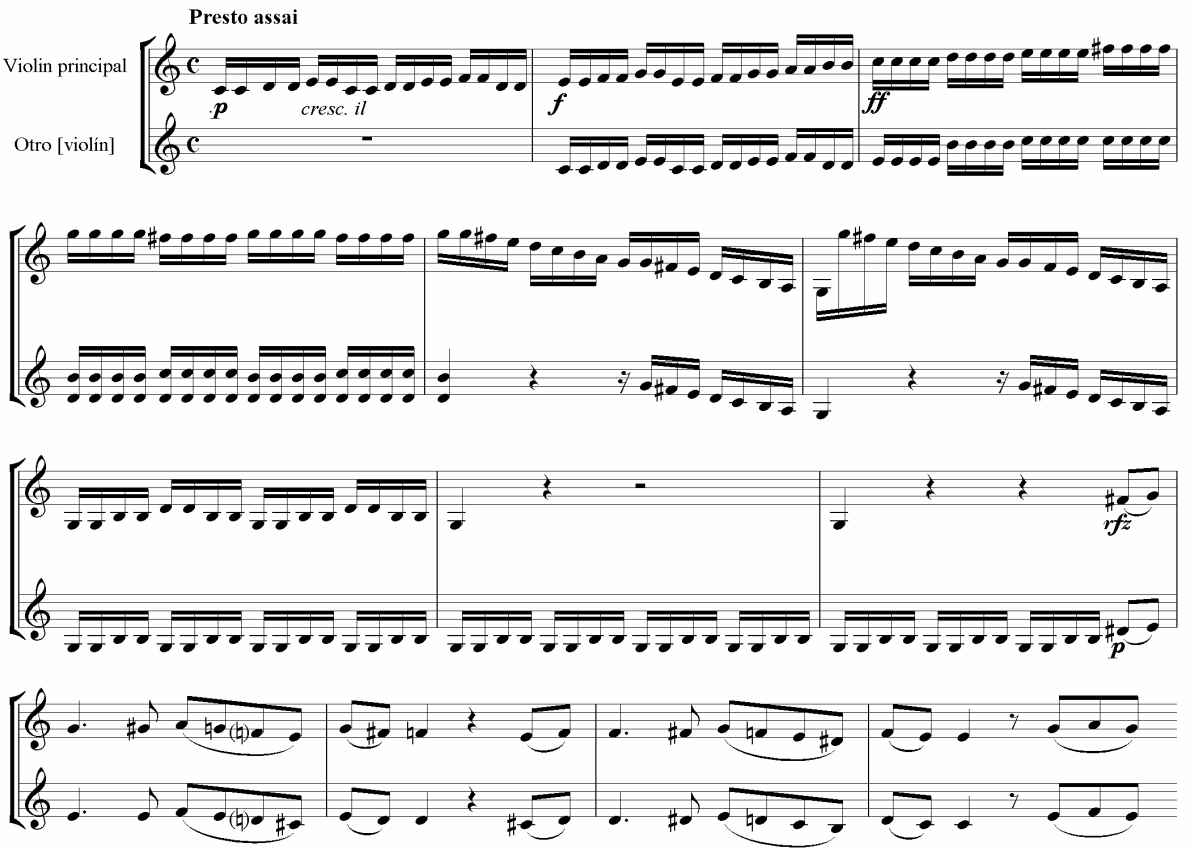

Ejemplo musical 7.

Giuseppe Ponzo: El extranjero.

Fragmento del aria de Don Plácido. Oíd los trinos suaves.

. Segundo Acto. Escena quinta. cc. 99-111

(BMM Mus 48-2)

Don Plácido continúa tratando de confortar a Doña Leonor, y el aria finaliza con un pasaje del violín en el que se imita a un "mal templado instrumento [...] en manos de un zagal". Después de esta intervención del violín solista, el aria enlaza con una Pastorella en compás de seis por ocho en la que se incorpora toda la orquesta. Don Plácido, cansado de que Doña Leonor no se haya animado ni siquiera con su música, abandona el violín y canta para cerrar su intervención los siguientes versos: 
(recitado)

¿Aún gime usted y llora?

Ya que hacer no me queda.

Vaya con Dios señora

muérase como pueda que yo

no he visto tal.

(deja el violin y vuelve fuerte)

Pero vaya usted segura de que muere despreciada

sin quedar eternizada

para su gloria futura

a las grandes heroínas

en el siglo más famosas por

amables, por hermosas

petimetras y ladinas

en la lista general.

\subsubsection{Clementina de Ramón de la Cruz y L. Boccherini (1786)}

La zarzuela o comedia con música Clementina, es la tercera de las piezas dramático-musicales que Ramón de la Cruz escribió para las funciones privadas organizadas por María Faustina Téllez Girón, Condesa-Duquesa viuda de Benavente en su palacio. La música de esta obra se encargó a Luigi Boccherini, que desde ese mismo año era "director y compositor" de la formación instrumental que mantenía María Josefa Alfonso Pimentel, Condesa-Duquesa de Benavente $^{171}$. El estreno "doméstico" de Clementina tuvo lugar a finales de $1786^{172}$

La zarzuela Clementina ha recibido la atención de numerosos investigadores que se han ocupado tanto de los aspectos literarios como de los

\footnotetext{
${ }^{171}$ La música de la obra se conserva en BMM Mus 366-11. Existe otra copia de la música en la Staatsbibliothek de Berlin. Mus, ms autogr. Boccherini 1. Para una descripción de las fuentes musicales de Clementina véase Luigi Boccherini, Clementina. Revisión y adaptación del texto por Jacinto Torres Mulas. Transcripción musical por Antonio Gallego. (Madrid: Consorcio para la Organización de Madrid Capital Europea de la Cultura, 1992), pp.12-16.

172 De la Cruz, Teatro, vol. V, advertencia, p. I-II
} 
musicales ${ }^{173}$. Por tanto, no insistiré aquí en los aspectos particulares de esta zarzuela que ya han sido ampliamente estudiados. Sí precisaré, en cambio, algunos datos sobre la producción y puesta en escena de la obra, basados en documentos hasta ahora desconocidos $\mathrm{y}$ en otros que adquieren una nueva interpretación a la luz de la visión global sobre las funciones de teatro doméstico patrocinadas por la Casa de Benavente comentadas en apartados anteriores.

Las funciones domésticas de Clementina se representaron en el "coliseo de la Excelentísima señora Condesa-Duquesa viuda de Benavente" ${ }^{174}$, es decir en una de las salas del Palacio de los Condes de Benavente situado en la calle Segovia de Madrid, donde vivió María Faustina Téllez Girón, y no en el Palacio de la Puerta de la Vega, tal y como se ha mantenido hasta la fecha, que era el lugar de residencia de su hija María Josefa ${ }^{175}$.

La composición de Clementina estuvo subordinada a las normas dictadas por la promotora de la obra. La Condesa-Duquesa viuda de Benavente impuso el número de personajes que debían intervenir en la obra y, como era habitual, seleccionó a sus intérpretes "entre su familia y sus talentos y genios diversos", según aclaraba Ramón de la Cruz en la introducción de la edición de libreto:

La Clementina, que ofrece el autor al público, sólo se representó a fines del año de 1786 en el coliseo de la Excelentísima señora Condesa-Duquesa viuda de Benavente, de cuya orden la escribió en el corto término de un mes.

\footnotetext{
173 Antonio Gallego, “La «Clementina» de Boccherini”, RMS, 10/2 (1987), pp.633-639; Luigi Boccherini, Clementina; De la Cruz, Clementina, introducción de María Grazia Profeti y Miguel Ángel Marín, texto crítico, traducción y notas de Nicoletta Lepri, Firenze Alinea Editrice,: 2003. 174 De la Cruz, Teatro, pp, III

${ }^{175}$ Véase la introducción a este apartado.
} 
Sin embargo de esta precisión, y de sujetarse al número de personas que señaló Su Excelencia entre su familia y sus talentos y genios diversos, se propuso el lucimiento de todos, y alentó su idea a una pieza original en la fábula, en el orden y en enlace de las escenas patéticas con las festivas, sin faltar a las más rigurosas reglas del arte ${ }^{176}$.

El conocimiento de los intérpretes que iban a estrenar la obra permitió a Ramón de la Cruz y a Luigi Boccherini adaptar sus papeles a las capacidades dramáticas y musicales de cada uno de los personajes. Un ejemplo claro de esta “composición a medida” es el papel del maestro de música Don Lázaro, que fue interpretado por Pedro Garisuain, violinista y fagotista de la formación instrumental de la Condesa-Duquesa María Josefa. La elección de Garisuain para este rol fue un evidente gesto metateatral, que trataba de proporcionar mayor comicidad al personaje. A buen seguro los espectadores de estas funciones que conocían a Garisuain sabían interpretar la duplicidad de versos como los que reproduzco a continuación, en los que Don Lázaro alardeaba de su condición de buen profesor de música:

apuesto cinco duros, y apostara quinientos a que en Madrid... ¿qué es en Madrid?, en Italia, no hay maestro que en seis meses las tuviese aún enteradas de los principios; y ya no sólo conmigo cantan cualquier aire, sino que a simple vista le sacan

\footnotetext{
${ }^{176}$ De la Cruz, Teatro, pp. III-IV.
} 
y en no siendo muy difícil,

al clave se le acompañan ${ }^{177}$.

No tenemos datos precisos sobre la orquesta que intervino en las funciones privadas de Clementina, aunque es muy posible que en ella participasen instrumentistas de la formación que mantenía la Condesa-Duquesa de Benavente (hija de María Faustina) y que hasta diciembre de 1787 estuvo dirigida por el propio Boccherini. Miguel Ángel Marín realizó una reconstrucción de la plantilla de la orquesta que intervino en las funciones domésticas de Clementina en la que existen algunos errores y omisiones que preciso a continuación ${ }^{178}$ :

1. Marín supone que en las funciones de Clementina participaron todos los músicos que figuran en las nóminas de noviembre y diciembre de 1786 de la orquesta que mantenía María Josefa Alfonso Pimentel, (es decir la Condesa-Duquesa de Benavente y no su madre la Condesa-viuda de Benavente que fue la mecenas de la representación). Aun considerando la posible participación de una parte de los músicos asalariados de la hija, no existe constancia de cuales ni cuantos de ellos formaron parte de la agrupación instrumental que intervino en las funciones de Clementina.

2. La plantilla de la orquesta que presenta Marín está incompleta ya que la instrumentación de la obra requiere violines primeros y segundos, dos violas (pues existen divisis en las partes instrumentales), dos oboes

\footnotetext{
${ }^{177}$ De la Cruz, Clementina, p. 54.

${ }^{178}$ Marín, "La zarzuela", p. 23.
} 
que mutan a flautas, dos fagotes, y dos trompas ${ }^{179}$. Faltan por tanto al menos un fagot, y una viola, y quizá varios violines de refuerzo que se contratarían entre los músicos que colaboraban habitualmente con la Casa de Benavente, como ocurrió en las funciones organizadas por la Condesa-Duquesa María Faustina, en abril de ese mismo año ${ }^{180}$.

3. Marín incluye erróneamente a Pablo Vidal entre los segundos violines, aunque este instrumentista se dedicó siempre a la interpretación de instrumentos de cuerda grave ${ }^{181}$.

Como era habitual en las representaciones dramático-musicales de la época, entre el primer y el segundo acto de la función privada de Clementina (1786) se interpretó una tonadilla, quizá compuesta por el propio Bocherinni. En un recibo fechado el 29 de junio de 1787 que se pagó a Antonio Lázaro y Moreno, “por la copia de música para la Condesa de Benavente Madre”, figuran varias cantidades pagadas a este copista por un "pico de la comedia de la Clementina [...], la tonadilla de dicha comedia, una voz y bajo de dicha tonadilla [más] seis arias con todos [los]instrumentos [y] un aria mudada en dicha comedia para Antonio Plaza”, cantante que estaba al servicio de la Condesa-Duquesa María Josefa y que, a tenor de este documento, parece que también intervino en alguna de las funciones domésticas de Clementina ${ }^{182}$

\footnotetext{
${ }^{179}$ Véase la plantilla en Boccherini, Clementina, p. 24.

180 AHN NOBLEZA, OSUNA-CARTAS, leg 391-31.

181 Véase Capítulo III.

182 BNE Mss 14.016.3/189 (Papeles Barbieri).
} 


\subsubsection{El Barón de Leandro Fernández de Moratín y José Lidón (1787)}

El dramaturgo Leandro Fernández de Moratín, antagonista y crítico habitual de las obras de Ramón de la Cruz, participó también en un proyecto fallido destinado a ser representado en las funciones domésticas de la CondesaDuquesa viuda de Benavente. En 1787, Francisco Cabarrús, a la sazón ministro de hacienda de Carlos III, encargó a Moratín el libreto de una zarzuela en dos actos. La obra fue compuesta durante un viaje a Francia en el que Moratín acompañó a Cabarrús como secretario ${ }^{183}$. La zarzuela escrita por Moratín, titulada El Barón, fue una pieza de compromiso muy lejos de sus ideales estéticos tal y como expresaba el propio dramaturgo en una carta que escribió a Jovellanos el 9 de abril de 1787, poco antes de iniciar la escritura de la obra:

[...] En fin, libre ya de este grave asunto [la redacción del Diario de su viaje a Francia], voy a disputar la corona melodramática al poeta cuadrillero [Ramón de La Cruz] dura y repugnante ocupación en la cual me metió el mayor amigo de Vuestra Señoría. ${ }^{184}$;

En junio de 1787, Moratín había terminado la escritura del libreto de $E l$ Barón $^{185}$, y poco después debió de enviarla a Madrid donde la obra corrió de mano en mano y comenzó a alterarse su redacción original:

Una dilatada ausencia del autor dio facilidad a algunos para que apoderándose de ella trataran como a cosa sin dueño. Alteraron a su voluntad

\footnotetext{
183 René Andioc: “Une «zarzuela» retrouvée El Barón de Moratín”, Mélanges de la Casa de Velázquez, 1 (1965), pp. 289.

184 Citado en Andioc, “Une «zarzuela»”, p. 289.

185 Ibid.
} 
situaciones, versos, añadieron personajes, aumentaron o suprimieron donde les pareció varios trozos cantables, y la desfiguraron de un modo lastimoso. $^{186}$

El libreto de El Barón, con las "desfiguraciones" a las que se refiere Moratín fue el que utilizó José Lidón para componer los números musicales de la zarzuela. La versión espuria de El Barón se representó sin música en diversas funciones de aficionados y se llegó a estrenar en uno de los teatros públicos de Cádiz:

Con estas enmiendas, supresiones y apostillas la tomó a su cargo Don. Josef Lidón organista de la Capilla Real y compuso la música según pudo y supo. Entretanto cayó en poder de los que se llaman apasionados: juventud ociosa y alegre, y poco difícil en materias de gusto. Parecióles muy buena (como era de temer), la estudiaron a porfía, la representaron sin música en varias casas particulares, y por último, en el teatro público de Cádiz apareció mutilada y deforme.

La zarzuela El Barón no llegó a ponerse en escena en las funciones domésticas organizadas por la Condesa-Duquesa viuda de Benavente ${ }^{187}$, y cuando Moratín regresó a España en 1788 tuvo que convencer a José Lidón para que no intentase estrenar públicamente la obra:

Restituido el autor a su patria, vio la mala suerte que había tenido su obra, $\mathrm{y}$ una de las mayores dificultades que tuvo que vencer fue la de persuadir a su amigo Don Josef Lidón, a que diera por perdido el tiempo que había

\footnotetext{
186 Leandro Fernández de Moratín, Obras dramáticas y líricas de D. Leandro Fernández de Moratín, Tomo I, (París: Augusto Bobée, 1825), pp. 251.

${ }^{187}$ Ibíd.
} 
gastado en componer la música, y a que desistiera del empeño que tenía en que los cómicos se la cantaran ${ }^{188}$.

A la vista de lo sucedido durante su ausencia de España, Moratín decidió corregir y transformarla la zarzuela en una comedia suprimiendo "todo lo añadido por mano ajena, y todo lo cantable [y de este modo dar] a la fábula mayor verosimilitud e interés, a los caracteres más energía, y alterando el primer acto, y haciendo de nuevo el segundo, de una zarzuela defectuosa compuso una comedia regular" ${ }^{189}$. El Barón de Leandro Fernández de Moratín se estrenó finalmente en una nueva versión (sin música) el 28 de enero de 1803 en el teatro de la Cruz de Madrid $^{190}$,

De la versión original de El Barón, (1787) sólo se conoce hasta el momento un ejemplar manuscrito del libreto que fue dado a conocer por René Andioc en $1965^{191}$. Según este autor el ejemplar conocido se conserva en la Biblioteca de la Facultad de Teología de la Universidad de Granada (España) y procede del llamado Fondo Saavedra, que había sido propiedad de Juan Arias Saavedra, amigo personal de Gaspar de Jovellanos ${ }^{192}$ La música que José Lidón compuso para El Barón no se ha localizado hasta la fecha.

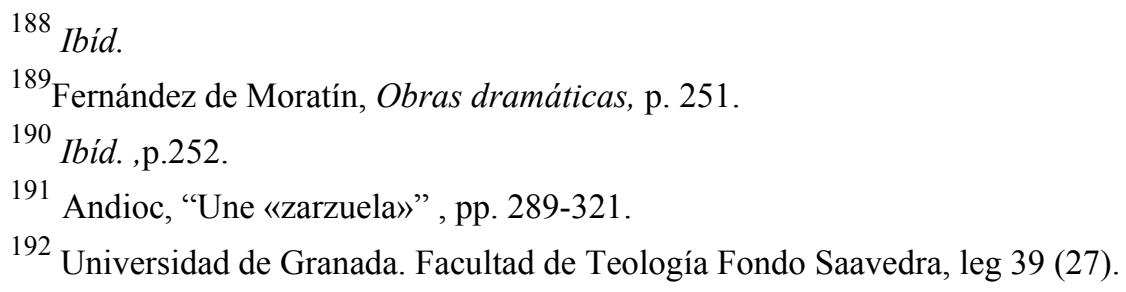




\subsection{Otras funciones domésticas con música celebradas en los palacios de los Benavente}

Las obras de teatro popular breve en español, que constituían gran parte del atractivo de las funciones teatrales para el público de la época, fueron también acogidas dentro de los espectáculos privados organizados por la Casa de Benavente, bien como complemento en los entreactos de las comedias y zarzuelas o como centro de las representaciones. A finales de 1782 o en los primeros días de 1783 María Faustina Téllez Girón, Condesa-Duquesa viuda de Benavente, organizó una representación de teatro musical, con la estructura habitual de las funciones que se desarrollaban en los coliseos públicos de Madrid. La representación comenzó con una loa, y continuó con una comedia con música que incluía una obertura instrumental. En los entreactos de la obra se intercalaron dos tonadillas y un sainete ${ }^{193}$. Durante este año de 1783 tuvieron lugar también otras funciones con música en el palacio de la Condesa-Duquesa de Benavente viuda. En el mes de abril de 1783 se representó la comedia con música Agradecer y no amar ${ }^{194} \mathrm{y}$ en el mes de julio del mismo año se interpretaron varios sainetes y tonadillas en los que intervinieron varios músicos contratados, entre ellos el violón José Vidal, hijo del violón Pablo Vidal ${ }^{195}$.

\footnotetext{
193 AHN NOBLEZA, OSUNA-CARTAS, leg 413-41. Recibo de copia de la música fechado el 15 de Enero de 1783.

194 AHN NOBLEZA, OSUNA-CARTAS, leg 389-30. Podría tratarse de la comedia del mismo nombre de Pedro Calderón de la Barca. Judith Ortega hizo referencia también a esta representación pero transcribió erróneamente su título como "Ayradeses y no amar". Véase Judith Ortega, "El mecenazgo musical de la Casa de Osuna durante la segunda mitad del siglo XVIII: el entorno musical de Luigi Boccherini en Madrid", RMS, XVII/ 2 (2004), p. 659.

195 AHN NOBLEZA, OSUNA-CARTAS, leg 389-30.
} 
En 1790 Tomás de Iriarte, personaje habitual del entorno cortesano de la Casa de Benavente, escribió la comedia El don de gentes para la CondesaDuquesa María Josefa. La obra se representó en el palacio de esta dama seguramente en el mismo año de 1790. Para cerrar las representaciones, Iriarte escribió también un "fin de fiesta" o zarzuela en un acto titulada Donde menos se piensa salta la liebre ${ }^{196}$ en cuya interpretación participó la propia CondesaDuquesa y varios miembros de su tertulia, como el militar Manuel Lapeña, o Pedro Gil [de Tejada], entre otros ${ }^{197}$. En uno de los entreactos de esta función se debió de interpretar la tonadilla a tres Donde menos se piensa el galgo salta la liebre con música de Blas de Laserna, que se conservaba en el archivo de música de la Condesa-Duquesa [3/287], [4/42] ${ }^{198}$.

\footnotetext{
${ }^{196}$ Emilio Cotarelo, Iriarte y su época. Estudios sobre la Historia del Arte Escénico en España (Madrid: Sucesores de Rivadeneyra, 1897), p.386.

${ }^{197}$ Ibid.

${ }^{198}$ Una copia de la música de esta tonadilla se conserva en BMM Mus 120-6.
} 


\section{Capítulo VII}

\section{El repertorio doméstico:}

La música instrumental y la música vocal

de cámara en las familias Osuna y Benavente

(1757-1844) 
El concepto Música de Cámara ha ido mutando paulatinamente su significado a lo largo de la historia. Durante el siglo XVIII y en las primeras décadas del siglo XIX, la expresión alemana Kammermusik, la inglesa Chamber Music, la italiana Musica da Camera, y su equivalente española Música de cámara, se utilizaron para definir a las obras musicales que, de acuerdo con el sentido etimológico del término "cámara", tenían una funcionalidad estrictamente doméstica.

Los teóricos europeos de las primeras décadas del siglo XVIII como Brossard (1703), Mattheson (1713) o Walter (1732), definieron Música de Cámara como sinónimo de la música vocal o instrumental de carácter profano que se interpretaba en las cámaras o aposentos de los grandes señores en contraposición a los otros dos grandes géneros, la música de iglesia y la música teatral ${ }^{1}$. La función doméstica de la música de cámara aparece también en la definición que Charles Burney redactó para la Cyclopaedia de Rees (1805). Para Burney, la Chamber Music era aquella que se interpretaba en salas pequeñas, por una formación de músicos poco numerosa y que estaba destinada a una audiencia también pequeña, lo que tácitamente suponía la exclusión de todas las obras musicales realizadas para la iglesia, el teatro o una gran sala de conciertos. Una descripción más precisa de las tipologías vocales e instrumentales que a finales del siglo XVIII se englobaban en la música de cámara es la que proporcionó el mismo autor en su General History of Music (1789). Según Burney dentro de la

\footnotetext{
${ }^{1}$ El concepto de "música de cámara" se utilizó también en España con el mismo significado e incluía tanto la música instrumental como la vocal. Por ejemplo en 1733, José de Cañizares trabajaba para el VII Duque de Osuna como gentilhombre "con el encargo de [escribir] la letra de la música de cámara". AHN NOBLEZA, OSUNA-CARTAS, leg 414.
} 
música de cámara se incluían las cantatas, las canciones o arias [single songs], la música para un instrumento, los tríos, los cuartetos y los conciertos y las sinfonías escritas para pequeños grupos [symphonies of few parts]. Esta diversidad tipológica aparece aún en algunas de las definiciones que se redactaron en las primeras décadas del siglo XIX. En el Dictionnaire de musique moderne (1828), Castil-Blaze clasificó como Música de cámara todas las piezas vocales e instrumentales "agradables" al oído y, reflejando la realidad musical de su época, citaba como ejemplos de repertorio camerístico las cantatas, madrigales, escenas líricas, canciones, cuartetos vocales, romanzas, boleros, barcarolas y nocturnos ${ }^{2}$.

En este capítulo utilizaré el concepto de Música de Cámara en su acepción etimológica y sociológica original, tal y como fue empleado a lo largo de todo el siglo XVIII y en las primeras décadas del XIX, que alude a la funcionalidad de un tipo de música que se realizaba básicamente para el consumo doméstico. Por consiguiente, incluiré en este apartado el estudio de todas aquellas obras profanas, vocales e instrumentales, que se interpretaron o fueron creadas en el entorno de las cortes nobiliarias y de los salones de las Casas de Osuna y Benavente, exceptuando únicamente aquellas que fueron objeto de representación escénica.

\footnotetext{
2 Christina Bashford, "Chamber Music", $N G$, vol. 5, pp. 434-448.
} 


\section{Los escenarios de la música instrumental y la música vocal de cámara: academias, bailes $\mathbf{y}$ fiestas}

La música de cámara fue cultivada en el ámbito doméstico de las Casas de Osuna y Benavente al menos desde el siglo XVI, como medio de entretenimiento y distracción para los titulares de la $\mathrm{Casa}^{3}$. En el siglo XVIII la música doméstica abandonó paulatinamente los espacios íntimos de las habitaciones de los nobles para convertirse en uno de los vehículos de sociabilidad que propiciaron la transformación de las rígidas costumbres cortesanas. Las academias o conciertos semipúblicos para una minoría selecta y los bailes privados domésticos y públicos, fueron los principales escenarios en los que se interpretó gran parte de la música de cámara que conformó el repertorio de las Casas de Osuna y Benavente durante los siglos XVIII y XIX.

\section{Academias y conciertos}

Las academias musicales que se celebraron en España a finales del siglo XVIII se enmarcan dentro del proceso de transformación de las relaciones sociales impulsadas por la Ilustración, una ideología que propició la valoración del ámbito privado y el inicio del cultivo de las relaciones entre personas de diferentes estratos socioculturales. En este contexto comenzaron a desarrollarse las reuniones o tertulias organizadas por instituciones ilustradas en sus sedes, como las Sociedades de Amigos del País, o por los miembros de la nobleza y la aristocracia (especialmente por las mujeres) en los salones de sus palacios. En estos espacios privados o semipúblicos, presididos por el lujo y la suntuosidad, se

\footnotetext{
${ }^{3}$ Véase Capítulo II.
} 
relacionaban personas de ambos sexos unidos por intereses comunes de ocio, culturales, políticos o económicos ${ }^{4}$.

La música fue uno de los principales atractivos de las reuniones sociales que se organizaron a partir de las últimas décadas del siglo XVIII en los salones de la alta nobleza de Madrid. La interpretación musical informal en el ámbito doméstico de las clases privilegiadas debió de ser algo habitual en esta época, tal y como relató el viajero inglés William Beckford a propósito de una visita realizada en diciembre de 1787 a la Duquesa de Berwick (tía abuela de Cayetana de Silva Álvarez de Toledo la futura Duquesa de Alba):

Madame de Berwick no ha perdido su amor por la música; por todo el apartamento yacen esparcidas partituras de óperas y sonatas, y no solamente partituras, sino también músicos de carne y hueso, pues tres de sus músicos, un paje y dos guapas señoras de honor estaban echados sobre la alfombra con languidez típicamente española, o mejor dicha morisca, listos para empezar a gorjear en cuanto ella hiciese una señal. ${ }^{5}$

Además de estas interpretaciones "espontáneas", en los salones de la nobleza madrileña se organizaron habitualmente academias o conciertos semipúblicos para una minoría selecta en los que participaban músicos profesionales junto a otros aficionados 6

\footnotetext{
${ }^{4}$ Sobre los salones ilustrados y la importancia que adquirieron las mujeres en esta nueva forma de sociabilidad véase Jean Sarrailh, La España Ilustrada en la Segunda mitad del siglo XVIII (México, Buenos Aires, Madrid: Fondo de cultura económica, 1957), pp. 111-121; y M Carmen Iglesias. "La nueva sociabilidad: Mujeres Nobles y Salones Literarios y Políticos", en Ma Carmen Iglesias (coord.), Nobleza y Sociedad en la España Moderna (Oviedo: Fundación Central Hispano y Ediciones Nobel,-1997), vol. 2, pp. 279-230.

${ }^{5}$ William Beckford, Un inglés en la España de Godoy (Cartas españolas), traducción y edición de Jesús Pardo (Madrid: Taurus, 1966), parte II, carta séptima, pp. 90-91.

${ }^{6}$ A este respecto es necesario aclarar que durante el siglo XVIII el término "academia" no se
} 
Desde las primeras décadas del siglo XVIII, los miembros de las Casas de Osuna y Benavente organizaron, en sus palacios urbanos y residencias de recreo, academias y conciertos privados o semipúblicos en los que intervenían los instrumentistas asalariados junto a otros músicos contratados al efecto y a los que se solía invitar a otros artistas españoles o extranjeros ${ }^{7}$. La presencia de afamados cantantes e instrumentistas en las academias que se celebraron en los palacios de las familias Osuna y Benavente fue una constante durante todo el siglo XVIII y XIX. Por sus salones pasaron los principales artistas que actuaron en las funciones de ópera y en los conciertos que se celebraron en los teatros de Madrid. Por ejemplo, la tiple Rosa Mancini, la cantante bufa Santa Marchesinni y el tenor Anibal Pio Fabri, entre otros, actuaron en recitales organizados por la VII Duquesa viuda de Osuna en su casa entre 1738 y $1739^{8}$. El famoso tenor Giovanni Manzuoli, actuó en una sesión musical que organizó María Faustina Téllez Girón XIV Condesa-Duquesa (consorte) de Benavente en su palacio de Madrid a finales de 1749 o a principios de $1750^{9}$. Entre los numerosos instrumentistas y cantantes que actuaron en las academias organizadas por María Josefa Alfonso Pimentel, XV Condesa-Duquesa de Benavente pueden señalarse al violinista Pierre Rode

refirió exclusivamente a la interpretación de música instrumental, sino a cualquier reunión "de profesores o aficionados a la música para ejercitarse en ella o por diversión”. Véase Diccionario de la lengua castellana compuesto por la Real Academia Española. Segunda impresión corregida y aumentada. (Madrid: Joaquín Ibarra, 1770), p. 30. En las academias musicales de las últimas décadas del siglo XVIII incluyeron también habitualmente piezas vocales operísticas. Véase,a demás de los datos presentados en este capítulo, Bernardo Illari. "Metastasio nel'indie", en Emilio Casares Rodicio y Álvaro Torrente (eds.): La ópera en España e Hispanoamérica, (Madrid: ICCMU, 2001), vol. I, p. 351.

${ }^{7}$ Véase, entre otros muchos, AHN NOBLEZA, OSUNA-CARTAS, leg 414.

8 AHN NOBLEZA, OSUNA-CARTAS, leg 413-37 y leg 413-44.

${ }^{9}$ Ibid., leg 379-40. 
que intervino en una velada musical organizada por esta dama en $1799^{10}$, y algunos de los cantantes españoles que desarrollaron importantes carreras internacionales como Lorenza Núñez Correa o Leandro Valencia ${ }^{11}$.

Las academias musicales que organizó María Josefa Alfonso Pimentel, XV Condesa-Duquesa de Benavente en los salones de sus residencias madrileñas de la Puerta de la Vega, de Aranjuez y de La Alameda, a partir de las últimas décadas del siglo XVIII, fueron uno de los principales entretenimientos de la alta sociedad que vivía en la capital al amparo de la Corte real ${ }^{12}$. Tomás de Iriarte, personaje habitual del entorno cortesano de la Casa de Benavente, dejó constancia en forma poética de la importancia que adquirió la música entre las actividades que gozaron del mecenazgo de la Condesa-Duquesa de Benavente:
Bien pudiera sino representarte
presidiendo tal vez una Academia
de música sonora
$\mathrm{y}$ siendo de aquel arte
el juez, la bienhechora
que a los le profesan honra y premia ${ }^{13}$

María Josefa Alfonso Pimentel fue una de las protagonistas indiscutibles de la vida social de Madrid hasta su fallecimiento en 1834. En los años 20 del

\footnotetext{
10 Ibíd., leg 391-34.

11 Ibid., leg 413-47 y leg 413-37-3.

12 La Condesa-Duquesa de Benavente también organizó algunos conciertos en Cádiz ciudad en la que residió entre 1810 y 1813 durante la ocupación francesa. Véase AHN NOBLEZA, OSUNACARTAS, leg 389-15; leg 392-36 y leg 392-40.

13 Tomás de Iriarte. Epístola jocoseria a la Condesa de Benavente reproducida en Emilio Cotarelo, Iriarte y su época. Estudios sobre la Historia del Arte Escénico en España (Madrid: Sucesores de Rivadeneyra, 1897), p. 480.
} 
siglo XIX, el salón del palacio de la Condesa-Duquesa se abría los domingos a "la sociedad más selecta y escogida" de la capital ${ }^{14}$. Estas reuniones sociales solían

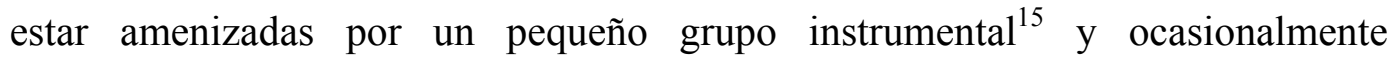
intervenían de algunos miembros las familias Osuna y Benavente aficionados al canto $^{16}$.

\subsection{Bailes $y$ fiestas}

La danza fue uno de los principales entretenimientos de la alta nobleza española durante los siglos XVIII y XIX ${ }^{17}$. Los miembros de las Casas de Osuna y Benavente aprendieron durante su niñez y adolescencia las danzas de moda ${ }^{18}$ que, a lo largo de su vida, exhibirían en los bailes "de familia" que se celebraban en los aposentos privados como entretenimiento para la corte nobiliaria, en los bailes públicos de los teatros de Madrid, y sobre todo en las fastuosas fiestas que se organizaban en sus palacios en determinadas épocas del año, como en Navidad y Carnaval, o para celebrar determinados acontecimientos familiares o públicos.

Desde su juventud María Faustina Téllez Girón, esposa del XIV CondeDuque de Benavente, celebró numerosos bailes privados en Madrid que solían estar amenizados por sus músicos asalariados y por otros que se contrataban para

\footnotetext{
14 Fernando Fernández de Córdoba, Mis memorias intimas (Madrid: [Tip. Sucesores de Rivadeneyra], 1886-1889) vol. I, p. 37.

15 AHN NOBLEZA, OSUNA-CARTAS, leg 392-34. Véase Apéndice 6, nº 20 y 21.

${ }^{16}$ Fernández de Córdoba, Mis memorias, vol. I, p. 37

17 Sobre la práctica de la danza en la alta sociedad española durante el siglo XVIII véase Antonio Martín Moreno, Historia de la música española, 4, Siglo XVIII (Madrid: Alianza, 1985).

${ }^{18}$ Véase el Capítulo III.
} 
la ocasión ${ }^{19}$. En estos bailes participaron también un grupo de violinistas ciegos que, al menos entre 1752 y 1765 estuvo dirigido por Carlos Dimas, y del que formaron otros músicos como Francisco Tranchi y otro apellidado Herrera. La formación habitual de los llamados "consortes músicos ciegos” que amenizaron los bailes de la Casa de Benavente en esta época solía estar compuesta por tres o cuatro violinistas, aunque para las celebraciones más importantes el grupo se reforzaba con un bajo, trompas y oboes ${ }^{20}$.

Los bailes y fiestas organizados por los titulares de la Casa de Benavente alcanzaron su máximo esplendor a partir de las últimas décadas del siglo XVIII coincidiendo con la titularidad de María Josefa Alfonso Pimentel al frente de la Casa de Benavente ${ }^{21}$. Entre las numerosas fiestas y bailes que organizó esta dama a lo largo de su vida destaca por su importancia y suntuosidad la que se celebró en su palacio de Madrid en septiembre de 1789 dentro de los actos festivos que tuvieron lugar en Madrid con motivo de la coronación de Carlos IV y la jura del Príncipe de Asturias (el futuro Fernando VII). El programa de fiestas promovido por el Ayuntamiento de la capital constaba de diez días de festejos públicos, que incluyeron corridas de toros y representaciones operísticas en el Teatro de los Caños del Peral. Las principales casas nobiliarias residentes en Madrid contribuyeron a estos actos celebrando fastuosas fiestas particulares en sus palacios. Las celebraciones particulares comenzaron con las fiestas del Marqués

\footnotetext{
19 Por ejemplo en 1749 el violinista Vicente Juan Amat asistió a 51 bailes organizados por esta dama. AHN NOBLEZA, OSUNA-CARTAS, leg 389-30.

20 AHN NOBLEZA, OSUNA-CARTAS, leg 389-30.

21 Sobre las fiestas y bailes organizados por la Casas de Osuna y Benavente para agasajar a los reyes y a otras personalidades políticas de paso por Madrid en las primeras décadas del siglo XIX véase AHN NOBLEZA, OSUNA-CARTAS, leg 375-3 y leg. 511.
} 
de Cogolludo, Duque de Santisteban en su palacio de la calle de Atocha, y continuaron con el baile que organizaron los IX Duques de Osuna y CondesDuques de Benavente el 26 de septiembre en su palacio de la Puerta de la Vega. La fiesta comenzó a las 8 de la noche y finalizó a las 8 de la mañana del día siguiente, y constó de una cena de gala y un baile ${ }^{22}$.

El baile tuvo lugar en la planta baja del palacio, en la zona destinada a antecámara, salón y gabinete de verano cuyo espacio se adornó con un costoso programa decorativo que fue encargado al arquitecto Mateo Guill. El salón del palacio destinado al baile se transformo con arquitecturas fingidas, cornucopias, espejos, y otros elementos alegóricos que evocaban el Templo de Minerva ${ }^{23}$. En el interior de este salón se colocaron dos retratos de Carlos IV y de su esposa realizados por Francisco de Goya ${ }^{24}$.

La velada estuvo amenizada por dos orquestas formadas por 32 instrumentistas cada una que interpretaron un repertorio de minuetos $y$ contradanzas $^{25}$. En ambas formaciones participaron algunos de los músicos asalariados que trabajaban en ese año al servicio de la unificada Casa de Benavente-Osuna junto a otros contratados para la ocasión. Las dos formaciones instrumentales tenían una plantilla de orquesta clásica con 6 violines primeros, 6 violines segundos, 1 violón, 2 contrabajos 2 flautas, 4 oboes, 2 clarinetes, 2 fagotes, 2 clarines, 4 trompas, y 1 timbalero ${ }^{26}$.

\footnotetext{
22 Emilio Cotarelo, Iriarte, pp. 369-377.

${ }^{23}$ AHN NOBLEZA, OSUNA-CARTAS, leg 311 y 506.

24 Ibid., leg 515.

25 Ibid., leg 391-21.

26 Ibíd., leg 391-15. Véase Apéndice 6. Judith Ortega citó también este documento pero olvidó contabilizar a los músicos de la casa que se incluían en lista aparte. Véase Judith Ortega, "El mecenazgo musical de la Casa de Osuna durante la segunda mitad del siglo XVIII: el entorno
} 
Durante el siglo XIX en el palacio de recreo de la Alameda, situado a las afueras de Madrid, la Condesa-Duquesa de Benavente y su nieto el XI Duque de Osuna celebraron suntuosas fiestas $y$ bailes en honor de importantes personalidades como los reyes de España, que acudieron habitualmente a varias fiestas entre 1814 y 1816, o los reyes de Sicilia $(1830)^{27}$. Para los acontecimientos mas señalados, además de los conjuntos musicales que intervenían en los bailes, se contrataba a una banda militar que solemnizaba la entrada de los homenajeados en el palacio ${ }^{28}$ 


\section{La música instrumental en las Casas de Osuna y Benavente}

A lo largo de todo el siglo XVIII la música instrumental estuvo presente en el ámbito doméstico de los palacios de las Casas de Osuna y Benavente. Aunque el estudio de la documentación administrativa no arroje datos concretos sobre el repertorio instrumental hasta las últimas décadas de dicho siglo, tenemos constancia, de que, desde las primeras décadas del siglo XVIII se celebraron en ambas casas nobiliarias numerosos bailes en los que seguramente se interpretaron las danzas de moda típicas de la época ${ }^{29}$. Por otra parte, dada la afición musical de los miembros de ambas familias, parece factible considerar que dentro de las obligaciones de las capillas musicales y de los músicos asalariados que trabajaron al servicio de las Casas de Osuna y Benavente en la primera mitad del siglo XVIII, además de la documentada intervención en las funciones teatrales y en los actos religiosos, se incluyera también la interpretación de obras instrumentales para el entretenimiento de la corte nobiliaria.

En este apartado realizaré una descripción del repertorio instrumental de las Casas de Osuna y Benavente entre 1757, fecha de la publicación de la Obra armonica de Francisco Manalt, primera obra de cámara documentada compuesta en el entorno de la Casa de Osuna, y 1844 límite cronológico de este trabajo. Asimismo estudiaré una selección representativa de las obras que formaron parte del repertorio instrumental doméstico de ambas familias nobiliarias.

29 En AHN NOBLEZA, OSUNA-CARTAS, leg 389 figuran varios recibos de pagos a músicos por la asistencia a los bailes celebrados en sus palacios. 


\subsection{La música de cámara en la época del VIII Duque de Osuna: Obra} armónica en seis sonatas de cámara de violín y bajo solo de Francisco Manalt (1757)

El violinista y compositor Francisco Manalt $\left({ }^{*} c a 1720-\uparrow 1759\right)$ dedicó en 1757 la edición de la primera parte de su Obra armónica en seis sonatas de cámara de violín y bajo solo a Pedro [Zoilo] Téllez Girón, VIII Duque de Osuna (Lámina 32$)^{30}$. Al menos desde 1745, Manalt trabajó como violinista al servicio de este noble en cuya casa coincidió con otros destacados músicos de cuerda como los violinistas Salvador Rexach, Francisco Landini, el violón Pablo Vidal o el contrabajista Francisco Torner ${ }^{31}$. La música de cámara para violín y bajo debió de formar parte del repertorio habitual doméstico de la Casa de Osuna durante la titularidad del VIII Duque de Osuna como demuestra el hecho de que, al menos hasta 1775, Pedro Zoilo Téllez Girón mantuviera siempre entre sus músicos asalariados a un violinista y a un violón ${ }^{32}$. Es posible, por tanto, que Francisco Manalt tuviese en mente la práctica cotidiana de interpretación de obras para violín y bajo en el entorno doméstico de los palacios de la Casa de Osuna a la hora de dedicar al Duque su Obra armonica.

\footnotetext{
${ }^{30}$ Francisco Manalt. Obra armónica en seis sonatas de cámara de violín y bajo solo (Madrid: Andrés Guinea, 1757). El único ejemplar conocido hasta la fecha se conserva en BNE M 1703. Lothar Siemens y Lourdes Bonnet realizaron una cuidada edición en 2001 a partir de esta fuente. Anteriormente estas sonatas habían sido editadas en una versión para violín y piano con la transcripción del bajo realizada por el Padre Donostia. Véase Francisco Manalt Obra Armónica en seis sonatas de cámara de violín y bajo solo (Madrid, 1757) Edición de Lothar Siemens y Lourdes Bonnet (Madrid: Sociedad Española de Musicología, 2001); Francisco Manalt. Sonatas para violín y piano transcripción por el P. José A. de Donostia (Barcelona: Instituto Español de Musicología, Consejo Superior de Investigaciones Científicas, 1955-1966).

${ }^{31}$ Los principales datos de la biografía de Francisco Manalt figuran en el Apéndice 5.

${ }^{32}$.AHN NOBLEZA, OSUNA-CARTAS, leg 447-1. Entre 1772 y 1775 los únicos músicos asalriados del VIII Duque de Osuna eran el violinista Salvador Rexach y el violón Pablo Vidal.
} 


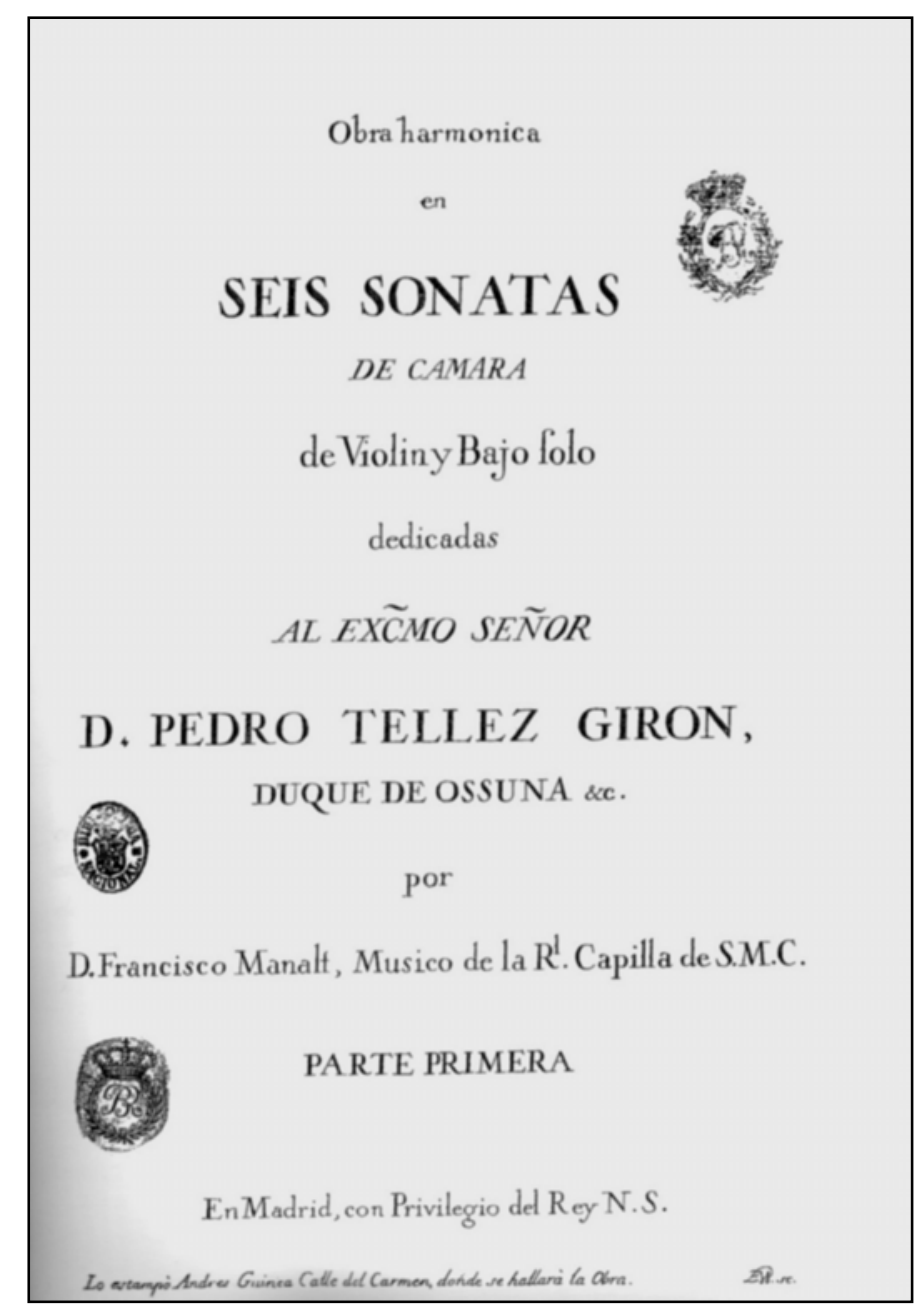

Lámina 32.

Francisco Manalt, Obra armónica en Seis Sonatas de Cámar. Portada.

(Madrid: Andrés Guinea, 1757)

La Obra armónica de Manalt es uno de los pocos ejemplos conocidos de música violinística compuesta por autores españoles editada durante el reinado de Fernando $\mathrm{VI}^{33}$, por lo que su estudio adquiere una especial relevancia para conocer la recepción y asimilación de las innovaciones del repertorio violinístico europeo en nuestro país.

\footnotetext{
${ }^{33}$ Véase Lothar Siemens Hernández. "Los violinistas compositores en la Corte Española durante el período central del siglo XVIII” RMS, XI/ 3 (1988), p. 666.
} 
La primera parte de la Obra armónica de Manalt, está formada por un conjunto de seis sonatas de cámara articuladas cada una de ellas en tres movimientos (lento-rápido-lento) que responden en términos generales a la habitual estructura de la sonata monotemática bipartita (A/BA'). Las variantes que Manalt introduce en este patrón formal muestran un deseo de experimentar las novedades que se estaban produciendo en el repertorio violinístico italiano y centroeuropeo $^{34}$. En las sonatas de la Obra armonica Manalt presenta fórmulas que más tarde cristalizarían en la estructura de la sonata bitemática clásica como la eliminación de la doble barra de repetición que separa las dos secciones de cada movimiento (lo que ocurre en 11 de los 18 movimientos de la colección) y la introducción de la reexposición temática en el tono principal dentro de la segunda sección, elementos que contribuyen a la unidad dentro la variedad.

El segundo movimiento (Allegro vivo) de la Sonata VI es un buen ejemplo de las citadas innovaciones formales y de las peculiaridades armónicas y melódicas que caracterizan la Obra armónica de Manalt. Este movimiento se encuadra en la citada estructura de sonata monotemática bipartita (A/BA') en la que se ha suprimido la repetición que separa a ambas secciones. El principio constructivo básico que utiliza aquí Manalt es la yuxtaposición de bloques temáticos. El característico inicio del motivo principal (un arpegio descendente sobre la tríada de tónica) se presenta en distintas regiones tonales y a diversas alturas, lo que proporciona una gran coherencia temática al movimiento (Ejemplo musical 8).

\footnotetext{
${ }^{34}$ Véase la introducción de Siemens en Manalt, Obra armónica, p. 8.
} 

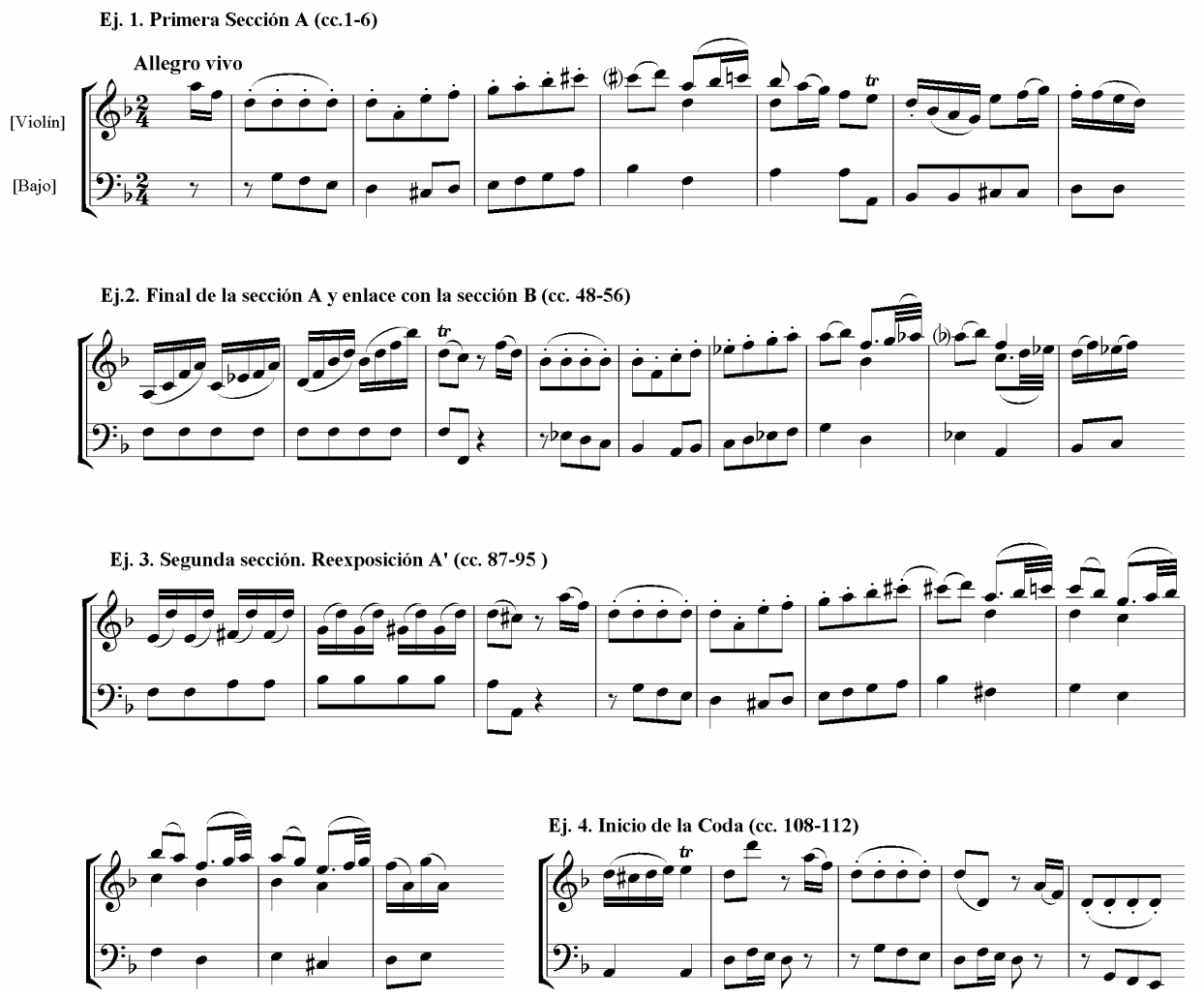

\section{Ejemplo musical 8.}

Francisco Manalt, Obra armónica en Seis Sonatas de Cámara (1757)

Ed. Lothar Siemens y Lourdes Bonnet, pp. 62-66.

Materiales temáticos del segundo movimiento de la Sonata VI

Una de las peculiaridades del estilo compositivo de Manalt que puede apreciarse en el segundo movimiento de la Sonata VI, es la constante fluctuación tonal. En la primera sección (A) de este movimiento, la tonalidad principal (re menor) se enriquece con flexiones modulantes a la región de la subdominante (sol menor) que conducen a la sección B (Ejemplo musical 8.1). En lugar de afirmar el tono de la dominante o el del relativo como es preceptivo en las soluciones más frecuentes de la sonata de estilo galante, la sección B se presenta en el tono de si 
bemol mayor (Ejemplo musical 8.2) lo que da lugar a una doble relación de mediante con la tonalidad principal (re menor) y con la tonalidad de la subdominante (sol menor).

El final de la segunda sección incluye una amplia reexposición del material temático en la tonalidad principal (Ejemplo musical 8.3) y concluye con una coda en la que se cita de nuevo la cabeza del tema principal en la tonalidad original (Ejemplo musical 8.4) lo que refuerza la homogeneidad temática del movimiento dentro de la variedad que proporciona el uso de diferentes regiones tonales.

En el análisis de las seis sonatas de la Obra armónica se aprecian también otras características del estilo galante presentes en las sonatas violinísticas de autores como Veracini, Locatelli y Tartini ${ }^{35}$. La llamada cadencia galante I-IVV- I se utiliza ampliamente en las seis sonatas, con o sin el habitual salto de octava del bajo y sustituyendo eventualmente el acorde de IV por la primera inversión del $\mathrm{II}^{36}$. Asimismo a lo largo de las sonatas aparecen también otros gestos "galantes" como los diseños melódicos descendentes de tres notas y los peculiares ritmos lombardos (Véase Ejemplo musical 9) ${ }^{37}$.

\footnotetext{
${ }^{35}$ Sobre las características generales del estilo galante y su aparición en las obras violinísticas italianas véase Daniel Heartz, Music in European capitals. The Galant Style, 1720-1780 (Nueva York y Londres: W.W. Norton \& Company, 2003).

${ }^{36}$ Sobre esta cadencia véase Heartz, Music, p. 23.

${ }^{37} \mathrm{La}$ aparición de estos rasgos en las sonatas para violín y bajo de obras de Pietro Locatelli aparece comentada en Heartz, Music, pp. 214-215.
} 


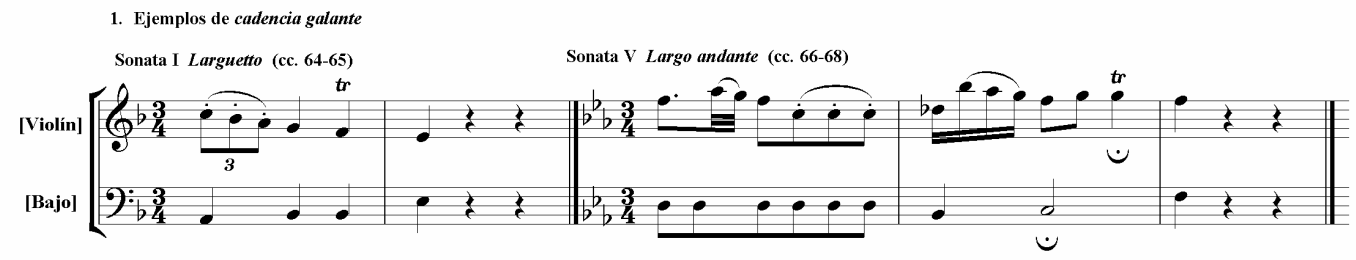

2. Ejemplos de utilización de ritmos lombardos

Sonata II Larguetto maestoso (cc. 60- 63)

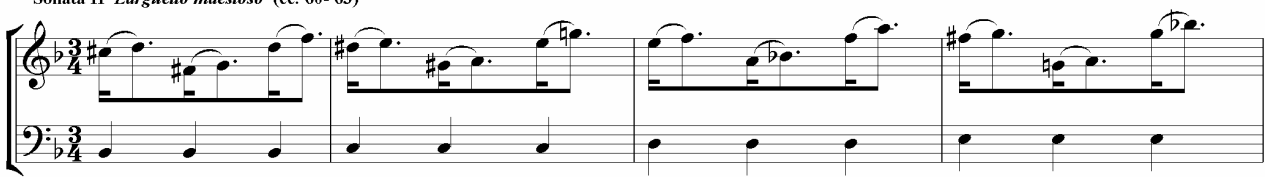

Sonata V Allegro (c. 62- 63)

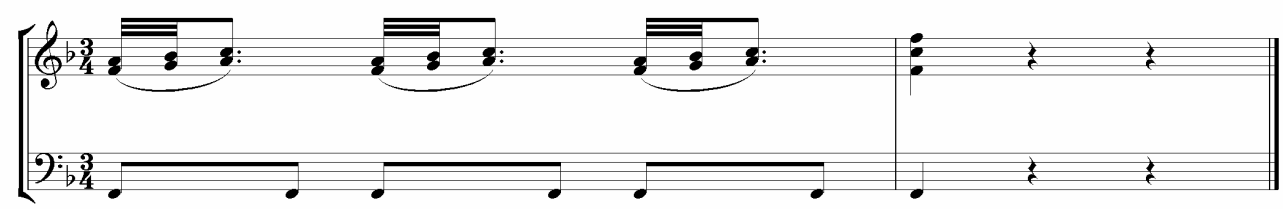

Ejemplo musical 9.

Francisco Manalt, Obra armónica en Seis Sonatas de Cámara (1757)

Ed. Lothar Siemens y Lourdes Bonnet

Rasgos del estilo galante

Aunque hasta la fecha sólo se conoce la existencia de una primera parte de la Obra armónica de Manalt, el hecho de que en la portada de la edición de esta colección que se realizó en 1757 figure la frase "parte primera" (véase Lámina 32), llevó a Lothar Siemens a considerar que Manalt compuso una segunda parte de la Obra Armónica que no ha sido localizada hasta la fecha y que contendría otra colección de sonatas. Según Siemens la existencia de una segunda parte aparecería documentada en 
una carta autógrafa de Gabriel Terri (1761) solicitando el cobro de tales sonatas manuscritas de Manalt encuadernadas en rojo, que había entregado a los Duques y el correspondiente libramiento al mismo Gabriel Terri como "apoderado de los herederos de Manalt" (1763) ${ }^{38}$.

La carta que cita Siemens es en realidad un certificado fechado en 1761 por el cual el violinista Gabriel Terri, miembro de la Real Capilla que actuaba como apoderado de los intereses testamentarios de las herederas de Manalt, afirmaba haber entregado a la Condesa de Benavente (es decir a María FaustinaTéllez Girón hermana del VIII Duque de Osuna y no esposa como da a entender Siemens) varios libros de sonatas de violín de Francisco Manalt (sin especificar cuales) cuyo importe se quedó a deber a la muerte de este en 1759:

Certifico el abajo firmado haber entregado a la Excelentísima Señora Condesa de Benavente, diferentes libros de Sonatas de violín compuestas por Don Francisco Manalt, apreciadas por Don Joseph Mir Maestro de la Real Capilla de las Señoras de la Encarnación y por otros inteligentes en// mil quinientos reales [de] vellón // cuya cantidad he solicitado su cobro y no habiendo tenido efecto, doy esta certificación para descargo de mi conciencia y satisfacción de los interesados de los expresados mil quinientos reales, que son las herederas de Don Francisco Manalt, la una Doña María Francisca de Dueñas su mujer y la otra Doña Teresa Palmés y Manalt, y por ser así verdad lo firmo en Madrid a 6 de abril de $1761 .$.

Gabriel Terri

Visto por orden de mi señora

Manuel Méndez 39

${ }^{38}$ Véase la introducción de Siemens en Manalt, Obra armónica, p. 6. 
Tampoco aclara nada al respecto el documento de 1763 al que alude Siemens, por el que se ordenó el pago Gabriel Terri de las cantidades reclamadas por los "varios libros y papeles de música” que éste había entregado a la CondesaDuquesa de Benavente:

Don Juan Antonio Eguilondo, Tesorero General de la Casa y Estados de la Excelentísima Señora Condesa Duquesa de Benavente, con aprobación de la Real Cámara de Castilla; de los caudales depositados en poder de vuestra merced para el pago de acreedores de la Casa de Su Excelencia, con intervención, y providencia mía; dará vuestra merced y pagará a Gabriel Terri, músico de la Real Capilla, de Su Majestad, como apoderado de los herederos de Francisco Manalt un mil y quinientos reales de vellón, que se los libro por otros tantos en que se regularon varios libros, y papeles de música que entregó a Su. Excelencia en 6 de abril de mil setecientos sesenta y uno; según consta en la contaduría de la misma casa. Que con este libramiento, de que se ha de tomar la razón en sus libros, y recibo a su continuación del expresado Don Gabriel Terri, se recibirán, y pasarán a vuestra merced en cuenta los dichos un mil y quinientos reales en las que diere del referido depósito de caudales, sin otro recado alguno. Dado en Madrid a dos de Marzo de mil setecientos setenta y tres.

Don Jul[ian] Moreno (rúbrica)

Tomo la razón

Andrés Merlo ${ }^{40}$

Como puede advertirse, en ninguno de los dos documentos arriba transcritos se especifica cuales eran las obras de Manalt que formaban parte de los “diferentes libros de sonatas de violín” y los "papeles de música” que Gabriel Terri entregó a la Condesa de Benavente. Por consiguiente, con la documentación

39 AHN NOBLEZA OSUNA CARTAS, leg 389-26.

40 AHN NOBLEZA, OSUNA-CARTAS, leg 389-26. 
conocida hasta la fecha, no podemos saber si Manalt llegó realmente a componer la segunda parte de su Obra armónica. Baltasar Saldoni afirmó que Francisco Manalt la "dio por terminada y anunció el 18 de febrero de 1766 "41. un hecho del todo punto imposible ya que Manalt falleció en enero de $1759^{42}$.

\subsection{La música instrumental en las Casas de Osuna y Benavente entre 1772} 1808

La música instrumental vivió uno de sus momentos de mayor esplendor en las Casas de Osuna y Benavente durante el matrimonio de María Josefa Alfonso Pimentel, Condesa Duquesa de Benavente con Pedro de Alcántara Téllez Girón, Marqués de Peñafiel y IX Duque de Osuna. En las dos últimas décadas del siglo XVIII ambos nobles fomentaron la práctica musical doméstica, y fundaron y mantuvieron importantes grupos instrumentales de músicos asalariados y $\operatorname{contratados}^{43}$. Para estos conjuntos los Duques de Osuna y Condes-Duques de Benavente consiguieron un exclusivo repertorio de obras de cámara y orquestales de algunos de los compositores europeos más destacados del momento como Gaetano Brunetti, Luigi Boccherini, Franz Joseph Haydn, Johann Nepomuk Hummel, Franz Aspelmayer o Karl Stamitz que fueron interpretadas habitualmente en los bailes, fiestas y academias musicales que se celebraron en sus palacios.

41 Baltasar Saldoni. Diccionario biográfico-bibliográfico de efemérides de músicos españoles (Madrid: Antonio Pérez Dubrull, 1868-1881), vol. IV, p. 181

42 Para la biografía de Manalt véase el Apéndice 5.

${ }^{43}$ Ver Capítulo IV. 


\subsubsection{Música de cámara de Gaetano Brunetti}

Gaetano Brunetti $\left({ }^{*} 1744-\dagger 1798\right)$ fue uno de los compositores italianos de música instrumental más prolíficos entre los que trabajaron en España durante la segunda mitad del siglo XVIII. Violinista y director de la Real Cámara, Brunetti fue también maestro de música del Príncipe de Asturias (el futuro Carlos IV) y entre abril de 1776 y febrero de 1780 impartió clases de violín a Pedro de Alcántara Téllez Girón, Marqués de Peñafiel y heredero de la Casa de Osuna ${ }^{44}$.

La música de Brunetti, compositor favorito de la Real Cámara de Carlos IV, formó también parte del repertorio de las Casas de Osuna y Benavente. En el archivo de música de la Condesa-Duquesa de Benavente había, entre otras obras suyas, una colección de Diez Dúos para dos violines [3/179], [4/119], y otra de Veintidós Sonatas para violín y bajo de diferentes óperas [3/178], [4/123], [4/117], que posiblemente fueron utilizadas por Brunetti en las clases de violín que impartió al Marqués de Peñafiel ${ }^{45}$.

Después de cesar en el cargo de maestro de violín de Pedro de Alcántara Téllez Girón, Brunetti siguió colaborando con las Casas de Osuna y Benavente. Hacia 1785, la Casa de Benavente le encargó unos sextetos con oboe ${ }^{46}$. La curiosa inclusión del oboe en dicha obra podría deberse a la presencia en la orquesta de la

\footnotetext{
44 Sobre la relación de servicio del Brunetti con el Marques de Peñafiel, véase el Capítulo III. El estudio más reciente y completo sobre la vida y obra de este autor es la tesis doctoral de Germán Labrador en la que sólo se presentan algunos datos de la relación de Brunetti con la Casa de Benavente basados en las investigaciones precedentes de Solar-Quintes. Germán Labrador, Gaetano Brunetti: un músico en la corte de Carlos IV, Tesis doctoral inédita (Madrid: Universidad Autónoma de Madrid, 2003).

${ }^{45}$ La numeración que figura junto a las obras a lo largo de este capítulo hace referencia a los inventarios y catálogos de libros de música y partituras de las Casas de Osuna y Benavente de los Apéndices 3 y 4.

46 AHN NOBLEZA OSUNA-CARTAS leg 391-38 y leg 391-32.
} 
Condesa Duquesa del excelente oboísta Gaspar Barli. Estos sextetos, cuyo paradero actual se desconoce, podrían ser los "Seis sextetos hechos expresamente para el Excelentísimo Señor Duque de Osuna" [3/187], u otra colección de "Seis sextetos" [3/132] que figuraban en el inventario de 1824 del archivo de música de la Condesa-Duquesa de Benavente.

En el archivo de música de la Condesa-Duquesa también se conservaban una colección de minuetos y contradanzas para dos orquestas de Brunetti [3/167] y [4/118]. Es muy probable que estas obras fueran interpretados en alguno de los suntuosos bailes organizados por los IX Duques de Osuna en los que solían participar dos grupos instrumentales ${ }^{47}$ que, siguiendo una práctica habitual en la música de baile del clasicismo, se disponían en salones contiguos o a cierta distancia para interpretar un repertorio compuesto expresamente para esta doble formación que solía jugar con efectos de espacialidad ${ }^{48}$.

${ }^{47}$ Dada la vinculación de Brunetti con la Casa Real y con el Duque de Osuna, la citada colección de minuetos y contradanzas podría haberse compuesto para las fiestas organizadas por los Duques de Osuna el 26 de septiembre de 1789 con motivo de la coronación de Carlos IV y la jura del Príncipe de Asturias (el futuro Fernando VII) en los que intervinieron dos orquestas que interpretaron un repertorio de minuetes y contradanzas. AHN NOBLEZA OSUNA-CARTAS leg 391-14 y leg 391-21. Sobre esta fiesta véase el apartado 1.2. de este capítulo.

48 Por ejemplo, la famosa Serenata K. 239 ("Serenata nocturna”) de W. A. Mozart está compuesta para dos pequeñas formaciones orquestales. Véase Jean y Brigit Masin, Wolfgang Amadeus Mozart (Madrid: Turner Música, 1987), p. 964. 


\subsubsection{Música instrumental de Luigi Boccherini}

En las dos últimas décadas del siglo XVIII las obras camerísticas y orquestales de Luigi Boccherini fueron una parte fundamental del repertorio de las formaciones instrumentales de la Casa de Benavente. Boccherini fue compositor y director de la orquesta de la Condesa-Duquesa de Benavente desde marzo de 1786 hasta, al menos, diciembre de $1787^{49}$ y aunque no sabemos si esta relación de servicio obligaba al compositor a entregar un determinado número de obras instrumentales para ser interpretadas por los músicos de la Casa, existe constancia documental de que durante dicho período se copiaron numerosas obras suyas para la Condesa-Duquesa. Entre mayo y diciembre de 1786, Salvador Feixas copió varios "minuetes", 9 sinfonías y un "concierto" a toda orquesta" de Boccherini y el violinista Francisco Font cobró a principios del año 1787, 458 reales y ocho maravedíes por la copia de 10 minuetos, un concierto, un quinteto y G sinfonías de Boccherini $^{50}$. Estas copias seguramente se incorporaron en dicha fecha al archivo musical de la Condesa-Duquesa que en 1824 conservaba cerca de un centenar del autor luqués ${ }^{51}$.

La hipótesis de que parte de las obras instrumentales compuestas por Boccherini durante los años 1786 y 1787, y algunas otras, fueran escritas expresamente para la Condesa-Duquesa de Benavente fue por primera vez

\footnotetext{
${ }^{49}$ Véase el Capítulo III.

50 AHN NOBLEZA OSUNA-CARTAS, leg 390-6.

${ }^{51}$ Véase el Apéndice 4. Con los datos que proporcionan los inventarios del archivo de música de la Condesa-Duquesa de 1824 y ca. 1838 no es posible efectuar un recuento definitivo de las obras de Boccherini que figuraron en este archivo pues es probable que existiera más de una copia de la misma obra. Tampoco es posible saber si todas las obras que recoge el segundo inventario son las mismas que figuran en el primero, o si se trataba de ejemplares manuscritos o impresos.
} 
planteada por Yves Gérard en su catálogo de la obra de Boccherini ${ }^{52}$.

Una de las obras instrumentales que, según Geràrd, compuso Boccherini expresamente para la Casa de Benavente, es una colección de Diez minuetos para dos violines, viola, violonchelo, dos oboes, dos trompas y un fagot $(\mathrm{G} .525)^{53}$, conocida como Gioco di minuetti ballabili a grande orchestra, título con el que figura en el catálogo de Boccherini transcrito por su biznieto dentro de la "Ópera 41 ” fechada en el año de $1788^{54}$.

En los inventarios del archivo de música de la Condesa Duquesa de Benavente de 1824 figuran "Diez minuetes" de Boccherini fechados en 1787 que fueron"expresamente escritos para la Excelentísima Señora Condesa de Benavente" $[3 / 175]^{55}$. Según Gérard, es posible que la colección que figura en el catálogo autógrafo de Boccherini fechada en 1788 con el título de Gioco di minuetti sea la misma que la que se conservaba en el archivo de la CondesaDuquesa de Benavente y que fue compuesta para los bailes de carnaval que la Condesa-Duquesa organizaba anualmente en su palacio de Madrid, probablemente para los celebrados en 1788 :

52 Yves Gérard, Thematic, Bibliographical and Critical Catalogue of the Works of Luigi Boccherini (London, New York, Toronto: Oxford University Press, 1969.

${ }^{53}$ Gérard, Thematic, pp.599- 602.

${ }^{54}$ Véase una transcripción de este catálogo en Jaime Tortella. Boccherini, un músico italiano en la España Ilustrada (Madrid: Sociedad Española de Musicología, 2002), p. 489. La única fuente del Gioco di minuetti ballabili (G.525) conocida hasta la fecha es una copia del siglo XIX realizada a partir del manuscrito de la colección de Louis Picquot (colección que desde 1851 se halla en paradero desconocido). La copia se conserva actualmente en la Biblioteca del Congreso de Washington. Gérard cita también otro manuscrito autógrafo de la misma obra, procedente de la colección del rey de Prusia Federico Guillermo II del que tampoco se conoce actualmente su paradero. Véase Gerard, Thematic, p. 601.

${ }^{55}$ Ver Apéndices 3 y 4. También figuran en el inventario realizado hacia 1838 [4/111] aunque sin la fecha de composición. 
This suite of minuets was composed for the balls given by the CountessDuchess of Benavente-Osuna in her palace of La Puerta de la Vega in Madrid at the time of Carnival. Whether the Carnival in question was that of 1787 or 1788 we do not know: the first date is given in the copy made from the autograph MS [copia conservada en la Biblioteca del Congreso de Washinghton] and in the inventory of the library of the Duchess of Benavente-Osuna, the second in Boccherini's autograph catalogue and in the Berlin MS [procedente de la Biblioteca de Federico Guillermo II]. The second date is more probably correct ${ }^{56}$.

Aunque Gérard se inclina por 1788 como la posible fecha de composición y estreno de la citada colección de minuetos, es muy probable que en realidad fuera compuesta y estrenada en los bailes de carnaval del año 1787, año que aparece en el inventario de1824 del archivo de la Condesa Duquesa y en la única copia que se conoce hasta ahora de esta colección que se conserva en la Biblioteca del Congreso de Washington (EE.UU). De este modo el Gioco di minuetti ballabili podría identificarse también con los "Diez minuetes" de Boccherini que figuran en un documento de pago al violinista Francisco Font por las obras de música que se realizaron para la Marquesa de Peñafiel (es decir la CondesaDuquesa de Benavente con su título de consorte del heredero la Casa de Osuna) en enero de 1787. Esta colección de danzas se ensayó seguramente en una "prueba

\footnotetext{
${ }^{56}$ Gérard. Thematic, p. 601. [Mi traducción]. "Esta suite de minuetos fue compuesta para los bailes que ofrecía la Condesa-Duquesa de Benavente en su palacio de La Puerta de la Vega en Madrid durante el Carnaval. No sabemos si fue el Carnaval de 1787 o el de 1788. La primera fecha aparece en la copia del autógrafo manuscrito [copia conservada en la Biblioteca del Congreso de Washinghton] y en el inventario de la Duquesa de Benavente-Osuna, la segunda en el catálogo autógrafo de Boccherini y en el manuscrito de Berlín [procedente de la Biblioteca de Federico Guilleromo II]. Es más probable que la segunda fecha sea la correcta."
} 
de minuetes" que tuvo lugar el 14 de enero de 1787 para los bailes de carnaval que tendrían lugar en el palacio de la Condesa-Duquesa de Benavente los días 15, 22, 29, de enero, y 5, 12 y 19 de febrero de 1787, en los que participaron los músicos asalariados de la Casa con un refuerzo de entre 11 y 15 instrumentistas ${ }^{57}$.

Al menos dos sinfonías de Boccherini fueron dedicadas a la "Excelentísima Señora Condesa de Benavente" ${ }^{58}$. La primera de ellas fechada en 1782, cuatro años antes de la entrada de Bocherinni al servicio de la CondesaDuquesa, pertenecía a un juego de Seis Sinfonías, dedicadas las cinco primeras “al Serenísimo Señor Infante Don Luis” y la sexta a la Excelentísima Señora Condesa de Benavente" [3/29]. Es posible que esta obra fuese la sexta de las sinfonías op. 35 catalogada por Yves Gerard como G. $514^{59}$.

En la segunda de las sinfonías que Boccherini dedicó a la CondesaDuquesa [3/30] aparece la indicación de "año de 1787”. Si consideramos que ese fue el año de composición de la obra ( y no el de copia) podría tratarse de alguna de las cuatro sinfonías de la op. 37 (G. 515-518) que fueron compuestas entre los últimos meses de 1786 y 1787 . La plantilla de estas obras coincide básicamente con la de los músicos asalariados al servicio de la Condesa-Duquesa María Josefa en ese momento. Por ejemplo la Sinfonía G. 515 en Do mayor está escrita para dos violines principales, dos violines ripieni, dos violas, violonchelo, flauta, dos oboes, dos fagotes y dos trompas. Las tres sinfonías de la op. 37 que se conservan en la actualidad (G. 515, G.517 y G.518) tienen amplios pasajes concertantes con varias intervenciones de los instrumentos solistas en los que Boccherini

\footnotetext{
57 AHN NOBLEZA OSUNA-CARTAS leg 390-1.

${ }^{58}$ Ver Apéndice 4, [3/30] y [3/31].

59 Gérard, Thematic, pp. 584-585.
} 
posiblemente trató de exhibir los recursos técnicos de los competentes instrumentistas de la orquesta de la Condesa- Duquesa ${ }^{60}$.

La primera de las dos series de quintetos de Boccherini dedicados a "la Excelentísima Condesa de Benavente" son los "Seis quintetos" del año 1786 [3/171], tradicionalmente identificados con los Sei quintettini per due violini, viola e due violoncelli, op. 36 (G-331-336) ${ }^{61}$. Es posible que Boccherini iniciase la composición de esta serie de quintetos en 1784 cuando estaba aún al servicio del Infante don Luis y que, después de empezar a trabajar para la Casa de Benavente, aprovechase borradores anteriores para terminar las obras y dedicársela a la Condesa-Duquesa ${ }^{62}$. Para Gérard, sin embargo, la composición de estos quintetos tuvo lugar entre mayo y octubre de $1786^{63}$. En cualquier caso, es muy probable que finalmente fueran interpretados en alguna de las academias organizadas por la Condesa-Duquesa de Benavente que tuvieron lugar en los últimos meses de 1786 y primeros de 1787 para las que se copió un quinteto de Boccherini, entre otras obras $^{64}$.

Los Tres Quintetos de 1787 “dedicados a la Excelentísima Señora Condesa de Benavente" que figuraban en el archivo de la Condesa-Duquesa [3/172], serían según Gérard los tres quintetos para dos violines, violín y violonchelo que forman parte de la opus 39 del catálogo manuscrito de Boccherini. La datación que

\footnotetext{
${ }^{60}$ Editadas por Antonio de Almeida en Luigi Boccherini, Sämtliche Sinfonien (Viena: Doblinger, 1992).

61 Estas son las únicas obras para quinteto que Boccherini compuso en dicho año según su catálogo manuscrito en donde aparecen con la denominación de Opera piccola que hace referencia a su estructura en dos movimientos. Tortella, Boccherini, p. 488.

62 Tortella, Boccherini, pp. 283-285.

${ }^{63}$ Gérard, Thematic, pp. 376-382.

64 AHN NOBLEZA OSUNA-CARTAS, leg 390-6.
} 
Gérard adjudica a estos tres quintetos (G.337, G.338 y G.339) se basa en las copias autógrafas manuscritas de la partitura conservada en la Deutsche Staatsbibliothek de Berlín ${ }^{65}$. En estos autógrafos figuran los meses de enero (G. 337), febrero (G.338), y marzo (G.339) de 1787 que corresponderían al mes de composición de las obras. En la portada de los tres manuscritos de Berlín, Boccherini se autocalifica con el título de profesor de música al servicio de $\mathrm{Su}$ Majestad Católica [el rey Carlos III], compositor de cámara del Rey de Prusia y director de la "[...] Academia della Excelentisima Signora Contessa de Benavente, Duchessa di Gandia, etc" (Lámina 33) lo que muestra el aprecio que Boccherini tenía por su cargo al servicio de la Casa de Benavente.

En los manuscritos de los Quintetos op. 39 conservados en Berlín el segundo violonchelo habitual en los quintetos de cuerda que Boccherini compuso en la etapa al servicio del Infante don Luis aparece sustituido por un contrabajo. Este hecho ha planteado diversas dudas a los investigadores sobre la fecha de composición de estas obras. Mangani y Colli sugieren la posibilidad de que estos tres quintetos se compusieran antes de $1787^{66}$, y que, por tanto, la escritura original fuera para dos violonchelos, tal y como figura en el catálogo autógrafo de Boccherini y en la edición realizada por Pleyel entre 1809 y $1813^{67}$.

\footnotetext{
65 Berlin Deustsche Staatsbibliotek M-517, M-518, y M- 519 respectivamente.

66 Marco Mangani y Remigio Colli. “Osservazioni sul catalogo autografo di Luigi Boccherini: I quintetti a due violoncelli”, Rivista Italiana di Musicologia, XXXII/2 (1997), pp. 315-326. Véase asimismo Xosé Crisanto Gándara. “Algunos aspectos sobre el contrabajo en la música de Luigi Boccherini”, RMS, XXII/2 (2000), pp. 443-464.

${ }^{67}$ Para las equivalencias entre la catalogación de Gérard y la numeración adjudica por Pleyel véase Tortella. Boccherini, pp. 299.
} 


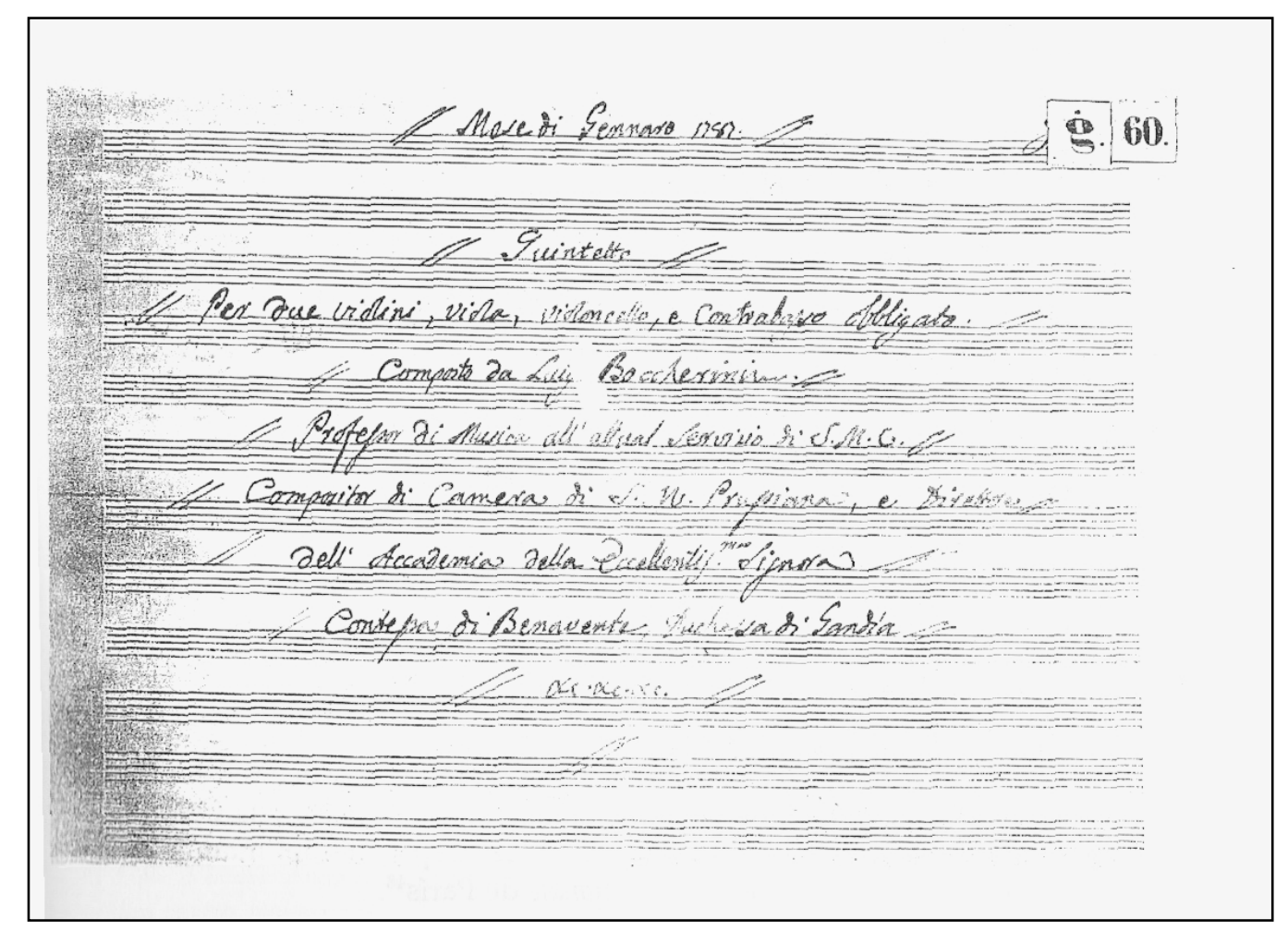

Lámina 33.

Portada del manuscrito del Quinteto Op 39/1 G. 338 de Luigi Bocherinni (Deustche Staatsbliotek de Berlín M 517)

Si admitimos que los Tres Quintetos de la op. 39 de Boccherini son los mismos que se conservaban en el archivo de la Casa de Benavente con fecha de 1787, es factible pensar que al componer esta obra Boccherini pensase en los instrumentistas que tenía a su disposición en dicho año en la plantilla de músicos asalariados de la Condesa-Duquesa de Benavente. En este caso, la sustitución del segundo violonchelo por un contrabajo podría estar motivada por la participación en su interpretación de alguno de los dos competentes contrabajistas que trabajaban en ese año para la Condesa-Duquesa Pedro Sebastián y Ramón Rodríguez Monroy ${ }^{68}$.

\footnotetext{
${ }^{68}$ Sobre las biografías de estos instrumentistas véase el Apéndice 5.
} 
Las partes de contrabajo de los Tres Quintetos op. 39 de Boccherini tienen una clara función de bajo del conjunto armónico y apenas intervienen en el desarrollo temático de la obra. La línea del contrabajo (tal y como figura en los manuscritos de Berlín) podría tocarse (salvo unos pocos pasajes) por un violonchelo en su registro más grave. Sin embargo, en la edición para dos violonchelos de estos quintetos que realizó Pleyel en las primeras décadas del siglo XIX aparecen algunas adaptaciones que, en mi opinión, apoyan la hipótesis de que la versión con contrabajo es anterior a la realizada para dos violonchelos, que fue la que finalmente recogió Boccherini en su catálogo manuscrito ${ }^{69}$.

En la edición de Pleyel (Ejemplo musical 10), el segundo violonchelo se mueve en su región más grave. Esta tesitura extrema respondería a la transposición a la octava superior de la parte de contrabajo que aparece en la versión del manuscrito de Berlín (Ejemplo musical 11). En los pasajes cadenciales donde es necesaria una mayor solidez armónica, la edición de Pleyel refuerza la línea del segundo violonchelo con una doble cuerda en octavas que evocaría el do grave del contrabajo (compárense los compases 14 y 15 de ambos ejemplos).

${ }^{69}$ Ellen Iris Amsterdam, The String Quintets of Luigi Boccherini. Tesis doctoral inédita (Berkeley: University of California, 1969), pp. 70-71. 

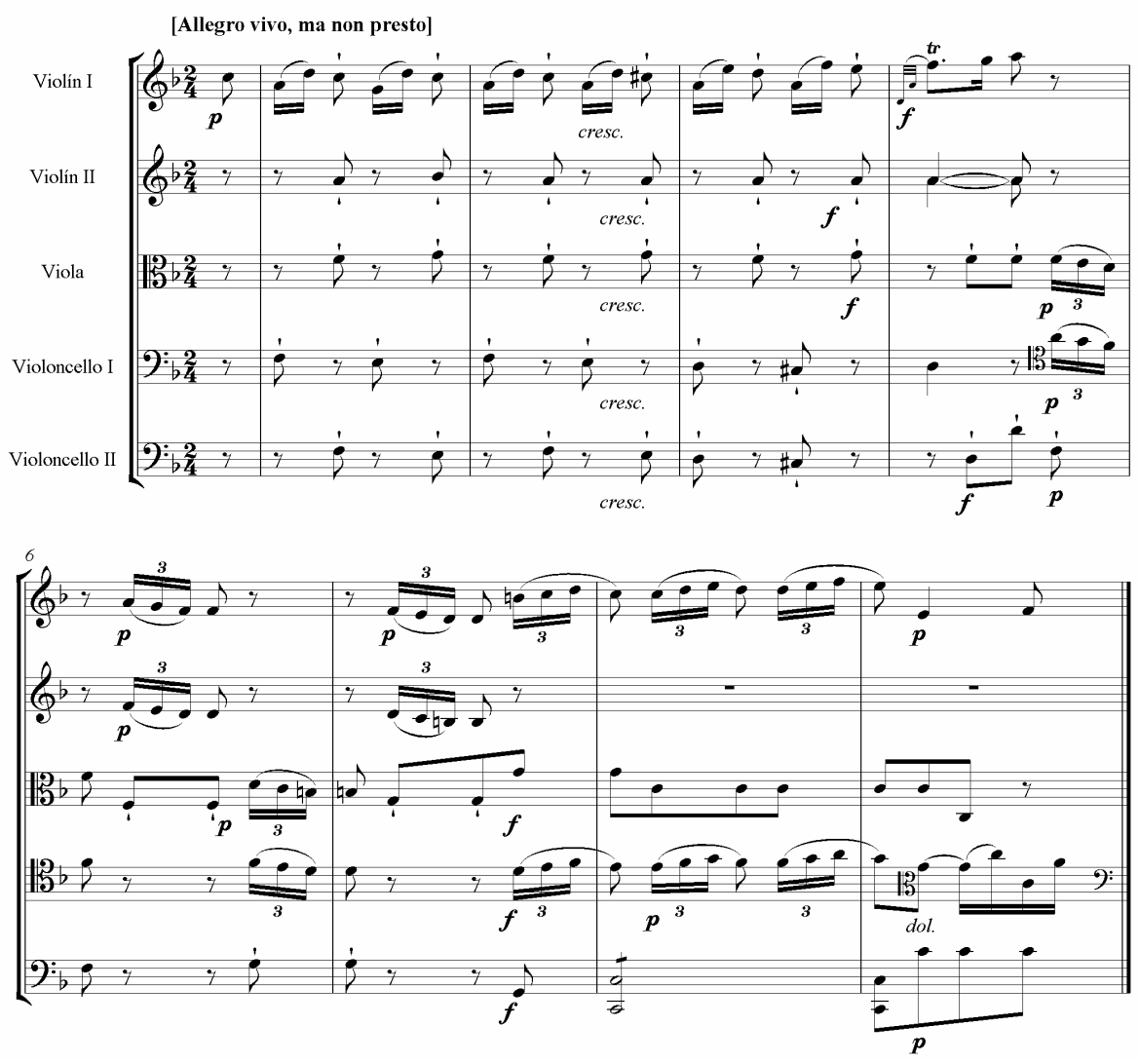

Ejemplo musical 10.

Luigi Boccherini, Quinteto op 39/2, G. 338

(I, Allegro vivo ma non presto, cc. .9-16)

Edición de Pleyel, París, 1809-1813 

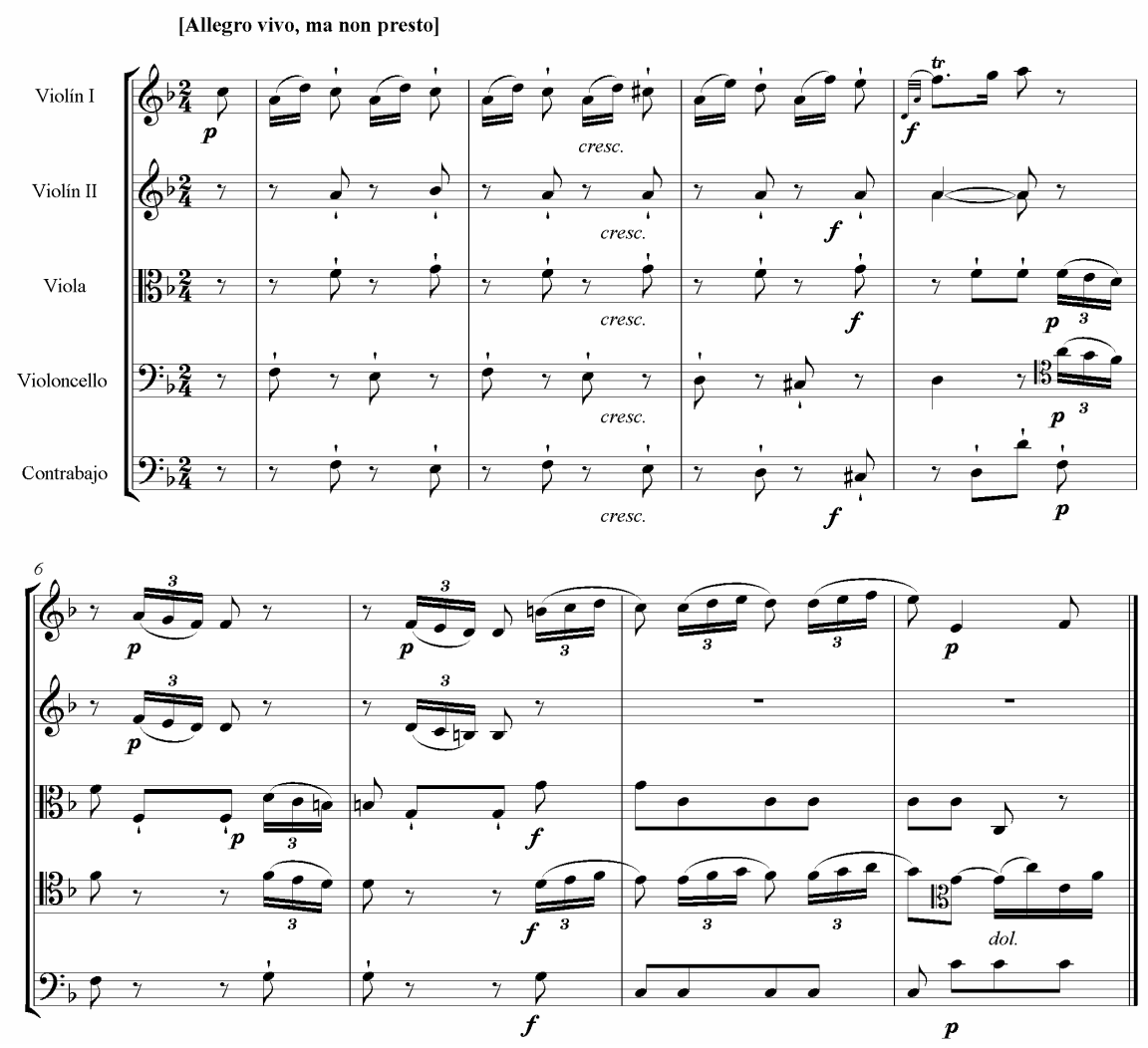

Ejemplo musical 11.

Luigi Boccherini, Quinteto op. 39/2, G. 338

(I, Allegro vivo ma non presto, cc. .9-16)

Deustche Staatsbibliothek, Berlín M 517

Los tres quintetos de la op. 39 de Boccherini presentan diversas soluciones estructurales que van desde el plan evocador de la suite que aparece en el Quinteto op. 39/1 (G. 337) a la estructura en tres tiempos (Allegro vivo, Pastorale amoroso ma non lento y Finale Presto) que presenta el Quinteto op. 39/3 (G.339) habitual de los esquemas formales del último barroco ${ }^{70}$.

${ }^{70}$ Gérard. Thematic, pp..382-386. 
La estructura general del Quinteto op. 39/2 (G. 338) en Fa mayor muestra el amplio conocimiento de Boccherini de las soluciones formales que se estaban gestando en la música de cámara centroeuropea, con el esquema habitual en cuatro movimientos que se generalizaría después para gran parte de las obras camerísticas $^{71}$. El primer tiempo (Allegro vivo ma non presto) adopta la forma de sonata bitemática reexpositiva con dos temas contrastantes claramente caracterizados en ritmo y área tonal que, sin embargo, no se someten a un desarrollo definido en la sección central del movimiento. El segundo tiempo (Adagio ma non tanto) está escrito en la tonalidad homónima de Fa menor y concede el protagonismo absoluto al violín primero. Una breve introducción (cc. 1-4) da paso al material temático principal del movimiento. La primera frase (c.5-8) es buen ejemplo de la gran destreza de Boccherini a la hora de desarrollar frases simétricas con una planificación melódica y tonal perfectamente definida. Como puede observarse en el Ejemplo musical 12, el tema principal de este movimiento está construido por un ornamentado motivo de un compás sobre el acorde de La bemol que se repite de forma secuencial a distancia de segunda ascendente en el compás 6 y se continúa en el compás 7 , en el que se rompe la progresión para buscar el punto culminante melódico ( $\mathrm{La} \mathrm{bemol}_{4}$ ). Después se inicia un descenso que busca el cierre de la frase sobre la tercera del acorde de dominante de la tonalidad relativa (Mi bemol mayor).

\footnotetext{
${ }^{71}$ Véase en el Apéndice 2 la partitura de este Quinteto en su versión para dos violonchelos que he realizado a partir de las partes instrumentales editadas por Pleyel.
} 


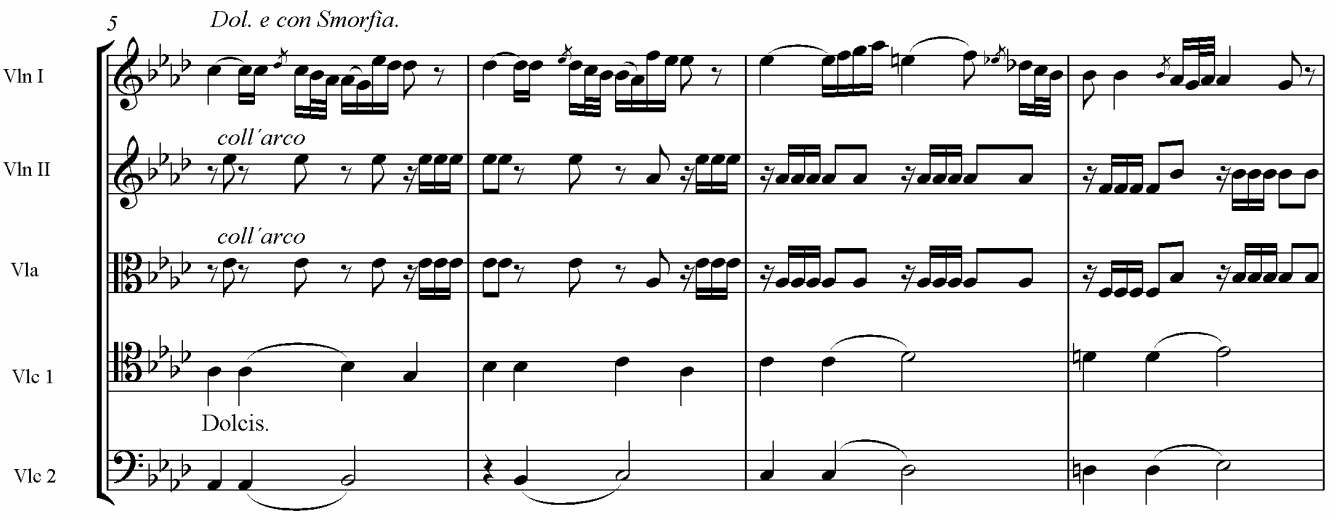

Ejemplo musical 12

Luigi Boccherini, Quinteto op. 39/2 G. 338

(II Allegro vivo ma non presto, cc. 5-8)

Según Douze noveaux quintetti pour deux violons, alto et deux violoncelles opera 47 :[1-4] livraison (Paris: Pleyel , 1813)

El tercer tiempo del Quinteto G. 338 es un minueto con trío también en la tonalidad homónima de fa menor. La obra se cierra con un Finale. Allegro vivo en el que se vuelve a la tonalidad principal de Fa mayor y que está realizado con una estructura bipartita heredera aún de las soluciones formales barrocas.

Los Cinco Sextetos y el Octeto que componían los seis Notturni op. 38 (G. 467-472) compuestos en 1787 es muy probable que también fueran creados para los competentes instrumentistas de cuerda y viento de la Condesa-Duquesa. En una carta que Boccherini escribió a Ignaz Pleyel en 1797, el compositor italiano relataba haber escrito unos nocturnos para instrumentos de viento para el excelente oboísta Gaspar Barli, (uno de los músicos asalariados de la CondesaDuquesa de Benavente) del que alababa la dulzura del sonido que extraía del instrumento y la gran capacidad para conseguir sonidos sobreagudos que 
Boccherini incorporó a sus obras ${ }^{72}$. De los seis Notturni de la op. 38 sólo se conocen tres en la actualidad: el Sexteto op. 38/1 (G.467) ${ }^{73}$, el Sexteto op. 38/ 5 $(\mathrm{G} .475)^{74}$, y el Octeto op. 38/ 4 (G. 470) $)^{75}$.

\subsubsection{Sinfonías y música de cámara de Joseph Haydn, Ignaz Pleyel y otros autores centroeuropeos.}

La música de Franz Joseph Haydn ocupó un papel prominente en el repertorio de las formaciones instrumentales privadas mantenidas por la Casas de Osuna y Benavente en las últimas décadas del siglo XVIII y probablemente también a comienzos del siglo XIX. En el inventario del archivo de música de la Condesa-Duquesa de Benavente realizado en 1824 figuran 76 sinfonías (algunas de ellas ya se habían perdido en ese año), 53 cuartetos y 15 tríos de Haydn ${ }^{76}$.

Las obras instrumentales de Haydn eran bien conocidas en el entorno de la Casa de Benavente antes de 1783 cuando se firmó un contrato con éste compositor para que proveyese de obras a la orquesta de la Condesa-Duquesa. En diciembre de 1781 Santiago Rodríguez copió por encargo de la Condesa-Duquesa varias “Sinfonías del Señor Ayden”, y en abril de 1782 Jerónimo Sánchez presentó un recibo a la administración de la Casa de Benavente por la copia de "Seis sinfonías

\footnotetext{
72 Germaine de Rothschild, Luigi Boccherini. Sa vie, son oeuvre (Paris: Plon, 1962), p. 121.

${ }^{73}$ Para violín, viola, fagot, flauta (u oboe), trompa y contrabajo.

${ }^{74}$ Para dos violines, viola, dos violonchelos y trompa. Aldo Pais ha realizado una edición moderna de los dos Sextetos a partir de las partes instrumentales editadas por Pleyel de 1798 y 1799. Luigi Due Notturni, op. 38, (Aldo Pais, editor) Padua, G: Zanibon, 1991. En el inventario de la Biblioteca de la Condesa- Duquesa de 1824 figuraba un Sexteto de Boccherini fechado en 1787 que podría ser uno de los citados Sextetos de la op. 38. [3/174].

75 Para dos violines, viola, dos violonchelos, flauta (u oboe) fagot y trompa

76 Ver Apéndices 3 y 4. Con los datos que figuran en este documento no es posible precisar si todas eran obras diferentes.

77 BNE Mss 14.016.3/28 (Papeles Barbieri).
} 
de Haydn con todos los instrumentos"

El contrato entre María Josefa Alfonso Pimentel, la XV Condesa-Duquesa de Benavente y Haydn se firmó en Octubre de 1783 y se mantuvo al menos hasta finales de septiembre de 1789. En febrero de 1785 se añadió al contrato una cláusula, que obligaba a Haydn a enviar anualmente al menos 12 piezas instrumentales de las que hubiera compuesto ese mismo año, entre las cuales ocho deberían ser siempre sinfonías, y el resto cuartetos, quintetos, sextetos o $\operatorname{conciertos}^{79}$

El poeta Tomás de Iriarte, músico aficionado y miembro de la tertulia de la Casa de Benavente, ejerció de intermediario entre la Condesa-Duquesa y el comisionado Carlos Alejandro de Lelis en Viena para las gestiones del envío de las obras contratadas con Haydn y es posible que influyese en la propia CondesaDuquesa para la firma del contrato con el compositor vienés. Iriarte fue uno de los principales propagandistas de la música de Haydn en España cuando la música del compositor vienés no era demasiado interpretada en Madrid tal y como afirmaba el propio Iriarte en 1779:

Si el elogio de Joseph Háyden o Héyden, se hubiese de medir por la aceptación que sus obras logra actualmente en Madrid parecería desde luego excesivo, ú apasionado. El autor de este poema, sin entrar en paralelos odiosos, ni quiere obligar a sus lectores a ser tan parciales de Háyden como él mismo se precia de serlo, se ha contentado con indicar algunas prendas

\footnotetext{
${ }^{78}$ Ibid., Mss 14.016.3/54

${ }^{79}$ AHN NOBLEZA OSUNA-CARTAS leg 391-2. Nicolás A. Solar Quintes. "I. Las relaciones de Haydn con la casa de Benavente. II. Nuevos documentos sobre Luigi Bocherini. III. Manuel García Íntimo”, AnM, II (1947), pp. 82.
} 
que más sobresale en las composiciones de aquel insigne maestro, y que nadie puede negarle, principalmente su fecundidad. ${ }^{80}$

La documentación administrativa consultada del archivo de la Casa de Osuna no proporciona datos definitivos sobre el número de obras instrumentales que Haydn envió a Madrid para cumplir las condiciones estipuladas en el contrato con la Condesa-Duquesa, pero parece que fueron muchas menos de las previstas. En marzo de 1785 Carlos Alejandro de Lelis recordó a Tomás de Iriarte las dificultades que tendría Haydn para cumplir lo pactado:

Fundaba yo mi esperanza de que Vuestras Mercedes estuviesen medianamente contentos de la remesa que en el año pasado les hice de obras de Haydn (ya que me bastó mi eficacia para lograr más) sobre la expresión de la contrata que decía in circa pezze dodeci, y en que Vuestra Merced mismo se hacía cargo en la referida carta de la semi-imposibilidad de que aquel autor cumpliese por entero su contrata diciendo " No concebimos cómo podrá tener Haydn tiempo y cabeza para desempeñar tanto como ofrece; y nos contentaremos con que cumpla con la mitad" 81

El número de ocho sinfonías nuevas al año que figura en la revisión del contrato de 1785 parece excesivo, y Haydn no debió de enviar nunca tal cantidad, simplemente porque no había compuesto tantas sinfonías en ese año. De haberse cumplido las condiciones establecidas en el contrato, Haydn debería haber enviado entre 1785 y 1789 un total de treinta y dos sinfonías. Según el catálogo de Hoboken, Haydn compuso sólo 14 sinfonías entre 1783 y 1789, entre las que figuran las llamadas Sinfonías de París (Hob. I: 82- 87), y las tres compuestas para

\footnotetext{
${ }^{80}$ Tomás Iriarte. La música (Madrid: Imprenta Real de la Gaceta, 1779), p. XXVII.

${ }^{81}$ AHN NOBLEZA OSUNA-CARTAS leg 391-2.
} 


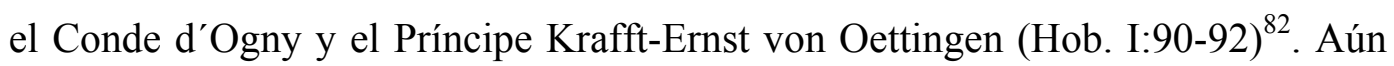
considerando la posibilidad de que Haydn compusiera durante este período algunas sinfonías que no se conocen o no se han identificado hasta la fecha, es factible considerar que la cifra real de sinfonías que se enviaron en esos años se acercara a la mitad de lo comprometido, como refería Lelis en su carta a Iriarte y como parece deducirse de las copias de Haydn realizadas para la CondesaDuquesa. Por ejemplo, a lo largo del año de 1786 Salvador Feixas copió un total de cuatro "sinfonías nuevas" de Haydn, posiblemente las mismas que se habían enviado desde Viena en ese año ${ }^{83}$.

El archivo de música de la Condesa-Duquesa conservaba también una nutrida colección de cuartetos de cuerda de F. J. Haydn ${ }^{84}$. A finales de 1784 o principios de 1785 Carlos Alejandro de Lelis envió a la Condesa de Benavente dos cuartetos (probablemente de cuerda) que, en un principio, estaban destinados al Duque de $\mathrm{Alba}^{85}$. En las cláusulas del contrato firmado con Haydn se estableció que las piezas enviadas debían haber sido compuestas durante el mismo año, una condición que tenía como objetivo presentar por primera vez en Madrid las novedades de la música del compositor vienés. En el caso de los dos cuartetos citados no se conoce ninguna obra de este género compuesta entre 1784 y 1785 por lo que, o bien se trataba de obras desconocidas hasta la fecha, o quizá de

\footnotetext{
${ }^{82}$ Anthony van Hoboken, J. Haydn, Thematisch-bibliographisches Werkverzeichnis (Mainz: B. Schott's Schone, 1957-.71), 3 vols.

${ }^{83}$ AHN NOBLEZA OSUNA-CARTAS legs. 389-22, 391-21.

${ }^{84}$ Veáse Aréndice 4.

85 AHN NOBLEZA OSUNA-CARTAS leg 391-2. La referencia a estos cuartetos figura en la carta que Alejandro de Lelis envió a Tomás de Iriarte el 24 de marzo de 1785 pero se refiere a un envío anterior.
} 
alguno de los seis cuartetos de la op. 33 (Hob III: 37-42) compuestos entre 1781 y 1782

En 1789, Carlos Alejandro de Lelis anunció el envió a la CondesaDuquesa "24 minués y otras tantas contradanzas de José Haydn" $"$. De esta colección recogida por Hoboken en su catálogo como "Gruppe IX, Nr. 9 d, e" no se conoce hasta la fecha ningún ejemplar ${ }^{87}$. En los inventarios del archivo de la Condesa-Duquesa no figuraba esta colección de minuetos de Haydn, si bien es probable que se conservase dentro de un legajo que contenía "minuetes y contradanzas de varios autores" [3/16].

Aunque una parte de la música instrumental de Haydn que perteneció al archivo de música de la Condesa-Duquesa debió de enviarse desde Viena para cumplir el contrato firmado en 1783, no fue esta la única vía por la que llegaron las obras de autores centroeuropeos a los atriles de los músicos de la CondesaDuquesa. Además de las ya citadas copias de varias sinfonías de Haydn que se realizaron entre 1781 y 1782, sabemos que Rafael García (primer violín de la orquesta y responsable del archivo musical) adquirió en abril de 1790 para la Condesa-Duquesa " 3 cuartetos de Haydn $n^{\circ} 59$ " al almacenista de libros y encuadernador de Madrid Gabriel de Sancha, dentro de un amplio lote de música orquestal y de cámara. En este mismo día se adquirieron 2 sinfonías, 21 cuartetos, y 6 quintetos de [Ignace] Pleyel ${ }^{88}$, autor cuya música gozó de una importante

\footnotetext{
${ }^{86}$ AHN NOBLEZA OSUNA-CARTAS leg 391-2. No sabemos si el envió llegó a verificarse pues en la carta de Lelis a Tomás de Iriarte fechada el 22 de abril de 1789 dice textualmente que procedería al envío "luego que me vengan los Minués y las Contradanzas".

${ }^{87}$ Hoboken, J. Haydn, vol II, p. 319.

88 AHN NOBLEZA, OSUNA-CARTAS, leg 391-1.
} 
difusión en España en las dos últimas décadas del siglo XVIII ${ }^{89}$.

Además de las obras de Haydn y Pleyel, el archivo de música de la Condesa-Duquesa tenía también otras composiciones instrumentales de autores centroeuropeos que trabajaron en las últimas décadas del siglo XVIII, como [Carl] Stamitz (13 sinfonías), [Johann Nepomuk] Hummel (6 cuartetos) [Leopold] Kozeluch, (6 sinfonías) y [Franz] Aspelmayer (una sinfonía y un cuarteto) ${ }^{90}$.

\subsubsection{Música instrumental de otros compositores e instrumentistas vinculados a la Casa de Benavente}

Dentro de las obras instrumentales que se conservaban en el archivo de música de la Condesa-Duquesa de Benavente se hallaban también algunas compuestas por los músicos que mantuvieron relaciones de servicio con la Casa de Benavente en las últimas décadas del siglo XVIII. De Giuseppe Ponzo (director en las funciones religiosas patrocinadas por la Casa de Benavente en honor a San Francisco de Borja y autor de música teatral) el archivo poseía los materiales musicales de Cinco oberturas [3/41] ${ }^{91}$, Seis Cuartetos [3/52], [4/163] y Cinco Quintetos [3/15], [4/175]. Dos de estos quintetos fueron probablemente los que copió Salvador Feixas para la Condesa-Duquesa de Benavente en $1786^{92}$.

\footnotetext{
89 En el archivo de música de la Condesa-Duquesa se conservaban un Quintetto per due violini, due viole et violoncello[3/96], [4/106], Dodici Minuetti per diversi instrumenti [3/97],[4/211]; y tres sinfonías [3/25-27], [4/162] de Pleyel. Acerca de la difusión de la música de Ignaz Pleyel en España véase José María Vilar. "Sobre la difusió de les obres de Pleyel a. Catalunya”, AnM 50 (1995), pp. 185-199 y David Wyn Jones."Austrian symphonies in the Royal Palace, Madrid" en Malcolm Boyd and Juan José Carreras (eds.). Music in Spain during the Eighteenth Century (Cambridge: Cambridge University Press, 1998), pp. 125-43.

${ }^{90}$ Ver Apéndices 3 y 4

91 En el inventario de ca. 1838 figura sólo una obertura de Ponzo [4/138].

92 AHN NOBLEZA OSUNA-CARTAS leg 391-21.
} 
Ramón Rodríguez Monroy, contrabajista de la orquesta de la Condesa Duquesa de Benavente y miembro de la Real Capilla, también compuso varias obras que se incorporaron al archivo de esta dama: 6 sinfonías [3/8 $]^{93}, 6$ oberturas. Juego $1^{\circ}$ [3/40], Seis Cuartetos [3/50], [4/131]; Doce minués a dos violines y bajo [3/74], Dos paspiés con sus minués a dos violines y bajo [4/210], y un Trío para la oposición de contrabajo en la Real Capilla de Su Majestad [3/181]. Las sinfonías cuarta, quinta y sexta y unas contradanzas de Monroy fueron copiadas por Salvador Feixas en 1786 para la Condesa-Duquesa ${ }^{94}$.

En el archivo de la Condesa-Duquesa se conservaban además cuatro sinfonías “de Iriarte” [4/173], que seguramente fueron escritas por el poeta Tomás de Iriarte, uno de los personajes habituales en los salones de la Casa de Benavente. Iriarte fue intérprete aficionado de violín y viola y buen conocedor de la música de Haydn ${ }^{95}$.

\subsection{El repertorio de música de baile de la Casa de Benavente en el primer tercio del siglo XIX}

Las fiestas y bailes organizados por la Condesa-Duquesa María Josefa en su palacio de la Puerta de la Vega de Madrid y en su residencia de recreo de La Alameda (situada a las afueras de la capital) fueron uno de los principales espacios de sociabilidad de la alta nobleza madrileña durante el primer tercio del

\footnotetext{
93 En el inventario de ca. 1838 figuran 5 sinfonías de Monroy [4/174] que posiblemente fueran parte de esta colección.

94 AHN NOBLEZA OSUNA-CARTAS leg 391-21.

95 Sobre Tomás de Iriarte véase Cotarelo y Mori, Iriarte y su época (Madrid: Sucesores de Rivadeneyra, 1897) y José Subirá, El poeta-compositor Iriarte y el cultivo español del melólogo (melodrama)( Barcelona: Instituto Español de Musicología, 1949-1950), 2 vols.
} 
siglo XIX. El repertorio musical de estos bailes estuvo formado principalmente por valses, contradanzas, rigodones y otros aires de moda que se interpretaban por pequeños grupos de músicos contratados para la ocasión.

Las plantillas de los conjuntos que participaron en las fiestas organizadas por la Condesa-Duquesa de Benavente en su casa entre 1825 y 1830 muestran una composición prototípica de un grupo instrumental de baile, que difícilmente podría haber interpretado otro repertorio sinfónico o camerístico más ambicioso sin someterlo a adaptaciones $\mathrm{u}$ arreglos. El conjunto que se contrataba para estos actos solía tener entre ocho y doce músicos e incluía siempre un grupo de violines (entre cuatro y seis), un violonchelo, un contrabajo, una o dos flautas, y uno o dos clarinetes. Eventualmente se contaba con la participación de una trompa o de un encargado de los triángulos. Por ejemplo, para los bailes de carnaval de 1829 fue contratado un grupo instrumental de seis violines, dos flautas, un clarinete, una trompa, un violonchelo y un contrabajo. Este conjunto interpretó dos cuadrillas de contradanzas francesas, ocho valses, cuatro contradanzas escocesas, que fueron arregladas por el violinista Francisco Bocolo que también actuaba como director de la formación ${ }^{96}$.

En el archivo de música de la Condesa-Duquesa había varias colecciones de contradanzas y valses que debieron formar parte del repertorio de los bailes que tuvieron lugar en sus residencias durante el primer tercio del siglo XIX. A este grupo de música de baile pertenecen la Collection de Walses pour deux violons et Basse de Masarnau-Moscheles [3/303] y Les folies Parisiennes. Collection de

\footnotetext{
${ }^{96}$ AHN NOBLEZA, OSUNA-CARTAS, leg 392-27.
} 
Contredanses et Walses pour 2 violons et Basse del compositor alemán [Johann Peter] Pixis [3/302], [4-47].

\subsection{Música para piano}

La música para piano solo del archivo de la Condesa-Duquesa de Benavente muestra las preferencias del repertorio doméstico y los gustos estilísticos personales de esta familia de la alta nobleza en las primeras décadas del siglo XIX. La mayoría de las obras para piano que figuran en los inventarios del archivo están escritas por compositores europeos que trabajaron en las últimas décadas del siglo XVIII o en las primeras del siglo XIX. Una parte importante de este repertorio estaba formado por pequeñas piezas características de salón (marchas, valses, contradanzas, y polacas) compuestas por autores europeos como [Josef] Galinek o Sigismund Neukomm y españoles como José Rodríguez León, entre otros. En un segundo grupo podrían clasificarse las adaptaciones para piano solo de oberturas y fragmentos de óperas francesas o italianas estrenadas en España en las primeras décadas del siglo XIX como, por ejemplo Il matrimonio secreto de Cimarosa, Semiramide de Rossini Les Deux Prisonniers de Dalayrac o Chapitre second de Solié. En el archivo había también varias obras para teclado de autores centroeuropeos como Joseph Haydn (13 sonatas, 18 contradanzas, una Sonata a cuatro manos, y un Rondó bailado en el teatro de Madrid), Wolfgang A. Mozart, (Doce variaciones) o Ignaz Pleyel (un Rondó). ${ }^{97}$.

La hija menor de los IX Duques de Osuna, Maria Manuela Téllez Girón (futura Duquesa de Abrantes) fue una competente cantante y pianista aficionada. 
Durante su residencia en Cádiz entre 1811 y 1813, se realizaron varias copias de obras de piano para su uso personal, que seguramente fueron utilizadas en las lecciones que le impartía el cantante Carlo Marinelli, cuya firma aparece en varios de los recibos de copia. Entre la música para piano que se copió para Mesta dama en Cádiz figuran obras de carácter pedagógico como unos Principios de música para fortepiano de Pleyel y Dussek, un minueto a cuatro manos de "Struchz" [= Paul Friedrich Struck (1776-1820)], un duetto para arpa y piano de [Jan Ladislav] Dussek, y varias obras características de la música de salón como valses y contradanzas de autores anónimos y un ejemplar de La Batalla de Praga ${ }^{98}$. Este último título podría identificarse con la sonata programática The Battle of Prague del compositor bohemio František Kocžwara (*ca. 1750-†1791) una de las obras más interpretadas del repertorio de música de salón de las primeras décadas del siglo XIX, que tuvo una gran difusión por toda Europa y América ${ }^{99}$

\footnotetext{
97 Ver Apéndice 4, apartado E 1.

98 AHN NOBLEZA OSUNA-CARTAS leg 392-4.

99 Ronadl R Kidd, “Kocžwara, František”, $N G$, vol. 13, pp. 715-716.
} 


\section{La música vocal de cámara.}

La música vocal fue cultivada en el ámbito doméstico de las Casas de Osuna y Benavente al menos desde las primeras décadas del siglo XVIII. El repertorio vocal doméstico que se interpretó en los palacios de los Osuna y los Benavente durante el siglo XVIII estaba formado por piezas vocales de cámara propiamente dichas (canciones, arias y cantatas con acompañamiento de bajo continuo o instrumento de teclado) y por números de obras dramático-musicales (fundamentalmente recitativos, arias y dúos de ópera) que se interpretaban por un grupo instrumental pequeño o en reducciones para instrumento de teclado (clave o piano). Estas adaptaciones, que formaron parte del repertorio habitual de las academias que se celebraron en Madrid e Iberoamérica desde las últimas décadas del siglo XVIII100, tenían un carácter “de cámara” en el sentido etimológico del término, pues estaban concebidas para su interpretación sin representación escénica en un ámbito privado e íntimo. La importancia que adquirió el repertorio vocal de origen teatral en las academias celebradas por la alta sociedad urbana española en las últimas décadas del siglo XVIII fue señalada por Tomás de Iriarte:

\footnotetext{
La urbana sociedad aficionada, a estas sonoras diversiones quiere la Música vocal tomar prestada del público teatro; mas prefiere dúos, arias, sublimes recitados a tercetos y coros complicados. Lo mejor de las óperas elige.
}

Aunque cediendo a veces

\footnotetext{
${ }^{100}$ Bernardo Illari, "Metastasio nel'indie", en Emilio Casares Rodicio y Álvaro Torrente (eds.): $L a$ ópera en España e Hispanoamérica, (Madrid: ICCMU, 2001), vol. I, p. 351.
} 
al ansia de captar aprobaciones

de pervertidos jueces,

se engaña en adoptar composiciones

que propagan el vicio

de los nimios adornos y artificio ${ }^{101}$.

Durante las primeras décadas del siglo XIX las adaptaciones de números de operas italiana y, en menor medida, francesa continuaron formando parte del repertorio vocal de los salones patrocinados por los miembros de las Casas de Osuna y Benavente. Aunque la interpretación de música dramática en versión de cámara tuvo su máxima eclosión en los salones aristocráticos y burgueses de España a partir de la segunda década del siglo $\mathrm{XIX}^{102}$, la importancia que adquirió este repertorio en las academias musicales de las últimas décadas del siglo XVIII y de los primeros años del siglo XIX muestra un proceso de continuidad que no estaba sometido únicamente a los imperativos de la moda y que, al menos en el ámbito aristocrático, contaba con una sólida tradición.

En las academias y recitales que se organizaron en los palacios de las Casas de Osuna y Benavente durante el siglo XIX actuaron habitualmente los cantantes de los teatros públicos, y también solían participar los miembros de la familia que habían recibido una formación vocal como María Manuela TéllezGirón, hija menor de los IX Duques de Osuna, Pedro de Alcántara II, XI Duque de Osuna, y su prima Encarnación Camarasa que según Fernando Fernández de

\footnotetext{
101 Iriarte, La música, p. 103.

102 Sobre la música de salón y su repertorio véase Celsa Alonso, "Los salones: un espacio musical para la España del XIX”. AnM 48 (1993), pp. 165-205; y los trabajos de María Antonia Virgili y Celsa Alonso publicados en José Peñín (coord.). Música Iberoamericana de salón. Actas del Congreso Iberoamericano de Musicología 1998. Caracas: Fundación Vicente Emilio Sojo, 2000, 2 vols.
} 
Córdoba era una consumada artista que poseía una "voz de sirena que enamoraba a cuantos la escuchaban al piano" ${ }^{\text {"103. }}$

En este apartado presentaré una mirada panorámica sobre la música vocal de cámara que se interpretó en el ámbito doméstico de las Casas de Osuna y Benavente durante el siglo XVIII y en las primeras décadas del siglo XIX. Asimismo analizaré una selección representativa de obras vocales que fueron escritas o recopiladas para las familias Osuna y Benavente en dicho periodo.

\subsection{El Libro de cantatas y arias italianas de la Duquesa de Osuna}

En la sección de Música de la Biblioteca Nacional de Madrid se conserva una interesante colección de arias y cantatas italianas para una voz y bajo continuo relacionada con la práctica musical doméstica de la Casa de Osuna en la primera mitad del siglo XVIII. Se trata de un volumen apaisado encuadernado en pergamino que contiene 43 obras manuscritas presentadas en partitura, copiadas por diversas manos y en distintos formatos de papel ${ }^{104}$.

Aunque Higinio Anglés y José Subirá describieron parcialmente su contenido, hasta la fecha esta colección no ha sido objeto de un estudio pormenorizado $^{105}$. Su buen estado de conservación y el gran número de obras que

\footnotetext{
103 Fernández de Córdoba. Mis memorias, vol I, p. 37.

104 BNE M 2245. De aquí en adelante me referiré a esta obra como Libro de Cantatas Italianas de la Duquesa de Osuna. El volumen lleva el sello de la Biblioteca Real lo que indica que perteneció a la Corona española antes de 1836, año en que esta institución cambió su denominación por la de Biblioteca Nacional y se integró en un organismo estatal dependiente del Ministerio de la Gobernación.

105 Higinio Anglés y José Subirá, Catálogo musical de la Biblioteca Nacional de Madrid, (Barcelona: Consejo Superior de Investigaciones. Científicas. Instituto Español de Musicología, 1946-1951), vol I, p. 400.
} 
contiene, la convierten en una interesante recopilación para estudiar la circulación de la recepción de la cantata profana italiana en el entorno de la nobleza española en la primera mitad del siglo XVIII ${ }^{106}$.

El título que figura en el folio I de la colección: “Cantadas Italianas escoxidas para la ex[celentísima] Se[eñora] Duquesa de Osuna mi señora" da a entender que la recopilación fue realizada por alguno de los músicos que trabajaron para los Duques de Osuna. Es probable que este volumen formase parte de una antología más amplia de arias y cantatas italianas recopiladas para la Duquesa de Osuna $^{107}$.

Las destinatarias del Libro de Cantatas Italianas pudieron ser dos personas diferentes, ya que en la primera mitad del siglo XVIII (período en el que se debió de realizar la recopilación según Anglés y Subirá), el título de "Duquesa de Osuna" fue utilizado por: María Remigia Fernández de Velasco, VI Duquesa de Osuna consorte (entre 1695 y 1721) y por Francisca Bibiana Alonso Pérez de Guzmán el Bueno, Duquesa de Osuna consorte tras su boda con José Téllez Girón VII Duque de Osuna en 1721 y administradora de la Casa de Osuna entre 1733 y $1748^{108}$. La colección contiene obras de autores que trabajaron en las últimas décadas del siglo XVII y en las primeras del XVIII, por lo que es más probable que su propietaria fuera Francisca Bibiana, VII Duquesa (consorte) de Osuna, gran aficionada a la música y asistente habitual a los espectáculos operísticos

\footnotetext{
${ }^{106}$ Véase la descripción y el inventario de las piezas que contiene este libro en el Apéndice 3.

107 En uno de los folios sin numerar de la introducción [con el número VII en mi inventario], y en fecha posterior a la fecha de encuadernación, este volumen se catalogó como el tomo segundo de una colección de "Arie italiane di diversi autori [...] escogidas para la Excelentísima Señora Duquesa de Osuna".

108 Después de la muerte del VII Duque y dada la minoría de edad de su hijo Pedro Zoilo, VIII Duque de Osuna. Veáse el Capítulo I.
} 
italianos del Teatro de los Caños del Peral de Madrid, que solía organizar conciertos de música vocal en su casa con algunos de los cantantes italianos del elenco de dicho teatro ${ }^{109}$. Es posible que esta recopilación, compuesta de piezas breves pero de dificultad vocal considerable, se usase durante estas sesiones musicales privadas. Si el libro perteneció a Francisca Bibiana, el encargado de realizar esta antología quizá fuera el napolitano Giovanni Battista Mele, que en 1733 llegó a Madrid desde Nápoles apoyado por el VII Duque de Osuna, y que posteriormente fue profesor de música de su hija Maria Faustina, la futura esposa del XIV Conde-Duque de Benavente ${ }^{110}$.

El contenido del Libro de Cantatas Italianas de la Duquesa de Osuna puede verse en el Apéndice 3. En conjunto contiene 24 cantatas, 18 arias y un arietta breve en tiempo ternario denominada "minuetta". A excepción de dos cantatas y un aria que requieren el uso de dos violines ([1/26], [1/41], [1/43]) el resto están escritas para voz solista y bajo continuo ${ }^{111}$

Todas las obras del Libro de Cantatas Italianas de la Duquesa de Osuna que aparecen identificadas con su autor pertenecen a compositores italianos que trabajaron en las últimas décadas del siglo XVII y en la primera mitad del siglo XVIII: Carlo [Antonio] Benati [1/2] y [1/3], Alessandro Scarlatti [1/4], [1/5], [1/14], Nicola Fago [1/8], [Giovanni] Bononcini [1/26] y Carlo Cesarini [1309]. Además de los citados autores en esta colección figuran obras de otros cuatro compositores: "M. Nibelle”, [1/1], "Abbate de Russi” [1/25], nombre que según Higinio Anglés y José Subirá podría identificarse con el compositor napolitano

\footnotetext{
${ }^{109}$ Veáse Capítulo VI.

${ }^{110}$ Los principales datos biográficos de Giovanni Battista Mele se recogen en el Apéndice 5.

111 Ver Apéndice 3.
} 
Francesco Rossi ${ }^{112}$, "Pistoulin” , [1/28], y "Gio. P. Handelli” (= ¿G. F. Händel?) $[1 / 39]$.

La cantata Clori pur troppo bella [1/15], cuyo autor no figura en esta recopilación, es una obra de Giacomo Facco $(* 1676-\uparrow 1753)$, compositor que trabajó en la corte española como violinista de la Real Capilla desde 1720 y como profesor de música del Príncipe de Asturias, el futuro Luis I de Borbón ${ }^{113}$. De esta cantata se conserva un ejemplar manuscrito en la Biblioteca del Conservatorio de Nápoles en la que figura como autor Giacomo Facco ${ }^{114}$. En 1782 la cantata Clori pur troppo bella de Facco se incluyó dentro de la obra didáctica L'art de perfectionner dans le Violon, de Monsieur Correte ${ }^{115}$.

Cada una de las obras que se recopilan en el Libro de Cantatas Italianas de la Duquesa de Osuna requiere un análisis y un estudio pormenorizado que excede los planteamientos de este capítulo. Con el fin de mostrar el valor que posee esta antología, estudiaré tres obras representativas del contenido del volumen: El aria con violines Pastorella che fra le selve de [Giovanni] Bononcini [1/26], uno de los tres ejemplos de la antología que utilizan acompañamiento instrumental de violines además de bajo continuo, y las cantatas E penar deggio ancora de Alessandro Scarlatti [1/4], el compositor más representado en esta

\footnotetext{
112 Anglés y Subirá. Catálogo, vol I, p. 402. No habría que descartar, sin embargo, la posibilidad de que esta cantata pudiera ser una obra de Antonio Vivaldi, cuya familia era conocida en su época por el sobrenombre de "Rossi", debido al color de su pelo.

113 Sobre este compositor véase José Subira, “Jaime Facco y su obra musical en Madrid”, AnM II, 1948, pp. 109-132 y .Anibal Cetrangolo, “Giacomo Facco”, DMEH, vol. 4, 876-879.

114 Biblioteca del Conservatorio di musica S. Pietro a Majella - Napoli - NA - Cantate 111(3).

115 Anibale Enrico Cetrangolo, Musica italiana nell'America coloniale. Premesse. Cantate del Veneto Giacomo Facco (Padova: Liviana Editrice, 1989), pp. 83-89. En este estudio Cetrangolo presenta una edición de Clori pur tropo bella tomando como fuente la versión del tratado de Corrette.
} 
antología y Lille vedi quel colle [1/16], una cantata anónima que en otras fuentes aparece atribuida Georg Friedrich Händel.

\subsection{1. [Giovanni] Bononcini: Pastorella che tra le selve. Aria}

El "Aria solo con violini del Signore Bononcini", que comienza con el verso Pastorella che tra le selve [1/26] es la única de las 18 arias sueltas que se recopilan en Libro de Cantatas Italianas de la Duquesa de Osuna, en la que figura el nombre de su autor, [Giovanni] Bononcini $(* 1670-\uparrow 1747)$. La pieza fue también incluida en el tercer volumen de la colección de Meilleurs airs italiens publicado en París por el impresor francés Christophe Ballard (1703). La colección de Ballard que contiene un total de 110 arias anónimas y una atribuida a Leopoldo I de Augsburgo, y ha sido recientemente estudiada por Barbara Nestola Para esta investigadora que ha realizado un inventario y una identificación de los autores de las arias el aria Pastorella che tra le selve, (cuyo incipit musical coincide con el del aria de Bononcini del mismo nombre que figura en el Libro de Cantatas italianas de la Duquesa de Osuna) podría ser de Bernardo Sabadini ${ }^{116}$.

El aria atribuida a Bononcini en la fuente de la Biblioteca Nacional de Madrid (Ver la transcripción en el Apéndice 2.1.) es una pieza breve de tema pastoral en la que se prescinde aún del ritornello como elemento de desarrollo temático. Esta estructura es una de las más utilizadas por los autores italianos en las últimas décadas del siglo XVII, antes de la estandarización del aria da capo $^{117}$.

\footnotetext{
116 Barbara Nestola. "Spoglio dei volumini dei « Meilleurs airs italiennes» pubblicati da Christoph Ballard (1699-1708)" Cahiers Philidor, Centre de Musique Baroque de Versailles, 26, (Versión electrónica http: //www.cmbv.com/images/banq/cp/cp026.pdf). Último acceso el 10-2-2005.

117 Sobre la evolución de las estructura de las arias en el siglo XVII véase Jack Westrup y Thomas Walker. “Aria. 2. 17th-century vocal music”, $N G$, vol 1, pp. 574-575.
} 
La primera sección del aria (A) se abre con una intervención de la voz a solo sobre un largo pedal de tónica en el bajo que subraya la tonalidad principal de La mayor. Este pedal será reforzado por el violín segundo al final de la primera frase con un doble pedal de tónica y dominante sobre la primera y segunda cuerdas al aire (cc. 8-12) que presta un soporte armónico a las coloraturas vocales, mientras que el violín primero dobla a la voz a una tercera superior. La segunda frase de la primera sección está construida sobre los versos que abren el aria, y finaliza con una breve coda a cargo de los dos violines y el bajo que cierra la primera parte con una cadencia en la tonalidad principal. La sección B (c.26) comienza en la región de la dominante (mi menor) y, a diferencia de la primera parte, muestra una notable variedad armónica, discurriendo por las regiones de la dominante de la dominante (si $\mathrm{m}$ ) y de su relativo (re mayor). Para equilibrar la variedad que proporciona la fluctuación tonal, tras una vocalización secuencial de carácter retórico sobre la palabra cantando, en el segundo verso de esta sección se recurre a una variante de la frase inicial del aria que contribuye a prestar coherencia al conjunto de la pieza (cc. 32-42).

La simplicidad de esta aria, que evita toda artificiosidad de tipo contrapuntístico, su breve duración y el tema pastoral son elementos característicos del estilo compositivo de Giovanni Bononcini, un autor que era alabado en su época por la "galante simplicidad" que mostraba en las arias de sus óperas $^{118}$.

118 Lowell Lindgreen, “Bononcini, Giovanni”, $N G$, vol 4, pp. 872-877. 


\subsubsection{Alejandro Scarlatti, E penar deggio ancora. Cantata para voz y bajo continuo}

Alessandro Scarlatti $(* 1660-\uparrow 1725)$ fue uno de los compositores más prolíficos de cantatas de cámara italianas de su época. Edwin Hanley catalogó 783 cantatas de este autor escritas entre 1688 y 1725, la mayor parte de ellas para soprano y bajo continuo ${ }^{119}$. A este grupo de obras pertenece la cantata $E$ penar deggio ancora una de las tres obras de Alessandro Scarlatti contenidas en el Libro de Cantatas Italianas de la Duquesa de Osuna (Lámina 34).

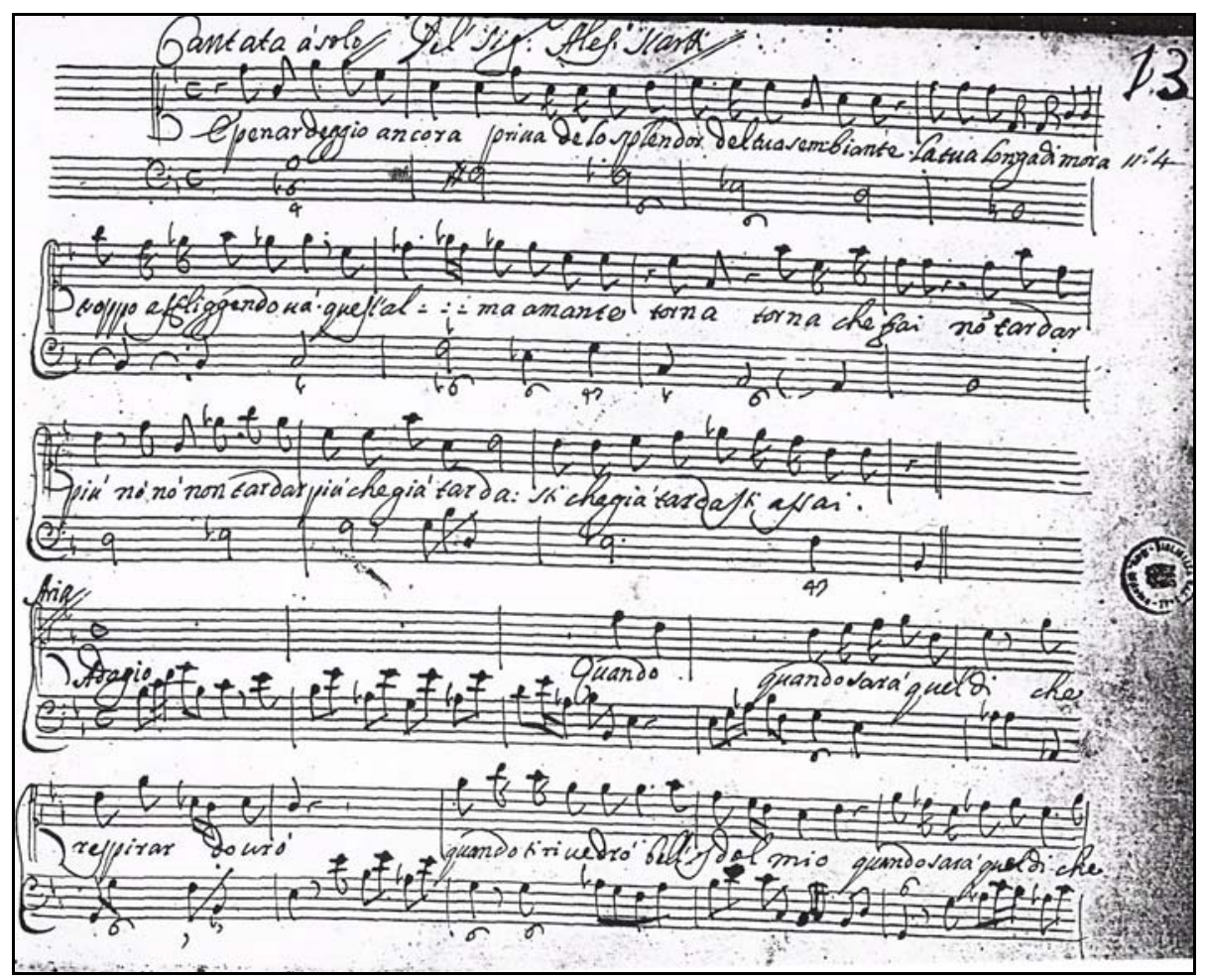

\section{Lámina 34.}

Alessandro Scarlatti E penar deggio ancora.

Cantata para voz y bajo continuo.

BNE M 2245, f. 13.

119 Roberto Pagano, Malcolm Boyd y Edwin Hanley, "Scarlatti, Alessandro", NG, vol. 2222, pp. 373-396. Véase asimismo Edwin Hanley. Alessandro Scarlatti's "Cantate da Camera" a Bibliographical Study. Tesis doctoral (Yale: Yale University ,1963). 
La estructura de E penar deggio ancora de Scarlatti (Recitativo-AriaRecitativo-Aria) responde a los habituales cánones de la cantata solística italiana de las primeras décadas del siglo XVIII. Según Malcolm Boyd, esta estructura es la más utilizada por Alessandro Scarlatti desde 1697, año que marca un nuevo período en su producción de cantatas de cámara. A partir de este momento Scarlatti utiliza preferentemente la forma de aria da capo, y abandona el uso de los recitativos ariosos y de las formas binarias. Las melodías de las cantatas compuestas a partir de 1697 son más fluidas y los saltos melódicos disjuntos de carácter simbólico aparecen con menos frecuencia ${ }^{120}$.

Los recitativos de E penar deggio ancora muestran algunas de las características recurrentes del estilo scarlattiano. En el recitativo que abre la cantata, el cromatismo descendente del bajo representa la pena y el anhelo que expresa el texto (Ejemplo musical 13).

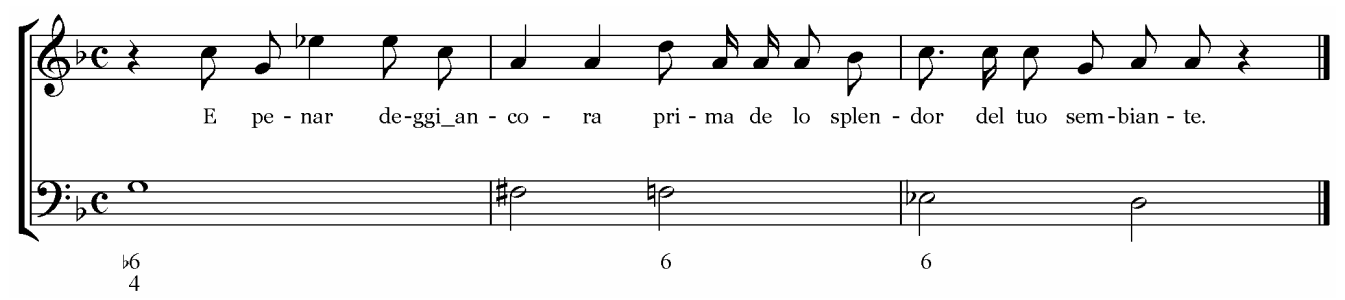

Ejemplo musical 13.

. Alessandro Scarlatti: E penar deggio ancora.

Cantata para voz y bajo continuo. (cc.1-3)

BNE M 2245, f. 13

La repetición de palabras o frases cortas en el recitativo y el predominio de intervalos disjuntos aleja toda referencia al estilo arioso y contribuye a la ruptura

${ }^{120}$ Malcom Boyd, "Form and Style in Scarlatti's Chamber Cantatas", Music Review 25 (1964), pp.17-26. 
de la regularidad métrica del texto y a la intensificación del contenido. Un ejemplo de esta técnica aparece en los compases 8 al 11 del primer recitativo. La repetición de la frase non tardar piú con un diseño secuencial enfatiza el sentido de prontitud que expresa el texto (Ejemplo musical 14).

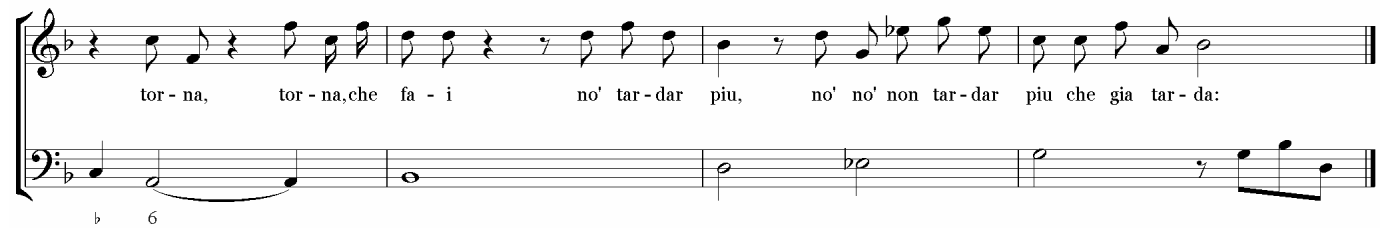

Ejemplo musical 14.

Alessandro Scarlatti, E penar deggio ancora.

Cantata para voz y bajo continuo. (cc. 8-11)

BNE M 2245, f. 13

Las dos arias de esta cantata son de estructura da capo y ambas contrastan en velocidad, compás y tonalidad: la primera está escrita en Adagio, compás de cuatro por cuatro y en Si bemol mayor, y la segunda en Andante, compás de tres por ocho y sol menor ${ }^{121}$.

El trabajo temático que desarrolla Scarlatti en las arias de E penar deggio ancora refuerza la interrelación entre el acompañamiento y la línea vocal. Las células motívicas que se presentan en el ritornello no se limitan a aparecer en la parte del bajo y se convierten en el elemento temático principal de las dos secciones de las arias. El diseño anacrúsico de tres semicorcheas descendentes seguido de una corchea con el que se abre la segunda aria (Ejemplo musical 15) está presente a lo largo de toda la pieza, y es sometido a diversos procedimientos 
de transformación motívica como el desplazamiento rítmico (c.76) o el movimiento contrario (cc.83-84) ${ }^{122}$.

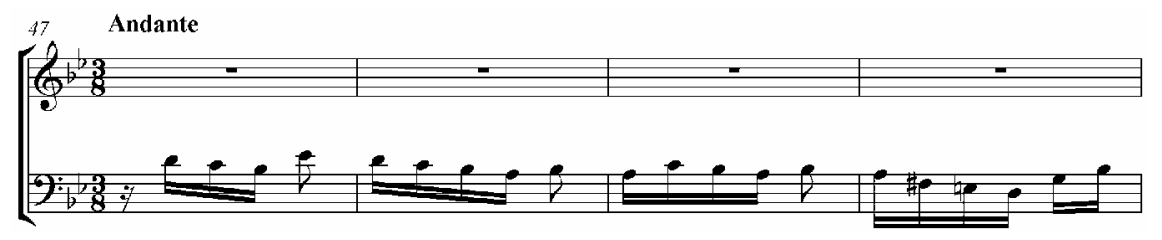

Ejemplo musical 15.

Alessandro Scarlatti, E penar deggio ancora.

Cantata para voz y bajo continuo. (cc. 47-51)

BNE M 2245, f. 14

Con esta estructura "monotemática" se consigue una continuidad y coherencia para el conjunto del aria. La utilización del mismo material motívico tanto en la sección A como en la B es uno de los rasgos característicos del cambio estilístico que se produce en el género de la cantata de cámara italiana en los últimos años del siglo XVII y en la primera década del siglo XVIII ${ }^{123}$, y puede observarse también en muchas de las arias de las cantatas de Händel compuestas en 1708 durante su estancia en Roma al servicio del marqués (después príncipe) Francesco Maria Ruspoli ${ }^{124}$.

\footnotetext{
121 Ver Apéndice 2.1

122 Ibíd.

123 Las principales características de este cambio estilístico serían la sustitución de las formas binarias y los ariosos por las arias da capo, el cierre preferente de las cantatas con un recitativo y la renuncia al uso de los intervalos disjuntos con un carácter simbólicos. Ellen T. Harris., Handel as Orpheus, Voice and desire in the Chamber cantatas (Cambridge, Massachusetts y Londres: Harvard University Press, 2001), p.64.

124 Harris, Handel, pp. 103-104.
} 


\subsection{3. [Georg Friedrich Händel] Lilla vedi quel colle Cantata para voz y bajo continuo}

Entre las obras sin autor identificado que forman parte del Libro de Cantatas italianas de la Duquesa de Osuna, figura una "cantata a voce sola" de temática pastoral que comienza con el verso Lilla vedi quel colle (Lámina 35). De esta misma obra se conservan al menos otras dos fuentes manuscritas en las que figura como autor Georg Friedrich Händel. La primera de ellas es el Libro de Cantatas de Agostino Steffani, una copia del siglo XVIII que se conserva en la British Library de Londres (manuscrito Add. 14.182) ${ }^{125}$. Esta fuente es la que utilizó Anthony Hicks para clasificar esta cantata en el grupo de obras de atribución dudosa [“doubtful and spurious"] en el catálogo de obras de Händel que figura en el New Grove Dictionary ${ }^{126}$. La segunda de las fuentes conocidas hasta la fecha Lilla vedi quel colle en la que también aparece atribuída a Händel se conserva en la Biblioteca del Conservatorio de Nápoles (Italia) con el título de "Cantata XXIII",

La atribución definitiva de esta obra a Händel precisa de la realización de un estudio comparativo entre las dos fuentes citadas y la que figura en el Libro de Cantatas italianas de la Duquesa de Osuna, una tarea que excede los planteamientos metodológicos de este apartado. No obstante, señalaré algunos aspectos que podrían tomarse como puntos de partida para un futuro estudio más amplio de esta obra.

\footnotetext{
125 British Library (Londres), Mss Add. 14.182, ff. 78-80.

126 Anthony Hicks, "Händel, George Friedrich", NG, vol. 10, p. 792.

127 Biblioteca del Conservatorio de Música San Pietro a Majella. Cantate, 153-23.
} 


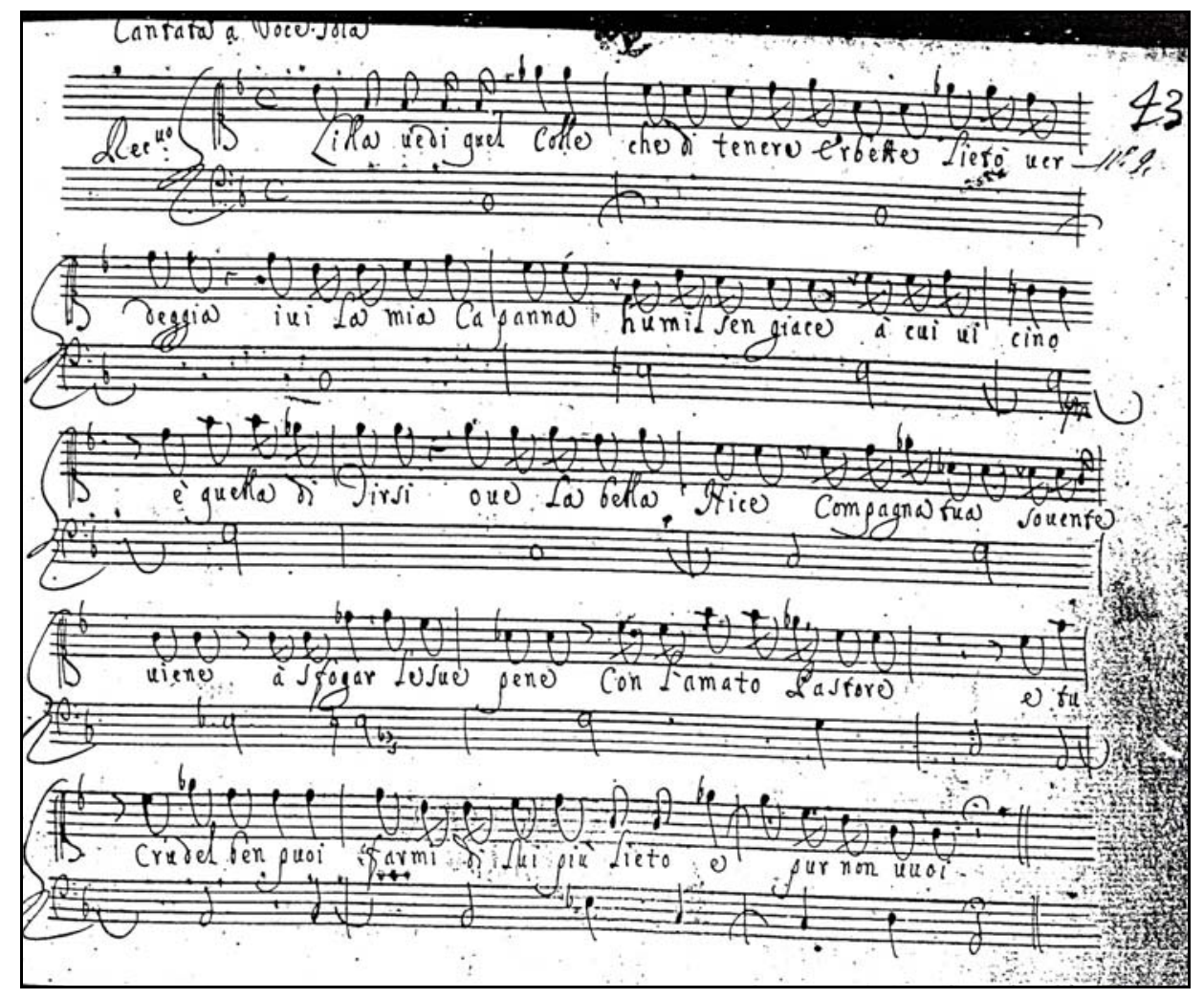

\section{Lámina 35.}

[G. F. Händel] Lilla vedi quel colle.

Cantata para voz y bajo continuo.

BNE M 2245, f. 43

En el Apéndice 2 presento la edición de la cantata Lilla vedi quel colle a partir de la fuente de Madrid. Varios rasgos estilísticos de esta obra coinciden con las cantatas compuestas por Händel a partir de $1708^{128}$. El molde estructural Recitativo-Aria-Recitativo-Aria, que articula Lilla vedi quel colle es el más utilizado por Händel en sus cantatas de la etapa italiana que se inicia en 1708. Las arias del tipo da capo que Händel compuso en esta época usan el ritornello como elemento temático, al igual que las de esta cantata y los recitativos no presentan

${ }^{128}$ Harris, Handel, p. 65. Véase la transcripción de esta cantata en el Apéndice 2.1. 
pasajes melódicos de tipo "arioso" que aparecían con frecuencia en las cantatas de Händel (y de otros autores) hasta finales del siglo XVII. La melodía de Lilla vedi quel colle discurre preferentemente por grados conjuntos, otro de los rasgos que define el estilo de las cantatas de Händel del citado período. Véase por ejemplo el comienzo de la primera aria (Ejemplo Musical 16):

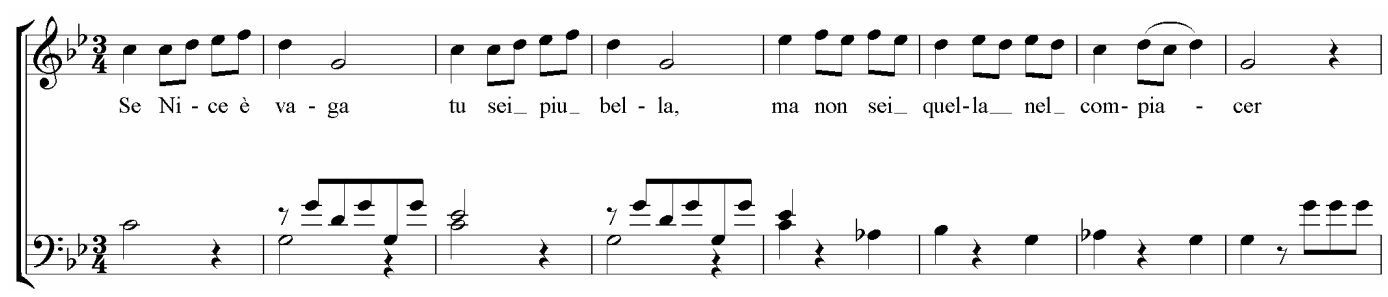

Ejemplo musical 16.

[G.F. Händel] Lilla vedi quel colle.

Cantata para voz y bajo continuo. (cc. 14-21).

BNE M 2245, f. 43v

En el Libro de Cantatas italianas de la Duquesa de Osuna, figura también otra pieza que acaso podría identificarse como una obra de Händel desconocida hasta la fecha. Se trata de la cantata para voz y continuo Fra dubbiosi pensieri "del Sig[no]r F. Gio. Handelli” [1/39]. El nombre del autor podría ser una italianización de Georg Friedrich Händel, realizada por el copista. En cualquier caso, la adjudicación definitiva de la autoría de esta obra debería someterse a un riguroso estudio de los aspectos estilísticos y de la existencia de posibles fuentes concordantes. 


\subsection{La música vocal de cámara en los palacios de los Benavente (1763-1799)}

La música vocal de cámara fue también fue cultivada frecuentemente en los palacios de la Casa de Benavente en las últimas décadas del siglo XVIII. María Faustina Téllez Girón, Condesa-Duquesa viuda de Benavente que recibió clases de música y canto de numerosos maestros de origen italiano como Giovanni Battista Mele, José Antonio Moroti o Luigi Marescalchi fue propietaria de varios libros que contenían arias y otras piezas vocales, y de un gran número de arias sueltas de autores italianos como Francesco di Majo o Niccolò Piccini que se copiaron para ella hacia 1763. Aunque no existe constancia documental de cual fue el uso que se dio a estos materiales, es posible que, dada la gran afición de la Condesa-Duquesa María Faustina a la música vocal, dichas obras fueran interpretadas por ella misma y sus músicos asalariados en pequeños recitales domésticos para la corte nobiliaria o en alguna de las academias que organizaba esta dama en su palacio $^{129}$.

María Josefa Alfonso Pimentel, XV Condesa-Duquesa de Benavente, continuó la tradición de la familia celebrando habitualmente academias musicales domésticas en las que se interpretaron arias y números de ópera en versiones para conjunto instrumental reducido o para voz y piano. En estas veladas solían intervenir los cantantes italianos que se hallaban de paso en Madrid para actuar en las funciones del Teatro de los Caños del Peral. Por ejemplo en 1787, la CondesaDuquesa organizó una función en la que actuó el tenor Giovanni Ansani “y su cuñada” en la que se interpretaron tres arias, una escena, un dueto y un terceto ${ }^{130}$.

\footnotetext{
${ }^{129}$ Ver Capítulos II y IV.

130 BNE Ms.14016.3/192 (Papeles Barbieri). Pago a Conrado Appenceller fechado el 2 de julio de 1787 por copias de música para esta función. No figuran los autores de las obras.
} 
El archivo musical de la Condesa-Duquesa de Benavente conservaba un importante número de piezas vocales en adaptaciones para voz e instrumento de teclado que fueron compuestas en las últimas décadas del siglo XVIII. Entre ellas figuraban varias arias y números de conjunto de óperas escritas Domenico Cimarosa, Sebastiano Nasolini y Giovanni Paisiello y cantatas como Ariadne en Naxos de F. J. Haydn ${ }^{131}$. Estas obras fueron posiblemente parte del repertorio que se interpretó en los conciertos domésticos y en las academias que se realizaron en los palacios de los Benavente en las últimas décadas del siglo XVIII y en los primeros años del XIX.

\subsection{El repertorio vocal de cámara de las Casas de Osuna y Benavente (1800- 1840)}

\subsubsection{El repertorio italiano y francés: Rossini, Asioli, Inzenga y Langlé}

El repertorio vocal que se interpretó en los salones de las familias Osuna y Benavente en las primeras décadas del siglo XIX estuvo dominado por la música dramática italiana. Las adaptaciones para voz y piano de arias, cavatinas y números de conjunto extraídos de las óperas italianas que se representaban en los escenarios de Madrid constituyó la base de los recitales vocales patrocinados por los titulares de las Casas de Osuna y Benavente en esta época. Un ejemplo de la importancia que tuvo la música vocal italiana en los programas que se ofrecían en las veladas musicales que organizó la Condesa-Duquesa de Benavente en los últimos años de su vida puede verse en la siguiente crónica de sociedad que se

\footnotetext{
131 Ver Apéndices 3 y 4.
} 
publicó en Cartas españolas, la revista literaria que dirigió Jose María Carnerero, de un concierto que se celebró el 17 de marzo de 1832 en la residencia de la Condesa- Duquesa ${ }^{132}$ :

[...] En medio del recogimiento general, ha principado ya.a rayar una nueva aurora de júbilo para los madrileños, y ha aparecido un concierto de familia que en la noche del sábado 17 dio en su casa la Excelentísima Señora Duquesa de Benavente. Han asistido no obstante a él casi todas las personas que componen el cuerpo diplomático. Sin embargo de que, por ser este concierto una diversión particular, está apenas comprendido en nuestra jurisdicción, no dejaremos de dar a nuestros lectores una pequeña reseña de él, así por la alta clase del dueño de la casa, como también por el mérito artístico de las partes cantantes. Las piezas que se ejecutaron son las siguientes: Dúo de Ricardo y Zoraida, cantado por la señora Lalande y el señor Passini, Cavatina de Ana Bolena, por la señora Lalande; Terceto de la Gazza, por la señora Lalande y señores Rossi y Passini. También el señor Rossi cantó una aria del Barón de Felchein y el señor Passini una cavatina de la Zelmira. Merecieron general aplauso una cavatina de Niobe y un dúo de los Arabes en las Galias en cuyas piezas desplegó la señorita E. su gran talento músico de aficionada ${ }^{133}$.

Al igual que en otros ámbitos públicos y privados, la música de Rossini fue una de las piedras angulares del repertorio de ambas casas nobiliarias desde los años 20 del siglo XIX. Como muy gráficamente afirmaba Antonio Peña y

\footnotetext{
${ }^{132}$ La fecha de este concierto figura en un documento administrativo que se conserva en el archivo de la Casa de Osuna. El pìnista de dicha velada fue Ángel Inzenga. Véase AHN NOBLEZA OSUNA-CARTAS leg 413-37-15

${ }^{133}$ Cartas españolas, 22 de Marzo de 1832. Citado en Celsa Alonso, La Canción Lirica Española en el siglo XIX (Madrid: ICCMU, 1998), p. 132.
} 
Goñi “en el teatro, en los salones, en todas partes, el rossinismo se hallaba entronizado, lo dominaba todo, reinaba y gobernaba en absoluto, sin rival”,134.

El interés de la Condesa-Duquesa por la música de Rossini queda patente en las numerosas copias de fragmentos de sus óperas que se realizaron por encargo entre 1823 y ca. 1826. El repertorio copiado incluía arias, cavatinas dúos y tercetos de óperas de Rossini que fueron estrenadas en la década de los años 20 en los teatros públicos madrileños, como Il barbiere di Siviglia, La Gazza ladra, Tancredi, Otello, o Il turco in Italia, entre otros (Tabla 27). La Condesa-Duquesa conservaba además en su archivo partituras completas de varias óperas de Rossini como La Donna del lago [3/298], Torvaldo e Dorliska [3/297] y Le siége de Corinte [4/33] y números sueltos de otras óperas como el terceto Quel sembiante quello sguardo, de L inganno Felice [3/233].

Las cantatas y arias de cámara de autores italianos y franceses formaron también parte del repertorio vocal doméstico de las Casas de Osuna y Benavente en las primeras décadas del siglo XIX. Dos de los compositores de música de cámara vocal más apreciados por María Josefa Alfonso Pimentel, Condesa Duquesa de Benavente y por su hija María Manuela fueron los hermanos Luigi $(* 1778-\uparrow 1815)$. y Bonifazio $(* 1769-\uparrow 1832)$ Asioli ${ }^{135}$. Varios dúos, cantatas y arias para una o varias voces y piano de ambos compositores fueron copiados para María Manuela Téllez Girón durante su residencia en Cádiz entre 1810 y $1813^{136}$. Hacia 1823 la Condesa-Duquesa María Josefa encargó también la copia de varias

\footnotetext{
134 Antonio Peña y Goñi. La ópera española y la música dramática en España en el siglo XIX. Apuntes históricos (Madrid: Imprenta de El Liberal, 1881), pp. 116-117.

135 Sergio Lates y Roberta Marvin Montemorra. “Asioli, Bonifacio” NG, vol.1, pp. 112-113.

${ }^{136}$ Ver Apéndice 3.
} 
piezas "de Asioli" entre las que figuraban las cantatas Il nome, La scusa, La Primavera y la escena lírica Pimmalion de Bonifacio Assioli. ${ }^{137}$

Tabla 27

Números de óperas de Gioacchino Rossini copiados para la Condesa-Duquesa de Benavente entre 1823 y $c a .1826$

Fuente: AHN NOBLEZA OSUNA-CARTAS leg. 392-4.

(Se ha identificado cada pieza con la ópera a la que pertenece)

\begin{tabular}{|l|l|}
\hline \multicolumn{1}{|c|}{ ÓPERA } & \multicolumn{1}{c|}{ PIEZA COPIADA } \\
\hline Aureliano in Palmira & Mille sospiri e lagrime. Tercetto \\
\hline Il Barbiere di Siviglia & Una voce poco fa. Cavatina \\
\hline Il turco in Italia & Non si da foglia maggiore \\
\cline { 2 - 2 } & Oh! Guardate che accidente \\
\hline \multirow{4}{*}{ La Gazza Ladra } & Di piacer mi balza il cor \\
\cline { 2 - 2 } & Ebben per mia memoria. Dúo \\
\cline { 2 - 2 } & Forse un di conoscerete. Dúo. \\
\hline \multirow{3}{*}{ La donna del lago } & Alma invitta, ah non paventa. Aria \\
\cline { 2 - 2 } & Palpita incerta l'alma \\
\hline La pieta del paragone & Quel dirmi, oh Dio non t'amo. Cavatina \\
\hline \multirow{3}{*}{ Tancredi } & Lasciami non t'ascolto. Dúo \\
\cline { 2 - 2 } & Perche turbar la calma. Aria \\
\cline { 2 - 2 } & Tu che accendi questo core \\
\hline Otello & Vorrei del tuo pensiero. Dúo \\
\hline
\end{tabular}

El italiano Angelo [Ángel] Inzenga, maestro de piano de la Casa de Osuna, compuso expresamente para Pedro de Alcantara II (XI Duque de Osuna) un aria breve para bajo y piano titulada La tomba. Un ejemplar impreso de esta obra ha llegado a nuestros días y se conserva actualmente en la Biblioteca Nacional de España (Madrid) ${ }^{138}$. Aunque en la partitura no figura la fecha de la obra, con los

\footnotetext{
${ }^{137}$ AHN NOBLEZA OSUNA-CARTAS leg 392-4.

138 Ángelo Inzenga. La tomba. Arietta per voce di basso con acompagnamento di Piano Forte (Madrid: Lit. de Palmaroli, [s.a]). BNE Mp/359/14. Ver Apéndice 2.
} 
datos que aparecen en la portada (Lámina 36) podemos deducir que fue editada entre 1834 (año en el que el XI Duque de Osuna heredó el título de Conde Duque de Benavente) y 1844 (año del prematuro fallecimiento del Duque).

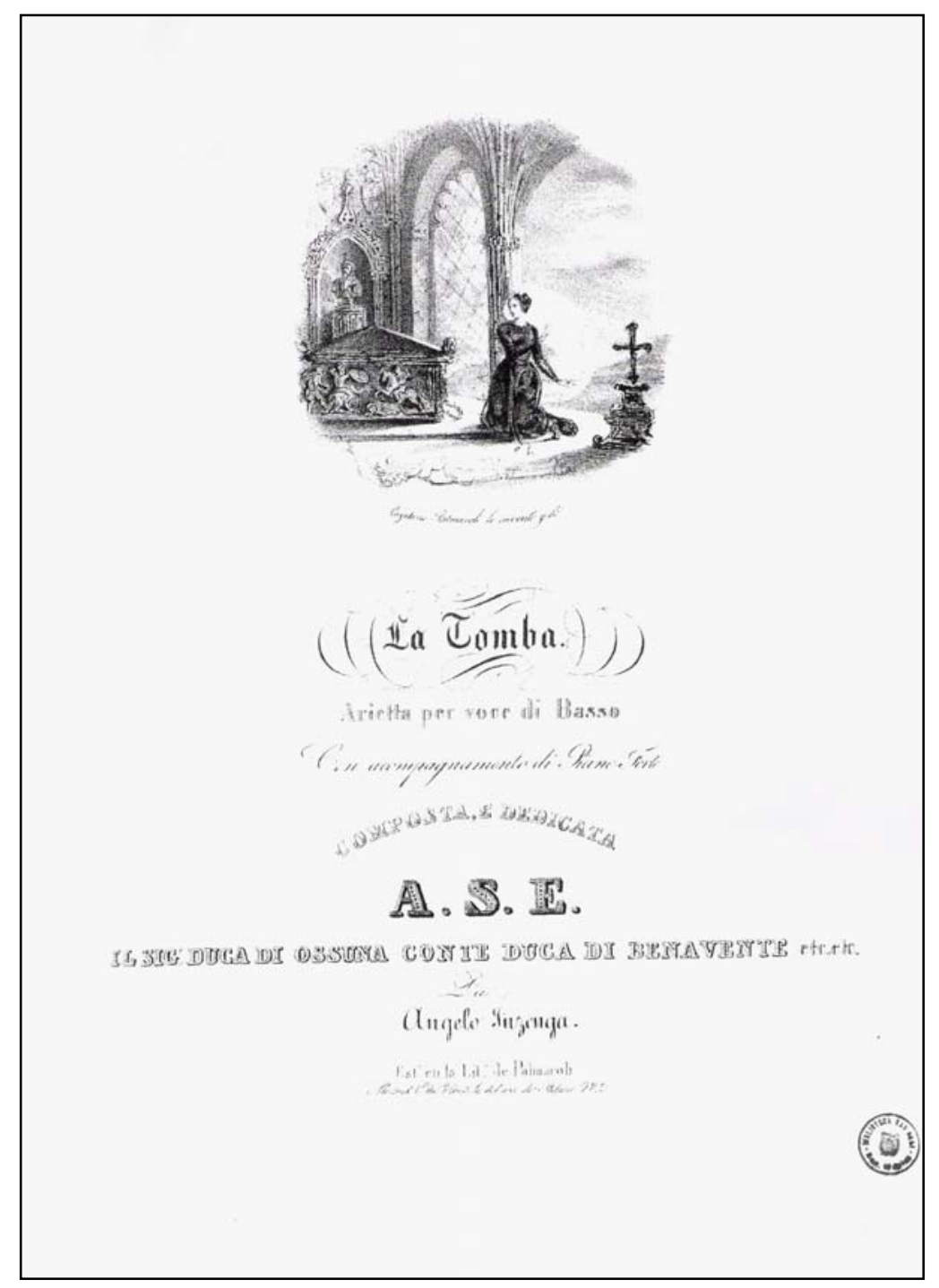

\section{Lámina 34.}

Portada de La Tomba, arietta para bajo y piano de Angel Inzenga (Madrid: Lit. de Palmaroli, [s.a])

BNE Mp/359/14. 
La tomba es una pieza prototípica del repertorio vocal de salón de las primeras décadas del siglo XIX. El texto de esta arietta (cuyo autor no figura en la partitura) es el conocido poema de Giuseppe Carpani $(* 1752-\uparrow 1825)$ In questa tomba oscura, un auténtico éxito del lied prerromántico, que fue objeto de más de sesenta versiones musicales en la primera mitad del siglo XIX. La mayor parte de ellas fueron escritas en 1808 cuando el editor de Viena T. Mollo invitó a algunos de los más importantes compositores europeos a musicalizar el poema de Carpani para incluir las obras resultantes en una colección que pensaba dedicar al importante mecenas musical Príncipe Franz Joseph von Lobkowitz. La invitación de Mollo dio lugar a diversas versiones de In questa tomba oscura realizadas por Ludwig van Beeethoven, Antonio Salieri, Friedrich Burgmüller, Hans Zelter, Niccolò Zingarelli, Bonifazio Asioli, Luigi Cherubini, Carl Czerny o Ferdinando Paer, entre otros ${ }^{139}$.

La versión de La Tomba compuesta por Inzenga sigue los cánones del género salón romántico: es una pieza breve y de dificultad técnica moderada, apta para ser interpretada por aficionados. La obra consta de dos secciones. En la primera sección (compases 1-44) ${ }^{140}$, el uso del trémolo en la introducción del piano y la fluctuación entre la tonalidad principal de mi bemol menor y la región tonal paralela (sol bemol mayor) contribuye a reforzar el carácter tenebroso del texto en el que el amado no correspondido pide desde la tumba a su ingrata amante que le deje reposar tranquilo. La última frase de la primera sección

\footnotetext{
${ }^{139}$ Helmuth C. Jacobs ha analizado extensamente desde el punto de vista literario y musical las diferentes versiones musicales de In questa tomba a lo largo del siglo XIX, pero en su estudio no incluyó la arietta de Inzenga en su estudio. JACOBS, Helmuth C:. Literatur, Musik und Gesellschaft in Italien und Österreich in der Epoche Napoleons und der Restauration. Studien zu Giuseppe Carpani (1751-1825). Frankfurt am Main./Bern/New York: Peter Lang 1988.
} 
(lasciami reposar) debe además ser cantada con voz oscura (con voce cupa), un gesto teatral con el que se trata de representar musicalmente la tumba desde la que el amado entona su canto.

La segunda sección de La tomba (desde el compás 46 al final de la pieza) se desarrolla en la tonalidad homónima de mi bemol mayor, que contrasta con la oscuridad armónica de la primera sección. Con este gesto de claroscuro claramente retórico, se trata de representar el apremio del amado muerto que desde su tumba invoca la paz para sus cenizas (e non bagnar mie ceneri d'inutile velen).

La elección de la voz de bajo para esta arietta se adaptó a las características vocales del destinatario de la pieza, Pedro de Alcántara II, cantante aficionado que según Saldoni, poseía una voz de barítono o bajo cantante con una "escuela irreprochable"141. Aunque la partitura está escrita en clave de sol, el ámbito real en que se mueve la parte vocal de La tomba de Inzenga abarca de un Si bemol 1 al $\mathrm{Mi}$ bemol$_{3}$, una zona cómoda para un barítono no profesional como era el Duque de Osuna. La línea de canto es fundamentalmente silábica y sólo presenta algunos breves pasajes ornamentados (cc. 31 y 36-39) que, aunque requieren una cierta habilidad vocal en la tesitura aguda, son fáciles de interpretar en el tempo lento en el que se desarrolla la pieza.

\footnotetext{
140 Incluyo la introducción del piano como parte de la primera sección.

141 Saldoni. Diccionario, III, p.167.
} 


\subsubsection{La Collecçao de modinhas portuguezas de la Biblioteca de la Casa de Osuna}

La Biblioteca de la Casa de Osuna tenía entre sus fondos una colección de modinhas portuguesas manuscritas encuadernadas en un volumen que actualmente forma parte de la Sección de Música de la Biblioteca Nacional de España (M.2261). Este ejemplar que lleva en la cubierta el título de Collecçao de modinhas portuguezas contiene once piezas vocales en partitura para una o dos voces con acompañamiento de orquesta ${ }^{142}$. Ocho de las obras que forman parte de esta colección son del compositor español residente en Portugal José Palomino $(* 1755-\uparrow 1810)^{143}$, dos del brasileño Joaquim Manoel [da Camera] $(† 1840)$ y una de Antonio Claudio [da Silva] Pereira (fl. 1780-1820) ${ }^{144}$.

La Collecçao de modinhas portuguezas pudo llegar hasta la Biblioteca de la Casa de Osuna a través de alguno de los personajes portugueses o residentes en Portugal con los que la Condesa-Duquesa María Josefa mantuvo una intensa relación desde los últimos años del siglo XVIII, como la famosa soprano portuguesa Luisa Rosa de Aguiar, (1753-1833) conocida por Luisa Todi, o la Marquesa de Oyra ${ }^{145}$. El volumen se debió de incorporar a la Biblioteca Nacional

\footnotetext{
${ }^{142}$ Ver la descripción y el inventario completo de este manuscrito en el Apéndice 3. Además de este volumen, en el archivo de música de la Condesa-Duquesa se conservaba una modinha de autor anónimo con acompañamiento de piano titulada $O$ meu coraçao me diz. [3/241]

143 Lothar Siemens. “Palomino, José”, DMEH, 8, p. 413.

144 Sobre la modinha en Brasil y sus autores véase Kieffer, Anna María. "Appuntamentos musicais dos viajantes", Revista USP Sao Paulo 30 (Junho- Agosto 1996), pp. 134-141. Las fechas de actividad de estos autores han sido tomadas de la Base Nacionalde datos bibliográficos de Portugal (http://opac.porbase.org/).

145 Sobre la relación de la Condesa-Duquesa con la cantante Luisa Todi véase el Capítulo VI. La Marquesa de Oyra residió en Lisboa entre 1794 y 1796 desde donde escribió en varias ocasiones a la Condesa-Duquesa María Josefa para recomendarle a varios cantantes y bailarines. AHN NOBLEZA, OSUNA-CARTAS, leg 388-17.
} 
a finales del siglo XIX, cuando esta institución adquirió la Biblioteca del Duque de Osuna ${ }^{146}$

La modinha fue el género más importante de la música vocal de salón en Brasil y Portugal durante el siglo XIX. La gran mayoría de estas obras son piezas breves a sólo o a dúo de-temática amorosa con acompañamiento de uno o varios instrumentos. Sus orígenes, poco conocidos hasta la fecha, se remontan al menos a principios del siglo XVIII. A lo largo de dicho siglo las modinhas adoptaron algunas características de la música dramática francesa e italiana, y ya en las últimas décadas del siglo XVIII incorporaron ritmos e influencias melódicas brasileñas como un característico ritmo sincopado. Durante el siglo XIX la modinha solía tener una estructura bipartita, y en la mayoría de las ocasiones estaba escrita en modo menor y en compás binario o cuaternario ${ }^{147}$.

La Collecçao de modinhas portuguezas es la única recopilación manuscrita conocida hasta el momento de modinhas inéditas que se conserva en España, y es una de las escasas colecciones de modinhas con autor identificado anteriores a la segunda mitad siglo $\mathrm{XIX}^{148}$.

El compositor más representado en la Collecçao de modinhas portuguezas

\footnotetext{
146 Anglés y Subirá. Catálogo, vol I, pp. 420-421

147 José A Mozart de Araujo. A Modinha e o Lundu no Século XVIII (São Paulo: Ricordi Brasileira, 1963), pp. 35-36. Behágue, Gerard, "Modinha”, NG, vol. 16, p. 875.

${ }^{148}$ En la Biblioteca Nacional de Portugal (Lisboa) se conserva un amplio fondo de modinhas que ha sido estudiado parcialmente. Véase Gerhard Doderer. Modinhas luso-brasileiras transcriçäo $e$ estudo de (Lisboa: Fundación Calouste Gulbenkian, 1984). Gerard Bèhague investigó otro importante fondo portugués de modinhas conservadoen Lisboa., Gerard Bèhague."Biblioteca de Ajuda (Lisbon) Mss 1595/1596) Two eighteen century Anonymous Collections of modinhas", Year book. Inter American Institute for Musical Reesarch, IV (1968) pp. 44-81. En BNE también se conserva una colección impresa de modinhas titulada Iornal de modinhas novas que contiene, entre otras, varias modinhas de José Palomino (BNE M 3895/45-53)
} 
es el madrileño José Palomino $(* 1755-\uparrow 1810)$. Miembro de una familia de violinistas vinculados al teatro, Palomino ocupó desde muy joven una plaza de violín primero en la compañía teatral de María Hidalgo que trabajaba en los teatros públicos de Madrid $^{149}$.y en 1770 fue admitido como violín primero de la Real Capilla. En 1774 José Palomino se trasladó a Lisboa donde trabajó como violinista de cámara del rey de Portugal ${ }^{150}$, y en los primeros años del siglo XIX ocupaba el cargo de compositor en el Teatro Nacional de Salitre de Lisboa ${ }^{151}$. Palomino residió en Portugal hasta 1808 cuándo se trasladó a Las Palmas de Gran Canaria donde trabajó como maestro de capilla de la Catedral hasta su muerte ${ }^{152}$.

Seis de las ocho modinhas de José Palomino que figuran en la Collecçao de modinhas portuguezas fueron representadas en las funciones de los Teatros Nacionales de Salitre y de la Rua dos Condes de Lisboa ${ }^{153}$. La integración de la modinha en los espectáculos teatrales y sus características musicales manifiestan la existencia de puntos en común con el género de la tonadilla escénica al que José Palomino se había dedicado en Madrid antes de trasladarse a Portugal ${ }^{154}$.

Un ejemplo de las obras que figuran en la Collecçao de modinhas portuguezas es la modinha a solo Todos dizem de José Palomino (1801), una breve pieza con texto amoroso-satírico formado por dos estrofas con versos

\footnotetext{
149 Al menos desde 1768, José Palomino trabajó como violinista de la orquesta de la compañía de María Hidalgo que actuaba en los teatros públicos de Madrid. BNE Mss 14.016.1/ 72(Papeles Barbieri).

${ }^{150}$ Lothar Siemens. "Palomino, José", DMEH, vol, 8, p. 413.

151 BNE M- 2261, f. 35.

152 Siemens. "Palomino" p. 413.

153 Ver Apéndice 3.

154 En BHM se conservan al menos tres tonadillas de José Palomino: A cantar va Joaquina (Mus 74-7), El canapé (Mus 74-17) y El chasco del forastero (Mus 173-15).
} 
octosílabos. La música de esta obra se desarrolla en un estilo galante con frases regulares y articuladas que se apoyan principalmente en las funciones tonales básicas de tónica, dominante y subdominante (ver la edición de la obra en el Apéndice 2).

La modinha Todos dizem muestra también el característico ritmo sincopado que algunos autores han atribuido a las influencias de la música brasileña y especialmente del lundú ${ }^{155}$. Véase por ejemplo la síncopa que se produce en el tercer y cuarto tiempo en la primera frase vocal de la pieza (Ejemplo musical 17)

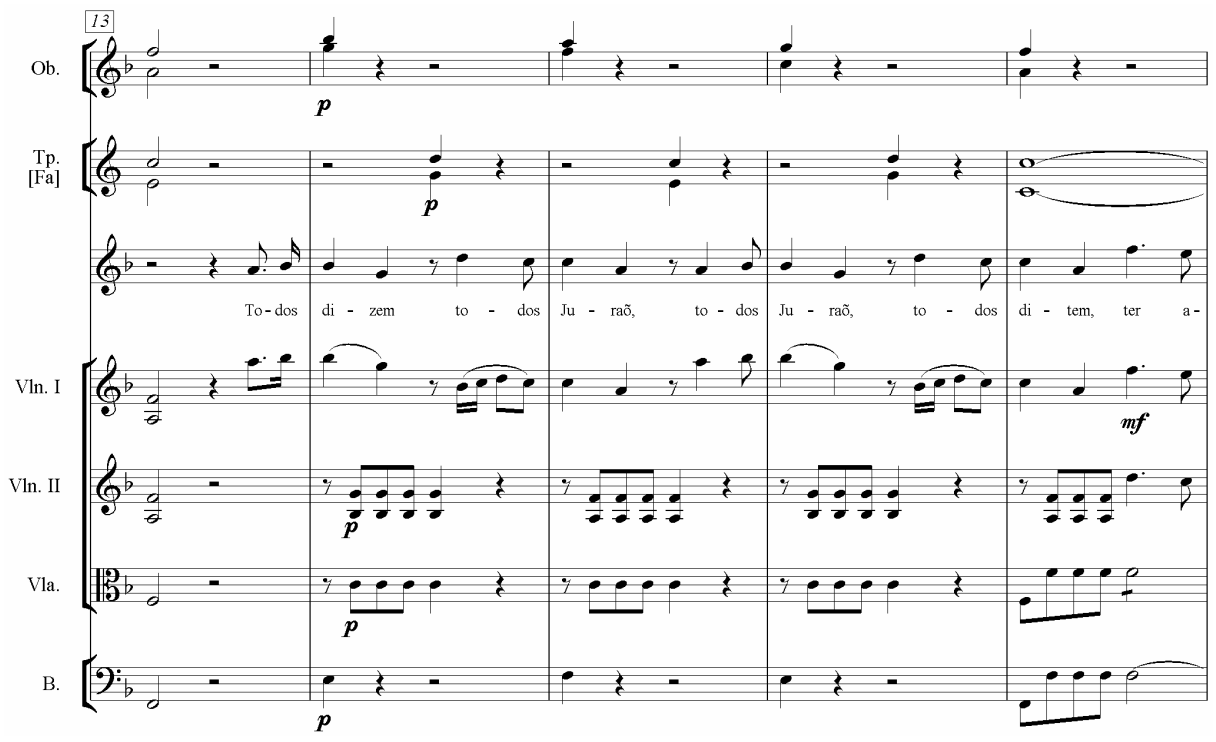

Ejemplo musical 17

José Palomino. Todos dicen. Modinha a solo (cc. 13-17).

(BNE M 2261, f. 37-38)

155 Sobre las influencias de la música brasileña en la modinha véase Mozart de Araujo, $A$ Modinha. 
José Palomino estuvo vinculado al mundo de la música teatral de Madrid desde los inicios de su carrera, lo que le permitió conocer bien el repertorio de tonadillas en la época en que este género se hallaba en sus primeras etapas de desarrollo. Es probable que ciertos rasgos de la tonadilla fueran "exportados" por José Palomino a Portugal e incorporados a la modinha, un género híbrido del que hasta ahora sólo se han señalado las influencias de populares y cultas de origen italiano, francés o brasileño ${ }^{156}$. Esta hipótesis, abre el camino para una nueva investigación sobre la circulación y recepción de la modinha y la tonadilla escénica, los dos géneros vocales breves de mayor éxito en la Península Ibérica durante las últimas décadas del siglo XVIII y las primeras del siglo XIX.

\subsubsection{Música vocal de cámara española}

La música vocal en castellano fue uno de los géneros preferidos en los salones españoles desde las primeras décadas del siglo XIX. Según las investigaciones de Celsa Alonso, las "canciones españolas y andaluzas" estuvieron presentes en los salones desde comienzos de siglo"157.

Aunque hasta la muerte de la Condesa-Duquesa María Josefa en 1834, la música italiana, y en menor medida la francesa, fue la protagonista absoluta del repertorio vocal de cámara de los salones de la Casa de Benavente es posible que, en estos espacios de sociabilidad se cnatasen también obras vocales en castellano, de las que apenas nos ha quedado constancia documental. En el rico archivo de la Condesa-Duquesa de Benavente, se conservaba una recopilación de canciones en

\footnotetext{
${ }^{156}$ Behágue, Gerard, "Modinha”, NG, vol. 16, p. 875.

157 Alonso, "Los salones", p. 168. Sobre la presencia de la canción lírica española en los salones burgueses y aristocraticos véase también Celsa Alonso, La canción lírica española en el siglo XIX (Madrid: ICCMU, Madrid, 1998).
} 
español: las Seguidillas y Canciones de Miguel López Remacha [3/248], varias Boleras [3/253] y un Polo o Caballo [3/246] que posiblemente fueran interpretadas en alguna de las veladas musicales organizadas por esta dama. 

Conclusiones Generales 

La investigación realizada en esta Tesis Doctoral ha permitido constatar y documentar la ingente labor de mecenazgo musical que desarrollaron las casas ducales de Osuna y Benavente desde el siglo XVI hasta mediados del siglo XIX, y muy particularmente la importancia de ambas familias en la vida musical española del período 1733-1844. La reconstrucción del árbol genealógico y de la historia de ambos títulos nobiliarios muestra que sólo puede hablarse estrictamente de una Casa de "Benavente-Osuna" entre 1787 y 1807, y desde 1834 en adelante. Fuera de esos períodos, ambas familias mantuvieron administraciones separadas, aunque con estrechas relaciones entre ellas, lo que dio lugar a numerosos aspectos comunes en sus políticas de mecenazgo musical.

Las familias Téllez Girón y Pimentel, titulares respectivamente de las Casas de Osuna y Benavente, fomentaron y protegieron las actividades culturales en general, y musicales en particular, al menos desde finales del siglo XV. Durante los siglos XVI y XVII, los Duques de Osuna mantuvieron en la villa sevillana del mismo nombre dos fundaciones religiosas dotadas de capillas musicales, la Colegiata de Santa María y la Capilla del Santo Sepulcro. Durante los períodos en que los titulares de la Casa de Osuna fueron virreyes de Nápoles (1582-1586 y 1616-1620), virreyes de Sicilia (1610-1615) y gobernadores de Milán (1669-1674), su mecenazgo musical se extendió también a esos territorios italianos. Por ejemplo, los Duques de Osuna contribuyeron al mantenimiento económico de las Capillas Reales en Nápoles y Sicilia, organizaron fiestas y espectáculos con importante presencia musical y protegieron a varios compositores italianos como Giuseppe Palazzoto y Antonio il Verso. 
La Casa de Benavente tuvo a su servicio, al menos desde finales del siglo $\mathrm{XV}$, una capilla musical (compuesta por un grupo variable de ministriles $\mathrm{y}$ cantores) y otro grupo de músicos "heráldicos" que acompañaban al CondeDuque en sus misiones militares y actos representativos. Entre los músicos que trabajaron para la Casa de Benavente en el siglo XVI hubo seis esclavos negros, cantores y ministriles, que fueron adquiridos en 1554 por el VI Conde de Benavente. Este dato es el testimonio más antiguo conocido hasta ahora de la presencia de músicos esclavos negros en las cortes nobiliarias españolas, un tema apenas tratado por los musicólogos.

A lo largo del siglo XVIII y en las primeras décadas del siglo XIX, las Casas de Osuna y Benavente fueron incorporando a sus títulos originales nuevos linajes (como los ducados de Arcos, Béjar y Gandía, entre otros), lo que supuso también la incorporación de prácticas culturales heredadas que enriquecieron aún más la actividad musical de ambas familias.

La música y el baile fueron una parte importante de la educación que recibieron los jóvenes de las Casas de Osuna y Benavente durante los siglos XVIII y XIX. He podido documentar numerosos profesores de música que formaron a los miembros de ambas familias. Muchos de esos profesores eran destacados músicos de origen italiano que trabajaban también en instituciones vinculadas a la monarquía o en compañías de los teatros públicos de Madrid, como fue el caso de Giovanni Battista Mele, Luigi Marescalchi o José Antonio Moroti. Entre los maestros de baile contratados para enseñar a los jóvenes de las Casas de Osuna y Benavente hubo sobre todo franceses (como Louis Moreau o Jean Joly) e italianos (como Domenico Rossi). Las dos familias contaron además con una nómina 
amplísima de instrumentistas y compositores a su servicio, entre los que estuvieron algunos de los más renombrados profesionales españoles y europeos del momento.

Los músicos que trabajaron para las Casas de Osuna y Benavente durante el siglo XVIII establecieron diferentes tipos de relaciones laborales con sus empleadores. Algunos eran músicos fijos que cobraban un salario mensual y formaban parte del personal al servicio de cada una de las familias. Cuando era necesario sustituir a los músicos asalariados o reunir un grupo instrumental más amplio del habitual, ambas Casas contrataban músicos para los actos concretos en que eran requeridos. La flexibilidad que caracterizó las relaciones laborales de los músicos de las Casas de Osuna y Benavente propició la contratación de algunos de los mejores compositores e instrumentistas de la época. Estar al servicio de estas importantes casas nobiliarias permitía a los músicos establecer relaciones profesionales que les facilitaban la obtención de otros empleos, e incluso poder recurrir a la poderosa intercesión de sus señores para obtenerlos.

La mayoría de los instrumentistas asalariados que trabajaron para las Casas de Osuna y Benavente durante el siglo XVIII compatibilizaron este trabajo con su actividad en prestigiosas instituciones musicales que les proporcionaban mayores ingresos y estabilidad laboral, como la Real Capilla, el Real Colegio de Niños Cantores, las capillas musicales de las instituciones religiosas de Madrid o las orquestas de los teatros madrileños. Una excepción a esta tónica general fue el oboísta Gaspar Barli, que en la primera etapa de su carrera (1778-ca.1784) trabajó en exclusiva para la Casa de Benavente. La presencia en las capillas musicales y orquestas mantenidas por las Casas de Osuna y Benavente de instrumentistas que 
trabajaron simultáneamente para la Real Capilla fue una constante a lo largo de todo el siglo XVIII. Este hecho hace cuestionar la efectividad de las distintas normas dictadas desde la época de los Austrias para que los músicos de la institución real tuvieran una dedicación exclusiva al servicio de la monarquía.

Los titulares de las Casas de Osuna y Benavente, interesados en perpetuar las tradiciones de su linaje, desarrollaron una amplia labor de mecenazgo de la música religiosa, que se concretó fundamentalmente en dos ámbitos de actuación: el mantenimiento de las capillas musicales de la Colegiata de Santa María y del Santo Sepulcro (en la villa sevillana de Osuna) y la promoción de solemnes funciones religiosas con música en Madrid, principal ciudad de residencia de las familias Osuna y Benavente durante los siglos XVIII y XIX. Las capillas de música de la Colegiata de Santa María y la Capilla del Santo Sepulcro de Osuna fueron instituidas por Juan Téllez Girón, IV Conde de Ureña (*1494-†1558) y gozaron de la protección económica de los Duques de Osuna hasta el siglo XIX. Particular relevancia tuvieron las honras fúnebres celebradas en 1787 en Madrid, a la muerte de Pedro Zoilo Téllez Girón, VIII Duque de Osuna, que se prolongaron durante más de tres meses, y constituyen un notable ejemplo del complejo ceremonial desarrollado en este tipo de actos solemnes en los que la música, la escultura, la arquitectura de carácter efímero, la pintura y la literatura contribuían a enfatizar el prestigio social y económico de la persona homenajeada y su linaje.

En la Casa de Benavente, destacaron por su esplendor y solemnidad las funciones religiosas dedicadas a San Francisco de Borja, patrón de la Casa de Gandía (una de las casas nobiliarias que se incorporó al patrimonio de la familia Pimentel desde 1740), que se celebraban todos los años entre los meses de 
septiembre y octubre, en el Real Oratorio de San Felipe Neri de Madrid, con la colaboración económica de otros personajes de la nobleza y de la Casa Real. En los actos religiosos patrocinados por la Casa de Benavente se presentó un interesante repertorio compuesto por vísperas, misas, motetes y otras obras de los más destacados compositores del momento, que fue encargado expresamente para ser estrenado en estas fiestas o adquirido en distintos lugares de Europa para presentarse como primicia en España. Por ejemplo, en las funciones de San Francisco de Borja que tuvieron lugar en Madrid durante la titularidad de María Josefa Alfonso Pimentel, XV Condesa-Duquesa de Benavente, se estrenaron misas y otras obras de música sacra de José Lidón (1780), Antonio Rosetti (1800), Saverio Mercadante (1827) y Angelo Inzenga (1828) compuestas expresamente para dichas fiestas, y se escucharon por primera vez en España misas de Franz Joseph Haydn (1784 y 1785), Ignaz Pleyel (1800) o Giovanni Paisiello (1807), entre otros.

El apoyo y fomento del teatro musical fue una constante en la política cultural de la Casa de Osuna desde el siglo XVI. Durante los siglos XVIII y XIX, tanto la Casa de Osuna como la de Benavente participaron en la promoción de música dramática, y apoyaron económica y profesionalmente a sus empresarios, creadores e intérpretes. Uno de los principales compositores de música teatral que estuvo al servicio de la Casa de Osuna en la segunda mitad del siglo XVIII fue el catalán Pablo Esteve y Grimau, que trabajó como "maestro de capilla y de la casa" de Pedro Zoilo Téllez Girón, VIII Duque de Osuna, al menos entre 1765 y 1768. A este noble dedicó Esteve tres de sus obras que fueron estrenadas en los teatros públicos de La Cruz y El Príncipe de Madrid: la zarzuela La buena muchacha 
(1765, adaptación del dramma giocoso Cecchina o La buona figlioula de Carlo Goldoni y Niccolò Piccinni), la música de la comedia No hay en amor fineza mas constante (1766), y la zarzuela u ópera cómico-bufo dramática en dos actos Los Jardineros de Aranjuez (1768). El análisis de estas tres obras muestra la importante contribución de Pablo Esteve a la renovación de los géneros teatrales cantados en español que se desarrolló a partir de la década de los años 60 del siglo XVIII, en la que jugó un destacado papel la asimilación de los modelos de la ópera bufa italiana.

Varios componentes de las familias Osuna y Benavente participaron en la financiación de proyectos empresariales de música teatral, como los desarrollados en los Teatros de los Reales Sitios (Aranjuez, San Lorenzo del Escorial, San Ildefonso y El Pardo) entre 1767 y 1776; y en los teatros públicos madrileños de la Cruz, el Príncipe y los Caños del Peral en las dos últimas décadas del siglo XVIII. Los miembros de las Casas de Osuna y Benavente fueron accionistas mayoritarios en la Asociación de Óperas Italianas, una sociedad en la que participaron destacados personajes de la alta nobleza y la aristocracia madrileña, que se hizo cargo de las representaciones de ópera italiana en el Teatro de los Caños del Peral de Madrid desde 1791 hasta 1795. Este interesante proyecto empresarial (del que apenas se conocían datos hasta la fecha) pasó por dos etapas claramente diferenciadas, una primera en la que se pretendió conseguir el apoyo de un gran número de aristócratas y miembros de la alta nobleza (1790-93) y una segunda (1793-95) en la que los accionistas de la Asociación se redujeron a ocho. En esta segunda etapa dirigió la empresa la llamada Asociación de los ocho señores, en la que el IX Duque de Osuna y su mujer, la XV Condesa-Duquesa de 
Benavente, tuvieron el veinticinco por ciento del capital económico. El grupo de notables que formaba la Asociación de los ocho señores, además de apoyar económicamente la empresa, se involucró activamente en la gestión artística y administrativa del teatro.

Los miembros de las Casas de Osuna y Benavente promovieron también funciones domésticas de teatro musical en español que se representaron en sus residencias de Madrid. En ellas solían participar los propios nobles, sus familiares y otros miembros de su corte nobiliaria. José Téllez Girón, VII Duque de Osuna, mantuvo un coliseo o pequeño teatro en su palacio de Madrid que funcionó al menos en la década de los años 20 del siglo XVIII, y en el que se representaron obras musicales. Su hija María Faustina Téllez Girón, casada con el XIV CondeDuque de Benavente, continuó la tradición que había mantenido su padre y organizó habitualmente funciones teatrales en su palacio de la calle Segovia de Madrid, destinadas al entretenimiento de la nobleza y la aristocracia madrileña. En esas funciones se estrenaron zarzuelas y comedias con música encargadas expresamente por la Condesa-Duquesa María Faustina a compositores como Blas de Laserna, Luigi Boccherini y Giuseppe Ponzo, y a dramaturgos como Ramón de la Cruz. Leandro Fernández de Moratín aceptó también escribir el libreto de una zarzuela para las funciones de la Condesa-Duquesa, aunque era un género muy alejado de sus preferencias estéticas.

En los palacios y residencias de recreo de las Casas de Osuna y Benavente se cultivaron constantemente la música instrumental y la música vocal de cámara, como queda patente por los numerosos instrumentos musicales documentados en ellas. Los instrumentos de teclado (clavicémbalos, clavicordios y pianofortes) 
fueron comprados a los más importantes constructores madrileños del momento o importados desde París y Londres. Algunos de los instrumentos de tecla adquiridos a lo largo del siglo XVIII fueron destruidos durante la Guerra de la Independencia de 1808-14 (cuando los palacios madrileños de los Osuna y los Benavente fueron saqueados por las tropas francesas) y otros fueron enajenados en subasta pública a finales del siglo XIX.

Desde la segunda mitad del siglo XVIII la música de cámara adquirió una especial relevancia en el entorno privado de la Casa de Benavente. El género camerístico destacó especialmente en dos tipos de actos: las academias o conciertos semipúblicos (a los que era invitada una selecta minoría de oyentes) y los fastuosos bailes organizados por los miembros de la Casa para conmemorar acontecimientos familiares e institucionales o para celebrar determinadas festividades (como Carnaval o Navidad). Al menos desde 1721 y hasta su unión con la Casa de Benavente en 1787, los Duques de Osuna tuvieron a su servicio a un grupo variable de músicos asalariados que intervinieron en las funciones profanas y religiosas organizadas por la familia. Existe constancia de que en 1755 los Condes-Duques de Benavente mantenían también un grupo estable de músicos a su servicio.

La llamada "orquesta" de la XV Condesa-Duquesa de Benavente (que se hallaba en funcionamiento en abril de 1781 y se disolvió en mayo de 1792) no fue en realidad una formación orquestal en el sentido moderno del término (tal y como se había dado a entender hasta la fecha por distintos estudiosos), sino un grupo versátil de entre trece y dieciocho instrumentistas que se adaptaba a cada una de las situaciones en las que intervenía. 
Luigi Boccherini fue el director de la orquesta de la Condesa-Duquesa de Benavente desde marzo de 1786 hasta, al menos, diciembre de 1787. Exceptuando esa etapa, la dirección de la orquesta fue probablemente ejercida por el "primer violín de la orquesta", cargo que tenía una asignación notablemente superior a la del resto de sus compañeros (aunque inferior a la del excelente oboísta Gaspar Barli) y que conllevaba además la utilización de una indumentaria diferente. Fueron primeros violines de la orquesta de la Condesa-Duquesa dos músicos de la Real Capilla: Bonifacio Zlotek, de origen polaco (desde abril de 1781 hasta su fallecimiento a principios de 1787) y Rafael García de Sena (entre 1787 y 1792). Diversos estudiosos habían afirmado que el compositor y clavecinista José Lidón fue el principal director de la orquesta de la Condesa-Duquesa de Benavente, pero no he encontrado evidencias documentales que confirmen este hecho. Lidón trabajó como "maestro de clave" al servicio de la Casa de Benavente entre 1781 y 1792, y es posible que durante ese período se encargara eventualmente de la dirección de algunas funciones musicales sacras o profanas, pero entre la abundante documentación manejada no hay pruebas de que tuviese propiamente el puesto de director de la orquesta.

En los últimos años del siglo XVIII las fiestas y academias de la Casa de Osuna-Benavente contaron con la presencia de una importante formación instrumental, conocida como la Capilla del Duque de Osuna, que estaba integrada por conocidos miembros de las orquestas de los teatros de Madrid, músicos militares y miembros de algunas de las capillas musicales religiosas de la capital. La excelencia de la llamada Capilla del Duque de Osuna fue alabada por un anónimo cronista en el Allgemeine Musikalische Zeitung de Leipzig en 1799, 
quien destacó que la calidad individual de los componentes era superior a la de la capilla del Duque de Alba y superaba a la de la Real Capilla.

El repertorio musical que sonó en el entorno de las Casas de Osuna y Benavente durante el período estudiado incluyó obras musicales de los más destacados autores del panorama español y europeo, algunas de las cuales fueron presentadas como primicia en los actos sociales y religiosos de ambas familias. Este repertorio se consiguió por diversas vías: compra de materiales impresos y manuscritos a proveedores españoles y europeos, encargos directos de composiciones concretas y firma con determinados compositores de contratos para adquirir sus obras. Entre los archivos musicales situados en los palacios de los Osuna y Benavente destacó por su valor y riqueza el que formaron en Madrid María Josefa Alfonso Pimentel (XV Condesa-Duquesa de Benavente) y su marido Pedro de Alcántara (titular de la Casa de Osuna desde 1787). En este archivo, conocido como "la papelera de música de la Condesa-Duquesa de Benavente", hubo cerca de un millar de obras de importantes compositores españoles y europeos de la segunda mitad del siglo XVIII y de las primeras décadas del XIX. Entre ellas destacaron las numerosas piezas instrumentales de Franz Joseph Haydn y Luigi Boccherini, las obras de música teatral de compositores italianos y franceses y las composiciones religiosas.

Gracias al contrato que la Condesa-Duquesa de Benavente estableció con Franz Joseph Haydn en octubre de 1783 (que se mantuvo al menos hasta finales de septiembre de 1789) llegaron a Madrid un número no determinado de sinfonías y cuartetos nuevos que, probablemente, se interpretaron por primera vez en España en las reuniones privadas organizadas por dicha dama. En 1824 el archivo 
de música de la Condesa-Duquesa conservaba cerca de un centenar y medio de obras instrumentales de Haydn, entre las que predominaban precisamente las sinfonías y los cuartetos de cuerda.

La vinculación contractual de Boccherini con la Condesa-Duquesa (documentada entre marzo de 1786 y diciembre de 1787) explica la significativa presencia de su música en el repertorio de la Casa. En el archivo de la CondesaDuquesa se conservaban en 1824 cerca de un centenar de piezas instrumentales de Boccherini, entre las que había varias colecciones de tríos, cuartetos y quintetos, además de sinfonías y conciertos. Boccherini dedicó a la Condesa-Duquesa al menos dos sinfonías y dos series de quintetos, y compuso expresamente para ella una colección de minuetos que fueron estrenados en los bailes de Carnaval de 1787 patrocinados por dicha dama.

Desde la década de los años 20 del siglo XIX, las danzas europeas de salón (valses, contradanzas, rigodones y otros aires de moda), arregladas para pequeños conjuntos instrumentales, fueron frecuentemente interpretadas en los salones de las Casas de Osuna y Benavente. La ejecución de estas piezas corrió a cargo de grupos de músicos contratados que solían incluir una pequeña sección de cuerda (entre cuatro y seis violines, violonchelo y contrabajo), una o dos flautas, clarinete y trompa.

En las academias o recitales organizados en los palacios de los Osuna y los Benavente se incluyeron también piezas vocales interpretadas por cantantes de los teatros públicos de Madrid contratados para la ocasión o por los propios miembros de ambas familias que tenían suficiente formación musical. María Faustina Téllez Girón (Condesa-Duquesa viuda de Benavente), su nieta la Duquesa de Abrantes y 
el XI Duque de Osuna fueron competentes cantantes aficionados que intervinieron frecuentemente en las veladas organizadas por la familia.

La presencia de numerosos músicos de origen italiano al servicio de las Casas de Osuna y Benavente y la eclosión de la ópera italiana en los teatros públicos y de corte de Madrid explican el predominio de la música italiana en el repertorio vocal consumido por ambas casas nobiliarias durante todo el siglo XVIII y en la primera mitad del siglo XIX. Una muestra representativa del repertorio vocal de la Casa de Osuna en la primera mitad del siglo XVIII es el Libro de Cantatas y Arias Italianas de la Duquesa de Osuna (Biblioteca Nacional de España, Madrid), una interesante recopilación manuscrita realizada seguramente para Francisca Bibiana Pérez de Guzmán el Bueno, esposa del VII Duque de Osuna, que ostentó dicho título entre 1721 y 1748. La mayoría de las obras del volumen son para voz femenina y bajo, y fueron compuestas por autores italianos de finales del siglo XVII y comienzos del XVIII, como Alessandro Scarlatti, Giaccomo Facco y Giovanni Bononcini. Entre las obras que figuran como anónimas en el volumen destacan dos cantatas posiblemente compuestas por Georg Friedrich Händel y hasta ahora desconocidas. El Libro de Cantatas y Arias Italianas de la Duquesa de Osuna es una valiosa fuente para estudiar la circulación y recepción de la cantata profana italiana en el entorno de la nobleza española durante la primera mitad del siglo XVIII. La calidad y el interés musical de los ejemplos de esta colección analizados en el presente trabajo evidencian la necesidad de acometer un estudio monográfico y sistemático de la misma, que hasta la fecha no había despertado la atención de los investigadores. 
Los recitales vocales patrocinados por los titulares de las Casas de Osuna y Benavente en las últimas décadas del siglo XVIII y durante las primeras del siglo XIX incluyeron adaptaciones para voz y piano de arias, cavatinas y números de conjunto extraídos de óperas italianas representadas en los escenarios madrileños. Al igual que en otros ámbitos públicos y privados, la música de Rossini fue predominante desde los años 20 del siglo XIX. La gran afición a la música vocal de los Osuna y los Benavente estimuló también la composición de pequeñas obras de dificultad técnica moderada para que fueran interpretadas por los propios nobles en los recitales semipúblicos que tenían lugar en sus salones a los que acudían los principales personajes de la nobleza madrileña.

Al menos una parte de los materiales musicales que fueron propiedad de las Casas de Osuna y Benavente se conservaron en los palacios de la familia hasta finales del siglo XIX. Después de la crisis económica que llevó a la quiebra definitiva de la Casa de Benavente-Osuna en 1882, la llamada Biblioteca del Duque de Osuna fue adquirida por el Estado español y una importante parte de sus fondos (incluidas algunas partituras y libros de interés musical, pero no el grueso de los archivos musicales) fue ubicada en la Biblioteca Nacional de España (Madrid) y en otras bibliotecas de instituciones públicas españolas. En las dos últimas décadas del siglo XIX y a lo largo del siglo XX, parte de los materiales musicales que habían pertenecido a las Casas de Osuna y Benavente fueron subastados públicamente $\mathrm{y}$ algunos fueron adquiridos por coleccionistas particulares.

La intensa actividad de mecenazgo musical que promovieron los miembros de las Casas de Osuna y Benavente durante los siglos XVIII y XIX 
invita a reconsiderar el tratamiento historiográfico que hasta ahora han tenido algunos aspectos de la realidad musical española de la época. La movilidad internacional de los músicos y del repertorio musical documentada en la presente investigación revela un dinamismo en los recursos y tendencias estéticas que difícilmente puede percibirse estudiando sólo la música en instituciones como las capillas musicales catedralicias, la Real Capilla o los teatros. Un caso paradigmático es la presencia de los miembros de la alta nobleza urbana en los más importantes proyectos empresariales de ópera italiana que se llevaron a cabo en Madrid y su entorno a partir de la segunda mitad del siglo XVIII. El apoyo económico e ideológico de esta clase social fue uno de los factores decisivos para la promoción de la ópera italiana y para que importantes compositores, cantantes y bailarines europeos pudieran conocerse en España. Pablo Esteve y Grimau, uno de los muchos músicos que trabajaron para las Casas de Osuna y Benavente en el siglo XVIII, opinaba que el conocimiento y emulación del repertorio dramático italiano eran un medio de progreso para la música española. Esta visión positiva de la influencia italiana en el repertorio musical español (probablemente compartida por los nobles que apoyaron a Esteve) contrasta con la valoración negativa que del italianismo ha venido haciendo gran parte de la historiografía musical española.

La intensa actividad musical generada por las Casas de Osuna y Benavente aporta nuevos y reveladores datos sobre la enorme importancia que tenían en determinados círculos de la sociedad española la música de cámara, el repertorio orquestal y la música teatral, géneros hasta ahora mucho menos conocidos que la música eclesiástica. Las fiestas religiosas patrocinadas por las Casas de Osuna y 
Benavente muestran perspectivas nuevas sobre el funcionamiento de diversas capillas musicales religiosas hasta ahora apenas estudiadas, como la de la Colegiata de Santa María y la del Santo Sepulcro en Osuna (Sevilla) y las madrileñas Real Capilla de San Cayetano, Capilla de Música del Real Oratorio de San Felipe Neri y Capilla del Colegio Imperial.

Las Casas de Osuna y Benavente utilizaron la música como un medio de autorrepresentación que servía para mostrar poder y posición de clase social dominante, y además practicaron la música como diversión y enriquecimiento cultural. Los datos aportados sobre estas familias, junto con los conocidos sobre otras casas nobiliarias españolas de la época (Alba, Medina Sidonia, Castelfuerte o Mortara, entre otras) sugieren que la música tuvo un papel fundamental en la educación de la nobleza y fue empleada como un importante elemento de proyección externa de esta clase social. Profundizar en el estudio del mecenazgo musical de la nobleza española e integrar sus aportaciones en la tradición historiográfica de la musicología hispana es un interesante reto para el futuro. 

Bibliografía 

Aguado González, Francisco Javier. El ascenso de un linaje castellano en la segunda mitad del siglo XV: Los Téllez Girón, Condes de Ureña: El Origen del Señorio de Osuna. Tesis Doctoral inédita. Madrid: Universidad Complutense, 1991.

Aguilar Piñal, Francisco. Bibliografía de autores españoles del siglo XVIII. Madrid: Consejo Superior de Investigaciones Científicas, Instituto Miguel de Cervantes, 1981.

Alcalá Cesar. "El palacio de la condesa y su capilla musical”. RMS, XXI/1 (1998), pp. 197-214.

Alenda y Mira, Jenaro. Relación de solemnidades y fiestas públicas de España. Madrid: Sucesores de Rivadeneyra, 1903.

Alier, Roger. L'òpera a Barcelona : orígens, desenvolupament $i$ consolidació de l'ópera com a espectacle teatral a la Barcelona del segle XVIIIBarcelona: Institut d'Estudis Catalans, Societat Catalana de Musicología, 1990.

Alonso, Celsa. "Los salones: un espacio musical para la España del XIX". AnM, 48 (1993), pp. 165-205. . La Canción Lírica Española en el siglo XIX. Madrid: ICCMU, 1998.

Álvarez María Salud. José de Nebra: vida y obra. Zaragoza: Institución Fernando el Católico-Sección de Música, 1993.

Álvarez Osorio, Francisco. "Breve Historia del Archivo que fue del Duque de Osuna”. Revista de Archivos, Bibliotecas y Museos, 15 (1906), pp. 79-100.

Álvárez y Baena, José Antonio. Compendio Histórico de las Grandezas de la Coronada Villa de Madrid, Corte de la Monarquía de España. Madrid: Antonio de Sancha, 1786.

Amsterdam, Ellen Iris. The String Quintets of Luigi Boccherini. Tesis doctoral inédita. Berkeley: University of California, 1969.

Andioc René. "Une «zarzuela» retrouvée El Barón de Moratín”. Mélanges de la Casa de Velázquez 1 (1965), pp. 289-321.

Andioc, René y Coulon Mireille. Cartelera teatral madrileña del siglo XVIII (1708-1808). Toulouse: Presses Universitaires, 1996, 2 vols.

Annibaldi, Claudio (ed.). La musica e il mondo. Mecenatismo e comitenza musicale in Italia tra Quattro e Settecento. Bologna: Il mulino, 1993. 
Antonio de Sancha, 1720-1790, reinventor de lecturas y hacedor de libros. Madrid: Calcografía Nacional, 1997.

Añón Feliu, Carmen y Luengo, Mónica. El Capricho de la Alameda de Osuna. Madrid: Ayuntamiento de Madrid, Área de Medio Ambiente, 2003.

Aragón Mateos, Santiago. "Nobleza y Opinión Pública en tiempos de Carlos III. Los Límites de la Crítica Social Ilustrada”. Pedralbes. Revista d'Historia Moderna, 8/I (1988), pp. 13-23.

"La Nobleza Narcisista. Ideología Nobiliaria en la España de la Ilustración”. Mélanges de la Casa de Velázquez, 25 (1989), pp. 279-301.

Ariza y Montero-Coracho Antonio María. Bosquejo biográfico de D. Juan Téllez Girón, IV Conde de Ureña. Osuna: Eulogio Trujillo, 1890.

Armiñán Odriozola, Luis de. El Gran Duque de Osuna. Madrid: Gran Capitán, 1948.

Arrese, José Luis, Aunós Eduardo y Gómez, Julio. Blas de Laserna. Corella: Biblioteca de Corellanos Ilustres-Impr. Delgado, 1952.

Arroyo Fernández, María Dolores. Cayetana de Alba: Maja y Aristócrata. Madrid: Aldebarán, 1999.

Ascargorta, Domingo de. Origen de los Excelentísimos Condes-Duques de Benavente y su apellido Pimentel. BNE, Ms. 11569.

Atienza Hernández Ignacio. "El poder real en el siglo XV, Lectura crítica de los documentos de donación de Villas y Lugares. La Formación de los Estados de Osuna”. Revista Internacional de Sociología, 41/48 (1983), pp. 557591.

. 'La 'Quiebra' de la Nobleza Andaluza en el siglo XVII. Autoridad real y Poder Señorial: El Secuestro de los bienes de la Casa de Osuna”, Hispania, 156/44 (1984), pp. 49-81.

"Las mujeres nobles: Clase dominante, grupo dominado. Familia y orden social en el Antiguo Régimen”. En García Ballesteros Aurora (ed.). Actas de las IV Jornadas de Investigación Interdisciplinaria: ordenamiento jurídico y realidad social de la mujer. Madrid: Instituto Universitario de Estudios de la mujer, 1986, pp. 140-167.

. Aristocracia, poder y riqueza en la España Moderna. La Casa de Osuna, siglos XV-XIX. Madrid: Siglo Veintiuno, 1987. 
Atienza Hernández Ignacio y Mata Olmo, Rafael. "La Quiebra de la Casa de Osuna”. Moneda y Crédito, 176/3 (1986), pp. 71-95.

Barber, Elinor G. The Bourgeoisie in 18th Century France. New Jersey: Princeton University Press, 1955.

Baselga Esteve, Ramón. "Pedro Cerone de Bérgamo, Estudio biobibliográfico". Tesoro Sacro Musical, 54 (1971), pp. 8-15, 40-48, 71-79, 99-102; 55 (1972), pp. 3-6, 35-41.

Beceiro Pita, Isabel. "La Biblioteca del Conde de Benavente a mediados del siglo $\mathrm{XV}$ y su relación con las mentalidades y usos nobiliarios de la época”. La España Medieval, 2 (1982), pp. 135-145.

Beceiro Pita, Isabel. El condado de Benavente en el siglo XV. Salamanca: Centro de Estudios Benaventanos Ledo del Pozo, 1998.

Beckford William. Italy; with sketches of Spain and Portugal. London: R. Bentley, 1834.

. The Journal of William Beckford in Portugal and Spain. Edición y notas de Alexander Boyd. Londres: Rupert-Hart Davis, 1954.

. Un inglés en la España de Godoy (Cartas españolas). Traducción y edición de Jesús Pardo. Madrid: Taurus, 1966.

Beladiez Emilio. El Gran Duque de Osuna, soldado, virrey, “un Girón”. Madrid: Prensa y Ediciones Iberoamericanas, 1996. .Osuna el Grande, El Duque de las Empresas. Madrid: Alhambra, 1954.

Benito García, Juan José. Afectos del más tierno amor fraternal con el que la excelentísima Señora Condesa Viuda de Benavente celebró las exequias de su difunto hermano el señor Duque de Osuna [...] Descripción del monumento erigido con este motivo en aquel templo. Madrid: Manuel González, 1787.

Bergia Cervantes, Ofelia. "La Nobleza en el Prado", Hidalguía, 146/26 (1978), pp. 115-144.

Boccherini Luigi. Clementina. Revisión y adaptación del texto por Jacinto Torres Mulas. Transcripción musical por Antonio Gallego. Madrid: Consorcio para la Organización de Madrid Capital Europea de la Cultura, 1992.

Bordas, Cristina. "Dos constructores de pianos en Madrid: Francisco Flórez y Francisco Fernández". RMS,, XI/ 3 (1988), pp. 807-851. . Hazen y el piano en España. 175 años. Madrid: Hazen, 1989. 
Bourligueux, Guy. "El violinista Pascual Juan Carriles, su familia y sus amigos". AnM, 42 (1987), pp.199-228.

Boyd, Malcolm. "Form and Style in Scarlatti's Chamber Cantatas". Music Review, 25 (1964), pp.17-26.

Boyd, Malcolm y Carreras, Juan José (eds.). Music in Spain during the Eighteenth Century. Cambridge: Cambridge Univesity Press, 1998. Edición en español: La música en España en el siglo XVIII. Madrid: Cambridge University Press, 2000.

Burke, Peter (ed.). Formas de hacer Historia. Madrid: Alianza Universidad, 1993.

Cabrera de Córdoba, Luis. Felipe II, Rey de España. Madrid: Aribau, 1874.

Cadenas y Vicent, Vicente de, et alt. Indice nobiliario español. Madrid: Hidalguia, 1956.

Cadenas y Vicent, Vicente de. "Fondos Genealógicos en los Archivos Españoles". Hidalguía, 98/18 (1978), pp. 103-144.

Capdepón, Paulino. La música en el Monasterio de la Encarnación (Siglo XVIII). Madrid: Alpuerto, 1997.

. La música en el Monasterio de las Descalzas Reales. Madrid: Alpuerto, 1999.

Carapezza Paolo Emilio. "O soave armonia, classicitá, maniera e barocco nella scuola polifonica siciliana". Studi musicali, III (1974), pp. 347-90.

Cárdenas Serván, Inmaculada. El polifonista Alonso Lobo y su entorno. Santiago de Compostela: Universidad de Santiago de Compostela, 1987. . Música Barroca andaluza en las Colegiatas de Osuna y Olivares. Tesis Doctoral inédita. Sevilla: Universidad de Sevilla, 1980.

Carmena y Millán, Luis. Crónica de la Ópera Italiana en Madrid desde 1738 hasta nuestros días. Madrid: Manuel Minuesa de los Ríos, 1878.

Carreira, Xoan María. "Ballet performed at the Teatro de los Caños del Peral de Madrid, and other Spanish Theaters 1787-1799", The Origins of the Bolero School, Studies on Dance History IV/I, (Pennington: The Journal of the Society of Dance History Scholars, 1993).

Carreras, Juan José. “«Terminare a Schiaffoni»: La primera compañía de ópera Italiana en Madrid”. Artigrama, 12 (1996-97), pp.99-121. 
- "Hijos de Pedrell. La historiografía musical española y sus orígenes nacionalistas (1780-1980)". Il Saggiatore musicale VIII (2001), pp. 123171.

Catálogo alfabético de las obras impresas pertenecientes a la Biblioteca del Duque de Osuna adquiridas en 1886. BNE Ms. 18953.

Catálogo de libros procedentes de los palacios de La Alameda, Aranjuez y Madrid. Precede al título Comisión Ejecutiva de Obligacionistas de Osuna, Venta en Pública subasta del mobiliario del Palacio de Osuna, Madrid: Est. Tip. de la Viuda e hijos de M. Tello, 1897.

Cetrangolo, Annibale Enrico. Musica italiana nell'America coloniale. Premesse. Cantate del Veneto Giacomo Facco. Padova: Liviana Editrice, 1989.

Cienfuegos, Álvaro. La heroyca vida, virtudes y milagros del Grande San Francisco de Borja. Madrid: Juan García Infanzón, 1702.

Claudio Sartori (ed.). I libretti italiani a stampa dalle origini al 1800. Cunneo: Bertola \& Locatelli, 1990.

Clemencin Diego. Proyecto para la educación del Excelentísimo Señor Marqués de Peñafiel y del Señor Príncipe de Anglona. Dirigido a sus padres, los Excelentísimos. Señores Duques de Osuna, Condes-Duques de Benavente. Biblioteca General del CSIC (Madrid), Archivo Rodríguez Marín, caja 78, doc. 11.

Contel Barea, Concepción. "Fondos nobiliarios en el Archivo Histórico Nacional" Cuadernos de Historia Moderna 5 (1994), pp. 397-413.

Cotarelo y Mori, Emilio. Iriarte y su época Estudios sobre la Historia del Arte Escénico en España. Madrid: Sucesores de Rivadeneyra, 1897.

. Don Ramón de la Cruz y sus obras. Ensayo biográfico y bibliográfico. Madrid: Imprenta de José Perales y Martínez, 1899.

- Estudios sobre la Historia del Arte Escénico en España III. Isidoro Maiquez y el Teatro de su tiempo, Madrid: Imprenta de José Perales y Martínez, 1902.

. "Las armas de los Girones. Estudios de Antigua Heráldica Española". Separata facticia de Revista de Archivos, Bibliotecas y Museos, Julio 1903. . Orígenes y establecimiento de la Ópera en España hasta 1800. Madrid: Tipografía de la Revista de Archivos, Bibliotecas y Museos, 1917. 
. Historia de la zarzuela, o sea el drama lírico en España, desde su origen a finales del siglo XIX. Madrid: Tipografía de Archivos, 1934. Reedición facsímil: Madrid: ICCMU, 2000.

de la Cruz, Ramón. Clementina. Introducción de Maria Grazia Profeti y Miguel Ángel Marín, texto crítico, traducción y notas de Nicoletta Lepra. Firenze: Alinea Editrice, 2003.

de la Torre María José. Música y ceremonial en las Fiestas Reales de proclamación de España e Hispanoamérica (1746-1814). Tesis doctoral. Granada: Universidad de Granada, 2004.

Decreto de 29 de Octubre sobre la concurrencia de actores y actrices a las casas de la nobleza. BNE Ms 11265.42.

Delaforce, Ángela. Art \& patronage in eighteenth century Portugal. Cambridge: Cambridge University Press, 2002.

Demerson, Paula. Catálogo de Socias de honor y mérito de la Junta de Damas matritense Madrid. Instituto de Estudios Madrileños, 1971. - María Francisca de Sales Portocarrero, Condesa de Montijo. Una figura de la Ilustración. Madrid: Editora Nacional, 1975.

Dewald, Jonathan. The European Noblity, 1400-1800. Cambridge: Cambridge University Press, 1996.

Diccionario de la lengua castellana, en que se explica el verdadero sentido de las voces[...] Compuesto por la Real Academia Española. Madrid: Imprenta de Francisco del Hierro, 1729.

Diccionario de la lengua castellana compuesto por la Real Academia Española, reducido a un tomo para su más fácil uso. Cuarta edición. Madrid: Viuda de Ibarra, 1803.

Diccionario de la Música Española e Hispanoamericana. Emilio Casares Rodicio, director. Madrid: Sociedad General de Autores y Editores, 19992002, 10 vols.

Die Musik in Geschichte und Gegenwart: Allgemeine Enzyklopädie der Musik. Ludwig Finscher (ed.). Basel: Bärenreiter; Stuttgart: Metzler, 1994-2005.

Discurso que la Excelentísima Señora Condesa Duquesa de Benavente, Marquesa de Peñafiel, hizo a la Real Sociedad Económica de Madrid el día de su recepción. Madrid: Antonio de Sancha, [1786]. 
Domínguez Ortiz, Antonio. La Sociedad Española en el siglo XVIII. Madrid: Instituto Balmes de Sociología- CSIC, 1955. . La Sociedad Española en el siglo XVII. Madrid: CSIC, 1963-1970. 2 vols. . Las clases privilegiadas en la España del Antiguo Régimen. Madrid: Istmo, 1973.

Durón, Sebastián y Cañizares, José de. Salir el Amor del mundo, zarzuela en dos jornadas Transcripción y estudio de Antonio Martín Moreno Málaga: Sociedad Española de Musicología, 1979.

Ester-Sala, María. "El Mecenazgo de la Nobleza en la Música del siglo XVI". Nassarre 4/ 1-2 (1988), pp. 37-58.

Esteve y Grimau, Pablo (ed.). Letras que se cantan en la Comedia de no hay en amor fineza más constante, que dejar por Amor su mismo amante: Inclusas las tonadillas, que se cantan igualmente en los Sainetes de esta Fiesta en el Coliseo de la Cruz. Año de 1766. Dadas a la luz por don Pablo Esteve y Grimau, compositor de música en esta Corte. Las dedica al Exelentísmo. Señor Duque de Osuna \&c. Madrid: Imprenta de Manuel Martín, 1766.

Esteve y Grimau, Pablo. Los Jardineros de Aranjuez (1768) Zarzuela en dos actos. Estudio y edición crítica de Juan Pablo Fernández Cortés. Granada: Universidad de Granada-Centro de Documentación Musical de Andalucía, 2005.

Exposición y venta de los cuadros y demás objetos de arte de la Casa Ducal de Osuna. Madrid: Viuda e hijos de M. Tello, 1896.

Examen público de las señoras Doña Josefa y Doña Joaquina Girón y Pimentel y de los señores Don Francisco y Don Pedro, sus hermanos, hijos de los Excelentísimos señores Duques de Osuna, Condes Duques de Benavente, el día 20 de abril de 1797. Madrid: Cano, [s.a].

Ezquerra del Bayo, Joaquín. Retratos de la familia Téllez Girón. Novenos duques de Osuna. Madrid: Junta de Iconografía Nacional, 1934.

Fernán-Núñez, Carlos Gutiérrez de los Ríos, Conde de. Vida de Carlos III escrita por el Conde de Fernán-Núñez; publicada con la biografía del autor, apéndices y notas por A. Morel-Fatio y A. Paz y Meliá y un prólogo de Juan Valera. Madrid: Librería de Fernando Fé, 1898. 
Fernández de Bethencourt, Francisco. Historia genealógica y heráldica de la Monarquía Española Casa Real y Grandes de España. Madrid: Enrique Teodoro, 1897-1920.

Fernández de Córdoba, Fernando. Mis memorias íntimas. Madrid: [Tip. Sucesores de Rivadeneyra ], 1886-1889, 3. vols.

Fernández de Latorre, Ricardo. Historia de la música militar de España. Madrid: Ministerio de Defensa, Secretaría General Técnica, 2000.

Fernández de Mendoza Tomás. Elogio fúnebre en que se da una idea cabal, de las circunstancias virtudes y premios, del Excelentísimo Señor Don Pedro Zoilo Tellez Girón, $8^{\circ}$ Duque de Osuna. BNE, Ms. 10494.

Fernández de Moratín, Leandro. Obras dramaticas y liricas de D. Leandro Fernandez de Moratin entre los arcades de Roma, Inarco Selenio. París: Augusto Bobée, 1825.

- Orígenes del Teatro Español, seguidos de una colección escogida de piezas dramáticas anteriores a Lope de Vega. París: Librería Europea de Baudry, 1838.

Fernández de Navarrete, Martín, Salvá, Miguel y Sainz de Baranda, Pedro. Colección de documentos inéditos para la historia de España. Madrid: Viuda de Calero, 1842.

Fernández Quintanilla, Paloma. La mujer ilustrada en la España del siglo XVIII. Madrid: Ministerio de Cultura, 1981.

Fernández. García, Matías. Parroquia Madrileña de San Sebastián. Algunos Personajes de su Archivo. Madrid: Caparrós, 1985.

Fernández-Cortés Juan Pablo. "El mecenazgo musical de Mariano Téllez Girón, XII Duque de Osuna (1844-1882). Actas del VI Congreso de la Sociedad Española de Musicología. Oviedo 2005, RMS,, XVIII/1 (2005), en prensa.

Fernández-Cortés Juan Pablo. “José Castel (1728-1807) un tonadillero maestro de capilla". RMS, XXIV/1-2, 2001, pp. 115-134.

Freire, Ana María. Los teatros en casas particulares en el siglo XIX. Madrid: Artes Gráficas Municipales, 1996.

Gallego Antonio. “La «Clementina» de Boccherini”. RMS, 10/2 (1987), pp.633639. . La música en tiempos de Carlos III. Madrid: Alianza, 1988. 
. "Breve nota sobre el Festero y la Festería". Nassarre, V/1 (1989), pp. 2757.

Gambassi, Osvaldo. L'accademia filarmonica di Bologna. Fondazione, statuti, aggregazioni. Firenze: Olschki, 1992.

Gándara, Xosé Crisanto. “Algunos aspectos sobre el contrabajo en la música de Luigi Boccherini”, RMS, XXII/2 (2000), pp. 443-464.

García Aser Rosario y Lafuente Urién Aránzazu. Archivos nobiliarios: cuadro de clasificación. Sección Nobleza del Archivo Histórico Nacional. (Madrid: Ministerio de Educación Cultura y Deporte, Centro de Publicaciones 2000).

García de Córdoba, Antonio. Compendio de las antigüedades de la villa de Osuna, y noticias de los preexcelsos dueños que ha tenido, desde su fundación. BNE, Ms.10479.

García Fraile Dámaso. Catálogo del archivo de música de la catedral de Salamanca. Cuenca: Instituto de Música Religiosa, 1981.

García Hernán, David. Aristocracia y señorío en la España: la casa de Arcos. Granada: Universidad de Granada 1999. . La Nobleza en la España Moderna. Madrid: Istmo, 1992.

Gatti, Francesco. Spettacoli musicali al Teatro Concordia di Jesi: (1798-1883). Roma, Torre de Orfeo, 1999.

Gembero Ustárroz, María. "El patronazgo ciudadano en la gestión de la música eclesiástica: la Parroquia de San Nicolás de Pamplona (1700-1800)". Nassarre, XIV/1 (1998), pp. 269-361.

. "El repertorio operístico en una Corte Nobiliaria española del siglo XVIII: La obra de Girolamo Sertori al Servicio de los Marqueses de Castelfuerte”. En: Emilio Casares Rodicio y Álvaro Torrente, eds. La ópera en España e Hispanoamérica. Madrid: ICCMU, 2001, vol 1, pp. 403-454.

Genealogía, origen y noticias de los comediantes en España. BNE Ms. 1291712918. Publicado con el mismo título por N D. Shergold y J.E Varey. Londres: Tamesis Books, 1985.

Gérard, Yves. Thematic, Bibliographical and Critical Catalogue of the Works of Luigi Boccherini. London, New York, Toronto: Oxford University Press, 1969. 
Gladstone, Lorna Jury. Aristocratic landholding \& finances in seventeenth century Castille: The case of Gaspar Téllez Girón, Duke of Osuna (16561694). Tesis doctoral inédita. Virginia: University of Virginia, 1977.

Gömez Amat, Carlos. Historia de la música española, 5, Siglo XVIII. Madrid: Alianza, 1984.

Gómez Fernández, Lucía. Mecenazgo musical de la Casa de Medina Sidonia (1500-1645): Aproximación a las fuentes documentales. Trabajo de investigación tutelado y dirigido por Emilio Ros-Fábregas, Inédito. Granada: Universidad de Granada, 2003.

Gómez Pintor, María Asunción. "Fuentes documentales para el estudio de las Casas de Osuna y Arcos”. RMS, XVI/ 6 (1993) pp. 3459-3475.

Grimaldi, Floriano. Cantori maestri organiste della Capella Musicale di Loreto nei secoli XVII-XIX, Loreto: Ente Rassegne Musicali, 1982.

Gudiel, Jerónimo. Compendio de algunas historias de España donde se tratan muchas antigüedades dignas de memoria y especialmente se da noticia de la antigua familia de los Girones, y de otros muchos linajes. Alcala de Henares: Juan Íñiguez de Lequerica, 1577.

Gurbindo, Beatriz. "José Castel y la tonadilla entre Tudela y Madrid". Nassarre, XVII/1-2 (2001), pp. 243-304.

Gutiérrez Núñez Francisco Javier. "El IX Duque de Osuna: Político, militar y mecenas (1755-1807)". Milicia y Sociedad Ilustrada en España y América, Actas de las XI Jornadas Nacionales de Historia Militar, organizada por la Cátedra General Castaños de la Región Militar Sur. (Sevilla: Demus, 2003), pp. 103-120.

Hammond Frederick. Music \& spectacle in baroque Rome: Barberini patronage under Urban VIII. New Haven: Yale University Press, 1994.

Harris, Ellen T. Handel as Orpheus, Voice and desire in the Chamber cantatas. Cambridge, Massachusetts y Londres: Harvard University Press, 2001.

Heartz Daniel. Music in European capitals. The Galant Style, 1720-1780. Nueva York y Londres: W.W. Norton \& Company, 2003.

Heilbron Ferrer, Marc. “«Umilissimi, devotissimi servi» Correspondencia de cantantes de ópera italiana con la Duquesa de Osuna". AnM, 57 (2002), pp. 199-227. 
Henares Cuéllar, Ignacio y Calatrava Juan. Romanticismo y teoría del arte en España. Madrid: Cátedra, 1982.

Higinio Anglés y José Subirá. Catálogo musical de la Biblioteca Nacional de Madrid, Barcelona: Consejo Superior de Investigaciones. Científicas. Instituto Español de Musicología, 1946-1951, 3 vols.

Hoboken, Anthony van. J. Haydn, Thematisch-bibliographisches Werkverzeichnis, Mainz: B. Schott's Schone, 1957-71, 3 vols.

Holmes William C. "Pamela Transformed", Musical Quarterly 38 (1952), pp. 581-594.

Ibáñez de Segovia, Gaspar. Memorias históricas y genealógicas de la Casa de los Ponces de León, duques de Arcos. BNE Ms. 3147.

Iglesias, $\mathrm{M}^{\mathrm{a}}$ Carmen (coord.). Nobleza y Sociedad en la España Moderna. Oviedo:

Fundación Central Hispano y Ediciones Nobel, 1996-1997, 2 vols.

Inventario General de Manuscritos de la Biblioteca Nacional (Madrid: Biblioteca Nacional de España, 1953-2001), 15 vols.

Iriarte, Tomás. La música. Madrid: Imprenta Real de la Gaceta, 1779.

Jackson, Roland: A Neapolitan festa a ballo and selected instrumental ensemble pieces. Madison: A-R Editions 1978.

Jauralde Pou, Pablo: "El Teatro en los Palacios", Teatro. Revista de Estudios Teatrales 1 (1992), pp. 33-56.

Kenyon de Pascual, Beryl. "Diego Fernández Harpsichord Maker to the Spanish Royal Family from 1722 to 1755 and his nephew Julián Fernández”. The Galpin Society Journal XXXVIII (1985), pp. 35-47.

Kleinertz, Rainer (ed.). Teatro y música en España (siglo XVIII).Actas del simposio internacional(Salamanca, 1994). Kassel-Berlín: Reichenberger, 1996.

Kleinertz, Rainer, Grundzüge des Spanischen Musiktheaters im 18 Jahrundert. Opera, comedia und Zarzuela. Kassel: Reichenberger, 2003.

Kieffer, Anna María. “Appuntamentos musicais dos viajantes”, Revista USP Sao Paulo, 30 (Junho- Agosto 1996), pp. 134-141.

Labrador López de Azcona Germán. Gaetano Brunetti: un músico en la corte de Carlos IV. Tesis doctoral inédita. Madrid: Universidad Autónoma de Madrid, 2003. 
. "Música, poder e institución: La Real Capilla de Carlos IV". RMS, XXVI/1 (2003), pp.243-244.

Lafarga Francisco (ed.). El teatro europeo en la España del siglo XVIII. Lleida: Universidad de Lleida, 1997.

Lafuente Urién, Aranzazu. "El Archivo de los Duques de Osuna en la Sección Nobleza del Archivo Histórico Nacional”. Hespérides, 4 (1997), pp. 485513.

Lasso de la Vega y López de Tejada, Miguel. "La Nobleza Española en el siglo XVIII”. Revista de Archivos, Bibliotecas y Museos, 60/2 (1954), pp. 417499.

Lastimoso fuego que se prendió sin saber ciertamente el como, en el Palacio y Coliseo del Excelentísimo Señor Duque de Osuna, el cual pereció sin remedio, por estar mas de seis días ardiendo [...]. sucediò en Madrid este presente año de 1723, (Madrid: [s,1] [s, a]) .

Leti, Gregorio. Vita di Don Pietro Giron, Duca d'Ossuna, Vicere di Napoli e di Sicilia, sotto il regno di Filippo Terzo. Amsterdam: Georgio Gallet, 1699.

Letra de la música contenida en la zarzuela intitulada en idioma italiano "La buona figliola" y en castellano "La buena muchacha compuesta por el insigne Nicolao Piccini a excepción de la que se nota con unas xxx que lo es por Don Pablo Esteve y Grimau, quien la dedica al Excelentísimo Señor Duque de Osuna ([s.1]: [s.n], 1765).

Leza, José Máximo. “Aspectos productivos de la ópera en los teatros públicos de Madrid (1730-1799)”. En: Emilio Casares Rodicio y Álvaro Torrente, eds. La ópera en España e Hispanoamérica. Madrid: ICCMU, 2001, vol 1. pp. 231-262.

. "Las orquestas de Ópera en Madrid entre los siglos XVIII Y XIX". Campos interdisciplinares de la Musicología. Actas del V Congreso de la Sociedad Española de Musicología. Madrid: Sociedad Española de Musicología, 2001, vol 1, pp. 115-139.

Libro en donde consta el por menor de los gastos causados con motivo de la Función de Parejas que se corrieron el día 12 de diciembre de 1765 en celebridad del casamiento del Serenísimo Príncipe de Asturias. BNE Ms. 10354. 
Lidón, José. Música para teclado. Edición crítica. Estudio y transcripción de Dámaso García Fraile. Madrid: Sociedad Española de Musicología, 20022004, 2 vols.

Lipmann, Edward A. Musical Thought in Ancient Greece. Nueva York: Columbia University Press, 1964.

Lolo, Begoña. "Consideraciones en torno al legado musical de Sebastián Durón después de su exilio a Francia", RMS, XV/ 1 (1992), pp.195-208.

López Calo, José. La música en la Catedral de Zamora. Zamora: Diputación Provincial, 1985.

López de Haro, Alonso. Nobiliario genealógico de los reyes y titulos de España. Madrid: Luis Sanchez, 1622.

López Ruiz, Antonio y Aranda Muñoz, Eusebio. Diego Clemencin, $2^{\mathrm{a}}$ edición corregida y ampliada. Murcia: Real Academia de Alfonso X el Sabio, 1994.

López, Marcial Antonio. Exposición en defensa del Duque de Osuna, contra el decreto de Isabel II de 16 de septiembre que le considera incurso en la pena de Secuestro de bienes por haber salido para país extranjero sin autorización y solicitud de permanencia por tiempo de un año en Bélgica e Italia a favor del mismo. [Madrid]: [s.n.], 1836.

López, Tomás. Plano geométrico de Madrid dedicado y presentado al rey nuestro señor Don Carlos III por mano del Excelentísimo señor Conde de Floridablanca. Madrid: [s.1], 1785.

Lynch, John. La España del siglo XVIII. Barcelona: Crítica, 1991.

Marco Mangani y Remigio Colli. "Osservazioni sul catalogo autografo di Luigi Boccherini: I quintetti a due violoncelli”. Rivista Italiana di Musicologia, XXXII/2 (1997), pp. 315-326.

Manalt, Francisco. Obra Armónica en seis sonatas de cámara de violín y bajo solo. Madrid: Andrés Guinea, 1757.

. Sonatas para violín y piano. Transcripción por el P. José A. de Donostia. Barcelona: Instituto Español de Musicología-CSIC, 1955-1966.

. Obra Armónica en seis sonatas de cámara de violín y bajo solo. (Madrid, 1757). Edición de Lothar Siemens y Lourdes Bonnet Madrid: Sociedad Española de Musicología, 2001. 
Maravall, Jose Antonio. Teatro y Literatura en la Sociedad Barroca. Madrid: Seminarios y Ediciones, 1972.

March, José María. La Real Capilla del Palau en la Ciudad de Barcelona: breve reseña. Barcelona: Residencia del Palau, 1921.

Marichalar Antonio. Riesgo y ventura del Duque de Osuna. Madrid: Espasa Calpe, 1930

Marín, Miguel Ángel. "Music Selling in Boccherini's Madrid”. Early Music, XXXIII/ 2 (2005), pp.165-177.

Martín Gaite, Carmen. Usos amorosos del siglo XVIII en España. Madrid: Siglo XXI, 1972.

Martín Moreno, Antonio. Historia de la música española, 4, Siglo XVIII. Madrid: Alianza, 1985.

Martínez del Barrio, Javier Ignacio. "Educación y Mentalidad de la Alta Nobleza en los siglos XVI y XVII. La Formación de la Biblioteca Ducal de Osuna”. Cuadernos de Historia Moderna, 12 (1991), pp. 67-81.

. Obra Armónica en seis sonatas de cámara de violín y bajo solo. (Madrid, 1757). Edición de Lothar Siemens y Lourdes Bonnet Madrid: Sociedad Española de Musicología, 2001.

Mecenazgo y Política Cultural de la Casa de Osuna en Italia (1568-1694). Tesis doctoral, Madrid: Universidad Complutense, Servicio de Reprografía, 1989.

Martínez Medina, África. "La vivienda aristocrática escenario de la fiesta. Festejos realizados por los Condes-Duques de Benavente con motivo de la Exaltación al trono de Carlos IV. 19 de Enero de 1789”. Anales del Instituto de Estudios madrileños 37 (1997), pp. 283-290.

. "Palacios madrileños del siglo XVIII". Madrid: Ediciones La Librería, 1997.

. La casa nobiliaria española en los suglos XVII y XVIII: Historia, función, estructura y ornamentación. Tesis doctoral inédita, Madrid: Universidad Complutense, 1992.

Masin Jean y Masin Brigit. Wolfgang Amadeus Mozart. Madrid: Turner Música, 1987.

Merry y Colón, Manuel. Del origen, fundación, privilegios y excelencias de la Universidad de Osuna. Madrid: Imprenta de Carlos Fontaura, 1868. 
Mitjana Rafael. "La musique en Espagne”. En: Enciclopédie de la musique et dictionnaire du Conservatoire, A. Lavignac, y L. de La Laurencie (eds.), vol I/4, París: Delagrave 1920, pp. 1913-2352. Traducción al español La música en España: arte religioso y arte profano. Madrid: Centro de Documentación Musical, Instituto Nacional de las Artes Escénicas y la Música, 1993.

Moll Roqueta, Jaime. "Músicos en la corte del cardenal Tavera (1523-1545): Luis Venegas de Hesnestrosa”. AnM, VI (1951), pp. 155-178.

. "Notas para la historia musical de la corte del duque de Calabria". AnM, XVIII (1963), pp. 123-135.

Monroy y Silva, Cristóbal. Las Mocedades del Duque de Osuna. Madrid: Rivadeneyra, 1884.

Morales Moya, Antonio. Poder político, economía e ideología en el siglo XVIII Español: La Posición de la Nobleza, Tesis doctoral. Madrid: Universidad Complutense- Servicio de reprografía, 1983.

Morales Moya, Antonio. "La Nobleza Española en el siglo XVIII”. En: Coloquio Internacional Unidad y Diversidad en el Mundo Hispánico del Siglo XVIII, Gonzalo Anés (ed.). Madrid: Universidad Complutense, 1996, vol 1, pp. 579-586.

Morales y Marín, José Luis. Luis Paret: vida y obra. Zaragoza: Aneto, 1997.

Morales, Nicolás. "A la sombra del poder. Usos sociales y lucrativos de la comunidad musical palaciega en el siglo XVIII". Campos interdisciplinares de la Musicología. Actas del V Congreso de la Sociedad Española de Musicología. Madrid: Sociedad Española de Musicología, 2001. vol 1, pp. 67-86.

. "Real Capilla y Festería en el siglo XVIII: Nuevas aportaciones para la historia de la institución musical palatina" RMS, XXII/1 (1999), pp.175208.

Moreno, Emilio. “Aspectos técnicos del tratado de violín de José Herrando (1756): El violín español en el contexto europeo de mediados del siglo XVIII". RMS, XI/3 (1988), pp. 555-656.

Moreuau, Mario. Luisa Todi (1753-1833). Lisboa: Hugin, 2002.

Mozart De Araujo, José A. A Modinha e o Lundu no Século XVIII. São Paulo: Ricordi Brasileira, 1963. 
Mugaburu y la Encina, Pedro Antonio. Oración fúnebre hecha en Valencia a las honras de la Excelentísima Condesa Duquesa de Benavente. BNE, Ms. $11319 / 12$.

Mujal Elias, Juan. Lérida. Historia de la música. Lérida: Dilagro ediciones, 1975. Navascués, Pedro. Antecedentes de la Alameda de Osuna. Madrid: COAM, 1977.

Nestola, Barbara. "Spoglio dei volumini dei « Meilleurs airs italiennes» pubblicati da Christoph Ballard (1699-1708)". Cahiers Philidor, Centre de Musique Baroque de Versailles 26. Versión electrónica: http: //www.cmbv.com/images/banq/cp/cp026.pdf.

O' Callaghan, John. "Don Pedro Girón master of the Order of Calatrava 14451466". Hispania 83 (1961), pp. 342-390.

Oración fúnebre que en las solemnes exequias del Señor Don Pedro Zoylo Tellez, Giron y Guzman, Duque de Osuna, etc. mandadas celebrar por su hermana la Condesa Duquesa Viuda de Benavente y Gandia, etc. en la Iglesia de San Hermenegildo de [los] Padres. Carmelitas Descalzos de Madrid el día 5 de Julio de 1787 dijo Antonio Tavira, del Orden de Santiago [...]. Madrid: Viuda de Ibarra, Hijos y Compañia, [1787].

Ortega Judith. "La Real Capilla de Carlos III: los músicos instrumentistas y la provisión de sus plazas", RMS, XXIII/2 (2000), pp. 395-442.

. "El mecenazgo musical de la Casa de Osuna durante la segunda mitad del siglo XVIII: el entorno musical de Luigi Boccherini en Madrid, RMS, XXVII/2 (2004), pp. 643-697.

Pando Fernández de Prado, Manuel, Marqués de Miraflores. Biografía del Excelentísimo Señor Pedro Téllez Girón, Príncipe de Anglona. Madrid: José Rodríguez, 1851.

Pastor, José Antonio (S.I). Oracion funebre, en las honras, que la Real Congregacion de San Francisco Xavier consagra à la memoria del Excelentisimo Señor don Joseph Téllez Girón, Duque de Osuna. Madrid: Imprenta de Pedro Enguera, [1733].

Paz Espeso, Julián. Catálogo de la Colección de Documentos Inéditos para la Historia de España. Madrid: Instituto de Valencia de Don Juan, 19301931.

Peña y Goñi, Antonio. La ópera española y la música dramática en España en el siglo XIX. Apuntes históricos. Madrid: Imprenta de El Liberal, 1881. 
Peñín, José (coord.). Música Iberoamericana de salón. Actas del Congreso Iberoamericano de Musicología 1998. Caracas: Fundación Vicente Emilio Sojo, 2000, 2 vols.

Pestelli Giorgio. "Contributi alla storia della forma-sonata. Sei sonate per cembalo di Girolamo Sertori (1758)”. Rivista Italiana di Musicologia II/1, pp. 131139.

Piccinni Niccoló. La Cecchina, ossia, La buona figliuola. Introducción de Eric Weimer. Garland: Nueva Cork, 1983.

Picquot, Louis. Notice sur la vie et les ouvrages de Luigi Boccherini. París: Chez Philipp, 1851.

Pinnell, Richard. "Women and the Guitar in Spain's upper Classes". AnM, 53 (1998), pp. 165. 189.

Piza Prohens, Antoni. Antoni Literes, introducció a la seva obra. Palma: Documenta balear, 2002.

Planos de Madrid de los siglos XVII y XVIII. Introducción, reseña y estudio por Miguel Molina Campuzano. Madrid: Instituto de Estudios de Administración Local, 1960.

Polo Barrera, Ángela. Santo Toribio de Mogrovejo: hijo y patrono de Mayorga. [Valladolid]: Diputación Provincial de Valladolid, 2002.

Prado Higuera, Cristina. El Todo Madrid: La Corte, La Nobleza, y sus Espacios de Sociabilidad en el s. XIX, Tesis Doctoral inédita. Madrid: Universidad Complutense, 1993.

Prieto Bernabé, José Manuel. “Análisis de un fondo Bibliográfico. La Biblioteca del Palacio de Pastrana durante la Edad Moderna”. Hispania, 169/69 (1988), pp.699-736.

Radomski James. Chronicle of the Life of a bel canto Tenor at the Dawn of Romanticism Oxford: Oxford University Press, 2000. Versión española: Manuel García (1775-1832) Maestro del Bel Canto y Compositor. Madrid: ICCMU, 2002.

Rayo y González, Juan Nepomuceno. Sermón fúnebre predicado en las solemnes exequias a la buena memoria [de] Pedro Zoylo Téllez Gyrón, duque de Osuna [...]. Ecija: [s.1.], [s.a.].

Regueras Grande, Fernando. Pimentel, fragmentos de una iconografí. Benavente: Centro de Estudios Benaventanos Ledo del Pozo, 1998. 
Rice, Albert R. The Clarinet in the Classical Period. New York: Oxford University Press, 2003.

Robledo Estaire, Luis. "La musica en la Corte de José I". AnM, XLVI (1992), pp. 205-243.

. "El Conservatorio que nunca existió: el proyecto de Melchor Ronzi para Madrid (1810)". Música, Revista del Conservatorio Superior de Música de Madrid 7-9 (2000-2002), pp. 13-26.

Rocamora José Mª Catálogo Abreviado de los manuscritos de la Biblioteca del Señor Duque de Osuna e Infantado. Madrid: Imprenta de Fortanet, 1882.

Rodríguez Marín; Francisco. Conferencia pronunciada el día 22 de mayo de 1920

(...) acerca del gran duque de Osuna. Madrid: R. Velasco imp., 1920.

Rodríguez Suso, María del Carmen. "La trastienda de la ilustración: El empresario Nicola Setaro y la Ópera Italiana en España”, Il Saggiatore Musicale, Revista Semestrale di Musicología, 5/2 (1998), pp. 245-268.

Rodríguez-Buzón Calle, Manuel. La Colegiata de Osuna. Sevilla: Diputación Provincial de Sevilla, 1982.

Romanillos Vega, José Luis y Harris Winspear, Marian. The vihuela de mano \& The Spanish Guitar. Guijosa: The Sanguino Press, 2002.

Ros Fábregas, Emilio. "Historiografía de la música en las catedrales españolas:

Nacionalismo y Positivismo en la investigación musicológica". CODEXXI.

Revista de la Comunicación Audiovisual I (1998), pp. 68-135.

. "The Cardona and Fernández de Córdoba Coats of Arms in the Chigi Codex". Early Music History, 21 (2002), pp. 223-258.

Rothschild Germaine de. Luigi Boccherini. Sa vie, son œuvre. Paris: Plon, 1962.

Rubio Sánchez, María Soledad. El Colegio-Universidad de Osuna (1548-1824) Sevilla: Caja de Ahorros de San Fernando, 1976.

Ruiz, Antonio. Don Diego Clemencín: ensayo bio-bibliográfico. Murcia: Suc. de Nogués, 1948.

Russell, Eleanor. "The Patrons of Juan Vasquez: a biographical contribution". AnM, XXVI (1971), pp. 61-74.

. "Music in the house of the third Duke of Béjar: ca. 1520-1544". En: Encomium Musicae. Essays in memory of Robert J. Snow, D. Crawford y G.G. Wagstaff, eds. Hillsdale, New York: Pendragon Press, 2002), pp. 285-303. 
Saguar Quer, Carlos. Arquitectura funeraria madrileña del siglo XIX. Tesis doctoral (Madrid: Universidad Complutense. Servicio de Reprografía, 1989).

Salazar de Mendoza, Pedro. Chrónico de la Excelentisima casa de los Ponces de Leon. BNE, Ms. 3462. (Copia del siglo XVIII).

Saldoni, Baltasar. Diccionario biográfico-bibliográfico de efemérides de músicos españoles. Madrid: Antonio Pérez Dubrull, 1868-1881, 4 vols.

Saltillo, Marqués del. "Casas madrileñas del Pasado", Revista de la Biblioteca Archivo y Museo, 1945, pp. 81-98.

Sánchez Marroyo, Fernando. "La mujer como Instrumento de perpetuación patrimonial". Norba, Revista de Historia 8-9 (1987-1988), pp. 207-213.

Sancho José Luis. El Palacio de Carlos III de El Pardo. [Madrid]: Fundación de Apoyo a la Historia del Arte Hispánico, 2002.

Santamarina, Blanca. "La platería madrileña y la Casa de Osuna. Las Piezas de la Vajilla de una Duquesa Ilustrada". Anales del Instituto de Estudios madrileños 38 (1998), pp. 99-142.

Sanz Cuesta, Miriam, Rubio Linares, Ma Cruz y García Hernán, David. BIHES (Bibliografias de Historia de España) La nobleza en España $n^{\circ} 11$. Madrid: Centro de Información y Documentación Científica (CINDOC)CSIC, 2001, 2. vols.

Sarrailh, Jean. La España Ilustrada en la Segunda mitad del siglo XVIII. México, Buenos Aires, Madrid: Fondo de cultura económica, 1957.

Schreiber Ulrich. Opernführer für Fortgeschrittene 1. Die Geschichte des Musiktheaters. von den Anfängen bis zur Französischen Revolution. Kassel: Bärenreiter, 2002.

Schwartz, Roberta Freund. En busca de Liberalidad: Music and Musicians in the Courts of the Spanish Nobility, 1470-1640. Tesis doctoral inédita. Illinois: University of Illinois at Urbana-Champaign, 2001.

Siemens Hernández, Lothar. "Los violinistas compositores en la Corte Española durante el período central del siglo XVIII”. RMS, XI/3 (1988), pp. 657765.

. "Sebastián Christiani de Scío y su familia: contribución a los maestros de danzar en la España del siglo XVIII”. RMS, XX/1 (1997), pp. 323-329. 
Silva y Sarmiento, Pedro. Oración fúnebre en las honras, exequias que celebraron los oficiales del Regimiento de Reales Guardias Españolas de Infantería por el alma del Excelentísimo Señor Duque de Osuna el día 30 de Abril de 1787, en la Iglesia de Padres mínimos de San Francisco de Paula de esta Corte, Madrid: Viuda de Ibarra, Hijos y Compañía, [s.a].

Simal López, Mercedes. Los condes-duques de Benavente en el siglo XVII. Patronos y coleccionistas en su villa solariega. Benavente: Centro de Estudios Benaventanos Ledo del Pozo, 2002.

Solar-Quintes, Nicolás A. "I. Las relaciones de Haydn con la casa de Benavente. II. Nuevos documentos sobre Luigi Bocherini. III. Manuel García Íntimo" AnM, II (1947), pp. 81-104.

. “El compositor Español José de Nebra (†11-VII-1768): Nuevas aportaciones para su biografía”. AnM, VI (1951), pp. 179-204

. "Saverio Mercadante en España y Portugal. Su correspondencia con la condesa de Benavente". AnM, VII (1952), pp. 201-208.

. "Morales en Sevilla y Marchena. Estampa de la época". AnM, VIII (1953), pp. 27-38.

. "Antonio Literes Carrión y sus hijos. Nuevos documentos para su biografía”. AnM, IX (1954), pp. 169-189.

. "Nuevos documentos para la biografía del compositor Sebastián Durón". AnM, X (1955), pp. 137-164.

. "Nuevas obras de Sebastián Durón y de Luigi Boccherini y músicos del Infante Don Luis Antonio de Borbón”, AnM, XIII (1958), pp. 225-259.

Solar-Quintes, Nicolás A. y Gérard, Yves. "La bibliothèque musicale d'un amateur éclairé de Madrid: La Duchesse-Comtesse de Benavente, Duchesse de Ossuna (1752-1834)". Recherches sur la Musique française classique, III (1963), pp. 179-188.

Sommer-Matthis, Andrea: "Entre Nápoles, Barcelona y Viena. Nuevos documentos sobre la circulación de músicos a principios del siglo XVIII", Artigrama 12 (1996-97), pp. 45-78.

Soriano Fuertes, Mariano. Historia de la música española desde la venida de los fenicios hasta el año 1850. Madrid y Barcelona: N. Ramírez, 1855-1859, 4 vols. 
Sotelo Álvarez, Avelino. 'Diarios' de Francesco Zazzera (1616-1620) sobre el megalómano, arbitrario, populista y voyeur virrey de Nápoles, duque de Osuna. Traducción y prólogos de José María García Sobrado. Torrevieja (Alicante): PhD Áristos, 2003.

Soubeyroux, Jacques. "El Real Seminario de Nobles de Madrid y la formación de las élites en el siglo XVIII”. Bulletin Hispanique 97/1 (1995), pp. 201-212.

Stein, Louise K. "De la Contera del mundo: Las navegaciones de la ópera entre los dos mundos y varias culturas”. En: Emilio Casares Rodicio y Álvaro Torrente, eds. La ópera en España e Hispanoamérica. Madrid: ICCMU, 2001, vol 1, pp. 79-94.

Stevenson, Robert. "Los Contactos de Haydn con el Mundo Ibérico". Revista Musical Chilena, 157 (Enero-Junio 1982), pp. 3-39.

. La música en las catedrales españolas en el Siglo de Oro. Madrid: Alianza, 1992.

Stowell, Robin. "Good execution and other necessary skills. The role of the concermaster in the late 18th century". Early Music XVI (1988), pp.21-33.

Subirá, José. La Música en la Casa de Alba: Estudios Históricos y Biográficos. Madrid: Tip. Sucesores de Rivadeneira, 1927.

.La tonadilla escénica. Madrid: Tipografía de la Revista de Archivos, Bibliotecas y Museos, 1928-1930. 3 vols.

.Tonadillas teatrales inéditas. Madrid: Tipografía de la Revista de Archivos, Bibliotecas y Museos, 1932.

."Jaime Facco y su obra musical en Madrid”, AnM, II, 1948, pp. 109-132.

.El poeta-compositor Iriarte y el cultivo español del melólogo (melodrama).

Barcelona: Instituto Español de Musicología, 1949-1950, 2 vols.

.El Teatro del Real Palacio (1849-1851). Madrid: CSIC-Instituto de Musicología, 1950.

. "Necrologías musicales madrileñas (1611-1808)". AnM, XIII (1958), pp. 201-223.

The New Grove Dictionary of Music and Musicians. Stanley Sadie y John Tyrrell, eds. New York: Grove's. Dictionaries Inc.; London: Macmillan, 2001, 29 vols.

Tiby, Ottavio. "La música nella Real Capella Palatina di Palermo". AnM, VII (1952), pp.176-192. 
Torrione, Margarita (ed.). Crónica festiva de dos reinados en la Gaceta de Madrid (1700-1759). [Toulouse]: CRIC \& Ophrys, 1998.

Tortella, Jaime. Boccherini, un músico italiano en la España Ilustrada. Madrid: Sociedad Española de Musicología, 2002. . Musics Catalans a la "Villa y Corte" (segle XVIII), Barcelona: Els llibres de la Frontera, 2005.

Truett Hollis, George. "Musical patronage in eighteenth century Spain: the music library and music instrument collection of the XII duke of Alba (d.1776). RMS, XVI/6 (1993), pp.3476-3485.

. "Inventario y Tasación de los Instrumentos y Papeles de Música, de la Testamentaria del Exmo. Sr. Don Fernando de Silba Albarez de Toledo, Duque que fue de Alba (1777)" AnM, 59 (2004), pp. 151-172.

Valverde Madrid, José. "La Marquesa de Santa Cruz por Goya". Boletín del Museo e Instituto Camón Aznar 31-32 (1988), pp. 53-63.

Varela, Javier. La muerte del rey. El ceremonial funerario de la monarquía española (1500-1885). Madrid: Turner, 1990.

Vigo Trasancos, Alfredo (ed.). Cultura, poder y mecenazgo. Santiago de Compostela: Universidad de Santiago de Compostela, 1998.

Vilar, Jose María. "Sobre la difusió de les obres de Pleyel a Catalunya". AnM, 50 (1995), pp. 185-199.

Viña Brito, Ana. Don Pedro Girón Maestre de Calatrava y los orígens de la Casa de Osuna. Tesis Doctoral inédita. Universidad de Sevilla: Departamento de Historia Medieval, 1986.

Virtuose: Viaggi e Stagioni Nell'Ultimo Decennio del Settecento. Madrid: Istituto Italiano di Cultura, 1979.

Vives Ramiro, José María. "La Pervivencia de la Visitatio Sepulchri de Gandía (Valencia) (1550-2004)". AnM, 59 (2004), pp. 23-84.

Yebes, Condesa de. La Condesa-Duquesa de Benavente. Una vida en unas cartas. Madrid: Espasa Calpe, 1958.

Zumalacárregui, Leopoldo. "El proyecto del Duque de Osuna para la reconstrucción económica de España en el siglo XVIII". Anales de Economía, 28 (Octubre-Diciembre 1947), pp. 476-494. 


\section{Índices}





\section{ÍNDICE DE TABLAS}

No. 1. Titulares de la Casa de Osuna hasta su unión con la Casa de Benavente en 1787.

No. 2. Principales títulos nobiliarios de la Casa de Benavente hasta

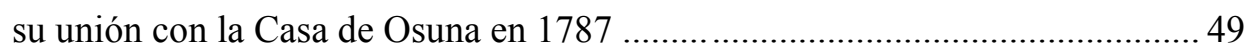

$\mathrm{N}^{\mathrm{o}}$. 3. Titulares de las Casas de Osuna y Benavente (1720-1900)...............................65

$\mathrm{N}^{\mathrm{o}}$. 4. Personal al servicio de los IX Duques de Osuna en 1794................................. 78

$\mathrm{N}^{\mathrm{o}}$. 5. Composición de la capilla musical de José Téllez Girón,

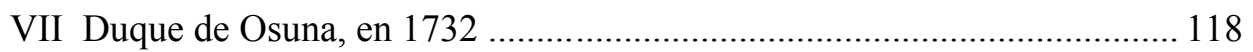

$\mathrm{N}^{\circ}$. 6. Músicos esclavos adquiridos por el VI Conde de Benavente en 1554 ........... 135

$\mathrm{N}^{\circ}$. 7. Maestros y profesores de música al servicio de la Casa de Osuna (1818-1844)

No. 8. Músicos al servicio de Pedro Zoilo Téllez Girón, VIII Duque de Osuna (1733-1787).

$\mathrm{N}^{\text {o. }}$ 9. Plantilla de la orquesta de la XV Condesa-Duquesa de Benavente (1781-1792).

$\mathrm{N}^{\mathrm{o}}$. 10. Salario mensual y ocupación principal de los músicos de la orquesta de la XV Condesa-Duquesa de Benavente (1781-1792).

$\mathrm{N}^{\mathrm{o}}$. 11. Músicos que asistieron a las academias y bailes organizados por la Condesa-Duquesa de Benavente entre el 28 de junio de 1796 y el 4 de enero de 1797.

$\mathrm{N}^{\circ}$. 12. Principales proveedores de música españoles y europeos de las Casas de Osuna y Benavente (1790-1840)...

$\mathrm{N}^{\circ}$. 13. Operas francesas e italianas encargadas por la Condesa-Duquesa de Benavente al editor y almacenista de música Jean Jerome Imbault (1801-1806)

No. 14. Música copiada por Salvador Feixas para la Casa de Benavente en 1786....... 276

$\mathrm{N}^{\circ}$. 15. Organistas de la Colegiata de Santa María de Osuna durante el siglo XVIII .

№ 16. Composición y salarios anuales de la capilla musical de la Colegiata de Santa María de Osuna cuando pasó al servicio de la Capilla del Santo Sepulcro en julio de 1813 
$\mathrm{N}^{0}$. 17. Miembros del coro $\mathrm{y}$ orquesta que solemnizaron los funerales del VIII Duque de Osuna celebrados el 5 de Julio de 1787 en la Iglesia del Convento de San Hermenegildo de Madrid

$\mathrm{N}^{o}$. 18. Plantilla de la orquesta y repertorio interpretado en las fiestas de San Francisco de Borja y Nuestra Señora del Pilar patrocinadas por la Casa de Benavente en 1798 .

$\mathrm{N}^{\text {o. }}$ 19. Plantilla de la orquesta y repertorio interpretado en las fiestas de San Francisco de Borja y Nuestra Señora del Pilar patrocinadas por la Casa de Benavente en 1800 .

$\mathrm{N}^{\text {o. 20. }}$ Música sacra de autores italianos adquirida en Italia o copiada para la XV Condesa-Duquesa de Benavente entre agosto y octubre de 1807

$\mathrm{N}^{\circ}$. 21. Estructura del Beatus vir a 4 voci concertato con tutti li strumenti de Giuseppe Gazzaniga .

№. 22. Accionistas de la Asociación de Óperas Italianas del Teatro de los Caños del Peral de Madrid (1791-1793).

No. 23. Departamentos administrativos de la empresa de ópera del Teatro de los Caños del Peral de Madrid creados en diciembre de 1793.

$\mathrm{N}^{\circ}$. 24. Distribución de las piezas musicales compuestas por Pablo Esteve para la comedia No hay en amor fineza más constante (1766)

$\mathrm{N}^{\circ}$. 25. Intérpretes que participaron en el estreno de Los jardineros de Aranjuez y en la reposición que se realizó entre 1773 y 1782

$\mathrm{N}^{\circ}$. 26. Intérpretes de la zarzuela El extranjero en las funciones celebradas en el palacio de celebradas en el palacio de la Condesa-Duquesa viuda de Benavente (1786)

No. 27. Números de óperas de Gioacchino Rossini copiados para la Condesa-Duquesa de Benavente entre 1823 y ca. 1826 


\section{ÍNDICE DE LÁMINAS}

$\mathrm{N}^{\circ}$. 1. Orígenes del Maestrazgo de Calatrava y primeros Condes de Ureña.

Gerónimo Gudiel: Compendio de algunas historias de España, s.f. .

$\mathrm{N}^{\circ}$. 2. Árbol genealógico de la Casa de Osuna desde el V al VIII Duque

$\mathrm{N}^{\circ}$. 3. Francisco de Goya y Lucientes: La Condesa-Duquesa de Benavente (1785)

№. 4. Francisco de Goya y Lucientes: El IX Duque de Osuna (ca. 1798) .................. 56

№. 5. Francisco de Goya y Lucientes: La Marquesa de Santa Cruz (ca. 1805)........... 62

№. 6. Francisco de Goya y Lucientes: La Duquesa de Abrantes (1816) ...................... 63

$\mathrm{N}^{\mathrm{o}}$. 7. Valentín Carderera: Pedro de Alcántara Téllez Girón........................................66 66

No. 8. Recibo del abono de la XV Condesa-Duquesa de Benavente para la temporada de 1833 en el Teatro del Príncipe de Madrid

No. 9. Francisco de Goya y Lucientes: La Familia de los Duques de Osuna (1788)

No. 10. Orden de pago a Francisco Fernández, maestro de arpa, por las clases impartidas a María Gómez criada de Ana Antonia de Benavides, V Duquesa de Osuna (1682). 106

$\mathrm{N}^{\mathrm{o}}$. 11. Dedicatoria al III Duque de Osuna de la edición de Il primo libro delle villanelle a tre voci, de Antonio il Verso (Venecia: G. Vicente, 1612).....

$\mathrm{N}^{\mathrm{o}}$. 12. Portada de Madrigali a Cinque: Libro primo de Giuseppe Palazzotto e Tagliavia (Nápoles: Costantino Vitale, 1617)

$\mathrm{N}^{\text {o. }}$ 13. Dedicatoria al III Duque de Osuna de la edición de Madrigali a cinque voci: Libro primo de Giuseppe Palazzotto e Tagliavia (Nápoles: Costantino Vitale, 1617)

$\mathrm{N}^{\circ}$. 14. Maestro de Ante-altares: Grupo de músicos de color con chirimías, bombarda y sacabuche. Detalle de una pintura española sobre tabla. (ca.1520).

Nº 15. Jacques-Jean Baptiste Augustin: Josefa Manuela Téllez Girón (1799) 
$\mathrm{N}^{\mathrm{o}}$. 16. Memoria de gastos por la contratación de instrumentistas para reforzar la capilla musical de la Casa de Osuna en las fiestas de la onomástica

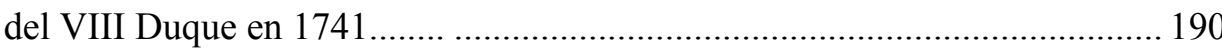

№ . 17. Portada de Arte y Escuela de violonchelo de Pablo Vidal ............................. 205

No. 18. Firma de María Faustina Téllez Girón, Condesa-Duquesa viuda de Benavente en un documento de 1764

$\mathrm{N}^{\circ}$. 19. Orden de pago de los salarios adeudados a los músicos de la orquesta de la Condesa-Duquesa de Benavente (1794).

$\mathrm{N}^{\circ}$. 20. Primera página de la relación de arias copiadas por José Alagueró para María Faustina Téllez Girón (1763).

No. 21. Portada del Inventario del archivo de música de la XV Condesa-Duquesa de Benavente (1824).

$\mathrm{N}^{\circ}$. 22. Primera página del Inventario del archivo de música de la XV Condesa-Duquesa de Benavente (1824)

$\mathrm{N}^{\circ}$. 23. Portada del Catálogo de libros subastados en Madrid en 1897 procedentes de los palacios de los Duques de Osuna

$N^{\circ}$. 24. Cartel de las fiestas en honor de San Francisco de Borja que se celebraron en el oratorio de San Felipe Neri de Madrid en 1818.

$\mathrm{N}^{\circ}$. 25. Juan de Villanueva (dibujo) y José Jimeno (grabado):

Monumento sepulcral del VIII Duque de Osuna. 348

No. 26. Portada de la edición de Salmodia orgánica de Pedro Carrera

y Lanchares (Madrid: 1792).

No. 27. Recibo del abono de la VIII Duquesa de Osuna a la temporada de ópera de 1787 del Teatro de los Caños del Peral de Madrid

No. 28. Anónimo: [Retrato y Soneto de Luisa Todi] (después de 1777).

No. 29. Recibo del abono de la XV Condesa-Duquesa de Benavente a la temporada de ópera de 1787 del Teatro de los Caños del Peral de Madrid.

No. 30. Pablo Esteve y Grimau: Los jardineros de Aranjuez. Portada del libreto publicado con motivo del estreno de la obra (1768)

$\mathrm{N}^{\circ}$. 31. Situación del Palacio de los Condes-Duques de Benavente en la calle Segovia de Madrid (siglo XVIII)

No. 32. Francisco Manalt, Obra armónica en Seis Sonatas de Cámara. Portada. 


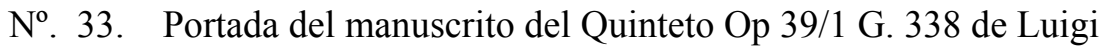

Boccherini

$\mathrm{N}^{\circ}$. 34. Alessandro Scarlatti E penar deggio ancora. Cantata para voz. y bajo continuo.

No. 35. [G. F. Händel] Lilla vedi quel colle. Cantata para voz.

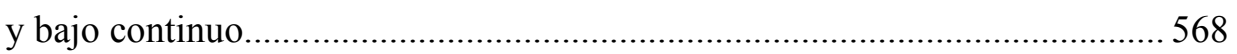

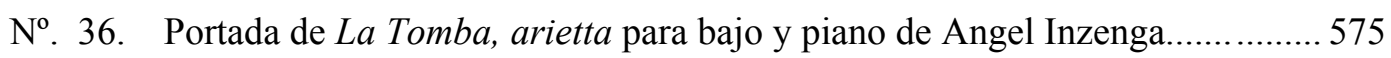




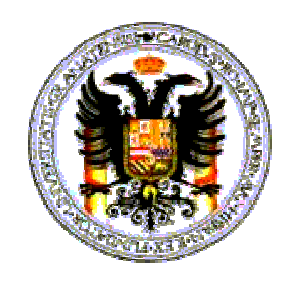

\title{
El mecenazgo musical de las Casas de Osuna y Benavente (1733-1844). Un estudio sobre el papel de la música en la alta nobleza española
}

\author{
Tesis Doctoral \\ presentada por \\ Juan Pablo Fernández González \\ Directora: Dra. María Gembero Ustárroz
}

\section{VOLUMEN 2}

Universidad de Granada

Facultad de Filosofía y Letras

Departamento de Historia del Arte

Programa de Doctorado en Historia y Ciencias de la Música

Granada, diciembre de 2005 



\section{ÍNDICE DEL VOLUMEN 2}

\section{APÉNDICES}

1. Cuadros genealógicos de las Casas de Osuna y Benavente 1

2. Edición de obras musicales seleccionadas............................................................. 7

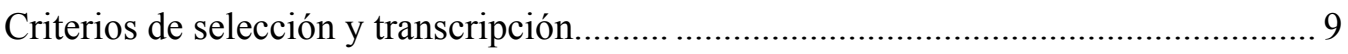

2.1. Libro de cantatas y arias italianas de la Duquesa de Osuna .................................... 11

[Giovanni] Bononcini $(* 1670-\uparrow 1747)$ Pastorella che tra le selve. Aria ......................... 13

Alessandro Scarlatti (*1660-†1725): E penar deggio ancora, cantata para voz

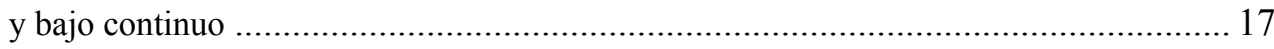

[Georg Friedrich Händel $(* 1685-\dagger 1759)$ ]: Lilla vedi quel colle, cantata para voz

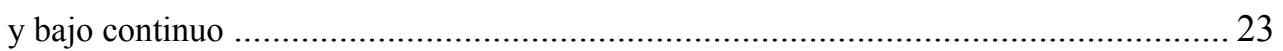

2.2. Luigi Boccherini (*1743-†1805): Quinteto, Op. 39/2 (G. 338) ........................... 31

2.3. José Palomino (1755-1810): Todos dizem. Modinha (ca. 1801) ............................ 61

2.4. Ángelo Inzenga: La tomba. Arietta per voce di basso .......................................... 71

3. Inventarios de libros de música y partituras de las Casas de Osuna

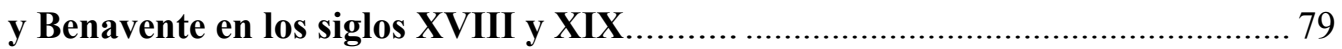

4. Catálogos de música de las Casas de Osuna y Benavente

(ca. 1781- ca. 1898) 126

5. Información biográfica sobre los principales músicos y bailarines que estuvieron al servicio de las Casas de Osuna y Benavente

(ca. 1720-1844), por orden alfabético de apellidos.

6. Apéndice documental.

A) Documentos sobre funciones y actos religiosos patrocinados por las Casas de Osuna y Benavente (1755-1830)

$\mathrm{N}^{\circ} 1$. Lista de músicos que asistieron a las funciones religiosas celebradas por el XIV Conde-Duque de Benavente en acción de gracias a San Francisco de Borja el 9 y 10 de agosto de 1755

$\mathrm{N}^{\circ}$ 2. Orden de pago a los músicos que intervinieron en los intermedios y función en honor a Santo Toribio de Mogrovejo realizada por el XIV Conde-Duque de Benavente en el Convento de Portaceli de Madrid el 27 de abril de 1757.

$\mathrm{N}^{\circ}$ 3. Orden de pago a Francisco Basset por los músicos de refuerzo que asistieron a las funciones religiosas de San Francisco de Borja celebradas en 1781 
$N^{o}$ 4. Orden de pago a Francisco Basset por los músicos de refuerzo que asistieron a las funciones religiosas de San Francisco de Borja celebradas en 1781.

$\mathrm{N}^{0}$ 5. Orden de pago a Pedro Ochoa, festero de la Capilla de Música del Real Convento de la Encarnación de Madrid por la asistencia de dicha capilla a las funciones religiosas de San Francisco de Borja celebradas en 1783

$\mathrm{N}^{\mathrm{o}}$ 6. Orden de pago a Francisco Basset por la copia de una misa de [Joseph] Haydn y la asistencia de nueve músicos para completar la orquesta de las funciones religiosas de San Francisco de Borja celebradas en 1785.

$\mathrm{N}^{\mathrm{o}}$ 7. Orden de pago a Joaquín Agramuntell, festero de la Capilla de Música del Convento de las Descalzas Reales de Madrid por la asistencia de dicha capilla a las funciones religiosas de San Francisco de Borja celebradas en 1788.

$\mathrm{N}^{\circ}$ 8. Orden de pago a la Capilla de Música de San Cayetano de Madrid y a otros músicos por los servicios prestados en las funciones religiosas de San Francisco de Borja celebradas en 1800

$\mathrm{N}^{0}$ 9. Orden de pago a la Capilla de Música de San Cayetano de Madrid y a otros músicos por los servicios prestados en las funciones religiosas de San Francisco de Borja celebradas en 1802

$\mathrm{N}^{\mathrm{o}}$ 10. Lista de músicos que asistieron a las funciones religiosas de San Francisco de Borja celebradas en 1808 y obras que se interpretaron en dichas funciones.

$\mathrm{N}^{\mathrm{o}}$ 11. Lista de los músicos que asistieron al funeral de Josefa Manuela Téllez-Girón, marquesa de Camarasa e hija de los IX Duques de Osuna, que se celebró el día 11 de diciembre de 1817 en la iglesia de San Felipe Neri de Madrid

$\mathrm{N}^{\mathrm{o}}$ 12. Lista de músicos que asistieron a las funciones religiosas de San Francisco de Borja y Nuestra Señora del Pilar patrocinadas por la XV Condesa-Duquesa de Benavente en 1825

$\mathrm{N}^{\mathrm{o}}$ 13. Lista de músicos que asistieron a las funciones religiosas de San Francisco de Borja y Nuestra Señora del Pilar patrocinadas por la XV Condesa-Duquesa de Benavente en 1829.

$\mathrm{N}^{\mathrm{o}}$ 14. Lista de músicos que asistieron a las funciones religiosas de San Francisco de Borja y Nuestra Señora del Pilar patrocinadas por la XV Condesa-Duquesa de Benavente en 1830

B) Documentos sobre teatro musical patrocinado por las Casas de Osuna y Benavente: funciones privadas y financiación de los teatros públicos de ópera de Madrid (1755-1794)

$\mathrm{N}^{\mathrm{o}}$ 15. Cuenta de gastos por la copia de música y letra de la función teatral titulada Endimión y Diana encargada en 1755 por María Faustina Téllez-Girón, Condesa-Duquesa de Benavente 
$\mathrm{N}^{\circ} 16$. Actas y anexos de las Juntas de Accionistas de la Asociación de Óperas Italianas del Teatro de los Caños del Peral de Madrid de los días 3 y 13 de septiembre de 1790 .

$\mathrm{N}^{\circ}$ 17. Informe sobre los gastos de la temporada de 1791-1792 del Teatro de los Caños del Peral de Madrid, y solicitud a la XV Condesa-Duquesa del importe de la segunda acción del año de 1792 .

NN$^{\circ}$ 18. Carta de los Comisionados de la Asociación de Óperas Italianas a María Josefa Alfonso Pimentel, XV Condesa-Duquesa de Benavente, comunicándole la decisión de contratar a la cantante Luisa Todi para la temporada de 1794

C) Documentación sobre los grupos instrumentales y orquestas que intervinieron en las fiestas, bailes y academias organizados por la XV Condesa-Duquesa de Benavente y el IX Duque de Osuna (1789-1819)

$\mathrm{N}^{\circ} 19$. Lista de músicos de refuerzo que asistieron a la fiesta realizada el 26 de de septiembre de 1789 con motivo de la Coronación de Carlos IV, y la Jura del Príncipe de Asturias por el IX Duque de Osuna en su palacio de Madrid

$\mathrm{N}^{\circ} 20$. Lista de músicos que asistieron a la academia de música celebrada por la Condesa-Duquesa de Benavente el 31 de octubre de [1819?]......

$\mathrm{N}^{\circ}$ 21. Lista de músicos que asistieron a la academia de música celebrada el 5 de diciembre de 1819 en casa de la Condesa-Duquesa de Benavente.

D) Correspondencia con músicos, cantantes, bailarines y otros personajes: peticiones de protección y recomendaciones solicitadas a los miembros de las Casas de Osuna y Benavente (1784-1807)

№ 22. Carta de la cantante Rosa Agostini a Pedro de Alcántara Téllez-Girón, Marqués de Peñafiel, solicitando su protección para volver a actuar en las academias de música que se celebraban en los Reales Sitios

$\mathrm{N}^{\circ}$ 23. Carta del cantante Giacomo Panati a María Josefa Alfonso Pimentel, XV Condesa-Duquesa de Benavente, solicitando su intercesión para actuar en las Óperas que se representaban en los Reales Sitios.

$\mathrm{N}^{\circ}$ 24. Carta de la bailarina María Medina a la XV Condesa-Duquesa de Benavente solicitando su intercesión para actuar en la compañía de baile de los teatros públicos de Madrid y borrador de la respuesta

$\mathrm{N}^{\circ}$ 25. Carta de la XV Condesa-Duquesa de Benavente a la bailarina María Medina Viganò

$\mathrm{N}^{\mathrm{o}}$ 26. Carta del bailarín Salvatore Viganò a la XV Condesa-Duquesa de Benavente..... 253 
$\mathrm{N}^{\mathrm{o}}$ 27. Carta del empresario de ópera Domenico Botti a la XV Condesa-Duquesa de Benavente, recomendando a la cantante Catalina Lusini y borrador de la respuesta

$\mathrm{N}^{\mathrm{o}}$ 28. Carta de la cantante Luigia Todi a la XV Condesa-Duquesa de Benavente comentándole los conciertos que dio en Italia y borrador de la respuesta.

$\mathrm{N}^{\text {o } 29 . ~ C a r t a ~ d e ~ l a ~ c a n t a n t e ~ L u i g i a ~ T o d i ~ a ~ l a ~ X V ~ C o n d e s a-D u q u e s a ~ d e ~ B e n a v e n t e ~}$ comunicándole su llegada a Nápoles y borrador de la respuesta

$\mathrm{N}^{\mathrm{o}}$ 30. Carta de la cantante Luigia Todi a la XV Condesa-Duquesa de Benavente comentándole sus actuaciones operísticas en Nápoles y borrador de la respuesta.

$\mathrm{N}^{\mathrm{o}}$ 31. Carta de la cantante Luigia Todi a la XV Condesa-Duquesa de Benavente comentándole sus proyectos operísticos.

$\mathrm{N}^{\mathrm{o}}$ 32. Carta de la cantante Luigia Todi a la XV Condesa-Duquesa de Benavente relatando la llegada a Caserta de la Princesa de Nápoles en 1797 y borrador de la respuesta

No 33. Carta de la cantante Luigia Todi desde Nápoles a la XV Condesa-Duquesa de Benavente relatando sus actuaciones en el teatro San Carlo y borrador de la respuesta

$\mathrm{N}^{\mathrm{o}}$ 34. Carta de la cantante Brigida Banti desde Londres a la XV Condesa-Duquesa de Benavente y borrador de la respuesta

$\mathrm{N}^{\mathrm{o}}$ 35. Carta de la cantante Brigida Banti desde Londres a la XV Condesa-Duquesa de Benavente y borrador de la respuesta

$N^{0}$ 36. Carta de Francisco Solano Ortiz de Rozas a la XV Condesa-Duquesa de Benavente recomendando al violinista Alejandro Boucher y borrador de la respuesta.

$\mathrm{N}^{\circ}$ 37. Carta del Conde de Valdeparaiso a la XV Condesa-Duquesa de Benavente recomendando a la cantante y violinista Luisa Gerbini y borrador de la la respuesta

$N^{o} 38$. Borrador de la carta que la XV Condesa-Duquesa de Benavente dirigió a Agustín Lancaster, Teniente General y Comandante General Interino de Cataluña para recomendarle a la cantante Luigia Todi.

$\mathrm{N}^{\text {o } 39}$. Borrador de la carta que la XV Condesa-Duquesa de Benavente dirigió al Conde de Valparais y al coronel Joseph Capelleti, para recomendarles a la cantante Luigia Todi

$\mathrm{N}^{\mathrm{o}}$ 40. Carta de la bailarina Teresa Monticini a la XV Condesa-Duquesa de Benavente, solicitando su intercesión para resolver problemas profesionales con el bailarín Charles-Auguste Favier en sus actuaciones en Cádiz y borrador de la respuesta

$\mathrm{N}^{\mathrm{o}}$ 41. Carta de Manuel Arenas a la XV Condesa-Duquesa de Benavente, informando del éxito de la bailarina Teresa Monticini en una actuación en Cádiz 
$\mathrm{N}^{\mathrm{o}}$ 42. Carta del Barón Josef Capelleti a la XV Condesa-Duquesa de Benavente recomendando a la cantante Mariana Vinci que había sido contratada para la temporada de ópera del Teatro de los Caños del Peral de Madrid

$\mathrm{N}^{\mathrm{o}}$ 43. Carta de los bailarines Louis Moreau y Achille Monroy a Giacomo Panati empresario del Teatro de los Caños del Peral de Madrid, expresándole su intención de solicitar la intercesión de la XV Condesa-Duquesa de Benavente, si no le pagan las cantidades que se les adeudan

$\mathrm{N}^{\mathrm{o}}$ 44. Carta del político francés Charles Maurice de Tayllerand a la XV

Condesa-Duquesa de Benavente recomendándole al pianista João

Domingos Bomtempo

E) Documentos sobre músicos que trabajaron al servicio de las Casas de

Osuna y Benavente (1781-1824)

$\mathrm{N}^{\mathrm{o}}$ 45. Borrador de la carta que la XV Condesa-Duquesa de Benavente

dirigió al Cardenal Patriarca recomendando a Manuel Carriles

para una plaza de viola vacante en la Real Capilla

$\mathrm{N}^{\mathrm{o}}$ 46. Decreto de nombramiento de Lorenzo Geisel como músico de la

Casa de Osuna

$\mathrm{N}^{\mathrm{o}}$ 47. Copia de la partida de defunción de Carlo Marinelli

F) Música y festejos populares en los estados de la Casa de Benavente.

$\mathrm{N}^{\mathrm{o}}$ 48. Relato de los festejos celebrados en la villa de Benavente para celebrar

el nacimiento de Josefa Manuela Téllez-Girón el 17 de agosto de 1783 
Apéndice 1

Cuadros genealógicos

de las Casas de Osuna y Benavente 



\section{Genealogía de la Casa de Benavente en el siglo XVIII}

Fuente: AHN NOBLEZA, OSUNA, Genealogía. Mercedes Simal López, Los condes-duques de Benavente en el siglo XVII. Patronos y coleccionistas en su villa solariega (Benavente: Centro de Estudios Benaventanos Ledo del Pozo, 2002), pp. 286-291.

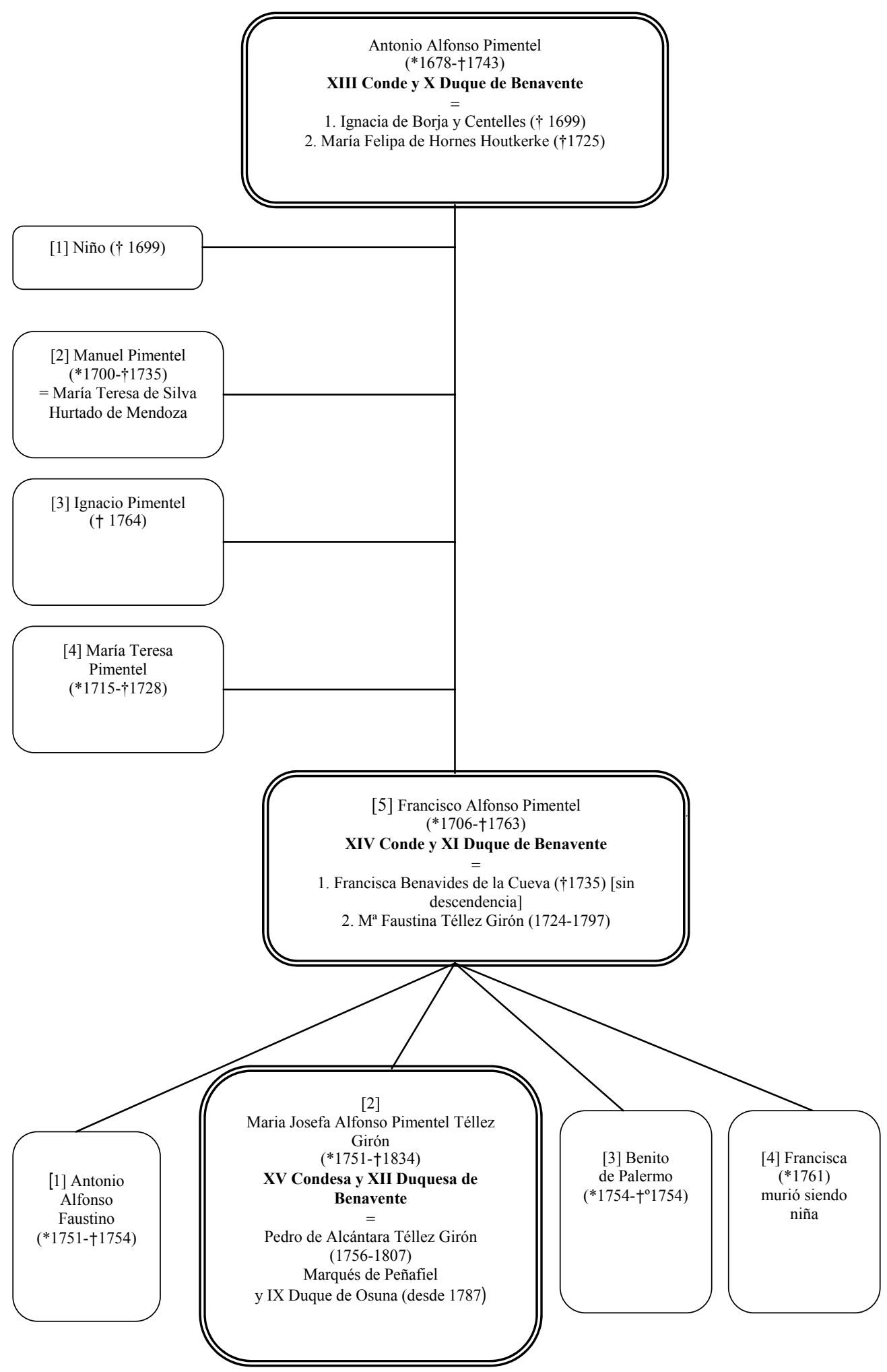




\section{Titulares de la Casa de Osuna desde el V hasta el X Duque (1656-1820)}

Fuente: AHN NOBLEZA, OSUNA, Genealogía. Pedro Mugaburu y la Encina, Oración fúnebre [...] a las honras de la Excelentísima Condesa Duquesa de Benavente. BNE, Ms. 11319/12. Tomás Fernández de Mendoza Tomás. Elogio fúnebre[...] del Excelentísimo Señor Don Pedro Zoilo Tellez Girón, 8º Duque de Osuna. BNE, Ms. 10494.

NOTA: María Josefa Alfonso Pimentel, XV Condesa-Duquesa de Benavente dio a luz al menos otros tres hijos que no superaron la niñez.

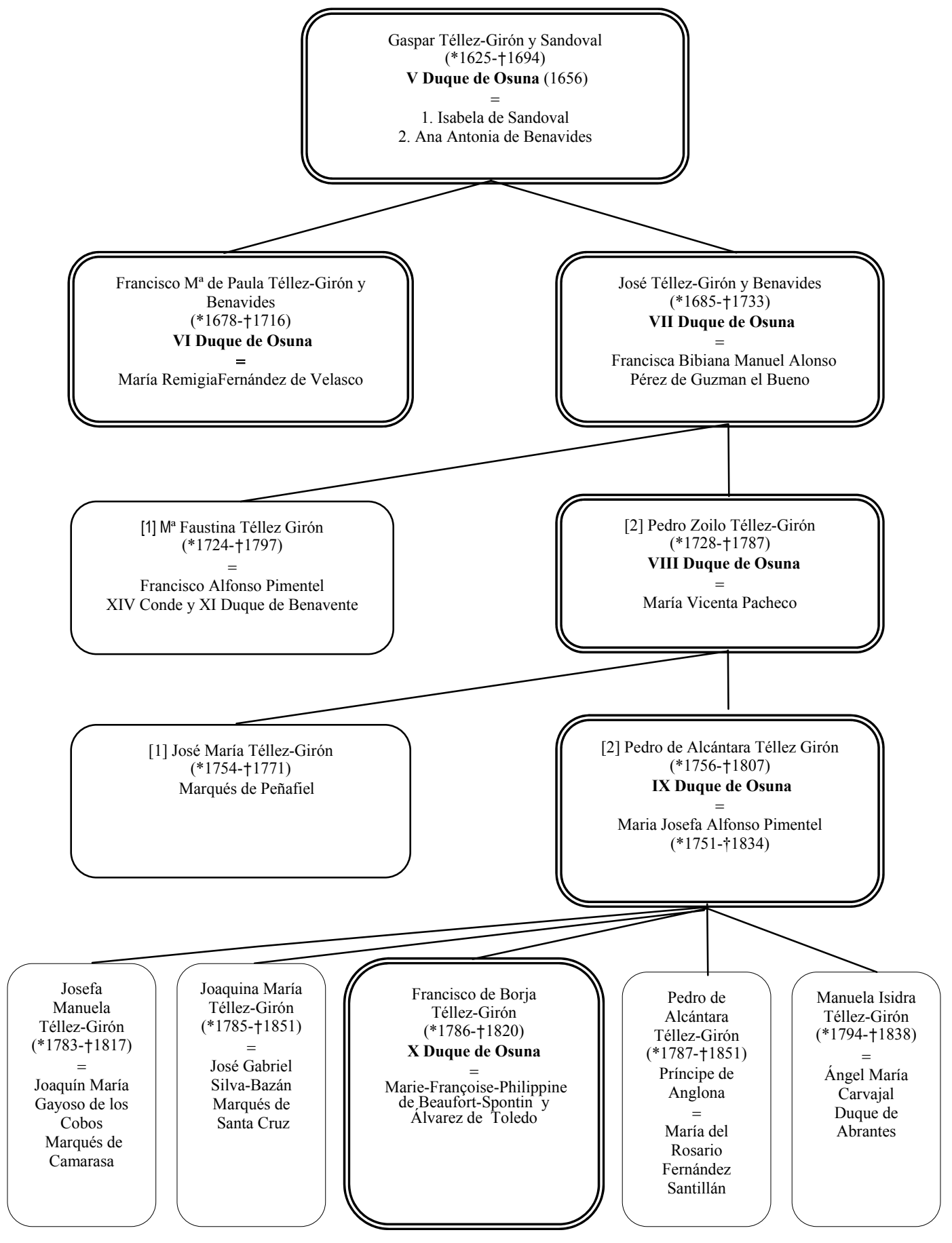




\section{Genealogía de las Casas de Osuna y Benavente en el siglo XIX}

Fuentes: AHN, NOBLEZA, Osuna, Genealogía; Fernando Regueras Grande. Pimentel, fragmentos de una iconografí. Benavente: Centro de Estudios Benaventanos Ledo del Pozo, 1998.

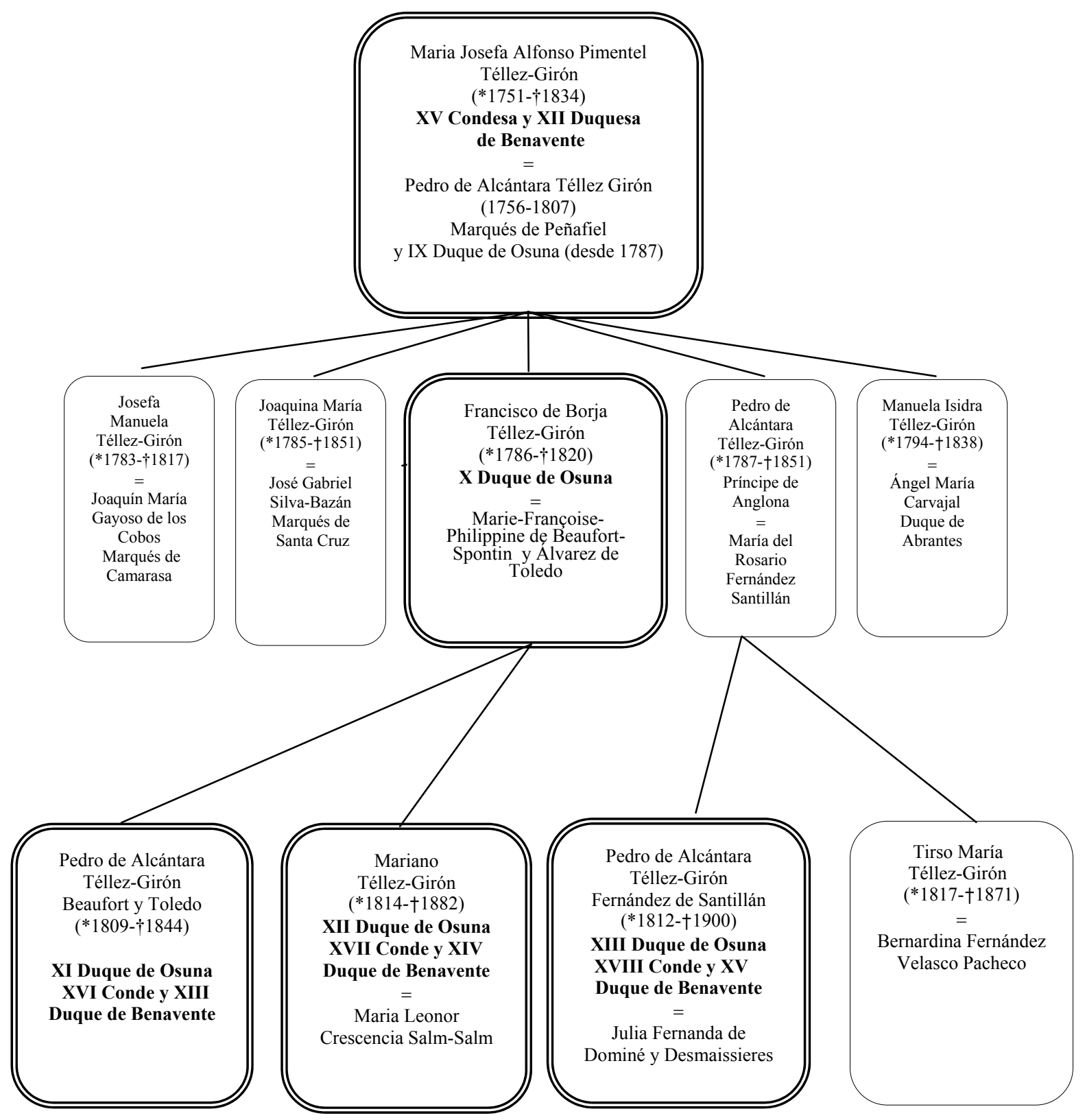



Apéndice 2

Edición de obras musicales seleccionadas 



\section{Criterios de selección y transcripción}

\section{Criterios de selección de obras}

La dispersión y probable pérdida de gran parte de los materiales que se conservaban en los archivos musicales que pertenecieron a las Casas de Osuna y Benavente durante los siglos XVIII y XIX dificultan la presentación de una selección de obras equilibrada en las que aparezcan representados todos los géneros musicales que fueron objeto del mecenazgo musical de ambas casas nobiliarias. En consecuencia, este apéndice no pretende proporcionar una visión panorámica y evolutiva de la importancia que tuvo la música para las familias Osuna y Benavente, sino ilustrar y complementar con algunos ejemplos significativos, aspectos concretos sobre la música vocal de cámara, la música instrumental y la música teatral que perteneció al repertorio doméstico de estas familias y que han sido objeto de estudio en el presente trabajo.

Cuatro de las obras que figuran en este apéndice se transcriben por primera vez a partir de materiales manuscritos. De las dos restantes, una de ellas ( $L a$ Tomba de Angelo Inzenga) se presenta en edición facsímil dado el interés artístico e histórico de la propia edición musical. La partitura del Quinteto G. 338 de Boccherini se ha realizado a partir de las partes instrumentales editadas en París por Pleyel con el objeto de poder contar con un material de estudio adecuado para poder analizar las principales características de esta obra. 


\section{Criterios de transcripción musical}

- Armadura y Tonalidad. Se mantiene la armadura del original incluso en aquellos casos en los que no se corresponde con la tonalidad real en que se desarrolla la obra.

- Bajo cifrado. Sólo se incluye en aquellos casos en los que aparece en el original.

- Claves. Se emplean las de uso común en la actualidad. En la transcripción de las trompas se utiliza la clave de sol en lugar de la de fa en $4^{a}$ que figura en el original y que ha caído en desuso.

- Signos de dinámica, expresión, agógica y ornamentación. Se reflejan aquellos que aparecen en el original, y sólo se completan en las situaciones en las que se da un paralelismo con otros pasajes.

- Textos. La ortografía de los textos cantados se regulariza y normaliza.

- Notas críticas. En aquellos casos en los que se ha sustituido alguna nota o signo musical relevante o que existe una omisión en el original se indican con una nota al final de cada página. 
2.1. Libro de cantatas y arias italianas de la Duquesa de Osuna 



\title{
[Giovanni María] Bononcini
}

\author{
Aria a solo con violines
}

Pastorella che tra le selve

BNE M 2245

ff. $67-70$

Edición de Juan Pablo Fernández
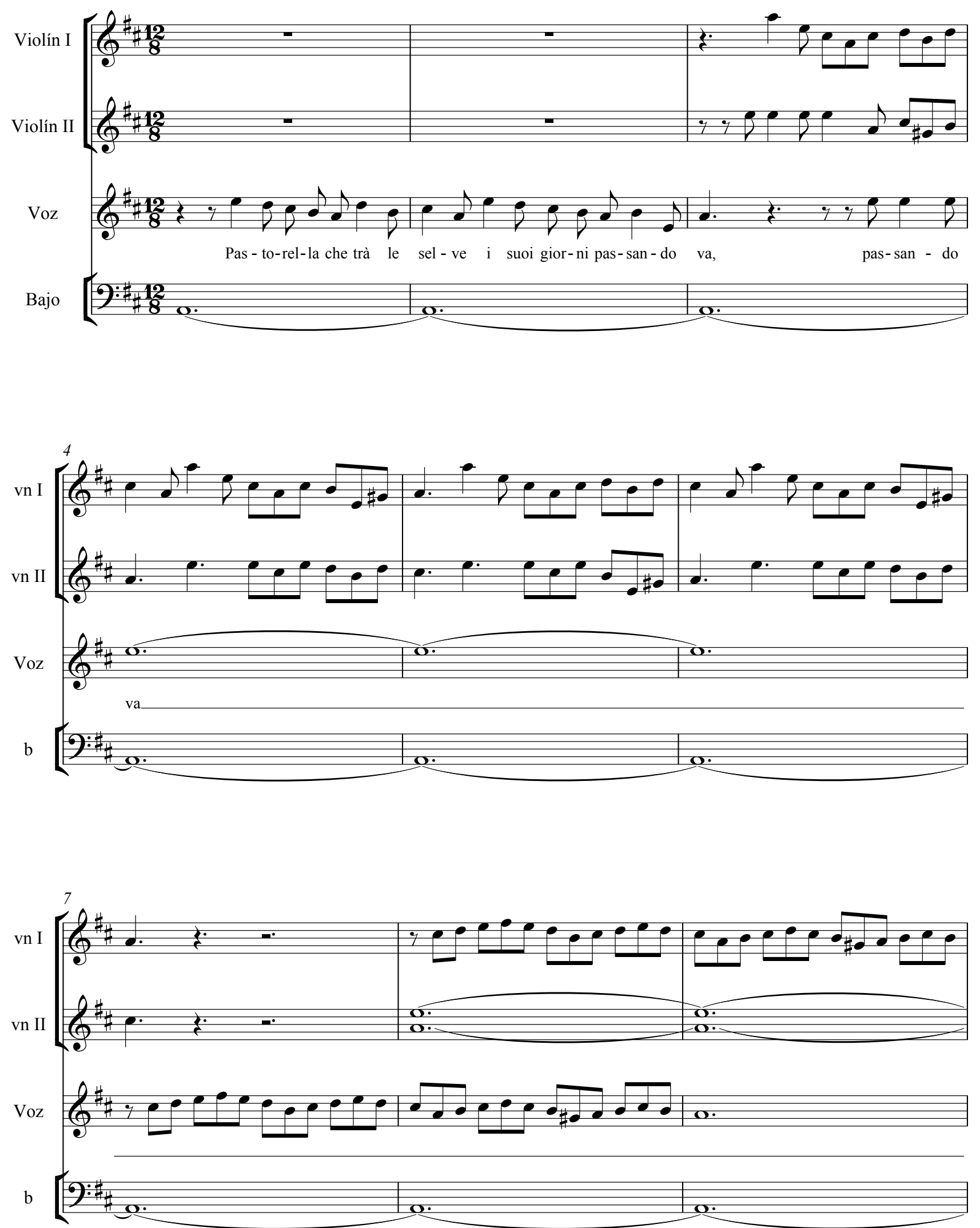

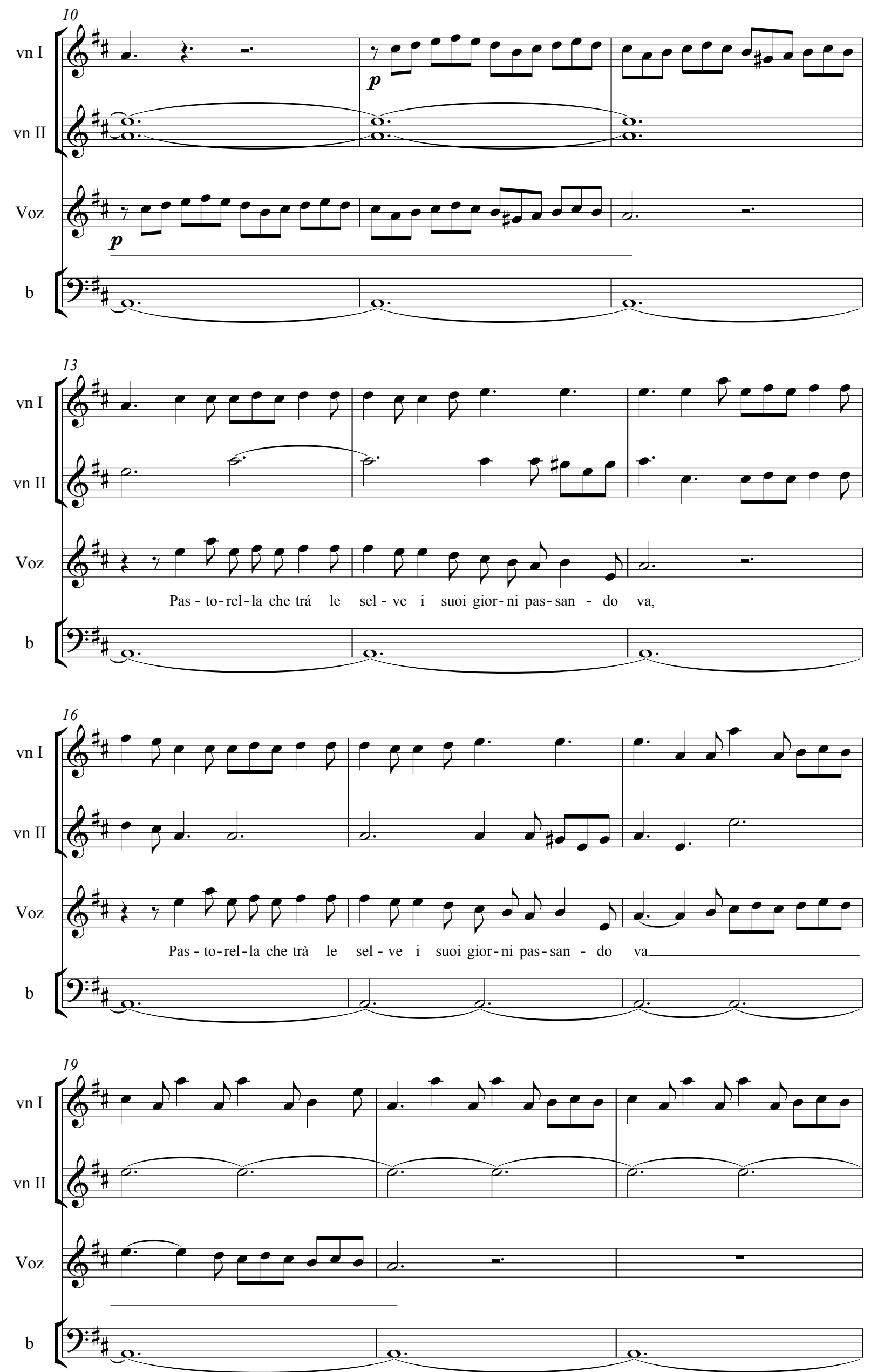

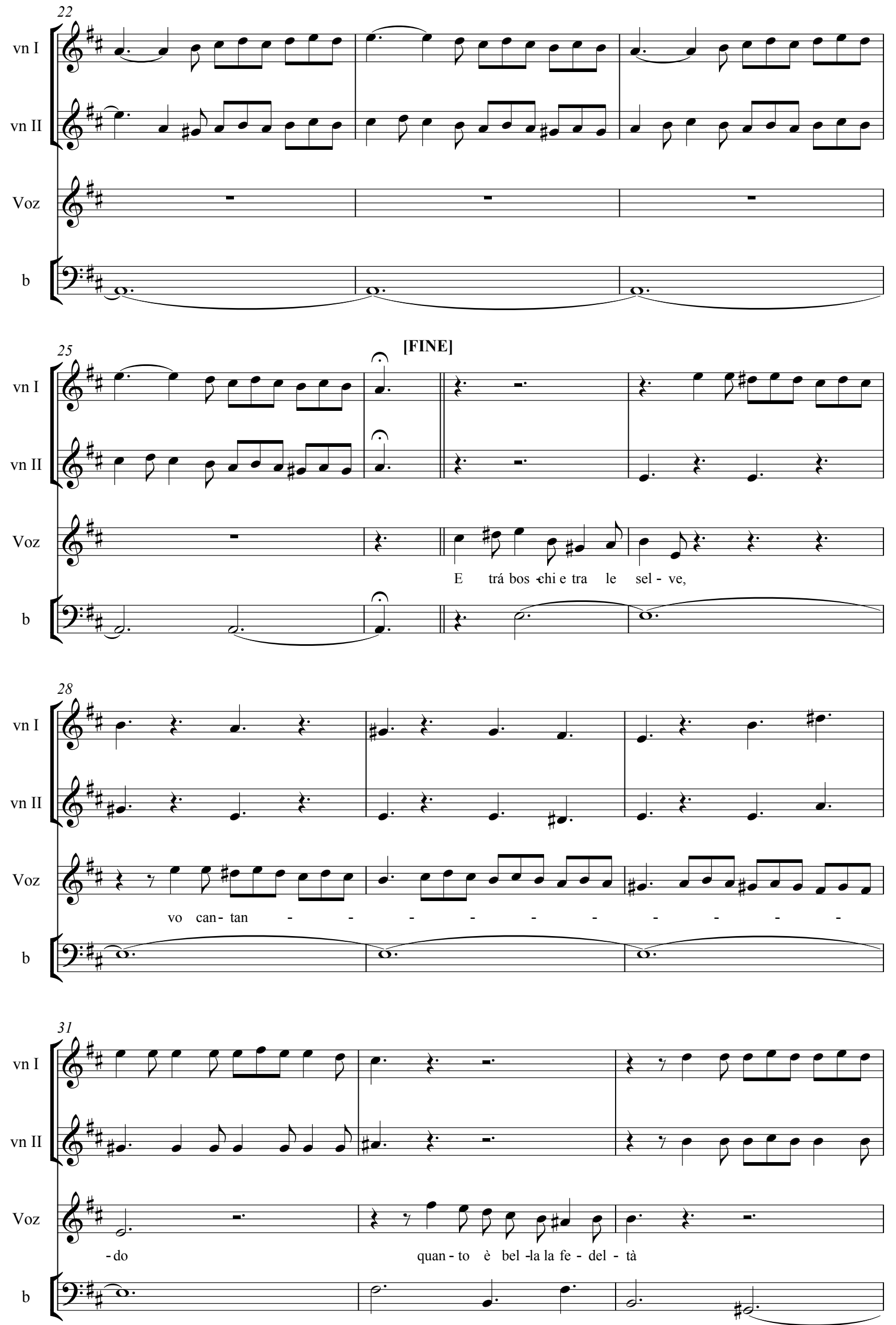

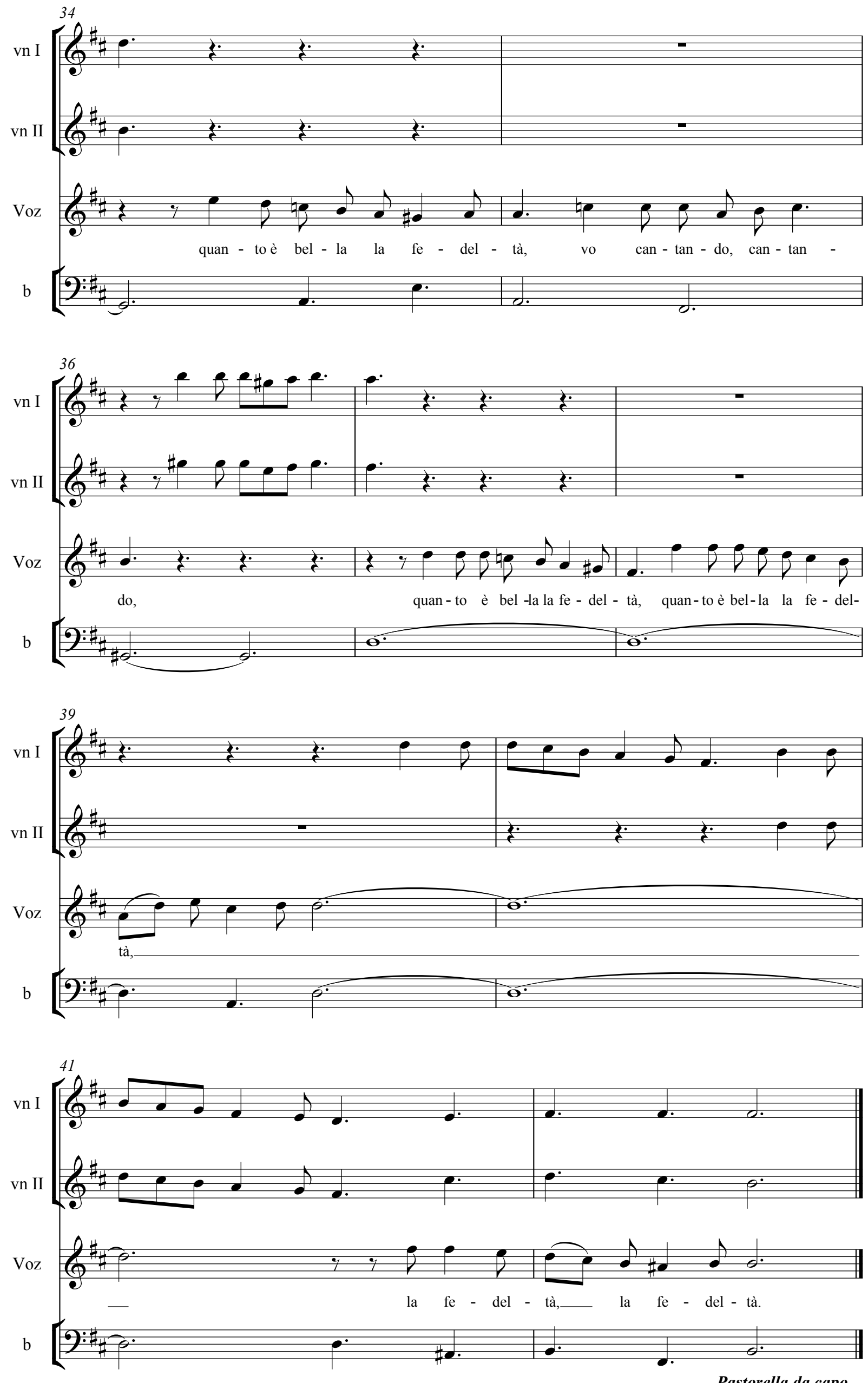


\section{Alessandro Scarlatti \\ Cantata a solo para voz y bajo contínuo \\ E penar deggio ancora}

BNE M 2245

ff. 13-14

\section{[Recitativo]}
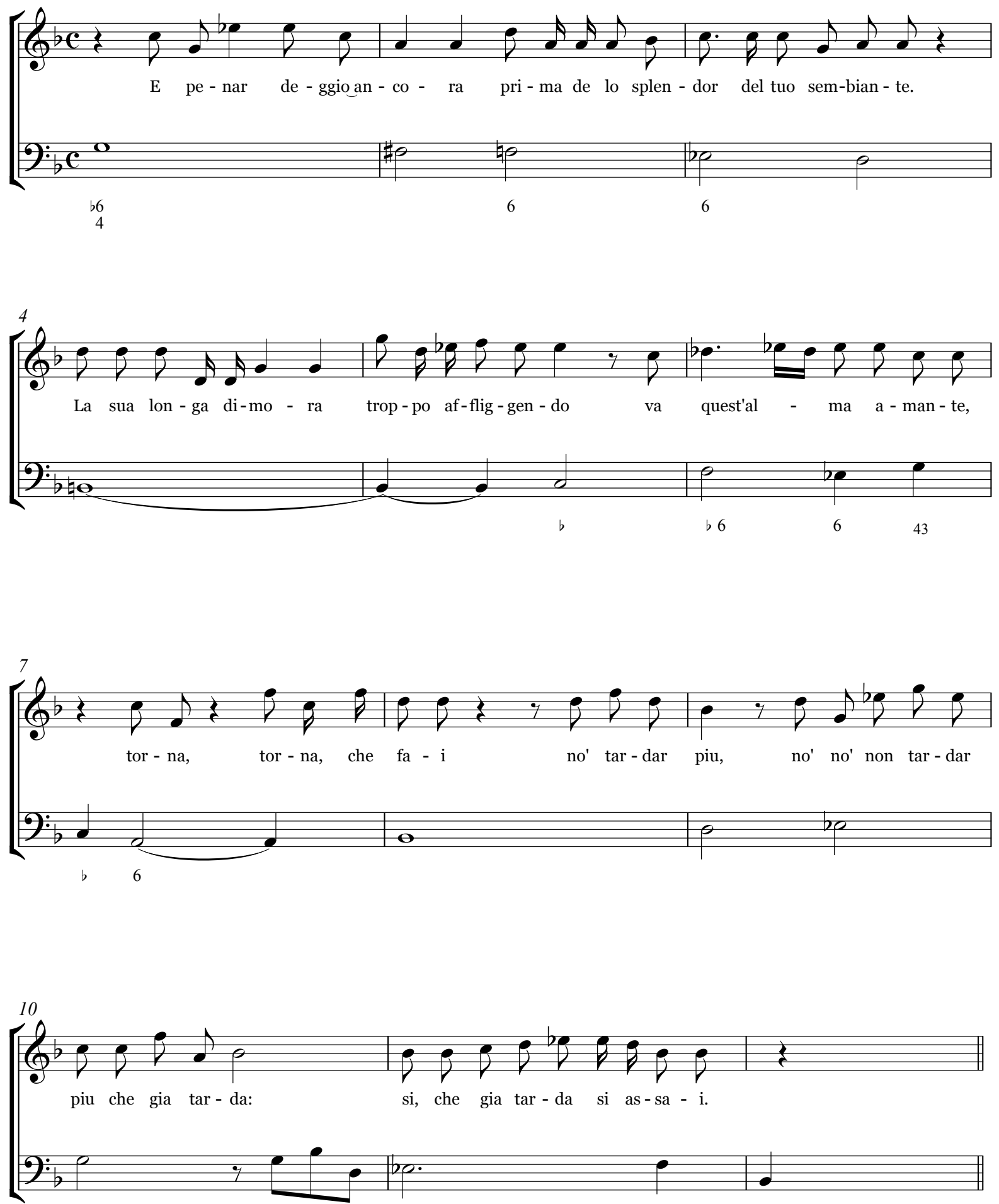

c.1.2. voz: re.

c.12. No se completan el resto de las partes. 


\section{Aria}
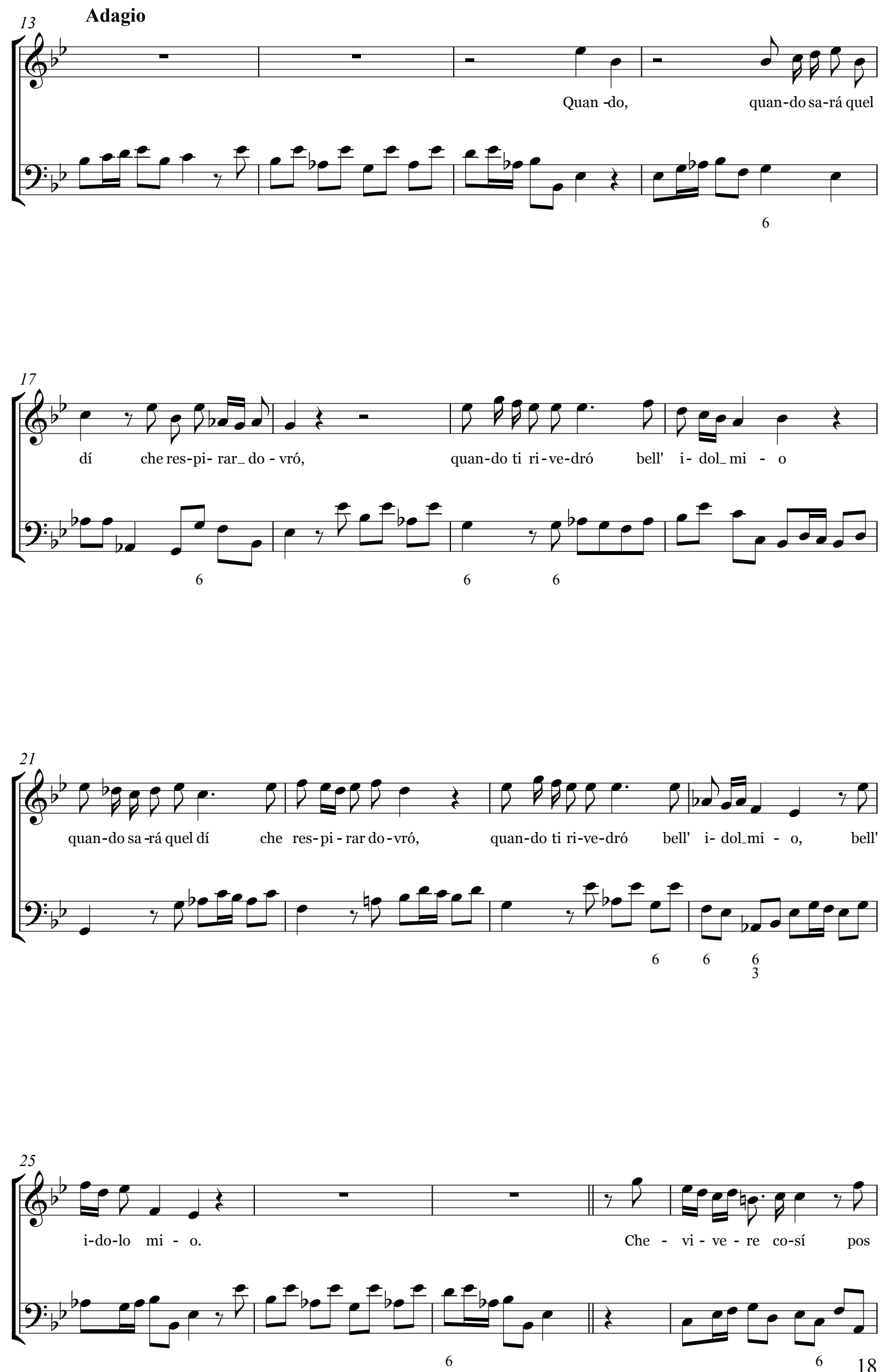

c. 16.3 voz: re. 

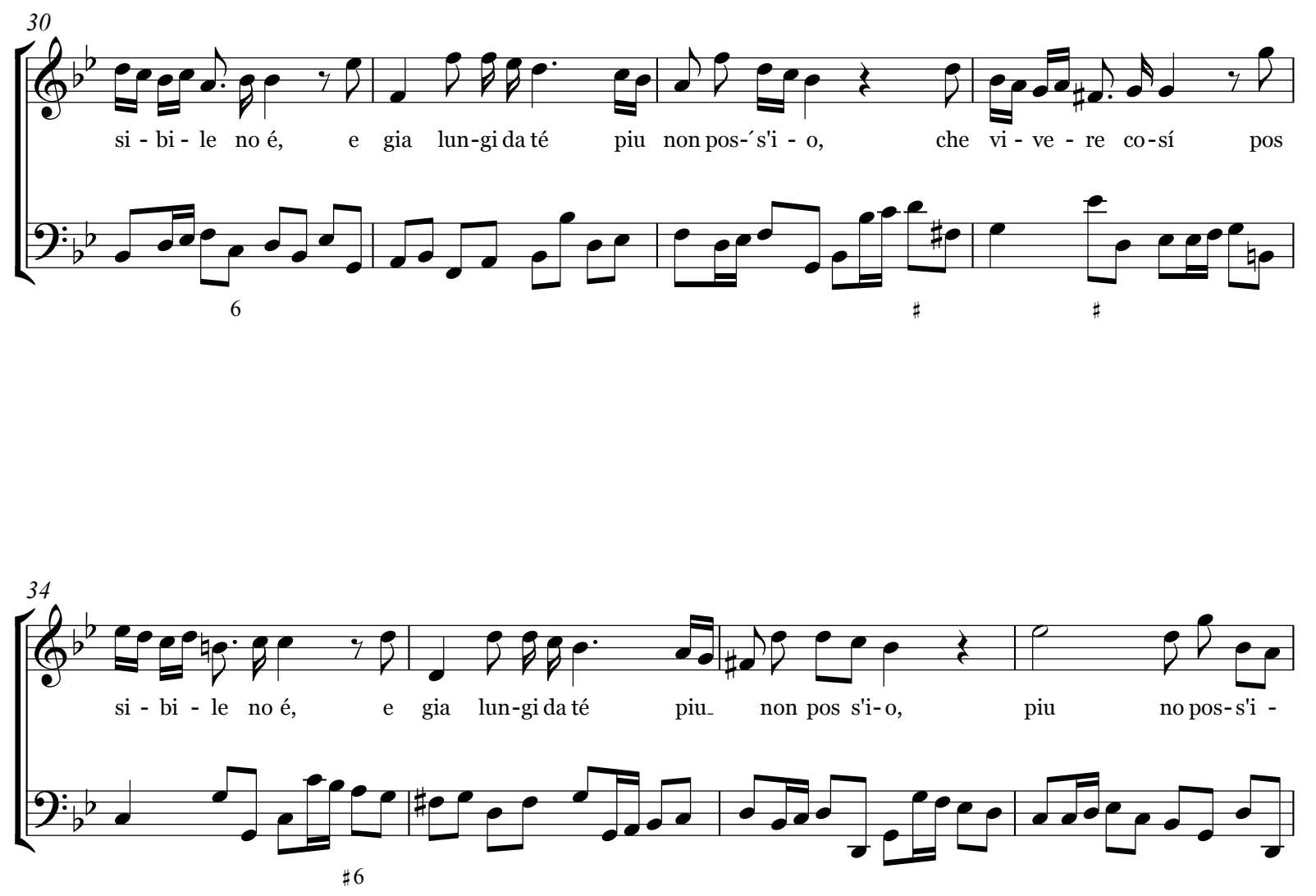

\section{[Recitativo]}

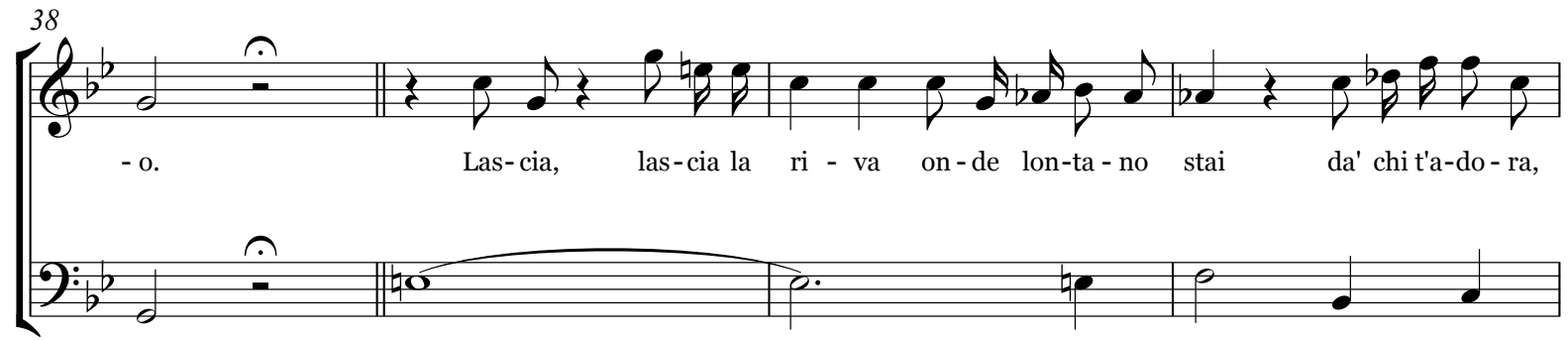

Da capo [l'aria]

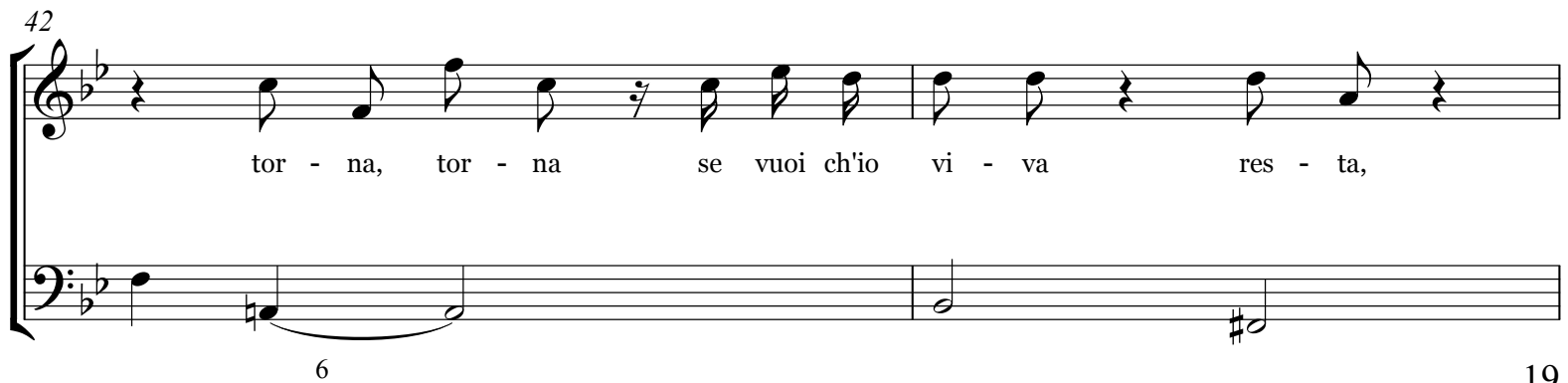




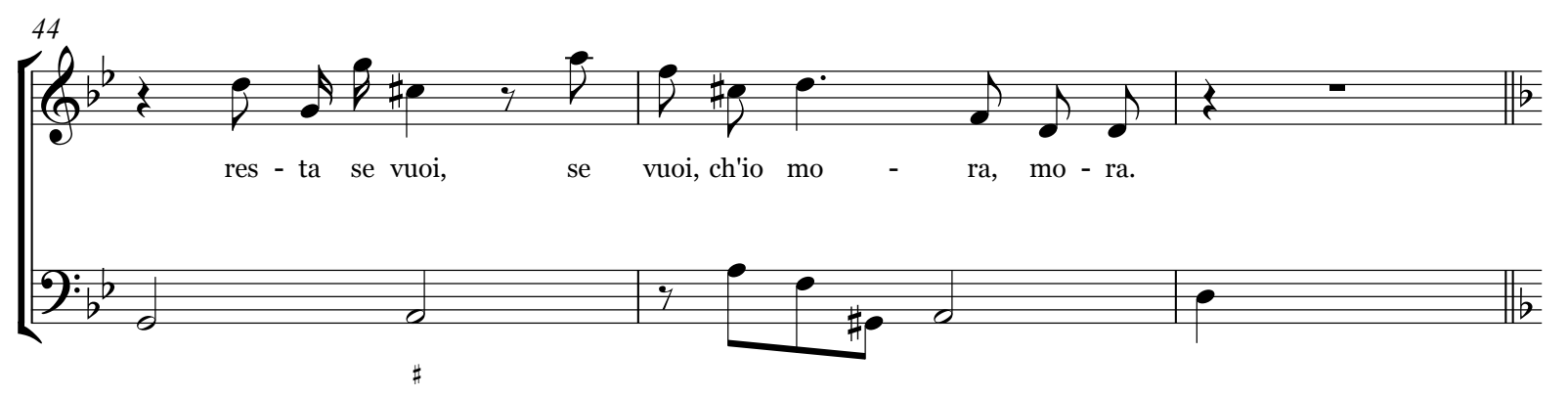

Aria
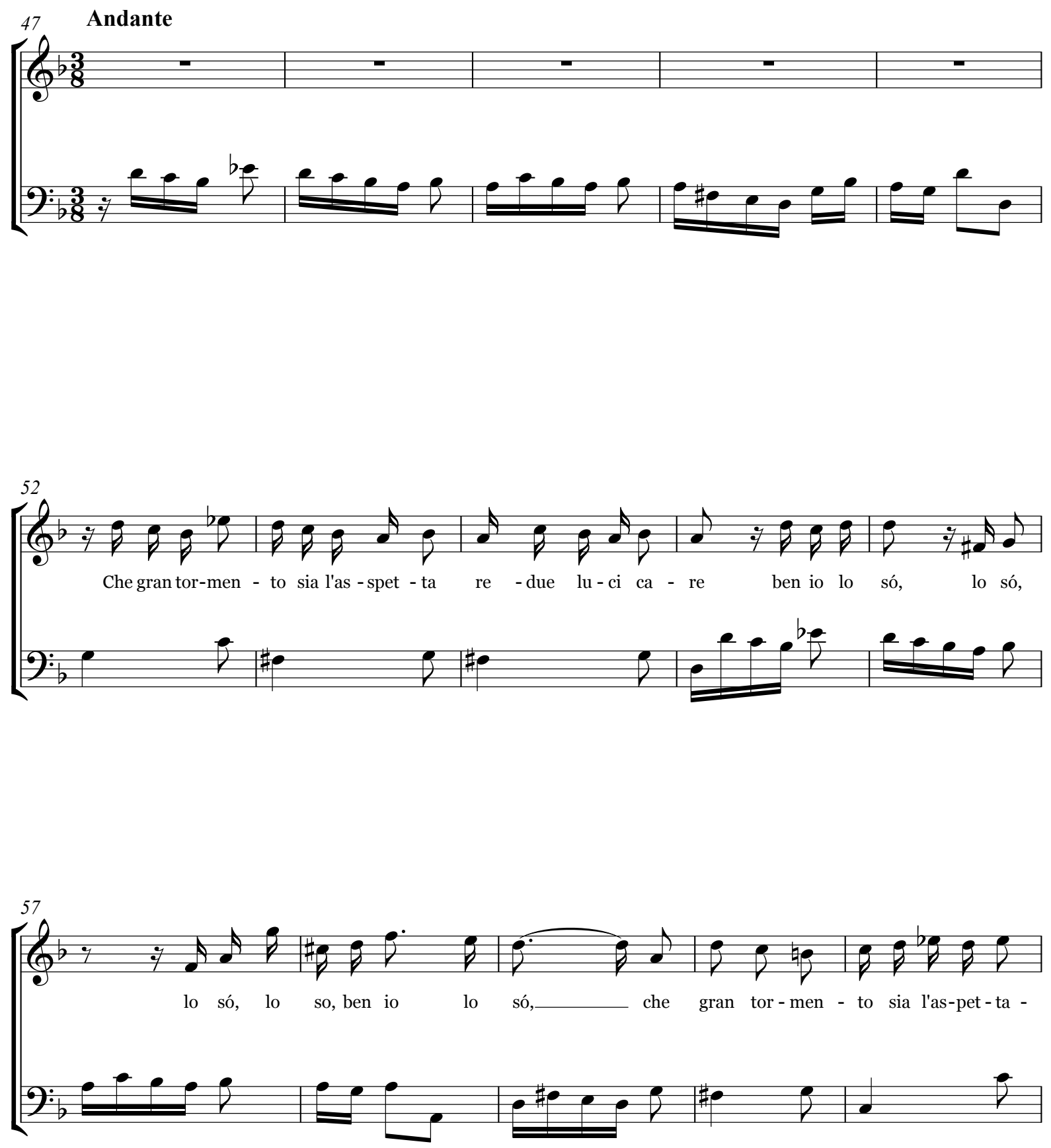

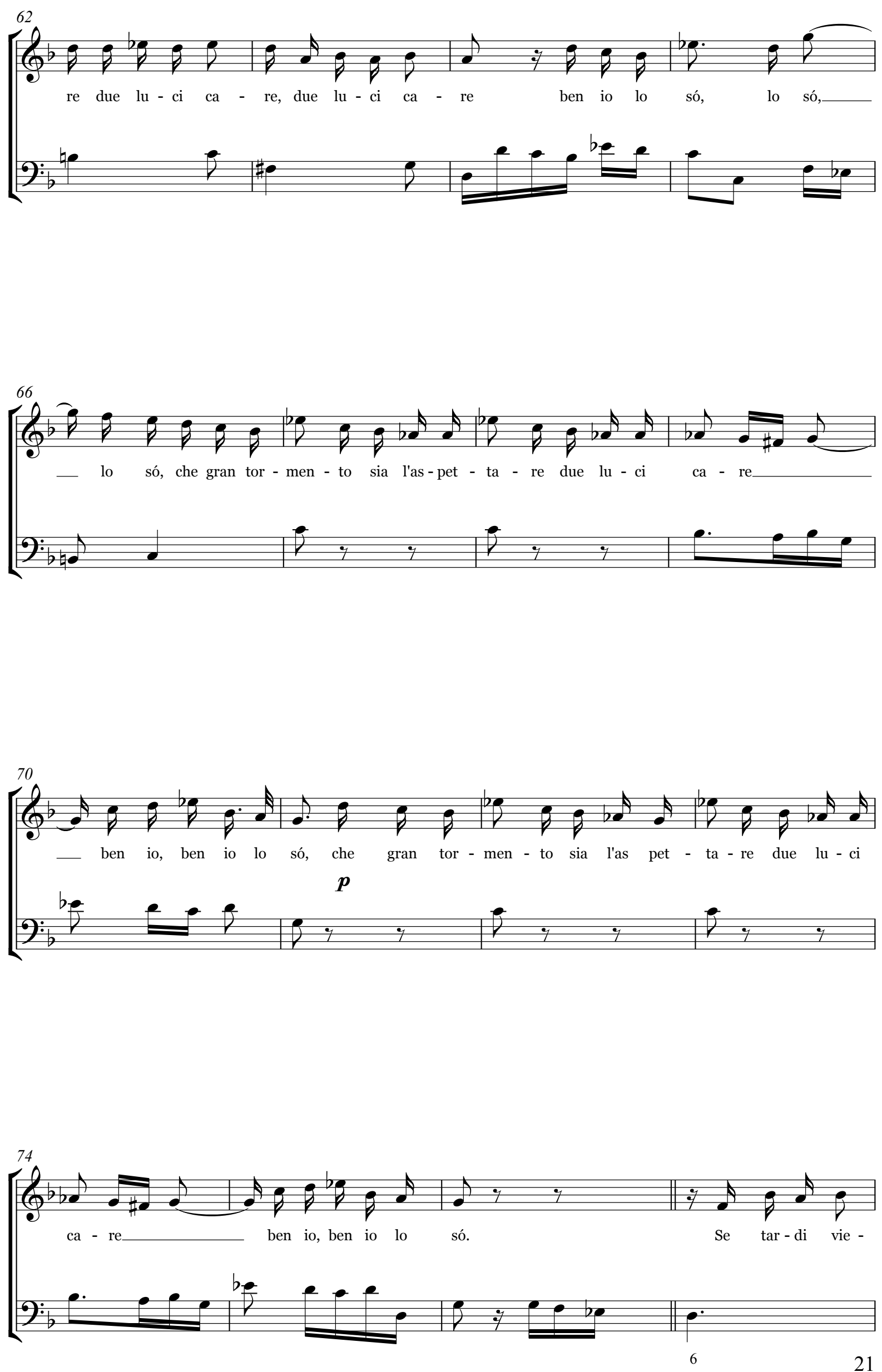

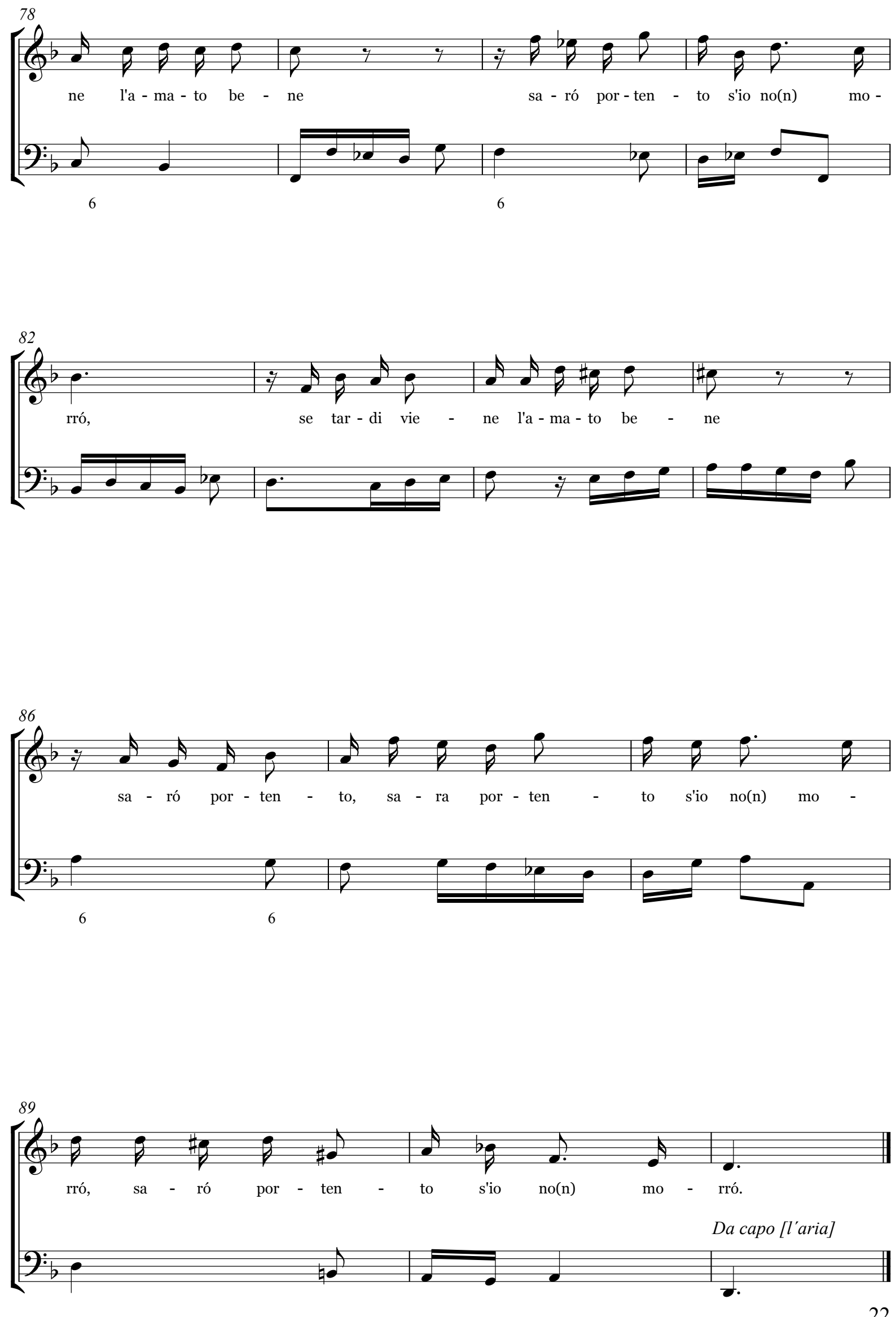


\section{[George Friedrich Händel] \\ Cantata a solo para voz y bajo contínuo \\ Lilla vedi quel colle}

BNE M 2245

Edición de Juan Pablo Fernández

ff. $43-46$

\section{Recitativo}
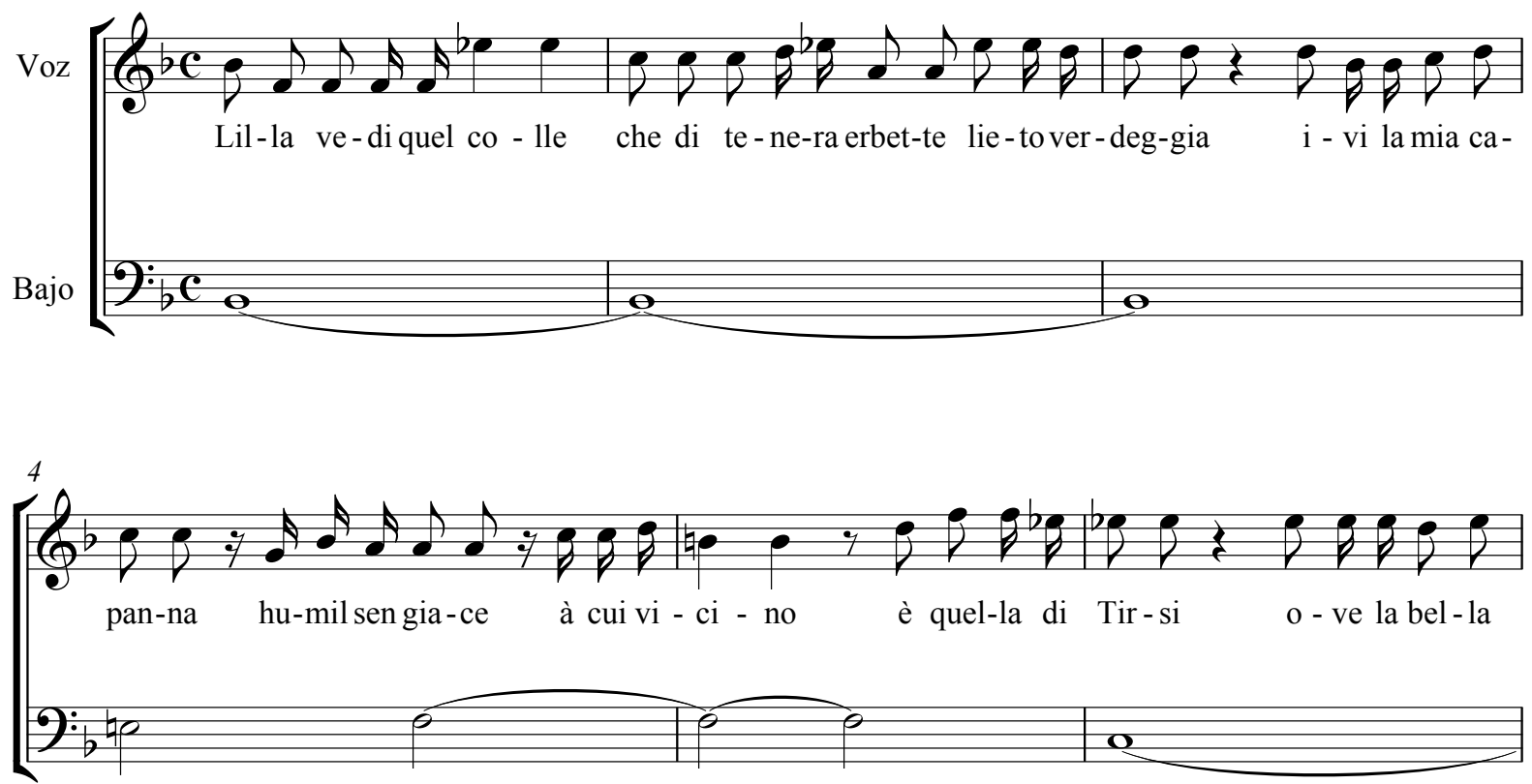

$+4$
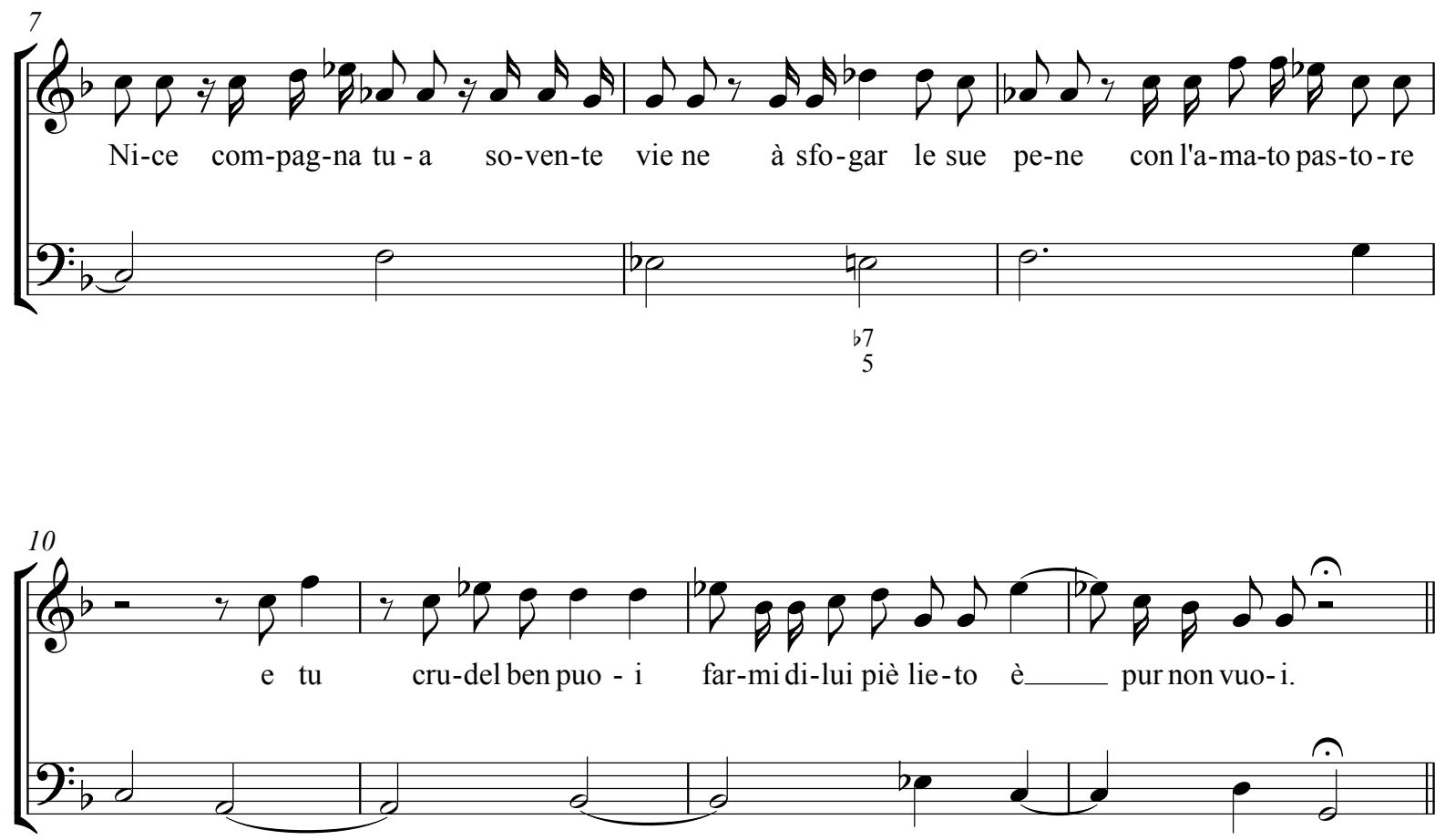


\section{Aria}
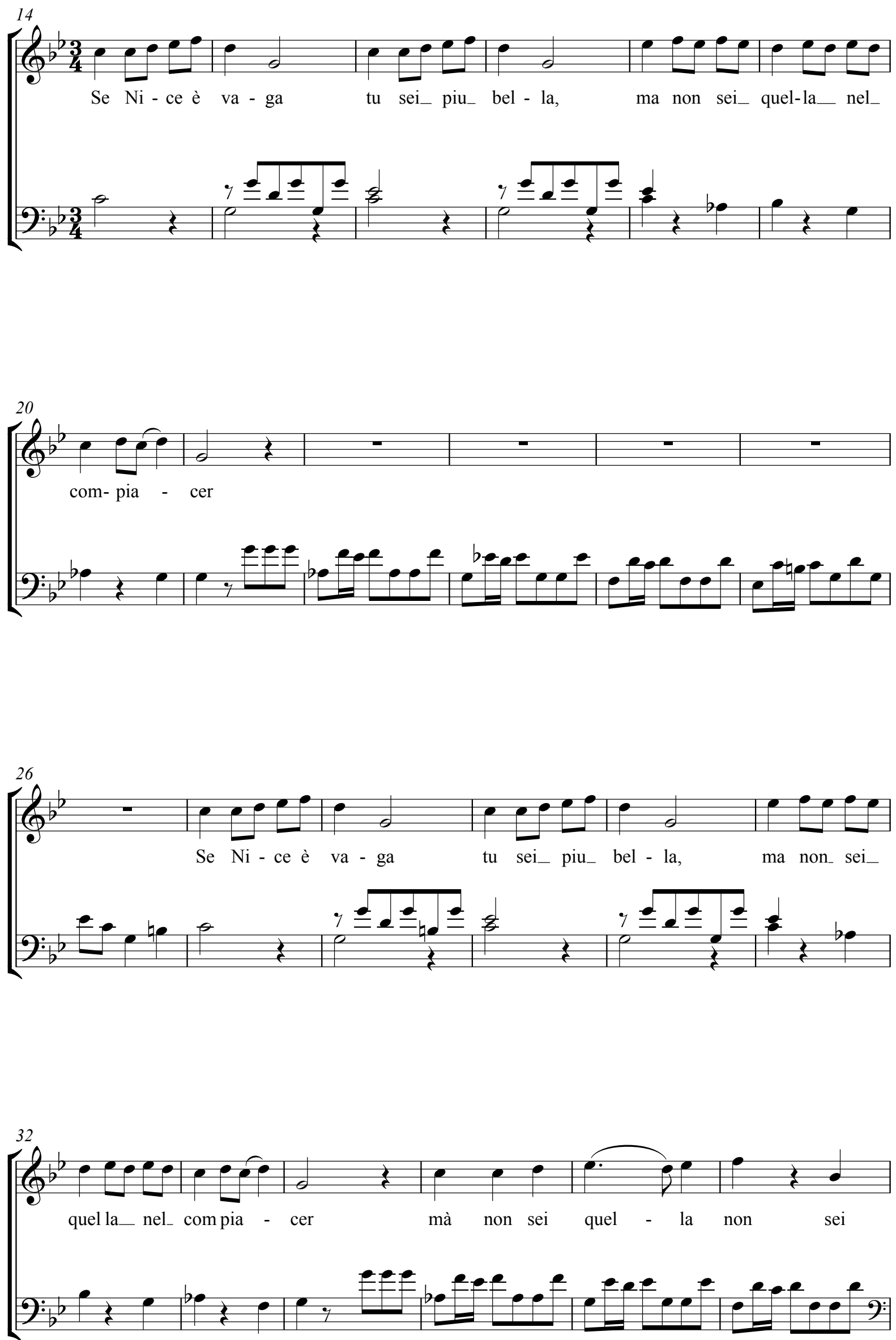

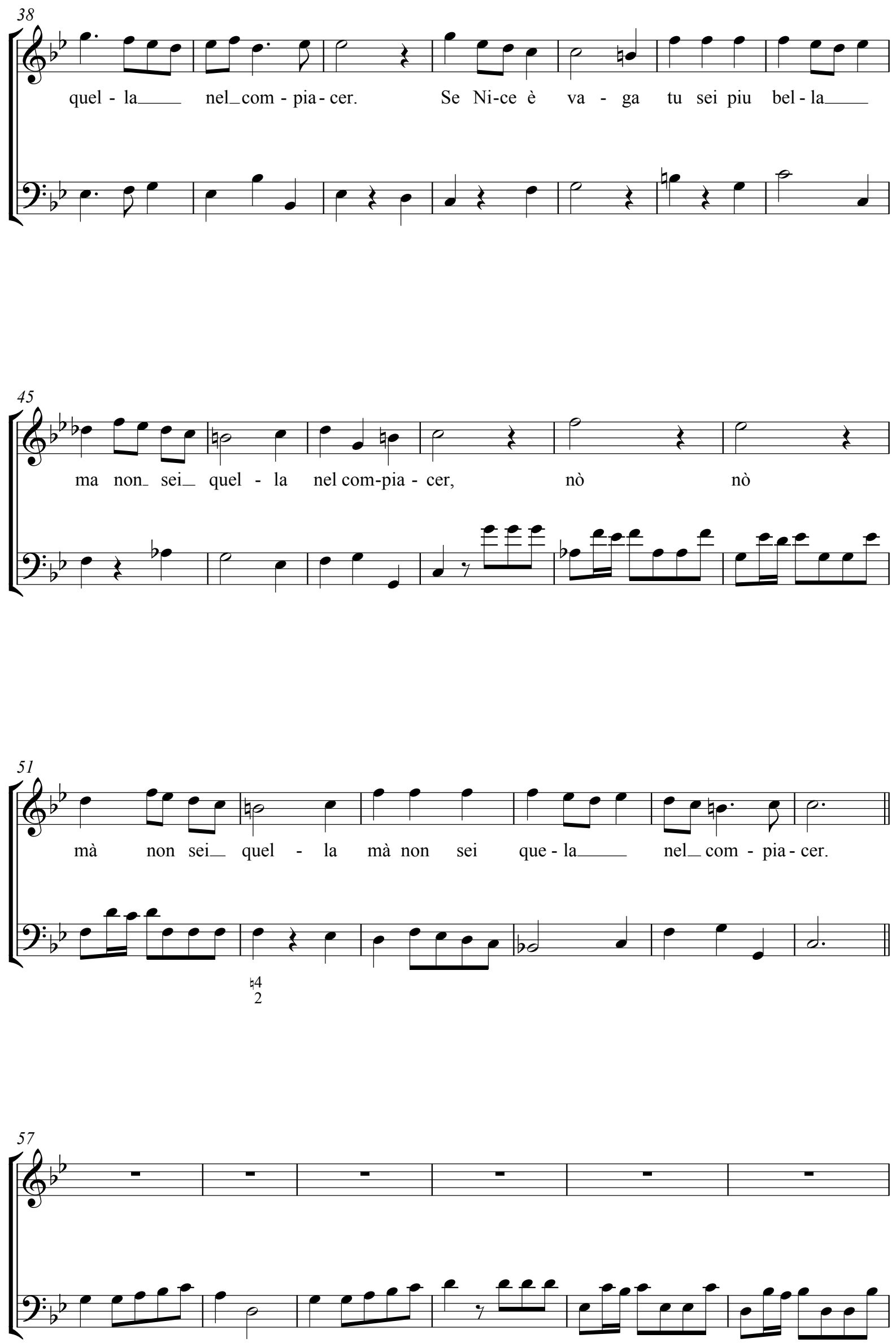

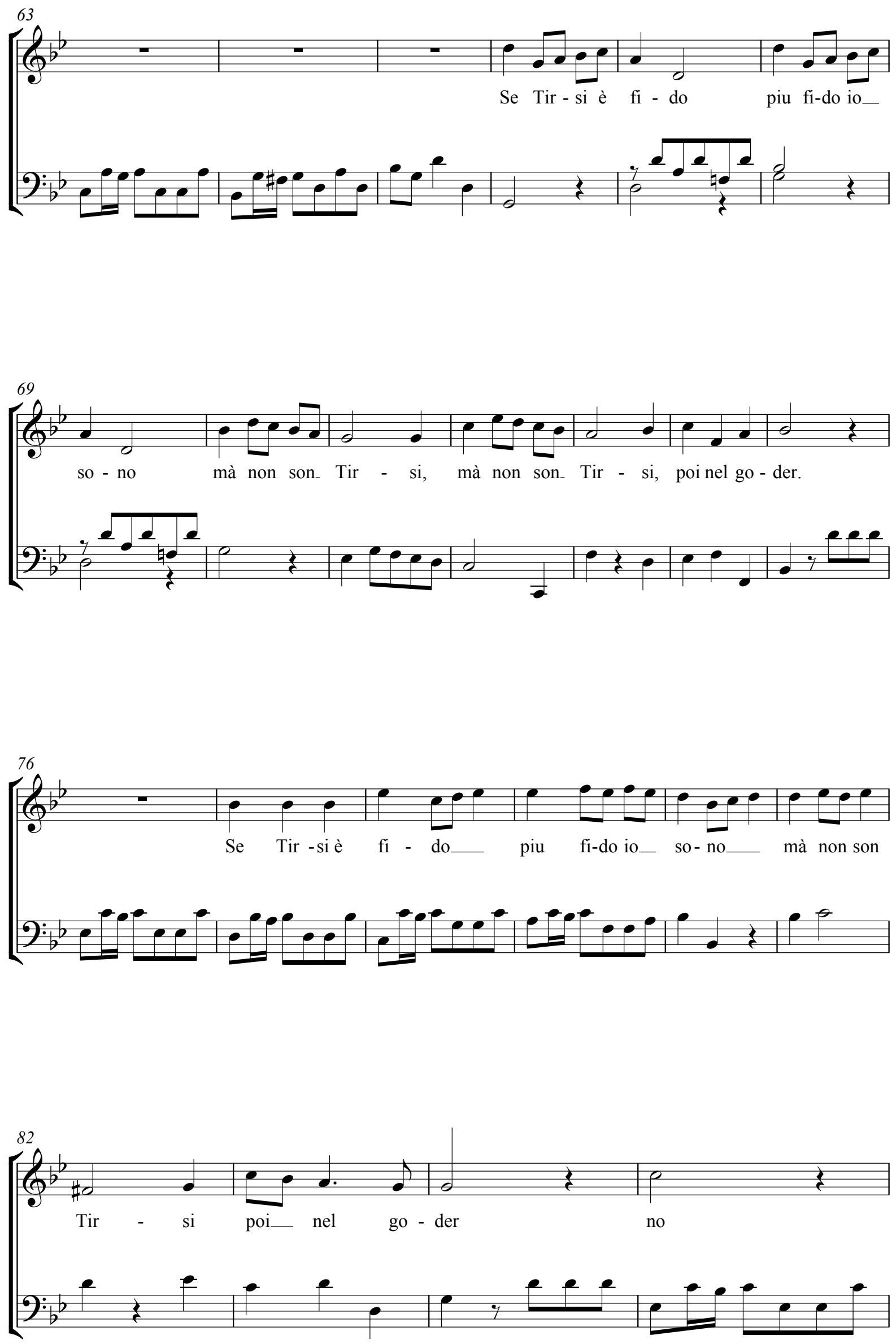


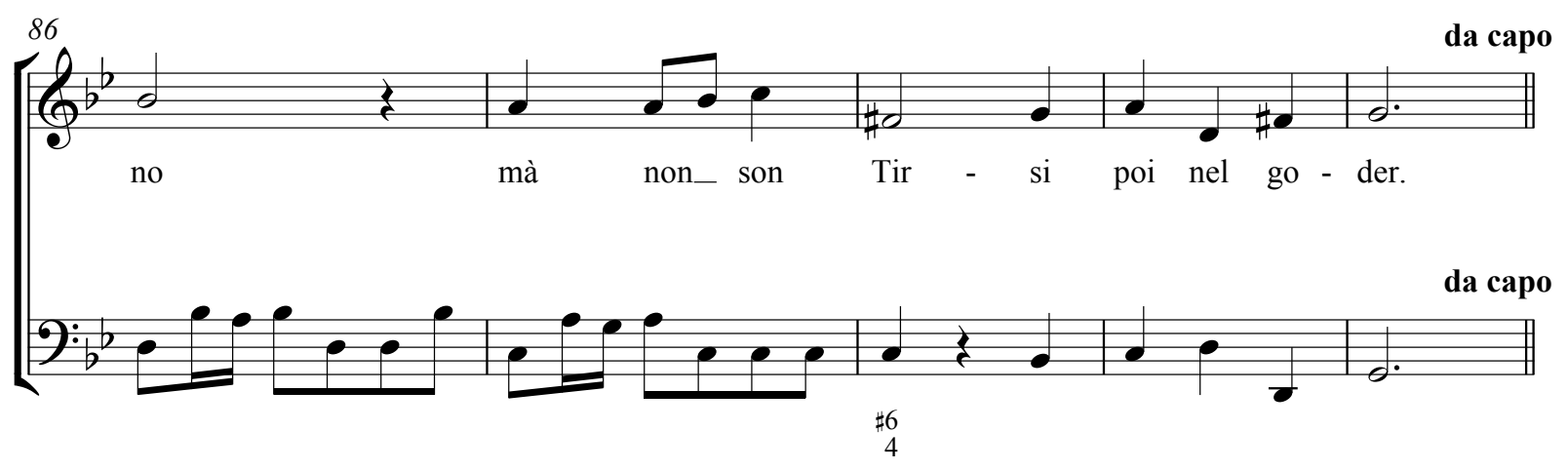

\section{Recitativo}
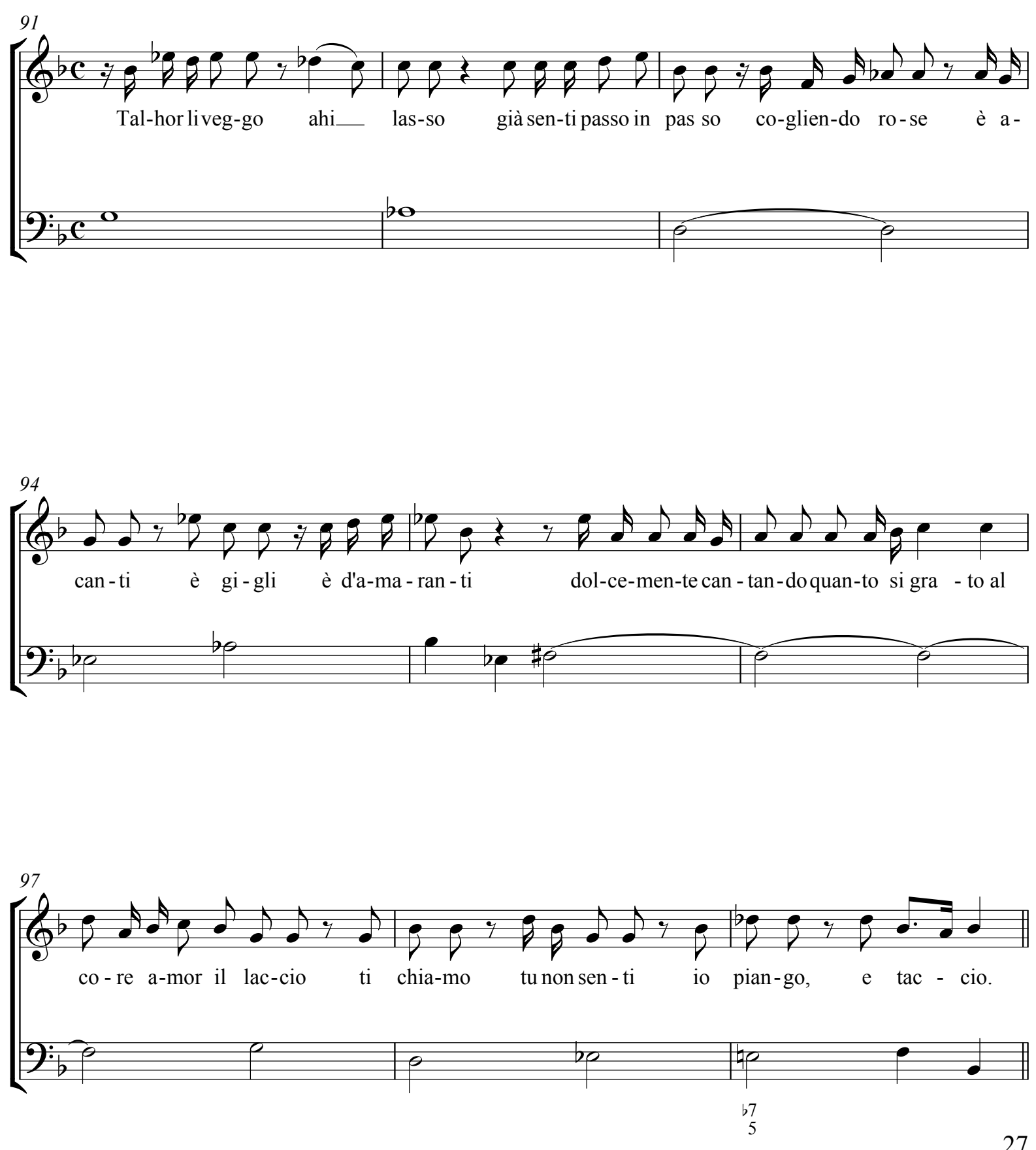


\section{Aria}
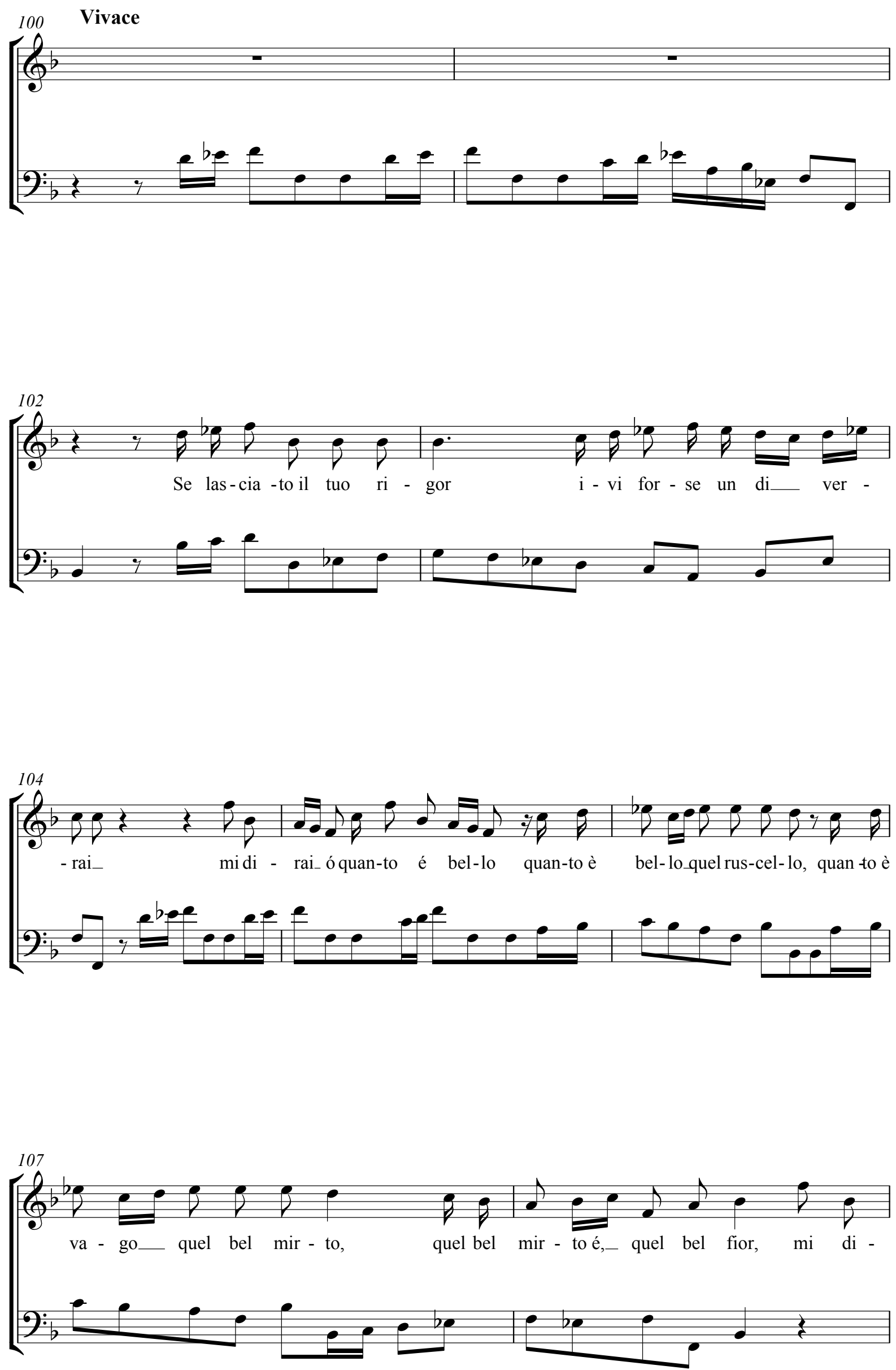

c. 100 al 101.3 bajo en clave de do en $4^{\mathrm{a}}$. 

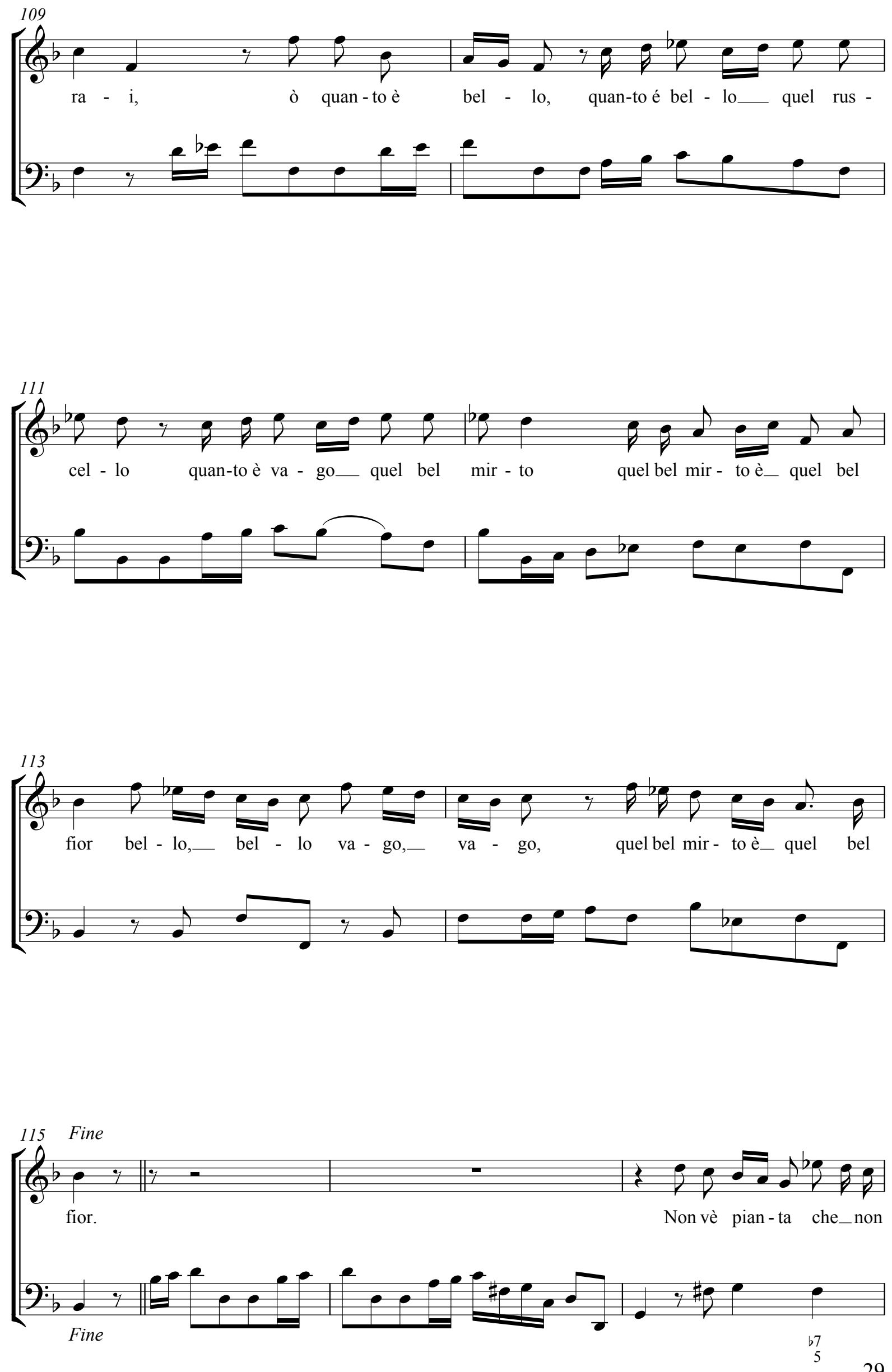

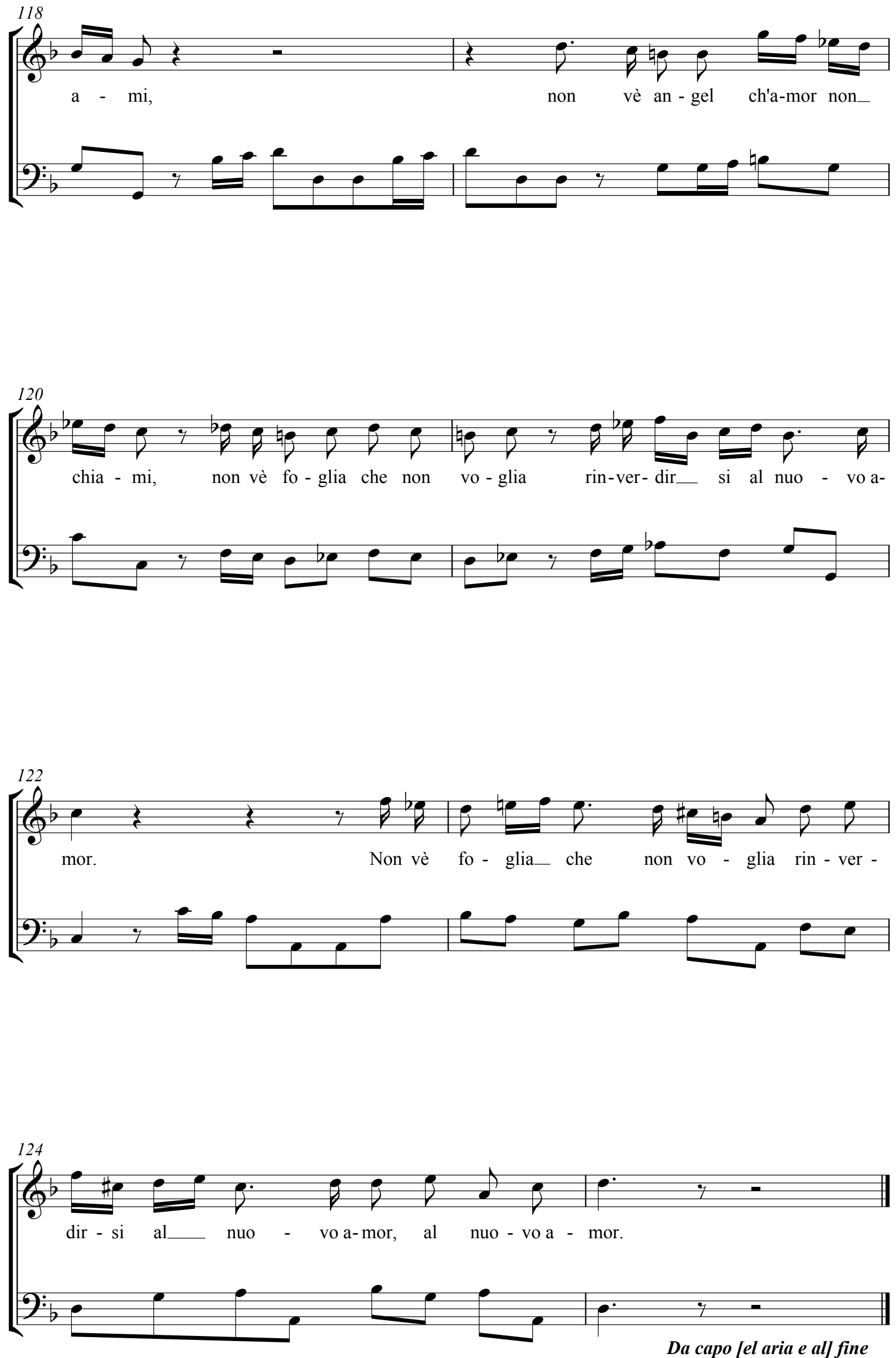
2.2. Luigi Boccherini:

Quinteto Op. 39/2 (G. 338) 



\section{Luigi Boccherini \\ Quinteto $N^{0} 78$ G. 338}

Edición de estudio basada en las partes instrumentales

editadas en Douze noveaux quintetti pour deux violons, alto et deux violoncelles:

opera 47 :[1-4] livraison Paris: Pleyel , 1813.

Ejemplar conservado en BNE Mp 2395
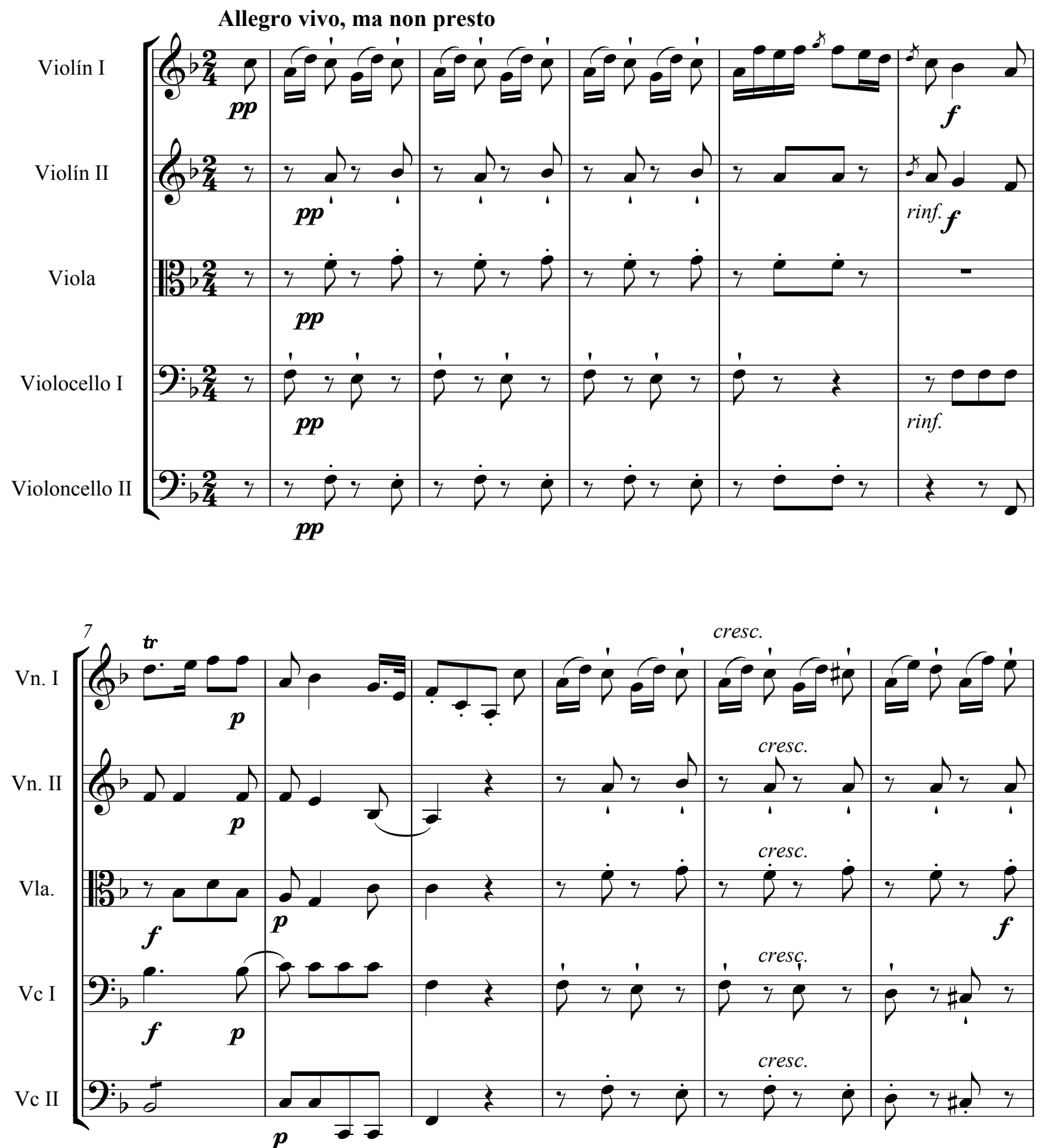

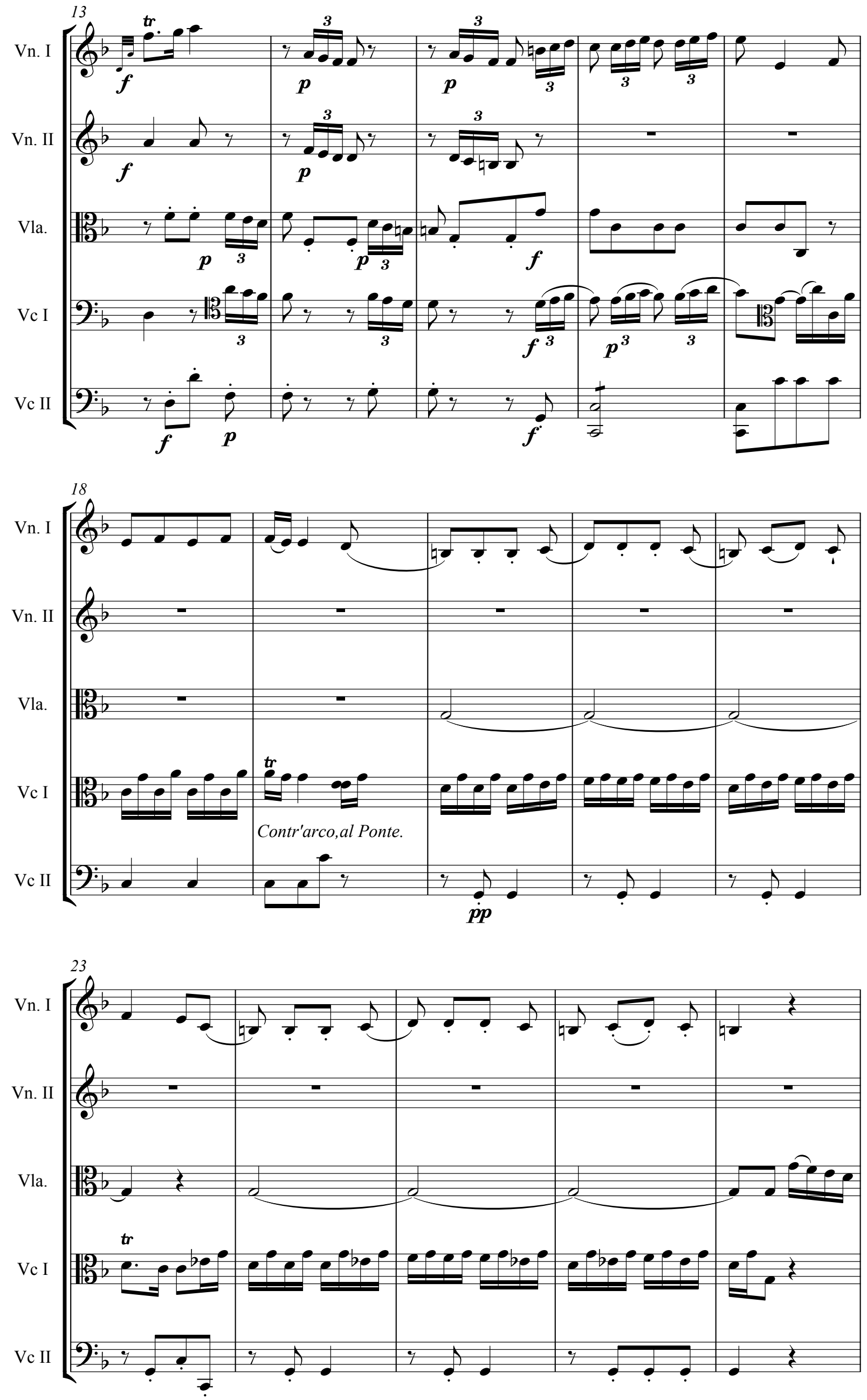

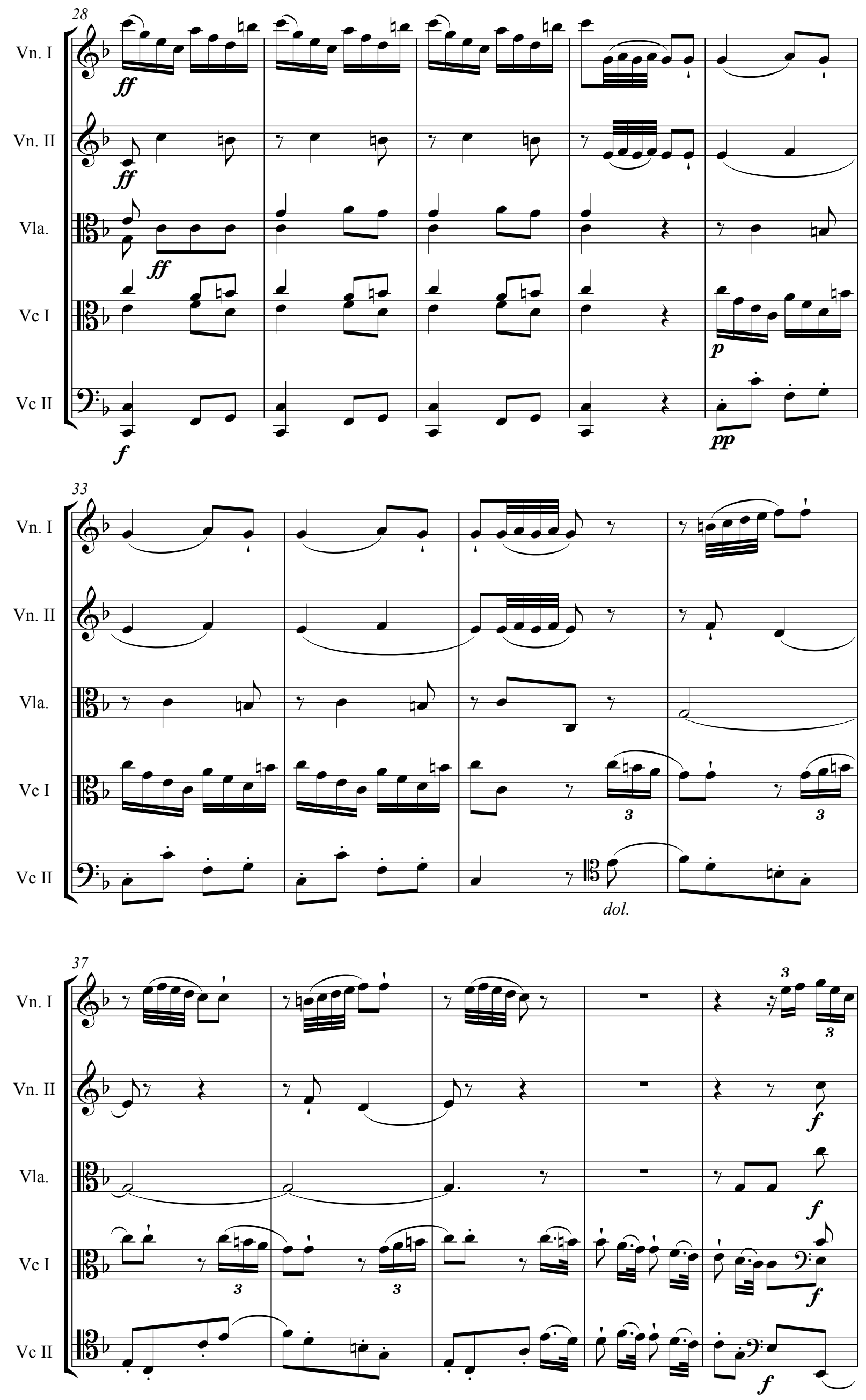

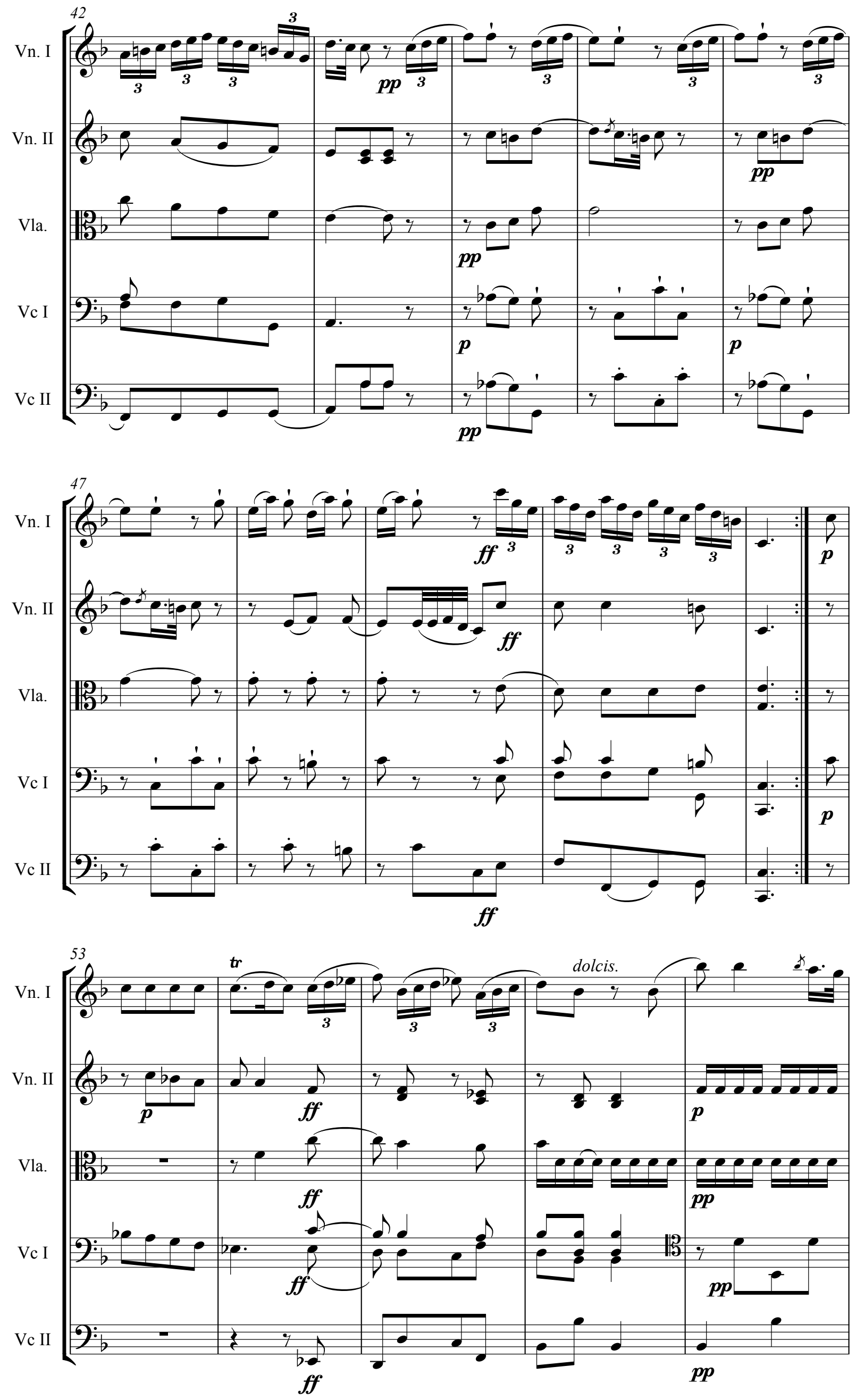

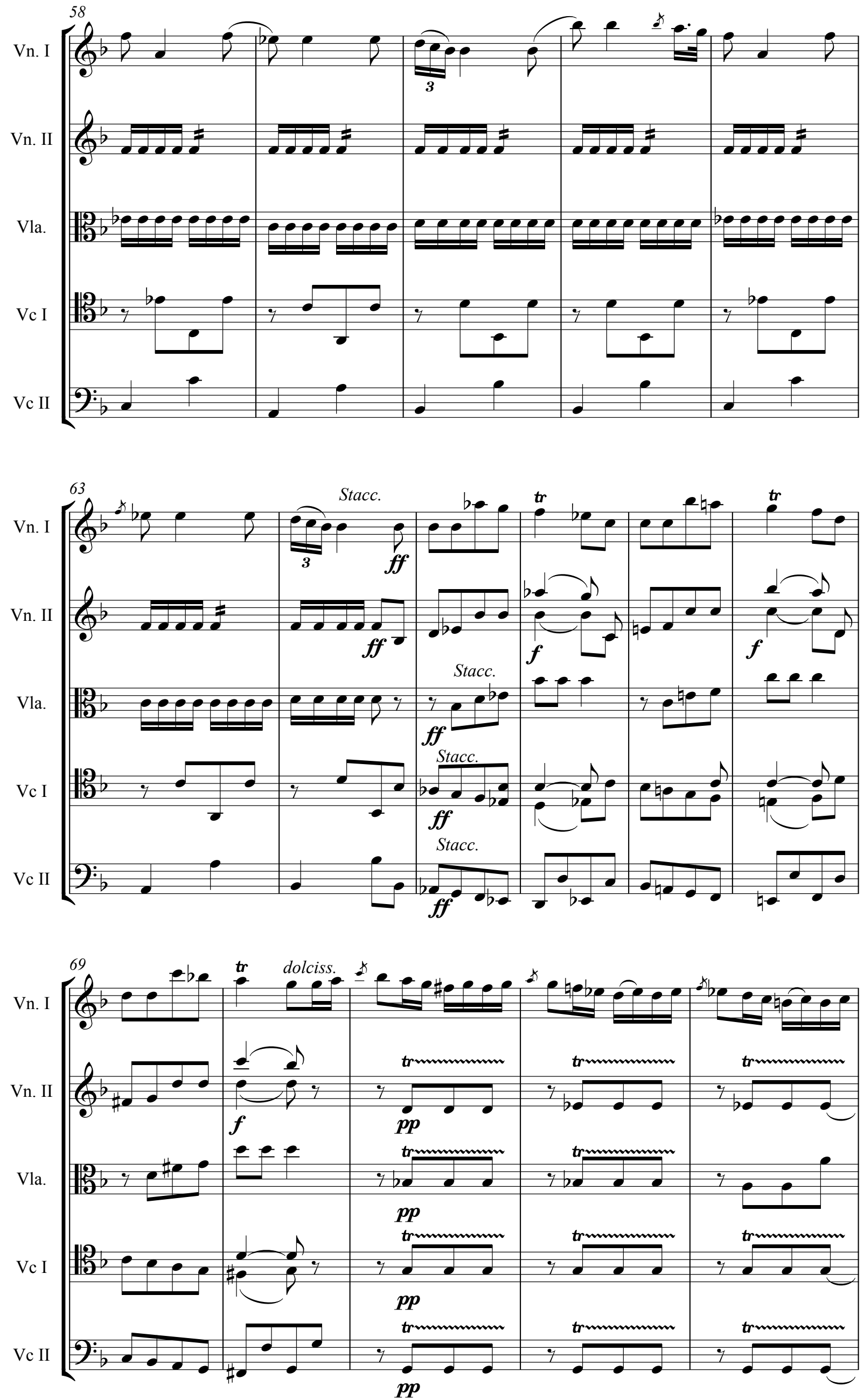
Vn. I

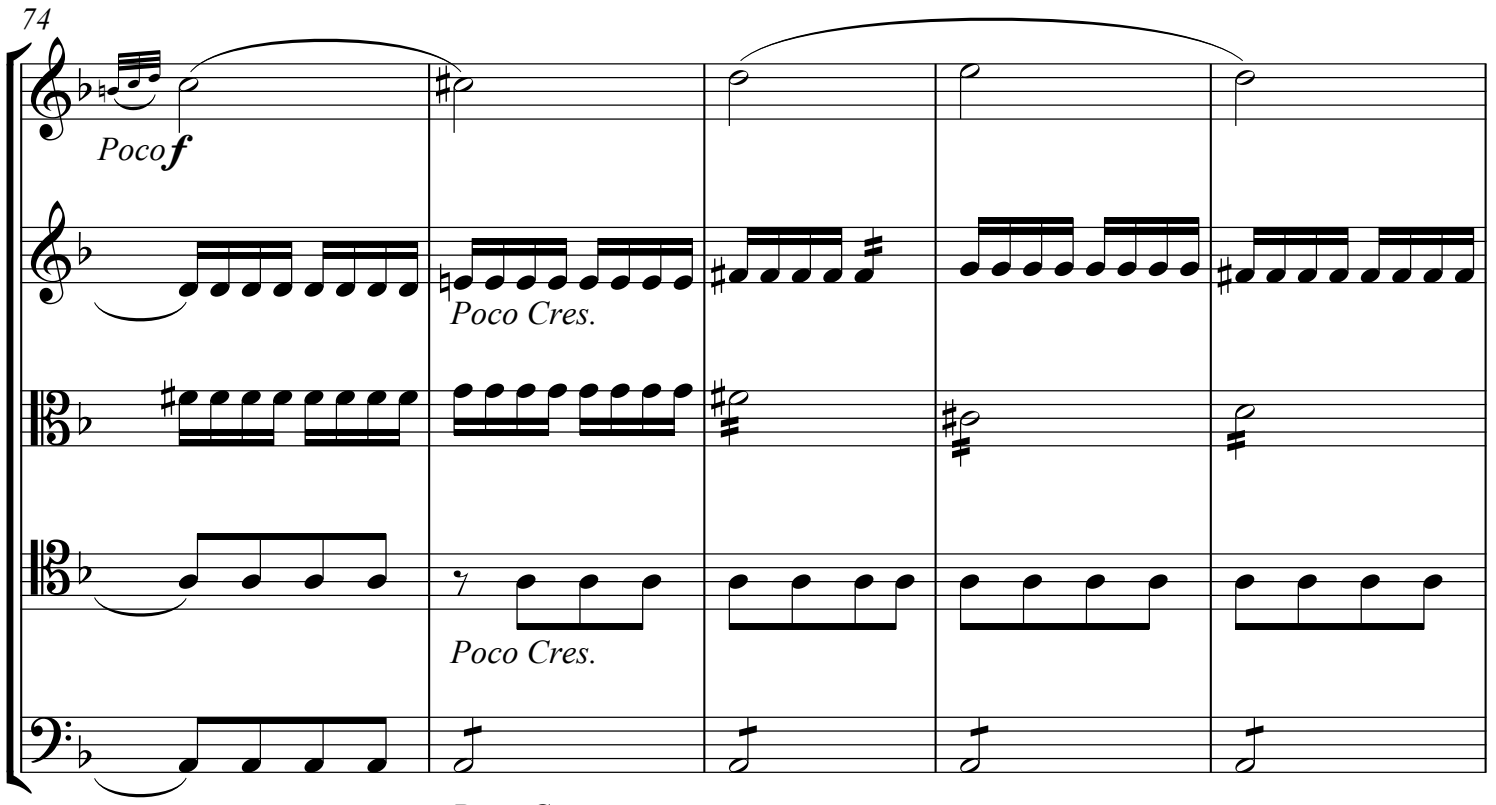
Poco Cres.
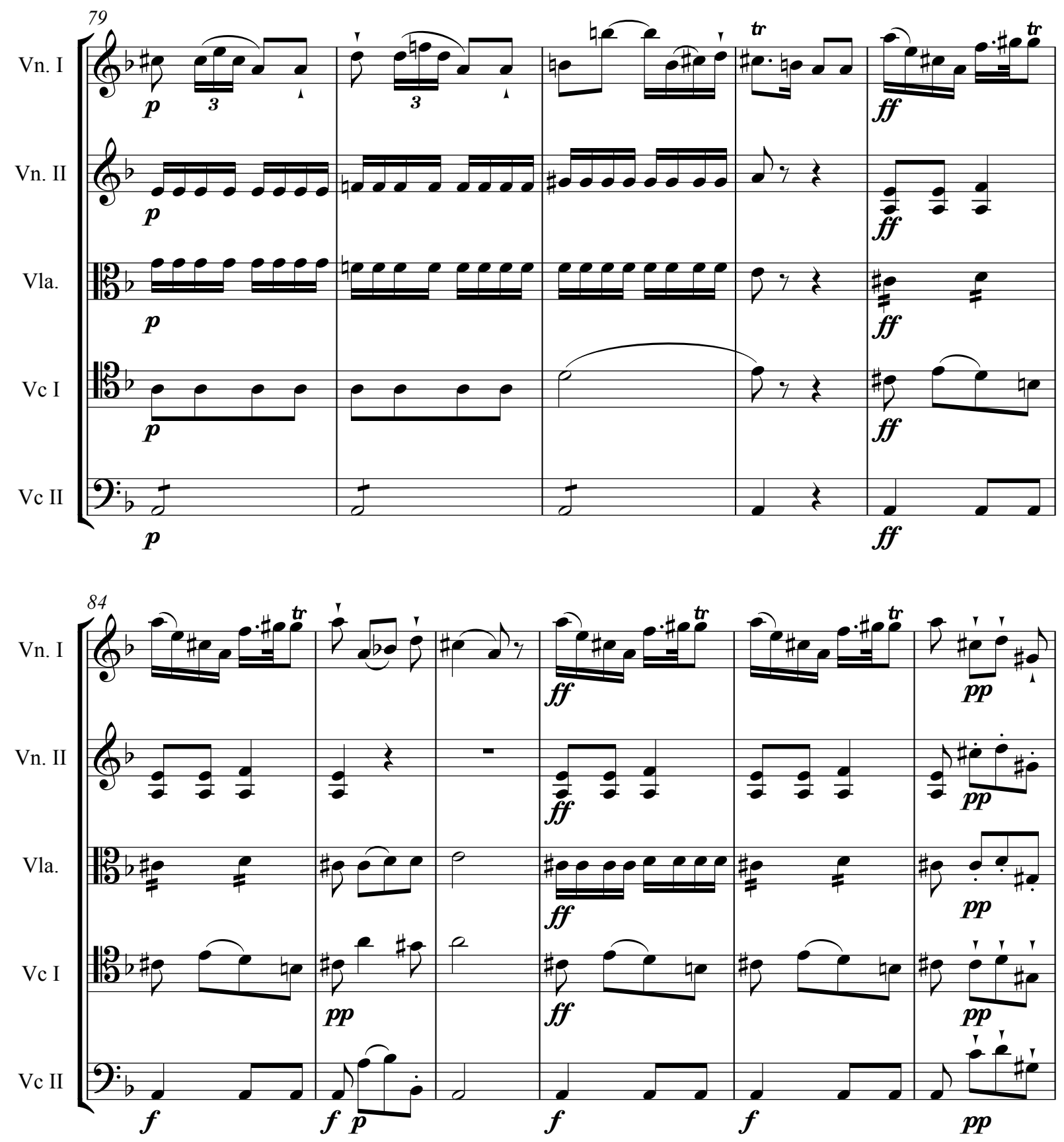

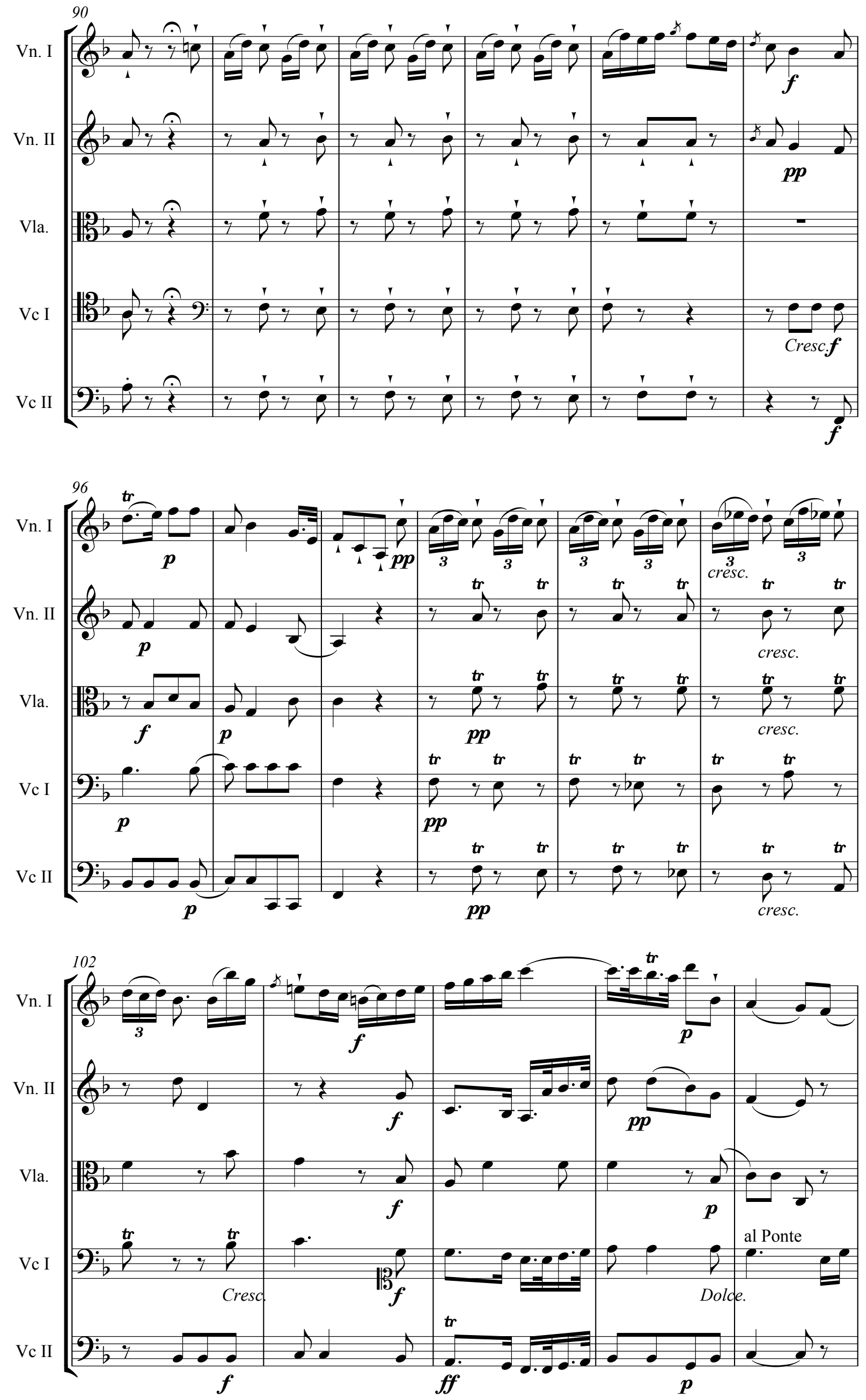

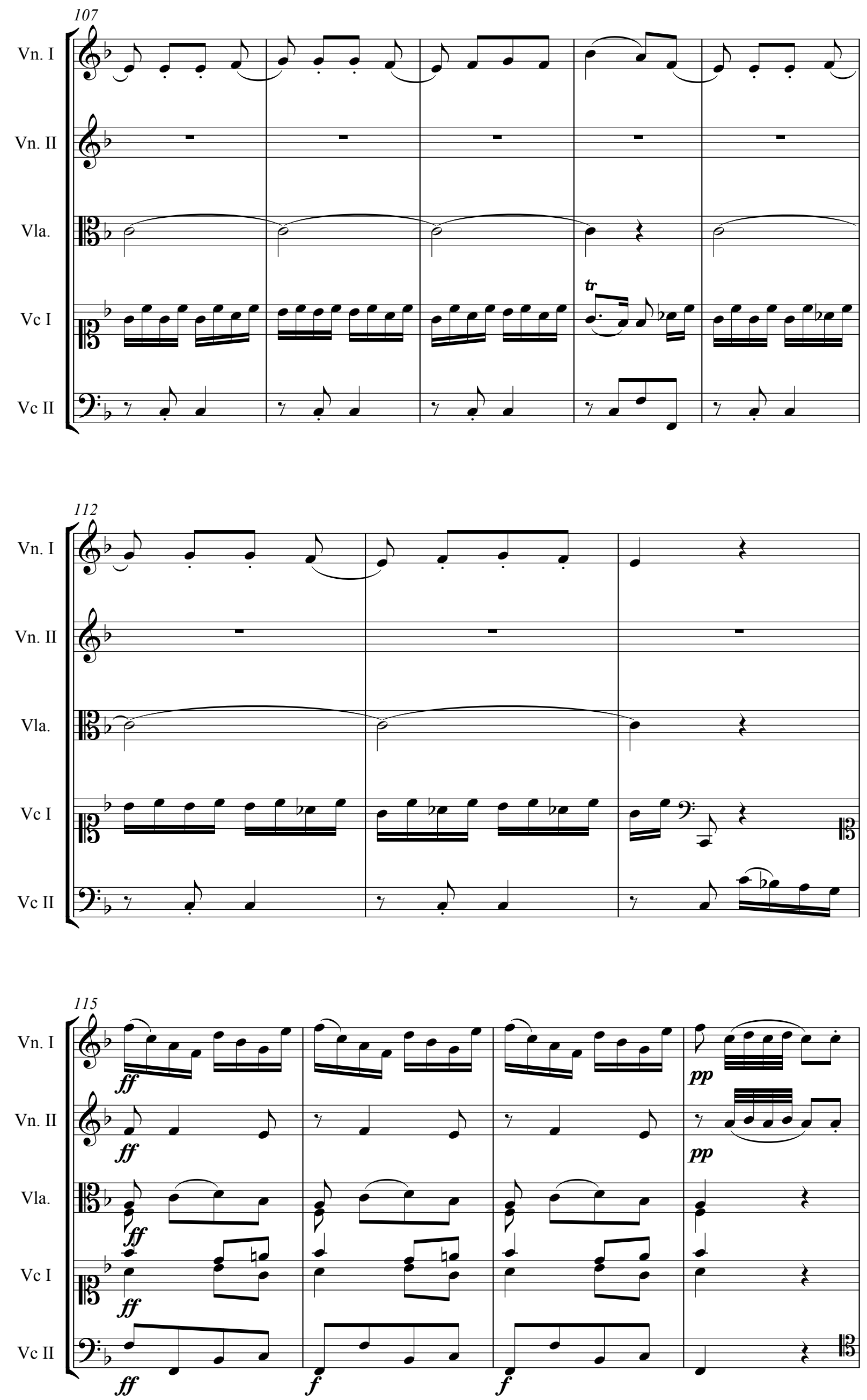

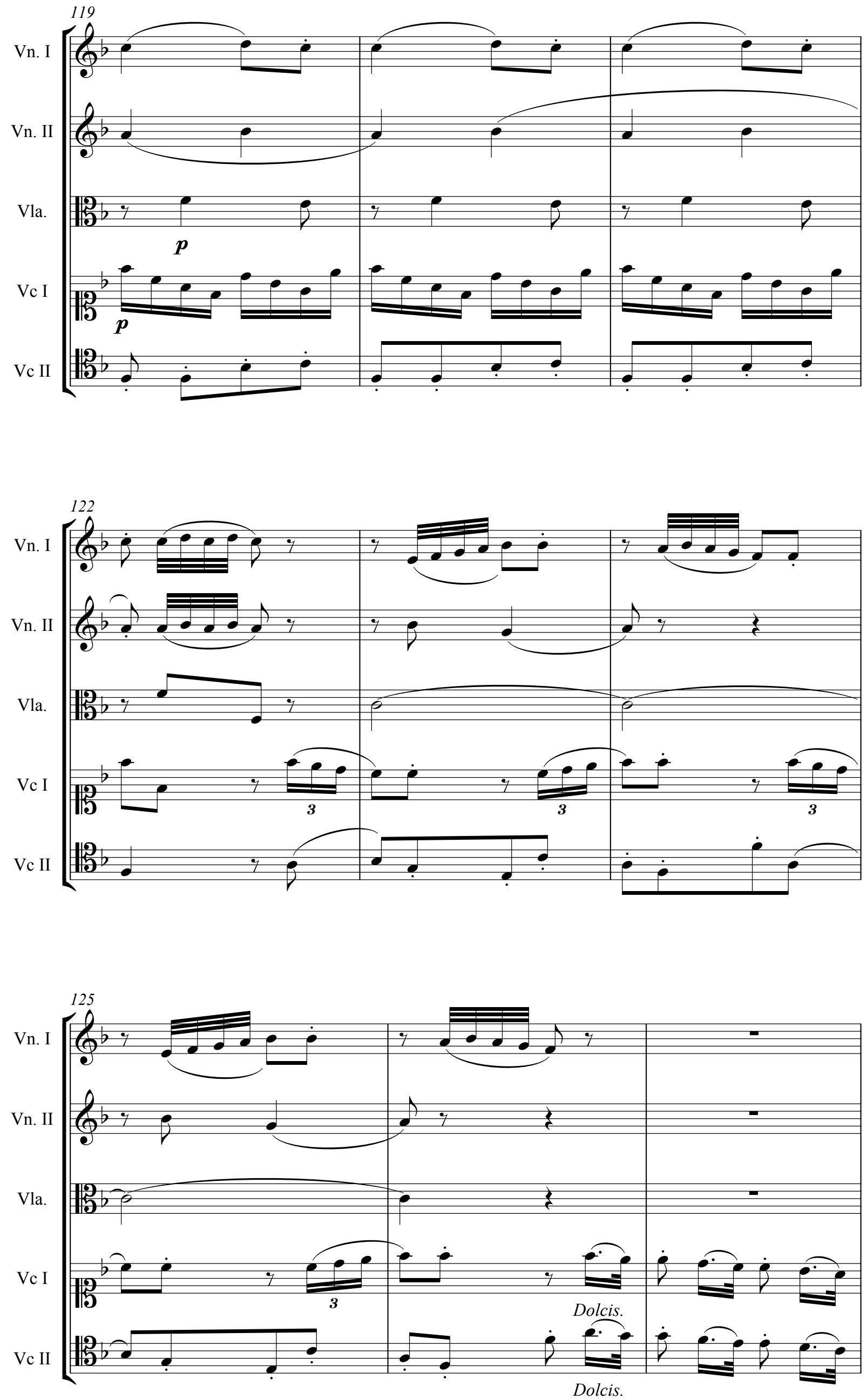

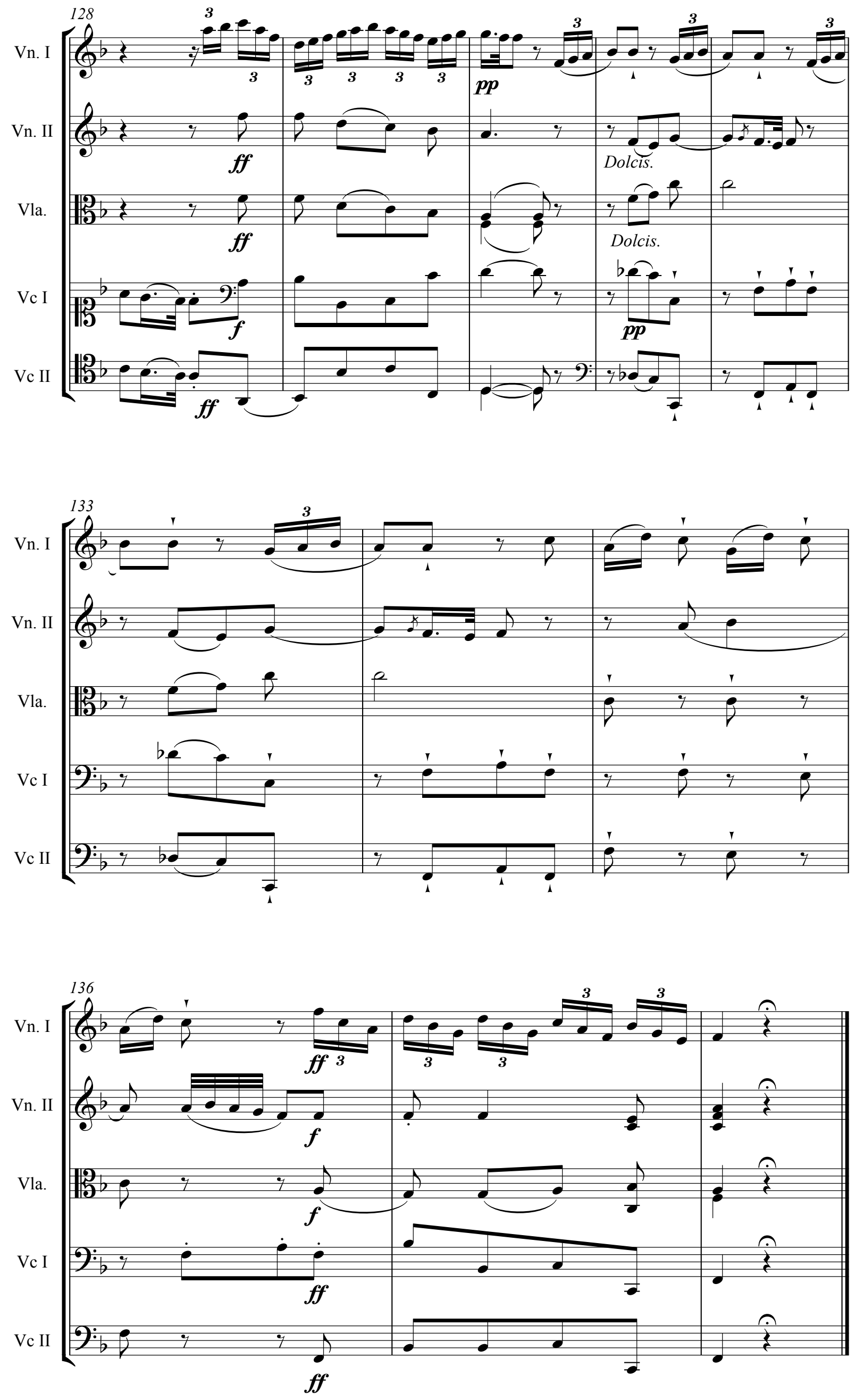


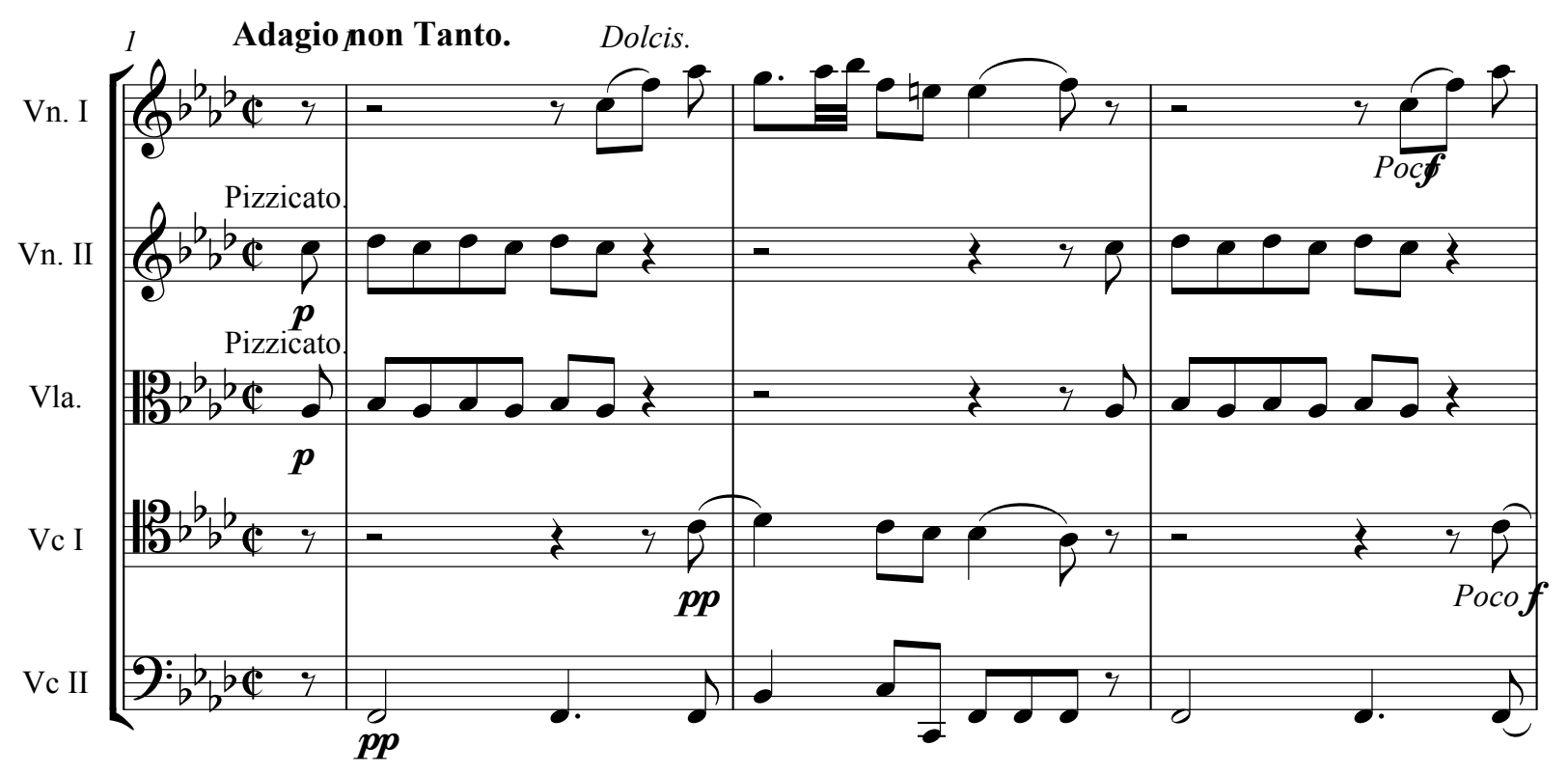

Dol. e con Smorfia.
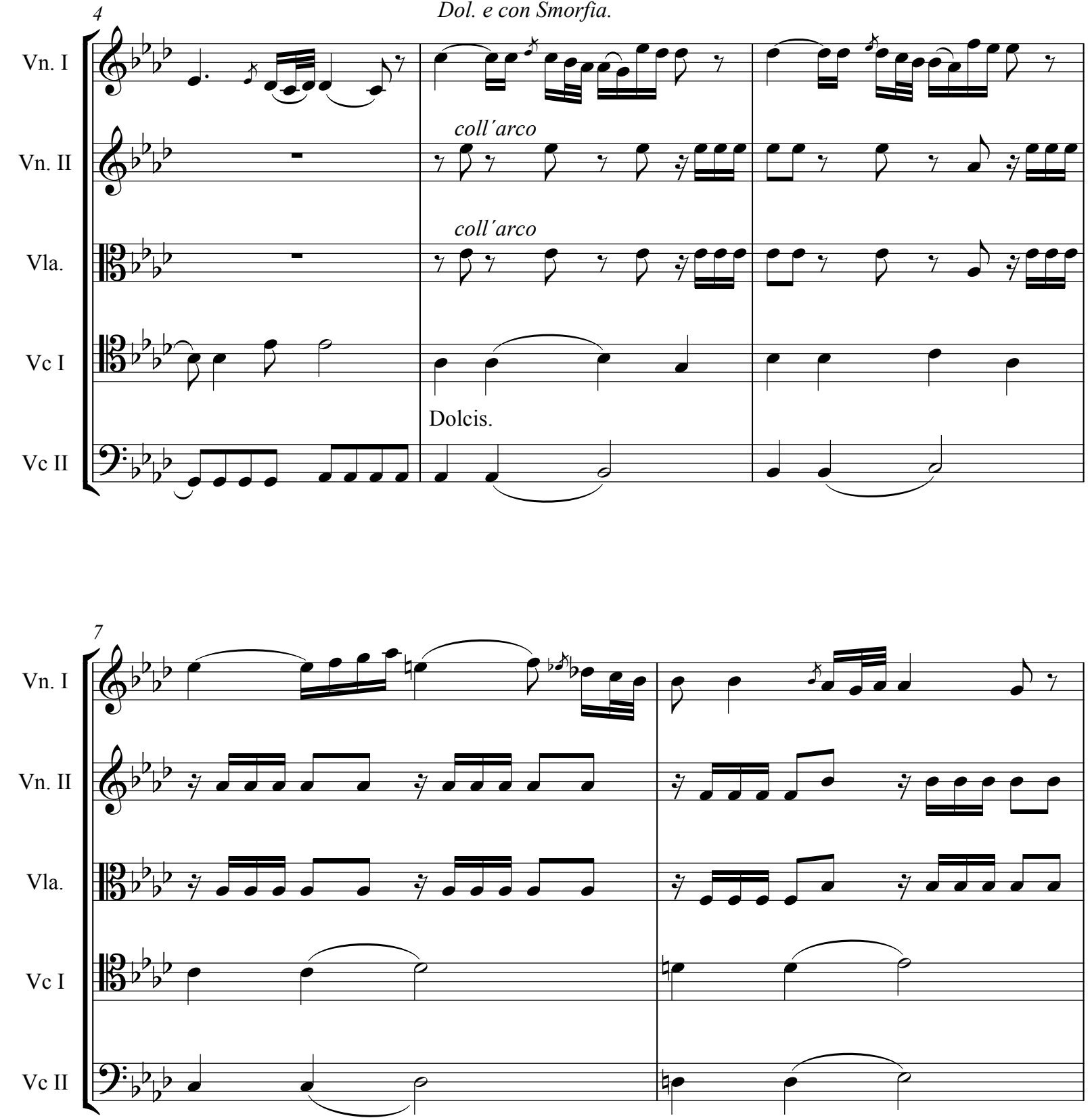

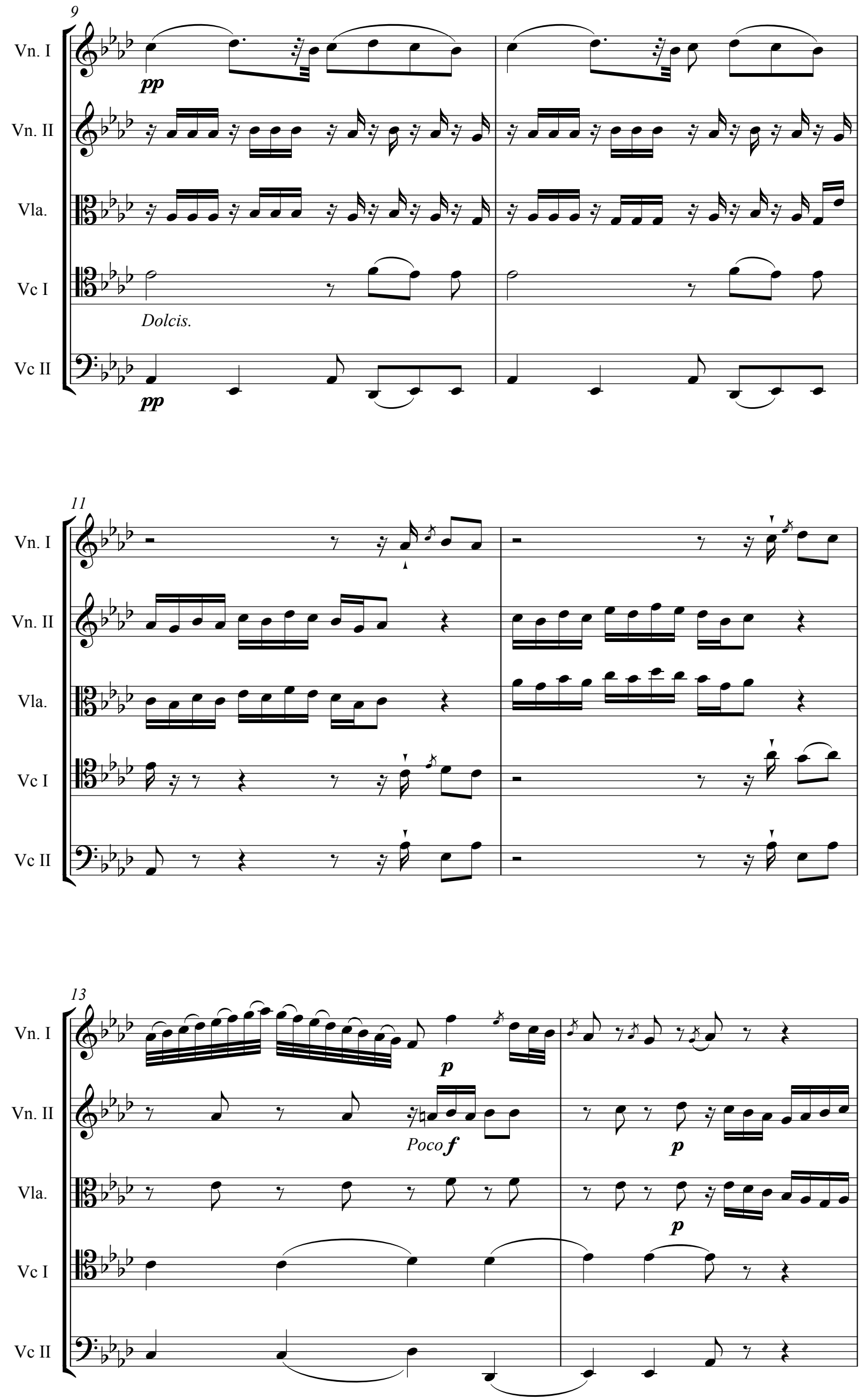

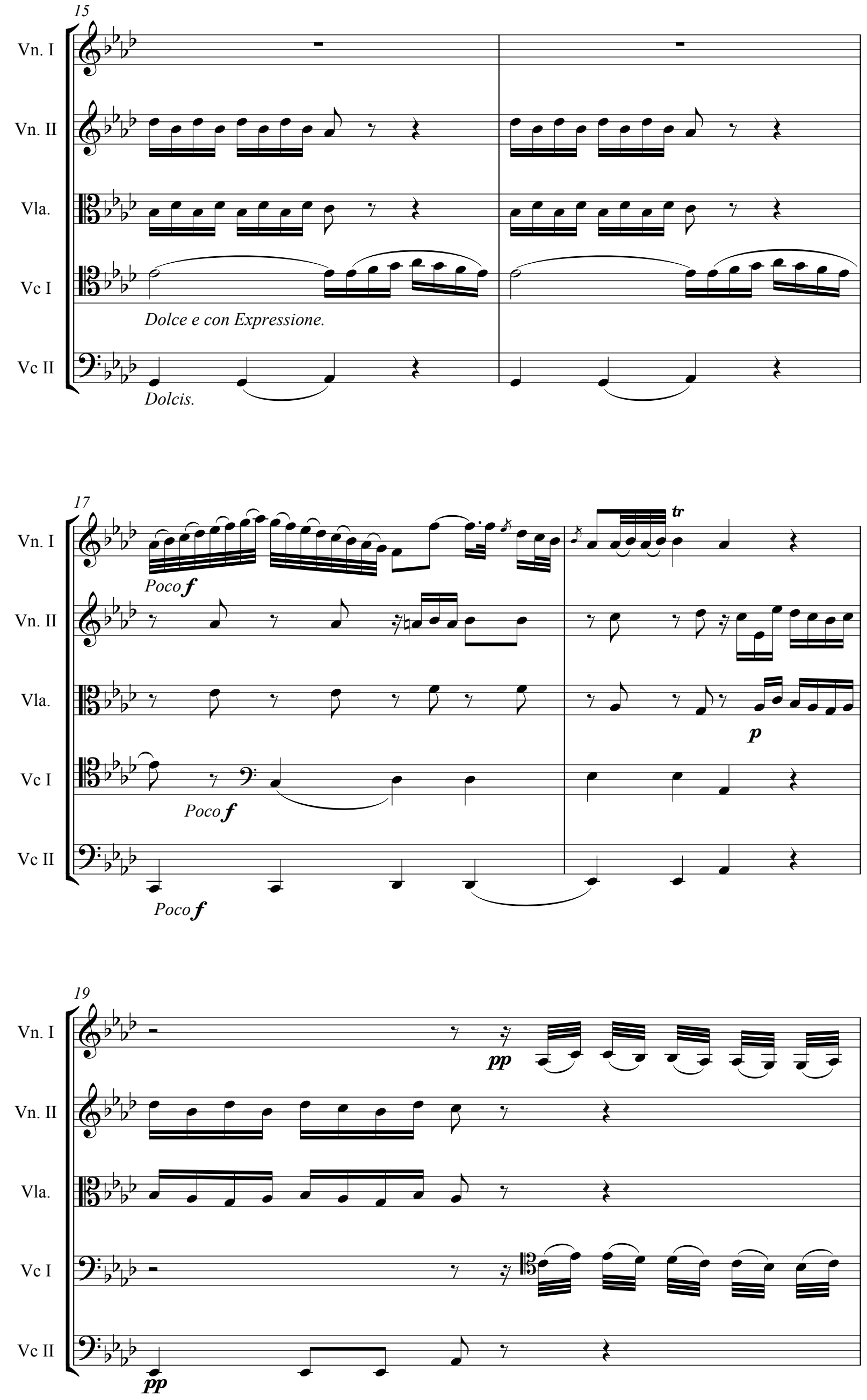

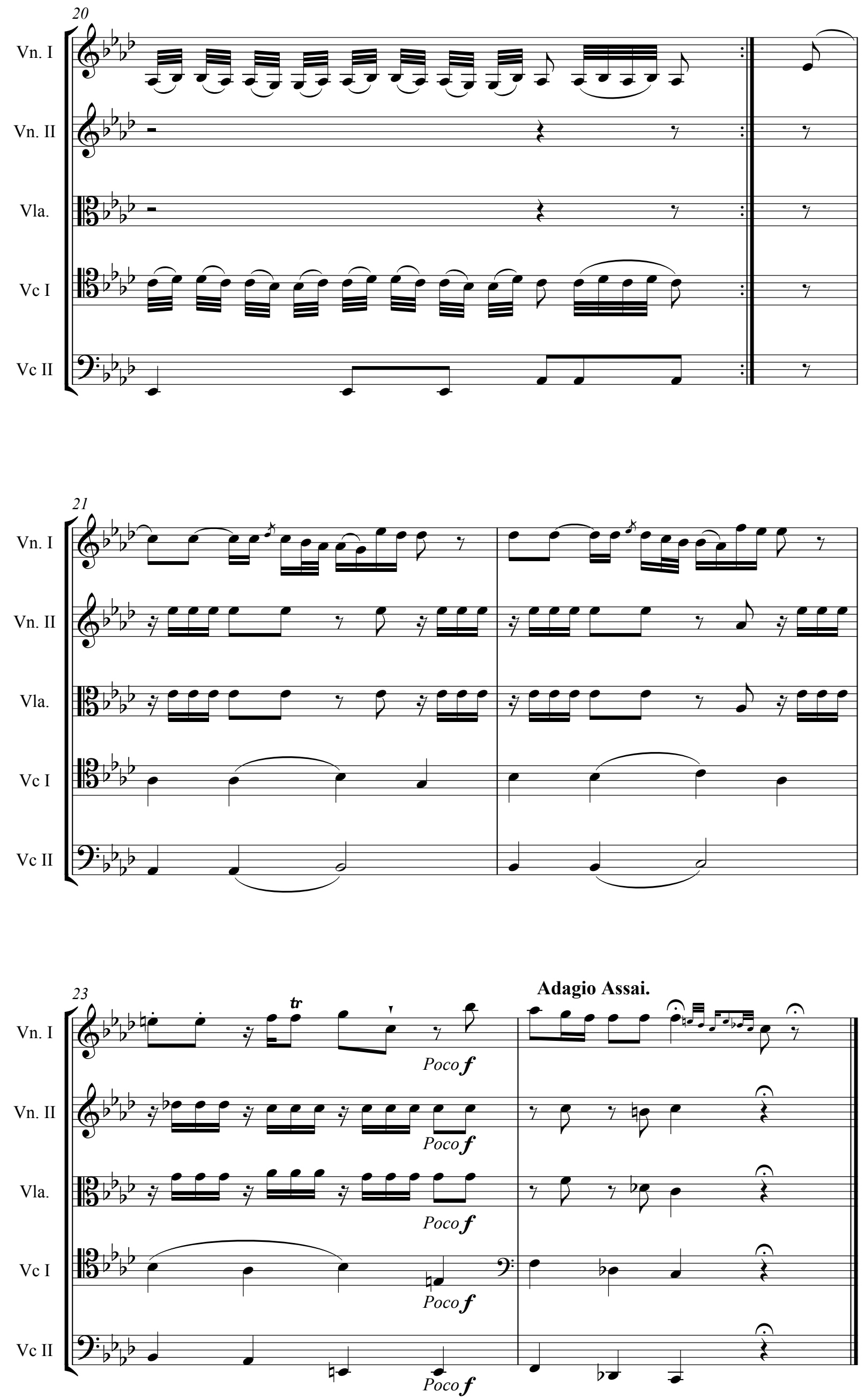
Minuetto
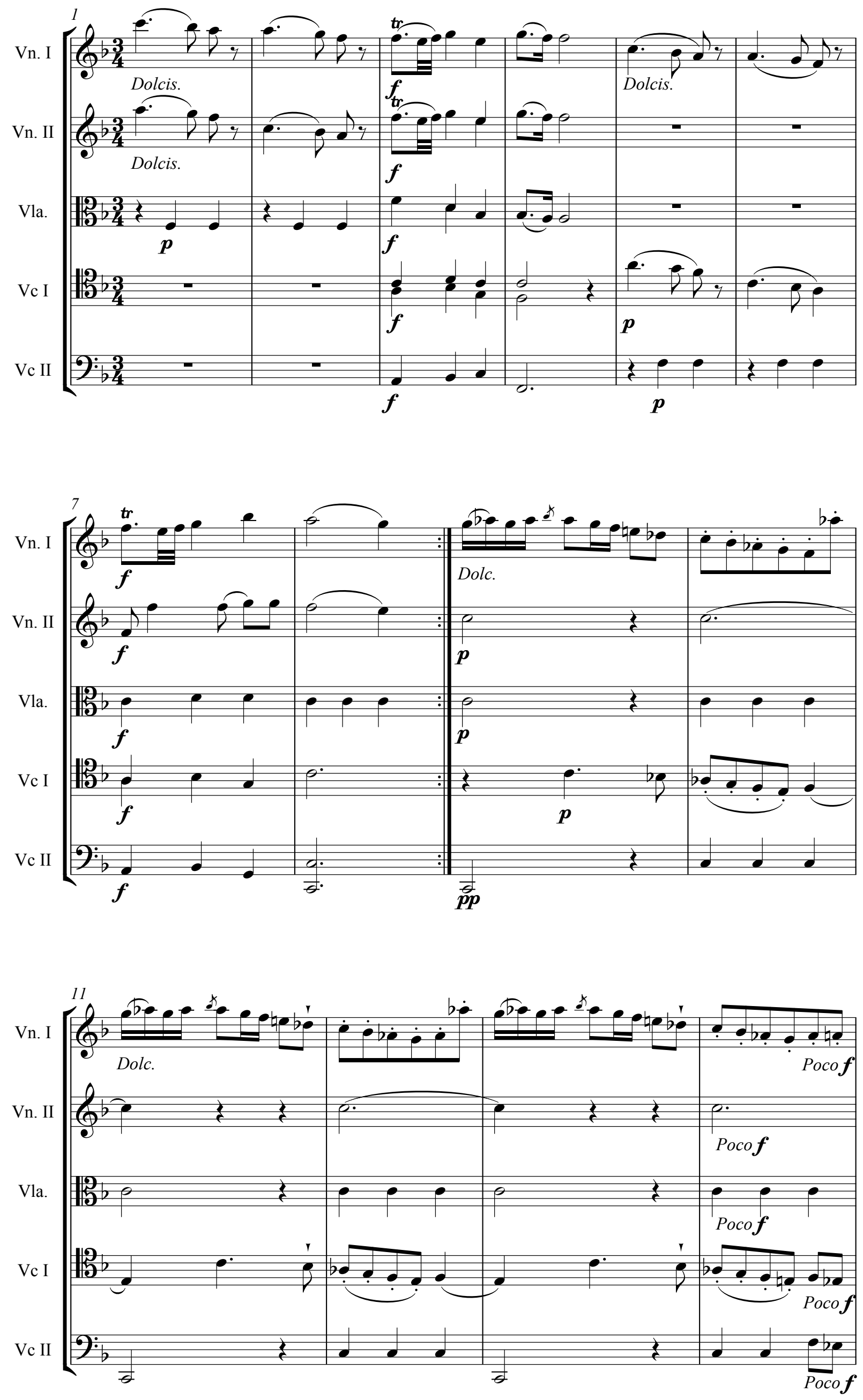

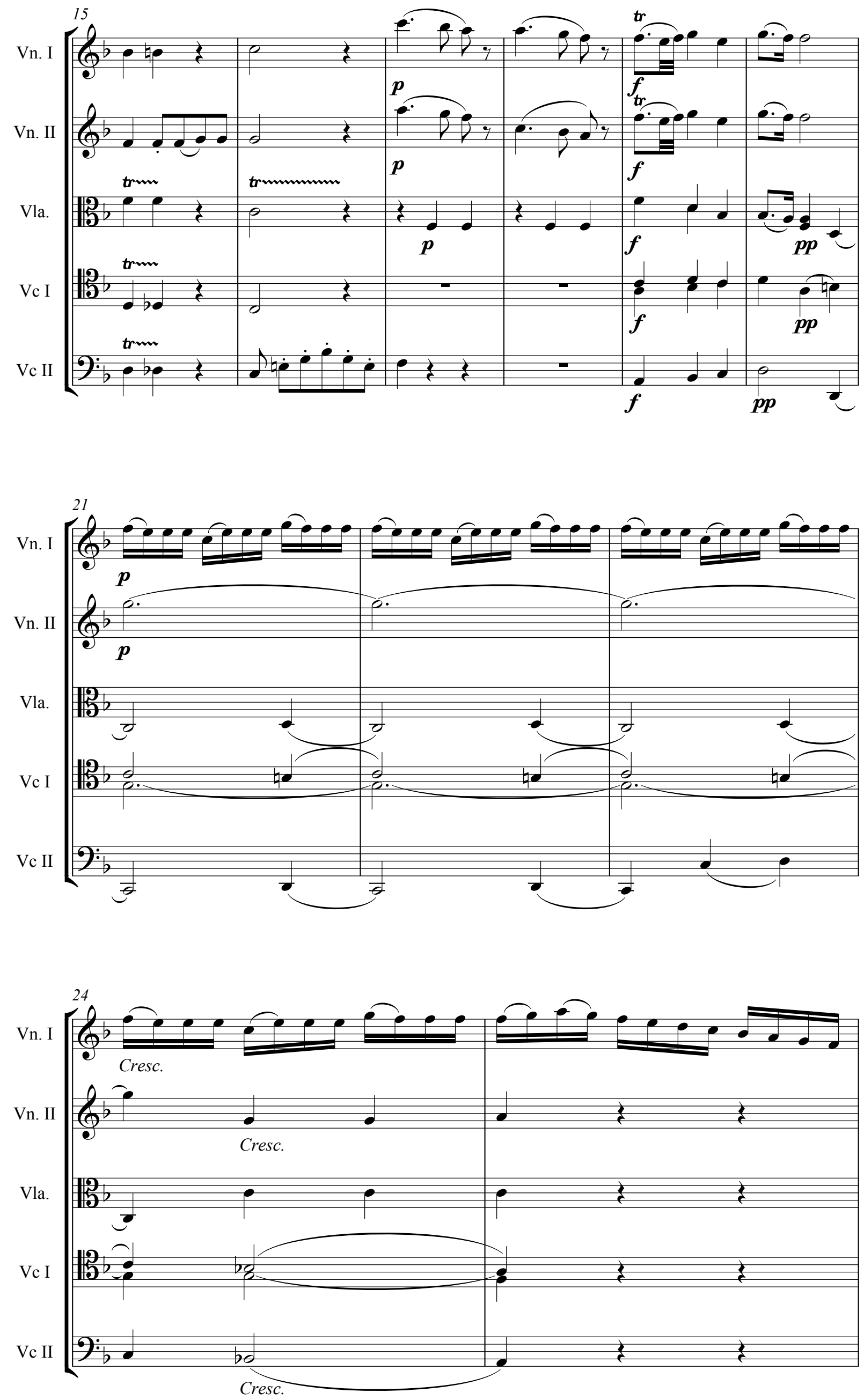


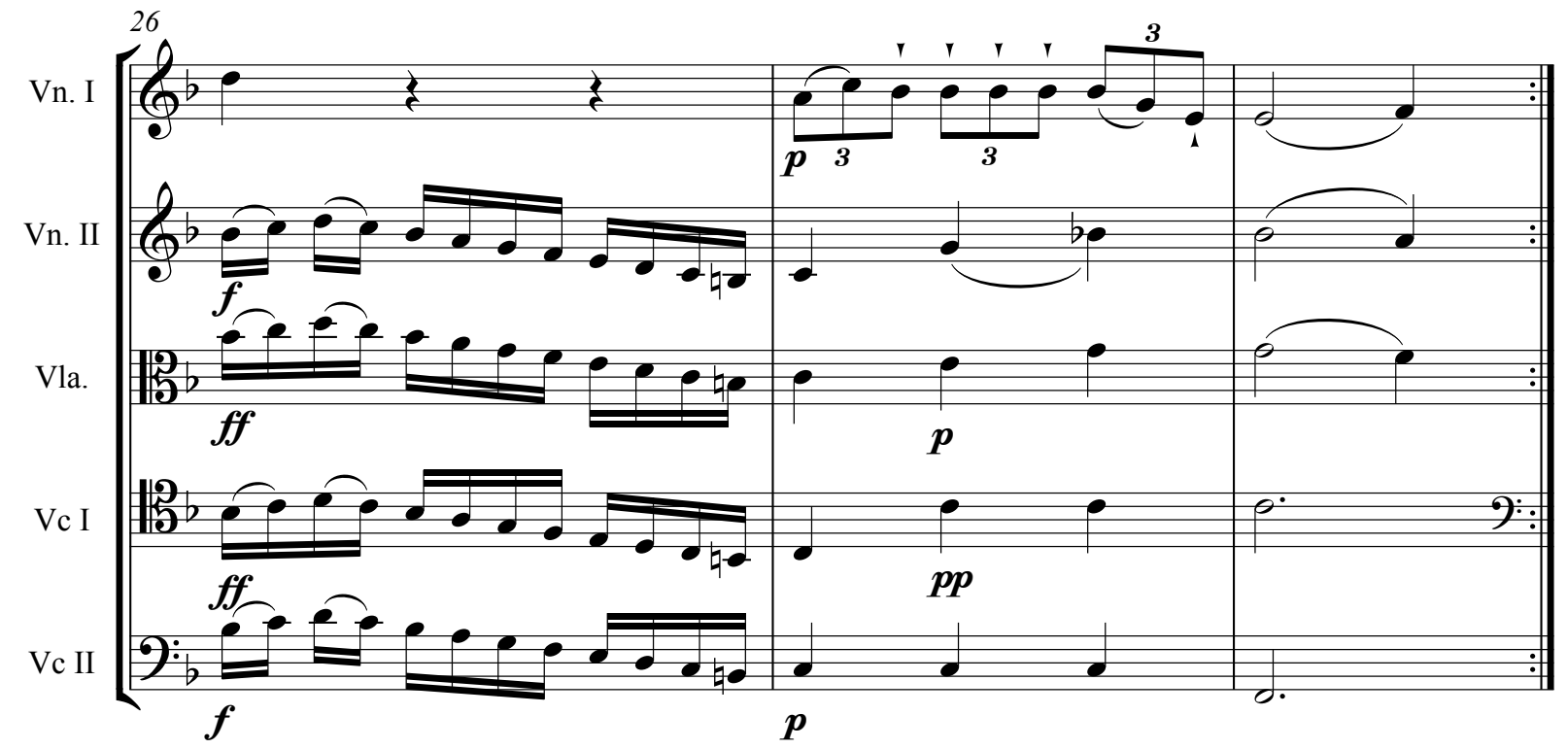

Trio.
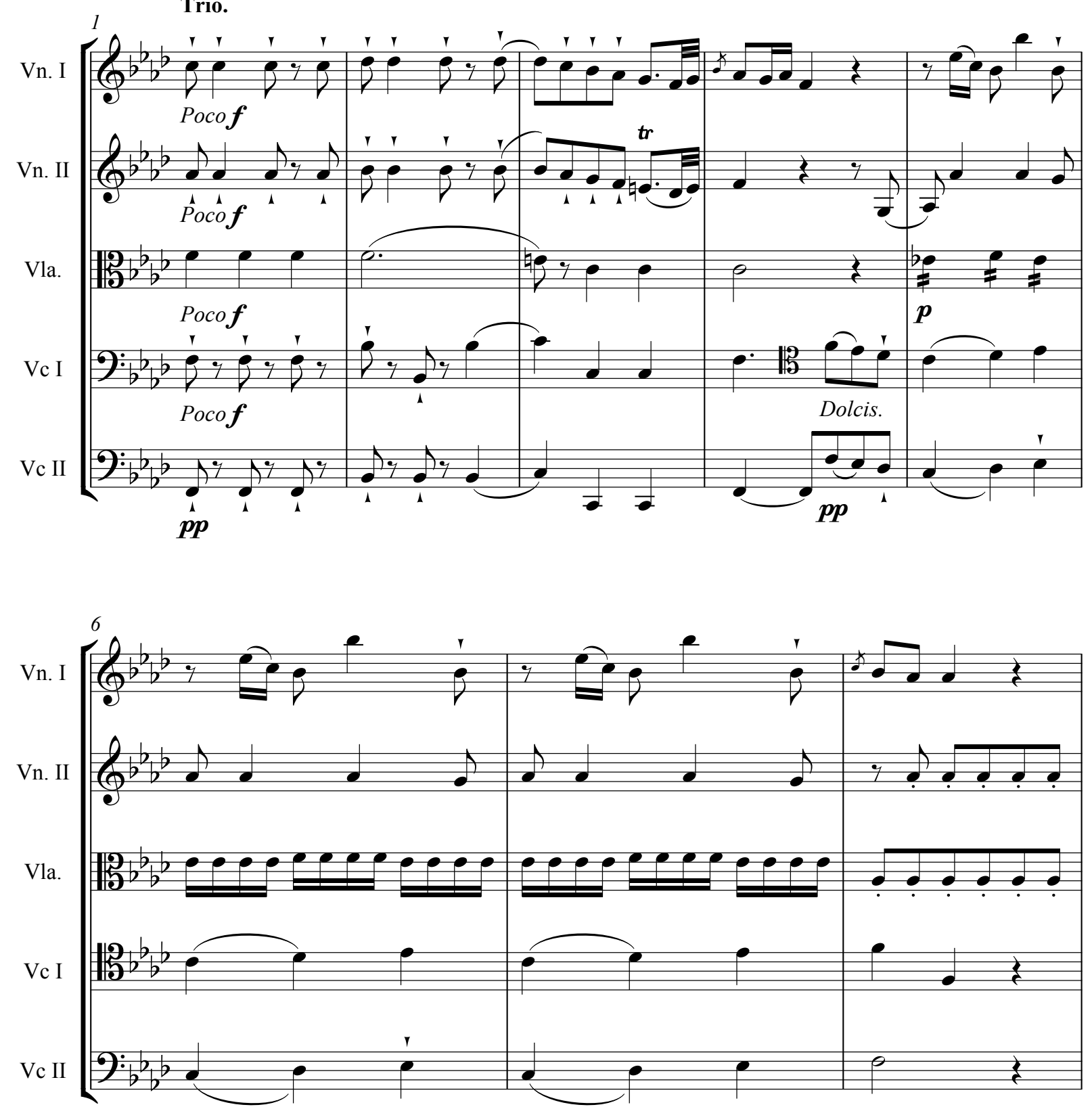

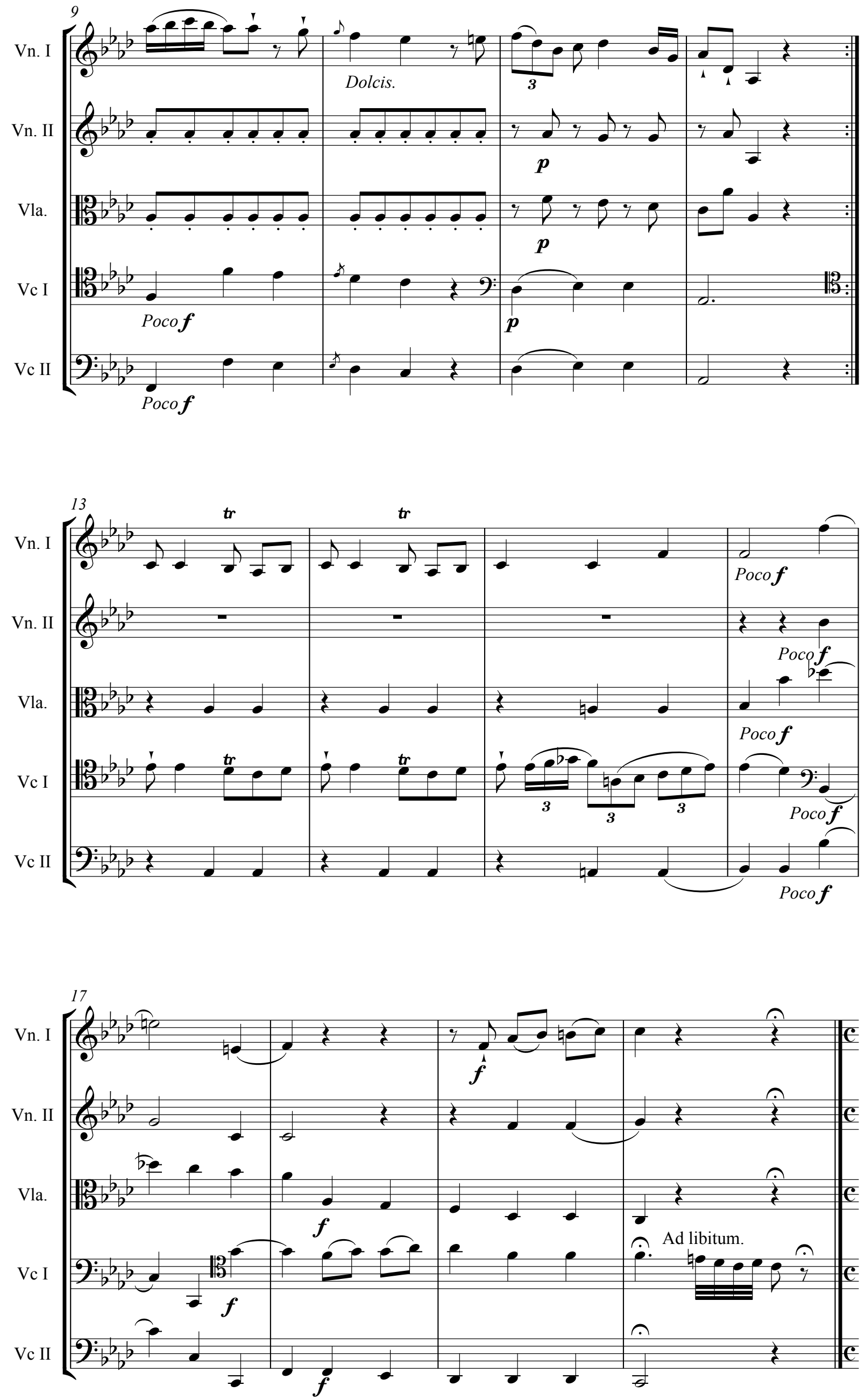
Finale

Allegro Vivo
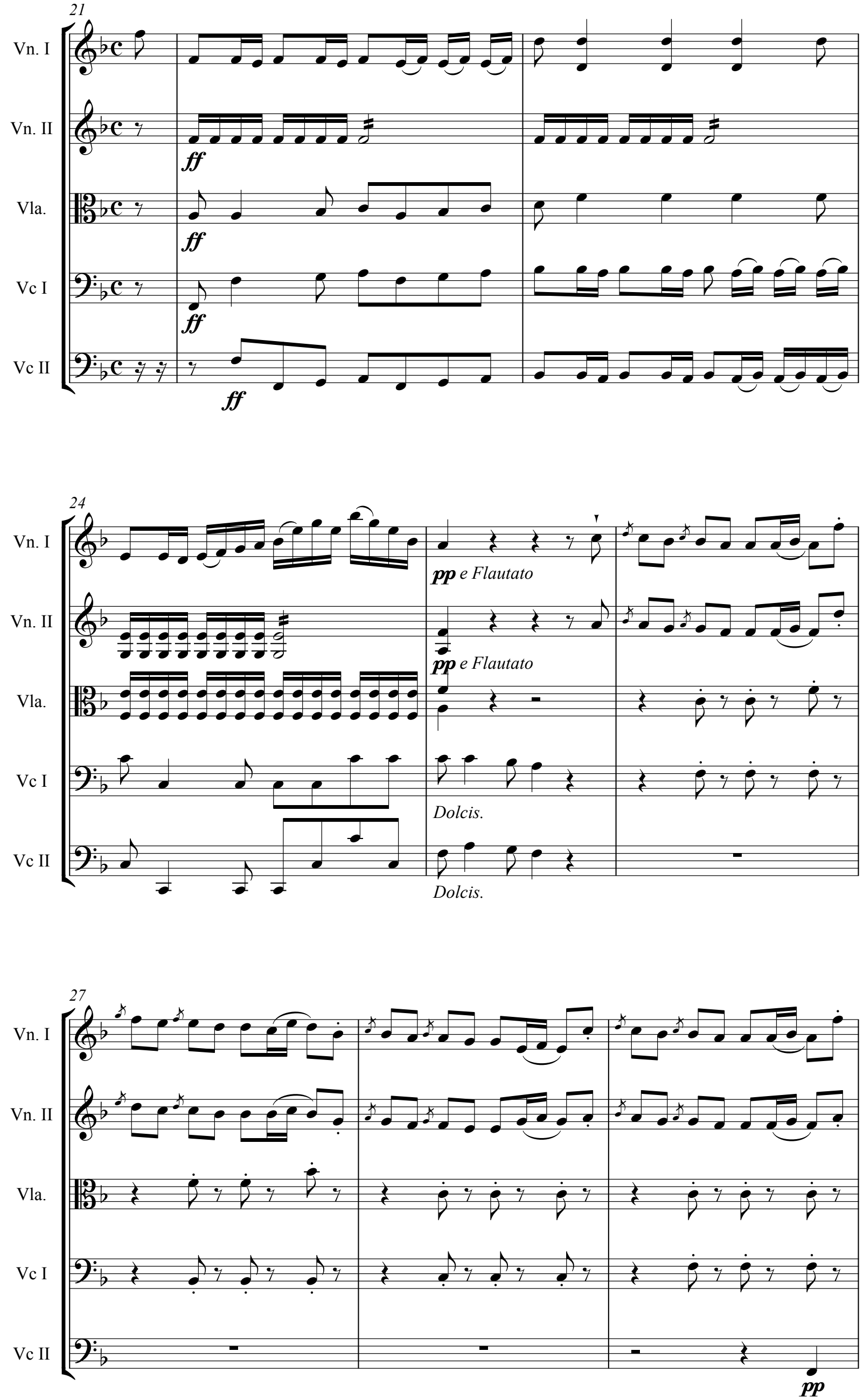

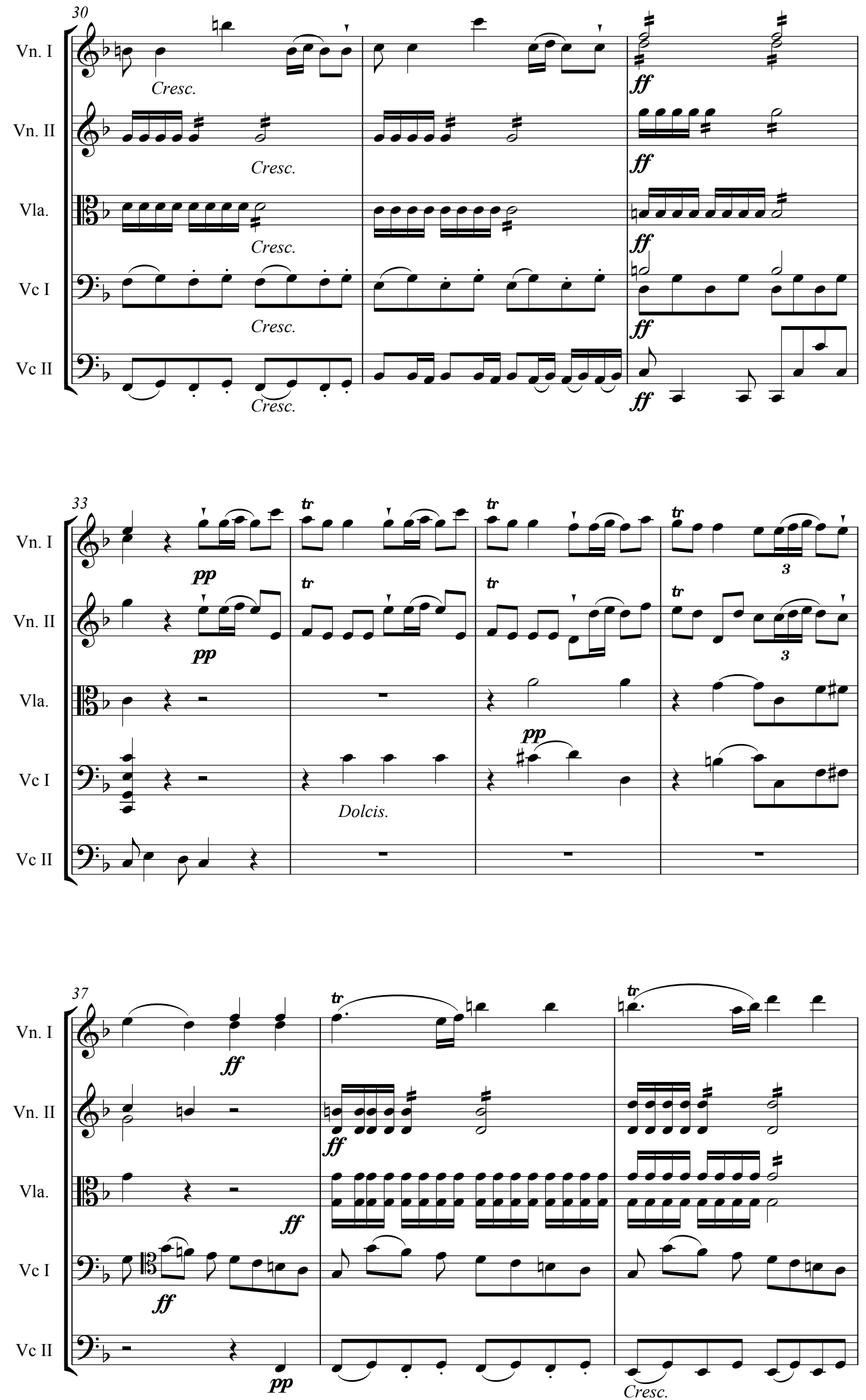

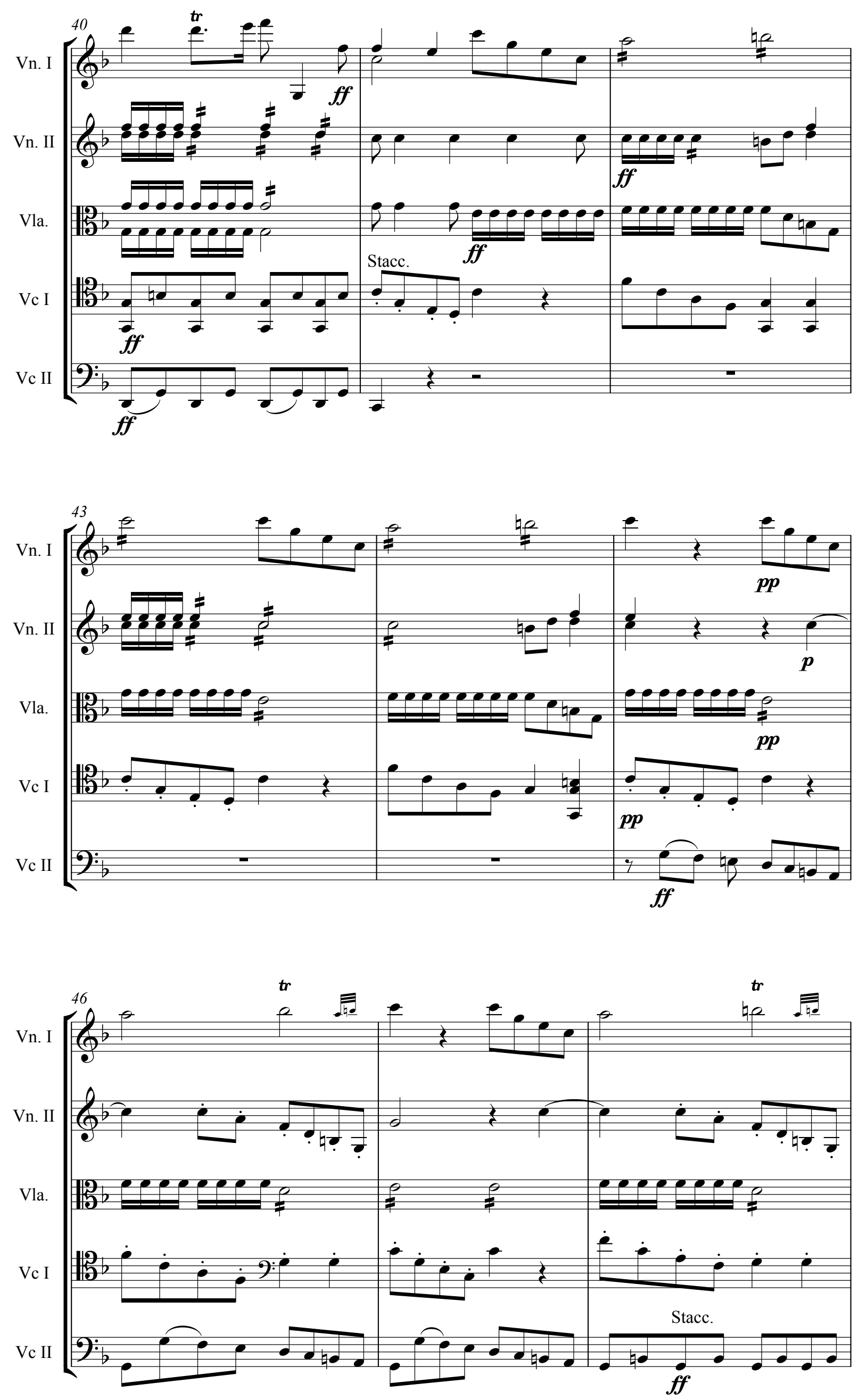

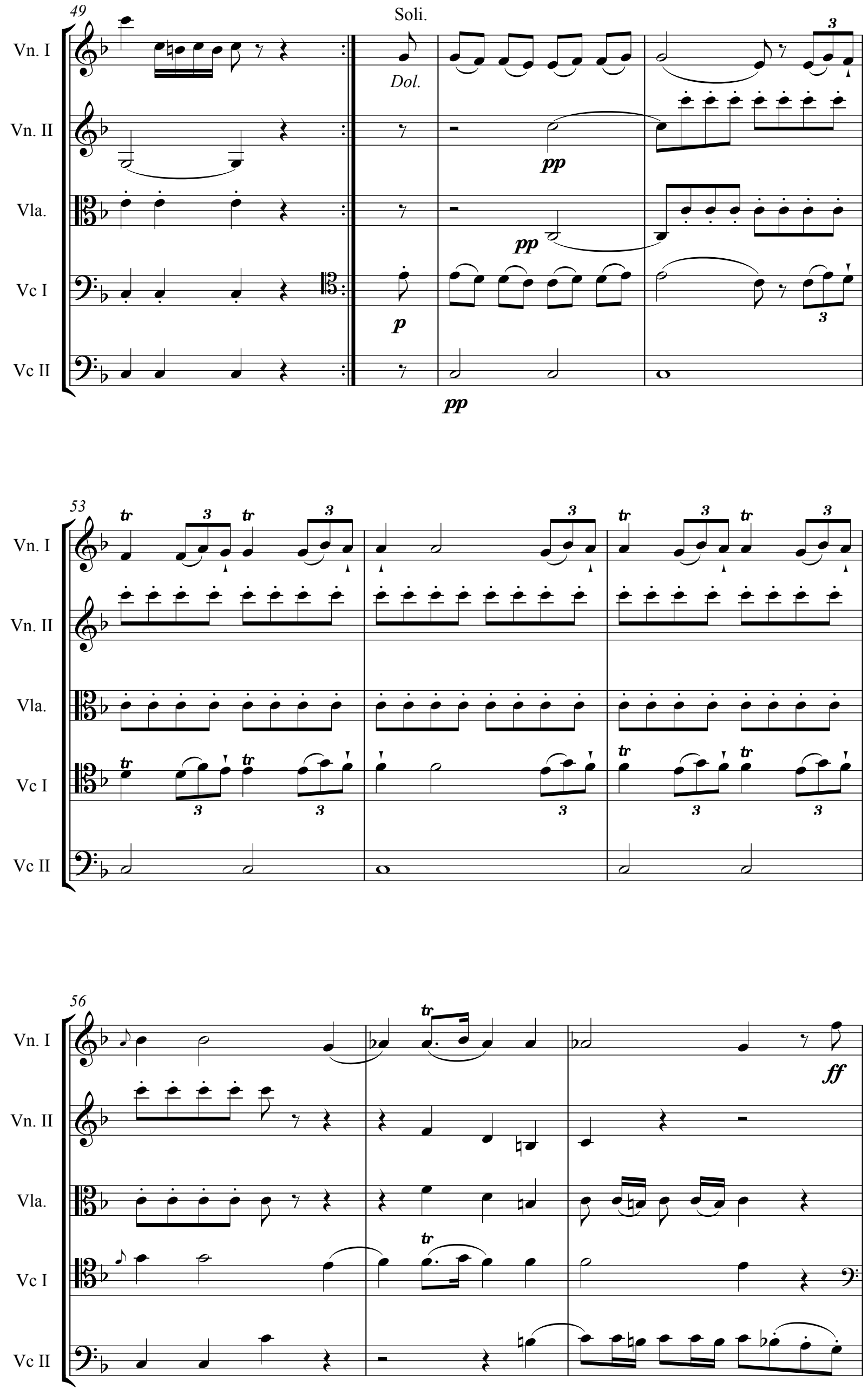

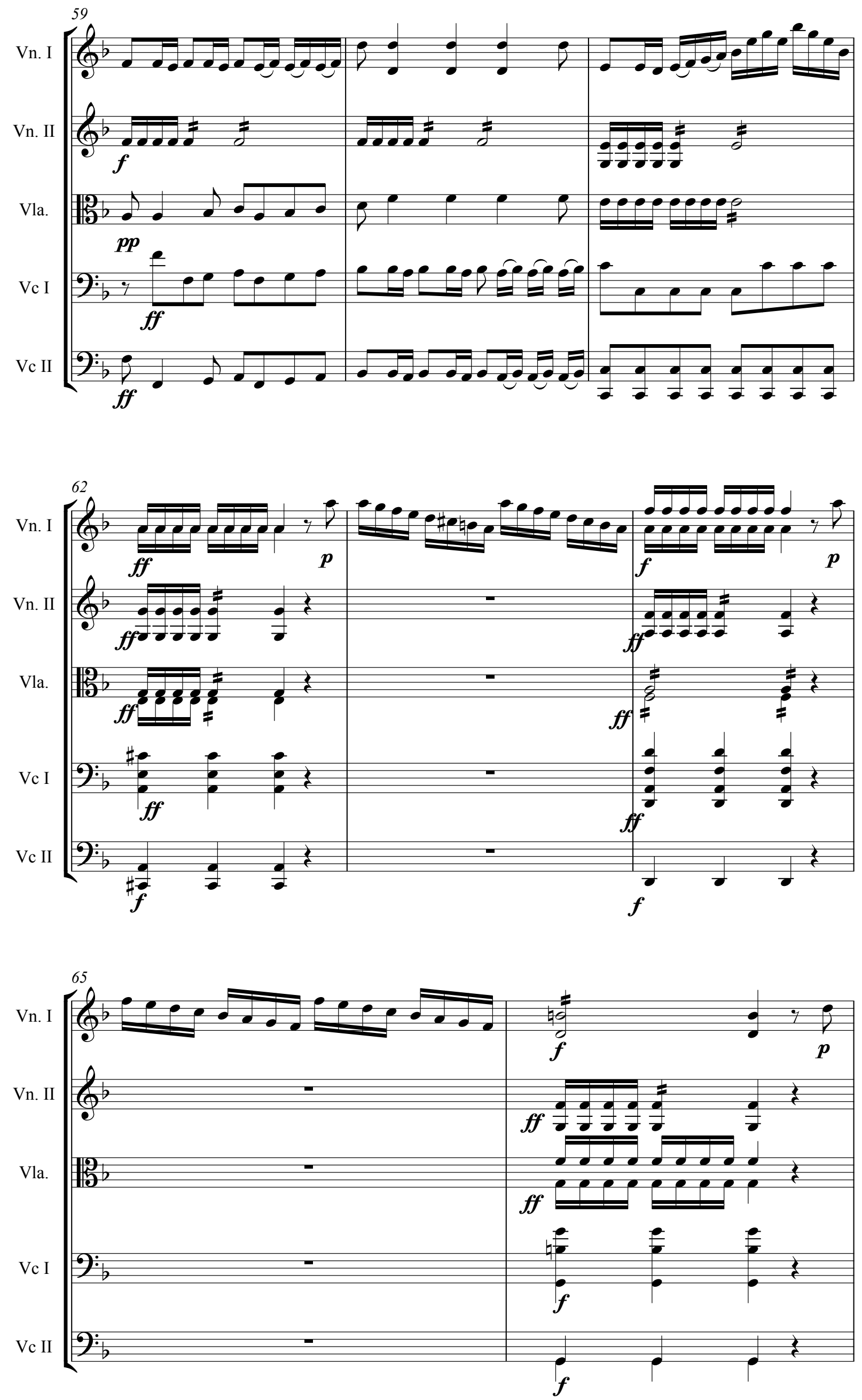

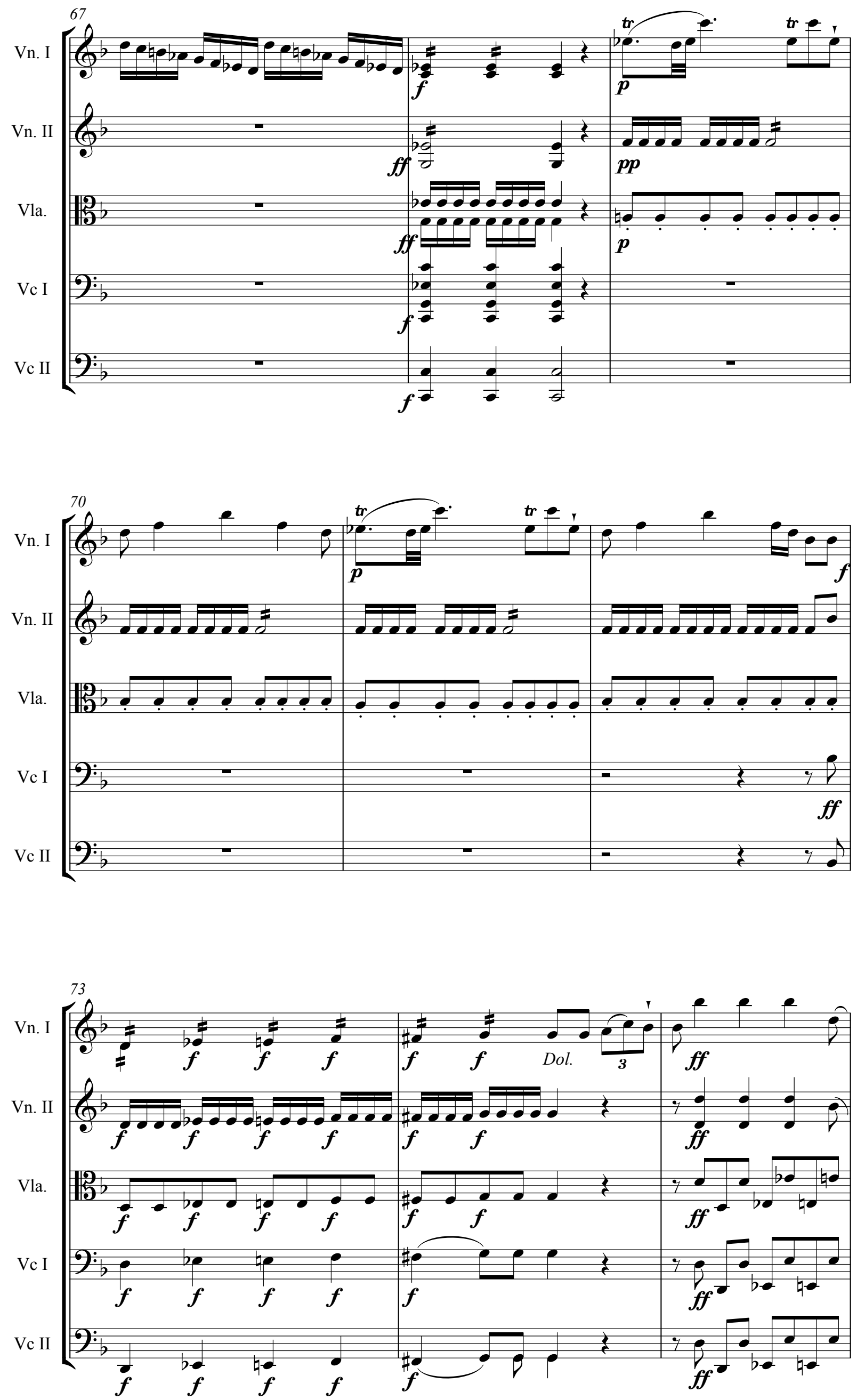

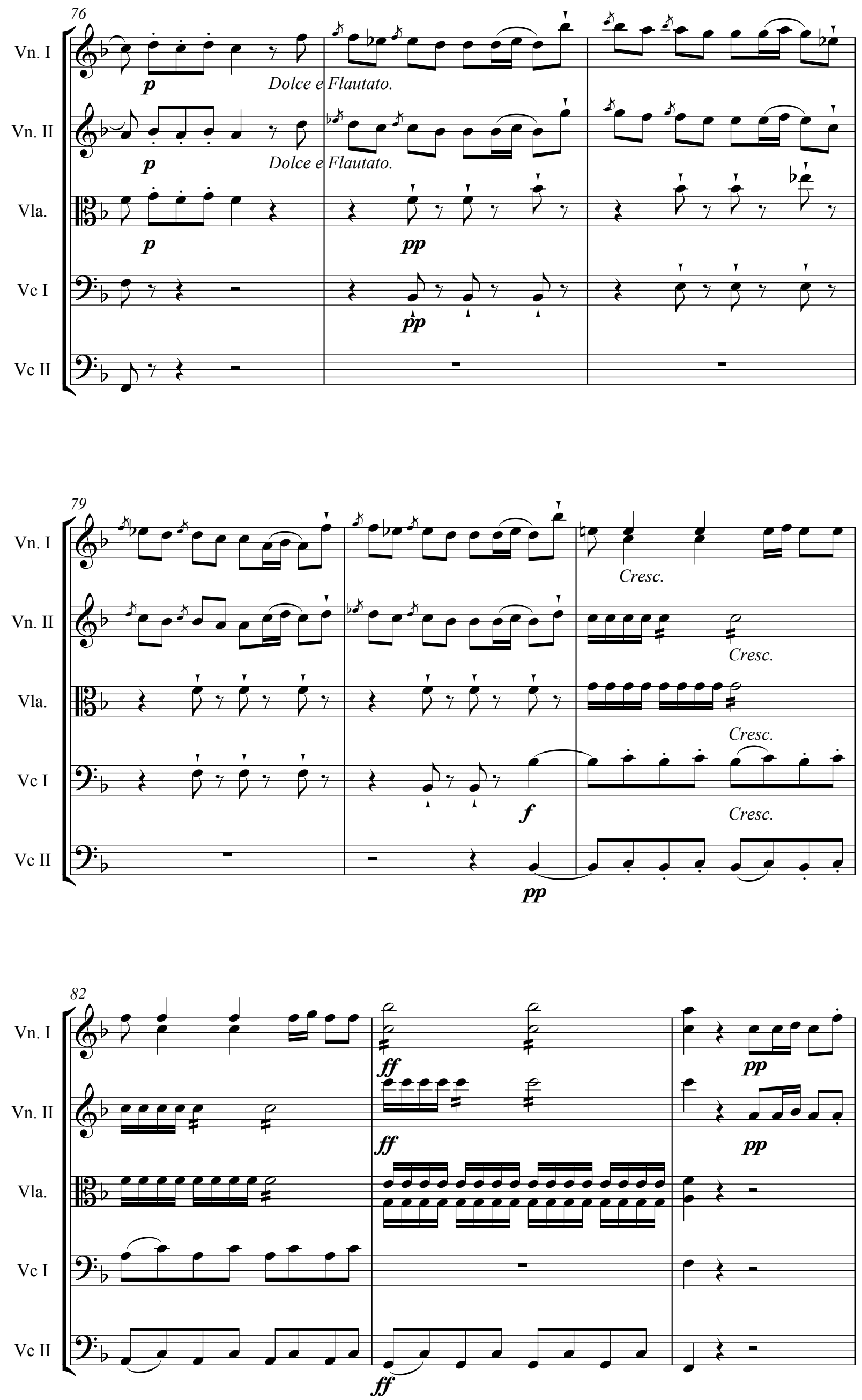

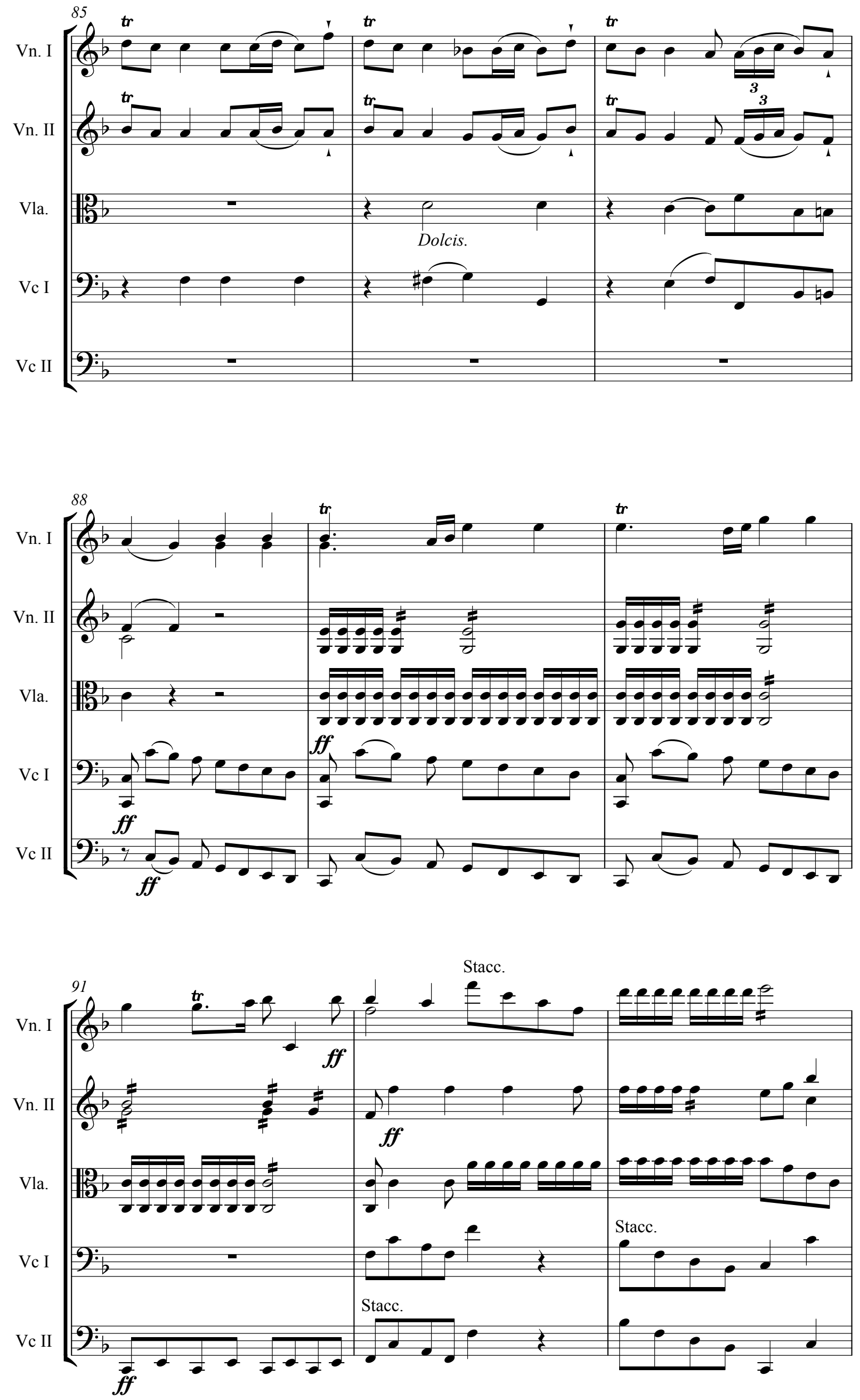

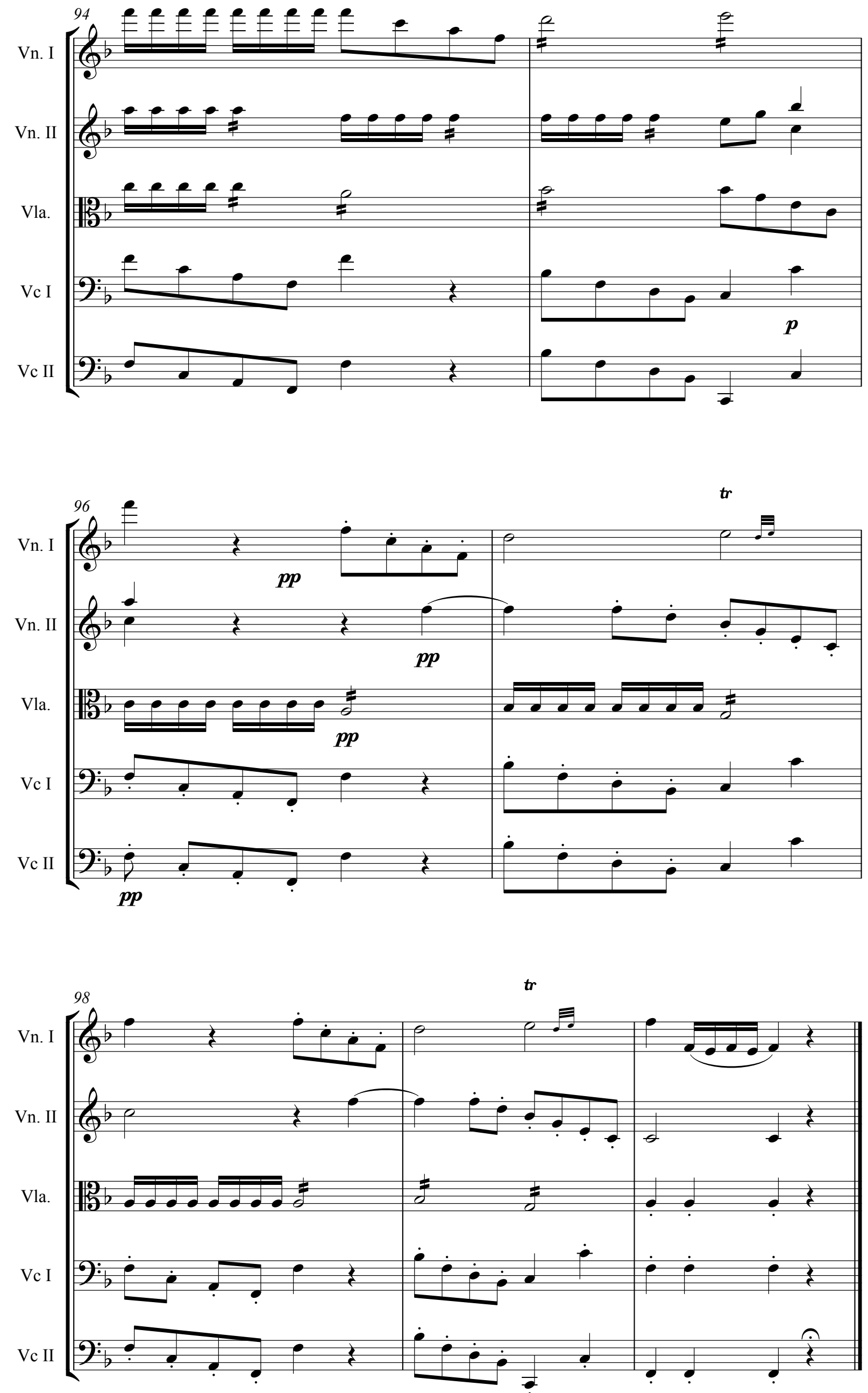

2.3. José Palomino:

Todos Dizem. Modinha 



\section{José Palomino}

\section{Modinha a solo Todos dizem}

(1801)

BNE M 2261

ff. 35 r.- 42 r.
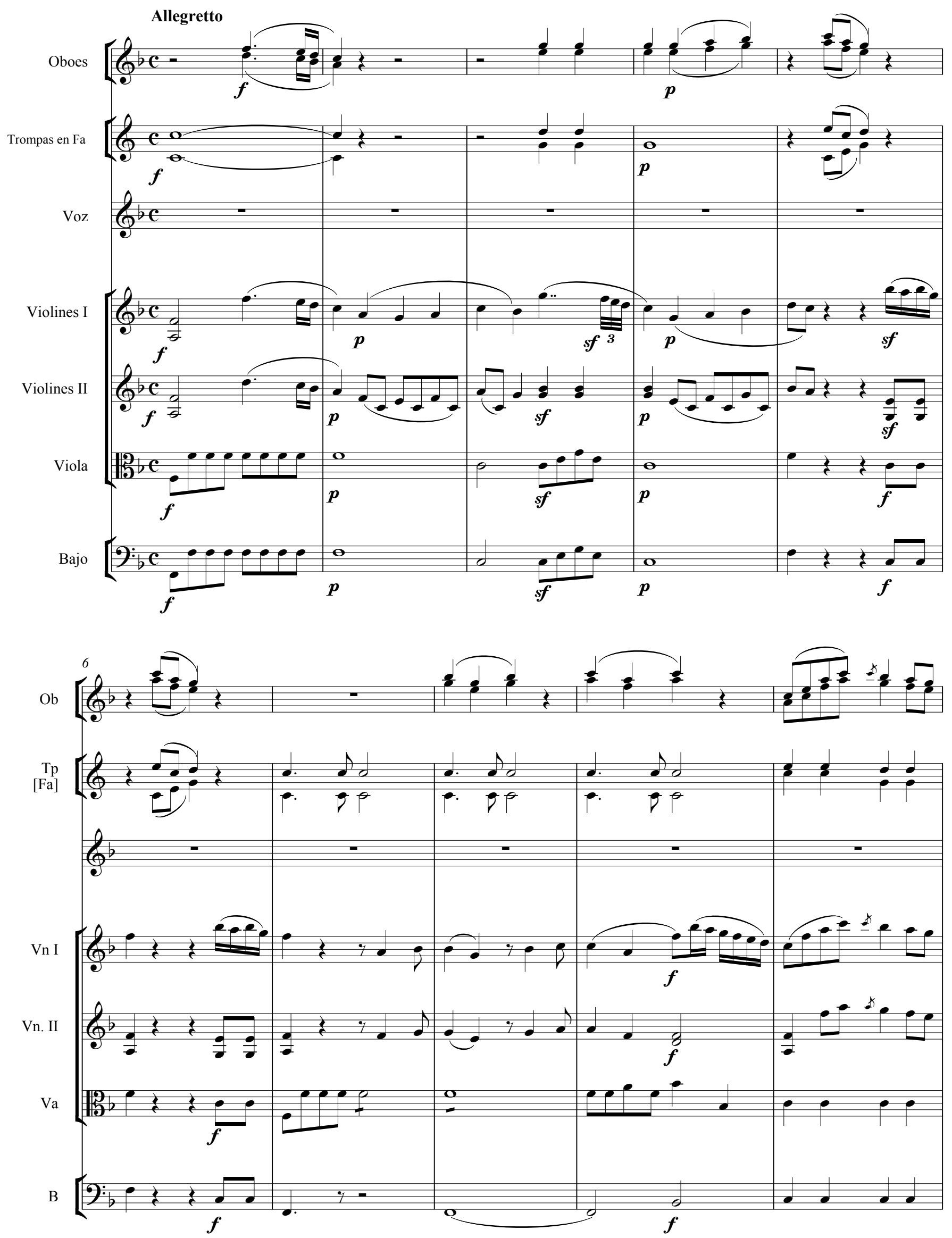

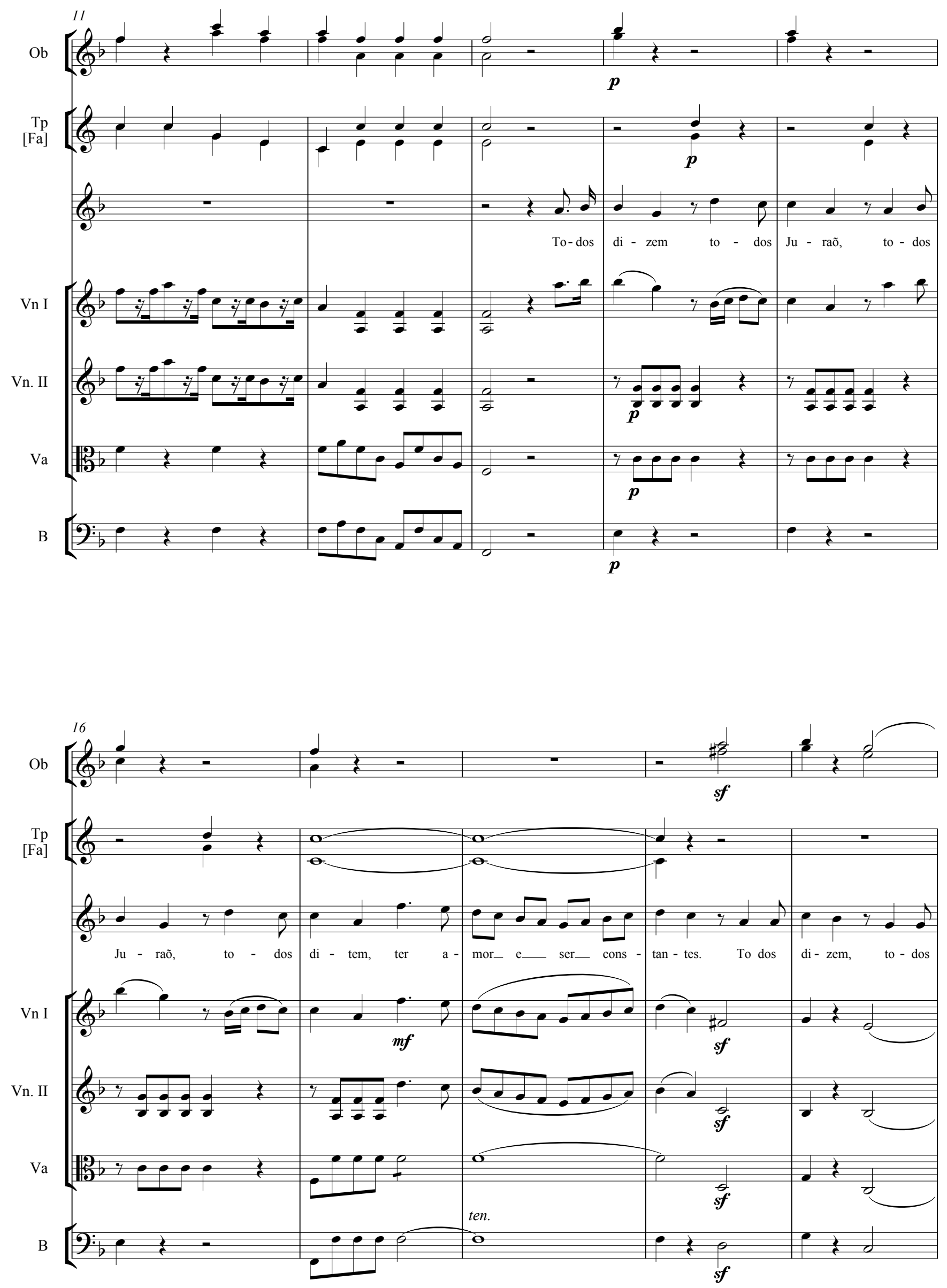

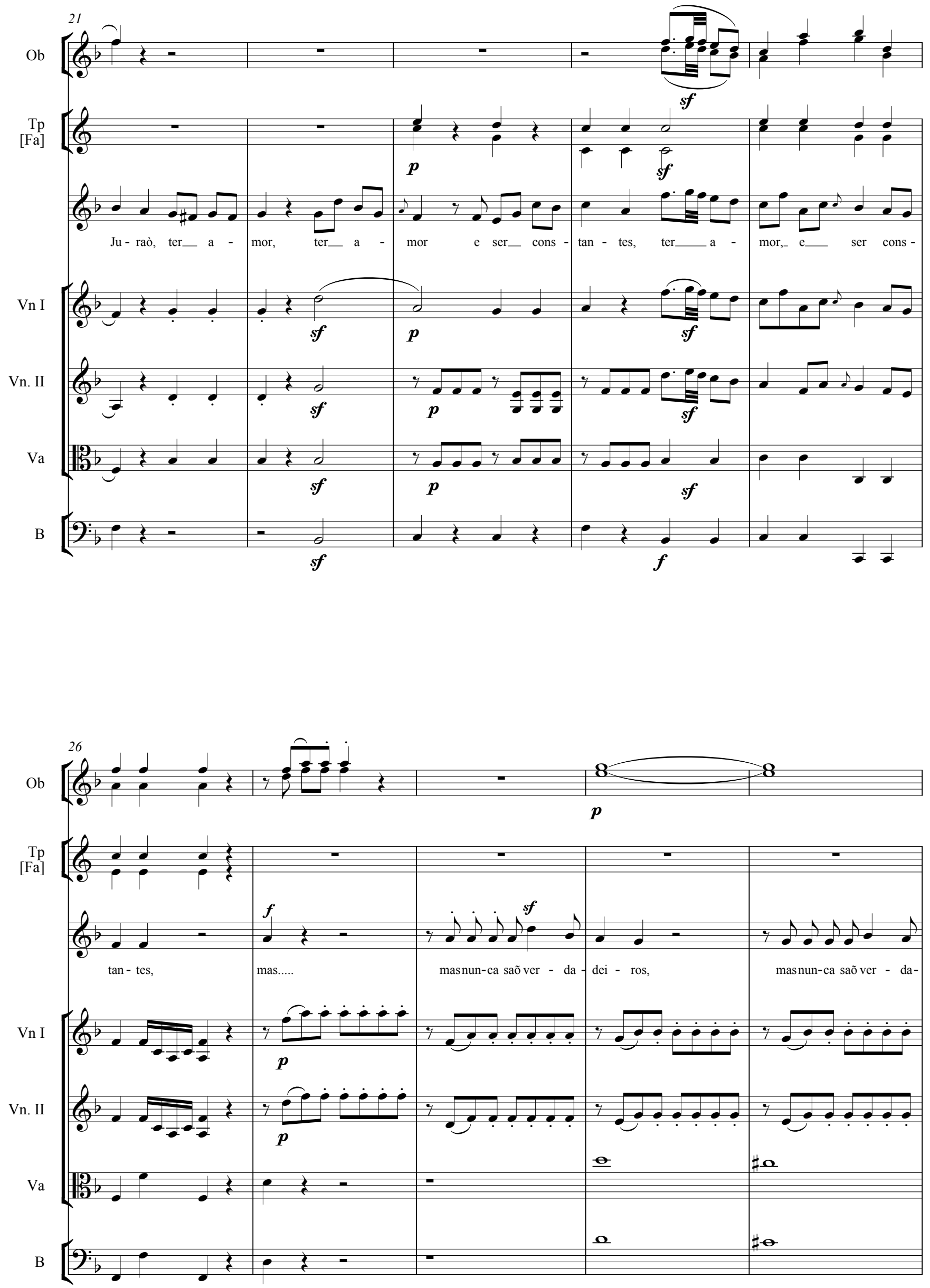

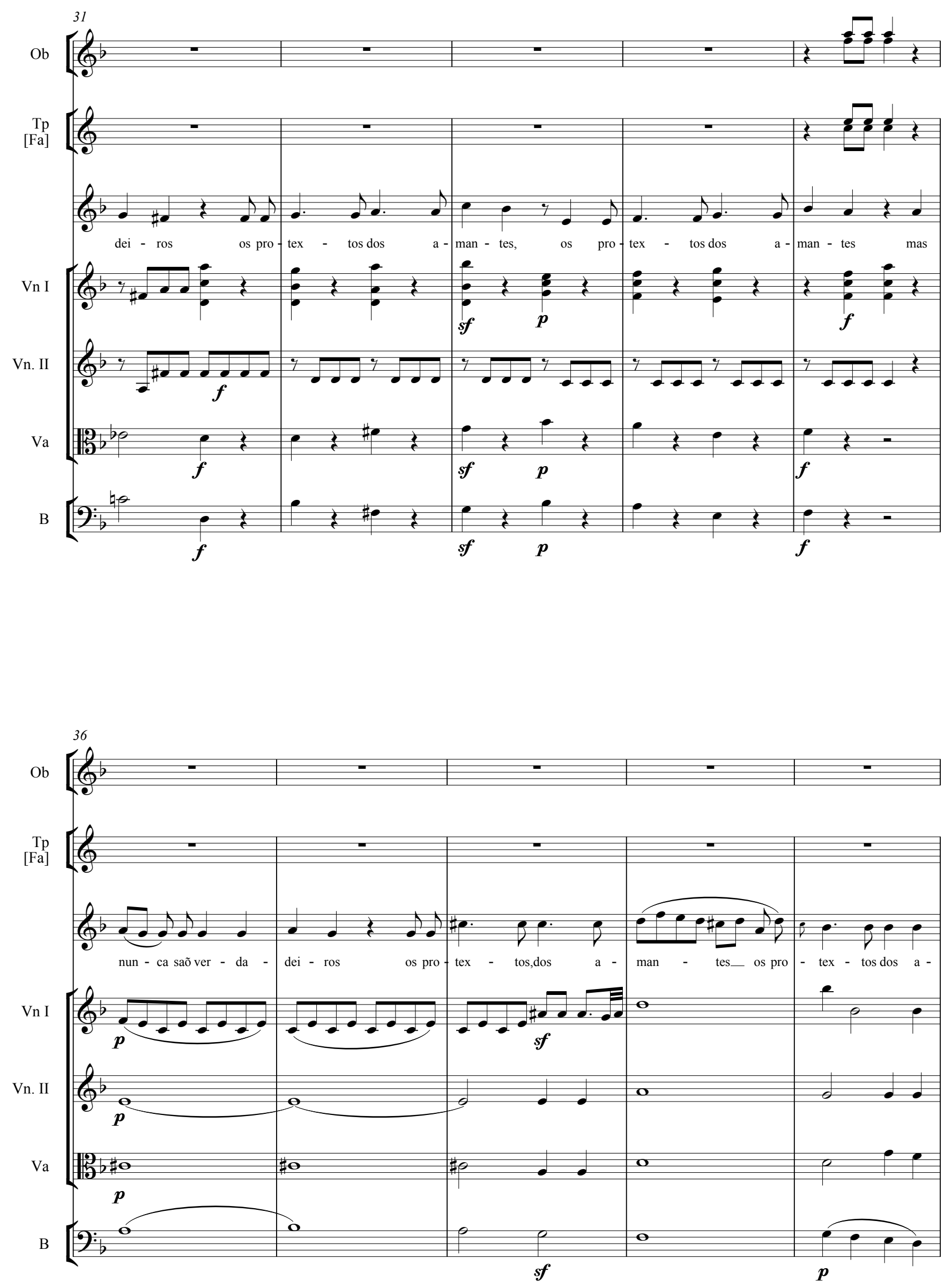

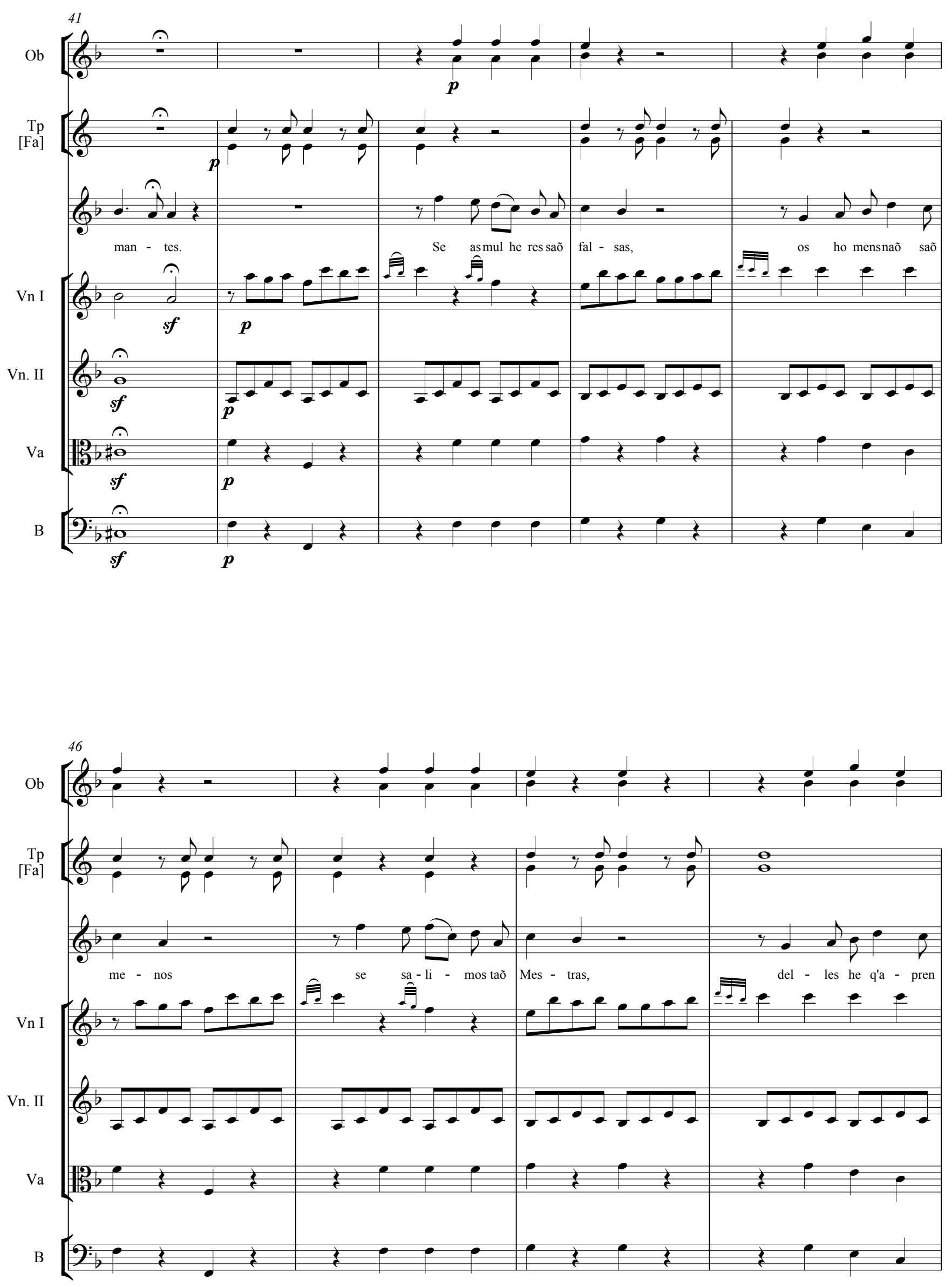

67 
$\mathrm{ob}$
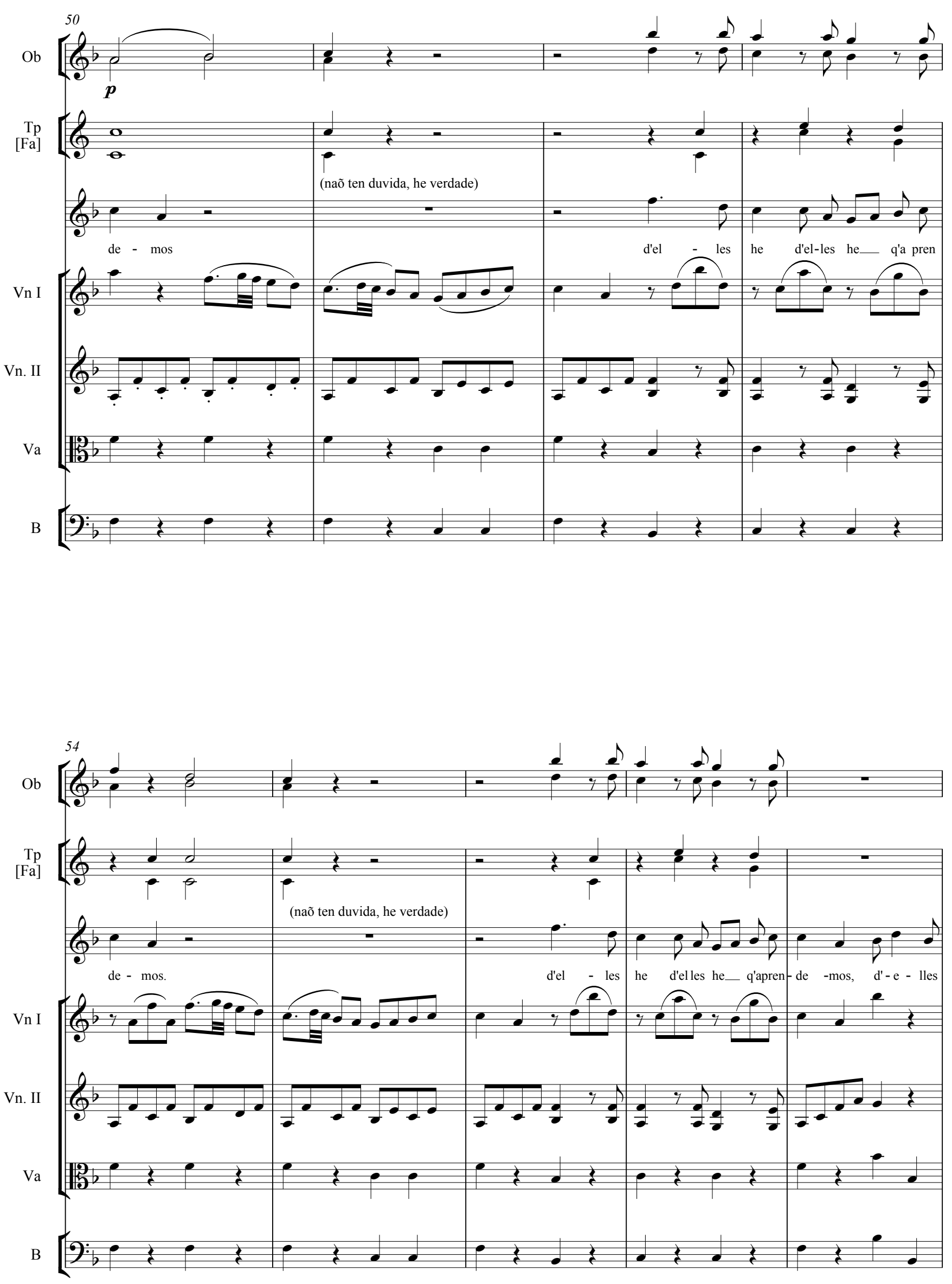

68 

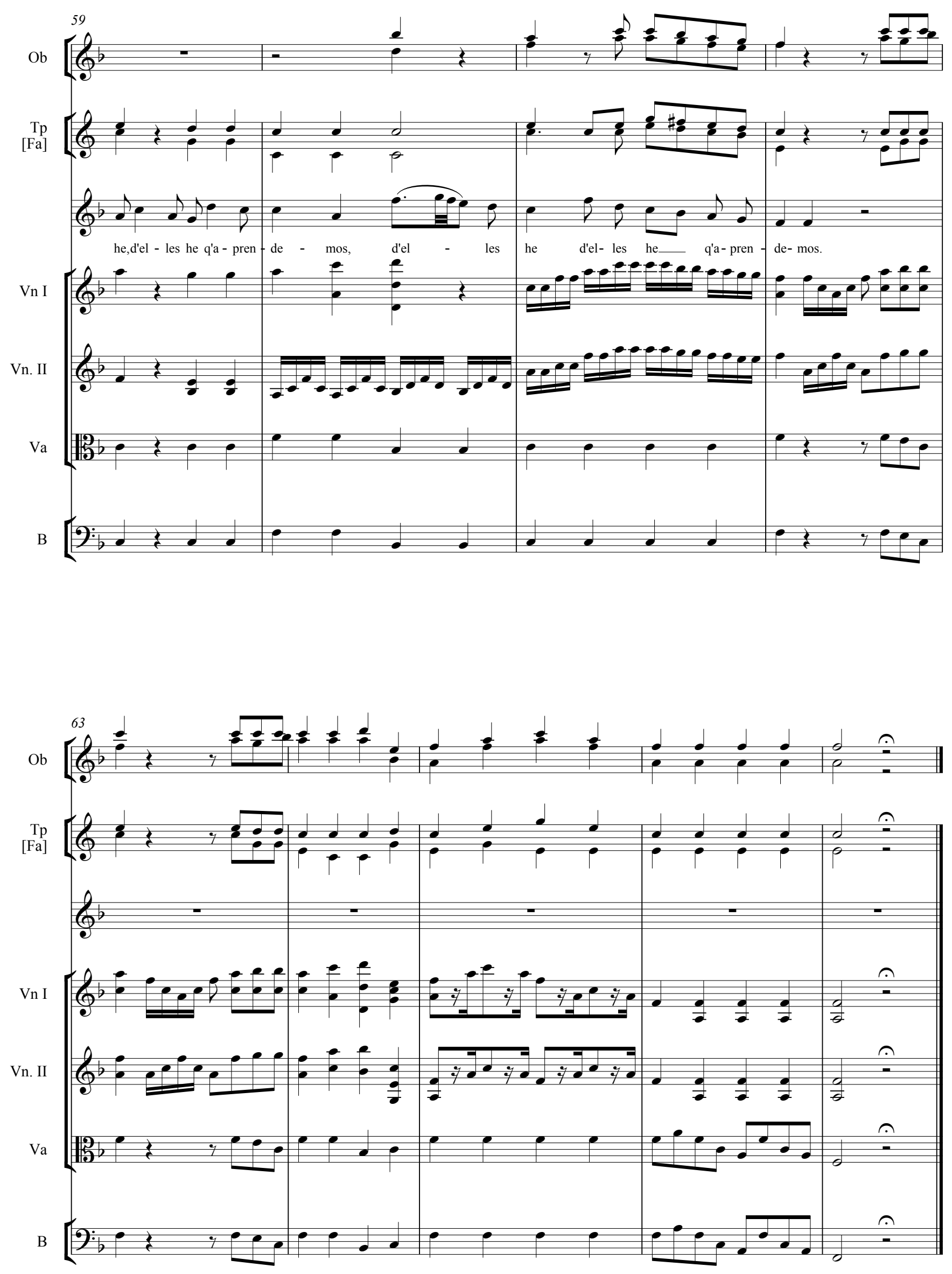



\section{4. Ángelo Inzenga}

La Tomba. Arietta per voce di basso 



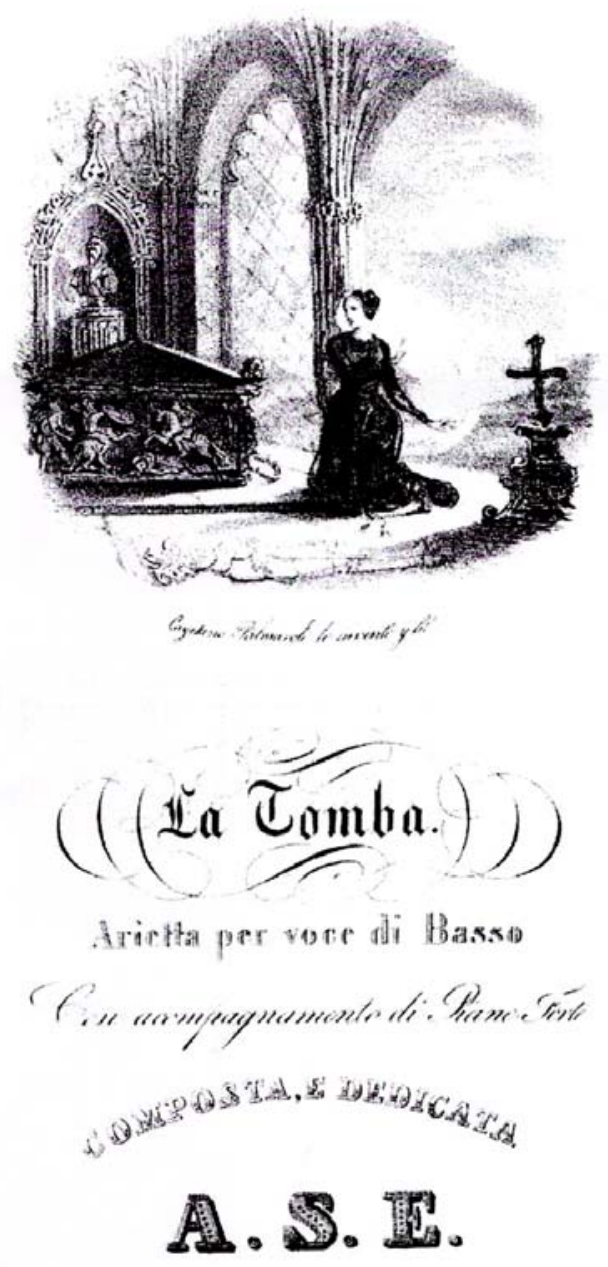

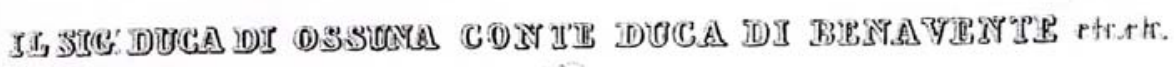

$$
\begin{aligned}
& \text { Origelo tingenga. } \\
& \text { fist en la lat de Paharaly }
\end{aligned}
$$

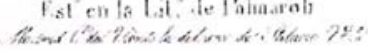

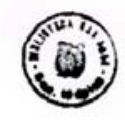


2 .

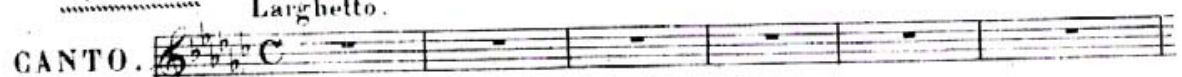
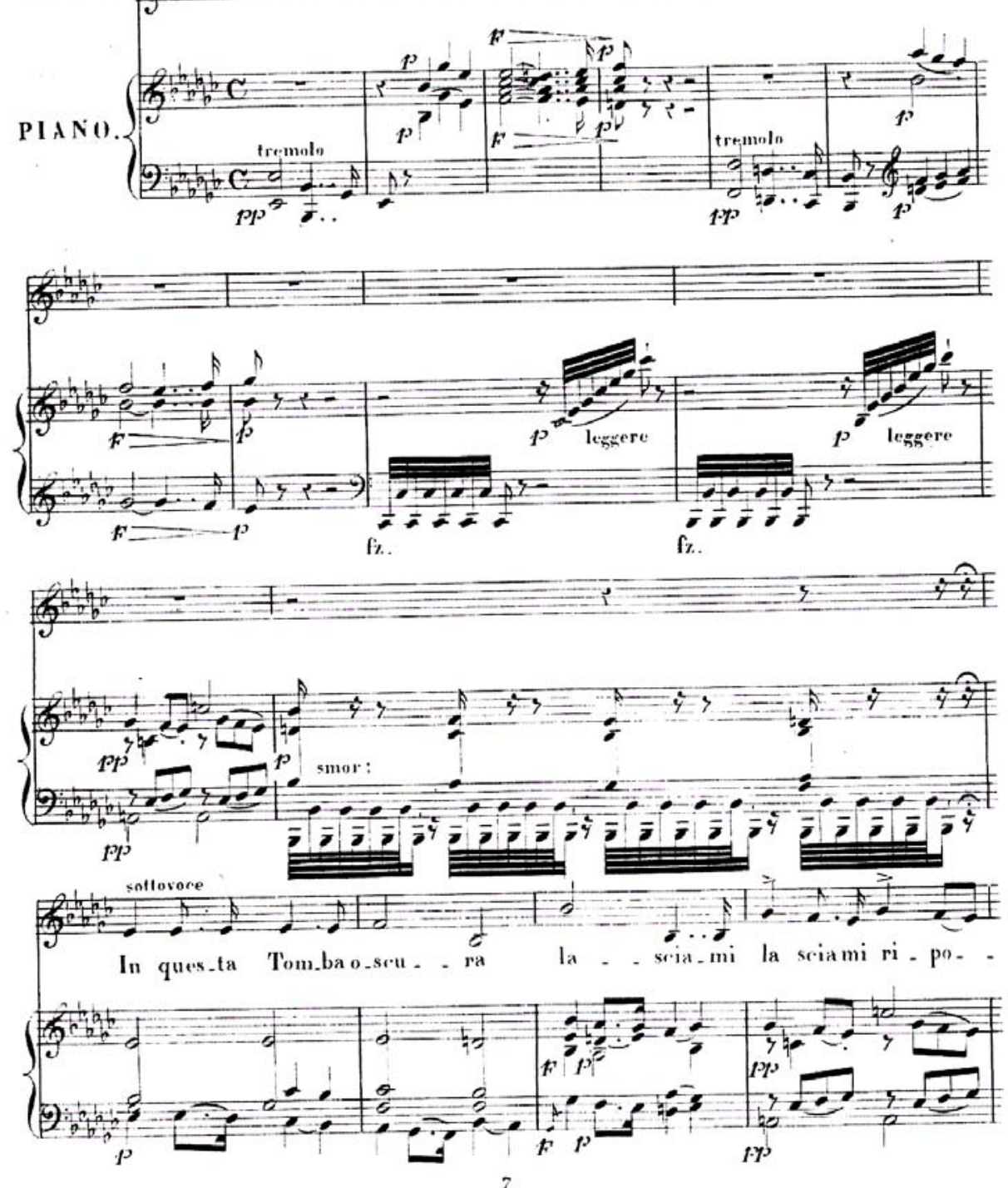


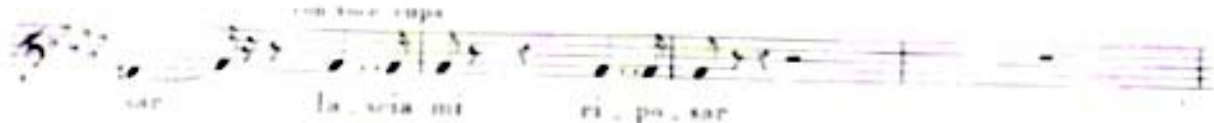

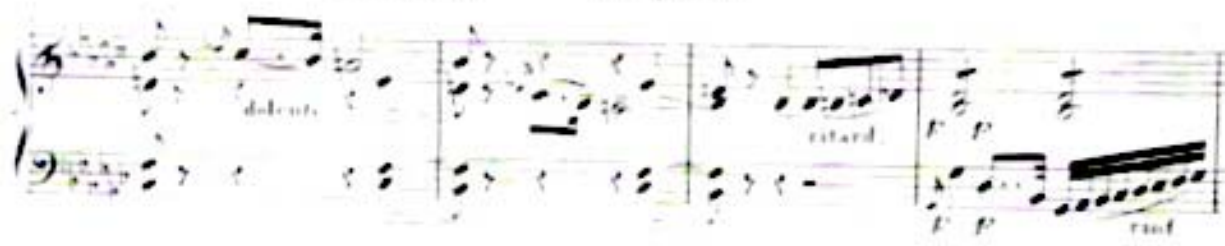

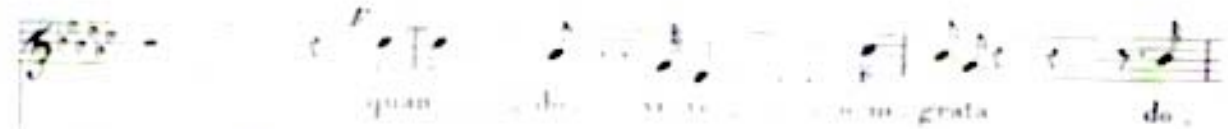

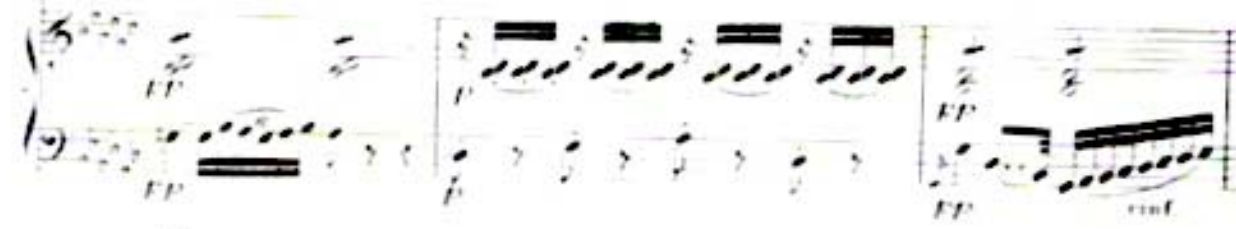

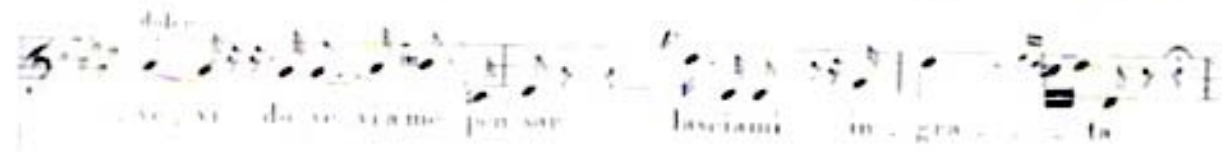

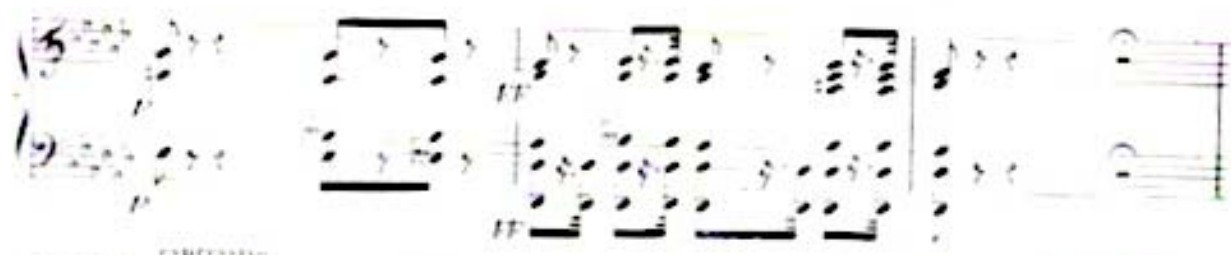

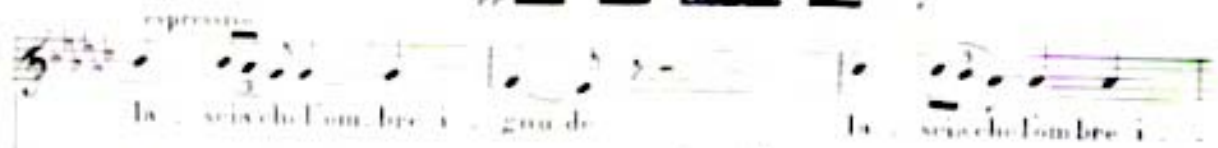

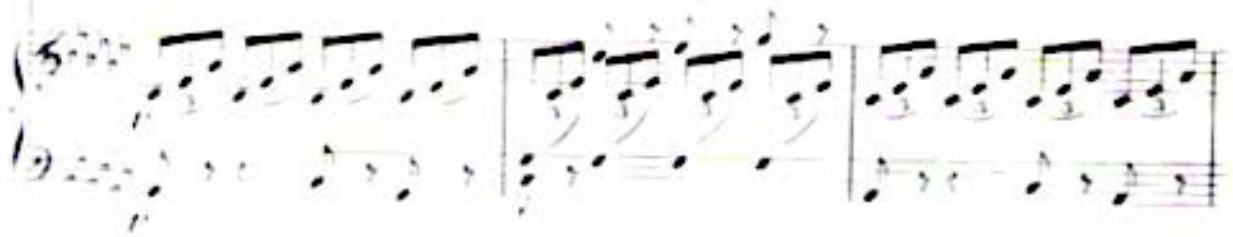



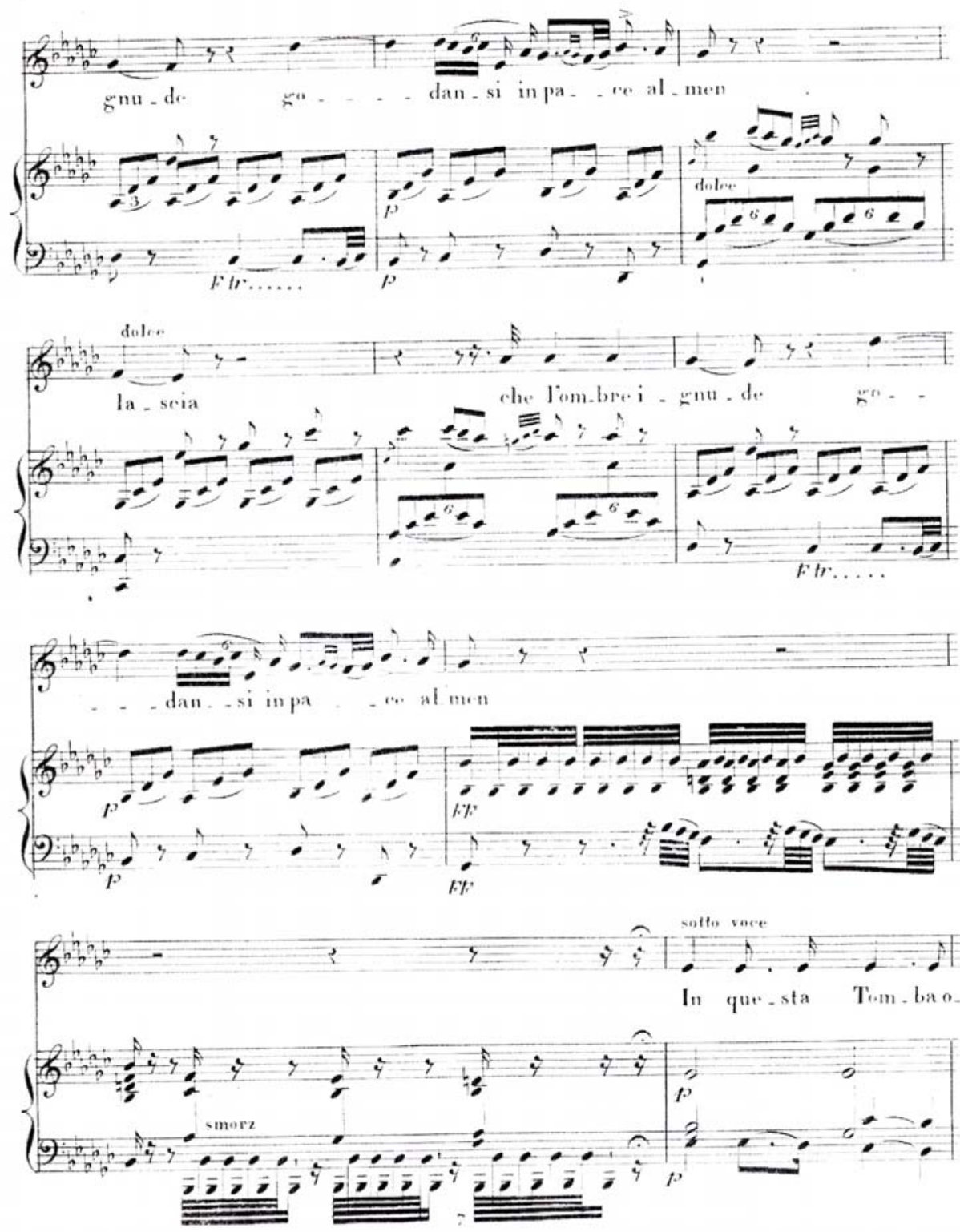
5
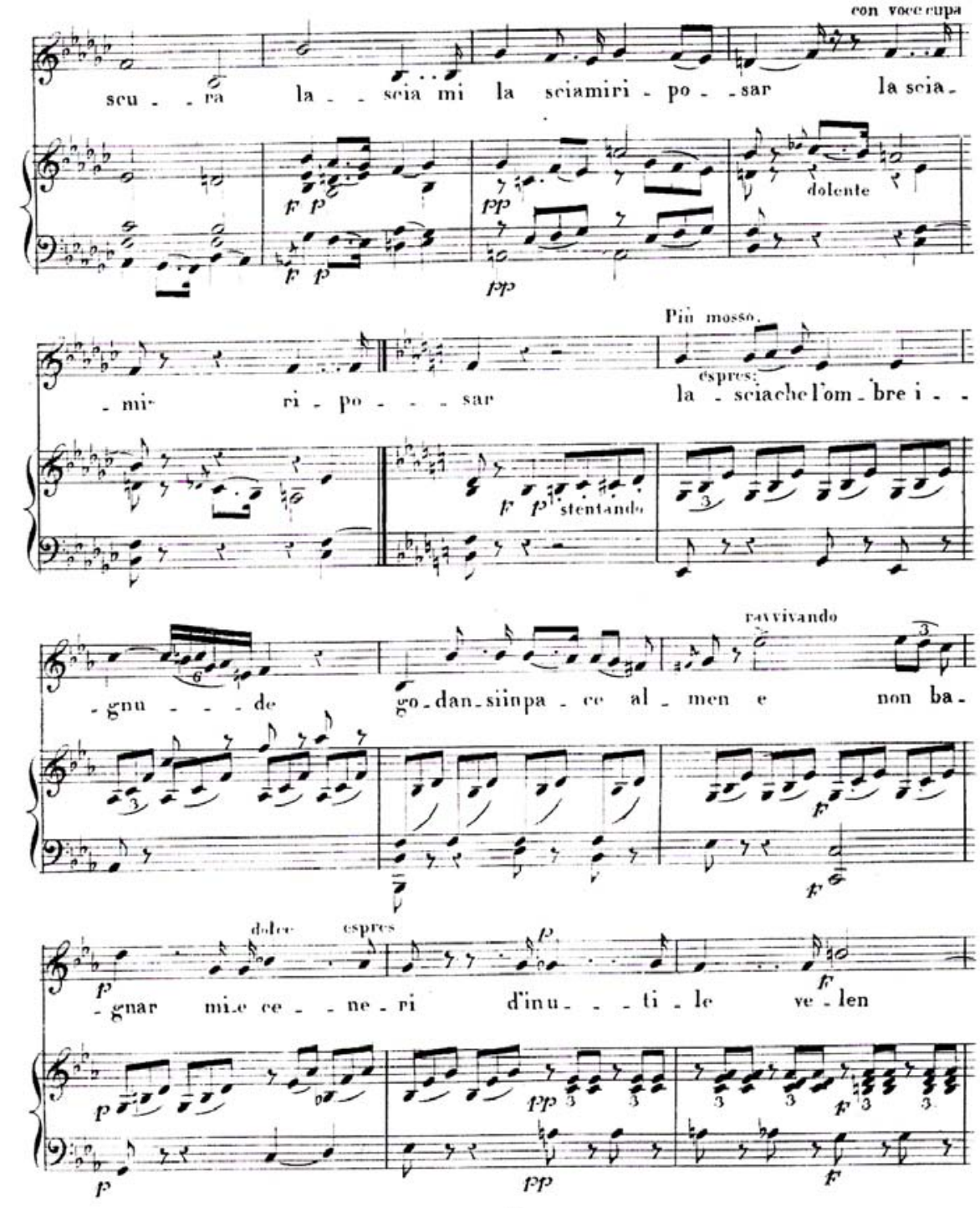


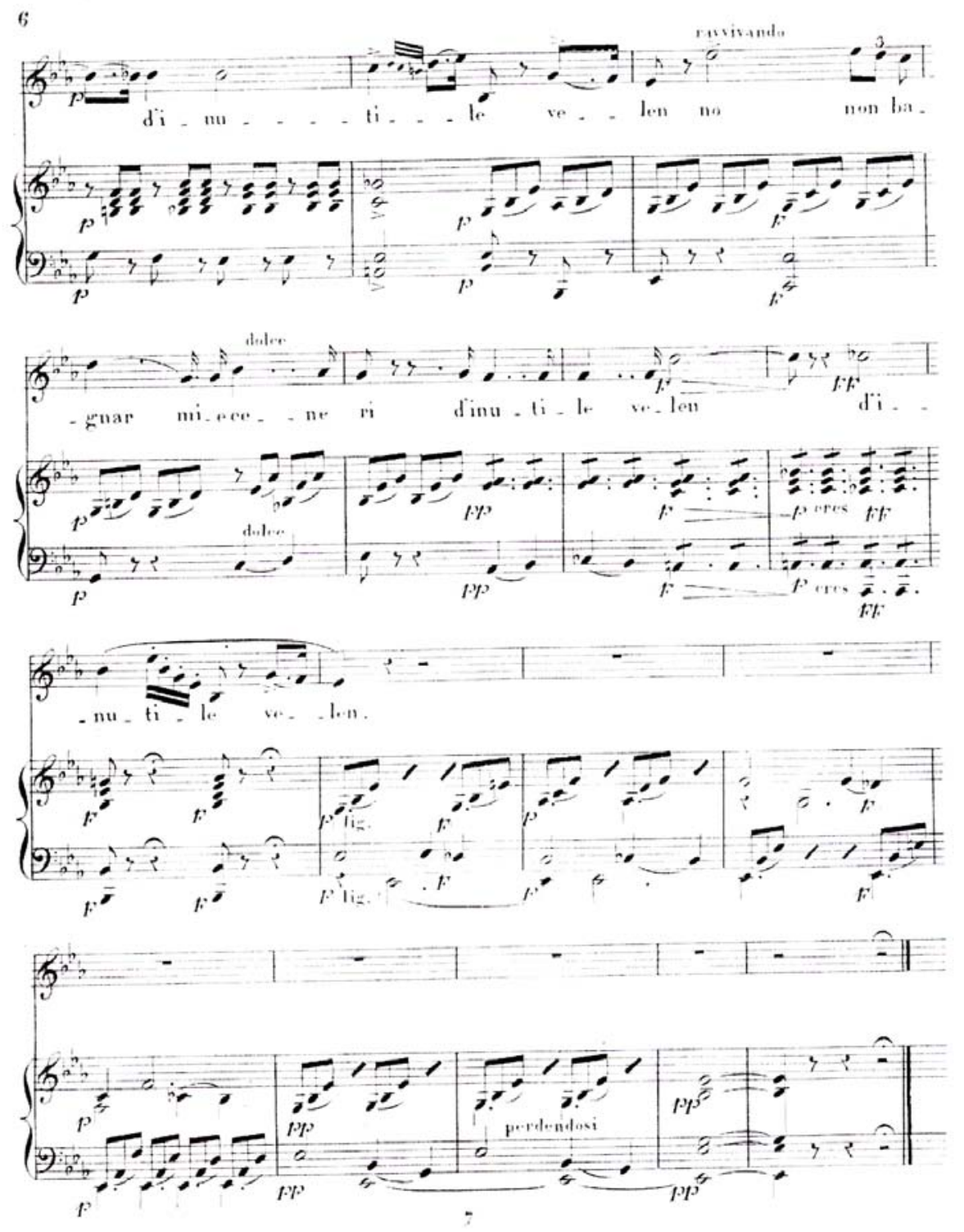




\section{Apéndice 3}

Inventarios de libros de música y partituras de las Casas de Osuna y Benavente en los siglos XVIII y XIX 



\section{[1] Inventario del Libro de Cantatas y arias Italianas de la Duquesa de Osuna}

[ca. 1730]

Madrid, Biblioteca Nacional, M 2245. Publicado parcialmente y con varios errores y omisiones en Higinio Anglés y José Subirá, Catálogo musical de la Biblioteca Nacional de Madrid. I. Manuscritos (Madrid: CSIC- Instituto Español de Musicología, 1946), pp. 400-404.

\section{Descripción del manuscrito}

Un volumen apaisado, encuadernado en pergamino, con hojas de papel, de distintos tamaños y formatos de caja. En el lomo añadido posterior: "Música manuscrita/ Tomo 15/ Piezas italianas / con bajo/ con orquesta".

Medidas exteriores: $28 \times 21 \mathrm{cms}$. (incluyendo los nervios de la encuadernación) [Según H. Anglés y J. Subirá, Catálogo Musical...,I, p .400, las medidas son 21 x $17,5 \mathrm{cms}]$.

Caja de los pentagramas: Varios formatos, siendo el más habitual el de 27 x $25 \mathrm{~cm}$. Pautados impresos en rojo en las piezas [1/1], [1/38].

Copista: Diferentes en cada obra.

Organización y numeración de las hojas: 11 folios al inicio sin numerar, 144 folios con números arábigos en tinta en el anverso.

\section{Contenido}

Fol. [I]. "Cantadas Ytalianas escoxidas para la ex[celentísima] Se[ñora] Duquesa de Osuna mi señora..."

En un renglón inferior y con otra caligrafía: "Cantao [sic] Cantadas Italianas"

Fols. [II-V] en blanco.

Fol. [VI]. Con caligrafía del siglo XIX o principios del XX y en tinta: "Música manuscrita. Tomo 15. Piezas de canto, unas con bajo y otras instrum[enta]das“. 
Fol. [VII]. Con caligrafia del siglo XIX o principios del XX y en tinta: "Arie italiane di diversi autori /de últimos del siglo $17 \mathrm{y}$ principios del $18^{1}$ /escogidas para la E[xcelentísi]ma S[eñor]a Duquesa de Osuna/ Tomo $2^{\circ \prime}$.

Fol. [VII r.] Índice de las cantatas que contiene el volumen.

"Tavola di cantate

1 Chi m'addita per qual via

Nibelle Fol.Prima

2 Veggio la sela e'[i]l monte

Benati

Fol.5

3 Irene bella Irene hor che soli

Benati

Fol.9

4 E penar deggio ancora prima

Scarlati

Fol.13

5 Sazio di piu soffrire le vicende

Scarlati

Fol. $15^{2}$

6 Bella a te de vezzoso quanto te

Fago

Fol.25

7 Tu parti idolo amato io vesto

Scarlati

Fol.33

8 Clori pur troppo bella senti quel

Fol.38

9 Lilla vedi que colle, che di tenere

Fol.43

10 Pastorelle hó perso il core ne

Fol.47

11 Tra l'ombre d'un romite d'un

Fol.51

12 Lunga stagion dolente missi Russi

Fol.63

13 Con l'arco, e con la face scherza

Fol.72

14 Amorosa pastorella un suspiro

Pistoulin

Fol.75

15 Per tormentarmi il core 1'alato

Fol.79

[16] Havrei ben folle il cor se alCesarini

Fol.83

[17] Sorge cinto di luce del giorno

Fol.87

[18] Amo e godo d'amare, peno e

Fol.91

[19] Ardo, misero me, e pur non

Fol.102

[20] Fra dubbiosi pensieri

Handelli

Fol.106

[21] Per dar piace alle sue pene volea

Fol.110

[22] Quanto é grato quanto é caro

Fol.122”

\footnotetext{
${ }^{1}$ La frase "de últimos del siglo 17 y principios del 18 " se añadió posteriormente.

${ }^{2}$ En el margen derecho se añadieron posteriormente los títulos de las arias sueltas que figuran en este volumen para que sirviera de índice general de la obra. El índice general de todas las arias figura en el fol. 149.
} 
Fols. [VIII-XI] en blanco.

Fols. 1-144: Partituras de arias y cantatas. La plantilla de todas las obras es voz y bajo cifrado mientras no se indique lo contrario.

[1/1] Fol. 1 Nibelle. M: "Chi m'addita per qual via". Cantata Título en Fol.1 r: "Cantata solo. Di M. Nibelle" En margen superior izquierdo: "Parole del Sig[no]r Ab[ate]. Giuseppe Alodio"

[1/2] Fol. 5. Benati, Carlo [Antonio]: "Veggio la selva il monte" Cantata. Título en Fol.5 r: "Cantata a voce sola, del Sig[nor] Carlo Benati"

[1/3] Fol. 9. Benati, Carlo [Antonio]: "Irene bella Irene", Cantata Título en Fol.9 r: "Cantata a voce sola, del Sig[nor] Carlo Benati"

[1/4] Fol. 13. Scarlatti, Alessandro: "E penar deggio ancora", Cantata. Título en Fol.13 r: "Cantata a solo, del Sig[no]r Ales[andr]o Scar[la]tti"

[1/5] Fol. 15. Scarlatti, Alessandro: "Sazio di più soffrire",.Cantata. Título en Fol.13 r: "Cantata a voce solo, Del Sig[no]r Aless[andro] Scarlatti”

[1/6] Fol. 21. [Anónimo]: "Bella immago del mio bene”, Aria. Título en Fol.21 r: "Aria"

[1/7] Fol. 22. [Anónimo]: "Per compaciarme un di”, Aria. Título en Fol.22 r: "Aria"

[1/8] Fol. 25. Fago, Nicola: "Bella à te di verzoso". Cantata. Título en Fol. 25 r: "Cantata da camera à voce sola Del Sig[no]r Nicola Fago/ Detto il Tarrantino, Bella à te di verzoso"

[1/9] Fol. 29. [Anónimo]: "Tu sei quella semplicetta”, Aria. Título en Fol.22 r: "Aria" 
[1/10]Fol. 30. [Anónimo]: "Trovasti un fido amante”, Aria.

Título en Fol.30 r: "Aria"

[1/11]Fol. 30 v. [Anónimo]: "Fammi saper se stringere", Aria. Título en Fol.30 v: "Aria"

[1/12]Fol. 31 v. [Anónimo]: "Si belle pupille", Aria.

Título en Fol.31 v: "Aria"

[1/13]Fol. 32. [Anónimo]: "La costanza del tuo afetto", Minuetta Título en Fol.32 r: "Minuetta"

[1/14]Fol. 33. Scarlatti Alessandro: "Tu parti idolo amato", Cantata. Título en Fol.33 r: "Cantata a voce sola, Del Sig[no]r Aless[andr]o Scarlatti"

Fol.36 v. Pautados sin música.

[1/15]Fol. 37. [Facco, Giacomo]: "Clori pur troppo bella", Cantata. Título en Fol.37 r: "Clori pur troppo bella/ Cantata a voce sola". En Fol 37.v pautados sin música. La obra comienza en fol. 38 r.

Fol.42 v. Pautados sin música.

[1/16]Fol. 43. [Händel, Georg Friedrich]: "Lilla vedi quel colle", Cantata. Título en Fol.37 r: "Cantata a voce sola"

Fol.46 v. Pautados sin música.

[1/17]Fol. 47. [Anónimo]: "Pastorelle, hò perso il core", Cantata. Título en Fol.47 r: "Cantata a voce sola" 
[1/18]Fol. 51. [Anónimo]: "Fra l'ombre più romite d'un ameno boschetto", Cantata $^{3}$.

Fol.56 v. Fragmento de música sin título ni letra para voz y bajo.

Los folios 57 a 62 contienen una colección de arias de autores anónimos agrupadas bajo el título de "Arie scelte de piu compositori"

[1/19]Fol. 57. [Anónimo]: "Cara sei bella bella si”, Aria.

Título en Fol. 57r: "Arie scelte de piu compositori”

[1/20]Fol. 58. [Anónimo]: “O Barbara crudele”, Aria.

Título en Fol. 58: “Aria”

[1/21]Fol. 58 v. [Anónimo]: "E pur dolce sentirse chiamare", Aria ${ }^{4}$.

[1/22]Fol. 59 v. [Anónimo]: “Con dolce simpatía”, Aria.

Título en Fol.58 v: "Aria"

[1/23]Fol. 60 v. [Anónimo]: "Se con me tu morirai”, Aria ${ }^{5}$.

[1/24]Fol. 61 v. [Anónimo]: "Si stanca il cielo ancora", Aria ${ }^{6}$.

[1/25]Fol. 63. [Francesco Rossi?]: "Lunga stazion dolente", Cantata.

Título en Fol. 63 r. "Cantata solo dell Abbate de Russi"

Fol.66 v. Después del final del número anterior una melodía anotada en los dos últimos pentagramas.

Fol.66 bis r. Hoja blanca con un dibujo de un jarrón con flores. La base de este jarrón tiene la inscripción "Viva Iesus".

\footnotetext{
${ }^{3}$ El título (primer verso de la cantata) figura en la "Tavola de Cantate" del fol VII.

${ }^{4}$ El título (primer verso del aria) figura en la "Tavola di Ariette" del fol 140.

${ }^{5}$ Ibid.

${ }^{6}$ Ibid.
} 
[1/26] Fol. 67. Bononcini [Giovanni Battista]: "Pastorella che tra le selve", Aria Título en Fol. 67 r. "Aria solo con violín del Sign[o]re Bononcini/

Pastorella che tra le selve"

Plantilla: voz, 2 violines y bajo.

Fol.71 r. Fragmento tachado de música para voz y bajo.

Fol.71 v. Dos versiones de un mismo fragmento melódico en dos compases diferentes cuatro por cuatro (tachado) y doce por ocho ${ }^{7}$.

[1/27]Fol. 72. [Anónimo]: “Con l'arco e con la face”, Cantata.

Título en Fol. 72 r. "Cantata à voce sola"

[1/28]Fol. 75. Pistoulin: "Amorosa Pastorella", Cantata.

Título en Fol. 75 r. "Cantata a voce sola del Sign[or] Pistoulin"

Fol.78 v. Pautados sin música.

[1/29]Fol. 79. [Anónimo]: "Per tormentarmi il core", Cantata.

Título en Fol. 79 r. "Cantata à voce sola"

Fol.82 v. Pautados sin música.

[1/30]Fol. 83. Carlo Cesarini: "Havrei ben folle il cor", Cantata.

Título en Fol. 83 r. "Cantata à voce sola del Sig[no]r Carlo Cesarini"

Fol.86 v. Pautados sin música.

[1/31]Fol. 87. [Anónimo]: "Sorge a Cinto di Luce", Cantata.

Título en Fol. 83 r. "Cantata à voce sola Sorge a Cinto di Luce"

[1/32]Fol. 91. [Anónimo]: "Amo e godo amare, Cantata.

Título en Fol. 91 r. "Amo e godo amare". Añadido posteriormente "Aria"

${ }^{7}$ Según el índice de arias del fol. 140 debe ser un fragmento del aria anónima "Digli, che non disprezzi". 
[1/33]Fol. 95 [Anónimo]: "Perchè non mi lasci", Aria $^{8}$.

[1/34]Fol. 96. [Anónimo]: "Se per te vivo io sono", Aria.

Título en Fol.96 r.: "Aria"

[1/35]Fol. 97. [Anónimo]: "Se vedi il mar senz'onde", Aria.

Título en Fol.97 r.: "Aria"

[1/36]Fol. 98. [Anónimo]: "Mio cor impara no ti fidar", Aria.

Título en Fol.98 r.: "Aria"

[1/37]Fol. 99 v. [Anónimo]: "Rendimi il core o perfido", Aria 9

Fol.101. Pautados sin música.

[1/38]Fol. 102. [Anónimo]: “Ardo miser me e pur non oso”, Cantata ${ }^{10}$.

Título en Fol. 102 r.: "Ardo miser me e pur non oso"

[1/39]Fol. 106. [¿Georg Friedrich Händel?]: “Fra dubbiosi pensieri”, Cantata.

Título en Fol. 102 r.:" Cantata à voce sola Del Sig[no]r F. Gio. Handelli”

Fra dubbiosi pensieri”

[1/40]Fol. 110. [Anónimo]: "Per dar pace alle sue pene”, Cantata.

Título en Fol. 102 r.: "Cantata à voce sola del M[aestr]o di Capella del $\mathrm{S}\left[\right.$ erenísimo] di $[\ldots]^{11,}$

[1/41]Fol. 118. [Anónimo]: "Semplicetta cangia core”, Cantata.

Título en Fol. 118 r. "Cantata con violini"

Plantilla: voz, 2 violines y bajo.

${ }^{8}$ El título (primer verso del aria) figura en la "Tavola di Ariette" del fol 140.

9 Ibid...

${ }^{10}$ El título (primer verso de la cantata) figura en la "Tavola de Cantate" del fol VII.

${ }^{11}$ El resto de la hoja está cortado. 
[1/42]Fol. 120. [Anónimo]: "Si belle pupille", Cantata.

Título en Fol. 120 r.:" Cantata à voce sola"

[1/43]Fol. 122. [Anónimo]: "Quanto è grato quanto è caro", Cantata.

Título en un folio roto sin numerar anterior a la 122, con el reverso en blanco: "Cantata a 3/con/ violini"

Plantilla: tres voces (Clori, Cileno, Gridone) 2 violines y bajo.

Fol.137 v. y 138 r. Pautados sin música.

Fol.139. En blanco.

Fol 140. Índice de las arias que contiene el volumen

"Tavola di Ariette

Bella Imago del moi bene

Fol. 21

Per compiacermi un di fingi

Fol. 22

Quanto sei cara delizia

Fol. $22 \mathrm{v}$.

Sei troppo amabile non

Fol. 23

Tu sei quella semplicetta

Fol. 29

Trovasti un fido amante

Fol. 30

Fammi saperse stringere

Fol 31 v.

Minuet La costanza del suo afetto

Fol. $32 \mathrm{v}$

Cara sei bella si ma'

Fol. 57

Ò barbara crudele giurasti

Fol. 58

E pur dolce sentirsi chiamare

Fol. $58 \mathrm{v}$

Con dolce simpatia adoro

Fol. $59 \mathrm{v}$.

Se con me tu morirai

Fol 60 v.

Si stanca il cielo ancora

Fol $61 \mathrm{v}$.

Pastorella che tra le selve

Fol 67 v.

Digli, che non mi disprezzi,

Fol. $71 v^{12}$

Perche non mi lasci

Fol 95

Perche mi disprezzi

Fol 95 v. ${ }^{13}$

Se per te vivo io sono

Fol 96

\footnotetext{
12 De este aria sólo se conserva un fragmento tachado

${ }^{13}$ Es la continuación del número anterior.
} 
Se vedi il mar senz' onde

Fol 97

Moi cor impara non fi..

Fol 98

Rendimi il core 'o perfida

Fol 99 v.

Semplicetta cangia core

Fol. 118

Si belle pupille, ch'io scoglio

Fol. 120." 


\section{[2] Inventario de la Colecçao de modinhas portuguesas conservadas en la Biblioteca de la Casa de Osuna [ca. 1800]}

Madrid, Biblioteca Nacional, M 2261. Publicado parcialmente en Anglés y Subirá, Catálogo Musical, pp. 420-421.

\section{Descripción del manuscrito}

Un volumen apaisado, encuadernado en cuero, con hojas de papel. En la tapa exterior un recuadro en rojo con letras grabadas en oro: "COLLECÇAO/ DE MODINHAS PORTUGUEZAS".

Medidas exteriores: 31 × $22 \mathrm{cms}$ (incluyendo los nervios de la encuadernación) [Según Anglés y Subirá, Catálogo Musical, p .420, las medidas son 20 x 25, 5 $\mathrm{cms}]$.

Caja de los pentagramas: 26 x 19, 5 cms. [Según H. Anglés y J. Subirá, Catálogo Musical, p.420, caja de 19, 5 x 21, $5 \mathrm{cms}$ ]. 10 pautados.

Copista: Parece el mismo en todas las obras.

Organización y numeración de las hojas: 1 hoja de guarda; 74 folios numerados a lápiz con números arábigos en anverso que contienen las partituras musicales: 1 hoja final de guarda sin numerar.

\section{Contenido}

Folio 1 en blanco

[2/1] Fol. 1. Palomino, José: "Menina que vive a la moda". Modinha. Título en fol.1 r: "Modinha/ Menina que vive á moda/ de J[osé] Palomino" Plantilla: [voz], 2 violines, viola y bajo.

Fol. 4 pautados sin música.

[2/2] Fol. 5. Manoel, Joaquim: "Quem quer comprar q'e eu vendo". Modinha. Título en Fol. 5r. "Modinha / cantada por Claudina Roza/ no Teatro nacional/ do Salitre/ de Joa[qui]m Manoel Brazileiro

Plantilla: [voz], 2 violines, viola y bajo.

Fol. 8 v., pautados sin música. 
[2/3] Fol. 9. Palomino, José: "Os fios q'amor fabrica” Duetto.

Título en Fol 9 r: "Duetto/ que se cantou no Teatro nacional/ da Rua dos Condes/ de José Palomino

Plantilla: [2 voces]: "Dama” y “Galán”, 2 violines, y bajo.

[2/4] Fol. 15. Pereira, Antonio Claudio: "Modinha da Beata. Os homens todos saō falsos"

Título en Fol.15 r.: "Modinha/ da Beata/ Cantada no Theatro nacional/ da Rua dos Condes / de Antonio Claudio Pereira

Plantilla: [voz], 2 violines, viola y bajo.

[2/5] Fol. 21. Palomino, José: "A tu alma ardendo em fogo" Modinha.

Título en Fol 21 r: "Modinha/ A tu alma ardendo em fogo/de J[osé] Palomino"

Plantilla: [voz], 2 violines, viola y bajo.

Fol. 24. pautados sin música.

[2/6] Fol. 25. Manoel, Joaquim: "O meu manso gádo" Modinha Brasileira.

Título en Fol. 25 r. "Modinha Brazileira /de Joa[qui]m Manoel Brazileiro Plantilla: [voz], 2 violines, viola y bajo.

Fol. 26 v. pautados sin música.

[2/7] Fol. 27. Palomino, José: “Algemas q' forj' amor”. Modinha.

Título en Fol 27 r: "Modinha/ Algemas q' forj' amor/de / J[osé] Palomino" Plantilla: [2 voces ], 2 violines, viola y bajo.

Fol. 30 v.: pautados sin música.

Fol. 31. Palomino, José: "O dextro sagaz Cupido". Modinha a Dúo.

Título en Fol 31 r: "Modinha a Duo/ no Entremez do miserable/ cantada no

Theatro Nacional/da Rua dos Condes /de/ J[os]é Palomino:

Plantilla: [2 voces]: $1^{\text {a }}$ Dama” y $2^{\text {a }}$ Dama, 2 violines, y bajo.

Fol. 34 v.: pautados sin música. 
[2/8] Fol. 35. Palomino, José: “Todos dizem”. Modinha.

Título en Fol 35 r: "Modinha a solo/ Todos dizem/ de J[os]é Palomino, Compositor do Theatro Nacional de Salitre/ Anno 1801:

Plantilla: [voz] 2 trompas, 2 oboes: 2 violines, viola y bajo.

Fol. 42 v.: pautados sin música

[2/9] Fol. 43. Palomino, José: "Tenho dentro de meu peito." Modinha

Título en Fol 43 r: Modinha/ do Entremez da Saloia/ de J[osé] Palomino/.

Compositor do Theatro Nacional de Salitre/ Anno 1801/

Plantilla: [voz] 2 trompas, 2 oboes: 2 violines, viola y bajo.

Fol. 46 v.: pautados sin música

[2/10]Fol. 47. Palomino, José: "Ya estou das Prizoens" Duetto.

Título en Fol 47r: Duetto/ no Entremez do Miserable/ Cantado no Teatro Nacional da Rua dos Condes/ Composto por/ J[os]é Palomino

Plantilla: [2 voces]: "Dama" y "Galán" 2 trompas, 2 oboes: 2 violines, viola y bajo.

[2/11]Fol. 67. Palomino, José: "Podebem dezengannarse". Duetto.

Título en Fol 67r: Duetto de Marujo e Regateira/ no Entremez das Regateiras Zelosas/ no Theatro Nacional do Salitre./ Composto por/ J[os]é Palomino/ Anno 1801

Plantilla: [2 voces]: "Dama" y "Galán" 2 trompas, 2 oboes: 2 violines, viola y bajo.

Fol. 74 en blanco. 


\section{[3] Inventario del archivo de música de la XV Condesa-Duquesa de Benavente (1824)}

AHN NOBLEZA, OSUNA-CARTAS, leg 392-15. Publicación parcial en francés por Nicolas A. Solar-Quintes e Yves Gérard, "La bibliothèque musicale d'un amateur éclairé de Madrid: La Duchesse-Comtesse de Benavente, Duchesse de Ossuna (1752-1834)", Recherches sur la Musique française classique III (1963), pp.179-188.

Transcripción literal excepto lo indicado entre corchetes.

Índice de las obras custodiadas en dos armarios que componen la papelera de música vocal e instrumental de la Excelentísima Señora Duquesa Condesa [sic] de Benavente. Año de 1824

\section{Estante grande \\ Tabla superior}

[3/1] $\quad N^{o}$. 1. Seis sinfonías de Hayd[n] marcadas con los números 1, 2, 3, 4 5, 6.

[3/2] $\quad \mathrm{N}^{\mathrm{o}}$. 2. Seis id. de id. con los números $7,8,9,10,11$, 12, faltan la 9a, 10 , 12.

[3/3] No. 3 Seis id. de id. con los números 13, 14, 15, 16, 17, 18.

[3/4] No. 4. Seis id. de id. con los números 19, 20, 21, 22, 23, 24, faltan la, $20^{\mathrm{a}}, 21^{\mathrm{a}}, 22^{\mathrm{a}}$.

[3/5] $\quad \mathrm{N}^{\mathrm{o}}$ 6. Seis id. de id. con los números $31,32,33,34,35,36$, faltan la $35,{ }^{\text {a }}$ y $36^{\mathrm{a}}$.

[3/6] No.7. Seis id. de id. con los números $37,38,39,40,41,42$, faltan la $39^{\mathrm{a}}$, $41^{\mathrm{a}}, 42^{\mathrm{a}}$.

[3/7] No. 10. Seis id. de Kozeluch.

[3/8] No 11. Seis id de Monrroy.

[3/9] No 16. Cuatro id. de Yriarte.

[3/10] No 22. Seis Cuartetos de Haydn.

[3/11] $N^{o} 31$. Dos id. de id.

[3/12] No 41 Seis id. de Huber. 
[3/13] No 43 Seis id. de Haydn

[3/14] No 46 Seis Tríos de Haydn

[3/15] No 54 Cinco Quintetos de Ponzo

[3/16] Legajo sin número Minuettes y Contradanzas de varios autores.

\section{Música suelta}

[3/17] Sinfonía de Haydn marcada con el no 25 .

[3/18] Id. de id. con el n ${ }^{\circ} 27$.

[3/19] Id. de id. con el $\mathrm{n}^{\circ} 28$.

[3/20] Id. de id. con el $\mathrm{n}^{\circ} 30$.

[3/21] Id. de id. con el $n^{\circ} 40$.

[3/22] Id. de id. con el $n^{\circ} 43$.

[3/23] Id. de id. con el $n^{\circ} 44$.

[3/24] Id. de id. $\sin n^{\circ}$.

[3/25] Sinfonía de Pleyel.

[3/26] Id. de id.

[3/27] Id. de id.

[3/28] Seis sinfonías de Boccherini dedicadas al Serenísimo Señor Infante Don Luis. Año de 1775.

[3/29] Seis id. de id. dedicadas las cinco primeras al Serenísimo Señor Infante Don Luis, y la sexta a la Excelentísima Señora Condesa de Benavente. Año de 1782.

[3/30] Otra de id. dedicada a la Excelentísima Señora Condesa de Benavente. Año de 1787.

[3/31] Otra de id. con la misma dedicatoria sin fecha.

[3/32] Otra de id. marcada con el no 2 y dedicada al Serenísimo Señor Infante Don Luis.

[3/33] Cuatro de id. impresas marcadas con los números 3, 4, 5, 6 con igual dedicatoria.

[3/34] Tres id. impresas de Haydn.

[3/35] Otra id. de id. impresa y marcada con el $n^{\circ} 46$.

[3/36] Tres sinfonías impresas de Rosetti.

[3/37] Una id. de Aspelmai[e]r. 
Tabla de el medio

Música encuadernada en cartón verde jaspeado

\section{Legajos}

[3/38] No 8, Catorce Sinfonías de Haydn. Juego $1^{\circ}$.

[3/39] $N^{o} 9$, Seis id. de id. Juego $2^{\circ}$.

[3/40] $N^{o} 12$. Seis oberturas de Monroy. Juego $1^{\circ}$.

[3/41] No 14. Cinco id. de Ponzo. Juego $1^{\circ}$.

[3/42] No 23. Seis Cuartetos de Haydn. Juego $3^{\circ}$.

[3/43] $N^{o} 25$. Seis id. de id. Juego $2^{\circ}$.

[3/44] $N^{o} 27$. Seis id. de id. Juego $4^{\circ}$.

[3/45] No 28. Seis id. de id. Juego $5^{\circ}$.

[3/46] $N^{\circ} 29$. Seis id. de id. Juego $6^{\circ}$.

[3/47] $N^{\circ} 33$. Seis id. de Davour. Juego $1^{\circ}$.

[3/48] $\mathrm{N}^{\mathrm{o}} 35$. Seis id. de Canales.

[3/49] No 37. Seis id. de Abel. Juego $1^{\circ}$.

[3/50] No 38. Seis id. de Monroy. Juego $2^{\circ}$.

[3/51] No 39. Seis id. de Hummel.

[3/52] No 42. Seis id. de Ponzo.

[3/53] No 45. Seis Tríos de Haydn. Juego $1{ }^{\circ}$

[3/54] No 49 Seis Tríos del Señor Duc L'Aine. Juego $1^{\circ}$.

[3/55] Canción con varios instrumentos de Ponzo.

\section{Continúan los mismos legajos sin numeración, y están colocados sobre los numerados}

[3/56] Seis Cuartetos de Boccherini del año 1761.

[3/57] Seis id. de id. del año 1769.

[3/58] Seis id. de id. del año 1770.

[3/59] Seis id. chicos de id. del año 1772

[3/60] Seis Tercetos de id. del año 1776.

[3/61] Concierto grande de id. 


\section{Música impresa}

\section{Legajo $1^{\circ}$ que contiene las cuatro obras siguientes.}

[3/62] Parties séparées de la Matinée de Catinat par Dalayrac

[3/63] Id. de Maison a vendre par id.

[3/64] Id. de Clemantine ou la Belle Mare par Fai.

[3/65] Id. de Marcelin par Lebrun.

\section{Legajo $2^{\circ}$ que contiene las quatro obras siguientes.}

[3/66] Parties séparées d'Adolphe et Clara ou les deux Prisonniers para Dalayrac.

[3/67] Id. del †ur trompé par Gaveux.

[3/68] Id. de Zoë par Plantade.

[3/69] Id. de Locataire par Gaveaux.

\section{Las obras siguientes están sueltas}

[3/70] Juego Filarmónico puesto en dos tablas para componer por medio de dos dados un número infinito de valses para la guitarra sin saber nada de la composición por Don Antonio Nava. Seis ejemplares.

[3/71] Gran Scena: Terzetto e Quintetto nel Melodramma Tragico il Maometto de Winter.

[3/72] De l'intrigue aux fenêtres: Rondocino avec accompagnement de piano forte par Nicoló.

[3/73] Trois quatuors pour deux violons, alto et Basse par Haydn.

[3/74] Doce minués y dos paspiés con sus minués a dos violines y bajo por Monroy.

[3/75] Ariane dans l'isle de Naxos: Cantata a voix seule avec accompagnement de piano forte par Haydn.

[3/76] Trois Sonates pour clavecin ou piano forte avec accompagnement de flûte et violoncelle par Pleyel.

[3/77] Adiciones a la Salmodia Orgánica: Versos de los tonos primero, sexto y cuarto punto bajo, y los del último con extensión en forma de Sonatas por el R. P M. Fray Pedro Carrera y Lanchares.

[3/78] Salmodia Orgánica: Juego de versos de todos los tonos compuestos por el mismo.

[3/79] Divertimiento instructivo para Forte Piano, compuesto de 38 valses por un profesor de esta corte. Dos ejemplares. 
[3/80] Divertimiento instructivo para Forte Piano, compuesto de 48 contradanzas por el mismo.

[3/81] Ouverture et airs du Chapitre second. Musique de Solié arranges pour le piano forte.

[3/82] Sei Notturni ou petits Duo Italiens a voix egales avec des paroles italiens et Françaises et un accompagnement de Harpe ou forte piano ad libitum par Langlé.

[3/83] Monument consacré a la tendresse maternelle, ou recueil de petits Airs avec accompagnement de Piano ou Harpe par Bidou. Cuatro ejemplares.

[3/84] Six Allemandes a plusieurs instruments composées par Jean Vanhall.

[3/85] Potpourri des plus jolis airs nouveaux arrangée pour le Piano par Ouvray.

[3/86] Ouverture del Califa de Bagdad. En partitura.

[3/87] Oeuvres diverses de Musique pour le forte piano ou Harpe par le Citoyen Beauvarlet-Charpentier.

[3/88] Dos canciones con acompañamiento de Forte Piano, dedicadas a los amantes de la música por Nielfa.

[3/89] Opressa mi sento: Rondó con accompagnamento di piano forte di Nasolini.

[3/90] Dei clementi: Cavatina con accompagnamento di piano forte di Nasolini. Cosida a la anterior.

[3/91] Polonaise et Rondeau de Viotti varié pour le forte piano par Pleyel.

[3/92] Romance d'Ariodant par Mehul. Femme sensible.

[3/93] Pria che spunti in Ciel 1'aurora: Aria de Cimarosa nel Matrimonio segreto.

[3/94] Ouverture de Demophon par Vogel arrangée pour clavecin ou forte piano avec violon et basse par Adam.

[3/95] Ouverture des Deux Prisonniers arrangée pour clavecin ou forte piano par Carbonel.

[3/96] Quintetto per due violini, due viole et violoncello da Pleyel.

[3/97] Dodici Minuetti per diversi instrumenti da Pleyel.

[3/98] Obra de música de arias italianas con acompañamiento de guitarra por Vidal. Dos ejemplares.

[3/99] Vederlo sol bramo: Duetto nella Griselda de Paer. 
[3/100] Aimable et belle: Rondó d'Adolphe et Clara, arrangée pour le piano forte.

[3/101] A lei che adoro: Aria nella Griselda de Paer.

[3/102] Giornale di Musica vocale Italiana di Ricordi e Festa composto di Cavatine, Arie, Rondó, Duetti e Terzetti etc. in piena partitura unitamente all'accompagnamento di piano forte.

[3/103] Tre Sonate per il clavicémbalo o forte piano con un violino e violoncello de Haydn.

[3/104] La Alegría pública: Marcha a grande orquesta, compuesta y arreglada para fortepiano a cuatro manos por Segismundo Neukomm.

[3/105] Himno marcial dedicado a Su Majestad la Reina de España por el mismo.

[3/106] Ah confida ad altra mano: Duetto nel melodrama tragico il Maometto de Winter.

[3/107] Otello: Gran Ballo Tragico inventato e posto sulle scene del Real Teatro alla Scala dal Signor Salvatore Viganó, ridotto per Cembalo solo.

[3/108] Pietá del mio dolore: Cavatina nel Faiello de Coccia.

[3/109] Trois Quatuors, deux a Flûte, Alto et Basse, et un a Flûte, deux violons et Basse par Schmittbauer.

[3/110] Primer Cuaderno: Música para Forte Piano, un Rondó, una Sonata, un Adagio con su Allegro y una Marcha, una Sonata con acompañamiento de violín y un Trio id. de dos violines, compuesto por Doña María de los Mártires García Quintano.

[3/111] Ronde des Visitandines avec accompagnement de Piano ou Harpe.

[3/112] Chanson du Montagnard d'Auvergne par Langlé avec accompagnement de piano forte.

[3/113] Felice Pastorella: Aria degli schiavi per amore de Paisiello.

[3/114] Un cuadernito de piezas pequeñas para fortepiano por Antón André.

[3/115] Ouverture de Blaisse et Babei, arrangée pour le Clavecin ou le piano forte avec accompagnement de violon par Fodor.

[3/116] Premier Quadrille, et une grande Valse sur des motifs de Rossini pour le forte piano arranges para Lemoine.

[3/117] La Serenade: Barcarole Venitienne arrangée pour le piano forte par Gail.

[3/118] Seis Sonate per violino solo e Basso di Nardini.

[3/119] Deuxieme Duo pour la Harpe et le Forte Piano, ou pour deux Pianos par Boieldieu. 
[3/120] Rondeau et Airs des Visitandines avec accompagnement de forte piano ou Harpe.

[3/121] Siete Canciones Francesas. Falta la portada y las últimas [h]ojas.

[3/122] Raccolta di dodici Minuetti composti dal Signore Santo Trento.

[3/123] Air de la Molinarella avec accompagnement de Forte Piano.

[3/124] Minué fúnebre para forte piano a la muerte de Su Alteza Serenísima el Señor Infante Don Antonio por Rafael Compta .

\section{Tabla inferior}

\section{Música encuadernada en cartón verde jaspeado}

\section{Legajos}

[3/125] Trece Sinfonías de Stamitz. Falta la $9^{\text {a }}$

[3/126] Seis Quintetos chicos de Boccherini. Opera $3^{\mathrm{a}}$ año de 1773.

[3/127] Seis id. de id. Ópera $2^{\mathrm{a}}$ año de 1771.

[3/128] Seis id. de id. Ópera $1^{\mathrm{a}}$ año de 1772.

[3/129] Seis id. de id. Ópera $1^{\mathrm{a}}$ año de 1771.

[3/130] Seis id. de id. Ópera $1^{\mathrm{a}}$ año de 1775.

[3/131] Seis cuartetos de Hayd[n]. Juego $1^{\circ}$.

[3/132] Seis Sestettos de Brunetti.

[3/133] Six Quatuor concertants pour deux violons, alto et Basse par Davaux. Cada instrumento encuadernado a la romana y falta el bajo.

[3/134] Trois Quatours pour deux violons, alto et violoncelle par Camille Barni. Cuatro libros encuadernados en tafilete.

\section{Libros encuadernados en media pasta}

[3/135] Le Gran Devil. Opera en un acte par Berton.

[3/136] Chapitre second. Opera comique en un acte par Solié.

[3/137] Fanny Morna ou 1'Ecossaise. Drame lyrique en trois actes et en prose par Persui.

[3/138] Les Confidences. Opéra en deux actes par Nicoló.

[3/139] Le Château de Montenero. Comédie en trois actes et en prose par Dalayrac.

[3/140] Léhéman ou la Tour de Neustadt. Opéra en trois actes par Dalayrac. 
[3/141] Le Major Palmer. Opéra en trois actes par Bruni.

[3/142] Le Concert interrompu. Opéra comique en un acte par Berton.

[3/143] Marcelin. Opéra en un acte et en prose par Lebrun.

[3/144] Zoë ou la Pauvre petite. Opéra en un acte par Plantade.

[3/145] Leonore ou l'Amour conjugal : Fait historique espagnol en deux actes per Gaveaux.

[3/146] Les deux petits savoyards. Comédie en un acte par Dal[ayrac].

[3/147] Adolphe et Clara, ou les deux Prisonniers. Comédie en un acte et en prose par Dalayrac.

[3/148] Le trésor supposé, ou le danger d'écouter aux portes. Comédie en un acte et en prose par Méhul.

[3/149] Palma ou le Voyage en Grèce. Opéra en deux actes par Plantade.

[3/150] Les promesses de mariage, ou la suite de l'épreuve villagerie. Opéra bouffon en deux actes, et en vers par Berton.

[3/151] Une heure de mariage. Comédie en un acte et en prose par Dalayrac.

[3/152] Un quart d'heure de silence. Opéra comique en un acte par Gaveaux.

[3/153] Le Bouffe et le Tailleur. Opéra comique en un acte par Gaveaux.

[3/154] Le Médecin Turc. Opéra Bouffon en un acte par Nicolo.

[3/155] La Romance. Opera en un acte par Berton.

[3/156] Le Diable en vacances, ou la suite du Diable couleur de rose. Opéra série et comique en un acte par Gaveaux.

[3/157] Milton. Opera in un atto e in prosa da Spontini. Faltan las últimas [h]ojas.

[3/158] L'intrigue aux fenêtres. Ópera. Falta la portada.

\section{Libros encuadernados en pasta verde imitando a tafilete.}

[3/159] Corisandre, ou les Joux par enchantement, Opéra Ballet par Langlé.

[3/160] Traite de la Basse sous le Chant précédé de toutes les règles de la Composition par Langlé.

[3/161] Recueil anacréontique, composé de Romances, Pastorales et Vaudevilles, formant 36 numéros pour le piano forte ou Harpe avec accompagnement ad libitum soit de Flûte, Violon, Clarinette, Cor, Basse ou Basson par Langlé.

[3/162] Traité d'Armonie et de Modulation par Langlé.

[3/163] Obra de Música de arias italianas con acompañamiento de guitarra por Vidal. 
Sobre los libros que están colocados verticalmente se hallan horizontalmente puestos los cuatro siguientes encuadernados en media pasta

[3/164] Dos libros intitulados: Il Crociatto in Egitto. Música de Meyerbeer.

[3/165] Otro intitulado: Feuille Filharmonique.

[3/166] Otro sin rotulo alguno que contiene un tema sobre el Crociatto in Egitto y la Sinfonía de la Semiramide de Rossini para fortepiano.

\section{Estante chico}

\section{Cajón $1^{\circ}$}

[3/167] Minuetes y contradanzas a dos orquestas de Brunetti.

[3/168] Seis Quintetos de Boccherini dedicados al Serenísimo Señor Infante Don Luis. Año de 1779.

[3/169] Seis Cuartetinos de id. con igual dedicatoria. Año de 1781.

[3/170] Seis Quintetos de id. con la misma dedicatoria. Año de 1780.

[3/171] Seis id. de id. dedicados a la Excelentísima Señora Condesa de Benavente. Año de 1786.

[3/172] Tres id. de id. con igual dedicatoria. Año de 1787.

[3/173] Un Cuarteto de id. Año de 1787.

[3/174] Un Sexteto de id. Año de 1787.

[3/175] Diez Minuetes de id. expresamente escritos para la Excelentísima Señora Condesa de Benavente. Año de 1787.

[3/176] Concierto $1^{\circ}$ de id. dedicado al Serenísimo Señor Infante Don Luis.

[3/177] Doce Sonatas para violín y bajo de Giardini.

[3/178] Veintidós Sonatas para violín y bajo de diferentes operas de Brunetti.

[3/179] Diez Dúos para dos violines de diferentes operas de Brunetti.

[3/180] Seis sextetos hechos expresamente para el Excelentísimo Señor Duque de Osuna por Brunetti. Falta el $1^{\circ}$.

[3/181] Trío para la oposición de contrabajo en la Real Capilla de Su Majestad por Monroy.

[3/182] Trío a dos violines y bajo por Montali.

[3/183] Dos trío s dos violines y bajo por el mismo.

[3/184] Duetto a due violini, disfidandosi ora l'uno, ora l'altro di Barbella.

[3/185] Ninna nonna per dormire. Duetto di violino e basso di Barbella. 
[3/186] Minuetto scordato di Barbella.

[3/187] Minuetes y contradanzas.

[3/188] Sonata de violín solo y bajo de Tartini.

[3/189] Cuarteto de Aspelmair.

[3/190] Concierto.

[3/191] Un espartito en papel pequeño de una ópera, cuyo título y autor se ignora.

\section{Legajo de partituras sueltas}

[3/192] Per queste amare lagrime. Aria de Portogallo.

[3/193] Troppo ingiusto amor. Aria

[3/194] Qual orror. Terceto di Giordaniello.

[3/195] Abelardo ed Eloisa. Cantata a due Voci de Paer.

[3/196] Mi parea a notte oscura. Aria.

[3/197] Dal mio cor sperate in vano. Aria de Lamaria.

[3/198] Parli di madre amante. Cavatina de Brunetti Pisano.

[3/199] Oh fortunato istante. Polacca de Federico.

[3/200] Io vi lascio. Aria. Dos copias, cada una en distinto tono.

[3/201] Nel bel volto amato bene. Rondó de Andreozzi.

[3/202] Hijo amado ten presente. Aria de Cimarosa.

[3/203] Io son tradito. Duetto.

[3/204] Idol mio pietoso il fato. Rondó de Cimarosa

[3/205] Il mio cor gli afetti miei. Aria de id.

[3/206] Partiro dal caro bene. Rondó.

[3/207] Se tu veder potessi. Duetto de Brunetti Pisano.

[3/208] La tua bella s'avvicina. Aria de Brunetti.

[3/209] Il mio garzon il pifano suonava. Cavatina e Duetto de Paisiello.

[3/210] Per pietá ma dove oh Dio. Aria.

[3/211] Cantate a Clori pour Mademoiselle d'Ossuna par Langlé.

[3/212] Doce Minuetes.

[3/213] Alle vesti ed all'aspetto. Aria de Portogallo.

[3/214] Piano un pó. Aria.

[3/215] Donne donne il vostro sesso. Aria.

[3/216] Caro consorte amato. Aria de Cherubini.

[3/217] Povero cuor per che. Romance. 
[3/218] Prudente mi chiedi. Aria.

[3/219] Serenata de Tozzi.

[3/220] Se non ti moro allato. Duetto de id.

[3/221] L'alba chiara il sol nascente. Aria de Fabrizzi.

[3/222] Dei pietosi in tal momento. Rondó de Brunetti. Tiene partes sueltas.

\section{Legajo de instrumentales sueltos}

[3/223] Volate di note musicali per ben suonare il Violino dal Signor Barbella.

[3/224] Ombra adorata aspetta. Rondó.

[3/225] Al mio ben che m'innamora. Rondó de Caruso.

[3/226] Parli di figlia amante. Cavatina.

[3/227] Che faro senza il mio bene. Aria.

\section{Legajo de música vocal con acompañamiento de Forte piano}

[3/228] Quanto e grave il mio tormento. Aria de Cimarosa.

[3/229] Alla mia bella ingrata. Aria di Marcello da Capua.

[3/230] Sul piu bello del mio sposalizio. Cavatina de Rutini.

[3/231] Que temor me acobarda. Aria.

[3/232] Qual tetro orror m'assale. Terceto de Federici.

[3/233] Quel sembiante quello sguardo. Terzetto de Rossini.

[3/234] Esto es hecho yo me caso. Cavatina.

[3/235] Sei Duetti d'Isouard.

[3/236] Ah son questi i preziosi momenti. Cavatina de Christiani.

[3/237] Fermati ingrato. Trio nella Ariana de Adam.

[3/238] Seguidillas y canciones por Don Miguel López Remacha.

[3/239] Infeliz que resuelves. Aria.

[3/240] Abelardo ed Eloisa. Cantata a due voci de Paer.

[3/241] O meu coraçao me diz. Modinha.

[3/242] Seis Cavatine.

[3/243] Le premier regard de Fanny. Romance.

[3/244] Saper bramate. Cavatina pour Mademoiselle d'Ossuna.

[3/245] Coplas de Zetulbe.

[3/246] Polo o Caballo.

[3/247] Perfida Clori. Canone a tre voci de Cherubini.

[3/248] Un cuaderno de solfeo. 
[3/249] Air de la folle soirée par Dalayrac.

[3/250] Te bien aimer. Air Français de Garpe.

[3/251] Un cuaderno de canciones francesas.

[3/252] Canzonette del Signor cavalier Don Michele la Grua, marchese di Branciforte, diletante.

[3/253] Coplas en la Opera La Travesura.

[3/254] Boleras.

[3/255] Doce dúos de Asioli.

[3/256] Due canzonette di Moisi.

\section{Legajo de música instrumental de Forte Piano.}

[3/257] Rondó para forte piano y toda Orquesta por Hergen.

[3/258] Overtura del Prisionero.

[3/259] Variaciones.

[3/260] Un libro de Sonatas sin principio ni fin.

[3/261] Overtura de la caza del joven Enrique por Méhul.

[3/262] Sonata.

[3/263] Overtura de Vernier.

[3/264] Overtura de deux Prisonniers par Dalayrac, arrangé pour le piano forte par Carbonel.

[3/265] Lecciones de solfeo para los Señores Don Francisco y Don Pedro Girón y Pimentel.

[3/266] Un cuaderno de pequeñas piezas.

[3/267] Doce variaciones de Mozart.

[3/268] Sonate a quatre mains par Kozeluch.

[3/269] Siete variaciones por Kirmair.

[3/270] Fantasía para fortepiano o clave y para órgano de Haydn.

[3/271] Variaciones.

[3/272] Minué.

[3/273] Minué con sus tríos y coda.

[3/274] Polaca.

[3/275] Sonata marcada con el $n^{\circ} 6$. Opera $1^{\text {a }}$.

[3/276] Sonata pour le clavecin avec accompagnement de violon et violoncelle ad libitum par Eichner.

[3/277] Una Sonata. 
[3/278] Una Polacca.

[3/279] Rondó de Pleyel.

[3/280] Rondó de Haydn bailado en el Teatro de Madrid.

[3/281] Vals para fortepiano dedicado al ilustre y Real Cuerpo de Guardias de Corps por Don José Rodríguez de León.

[3/282] Diez Sonatas de Haydn.

\section{Cajón $2^{\circ}$}

[3/283] I fratelli ridicoli. Opera in due atti di Gaz[z]aniga. Espartito.

[3/284] Il Barbiere di Siviglia. Opera in due atti di Paisiello. Espartito y partes sueltas.

[3/285] El espartito de una obra, cuyos interlocutores son Giunone, Pallade, Giove e Marte. Se ignora su título y Autor.

[3/286] Zarzuela. El Extranjero de Ponzi. Opera en dos actos. Particella y partes sueltas.

[3/287] Donde menos piensa el galgo, salta la liebre. Tonadilla a tres de Laserna. Particella.

\section{Libros}

[3/288] La Posadera sutil. Ópera en dos actos. Espartito. Se ignora el autor y faltan las primeras [h]ojas del $2^{\circ}$ acto.

[3/289] La Italiana en Londres en dos actos. Espartito. Se ignora el autor.

[3/290] Lorenza la incluserita. Opera compuesta por Francisco Capmany, y dedicada al Excelentísimo Señor Don Pedro Girón Duque de Osuna.

[3/291] La Frascatana. Ópera en tres actos. Sólo existe el Espartito del tercero, y se ignora el autor.

[3/292] Un libro cuyo título es Música de fortepiano.

[3/293] Seis Cuartetos instrumentales en partitura. Se ignora el autor.

[3/294] Ventiquattro Duetti con accompagnamento di piano forte de Asioli.

[3/295] Trois Sonates pour Clavecin ou forte-piano avec accompagnement de Flûte et Violoncelle par Pleyel.

\section{Cajón $3^{\circ}$}

[3/296] Espartito de la ópera intitulada: La Festa della Rosa. Se ignora su autor.

[3/297] Idem de la ópera: Torvaldo e Dorliska de Rossini.

[3/298] Idem de la ópera: La Donna del lago de Rossini. 
[3/299] Idem de la ópera: La Clotilde de Coccia.

\section{Un legajo que contiene las obras siguientes.}

[3/300] Figuras de contradanzas traducidas del francés al español.

[3/301] Contradanzas y valses para fortepiano.

[3/302] Les folies Parisiennes. Collection de Contredanses et valses par Pixis pour 2 violons et Basse.

[3/303] Collection de Valses par Masarnau et Moscheles pour deux violons et Basse.

[3/304] Colección de Contradanzas para dos violines.

[3/305] Contradanzas y valses para dos violines.

[3/306] Valses para fortepiano.

Sobre todas estas obras colocadas verticalmente se halla un legajo de música impresa con las obras siguientes todas para piano.

[3/307] Invocación al Sacratísimo corazón de Jesús por [sic] S. M. La Reina de España. Música de la Señora B.H.R. Luisa de P. de Bessieres.

[3/308] Feuille Filharmonique ou Recueil des meilleurs morceaux des opéras italiens avec accompagnement de piano. Cinco cuadernos.

[3/309] Nueve cuadernos con varias polonesas para piano y violín.

[3/310] Cuatro cuadernos. Colecciones de valses para piano.

[3/311] Les charmes de Paris. Rondeau brillant pour le forte-piano par Moscheles.

[3/312] Thème Danois par Monsieur le Comte Maurice Ditrichstein.

[3/313] Cuatro Cuadernos: Colecciones de Contradanzas con el título Quadrille etc.

[3/314] Cuatro cuadernos intitulados: Les Folies Parisiennes. Contradanzas y valses de Pixis.

[3/315] Tres Cuadernos intitulados: Le Caprice des Parisiennes. Contradanzas y valses de Constantin. 


\section{Cajón $4^{0}$}

\section{Música eclesiástica}

[3/316] Stabat Mater a cuatro voces, dedicado a la Excelentísima Señora Condesa de Benavente por Delgado.

[3/317] Misa dedicada a la Excelentísima Señora Duquesa de Osuna compuesta por Capmany.

[3/318] Miserere a quatro de Sarti.

[3/319] Miserere a quatro de Doña Mariana Martínez.

[3/320] Le sette parole. Oratorio de Haydn.

[3/321] Stabat Mater a tres de Inzenga.

[3/322] Messa a due cori de Pergolesi.

[3/323] Responsorios de difuntos de David Pérez. Libro desencuadernado. Le falta el último responsorio que está en el legajo inmediato.

[3/324] Oficio de Difuntos a ocho por Don Manuel Doyagüe. Partitura y partes sueltas.

[3/325] Libera me Domine. Responsorio de David Pérez. Partitura y partes sueltas. Está junto con el anterior en un legajo.

[3/326] Psalmo 50 a tres voces de Fioravanti. Partitura y partes sueltas.

\section{Cajón $5^{\circ}$}

[3/327] Misa a ocho por Don José Lidón, dedicada a la Excelentísima Señora Condesa de Benavente. Partitura y partes sueltas.

[3/328] Misa a ocho de Monroy. Partes sueltas sin partitura.

[3/329] Misa a tres de Abril. Partitura y partes sueltas.

[3/330] Messa a due cori di Paisiello. Partitura y partes sueltas.

[3/331] Messa a quattro di Kraft. Partitura y partes sueltas.

[Sigue otro grupo de obras separadas de las anteriores por una línea]

\section{Legajo}

[3/332] Lamentación primera del miércoles para el jueves. Incipit lamentatio a 12 por Ortells. Partes sueltas sin partitura.

[3/333] Responsorios a ocho con violines sobrepuestos para la procesión del Corpus por Fray Ignacio Ramoneda, partes sueltas.

[3/334] Responsión al Santísimo a ocho de Don José Lidón, partes sueltas.

[3/335] Misa a ocho de Durón con acompañamiento de bajo, partes sueltas. 
[3/336] Beatus vir. Salmo de vísperas a ocho con acompañamiento de bajos. Partes sueltas.

[3/337] Beatus vir. Salmo de vísperas a ocho por Don Diego Martín. Partes sueltas.

[3/338] Misa a ocho con violines y trompas y sin ellos de Moya. Partes sueltas.

[3/339] Himno a ocho para la Fiesta de las Santas Reliquias por Durango. Partes sueltas.

[3/340] Dixit Dominus. Salmo de vísperas a ocho por Don Diego Martín, partes sueltas.

[Sigue otro grupo de obras separadas de las anteriores por una línea]

[3/341] Messa a due cori di Paisiello. Partitura inutilizada por haberse copiado de nuevo.

[3/342] Messa a due cori del Signore Michele Haydn. Partitura y partes sueltas.

[3/343] Misa de Brunetti. Partes sueltas.

[3/344] Misa a cuatro de Paer. Partitura.

[3/345] Misa a quatro del Signor Giuseppe Haydn. Partes sueltas.

[3/346] Misa a cuatro y a ocho. Se ignora el autor. Tiene partes sueltas y no todas.

[3/347] Miserere a cinco de Jommelli. Partitura y partes sueltas.

[3/348] Stabat Mater de Pergolesi. Partitura, particella y partes sueltas.

[3/349] Libera me Domine. Responsorio de Difuntos. Partes sueltas, Se ignora el autor.

[3/350] Salve de Medina. Partitura y partes sueltas.

[3/351] Ingredere in Sanctam Ecclesiam. Motete. Particella y partes sueltas.

[3/352] O salutaris hostia. Motete de Kraft. Partitura.

[3/353] O salutaris hostia a trois voix sans accompagnement par Rousseau, Lais et Cheron.

[3/354] Lauda Sion Salvatorem. Motete. Partes sueltas. Se ignora el autor.

[3/355] Ofertorio a cinco de Don Juan Prenestrina [sic] para las Dominicas de Septuagesima, $1^{\mathrm{a}}, 2^{\mathrm{a}}, 3^{\mathrm{a}}, 4^{\mathrm{a}}$ de Cuaresma, In Passione y Miércoles Santo. Partes sueltas.

[3/356] Villancico de Navidad a solo y a dúo.

[3/357] Villancico de Navidad a solo. 


\section{Cajón $6^{\circ}$}

Legajo de las cinco obras siguientes, que componen un juego de vísperas.

[3/358] Dixit Dominus. Salmo a cuatro de Bonfichi. Partituras y partes sueltas.

[3/359] Beatus vir. Salmo a cuatro de Gazzaniga. Partes sueltas.

[3/360] Laudate pueri Dominum Psalmo a quatro de Bonfichi. Partitura y partes sueltas.

[3/361] Iste Confessor. Himno a quatro de Pacheco. Partitura y partes sueltas.

[3/362] Magnificat. Cántico a ocho de Doyagüe. Partitura y partes sueltas.

[3/363] Índice de la papelera de música de la Excelentísima Señora Duquesa de Osuna, hecho en el año de 1791. 


\section{[4] Inventario del archivo de música de la XV Condesa-Duquesa de Benavente (ca.1838)}

AHN NOBLEZA, OSUNA-CARTAS, leg 392-16. Transcripción literal excepto lo indicado entre corchetes.

\section{Óperas francesas}

[4/1] Les promesse de Marriage de Monsieur Berton 1

[4/2] Parties séparées du Locataire Monsieur Gaveaux

[Los siete items subsiguientes en un legajo]

[4/3] Id. de Zóe de Plantade.

[4/4] Id. de Adolphe de Dalayrac.

[4/5] Id. de Marcelin de Lebrun.

[4/6] Id. de Clemantine de Fay.

[4/7] Id. de Maison a vendre par id.

[4/8] Id. de la Matinée a Catinat

[4/9] Marcelin [de] Lebrun 1

[4/10] Chapitre second [de] Solié 1

[4/11] Milton [de]Spontini 1

[4/12] Le medecin turc [de] Nicolo 1

[4/13] Adolphe et Clara [de] Dalayrac 1

[4/14] Le bouffe et le tailleur [de] Gaveaux 1

[4/15] Les deux petits savoyards [de] Dal[ayrac] 1

[4/16] L'Ecossaise [de] Persuis 1

[4/17] Le château de Montenero [de] Dalayrac 1

[4/18] Un quart d'heure de silence [de] Gaveaux 1

[4/19] Les confidences [de] Nicolo 1

[4/20] La Romance [de] Berton 1

[4/21] Le Gran Devil. Id. 1

[4/22] Le concert interrompu. Id. 1

[4/23] Une heure de mariage [de] Dalayrac 1

[4/24] Le Diable en vacances [de] Gaveaux 1

[4/25] Palma ou le Voyage en Grèce. [de] Plantade. 1

[4/26] Le trésor supposé [de] Mehul 1

[4/27] Leonore ou l'amour conjugal [de] Gaveaux 1 
[4/28] Zoë ou la pauvre petite [de] Plantade. 1

[4/29] Le Major Palmer [de] Bruni 1

[4/30] L intrigue aux fenêtres [de] Nicolo 1

[4/31] Leheman [de] Dalayrac 1

[4/32] Corissandre ou les joux [de] Langlé $\quad 1$

[4/33] Le siége de Corinte [de] Rossini 2

[4/34] Recueil Anarcontique [de] Langlé 1

[4/35] Traité d'Armonie et de Modulation [de] Langlé.

[4/36] Traité de la basse sour le chant [de] id. 1

[4/37] Dos legajos al Barbiere di Seviglia a Paisiello

[4/38] Uno dei fratelli ridicoli

[Los ítems subsiguientes están separados de los anteriores por dos líneas horizontales]

[4/39] La Italiana en Londres 2

[4/40] La Posadera sutil 1

[4/41] La Frascatana 2

[4/42] Tonadilla de donde menos se piensa salta la liebre de Laserna

[4/43] La Incluserita [de] Capmany 2

[4/44] Zarzuela. El extranjero [de] Ponzo 1

\section{Música moderna}

[4/45] 8 cuadernos de Polonesas.

[4/46] 3 id. de la Caprice des Parisiennes. Collection a contredanses et valses.

[4/47] 4 id. de Folies Parisiennes id. [de] id.

[4/48] 5 id. de Feuille Filharmonique ou Recueil des meilleurs morceaux des opéras italiens.

[4/49] Sonate a 4 mains de Haydn.

[4/50] 3 cuadernos de Quadrilles de 6 nouvelles contredanses.

[4/51] 6 grandes valses de Hummel.

[4/52] Les charmes de Paris. Rondeau [de] Moscheles.

[4/53] Thème Danois [de] Maurice .

[4/54] Valse favorite a Roland des Bois [de] Galinek.

[4/55] 21 valses [de] Moscheles.

[4/56] Le Parnasse. Recueil a Valses [de] Masarnau. 


\section{Música sagrada}

[4/57] Misa de Campany

[4/58] Misa a tres voces de Don Tomás Abril.

[4/59] Una misa cuatro y a ocho.

[4/60] Misa de Don ramón Monroy.

[4/61] Misa a ocho de Miguel Haydn.

[4/62] Misa a cuatro y a ocho de José Haydn.

[4/63] Ofertorio a cinco voces por Prenestrina.

[4/64] Misa a ocho por Don José Lidón.

[4/65] Misa a cuatro por José Haydn.

[4/66] Misa a dos coros por Paisiello.

[4/67] Stabat Mater de Inzenga.

[4/68] Salmo cincuenta por Fiorabante.

[4/69] Salmo id. Por Martínez.

[4/70] Miserere a cuatro de Sarti.

[4/71] Matutino de Morti por David Pérez.

[4/72] Misa a dos coros de Pergolessi.

[4/73] Stabat Mater de Delgado.

[4/74] Beatus vir por Diego Martín.

[4/75] Dixit Dominus por id.

[4/76] Himno a ocho del maestro Durango.

[4/77] Acompañamiento de la misa a ocho del maestro Moya.

[4/78] Id. general de la misa a ocho del id. Durón.

[4/79] Responsorios a ocho del Padre Ramoneda.

[4/80] Lamentación a Doce del Maestro Ortellez.

[4/81] Ingredere in sanctam a cuatro voces.

[4/82] Motete O Salutaris ostia de Krafft.

[4/83] Lauda Sion.

[4/84] Miserere de Jomelli

[Los ítems subsiguientes separados de los anteriores]

[4/85] Tríos del Señor Duc.

[4/86] Seis cuartetos de Haydn.

[4/87] Dos id. de id.

[4/88] Sinfonía de Haydn.

[4/89] Otra id. ce id. 
[4/90] Sinfonía para dos violines de Pleillen.[ = Pleyel ].

[4/91] Id. de Haydn.

[4/92] Otra de id.

[4/93] Otra de id.

[4/94] Tres sinfonías de Haydn.

[4/95] Sinfonía de Boccherini.

[4/96] Tres cuartetos de Haydn.

[4/97] Rondocino de Nicolo de Malta.

[4/98] Tres cuartetos de Schmittbauer.

[4/99] Tres cuartetos de Camilo Barni.

[4/100] 11 quintetos de Boccherini.

[4/101] Cinco id. del mismo.

[4/102] Dueto a dos violines por Floriot

[4/103] Dos tríos de Montali.

[4/104] Cuarteto de Aspelmaier.

[4/105] 12 sonatas [para] violín y bajo de Giardini.

[4/106] Sonata para violín por Tartini.

[4/107] Minueto de Barbola [=Barbella].

[4/108] Ninna Nonna del mismo.

[4/109] Trio de Montali.

[4/110] Id. de Monroy.

[4/111] Diez minuetes de Boccherini.

[4/112] Rondó, Che faró senza il mio bene a toda orquesta.

[4/113] Cavatina Parli di figlia amante a toda orquesta.

[4/114] Bolatas para violín de Barbella

[4/115] Rondó, Ombra adorate aspetta.

[4/116] Seis cuartetos de Bocherini.

[4/117] Una Sonata para violín y bajo de Brunetti.

[4/118] Un legajo de minuetes y contradanzas para dos orquestas de Bruneti.

[4/119] Diez Duetos del mismo.

[4/120] Un concierto a toda orquesta de Boccherinni.

[4/121] 6 quintetos del mismo.

[4/122] Seis cuartetos de Dabaux (falta la parte del bajo)

[4/123] 21 sonatas para violín y bajo de Brunetti

[4/124] Minués y contradanzas de Haydn a toda orquesta.

[4/125] 18 mismas por el mismo para piano. 
[4/126] 12 minués y 12 contradanzas para orquesta por Carril.

[4/127] 6 contradanzas por Monrroy.

[4/128] 6 id. por Colbran.

[4/129] 4 marchas por Espinosa.

[4/130] Minués y contradanzas por Aspelmair.

[4/131] Cuartetos de Monrroy.

[4/132] Seis oberturas del mismo a toda orquesta.

[4/133] Cuartetos chicos de Boccherini.

[4/134] Id. de Abel.

[4/135] Id de Davaux.

[4/136] Id de Canales.

[4/137] Id de Humell.

[4/138] Obertura de Ponzo a toda orquesta.

[4/139] Sextetos de Bruneti.

[4/140] 12 sinfonías para varios instrumentos de Stamitz.

[4/141] 10 sonatas para piano de Haydn..

[4/142] Vals para piano de León.

[4/143] Fantasía para piano de Haydn.

[4/144] Variaciones para piano de Kirmair

[4/145] Lecciones de solfeo.

[4/146] Obertura de los dos prisioneros para piano por Carbonell.

[4/147] Id. para piano de Vermer.

[4/148] Una sonata para piano.

[4/149] Obertura para piano de Maztel ?

[4/150] Tema con variaciones para piano.

[4/151] Obertura del Prisionero para piano.

[4/152] Rondó para piano y toda orquesta por Ergent.

[4/153] Variaciones para piano.

[4/154] Sonata para piano por Eichner.

[4/155] Polaca para piano.

[4/156] Rondó de Pleyer para piano.

[4/157] Id. bailable de Haydn..

[4/158] Polaca para piano.

[4/159] 4 sinfonías de Haydn. a toda orquesta.

[4/160] Tercetos de Boccherini 3

[4/161] Cuartetos de id. 12 
[4/162] Quintetos de id.

[4/163] Cuartetos de Ponzo

[4/164] 6 sinfonías a orquesta de Boccherini

[4/165] 6 id. a cuatro de id.

[4/166] Concierto grande.

[4/167] Cuartetos de Haydn 24

[4/168] Sinfonías de id. 22

[4/169] Tríos de id 3

[4/170] Sinfonías de Hayd[n] 23

[4/171] 6 tríos de id.

[4/172] Sinfonías de Pleyel. 2

[4/173] Sinfonías de Iriarte. 4

[4/174] Id. de Monroy 5

[4/175] 5 Quintetos de Ponzo.

[4/176] 6 sinfonías de Floreluk.

[4/177] 6 cuartetos de Haydn.

[4/178] Seis cuartetos de Hubert.

[4/179] Varias canciones del maestro Ponzo. 10

[4/180] 3 sinfonías de Rosetti . 1

[4/181] Sinfonía de Aspelmayer. 1

[4/182] 3 sinfonías de Boccherini. 3

[4/183] 3 sonatas para piano de Haydn. 1

[4/184] Air de la molinarella para piano.

[4/185] Un allegro y una pastorela para piano.

[4/186] Chanson du Montagnard para piano.

[4/187] Aria degli schiavi per amore de Paisiello.

[4/188] Ronde des visitandines para piano.

[4/189] Tanze für Klavier su autor André.

[4/190] Ouverture de Blaise et Babet par Fodor [para] piano.

[4/191] La Serenade. Barcarole venitienne par Gail [para] piano.

[4/192] Ouverture et airs des Chapitre second par Solié [para] piano.

[4/193] Ouverture des deux Prisonniers por Carbonell [para] piano.

[4/194] .Ouverture Demophon para piano por Adam.

[4/195] Aria del matrimonio segretto de Cimarosa para piano.

[4/196] Romance d'Ariodant para piano por Jadin.

[4/197] Opresa mi sento para piano de Nasolini. 
[4/198] Dos canciones con acompañamiento para piano.

[4/199] La Alegría pública para piano a 4 manos por Neukomm.

[4/200] Himno marcial por id.

[4/201] Otello gran Ballo Trágico, música de varios autores para piano.

[4/202] Un cuaderno de música para piano por María Dolores García.

[4/203] Obra de música de Arias Italianas con acompañamiento de guitarra por Vidal. 3 cuadernos.

[4/204] Gran Sinfonía para varios instrumentos por Haydn.

[4/205] Seis nocturnos [con] acompañamiento de piano por Langlé.

[4/206] Un quinteto de Pleyel.

[4/207] Recueil de petits airs avec accompagnement de piano par Bidou.

[4/208] Una sinfonía de Haydn.

[4/209] 2 cuadernos de valses y contradanzas.

[4/210] 12 minués de Monroy.

[4/211] 12 minués de Pleyel.

[4/212] 12 minués de Santo Trento.

[4/213] 6 alemandas de Vanhall.

[4/214] Minué fúnebre por Compta.

[4/215] Juego Filarmónico.

[4/216] Sinfonía para la comedia Il distratto por Haydn.

[4/217] 6 Sonatas de Nardini.

[4/218] Dos cuadernos de salmodia orgánica por el padre Lanchares. 
[5] Inventario de libros de música y partituras procedentes de los palacios de La Alameda, Aranjuez, y Madrid que se subastaron en 1897 por la Comisión de Obligacionistas de Osuna

Catálogo de libros procedentes de los palacios de La Alameda, Aranjuez y Madrid. Precede al título: Comisión Ejecutiva de Obligacionistas de Osuna, Venta en pública subasta del mobiliario del Palacio de Osuna, Madrid, Est. Tip. de la Viuda e hijos de M. Tello, 1897.

[5/1] ELWART (A): Manual de armonía (versión castellana de Valldemosa): Madrid, $1845.4^{\circ}$ Piel y rústica (tres ejemplares).

[5/2] CHANSONS choisies. Londres, 1783-85, Cinco vols. En $16^{\circ}$.Pasta.

[5/3] ADAM (L.): Méthode de piano du Conservatoire: París, ou Magasin du Conservatoire Royal. Folio. Pasta.

[5/4] ADAM (L.): Sistema armonico per il piano forte ad uso del Liceo musicale di Parigi (tomos I, II y III; dos encuadernados): Firenze, nella Calcografia di musica di Giuseppe Lorenzi.

[5/5] ALBÉNIZ. Huit valses pour le piano forte: París.

[5/6] ARCHE (Luis Vicente). Misa solemne a grande orquesta para tiple, contralto, tenor y bajo (partitura orquestal). Manuscritos encuadernados en piel.

[5/7] BAYADÉRES (Les) (recueil de contredanses composées pour piano. par G.) Six contredanses extraites des symphonies d'Haydn pour piano avec accompagnement de violon ad-libitum, par L. S : París, Cousieneau.

[5/8] BELLINI (Vincenzo). I Capuleti ed y Montechi, ó sia Romeo e Giulietta (melodramma romantico in quatro parti, ridotto per piano forte solo): Napoli, presso B. Girard. Apaisado. Holandesa.

[5/9] COLLINET. Les soirées de famille (4 recueil[s] de nouvelles contredanses françaises et valses de plusieurs bons auteurs, choisies et mises en quadrilles à l'usage de la société. Arrangées pour le piano avec un accompagnement de violon ou flûte non oblige): París, Collinet. Apaisado. Holandesa.

[5/10] COLLINET. Le cotillon (danse nouvelle avec douze figures variées), Les soirées de famille $\left(36^{\mathrm{me}}\right.$ recueil de contredanses firées de l'opera de Meyerbeer «Il crociato in Egitto»). Soirées de Paris et de Londres (recueil de contredanses françaises arrangées pour piano avec l'accompagnement de flûte ou violon ad-libitum, par Defrance). 
[5/11] GATAYES. Nouvelle méthode de harpe: París, Imbault. Folio. Piel (hay otro ejemplar en rústica y sin portada).

[5/12] GENOVÉS (Tomás). Misa en mi bemol á cuatro voces y coro con orquesta (partitura orquestal manuscrita). Pasta.

[5/13] GONDOIS. Alemana y galope (en el baile pantomímico en tres actos titulado «La joven tirolesa ó la vuelta á la aldea» arregladas por el autor para piano solo): Barcelona, imprenta de Roger.

[5/14] HAYDN (J.) Études en $u t$ variées pour le piano seul ou clavecin: París, Porro.

[5/15] HUMEL (J. N.) Nuovi walzer con trío per piano forte composti per la gran Sala d' Apollo in Vienna: Firenza, presso Giu. Torenzi.

[5/16] LEDESMA (Mariano R. de). Misa á grande orquesta en honor de San Francisco de Borja, para tiples, contraltos, tenores y bajos (manuscrita; están la partitura orquestal y las particellas). Encuadernación en piel.

[5/17] MERCÉ DE FONDEVILLE (Antonio). Misa á cuatro voces con grande orquesta (partitura orquestal manuscrita). Encuadernada ricamente en terciopelo, con corona ducal y cantoneras doradas.

[5/18] MÉTHODE (Nouvelle) de toucher le piano forte (sin portada).

[5/19] MEYERBEER (G.) Il Crociato in Egitto (opera seria in due atti; ridotta per il cembalo; partitura completa para piano y canto): París, Maurice Schlesinger. Apaisado. Holandesa.

[5/20] PRINCIPES élémentaires de musique, arrêtes par les membres du Conservatoire (première partie: solfège): París, Magasin de musique, an 1816.

[5/21] ROSSINI (Gioachino). La donna del lago (ridotta per solo cembalo): Milano, presso Giu. Ricordi. Apaisado. Holandesa.

[5/22] TROZOS escogidos de las óperas «Bianca» «L' Straniera»y «El pirata» para piano forte solo (impreso en Madrid).

[5/23] TROZOS de varias óperas, principalmente de «Guillermo Tell,» «Sonámbula,» «Muta di Portici» «Gemma di Vergii,», «Mahomet» «Moisés en Egipto,»,etc., para canto y piano: manuscritos. Dos tandas de valses para piano á cuatro manos, de Strauss: manuscritos. Cavatina de la «Donna Selvaggia»y una romanza, arregladas para arpa: manuscritos. «Quadriglie e Waltzer,» de Alejandro Javier, ridotte per piano forte, con alcance. Waltzer Tedesche: manuscrito. Holandesa. 
[5/24] ROSSINI. Guglielmo Tell, ópera en cuatro actos; partitura completa para flauta. y violín. Impresa. Rústica.

[5/25] SOBEJANO AYALA (J.) El Adam español, o lecciones métodicoprogresivas de piano (tres cuadernos y fragmentos de otros): Madrid, 1826.

[5/26] STRAUSS (J.) Gabrielen-Waltzer für das piano forte: Wien, bei Tobioll Haslinger (edición para cuatro manos).

[5/27] VIRUÉS (José). Cartilla harmónica ó el contrapunto, explicado en seis lecciones: Madrid, Imprenta Real, 1824. Folio. Rústica.

[5/28] FANTASIAS, variaciones, sonatas etc, para arpa sola, y algunas con acompañamiento de violón, piano y tambor vasco, escritas por Cardou, Prufumier, Cousineau, Krumphoetz, Mad. Pallet, De Morin, Henry, Bochsa, Blattamn, Malino, Duvernoy, Argus y Deleplanque. Editadas en Londres, París y Bruselas.

[5/29] LEGAJO de papeles de música para piano, arpa, violín, etc., manuscritos. Son fragmentos, con excepción de dos piezas de poca importancia, un nocturno y un pasodoble. 



\section{Apéndice 4}

Catálogos de música de la Casa de Benavente ordenados por géneros

$$
\text { (ca. 1781-ca. 1838) }
$$



En este apéndice presento dos catálogos de las obras musicales que pertenecieron a la Casa de Benavente agrupadas por géneros: 1) el catálogo de las obras que se conservaban en el archivo de música de María Josefa Alfonso Pimentel, XV Condesa-Duquesa de Benavente (*1751-†1834) según los inventarios realizados en 1824 y ca. $1838^{1}$, y 2) El catálogo de las obras que fueron copiadas para Manuela Isidra Téllez Girón y Pimentel (*1794-†1838), hija menor de Pedro de Alcántara Téllez Girón y María Josefa Alfonso Pimentel (IX Duques de Osuna y XV Condes-Duques de Benavente) durante el período en que esta joven dama residió en Cádiz junto a su madre (1810-1813).

Para la organización formal de estos catálogos he seguido las recomendaciones de la International Standard Bibliographic Description (ISBD) y del Répertoire International des Sources Musicales (RISM) ${ }^{2}$. Dada la singularidad de las fuentes en las que baso esta catalogación, la aplicación automática de cualquiera de las normas generales descritas no resulta posible. No obstante, he procurado seguirlas hasta donde ha sido razonablemente aconsejable, intentando mantener los criterios básicos que contienen dichas normas, y en particular el agrupamiento de la información en áreas de contenido homogéneo. Por lo que concierne al aspecto sistemático, he establecido las siguientes categorías:

\footnotetext{
${ }^{1}$ AHN NOBLEZA, OSUNA-CARTAS leg.392-15 y 392-16.Véase Apéndice 3.

${ }^{2}$ General International Standard Bibliographic Description. Munich- K. G. Saur, 1992; y RISM. Normas internacionales para la catalogación de fuentes musicales históricas, Madrid, Arco Libros, 1996.
} 


\section{Música profana}

A. Música escénica

A.1. Óperas.

A.2. Zarzuela y Tonadilla.

A.3. Ballet.

B. Música para orquesta

C. Música instrumental de cámara

C.1. Dúos.

C.2. Tríos.

C.3. Cuartetos

C.4 Música de cámara para más de cuatro intérpretes

D. Música vocal

D.1 Voz y piano

D.2.Voz y otros instrumentos

D. 3 Voz y orquesta

E. Música para instrumentos a solo

E.1.Música para piano

E.2. Música para piano o arpa

E.3 Música para arpa y piano o dos pianos

\section{Música religiosa}

F. Misas

G. Otras obras litúrgicas o paralitúrgicas

\section{Obras de carácter pedagógico}

Desde el punto de vista descriptivo, presento las informaciones relativas a cada una de las obras de acuerdo con los siguientes criterios:

1. Dentro de cada categoría las obras están ordenadas alfabéticamente por autores. Las obras de cada autor se ordenan cronológicamente cuando existe en la fuente alguna referencia. Aquellas obras en las que sólo figura el título genérico (por ejemplo "Sinfonía") se sitúan al final de la relación, ordenadas por orden alfabético y el número de inventario.

2. Los números entre corchetes se refieren a la ubicación de las obras dentro de los inventarios del Apéndice 3. Cuando no es posible establecer correspondencias entre las obras de títulos similares que figuran en dos 
inventarios he optado por presentarlas como obras distintas.

3. He traducido al castellano los títulos genéricos de las obras. El resto de títulos permanecen en el idioma con el que figuran en los inventarios.

4. En las obras señaladas con * no aparece en los inventarios ninguna información sobre su instrumentación. He optado por incluirlas en la categoría que predomina en el legajo o estante en que se hallaban agrupadas.

5. Al final de cada obra recojo las observaciones significativas que aparecen en los inventarios. 


\section{Catálogo del archivo de música de la XV Condesa-Duquesa de Benavente (ca. 1781-ca. 1838)}

Fuente: AHN NOBLEZA, OSUNA-CARTAS, leg 392-15. Índice de las obras custodiadas en dos armarios que componen la papelera de música vocal e instrumental de la Excelentísima Señora Duquesa Condesa [sic] de Benavente. Año de 1824 y leg 392-16.

\section{Música profana}

\section{A. Música escénica}

\section{A.1. Óperas}

\section{Anónimo}

La Festa della Rosa. [3/296]

La Posadera sutil.

Ópera en dos actos. [3/288], [4/40]

Un espartito [= partitura] en papel pequeño de una ópera, cuyo título y autor se ignora. [3/191]

Una obra cuyos interlocutores son Giunone, Pallade, Giove e Marte [3/285]

\section{Berton, [Henri-Montan]}

La Romance.

Ópera en un acto [3/155], [4/20]

Le Concert interrompu.

Ópera cómica en un acto [3/142], [4/22]

Le Gran Devil.

Ópera en un acto. [3/135], [4/21]

Les promesses de mariage, ou la suite de l'épreuve villagerie.

Ópera bufa en dos actos. [3/150], [4/1]

\section{Bruni, [Antonio Bartolomeo]}

Le Major Palmer.

Ópera en tres actos. [3/141], [4/29] 


\section{Capmany, [Francisco]}

Lorenza la incluserita.

Ópera [3/289], [4/43]

Dedicada al Excelentísimo Señor Don Pedro Girón Duque de Osuna.

\section{[Cimarosa] Domenico}

La Italiana en Londres. [3/289], [4/39]

\section{Coccia, [Carlo]}

La Clotilde. [3/299]

\section{Dalayrac, [Nicolas-Marie]}

Adolphe et Clara, ou les deux Prisonniers.

Comedia en prosa en un acto. [3/66], [3/147], [4/4], [4/13]

Le Château de Montenero.

Comedia en prosa en tres actos. [3/139],[4/17]

Le Matinée de Catinat. [3/62], [4/8]

Léhéman ou la Tour de Neustadt.

Ópera en tres actos. [3/140], [4/31]

Les deux petits savoyards.

Comedia en un acto. [3/146], [4/15]

Une heure de mariage.

Comedia en prosa en un acto [3/151], [4/22]

La Maison à vendre. [3/63], [4/7]

\section{Fai}

Clemantine ou la Belle Mare [3/64], [4/6]

\section{Gaveaux, [Pierre]}

Leonore ou l'amour conjugal.

Hecho histórico español en dos actos [3/145], [4/27]

Le Diable en vacances, ou la suite du Diable couleur de rose.

Ópera seria y cómica en un acto. [3/156], [4/24]

[Le] Locataire [3/69], [4/2]

Un quart d'heure de silence.

Ópera cómica en un acto. [3/152], [4/18]

Le Bouffe et le Tailleur.

Ópera cómica en un acto. [3/153], [4/14]

[Le] Trompeur trompé. [3/67] 


\author{
Gazzaniga, [Giuseppe] \\ I fratelli ridicoli. \\ Ópera en dos actos. [3/283], [4/38]
}

Isouard, Nicolas [= Nicolò, Nicolò de Malta]

Le Médecin Turc.

Ópera bufa en un acto. [3/154], [4/12]

Les Confidences.

Ópera en dos actos. [3/138], [4/19]

L'intrigue aux fenêtres.

Ópera [3/158], [4/30]

\title{
Langlé, [Honoré de]
}

Corisandre, ou les Joux par enchantement.

Ópera-ballet [3/159], [4/32]

\section{Lebrun, [Louis-Sébastien]}

Marcelin.

Ópera en prosa en un acto. [3/65], [3/143], [4/5], [4/9]

\section{Méhul, [Etienne-Nicolas]}

Le trésor supposé, ou le danger d'écouter aux portes.

Comedia en un acto. [3/148], [4/26]

\section{Meyerbeer, [Giacomo] \\ Il Crociatto in Egitto. [3/164], [3/166] \\ En [3/166] se conservaba "un tema" de esta ópera.}

\section{Paisiello [Giovanni]}

Il Barbiere di Siviglia.

Ópera en dos actos. [3/284], [4/37]

\section{[Paisiello, Giovanni]}

La Frascatana.

Ópera en tres actos [3/291], [4/41]

\section{Persuis [Louis-Luc Loiseau de]}

Fanny Morna ou l'Ecossaise. Drama lírico en prosa en tres actos. [3/137], [4/16]

\section{Plantade, [Charles-Henri]}

Zoë ou la Pauvre petite.

Ópera en un acto. [3/68], [3/144], [4/3]. [4/28] 
Palma ou le Voyage en Gréce.

Ópera en dos actos. [3/149], [4/25]

\section{Rossini, [Gioachino] \\ La Donna del lago. \\ Ópera [3/298]}

Torvaldo e Dorliska. [3/297]

Ópera

Le siége de Corinte. [4/33]

\section{Solié, [Jean Pierre]}

Chapitre second.

Ópera cómica en un acto. [3/136], [4/10]

\section{Spontini, [Gaspare]}

Milton.

Ópera en prosa en un acto. [3/157], [4/11]

\section{Winter [Peter von]}

Il Maometto. Melodrama Trágico. [3/71]

Se conservaba una "Gran Escena: Terzetto e Quintetto" de esta ópera

\section{A.2. Zarzuela y Tonadilla}

\section{Ponzo [Giuseppe]}

El Extranjero.

Zarzuela [3/286], [4/44]

En [4/44] "Ópera en 2 actos"

\section{Laserna, [Blas de]}

Donde menos piensa el galgo, salta la liebre.

Tonadilla a tres. [3/287], [4/42]

\section{A.3. Ballet.}

\section{Anónimo}

Otello: Gran Ballo Tragico [3/107], [4/201]

"inventato e posto sulle scene del Real Teatro alla Scala dal Signor Salvatore Viganó"

Reducción para clave. 


\title{
B. Música para orquesta
}

\section{B.1. Orquesta sin solista}

\author{
Anónimo \\ Minuetes y contradanzas. [3/187]* \\ Concierto. [3/190]
}

Aspelmayr, [Franz]

Sinfonía [3/37], [4/181]

[Boieldieu, François-Adrien]

Obertura de El Califa de Bagdad [3/86]

\section{Boccherini, [Luigi]}

Concierto a toda orquesta. [4/120]

Concierto grande. [3/61], [4/166]

Concierto $1^{\circ}$. [3/176]

"Dedicado al Serenísimo Señor Infante Don Luis".

Diez Minuetes. [3/175], [4/111]

"Expresamente escritos para la Excelentísima Señora Condesa de Benavente. Año de 1787'.

Seis Sinfonías. [3/28].

"Dedicadas al Serenísimo Señor Infante Don Luis. Año de 1775".

Seis Sinfonías. [3/29].

"Dedicadas las cinco primeras al Serenísimo Señor Infante Don Luis, y la sexta a la Excelentísima Señora Condesa de Benavente. Año de 1782”.

Sinfonía. [3/30]

"Dedicada a la Excelentísima Señora Condesa de Benavente. Año de 1787'.

Sinfonía. [3/31]

"Dedicada a la Excelentísima Señora Condesa de Benavente".

Sinfonía $n^{\circ} 2[3 / 32]$.

"Dedicada al Serenísimo Señor Infante Don Luis"

Sinfonías. $n^{\circ} 3,4,5,6 .[3 / 33]$.

"Dedicadas al Serenísimo Señor Infante Don Luis"

Sinfonía. [4/95]

Seis Sinfonías a toda orquesta. [4/146] 
Seis Sinfonías. [4/165].

Seis Sinfonías a cuatro. [4/166].

Tres Sinfonias. [4/182].

Gran Sinfonía para varios instrumentos. [4/204]

\section{Brunetti, [Gaetano]}

Minuetes y contradanzas a dos orquestas. [3/167], [4/118]

\section{Carril [Manuel?]}

Doce minués y doce contradanzas a toda orquesta. [4/126]

\section{Colbran}

Seis contradanzas. * [4/128]

\section{Espinosa, [Manuel de]}

Cuatro marchas.* $[4 / 130]$

\section{Floreluk}

Seis Sinfonías [4/176]

\section{Haydn, [Joseph] (1732-1809)}

Minués y contradanzas a toda orquesta. [4/124]

Seis Sinfonías $n^{\circ}$ 1, 2, 3, 4, 5, 6. [3/1]

Seis Sinfonías $n^{\circ}$ 7, 8, 9, 10, 11, 12 [3/2]

No se conservaban las $n^{\circ} 9,10$ y 12 .

Seis Sinfonías. $n^{\circ} 13,14,15,16,17,18$ [3/3]

Seis Sinfonias. $n^{\circ} 19,20,21,22,23,24$ [3/4]

No se conservaban las $n^{\circ} 20,21,22$.

Sinfonía $n^{\circ} 25 .[3 / 17]$

Sinfonía $n^{\circ}$ 27. [3/18]

Sinfonía $n^{\circ}$ 28. [3/19]

Sinfonía $n^{o}$ 30. [3/20]

Seis Sinfonías. Números 31, 32, 33, 34, 35, 36 [3/5]

No se conservaban las $n^{\circ} 35$ y 36 
Seis Sinfonías marcadas con los números 37, 38, 39, 40, 41, 42 [3/6]

No se conservaban las $n^{\circ} 39^{a}$ y $41^{a}, 42^{\prime}$

Sinfonía $\mathrm{n}^{\circ}$ 40. [3/21]

Sinfonía $\mathrm{n}^{\circ}$ 43. [3/22]

Sinfonía $\mathrm{n}^{\circ} 44$ [3/23]

Sinfonía $n^{\circ} 45 .[3 / 35]$

Catorce sinfonías. Juego $1^{o}$. [3/38]

Catorce sinfonías. Juego $2^{\circ}$. [3/39]

Tres sinfonías. [3/34], [4/94]

Sinfonía para la comedia Il distratto. [4/89]

Cuatro Sinfonias a toda orquesta. [4/159]

Sinfonía. [3/24]

Sinfonía. $[4 / 88]$

Sinfonía. [4/89]

Sinfonía. [4/91]

Sinfonía. [4/92]

Sinfonía. [4/93]

Sinfonía. [4/108]

Veintidós Sinfonías. [4/168]

Veintitrés Sinfonías. [4/170]

\section{Iriarte [Tomás ]}

Cuatro Sinfonías. [3/8], [4/173]

\section{Kozeluch, [Leopold]}

Seis sinfonías. [3/7] 
Monroy, [Ramón Rodríguez]

Seis oberturas. Juego $1^{\circ}$ [3/40], [4/132]

Seis sinfonías. [3/8]

Cinco sinfonías. [4/174]

Pleyel [Ignaz]

Sinfonía. [3/25]

Sinfonía. [3/26]

Sinfonía. [3/27]

Dos sinfonías. [4/172]

\section{Ponzo, [Giuseppe]}

Cinco oberturas. Juego $1^{\circ}[3 / 41]$

Obertura a toda orquesta [4/138]

\section{Rosetti Antonio [=Franz Anton Rösler]}

Tres sinfonías. [3/36], [4/180]

\section{Stamitz [Carl ?]}

Trece sinfonías. [3/125], [4/140]

No se conservaba la $n^{\circ}$ 9"

\section{B.2 Orquesta y solista instrumental.}

\section{Hergen [Ergent] \\ Rondó para forte piano y toda orquesta. [3/257], [4/152]}




\section{Música instrumental de cámara}

\section{C.1. Dúos}

\section{Anónimo}

Colección de contradanzas y valses para dos violines [3/305]

Contradanzas y valses para dos violines. [3/304]

Minuettes y Contradanzas de varios autores. [3/16]

Doce Minuetes * [3/212]

Polonesas para piano y violín. [3/308]

9 cuadernos

Polonesas .* [4/45]

8 cuadernos

\section{Barbella, [Emanuele]}

Duetto a due violini, disfidandosi ora l'uno, ora l'altro. [3/184]

Minuetto scordato. [3/185], [4/107]

Ninna nonna per dormire. Duetto di violino e basso. [3/186], [4/108]

Volate di note musicali per ben suonare il Violino. [3/223], [4/114]

\section{Brunetti, [Gaetano]}

Diez Dúos para dos violines. [3/179], [4/119]

Veintidós sonatas para violín y bajo de diferentes óperas. [3/178], [4/123], [4/117]

\section{[Dezède, Nicolas]/ Fodor (adapt. )}

Obertura de Blaise et Babet. [3/115], [4/190]

Arreglo para clave o fortepiano de Fodor.

\section{Floriot}

Dueto a dos violines. [4/102]

\section{García Quintano, María de los Mártires}

Sonata [para fortepiano] con acompañamiento de violín. [3/110].

En Primer cuaderno: Música para forte piano.

\section{Giardini, [Felici]}

Doce Sonatas para violín y bajo. [3/177], [4/105] 


\title{
Haydn, [Franz Joseph]
}

Fantasía para fortepiano o clave y para órgano. [3/270], [4/1430]

\author{
Nardini, [Pietro] \\ Seis Sonate per violino solo e Basso. [3/118], [4/217]
}

\section{Pleyel, [Ignaz]}

Sinfonía para dos violines. [4/90]

\section{Tartini, [Giuseppe]}

Sonata de violín solo y bajo. [3/188]

\section{C.2. Tríos}

\section{Boccherini, [Luigi]}

Seis Tercetos. [3/60]

"Año de 1776"

Tres tercetos. [4/160]

\section{[Le] Duc L'Aine, [Simon]}

Seis Tríos. Juego $1^{o}$. [3/54], [4/85]

\section{Eichner, [Ernst]}

Sonate pour le clavecin avec accompagnement de violon et violoncelle ad libitum $[3 / 276]$

\section{García Quintano, María de los Mártires}

Trio [con acompañamiento] de dos violines. [3/110].

Publicada en Primer cuaderno: Música para fortepiano.

\section{Haydn, [Joseph] (1732-1809)}

Tre Sonate per il clavicémbalo o forte piano con un violino e violoncello [3/103]

Seis Tríos. [3/14]

Seis Tríos. Juego $1^{\circ}[3 / 53]$

Tres Trios. [4/169]

Seis Tríos. [4/171] 
Masarnau, [Santiago?] - Moscheles, [Ignaz]

Collection de Valses pour deux violons et Basse. [3/303]

\section{Montali,}

Dos Tríos a dos violines y bajo. [3/183]

Trío a dos violines y bajo.[3/182], [4/109]

\section{Monroy, [Ramón Rodríguez]}

Doce minués y dos paspiés con sus minués a dos violines y bajo. [3/74]

Doce minués. [4/210]

Dos paspiés con sus minués a dos violines y bajo.

Trío para la oposición de contrabajo en la Real Capilla de Su Majestad. [3/181] [4/110]

\section{Pixis, [Johann Peter ?]}

Les folies Parisiennes. Collection de Contredanses et valses pour 2 violons et Basse. [3/302], [4/47]

\section{Pleyel, Ignaz}

Trois Sonates pour clavecin ou piano forte avec accompagnement de flute et violoncelle. [3/76], [3/295]

\section{Schmittbauer, [Joseph Aloys]}

Trois Quatuors, deux a Flûte, Alto et Basse, et un a Flûte, deux violons et Basse [3/109], [4/98]

\section{Vogel [Johann Christoph] / Adam (adapt.)}

Obertura de Demophon [4/190], [4/194]

Arreglo para clave o fortepiano, violín y bajo de 


\title{
C.3. Cuartetos
}

\author{
Abel, [Carl Friedrich] \\ Seis Cuartetos. Juego 1º [3/49] [4/134]
}

\section{Anónimo}

Seis Cuartetos instrumentales. [3/293]

\section{Aspelmayr, [Franz] \\ Cuarteto. Juego 1'. [3/189], [4/104]}

\section{Barni, Camille}

Trois Quatours pour deux violons, alto et violoncelle. [3/134], [4/99]

\section{Boccherini, [Luigi]}

Seis Cuartetos. [3/56]

"Año 1761"

Seis Cuartetos. [3/57]

"Año 1769"

Seis Cuartetos. [3/58]

"Año 1770"

Seis Cuartetos chicos. [3/59], [4/133]

"Año 1772"

Seis Quartettinos. [3/169]

"Dedicados al Serenísimo Señor Infante Don Luis. Año de 1781"

Cuarteto. [3/173]

"Año $1787 "$

Seis Cuartetos. [4/116]

Doce Cuartetos. [4/161]

\section{Canales, [Manuel]}

Seis Cuartetos. [3/48]

\section{Davour}

Seis Cuartetos. Juego 1. ${ }^{o}[3 / 47]$

\section{Davaux, [Jean Baptiste]}

Six Quatuor concertants pour deux violons, alto et Basse. [3/133], [4/122] 


\author{
Haydn, [Joseph] (1732-1809) \\ Seis Cuartetos. Juego 1 ${ }^{\circ}$. [3/131] \\ Seis Cuartetos. Juego 2 ${ }^{\circ}$. [3/43] \\ Seis Cuartetos. Juego 3. [3/42] \\ Seis Cuartetos. Juego 4º [3/44] \\ Seis Cuartetos. Juego 5 . [3/45] \\ Seis Cuartetos. Juego 6 ${ }^{\circ}$ [3/46] \\ Trois quatuors pour deux violons, alto et Basse. [3/73] \\ Seis Cuartetos. [3/10] \\ Dos cuartetos. [3/11] \\ Seis Cuartetos. [3/12] \\ Seis Cuartetos. [4/86] \\ Dos cuartetos. [4/87] \\ Tres cuartetos. [4/96] \\ Veinticuatro cuartetos. [4/167] \\ Seis cuartetos. [4/177]
}

\title{
Hummel, [Johann Nepomuk]
}

Seis Cuartetos. [3/51], [4/137]

\section{Hubert}

Seis Cuartetos. [3/12]

\section{Monroy, [Ramón Rodríguez]}

Seis Cuartetos. [3/50], [4/131]

\section{Ponzo, [Giuseppe]}

Seis Cuartetos. [3/52]

Cuatro cuartetos. [4/163] 


\section{C.4 Música de cámara para más de cuatro intérpretes}

\section{Brunetti, [Gaetano]}

Seis Sextetos. [3/180]

"Hechos expresamente para el Excelentísimo Señor Duque de Osuna" "Falta el $1^{\circ}$ "

Seis Sextetos. [3/132]

Sextetos. [4/139]

\section{Boccherini, [Luigi]}

Seis Quintetos chicos. Ópera 2a. [3/127]

"Año de 1771"

Seis Quintetos chicos Ópera $2^{a}$. [3/129]

"Año de 1771"

Seis Quintetos chicos. Ópera 1 $1^{a}$. [3/128]

"Año de 1772"

Seis Quintetos chicos. Ópera $3^{a}$. [3/126]

"Año de 1773"

Seis Quintetos chicos Ópera 2 $2^{a}$ [3/130]

"Año de 1775"

Seis Quintetos. [3/168]

"Dedicados al Serenísimo Señor Infante Don Luis. Año de 1779"

Seis Quintetos. [3/170]

"Dedicados al Serenísimo Señor Infante Don Luis. Año de 1780"

Seis Quintetos. [3/171]

"Dedicados a la Excelentísima Señora Condesa de Benavente. Año de 1786"

Tres Quintetos. [3/172]

"Dedicados a la Excelentísima Señora Condesa de Benavente. Año de 1787"

Cinco Quintetos [4/101]

Once Quintetos [4/100]

Seis Quintetos [4/121]

Veinticinco Quintetos [4/162]

Sexteto [3/174]

"Año 1787" 


\section{Langlé, [Honoré de]}

Recueil anacréontique, composé de Romances, Pastorales et Vaudevilles, formant 36 numéros pour le piano forte ou Harpe avec accompagnement ad libitum soit de Flûte, Violon, Clarinette, Cor, Basse ou Basson. [3/161].

\section{Pleyel, [Ignaz]}

Dodici Minuetti per diversi instrumenti. [3/97], [4/211]

Quintetto per due violini, due viole et violoncello. [3/96], [4/106]

\section{Ponzo, [Giuseppe] \\ Cinco Quintetos. [3/15], [4/175]}

\section{Vanhall, [Johann]}

Six Allemandes a plusieurs instruments. [3/84], [4/213]

\section{Música vocal}

\section{D.1 Voz y piano}

\section{Adam, [Adolphe?]}

Fermati ingrato. [3/236]

Terceto de la ópera Ariadna.

\section{Anónimo}

Boleras [3/253]

Coplas en la ópera La Travesura [3/254]

Coplas de Zetulbe [3/245]

Cuaderno de canciones francesas. [3/251]

Dos canciones con acompañamiento de piano. [4/198]

Esto es hecho yo me caso. Cavatina. [3/234]

Feuille Filharmonique ou Recueil des meilleurs morceaux des opéras italiens avec ccompagnement de piano. [3/308] , [3/165], [4/48]

Cinco cuadernos

Infeliz que resuelves. Aria. [3/239]

Le premier regard de Fanny. Romance. [3/243] 
O meu coraçao me diz. Modinha. [3/241]

Polo o Caballo. [3/246]

Que temor me acobarda. Aria. $\{3 / 231]$

Saper bramate. Cavatina. [3/244]

Escrita para"Mademoiselle d'Ossuna"

Siete Canciones Francesas. [3/121]*

\section{Asioli, [Bonifacio?]}

Doce dúos [3/255]

Veintiquattro Duetti con accompagnamento di pianoforte [3/294]

\section{Bernardini, Marcello [=Marcello da Capua]}

Alla mia bella ingrata. Aria. [3/229]

\section{Christiani}

Ah son questi i preziosi momenti. Cavatina.[3/236]

\section{Cherubini, [Luigi]}

Perfida Clori. Canone a tre voci de Cherubini. [3/247]

\section{Cimarosa, [Domenico]}

Pria che spunti in ciel l'aurora: Aria de "Il Matrimonio segreto". [3/93]

Quanto e grave il mio tormento. Aria. [3/228]

\section{Coccia, [Carlo]}

Pietá del mio dolore: Cavatina [3/108] *

\section{Dalayrac, [Nicolas-Marie] \\ Air de folle soirée [3/249]}

\section{de Bessieres, Luisa de P.}

Invocación al Sacratísimo corazón de Jesús. [3/307]

Dedicada a "S. M. La Reina de España"

de la Grua, Miguel (Marqués de Branciforte)

Canzonette [3/252]. 


\section{Federici, [Vincenzo]}

Qual tetro orror m'assale. Tercetto. [3/232]

\section{Garpe}

Te bien aimer. Air Français. [3/250]

\section{Haydn, [Franz Joseph]}

Ariane dans l'isle de Naxos: Cantata a voix seule avec accompagnement de piano forte [3/75]

\section{Isouard, Nicolas [= Nicolò, Nicolò de Malta]}

Rondocino de [la ópera] L'intrigue aux fenêtres: [3/72]

Rondocino [4/97]

Sei Duetti. [3/235]

\section{[Langlé, Honoré de]}

Aimable et belle: Rondó. [3/100]

Es un número de la ópera Adolphe et Clara ou Les deux Prissioners

Chanson du Montagnard d'Auvergne [3/112], [4/186]

\section{López Remacha, Miguel}

Seguidillas y canciones [3/238]

\section{Méhul, [Etienne-Nicolas]}

Femme sensible. Romance de la ópera Ariodant [3/92]

\section{Moisi}

Due canzonette. [3/256]

\section{Nasolini, [Sebastiano]}

Dei clementi. Cavatina. [3/90]

Opressa mi sento. [3/89], [4/197]

\section{Nielfa, [Lorenzo]}

Dos canciones con acompañamiento de fortepiano [3/88]

"Dedicadas a los amantes de la música" 


\section{Paer, [Ferdinando]}

Abelardo ed Eloisa. Cantata a due voci [3/240].

A lei che adoro: Aria. [3/101] *

Es un número de la ópera Griselda.

Vederlo sol bramo: Duetto. [3/99] *

Es un número de la ópera Griselda.

\section{Santo Trento}

Raccolta di dodici minuetti. [3/122], [4/212]

\section{Paisiello, [Giovanni]}

Felice Pastorella Aria. [3/113], [4/187] *

Es un número de la ópera Gli schiavi per amore.

\section{[Piccini, Nicola]}

Air de la Molinarella [3/123], [4/184]

\section{Rossini, [Gioacchino]}

Quel sembiante quello sguardo. Terceto. [3/233]

Es un número de la ópera L'inganno Felice.

\section{Rutina, [Giovanni Marco]}

Sul piu bello del mio sposalizio. Cavatina [3/230]

\section{Winter, [Peter von]}

Ah confida ad altra mano: Duetto [3/106] *

Es un número de la ópera Il Maometto.

\section{D.2.Voz y otros instrumentos}

\section{Bidou}

Monument consacré a la tendresse maternelle, ou recueil de petits airs. [3/83], [4/207]

Con acompañamiento de fortepiano o arpa.

\section{[Devienne, François]}

Rondeau et Airs des Visitandines. [3/120]

Con acompañamiento de fortepiano o arpa. 


\section{Langlé , [Honoré]}

Sei Notturni ou petits duos Italiens a voix égales avec des paroles italiens et Françaises. [3/82], [4/205]

Con acompañamiento de fortepiano o arpa ad libitum.

\section{Vidal}

Obra de música de arias italianas con acompañamiento de guitarra.

[3/98], [3/163], [4/203]

\section{D.3 Voz y orquesta}

\section{Andreozzi, [Gaetanno?]}

Nel bel volto amato bene. Rondó. [3/201]

\section{Anónimo}

Che faro senza il mio bene. Aria. [3/227]

Che faro senza il mio bene. Rondó. [4/112]

"a toda orquesta"

Donne donne il vostro sesso. Aria. [3/215]

Giornale di Musica vocale Italiana di Ricordi e festa composto di Cavatine, Arie, Rondó, Duetti e Terzetti etc. [3/102]

Partitura y reducción para piano.

Io son tradito. Duetto. [3/203]

Io vi lascio. Aria. [3/200]

Mi parea a notte oscura. Aria. [3/196]

Ombra adorata aspetta. Rondó. [3/224], [4/115]

Parli di figlia amante. Cavatina. [3/226], [4/113]

Partiro dal caro bene. Rondó. [3/205]

Per pietá ma dove oh Dio. Aria. [3/210]

Piano un pó. Aria. [3/214]

Povero cuor per che. Romance. [3/217]

Prudente mi chiedi. Aria. [3/218]

Troppo ingiusto amor. Aria. [3/193] 


\section{Brunetti, [¿Giovanni Gualberto?]}

La tua bella s'avvicina. Aria [3/208]

Dei pietosi in tal momento. Rondó [3/222]

\section{Brunetti, Giovanni Gualberto [= Brunetti Pissano]}

Parli di madre amante. Cavatina. [3/198]

Se tu veder potessi. Duetto. [3/207]

\section{Caruso, [Luigi?]}

Al mio ben che m'innamora. [3/225]

Cherubini, [Luigi]

Caro consorte amato. Aria. [3/216]

\section{Cimarosa, [Domenico]}

Hijo amado ten presente. Aria. [3/202]

Idol mio cor pietoso il fato. Rondó. [3/204]

Il mio cor gli afetti miei. Aria. [3/205]

\section{Fabrizi, [Vincenzo]}

L'alba chiara il sol nascente. Aria. [3/221]

\section{Federici, [Vincenzo]}

Oh fortunato istante. Polacca. [3/199]

\section{Giordani, Giuseppe [= Giordaniello] \\ Qual orror. Terceto [3/194]}

\section{Langlé, [Honoré de]}

Cantata a Clori. [3/211]

Escrita "pour Mademoiselle d'Ossuna"

\section{Lamaria}

Dal mio cor sperate in vano. Aria. [3/197]

\section{Paer, [Ferdinando]}

Abelardo ed Eloisa. Cantata a due voci. [3/195] 


\section{Paisiello, [Giovanni]}

Il mio garzon il pifano suonava. Cavatina e Duetto. [3/209]

\section{Ponzo, [Giuseppe]}

Canción con varios instrumentos. $\{3 / 55]$

Diez canciones con varios instrumentos. [4/179]

Portugal, Marcos Antonio [=Portogallo]

Alle vesti ed all'aspetto. Aria [3/192]

Per queste amare lagrime. Aria [3/193]

\section{Tozzi, [Antonio]}

Se non ti moro allato. Duetto [3/220]

Serenata [3/219]

\section{E. Música para instrumentos a solo}

\section{E.1.Música para piano}

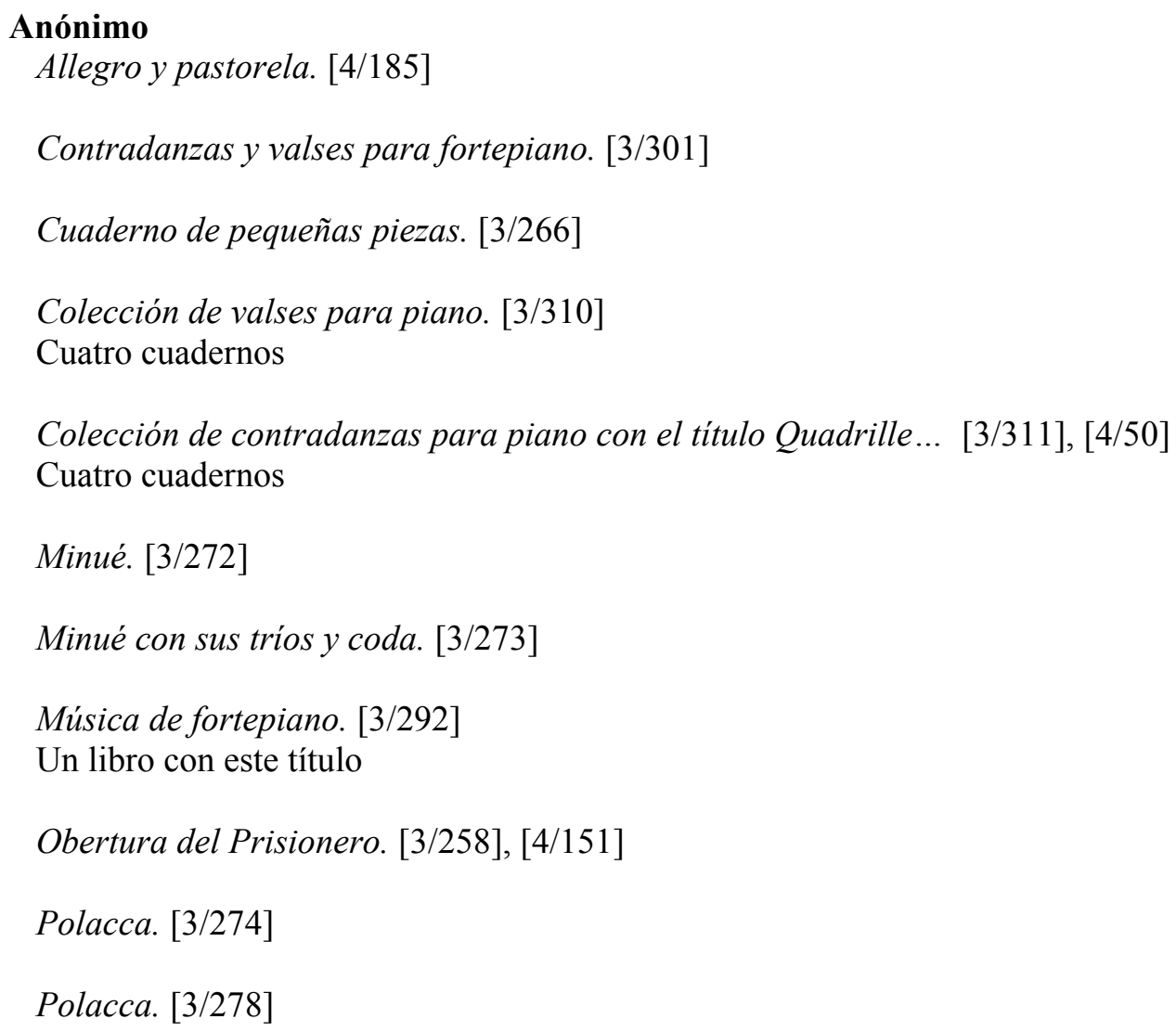


Polaca. [4/155]

Polaca. [4/158]

Sonata marcada con el n $n^{\circ}$ 6. Ópera 1. [3/275]

Sonata. $[3 / 277]$

Sonata. $[3 / 262]$

Sonata. $[4 / 148]$

Sonatas. [3/260]

"Un libro de sonatas sin principio ni fin"

Tema con variaciones. [4/150]

Ronde des Visitandines [4/188]

Valses y contradanzas [4/209]

Dos cuadernos

Valses para fortepiano [3/306]

Variaciones [4/153]

Variaciones [3/271]

Variaciones [3/259]

\section{Anónimo ["Un profesor de esta corte"]}

Divertimiento instructivo para fortepiano, compuesto de 38 valses. [3/79]

Divertimiento instructivo para fortepiano, compuesto de 48 contradanzas. [3/80]

\section{André, Antón}

Un cuadernito de pequeñas piezas para fortepiano. [3/114]

Tanze für Klavier. [4/189]

\section{Cimarosa, [Domenico]}

Aria del matrimonio secreto para piano. [4/195]

\section{Constantin}

Le Caprice des Parisiennes. Contradanzas y Valses. [3/315], [4/46]

Tres cuadernos. 


\section{Compta, Rafael}

Minué fúnebre para fortepiano a la muerte de Su Alteza Serenísima el Señor Infante Don Antonio. [3/124], [4/214]

[Dalayrac, Nicolas-Marie] / Carbonell (adapt.)

Ouverture des Deux Prisonniers. [3/95], [3/265] [4/146], [4/193]

Arreglo para clavecin o fortepiano

\section{Ditrichstein, Maurice}

Théme Danois. [3/312], [4/53]

\section{Eichner, [Ernst]}

Sonata para piano. [4/154]

\section{Gail (adapt)}

La Serenade: Barcarole Venitienne. [3/117] [4/191]

Arreglo para fortepiano

\section{Galinek, [Josef]}

Valse favorite a Rolând des Bois. * [4/54]

\section{García Quintano, María de los Mártires}

Adagio con su Allegro. [3/110].

Publicada en Primer cuaderno: Música para fortepiano

Cuaderno de música para piano. [4/202]

Marcha. [3/110].

Publicada en Primer cuaderno: Música para fortepiano

Rondo. [3/110].

Publicada en Primer cuaderno: Música para fortepiano

Sonata. [3/110].

Publicada en Primer cuaderno: Música para fortepiano

\section{Haydn, Joseph}

Dieciocho contradanzas [4/125]

Rondó bailado en el teatro de Madrid. [3/280], [4/157]

Sonata a 4 mains. [4/49]

Tres sonatas. [4/183] 
Diez sonatas. [3/281], [4/141]

\section{Hummel, [Johann Nepomuk]}

Seis grandes valses. *[4/51]

\section{Kirmair}

Siete variaciones. [3/269], [4/144]

\section{Jadin, [Hyacinthe?]}

Romance d'Ariodant. [4/196]

\section{Kozeluch, [Leopold]}

Sonate a quatre mains. [3/268]

\section{Lemoine}

Premier Quadrille, et une grande Walse sur des motifs de Rossini pour le forte piano [3/116]

\section{Martel ?}

Obertura para piano. [4/149]

\section{Masarnau, [Santiago de]}

Le Parnasse. Recouil a Walses * [4/56]

\section{Méhul, [Etienne-Nicolas]}

Obertura de la caza del joven Enrique. [3/261]

\section{Moscheles, [Ignaz]}

Les charmes de Paris. Rondeau brillant pour le forte piano. [3/311], [4/52]

21 valses $*[4 / 55]$

\section{Mozart, [Wolfgang Amadeus]}

Doce variaciones. [3/267]

\section{Neukomm, Segismundo}

La Alegría pública: Marcha a grande orquesta, compuesta y arreglada para forte piano a cuatro manos. [3/104], [4/199]

Himno Marcial. [3/105], [4/200]

"Dedicado a Su Majestad la Reina de España" 


\title{
Ouvray
}

Potpourri des plus jolis Airs nouveaux. [3/85]

\section{Pixis, [Johann Peter ?]}

Les Folies Parisiennes. Contradanzas y Valse.s [3/314]

Cuatro cuadernos.

\author{
Pleyel, Ignaz \\ Rondó [3/279], [4/156]
}

\section{Rodríguez León, José}

Vals para forte piano [3/280], [4/142]

"Dedicado al ilustre y Real Cuerpo de Guardias de Coros"

\section{Rossini, [Gioacchino] \\ Sinfonía de la Semiramide [3/166]}

\section{Solié, [Jean Pierre]}

Ouverture et airs du Chapitre second. [3/81], [4/192]

\section{Vernier [Vermer] \\ Ouverture. [3/263], [4/147]}

\section{Viotti, [Giovanni Battista] / Pleyel. [Ignaz] (adapt) \\ Polonaise et Rondeau. [3/191] \\ Original de Viotti y arreglada para piano por Pleyel}

\section{E.2. Música para piano o arpa}

\section{Beauvarlet-Charpentier}

Oeuvres diverses de Musique pour le forte piano ou Harpe [3/187]

\section{E.3 Música para arpa y piano o dos pianos}

\section{Boieldieu, [François-Adrien]}

Deuxieme Duo pour la Harpe et le forte Piano, ou pour deux Pianos. [3/119] 


\title{
2. Música religiosa
}

\section{F. Misas}

[Anónimo]

Misa a cuatro y a ocho. [3/346], [4/59].

\author{
Abril, Tomás \\ Misa a tres. [3/329], [4/58].
}

Brunetti, [Gaetano]

Misa. [3/343].

Capmany, Francisco

Misa [3/317], [4/57]

"Dedicada a la Excelentísima Señora Duquesa de Osuna"

\section{Durón, [Sebastián?]}

Misa a ocho con acompañamiento de bajo. [3/335], [4/77]

\author{
Haydn, [Michael] \\ Messa a due cori. [3/322], [4/72].
}

\author{
Haydn, [Joseph] \\ Misa a cuatro. [3/345], [4/72]. \\ Misa a cuatro y a ocho [4/62]. \\ Kraft \\ Misa a ocho. [3/331].
}

\section{Lidón, José (1746-1827)}

Misa a ocho. [3/327], [4/64]

Dedicada a "la Excelentísima Señora Condesa de Benavente"

\section{Monroy, Ramón [Rodríguez] (17-18?)}

Misa a ocho. [3/328], [4/60].

\section{Moya, [Eugenio?]}

Misa a ocho con violines y trompas y sin ellos. [3/338], [4/77] 


\section{Paer, [Ferdinando] \\ Misa a quatri. [3/344]}

\section{Paisiello, [Giovanni] \\ Messa a due cori. [3/330], [3/341], [4/66].}

\section{Pergolessi, [Giovanni Battista]}

Messa a due cori. [3/322], [4/72]

\section{G. Otras obras litúrgicas o paralitúrgicas}

\section{[Anónimo]}

Beatus vir. Salmo de vísperas a ocho con acompañamiento de bajos [3/336]

Ingredere in Sanctam Ecclesiam. Motete. [3/351], [4/81]

Lauda Sion salvatorem. Motete. [3/354], [4/83]

Libera me Domine. Responsorio de Difuntos. 3/349]

Villancico de Navidad a solo y a dúo. [3/356]

Villancico de Navidad a solo. [3/357]

\section{Bonfichi, [Paolo]}

Dixit Dominus. Salmo a cuatro [3/358]

Formaba parte de un juego de vísperas con la pieza siguiente y las obras de Gazzaniga [3/359], Pacheco [3/361] y Doyagüe, [3/362]

Laudate pueri Dominum Salmo a cuatro [3/360

Formaba parte de un juego de vísperas con la pieza anterior y las obras de Gazzaniga [3/359], Pacheco [3/361] y Doyagüe, [3/362]

\section{Carrera y Lanchares, R.P.M Fray Pedro}

Adiciones a la Salmodia Orgánica: Versos de los tonos primero, sexto y cuarto punto bajo, y los del último con extensión en forma de sonatas [3/77], [4/218]

Salmodia Orgánica: Juego de versos de todos los tonos. [3/78], [4/218]

\section{Durango}

Himno a ocho para la Fiesta de las Santas Reliquias [3/339] 


\section{Delgado, [Francisco?]}

Stabat Mater a cuatro voces. [3/316], [4/73]

"Dedicado a la Excelentísima Señora Condesa de Benavente"

\section{Doyagüe, Manuel}

Oficio de Difuntos a ocho [3/324],

En el mismo legajo se conservaba el Responsorio Libera me Dómine de David Pérez [3/325]

Magnificat. Cántico a ocho.

Formaba parte de un juego de vísperas con los dos salmos de Bonfichi [3/358]

[3/360] las obras de Gazzaniga [3/359], Pacheco [3/361] y Doyagüe, [3/362].

\section{Fioravanti, [Valentino]}

Salmo 50 a tres voces [3/326], [4/68]

\section{Gazzaniga, [Giuseppe]}

Beatus vir. Salmo a cuatro.

Formaba parte de un juego de vísperas con los dos salmos de Bonfichi [3/358], [3/360] y las obras de Pacheco [3/361] y Doyagüe, [3/362].

\section{Haydn, [Joseph]}

Le sette parole. Oratorio [3/320]

\section{Inzenga, [Angelo]}

Stabat Mater a tres. [3/321]

\section{Jomelli [Nicolò]}

Miserere a cinco [3/347], [4/84]

\section{Kraft,}

O salutaris hostia. Motete [3/352], [4/82]

\section{Lidón, José \\ Responsorio al Santísimo a ocho [3/334]}

\section{Martín, Diego}

Beatus vir. Salmo de vísperas a ocho. [3/337], [4/74]

Dixit Dominus. Salmo de vísperas a ocho. [3/340], [4/75] 


\section{Martínez, Mariana}

Miserere a cuatro. [3/319], [4/69]

\section{Medina}

Salve. [3/350]

\section{Pérez, Davide}

Responsorios de difuntos. [3/323], [4/71]

En [4/71] figura como "Matutino de morti"

El Responsorio Libera me Dómine de Davide Pérez [3/325] se conservaba separado en el mismo legajo del Oficio de difuntos de Doyagüe [3/324].

\section{Pacheco}

Iste confessor. Himno a cuatro.

Formaba parte de un juego de vísperas con los dos salmos de Bonfichi [3/358] y [3/360] y las obras de Gazzaniga [3/359] y Doyagüe [3/362].

\section{Palestrina [Juan de Prenestrina]}

Ofertorio a cinco para las Dominicas de de Septuagésima, $1^{a}, 2^{a}, 3^{a}, 4^{a}$ de Cuaresma ,In Passione y Miércoles Santo. [3/355], [4/63]

\section{Pergolessi, Giovanni Battista}

Stabat mater. [3/348]

\section{Ortells [Ortellez]}

Lamentación primera del miércoles para el jueves. Incipit lamentatio a 1. [3/332], [4/80]

\section{Ramoneda, Fray Ignacio}

Responsorios a ocho con violines sobrepuestos para la procesión del Corpus. [3/333], [4/79]

\section{Rousseau, Lais et Cheron.}

O salutaris hostia a trois voix sans accompagnement. [3/353] 


\section{Obras de carácter pedagógico}

\section{Anónimo}

Figuras de contradanzas traducidas del francés al español.[3/300]

Cuaderno de solfeo. [3/24]

Lecciones de solfeo para los señores Don Francisco y Don Pedro Girón y Pimentel [3/265], [4/145]

\section{Barbella, [Emanuele]}

Volate di note musicali per ben suonare il Violino [3/223], [4/114]

\section{Langlé, [Honoré de]}

Traité d'Armonie et de Modulation. [3/162], [4/35]

Traite de la Basse sous le Chant précédé de toutes les règles de la Composition [3/160], [4/36]

\section{Nava, Antonio}

Juego Filarmónico puesto en dos tablas para componer por medio de dos dados un número infinito de valses para la guitarra sin saber nada de la composición [3/70], [4/115] 
2. Catálogo de las obras musicales copiadas para Manuela Isidra Téllez-Girón y Pimentel durante su estancia en Cádiz (1810-1813)

Fuente: AHN NOBLEZA, OSUNA-CARTAS, leg 392-4.

\title{
1. Música profana
}

A. Música vocal con acompañamiento de piano u orquesta

\section{Anfossi, Pasquale}

Già saggira a noi de intorno. Dúo.

\author{
Anónimo \\ A compir io voli impar. \\ Abelardo ed Eloisa. Cantata. \\ Non só donde viene. Escena y Aria. \\ Quelle pupile tenere. \\ Taci con quegli acenti. \\ Trece canciones para fortepiano. \\ Vieni pur fra le mie braccia. Dúo.
}
Asioli
Canciones patrióticas.
Cinque terzetti.
El Feo. Canción.
La partenza. Cantata.
La tempesta.
Quartetto.
Quatro ariette. 
Seis canciones"con acompañamiento de fortepiano.

Sonetto.

Tre Duetti.

Veinticuatro dúos.

\section{Asioli, Bonifacio}

Cuatro Duetos con acompañamiento de piano.

Il nome. Cantata.

Pimmalione. Azzione Teatrale.

Reducción para piano del autor.

Tre Cantate con accompagnamento di pianoforte.

Once arias con acompañamiento de fortepiano.

\section{Asioli, Luigi}

Cuatro Dúos característicos con acompañamiento de piano.

Tres Dúos con acompañamiento de piano.

Tres Terzettos con acompañamiento de piano.

\section{Bertoni, [Ferdinando]}

Se ti perdo amato oggeto. Rondó.

\section{Bianchi, [Francesco?]}

Se fida sei ben mio. Aria.

\section{Bontempo , [João Domingos]}

¡Qué miro, qué escucho!. Himno hispano.

\section{Cimarosa, [Domenico]}

Deh parlate, che forse tacendo. Scena ed aria.

Non so donde viene. Scena ed aria. [de Gli Orazi e Curiazi]

Non v'e più barbaro. Cavatina.

Qual instante sventurato. Rondó.

Tremante confusa, risolvo, mi pento. Tercetto. 


\title{
Della Maria, Domenico
}

Chi v'adora.

\section{Farinelli, Giuseppe \\ Del figlio diletto. Duetto.}

Ehi ti burzio camarieri. Duetto.

\section{Federici, [Francesco]}

Qual tetro orror m'assale. Terzetto

\section{Federici, Vincenzo}

Dille che l'aire inspiro. Duetto.

\section{Gnecco, [Francesco]}

Misera io vado a morte. Aria con accompagnamento di pianoforte.

\section{Guglielmi, Pietro}

Da un armonico concerto.. Scena e aria

Partir da questo addio. Duetto

\author{
Mayer, Simone \\ Io sono un diavolino. Duetto. \\ Vieni colá t'attendo. Duetto.
}

\section{Moretti, Federico}

[...] fei di amore

\section{Mozart, [Wolfgang Amadeus]}

Ah qual mai sofre o Dei. Recitativo e Duetto.[Don Giovanni].

Ah! taci, ingiusto core. Terzetto. [Don Giovanni].

Final del Convidado de piedra. [Don Giovanni].

Ma qual mai s'offre, oh Dei. [Recitativo y Dúo de Don Giovanni]

Non fidar o misera. Quartetto. [Don Giovanni.]

Non piu di fiori. Aria. [La Clemenza di Tito.]

Presto, presto, pria chei venga. Finale a sette voci. [Don Giovanni].

Sola, Sola in buio loco. Sestetto. [Don Giovanni]. 
Voi che sapete. Cavatina. [Las Bodas de Fígaro].

\section{Nasolini Sebastiano}

Ah, che vicina a perderte. Recitativo e Rondó.

Oppresa mi Sento. Recitativo y Rondó.

\section{Nasolini, Sebastiano}

Dei Clementi. Recitativo y Cavatina.

A questo ampleso o cara. Duetto.

\section{Orgotano, Rafaelle}

Arianna abbandonata da Teseo. Monologo per fortepiano.

\section{$\mathbf{P}[\mathbf{a}]$ er, Ferdinando}

Alma benefica. Preghiera con coro e instrumental.

Assustate il pie tremante. Aria con coro e instrumental.

Caro Padre Scena ed aria.

Deh per pieta. Dúo.

Di chi fedel t'adora. Dúo.

Dunque andiam piu non si tardi. Terzetto

Frena le lagrime. Cavatina con coro

Justi Numi ah sostente. Scena e duo

Languiro vicino a quelle. Scena ed ari.a

Le ostili spoglie. Quartetto con coro e instrumental.

Non obbliar ch'io vedo. Aria con instrumental.

Parte mio tesoro. Duo.

Quando il diadema e il trono. Grande finale con coro e instrumental.

Se il fatto scrisse. Dúo con coros.

Se piango mio bene. Rondó..

Voi non vedesti mai. Duetto. 


\author{
Paisiello, [Giovanni] \\ Ne giorni tuoi felici. Duetto. \\ Regnante tradito. Scena e Aria. \\ Sognai tormenti affani. Aria \\ Va caro figlio addio. Rondó.

\section{Pavessi, Stefano} \\ Amami sempre oh caro. Scena e duetto

\section{Zingarelli [Niccolò Antonio]} \\ Hombra adorata aspetta \\ Terzetto
}

\title{
B. Música instrumental
}

\section{Anónimo}

Cuaderno de valses y contradanzas para fortepiano.

Sonata a cuatro manos.

Valses.

\section{Dussek, [Jan Ladislav]}

Duetto para arpa y fortepiano.

\section{Kocžwara, František}

La Batalla de Praga para fortepiano.

Pleyel, [Ignaz] y Dussek, [Jan Ladislav]

Principios de música para fortepiano.

\section{Struchz [=Paul Friedrich Struck ?]}

Minuetto a quatro mani. 


\section{Música religiosa}

\section{Anónimo}

Lauda Sion. Motete

Vitam Petit. Motete.

Fioravanti, [Valentino] Miserere

Pergolessi, [Giovanni Battista] Stabat Mater Dolorosa. 



\section{Apéndice 5.}

Información biográfica sobre los principales músicos y bailarines que estuvieron al servicio de las Casas de Osuna y Benavente (ca. 1720 hasta 1844), por orden alfabético de apellidos 



\section{ÁLVAREZ GARCÍA, José Rafael [“PEPITO”] (“1780 - +1855$){ }^{1}$}

Nació el 24 de octubre de 1780 en la calle de Alcalá de Madrid. Hijo del criado de la Casa de Benavente Joaquín Álvarez ${ }^{2}$ y de María Ignacia García, natural de Madrid. Su padrino de bautizo fue Manuel de Cubas (contador general de la Casa y Estados de la Casa de Osuna y Benavente) en representación de María Josefa Alfonso Pimentel (Condesa-Duquesa de Benavente y Marquesa de Peñafiel $)^{3}$, que sería su protectora al menos durante su infancia y juventud. Fue discípulo de Gaspar Barli, oboísta de la Real Capilla y músico de la Casa de Benavente, y al menos desde 1796 colaboró en los conciertos y academias que organizaba la Condesa-Duquesa de Benavente en sus palacios de Madrid y La Alameda ${ }^{4}$

El 8 de marzo de 1797, José Rafael Álvarez participó como solista en uno de los conciertos de música vocal e instrumental organizados por Melchor Ronzi, en el Coliseo de la Cruz de Madrid durante el período de Cuaresma interpretando un aria con oboe obligado ${ }^{5}$. Cuando las tropas francesas invadieron Madrid, José Rafael Álvarez se trasladó a Cádiz donde también gozó de la protección de la Condesa-Duquesa de Benavente ${ }^{6}$.

Desde 1796 estuvo también vinculado a la Real Capilla seguramente gracias a la intercesión de su maestro Barli. En dicha institución ocupó los puestos de oboísta supernumerario (1796), primer solista agregado a la Real Capilla (1814) y de Profesor de la Real Cámara (1816). A la muerte de Barli en 1826 fue nombrado primer oboe de la Real Capilla. Permaneció en dicho puesto hasta su muerte en 1855 , si bien a partir de 1851 , debido a su precario estado de salud,

\footnotetext{
${ }^{1}$ Una síntesis de la biografía de este músico figura en Javier Suárez Pajares, “Álvarez García, José Rafael", $D M E H$, vol. 1, p. 370. De esta referencia he tomado los datos fundamentales añadiendo algunos más no contemplados en esta referencia relacionados con el mecenazgo de los Osuna y Benavente.

2 AHN NOBLEZA, OSUNA-CARTAS, leg 460. En 1794, Joaquín Álvarez desempeñaba el puesto de "portero de entradas" al servicio de la Casa de Benavente-Osuna.

${ }^{3}$ Parroquia de San Sebastián de Madrid. Libro de Bautismos 49, fol. 51 v.

4 AHN NOBLEZA, OSUNA-CARTAS legs 390-1.

5 Diario de Madrid, 8 de Marzo de 1797, nº. 68, p. 276.

${ }^{6}$ AHN NOBLEZA, OSUNA-CARTAS legs 387-8 y 392-4.
} 
consiguió una dispensa de la reina para asistir a la capilla sólo cuando se encontrase bien. Fue el primer profesor de oboe y corno inglés del Conservatorio de Madrid.

\begin{abstract}
ANDREOZZI, Cristóbal
Violinista y director de origen italiano. Formó parte de la orquesta de la Condesa-Duquesa de Benavente como "segundo violín de primeros" al menos entre abril y noviembre de 1781, y actuó como director musical en los funerales del VIII Duque de Osuna ${ }^{7}$. En 1789 fue nombrado por el rey "maestro de música con destino a los teatros" para enseñar a tres o cuatro discípulos "en quienes encuentre las disposiciones necesarias" ${ }^{\prime 8}$. Fue empresario de los teatros de los Reales Sitios a finales del siglo XVIII y estuvo casado con la célebre actriz y cantante Catalina Tordesillas ${ }^{9}$
\end{abstract}

\title{
BARDIN, [?]
}

Músico de origen francés. Aparece citado en un número Allgemeine musicalische Zeitung de 1799 como serpentista ("serpentist") del Duque de Osuna a finales del siglo XVIII Según el redactor de esta noticia, Bardin conseguía con su instrumento un delicado sonido en los agudos utilizando para ello una boquilla de trompa. Falleció antes de $1799^{10}$.

\footnotetext{
${ }^{7}$ BNE Ms. 14.016.3/188 (Papeles Barbieri)

${ }^{8}$ Ibid., Ms. 14.016.3/258.

${ }^{9}$ Emilio Cotarelo y Mori, Orígenes y establecimiento de la Ópera en España hasta 1800 (Madrid: Tipografía de la Revista de Archivos, Bibliotecas y Museos, 1917), p.394.

${ }^{10}$ Allgemeine Musikalische Zeitung, Leipzig (AMZ), nº 26, 27 de marzo de 1799, pp. 403-404.
} 


\section{BARLI, Gaspar (†1826)}

Oboísta, fagotista y compositor de origen italiano. Estuvo vinculado al servicio de la Casa de Benavente al menos desde $1778^{11}$. Durante varios años se se dedicó exclusivamente al servicio de esta casa nobiliaria, situación que, seguramente se prolongó hasta su ingreso en la Real Capilla en $1784^{12}$.

Barli desempeñó el puesto de oboe primero en la orquesta de la CondesaDuquesa de Benavente desde 1781 hasta su clausura en mayo de 1792 con el sueldo de treinta y dos reales diarios. En 1783 fue uno de los músicos que se trasladó a Barcelona para servir a la Condesa-Duquesa durante su estancia en dicha ciudad $^{13}$. Al menos en 1791 colaboró como instrumentista en las lecciones de baile que impartía el bailarín Domenico Rossi a los hijos de los IX Duques de Osuna ${ }^{14}$.

En una información publicada en un número de Allgemeine musicalische Zeitung de 1799 un informante anónimo que había estado recientemente en Madrid dice que Barli ocupaba la plaza de primer oboe en la Orquesta del Duque de Osuna y en la Real Capilla. Este informante alaba el sonido cálido de Barli, los efectos de eco que conseguía con su instrumento y la calidad de las obras que componía al estilo de Pleyel. Su fama debía de ser considerable pues, según este periodista, los madrileños consideraban a Barli como un "semidios". Permaneció al servicio de la Casa de Osuna y Benavente al menos hasta enero de 1807 con un sueldo de quinientos reales al mes ${ }^{16}$. En 1813 se hallaba en Cádiz, ciudad en la que siguió gozando de la protección de la Condesa-Duquesa de Benavente, y donde dio algunos conciertos junto a su hija ${ }^{17}$.

Fue fagotista en la Real Capilla desde 1784, y oboe de la misma institución

\footnotetext{
11 BNE Ms. 14.016.3/65 (Papeles Barbieri). En 1782 se le pagaron por la Casa de Osuna 900 reales como gastos del alojamiento "y por lo correspondiente al año cumplido en octubre de $1779 "$.

12 AHN NOBLEZA, OSUNA-CARTAS, leg 390-4.

${ }^{13}$ Ibid., leg 390-1.

${ }^{14}$ Ibid., leg 391-31.

15 "Die Madrider vereheren ihn wie einen Halbgott" AMZ 26, p. 403.

${ }^{16}$ AHN NOBLEZA, OSUNA-CARTAS legs 459-468.

${ }^{17}$ Ibid., legs $387-8$ y 392-4.
} 
desde finales de 1790. En 1796 fue nombrado músico de la Real Cámara de Carlos IV. Formó parte de la Real Capilla y Cámara de José I, aunque parece ser que mantuvo algunas reticencias a servir al nuevo rey. Tras período de la Guerra de la Independencia recuperó su puesto en la Real Capilla, primero como supernumerario $^{18}$ y después como miembro de pleno derecho, permaneciendo en este empleo hasta su muerte que acaeció el 28 de abril de 1826 en la calle Ancha de de San Bernardo n 2 y 3 de Madrid $^{19}$.

\section{BASSET, Francisco $(† 1808)$}

Violinista, oboísta y encargado de los asuntos musicales de la Casa de Benavente. Posiblemente era familiar de Vicente Basset, violinista que trabajó en Madrid en la orquesta de la Compañía teatral de María Hidalgo entre 1758 y $1762^{20}$.

Francisco Basset colaboró con la Casa de Benavente al menos desde febrero de 1774 tocando el violín en las lecciones de baile que recibía la CondesaDuquesa de Benavente ${ }^{21}$. En 1775 era ya "músico de la Casa de Su Excelencia el Marqués de Peñafiel, y Conde Duque de Benavente" [= Pedro de Alcántra Téllez Girón]. Por decreto del 4 de agosto de este mismo año se le ascendió el sueldo (con efecto retroactivo desde el 1 de enero de 1775) a cuatro reales diarios en lugar de los dos que percibía hasta el momento ${ }^{22}$. Al menos desde 1776, Basset fue el encargado de los "asuntos musicales" de la Casa de Benavente, siendo el responsable de la contratación de los músicos para las fiestas religiosas, bailes y

${ }^{18}$ Luis Robledo Estaire. "La musica en la Corte de José I", AnM, XLVI, 1992, p. 239.

Según Luis Robledo, cuando Gaspard Barli solicitó la rehabilitación de su puesto tras la Guerra de la Independencia llegó a afirmar que no había nunca tocado ante José I poniendo como excusa el estar enfermo.

19 Baltasar Saldoni, Diccionario biográfico-bibliográfico de efemérides de músicos (Madrid:

Antonio Pérez Dubrull, 1868-1881), vol III, p. 302.

${ }^{20}$ BNE, Ms. 14.015.2/ 18 y Ms.14.016.1/16 (Papeles Barbieri).

${ }^{21}$ AHN NOBLEZA, OSUNA-CARTAS, legs 459-468.

22 Ibid., leg 418. 
academias organizadas por sus señores.

Francisco Basset fue uno de los músicos más apreciados por la CondesaDuquesa de Benavente que, en diversas ocasiones, le prestó su protección económica. En 1778 Basset recibió una ayuda de costa de 480 reales para los gastos del bautizo de su hija que recibió el nombre de María Josefa y fue amadrinada por la Condesa-Duquesa de Benavente ${ }^{23}$, y en julio de 1780 recibió otra ayuda económica para el bautizo de un hijo ${ }^{24}$.

Fue miembro de la orquesta de la Condesa-Duquesa, primero como violinista, y a partir de agosto de 1781 como segundo oboe junto a Gaspar Barli. En 1783 se trasladó a Barcelona para servir a la Condesa-Duquesa de Benavente durante su estancia en esta ciudad ${ }^{25}$.Tras la disolución de la orquesta continuó trabajando al servicio de la Casa de Benavente-Osuna con un sueldo de seis reales al día hasta su muerte el 2 de septiembre de $1808^{26}$.

\section{BELBÉN [BELVER], Antonio}

Maestro de clavicordio de la Casa de Benavente-Osuna en $1796^{27}$. En 1818 trabajaba como "maestro de piano" de la Casa de Osuna con un sueldo de 320 reales al mes ${ }^{28}$. Según Saldoni, en 1808 era organista de la Real Capilla ${ }^{29}$.

\footnotetext{
${ }^{23}$ Ibid., leg 390-1.

${ }^{24}$ Ibid., leg 458.

${ }^{25}$ Ibid., leg 390-1.

${ }^{26}$ Ibid., leg 468.

${ }^{27}$ Ibid., leg 391-31.

${ }^{28}$ Ibid., leg 470.

${ }^{29}$ Saldoni, Diccionario, vol IV, p. 32.
} 


\section{BELBEN, Modesto}

Maestro de piano de la Casa de Osuna en las primeras décadas del siglo XIX. Entre 1840 y 1842 se dirigió en varias ocasiones al XI Duque de Osuna para pedirle una ayuda con el fin de poder mantener a su familia. En las solicitudes afirmaba haber sido ."antiguo maestro de fortepiano de la [X] Duquesa de Osuna" y cesante en la plaza de organista de la Real Capilla" ${ }^{30}$

\section{BLUMENSTENGEL [BLUMEN], Juan Martín}

Clarín y trompa de origen alemán. En 1732 era clarín de la capilla musical de José Téllez Girón, VII Duque de Osuna ${ }^{31}$. Fue trompa en la Real Capilla entre enero de 1734 y diciembre de 1743 con un sueldo de 500 ducados $^{32}$. Cuando en abril de 1749 se reformó el estatuto de la planta de la Real Capilla, Blumenstengel fue incluido en el grupo de refuerzo de la plantilla fija que no estaba obligado a asistir diariamente a todos los actos, aunque seguía cobrando el salario íntegro ${ }^{33}$.

BOCCHERINI, Luigi (*1743 - †1805)

(Para la relación de Boccherini con la Casa de Benavente véase el Capítulo III)

\footnotetext{
${ }^{30}$ AHN NOBLEZA, OSUNA-CARTAS, leg 392-23.

31 Ibid., leg 446-1.

32 José Subirá. Temas musicales madrileños (Madrid: CSIC, 1971), pp. 222-223.

33 Lothar Siemens Hernández. "Los violinistas compositores en la Corte Española durante el período central del siglo XVIII" RMS, XI/3 (1988), p. 671.
} 


\section{BONFANTI, José (†1770)}

Violinista. Colaboró con la Casa de Osuna al menos desde 1741, como instrumentista de refuerzo en las funciones religiosas organizadas por la Duquesa viuda de Osuna $^{34}$ y entre el uno de enero de 1748 y finales de agosto del mismo año está documentada su presencia como músico asalariado al servicio de la Duquesa viuda de Osuna ${ }^{35}$. Fue miembro de la Real Capilla desde 1747 hasta su muerte en 1770 y participaba habitualmente en las academias organizadas por el infante Luis Antonio de Borbón ${ }^{36}$.

\section{BRUNETTI, Gaetano $(* 1744-\uparrow 1798)^{37}$}

Violinista y compositor de origen italiano. Fue uno de los principales autores de música de cámara y orquestal de la segunda mitad del siglo XVIII en España. Nació en Fano (Italia) en 1744, hijo de Esteban Brunetti y Victoria Peruzini y falleció en Colmenar de Oreja (Madrid) el 17 de diciembre de 1798. En junio de 1760, se presentó en Madrid a unas oposiciones a la Real Capilla, en las que, aunque no obtuvo la plaza fue elogiado por varios miembros del tribunal.

En 1762, Gaetano Brunetti trabajaba como violinista en la orquesta de la compañía teatral de Águeda de la Calle que actuaba en los teatros públicos de Madrid $^{38}$. En este mismo año compuso la música para las comedias García del Castañal (con texto de Francisco de Rojas Zorrilla) y Faetón. Su labor como compositor de música teatral parece cerrarse en 1768, año en el que estrenó en el

\footnotetext{
34 AHN NOBLEZA OSUNA-CARTAS leg 390-3-4.

35 Ibid., leg 390-4-5. Carta de Pago otorgada en 1761 ante Don Cosme Damián de los Reyes por la testamentaría de la Duquesa [viuda] de Osuna a favor de José Bonfanti como músico violón que sirvió en su casa desde el uno de enero de 1748 hasta fin de agosto del mismo año 1748.

36 Antonio Martin Moreno. Historia de la música española, 4, Siglo XVIII (Madrid: Alianza, 1985), p.242.

37 La síntesis biográfica más actualizada sobre Gaetano Brunetti es la realizada por Germán Labrador en su tesis doctoral. Germán Labrador López de Azcona. Gaetano Brunetti: un músico en la corte de Carlos IV, Tesis doctoral inédita (Madrid: Universidad Autónoma de Madrid, 2003). 38 BNE Ms. 14.015.1/15 (Papeles Barbieri).
} 
teatro del Príncipe de Madrid la zarzuela mitológica El Jasón o la conquista del vellocino.

En octubre de 1767 Brunetti ingresó como violinista en la Real Capilla y desde 1770 fue maestro de música del Príncipe de Asturias, el futuro Carlos IV, quien cuando ascendió al trono en 1788 le nombró director de su Real Cámara en la que permaneció hasta su muerte en 1798.

Paralelamente a su labor como músico para la Casa Real mantuvo una intensa relación con la alta nobleza. Al menos entre 1767 y 1793 trabajó al servicio de la Casa de Alba. Su vinculación con la Casas de Osuna y Benavente se inició posiblemente en abril de 1776 cuando fue contratado con un sueldo de quince reales diarios como maestro de violín de Pedro de Alcántara Téllez Girón, Marqués de Peñafiel y futuro IX Duque de Osuna ${ }^{39}$. Brunetti fue cesado en este cargo el 1 de febrero de $1780^{40}$, pero continuó relacionándose con los miembros de esta familia. La cordialidad de la relación que Brunetti mantuvo con los miembros de esta casa nobiliaria queda patente en una carta que la CondesaDuquesa de Benavente le dirigió el 10 de septiembre de 1788 para solicitar que le fuese concedida al músico de su orquesta Pedro Garisuain, la plaza de fagot que se hallaba vacante en la formación instrumental que participaba en el espectáculo ecuestre de "Las Parejas" que se celebraba durante las Jornadas de la Corte en Real Sitio de Aranjuez, y de cuya gestión se encargaba el propio Brunetti ${ }^{41}$.

\footnotetext{
${ }^{39}$ AHN NOBLEZA, OSUNA-CARTAS, leg 473-2.

${ }^{40}$ Ibid.

${ }^{41}$ Ibid., leg 391-25.
} 


\section{BUSQUET[S], Juan}

Violinista. Desarrolló parte de su carrera en el entorno de la Corte. Fue violinista de la orquesta del Real Coliseo del Buen Retiro y primer violín suplente en la Real Capilla ${ }^{42}$. Junto a Gabriel Terri, fue uno de los albaceas en el testamento firmado en 1750 por el también músico de la Casa de Osuna Francisco Manalt ${ }^{43}$. En junio de 1760, se presentó a las oposiciones a la Real Capilla, pero según el informe elaborado por Francisco Courcelle, parece que no dio una buena impresión en las pruebas por "la desgracia de hallarse comprimido por el miedo"44 Trabajó como violinista para Pedro Zoilo Téllez Girón, VIII Duque de Osuna hasta el 10 de diciembre de 1766, cuando cesó en dicho puesto para trasladarse a Córdoba tras haber ganado una plaza de primer violín en la catedral de esta ciudad ${ }^{45}$.

\section{CANAUT, Cayetano}

Fue el segundo trompa de la orquesta de la Condesa-Duquesa de Benavente desde 1781 hasta su disolución en 1792. Desde marzo de 1781 era músico de las Reales Caballerizas, institución a la que también pertenecían varios miembros de su familia ${ }^{46}$.

\footnotetext{
${ }^{42}$ APR, Real Capilla cajas 119 y 138, citado en Siemens. "Los violinistas", p. 755.

43 AHPM, leg 19142. Escribano Manuel Fernández Sánchez. Reproducido en Siemens. "Los violinistas" p. 748.

44 APR, Real Capilla cajas 119 y 138, citado en Siemens. "Los violinistas", p. 755.

45 AHN NOBLEZA OSUNA CARTAS, leg 389-30.

46 Judith Ortega, "El mecenazgo musical de la Casa de Osuna durante la segunda mitad del siglo XVIII: el entorno musical de Luigi Boccherini en Madrid, RMS, XXVII/2 (2004), pp. 670-671.
} 


\section{CARRERAS Y GAYOSO, Manuel († después de 1787)}

Violinista. En 1758 era segundo violín en la orquesta de la compañía de María Hidalgo que actuaba en los teatros de la Cruz y el Príncipe de Madrid ${ }^{47}$ y en 1769 violín primero de la Compañía de Juan Ponce ${ }^{48}$. Al menos entre 1773 y 1774 fue maestro de violín de Pedro de Alcántara, Marqués de Peñafiel y futuro IX Duque de Osuna ${ }^{49}$. Ingresó en la Real Capilla en 1774, después de que José Palomino abandonase su plaza sin permiso para marcharse a Portugal ${ }^{50}$. En 1787 ocupaba la octava plaza de los violines en la Real Capilla ${ }^{51}$.

\section{CARRIL MARTÍNEZ, Manuel Antonio (*1752 - †1828)}

Violinista y violista conocido por el apodo de "Carriles". Nació en Madrid el 20 de noviembre de 1752 y falleció en esta misma ciudad el 28 de enero de $1828^{52}$. En 1780 era músico de la compañía de Juan Ponce que trabajaba en los teatros públicos de Madrid.

En 1778 Manuel Carril se presentó a las oposiciones de violín a la Real Capilla, pero no consiguió dicha plaza. Los examinadores señalaron en sus informes que le faltaba un ojo lo que, a pesar de su calidad como instrumentista le impediría realizar su trabajo adecuadamente ${ }^{53}$. En 1785 se presentó a una plaza de viola en la misma institución pero tampoco la consiguió a pesar de la intercesión de la Condesa-Duquesa de Benavente ante el Cardenal Patriarca ${ }^{54}$. Logró ingresar

\footnotetext{
${ }^{47}$ BNE Ms. 14.015.2/18 (Papeles Barbieri).

48 Ibid., Ms. 14.016.1/92

49 AHN NOBLEZA, OSUNA-CARTAS, leg. 418.

50 Guy Bourligueux, "El violinista Pascual Juan Carriles, su familia y sus amigos", AnM 42 (1987), pp. 200.

51 Judith Ortega, "La Real Capilla de Carlos III: los músicos instrumentistas y la provisión de sus plazas", RMS XXIII/2 (2000), p. 434.

52 Guy Bourligueux ha estudiado sucintamente la biografía de este músico en Bourligueux "El violinista”, pp. 196--197.

53 APR, Real Capilla, caja 138. Citado en Ortega, "La Real Capilla", p. 415.

54 AHN NOBLEZA OSUNA-CARTAS leg 391-29.
} 
en la Real Capilla en 1789 como viola, pasando en 1795 al último puesto de violines de la misma institución de acuerdo con la práctica de ascenso por antigüedad. Fue también miembro de la Real Cámara de Carlos IV. Durante el gobierno de José I Bonaparte no figuró entre los músicos de la nueva planta de la Real Capilla aunque posteriormente fue rehabilitado en su puesto y terminó su carrera en la institución palatina en el puesto de segundo violín al que ascendió en 1822. ${ }^{55}$.

Manuel Carril se incorporó a la orquesta de la Condesa-Duquesa de Benavente el 13 de mayo de 1781 como primer violín de segundos y permaneció en este puesto hasta la disolución de la formación en 1792. Según Saldoni, fue también primer violín y director de la orquesta de la Duquesa de Alba ${ }^{56}$.

\section{CARRILES, Pascual Juan (*1767?- †1823)}

Hijo del violinista valenciano Vicente Juan, músico que trabajaba al servicio de la Casa de Benavente en $1749^{57}$. Fue educado por el también violinista Manuel Antonio Carril, segundo marido de su madre. Trabajó en la capilla de las Descalzas Reales y en las orquestas de los teatros de Madrid en los primeros años de su carrera ${ }^{58}$. Entre 1781 y 1789 ocupó la plaza de segundo violín de segundos en la orquesta de la Condesa-Duquesa de Benavente, junto a su padrastro. En agosto de 1789 se presentó a la oposición de viola en la Real Capilla pero no obtuvo la plaza. Después de ofrecer varios conciertos en diversos lugares de España, regresó a Madrid en 1792 y comenzó a trabajar al servicio del hermano del Duque de Medinaceli. Su carrera de concertista le llevó a viajar por diversos países europeos entre 1793 y 1800. Al final de su vida se estableció en Francia,

\footnotetext{
55 Robledo, “La música”, pp.218-219.

${ }^{56}$ Saldoni, Diccionario., vol I, p. 202.

57 AHN NOBLEZA OSUNA-CARTAS leg 391-29.

${ }^{58}$ Una aproximación a la biografía de este músico figura en Guy Bourligueux, "Carriles Pascual [Pascual Juan Martín de Vidales]" DMEH, vol. 3, p. 252. De esta referencia he tomado los datos fundamentales añadiendo algunos más relacionados con el mecenazgo de los Osuna y Benavente.
} 
donde fue primer violín en el Gran Teatro Graslin de Nantes y se dedicó también a la enseñanza.

\section{CEDILLO, Miguel}

Músico de la Capilla de la Colegiata de Santa María de Osuna. Como el resto de miembros de esta institución pasó a ser criado del Duque de Osuna a partir de 1813 cuando dicha capilla se dedicó al servicio exclusivo de la Capilla del Santo Sepulcro. Su salario anual en 1813 era de 12 fanegas de trigo y 48 ducados anuales ${ }^{59}$.

\section{CHRISTIANI [DE SCÍO] Carlo}

Miembro de una familia de maestros de danza que trabajaron para los reyes de España durante el siglo XVIII ${ }^{60}$. En 1769 era maestro de baile de Pedro de Alcantara Téllez Girón, Marqués de Peñafiel, y futuro IX Duque de Osuna ${ }^{61}$.

\section{DE LA PLAZA, Antonio (†1791)}

Cantante y profesor. Comenzó a colaborar con la Casa de Benavente en $1781 \mathrm{y}$, al menos en esta época, una de sus tareas al servicio de la familia Benavente era la adquisición y mantenimiento de los instrumentos musicales de la Casa $^{62}$. En 1784 se incorporó a la plantilla fija de músicos de la Casa de

\footnotetext{
${ }^{59}$ Ibid., leg 486-8.
}

${ }^{60}$ Lothar Siemens Hernández, "Sebastián Christiani de Scío y su familia: contribución a los maestros de danzar en la España del siglo XVIII" RMS XX/1 (1997), pp. 323-329.

${ }^{61}$ AHN NOBLEZA OSUNA-CARTAS, leg 390-30.

${ }^{62}$ BNE Ms. 14.016.3/44 (Papeles Barbieri). 27 de septiembre de 1781. Pago de 660 reales "para comprar una vihuela" y BNE Ms. 14.016.3/65 (Papeles Barbieri). 19 de abril de 1782 pago a 
Benavente como "músico de voz",63, y permaneció en este puesto hasta su muerte. Durante este período se encargó también de contratar a los músicos de refuerzo para las fiestas religiosas de la $\mathrm{Casa}^{64}$. Gracias a la intercesión de la CondesaDuquesa de Benavente ante el Patriarca de las Indias, Antonio de la Plaza consiguió en 1788 como "maestro de rudimentos" en el Real Colegio de Niños Cantores $^{65}$. Falleció en septiembre de $1791^{66}$

\section{DUNI, Antonio (*ca. $1700-\uparrow$ después de 1766)}

Compositor de origen italiano. Hijo de Francesco Duni, maestro de capilla en Matera, y hermano mayor del también compositor Egidio Duni. Estudió con Nicola Fago en el Conservatorio de Nápoles ${ }^{67}$. Después de un período en la corte arzobispal de Trier se trasladó a Madrid en donde sirvió a José Téllez Girón, VII Duque de Osuna como maestro de capilla y profesor de música. Durante su estancia en España estrenó variasobras para la escena. El 23 de febrero de 1726 en el Coliseo de la Cruz de Madrid se estrenó su zarzuela Locuras que hay que dan juicio y sueños que son verdad con texto de Antonio de Zamora, y al año siguiente la comedia de música Santa Inés de Montepoliciano y la música para el auto sacramental de Calderón de la Barca El Maestrazgo del Tusón ${ }^{68}$. También fue autor de la ópera Triunfo y error de los celos y el amor, Drama musical al estilo italiano, compuesto a instancias de Antonio Guedes Pereira, enviado extraordinario de su majestad portuguesa en la corte de Madrid para la onomástica de celebración de María Ana Victoria, futura princesa de Brasil ${ }^{69}$.

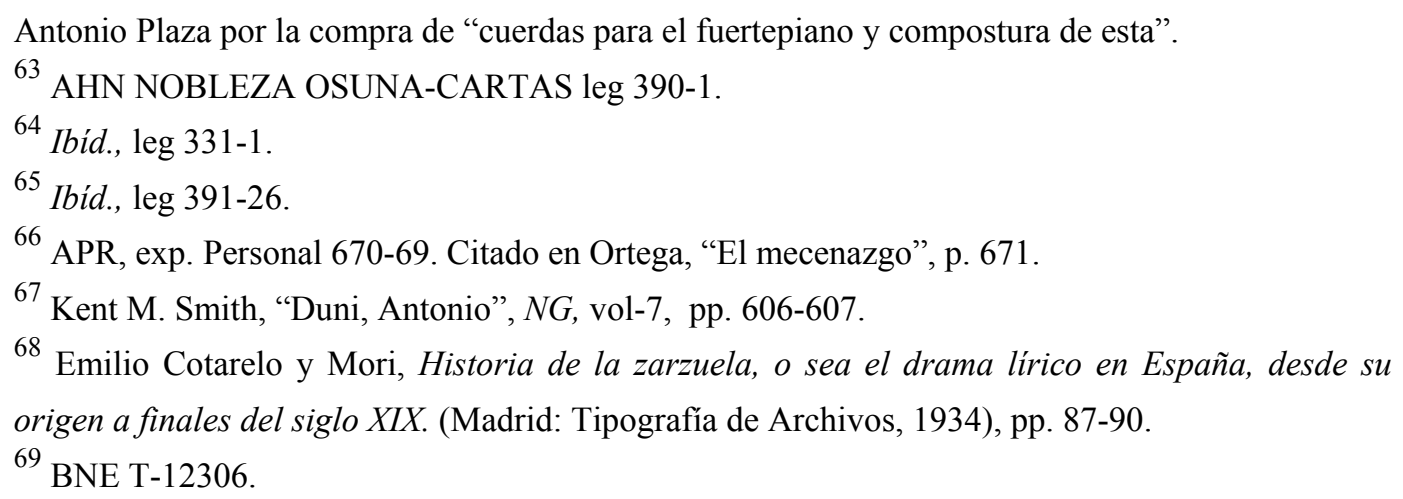


Después de un breve paso por Schwerin (Alemania) como·maestro di capella en una compañía de ópera Italiana se trasladó a Moscú ciudad en la que impartió clases en la universidad y posteriormente a Riga. En julio de 1766 se hallaba de nuevo en Schwerin, en donde solicitó a la Duquesa Louise Friedericke de Meklenburg un puesto y protección para su familia ${ }^{70}$.

\section{ESTEVE Y GRIMAU, Pablo (* ca. 1730 - $\uparrow 1794)$ \\ (Véase el Capítulo III)}

\section{FONT FORNS, Pablo [Pau]}

Miembro de una familia de músicos de origen catalán, era hermano del también músico Francisco Font que trabajó para el infante Don Luis de Borbón. Nació en Barcelona, y llegó a Madrid, posiblemente hacia $1760^{71}$ En 1767 firmó junto al carmelita fray José Flores y Salvador Rexach, músico de la Casa de Osuna, como albacea testamentario del también músico de la Casa Francisco Torner $^{72}$. La última noticia que conocemos sobre su vida es la declaración notarial de pobre que firmó en Madrid el 30 de marzo de 1789 junto a su hermano Francisco y la mujer de este. En dicho documento se detalla que Pablo Font ya estaba viudo de su mujer llamada Ramona Manalt, quien posibalemente fuera familiar del violinista de la Casa de Osuna Francisco Manalt ${ }^{73}$.

\footnotetext{
70 Smith, "Duni”, p.606.

71 Jaime Tortella, Musics Catalans a la "Villa y Corte" (segle XVIII) (Barcelona: Els llibres de la Frontera, 2005), pp.110-116.

72 José Subirá, "Necrologías musicales madrileñas (1611-1808)” AnM XIII (1958), p.216.

73 AHPM (Escribano Antonio Martínez Llorente) Protocolo 20909, fols. 80-82. Citado en Jaime Tortella, Boccherini, un músico italiano en la España Ilustrada (Madrid: Sociedad Española de Musicología, 2002), p 248.
} 


\section{FRANÇOIS [Fransua, "el músico del regimiento"] Esteban}

Fagotista. Al menos desde agosto de 1786 fue músico del Regimiento de América que comandaba y mantenía Pedro de Alcántara Téllez-Girón, IX Duque de Osuna. Por este empleo cobraba un sueldo de la Casa de Osuna de 10 reales diarios $^{74}$. Entre 1788 y 1790 intervino como solista en los conciertos cuaresmales que se celebraron en los teatros del Príncipe y de los Caños del Peral de Madrid $^{75}$. Fue primer fagotista en la Capilla musical del Duque de Osuna y de la ópera italiana a finales del siglo $\mathrm{XIX}^{76}$.

\section{FRONTERA Y LASERRA ["FRONTERA DE VALLDEMOSA"] Francisco $(* 1807-\dagger 1891)$}

Cantante, maestro de música y compositor. Fue conocido en el mundo musical por Frontera de Valldemosa, toponímico de su localidad de nacimiento en Mallorca. Estudió en París con Mollet y Elwart ${ }^{77}$. En 1841 regresó a España y fue nombrado maestro de la reina Isabel II, y de su hermana (la futura duquesa de Montpensier), profesor del Real Conservatorio María Cristina, y posteriormente director de la Real Cámara. En esta misma época fue profesor de canto de Pedro de Alcántara Téllez Girón, XI Duque de Osuna ${ }^{78}$ a quien dedicó un himno compuesto para la proclamación de Isabel II que se cantó en el Teatro de Mallorca $^{79}$.

\footnotetext{
74 AHN NOBLEZA, OSUNA-CARTAS, leg 391-16.

${ }^{75}$ Cotarelo, Orígenes, pp. 305-365.

76 AMZ 26, p. 403.

77 Saldoni, Diccionario, vol. III, pp.205-207.

78 Saldoni, Diccionario, vol. III, p. 167.

${ }^{79}$ Francisco Francisco F[rontera] de Valldemosa, Himno cantado en el Teatro de Mallorca. En ocasión de la Solemne Proclamación de la Reina Doña Isabel II. Compuesto por [...] y dedicado a su discípulo el Excelentísimo Seño. Duque de Osuna. Propieté de l'auteur, a Paris, chez Bernard Latte. Citado en José Subirá, La Música en la Casa de Alba: Estudios Históricos y Biográficos (Madrid: Tip. Sucesores de Rivadeneira, 1927), p. 305.
} 


\section{GARCÍA DE SENA, Rafael $(* 1758-\dagger 1810){ }^{80}$}

Violista y violinista. Nació en Madrid en 1758. Hijo de José García de Sena, natural de San Sebastián de los Reyes (Madrid) y de Teresa Ruano, nacida en Aldea del Rey (Segovia). Ingresó en la Real Capilla en diciembre de 1781, y en el mes de marzo de 1789 obtuvo por oposición la plaza de duodécimo violín de dicha institución. Continuó ascendiendo por antigüedad en las plazas de su cuerda y llegó hasta el puesto de cuarto violín al final de su vida. También se dedicó a la enseñanza y fue profesor de violín en el Real Seminario de Nobles. Entre sus discípulos se hallaban los violinistas Francisco Balcarén, y Cristóbal de Ronda, que más tarde serían también miembros de la Real Capilla

En la orquesta de la Condesa-Duquesa de Benavente Rafael García de Sena ocupó el puesto de viola desde 1781 hasta finales de 1786. Tras la muerte de Bonifacio Zlotek a principios de enero de 1787, fue primer violín de la orquesta hasta la disolución de la formación en 1792. Fue también el archivero o encargado de la "papelera" de música de la Condesa Duquesa, ocupación en la que prosiguió al menos hasta $1795^{81}$.

Fue propietario de tres excelentes violines, un Amati, un Gaglianus y un Guillamí. En su testamento legó "uno de sus mejores violines a uno de los hijos del Conde de Polentinos", que, según Bourligueux, es probable que fuera discípulo suyo. Falleció en Madrid el 15 de agosto de $1810^{82}$.

\footnotetext{
${ }^{80}$ El resumen más completo realizado hasta ahora de la biografía de este músico se halla en Guy Bourligueux, "El violinista", pp. 192-193. De esta referencia he tomado los datos fundamentales y he añadido algunos más relacionados con el mecenazgo de los Osuna y Benavente.

81 AHN NOBLEZA, OSUNA-CARTAS leg 387-7.

${ }^{82}$ Saldoni, Diccionario, vol III, p. 141.
} 
GARDEL, Pierre Gabriel (*1758 - †1840)

Bailarín, coreógrafo y músico, miembro de una saga de bailarines franceses. Director de la Ecole de Danse y de los ballets de la ópera de París ${ }^{83}$. Fue el maestro de baile de los cuatro hijos de los IX Duques de Osuna durante su residencia en París en $1799^{84}$. La relación de la Casa de Benavente-Osuna con la familia Gardel continuó después del regreso de los Duques a España. La CondesaDuquesa María Josefa fue madrina de Josefina Gardel, una de las hijas de Pierre Gabriel Gardel y de la bailarina Marie-Elisabeth Anne Boubert ${ }^{85}$.

\section{GARISUAIN ELETA [LETA], Joaquín (*1751-†1810)}

Bajonista y fagotista. Natural de Tudela (Navarra), fue hijo y alumno de Vicente Garisuain, músico en el monasterio de las Descalzas Reales de Madrid. Ingresó en la Real Capilla en 1775 como tercer bajonista y continuó ascendiendo hasta alcanzar la plaza de primer bajonista en $1798^{86}$. Desde 1798 fue también miembro de la Real Cámara de Carlos IV. Se incorporó a la orquesta de la Condesa-Duquesa de Benavente en mayo de 1781 y ocupó el puesto de primer fagot y "fagot de cámara" en dicha formación hasta su disolución en mayo de 1792.

\footnotetext{
${ }^{83}$ AHN NOBLEZA, OSUNA-CARTAS, leg 391-31. Sobre este personaje véase Friderica Derra de Moroda, "Pierre Gabriel Gardel", $N G$, vol 9, p.534.

${ }^{84}$ AHN NOBLEZA, OSUNA-CARTAS, legs 388-29 y 391-31.

${ }^{85}$ Ibid., legs 388-15 y 388-16.

${ }^{86}$ Guy Boyurligueux, "Garisuain Eleta”, DMEH, vol. 5, p. 517.
} 


\section{GARISUAIN ELETA [LETA], Pedro $(* 1755-\uparrow 1833)$}

Violinista y fagotista. Nacido en Haro (Logroño), hermano de Joaquín Garisuain. Trabajó como violinista en el Teatro de los Caños del Peral, y desde 1790 fue fagotista en la Real Capilla ${ }^{87}$. Fue también violinista de la orquesta de la Condesa-Duquesa de Benavente entre 1783 y 1787, y desde 1787 ocupó la plaza de fagot segundo en dicha formación junto a su hermano Joaquín. Interpretó el papel del maestro de música Don Lázaro en las funciones privadas de estreno de La Clementina de Ramón de la Cruz y Boccherini ${ }^{88}$. En 1788 la Condesa-Duquesa de Benavente solicitó a Gaetano Brunetti que se le concediese a Pedro Garisuain la plaza de fagot que había quedado vacante en la orquesta que se formaba para la "diversión de parejas", espectáculo ecuestre cortesano que se celebraba durante la estancia de la Corte en el Real Sitio de Aranjuez ${ }^{89}$. Falleció el 17 de diciembre de 1833 en Madrid $^{90}$

\section{GEISEL, Lorenzo}

Fagotista. Fue nombrado músico de la Casa de Osuna por el IX Duque el 1 de febrero de 1794 con efecto retroactivo desde el 17 de diciembre de 1793, asignándole un sueldo de ocho reales diarios. Dentro de las obligaciones de este cargo se hallaban la de tocar el fagot con los músicos del Regimiento de América que estaba comandado por el Duque de Osuna y de acompañarle en las campañas militares y en otras ocasiones en las que el Duque estimase conveniente. En 1802 Lorenzo Geisel consiguió una plaza de músico de la Real Capilla, pero siguió trabajando para el Duque de Osuna. El 1 de junio de este año tras la incorporación de Geisel a la Real Capilla, el Duque le redujo el sueldo a 5 reales diarios y le

\footnotetext{
87 Ibid. Europea de la Cultura, 1992.

${ }^{89}$ AHN NOBLEZA, OSUNA-CARTAS, leg 391-25.

90 Saldoni, Diccionario, vol III, p. 366.
}

88 Luigi Boccherini, Clementina, Revisión y adaptación del texto por Jacinto Torres Mulas. Transcripción musical por Antonio Gallego. Consorcio para la Organización de Madrid Capital 
concedió una ayuda de costa de seiscientos cuarenta reales para que se hiciese el "peti[t] uniforme" de músico de la Real Capilla ${ }^{91}$

\section{GERMÁN Y CLARAT, Jerónimo (†1810)}

Primer trompa de la orquesta de la Condesa-Duquesa desde el 13 de mayo de 1781 hasta la disolución de esta formación en 1792. Ingresó como clarín en la Real Capilla el 30 de abril de $1775^{92}$. Durante el reinado de José I Bonaparte fue incluido como clarín en la planta de la Capilla que se realizó en diciembre de $1809^{93}$, pero probablemente no llegó a integrarse en esta formación pues falleció el 20 de enero de $1810^{94}$.

\section{GIBERT, Francisco Javier (*1779 - †1848)}

Maestro de capilla, profesor y compositor. Nació en La Granadella (Lérida), fue nombrado Maestro de Capilla en la catedral de Tarazona en 1800. Permaneció en este cargo hasta 1804 cuando ganó una plaza similar en el Convento de las Descalzas Reales de Madrid, cargo que desempeñó hasta su muerte $^{95}$. En marzo de 1807 estrenó un Miserere en las fiestas religiosas organizadas por la Real Congregación de San José" ${ }^{96}$. Trabajó como "maestro de piano” para la X Duquesa de Osuna al menos entre enero y abril de 1818, seguramente ocupándose de la formación de su hijo Pedro de Alcántara, marqués de Peñafiel y heredero de la Casa de Osuna ${ }^{97}$. Falleció el 27 de febrero de $1848^{98}$.

\footnotetext{
91 AHN NOBLEZA, OSUNA-CARTAS, leg 392-31.

92 Ortega, "La Real Capilla”, p. 427.

93 Robledo, "La música”, p. 219.

94 Saldoni, Diccionario, vol. I, p. 177.

95 Juan Mujal Elias, Lérida. Historia de la música (Lérida: Dilagro ediciones, 1975), pp.121-122.

96 Diario de Madrid, no 77, 18 de marzo de 1807, pp. 318-319.

97 AHN NOBLEZA, OSUNA-CARTAS leg 470.
} 


\section{INZENGA, Ángel [Angelo]}

Compositor y maestro de música de origen siciliano. Fue profesor de canto en el Conservatorio de Madrid y "maestro de música habilitado para componer obras para la Real Capilla" 99 Hacia 1837 organizaba conciertos vocales en su casa de la calle Segovia $n^{0} 8$ de Madrid a los que según Saldoni asistían toda la aristocracia y acreditados aficionados ${ }^{100}$.

Al menos entre 1826 y 1829 Ángel Inzenga trabajó como maestro de piano de Pedro de Alcántara I, XI Duque de Osuna ${ }^{101}$, para el que compuso expresamente la arietta La tomba sobre el famoso texto de Carpani.

En 1828 y 1830 dirigió las funciones religiosas de San Francisco de Borja y Nuestra Señora del Pilar patrocinadas por la Casa de Benavente ${ }^{102}$. Al menos hasta 1833 participó habitualmente en las academias y conciertos vocales organizados por la Condesa-Duquesa en sus lugares de residencia en los que intervenían los cantantes de los teatros de ópera de Madrid ${ }^{103}$. Su hijo, el compositor y pianista José Inzenga gozó de la protección de la Casa de Osuna que en 1843 le concedió una ayuda económica para ampliar sus estudios musicales en París ${ }^{104}$.

\section{JÁUREGUI, Antonio}

Violinista y violista. Fue "segundo violín de primeros" en la orquesta de la Condesa-Duquesa desde diciembre de 1781 hasta marzo de 1790. En 1780 se presentó a las oposiciones de violín en la Real Capilla y en noviembre de 1781 para una plaza de viola, pero no obtuvo ninguna de las plazas convocadas ${ }^{105}$.

\footnotetext{
98 Saldoni, Diccionario, vol III, pp.308-309.

99 Ramón Sobrino, “Inzenga, Angel [Angelo]”, DMEH, vol. 6, p.441.

100 Saldoni, Diccionario, vol II, p. 447

101 AHN NOBLEZA, OSUNA-CARTAS leg 470.

${ }^{102}$ Véase Apéndice 6, $\mathrm{n}^{\text {os }} 13$ y 14.

103 AHN NOBLEZA, OSUNA-CARTAS leg 413-37-15.

${ }^{104}$ Ibid., leg 617-15.

105 Ortega, "La Real Capilla de Carlos III”, p. 411.
} 


\section{JOLY, Jean}

Maestro de baile. Se trasladó a España en 1801 para trabajar como maestro de baile de los tres hijos mayores de los IX Duques de Osuna gracias a la recomendación del bailarín francés Pierre Gabriel Gardel que había sido profesor de los hijos de los IX Duques de Osuna durante su estancia en Francia,. Desde diciembre de 1801 figuraba en la nómina de criados fijos al servicio de la Casa de Benavente-Osuna, con un sueldo de ocho reales diarios y la obligación de seguir a la Duquesa en todos sus desplazamientos ${ }^{106}$. Fue cesado en dicho puesto en 1807, y con este motivo la Condesa Duquesa de Benavente le concedió una ayuda de 3000 reales para los gastos del viaje de su regreso a París, de él y de su familia ${ }^{107}$.

Desde París Jean Joly, continuó solicitando la protección de la CondesaDuquesa de Benavente para conseguir trabajo ${ }^{108}$. En 1814, Joly solicitó su intercesión para volver a España, alegando graves apuros económicos, pero la Condesa-Duquesa no volvió a contratarle pues, como le relató en su respuesta ya no tenía hijos en edad para aprender a bailar y que dada su situación y circunstancias (después de la Guerra de la Independencia) no podía dispensarle su apoyo $^{109}$.

\section{JULIÁN, Manuel}

Flautista y oboísta. En 1769 trabajaba como oboe en la orquesta de la Compañía de Juan Ponce que actuaba en los teatros públicos de Madrid ${ }^{110}$. En 1777 se presentó a las oposiciones para el puesto de oboe y flauta en la Real Capilla pero, a pesar de que fue bien valorado en los ejercicios, no se le adjudicó la plaza por faltarle el ojo derecho ${ }^{111}$. Perteneció a la orquesta de la Condesa-

\footnotetext{
106 AHN NOBLEZA, OSUNA-CARTAS, leg 462.

107 Ibíd., leg 388-6.

108 Ibíd., leg 274-1 y leg 277-4.

109 Ibid., leg 617-38.

${ }^{110}$ BNE Ms. 14.016.1/92 (Papeles Barbieri).

111 Ortega, "La Real Capilla", pp. 413-414 y p. 442.
} 
Duquesa de Benavente en los primeros meses de funcionamiento de la orquesta como oboe, y después como flauta, puesto en el que permaneció hasta la disolución de la formación en mayo de 1792. Fue segundo flauta y primer oboe de la orquesta del Teatro de los Caños del Peral en la temporada de $1790^{112}$, y participó como solista interpretando un concierto suyo en los conciertos instrumentales que se celebraron en la Cuaresma de 1794 en dicho teatro ${ }^{113}$. Fue también músico en las Reales Guardias Valonas ${ }^{114}$

\section{LANDINI, Francisco (*ca. $1725-\uparrow 1794)$}

Violinista, nacido en Bolonia hacia 1725. Gracias a su excelente habilidad como instrumentista ingresó en la Real Capilla sin oposición el 13 de febrero de 1742 con 300 reales de salario mensual. Desde 1748 fue también "maestro de violín" del infante Don Luis de Borbón, y en julio de 1760 fue nombrado miembro de la Real Cámara de Isabel de Farnesio a la que siguió adscrito (además de a la Real Capilla) incluso después de la muerte de la Reina Madre ${ }^{115}$. Ascendió por antigüedad en el escalafón de la cuerda de violines en la Real Capilla y desde 1775 ocupó la plaza de violín primero ${ }^{116}$.

Paralelamente a su trabajo al servicio de la familia real fue "músico violín" de la Duquesa viuda de Osuna puesto al que se incorporó antes de mayo de 1745, y en el que cesó en diciembre de $1747^{117}$.

Falleció en Madrid el 1 de noviembre de $1794^{118}$

\footnotetext{
${ }^{112}$ Cotarelo, Orígenes, p. 420.

113 Ibid., p. 364.

${ }^{114}$ Saldoni, Diccionario, vol. IV, p. 151.

${ }^{115}$ Siemens, "Los violinistas”, pp. 732-733.

${ }^{116}$ Ortega, "La Real Capilla”, p. 434.

${ }^{117}$ AHN NOBLEZA, OSUNA-CARTAS, leg 390-4-2.

${ }^{118}$ Subirá, "Necrologías", no 252.
} 


\section{LANGLÉ, Honoré (*1741-†1807)}

Compositor, profesor y teórico de origen monegasco. Se educó en el Conservatorio de Nápoles gracias a la ayuda económica del príncipe Honoré III de Mónaco $^{119}$. Aunque compuso varias obras musicales que se estrenaron durante su vida, su principal ocupación fue la enseñanza. En 1784 fue nombrado profesor de canto de la Ecole Royale de Chant et Déclamation de París, y continuó en este puesto cuando esta institución fue reorganizada como Conservatorio en $1791 \mathrm{y}$ 1795. Fue profesor de música de los cuatro hijos de los IX Duques de Osuna durante la estancia en París en 1799 de la familia Benavente-Osuna. Por este trabajo recibía un sueldo de veintidós luises y medio al mes ${ }^{120}$.

\section{LASERNA NIEVA, Blas de (*1751- †1816)}

Compositor y director. Fue uno de los autores más prolíficos de música teatral en la segunda mitad del siglo XVIII en España ${ }^{121}$. Natural de Corella (Navarra). Llego a Madrid en 1768, y hacia 1772 trabajaba al servicio de los Marqueses de Mortara. Desde 1774 colaboró como músico en los teatros públicos de Madrid. En 1776 tras la muerte del compositor Antonio Guerrero, fue nombrado músico de la Compañía de Eusebio Ribera, y en 1779 consiguió el cargo de compositor en la compañía de Juan Ponce. Este puesto le obligaba a componer 62 tonadillas, y el resto de la música que se necesitase para las producciones del teatro durante el año cómico. Además debía ensayar y dirigir todos los

119 Sobre este compositor véase Paule Druilhe, "Langlé, Honoré (François Marie) », NG, vol. 14, pp. 246-247. De esta referencia he tomado los datos fundamentales y he añadido algunos más relacionados con el mecenazgo de los Osuna y Benavente.

120 AHN NOBLEZA, OSUNA-CARTAS, leg 388-29.

${ }^{121}$ La biografía más completa sobre Blas de Laserna sigue siendo la de Julio Gómez publicada en 1925 que fue reeditada y complementada por los trabajos de José Luis de Arrese y Eduardo Aunós publicados en José Luis Arresé, El músico Blas de Laserna. En colaboración con E. Aunós y J. Gómez (Corella: Biblioteca de Corellanos Ilustres- Impr. Delgado, 1952). He tomado de esta obra los principales datos y he añadido algunos desconocidos hasta ahora acerca de la relación de servicio de Blas de Laserna con la Casa de Benavente. 
espectáculos dramáticos-musicales, y tocar el calve durante las funciones. Entre marzo de 1792 y abril de 1797, Laserna fue el compositor de las dos compañías titulares de teatro español de Madrid como compositor, auxiliado por Bernardo Álvarez Acero. Al menos hasta 1808 Blas de Laserna continuó trabajando como compositor para los teatros de Madrid, si bien no se conocen demasiados datos de la última etapa de su vida. Durante el reinado de José I, Laserna se anunciaba en la prensa como profesor de música para niños para impartir clases de música a niños y como distribuidor de música vocal e instrumental manuscrita que vendía en su propio domicilio de la calle del Príncipe de Madrid.

Al menos durante 1781, Blas de Laserna trabajó como "maestro de clave" para la Casa de Benavente ${ }^{122}$, y en las veladas musicales organizadas por la XV Condesa-Duquesa de Benavente y su madre se escucharon algunas de sus tonadillas $^{123}$. En los siguientes años Laserna continuó relacionándose con la Casa de Benavente. La condesa-Duquesa viuda de Benavente fue madrina en el bautizo de una de sus hijas que nació en 1786 y que fue bautizada como María Faustina, en honor a su madrina.

Blas de Laserna falleció en Madrid el 8 de agosto de 1816. Antes de su muerte había hecho declaración de pobre. Su cadáver se depositó en la bóveda de la iglesia de San Lorenzo y fue enterrado en el cementerio extramuros de la Puerta de Toledo ${ }^{124}$.

\footnotetext{
122 AHN NOBLEZA, OSUNA-CARTAS, leg 389-27 y 390-8.

123 José Subirá, La tonadilla escénica (Madrid: Tipografía de la Revista de Archivos, Bibliotecas y Museos, 1928-1930), 3 vols.

${ }^{124}$ Parroquia de San Sebastián Libro de Bautizos 53, fol. 69. Esta hija no aparece en ninguna de las biografías de Laserna, y ya no vivía a la muerte de su padre en 1816.
} 


\section{LIDÓN, José (*1748- 127) ${ }^{125}$}

Compositor, clavecinista y organista. Nació el 2 de julio de 1748 en Bejar, (provincia de Salamanca) y falleció en Madrid el 11 de febrero de 1827. Se formó en el Real Colegio de Niños Cantores de Madrid. Después de un breve período como Maestro de Capilla en la catedral de Orense en los primeros meses de 1768, en octubre de ese mismo año gano la plaza de cuarto organista de la Real Capilla. En 1787 ascendió a vicemaestro de esta y desde 1805 fue el primer maestro de la Real Capilla. Desde 1771, fue también maestro de estilo italiano en el Real Colegio de Niños Cantores, y desde 1805 rector de esta institución asociada a la Real Capilla.

En 1780 Jose Lidón compuso, por encargo de Condesa-Duquesa María Josefa un juego de vísperas y una misa para las funciones de San Francisco de Borja que se estrenaron, respectivamente, el día 31 de septiembre y 1 de octubre de dicho año ${ }^{126}$.

Entre 1781 y 1792 Lidón trabajó como "maestro de clave" y "maestro de música" en la Casa de Benavente, y colaboró al menos eventualmente en la realización de arreglos y adaptaciones de obras dramáticas para las funciones y conciertos patrocinados por los miembros de esta casa nobiliaria ${ }^{127}$.

\footnotetext{
${ }^{125}$ Los datos que se conocían hasta la fecha sobre José Lidón figuran en Dámaso García Fraile, "Vida y obra de José Lidón Blázquez (1748-1827)". En: Jose Lidón, "La música para Teclado. Edición crítica". Madrid: Sociedad Española de Musicología, 2002 vol. I pp. 23-36 y María Gembero Ustárroz, “Lidón Blázquez, José”, $N G$, vol. 14, pp. 657-659. He tomado los principales datos de estas dos referencias y los he completado con algunos nuevos relacionados con la actividad de Lidón al servicio de la Casa de Benavente.

${ }^{126}$ AHN NOBLEZA, OSUNA-CARTAS, leg 389-27 y 390-8.

127 BNE Mss. 14.016.3/191 (Papeles Barbieri). En 1787 José Lidón arregló por orden de la Condesa-Duquesa María Faustina un aria "con todos instrumentos" cuya letra había sido traducida y adaptada ["trovada"] por Ramón de la Cruz para que la actriz y cantante Nicolasa [Palomera] la cantase en el teatro.
} 


\section{LITERES CARRIÓN, Antonio (*1673- †1747)}

Compositor y violón. Nacido en Mallorca. Se formó musicalmente en el Real Colegio de Niños Cantores y desde 1693 hasta su muerte fue primer violón de la Real Capilla. Fue "músico de cámara" del VII Duque de Osuna al menos desde 1722 y hasta $c a .1732^{128}$.

\section{LITERES SÁNCHEZ, José (†1746)}

Violón. Hijo Antonio Literes Carrión, músico del VII duque de Osuna y miembro de la Real Capilla, y de su primera esposa Manuela Sánchez de Aguiar. Fue violón de la Real Capilla ${ }^{129}$.y de la capilla musical de la Casa de Osuna al menos entre 1732 y $1737^{130}$. Falleció el 26 de septiembre de $1746^{131}$.

\section{LÍTERES MONTALVO, Antonio (†1768)}

Organista y clavecinista. Hijo de Antonio Literes Carrión, violón de la Real Capilla y músico del VII duque de Osuna y de su segunda esposa María Montalvo. Trabajó como organista de la Real Capilla desde antes de 1749 y hasta su muerte el 2 de diciembre de $1768^{132}$. Fue "maestro de clave" de la XV Condesa Duquesa de Benavente al menos entre septiembre de 1759 y marzo de $1761^{133}$.

\footnotetext{
${ }^{128}$ Para la biografía de Antonio Literes Carrión véase Nicolás, A. Solar Quintes, “Antonio Literes Carrión y sus hijos" Nuevos documentos para su biografía” AnM IX (1954), pp. 169-189 y PIZA PROHENS, Antoni: Antoni Literes, introducció a la seva obra. (Palma: Documenta balear, 2002). 129 Solar Quintes, “Antonio Literes”, p. 189.

130 AHN NOBLEZA OSUNA-CARTAS legs 389-30 y 446-1.

131 Solar Quintes, “Antonio Literes”, p. 189. 132 Ibid.

133 AHN NOBLEZA, OSUNA-CARTAS, leg 457-1 Nóminas de las raciones atrasadas en los diecinueve meses hasta el fin de marzo de 1761 de la Señora Duquesa de Benavente.
} 
MANALT, Francisco (*ca. 1720 - †1759)

Violinista y compositor. Nació en Barcelona hacia 1720. Desde principios de los años 30 de este siglo fue miembro de la Capilla del Palau de Barcelona institución que, según Lothar Siemens, estaba en dicha época bajo el gobierno de los Duques de Osuna ${ }^{134}$.

Al menos desde 1735 se hallaba en Madrid donde colaboró como violinista en funciones y acontecimientos musicales celebrados en el entorno de la Corte. En 1737 se incorporó a la plantilla de la Real Capilla en la que permaneció hasta su fallecimiento el 16 de enero de $1759^{135}$.

Manalt trabajó como violinista al servicio de la VII Duquesa viuda de Osuna al menos entre enero de 1745 y diciembre de 1747. En 1757 Francisco Manalt dedicó la edición de su Obra armónica de Seis Sonatas de Cámara de Violín y bajo solo, a Pedro [Zoilo] Téllez Girón, VIII Duque de Osuna de quien se declara su "menor criado" lo cual verifica que Manalt continuaba en dicha fecha al servicio de la Casa de Osuna ${ }^{136}$.

\section{MARESCALCHI, Luigi $(* 1745-\dagger 1812)$}

Empresario, compositor y editor musical. Nació en Bolonia y estudió composición con el Padre Martini ${ }^{137}$. En 1767 se hallaba en España como empresario y, probablemente director, de la Compañía de Ópera de los Reales Sitios ${ }^{138}$. Durante su estancia en España fue maestro de música de María Faustina

\footnotetext{
${ }^{134}$ Obra Armónica en seis sonatas de cámara de violín y bajo solo. (Madrid, 1757). Edición de Lothar Siemens y Lourdes Bonnet (Madrid: Sociedad Española de Musicología, 2001), p. 5.

${ }^{135}$ Siemens, "Los violinistas", pp. 695-702.

${ }^{136}$ Francisco Manalt, Obra Armónica en seis sonatas de cámara de violín y bajo solo. Madrid: Andrés Guinea, 1757. [dedicatoria].

${ }^{137}$ Para la biografía de Luigi Marescalchi véase Richard Macnutt, "Marescalchi, Luigi”. NG, vol. 15, pp.845-846. He tomado los principales datos de esta referencia y los he completado con los de su actividad en España.

${ }^{138}$ Cotarelo, Orígenes, pp 197-199 y 243-275.
} 
Téllez-Girón, Condesa-Duquesa viuda de Benavente ${ }^{139}$. En los inviernos de 1768 y 1769, Marescalchi se trasladó con su compañía a Valencia donde representó varias funciones públicas de ópera en el palacio de los Duques de Gandía ${ }^{140}$, que fue cedido por la Condesa-Duquesa viuda de Benavente, administradora en esa época del ducado de Gandía. Aproximadamente desde 1770 desarrolló una intensa actividad como editor musical, primero en Venecia y desde 1786 en Nápoles, ciudad en la que consiguió una licencia real que le concedía la exclusiva de impresión de música.

\section{MARINELLI, Carlo $(* 1755-\uparrow 1823)$}

Cantante y profesor de música. Nació en Fermo (Estados Pontificios) el treinta de Marzo de $1755^{141}$. Desarrolló en Italia la primera parte de su carrera como cantante. En 1772 y 1777 participó en las oposiciones para contralto en la capilla musical de Loreto (Italia) pero no fue admitido ${ }^{142}$. En la primavera de 1783 representó las óperas La scuola de' gelosi de Antonio Salieri y Il vecchio geloso de Felipe Alessandri en el Teatro del Leone de Jesi y en la temporada siguiente cantó en Perugia, Ezio de Gabrielle Porta y Giulio Sabino de Giuseppe Sarti. En 1788 trabajó en la temporada de ópera de Roma donde participó en las representaciones de Alciade e Telesi de Giuseppe Giordani y Olimpiade de Ambrosio Minoja, y en el 1790 trabajó en Bolonia en las representaciones de $\mathrm{Il}$ pirro de Giovanni Paisiello ${ }^{143}$. En 1790 se integró en la Academia Filarmónica de Bolonia $^{144}$.

\footnotetext{
${ }^{139}$ AHN NOBLEZA, OSUNA-CARTAS, leg 387-16.

${ }^{140}$ Cotarelo, Origenes, p. 271.

141 AHN NOBLEZA, OSUNA-CARTAS, leg 392-4.

${ }^{142}$ Floriano Grimaldi, Cantori maestri organiste della Capella Musicale di Loreto nei secoli XVIIXIX (Loreto: Ente Rassegne Musicali, 1982), pp. 89-90 y pp. 180-182.

143 Indici de'teatrali spettacoli dal 1764 al 1823. Reproducido en Francesco Gatti, Spettacoli musicali al Teatro Concordia di Jesi: (1798-1883) (Roma: Torre de Orfeo, 1999).

144 Osvaldo Gambassi. L'accademia filarmonica di Bologna. Fondazione, statuti, aggregazioni, (Firenze: Olschki 1992), p. 443.
} 
Carlo Marinelli llegó a Madrid en 1791 como primer soprano para las representaciones de ópera seria en el elenco contratado para el Teatro de los Caños del Peral para la primera temporada patrocinada por la Asociación de Óperas Italianas de la que formaban parte varios miembros de las familias Osuna y Benavente. Al menos hasta la temporada de 1793-1794 continuó formando parte de la compañía de ópera del Teatro de los Caños del Peral. El 9 de diciembre de 1793 interpretó el papel de Seleuco en las funciones de la ópera La venganza di Nino de Francesco Bianchi que se representó en dicho teatro para celebrar el cumpleaños de la reina María Luisa de Borbón ${ }^{145}$.

Al menos desde 1800, Marinelli trabajó como maestro de música de los hijos de los IX Duques de Osuna. Entre marzo de 1803 y octubre de 1807 perteneció al servicio fijo de la Casa de Benavente-Osuna con el cargo de "maestro de música"146 Tras la supresión de este puesto Marinelli continuó impartiendo clases a Manuela Isidra, hija menor de los IX Duques de Osuna y futura Duquesa de Abrantes, y encargándose de los asuntos musicales de la Casa. Durante la invasión francesa residió en Cádiz gozando de la protección de la Condesa-Duquesa de Benavente y continuó impartiendo clases a la hija menor de los Duques ${ }^{147}$. Su relación con la Casa de Osuna se prolongó al menos hasta diciembre de 1817 fecha en la que aparece el "visto bueno" con su firma en la lista de los músicos que intervinieron en el funeral de la Marquesa de Camarasa, hija primogénita de los IX Duques de Osuna ${ }^{148}$.

En 1821 era director de la Real Cámara de Fernando VII ${ }^{149}$. Falleció soltero en Madrid el 31 de diciembre de $1823^{150}$.

\footnotetext{
145 Cotarelo, Orígenes, p. 335.

146 AHN NOBLEZA, OSUNA-CARTAS, legs 392-4; 392-15 y 463.

147 Ibid., leg 392-4.

148 Ibíd.

149 José Subira, El Teatro del Real Palacio (1849-1851) (Madrid: CSIC-Instituto de Musicología, 1950), pp.121.

${ }^{150}$ AHN NOBLEZA, OSUNA-CARTAS, leg 392-4.
} 


\section{MAUS}

Fagotista de origen alsaciano ${ }^{151}$. Trabajó como músico de las Reales Guardias de Infantería Valonas ${ }^{152}$. Participó como solista en los Conciertos de Cuaresma de las temporadas de 1792 a 1794 que se celebraron en el Teatro de los Caños del Peral. Hacia 1798 ocupaba las plazas de segundo fagotista de la Capilla del Duque de Osuna y del Teatro de los Caños del Peral de Madrid ${ }^{153}$.

\section{MELE, Giovanni Battista (*1701-†después de 1752)}

Compositor y profesor de música. Se formó en el Conservatorio de Poveri di Gesù Christo de Nápoles con Gaetano Greco. Se conoce muy poco de los primeros años de su carrera profesional en Italia ${ }^{154}$. En 1733 se trasladó desde Nápoles a Madrid apoyado por el VII Duque de Osuna quien se hizo cargo de los gastos del viaje ${ }^{155}$. Al menos entre 1743 y 1744 fue profesor de música de María Faustina Téllez-Girón, hija primogénita del VII Duque de Osuna y futura Condesa-Duquesa de Benavente ${ }^{156}$. A partir de 1736 se tiene constancia de la representación de sus obras dramático-musicales en los teatros madrileños. El 31 de Enero de 1736 estrenó la ópera Por amor y lealtad recobra la majestad. Demetrio en Siria (con texto de Pietro Metastasio) en el corral de la Cruz. Junto con Corradini y Courcelle fue uno de los compositores habituales de las óperas, pasticci y serenatas que se organizaron bajo la dirección de Carlos Broschi "Farinelli" en el Teatro del Buen Retiro de Madrid y en otros escenarios de la Corte. En 1752 Mele solicitó permiso a Fernando VI para retirarse a Nápoles. El

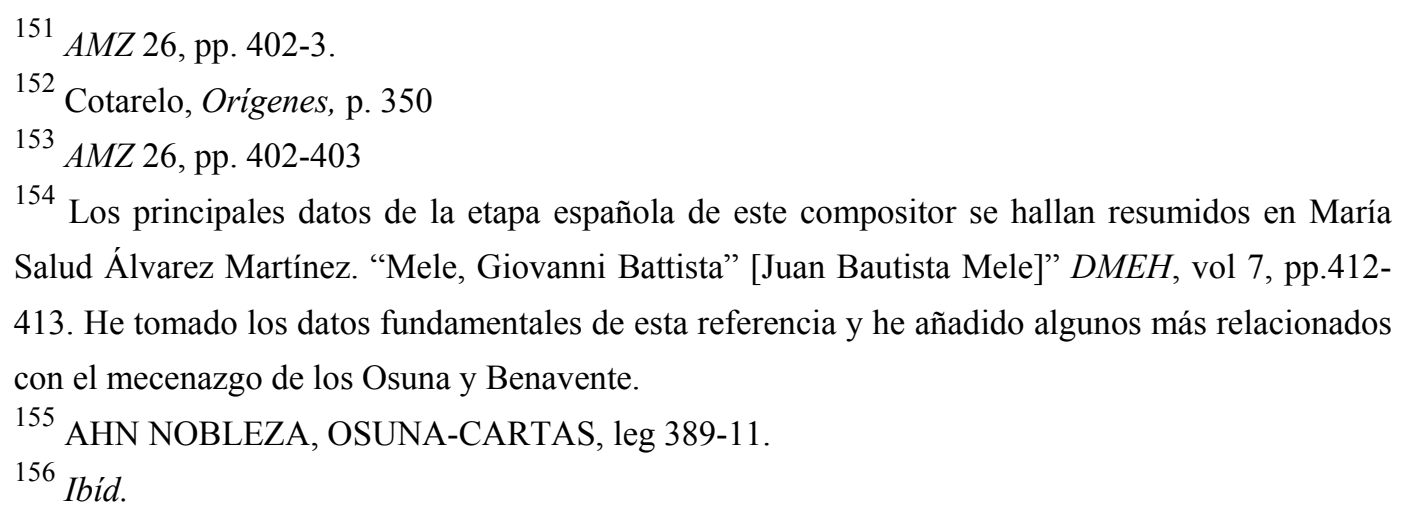

${ }^{154}$ Los principales datos de la etapa española de este compositor se hallan resumidos en María Salud Álvarez Martínez. "Mele, Giovanni Battista" [Juan Bautista Mele]" DMEH, vol 7, pp.412413. He tomado los datos fundamentales de esta referencia y he añadido algunos más relacionados con el mecenazgo de los Osuna y Benavente.

155 AHN NOBLEZA, OSUNA-CARTAS, leg 389-11.

${ }^{156}$ Ibid. 
rey le concedió dicha licencia junto con una gratificación de 400 doblones. A partir de entonces no se conocen más datos sobre su vida.

\section{MISERACHS, Juan}

Fagotista. Se incorporó a la nómina de músicos del VIII Duque de Osuna el 1 de abril de 1753. En esta misma fecha fueron nombrados otros tres músicos de origen catalán, el violinista Salvador Rexach, el violón Pablo Vidal, y el contrabajo Francisco Torner ${ }^{157}$

\section{MOROTTI, [José] Antonio (*1709- †1771)}

Compositor y pedagogo. Maestro del Real Colegio de Niños Cantores de Madrid desde 1738 hasta su muerte ${ }^{158}$. Fue también "maestro de música" en la Casa de Benavente, al menos entre el 1 de septiembre de 1749 y el 31 de diciembre de 1751 con un sueldo de seis reales diarios ${ }^{159}$.

Entre 1768 y 1769 colaboró con los teatros públicos de Madrid enseñando las partes musicales a los actores en las producciones de las zarzuelas Las segadoras de Vallecas, Las labradoras de Murcia de Antonio Rodríguez de Hita y Ramón de la Cruz ${ }^{160}$ y Los jardineros de Aranjuez, de Pablo Esteve y Grimau $^{161}$.

\footnotetext{
${ }^{157}$ AHN NOBLEZA, OSUNA-CARTAS leg 389-30.

${ }^{158}$ Guy Bourligueux,"Moroti, Antonio [Corvi Moroti], DMEH, vol. 7, p. 827.

159 AHN NOBLEZA, OSUNA-CARTAS leg 389-14.

160 Emilio Cotarelo, Don Ramón de la Cruz y sus obras. Ensayo biográfico y bibliográfico. (Madrid: Imprenta de José Perales y Martínez, 1899).

${ }^{161}$ Pablo Esteve y Grimau, Los Jardineros de Aranjuez (1768) Zarzuela en dos actos. Estudio y edición crítica de Juan Pablo Fernández-Cortés. Granada: Universidad de Granada-Centro de Documentación Musical de Andalucía, 2005, p. XXXIII.
} 


\section{NONÓ, José (*1776- †1845)}

Compositor, teórico y pedagogo de origen catalán. Según Saldoni desde 1802 fue "maestro compositor de la casa del Duque de Osuna para el cual compuso más de treinta óperas algunas de ellas por indicación de la duquesa"162. Sin embargo José Nonó no aparece en ninguna de las nóminas del personal al servicio del Duque de los años 1802 a 1808, en la que figuran varios músicos y profesores de danza y baile. Las obras de este autor, a las que alude Saldoni, tampoco figuran en los dos inventarios de la papelera de música de la Condesa Duquesa de 1824 y ca. $1838^{163}$.

En 1808 Nonó ocupaba el cargo de "profesor de cámara de las Bellas Artes Al servicio de Carlos IV. Fue autor de varias obras teóricas entre ellas figuran Escuela completa de música (1814), y un Método de piano (1821), que puso en práctica en un conservatorio privado que fundó en Madrid a finales de 1816 y que funcionó hasta 1822. En 1833 ingresó como profesor numerario de solfeo del Real Conservatorio de María Cristina ${ }^{164}$.

\section{ORRI, Juan († 1770)}

Trabajó como "músico violón" al servicio de la VII Duquesa viuda de Osuna desde antes de $1747 \mathrm{y}$ al menos hasta agosto de $1748^{165}$. Fue miembro de la Real Capilla, en 1749, fue incluido con otros once músicos en una nómina de instrumentistas de refuerzo que cobraban mensualmente de la institución monárquica pero que no tenían obligaciones de asistencia diaria. En 1756 ocupaba el puesto de tercer violón de la Real Capilla en el que permaneció hasta su muerte que acaeció el día 6 de junio de $1770^{166}$.

\footnotetext{
162 Saldoni, Diccionario, vol III, pp. 394.

163 Véase Apéndice 3.

164 James Radomsky, "Nonó, José”. DMEH, vol 7, pp.1056.

165 AHN NOBLEZA, OSUNA-CARTAS leg 390-4-4.

166 Subirá, "Necrologías", p. 217.
} 


\section{PICÓ, Jerónimo († después de 1814)}

Violinista y Maestro de capilla. Hijo de José Picó, bajonista y Maestro de Capilla de la Colegiata de Santa María de Osuna. Fue primer violín de la capilla musical de esta colegiata, hasta 1814 cuando solicitó la plaza vacante de maestro de capilla de la recién creada capilla musical del Santo Sepulcro de Osuna mantenida directamente por el Duque de Osuna. En su solicitud declaraba haber servido al Duque desde su infancia y por "más de cuarenta años". En los informes que el administrador de la Casa ducal en Osuna remitió al Duque para informar sobre esta solicitud, declaraba que Jerónimo Picó era "un músico de una muy regular habilidad con superioridad a todos sus compañeros" y que había servido muchos años en el puesto de "primer violín de la Capilla de Música que era de la Insigne Iglesia Colegial y fue destinada por orden de Vuestra Excelencia a la del Santo Sepulcro de la misma". El 17 de de febrero de 1814 el X Duque de Osuna nombró a Jerónimo Picó maestro de la capilla musical del Santo Sepulcro ${ }^{167}$.

\section{PICÓ, José}

Bajonista y maestro de capilla de la Colegiata de Santa María de Osuna. En 1787, acogiéndose al derecho de ascenso por antigüedad le fue concedida por el Duque de Osuna la plaza vacante de maestro de dicha institución. Falleció antes de $1813^{168}$

\section{PONZO, Giuseppe (fl. 1759-1791)}

Compositor de origen napolitano. Los pocos datos conocidos sobre su trayectoria biográfica y artística indican que desarrolló la primera parte de su carrera en Italia donde estrenó al menos cuatro óperas: Demetrio, con libreto de

${ }_{168}^{167}$ AHN NOBLEZA, OSUNA-CARTAS leg 486-8.

168 Ibíd. 
Pietro Metastasio, que se puso en escena en el Teatro del Falcone de Génova en el carnaval del año de 1759; Arianna e Teseo, dramma per musica (libreto de P. Pariati) representada en el Teatro Regio-Ducale de Milán en el carnaval del año 1762; Artaserse, dramma per musica (libreto de . Metastasio) que se representó en el Teatro di S. Benedetto de Venecia en el carnaval del año de 1766 y por último, Il re alla caccia, dramma giocoso con libreto de G. Goldoni, representado en el Teatro Privilegiatti di Viena el año $1777^{169}$.

Antes de 1778 Ponzo se trasladó a España para trabajar en el entorno de la Corte de Carlos III. En la Real Biblioteca del Palacio Real de Madrid se conservan siete obras dramático-musicales de Giuseppe Ponzo compuestas para el Principe de Asturias, el futuro Carlos IV. ${ }^{170}$

En 1778 Giuseppe Ponzo fue el encargado de dirigir las funciones religiosas de San Francisco de Borja que organizaba anualmente la Casa de Benavente $^{171}$ y en 1789 fue copiada una misa suya para ser interpretada durante las funciones de San Francisco de Borja en aquel año ${ }^{172}$. En 1785 Ponzo puso música a la zarzuela de Ramón de la Cruz El extranjero que se representó en el teatro particular de María Faustina Téllez Girón, Condesa-Duquesa viuda de Benavente. En los inventarios del archivo musical de la Casa de Osuna de 1824 y ca. 1838, figuraban también varias obras instrumentales de Ponzo ${ }^{173}$

Según el Indice de spettacoli teatrali de Milán, Giuseppe Ponzo aún vivía en $1791^{174}$.

\footnotetext{
${ }^{169}$ Los datos sobre de Giuseppe Ponzo las obras representadas en Italia de proceden de la Base de datos electrónica del ICCU Instituto Centrale per il catalogo Unico de Italia (http://opac.sbn.it)

170 Catálogo electrónico de la Real Biblioteca de Madrid (Palacio Real) (http://realbiblioteca.patrimonionacional.es).

171 AHN NOBLEZA, OSUNA-CARTAS leg 350.

172 Ibíd., leg 391-21.

173 Véase Apéndice 3.

174 James L. Jackmann, “Ponzo, [Ponzio] Giuseppe, NG, vol 20, p. 99.
} 


\section{PRADELL, Manuel}

Compositor. En 1732 trabajaba como músico compositor para José Téllez Girón, VII Duque de Osuna con un salario de 22 reales y medio al día ${ }^{175}$. A la muerte del Duque en 1733 realizó la tasación de los instrumentos musicales que habían sido de su propiedad ${ }^{176}$. Aún prestaba su servicio a la Casa de Osuna en septiembre de 1741, cuando se encargó de pagar a los músicos de refuerzo que asistieron a las fiestas de San Pedro y San Zoilo, en las que se festejó la onomástica del VIII Duque Pedro Zoilo Téllez Girón ${ }^{177}$.

\section{REINA, Francisco [de]}

Músico de la Capilla de la Colegiata de Santa María de Osuna. A partir de 1813 se convirtió en criado del Duque de Osuna cuando esta formación musical se dedicó al servicio exclusivo de la Capilla del Santo Sepulcro ${ }^{178}$.

\section{REXACH, Salvador $(* 1725-\uparrow 1780){ }^{179}$}

Violinista y compositor natural de Barcelona ${ }^{180}$. Al menos en la temporada de 1752-1753, fue violín en la compañía de ópera de Nicola Setaro que actuó en el Teatro de la Santa Cruz de Barcelona hasta marzo de 1753 y en la que también trabajaron el violonchelista Pablo Vidal, y el contrabajo Francisco Torner ${ }^{181}$. El 1

\footnotetext{
175 AHN NOBLEZA, OSUNA-CARTAS, leg 446-1.

176 Ibid., leg 48-1.

177 Ibid., leg 389-30.

178 Ibíd., leg 391-29.

179 Los principales datos de la biografía de Salvador Rexach proceden de diversos estudios realizados por Lothar Siemens Hernández que aparecen sintetizados en "Rexach, Salvador". $D M E H$, vol. 9, p.149. A los datos que figuran en esta referencia he añadido algunos desconocidos hasta ahora relacionados con su actividad en los teatros de Madrid y en la Casa de Osuna.

180 Subirá, "Necrologías". p. 216.

181 Archivo del Hospital de la Santa Cruz de Barcelona. Teatro, Carpeta 6, n 5. Cuentas 1750-
} 
de abril de 1753 pasó a servir como violinista a Pedro Zoilo Téllez Girón, VIII Duque de Osuna con un salario de nueve reales al día. En esta misma fecha comenzaron a trabajar el violonchelista Pablo Vidal, el contrabajo Francisco Torner y el fagotista Juan de Miserachs ${ }^{182}$. En Madrid compatibilizó su trabajo al servicio de la Casa de Osuna con diversos empleos. En 1760 Rexach ocupaba la plaza de primer violín de la capilla del Colegio Imperial, y al menos entre 1762 y 1768, formó parte de la orquesta de la compañía teatral de María Hidalgo, que actuaba en los teatros madrileños de La Cruz y el Príncipe ${ }^{183}$. Rexach debió de abandonar su empleo en la compañía de María Hidalgo cuando ingresó en la Real Capilla en octubre de $1768^{184}$, pero continuó trabajando al servicio del Duque de Osuna al menos hasta $1775^{185}$.

\section{RODRÍGUEZ [DE] LEDESMA, Maríano(*1779 -†1847)}

Cantante, compositor, y director. Natural de Zaragoza, se formó musicalmente en el colegio de infantes de la Catedral de la iglesia metropolitana de la Seo ${ }^{186}$. Con 17 años ganó una plaza de racionero de la catedral de Zaragoza y con 18 la de maestro de capilla de la catedral de Vinaroz, en la que permaneció tres años. En los primeros años del siglo XIX abandonó la carrera de músico de

1759. Transcrito en Alier, Roger, L'òpera a Barcelona : orígens, desenvolupament i consolidació de l'ópera com a espectacle teatral a la Barcelona del segle XVIII- Barcelona: Institut d'Estudis Catalans, Societat Catalana de Musicología, 1990, p. 522.

182 AHN NOBLEZA, OSUNA CARTAS, leg 389-30.

183 BNE Mss 14.016.1 (Papeles Barbieri). En 1762 aparece con el nombre de "Salvador" entre los violines primeros de la compañía, con la asignación de 20 reales diarios. En otro documento que detalla los sueldos que se les pagó a los músicos hasta el 30 de abril de 1768 figura "Salvador Rexach" con la misma asignación.

184 Siemens, "Los violinistas", p. 728.

185 AHN NOBLEZA, OSUNA CARTAS, leg 448-1. En 1775 Rexach continúa figurando en las nóminas de Osuna con el mismo sueldo de 9 reales con el que comenzó a servir en 1753.

${ }^{186}$ La biografía más completa y actualizada de Rodríguez de Ledesma es la realizada por Tomás Garrido para el DMEH. Tomás "Rodríguez de Ledesma, Maríano Nicasio", DMEH, vol. 9, pp. 293-301. De esta referencia he tomado los datos fundamentales de la trayectoria biográfica de Rodríguez de Ledesma y he añadido algunos nuevos relacionados con el mecenazgo de los Osuna y Benavente. 
iglesia y después de trabajar un tiempo como cantante y director de una compañía de ópera en Andalucía se presentó como tenor en el Teatro de los Caños del Peral de Madrid. En 1806 fue nombrado tenor supernumerario de la Real Capilla con un sueldo de 10.000 reales al año.

En 1808 Rodríguez de Ledesma intervino como primer tenor y director en las funciones de San Francisco de Borja patrocinadas por la Casa de Benavente. En esta época Mariano Rodríguez de Ledesma debió de disfrutar de la protección de esta casa ducal pues renunció a cobrar el importe que le correspondía por su participación en estas funciones, gesto que era habitual en los criados de la familia para honrar a sus señores ${ }^{187}$.

Tras combatir en la Guerra de la Independencia contra los franceses, se trasladó a Sevilla y a Cádiz, ciudad donde residió hasta su traslado a Inglaterra a principios de 1813. En Londres fue maestro de canto de la princesa Carlota, hija del futuro rey Jorge IV, y participó en los conciertos de la Philarmonic Society. Regresó a España en 1815, y fue nombrado profesor de música "en clase de voz" de la Real Cámara de Felipe IV con un sueldo de 12.000 reales al año. En 1818 accedió a la plaza de tercer contralto en la Real Capilla. Antes de su regreso a España, Rodríguez de Ledesma trato de obtener de nuevo el patrocinio de la Condesa-Duquesa María Josefa, que había finalizado antes de su traslado a Londres debido a algún incidente provocado por el propio Ledesma ${ }^{188}$. Posiblemente tras las pertinentes disculpas, Rodríguez de Ledesma, volvió a gozar de la protección de los la Condesa Duquesa de Benavente, pues al menos entre mayo de 1820 y septiembre de 1821 fue maestro de música de su nieto el joven Pedro de Alcantara, XI Duque de Osuna ${ }^{189}$.

Entre 1823 y 1834, Rodríguez de Ledesma residió principalmente en Londres, ciudad en la que fue nombrado profesor de canto en la Royal Academy of Music (1827). En noviembre de 1834, regresó de nuevo a España y en junio de 1836 fue nombrado maestro de la Real Capilla, puesto en el que permaneció hasta

187 AHN NOBLEZA, OSUNA-CARTAS, legs 392-37 y 570.

${ }^{188}$ Ibid., leg 392-8.

${ }^{189}$ Ibíd., leg 392-17. 
finales de 1846 en que fue relevado por Hilarión Eslava debido a su grave enfermedad. Falleció en Madrid en marzo de 1847.

\section{RODRÍGUEZ MONROY, Ramón (†1812)}

Violón, contrabajo y compositor. Era conocido en los círculos musicales madrileños por el segundo apellido. Según Saldoni era natural de la localidad de Gata en el obispado de Coria (Extremadura) y falleció en $1812^{190}$. Ingresó en la Real Capilla en 1780 como tercer violón y en 1787 promocionó al puesto de segundo violón ${ }^{191}$. En 1809 fue incluido en la planta de la Real Capilla y Cámara de Jose $\mathrm{I}^{192}$.

Ocupó la plaza de contrabajo primero en la orquesta de la CondesaDuquesa de Benavente durante todo el período de su funcionamiento (17811792). Fue también autor de varias obras instrumentales y de una misa que se conservaban en el archivo musical de la Condesa-Duquesa ${ }^{193}$.

\section{RONZI, Melchor}

Violinista, director y empresario de ópera. Natural de Bolonia. A partir de 1787 trabajó en los primeros puestos de violines de la orquesta del teatro de los Caños del Peral de Madrid. En este coliseo desarrolló gran parte de su actividad musical siendo uno de los intérpretes habituales de los conciertos que se organizaban durante la Cuaresma en dicho teatro.

En 1802 se hizo cargo como empresario de los teatros de los Caños del Peral, del Príncipe y de la Cruz, pero la empresa fracasó. Decidió entonces trasladarse a Barcelona y reemprender allí su actividad pero tampoco consiguió salir adelante su empresa de ópera. Durante la invasión francesa José I le nombró primer violín de la capilla y cámara reales. Fue autor de un proyecto para la

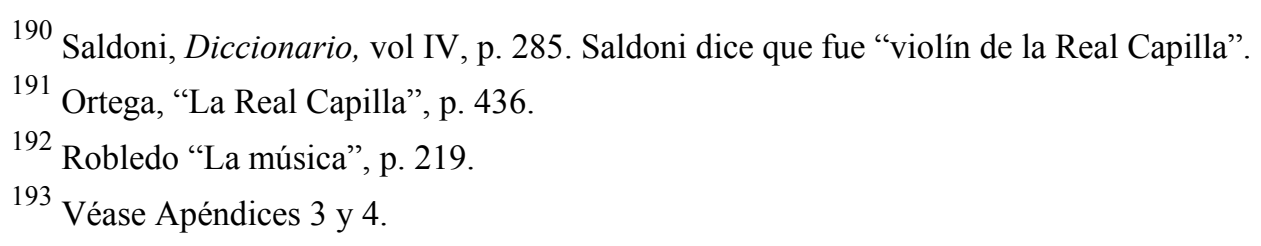


creación de un conservatorio en Madrid que nunca se llevó a cabo ${ }^{194}$.

Al menos entre 1796 y 1803 Melchor Ronzi trabajó para la Casa de Benavente-Osuna, aunque probablemente nunca formó parte de la plantilla de criados de la Casa. Entre octubre y diciembre de 1797 se encargó de buscar varios músicos para las fiestas que se organizaron en la casa de los duques ${ }^{195}$, y en 1798 se encargó de contratar a varios músicos para las funciones de iglesia de San Francisco de Borja y Nuestra Señora del Pilar. Para las fiestas de este mismo año adquirió en Italia una misa de [Ferdinando] Paer y otra de [Giuseppe] Nicolini ${ }^{196}$. En 1803 recibió una gratificación de 880 reales de la Casa de Benavente-Osuna por su participación en las funciones de San Francisco de Borja.

\section{ROSSI, Domenico}

Bailarín, coreógrafo y compositor italiano. Fue el maestro de baile de los hijos de los IX Duques de Osuna al menos entre 1788 y $1792^{197}$. En 1772 participó como bailarín en la temporada de Barcelona ${ }^{198}$. Al menos desde 1787 se ubicó en Madrid trabajando como coreógrafo y primer bailarín en el Teatro de Los Caños del Peral. Fue director de la compañía de Ópera y Baile de los Caños del Peral entre abril de 1788 y marzo de 1790, y en las temporadas de 1791, 1792 y 1794 período en que la gestión del teatro estuvo a cargo de la Asociación de Óperas Italianas, a la que pertenecieron varios miembros de las familias Osuna Y Benavente. Una vez disuelta la Asociación Domenico Rossi continuó ocupándose de la dirección del Teatro de los Caños, en las temporadas comprendidas entre abril de 1795 y marzo de $1799^{199}$.

\footnotetext{
${ }^{194}$ Sobre este personaje véase Cotarelo, Orígenes, pp. 297-396. Robledo, "La música”; Idem "El Conservatorio que nunca existió: el proyecto de Melchor Ronzi para Madrid (1810)", Música, Revista del Conservatorio Superior de Música de Madrid 7-9 (2000-2002), pp. 13-26.

${ }^{195}$ AHN NOBLEZA OSUNA-CARTAS leg 391-34.

${ }^{196}$ Ibid., legs 391-12; 391-26 y 391-30

${ }^{197}$ Ibid., legs 387-10 y 413-20.

${ }^{198}$ Alier, L'òpera, p 279.

${ }^{199}$ Cotarelo, Orígenes, pp. 331-342.
} 


\section{SÁNCHEZ, Juan (Capilla de Osuna)}

Maestro de Capilla y músico de la Capilla de la Colegiata de Santa María de Osuna. El 8 de julio de 1813 solicitó al Duque de Osuna el abono de los atrasos que se le debían por parte de la fábrica y la administración ducal a todos los músicos de la Capilla. En dicho documento declaraba ser el "maestro de la capilla de la insigne Iglesia Colegial de la villa de Osuna" aunque en realidad debía de ejercer este cargo de forma interina pues en 1814, la plaza de maestro de capilla estaba vacante $^{200}$. Se convirtió en criado del Duque de Osuna a partir de julio de 1813 cuando la Capilla de la Colegiata pasó al servicio exclusivo de la Capilla del Santo Sepulcro. En 1813 su salario era de 12 fanegas de trigo y 48 ducados anuales $^{201}$.

\section{SEBASTIÁN, Pedro}

Contrabajista. El 8 de abril de 1780 fue nombrado contrabajo de la orquesta del Coliseo de la Cruz, puesto que desempeñó al menos hasta $1801^{202}$. Según Saldoni a principios del siglo XIX era también "contrabajo de cámara" del Duque de Medinaceli ${ }^{203}$.

Ocupó el puesto de segundo contrabajo en la orquesta de la CondesaDuquesa de Benavente durante todo el período de funcionamiento de esta formación. Tras la disolución de la orquesta en 1792 siguió interviniendo en las actividades musicales organizadas por la Casa de Benavente-Osuna. Participó en varias de las academias y bailes organizadas en la Casa de Osuna en 1796 y $1797^{204}$, y en las funciones en honor de San Francisco de Borja en $1808^{205}$.

\footnotetext{
${ }^{200}$ AHN NOBLEZA OSUNA-CARTAS leg 486-8.

201 Ibid.

202 BNE Ms. 14.016.3/3 (Papeles Barbieri).

203 Saldoni, Diccionario, vol. IV, p. 320.

204 AHN NOBLEZA, OSUNA-CARTAS, leg 390-1.

205 AHN NOBLEZA, OSUNA-CARTAS, legs 392-37 y 570.
} 
Su hijo Diego, fue violón supernumerario de los coliseos del príncipe y de la Cruz de Madrid desde $1801^{206}$, y en 1806 era primer violonchelo del teatro del Príncipe y violonchelo de cámara del Duque de Medinaceli. ${ }^{207}$

\section{TORNER, Francisco $(\dagger 1767)$}

Contrabajista. Natural de Villafranca del Penedés (Barcelona) ${ }^{208}$. Al menos en la temporada de 1752-1753, fue contrabajo en la compañía de ópera dirigida por Nicola Setaro que actuó en el Teatro de la Santa Cruz de Barcelona hasta marzo de 1753 y en la que también figuraban el violonchelista Pablo Vidal, y el violinista Salvador Rexach ${ }^{209}$. El 1 de abril de 1753 pasó a servir como contrabajista a Pedro Zoilo Téllez Girón, VIII Duque de Osuna con un salario de nueve reales al día. En esta misma fecha comenzaron a trabajar para el Duque el violinista Salvador Rexach, el violón Pablo Vidal y el fagotista Juan de Miserachs. En 1755 Torner se encargó de buscar a los músicos necesarios para las fiestas de Santo Toribio de Mogrovejo organizadas por la Casa de Osuna ${ }^{210}$.

Al menos entre 1758 y 1765, Torner trabajó también como contrabajista de la orquesta de la compañía teatral de María Hidalgo, donde coincidió con el músico de la Casa de Osuna Salvador Rexach ${ }^{211}$. En el momento de su fallecimiento, el 25 de Julio de 1767, seguía aún al servicio de la Casa de Osuna. Entre sus albaceas testamentarios figuraron los músicos del Duque de Osuna Salvador Rexach y Pablo Font ${ }^{212}$.

\footnotetext{
${ }^{206}$ BNE Ms. 14.016.3/3 (Papeles Barbieri).

${ }^{207}$ Saldoni, Diccionario, vol. IV, p. 320.

${ }^{208}$ Subirá, "Necrologías", p.216.

209 Archivo del Hospital de la Santa Cruz de Barcelona. Teatro, Carpeta 6, n 5. Cuentas 17501759. Transcrito en Alier, L'ópera, p.522.

${ }^{210}$ AHN NOBLEZA, OSUNA CARTAS, leg 389-30.

${ }^{211}$ BNE Mss.14.015-14.016 (Papeles Barbieri).

${ }^{212}$ Subirá, "Necrologías", p.216.
} 


\section{VIDAL Pablo [Pau] $(* c a .1730-\uparrow 1807)$}

Violonchelista, pedagogo y compositor de probable origen catalán. Trabajó en Barcelona como "viola" de la cuerda de bajos (=viola de gamba) en la orquesta de la Compañía de Ópera de Nicola Setaro que cesó sus representaciones en marzo de $1753^{213}$. Tras la finalización de la temporada de esta compañía abandonó Barcelona y el 1 de abril de 1753 se incorporó al servicio de la Casa de Osuna como violón con un sueldo de 9 reales diarios. En esta misma fecha también pasaron a servir a Pedro Zoilo Téllez Girón, VIII Duque de Osuna, otros dos músicos procedentes de Cataluña: el contrabajista Francisco Torner y el violinista Salvador Rexach, ambos compañeros de Vidal en la orquesta de la compañía de ópera de Nicola Setaro, y el fagotista Juan de Miserachs ${ }^{214}$.

Vidal continuó al servicio de las Casas de Osuna como violón hasta su muerte en 1808. Como otros músicos de su casa colaboraron frecuentemente en las funciones y academias organizados por su hermana María Faustina, CondesaDuquesa viuda de Benavente lo que ha dado lugar a frecuentes confusiones. En 1766 la tesorería de Casa de Benavente pagó a Pablo Vidal, Salvador Rexach, y a Pablo Esteve, los tres músicos de la Casa de Osuna, el importe de la confección de un traje, seguramente para que participasen como músicos en una de sus fiestas ${ }^{215}$. En 1781 Vidal se incorporó como violón a la orquesta de la Condesa-Duquesa de Benavente en la que permaneció hasta la disolución de esta formación en 1792. En 1806 estaba ya jubilado y recibía la misma consignación de 9 reales al día de la Casa de Osuna ${ }^{216}$

Paralelamente a su actividad al servicio de la Casa de Osuna, Vidal trabajó como primer violón en la capilla del Real Monasterio de la Encarnación

\footnotetext{
213 Archivo del Hospital de la Santa Cruz de Barcelona. Teatro, Carpeta 6, $\mathrm{n}^{\circ}$ 5. Cuentas 17501759. Transcrito en Alier, L'ópera, p.522.

${ }^{214}$ AHN NOBLEZA, OSUNA-CARTAS, leg 389-30.

${ }^{215}$ Ibid.

${ }^{216}$ Ibíd leg 452. En las nóminas de la Casa de Osuna de enero a mayo de 1806 Pablo Vidal figura en el apartado de "consignaciones y limosnas", como "músico que fue de la Casa de Su Excelencia".
} 
seguramente desde $1775^{217}$. Al menos en dos ocasiones intentó ingresar en la Real Capilla. En 1770, cuando se quedó vacante una plaza tras el fallecimiento de Juan Orri $^{218}$, y de nuevo en 1783. El 21 de agosto este año la Condesa-Duquesa de Benavente se dirigió al Patriarca de la Indias, máxima autoridad de la institución musical palatina, para recomendar a Vidal resaltando su habilidad y "su irreprehensible conducta, acreditadas muchos años hace en la Real Capilla de la Encarnación",219.

Su hijos José [Joseph], violonchelista y Cayetano (violinista) colaboraron frecuentemente en las funciones organizadas en la Casas de Benavente y Osuna aunque no figuran como músicos en ninguna de las formaciones estables de la $\mathrm{Casa}^{220}$.

Pablo Vidal fue autor de dos obras pedagógicas para la enseñanza del Arpegio Armónico de Violonchelo y Bajo ${ }^{221}$ y Arte y Escuela de Violonchelo ${ }^{222}$. En el Diario de Madrid del 15 de Abril de 1796, Pablo Vidal ofreció dos violonchelos a la venta y una semana más tarde anunció un concierto para violonchelo de su composición ${ }^{223}$.

\footnotetext{
${ }^{217}$ Con este cargo figura en la portada de su obra didáctica Arte y escuela de violonchelo (BNE MC/5307/70). Según Judith Ortega, Pablo Vidal consiguió una plaza de violinista (sic. por violinista) en el Real Monasterio de la Encarnación en 1775. Judith Ortega, "Vidal, Pablo", DMEH, vol. 10, p. 864.

${ }^{218}$ Ortega, "Vidal, Pablo", p. 864.

${ }^{219}$ AHN NOBLEZA, OSUNA CARTAS, leg 389-30 ${ }^{220}$ Ibid.

${ }^{221}$ Emilio Moreno, “Aspectos técnicos del tratado de violín de José Herrando (1756): El violín español en el contexto europeo de mediados del siglo XVIII”, RMS XI/3 (1988), pp. 555-656.

${ }^{222} \mathrm{BNE} \mathrm{MC} / 5307 / 70$.

${ }^{223}$ Ortega, "Vidal, Pablo", p. 864-865.
} 


\section{WISSE [Bis, Vis, Weils]}

Clarinetista de origen alemán. Trabajó en la orquesta del Teatro de los Caños del Peral de Madrid al menos desde 1790. En dicho teatro participó en los conciertos cuaresmales interpretando obras a solo para clarinete. Era el primer clarinetista en la capilla musical del IX Duque de Osuna a finales del siglo XVIII $^{224}$. Participó en varios de los bailes organizados por la Condesa Duquesa de Benavente en sus palacios de la Puerta de la Vega y de la Alameda entre 1796 y $1797^{225}$. En 1799 se hallaba en Lisboa ${ }^{226}$

\section{ZLOTEK, Bonifacio [Bonifacy] $(\dagger 1787)$}

Violinista natural de Varsovia (Polonia), conocido en España por el sobrenombre de "el Polaco". Fue miembro de la Real Capilla desde 1770 hasta su muerte $^{227}$. Entre 1772 y 1773 se trasladó a Varsovia con licencia de la Real Capilla $^{228}$.

Fue "primer violín" (=concertino) de la orquesta de la Condesa-Duquesa desde 1781 hasta su muerte que acaeció a finales de 1786 o principios de $1787^{229}$. En 1783 viajó a Barcelona con su familia y otros músicos de la orquesta por orden de la Condesa-Duquesa de Benavente que se había trasladado a dicha ciudad para acompañar a su marido, Pedro de Alcántara Téllez Girón en su destino militar en dicha ciudad ${ }^{230}$.

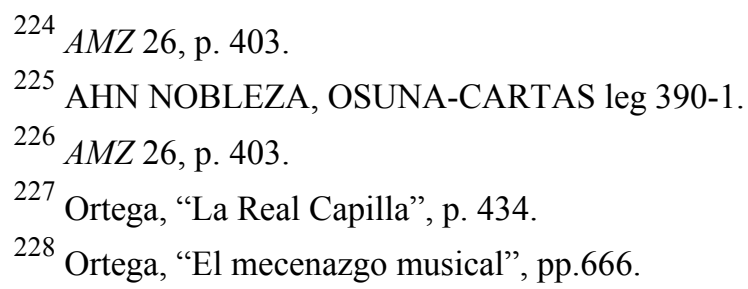

229 AHN NOBLEZA, OSUNA-CARTAS, leg 390. Bonifacio Zlotek falleció a finales de 1786 o en los primeros días de 1787. En la nómina de la orquesta de la Condesa-Duquesa de diciembre de este año, fechada a finales de enero de 1787, se señala que su paga de ese mes deberá ser cobrada por su viuda y herederos. Según Judith Ortega en la documentación del Palacio Real figura el mes de febrero como fecha de fallecimiento. Ortega, "La Real Capilla", p. 434.

${ }^{230}$ AHN NOBLEZA, OSUNA-CARTAS, legs 389-24 y 390-1. 
6. Apéndice documental 



\section{A) DOCUMENTOS SOBRE FUNCIONES Y ACTOS RELIGIOSOS PATROCINADOS POR LAS CASAS DE OSUNA Y BENAVENTE (1755- 1830)}

$\mathbf{N}^{\mathbf{0}}$ 1. Lista de músicos que asistieron a las funciones religiosas celebradas por el XIV Conde-Duque de Benavente en acción de gracias a San Francisco de Borja el 9 y 10 de agosto de 1755

AHN NOBLEZA, OSUNA-CARTAS, leg. 389-16, Agosto de 1755.

"Lista de los músicos que asistieron a tocar a las vísperas intermedios por la mañana y tarde, misa y siesta a la Casa profesa de padres Jesuitas de esta Corte en acción de Gracias al Señor San Francisco de Borja por orden del Excelentísimo Señor Conde Duque de Benavente y mi señor el día 9 y 10 del mes de agosto año de 1755

$\underline{\text { violines }}$

Don Juan Bautista

120 reales a 90

Don Juan Machado

120 reales

Don Miguel Aguilera

120 reales

Don Salvador Rexach

120 reales

Don Francisco Doti

120 reales

Don Antonio Rodil

120 reales

Don Julian Muñoz

120 reales

Don Leon Bissenlau

120 reales

obues

Don Francisco Gónima

120 reales

Don Joseph Escolanet

120 reales

Don Juan Ballart

120 reales

Don Joseph Lerch

120 reales

Trompas

Don Juan Canaut

120 reales

Don Antonio Enrique

120 reales

Bajos

Don Manuel Rio

120 reales

Don Juan Antonio Rio

120 reales 
Don Onofre Ginesta

Timbales

Don Sebastián Moneva
120 reales

120 reales

2280

Baja $\quad 570$

Líquido 1710

Capilla $\quad 3300$

Total 5070"

$\mathbf{N}^{\circ}$ 2. Orden de pago a los músicos que intervinieron en los intermedios y función en honor a Santo Toribio de Mogrovejo realizada por el XIV Conde-Duque de Benavente en el Convento de Portaceli de Madrid el 27 de abril de 1757

AHN NOBLEZA, OSUNA-CARTAS, leg. 389-28. 19 de junio de 1757.

"Madrid 19 de junio de 1757

Abono de Su Excelencia por la propina que mandó dar a los músicos que de su orden tocaron los intermedios y asistieron a la función de Santo Toribio Mogrovejo.

Reales de vellón 465

Lista de los intermedios que en el Convento de Portaceli de esta Corte se han hecho a la fiesta de Santo Toribio Mogrovejo en el día 27 de abril de este presente año de 1757, de orden del Excelentísimo Señor Conde de Benavente.

[reales de vellón]

Cuatro violines

120

Dos obues

Un contrabajo

Violón, fagot y órgano 90

Trompas y clarines 120

De un concierto de violín 15

Joseph Herrando [rúbrica] 
Háganse buenos a Don Juan Hernández Lobato, en las cuentas que diese de la Tesorería General de mi Casa y estados en esta corte, los cuatrocientos sesenta y cinco reales de vellón, que se expresan en la memoria antecedente, y lo [que] han importado las propinas que se dieron a los músicos que tocaron los intermedios el día veinte y siete de abril de este año en la fiesta que a mi devoción se celebró al glorioso Santo Toribio Mogrovejo, como se verifica de la misma citada memoria cuya cantidad les ha satisfecho de mi orden, y se previene que de este abono se ha de tomar la razón en mi contaduría

Madrid, 19 de junio de 1757

El Conde Duque

Tomo la razón Andrés Merlo"

\section{$\mathbf{N}^{\circ}$ 3. Orden de pago a Francisco Basset por los músicos de refuerzo que asistieron a las funciones religiosas de San Francisco de Borja celebradas en 1781.}

AHN NOBLEZA, OSUNA-CARTAS, leg. 390-1. 14 de diciembre de 1781.

"Muy Señor mío: Queriendo la Condesa-Duquesa mi Señora que las fiestas, que a nombre de Su Excelencia y del Señorito Conde de Mayorga, y de Belalcazar, Marqués de Lombay y Zahara, mi Señor se han celebrado a expensas de sus Excelencias en la Real Iglesia de San Felipe Neri de esta Corte en los días $1^{\circ}$ y $5^{\circ}$ de octubre de este año, se adornasen con el correspondiente lleno de instrumentos, mandó se llamasen para concurrir a ella varios músicos instrumentistas (a más de los que están asalariados por $\mathrm{Su}$ Excelencia) los cuales concurrieron con efecto, seis a la prueba de música, que se hizo en casa de Su Excelencia el día 28 de septiembre; ocho a las Vísperas el día 30 del mismo, y los mismos a las misas de los días $1^{\circ}$ y $5^{\circ}$ de octubre, cuyas pagas al respecto de 20 reales cada uno por cada una de dichas asistencias (conforme a lo que Su Excelencia arregló, y dispuso en el año anterior) importan seiscientos reales [de] vellón según la razón adjunta que con fecha de 12 del corriente me ha entregado Don Francisco Basset, encargado por $\mathrm{Su}$ Excelencia del cobro, distribución de estas pagas en consecuencia de todo lo aviso a Vuestra Merced de orden de la Condesa-Duquesa, mi Señora para que se sirva de poner a la firma de Su Excelencia el correspondiente libramiento de esta cantidad a favor del expresado Don Francisco Basset. 
Quedo con el mayor afecto a la disposición de Vuestra Merced cuya vida guarde Dios muchos años. Madrid 14 de diciembre de 1781.

Besa la mano de Vuestra Merced, su mas afecto servidor, y amigo

Manuel de Ascargorta

Señor Don Francisco Grande Torrejón"

\section{$\mathbf{N}^{\circ}$ 4. Orden de pago a Francisco Basset por los músicos de refuerzo que asistieron a las funciones religiosas de San Francisco de Borja celebradas en 1782.}

AHN NOBLEZA, OSUNA-CARTAS, leg. 390-1. 6 de noviembre de 1782.

"Muy Señor mío: Queriendo la Condesa-Duquesa, mi Señora que a las fiestas que se hacían de su orden en la Real Iglesia de San Felipe Neri de esta Corte, se adornasen con el correspondiente lleno de instrumentos y demás circunstancias de solemnidad que en los años anteriores, me lo mandó así con fecha de 24 de Agosto de este año, y para su cumplimiento a más de emplearse los músicos instrumentistas asalariados por $\mathrm{Su}$ Excelencia (por impedirles la asistencia a algunos de estos su destino en la Capilla Real) suplir su falta con otros a quienes se ha llamado (como también lo hizo Su Excelencia en los años anteriores) encargando de todo esto a Don Francisco Basset, quien me ha entregado firmada la adjunta noticia de los músicos que ha buscado de fuera y importe de sus pagos por la asistencia a las vísperas del día 30 de septiembre y misas de los días $1^{\circ} \mathrm{y}$ $5^{\circ}$ de octubre que asciende a cuatrocientos cincuenta reales de vellón de cuya cantidad se servirá Vuestra Merced extender y poner a la firma de los apoderados de Su Excelcnia el correspondiente libramiento a favor del citado Basset. Para que cobrada por este, pueda el mismo efectuar su distribución.

Me repito con todo afecto a la disposición de Vuestra Merced cuya vida guarde Dios muchos años. Madrid 6 de Noviembre de 1782.

Besa la mano de Vuestra Merced, su mas afecto servidor, y amigo

Manuel de Ascargorta

Señor Don Francisco Grande Torrejón” 


\section{N $^{0}$ 5. Orden de pago a Pedro Ochoa, festero de la Capilla de Música del Real Convento de la Encarnación de Madrid por la asistencia de dicha capilla a las funciones religiosas de San Francisco de Borja celebradas en 1783.}

AHN NOBLEZA, OSUNA-CARTAS, leg. 390-3. 17 de noviembre de 1783.

"Muy Señor mío: Habiendo dispuesto la Condesa-Duquesa, mi Señora que la música que hubiese de asistir a las Vísperas y Misas que respectivamente hubiesen de celebrarse a nombre de Su Excelencia y de la Excelentísima Señora Condesa de Mayorga, mi Señora como Marquesa de Lombay, a San Francisco de Borja en la Real Iglesia Oratorio de esta Corte en los días 30 de septiembre, $1^{\circ}$ y $5^{\circ}$ de octubre próximo pasado fuese la misma que se acostumbraba y que había asistido en los años anteriores; se pasó un aviso a la Capilla [de] música del Real Convento de Señora de la Encarnación; para que concurriese a cantar dichas víspera y misas según la había ejecutado en el año último, y en algunos otros anteriores; y en efecto lo hizo así en las Vísperas del 30 de septiembre, $1^{\mathrm{o}}$ y $5^{\mathrm{o}}$ de octubre lo cuales componen tres puntos cada uno de cuatrocientos veinte reales, que es lo que dicha capilla tiene tratado llevar, importan mil doscientos sesenta reales [de] vellón de cuya cantidad se servirá vuestra merced extender y poner a la firma de los apoderados de Su Excelencia el correspondiente libramiento a favor de Don Pedro Ochoa, festero de la misma Capilla.

Quedo como debo a la disposición de Vuestra Merced cuya vida guarde Dios muchos años. Madrid 17 de Noviembre de 1783.

Besa la mano de Vuestra Merced, su mas afecto servidor, y amigo

Manuel de Ascargorta

Señor Don Manuel de Cubas"

[En el margen de la primera página]:“ En 21 de noviembre de dicho año de 1783 se despachó libramiento a favor del festero de la Capilla de la Encarnación por los motivos que expresa este papel"] 
$\mathbf{N}^{\circ}$ 6. Orden de pago a Francisco Basset por la copia de una misa de [Joseph] Haydn y la asistencia de nueve músicos para completar la orquesta en las funciones religiosas de San Francisco de Borja celebradas en 1785.

AHN NOBLEZA, OSUNA-CARTAS, leg. 390-1. 31 de octubre de 1785.

"Muy Señor mío: Con motivo de las fiestas que se celebraron en este año por los Condes-Duques, mis Señores, al glorioso San Francisco de Borja, en la Real Iglesia Oratorio de San Felipe Neri de esta corte, se copió de orden de mi Señora la misa de Haydem que había de servir y sirvió en las mismas fiestas y también se buscaron nueve músicos para completar la orquestra [sic] que debía concurrir; y importando el gasto ejecutado con dichos dos motivos 1251 reales [de] vellón como resulta de las dos adjuntas notas, puestas por Don Francisco Basset a quien hizo la Condesa-Duquesa mi señora estos encargos, se servirá Vuestra Merced entender y poner a la firma de $\mathrm{Su}$ Excelencia el correspondiente libramiento de dicha cantidad a favor del citado Basset.

Quedo con el mayor afecto a la disposición de Vuestra Merced, y ruego a Nuestro Señor guarde su vida muchos años.

Madrid, 31 de Octubre de 1785

Señor Don Manuel de Cubas"

N$^{\circ}$ 7. Orden de pago a Joaquín Agramuntell, festero de la Capilla de Música del Convento de las Descalzas Reales de Madrid por la asistencia de dicha capilla a las funciones religiosas de San Francisco de Borja celebradas en 1788.

AHN NOBLEZA, OSUNA-CARTAS, leg. 390-3. octubre de 1788.

"Muy Señor mío: Habiendo dispuesto la Condesa-Duquesa, mi Señora que a las Víspera sque habían de celebrarse en obsequio de San Francisco de Borja en los días 30 de septiembre próximo pasado, y a las misas de los días $1^{\circ} .6^{\circ} .7^{\circ} .8^{\circ}$, y $9^{\circ}$ del corriente a nombre respectivamente de la Señora Condesa Duquesa mi Señora, y de las dos señoritas en la Real Iglesia Oratorio de San Felipe Neri, asistiese la Capilla de música de las Señoras Descalzas Reales de esta corte, se pasó aviso a dicha capilla para que concurriese, como en efecto lo ejecutó en los citados 6 días que componen otros tantos 
puntos, los cuales a razón cada uno de 420 reales (pues está convenida dicha Capilla en llevar lo mismo que la de la Encarnación en los años anteriores) importan 2.520 reales de vellón de cuya cantidad se servirá Vuestra Merced poner a la firma de Su Excelencia el correspondiente libramiento a favor de Don Joaquín Agramuntell, festero de dicha Capilla de [las] Señoras Descalzas Reales.

Con este motivo ofrezco a la obligación de Vuestra Merced mi verdadera amistad, y ruego a Dios guarde su vida muchos años. Madrid [ ] de Octubre de 1788.

Señor Manuel de Cubas"

\section{$\mathbf{N}^{\circ}$ 8. Orden de pago a la Capilla de Música de San Cayetano de Madrid y a otros músicos por los servicios prestados en las funciones religiosas de San Francisco de Borja celebradas en 1800.}

AHN NOBLEZA, OSUNA-CARTAS, leg. 390-1. 4 de diciembre de 1800.

"Muy Señor mío: A la fiesta solemne que se celebró a devoción de la CondesaDuquesa, mi señora, el día 12 de Octubre de este año en el Convento de Religiosas Capuchinas de esta Corte en obsequio de Nuestra Señora del Pilar asistieron por disposición de Su Excelencia, la Capilla [de] música de San Cayetano y otros profesores instrumentistas que proporcionó Don Francisco Basset, quien según costumbre ha cuidado de los respectivo a la música. Y importando el coste de las voces cuatrocientos veinte reales y cuatrocientos el de instrumentos, según resulta de las cuentas de Don Antonio de Arche y Don Francisco Basset, que en el día paso a Vuestra Merced con otro oficio respectivo a las fiestas de San Francisco de Borja; se servirá Vuestra Merced a quien Su Excelencia se sirvió comisionar especialmente de poner a la firma del Duque, mi Señor, los correspondientes libramientos de cuatrocientos veinte reales el primero a favor de Arche, y el otro de solo cuatrocientos reales al de Don Francisco Basset.

Nuestro Señor [guarde] a Vuestra Merced muchos años. Madrid 4 de Diciembre de 1800.

Besa la mano de Vuestra Merced, su mas afecto servidor, y amigo

Manuel de Ascargorta

Señor Don Juan Bautista Guitart" 


\section{No 9. Orden de Pago a la Capilla de Música de San Cayetano de Madrid y a otros músicos por los servicios prestados en las funciones religiosas de San Francisco de Borja celebradas en 1802}

AHN NOBLEZA, OSUNA-CARTAS, leg. 331-1, 18 de noviembre de 1802.

"Muy Señor mío: La Condesa- Duquesa, mi señora se sirvió disponer que la Capilla [de] Música de San Cayetano de esta Corte asistiere, como lo ejecutaron, a las solemnes vísperas y fiestas celebradas en obsequio de su glorioso Abuelo San Francisco de Borja en los días 30 de septiembre 1, 7, 8, 10, 13, 15 de Octubre de este año en la Real Iglesia de San Felipe Neri por Su Excelencia el Duque mi Señor y sus Señores hijos el Excelentísimo Marques de Peñafiel y [los] Señores Príncipe de Anglona y Condesa de Coguinas, mis Señores, y continuando la devoción de su difunta madre la Excelentísima Señora Condesa de Benavente, que de Dios goce.

La asistencia de dicha Capilla en los referidos días compone otros tantos puntos cada uno de los cuales se halla regulado en 420 reales.

Además de esto se han agregado a la misma capilla varios profesores particulares de otras, y se ha hecho una prueba para la misa nueva que se estreno el día de San Francisco de Borja, cuyas partidas todas suman 5710 reales según resulta por menor de las cuentas que acompaño de Don Francisco Basset a quien Su Excelencia se sirvió comisionar especialmente para las disposiciones relativas a la música, así como también se halla habilitado para el percibo y distribución de dicha cantidad, por lo que se servirá Vuestra Merced de poner a la firma de Su Excelencia mi Señor el correspondiente libramiento de los 5710 reales a favor del expresado Basset.

Nuestro Señor que a Vuestra Merced [guarde] muchos años. Madrid 18 de Noviembre de 1802

Manuel de Ascargorta

Señor Don Juan Bautista Guitart” 
$N^{0}$ 10. Lista de músicos que asistieron a las funciones religiosas de San Francisco de Borja celebradas en 1808 y obras que se intepretaron en dichas funciones

AHN NOBLEZA, OSUNA-CARTAS, legs. 392-37 y 570 ${ }^{1} .15$ de octubre de 1808

"Cuenta de los profesores que han asistido a las funciones del Excelentísimo Señor Duque de Osuna en San Felipe Neri.

[reales de vellón]

Día 4 de octubre, La Misa Grande de Rosetti importa 884

Día 8. Ensayo de la Misa de Paisiello 705

El mismo día dicha misa $\quad 944$

Día 10. La misa de Brunetti $\quad 844$

Día 11. La misa chica Haydn 844

4221

960

Total $5 \overline{181}$

Visto Bueno. Josef Gascón

Recibí del Señor Don Manuel Calvo la cantidad que antecede, hoy día 15 de octubre de 1808.

Salvador Feixas

Nombres de los profesores que han asistido a dichas funciones Primer Coro

Don Felipe Mayo

Tiple

Don Francisco Gómez

Alto

Don Mariano Ledesma

Tenor

Don Eusebio Fernández

Bajo

${ }^{1}$ En AHN NOBLEZA, OSUNA-CARTAS, leg. 510 se conserva un borrador incompleto con el listado de los profesores "que asisten a las funciones de San Francisco de Borja" sin fecha y con las cantidades que percibirían cada músico por estas funciones. 
Segundo Coro

El sobrino de Don Bernardino Tiple

El hijo de Lledó Tiple

Don Bernardino Contralto

Don Manuel Setta. Contralto

Don Sebastián Tenor

Don Juan Tárraga $\quad$ Tenor

Don Fermín Bajo

Don Manuel Maniel Bajo

Orquesta

Don Andres Rosquillas

Violín $1^{\mathrm{o}}$

Don Francisco Camocia

Violín

Don Miguel Camocia

Violín

Don Ignacio Feixas

Violín

Don Josef García

Violín

Don Sebastián Dimas

Don Félix Silesio

Violín

Don Jaime Rivas

Violín

Violín

Don Marcos Balado

Viola $1^{\text {a }}$

Don Félix Segura

Viola $2^{\mathrm{a}}$

Don Santiago Al[h]ambra

Clarín $1^{\circ}$

Don Antonio Correa

Clarín $2^{\circ}$

Don Josef Álvarez

$1^{\text {er }}$ Oboe

E1 Hermano

$2^{\circ}$ Oboe

Don Juan León

$1^{\mathrm{a}}$ Flauta

Don Eugenio Laserna

$2^{\text {a }}$ Flauta

Don Francisco

$1^{\text {er }}$ Clarinete

Don Andrés Martínez

$2^{\circ}$ Clarinete

Don Manuel Roig

Trompa $1^{\mathrm{a}}$

Don Josef Roig

Trompa $2^{\circ}$

Don Lorenzo

Don Antonio García

$1^{\text {er }}$ Fagot

Don Pedro Sebastián

$2^{\circ}$ Fagot

Contrabajo

Don Juan Antonio Gamarra

Contrabajo

Don Fernando

Organista

Don Antonio Mansilla

Bajón

Don Salvador Feixas

Cuidar de los papeles 
Don Mariano Ledesma $1^{\text {er }}$ Tenor y director no quiere tomar nada

y Don Josef Álvarez $1^{\text {er }}$ Oboe tampoco

Visto bueno Mariano Rodríguez de Ledesma"

\section{$\mathbf{N}^{0}$ 11. Lista de los músicos que asistieron al funeral de Josefa Manuela Téllez-Girón, marquesa de Camarasa e hija de los IX Duques de Osuna, que se celebró el día 11 de diciembre de 1817 en la iglesia de San Felipe Neri de Madrid}

AHN NOBLEZA, OSUNA-CARTAS, leg. 392-4, 13 de diciembre de 1817.

"Lista de profesores que han asistido al funeral que se ha celebrado por el alma de la Excelentísima Señora Marquesa de Camarasa en el día 11 del presente en la Iglesia de San Felipe Neri, por orden de la Excelentísima Señora Condesa-Duquesa de Benavente, mi Señora.

[Coro]

Padre Ordóñez

Don Domingo Andrés

Don Ángel Arteaga

Don Benito Torrellas

Don Felipe Mayo

Don Ramón Biosca

Don Francisco Gómez

Don Martín Salcedo

Don Faustino

Don Francisco Viñal

Don Miguel Maniel

Don Juan Ofaril

Don Salvador Casado

Don Juan Carballo 
Don Manuel Jiménez $\quad 70$

Don Diego López $\quad 70$

Don Juan San Martín $\quad 70$

Don Domingo Aguirre $\quad 70$

Don Juan San Martín $\quad 70$

$\begin{array}{ll}\text { Don Domingo Aguirre } & 70\end{array}$

$\begin{array}{ll}\text { Don Juan Martín } & 70\end{array}$

Don Antonio Aguado $\quad 70$

Violines

$\begin{array}{ll}\text { Don Juan Balado } & 180\end{array}$

Don Marcos Balado 120

Don Francisco Ramos 120

Don Pedro Cruz 120

Don José Garcíar $\quad 140$

$\begin{array}{ll}\text { Don Juan Lloria } & 120\end{array}$

Don Antonio Ardisoni 120

Don Vicente García 120

Violas

Don Miguel Palomero $\quad 120$

Don Félix Segura $\quad 120$

Oboes

Don Joaquín Álvarez $\quad 120$

Don Manuel Retamar $\quad 120$

Clarinetes

D............ Ortega 120

Don ............ Julia 120

Fagots

Don ..............Menagé $\quad 120$

Don .............. Blanco 120

Contrabajos

Don Gabriel 140

Don Paulino Sesé 140

Violón

$\begin{array}{ll}\text { Don Enrique } & 140\end{array}$

Timbales

Don Antonio Cruz 120

Trompas 
Don Juan Carretero

Trombón

Don Santos Carretero

Don N. Fraile

Bajones

Don Santos Marito

120

Don Juan Hernández

Alquiler de timbales $\quad 30$

Idem de bancos $\quad 40$

Mozos 10

$\begin{array}{ll}\text { Comisión } & 120\end{array}$

Madrid, 13 de diciembre de 1817

Visto Bueno Marinelli

Recibí Francisco Gómez"

$\mathbf{N}^{0}$ 12. Lista de músicos que asistieron a las funciones de San Francisco de Borja y Nuestra Señora del Pilar patrocinadas por la XV Condesa-Duquesa de Benavente en 1825

AHN NOBLEZA, OSUNA-CARTAS, leg. 392-20. 16 de octubre de 1825.

"Lista de los Profesores que han asistido a las funciones de San Francisco de Borja y Nuestra Señora del Pilar por orden de la Excelentísima Señora Condesa-Duquesa de Benavente mi Señora

\section{Día 30 de Septiembre. Vísperas en San Felipe Neri}

Primer Coro

Don Luciano Galán

Don Faustino Brea

Don Leandro Valencia 60 
Don Andrés Gargallo $\quad 40$

Don Juan Munne $\quad 40$

Segundo Coro

Don Isidro Ferrer 30

Don Pedro Inclán 30

Don José Echeverría 30

Don Francisco Vitralls $\quad 30$

Bajón

Don Anacleto Ortiz 30

Organista

Don Antonio Belbén 30

Violines

Don Miguel Reynaldi 40

Don Trifón Daroca 30

Don Antonio Cruz $\quad 30$

Don Diego Román 30

Don José García 30

Don Francisco Ramos 30

Don Manuel Sánchez $\quad 30$

Don Manuel García 30

Violas

Don Tomás Ardisoni 30

Don Victoriano Daroca 30

Clarinetes

Don Benito Schindelert 30

Don Pedro Broca 30

Flautas

Don Juan Fichers 30

Don Pablo Solano 30

Fagot

Don Aquilino López 30

Trompas

Don José Mayorito 30

Don Félix Carretero 30

Clarín

Don Santos Carretero 30 
Violón

Don Felipe García

Contrabajos

Don Paulino Sese $\quad 30$

Don Gabriel López $\quad 30$

Don José López 30

Don Francisco Gómez $\quad 30$

Tres libras de bujías $\quad 45$

Subir los bancos y entonar 16

1.161

[Sigue una lista del día "10 de Octubre en dicha iglesia" con los mismos músicos y asignaciones excepto Leandro Valencia que cobró 50 [reales]. No se apuntaron "Gastos de bujías" y el "entonador cobró 4 reales"]

Día 6 de Octubre. Misa a canto llano en San Felipe Neri

Salmistas

Don Pedro Inclán 30

Don Andrés Gargallo 30

Don José Echeverría 30

Don Diego Soldevilla 30

Don Antonio Robles 30

Don Isidro Ferrer 30

Don Francisco Gómez 30

Bajón

Don Anacleto Ortiz 30

Organista

Don Antonio Belbén 30

Entonador 4

Total 304

Día 12 de Octubre. Misa en el convento de las Religiosas Capuchinas

Primer Coro

Don Luciano Galán 
Don Faustino Brea $\quad 40$

Don Leandro Valencia $\quad 50$

Don Andrés Gargallo $\quad 40$

Don Juan Munne $\quad 40$

Segundo Coro

Don Isidro Ferrer $\quad 30$

Don Pedro Inclán 30

Don José Echeverría 30

Don Francisco Vitralls 30

Don Francisco Gómez 30

Bajón

Don Anacleto Ortiz 30

Organista

Don Antonio Belbén 30

Primer violín

Don José León $\quad 80$

Violines

Don Miguel Reynaldi $\quad 40$

Don Trifón Daroca 30

Don Antonio Cruz 30

Don Diego Román 30

Don José García 30

Don Francisco Ramos 30

Don Manuel Sánchez $\quad 30$

Don Manuel García 30

Violas

Don Tomás Ardisoni 30

Don Victoriano Daroca 30

Clarinetes

Don Pedro Broca 30

Don Benito Schindelert 30

Flautas

Don Juan Fichers 30

Don Pablo Solano 30

Fagot

Don Aquilino López 
Trompas

Don José Mayorito 30

Don Félix Carretero $\quad 30$

Clarín

Don Santos Carretero $\quad 30$

Violón

Don Felipe García $\quad 30$

Contrabajos

Don Paulino Sese $\quad 30$

Don Gabriel López $\quad 30$

Don José López $\quad 30$

$\begin{array}{ll}\text { Conducción de atriles y entonador } & 16\end{array}$

Total 1186

\section{$\underline{\text { Resumen General }}$}

Día 30 de septiembre a Víspera en San Felipe Neri

Día 1 de Octubre a misa en dicha iglesia $\quad 1.094$

Día 6 idem misa en idem 304

Día 12 idem Misa en el Convento de Religiosas Capuchinas $\quad 1.186$

A Don Francisco Gómez de orden de Su Excelencia 160

Total reales de vellón $\quad 3.905$

Madrid 14 de octubre de 1825

Páguese [Rúbrica de la Condesa-Duquesa]

Recibí dicha Cantidad Francisco Gómez” 
$\mathbf{N}^{\circ}$ 13. Lista de los músicos que asistieron a las funciones de San Francisco de Borja y Nuestra Señora del Pilar patrocinadas por la XV Condesa-Duquesa de Benavente en 1829

AHN NOBLEZA, OSUNA-CARTAS, leg. 392-20. 16 de octubre de 1829.

"Profesores que han asistido a las funciones de San Francisco de Borja y Nuestra Señora del Pilar en el presente año por orden de la Excelentísima Señora CondesaDuquesa de Benavente mi Señora

\section{$\underline{\text { Vísperas }}$}

$$
\text { [reales de vellón] }
$$

Primer Coro

Don Ambrosio Pérez

Don Faustino Brea

Don Leandro Valencia

Don Pedro Clariana

Segundo Coro

Don Manuel Calvo

Don Nicolás Gómez

Don Evaristo Sanz

Don Pedro Inclán

Don Juan Aguado

Don Francisco Gómez

Bajón

Don Elias Sánchez

Organista

Don Juan López

Violines

Don Manuel Ocón

Don Francisco Bocolo 30

Don Manuel Salvatierra 30

Don Antonio Cruz 30

Don José García 30

Don Manuel Sánchez 30

Don José Rodríguez 30 
Don Francisco Ramos

Violas

Don Andrés Ardisoni 30

Don Victoriano Daroca 30

Clarinetes

Don Magín Jardín 30

Don Ramón Broca 30

Flauta

Don José Ficher

Oboes

Don Eusebio Julia $\quad 30$

Don Antonio Panfil 30

Fagots

Don José Puch 30

Don Antonio Carmelo 30

Trombones

Don Isidro Fuster $\quad 30$

Don Bernardino Prados 30

Violones

Don Felipe García 30

Don Nicolás Aguirre $\quad 30$

Contrabajos

Don José López $\quad 30$

Don Sinforiano López 30

Trompas

Don Manuel Sineo $\quad 30$

$\begin{array}{ll}\text { Don Santos Carretero } & 30\end{array}$

Clarines

Don Lesmes Ramos $\quad 30$

Don Antonio Carretero 30

Entonador 4

Suma $\quad 1334$

Día $1^{\circ}$ [de Octubre] a misa

Los mismos profesores que a Vísperas 1334

Día 7 [de Octubre] misa

Los mismos que el día $1^{\circ}$ 
Día 12 [de Octubre] a misa

Los mismos que el día 1 y 7

$\underline{\text { Profesores que asistieron al ensayo de la misa de Don Ángel Inzenga el día } 28}$

Don Ambrosio Pérez

Don Faustino Brea

Don Leandro Valencia

Don Pedro Clariana

Don Manuel Calvo

Don Nicolás Gómez

Don Evaristo Sanz

Don Pedro Inclán

Don Juan Aguado

Don Francisco Gómez

Don Manuel Ocón 20

Don Francisco Bocolo

Don Manuel Salvatierra

Don Antonio Cruz

Don José García

Don Manuel Sánchez

Don José Rodríguez

Don Francisco Ramos

Don Andrés Ardisoni

Don Victoriano Daroca

Don Magín Jardín

Don Ramón Broca

Don José Ficher

Don Eusebio Julia

Don Antonio Panfil

Don José Puch

Don Antonio Carmelo

Don Isidro Fuster

Don Felipe García

Don Nicolás Aguirre

Don José López

Don Sinforiano López

Don Manuel Sineo 
$\underline{\text { Gastos particulares }}$

Copia de la misa a toda orquesta

de Don Ángel Inzenga

97 pliegos

Tres libras de cera

A los mozos por llevar los bancos a San Felipe

Total

\section{$\underline{\text { Resumen }}$}

Vísperas del día 30 de septiembre

Misa el $1^{\circ}$ de octubre

Ídem el día 7 [de] ídem

Ídem el 12[de] ídem

1.334

Ensayo

605

Gastos particulares

828

Total

6769

Madrid 14 de octubre de 1829"

[Con letra de la Condesa-Duquesa]: "16 de octubre de 1829. Añádase la gratificación de 320 reales a Don Francisco Gómez y de 640 a Inzenga"

Importe total de esta cuenta aumentadas las gratificaciones que manda dar Su Excelencia reales de vellón 7729

Recibí del Señor Don Enrique

[Francisco Gómez]" 
No 14. Lista de los músicos que asistieron a las funciones de San Francisco de Borja y Nuestra Señora del Pilar patrocinadas por la XV Condesa-Duquesa de Benavente en 1830

AHN NOBLEZA, OSUNA-CARTAS, leg. 392-20. 16 de octubre de 1830.

"Profesores que han asistido a las funciones de San Francisco de Borja y Nuestra Señora del Pilar en el presente año por orden de la Excelentísima Señora CondesaDuquesa de Benavente mi Señora

Vísperas

Primer Coro reales de vellón

Don Ambrosio Pérez 80

Don Faustino Brea 40

Don Manuel Ruiz 40

Don Pedro Clariana

Segundo Coro

Don Manuel Calvo 30

Don Nicolás Gómez 30

Don Evaristo Sanz 30

Don Pedro Inclán 30

Don Juan Aguado 30

Don Francisco Gómez 30

Bajón

$\begin{array}{ll}\text { Don Elias Sánchez } & 30\end{array}$

Organista

Don José Sanz $\quad 30$

Violines

Don José León $\quad 40$

Don Francisco Bocolo 30

Don Manuel Díez 30

Don Manuel Sánchez $\quad 30$

Don José García 30

Don Antonio Cruz 30

Don Francisco Ramos 30

Don José Rodríguez 30 
Violas

Don Andrés Ardisoni 30

Don Victoriano Daroca 30

Clarinetes

Don Magín Jardín 30

Don Juan Magesté $\quad 30$

Flauta

Don José Ficher 30

Oboes

Don Eusebio Julia $\quad 30$

Don Antonio Panfil 30

Fagots

Don José Puch $\quad 30$

Don Antonio Carmelo $\quad 30$

Trombones

Don Isidro Fuster $\quad 30$

Don Bernardino Prados 30

Violón

Don Nicolás Aguirre $\quad 30$

Contrabajos

Don José López $\quad 30$

Don Sinforiano López $\quad 30$

Trompas

Don Manuel Sineo $\quad 30$

Don Santos Carretero $\quad 30$

Clarines

Don Lesmes Ramos 30

Don Antonio Carretero 30

Entonador 4

Suma $\quad 1.264$

Día $1^{\circ}$ [de octubre] a misa

Los mismos que a Vísperas 1264 
Día 7 [de octubre] misa a canto llano

Don Pedro Inclán 30

Don Pedro Bueno 30

Don Pedro Clariana 40

Don Diego Soldevilla 30

Don Manuel Ruiz $\quad 30$

Don Juan López $\quad 30$

Don Isidro Ferrer $\quad 30$

Don Francisco Gómez $\quad 30$

Don Anacleto Ortiz 30

Don Antonio Belbén 30

Entonador 4

Suma $\quad 304$

Día 12 [de Octubre] a misa

Los mismos que el día $1^{\circ}$

Gastos particulares

Tres libras de cera 33

A los mozos por llevar los bancos 16

Suma 49

$\underline{\text { Resumen }}$

reales de vellón

Vísperas del día 30 de septiembre $\quad 1.264$

Misa el $1^{\circ}$ de octubre $\quad 1.264$

Idem el día 7

Idem el $12 \quad 1.264$

Gastos particulares $\quad 49$

Suma total $\quad 4.145$

Según queda demostrado la suma total asciende a la cantidad de \#cuatro mil, ciento cuarenta y cinco reales de vellón\# Madrid 14 de octubre de 1830 
[Añadido con letra de la Condesa-Duquesa]:

$\begin{array}{ll}\text { A Inzenga } & 2 \text { onzas } \\ \text { A Paco } & 1 \text { onza } \\ \text { A León } & 1 / 2 \text { onza por su asistencia } \\ & 1 \text { por la misa que me regaló. }\end{array}$

Páguese

Importe total de la cuenta inclusas las gratificaciones que manda dar Su Excelencia mi Señora reales de vellón 5.585 .

Recibí del Señor Don Enrique Estor Tesorero de Su Excelencia la cantidad de cinco mil quinientos ochenta y cinco reales de vellón como consta en la suma anterior. Madrid y octubre 16 de 1830.

$$
\text { Francisco Gómez [rúbrica]” }
$$

[Tachado]: "Nota. Por decreto de 8 de Noviembre sirvió Su Excelencia mandar entregar al maestro Inzenga 660 reales y a Gómez 320 reales como el año anterior de 1830 [sic por 1829 ]" 
B) DOCUMENTOS SOBRE TEATRO MUSICAL. PATROCINADO POR LAS CASAS DE OSUNA Y BENAVENTE: FUNCIONES PRIVADAS Y GESTIÓN Y FINANCIACIÓN DE LOS TEATROS PÚBLICOS DE ÓPERA DE MADRID (1755-1794)

$N^{0}$ 15. Cuenta de gastos por la copia de música y letra de la función teatral titulada Endimión y Diana encargada en 1755 por María Faustina Téllez-Girón, CondesaDuquesa de Benavente

AHN NOBLEZA, OSUNA-CARTAS, leg. 389-28. 10 de noviembre de 1755.

"Cuenta de lo que importa la copia de música y letra, en encuadernación de libros e impresión, de la Serenata de Indimión [sic] y Diana, para la Excelentísima Señora Condesa de Benavente, en el año 1755.

[reales de vellón]

Primeramente de las cuatro partes de recitados y arias

...que se sacaron para las cuatro señoras treinta y ocho pliegos

De cuatro arias que se volvieron a copiar

y otras cosas por la mutación de arias cuatro pliegos

De la parte de clave, voz y bajo de recitado y arias, y obertura, veinte pliegos

De cuatro violines con su obertura de toda la fiesta veinte $\mathrm{y}$ tres pliegos 23

De los dos oboes con su obertura siete pliegos 07

De las dos trompas con su obertura seis pliegos 06

De la viola con su obertura cinco pliegos y medio

De un bajo de acompañamiento de recitados, arias y obertura diez pliegos y medio

De la aria nueva que últimamente se hizo voz y bajo

[e] instrumentos cuatro pliegos. 
De la parte segunda de clave de toda la fiesta en partitura con todos los instrumentos y obertura, cuarenta y ocho pliegos

Pliegos

que a ocho reales

Idem de encuadernar los trece libros de la música ochenta reales de vellón

[A]demás [de] copiar la letra de la fiesta cuarenta reales mas de siete pliegos y medio del molde de encuadernación de la Serenata quince reales cada pliego ciento y doce reales y medio

De trescientos ejemplares que se han impreso en papel fino, que se tienen dos mil doscientos y cincuenta pliegos a ocho maravedies cada uno, importan quinientos y veintinueve reales y medio

De encuadernar los trescientos libros en papel dorado y los demás en blanco ciento y veinte reales

Importa toda la cuenta según se expresa de todos los gastos dos mil doscientos y diez reales de vellón.

Madrid, 10 de noviembre de 1755

Joseph Herrando [rúbrica]" 


\title{
$\mathbf{N}^{\circ}$ 16. Actas y anexos de las Juntas de Accionistas de la Asociación de Óperas Italianas del Teatro de los Caños del Peral de Madrid de los días 3 y 13 de septiembre de 1790
}

\author{
AHN NOBLEZA, OSUNA-CARTAS, leg. 414-12. [Sin fecha]
}

"Junta de Accionistas de las óperas italianas celebrada en tres de septiembre de 1790, en la que se acordó lo siguiente:

$1^{\mathrm{o}}$. Que respecto de que algunos de los Señores Accionistas juzgan no ser suficiente el fondo para dos años, se pase oficio al Hospital, pidiéndole que el propuesto contrato para dos años se limite a uno, dando facultad dichos Señores Accionistas para ello a Don Felipe Marescalchi.

$2^{\circ}$. Que se confirme la ópera seria y bufa.

$3^{\circ}$. Que aprobada por el Hospital la proposición enunciada en el $n^{\circ} 1$, se recauden por Don Felipe Marescalchi los caudales de la subscripción, y verificándolo haga la entrega de ellos.

$4^{\circ}$. Que el Señor Don Fernando Josef Mangino queda nombrado depositario del fondo que resulte como caudal de la expresada subscripción.

$5^{\circ}$. Se han elegido por uniformidad de votos como comisionados protectores de esta empresa el Excelentísimo Señor Don Pablo Sangro y el Señor Don Jerónimo Mendinueta, en quienes han de residir todas las facultades de la Asociación, y Don Felipe Marescalchi acordará con estos Señores las disposiciones relativas a dicha empresa.

$6^{\circ}$. Que luego que la Real Junta de Hospitales condescienda con la nueva proposición que se le hará en el citado oficio y esté recogido el fondo, proceda Don Felipe Marescalchi de acuerdo con los Señores Protectores a la formación de la compañía, ajustes de partes y demás funciones propias de su encargo. Y lo firmaron los Señores Accionistas que se hallaron presentes, a tres de septiembre de mil setecientos y noventa.

La Marquesa de Villalópez, María Faustina Girón y Guzmán, Pablo Sangro, el Príncipe de Maserano, Fernando Josef Mangino, Vicente Hore, Jerónimo de Mendinueta. Por la Excelentísima Señora Duquesa de Alba, Francisco Josef Fierro Sotomayor" 
"Junta de Accionistas de trece de septiembre de 1790

Acuerdos:

$1^{\circ}$. Los diez y siete Señores Accionistas, ${ }^{2}$ (esto es, los 8 que firman el presente acuerdo, y los Excelentísimos Señores Don Antonio Valdés, Condesa-Duquesa de Benavente y Osuna por sus 2 acciones, Duquesa de Osuna viuda, Princesa de Castelfranco, Duque de Berwick por sus 2 acciones, Príncipe de Raffadale y Marqués de Oyra, quedando dudosa la $2^{\circ}$ oferta en cuanto a la acción del Señor Conde de Vistaflorida, con la cual serían 18 acciones las duplicdas de esta Junta) han expuesto algunos de ellos en sus votos por escrito para duplicar el fondo en caso de perderse el primer año capital consideran deberse proceder al otorgamiento de la escritura por Don Felipe Marescalchi, acordaron que se presente el día de mañana para ejecutarlo; quedando a su cargo el practicar las diligencias correspondientes para con los demás Señores Accionistas que por falta de haber concurrido se ignora si se conforman con el ofreciemiento de los demás en cuanto a la segunda exhibición

$2^{\circ}$. Que se lleven a debido efecto los acuerdos de la Junta anterior, a excepción del primero, que se revoca por este. Príncipe de Castelfranco, María Faustina Girón y Guzmán, Vicente Hore, la Marquesa de Villalópez, Jerónimo de Mendinueta, el Príncipe de Maserano, la Condesa de Campo Alange, Fernando Josef Mangino.

Los abajo firmandos nos convenimos en lo mismo que han ofrecido los diez y siete Señores Accionista que menciona el acuerdo anterior, y que han firmado sus respectivos ofrecimientos en los papeles que se leyeron en la Junta de 13 de septiembre de 1790.

El Duque de Abrantes., la Duquesa de Abrantes.

Señores accionistas vocales de dicha junta que presentaron en ella sus esquelas que leyó el secretario, ofreciendo en ellas poner otros seis mil reales por acción y no más, para el segundo año de la empresa:

Señor Don Fernando Josef Mangino

Excelentísima Señora Condesa del Campo de Alange.

$\mathrm{Y}$ al pie de la esquela firmaron igual ofrecimiento, conformándose con el contenido de dicho oficio, los señores vocales siguientes:

Señor Don Jerónimo de Mandinueta

Señor Don Vicente Hore

Señora Marquesa de Villalópez

Señores Accionistas que enviaron a la Junta sus oficios que también se leyeron en ella, haciendo igual oferta.

Excelentísimos Señores Don Antonio Valdés

\footnotetext{
${ }^{2}$ Lo incluido en el paréntesis figura en nota al margen con una llamada en el texto.
} 
Condesa de Benavente Duquesa de Osuna por sus dos acciones

Condesa de Benavente viuda (que después concurrió también a la Junta) decía su esquela que su voto era y sería siempre el de la Excelentísima Señora Condesa Duquesa du hija

Duquesa de Osuna viuda

El Excelentísimo Señor Príncipe de Castelfranco hizo la misma oferta por si, verbalmente, y por los Señores siguientes en virtud de poder verbal:

Excelentísimos Señores Duque de Berwick por sus dos acciones.

Princesa de Castelfranco

Príncipe de Raffadale

Marqués de Oyra

y Señor Conde de Vista Florida

La Excelentísima Señor Duquesa de Alba remitió después de la Junta a Don Felipe Marescalchi un papel en que hizo igual ofrecimiento.

Lo mismo hizo el Excelentísimo Señor Duque de Frías y Uceda en carta de 6 de octubre de 1790 al propio Don Felipe Marescalchi.

El Excelentísmo Señor Duque de Medinaceli y Santisteban ofreció verbalmente al citado Don Felipe Marescalchi que daría los 6000 reales segunda vez si fuese necesario, preguntando al mismo donde vivía para enviarle la correspondiente esquela firmada, pero Su Excelencia no la remitió. Pasado algún tiempo volvió dicho Don Felipe a pedir a su Excelencia su resolución, y respondió que se había entendido con los señores.

Nota. El Excelentísimo Señor Príncipe de Maserano aunque concurrió a la Junta de 13 de septiembre, según se ha visto, no hizo oferta alguna positiva por escrito.

Por último, de los 3 Señores Accionistas de que no se ha hecho mención uno (Excelentísima Señora Duquesa de Alburquerque) envió esquela a la Junta diciendo positivamente que no contribuiría con los 6000 reales [por] segunda vez. Otro (Señor Don Rafael de Aguilar) que los daría y aún mas, si se le concedía asistir a las conferencias de los caballeros protectores sobre formación de compañía y gobierno de la empresa; y el otro Señor Don Francisco Moñino no dijo nada, pues no se le preguntó, porque así se juzgó conveniente.

En todo 26 acciones, 22 de las cuales parece debían repetirse para el segundo año, no contando el Señor Conde de Vistaflorida, porque dijo no había consentido en igual oferta." 


\section{$\mathbf{N}^{0}$ 17. Informe sobre los gastos de la temporada de 1791-1792 del Teatro de los Caños del Peral de Madrid, y solicitud a la XV Condesa-Duquesa del importe de la segunda acción del año de 1792.}

AHN NOBLEZA, OSUNA-CARTAS, leg. 414-12/7. 25 de Enero de 1792.

\section{"Excelentísima Señora}

Muy Señora Nuestra. Para corresponder a las ideas y plan que indicó la Asociación de Óperas en su última Junta General, para sostener con dignidad el respetable nombre de este cuerpo, y para convencer al público de que su empresa tuvo por objeto la conservación y mejora de un teatro tan necesario hoy en Madrid, han tenido que unir a las fatigas y disgustos que causa un establecimiento de esta naturaleza, los gastos extraordinarios que las circunstancias del tiempo, y el mal estado de la Ópera cuando la administraba el Hospital, exigían.

Estos motivos fueron la causa de haberse gastado 140.000 reales de vellón antes de abrir el Teatro en viajes de actores, obras del Coliseo, e importe del arrendamiento. Y si a estos desembolsos se agrega la pérdida de los Conciertos de la Cuaresma, y de lo que hubieran producido las Representaciones desde Pascua hasta el cinco de mayo, que se abrió el Teatro, conocerá Vuestra Excelencia que éste ha tenido a lo menos 200.000 reales de vellón de gastos o perjuicios, que no se han podido evitar este primer año, y que no se vuelven a sufrir.

A pesar de ello, como las entradas o productos han sido mayores que los años anteriores, no se han experimentado las pérdidas que ofrecía el gasto extraordinario que va referido, y con que empezó el año. Para el próximo, se han tomado las providencias más convenientes, a fin de que queden mejoradas las Compañías; para. hacer todas las economías posibles; y aprovechando la Cuaresma con Conciertos, abrir el Teatro por Pascua.

Para este efecto, y a fin de que quede asegurado el fondo segundo de pérdidas con arreglo a lo acordado en la Junta General de Accionistas, que queda citado, se servirá Vuestra Excelencia mandar entregar el importe de su segunda acción a Don. Juan Josef Redondo Verdugo, Tesorero del Coliseo y comisionado para esta recaudación.

Dios guarde a Vuestra Excelencia muchos años. Madrid 25 de Enero de 1792.

Excelentísima Señora Besan los pies de Su Excelencia sus más atentos servidores Jerónimo Mendinueta, El Príncipe de Castelfranco

Excelentísima Señora Duquesa de Osuna casada” 


\section{$\mathbf{N}^{0}$ 18. Carta de los Comisionados de la Asociación de Óperas Italianas a María Josefa Alfonso Pimentel, XV Condesa Duquesa de Benavente, comunicándole la decisión de contratar a la cantante Luisa Todi para la temporada de 1794}

AHN NOBLEZA, OSUNA-CARTAS, leg. 387-18. 17 de noviembre de 1793.

\section{"Excelentísima Señora}

Muy Señora nuestra: En consecuencia de la carta de Vuestra Excelencia de 14 de el presente hemos extendido y firmado la escritura a favor de la Todi, en los mismos términos que propusimos a Vuestra Excelencia en el plan $n^{0} 1$, el que ha parecido muy bien a Vuestra Excelencia según nos asegura; de lo que hemos quedado muy satisfechos por haber acertado en su opinión. Hemos agregado a las escrituras, como Vuestra Excelencia verá la casa, siguiendo en esto al idea que Vuestra Excelencia nos propone adelantar alguna cosa más a los 100.000 reales y el beneficio. Adjunta la encontrará Vuestra Excelencia firmada por todos nosotros para que se sirva hacer lo mismo pues esto animará a la Todi a no desairarla por la mucha estimación que hace su persona. Vuestra Excelencia nos devolverá a vuelta de parte para dirgirla con seguridad en el primer correoa Lisboa.

También incluimos a Vuestra Excelencia unos papeles relativos a un Bufo que escribió a Vuestra Excelencia de Barcelona para que Vuestra Excelencia se sirva hacerle contestar manifestándoles nuestrras ideas y los pactos con que nos es útil. Al mismo tiempo le suplicamos haga lo mismo si tiene proporcion con otra segunda parte que está también en Barcelona y que nos acomodaría en los términos en que verá Vuestra Ecelencia en la resolución que está a continuación de la carta que incluimos.

Celebramos goce Vuestra Excelencia de perfecta salud, y que Nuestro Señor le guie muchos años. Madrid 17 de Nov bre de 1793

Besan los pies de Vuestra Excelencia sus atentos seguros servidores

El Duque del Infantado

Marqués de Astorga

El Conde de Jaruco

Jerónimo de Mendinueta

Excelentísima Señora Duquesa de Osuna" 
C) DOCUMENTACIÓN SOBRE LOS GRUPOS INSTRUMENTALES Y ORQUESTAS QUE INTERVINIERON EN LAS FIESTAS, BAILES, Y ACADEMIAS ORGANIZADOS POR LA XV CONDESADUQUESA DE DE BENAVENTE Y EL IX DUQUE DE OSUNA (1789-1819)

$\mathbf{N}^{0}$ 19. Lista de músicos de refuerzo que asistieron a la fiesta realizada el 26 de septiembre de 1789 con motivo de la Coronación de Carlos IV, y la Jura del Príncipe de Asturias por el IX Duque de Osuna en su palacio de Madrid.

AHN NOBLEZA, OSUNA-CARTAS, leg. 391-31. Madrid 4 y 5 de enero de 1790

"Madrid 4 de enero de 1790

Nómina o relación de los músicos que asistieron fuera de los de la Orquesta de $\mathrm{Su}$ Excelencia a la función celebrada en la noche del 26 de septiembre de 1789 con motivo de la Coronación de sus majestades y de lo que ha de percibir cada uno según lo acordado por mi Señora.

Reales de vellón

28.640

En cinco de dichos se despachó libranza de esta cantidad a favor de los interesados.

Razón de los Músicos que asistieron a la función celebrada en la Casa de $\mathrm{Su}$ Excelencia en la noche del 26 de septiembre de este año de 1789, con motivo de la coronación de Sus Majestades y de lo que ha de percibir cada uno, según lo acordado por Su Excelencia.

\section{Primera Orquesta}

Violines primeros [reales de vellón]

Don Ramón Montejano 480

Don Juan Corverán 480

Don Francisco Xavier Moreno 480

Gamuchín 480

Don Sebastián Dimas

Violines segundos

$$
\text { León }
$$
640

Cruz

480 
Bala 480

Resac [Francisco Rexach] $\quad 480$

Vidal [Cayetano] $\quad 480$

Oboeses

Don Manuel García 480

Terradellas $\quad 480$

Molina $\quad 480$

Soler $\quad 480$

Clarinetes

Vis [Juan Wise] $\quad 480$

García $\quad 480$

Fagotes

Fransua [Esteban François] 480

Lorenzo [Geisel] 480

Violón

El hijo de Vidal [José Vidal] 480

Flautas

León $\quad 480$

Trompas

Apenceller $\quad 480$

Manfredi 480

Miguel 480

Nicolás $\quad 480$

Clarines

Don Antonio Canaot [Canaut] 480

Contrabajo

Don Juan Antonio $\quad 480$

Timbal

Guerra

480

$\underline{\text { Segunda Orquesta }}$

Violines primeros

Don Pascual [Juan] Carriles $\quad 800$

Don Miguel Mariuchi $\quad 480$

Don Marcos Balao [Balado] 480

Guerra 480

Fons [Font] 480

Rivas $\quad 480$ 
Violines segundos

Don Juan Balao [Balado] 480

Spontoni 480

El Granadino $\quad 480$

El hijo de Rosquellas $\quad 480$

Don Tomás Alonso $\quad 480$

Oboeses

Don Antonio García 480

El de la Reina $\quad 480$

Pamphili 480

Forjes $\quad 480$

Clarinetes

Carlet $\quad 480$

Herpen $\quad 480$

$\begin{array}{ll}\text { El hijo del primer pífano de guardias } & 160\end{array}$

Fagotes

Don Félix el de[1 Convento de] las Descalzas $\quad 480$ Violón

$\begin{array}{ll}\text { Pareja } & 480\end{array}$

Flautas

Don Josef Julián $\quad 480$

Don Vicente Julián $\quad 480$

Trompas

Marsala 480

Don Francisco $\quad 480$

El hermano de Germán $\quad 480$

Granier $\quad 480$

Clarines

Orverá $\quad 480$

Catielo 480

Contrabajos

Don Manuel Salido $\quad 480$

Don Joaquín Guerra $\quad 480$

Timbales

El hijo de Mir 480

Total 28640 
Importa esta razón veinte y ocho mil seiscientos cuarenta reales de vellón. Madrid cuatro de enero de mil setecientos noventa. Manuel de Cubas

Páguense por los claveros del arca veinte y ocho mil seiscientos cuarenta reales de vellón que importa la relación antecedente que en virtud de esta libranza y recibo de los interesados se abonará dicha cantidad. Madrid cinco de enero de mil setecientos y noventa"

$\mathbf{N}^{0}$ 20. Lista de músicos que asistieron a la academia de música celebrada La Condesa Duquesa de Benavente el 31 de octubre de [1819?]

AHN NOBLEZA, OSUNA-CARTAS, leg. 392-34. [Sin fecha ¿1819?]

"Profesores que asistieron a la Academia de Música el día 31 de octubre por orden de la Excelentísima Señora Duquesa Condesa de Benavente, mi Señora

[reales de vellón]

Violines

Don Filipo Calixto 100

Don José García $\quad 80$

Don Juan Balado $\quad 80$

Don Manuel Lloria $\quad 80$

Viola

$\begin{array}{lr}\text { Don Marcos Balado } & 80\end{array}$

Oboes

Don Joaquín Álvarez $\quad 80$

Don Juan Laserna $\quad 80$

Trompa

Don Santos Carretero $\quad 80$

Don Félix Carretero $\quad 80$

Violón

Don Francisco Pareja $\quad 80$

Contrabajo

Don Gabriel López $\quad 100$ 
Recibí Francisco Gómez [rúbrica]

$\mathrm{N}^{\mathrm{o}} 19$

$\mathrm{N}^{\circ}$ 21. Lista de músicos que asistieron a la academia de música celebrada el 5 de diciembre de 1819 en casa de la Condesa-Duquesa de Benavente

AHN NOBLEZA, OSUNA-CARTAS, leg. 392-34. Madrid, 12 de diciembre de 1819

"Profesores que asistieron a la academia de música el día cinco del presente en la casa de la Excelentísima Señora Duquesa Condesa de Benavente, mi Señora.

[reales de vellón]

Don Filipo Calixto 100

Don Juan Balado $\quad 80$

Don Vicente Asensio $\quad 80$

Don Juan Lloria $\quad 80$

Don Francisco Ramos $\quad 80$

Don Joaquín Álvarez $\quad 80$

Don Manuel Broca $\quad 80$

Don Manuel Sineo $\quad 80$

Don Santos Carretero $\quad 80$

Don Julian Panfil $\quad 80$

Don Francisco Pareja $\quad 80$

$\begin{array}{lr}\text { Don Mariano Aguirre } & 80\end{array}$

Avisador $\quad 80$

Madrid 12 de diciembre de 1819

Visto bueno Marinelli [rúbrica]

Recibí Francisco Gómez [rúbrica]

$\mathrm{N}^{\mathrm{o}} 22$ " 


\title{
D) CORRESPONDENCIA CON MÚSICOS, CANTANTES, BAILARINES y OTROS PERSONAJES. PETICIONES DE PROTECCIÓN Y RECOMENDACIONES SOLICITADAS A LOS MIEMBROS DE LA CASAS DE OSUNA Y BENAVENTE (1784-1807)
}

\author{
$\mathbf{N}^{0}$ 22. Carta de la cantante Rosa Agostini a Pedro de Alcántara Téllez-Girón, \\ Marqués de Peñafiel, solicitando su protección para volver a actuar en las \\ academias de música que se celebraban en los Reales Sitios
}

\begin{abstract}
AHN NOBLEZA, OSUNA-CARTAS, leg. 387-11. 2 de febrero de 1784. Original italiano transcrito en Marc Heilbron, "Umilissimi, devotissimi servi, Correspondencia de cantantes de ópera italiana con la Duquesa de Osuna." AnM, 57, (2002), pp. 203-204.
\end{abstract}

\section{"Eccelenza}

Non sò sé l' Eccelenza Vostra avrà più memoria della mia, io affidata sulla sua bontà mi prendo l'ardire di scriverle questa mia, per significarla che doppo aver girato tutta l'Italia in questi anni che manco di Madrid, o sempre bramato e bramo rivedere la Spagna, quatunque io sappia che non si fa più opera alli Siti Reali, ma ancora proseguendo sempre il gusto della musica si fanno delle Accademie:

Io dunque supplico I' Eccelenza Vostra volermi accordare I'alta Sua protezione e degnarsi di dirmi se si ritrova in Madrid, avendo saputo, che e stato in altre parti, pero io diriggo la presente in Madrid dove non essendoci Vostra Eccelenza la manderanno dove si ritrova. Per Pasqua io penso intraprendere il mio viaggio verso la Spagna, dove saro bramosissima di aver I'onore di rivedere Vostra Eccelenza, doppo quasi otto anni che non o avuto questa sorte, di nuovo sperando che Vostra Eccelenza mi onorera di sua risposta mi so una gloria di dirmi dell Eccelenza vostra.

Bologna Ii 2 di febbraio 1784.

Umilissima devotissima Serva Rosa Agostini

Sua Eccelleza 1'Excelentisimo Señor Conde Pegnafiel" 
[Mi traducción]:

Excelencia:

No sé si Vuestra Excelencia se acordará de mí, confiada de su bondad me atrevo a escribirle esta, para informarle de que después de haber actuado por toda Italia en estos años que he faltado de Madrid, siempre he deseado y deseo volver a España, aunque sepa que ya no se hace ópera en los Reales Sitios, ahora continuando el gusto de la música se dan Academias.

Por ello suplico a Vuestra Excelencia me conceda su protección, se digne a decirme si se encuentra en Madrid, pues aunque he sabido que ha estado en otros lugares, yo le envío la presente a Madrid, de donde de no estar allí Vuestra Excelencia se la enviarán a donde se encuentre. Por Pascua tengo pensado emprender mi viaje hacia España, donde estaré deseosa de tener el honor de volver a ver a Vuestra Excelencia, después de casi ocho años que no he tenido esa suerte, esperando de nuevo que Vuestra Excelencia me honre con su respuesta, para mi es una suerte poder dirigirme a Vuestra Excelencia.

Bolonia 2 de febrero 1784.

Humildísima y devotísima sierva Rosa Agostini

Su Excelencia el Excelentisimo Señor Conde [sic] Peñafiel

$\mathbf{N}^{\circ}$ 23. Carta del cantante Giacomo Panati a María Josefa Alfonso Pimentel, XV Condesa Duquesa de Benavente, solicitando su intercesión para actuar en las Óperas que se representabane los Reales Sitios

AHN NOBLEZA, OSUNA-CARTAS, leg. 387-5. 4 de marzo 1784. Publicada en Heilbron, “Umilissimi”, p. 216.

"Barcelona, Marzo 4, de [17]86

Excelentísima Señora y de mi mayor veneración, estando noticioso de que en uno de los sitios de esta ReaI Corte se quieren hacer Óperas Italianas, y no ignorando lo mucho que Vuestra Excelencia me ha honrado y favorecido con su buena protección han sido motivos para que me precisase a renovarme al mas y mayor amparo en la protección 
de Vuestra Excelencia a quien suplico con todo rendimiento sea del agrado de Vuestra Excelencia interponer su soberana autoridad y favor con el empeño y veras, que sabe hacerlo, para que su apasionado Jaime Panati y su esclava Adriana mi mujer tengamos el honor de representar en dicho sitio y al mismo tiempo tener la fortuna de estar en la nueva obligación de habernos de presentar a la buena y anhelada presencia de Vuestra Excelencia para darle repetidas gracias de su continua protección. Lo que espero de su buen proceder. Retardando al mismo tiempo mi partida para Italia hasta tener el honor de su respuesta [....] de mi mujer y de mí pidiéndole se sirva mandar para manifestar la voluntad sincera en cuanto fuera de su mayor agrado. Suplicando á Dios guarde muchos años

Besa la mano de Vuestra Excelencia Giacomo Panati

Excelentísima Señora Duquesa de Peñafiel.”

$N^{\circ}$ 24. Carta de la bailarina María Medina a la XV Condesa-Duquesa de Benavente solicitando su intercesión para actuar en la compañía de baile de los teatros públicos de Madrid y borrador de la respuesta.

AHN NOBLEZA, OSUNA-CARTAS, leg. 388-13. 15 de septiembre de 1790. Carta original en francés publicada en "Virtuose": Viaggi e Stagioni Nell'Ultimo Decennio del Settecento (Madrid: Istituto Italiano di Cultura, 1979), pp. 18-19.

“Bordeaux, le 15 septembre 1790

Excellence et chère Marraine

Je ne doute pas que vous me ferez I'honneur de me répondre, mais je ne peux [...] vouloir vous informer de nos affaires.

Madame Dauberval, qui toujours m'aime, ne m'a pas oubliée pour le voyage de Londres, qui est dans deux mois, et nous dit qu'elle compte demander douze mille francs pour la saison, et qu'a l'autre année nous pourrons mieux faire nos affaires et bien étudier.

Cependant je [...] cet affaire sans savoir quel sort vous nous destinez.serait fort inutile d'aller a Londres pour retourner a Madrid.

Ma bonne Marraine, vous ne douterez pas que nous aimerions mieux de pouvoir 
encore baiser la main. Si votre bonté nous donnait que assurance, nous nous arrangerions a la circonstance. Enfin, j'espère tout de votre bontè et ne ferai rien sans vos bons conseils. Rèpondez-moi de [...] que vous le pourrez.

Viganó vous assure de sa reconnaissance ainsi que moi, et nous restons pur la vie vos plus soumis serviteurs.

$\mathrm{F}[\mathrm{emme}]$. Viganò

Nos respects à Monsieur le Duc et à Don Manuel de la Peña”

[Mi traducción]:

"Burdeos, 15 de septiembre de 1790

Excelencia y mi querida Madrina

Aunque no dudo que vos me haréis el honor de contestar, no puedo sino [...] informaros de nuestros asuntos.

La Señora Dauberval, que siempre me estima, no me ha olvidado para la gira de Londres, que será dentro de dos meses y por la que pedirá para nosotros doce mil francos por la temporada, y a que en la otro año podríamos dedicarnos a nuestros asuntos y a estudia.

Sin embargo [no me gustaría aceptar] este asunto sin saber la suerte que vos nos habéis detinado, pue sería inútilmarchar a Londres para después volver a Madrid.

Mi buena madrina, no dudéis que eestaríamos encantados de poder besar su mano de nuevo. Si vuestra bondad nos diese tal seguridad nosotros nos arreglaríamos a tal. Enfin espero todo de vuestra bondad y no haré nada sin vuestros buenos consejos Respondedme [...]

Viganò os presenta sus respetos al igual que yo, y seremos siempre sus mas sumisos servidores.

Señora Viganò

Nuestros respetos para el Señor Duque y Don Manuel de la Peña 


\section{$\mathbf{N}^{\circ}$ 25. Carta de la XV Condesa-Duquesa de Benavente a la bailarina María Medina}

Viganò.

AHN NOBLEZA, OSUNA-CARTAS, leg. 388-14. 23 de septiembre de 1790. Publicada en "Virtuose", pp. 18-19.

"Querida Mariquita: La asociación proyectada para tomar de su cuenta el teatro de la ópera en esta Corte se ha verificado, y quedan con el teatro los accionistas de ella por los dos años inmediatos. A pluralidad de votos han sido elegidos comisarios para dirigirlo todo con Don Felipe Marescalqui los Señores Don Jerónimo de Mendinueta y Don Pablo de Sangro, los cuales son los únicos a quienes debes dirigir tus pretensiones y propuestas para venir a este teatro, pues los demás accionistas nada podemos hacer en esto, y menos yo que particularmente me he propuesto por justas causas no mezclarme en nada.

Pero, respecto de que Madame Dauberval te ofrece en Londres un partido de cuarenta y ocho mil reales por la temporada, debo decirte con ingenuidad que este partido me parece muy digno de preferencia al de venir aquí, donde por todo un año no te darán los cuarenta y ocho mil reales, además de que el teatro de Londres tiene otro crédito que éste, y desde él podrás lograr ajustes más ventajosos para los teatros de Italia, al mismo tiempo que al lado y con la escuela de Madame Dauberval debes prometerme adelantar mucho en el baile. Este es mi parecer por lo que me intereso en tu bien estar; pero si tú, o Viganó, o ambos tuviereis más gusto en venir a Madrid, aunque sea con menor partido, no tengo inconveniente en que lo procuréis por medio de los dos citados señores Mendinueta y Sangro, que son, como he dicho, los únicos que pueden hacer en esto.

Por lo demás, debes estar segura de mi afecto, y de que, para atenderte yo en lo que se te ofrezca, lo mismo es que te halles en Bourdeaux o Londres que en Madrid.

Mi Madre la Duquesa de Osuna ha recibido tu carta: todos celebramos tu salud y la de Viganó, y deseamos que en su compañía te guarde Dios muchos años.

Madrid, 23 de septiembre de 1790 


\section{N$^{0}$ 26. Carta del bailarín Salvatore Viganò a la XVCondesa-Duquesa de Benavente}

AHN NOBLEZA, OSUNA-CARTAS, leg. 388-14. 9 de octubre de 1790. Carta original en italiano publicada en "Virtuose", pp. 20.

\section{"Eccellenza}

Mi prendo la libertà di risponderre a nome della consorte ritrovandosi la detta un poco incomodata la per la nota gravidanza. Molto bene vediamo che in Madrid non ci è restato per noi che la infinita bontá dell'Eccellenza Vostra, che non lascia di consigliarci a nostro vantaggio, e nel tempo stesso ci assicura la sua protezione. Questo è quanto a noi vi è di più caro e prezioso, e non mancheremo mai di coraggio, sempre quando Vostra Eccellenza si degnerà di proteggerci. Se gli altri Signori di Madrid mi hanno mancato, non solo l'anno passato, ma questo anno ancora, non posso su ciò altro che consolarmi pensando che non godo una si Illustre nascita non sono capace di mancare a nessuna promessa né parola da me data a qualunque persona. Doppo il consiglio della sua lettera in quanto a Londra, abbiamo subbito accettato, e il di 11 del corrente partiremo di Bordeaux per colá giugnere.

Come noi riguardiamo l' Eccellenza Vostra come nostra protettrice, mi pare dovere di comunicargli tutti Ii nostri sentimenti, per ciò mi sono tenuto troppo longo, del quale difetto gliene chiedo mille volte scusa, e baciandogli devotamente le mani, unito alla Conzorte, passo con iI più profondo rispetto a dirmi dell'Eccelenza Vostra

\section{Ummilissimo, Devotissimo, Obbligatissimo servitore}

Salvatore Viganò

Bordeaux, 9 de ottobre 1790"

[Mi traducción]:

Excelencia:

Me tomo la libertad de responder en nombre de mi esposa que se encuentra un poco indispuesta a causa de su avanzado embarazo. Vemos bien que lo único que nos queda en Madrid es la infinita bondad de Vuestra Excelencia, que no deja de aconsejarnos en nuestro provecho, y a la vez de asegurar nuestra protección. Esto es lo que nosotros más apreciamos, y no nos faltará el valor, siempre que Vuestra Excelencia se digne a protegernos. Si los otros Señores de Madrid me han olvidado, no sólo el año pasado sino también en este año, no puedo más que consolarme pensando que yo que no provengo de 
una ilustre cuna no soy capaz de faltar a ninguna promesa ni palabra que de a cualquier persona. Después del consejo de su carta en lo relativo a Londres, hemos aceptado de inmediato, y el día 11 del presente partiremos hacia allí.

Como nosotros consideramos a Vuestra Excelencia como nuestra protectora, me parece nuestro deber comunicarle todos nuestros sentimientos, aunque me halla extendido en exceso, de cuyo defecto le pido mil veces disculpas, y besando devotamente la mano junto a mi esposa, que con el mas profundo respeto

De vuestra excelencia

Humildísimo, Devotísimo y Obligadísimo Servidor Salvatore Viganò

Burdeos, 9 de octubre de 1790"

N$^{\circ}$ 27. Carta del empresario de ópera Domenico Botti a la XV Condesa Duquesa de Benavente, recomendando a la cantante Catalina Lusini y borrador de la respuesta

AHN NOBLEZA, OSUNA-CARTAS, leg. 387-3. 26 de julio de 1790.

\section{"Excelentísima Señora}

Señora

Confiado de que me perdone Vuestra Excelencia la osadía, me he tomado la libertad de entregar esta humilde mía para Vuestra Excelencia a la Señora Cathalina Lusini, a fin de que con este medio pueda tener el honor de ponerse a sus pies, así como me ha manifestado desearlo vivamente la interesada.

Esta es una virtuosa de música de una habilidad y una voz sorprendente, y de una conducta irreprehensible cuyas circunstancias pueden merecer el alto padrocinio [sic] de Vuestra Excelencia el que espero consiga luego que Vuestra Excelencia conozca sus méritos, y yo el indulto de mi atrevimiento, quedando en el ínterin con los más finos deseos de que Vuestra Excelencia me honre con sus siempres venerados preceptos

Nuestro Señor dilate y felicite la preciosa, e importante vida de Vuestra Excelencia muchos años

Barcelona 26 de julio de 1790

Excelentísima Señora 
Besa los pies de Vuestra Excelencia

Su más humilde criado

Domingo Botti

Excelentísima Señora Condesa de Benavente Duquesa de Osuna"

[Borrador de la respuesta de la Condesa-Duquesa de Benavente]:

"Muy Señor mío: La Lusini me ha entregado la estimada de Vuestra Merced de 26 del pasado, ya tendiendo a la recomendación que merece Vuestra Merced la oiré y proporcionaré que algunas gentes conozcan su mérito contribuyendo gustosa a su favor en cuanto se proporcione.

Deseo complacer a Vuestra Merced en cualquier otra cosa, y ruego a Dios le guarde muchos años

Madrid 25 de Agosto de 1790

La Condesa Duquesa

Señor Don Domingo Botti"

$N^{\circ}$ 28. Carta de la cantante Luigia Todi a la Condesa-Duquesa a la XV Condesa Duquesa de Benavente comentándole los conciertos que dio en Italia y borrador de la respuesta

AHN NOBLEZA, OSUNA-CARTAS, leg. 387-2. 2 de julio de 1793 (respuesta de la Condesa-Duquesa). Original italiano y borrador de la respuesta publicados en "Virtuose", pp. 53-54.

"Eccellentissima Signora

Carissima mia Signora. Ho avuto I'onore di ricevere la risposta di Vostra Eccelenza la quale mi riempì di gran giubilo per avere tutta la sicurezza della perfettissima salut di Vostra Eccelenza e dell'Eccellentissimo Duca, a chi io desidero ed auguro gran felicità in tutte le sue imprese, il che si deve sperar secondo il me rito e la gran fama che corre in tutto I'Europa: questa serve di gloria a tutti, ma maggiormentc a chi gli è tanto obligata come io son. lo non risposi subito a Vostra Eccellenza per esser stata non solamente incomodata qualche poco, ma anche occupata col travaglio di due Serenate che cantai in occasione delle pubbliche feste della nascita della Serenissima 
Principessa della Beira; adesso pero la mia prima premura e stato di scrivere a Vostra Eccellenza. ringraziandola all' istesso tempo de l'onore che mi ha compartito delle sue notizie e di tanti altri favori che per il passato ho ricevuto espero ricevere per il futuro, $i$ quali mi serviranno di eterne rimembranze al mio gradimento, non essendomi altrimenti possibile la ricompensa che la mia eterna confessione; e se mai sono abile in questa Città a poter servire a Vostra Eccellenza. in qual si sia cosa che mi sia possibile, troverà in me un fervoroso desiderio di obedire e servire a Vostra Eccellenza per avere l'onore de' suoi commandi.

Desidererei ansiosamente, tanto io come mio Marito, sapere della salute del Eccellentissimo Signore Duca e de' suoi amabilissimi figli, e mi farà l'onore nella prima occasione d'incontro di partecipare a Sua Eccelnza la Signora Duchessa di Benavente i miei dovuti ed obsequiosi rispetti, assicurandogli la nostra servitù e gratitudine Mio Marito baccia le rispettose mani di Vostra Ecccelenza e per tine mi dichiaro qual fui e sarò.

Di Vostra Eccellenza.

Devotissima ed Obligatissima Serva

Luigia Todi"

[Mi traducción]:

Excelentísima Señora:

Queridísima Señora mía. He tenido el honor de recibir la respuestas de Vuestra Excelencia, la cual me llenó de gran alegría por tener toda la seguridad de Vuestra Excelencia y del Excelentísimo Duque, a quien deseo y auguro una gran felicidad en todas sus empresas, lo que se be esperar según el mérito y la gran fama que corre por toda Europa: esta sirve de gloria a todos, pero mayormente a quien está tan agradecida como yo lo estoy. Yo no respondí rápido a Vuestra Excelencia por haber estado no sólo un poco indispuesta, sino también ocupada con el trabajo de dos Serenatas que canté con ocasión de las fiestas públicas del nacimiento de la Serenísima Princesa de Beira, ahora sin embargo mi primera urgencia ha sido escribir a Vuestra Excelencia agradeciéndola al mismo tiempo el honor que me ha compartido de sus noticias y de tantos otros favores que en el pasado recibí y espero recibir en el futuro los cuales me servirán de eterno recuerdo a mi agrado, no siendo posible mas recompensa que mi eterna confesión, y si es necesario poder servir en esta ciudad a Vuestra Excelencia en cualquier cosa que me sea posible, encontrará en mi un ferviente deseo de obedecer y servir a Vuestra Excelencia por tener el honor de sus encargos. 
Tanto yo como mi marido, deseamos ansiosamente saber de la salud del Excelentísimo Señor Duque y de sus amabilísimos hijos y me hará el honor en la primavera ocasión posible de participar a Su Excelencia la Señora Duquesa de Benavente mis debidos y obsequiosos respetos, asegurándole nuestra servidumbre y gratitud mi marido besa la respetuoso a mano de Vuestra Excelencia, y por fin me declaro como fui y seré

De Vuestra Excelencia

Devotísima y obligadísima sierva Luigi Todi

[Borrador de la respuesta de la Condesa Duquesa]:

"Estimada Todi: He celebrado mucho los lucimientos de Vuestra Merced en las dos Serenatas cantadas con motivo del nacimiento de la Princesa de Beira, en que debo suponer habrá quedado Vuestra Merced. Como acostumbra, y deseo que este servicio la produzca una recompensa correspondiente a su mérito.

Las últimas cartas de mi Marido me aseguran de su salud, y tengo también la satisfacción de que los chicos todos estén buenos.

Deseo que Vuestra Merced. Lo esté con toda su familia, y ruego a Dios guarde A Vuestra Merced muchos años.

Madrid, 2 de julio de 1793.

\section{$N^{0}$. 29. Carta de la cantante Luigia Todi a la XV Condesa Duquesa de Benavente comomicándole su llegada a Nápoles y borrador de la respuesta}

AHN NOBLEZA, OSUNA-CARTAS, leg. 387-1. 3 de mayo de 1796. Original italiano y borrador de la respuesta publicados en "Virtuose", pp. 60-62.

\section{"Eccellentisima Signora}

Siamo arrivati felicemente a questa Corte avant'ieri primo corrente alle tre ore doppo mezzogiorno, avendo fatto il viaggio da Barcelona qui in sette giorni di tempo, felicità alla quale io non osavo aspirare. La mia prima cura e quella di parteciparlo a Vostra Eccelenza, sicura che ella per la sua bontà gode al par di me di sapere che sia in sicurtà e libera del'affano che mi cagionava la ristreteza del tempo e del lungo viaggio che avevo daffare. Tutto finì, e sol mi resta adesso la cura del mio ristabelimento, 
trovandomi sommamente indebolita del patimento del mare, il quale mi privò talmente delle forze, che ci vorrà qualche giorno per ricompore lo stomaco e la fiacheza di testa. Le mie figlie anno sofferto soltanto i primi due giorni, mio Marito la pasò da bon marinaro, e tutti si portano bene e mi pregano meterli ai piedi di Vostra Eccellenza con mille e poi mille sprezioni del loro sincero affetto e riconoscenza alle di lei bontà. Mi riuscì trovare il libero che vostra Eccelenza desiderava, e lo includo in questa. Di Napoli non posso dir nulla tuttavia, perché il mio stato non mi permete di sortire, e in quanto agli affari teatrali, quando sarò più al fatto, daro esato raguaglio a Vostra Eccellenza, a chi prego conservarmi la sua grazia, abraciare teneramente per parte mia tutte le Signorine e Signorini, mettermi ai piedi del Eccellentissimo Signore Ducha e Duchessa, ricordarmi a gli amici e credermi col più profondo rispetto ed amore

Di Vostra Eccellenza.

Umilissima e Devotissima serva

Luigia Todi

Napoli, li 3 magio 1796"

[Mi traducción]:

Excelentísima Señora

Hemos llegado felizmente a esta Corte anteayer a las tres de la tarde mediodía, habiendo durado el viaje desde Barcelona siete días, una felicidad a la cual no osaba a aspirar. Mi primera atención ha sido comunicárselo a Vuestra Excelencia, segura de que por su bondad se alegre al igual que yo al saber que esté tranquila y libre de los los pesares y de las penurias del clima y del largo viaje que hemos hecho. Todo acabó, y ahora sólo me queda restablecerme, encontrándome sumamente débil por el padecimiento de la navegación, lo que me privó totalmente de las fuerzas, y que me provoca padecimiento de estómago y debilidades la cabeza. Mis hijas sólo lo pasaron mal los dos primeros días, mi marido se comportó como un buen marinero, y todos se encuentran bien y me piden que les ponga a los pies de Vuestra Excelencia con miles y miles expresiones de su sincero afecto y reconocimiento de su bondad. He conseguido el libro que Vuestra Excelencia deseaba y lo incluyo con esta carta. No sé nada de Nápoles todavía porque mi estado no me permite salir, y en cuanto a los asuntos teatrales en cuanto esté más al tanto, daré cumplida noticia a Vuestra Excelencia, a quien ruego me conserve su gracia, abrace tiernamente de mi parte a todos los Señoriítos y Señoritas, y me ponga a los pies de Excelentísimo Señor Duque y Duquesa, de recuerdos a los amigos y me estime con el más profundo respeto y amor 


\section{De Vuestra Excelencia}

Humildísima y Devotísima sierva

Luigia Todi

Nápoles, 3 de mayo de 1796.

[Borrador de la respuesta de la Condesa-Duquesa]

"Mi estimada Todi: De grande satisfacción me han sido las noticias que Vuestra Merced. me da en su carta de 3 de mayo de su feliz llegada a esa Corte el día 10 y de la brevedad de su viaje desde Barcelona, sin haber en él padecido azar alguno, pues no deben mirarse como tales, aunque incomodan mucho, las molestias ordinarias de la navegación, de que supongo se habrá Vuestra Merced reparado prontamente.

El día de San Fernando nos acordamos mucho de Vuestra Merced. suponiendo que sería el primer día que Vuestra Merced cantaría en ese Real Teatro, y sentíamos mucho no participar de tan buen rato y del placer de presenciar los aplausos con que se haría justicia al mérito de nuestra Todi. Cuento con que Vuestra Merced. me informará puntualmente de las ocurrencias de aquel día.

Doy a Vuestra Merced muchas gracias por su memoria y cuidado de remitirme el libro desde esa Corte, aunque ya la Marchetti, por el encargo que Vuestra Merced la dejó, me le había remitido desde Barcelona.

Mil expresiones a Todi y a las chicas, que celebro sintiesen menos la navegación; y reciban Vuestras Mercedes también recuerdos del Duque, mis chicos y toda la tertulia, con muchas enhorabuenas por su feliz arribo que todos han celebrado.

Deseo vivamente noticias de la salud de Vuestra Merced, y las demás que sabe Vuestra Merced no pueden ser indiferentes a quien tan de veras la estima como [...]

P.D. de Su Excelencia. Nada sé de América, y sólo una carta he recibido, por lo que mi humor no es muy bueno.

Aranjuez, 6 de junio de 1796" 


\section{$N^{0}$. 30. Carta de la cantante Luigia Todi a la XV Condesa Duquesa de Benavente comentándole sus actuaciones operísticas en Nápoles y borrador de la respuesta}

AHN NOBLEZA, OSUNA-CARTAS, leg. 387-1. 4 de agosto de 1796. Original italiano y borrador de la respuesta publicados en "Virtuose", pp. 64-65.

"Eccellentissima Signora:

Molto grata mi fu la stimatissima di Vostra Eccelenza del 6 giugno, nella quale mi certifica iI felice stato di sua salute e di tutta la di lei per.me tanto rispettabile ed adorata famiglia. Non risposi prima aquella perché aspettavo (secondo la voce publica) anunziare a Vostra Eccelenza la desiderata pace in questo Regno, ma vol e la sorte ritardarci tuttavia questa consolazione, la qua le per altro credo non sara lontana, ateso gli ordini gia dati per Ii preparativi del Matrimonio di questo Principe Ereditario, e nel Reggio Teatro cesseranno le recite il giorno 19 del presente a line di accomodarlo e dipingerlo per iI mese di novembre che si riaprirà con la nuova Opera Andromaca, con gran spettacolo e musica di Paesiello. Questo riposo è per me un gran solievo, mentre il Maestro Guglielme scrisse una Cleopatra assai faticante sopra tutto in questa stagione e clima adove il calore è insoportabile. Con tutto ciò, il Teatro e sempre pieno, li Sovrani ed il publico non cessano di colmarmi di favore, e l'opera ogni giorno piace più, non ostante che molti vogliano che la musica non sia la più bella che il Maestro abbia fatto. Godo che la Marchetti abbia sodisfatto il mio incarico, e desidero che Vostra Eccellenza sia persuasa che in qual si sia tempo e luogo ambisco obedire ai suoi comandi. Mio Marito e figlie sono grati alla memoria e favore di Vostra Eccellenza e mi raccomandano meterli ai suoi piedi, augurandogli mille e poi mille felicità. L'istessi votti fo io, pregandola di presentare li nostri rispetuosi osechi al Eccellentissimi Signore Ducha, Duchessa e Contessa Madre, ringraziare le Signorine e Signorini, raccomandandoci a tutti grati e memore alle loro bonta. Gradisco moltissimo i votti dell'amabile tartuglia, la quale è presente ben che lontana, espero che questa contribuisca a solevare Vostra Eccelenza, a chi desidero perfettamente felice e contenta. Questi sono e saranno constantemente i votti della che piena di riconoscenza e stima ha l'onore di dirsi

Di Vostra Eccellenza

Affetuosissima e fedel serva

Luigia Todi

Napoli, 4 agosto 1796" 
[Mi traducción]:

Me agrado mucho recibir la estimadísima carta de Vuestra Excelencia del 6 de junio, en la cual me certifica el feliz estado de su salud y de toda la de su familia a la que tanto respeto y adoro. No he respondido antes a aquella porque esperaba (según la opinión pública) anunciar a Vuestra Excelencia la deseada paz en este reino, pero la suerte ha retrasado aún esta alegría, que, no obstante no creo que se hallé muy lejos, como se han dado ya las órdenes para los preparativos del matrimonio del Príncipe Heredero, las representaciones del Teatro Regio cesarán el día 19 para acomodarlo y pintarlo para los meses de noviembre que se volverá a abrir con la ópera Andromaca, con gran espectáculo y música de Paisiello. Este descanso es para mí un gran alivio, aunque el Maestro Guglielme ha escrito una Cleopatra muy fatigosa sobre todo en esta estación y clima donde el calor es insoportable. A pesar de todo, el teatro está siempre lleno, los Soberanos y el público no cesan de colmarme de favores y la ópera cada día gusta más aunque muchos creamos que la música no es la más bella que ha hecho el maestro. Me alegro de que la Marchetti haya cumplido mi encargo, y deseo que Vuestra Excelencia sepa que en cualquier momento y lugar obedeceré sus órdenes. Mi marido e hijos se alegran de la memoria y favores de Vuestra Excelencia, y me piden que les ponga a sus pies, deseándola una inmensa felicidad. Lo mismo hago yo pidiéndola presente nuestros respetuosos saludos a los Excelentísimos Señores Duque, Duquesa y Condesa Madre, agradezca a los Señoritas y los Señoriítos, agradeciéndoles a todos su bondad. Agradezco mucho los deseos de la amable tertulia, a la que tengo presente aunque esté lejos, y espero que esta contribuya a entretener a Vuestra Excelencia que deseo esté feliz y contenta. Estos son y serán constantemente los deseos de la que llena de reconocimiento y estima tiene el honor de decirse

De Vuestra Excelencia

Afectuosísima y fiel sierva Luigia Todi

Nápoles, 4 agosto 1796”

[Borrador de la respuesta de la Condesa-Duquesa]

"Estimada Todi: Considero a Vuestra Merced muy divertida en esa Corte cuando se verifique el matrimonio de ese Príncipe heredero, que Vuestra Merced se persuade próximo, en su carta de 4 de agosto anterior, por los preparativos que a este fin se estaban ya haciendo, y aumentarán sin duda la satisfacción pública, si a este regocijo precede, como es creíble, la paz que en ese reino se espera. 
Entre tanto tiene Vuestra Merced el gusto de que la nueva obra que se va a hacer en el teatro la proporcione algún tiempo de descanso a las fatigas que la habrá ocasionado la rigurosa estación de verano, y así la será menos sensible el trabajo que la espera por noviembre, en que principiará con la nueva ópera Andrómaca, de que Vuestra Merced me habla y que se estaba disponiendo para entonces, pero yo creo que deba suavizar la molestia de sus tareas la racional prevención con que debe Vuestra Merced estar de que ese público la continuará, como lo ha hecho hasta aquí, el justo aplauso que merece su habilidad, y de la que han hecho ya tanto aprecio esos Soberanos.

Espero que no se olvidará Vuestra Merced de darme noticia de lo que ahí ocurra, para que en la tertulia renovemos sus apasionados la memoria de los buenos ratos que hemos tenido admirando y oyendo su habilidad; y agradeciendo a Vuestra Merced sus finas expresiones mis Madres, $\mathrm{m}$ arido y chicos, la ratifica su verdadero afecto...

Madrid, 27 de septiembre de 1796"

\section{No. 31. Carta de la cantante Luigia Todi a la XV Condesa Duquesa de Benavente comentándole sus proyectos operísticos}

AHN NOBLEZA, OSUNA-CARTAS, leg. 387-1. 22 de octubre de 1796. Original italiano y borrador de la respuesta publicados en "Virtuose", pp. 66-67.

"Napoli, 22 ottobre 1796

\section{Eccelentissima Signora}

Pregola di compatirmi se ho ritardato a rispondere alla di lei stimatissima, come non avrei mancato di fare se non fossi stata assente da Napoli per profitare di queste belle campagne nell'intervallu delle mie fatiche. Le nuove di Vostra Eccellenza mi sono state molto care, nel sentire lo stato perfetto di salute che gode, come ancora la sua degnissima famiglia, alla quale prendo molto interesse per le tante obligazioni che le professo. Mi rineresce moltissimo di non poterle ancora dire il giorno che l' Andromaca anderà in scena, poiché nella ristaurazione del Teatro, essendosi trovata lesione su una scala, il detto riparo prolungando il tempo impedisce che I'opera si rappresenta senonché sulla fine di novembre. Perciò Paesiello non s'affretta di terminarla, e di qualche porzione che ho di già ricevuta ne son $\mathrm{o}$ molto contenta. Vorrei poter dire altrettanto circa I'organizazione di questo Teatro, il quale a cagione de' cattivi Impressari decade in modo 
a disgustare non solamente i suggetti, ma anche I'istesso Publico. Si aspetta per altro un cambiamento, essendo questo troppo necessario per rimettere il buon ordine, senza di che non potrebbero conciliare I'animo di qual si voglia suggetto che facessi I'interesse del Teatro. Quantunque mi piace moltissimo questa città, eche il clima si confà a tutti quanti, e amando sopra ogni cosa la mia tranquillità, se le cose non cambiano di aspetto, non sarò per rinovare il mio contratto. Mio marito e le mie figlie sono sensibili a l'onore che Vostra Eccellenca li compartisce e la pregano di accettare i loro rispettuosi omaggi e di porgerli anche all Eccellentissimo Signore Ducca, Signorini e Signorine, memori sempre delle grazie compartite dall Eccellenze. Altro non posso aggiungere per parte mia che assicurarla della mia eterna riconoscenza, e pregare l'Altissimo per la conservazione de' suoi prezziosi giorni, e quelle prosperità che si merita, mentre col maggior ossequio mi professo di Vostra Eccellenza.

Umilissima e Devotissima Serva

Luigia Todi”

[Mi traducción]:

Nápoles 22 de octubre de 1796

Excelentísima Señora:

Le ruego me disculpa por haber tardado en responder a su estimadísima carta, pues no hubiese dejado de hacerlo si no hubiera estado ausente de Nápoles para disfrutar de estos bellos campos en el momento de mis fatigas. Las noticias de Vuestra Excelencia me agradan mucho, y me alegro del perfecto estado de salud que goza, como también el de su dignísima familia, en la cual estoy muy interesada por lo mucho que les debo. Siento mucho no poder anunciarle todavía el día que se pondrá en escena [la ópera] Andrómaca, porque en la restauración del teatro se ha dañado una escalera y su reparación se ha demorado impidiendo que la ópera se represente ante de finales de noviembre. Por eso Paisiello no se apresura a terminarla, y de los fragmentos que he recibido no estoy muy contenta. Otro tanto os podría decir de la organización de este teatro, el cual a causa de los malos empresarios está en una decadencia que no sólo disgusta a sus artistas sino al mismo público. Es necesario que se acometan un cambio para volver al buen orden, sin el cual no se podrá conciliar el ánimo que necesitan las personas que tienen intereses en el teatro. Aunque me gusta muchísimo esta ciudad, y el clima es bueno para todos, como aprecio la tranquilidad por encima de todas las cosas, si la cosa no cambia de aspecto no renoaré mi contrato. Mi marido y mis hijos agradecen los honores que Vuestra Excelencia les dispensa y le ruegan acepte sus respetuosos homenajes y le ofrezca al Excelentísimo Señor Duque, Señoritas y Señoritos, memoria 
siempre de las gracias entregadas por Sus Excelencias. No puedo añadir nada más por mi parte que asegurarla mi eterno reconocimiento, y rogar al Altísimo por la conservación de sus preciosos días y por la prosperidad que se merece, mientras con el mayor obsequio me profeso de Vuestra Excelencia

Humildísima y Devotísima Sierva

Luigia Todi

[Borrador de la respuesta de la Condesa-Duquesa]:

"Estimada Todi: Celebro mucho la salud de Vuestra Merced y toda su familia, de que me asegura su carta de 22 de octubre, Y que mientras ha podido se haya recreado por la hermosa campiña de esas inmediaciones.

Debo suponer que al presente se habrá representado en ese Teatro la Andrómaca, o que cuando más se represente en las próximas Pascuas, pero será mucha lástima ciertamente que Paisiello por indolencia o por otro cualquier motivo no haya hecho en esta ópera lo que tan acreditado tiene que sabe hacer, principalmente si en la parte de Vuestra Merced no la proporciona el lucimiento que Vuestra Merced tiene asegurado en cual quiera música de mérito que se fíe a su ejecución.

No es de esperar permitan que siga ese Teatro en el estado de decadencia que Vuestra Merced me dice hallarse por sus malos empresarios, ni que den lugar a que Vuestra Merced por esto no renueve su contrata.

No me pesaría si hubiese Vuestra Merced de volver a Madrid, pero nuestra Opera está en el estado más lastimoso. Han traído un tenor que no es malo, y por de contado es mejor que Panizza, pero todo lo demás es muy malo, incluso la decoración, pues ya no está a cargo de los Tadéis y se pinta como antes en el teatro español, o peor. En fin, casi siempre está desierto el coliseo, y yo no sé cómo podrá subsistir en el año siguiente si no hay muchas mejoras.

Reciba Vuestra Merced mil expresiones de toda mi tertulia, donde continuamente sale Vuestra Merced a la conversación, y echamos de menos su apreciable compañía. Mis hijos todos se acuerdan de Vuestra Merced siempre y me encargan la dé memorias suyas. Celebraré que Todi y mis colegialas estén buenos, y que en su compañía guarde Dios a Vuestra Merced como desea[...]

Madrid, 20 de diciembre de 1796." 


\section{$\mathbf{N}^{\circ}$ 32. Carta de la cantante Luigia Todi a la XV Condesa Duquesa de Benavente relatando la llegada Caserta de la Princesa de Nápoles en 1797 y borrador de la respuesta}

AHN NOBLEZA, OSUNA-CARTAS, leg. 387-1. 18 de julio de 1797. Original italiano y borrador de la respuesta publicados en “Virtuose”, pp. 68-69.

\section{"Eccellentissima Signora}

Con la sua solita bontà essendosi benignata onorarmi de' suoi preziosi caratteri, la mia maggior premura è quella di testificarle la mia riconoscenza ed averarle iI contento ch'essi mi caggionaro, poi che m'assicurano della di lei grazia che ambisco tanto, e del felice statto di sua salute tanto da me desiderata. Finalmente avro l'onore di raguagliare a Vostra Eccellenza il felicissimo arivo della Principessa, la quale giunse a Caserta sabato a 6 del presente mese. Essa, dicono, riuniscc tutte le virtù e talenti al piu bel core. Le dirò dunque ch'ebbi l'onore ed il piacere di vederla da vicino, avendo cantato in presenza sua e di Sua Maestà la Regina una cantata composta dal maestro Paesiello, la quale doveva eseguirsi dalle Principessine sorelle del Principe Reale, ed una raucedine delle medesime fece che Sua Maestá la Regina si compiacese compartimi l'onore di farmi avisare, ed il lunedì andiedi a Caserta. Non so esprimere a Vostra Eccellenza di quale maniera io venni aceolta da Sua Maestá la Regina, onorandomi dell'espressioni le piu obbliganti. Terminata la cantata, volle ehe io cantas si un' aria mia, e dopo molte graziosita di sua parte mi fece regalo d'un anello di brillanti in mezzo al quale v'e la sua ciffra. L' ingresso della Principessa in Napoli fu il martedì, accompagnata da Sua Maestá la Regina e dal Principe suo sposo, con bastante corteggio. Giunse al Real Palazzo sul tramontare del sole, e l'istessa sera principio l' Illuminazione in tutti i quartieri della Citta, ciò che segui sin al giovedì. Il Teatro di San Carlo si aprì il mercordì, il quale, parlando dell'interno, si può considerare come nuovo, e le pitture e altri ornamenti lo rendono veramente magnifico, malgrado la cabala degli invidiosi. Artemisia è il titolo del dramma che andiede in scena per l'appertura, e la musica di Cimarosa. Tutta la Corte comparse al Teatro nella maggior Gala, e l' iluminazione (che era surprendente) non essendo ancor terminata, dispiaque talmente al Sovrano che ordinò si metesse in prigione l'Impresario. La musica e i balli non hanno piaciuto né alla Corte né al pubblico, talmente che iI sovrani e tutta la famiglia andiedero via prima che terminas se il Primo ballo e non si curarono di vedere né il secondo atto né il secondo ballo, che ebbero il medesimo sucesso. Non posso su di ciò entrare in maggiori detagli né dire il mio sentimento a Vostra Eccellenza essendo da più mesi in campagna con tutta la mia famiglia e non 
essendomi ancora curata d'andare all'opera. Il giovedì ci fu gran festino in Corte, e tuto risucì brillantissimo. Adesso si prepara a Santo Leuci, delicia del Sovrano, una festa che dicono assai complicata di piaceri, la quale avrà luogo questa setimaza, e ne faro distinto raguaglio a Vostra Eccellenza.

Riguardo a miei interessi teatrali, sono sempre nell'istessa situazione. Rinunciai per tutto l'anno a Venezia, e qui non ho potuto finora avere la meta della mia paga, mal grado le continue supliche. Non so se lo spirito di vendetta mal intesa o se la mia poca fortuna mi procurò questo disapore.

Il mio marito e le mie figlie presentano a Vostra Eccellenza li loro umilissimi rispetti e la pregano di porgerli per parte loro ed anche mia all'Eccelentissimo Signore Ducha e tutta la sua rispettabilissima famiglia, mentre dedicandomi a' suoi grati voleri ed a qualunque suo comando, con tutto l'attaccamento e rispetto ho l'onore di dirmi

Di Vostra Eccellenza.

Umilissima e Devotissima Serva

Luigia Todi

Napoli, 18 luglio 1797"

[Mi traducción]:

Excelentísima Señora:

Con la bondad que ha hecho al dirigirme su preciosa carta, mi mayor premura es testificar mi reconocimiento y la alegría que me proporciona, pues me asegura su gracia que tanto anhelo, y el feliz estado de su salud que tanto deseo. Finalmente tengo el honor de comunicar a Vuestra Excelencia la felicísima llegada de la Princesa, que arribó a Caserta el sábado 6 del presente mes. Ella, dicen, que reúne todas las virtudes y talentos en el corazón más bello. He tenido el honor y el placer de verla de cerca, pues he cantado en presencia de Su Majestad la Reina, una cantata compuesta por el maestro Paisiello que debía haberse interpretado por la Princesita hermana del príncipe real, pero que por una ronquera de la misma, Su Majestad se complació en avisarme, y el lunes estuve en Caserta. No se expresar a Vuestra Excelencia de que manera fui escuchada por $\mathrm{Su}$ Majestad la Reina, que me honró con las expresiones más amables.

Terminada la Cantata, quiso que yo cantase un aria mía, y después muy agradecida me regaló un anillo de brillantes en medio del cual estaba su divisa. La entrada de la Princesa de Nápoles fue el martes, acompañada de su majestad la reina y del Príncipe su esposo, con bastante séquito. Llegaron al Palacio Real a la ciada del sol, y la misma noche comenzó la iluminación en todos los barrios de la Ciudad, que siguió hasta el 
jueves. El teatro de San Carlos se abrió el miércoles, el cual, hablando del interior se puede considerar como nuevo, y las pinturas y otros ornamentos lo han dejado verdaderamente magnífico, a pesar de las conjeturas de los envidiosos. Artemisia es el título de la ópera que se puso en escena para la apertura, y la música es de Cimarosa. Toda la Corte compareció en el teatro con sus mayores galas, y la iluminación (que era sorprendente) al no estar terminada desagradó tanto al Soberano que ordenó se metiese en prisión al Empresario. La música y los bailes no han gustado mucho ni a la Corte ni al público, de manera que el Soberano y toda la familia se marcharon antes de que terminase el primer baile y no se quedaron a ver ni el segundo acto ni el segundo baile , que tuvieron el mismo éxito. No puedo entrare en mayores detalles ni contar mi parecer a Vuestra Excelencia, pues llevo dos meses en el campo con toda mi familia y aún no me he curado para volver a trabajar. El jueves hubo una gran fiesta en la Corte y todo fue brillantísimo. También se prepara en Santo Leuci, delicia del Soberano, una fiesta que dicen que será muy complicada de diversiones, la cual tendrá lugar esta semana, y de la cual no podré contar nada más a Vuestra Excelencia.

Respecto a mis intereses teatrales, estoy siempre en la misma situación. Renuncié para todo el año en Venecia, y no he podido hasta ahora conseguir la mitad de mi paga, a pesar de las continuas súplicas. No sé si fue un espíritu de venganza mal entendida o si fue la mala suerte la que procuró este sinsabor.

Mi marido y mis hijos presentan a Vuestra Excelencia sus humildísimos respetos y le ruega los ofrezca de su parte y de la mía al Excelentísimo Señor Duque y a toda su respetabilísima familia, mientras espero sus gratos encargos y a cualquier cosa que desee, con todo el acatamiento y respeto tengo el honor de llamarme

De Vuestra Excelencia

\author{
Humildísima y Devotísima Sierva \\ Luigia Todi
}

[Borrador de la respuesta de la Condesa-Duquesa]:

"Estimada Todi: Mucho celebro haya Vuestra Merced tenido la satisfacción que me dice en su carta de 18 de julio último de que la hayan oído la Reina y Princesa de Nápoles, que agradase tanto a Su Majestad y Alteza que lo manifestasen con la fineza de regalar a Vuestra Merced la sortija con la cifra de Su Majestad

Agradezco las noticias que Vuestra Merced me da sobre las particularidades de las fiestas verificadas en esa Corte con motivo de la entrada de la Serenísima Princesa, así como las puntuales respectivas a la representación de Artemisia, adorno y magnífica 
iluminación del teatro que realmente estaría digno de verse.

Siento que nada se haya adelantado en su asunto de Vuestra Merced y que por lo mismo se vea privada de la mitad a lo menos del sueldo del año contratado para Venecia, como Vuestra Merced desea.

He tenido el pesar de que mi hijo Perico haya padecido unas viruelas que le tuvieron en riesgo de perecer, pero ya a Dios gracias está perfectamente restablecido sin que le haya quedado la menor lesión. Y apreciando las afectuosas expresiones que Vuestra Merced me hace con su Marido y hijas, se las devuelvo, deseando les vaya bien y que Nuestro Señor guarde su vida muchos años como apetece su apasionada que estima a Vuestra Merced.

Madrid, 10 de octubre de 1797"

\section{$\mathbf{N}^{0}$ 33. Carta de la cantante Luigia Todi desde Nápoles a la XV Condesa Duquesa de Benavente relatando sus actuaciones en el Teatro San Carlos y borrador de la respuesta}

AHN NOBLEZA, OSUNA-CARTAS, leg. 387-1. 28 de noviembre de 1797. Original italiano y borrador de la respuesta publicados en "Virtuose”, pp. 72-73.

"Eccellentissima Signora

Avendole partecipato nell'ultima mia l'essermi scriturata al Real Teatro di San Carlo, provo il piu gran contento nell'avere l'onore di dire a Vostra Eccellenza che il 18 del presente si è datta la prima recita dell'Opera intitolata l'Andromaca, la di cui poesia e del Cavaliere Calcagni, ma lo stile ritoccato da! Signoreo Don Tito di Lorenzo poeta di Corte la composizione della musica è del Maestro Don Giovanni Paisiello, il quale ha dato le solite prove del suo grazioso ingegno avendo posta in questa sua nuova composizione tutto quel gusto e tutta quella sublime armonia che sempre l'ha distinto tra i suoi competitori. Dal canto mio ha posta quell' impegno che mi aditava il mio dovere ed il mio onore, e grazia Dio l'Opera ha avuto il maggior incontro e tuttavia ha il più gran concorso. Il primo Ballo parimente, che ha per titolo Ginevra di Scozzia, è stato molta piaciuto dal pubblico. Alla prima recita ci fu illuminazione, coll'intervenzione de' Sovrani, de' Reali Sposi e di tutta la famiglia Reale, ed es si tutti mi mostrarono la maggior sodisfazione. Avro anche l'onore di dire a Vostra Eccellenza che quasi si è stabilito di dare l'Antigono per il prossimo Carnovale, la quale musica si trova gia scritta 
dal Maestro de Santi, ma che dovra ritoccarla, poiché nella sudetta ci dovea cantare la SIgnora Grassina ma che per la sua malatia no si nè potuto dare $e$, la quale, non cantando il soprano ma al contralto, né le sue arie né i pezzi concertati possono convenirme; ed a suo tempo non macherò di darme un distinto raguaglio a Vostra Eccelenza. Intanto pregona di presentare all'Eccellentissimo Signore Duca i nostri piu profondi ossequi tanto di mia parte che di mio marito e della mia famiglia, come ancora porcergerli alla sua degnissima famiglia, mentre con il più rispettoso attaccamento e maggior ossequio ho l'onore di dirmi

Eccellentissima Signora

Umilissima e Devotissima Serva

Luigia Todi

Napoli, 28 novembre 1797"

[Mi traducción]:

Habiéndole participado en mi última carta que estoy contratada en el Real Teatro de San Carlos, me alegro de tener el honor de anunciar a Vuestra Excelencia que el 18 del presente se estrenó la ópera titulada Andromaca, con poesía del Caballero Calcagni, pero arreglada por el Señor Don Tito di Lorenzo poeta de Corte; la composición de la música es del maestro Giovanni Paisiello, el cual ha dado las habituales pruebas de su gracioso ingenio al poner en esta su nueva composición todo el gusto y toda la sublime armonía que siempre le ha distinguido entre sus competidores. En mi canto he puesto el empeño que se esperaba de mi deber y mi honor y gracias a Dios la ópera ha tenido la mayor aceptación y todavía tiene una gran concurrencia. El primer baile, titulado Ginebra di Scozzia, ha sido muy bien acogido por el público. El estreno fue iluminado con la asistencia del Soberano, los Reales Esposos y de toda la familia Real, y todos me mostraron la mayor satisfacción. También tengo el honor de decirla a Vuestra Excelencia que casi está decidido representar el Antigono para el próximo Carnaval, cuya música ya está escrita por el Maestro de Santi, pero que deberá retocarla, pues en la susodicha debía cantar la Señor Grassina, pero por su enfermedad no se pudo hacer, y puesto que ella no canta de soprano sino de contralto, y sus arias y números concertantes no pueden convenirme; en su debido momento no dejaré de informar de ello a Vuestra Excelencia. Entretanto tanto presente al Excelentísimo Señor Duque nuestros más profundos respetos, tanto de mi parte como de mi marido y de mi familia, como también a su dignísima familia mientras con el más respetuoso acatamiento y el mayor obsequio tengo 
el honor de llamarme

Excelentísima Señora

\section{Humildísima y Devotísima Sierva \\ Luigia Todi}

Nápoles, 28 de noviembre de 1797

[Borrador de la respuesta de la Condesa-Duquesa]:

"Estimada Todi: No sabe Vuestra Merced cuánto hubiera yo celebrado verla en la Andrómaca nueva de Paisiello la noche del 18 de noviembre, contemplando el gran efecto que precisamente haría un teatro magnífico, tan bien iluminado, un concurso tan brillante y una Andrómaca renovada con la representación de Vuestra Merced.

Es preciso agradase a cuantos lo viesen, $\mathrm{Y}$ siento no me haya cabido la suerte de ser uno de los que aplaudiesen el mérito de Vuestra Merced pues hace tiempo que aquí no tenemos una ópera mediana en el todo. Celebraré tener noticia cómo se haya arreglado el Antígono que me dice Vuestra Merced ha debido darse en el Carnaval que acaba de pasar, pues por más que Vuestra Merced tema, como me asegura, que no pueden convenida las arias de dicha ópera por estar arregladas para la Grasini, Vuestra Merced hace milagros, y de cualquier modo, siendo Vuestra Merced quien la haga, tendría yo gran placer en oírla.

Sobre todo deseo continúe Vuestra Merced con salud, y que su permanencia en esa Corte la proporcione, sobre aplausos, terminar bien el antiguo asunto de intereses por el particular que de ello resultará a su final apasionada que estima a Vuestra Merced de corazón.

Alameda , 23 de febrero de 1798" 


\section{$N^{0}$ 34. Carta de la cantante Brigida Banti desde Londres a la XV Condesa Duquesa de Benavente y borrador de la respueesta}

AHN NOBLEZA, OSUNA-CARTAS, leg. 387-2. 15 de abril de 1794. Original italiano y respuesta publicados en "Virtuose", pp. 43-44.

\section{"Eccellentissima mia Signora}

Alla fine doppo di tre giorni e mezzo per la Posta sono gionta felicemente in Londra. Qui non ho trovato né David Crescentini, stante che gli medemi sono imegnati sino a tutto settembre in Italia e per il mese di ottobre si ritroveranno in Londra. Questo Impresario affida in me la sua sorte, e per questa ragione mi à di già pregato acciò vadi in scena piú presto possibile l'opera serie, e facilmente oggi ad otto canteró l'Opera della Vendetta di Nino, ed a suo tempo non mancherò raguagliarli la sincera verità del esito. Il Prim'omo interino è un certo Rosselli, che non so come sia mentre non ò mai intenso; il Tenore sarà pure interinamente Rovidino. Basta, vedo che a me sola tocherà di tirare il carro (come suol dirsi).

Spero che 1'Eccellenza Vostra goderà perfetta salute e che non si sarà scordata di una sua debbule serva, la quale professa tan te obligazzioni al Eccellenza Vostra. Per ciò rinnovo le mie preghiere pregandola a volermi conservar'e sempre la sua a me valevolissima protezzione, e presentandole Ii piú umili rispetti di mio Marito, e mettendomi a suoi piedi e baciandole umilmente la mano e pregandola a volermi mettere a piedi del Excellentissimo di lei sposo, come ancora al Signor Cavaliere Pegna [Peña] ed a suoi figli e figlie, mi do I'onnoe di ripetermi.

P. S: Li raccomandano iI mio Pepitto. Mi scordavo dirle che il Teatro di Londra è magnifico, sia per la grandezza come per il buon gusto e la richezza. Se Vostra Eccellenza grazziarmi di risposta, la prego derruyere la letrera al Imbasciatore di Spagna presso questa Corte.

Di Vostra Eccellenza.

Obligatissima Devotissima Serva e Commare

Brigida Banti

Londra, 15 aprile 1794" 
[Mi traducción]:

Excelentísima Señora Mía:

Después de tres día y medio en el coche he llegado felizmenete a Londres. Aquíi no me he encontrado con David y Crescenti pues trabajarán todo el mes de septiembre en Italia y estarán en Londres el mes de octubre. Este empresario confía en mi su suerte, y por ello me ha pedido que ponga en escena cuan to antes la ópera seria, y así cantaré hoy la ópera de la Vendetta di Nino, y a su debido tiempo no me faltará la sincera verda del éxito. El Primer Cantante masculino interino es un tal Rosselli del que no sé nada pues no lo he escuchado, el tenor será interinamente rovidino. Ya veo que entonces me tocará a mi torrar del carro (como suele decirse).

Espero que Vuestra Excelencia goce de una perfecta salud y que no se olvide de una débil sierva que tanto debe a Vuestra Excelelencia. Por eso renuevo mis súplicas rogándola me conserva su valiosísima protección, y presentándole los más humildes respetos de mi marido, y poniéndome a sus pies y besándole humildemente su mano y rogándola me ponga a los pies de su Excelentísimo Esposo y del Señor Caballero Pegna [Peña] y de sus hijos e hijas.

P.S. Le recomioendo a mi Pepito. Olvidaba decirle que el Teatro de Londres es magnífico tanto por su grandeza como por el buen gusto y la riqueza. Si Vuestra Excelencia quisiera agraciarme con una respuesta, le ruego que dirija su carta al Embajador de España en esta Corte.

De Vuestra Excelencia

Obligadísima, Devotísima Sierva y Comadre

Brigida Banti

Londres, 15 de abril de 1794"

[Borrador de la respuesta de la Condesa-Duquesa]:

"Estimada Banti: Por la carta de Vuestra Merced de 15 del mes de abril próximo veo con mucho gusto que Vuestra Merced ha llegado ya y está establecida en esa Corte, y el estado en que ha encontrado ese teatro; pero, aunque es cierto que la constitución de él obligará a Vuestra Merced a sostener todo el trabajo, y que éste la será bastante penoso, también no hay duda que esto mismo proporcionará a Vuestra Merced más motivo de ejercitar su habilidad, y de que conozcan todos los inteligentes cuán acreedora es a su aprecio.

Yo deseo que a Vuestra Merced la vaya bien y que en toda la temporada experimente Vuestra Merced en esa Ciudad cuantas satisfacciones apetezca y sus apasionados la deseamos.

Nuestro Señor etc. Aranjuez, 26 de mayo de 1794" 


\section{$\mathbf{N}^{\circ}$. 35. Carta de la cantante Brigida Banti desde Londres a la XV Condesa Duquesa de Benavente y borrador de la respueesta}

AHN NOBLEZA, OSUNA-CARTAS, leg. 387-2. 9 de mayo de 1794. Original italiano y publicado en "Virtuose", pp. 45-46.

"Eccellentissima Signora mia Padrona e Commare

Non manco partecipare a l' Eccelenza Vostra l' esito del mio dibutto, il quale segui la sera del 25 scorso. Io mi ritrovavo molto raffreddata, motivo per cui non potiedi cantare secondo il mio solito; con tutto ciò, questo indulgente publico è restato contentissimo di me. Sabbato scorso ritornai in scena per la seconda volta, e siccome stavo molto meglio, posso assicurare l' Eccelenza Vostra. che o fatto un vero furore, il maggior che io abbi fatto doppo che io canto, a segno tale che Sua Altezza il Principe di Gales, figlio del Re, è venuto sopra le scene a farmi de più seducenti elogi. II Pubblico dice che mai vi e simmile cantante in Inghilterra, e che mai verrà. OItre a questo sono restati così contenti della mia azzione che le carte pubbliche mi apparagonano a M. Sidon, una delle più eccellenti attrici del Teatro Inglese. Lascio considerare a Vostra Eccellenza in qual momento di giubbilo io mi ritrovi. La Morichelli anderà in scena in breve con l'opera buffa il Burbero di buon cuore. Altro non mi resta che di pregare 1'Eccellenza Vostra a volere mettermi a piedi del Excellentisimo di lei Sposo, come ancora del Signori Cavaliere Pegna [Peña]. Mio Marito anch'esso si aggiunge a questi doveri, e dio mettendomi a suoi piedi e baciandole umilmente la mano, mi do l'onnore di dirmi.

Di Vostra Eccellenza.

Devotissima Obligatissima Serva e Commare

Brigida Banti

Londra, 9 maggio 1794"

[Mi traducción]:

Excelentísima Señora, mi Patrona y Comadre.

No puedo dejaer de participar a Vuestra Excelencia el éxito de mi debut, que tuvo lugar la noche del paso 25. Yo me encontraba muy resfriada, motivo por el cual no pude cantar según suelo; a pesar de llo, este indulgente público se ha quedado muy contento de mi. El sábado pasado volví a la escena para la segunda representación, y como estaba 
mucho mejor, puedo asegurar a Vuestra Excelencia che he conseguido un verdadero éxito, el mayor que he tenido desde que yo canto, hasta el punto de que SU Alteza el Príncipe de Gales, hijo del Rey, vino al escenario a darme los mas agradables elogios. El público dice que no ha visto una cantatnte igua en Inglaterra ni que nunca la volverá a ver. Otros han quedado tan contentos de mi actuación que en una Carta pública me han comparado con Madame Sidon, una de las mejores actrices del teatro inglés. Dejo considerar a Vuestra Excelencia en que momento de júbilo me encuentro. La Morichelli pronto volverá a escena con la ópera bufa el Barbero di buon cuore. No me queda más que rogar a Vuestra Excelencia me ponga a los ìes del Excelentísimo vuestro espos, como también del Señor Caballero Pegna [Peña]. Mi marido también se une a estos deberes, y yo poniéndome a sus pies y besándole humildemente la mano, tengo el honor de considerarme

De Vuestra Excelencia.

Devotísima Obligatissima Sierva y Comadre

Brigida Banti

Londres, 9 de mayo de 1794

$N^{\circ}$ 36. Carta de Francisco Solano Ortiz de Rozas a la XV Condesa Duquesa de Benavente recomendando al violinista Alejandro Boucher $y$ borrador de la respuesta

AHN NOBLEZA, OSUNA-CARTAS, leg. 391-8. 30 de agosto de 1796 (borrador de la respuesta)

\section{"Excelentísima Señora}

Monsieur Boucher es un joven de extrema habilidad en el violín, pasa a esa capital para hacerse su establecimiento y la suerte de su familia. Estas circunstancias me impelen a dirigírselo a Vuestra Excelencia conociendo la constante protección y buena acogida que ha dado Vuestra Excelencia siempre a las Artes; presentando a vuestra excelencia su posición y sus grandes talentos músicos.

Con esta ocasión recuerdo a vuestra excelencia los sentimientos con que tengo el honor de ser de Vuestra Excelencia.

Excelentísima Señora 
El más atento servidor que sus pies besa

Francisco Solano Ortiz de Rojas

Excelentísima Señora Duquesa de Osuna"

[Borrador de la respuesta de la Condesa-Duquesa de Benavente]:

"Muy Señor mío y estimado amigo: Nada he tenido que hacer en obsequio de Vuestra Merced respecto al músico Monsieur Boucher, pues desde luego supo adquirirse el aprecio y protección de las personas que pudieran serle muy útiles en palacio, y habiendo estas proporcionado que Su Majestad le oyese tocar, ha merecido que le coloque en su Real Capilla. Las ocupaciones que le ocasionaba esta pretensión no le permitieron venir a tocar en mi casa un día que le llamé a este fin, por lo que nada sé de su habilidad sino por las noticias de Vuestra Merced y demás que le han oído. Celebro mucho la felicidad que ha tenido este su ahijado; ratificándola Vuestra Merced con que desea servirle su fina amiga que su mano besa.

San Ildefonso 30 de agosto de 1796

Señor Don Franciso Solano Ortiz Rojas"

[Nota al final de la página]: "Se devolvió esta carta formada a Su Excelencia por que dijo que se la dirigiría a la madre del sujeto para quien es."

\section{N $^{0}$ 37. Carta del Conde de Valdeparaiso a la XV Condesa Duquesa de Benavente recomendando a la cantante y violinista Luisa Gerbini y borrador de la respuesta}

AHN NOBLEZA, OSUNA-CARTAS, leg. 391-7. 29 de septiembre de 1796.

\section{"Excelentísima Señora.}

Muy Señora mía: ¿A quien mejor que a Vuestra Excelencia, amante declarada de la encantadora artes de la Música, podré yo recomendar una cantarina e insigne profesora de violín al mismo tiempo? Lo es en efecto la Señora Gerbini, que mediante esta mi carta se procurará la honra de presentarse a Vuestra Excelencia. La habilidad de las referida en el mencionado instrumento me lisonjeo excitará la admiración de Vuestra Excelencia, cuyo 
delicado gusto, y alma sensible al Bello Musical no dudo tampoco la concederán su protección generosa. En tal inteligencia me determino a suplicar a Vuestra Excelencia reciba bajo su amparo a la expresada Luis Gerbini, que, con su padre y hermano defendente y Josef, se transfiere a esta Corte. Los reiterados favores que siempre he debido a Vuestra Excelencia me inducen a creer admitirá con su acostumbrada bondad mi indicado ruego, quedando igualmente persuadido de que tendrá también la de facilitarme ocasiones en que, obedeciendo yo puntualmente cuantas deseadas órdenes de su agrado quiera Vuestra Excelencia comunicarme, la pueda manifestar mi indeleble reconocimiento.

Dios guarde a Vuestra Excelencia muchos años. Parma 29 de octubre de 1796.

Excelentísima Señora. Besa los pies de Vuestra Excelencia su más venerado servidor

El Conde de Valdeparaiso

Excelentísima Señora Condesa de Benavente Duquesa de Osuna"

[Borrador de la respuesta de la Condesa-Duquesa de Benavente]

"Muy Señor mío: Hasta el día 14 del corriente no ha llegado a mis manos la apreciable recomendación de Vuestra Excelencia de 29 de octubre del año de 1796 a favor de Luisa Gerbini, cuya habilidad en el cantado me ha parecido bien, y mucho mas la de su destreza y conocimiento músico para el violín, Lo mismo ha sucedió a varios profesores que la han oído esta cuaresma en los Caños del Peral donde han cantado y tocado en los conciertos públicos que ha habido, excitando juntamente la admiración de cuantos hemos visto su rara habilidad en este instrumento. El gusto particular que he tenido en oírla, y mas que esto, la poderosa recomendación con que Vuestra Excelencia la favorece, me obligó a ofrecerla mi protección cuando me entregó ella misma la carta de Vuestra Excelencia, y en efecto puede Vuestra Excelencia estar seguro de que haré a favor de esta célebre tocadora de violín y su familia cuanto penda de mi arbitrio. Lo [que] me persuado hubiera hecho mi madre si hubiese podido recibir la otra recomendación de Vuestra Excelencia que la traía la interesada; pero falleció S. Excelencia el 7 de Enero del año pasado de 1797.

Deseo repetidas ocasiones de poder acreditar a Vuestra Excelencia mi fina voluntad, y que Nuestro Señor que su vida [guarde] muchos años. Madrid, 18 de abril de 1798

Excelentísimo Señor Conde de Valparaíso (Parma)" 
[Nota al margen]: "Estoy en que lo que se lee de letra de mi Señora es que recibió la carta el día 4, y no el 14; pues aquella rayita no me parece número 1 sino principio de otro 4"

$N^{0}$ 38. Borrador de la carta que la XV Condesa Duquesa de Benavente dirigió a a Agustín Lancaster, Teniente General y Comandante General Interino de Cataluña para recomendarle a la cantante Luigia Todi

AHN NOBLEZA, OSUNA-CARTAS, leg. 387-26. 6 de abril de 1796. Publicada en Heilbron, "Umilissimi”, p. 209.

"Mi estimado amigo: Se presentará a Vuestra Merced la Señora Luisa Todi, celebre actriz de la Opera Italiana que va á Nápoles, y ha de embarcarse en ese puerto para Génova. De su singular habilidad excuso hablar a Vuestra Merced pues podrá asegurarse conocerla por si mismo. De sus prendas le puedo asegurar, como que la he tenido en mi casa cuatro meses, que son excelentes: constituyéndola uno y otro muy digna de la mi estimación, y de que interesándome verdaderamente por ella suplique a Vuestra merced la favorezca en lo que se la ofreciese, principalmente en proporcionar que se embarque en el primer paquebote correo y en que en el reconocimiento que se haga de su equipaje la eviten la incomodidad de desbaratar sus baúles en la seguridad de que nada lleva de contrabando.

Disimúleme el favor de Vuestra Merced esta confianza y la de escribirle de mano ajena, porque voy a partir hoy mismo al sitio y que no me queda tiempo para otra cosa, sino para ratificar a Vuestra Merced de este modo el constante afecto de su fina amiga que su mano besa..

La Condesa Duquesa

Madrid 6 de abril de 1796

Excelentísimo Señor Don Agustín Lancaster

Teniente General de los Reales Ejércitos y Comandante General interino de Cataluña

Barcelona" 
$\mathrm{N}^{\circ}$ 39. Borrador de la carta que la XV Condesa Duquesa de Benavente dirigió al Conde de Valparaíso y al coronel Joseph Capelleti, encargado de negocios de Carlos IV en Bolonia para recomendarles a la cantante Luigia Todi

AHN NOBLEZA, OSUNA-CARTAS, leg. 387-26. 18 de abril de $1796 .^{3}$

"Muy Señor mío y mi favorecedor:

Tendrá el honor de poner esta en manos de Vuestra Señoría la Señora Luisa Todi, célebre actriz de la ópera italiana, que pasa al teatro de Nápoles, cuyo extraordinario mérito en el canto es la menor de sus apreciables prendas, que he experimentado muy de cerca, teniéndola en mi casa cuatro meses. Por todo se ha merecido singular estimación mía, y que no pudiendo dejar de contribuir a cuanto sea de sus satisfacción, me tomé la liberta de recomendarla eficazmente a Vuestra Señoría de quien espero se servirá protegerla y atenderla en lo que se la ofreciere en esa capital; dispensando la bondad de V.S esta confianza a su más grata servidora que su mano besa.

Madrid, 18 de Abril de 1796

Señor Conde de Valparaiso. Ministro Plenipotenciario de Su Majestad Católica en la Corte de Parma"

$\mathbf{N}^{0}$ 40. Carta de la bailarina Teresa Monticini a la XV Condesa Duquesa de Benavente, solicitando su intercesión para resolver problemas profesionales con el bailarín Charles-Auguste Favier en sus actuaciones en Cádiz y borrador de la respuesta

AHN NOBLEZA, OSUNA-CARTAS, leg. 388-9. 26 de mayo de 1797. Original italiano y respuesta publicados en "Virtuose", pp. 96-98.

"Excelentísima Señora

Muy Señora mía y de mi mayor aprecio. En debido tiempo he recibido muy apetecida de Vuestra Excelencia de 19 del corriente la cual a la verdad me ha llenado de

${ }^{3}$ En el mismo legajo figura una copia de esta carta dirigida a Joseph Capelleti, encargado de negocios del rey en Bolonia. 
gozo por saber de su buena salud, en compaña de toda su familia y juntamente de su señor esposo.

Le doy infinitas gracias por la atención de haber entregado al Señor Solano el consabido papel, y espero una buena resulta, todo lo cual he participado al Señor empresario.

En mis anteriores me he hecho deber de notificar a Vuestra Excelencia de cuanto ocurría acerca de mi establecimiento, y aún mas dije ya de estar todo concluido como a la verdad verifiqué los ensayos y que continúan con mas vigor, para estar pronto de ir en escena el 31 corriente, pero hace un tropiezo, que era menester con su poderos influjo allanar.

Después de varias disputas tenidas con Monsieur Favier para convenirse de bailar a perfecta vicenda, por lo cual seguramente, según cuentas palmarias formadas, le habría resultado en un año un producto 13 a 14 mil cuartos, y convenidos cuasi según un papel firmado por él mismo, se citó a una junta en Casa del Excelentísimo Señor Gobernador, pero sublevado Monsieur Favier de varios partidarios carretacos, dijo que de ningún modo bailaría conmigo, y menos Madama Favier. En vista de estas impertinencias y ridiculezas tomó el Excelentísimo Señor Gobernador el asunto enteramente en sí, y resultó que bailásemos todos los miércoles, a cargo enteramente del Impresario, dándome 5 beneficios, y de este modo quedó el asunto finalizado. Según indicios seguros sabemos que el Favier ha entablado sus pretensiones, apoyados a su Cónsul, y dirigidos al Embajador en la Corte, y así he de suplicar a la bondad de Vuestra Excelencia por todo lo que pudiese suceder de hacerme una calorosa prevención a mi favor con el Gobernador del Consejo, el Corregidor, y por mayor abundamiento, al Señor Príncipe de la Paz, pues sentirá mucho quedar fea, y aún más desairados los empeñados, que por Vuestra Excelencia tanto se han esmerado en protegerme. Hago este paso de acorde del Señor. Gobernador, quien en este correo mismo lo previene a sus amigos.

Me he alegrado muy muchísimo de la mejoría de mi Señor Don José de Aróstegui, y espero que cuanto antes se restituirá a su natural robustez, a lo cual me hará el favor de pasar mis respectos. Y Vuestra Excelencia recibirá los míos que con el mayor aprecio desea servirle, y Nuestro Señor guarde su vida muchos años.

Besa las Manos su segura y reconocida servidora

Teresa Monticini

Cádiz y mayo 26 / [17]97” 
[Borrador de la respuesta de la Condesa-Duquesa de Benavente]

"Estimada Monticini: Quedo enterada por la carta de Vuestra Merced última de 26 del pasado y las antecedentes de todo lo ocurrido acerca de su establecimiento en ese teatro, que he celebrado haya sido con el partido mas ventajoso que pudo sacar. Por lo mismo que me intereso en las satisfacciones de Vuestra Merced siento muchísimo el disgusto que le ha ocasionado Monsieur Favier. Pero yo no tengo proporción de pasar a favor de Vuestra Merced los oficios que me pide al Gobernador de Consejo, Corregidor y mucho menos al Príncipe de la Paz, con cuyos Señores no tengo la confianza necesaria para estas insinuaciones. Vuestra Merced recordará que cuando vino me ofrecí muy gustosa a servirle con mi bolsillo y con cuanto pendiera de mi arbitrio. Consiguiente a esta oferta, he pasado a esa ciudad a favor de Vuestra Merced las recomendaciones que he podido, interesándome con todas veras en su buen establecimiento, siendo esto a lo que ha podido Ilegar mi valimiento, que como he dicho me falta con dichos Señores, a quienes sabe Vuestra Merced que no [...] ni para mis asuntos propios. Y si Favier ha dirigido los recursos que Vuestra Merced recela al Embajador, apoyados por el Cónsul, esta circunstancia es un nuevo estorbo para que yo no me deba mezclar en el asunto aun cuando tuviera alguna proporción. Acaso no será cierto este paso, y si lo fuere, Vuestra Merced no debe temer ni esperar malas resultas, teniendo de su parte a ese Señor Gobernador, quien, habiendo tomado el asunto con el calor que Vuestra Merced me manifiesta, su sombra y recomendable autoridad es muy suficiente para sacar a Vuestra Merced triunfante de las ideas y contradicciones de Favier.

El Señor Don. Joseph de Aróstegui ha estimado las expresiones de Vuestra Merced, .y yo le ratifico mi voluntad, rogando a Dios guarde su vida muchos años. Aranjuez, 2 de junio de 1797." 


\section{$N^{o}$ 41. Carta de Manuel Arenas a la XV Condesa Duquesa de Benavente, informando del éxito de la bailarina Teresa Monticini en una actuación en Cádiz}

AHN NOBLEZA, OSUNA-CARTAS, leg. 388-209. 6 de junio de 1797.

Excelentísima Señora Duquesa de Osuna.

Mi mas venerada Señora: En consecuencia de lo que tengo ofrecido a Vuestra Excelenciaen mi anterior con respecto a la Señora Montechini, le participo que la expresada salió a bailar en este Teatro en la noche del 3 del corriente con el baile intitulado Blanca de Rosi, en el cual hizo ver a este publico su singular habilidad, tanto en la parte sublime de su pantomima, como en la inexplicable maestría y agilidad de sus pies.

Por lo que corresponde a vestuario, decoraciones, y magnificencia con que se ha servido este baile, no me toca a mi el decirlo, y si a la la Sra Montechini la cual estoy persuadio lo hará, pues no debe olvidar que estos grandes desemboslos hechos en su obsequio, tiene el principal origen la alta recomendación de Vuestra Excelencia a quien se propuso servir en un todo este su afectísimo servidor que besa los pies de Vuestra Excelencia

Manuel de Arenas

Cádiz 6 de Junio de 1797”

No. 42. Carta del Barón Josef Capelleti a la XV Condesa Duquesa de Benavente recomendando a la cantante Mariana Vinci que había sido contratada para la temporada de ópera del Teatro de los Caños del Peral de MAdrid

AHN NOBLEZA, OSUNA-CARTAS, leg. 387-4. 11 de abril de 1797. Publicada en M. Heilbron. "Umilissimi...", pp. 210-211.

\section{"Excelentísima Señora}

La señora Mariana Vinci, que entregará a Vuestra Excelencia esta carta, pasa a esa Corte para cantar en calidad de primer mujer bufa y seria; es una virtuosa de merito, que ha hecho los primeros teatros de Italia en compañía de los más acreditados profesores, y 
siempre con general aplauso. La acompaña su marido también sujeto de merito, profesor diletante de música, y de anticuario. Permítame Vuestra Excelencia que se los recomiende, y dígnese acordarles su alta protección, que espero no desmerecerán, y particularmente la Señora Vinci, con su buen modo y habilidad sabrá granjearse el general aplauso, la benevolencia de Vuestra Excelencia llenando los deseos de esa Corte.

Me hallo en esta capital de orden de Su Majestad y en ella, y en todas partes a las veneradas ordenesde Vuestra Excelencia cuya preciosa vida que Dios [guarde] muchos años.

Florencia 11 de abril de 1797

Excelentísima Señora

Besa los pies de Vuestra Excelencia su más atento obsequioso rendido servidor Josef Capelletti.

\author{
Excelentísima Señora \\ Duquesa de Osuna, Condesa de Benavente."
}

[Borrador de la respuesta de la Condesa-Duquesa de Benavente]:

"Muy Señor mío y mi favorecedor:

La Señora Mariana Vinci, prima dama Bufa y seria que ha venido para el teatro de operas de esta corte me ha entregado la apreciable carta de Vuestra Señoría de 11 de Abril en que se sirve recomendármela para que le dispense mi protección y con ella le procure la aceptación que merece, y las ventajas posibles en el teatro. Pero las circunstancias en que este actualmente se halla no me permiten complacer a Vuestra Señoría como quisiera, y me obliga a abstenerme de protegerla. La experiencia repetida que tengo de la desatención particular con que los Señores Directores han mirado a mis protegidas anteriormente por el mero hecho de serlo, lo cual me hace temer con sobrado fundamento que, harían ahora lo mismo la suerte a la recomendada de Vuestra Señoría seria desgraciada si viesen que le dispensaba algún género de protección, pues ella misma la haría servir de blanco a las intrigas, emulaciones y desprecios de las demás operistas y sus protectores. Así lo he hecho saber a la señora Vinci y su marido, a quienes me privaré de servir con mi casa y con mi palco para libertarles de los inconvenientes expuestos: pero asegurándoles que cumplida la contrata les serviré con cuanto pueda en obsequio a la recomendación vuestra. Sintiendo no poderles ahora atender por los motivos referidos.

Estimo mucho las expresiones que Vuestra Señoría me hace con motivo de su residencia en esa capital en donde celebraré que le vaya bien, y que seguro de mi buena 
voluntad me ocupe en cuanto fuere de su agrado.

Nuestro Señor guarde a Vuestra Señoría muchos años.

Madrid 15 de julio de1797

Señor Don Joseph Capelleti”

\begin{abstract}
$N^{0}$ 43. Carta de los bailarines Louis Moreau y Achille Monroy a Giacomo Panati empresario del Teatro de los Caños del Peral de Madrid, expresándole su intención solicitar la intercesión de la XV Condesa Duquesa de Benavente, si no le pagan las cantidades que se les adeudan
\end{abstract}

BNE Mss 13.994.2/22 (Papeles Barbieri). 5 de diciembre [de 1800]

"Hoy 5 de diciembre [de 1800]

Muy Señor mío:

No es menester saber mucho para conocer que tiene usté [sci] la intención de hacer con nosotros lo mismo que con nuestros conmpagneros; así le reprevenimos que si hoy (sic) no nos paga usté o nos hace pagar lo que nos debe nos veremos en la dura precisión de escribir a la Excelentísima Señora Duquesa de Osuna para instruirla del modo [que] estamos aquí, teniendo que ${ }^{\mathrm{v}}$ ender las pocas cosas que tenemos para nuestra existencia persuadidos que $\mathrm{Su}$ Excelencia nos hará Justicia. También escribiremos a nuestros compagneros de Paris por si le daba a usté la gana de mandar venir algunos para que sepan del modo que se trata aquí a los artistas, y tomen mucho cuidado en las contratas que pudieran formar o hacer con usté.

Su respuesta muy Señor mío hará ver el caso que se puede hacer de sus palabras.

Los que su mano besan

Moreau y Monroy" 
$N^{0}$ 44. Carta del político francés Charles Maurice de Tayllerand a la XV Condesa Duquesa de Benavente, recomendándole al pianista João Domingos Bomtempo

AHN NOBLEZA, OSUNA-CARTAS, leg. 338-29. 20 de abril de 1806

"Paris le 20 avril 1806

Je saisis toujours avec empressement Madame la Duchesse les occasions de me rappeler á votre souvenir. M. Bontempo que aura l'honneur de vous remettre ma lettre, s'en retourne en Portugal et compte s'arrêter quelques jours à Madrid. Durant son séjour à Paris il s'est fait estimer pour son caractère et admirer par un talent très brillant et très rare pour le forte-piano. Je sais combien vous aimez la musique et avec quel succès vos charmantes demoiselles la cultivent. Vous serez bien aises de l'entendre et de le connaître: et à son retour j'aurai l'avantage de savoir de vos nouvelles par un témoin oculaire. Nous entretenons de vous très fréquemment, Madame et de vôtre aimable famille. On ne cesse et on ne cessera jamais de vous regretter á Paris. Mais particulièrement Madame de Talleyrand et moi, nous aurions bien désiré vous voir assister aux brillantes fêtes qui se préparent pour le mois prochain et que votre présence sent bien embellies. Vous connaissez, Madame la Duchesse, tous les sentiments que je vous a voues: Veuillez bien en agréer de nouveau l'assurance [de mes sentiments les meilleurs]

Talleyrand

Madame la Duchesse d'Osuna"

[Mi traducción]:

"Paris, 20 de abril de 1806

Aprovecho siempre, con diligencia, Señora Duquesa, las ocasiones de rememorar su recuerdo. El señor Bontempo, que tendrá el honor de remitirle mi carta, regresa a Portugal y espera pasar unos días en Madrid. Durante su estancia en París se ha hecho estimar por su carácter y admirar por un muy brillante y muy raro talento para el fortepiano. Sé cuánto ama usted la música y con qué éxito sus encantadoras doncellas la cultivan. Le encantará escucharle y conocerle, y [de este modo] a su vuelta tendré la 
ventaja de conocer sus noticias mediante un testigo ocular. Hablamos sobre usted frecuentemente, Señora, y sobre su amable familia. Ni ahora ni nunca se le dejará de echar de menos en París. Particularmente la Señora Talleyrand y yo, desearíamos mucho verla asistir a las brillantes fiestas que se preparan para el próximo mes y que con su presencia se embellecerían. Usted conoce, Señora Duquesa, todos los sentimientos que yo le prodigo. Tenga a bien autorizar de nuevo la segura [expresión de de mis mejores sentimientos].

Talleyrand

Señora Duquesa de Osuna" 


\section{E) DOCUMENTOS SOBRE MÚSICOS QUE TRABAJARON AL SERVICIO DE LAS CASAS DE OSUNA Y BENAVENTE (1781-1824)}

\section{$\mathrm{N}^{0}$ 45. Borrador de la carta que la XV Condesa-Duquesa de Benavente dirigió al Cardenal Patriarca recomendando a Manuel Carriles para una plaza de viola vacante en la Real Capilla}

AHN NOBLEZA, OSUNA-CARTAS, leg. 391-29. 24 de noviembre de 1781.

"Madrid, 24 de Noviembre de 1781

La Condesa-Duquesa, mi Señora al Excelentísimo Cardenal Patriarca recomendando a Don Manuel Carriles para la Plaza de viola vacante en la Real Capilla, a [la] que ha hecho oposición.

Muy Señor mío: Noticia del lucimiento que ha quedado Don Manuel Carriles en la oposición que ha hecho a la plaza de viola vacante en la Real Capilla, y respecto que en la última anterior mereció la bondad de Vuestra Excelencia le asegurase que lograría la primera si mereciese buen lugar, cuya circunstancia presumo se verifique ahora; me tomo la confianza de suplicar a Vuestra Excelencia que en atención a todo se digne preferirle para la citada plaza, que seguramente no desmerece por su conducta y demás buenas prendas que le acompañan.

Disimúleme Vuestra Excelencia esta satisfacción; y espero que asegurado de mi gratitud y fina voluntad me proporcione Vuestra Excelencia frecuentes ocasiones de complacerle.

Excelentísimo Señor

Besa la mano de Vuestra Excelencia su mayor servidora

La Condesa-Duquesa

Excelentísimo Señor Cardenal Patriarca" 


\section{$N^{0}$ 46. Decreto de nombramiento de Lorenzo Geisel como músico de la Casa de Osuna}

AHN NOBLEZA, OSUNA-CARTAS, leg. 392-31. 12 de febrero de 1781.

"Madrid 12 de Febrero de 1794

Mis Contadores: Yo os mando sentéis en la nómina de músicos de mi Casa a Don Lorenzo Geisel, con la obligación de tocar el fagotto con los de mi Regimiento y la de salir a campaña cuando este salga con el mismo cargo, como igualmente en todas las demás ocasiones que yo tenga por conveniente; por cuyo trabajo le señalo nueve reales de vellón diarios, ínterin se mantenga en Madrid y además cuarto material en que dormir si le quisiese; y si saliere a campaña ha de gozar de diez reales diarios, siendo de mi cuenta el pagarle sus bagajes. Todo durante el tiempo que permanezca en mi casa, desempeñando su encargo, como corresponde, y con el goce desde diez y siete de Diciembre del año próximo pasado de noventa y tres.

E1 Duque [rúbrica]

Me conformo y obligo a cumplir lo que previene el Decreto de Su Excelencia que antecede. Madrid dicho día.

Lorenzo Geisel [rúbrica]”

\section{$N^{\circ}$ 47. Copia de la partida de defunción de Carlo Marinelli}

AHN NOBLEZA, OSUNA-CARTAS, leg. 392-4, 26 de enero de 1824.

"Yo el infrascripto [...] de Su Majestad, Notario de Reinos del Ilustre Colegio de la Corte y del Juzgado de la Real Casa.

Doy fe: Que en treinta y uno de diciembre del año próximo pasado falleció en esta corte Don Carlos Antonio Pascual Marinelli que nació en la ciudad de Fermo en los estados pontificios, hijo de Juliano Marinelli y Magdalena su esposa hoy difuntos de estado soltero, instruido expediente de orden del Señor Don Francisco Xavier Ojeda del Supremo Consejo de Hacienda Juez Asesor General de la Real Casa resuelvo que el citado Don Carlos no había hecho disposición alguna testamentaria aunque era católico 
apostólico romano por lo que se mandó darle sepultura sagrada en el distrito de la Iglesia Parroquial donde era feligrés. Y para que conste en ellos a los efectos convenientes, lo signo en Madrid a veinte y seis de enero de mil ochocientos veinte y cuatro

\section{Juan Villa [rúbrica]}

Nota: El expresado difunto Don Carlos Antonio Marinelli, nació el día treinta de marzo de mil setecientos cincuenta y cinco según consta en su partida de bautismo.

Villa [rúbrica]" 


\section{F) MÚSICA Y FESTEJOS EN LOS ESTADOS DE LACASA DE BENAVENTE}

\section{$\mathbf{N}^{0}$ 48. Relato de los festejos celebrados en la villa de Benavente para celebrar el nacimiento de Josefa Manuela Téllez-Girón el 17 de agosto de 1783}

AHN NOBLEZA, OSUNA-CARTAS, leg. 472-6, 6 de septiembre de 1783.

"Diario de los regocijos y funciones que con el motivo de el feliz parto que tuvo el día 17 de Agosto de 1783, en la Ciudad de Barcelona, la Excelentísima Señora Condesa Duquesa de Benavente, Bejar, Gandía, Arcos, mi Señora se han ejecutado por los vasallos y criados de Su Excelencia en dicha villa de Benavente.

Recibida la noticia del feliz parto de Su Excelencia en el correo del martes 26 de Agosto, luego Don Evaristo Gómez corregidor de dicha villa por gracia especial de $\mathrm{Su}$ Excelencia y su Ayuntamiento de capitulares, regidores, diputados y procuradores del común, dispuso dar suelta al reloj, y repique de campanas en todas las parroquias y conventos precediendo recado político a los prelados y curas párrocos, y así tuvo efecto a la hora de las doce de dicho día.

En la tarde inmediata a la hora de las cuatro dispuso sacar un toro enmaromado y que se capease den la plaza pública y demás plazuelas y calles de la villa.

Luego mandó dicho Corregidor que por el mismo pregonero a son de la caja en los sitios acostumbrados se publicase que en la noche del citado día 26 y en las del 27 y 28 iluminasen todos los vecinos los balcones y ventanas de sus casas, poniendo hogueras por las calles públicas desde la hora de las ocho que había de principiarse a tocar el reloj y demás campanas hasta la de las nueve, estando en esta hora igualmente iluminados los balcones de las casas del Ayuntamiento.

En el día 29 viernes del citado mes de agosto el guardián y religiosos de San Francisco celebraron en su convento una misa solemne de gracias.

El día sábado 30, dicho corregidor y cuerpo político del Ayuntamiento hizo celebrar una solemne función de Iglesia en la parroquia de Santa María, habiendo precedido convite al cabildo y comunidades religiosas e igualmente al administrador general don Vicente Ruiz de Alcalá y demás criados de Su Excelencia dependientes de la contaduría y subalternos del juzgado, excelentísimos procuradores, alguaciles y demás ministros que concurrieron puntualmente habiendo salido dicho corregidor $\mathrm{y}$ 
ayuntamiento formando orden desde las Casas Consistoriales hasta dicha Iglesia y vuelto después con esta misma formalidad. Se principió la función cantando el Te deum a que siguió la misa de la festividad de Nuestra Señora con asistencia de diácono y subdiácono y a consecuencia del evangelio predicó un sermón de gracias el predicador conventual de San Francisco de dicha villa.

En la noche de este día a caballo con un lucido acompañamiento y conmoción plausible de regocijo de todo el vecindario habiendo mandado iluminar la plaza, plazuelas, calles y casas, sacó dicho Corregidor de las de Ayuntamiento llevando las cintas de los lados igualmente a caballo uno de los diputados y otro de los procuradores del común, un bien compuesto víctor con la inscripción de que viva para felicidad de los vasallos la sucesora de los estados de Benavente dicha hija de los Excelentísimos Señores Condes Duques que nació en 17 de agosto del año que rige en la ciudad de Barcelona y después de haber paseado la plaza, plazuelas y calles de la villa con dicho víctor y todo género de personas habiéndose en todo tiempo tocado las campanas y hecho muchas salvas en escopetas y pistolas y respectivamente muchos vecinos algunas mojigangas, le colocó en el balcón de dichas casas de Ayuntamiento y dio fin a la diversión el dicho corregidor con un baile en la casa de su habitar de paspies, minues, contradanzas, y al ultimo para todo género de gentes que concurrieron porque fue a puerta abierta con un fandango a la hora de la una de la noche.

Día domingo 31 de agosto, don Vicente Ruiz de Alcalá administrador general de este estado dispuso celebrar función de Iglesia con Te Deum y misa solemne en el convento de San Francisco de esta villa, habiendo convidado al corregidor y ayuntamiento que asistió yendo igualmente con la formalidad que se ha referido desde las casas consistoriales hasta el predicho convento, volviendo así también y asistido a dicha función los dependientes de dicha contaduría y demás criados y favorecedores de $\mathrm{Su}$ Excelencia.

En la noche de este día precedido el bando del corregidor para la iluminación de calles, balcones y ventanas de las casas del vecindario con igual festejo, regocijo y concurrencia de gentes don Simón Joaquín Ponce de León sacó otro victor a caballo llevando las cintas de los lados el teniente de corregidor don Agustín Caballero y el abogado don Manuel Najera.

Habiendo dado el Corregidor las correspondientes órdenes y providencias consiguió cerrar y disponer bien la plaza pública para las funciones de capeos y en el día lunes primero de septiembre desde la hora de las diez y media de la mañana hasta las doce hizo que se sortearan cuatro y después desde la hora de las tres de la tarde hasta ponerse el sol que se continuase con la misma función.

Día martes, se ejecutó lo mismo y de la misma orden. 
Día miércoles a solicitud de Don Vicente Ruiz de Alcalá bajo de las órdenes y reglas antecedentes se hizo otra semejante función de capeo de tarde y mañana.

Día jueves, cuatro del mes que rige por el dicho corregidor y de un común acuerdo de los capitulares del ayuntamiento se repitió otra función igual de capeos de mañana y tarde, y habiendo el publico a voces en la plaza pedido a dicho corregidor la continuación se verificó porque por don Simón Joaquín Ponce se ofreció facilitar los capeos y verificada en todas sus partes su expresión.

Día viernes cinco del mes de septiembre que rige tuvo efecto la función en las mismas circunstancias que los antecedentes y al finalizarse en la tarde llegaron al corregidor los jóvenes de la villa y forasteros a pedir se concediese la plaza para el día siguiente significar en expresiones el júbilo que habían tenido en el feliz nacimiento de la Excelentísima Señora sucesora con otra función que concedida la licencia de dicho corregidor ejecutaron en la forma siguiente: en la mañana del sábado seis del mes de septiembre que rige habiendo traído una lucida corrida de novillos desde la hora de las diez hasta la de las doce se capearon cinco; después para la tarde en medio de la plaza formaron un tabladillo cubierto de tafetanes y luego que todas las gentes ocuparon los balcones y tablados entraron en dicha plaza siete u ocho de dichos jóvenes vestidos de corto y ocupando el tabladillo principiaron una música de violines y dada la orden por el corregidor para sacar a la plaza el primer capeo, cesaron y se continuó la función hasta concluirla con la muerte de un torete de poco más de un año que manifestó la braveza más extraordinaria con lo que hubo mucho festejo y se verificaron diversos chistes porque unas veces decían dichos jóvenes que se les dejase solos, otras a vista de su miedo había que mandar salir a los aficionados y en conclusión un viejo frutero pidió que se le dejase estoquear y echo así a la segunda estocada le mató con que toda la gente empezó a chulearse de los jóvenes y todo se redujo a la más plausible función, y dieron fin las que movió el justo júbilo de el nacimiento de la sucesora de estos estados de Benavente.

En esta villa y septiembre 6 de 1783

Evaristo Gómez Vea" 